\title{
Tiempo vegetal Referencias botánicas en la escultura mexicana contemporánea (1990-2010)
}

Inmaculada Abarca Martínez 



\section{UNIVERSITATPOபTIECCNICA DE VALÈNCIA}

Facultad de Bellas Artes de San Carlos

Departamento de Pintura

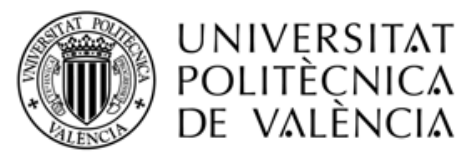

\section{TESIS DOCTORAL}

\section{TIEMPO VEGETAL. \\ Referencias botánic as en la esc ultura mexicana contemporánea (1990-2010)}

Presentada por:

Inmac ulada Abarca Martínez

Dingida por:

Dr. D. J uan Bautista Peiró López

Dr.a D.a M.a Paula Santiago Martín de Madrid

Valencia, 2012 


\title{
Colección Tesis Doctorales
}

Tiempo vegetal. Referencias botánicas en la escultura mexicana contemporánea (1990-2010)

\author{
Autora \\ Inmaculada Abarca Martínez
}

\section{Edita}

Editorial Universitat Politècnica de València, 2019

Telf.: 963877012 / www.lalibreria.upv.es

ISBN: 978-84-9048-773-0

\section{(c) $(1)(9)$}

Tiempo vegetal. Referencias botánicas en la escultura mexicana contemporánea (1990-2010)

Se distribuye bajo una licencia Creative Commons ReconocimientoNoComercial-SinObraDerivada 4.0 Internacional 
Quisiera agradecer a todas las personas que me apoyaron para la realización de este trabajo:

A Juan Bautista Peiró López por su dedicación, paciencia y comprensión durante todo el proceso de elaboración de esta tesis, así como por sus comentarios, sugerencias y en todo momento, buen criterio.

A M. ${ }^{a}$ Paula Santiago Martín de Madrid, por sus consejos, apreciaciones e invaluable apoyo para llevar a buen término esta investigación.

A Miguel Molina Alarcón, por su confianza, su entusiasmo y por su generosas y siempre oportunas orientaciones.

A Dubravka Mindek, Naomi Siegmann, Elena López de la Fuente, Mónica Dower, Patricia Yossen, Jeannette Betancourt, Diana Shkurovich, Yolanda Gutiérrez, Cáliz Vila e Isabel Soler que, como artistas y/o como mis muy entrañables amigas, se mantuvieron cerca de mí durante todo este tiempo.

A todos los artistas que me recibieron en sus casas y talleres y que, generosamente, compartieron conmigo su trabajo. A todos ellos, en general, porque sus obras han nutrido mi espíritu en estos años, consiguiendo que finalmente germinaran la semillas de este exuberante jardín.

A todas las personas que de una u otra forma me han ayudado a hacer posible este proyecto. 

A la memoria de mis padres, Rafaela y Francisco, a mi hermana Vicen, a mis hermanos Rafael y Pepe, a mis amados sobrinos y a todos los amigos que me han acompañado en este viaje de la vida a través de la escultura... 

POEMA EN TIEMPO VEGETAL

...En este bosque en que los árboles tienen historia y se acompañan espaciosos a tiempo en luz, a tiempo en sombra, saqueo al aire los flautines en que los pájaros devoran la soledad húmeda y viva de la raíz y la memoria...

...Entrar a un bosque en que los árboles tienen historia y se acompañan espaciosos a tiempo en luz, a tiempo en sombra, vale como entrar a un huerto tan lleno de frutos que todo es sombra $y$ en el que uno pasa sin tocar nada porque la sed y el hambre habitan siempre nuestra boca...

...jHermosos y fuertes árboles! Como estos árboles han de ser un día en México, los hombres...

...El hombre árbol sus palabras ha extendido. La tierra de marzo abre su entraña, pronto recibirá la semilla...

Carlos Pellicer 



\section{ÍNDICE}

1. Humanos y vegetales: historia de un vínc ulo.............................

1.1. Una aproximación a la naturaleza vegetal........................................... 25

1.2. Natural y artificial: acerca de lo vegetal y sus implicaciones en el arte, la simbología, la mitología, la antropología y la sociología.......................... 36

1.3. El híbrido Arte y Naturaleza en México...................................................

1.4. La presencia de lo vegetal en el arte contemporáneo.............................. 73

2. México, antecedentes y estado de la cuestión...................... 133

2.1. Contexto histórico........................................................................... 135

2.2. Intervenciones permanentes y exposiciones más relevantes de los últimos 30 años.

2.3. La reivindicación del medio ambiente. Helen Escobedo.......................... 173

2.4. Una visión mágico-ancestral. Marta Palau.............................................. 182

2.5. Contemplación y denuncia de la devastación. Jan Hendrix....................... 189

3. Las plantas como referente formal.......................... 201

3.1. Lo cotidiano como natural. Naomi Siegmann........................................ 206

3.2. Habitar el espacio urbano. Fernando González Gortázar y Federico Silva Lombardo

3.3. La semilla como referente formal y simbólico. Ivonne Domenge, Xawery Wolski y Miriam Medrez.

3.4. Tradición y problemática social. Betsabée Romero y Maribel Portela.........

3.5. La metamorfosis de los materiales. Gabriela León, Verónica Sahagún, Alfredo de Stéfano, Hisae Ikenaga y Sergio Rodríguez.... 
4.1. Simbolismo y herencia cultural. Yolanda Gutiérrez................................. 308

4.2. El discurso de la identidad, entre el interior y el exterior. Yolanda 328 Paulsen

4.3. La aproximación a otras culturas. Laura Anderson Barbata.

4.4. Cuerpo y ritual como proceso de intervención. Rosario García Crespo.

5. De la representación a la presentación: plantas vivas en el arte contemporáneo.

5.1. El referente vegetal como agente y proceso. Sofía Taboas, Jerónimo Hagerman, Gabriel Orozco, Colectivo Tercerunquinto y Sebastián Romo

5.2. Naturaleza y memoria: Perla Krauze, Antonio Ortiz Gritón y Ander Azpiri

5.3. Participación y percepción del espectador. Aurora Noreña y Pedro Reyes.

5.4. Naturaleza como moneda de cambio e imagen de mercado. Thomas Glassford, Melanie Smith y Máximo González.

5.5. El conocimiento científico y la pulsión entre lo natural y lo artificial. Daniel Rivera y Eduardo Rincón.

5.6. El mensaje de los materiales. Paola de Anda y Gustavo Gómez Brechtel.

6.1. Primeras hierbas: vegetales y propiedades proyectivas.

6.2. Híbridos cuerpo humano-cuerpo vegetal.

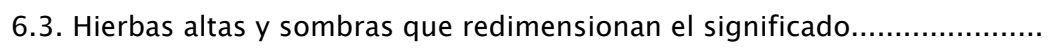

6.4. Rizomas y epífitas que se reproducen en el tiempo. 
Esta tesis se inscribe en la dialéctica cultural en torno al binomio Arte y Naturaleza, acotándose en concreto, en el contexto de la escultura contemporánea mexicana. Nuestro estudio considera el concepto de Naturaleza como un lugar de investigación y creatividad artística dentro del arte contemporáneo, delimitando el objeto de análisis específicamente, al elemento vegetal, como eje vertebrador del mismo. Cronológicamente, la investigación se centra en la última década del s. XX, si bien, dentro de la historia del arte mexicano contemporáneo, atiende a los años previos a 1990 y expande su repercusión aproximadamente, hasta el año 2010. Para este estudio, utilizamos la obra de artistas representativos de esta tendencia que, mediante la presentación y/o representación de lo vegetal en términos relacionados con la escultura, buscan plantear problemáticas actuales que a su vez, se enraízan en la historia del arte universal. El objetivo principal de este trabajo es definir la existencia de un marcado interés en torno a nuestra materia de estudio -el referente vegetal en la escultura contemporánea mexicana- por parte de un número considerable de artistas, en la última década del siglo XX y primera del XXI (1990-2010).

Determinar las motivaciones que mueven a dichos artistas a emplear las plantas en su repertorio discursivo y definir las diferentes poéticas que plantean sus prácticas artísticas, nos permitirá establecer las conexiones existentes entre ellas y entrever estrategias paralelas para comprender las mismas. Por otra parte, consideramos fundamental investigar las influencias y los artistas que, en décadas anteriores podrían considerarse antecedentes previos de los actuales. Inferir los artistas que previamente han trabajado estas temáticas así como determinar, desde qué puntos de vista lo hicieron, nos orientará a circunscribir pautas de estudio. Con todo ello, generaremos un panorama que verificará el interés despertado por la materia en el contexto mexicano, recopilando información que documente el mismo y llenando así, el vacío testimonial al respecto. Para describir las prácticas empleadas por los artistas, se han seleccionando obras que permiten evidenciar cómo la referencia Arte y Naturaleza y, en particular, lo vegetal en el arte mexicano, se ha ido perfilando como un medio socialmente útil para describir problemáticas sociales actuales. Como veremos, la reflexión actual en torno a la relación entre Naturaleza y Arte tiene una serie de parámetros de estudio que se manifiestan de forma global, en el trabajo de muchos artistas contemporáneos.

La Naturaleza y todas las experiencias que su cercanía convoca, ha sido y sigue siendo, un tema de minuciosas reflexiones para el hombre de todos los tiempos. Presente en todos los escenarios del ser humano y, a lo largo de toda su historia, el hombre ha tratado de explicarse su propia naturaleza en el contexto de esa otra Naturaleza, en la cual se ve inmerso. Esta convivencia/dependencia se pone de manifiesto en un profundo sentimiento de pertenencia, a la vez que, en una especie de continua rivalidad con la misma, fruto de la natural tendencia a la sobrevivencia. En este contexto, el arte ha sido una disciplina más -entre las 
muchas desarrolladas por el hombre- con la que analizar y asimilar estos procesos de conocimiento. Así, los estudios sobre Arte y Naturaleza han sido revalorizados en la actualidad, por la historia y las prácticas artísticas, a partir específicamente de la segunda mitad del siglo XX, cuando en el transcurso de los años sesenta, un grupo de artistas exploró este terreno, si bien, con motivaciones muy diferentes a las que mueven en la actualidad a los artistas. El hecho es que, en las últimas décadas del siglo XX, se ha producido una eclosión de manifestaciones artísticas relacionadas con la Naturaleza y que en los últimos años, numerosas publicaciones se han hecho eco de las acciones de artistas y colectivos que, de una u otra manera, han estado relacionados con esta temática. Estas circunstancias, sumadas a una mayor conciencia ético-ecológica han propiciado que un determinado número de artistas orientaran su obra en esta dirección.

El presente trabajo verifica el interés que el binomio Arte y Naturaleza ha despertado en el arte contemporáneo, a través de las diferentes manifestaciones artísticas de escultores mexicanos que en la actualidad, vertebran su obra en torno a esta dialéctica. En este amplio conjunto de realidades, el acento recae en la representación de un determinado elemento de la Naturaleza -el reino vegetal y su influencia-. La hipótesis que defendemos es que la relación que el ser humano mantiene con las plantas - la cual, a través de los tiempos se ha visto reflejada en el arte de muy diferentes maneras- es también actualmente, una de las manifestaciones que unifica el discurso sobre Arte y Naturaleza. Dado que los artistas utilizan este material conceptual en sus obras, analizaremos la forma y los motivos que les impulsan a su utilización. La insistencia de ciertos artistas en proyectar con su obra, una visión contemporánea sobre el mundo vegetal es reflejo de un sentimiento que va más allá de la reivindicación ecologista. En el fondo, se trata de una necesidad de hablar de todo lo humano, a través de una serie de representaciones vegetales. Intuimos que se trata de un leiv motif similar al desarrollado por el fotógrafo Karl Blossfeldt, como una forma de acercarse a lo pequeño y a lo aparentemente insignificante, magnificándolo. Más allá de las especulaciones sobre lo verde y sobre los orígenes del concepto de Naturaleza o de paisaje hay una vívida necesidad de contacto con esta realidad, la añoranza de una Naturaleza de la que como género humano, nos hemos alejado.

Las motivaciones que generan esta investigación surgen de la trascendencia que esta temática ha suscitado en la obra escultórica personal desarrollada en los últimos años, convirtiéndose en una importante fuente de inspiración. Por otra parte, el hecho de constatar que el referente vegetal es asimismo y, dentro del contexto mexicano del arte, un motivo de interés, para otros escultores. Esta circunstancia ha sido determinante puesto que México - país en el que he vivido desde 1986 hasta 2003- ha sido el lugar donde he realizado la mayoría de mi obra escultórica y donde mantengo una vinculación artística profesional. Esto me ha permitido conocer en cierta medida, las políticas culturales de los últimos años así como a numerosos artistas, entre los que se encuentran algunos a los que haremos referencia. 
La estructura general de este trabajo parte del elemento vegetal, como material físico y conceptual de trabajo, así como idea fundamental, capaz de trasmitir los conceptos de crecimiento, transformación y desarrollo. Estas ideas son tomadas en cuenta como ejes vitales de todo ser vivo, planteamiento que nos lleva en primera instancia, a equiparar el arte con la vida, como proceso vital, en desarrollo y, en esencia, creativo. De aquí, se derivan muchas de las consideraciones que revisaremos y que llevan a nuestros sujetos de estudio a considerar arte y vida como una unidad inseparable. Por otra parte, estas ideas nos Ilevan a plantearnos las relaciones entre Naturaleza y Cultura como polos que dinamizan nuestro entendimiento del mundo y que, por lo tanto, describen nuestras nociones en torno a lo natural y lo artificial.

El concepto de tiempo, como organizador cultural, subyace en la estructura de esta investigación, en tanto que entendemos que el devenir entre pasado, presente y futuro, es un proceso tanto lineal, como cíclico, que vincula los parámetros en los que nos basamos para analizar las obras de los artistas. Para entendernos, veremos artistas cuya obra tiene como referente la Historia, la Antropología y en general la Cultura de un pasado más o menos cercano, a través del cual se estructura su obra. Por otro lado, hay artistas que, anclados en el presente, exploran territorios críticos relacionados con la identidad personal y la conciencia social, a través de los materiales, las formas o las estructuras y, finalmente aquellos que, en una búsqueda semejante se acercan a planteamientos relacionados con un futuro próximo, la Ciencia, la técnica, la ecología o la sostenibilidad. Todos ellos en general, escapan a cualquier clasificación cerrada que pretendamos establecer, con lo cual anticipamos que las categorías que aquí generamos no son espacios cerrados sino receptáculos -en el amplio sentido de habitar los conceptos- con espacios y pasadizos intercomunicables y abiertos a la conciencia del espectador.

La relevancia actual de enmarcar esta investigación en el diálogo sobre Arte y Naturaleza en el panorama del arte contemporáneo mexicano más reciente, estriba en la falta de atención prestada hasta el momento por los estudiosos en la materia, en este país. Si bien, es un tema ampliamente estudiado y documentado a nivel internacional, en otras geografías, la ausencia de estudios al respecto en México, plantea la necesidad de un estudio más concreto. La intención es dar a conocer ciertos conceptos en torno a lo vegetal que, como objeto de estudio, merece una consideración especial. Desde esta necesidad, exploramos la cuestión vegetal, planteándonos aquí un análisis del contexto específico mexicano que, en la práctica artística mexicana tiene una relevancia singular manifiesta, a través del conjunto de obras de una serie de artistas que han detenido su mirada en esta temática.

México presenta -como muchos otros países latinoamericanos- ciertas dificultades para integrarse en el contexto artístico internacional. El interés que el mundo occidental ha mostrado en cuanto al arte contemporáneo de estos países es muy reciente. México es un país que, en determinados aspectos, presenta características bastante occidentalizadas, sin embargo, a lo largo de su historia, podemos observar un cierto retraso respecto al mainstream 
internacional, debido en gran parte, a las dificultades económicas, la presencia de lo indígena y las contradicciones sociales y de identidad que se manifiestan en los diferentes ámbitos de la sociedad mexicana. Por otro lado, el arte en México se ha visto, en gran parte, supeditado a discursos políticos que, frente a la tendencia globalizadora, favorecen la autoafirmación de un fuerte sentimiento nacionalista, en favor de la construcción de una identidad nacional. La preponderancia de este tipo de investigaciones, conlleva carencias que, más allá de favorecer el análisis de las individualidades artísticas que destacan fuera del ámbito nacional, se exploren relaciones internas y temáticas comunes, que permitan visiones alternas.

A través de esta investigación, queremos ofrecer una perspectiva diferente en el contexto de la escultura en México y, si no resolver los motivos que han mantenido la problemática Arte y Naturaleza en la indiferencia, por lo menos ofrecer visibilidad y asentar un precedente que permita en el futuro, nuevos estudios al respecto. El objetivo final no es realizar una compilación de todos los artistas ni de todas sus obras sino, únicamente llenar la ausencia que percibimos en torno a la temática, presentando nuevos puntos de vista con respecto a las prácticas y motivaciones últimas por las cuales se utiliza el referente vegetal en el arte. Por otro lado, no pretendemos establecer una taxonomía que vincule a los artistas ni como colectivo, ni como movimiento, porque en definitiva, todos ellos, mantienen su individualidad como artistas, mostrando una obra bien definida y puntos de vista muy diferentes en sus obras. El sentido de actualidad que presenta este trabajo obedece a la circunstancia personal de sentirnos parte integrante de esta realidad y, desde esta posición, nos interesa conocer cuales son en primer lugar las prácticas de otros artistas y sus motivaciones para, a partir de todo ello, buscar, como apuntaba Gregory Bateson, la "pauta que conecta" . Con este planteamiento nuestra metodología se enfoca siguiendo a D'Arcy Thompson, en la forma de conocimiento que establece relaciones entre elementos aparentemente inconexos, buscando las semejanzas en los aspectos disímiles, para generar un punto de vista común que permita la comprensión de una manera más fluida.

La búsqueda de diferencias o contrastes fundamentales entre los fenómenos de lo orgánico y lo inorgánico, de los seres animados e inanimados, ha ocupado muchas mentes humanas, mientras que pocos han trabajado en la búsqueda de principios comunes o semejanzas esenciales; y hay propensión a conceder demasiada importancia a los contrastes, por grandes que estos pudieran ser.

Hemos utilizado un método empírico para acercarnos a las obras y a los artistas que, mediante diferentes técnicas como la observación, los cuestionarios y las entrevistas directas con artistas, críticos y agentes culturales, nos han permitido

\footnotetext{
1 BATESON, Gregory, Una unidad sagrada: pasos ulteriores hacia una ecología de la mente, Gedisa, Barcelona, 1999, pp. 312-313.

2 THOMPSON, D' Arcy, Sobre el crecimiento y la forma, Cambridge University Press, Madrid, 2003, p. 23.
} 
construir una red de relaciones entre las diferentes realidades analizadas. En esta dinámica, recopilamos el trabajo de reconocidos escultores que, en México trabajan aspectos de la naturaleza vegetal y establecemos relaciones y vínculos no sólo entre ellos y sus obras, sino también, explorando afinidades con otros artistas que, en el contexto global, muestran inquietudes similares. En la metodología empleada ha sido fundamental la consulta sistemática de fuentes bibliográficas (libros, catálogos de exposiciones, monografías, folletos, artículos en revistas y periódicos, etc.) incluyendo algunas referencias puntuales a los artistas en internet o en sus propias páginas web. La circunstancia eventual de la distancia con algunos de los artistas, se ha paliado mediante comunicación por teléfono, mail y tomas de contacto a través de entrevistas directas que han subsanado la mayoría de las carencias bibliográficas. La inmediatez de este medio de información nos ha permitido construir un panorama consistente, a la vez que, establecer los parámetros para observar de cerca la obra de los artistas, en sus talleres o en sus exposiciones.

Dado que el objeto de nuestro interés es el mundo vegetal y su relación con el ser humano, a través de la escultura contemporánea, nos acercaremos a movimientos artísticos como el Arte Povera, el arte de la tierra o Earth Works y el Land Art, movimientos artísticos que comenzaron en los años sesenta del siglo $\mathrm{XX}$ y que, con planteamientos diferentes, se mantienen vigentes en la obra de numerosos artistas. Por otro lado y con los datos obtenidos, pretendemos analizar cómo éste fenómeno de búsqueda de un arte más cercano a la Naturaleza se refleja, en un país determinado como es México y sus artistas.

Para hablar de las poéticas de lo vegetal en la escultura contemporánea partimos del concepto de escultura en el campo expandido clarificado por Rosalind Krauss 3 y José Luis Brea ${ }^{4}$, y concretamos nuestra investigación en las manifestaciones que operan a través de la tridimensionalidad, así como en el empleo de materiales que involucran a la escultura, si no siempre, como objeto, sí como práctica discursiva. Sin embargo, en ocasiones nuestra investigación incluye, en interés de nuestro objetivo, otras prácticas artísticas como la pintura, el dibujo, el grabado, la fotografía o el video.

\footnotetext{
3 "En la situación de la posmodernidad, la práctica no se define en relación a un determinado medio -la escultura-, sino en relación a las operaciones lógicas sobre un conjunto de términos culturales, para las que puede utilizarse cualquier medio -fotografía, libros, líneas en las paredes, espejos o la propia escultura", KRAUSS, Rosalind E., "La escultura en el campo expandido", en KRAUSS, Rosalind E., La originalidad de la Vanguardia y otros mitos modernos, Alianza, Madrid, 1996, pp. 289-303.

4 BREA, José Luis, "Ornamento y utopía. Evoluciones de la escultura en los años 80 y 90", en CUESTA, Salomé et al., Selección de textos sobre prácticas artísticas y espacio público II, Universitat Politècnica de València, Facultad de Bellas Artes, Departamento de Escultura, Valencia, 2002, pp. 25-39.
} 
Desde el tipo de imaginario de Regis Debray 5 la producción de imágenes puede ser dividida en tres apartados o esferas de la imagen: la logosfera, la grafosfera y la videosfera. En su división, las imágenes, concebidas no como objetos, sino como apropiaciones de la mirada o formas de mirar, importa el origen de la imagen, la tecnología y los usos. Para el caso de nuestra investigación, reflexionamos sobre dos de estas esferas directamente relacionadas con la producción de escultura u objetos. La escultura relacionada con lo vegeta/ puede convertirse en elemento sobrenatural, donde uno de los análisis podría ser en cuanto a la logosfera: todo aquello que tiene que ver con el culto del ídolo. Será el caso de artistas que representan lo natural para establecer una relación con lo trascendente a través del mito y la creencia en un orden cósmico. Artistas como Ana Mendieta y Giuseppe Penone en los que la producción de imagen tiene que ver con la identificación del artista con el entorno natural y donde el cuerpo mismo del artista es considerado uno y lo mismo con la Naturaleza, evidenciando aquí el vínculo Arte-Vida. Lo espiritual, como una energía interna lleva al artista a una búsqueda exterior, dentro de la Naturaleza para reconocer el auténtico carácter del medio ambiente. El respeto por el medio ambiente los lleva a adoptar la práctica artística como una actividad pseudo espiritual.

Por otro lado, también se dan casos de prácticas que, aunque tienen un origen espiritual, adoptan materiales no naturales, como flores de plástico, para generar el mismo motivo reverencial, o sea que los usos del imaginario no están reducidos al origen y características del material empleado, sino que se concentran en los beneficios prácticos que éstos aportan. Estos artistas divinizan la Naturaleza y la conciben como un reino sobrenatural donde surgen los mitos y mitologías que animan a la Cultura, como por ejemplo lo hace la mitología griega o la mitología de los pueblos mesoamericanos. Podríamos hablar de un panteísmo contemporáneo, donde observamos la animación como poder mágico que infunde vida a la presentación de lo natural. Es así el caso de por ejemplo, la diosa del maíz o la diosa del pulque en la cosmovisión prehispánica o saltando en el tiempo, la obra de Yolanda Gutiérrez, en la que las hormigas son representadas con maíz, que al igual que en el mito prehispánico, son las que enseñan a Quetzalcóatl el lugar en dónde encontrar el maíz, alimento básico que el dios hace llegar a los hombres. Estos procedimientos se acercan al planteamiento que el jefe indio de las tribus norteamericanas, Noah Sealth ya expresaba en 1855, en la carta dirigida al Presidente de los Estados Unidos de América:

Somos parte de la tierra y asimismo ella es parte de nosotros. Las flores perfumadas son nuestras hermanas; el venado. El caballo, el águila majestuosa, éstos son nuestros hermanos. Las peñas escarpadas, los prados

\footnotetext{
5 DEBRAY, Régis, Vida y muerte de la imagen: Historia de la mirada en Occidente, Paidós, Barcelona, 1994, pp. 178-179.
} 
húmedos, el calor del cuerpo del caballo y el hombre, todos pertenecemos a la misma familia6.

La visión no dicotómica de la Naturaleza expresada en estas palabras conlleva dos ideas fundamentales, por un lado la idea de filiación del ser humano con respecto al medio del que depende íntimamente para su subsistencia y la atribución con ello, de un valor sagrado y por lo tanto no meramente utilitario de la Naturaleza. La otra idea importante que surgiendo de la anterior, se rescata en la actualidad, es la interdependencia y mismo destino que comparten con el lugar, aquellos que lo habitan.

En cuanto a la grafosfera, la práctica escultórica y la representación de lo vegetal encontramos la obra de artistas que representan o hacen presentaciones de materiales que unen al espectador-intérprete con un conjunto de símbolos, metáforas y alegorías que relacionan la Cultura material con lo imaginario simbólico de la Naturaleza. En otros casos, la producción de objetos pretende lograr una estetización de la Naturaleza a través de la construcción de formas y la utilización de materiales a los cuales se les atribuye un poder representativo, como es el caso de las esculturas de Naomi Siegmann e Ivonne Domenge. Aquí también encontramos artistas que oponen el problema de la representación de la Naturaleza con el del mundo artificial, tal sería el caso de Sofía Táboas, Jan Hendrix y Laura Anderson.

En cuanto a la videosfera, la experiencia del video y las artes o los juegos digitales, ambientes virtuales y todas aquellas disciplinas que integran de una $u$ otra manera un concepto científico de comprensión de la Naturaleza, encontramos a artistas que realizan su trabajo partiendo de todas estas escenas, es el caso de Natalie Jeremijenko, con la clonación de árboles, George Gessert y sus flores genéticamente intervenidas o Daniel Rivera y su pasto transgénico. En general para todos estos artistas y, siguiendo a Debray, la simulación actúa eliminando al simulacro y levantando la inmemorial maldición que ha unido siempre imagen e imitación:

La imagen estaba encadenada a su estatuto especular de reflejo, calco o añoranza, a lo mejor sustituto, a lo peor superchería, pero siempre ilusión [...] Con la concepción asistida por ordenador, la imagen reproducida, ya no es copia secundaria de un objeto anterior, sino lo contrario. Al eludir la oposición del ser y el parecer, de lo parecido y lo real, la imagen infográfica ya no tiene por qué seguir imitando una realidad exterior, pues es el producto real el que deberá imitarla a ella para existir?.

Con respecto a la relación entre las creencias prehispánicas y el arte contemporáneo mexicano que utiliza lo vegetal -sea como referente formal o

\footnotetext{
${ }^{6}$ ALBELDA, José y SABORIT, José, La construcción de la naturaleza, Direcció General de Promoció Cultural, Museus i Belles Arts, Conselleria de Cultura, Educació i Ciència, Colección Arte, estética y pensamiento, Valencia, 1997, p. 66.

7 DEBRAY, Régis, op. cit., pp. 237-238.
} 
contextual- si bien es cierto que no debemos, ni es intención de este trabajo, establecer ningún criterio de continuidad -ni formal ni de significado- sí queremos dar cuenta de la importancia vital de una herencia cultural que ha permitido adaptar las formas de sus antecesores a nuevos significados. Éstos nuevos significados no son independientes del contexto artístico globalizado, pero sí, en el caso específico de algunos artistas, permean particularidades específicas que recogen aquellas ideas, mitos y símbolos que tienen que ver con una continuidad cultural en Mesoamérica, algunos de los cuales se han mantenido vivos, desde la Conquista hasta ahora, durante más de quinientos años. Este razonamiento tiene que ver con la importancia y la persistencia cultural sostenida por la tradición oral y las manifestaciones artísticas tanto en México, como también en otras áreas del mundo, en las que el hombre está íntimamente ligado con la Naturaleza y donde el mundo se percibe como un microcosmos que refleja al macrocosmos y el universo. Culturas en las cuales los ciclos agrícolas determinan las pautas sociales y en donde, el poder y las propiedades de las plantas contribuyen a mantenerlas en un estatus cercano a lo divino.

La investigación realizada, el trabajo de campo y la recopilación de datos tanto bibliográficos como fotográficos sobre la influencia de lo vegetal y su relación con lo humano, nos han llevado a constatar la pervivencia del vínculo vegetal/humano manifestado a través de la escultura contemporánea. El panorama que nos ofrece el mundo de la escultura en sus manifestaciones más recientes, mantiene cierta dialéctica con épocas anteriores. Crear o decorar, hacer de las figuras vegetales un elemento revelador de una estética y una ética o, por el contrario, un uso emblemático y decorativo de la Naturaleza para minimizar la participación de ésta en la Cultura. La metáfora vegetal es empleada en el arte contemporáneo como una metáfora social y, entre las hipótesis posibles para explicar el interés que en la actualidad continúa despertando en los artistas lo natural, encontramos que una de ellas es la debacle que se observa a nuestro alrededor. A saber, el ser humano no ha podido desarrollar un plan de convivencia con su entorno, por tal motivo el artista crítico se ha centrado en revisar los paradigmas básicos sobre qué es lo humano, qué es lo natural, lo artificial o lo real. A través de las respuestas que se ofrecen en estos campos, se ofrece un diagnóstico y una prognosis sobre lo que puede hacer el ser humano para conservar el medio en el que vive y del cual depende.

A pesar de que existen numerosas representaciones del medio natural en nuestra Cultura, éstas no implican una conciencia de la urgencia del problema de la subsistencia del entorno natural. Es así cómo a través de la obra artística se genera un discurso ideológico sobre qué es Naturaleza y qué es lo natural en el ser humano. Con todo ello el discurso sobre la Naturaleza se trasfiere desde la estética a la ética. Dentro de cierto constructo ideológico-ético lo vegetal representa los valores más puros y trascendentes de lo humano. Desde siempre, en la historia del ser humano, ha existido una relación simbólica y/o metafórica entre ciertos elementos vegetales, como por ejemplo el árbol, las flores, etc. y el hombre. Las formas vegetales proporcionan modelos de identificación de la 
Naturaleza con la conducta humana y conceden un valor estético y ético a la acción del hombre y a la producción artística, otorgándole una característica trascendente al discurso artístico. Sin embargo, también es cierto que en algunas manifestaciones artísticas -como por ejemplo en la época modernista y el Art Nouveau- el discurso vegetal ha elaborado constructos de belleza que intrínsecamente transforman la experiencia de la Naturaleza, reduciéndola a un elemento meramente decorativo, accesorio y, en consecuencia, no trascendente.

De entre los procedimientos a seguir para analizar el tema de nuestra elección nos decantamos en primera instancia, por revisar la obra de artistas contemporáneos, revisando asimismo, los probables orígenes de ciertos usos en la Historia del Arte de los últimos años. Para establecer las categorías posibles, fuimos detectando entre los artistas, a aquellos en cuya obra resalta el carácter urgente y esencial de las formas naturales vegetales. Por método de trabajo, podemos encontrar artistas que representan formalmente diferentes motivos vegetales, con una cierta idea de germinación, floración o recurriendo a procesos característicos de lo vegetal. Por otro lado, se encuentran aquellos artistas que trabajan dentro de la Naturaleza, en el bosque, en el paraje, en los litorales, transformando o adaptándose al medio ambiente. Algunos trabajan indistintamente con elementos naturales $\mathrm{y} / \mathrm{o}$ artificiales. Otros sin embargo, independientemente de los materiales utilizados, emplean el paradigma de lo vegetal para crear un discurso sobre su propia naturaleza personal o sobre la naturaleza del devenir de la vida y de la Cultura, generando así un discurso conceptual. Por último, encontramos una serie de artistas que, a partir de las nuevas tecnologías, trabajan con el imaginario natural, definiendo nuevos paradigmas.

En resumen, la metáfora vegetal como objeto de la escultura, tanto desde el punto de vista formal, como tomando en cuenta sus implicaciones y sus múltiples lecturas (el crecimiento, lo vivo, lo pequeño, lo exuberante, etc.) es una manifestación que amerita un punto y aparte en los estudios sobre Arte y Naturaleza. Urge pues un análisis de los usos trascendentes de la Naturaleza en la práctica escultórica contemporánea, vinculando la obra escultórica, a la ideología y filosofía del desarrollo de los trabajos, concretando el sistema representacional utilizado por los artistas en sus prácticas individuales: Mimesis-Ornamentación-Representación-Abstracción-Presentación. El objetivo que en definitiva, nos hemos marcado para este trabajo es evaluar y analizar las diferentes representaciones y presentaciones que, dentro del campo de la escultura, se ha desarrollado en torno a la relación Naturaleza-humano-vegetal.

En el primer capítulo y, a través de diferentes autores, analizaremos históricamente el fuerte vínculo que ha unido al ser humano con los vegetales. Para ello, partiremos de la comprensión de la idea de Naturaleza y de sus orígenes históricos, para llegar a la diferenciación entre Naturaleza y Cultura y, finalmente incidir en la relación entre el elemento vegetal como parte manifiesta de una Naturaleza que hunde sus raíces en lo más profundo de la representación simbólica de lo humano. En primera instancia, la idea de lo vegetal, el mundo verde, las plantas, su historia y sus características, serán 
estudiadas desde el punto de vista de la evolución, lo cual nos permitirá tener una perspectiva exhaustiva de su trascendencia en relación con la vida humana. Posteriormente, estableceremos las particularidades que caracterizan las diferencias entre natural y artificial, para establecer las implicaciones de estos conceptos en diferentes ámbitos del conocimiento, como el arte, la simbología, la mitología, la antropología o la sociología. Asimismo, estudiaremos dentro de la Historia del Arte, las ideas asociadas a las primeras representaciones de vegetales así como sus posteriores percepciones vinculadas a la filosofía y a los conocimientos científicos. Algunos aspectos de la filosofía de Deleuze y la idea de utilizar partes estructurales de la planta como el rizoma, nos ayudará a entender los procesos de contaminación temática en un mundo globalizado que preconiza la importancia de la ecología y las conexiones metafóricas entre realidades disímiles como las plantas y el ser humano.

En principio, para referirnos al binomio Arte y Naturaleza en México, nos remontaremos a algunas referencias que parten de la historia y la antropología particulares de este país, así como de la medicina, la religión, la cosmovisión, la simbología o el arte prehispánico, las tradiciones y la artesanía. También serán importantes algunas aportaciones específicas de la pintura, tanto antigua como colonial y moderna (Frida Kahlo), que harán su aparición en este periplo, haciendo especial hincapié en las representaciones de un determinado constructo híbrido entre vegetal y humanos. Por último y, antes de entrar en concreto en el arte contemporáneo mexicano, haremos una revisión en torno a algunos escultores que, en el ámbito internacional, han empleado la referencia vegetal como un método discursivo. Entre ellos veremos obras de Joseph Beuys, Agnes Denes, David Nash, Pipilotti Rist, Sanja Ivekovic, Hiroshi Teshigahara, Maurizio Cattelan, Samm Kunce, Henrik Hakansson, Yoko Ono, Carsten Höller, Robert Smithson, James Pierce, Newton Harrison, Hans Haacke, Giovanni Anselmo, Charles Simonds, Olaf Nicolai, Lois Weinberger, Alan Sonfist, Herman de Vries, Giuseppe Penone, Andy Goldsworthy, Nils-Udo, Wolfgang Laib, Anish Kapoor, Eduardo Catalano, Ed Carpenter, Barb Hunt, Monique Bastiaans, Isa Genzken, Iraida Cano, Petah Coyne, Joao Pedro Vale, Paul Morrison, Ana Mendieta, Patrick Dougherty's, Vito Acconci, Anya Gallaccio, Pamen Pereira, Meg Webster, M. ${ }^{a}$ Fernanda Cardoso, Alberto Baraya, Ester Partegás, Olafur Eliasson, Roxy Paine, Gerda Steiner y Jörg Lenzlinger, Doug Buis, Natalie Jeremijenko, George Gessert, Eduardo Kac, Jeff Koons, Marc Quinn, Jane Benson, Jerilea Zempel, Joana Vasconcelos y Yayoi Kusama. Estos artistas -relacionados con la materia de nuestro análisis- nos servirán para enmarcar en un contexto internacional, occidental e iberoamericano, la labor de los artistas mexicanos que son el objeto final de nuestro interés.

En el segundo capítulo, nos sumergiremos en el caso específico de México, donde retrocederemos en el tiempo para ver si la obra de los artistas que actualmente trabajan con la Naturaleza -y que revisaremos en los siguientes capítulos- presupone la existencia de otros artistas que hayan trabajado anteriormente con este paradigma y quienes podrían ser éstos. El análisis de las intervenciones permanentes así como de las exposiciones temporales que se han llevado a cabo en México a partir de los setenta, será determinante para 
concluir estas influencias. La importancia de construcciones como el Espacio Escultórico (1979), las referencias culturales en el imaginario popular en torno al espacio conocido como Xilitla (1962-1984) y el análisis de exposiciones como 14 artistas en torno a Beuys (1989), Lesa Natura (1993), Escultura Mexicana del Siglo XX: De la Academia a la Instalación (2001), Alter Natura (2004) y El bosque de Naomi Siegmann (2005) nos darán la pauta para proponer como artistas precursores en la temática de Arte y Naturaleza en México a Helen Escobedo, a Marta Palau y Jan Hendrix.

En el tercer capítulo nos centraremos en los artistas que, sin recurrir a la mímesis ni a representaciones decorativas, utilizan las plantas como referente formal para explorar aspectos de la cotidianeidad que trascienden de lo íntimo a lo público (Naomi Siegmann), de la inserción de lo vegetal en la escultura monumental de ámbito público (Fernando González Gortázar, Federico Silva Lombardo) o del vegetal como principio simbólico de vida (Ivonne Domenge, Xawery Wolski, Miriam Medrez). En este apartado, encontraremos obras vinculadas a las nuevas problemáticas sociales de la migración (Betsabée Romero) que inciden en la recuperación de la identidad nacional a través del imaginario de la tradición popular o de la memoria antropológica (Maribel Portela). Otro punto de vista lo aportan los materiales como productores de significado (Gabriela León, Verónica Sahagún, Alfredo De Stéfano, Hisae Ikenaga, Sergio Rodríguez).

En el cuarto capítulo, analizaremos algunos artistas cuya preocupación principal radica en el pensamiento ecológico y que, haciéndose eco del deterioro del entorno, extrapolan el principio ecológico a una suerte de concepción mística de la Naturaleza, en la que de alguna manera, el artista comienza a formar parte de la obra, cobrando importancia la relación arte-vida, manifiesta en el cumplimiento de determinados rituales (Yolanda Gutiérrez, Yolanda Paulsen, Laura Anderson Barbata y Rosario García Crespo).

En el quinto capítulo, el proceso de desmaterialización del objeto y la autorreferencialidad dentro de la Historia del Arte da paso a procesos conceptuales en el arte contemporáneo, en los que se transita de la representación vegetal a la presentación de plantas vivas, que ejercen como constancia de la relación arte y vida -trazada anteriormente- $y$, en la que los procesos naturales introducen el paso del tiempo, como factor determinante que materializa el cumplimiento de dichos procesos (Sofía Táboas, Jerónimo Hagerman, Gabriel Orozco, Colectivo Tercerunquinto, Sebastián Romo). Naturaleza y memoria son capaces de recuperar la historia colectiva (Perla Krauze, Antonio Ortiz Gritón, Ander Azpiri), dando pie a que el propio espectador participe en la creación de la obra (Aurora Noreña, Pedro Reyes). Asimismo, en un proceso de crítica generalizada a la banalidad de la sociedad del exceso actual, la Naturaleza -con lo vegetal como estandarte- se transforma en mercancía y objeto de consumo (Thomas Glassford, Melanie Smith, Máximo González), reinterpretando la relación del hombre con su entorno natural. En el extremo más radical, la Ciencia y la Biología se utilizan como herramientas, para provocar nuevos escenarios de participación de una controlada naturaleza 
vegetal que revierte sus beneficios en el ámbito social (Daniel Rivera, Eduardo Rincón). Por último, las generaciones más jóvenes de artistas utilizan materiales vegetales en sus obras decantándose definitivamente por explorar nuevas trayectorias que hablan de la Naturaleza y de lo vegetal, desde sus propios tiempos y procesos, generando así nuevos interrogantes (Paola de Anda y Gustavo Gómez Brechtel).

En el sexto capítulo analizaremos la obra personal realizada entre 1990 y 2010 , en relación específica con la temática. Nuestra obra se ha decantado por una expresividad que parte de un sentimiento de lo vegetal relacionado estrechamente con lo humano. En origen, esta investigación explora las circunstancias que han propiciado que este tipo de obra surgiera como proyecto personal, pero también como parte integrante del contexto del arte contemporáneo en México. Para ello hemos estructurado una serie de apartados que parten de la idea, fundamental en nuestra obra, de vincular lo vegetal con el discurso en torno a lo humano. Por este motivo, se recurrirá a las propiedades proyectivas para explicar la aparición de las primeras plantas en nuestras esculturas. Seguidamente, el cuerpo vegetal y el cuerpo humano (de la artista) aparecen en el escenario, para fundirse en un híbrido que identifica ambas naturalezas. Finalmente, la completa sustitución de lo humano por lo vegetal se materializa en la casi desaparición de la temática antropomorfa y su total conversión en vegetales que se transforman e inundan los espacios, multiplicándose en rizomas y epífitas que conquistan diferentes lugares y tiempos. La aparición de nuevas estrategias nos empuja a recurrir a nuevos materiales con los que lograr fundir de manera explícita la metáfora vegetal en un paisaje complejo que se inserta en una práctica artística, contemporánea, reflexiva y crítica.

Frente a comentarios como el de Lucy R. Lippard en los que afirma que "[...] los títulos de las exposiciones que tienen la tierra y la naturaleza como tema están adoptando un tono melancólico e incluso apocalíptico: por ejemplo, Against Nature, The Demoralized Landscape, The Unmking of Nature, Lost Ilusions y Utopia, Post-Utopia"8, nuestra investigación recoge las inquietudes actuales que reflejan los artistas, respecto al diálogo entre Arte y Naturaleza y que, sin duda aportan nuevos y esperanzadores planteamientos.

\footnotetext{
8 LIPPARD, Lucy R., "Mirando alrededor: dónde estamos y dónde podríamos estar", en BLANCO, Paloma et al., Modos de Hacer: Arte crítico, esfera pública y acción directa, Universidad de Salamanca, Salamanca, 2001, p. 56.
} 


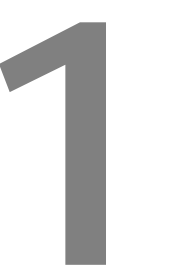

HUMANOS Y VEGETALES: HISTORIA DE UN VÍNCULO 



\subsection{Una aproximación a la naturaleza vegetal}

El ser humano, inmerso en el caos de una Naturaleza compleja y cambiante, ha analizado el mundo que le rodea desde todos los ámbitos del conocimiento que se encuentran a su alcance, para lograr entender en última instancia, el trasfondo último de su propia naturaleza humana. A lo largo de toda nuestra historia y hasta el día de hoy, éste ha sido un tema fundamental de reflexión que ha dado origen a numerosas disquisiciones filosóficas. Sin el ánimo de agotar toda la extensión que abarca el término, podemos decir que, en la actualidad, la palabra Naturaleza en su sentido más amplio, hace referencia al mundo natural, es decir, a aquello que conocemos como mundo o universo físico o material, así como a todos los fenómenos que se manifiestan en él, incluyendo la vida. Por tanto habitualmente, los objetos artificiales o realizados mediante intervención o artes humanas quedan excluidos del estereotipo y concepto de Naturaleza.

El origen de la palabra proviene del vocablo en latín natura, que significa curso o carácter natural de las cosas. En latín, el término incluye a los seres vivos y su significado está relacionado con la acción de nacer, la sustancia primigenia o los órganos de generación. Natura es a su vez, la traducción latina de la palabra griega Physis $^{9}$ que, en su significado original, hace referencia a la forma innata en la que, de manera espontánea crecen, plantas y animales. Para Lucrecio, en su libro De Rerum Natura (Sobre la naturaleza de las cosas), Natura es el orden natural de las cosas: "el orden bello de Naturaleza" 10 y lo que está antes de que los hombres existan.

En Grecia, apunta el poeta y catedrático Jaime Siles ${ }^{11}$, encontramos la idea de Naturaleza, reflejada en dos conceptos diferentes, por un lado Physis (Naturaleza) y por otro Nomos (la ley o lo que es por convención). Generalmente, el término se identifica con todo aquello que nos rodea, el paisaje y todo lo que

\footnotetext{
9 BRANSCHWIG, Jacques et al., El saber griego, diccionario crítico, Akal, Madrid, 2000, p.

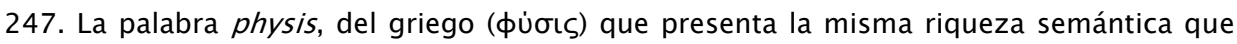
natura, significa crecimiento, brotar, surgir, nacer o salir a la luz. En la filosofía arcaica se interpretaba como el ser de las cosas. Los sofistas lo consideran opuesto a lo convencional o Nomos. Con Platón es el eidos (más relacionado con la morfé o forma, lo que sustituye a physis, como el aspecto de algo o lo que lo hace ser como es. Lo que sale a la luz se manifiesta como esencia, de forma estática. Aristóteles retomaría el sentido originario y más dinámico de nacer, surgir o salir a la luz, que no estaba presente en Platón y contrapone physis a techné, planteando la dicotomía natural-artificial.

10 LUCRECIO CARO, Tito, De Rerum Natura, Libro V(220-280), en GARCíA CALVO, Agustín, Lucrecio. De la naturaleza de las cosas, Cátedra, Madrid, 2004, pp. 298-299.

11 SILES, Jaime, Conferencia: "De Homero a la Vanguardia: la naturaleza como objeto artístico", dictada por Jaime Siles (Valencia, 1951), dentro del XIV Ciclo de Conferencias Arte y Naturaleza, organizadas por el Grup De Reüll, Casa de la Cultura de Ondara, 20, abril, 2007. Jaime Siles es poeta, Premio de las Letras Valencianas (2004), Catedrático de Filología Latina y Director del Departamento de Filología Clásica de la Universitat de València.
} 
lo compone, en estado natural: animales, plantas, montañas, ríos, mares; siempre y cuando la mano del hombre no haya intervenido significativamente. Este concepto más tradicional de las cosas naturales implica una distinción entre lo natural y lo artificial (lo hecho por los humanos). Así pues, para los antiguos la palabra "Naturaleza" como Physis responde a tres acepciones. Por un lado, hace referencia al poder de producción, a la capacidad de desarrollo, a la causa y al origen. En segundo lugar, hace referencia a los modos y maneras de ser, diferenciando tres aspectos: a) el estado físico, la apariencia o el tamaño de las cosas; b) el estado natural de una cosa: el clima, la geografía y c) la disposición natural, entiéndase, las virtudes que pueden presentar las cosas. En tercer lugar, "Naturaleza" es también todo lo relativo al orden de la Naturaleza en bruto.

Si atendemos a la relación entre Naturaleza y Cultura, podemos observar que en Grecia -la Cultura escrita más antigua- Homero nos refiere siempre la Naturaleza como un correlato, utilizando generalmente una metáfora o una comparación para referirse a cualquier aspecto de la misma. Una cosa es siempre dura como una piedra o fuerte como un león o alta como un árbol. En definitiva, frente a la caducidad y las contingencias a las que estamos expuestos los humanos, tanto el mundo griego como el romano admiraban, ese ciclo perfecto de las estaciones que se suceden, ese sistema regular de la Naturaleza, en el que todo y nada a la vez, cambia. De aquí proviene la idea de que una Cultura perfecta debería imitar el ritmo de la Naturaleza, tener leyes perfectas como las de la Naturaleza. De este pensamiento deriva también la necesidad de adorar las manifestaciones físicas -entiéndase elementos- de la misma.

La historia del conocimiento se sucede vertiginosamente $y$, tras las primeras ideas expresadas por Homero, encontramos las concepciones de Zenón y su alabanza del vivir bien, entendido y relacionado con un vivir de acuerdo con la Naturaleza. Posteriormente en la Edad Media, el arte medieval identificará a la Naturaleza como una manifestación de Dios, para llegar en el Renacimiento, a cuestionar la inmanencia o la trascendencia de la misma. El cambio en los procesos de imitación de la Naturaleza y la sustitución de estos, por los valores de la esfera de la Cultura y el asentamiento de la idea de Naturaleza como un producto de la Cultura, referirá cómo la concepción de la Naturaleza ha ido transformándose, hasta concebir al hombre como un producto híbrido, resultado tanto de la Naturaleza, como de la Cultura y de la historia. Las fronteras que en él confluyen, se tornan flexibles para permitir que el devenir de las cosas se convierta para el hombre, en una segunda Naturaleza que lo identifica. En este sentido, el arte como fruto de la mano del hombre genera una ficción que, de manera hipotética, imita a la Naturaleza.

Las referencias históricas en las que los humanos son comparados con ciertos aspectos de la Naturaleza son múltiples. Ya en el siglo VIII a. de C., Homero hablando del linaje, comparó a los hombres con las hojas que el viento esparce para propiciar que surjan nuevas generaciones. Por otra parte, haciendo referencia no a la totalidad de la Naturaleza, sino únicamente a un aspecto de la misma, Homero relaciona la recuperación de la naturaleza humana gracias a una 
planta mágica (Moly) que Hermes da a Ulises y a sus hombres, para devolverles la forma humana que Circe les había quitado al convertirles en cerdos:

Así diciendo, me entregó el Argifonte una planta que había arrancado de la tierra y me mostró sus propiedades: de raíz era negra, pero su flor se asemejaba a la leche. Los dioses la llaman moly, y es difícil a los hombres mortales extraerla del suelo, pero los dioses lo pueden todo'2.

Este tipo de ideas influirán como veremos más adelante, en los procesos artísticos que relacionan la naturaleza humana con la naturaleza vegetal. En nuestra investigación y, a partir de aquí, para las ideas sobre Naturaleza, natural, artificial, vegetal, flor, hierba, ramas, árbol, verde y, en general todo aquello que involucre a las plantas y a su representación, si bien tendremos en cuenta otras aportaciones, nos guiaremos fundamentalmente por las ideas expuestas por Albelda y Saborit en su libro La construcción de la Naturalezal3. En dicho estudio, además de cuestionar los tópicos social y culturalmente establecidos en torno a este término, al hablar de Naturaleza se establecen, varias diferencias puntuales que proporcionan numerosas herramientas para reflexionar conceptualmente sobre la misma y su relación con el arte. Sus aclaraciones permiten trascender el terreno de la especulación teórica, para incidir en los movimientos y artistas que han vinculado su obra a la especifidad de este constructo cultural.

Saborit nos habla del término dividiéndolo en dos acepciones generales que habitualmente, comenta, se solapan entre sí. Por un lado encontramos Naturaleza (con mayúscula) y por otro naturaleza (con minúscula), ésta última empleada en el sentido de "naturaleza de un ser" o de sus propiedades constitutivas. La primera acepción del término remite en principio a todo lo que existe y nos rodea, incluyendo dos matices importantes: por $\mathrm{N}-1$ entiende el conjunto de todos los seres y fenómenos del mundo físico, incluyendo al ser humano, lo que equivaldría al sentido que ya en la Edad Media, se atribuía a la Natura-Naturans, y se asimilaba a la idea de Dios. Aunque en oposición a "lo sobrenatural", esta acepción se relaciona más con las nociones de "realidad" o "mundo". Por otro lado Saborit identifica como N-2, a aquella Naturaleza que incluye todo, excepto lo humano, excluyendo así al hombre y todo lo hecho por él, idea por lo tanto, opuesta al concepto de artificio, de Arte o de Cultura. A la palabra "Naturaleza" escrita con minúsculas Saborit la describe como lo que se refiere no tanto a las cosas visibles, sino a aquellas invisibles que nos hacen ser como somos, lo que entendemos por el ser, es decir, el origen, el principio, carácter o la esencia de las cosas, el "origo rerum-lex natural" y asimismo se opone a lo adquirido, lo aprendido o lo cultural. En este caso estaríamos hablando de la idea medieval de natura naturata o las formas finitas y relacionables en las que la $\mathrm{N}-1$ se manifiesta.

12 HOMERO, La Odisea. La lliada, Edimat Libros, Madrid, 2000, Canto X, Verso 303.

13 ALBELDA, José y SABORIT, José, op. cit., pp. 24-25. 
Por último con Naturaleza escrita con cursivas, Saborit nos remite a la confusión que ineludiblemente sugiere la Naturaleza intervenida, domesticada, como en el caso de la agricultura, pero también prácticamente a la totalidad del mundo que, en la actualidad nos rodea, pues ya no existe un lugar en este planeta que no esté intervenido de una u otra manera por la mano del hombre.

Naturaleza: la esencia o lo propio de un ser, la Naturaleza de un árbol, por ejemplo, que le hace crecer a partir de una semilla cobijada en la tierra y humedecida por la lluvia, se confunde pues con el árbol, la tierra o la lluvia, que son también Naturaleza. Habrá que preguntarse entonces qué pasa cuando un ser humano altera el régimen de riego del árbol, cuando elabora y utiliza "artificialmente" un abono para mejorar su crecimiento, o cuando le injerta unas ramas procedentes de otro árboll4.

En nuestro caso, no pretendiendo ser específicos en nuestra selección del léxico $y$, asumiendo la casi total implicación del ser humano en las circunstancias de este planeta, utilizaremos la palabra Naturaleza, escrita con cursiva y con mayúsculas, para designar en general, al conjunto de todo lo que nos rodea, incluyendo al ser humano y parte de sus elaboraciones. Por otra parte, usaremos la palabra naturaleza, sin cursiva y en minúscula, cuando nos refiramos a la forma de ser de las cosas (naturaleza vegetal, naturaleza humana, etc.).

Nos haremos eco aquí también de las ideas expresadas por Fernando Savater quien, cual abogado del diablo, nos advierte sobre los peligros y excesos a los que puede conducir un malentendido planteamiento naturalista, que convertiría el ensalzamiento de lo natural, en argumento derogatorio de artificios y convenciones, involucrando cuestiones morales que exceden de su ámbito.

Para tales naturalistas, la importancia metafísica, moral y política de la Naturaleza es servir de baremo, de patrón de oro para juzgar las obras humanas, mostrar insuficiencias y errores, en suma: alertar contra ellas. Lo antinatural es equivocado, ilícito y dañino, trátese del cosmopolitismo, las centrales nucleares o la homosexualidad15.

Para Maderuelo la idea de Naturaleza que nosotros manejamos surge como invención o convención humana durante el Romanticismo, construyéndose como un paradigma, un misterio y como una fuerza impetuosa a la que el hombre debe enfrentarse constantemente para comprenderla y dominarla. Por analogía natural, la Naturaleza deviene un mito creado por la razón laica para sustituir las creencias religiosas de la antigüedad 16 .

\footnotetext{
${ }^{14}$ ALBELDA, José y SABORIT, José, op. cit., p. 26.

15 SAVATER, Fernando, Diccionario filosófico, Ariel, Barcelona, 2007, p. 241.

16 MADERUELO, Javier (dir.), Huesca: Arte y naturaleza, Actas del I Curso, Diputación de Huesca, Huesca, 1995, p. 14.
} 
Significativa es también la revisión que Michel Foucault ${ }^{17}$ hace en torno al surgimiento, alrededor del s. XVII, de la historia natural tal como la conocemos ahora y a su condición de posibilitar la pertenencia común de las cosas y del lenguaje a la representación. Hasta entonces la historia de una planta o de un animal, incluía tanto la descripción de sus elementos y órganos, como las semejanzas que éstos pudieran presentar entre ellos. También eran objeto de estudio tanto las virtudes como los medicamentos o alimentos que pudieran llegar a elaborarse con su sustancia, así como las leyendas e historias anexas que desde la antigüedad pudieran referirse en torno a cualquiera de los seres estudiados: la historia de un ser vivo era el mismo ser, en el interior de toda una red semántica que lo enlazaba con el mundo.

Foucault nos recuerda la partición tripartita que a partir de los estudios de esa época se realiza entre aquello que podemos ver, lo que otros han observado o trasmitido y por último, lo que otros han sencillamente imaginado o ingenuamente creído. Hasta el s. XVII, los signos formaban parte de las cosas, mientras que a partir de este momento, los signos se convierten en modos de representación, estableciéndose la evidente diferencia entre observación, documento y fábula. Tuvo que llegar Linneo para asentar una nueva dinámica de análisis dentro de la historia natural, estableciendo un orden descriptivo y proponiendo referencias en base a un análisis que se centrara en el juego de la representación, para que las cosas y las palabras se comunicaran finalmente entre sí. A partir de él cualquier ser debía ser descrito siguiendo el curso siguiente: nombre, teoría, género, especie, atributos, uso, para terminar con la litteraria. En base a este parámetro establece cuatro variables fundamentales a considerar: la forma de los elementos, la cantidad de los mismos, la manera en que se distribuyen en el espacio los unos en relación con los otros y la magnitud relativa de cada uno. Así se instaura en el lenguaje la clasificación que Linneo defendía por ejemplo, respecto a las cinco partes de la planta: raíces, tallos, hojas, flores y frutos, de manera que cualquier observador pudiera unificar criterios y eliminar incertidumbre en el momento de la comprensión del elemento analizado. Si como señala Foucault, "la historia natural no es otra cosa que la denominación de lo visible" 18 , las representaciones visuales, aun aquellas pertenecientes al mundo del arte -aparentemente exentas de la exhaustividad y las taxonomías científicas- evidencian la necesidad humana de reducir variables. Así, podremos prever el objeto final de la historia natural como la extensión de la que están constituidos los seres de la Naturaleza. En esta observación, la visión será el órgano privilegiado para transcribir la representación desnuda de la estructura de los seres. Por estructura de las partes de la planta se entenderá la composición y la disposición de las piezas que forman su cuerpo, de manera que tanto el texto como las representaciones visuales, prescindirán hasta del tacto o del color para concedernos únicamente la esencia de la estructura vegetal, aquella misma que sigue la Naturaleza, pasando de la raíz a los tallos, a los peciolos, a las hojas, a los pedúnculos y a las flores.

17 FOUCAULT, Michel, Las palabras y las cosas, Siglo XXI, México, D.F., 1979, pp. 128-136.

18 FOUCAULT, Michel, op. cit., p.133. 
Será entonces, en este último límite -el de la litteraria, apuntado por Linneo- en el que, a manera de suplemento, se incluye el lenguaje depositado por el tiempo y donde, más allá de las realidades visibles, se nutrirá el discurso sobre la Naturaleza que utiliza el arte (tradiciones, creencias y todas aquellas figuras poéticas que han sido objeto de un conocimiento complementario). En la retórica y en el uso de las figuras poéticas aplicado a las diferentes partes de las plantas, veremos cómo el arte contemporáneo y los artistas enfocan las características y la Naturaleza simbólica que a lo largo de la historia del ser humano se ha vertido en cada una de ellas, para expresar conceptos que van más allá de la Naturaleza natural de las cosas en la búsqueda, no sólo de la verdadera identidad del arte o de la Naturaleza, sino también de la suya propia.

Puesto que el término Naturaleza es excesivamente amplio y en alto grado polisémico, hemos decidido acotar el objeto de nuestra investigación centrándonos específicamente en la parte de la misma que se corresponde con el mundo vegetal. De esta manera, delimitamos nuestro objeto de estudio a una de las manifestaciones de la Naturaleza que percibimos como un elemento visible, físico y fundamental que nos permitirá, como es nuestra intención, establecer vínculos en la relación entre el mundo natural, la percepción que el hombre tiene de él y el arte. En particular el arte escultórico o tridimensional, como una de las manifestaciones de la Cultura, que recoge la visión que el hombre contemporáneo tiene en la actualidad sobre este concepto.

En relación al reino vegetal podemos afirmar que desde el principio de la historia del ser humano, éste ha estado imprescindiblemente vinculado al mismo. A pesar de esto, curiosamente, no podemos precisar en qué momento de la Edad de Piedra nuestros antepasados adquirieron los conocimientos necesarios sobre las plantas. Por lo que puede observarse en las sociedades primitivas actuales, el conocimiento de las plantas, así como de sus propiedades, es sumamente antiguo, sin duda y lógicamente, porque las plantas constituyen la base de la pirámide alimenticia de todos los seres vivos, incluso de otras plantas. De la misma manera, el mundo vegetal ha sido y es fundamental en todos los aspectos de la cotidianeidad del ser humano, desde el cobijo y la posibilidad de un hábitat, a la vestimenta, medicinas, armas y todo tipo de utensilios.

En las sociedades primitivas los conocimientos de las plantas siguen siendo aún hoy, fundamentales para la sobrevivencia. Con el desarrollo de la civilización, estos conocimientos han quedado circunscritos a ámbitos muy especializados, aun así, el corriente denominador de las personas somos capaces de diferenciar una rosa de una manzana o un árbol de una lechuga.

Históricamente, se le atribuye al hombre del Neolítico en el Oriente Próximo, (10.000-7.500 a. C.) ${ }^{19}$, el cosechar ciertas hierbas y el haber plantado las primeras semillas, dando así un paso muy importante en la historia del vínculo

19 LIVERANI, Mario, El antiguo Oriente, Historia, sociedad y economía, Crítica, Barcelona, 2008 , p. 65. 
que nos ocupa, estrechándose éste a partir de aquí mucho más. La domesticación de los cereales fue paralela al desarrollo de sociedades más sedentarias. Hasta finales del siglo XIX, la diversidad de los seres vivos se clasificaba únicamente en dos categorías o pertenecientes a dos reinos: el de los animales o Animalia y el de las plantas o Plantae. Hoy en día, el término Plantae está más acotado y, aunque el uso de la palabra planta sigue siendo sinónimo de vegetal, es la botánica 20 , la Ciencia que estudia lo que tradicionalmente se ha considerado el mundo vegetal, pudiendo definir un vegetal como aquel ser que contiene clorofila.

Haciendo un poco de historia y dado que en esta investigación los vegetales y su vínculo con el ser humano, son los protagonistas, deberíamos recordar que durante más de dos millones de años la vida en este planeta llamado Tierra, fue exclusivamente vegetal. Así, el de los vegetales como seres vivos es aparentemente, un destino incomprensible a la vez que generoso, puesto que proporcionan el alimento y el oxígeno necesario para respirar, a los mismos seres por los que son devorados. Con el cultivo de las plantas por parte del hombre y el desarrollo de la agricultura, las plantas fueron modificando su natural proceso de selección hasta el punto de no guardar el más mínimo parecido con la variedad original. El hecho es que hoy en día y, mediante las nuevas tecnologías, la evolución de las plantas depende en grado sumo de la acción humana, resultando este proceso extremadamente conflictivo ya que en la actualidad son las leyes del mercado las que prácticamente imperan sobre las de la Naturaleza.

Sin embargo en opinión de los expertos, la de los vegetales es una odisea cuya historia comienza mucho antes que la nuestra y, lejos de lo que pudiera parecer como veremos más adelante, no está cerca de su final21. Nuestra relación con estos seres vivos es mucho más cercana de lo que las evidencias constatan, al punto que podríamos afirmar, que nuestros antepasados más remotos en lugar de monos como se suele decir, eran plantas22. Tomando como base estos planteamientos y, sin ser nuestro objetivo el exponer aquí la evolución de las plantas o nuestro origen a partir de ellas, haremos una breve semblanza de la historia de las plantas para de esta manera, establecer algunos parámetros que nos permitirán posteriormente, dentro del contexto artístico, dilucidar las razones por las cuales algunos artistas manifiestan a través de sus obras, un marcado interés por vincular ambos mundos.

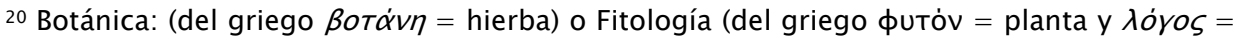
tratado) es la Ciencia que se ocupa del estudio de los vegetales. El concepto de vegetal, que estaba claro en tiempos de Aristóteles, ha quedado desdibujado por el avance del conocimiento, llegándose a definir como todo aquello que es objeto del estudio de la Botánica. En la práctica, los botánicos estudian las plantas, las algas y los hongos.

21 Para un análisis más detallado de la historia de las plantas y su evolución, consultar: PELT, Jean Marie et al., La historia más bella de las plantas. Las raíces de nuestra vida, Anagrama, Barcelona, 2001, de donde se ha extraído parte de la información aquí aportada.

22 PELT, Jean Marie et al., op. cit., p. 17.
} 
La vida se originó en nuestro planeta hace tres mil quinientos millones de años, en lo que era el primitivo océano, y ésta, en sus comienzos era primordialmente vegetal. Nuestro antepasado más remoto era un alga llamada Cystodinium (que todavía existe) y a la que podemos considerar la célula vegetal por excelencia. Esta alga contenía clorofila mediante la cual realizaba la fotosíntesis, es decir que transformaba, gracias a la energía solar, el gas carbónico y el agua, en azúcares que se adherían a su membrana. Con el tiempo desarrolló una especie de "boca" con la que se alimentaba de otros seres, iniciando así la transición hacia el reino animal. Junto con las algas azules, las verdes, las bacterias, los hongos y los virus, surge la invención del núcleo y la sexualidad, las algas originarias salen del mar y finalmente llegan a tierra firme. En definitiva, el mundo animal existe gracias a las plantas que hicieron que el planeta fuera respirable.

Estamos ante organismos pluricelulares que "inventaron" la división del trabajo, especializándose y desarrollando diferentes funciones. A partir de este punto, en la escala de la evolución surgen las primeras plantas erguidas, en cuyo interior hay vasos que permiten que la savia circule, la planta absorbe el agua del suelo y a su vez puede elevarse a sí misma hacia el cielo. Se trata de las plantas más antiguas con madera, las "Cooksonia", una suerte de vegetación con tallo pero sin hojas, a las que sucedió la "Rhynia" la cual tenía una especie de pilosidades que, aunque no llegaban a ser hojas, eran un esbozo de ellas. La que inventó el tallo con hojas fue una planta minúscula hace 350 millones de años, lo que fue fundamental porque a partir de ahí las plantas terrestres pudieron desarrollar considerablemente su superficie. A mayor número de hojas, mayores posibilidades de captación de aire y de luz.

Hablando en términos de evolución y de organismos pluricelulares, cuanto más sofisticado es un organismo es, en consecuencia, más frágil y ello implica una evolución más radical. Esta tendencia se puede observar tanto en referencia a la desaparición de los dinosaurios como a la de los grandes árboles: un gran tamaño lleva aparejada una gran debilidad, de manera que necesariamente en la escala de la adaptación, tanto animales, como insectos y plantas, se han visto obligados a disminuir su tamaño o a desaparecer.

El mundo verde evoluciona sin cesar, con el desarrollo del aparato sexual y vegetativo las plantas consiguen desprenderse del mar. Una adaptación muy ajustada a un medio puede convertirse en una debilidad, en realidad la que constituye de verdad una fuerza es la capacidad de adaptación. En este sentido, las plantas nos dan una gran lección. El sistema de reproducción de las plantas ha evolucionado poderosamente. Mientras que los animales dependen del líquido para su reproducción, los vegetales han diversificado ampliamente sus vectores a través del viento, los insectos y los animales. En cuanto a lo sexual y la capacidad reproductiva las plantas se adaptan al medio inventando el "huevo" antes incluso, que los mamíferos. 
Con las angiospermas 23 aparece una de las constantes más importantes de la vida: proteger las células hembras. La capacidad de reproducción en el interior protegido de la semilla, recurso destacable, permite a las plantas el reproducirse en cualquier medio y no exclusivamente en el acuático. Una de las últimas adaptaciones al medio que las plantas han desarrollado, consiste en una estrategia que, sorprendentemente, está también muy cercana a nuestra naturaleza humana. En el Cretácico, hace apenas un centenar de millones de años y debido a un recalentamiento de las regiones del planeta, surgen las flores en las regiones tropicales, extendiéndose por todo el planeta con un éxito inusitado para los botánicos. La invención de las flores por parte de las plantas estriba en poner en práctica una nueva política de fecundación que incluye, para nuestra sorpresa, la noción de transporte.

La novedad de las plantas con flores consiste en el revestimiento del óvulo que posteriormente será semilla y por último fruto, pero además con las flores, las plantas establecen un nuevo tipo de relaciones con los animales: pájaros e insectos se convierten en cómplices de las plantas. Si con anterioridad la polinización se producía ingeniosamente con el transporte de las semillas por el viento, ahora la nueva estrategia aporta un fenómeno nuevo y sumamente ingenioso: la seducción. Con el surgimiento de las flores, las plantas desarrollan de manera notable la química, convirtiendo ésta en una cuestión universal. Con los aromas, las formas y los colores seducen a los animales de la misma manera que han seducido al hombre a lo largo de toda su historia. A pesar de que todos las devoran, las plantas son precursoras también en la evolución de los sistemas de protección, no sólo con el elemento defensivo de las espinas sino de nuevo, mediante la química, nos sorprenden con el desarrollo de las plantas venenosas.

Ya hemos adelantado cómo la química es fundamental en el reino vegetal, convirtiéndose en una vía de comunicación con otros seres vivos, pero una investigación en ciernes revela que las plantas disponen también de mecanismos de comunicación específicos, que les otorgan ventajas adaptativas muy poderosas 24 . Para ello, usan un "lenguaje" especial: el químico. Algunas plantas secretan sustancias químicas volátiles que se dispersan rápidamente por su entorno, enviando mensajes concretos. Estos productos son llamados semioquímicos, porque actúan como señales de comunicación a distancia que provocan una acción determinada en ciertos sistemas biológicos, atrayendo

23 Plantas cuya semilla se encuentra en una cavidad o urna. Del griego $\alpha \gamma \gamma \epsilon \iota o v$ (angíonvaso, ánfora) y $\sigma \pi \epsilon ́ \rho \mu \alpha$ (sperma, semilla); este término compuesto significa semillas envasadas, en referencia a que sus óvulos (y posteriormente sus semillas) están encerrados por la hoja fértil portadora de los óvulos o carpelo.

24 HERRERO UCEDA, Miguel, "Sistema de comunicación en el mundo vegetal", en Tecnociencia, Periódico gratuito de divulgación científico-técnica, $\mathrm{N}^{\circ} 4$, junio, 2006, p. 5, Disponible en línea: <http://www.tecnociencia.org/pdf/Tecnociencia4.pdf >, [Consulta 30, enero, 2008]. Miguel Herrero Uceda es autor del libro El alma de los árboles, Hedras, León, 2005. 
agentes polinizadores o defendiendo a la planta de invasores patógenos o de plagas de insectos.

El eje dominante de la vida de las plantas y de la lucha entre ellas es la carrera por la luz, misma que les empuja a crecer, a ascender hacia lo alto, en busca de la luz necesaria para producir la fotosíntesis. Esta tendencia tan natural y cotidiana de las plantas, sin ir más lejos y anticipando lo que serán nuestros encuentros con la obra de muchos escultores que trabajan plantas, también genera ecos en todo lo relacionado con lo humano.

En otro orden de cosas, y desde la perspectiva espacio-tiempo, el mundo vegetal también nos sorprende. Debemos considerar que aparentemente, las plantas nos parecen inmóviles porque desde nuestra perspectiva de humanos, éstas no se desplazan, pero esto no es exactamente así. Las plantas tienen parámetros temporales diferentes a los nuestros. El vegetal domina el tiempo, el animal el espacio. El vegetal no puede desplazarse, pero en contraposición puede esperar, la planta espera a que el medio cambie. Si pensamos en su capacidad de propagación, la imposibilidad de movimiento se presenta en cuanto al individuo, no así con respecto a la especie.

Podríamos decir que los vegetales viven en "otro tiempo" distinto al nuestro, tienen una capacidad diferente para aliar la vida y la muerte. Son capaces de detener el crecimiento de un embrión hasta que las condiciones medioambientales sean las propicias, cosa que animales y humanos no han podido evolutivamente desarrollar. Es lo que conocemos como vida latente. Un árbol puede estar aparentemente muerto en la mayoría de su superficie y sin embargo y a la vez, seguir brotando. Pueden morir por partes pero seguir vivos, esto se debe a su gran capacidad de regeneración. El rizoma y su poder de perpetuarse bajo el suelo aun en las condiciones más adversas o la invención hace 20.000 años del otoño -con la caída de las hojas como recurso, para protegerse del frío- son otro tipo de soluciones que sorprenden por su capacidad de adaptación. También pueden estar enfermos de cáncer y admirablemente, al contrario que los humanos u otros animales, aislar esa parte dañada o enferma, no realizando metástasis y seguir con vida. En cuanto al ritmo, la duración de la vida de ciertos árboles puede prolongarse hasta durante varios siglos comparándose, aunque en menor medida, tan sólo con las tortugas. En definitiva, pueden presentar los mismos problemas que el resto de seres vivos pero sus respuestas y esto es lo fundamental, son diferentes.

Empezando por nuestra alimentación, los vegetales estarán siempre en la base de nuestra nutrición, aun y cuando sólo comiéramos carne. Si las catástrofes son los motores de la evolución, nosotros los hombres, somos la última de las grandes catástrofes tanto para los animales como para las plantas. Nuestra acción ha desencadenado la desaparición de muchas especies tanto del mundo animal como del vegetal. Pero no todo son aspectos negativos, nosotros mismos hemos sido vehículo para la dispersión de las especies vegetales, el hombre ha sido y es, un factor favorecedor para ciertas especies. Y en último extremo, la vida tiene recursos para perpetuarse más allá incluso de nosotros mismos. Las 
plantas continúan evolucionando y, como queda patente en estas líneas, tenemos mucho que aprender de ellas. Sin lugar a dudas, su adaptación al medio es infinitamente mucho mayor que la nuestra, de esta manera pagamos nuestra sofisticación como organismos complejos en términos de evolución con una mayor dependencia.

Todos estos aspectos ponen de manifiesto la relación tan cercana que el hombre ha mantenido con todo lo relacionado con lo vegetal y sirven para introducirnos en un mundo que, como hemos podido comprobar, está muy próximo a muchos de los valores que, como seres humanos hemos desarrollado en el transcurso de nuestra historia. En muchas ocasiones el hombre y diferentes corrientes de pensamiento, desde la Edad Media hasta Goethe han explicitado estas relaciones y planteado el orden de la Naturaleza mediante analogías tanto simbólicas como formales, haciéndolas visualmente evidentes. Una de estas analogías entre plantas y humanos nos es referida por Jean-Marie Pelt en el libro La historia más bella de las plantas, remitiéndonos a la semejanza entre las ramas de los árboles -que sumergidas en el aire, toman el gas carbónico de él, fabricando azúcares y expulsando oxígeno- y el ser humano, quien no tiene ramas, pero cuyos bronquios con una estructura formal similar, realizan esta misma función sumergidos en la sangre, de la que toman el oxígeno, descomponiendo y absorbiendo los azúcares disueltos en ella por la alimentación y expulsando gas carbónico.

Esta curiosa similitud entre el mundo verde y el mundo rojo es reiteradamente retomada, como veremos, por diferentes artistas. Se trata de proyecciones complementarias entre ambos mundos, uno proyectado hacia el exterior, el otro protegido hacia el interior. Teniendo en cuenta todas estas interpretaciones nos adentraremos en las traslaciones que se hacen tanto en el arte del pasado como en el presente, del término Naturaleza. Analizaremos el aparentemente naturalismo con el que indiscriminadamente se apela a aquello considerado como natural, para presentarnos un panorama en el que la recreación de lo visible nos remite a una suerte de nuevo paraíso o nueva historia natural, en la que la tendencia se inclina por la vegetación como líder, para rescatar a la devastada Naturaleza de una Cultura voraz. Sin embargo, teniendo presente el gran número de ejemplos que podríamos observar y, ante la imposibilidad de abarcar la realidad de todo lo que acontece, para minimizar nuestras limitaciones, usaremos las palabras de Roger Caillois que señala: "Como quien, al hablar de flores, dejara de lado tanto la botánica como el arte de los jardines y de los ramos -tendría aún mucho que decir -"25, así, por nuestra parte será imprescindible dejar de lado ciertas manifestaciones.

25 CAILLOIS, Roger, Piedras y otros textos, Siruela, La Biblioteca Azul, Serie mínima, Madrid, 2011 , p. 25. 


\subsection{Natural y artificial: acerca de lo vegetal y sus implicaciones en el arte, la simbología, la mitología, la antropología y la sociología}

Asentar las diferentes acepciones que el término Naturaleza y en particular, la Naturaleza del mundo vegetal han generado en la historia del ser humano, nos acerca a la comprensión que las resonancias de este concepto producen en el contexto artístico. En este ámbito, todo lo relacionado con el arte se ha considerado habitualmente fruto del artificio humano. A pesar de que todos podemos diferenciar e identificar claramente como opuestos, los conceptos de natural y artificial, las complejas relaciones entre arte (entendido como techné) y Naturaleza han sido objeto, desde la Antigüedad, de numerosas polémicas. En este sentido, Demócrito afirmaba que el arte sigue a la Naturaleza, pero no en el sentido de la imitación, sino en el de que asume y prolonga sus procesos y por lo tanto, debemos aceptar que todo aquello realizado por el hombre es también natural, aun cuando sea producto del artificio humano ${ }^{26}$. Tatarkiewicz apunta la relación que en esa misma línea, establecía Goethe entre Arte y Naturaleza. Este nexo se basaba en la idea de que una obra de arte no sólo es fruto de la Naturaleza, sino que es la "obra suprema de la Naturaleza realizada por los hombres según las verdaderas leyes de la Naturaleza"27. Dorfles por su parte, siguiendo también a Goethe, afirma que el artificio es también Naturaleza, acercando así, las relaciones entre Naturaleza y hombre, Naturaleza y artificio, natural o artificial28.

Saborit, nos advierte sobre los peligros de concebir una Naturaleza mediada por el hombre, alejada de la verdadera Naturaleza. Los límites entre lo natural y el artificio, en esta Naturaleza intervenida por el hombre, aunque confusos, suelen identificarse con la concepción dicotómica en la que lo natural se caracteriza por ser todo aquello que ha permanecido intacto, inalterado, alejado y no tocado por la mano del hombre. Pero de la misma manera que todo ser vivo usa diferentes medios con vistas a la realización de sus fines -entiéndase sobrevivencia- también el ser humano y con él, todas las técnicas por él empleadas, deben considerarse como naturales en el sentido de que forman parte de su naturaleza humana. Desde este punto de vista, no podemos culpabilizar al hombre o a la técnica en sí misma, del mal uso que el excesivo culto al progreso, por parte del ser humano, ha logrado infringir a nuestro planeta, ni tampoco señalarlo como único responsable de todos los problemas medioambientales derivados de este culto, o de las precarias condiciones de vida del resto de seres vivos.

En definitiva, la idea de la relación entre Arte y Naturaleza ha cambiado a lo largo de la historia, entre otras cosas, debido a los cambios en la interpretación de ambos conceptos. En este sentido, es importante considerar cómo el estudio de las manifestaciones artísticas, incluyendo la artesanía y dentro de ella, el

\footnotetext{
26 ALBELDA, José y SABORIT, José, op. cit., pp. 44-52.

27 TATARKIEWICZ, Wladyslaw, Historia de seis ideas. Arte, belleza, forma, creatividad, mimesis, experiencia estética, Tecnos-Alianza, Madrid, 2004, p. 333.

28 DORFLES, Gillo, Naturaleza y artificio, Lumen, Barcelona, 1972, p. 16.
} 
estudio de la ornamentación desarrollada en cada Cultura es generalmente, muy revelador de las dotes estéticas de un pueblo puesto que pone de manifiesto la voluntad artística absoluta, sus particularidades específicas así como la manera específica de concebir y plasmar sus ideas sobre la Naturaleza. Desde el punto de vista de la ornamentación, la representación de la Naturaleza y en particular, de las formas vegetales, tiene su origen en el mundo griego. Podríamos afirmar que la Cultura occidental con un planteamiento naturalista basado fundamentalmente en la tradición griega, ha tendido a la naturalización de la representación de la Naturaleza eligiendo habitualmente las plantas como motivo central. Sin embargo, en la historia de la ornamentación, la idea de una simple imitación de los motivos naturales no es relevante. En la selección de este tipo de modelos, Wilhelm Worringer concede una importancia mínima a la aparición del ornamento vegetal basado en las tendencias imitativas de tipo naturalista29. Según Worringer, en el contexto de la historia del arte, la elección de una u otra planta para ser convertida en motivo ornamental, no obedece a su aspecto más o menos agradable, puesto que esta tesis entraría en contradicción con la sensibilidad artística de la antigüedad que se inclinaba por realizar esta selección en función de unos criterios geométricos muy austeros, en armonía con una simetría y una estilización particulares. Por otra parte, admite el valor simbólico de algunos motivos como factor determinante en la aparición de ciertos ornamentos vegetales, pero su principal afirmación en cuanto a estos procesos de síntesis se resume en que el artista o artesano, lo que realiza primordialmente, es un proceso de asimilación de las leyes naturales, para posteriormente manifestarlo en los diferentes modelos de la Naturaleza.

El proceso consiste, pues, en que un ornamento puro, es decir, un producto abstracto, es acercado posteriormente a la Naturaleza y no en que se estiliza posteriormente un objeto natural. Esta síntesis es decisiva; pues de ella se infiere que lo prístino no es el modelo natural sino la ley abstraída de él. Lo que provocaba, gracias a la íntima relación orgánica de todas las cosas vivientes, la experiencia estética del espectador, era la proyección al terreno artístico, de la sujeción a la ley inherente a la estructura orgánica, y no la coincidencia con el modelo natural30.

Este tipo de diferenciaciones son de particular importancia para nuestra investigación, puesto que en las obras de muchos de los artistas que aquí estudiamos, podemos observar este proceso de abstracción, enfocado en la búsqueda de una esencia que vincule su trabajo, específicamente con los procesos que se desprenden de las leyes de la Naturaleza.

En la búsqueda de los orígenes del ornamento vegetal, Worringer, siguiendo a Alois Riegli1 recuerda la sorpresa de éste último, al advertir lo inverosímil de

29 WORRINGER, Wilhelm, Abstracción y naturaleza, Fondo de Cultura Económica, México, D.F., 1983, p. 61.

30 WORRINGER, Wilhelm, op. cit., p. 69.

31 Alois Riegl (1858-1905) fue el primer historiador del arte que introdujo dentro de la investigación de la Historia del arte, el concepto de "voluntad artística", con la que nos 
que en el transcurso de la historia, una mala hierba cualquiera como el acanto, se elevara al rango de motivo artístico. Esta planta aparece representada en la decoración arquitectónica a partir de la antigüedad clásica y particularmente en el arte griego, respetando siempre la subordinación de los elementos decorativos al marco arquitectónico. La creación del capitel corintio remite a la leyenda de la aparición de plantas de acanto sobre la tumba de una niña en la que su nodriza había depositado amorosamente, una canasta con los objetos más queridos por aquella, ocultándolos a manera de protección y para evitar robos, con una reja cuadrada. Cuando en la siguiente primavera el arquitecto Calímaro pasaba por allí, observó que la reja estaba levantada por un armonioso manojo de hojas de acanto que surgían de la tumba misma. Esta imagen sugirió al arquitecto la idea de la cesta del capitel corintio, decorado con este tipo de hojas. Así surge, en la Cultura occidental, el mito de la planta que brota del cadáver de un dios o de un héroe, leyenda que sería notablemente difundida puesto que en ella se percibía una señal de inmortalidad32.

El simbolismo presente en la mayoría de las representaciones vegetales ha sido estudiado por la iconografía, tanto en las imágenes que se presentan de manera esquemática como en aquellas que conservan un sentido naturalista. En todas las civilizaciones podemos apreciar la gran relevancia que este tipo de representaciones ha adquirido en su Cultura, por ello consideramos de suma importancia el realizar, desde diferentes ángulos, un pequeño periplo por este tipo de concepciones. Más allá del juego estético, la flora, por ejemplo, encierra frecuentemente, contenidos morales, filosóficos o de la cosmovisión de cada civilización. En general y desde la simbología podemos decir que el hombre ha identificado siempre las flores como imagen de la vida.

Cirlot apunta las razones específicas por las cuales el hombre se sentía identificado con lo vegetal. Si biológicamente, se sabía muy próximo a los animales, su posición erecta le hizo identificarse y sentirse mucho más relacionado con los árboles, los arbustos e incluso con la hierba, que con la posición a ras de tierra del animal. Por otro lado, el aspecto esencial de las plantas, su ciclo anual, le permitía experimentar en el plano simbólico el misterio de la muerte y la resurrección 33 . Las referencias de Cirlot remiten a Mircea Eliade, quien a su vez, en su Tratado de Historia de las Religiones (1949), hace un estudio exhaustivo de las relaciones hombre-planta a través de innumerables ritos de paso, leyendas y cuentos que perdurarán a lo largo de la historia y en los que se hace evidente la "solidaridad" entre la especie humana y

ayuda a comprender la idea de que cada sociedad y por lo tanto cada período artístico, expresa determinadas convicciones respecto a lo que entiende por una forma bella. En este sentido, determinadas obras de arte no necesariamente revelan una incapacidad de poder lograr determinado estándar de belleza, sino que revelan una voluntad de lograr otra forma distinta, como es el caso por ejemplo, del artista gótico que no busca la forma bella de la misma manera que el griego clásico.

32 BEIGBEDER, Olivier, Léxico de los símbolos, Encuentro, Vol. 15, Serie Europa Románica, Madrid, 1989, p. 27.

33 CIRLOT, Juan Eduardo, Diccionario de símbolos, Labor, Barcelona, 1988, p. 367. 
la vegetal, manifiesta constantemente, mediante un circuito continuo de transformaciones.

Una vida humana a la que se ha puesto fin de forma violenta se continúa en una planta; la planta, a su vez, si se corta o se quema da origen a un animal o a otra planta, que acaban por recobrar la forma humana34.

Eliade destaca las implicaciones vitales que tiene la creencia racionalizada de que toda una raza proceda de una especie vegetal. Este mito presupone que la fuente de la vida está concentrada en dicho vegetal y que la "modalidad humana" está de forma virtual en los gérmenes y las semillas. En numerosas ocasiones, la vida se manifiesta a través de un símbolo vegetal (una mujer toca un árbol para quedarse encinta o para proteger el recién nacido, etc.). Estos hechos equivalen a decir que la vegetación se convierte en una hierofanía ${ }^{35}$, en la medida que revela algo distinto de ella misma.

Un árbol o una planta no son nunca sagrados en tanto que árbol o planta; llegan a serlo en cuanto que participan de una realidad trascendente, en cuanto significan esa realidad trascendente ${ }^{36 .}$

Como podemos apreciar, es imprescindible hacer alusión al simbolismo inmanente en la mayoría de las representaciones vegetales puesto que su estudio, nos ayuda a comprender su utilización dentro de las representaciones artísticas. De esta forma, podemos apreciar cómo la carga semántica del ornamento vegetal extiende su ámbito de influencia con el surgimiento de numerosas correspondencias formales entre las formas de representación de los seres vivos. Asimismo, este tipo de correspondencias se dan también entre animales, vegetales y en las formas geométricas de la arquitectura, generando híbridos en los que aparece estrechamente involucrada la figura humana. El ornamento, así concebido, se torna soporte material de una idea que conforma una unidad difícilmente escindible, una fuente fundamental de conocimiento del ser humano y de su relación con la Naturaleza.

Johann Jakob Bachofen, apunta que en la mitología griega fue Hipóloco - el progenitor de Glauco- el que, ante la pregunta sobre su ascendencia, grita a Diomedes, el conocido como "símil de las hojas", que Homero antepone a la explicación del mito de Belerofonte (Ilíada, VI, 145-149), y que por su veracidad inherente, conseguiría en la Antigüedad gran celebridad, al punto de ser repetido por muchos otros escritores como Plutarco y Luciano:

34 ELIADE, Mircea, "La vegetación. Símbolos y ritos de renovación”, en Tratado de Historia de las religiones. Morfología y dialéctica de los sagrado, Cristiandad, Madrid, 2000, p. 438.

35 Hierofanía: término acuñado por Mircea Eliade que significa aquello que encarna y revela lo sagrado, es decir, la manifestación de lo sagrado en lo profano.

36 ELIADE, Mircea, op. cit., p. 467. 
Como hojas en el bosque, asi es la raza de los hombres: el viento dispersa unas hojas por la tierra, otras vuelven a brotar en el bosque, cuando de nuevo renace la primavera; así es el linaje de los hombres, éste crece y aquél desaparece37.

Asimismo, en la tradición judeocristiana, encontramos varios ejemplos en los que se establece un paralelismo entre los hombres, las plantas y las diferentes etapas del ciclo reproductivo de estas últimas, utilizándose generalmente como una clara comparación con los seres humanos. En la Biblia, son varios los paralelismos que se establecen entre la hierba, las personas, sus vidas y sus logros:

Toda carne es hierba y todo su esplendor como flor del campo. La flor se marchita, se seca la hierba, [...] cierto, hierba es el pueblo38.

Pues toda carne es como hierba y todo su esplendor como flor de hierba; se seca la hierba y cae la flor [...]39.

Cirlot confirma que desde el punto de vista de la simbología, la representación de las hierbas, en muchas ocasiones, hace alusión a los hombres: las plantas, señala, "tienen el significado simbólico de seres humanos. La etimología de la voz griega neophytos (hierba nueva) así lo indica"40. Esta identificación de los humanos con las plantas, converge en la creencia religiosa cristiana que marcaba cómo a los recién bautizados se les llamaba neophytos, que significaba "planta nueva" o acabado de plantar.

En torno a la representación de hierbas en el arte, Jean Mottet recuerda la atención privilegiada que, en representación del mundo vegetal, la pintura europea reserva a la superficie herbosa. De la misma manera que la mayoría de los motivos relacionados con el paisaje, Mottet apunta al origen religioso de este tipo de representaciones, vinculadas en su mayoría con el jardín del Edén, el topos del paraíso y los conceptos relacionados con el prado divino, en el que Dios sitúa a los árboles y más tarde, a los hombres. Posteriormente y en la actualidad, la prevalencia de la hierba como protagonista y representación del mundo natural obedece, según Mottet, a la necesidad del hombre citadino de recuperar la noción poética de habitar el mundo y lo cotidiano como eje de la creatividad41.

\footnotetext{
37 BACHOFEN, Johann Jakob, El matriarcado. Una investigación sobre la ginecocracia en el mundo antiguo según su naturaleza religiosa y jurídica, Akal, Madrid, 2008, p. 80.

38 UBIETA, José Ángel, ISAÍAS, 40: 6-7, en Biblia de Jerusalén, Editorial Española Desclée de Brouwer, Bilbao, 1975.

39 UBIETA, José Ángel, 1 a PEDRO, 1 : 24, en Biblia de Jerusalén, op. cit.

40 CIRLOT, Juan Eduardo, op. cit., p. 240.

${ }^{41}$ MOTTET, Jean, "Análisis de una manera de domesticar la naturaleza: la casa en la hierba de las series americanas", en SALABERT, Pere et al., Estética plural de la naturaleza, Laertes, 2006, pp. 158-159.
} 
Por otro lado, las hierbas y su representación están asociadas a la idea de poderes naturales y sobrenaturales y al dualismo entre el bien y el mal, debido al poder de las mismas tanto medicinal -para curar-como por la posibilidad de ser empleadas como veneno. Por estas cualidades tan específicas han sido utilizadas con frecuencia en leyendas y cuentos folklóricos, constituyendo un caso evidente de especialización en cuanto a la simbología. Aunque no es nuestra intención desvelar aquí las múltiples correspondencias simbólicas con las que el hombre ha identificado las diferentes especies vegetales y sobre las que ha proyectado características de su propia naturaleza, es importante anotar que efectivamente, entre numerosas culturas, el árbol por ejemplo -por su conexión particular entre el cielo y la tierra- ha sido visto como centro, principio, origen y eje del mundo, representaciones que lo convierten en el nexo que une ambos mundos. En muchas ocasiones estas relaciones se han antropomorfizado, por ejemplo, en el arte Egipcio, en una de las pinturas que se observan en la Tumba de Tutmosis III (Tebas) la diosa Isis adopta la forma de un árbol de sicomoro con un pecho y un brazo humanos, en actitud de amamantar al faraón. También en el arte Románico la simbología vegetal, floral y frutal tiene una relación directa con alusiones a lo humano. El árbol, la vegetación y los frutos que crecen y se desarrollan expresan una gradación vinculada con las edades de la vida.

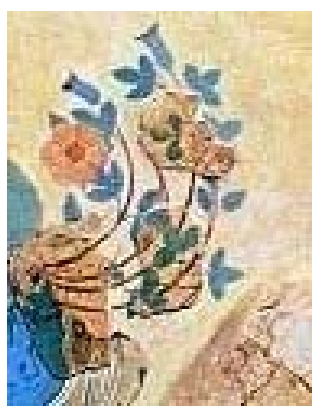

Fresco del pájaro azul, 2000 a. C.

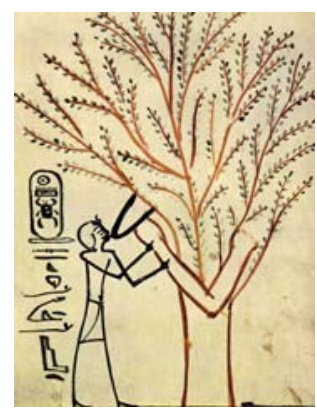

Tumba de Tutmosis III, 1479-1425 a. C.

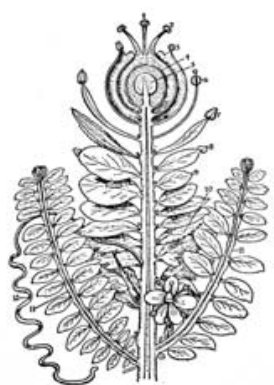

Goethe, Urpflanze, 1790.

Históricamente, en el ámbito artístico, encontramos la primera representación de una rosa, con una antigüedad de 3.900 años en el Fresco del pájaro azul, en el palacio de Cnossos (Creta) ${ }^{42}$. Asimismo, una de las primeras anécdotas que hacen referencia a la representación plástica en general, es en relación a un vegetal y nos viene referida por Plinio el Viejo ( $N H, X X X V, 65)$ en su Historia Natural, en alusión a la competición que en el siglo $V$, se llevó a cabo entre dos pintores de Éfeso: Zeuxis y Parrhasio, para determinar cual de los dos era mejor artista. Zeuxis, había pintado unas uvas tan vívidas que unos pájaros engañados por el parecido con las uvas reales, se acercaron volando para picotearlas. Si bien es ésta una clara alusión a los engaños de la representación y los efectos confusos de la mímesis, podemos considerar que, en general los motivos vegetales en pintura $y$, refiriéndonos en mayor medida al concepto de

42 PELT, Jean Marie et al., op. cit., p. 155. 
paisaje eran, según Saborit43, complementos del motivo "hombre" y se usaron habitualmente hasta el s. XVII, como escenografía complementaria, no cobrando excesiva importancia y empleándose como algo decorativo. En escultura, sucede otro tanto pues los motivos vegetales se usaron en sus orígenes $y$, durante mucho tiempo, como complemento de la ornamentación arquitectónica o como elementos de orfebrería.

Posteriormente la percepción de la Naturaleza y, con ella, los elementos que la caracterizan, cambiaría. Durante el siglo XVIII, Goethe trasmitía en sus escritos, la idea de una filosofía integradora de la Naturaleza, en la que confluyeran también, Ciencia y vida. Su pensamiento consideraba el entendimiento intuitivo como un órgano supremo para el saber científico, en cuanto que hace posible una comunicación con la Naturaleza como totalidad viviente. Esta forma de pensar tiene como objetivo el observar el mundo atentamente, poniéndose en sintonía con la realidad y dejando que el juicio brote de los hechos mismos. Realizando este tipo de procesos, se evita que el pensamiento sea el juez de los acontecimientos y así, éste se convierte en un instrumento que permite que las cosas develen su propia esencia. Ésta debería ser sin duda la verdadera actitud del poeta, del artista o del verdadero investigador científico, abiertos a la inspiración y en la búsqueda de la idea activa que existe detrás de todo fenómeno. Revelando una actitud precursora en su tiempo, sus teorías sobre la Naturaleza argumentaban una relación hombre-Naturaleza distinta al característico vínculo de dominio y explotación44. A partir de su viaje a Italia, donde se sumergiría en el estudio de la Naturaleza, la botánica sería una de las constantes pasiones de Goethe. Sus estudios previos se habían centrado en descubrir los rasgos comunes que los seres vivos compartían entre sí, reuniendo sus ideas en su obra La metamorfosis de las plantas45, publicada en 1790 en Alemania. Su teoría defendía que tras las múltiples apariencias de las plantas podía descubrirse un arquetipo común a todas ellas, una forma originaria y ancestral, una planta-tipo primordial o esencial, a la que Ilamó Urpflanze. Esta planta sería una suerte de modelo idealizado del que derivarían el resto de las plantas existentes en la Naturaleza a manera de diferentes manifestaciones o encarnaciones del tipo fundamental.

Goethe validaba la real existencia de esta utópica planta argumentando que, si las plantas no fueran copia de un modelo, no podríamos reconocerlas como tales46. Si bien, Goethe esperaba encontrar algún día su Urpflanze, su teoría derivaría hacia planteamientos más abstractos, desarrollando un sistema permutativo de representación de los tipos de plantas que, partiendo de los

\footnotetext{
43 ALBELDA, José y SABORIT, José, op. cit., p. 79.

${ }^{4}$ SÁNCHEZ MECA, Diego, "Los conceptos griegos de physis y theoria en la interpretación de Goethe", en Daimon, Revista de Filosofía, N 16, Universidad de Murcia, Murcia, 1998, pp. 57-71.

45 GOETHE, Johann Wolfgang, La metamorfosis de las plantas, Beta III Milenio, Bilbao, 1994.

46 STEADMAN, Philip, Arquitectura y Naturaleza. Las analogías biológicas en el diseño, Blume, Madrid, 1982, pp. 42-44.
} 
autores anteriores, desarrollaba incluso una serie de plantas inventadas que, teóricamente formarían parte de un modelo único de estructura vegetal. Este arquetipo se constituye no como una entidad material, sino como una idea general del Arquetipo, anticipándose a Darwin en su visión básica de que todas las especies tienen un origen común.

Tras su experiencia científico-artística, Goethe buscaba hacer confluir todos los procesos de germinación, crecimiento, metamorfosis de los órganos, nutrición y reproducción de todos los seres vivos en secuencias que obedecieran a un arquetipo fundamental o idea primordial de la planta. Todo ello permitía desplegar resonancias de una concepción bipolar entre la materia y las fuerzas suprasensibles, fenómenos no directamente medibles con los aparatos físicos convencionales pero que nuestros predecesores podían elaborar mediante un pensamiento más ligado a las fuerzas formativas del cosmos. El pensamiento de Goethe, caracterizado por un empirismo identificado totalmente con el objeto de estudio, resulta en nuestros días sumamente atractivo. Como señala Henri Bortoft, hoy en día existe un creciente interés en el impacto que la Ciencia y la tecnología tienen en la Naturaleza y en este sentido, el pensamiento goethiano podría conducirnos "a una tecnología que sea sinérgica más que agresiva, en la que la Naturaleza y el hombre cooperen para su mutuo acrecentamiento"47.

Históricamente, desde el punto de vista de las creencias y la mitología, en todas las sociedades ha habido analogías entre los dioses y la Naturaleza como fuente de sobrevivencia de las comunidades. Dioses y diosas que aplacaban o favorecían a los hombres, eran representados con atributos vegetales, la mayoría de ellos también antropomorfizados. Más no siempre la Naturaleza ha sido un ente benefactor en todo momento para el hombre. De hecho, el hombre siempre ha sabido que ésta tiene sus propios principios organizativos al margen de nosotros los humanos. Lo que es un hecho incontestable es que el hombre ha necesitado siempre entender y explicar su entorno. Esta necesidad oscila entre las explicaciones de una cosmovisión relacionada con númenes invisibles, y las identificaciones de aquello que le sucede a su alrededor, con las fuerzas de la Naturaleza.

Durante mucho tiempo y en diferentes culturas, el hombre trató de explicarse los fenómenos de la Naturaleza mediante deificaciones de esos mismos fenómenos, antropomorfizados en diosas y dioses de la Naturaleza Era, Afrodita, Ceres, Coatlicue, etc. que se plasmaban en obras artísticas según las diferentes culturas. Dentro de la mitología clásica, los humanos pueden llegar a encarnar también ciertas características de la Naturaleza, convirtiéndose en determinadas circunstancias $y$, mediante procesos de metamorfosis, en vegetales con características análogas a la planta protagonista, así sucede con Dafne o con Narciso.

47 BORTOFT, Henri, "Prólogo", en NAYDER, Jeremy y GAUGER, Gloria, Goethe y la Ciencia, Biblioteca de ensayo Siruela, Madrid, 2002, p. 18. 


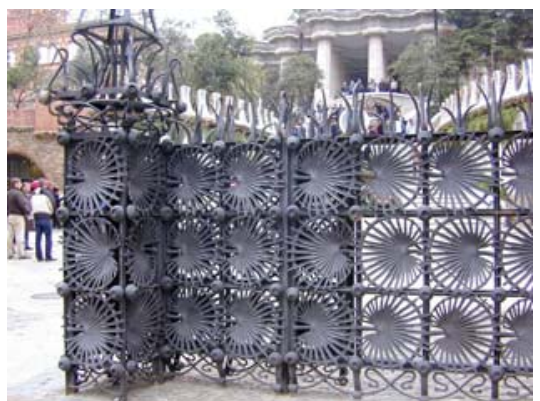

Antonio Gaudí, Parque Güell, 1914.

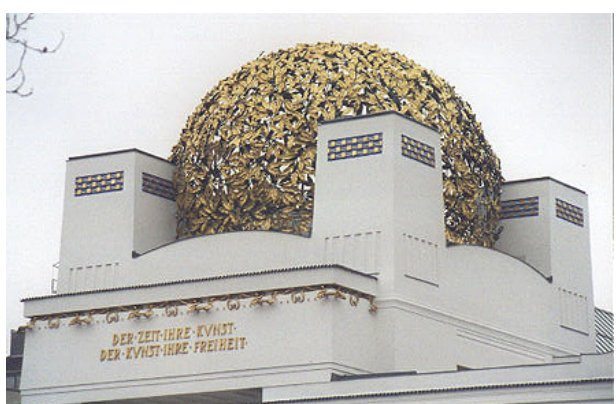

Joseph Maria Olbrich, Casa de la Secesión, 1896.

Como vemos, la Historia del Arte da cuenta de varios momentos en la historia del hombre, en los que éste se ha sentido más cercano a la Naturaleza que en otros. El Romanticismo, el Modernismo, el Art Nouveau o la Escuela Vienesa son movimientos culturales que, alejándose del Academicismo y de las formas del pasado abundan en ejemplos de una tendencia organicista como Antonio Gaudí, (Parque Güell, Barcelona, 1900-1914) o Joseph Maria Olbrich, (Casa de la Secesión, Viena, 1896), etc.

También en la actualidad, la sociedad occidental, moderna y contemporánea, ha tenido momentos puntuales en los que la atención de la Cultura se ha centrado en replantear algunos aspectos de la Naturaleza. En estos períodos, el hombre ha tratado de buscar un mayor acercamiento a otros seres vivos y a formas de vida más sencillas y más cercanas a la Naturaleza. Nuestra investigación nos conduce a valorar si el reflejo de estas circunstancias en el hecho artístico, obedece a una necesidad imperiosa, a una nostalgia pasajera o a una seducción perpetua. En el caso de las plantas por ejemplo, la carga simbólica que pudiera tener la hipotética idea de una transformación vegetal, generalmente considerada negativa por la inmovilidad que conlleva, actualmente se percibe como algo pseudo positivo: todo el mundo quiere ser verde y ecológico. Dentro del campo semántico de los mass media y la publicidad, Albelda y Saborit nos hablan de éstos y otros espejismos contemporáneos, en su estudio sobre el fenómeno de ser verde. Este color, por sus características intrínsecas de vida, de fertilidad, de frescura, limpieza o salud, tiene la propiedad de asumirse como abstracción de todo lo natural, constituyéndose así en metáfora de todas las cosas verdes de la Naturaleza48. Frente a la crisis ecológica, el empleo del color verde en cualquier ámbito, con una inevitable carga metafórica dentro de nuestra sociedad, se relaciona actualmente con un consumo responsable de los recursos naturales. Frente a la naturaleza animal y el color rojo, se impone la naturaleza vegetal y el paradigma de lo verde, como último reducto de esperanza ante un futuro dudoso.

Efectivamente, el color verde está, de forma natural, subliminal e históricamente, directamente relacionado con la Naturaleza. En el simbolismo

48 ALBELDA, José y SABORIT, José, op. cit., pp. 277-297. 
popular, siguiendo a Hans Biedermann, el verde, considerado como el reverdecer de la esperanza, está vinculado tradicionalmente a los cultos relacionados con la vegetación:

Allí donde brota el verde, allí está sencillamente la Naturaleza, allí está naturalmente el crecimiento [...] el hecho concreto de la primavera. Cuando, por ejemplo, se aparece el diablo como "el verde", es que ha conservado la vestidura de un antiguo dios de la vegetación ${ }^{49}$.

Por su parte, Frédéric Portal, en torno a la importancia de los colores, establece tres grados para la generación simbólica de los mismos. En primer lugar presupone la existencia en sí del color, en segundo plano que el color sea una manifestación de vida $y$, en tercer lugar, considera el valor de la acción resultante. Según estos principios, el verde pertenece al tercer grado, aquel que se corresponde con la esfera de la creación, una de las tres esferas que, según los profetas emanan de Dios y que llenan los tres cielos. Siendo el verde, un color habitualmente relacionado con la tierra y la vegetación, ésta última es posible, gracias a la confluencia de la acción de los elementos tierra y agua, de manera que el verde indica la unión fecunda entre los mismos. En la tradición cristiana, la parábola del sembrador enseña a los creyentes que la regeneración es semejante al germen de la planta que renace en el seno de la muerte y reverdece en una vida nueva. Esta oposición entre lo verde y lo profano asienta que la hierba verde era símbolo de los regenerados.

En el Apocalipsis, se ordena a las langostas que no dañen la hierba de la tierra, ni ninguna cosa verde, ni árbol alguno, sino solamente a los hombres que no tengan marcado el sello de Dios en la frente50.

Asimismo, el color verde tiene una valoración particular en las visiones, cartas y libros de la mística Hildegard Von Bingen (1098-1179), quien poseía el don de la videncia $y$, cuyas dotes intelectuales permitieron que su obra trascendiera ochocientos años. Con una fuerte vinculación con el mundo de las plantas y una gran sabiduría popular respecto al uso medicinal de las mismas, concibe la trascendencia del concepto de "viriditas", entendido éste como el verdor o la fuerza germinativa que es reflejo de la vida:

[...] el verdor que penetra hasta la última fibra del universo, el cual está presente en el arreglo cósmico de su obra: El mundo en primavera está lleno de viriditas; Dios exaló viriditas a los hombres: el sol irradia viriditas al mundo [...] $]^{51}$.

\footnotetext{
49 BIEDERMANN, Hans, Diccionario de Símbolos, Paidós, Barcelona, 1993, p. 476.

50 PORTAL, Frédéric, El simbolismo de los colores. En la Antigüedad, la Edad Media y los tiempos modernos, José J. de Olañeta, Palma de Mallorca, 2005, p. 98.

51 MARTÍNEZ LIRA, Verónica et al., El lenguaje secreto de Hildegard Von Bingen. Vida y obra, Espejo de viento, UNAM, Fondo de Cultura Económica, Conaculta, México, D.F., 2004, p. 68.
} 
El pensamiento de Hildegarda -quien hipotéticamente habría tenido conocimiento de los trabajos de Hipócrates, Plinio el Viejo, Isidoro de Sevilla, Soranus de Éfeso, Galeno de Pérgamo, Constantino de África, Apuleyo, de los tratadistas árabes y de Dioscórides- es sorprendentemente analógico cuando valora, por ejemplo, la piedra de la esmeralda a causa de su color, afirmando que esta piedra se origina por la mañana temprano al salir el sol.

El verde de la tierra y de las hierbas florece entonces con el mayor frescor, porque el aire aún está frío, pero el sol ya calienta y los vegetales absorben el verde con la misma avidez que el cordero la leche. El calor del día apenas es suficiente para cocer ese verdor y alimentarlo. Por ello la esmeralda es un poderoso remedio contra todas las debilidades y enfermedades del hombre, porque el sol la produce y su sustancia procede del verde del aire ${ }^{52}$.

Todas estas apreciaciones nos orientan en torno al hecho de que metafóricamente hablando, lo verde, así como todo lo relacionado con 10 vegetal, ha estado siempre vinculado a todo aquello que tiene que ver con los procesos de crecimiento y desarrollo interior o exterior de los humanos. En 1860, John Ruskin describía la pujanza con la que la joven planta describe su futuro crecimiento.

El joven vástago se comporta desde un principio con toda la dignidad de un árbol: sólo él conduce sus ramas de tal manera que, con un tallo fuerte y recto que le mantendrá en pie sobre el suelo, creará la base para su vida futura53.

Partiendo de estas consideraciones nos apoyamos también en Lakoff y Jonhson, para quienes también las metáforas son capaces de crear realidades:

Las metáforas tienen implicaciones por medio de las cuales destacan y hacen coherentes ciertos aspectos de nuestra experiencia. Una metáfora determinada puede ser la única forma de destacar y organizar de forma coherente precisamente esos aspectos de nuestra experiencia. Las metáforas pueden crear realidades, especialmente sociales. Una metáfora puede convertirse en guía para la acción futura. Estas acciones desde luego se ajustarán a la metáfora. Esto reforzará a su vez la capacidad de la metáfora de hacer coherente la experiencia. En este sentido, las metáforas pueden ser profecías que se cumplen 54.

Siguiendo la línea metafórica apuntada por Lakoff y Jonhson, la filosofía y el pensamiento contemporáneos han relacionado los conceptos de Naturaleza y sociedad con una imagen específica del mundo vegetal: el rizoma. Este elemento

52 BIEDERMANN, Hans, op. cit., p. 476.

53 RUSKIN, John, en SACHSSE, Rolf, Karl Blossfeldt. Fotografías, Benedikt Taschen, Köln, 1994 , p. 16.

${ }^{54}$ LAKOFF, George y JOHNSON, Mark, Metáforas de la vida cotidiana, Cátedra, Colección Teorema, Madrid, 2007, p. 198. 
particular de la Botánica, se ha utilizado para representar los síntomas de una sociedad caracterizada por específicas dinámicas sociales, como desplazamientos y nuevas migraciones, fruto lacerante de las políticas y de las economías capitalistas y neoliberales. Estos procesos han determinado nuevas estrategias geopolíticas en el mundo del arte. A su vez, ciertos pensadores han construido todo un sistema de pensamiento en base a las características particulares de este pequeño ser tan aparentemente intrascendente, como la hierba. La hierba, como elemento característico del mundo vegetal, refleja en nuestra opinión, ciertas cuestiones en las que se insertan los intereses del arte de hoy con respecto no sólo a lo vegetal, sino también en lo que se refiere a la filosofía contemporánea y en otro extremo, a tecnologías tan nuevas como Internet. En la actualidad, se habla del mundo de Internet haciendo referencia a una suerte de red-rizoma, un sistema que no tiene ni principio ni fin. La obra de Deleuze y Guattari es un claro ejemplo de ello:

Aunque la obra de Deleuze-Guattari tiene un alcance más restringido, pues es una crítica a las ideas del capitalismo que se inició utilizando categorías del psicoanálisis (El Anti-Edipo), ha sido la difusión del nuevo Medium que es el WEB (Internet) lo que ha reactivado el interés por el uso de esta metáfora como categoría epistemológica al encontrar ciertas similitudes con los conceptos de "Redes" (Redes Neuronales - Hipertexto - etc 55.

En 1977 Deleuze presenta como eje de su pensamiento, su ensayo Rizoma56. Nuestro encuentro con este pensador hizo que el sentimiento formal y las inquietudes que a través de la escultura nos estábamos planteando tuvieran una razón más clara de ser. Como artista, la reiterativa realización de esculturas con reminiscencias vegetales respondía, no a una mera representación de las plantas en sí, sino al planteamiento de generar un discurso sobre el ser humano partiendo de lo formal y estructural del vegetal. El sentimiento estético-social plasmado en la filosofía de Deleuze y Guattari, sirve de hilo conductor para el análisis de la proliferación de artistas relacionados con lo vegetal. Nuestro primer encuentro con estos pensadores a través del libro de Maite Larrauri: El deseo según Gilles Deleuze 57 plantea la comparación social del ser humano con la hierba como elemento rizomático, acercándonos a la temática vegetal para tratar de encontrar un fundamento a la obra de escultores que utilizan lo vegetal en sus prácticas. El resurgir del interés en un nuevo concepto de Naturaleza, favorece la aparición de nuevas prácticas escultóricas como vía de experimentación para evidenciar estas cuestiones.

55 BARBROOK, R., "Die heiligen Narren. Deleuze, Guattari und die High-tech Geschenksökonomie“, 22, diciembre, 1998, en Telepolis: Medientheorie, Diponible en red en: <http://www.heise.de/tp/deutsch/special/med/6344/1.html>, [Consulta 13, septiembre, 2011 ].

56 DELEUZE, Gilles y GUATTARI, Félix, Rizoma. Introducción, Pretextos, Valencia, 2008.

57 LARRAURI, Maite, El deseo según Gilles Deleuze, Tándem, Colección Filosofía para profanos, Valencia, 2000. 
En Botánica, entendemos el rizoma como tallo o parte subterránea y generalmente horizontal del entretejido de las raíces de ciertas plantas. Este tipo de estructuras pueden ramificarse, permitiendo que desde una parte de ese entramado surjan otros tallos, facilitando así la multiplicación vegetativa y la proliferación de la planta. Para comprender el concepto de rizoma en su sentido originario debemos establecer una primera diferencia entre la habitual configuración individual arborescente y la configuración rizomática. Es necesario corregir la tendencia habitual en el observador de la vida vegetal, de dar más importancia a lo que se ve desde arriba, como los tallos, los troncos o las ramas etc., que a lo que está abajo. En el tipo de estructuras rizomáticas, además de la parte visible superior, encontramos por debajo un entramado aparentemente caótico, que parece no responder a ningún orden jerárquico pero con una capacidad de auto-regeneración de la que carecen por ejemplo, organismos superiores como los animales, que no tienen la posibilidad de regenerar un individuo nuevo desde una parte de ellos mismos. En cambio, muchas plantas en especial las rizomatosas, tienen la capacidad de reproducirse a partir de un fragmento.

Un primer uso de la aplicación de la metáfora de la vida vegetal al ámbito de las Ciencias Humanas es atribuido a Carl Jung.

La vida se me ha parecido siempre como una planta que vive de su rizoma. Su vida propia no es perceptible, se esconde en el rizoma. Lo que es visible sobre la tierra dura sólo un verano. Luego se marchita. Es un fenómeno efímero. Si se medita el infinito devenir y perecer de la vida y de las culturas se recibe la impresión de la nada absoluta; pero yo no he perdido nunca el sentimiento de algo que vive y permanece bajo el eterno cambio. Lo que se ve es la flor, y ésta perece. El rizoma permanece58.

De la misma manera Gilles Deleuze y Félix Guattari utilizan la metáfora del rizoma para definir uno de los conceptos centrales de su obra. En el capítulo de introducción de Mille plateaux. Capitalisme et schizophrénie (Mil Mesetas) afirman que un rizoma no tiene ni principio ni fin, siempre está en el medio, entre las cosas, es un ser-entre, una especie de intermezzo. Mientras que el árbol es filiación, el rizoma es suma, alianza. Si el primero impone el verbo ser, el segundo se caracteriza por la conjunción y la adicción.

¡Haced rizoma y no raíz, no plantéis nunca! ¡No sembréis, horadad! ¡No seáis uno ni múltiple, sed multiplicidades! jHaced la línea y no el punto! La velocidad transforma el punto en línea. iSed rápidos, incluso sin moveros! Línea de suerte, línea de cadera, línea de fuga. ¡No suscitéis un General en

58 JUNG, Carl Gustav, Recuerdos, sueños, pensamientos, Seix Barral, Los Tres Mundos, Barcelona, 2001, p. 18. 
vosotros! Nada de ideas justas, justo una idea (Godard). Tened ideas cortas 59 .

Si bien Deleuze y Guattari son conocidos como precursores de estas formas de pensamiento, es imprescindible en este hilo de ideas, el análisis filosófico de la obra de Gregory Bateson, quien con una trayectoria anclada en diversas disciplinas, constituye uno de los últimos intentos de integración de lo uno y lo múltiple en un marco explicativo global. Bateson nos refiere el siguiente silogismo sobre la hierba, con el que consigue establecer una simbiosis similar a la que Goethe trataba de acercarnos:

\section{La hierba muere. \\ Los hombres mueren. \\ Los hombres son hierba60.}

Bateson usa este silogismo -cuyo verdadero autor es E. Von Domarus61- y lo contrapone al silogismo tradicional de Sócrates llamado Bárbara62, para explicarnos que ésta es la manera en la que se desarrollaba buena parte de su pensamiento y también la manera, en la que los poetas exponen el suyo. Bateson afirma que esa forma de pensar se llama metáfora y que, aun no siendo lógicamente genuina, es una útil contribución a los principios de la vida, alegando que la vida misma, tal vez no se rige siempre por aquello que es lógicamente genuino.

Tras examinar largamente la estructura del silogismo de la hierba, Bateson comprobó que difiere del silogismo de Sócrates por el hecho de que éste último, lingüísticamente hablando, identifica a Sócrates como sujeto y miembro de la clase de los mortales, mientras que el silogismo de la hierba, en lugar de clases o sujetos de oraciones, identifica predicados, en tanto que aquello que muere es igual a todo aquello que muere. El mundo de las analogías y de la homología63 es retomado por Bateson para proponer que en los comienzos del mundo, los

59 DELEUZE, Gilles y GUATTARI, Félix, op. cit., p. 56.

60 BATESON, Gregory, "Los hombres son hierba: La metáfora y el mundo del proceso mental", en BATESON, Gregory, op. cit., pp. 305-313.

61 DOMARUS, Von E., "The Specific of Logic in Schizophrenia", en BATESON, Gregory, op. cit., pp. 305-313. DOMARUS fue un psiquiatra de la primera mitad del siglo XX que escribió un ensayo en el que señalaba la forma en la que los esquizofrénicos tienden a hablar y a pensar mediante silogismos que tienen la estructura general del silogismo de la hierba.

62 "Los hombres son mortales. Sócrates es un hombre, luego Sócrates es mortal".

63 La homología es el estudio comparativo de los seres vivos, estableciendo las relaciones existentes entre las partes orgánicas de los mismos que aun siendo diferentes, tienen determinantes genéticos que implican un mismo origen evolutivo. Las analogías por contra, fruto de una convergencia evolutiva, se establecen cuando encontramos estructuras semejantes o con funciones similares, pero cuyo origen y desarrollo embrionario fueron diferentes. 
organismos se desarrollaban mediante procesos evolutivos que compartían predicados puesto que, hasta la invención del lenguaje, el mundo biológico se las ingeniaba sin la separación entre sujetos y predicados.

Se las compusieron para organizarse en su evolución, de suerte que hubo predicados compartidos entre el caballo y el hombre, que es lo que los zoólogos llaman hoy homología. Y era evidente que la metáfora no pertenecía sólo a la bonita poesía, la metáfora no era ni buena ni mala lógica, pero era en verdad la lógica sobre la cual se había construido el mundo biológico, su característica principal y el cemento organizador de este mundo del proceso mental que he estado tratando de esbozar para ustedes de uno u otro modo64.

Las resonancias que estas teorías aportan a nuestra investigación son múltiples. Por un lado, podemos comprobar que el tema de lo vegetal es una fuente importante de reflexión y una amalgama de metáforas no sólo para artistas sino también para filósofos. Por otro lado, Bateson nos ayuda, con sus teorías, a explicar en parte, el sentir contemporáneo de los artistas que utilizan lo vegetal en su trabajo, referenciando su discurso con el sentir contemporáneo de lo social en el mundo. Bateson formula que si dos individuos tienen un atributo determinado, ambos son en cierta manera iguales, remitiéndonos a que ésta, que aparentemente, podría ser la forma habitual de pensamiento de los sicóticos, es asimismo la lógica de múltiples fenómenos como la metáfora o el sacramento. La ecología batesoniana sostiene que éste es un modelo de pensamiento válido y capaz de construir un sistema ecomental plausible, para entender la epistemología, entendida como objeto de conocimiento científico. El método de búsqueda denominado por Bateson: "método de la comparación doble o múltiple", se ancla en los terrenos de la estética y lo sagrado, observando varios fenómenos distintos entre sí, para descubrir la analogía subyacente en ellos. En definitiva, la lógica de Bateson busca (y por eso nos parece pertinente nombrarla aquí), como muchos de los artistas que utilizan como referente lo vegetal en su obra, la pauta que conecta lo humano con la Naturaleza. Una Naturaleza representada en lo vegetal y que se traduce en un proceso que fluye, de forma continua entre las relaciones humanas y el mundo de las plantas.

La pauta batesoniana ofrece un problema de organización y de morfogénesis. Cuando Bateson se plantea cual es la pauta que conecta al cangrejo con la langosta, a la orquídea con el narciso y a los cuatro con él mismo, no busca una identidad de patrones estáticos, susceptibles de clasificación, sino el resultado de la relación entre ellos. Patrones y procesos no deben concebirse por separado, puesto que la vida, desde el punto de vista evolutivo, comporta estructura, pero también tiempo y movilidad: la visión correcta del mundo es aquella que atiende a las relaciones dinámicas que rigen el crecimiento.

64 BATESON, Gregory, op. cit., pp. 312-313. 
Lo que nos interesa subrayar de todas estas reflexiones es que en nuestra opinión, lo que mueve a los artistas que estamos estudiando a referenciar su obra con lo vegetal (tanto a aquellos que utilizan la representación más o menos literal, como aquellos que no), es que todos ellos presentan una búsqueda centrada en las pautas que conectan ambos mundos, el humano y el vegetal. Estos aspectos son los que nos interesa tratar en nuestra investigación: encontrar la o las pautas que conectan los diferentes usos que, de lo vegetal, desarrollan los artistas en el arte contemporáneo.

Siguiendo a Bateson, las interpretaciones o las historias a las que el arte y los artistas nos remiten, establecen coincidencias entre los fenómenos, por muy dispares que éstos nos pudieran llegar a parecer, de la misma manera que para él, el pensar en términos de historias no configura a los seres humanos como algo distinto de las estrellas de mar, las anémonas, los cocoteros o los narcisos. Suponiendo que el mundo está conectado, pensar en términos de historias es algo compartido por todos los espíritus o por todo el espíritu, tanto el nuestro como humanos, como el de los bosques o el de las anémonas.

Posteriormente relacionando literatura y psicoanálisis, la metáfora de la hierba será nuevamente abordada por Deleuze y Guattari quienes, basándose en los escritos de Bateson, desarrollaron su pensamiento en torno a una Cultura rizomática. La idea de retomar en nuestra investigación el concepto de rizoma para analizar el recurso de lo vegetal, tiene la finalidad de recuperar el discurso sobre el devenir usado por Deleuze. Esto es, si Vida es igual a Naturaleza, entonces ambos tienden al devenir como pauta o, lo que es lo mismo, ambos se expresan mediante el devenir. Los elementos que conforman ambos conceptos nacen y mueren es decir, se transforman, pero más allá de su proceso de desmaterialización, se mantienen en el proceso de lo cambiante, en la dinámica de que lo constante es el cambio y esta característica es fundamental para muchos artistas que justamente, abordan en su trabajo, el arte como un proceso.

En esta investigación observamos la metáfora vegeta/identificando la utilización de la misma en un contexto artístico, como un fenómeno cercano a una representación de lo social en el contexto humano. El ser humano deviene hombre más allá de su existencia como individuo, en un entorno social, de la misma manera que la vida, en lo vegeta/se mantiene: una planta muere, una flor se marchita, pero su existir vegetal continúa manifestándose en el resto de sus congéneres. Pensamos que esta característica es fundamental en el sentimiento que el ser humano tiene hacia el reino vegetal, por lo que le mantiene vinculado con los ciclos de la Naturaleza, convirtiendo su utilización en un recurso eficiente para mostrar determinadas circunstancias como son los procesos de formación y transformación de la identidad, personal o colectiva, así como los movimientos y los flujos migratorios dentro de la sociedad contemporánea.

Más que hablar de una analogía formal o simbólica, la comparación que pretendemos establecer es la de lo vegetal entendido como una sutil representación de lo social, metáfora social de los cambios que en las últimas 
décadas se han producido en la sociedad contemporánea. Para utilizar elementos similares utilizamos el rizoma y su distribución horizontal, en contraposición a la verticalidad del árbol, como elemento clave en la clarificación del proceso.

De nuevo en Deleuze, la lógica de Bateson subyace en la idea del silogismo de la hierba, donde la mortalidad -como concepto- es la que transita, dejando a su paso tanto a los hombres como a la hierba.

Nada fácil percibir las cosas por el medio, y no de arriba abajo o al revés, de izquierda a derecha o al revés: intentadlo y veréis como cambia todo. No es fácil ver la hierba en las cosas y las palabras65.

El silogismo de la hierba cuyo origen explicamos anteriormente, establece una "relación loca", siguiendo a Larrauri: "una identificación sin sentido en el plano de la lógica, entre el sujeto universal los hombres y el sujeto particular la hierba". Sin embargo nos ayuda a entender el concepto de rizoma y el por qué deberíamos aprender a observar el crecimiento horizontal de las plantas, dejando de lado la estructura arborescente de la Cultura que mediante la imagen del árbol, las estructuras arborescentes y las raíces fijas, impide el movimiento.

La cultura rizomática multiplica las relaciones colaterales, crece y se amplía hasta donde llega su propia fuerza; su territorio no conoce las vallas porque se delimita por la potencia con la que es capaz en cada momento de ocupar el espacio66.

Hasta aquí, la metáfora empleada por Deleuze para explicar su epistemología, converge con la decisión, de emplear las plantas como un referente, dentro del arte, que va más allá de la realidad de las mismas. Su utilización, lleva implícita conceptos como los de conexión, multiplicación, dispersión, crecimiento, semejanza, muchos de los cuales, son rescatados en la actualidad por los artistas para replantear una nueva conciencia frente al deterioro de nuestro mundo. En la conjunción, en la suma se desenraíza el verbo ser. Deleuze y Guattari plantean incluso el rizomorfismo como lo más específico de la Botánica y dan continuidad a este principio en estructuras habitacionales de diferentes colectivos de animales, como hormigas o ratas. Más allá de estos planteamientos, en esta investigación extendemos el concepto de rizoma a la praxis y la producción artística relacionada con las plantas, en este devenir que sugiere Deleuze, dirigido a la producción de inconsciente.

Todas estas consideraciones nos llevan a afirmar que, en el terreno artístico, representar la Naturaleza no es el objeto último, no sólo de la pintura sino tampoco de la escultura. El elemento polisémico y la riqueza expresiva que conlleva dicha representación, restringen el análisis pormenorizado sobre cómo, a lo largo de la historia, se ha representado la misma más o menos

65 LARRAURI, Maite, op. cit., p. 18.

66 LARRAURI, Maite, op. cit., p. 58. 
naturalísticamente, dirigiendo el objetivo hacia las diferentes voluntades artísticas de cada sociedad o artista. Cabe apuntar, que la tridimensionalidad y lo matérico de la escultura han impedido habitualmente confundir la realidad con su representación, salvo en lo que se refiere a los hiperrealismos, con lo cual podríamos sugerir que no ha habido, como sucede en la pintura, una ilusión de engaño o el conocido trompe /'oeil.

La omnipresencia en todos los ámbitos del conocimiento humano de las categorías de estudio sobre lo vegetal es sin lugar a dudas, como hemos visto hasta aquí, uno de los factores interesantes a resaltar. Tradicionalmente la Naturaleza ha sido la gran maestra de las formas no sólo en lo que se refiere a lo orgánico, sino también en el mundo de la ficción. Así sucede por ejemplo, con las aparentemente extrañas formaciones que a partir de los años setenta, han aparecido en ciertos lugares del mundo. Construcciones en las que se observan formaciones y desarrollos geométricos, inscritos o trazados en campos de cultivo de grandes dimensiones, que aparecen cultivados y cosechados con estratégicas formas. Todo ello e incluso, hasta la simple representación de una calabaza nos habla de un tiempo en el que se produce un crecimiento o la inversa, de un crecimiento que necesita de un tiempo.

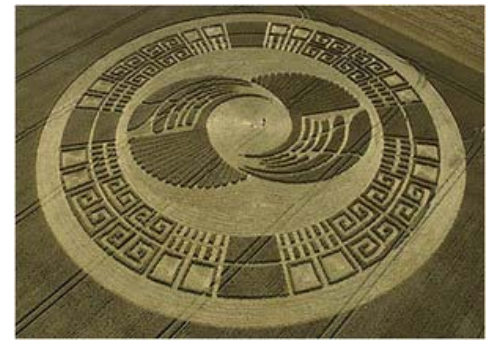

Círculos de cultivo, Sibury Hill, 2004.

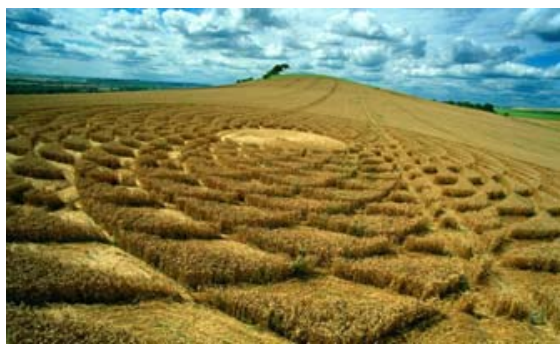

Bert Janssen, Woodborough Hill, 2000.

En la actualidad los llamados Crops circles (Círculos de cultivo) constituyen dentro de la Cultura popular, una peculiar muestra de conjunción entre matemáticas, vegetación y Naturaleza domesticada. Un ejemplo contemporáneo de -como ya había sugerido Eugène Emmanuel Viollet-Le-Duc en 1879- de que la geometría forma parte tanto de la Naturaleza, como de nuestra cotidianeidad.

La geometría está en todas las cosas, se la encuentra por todas partes, es la gran maestra de la Naturaleza. Por ello hay que conocerla si se quieren observar y comprender las cosas de la creación67.

En nuestro caso y, en lo que a nuestra práctica como artista se refiere, el sentirse directamente relacionado con una pequeña planta, como puede ser la hierba y hacerle un homenaje, sugiere un proceso que nos acerca al mundo vegetal, con una admiración similar a la del fotógrafo Karl Blossfeldt, cuyos recorridos y paseos sistemáticos por los campos cercanos a su casa, para recolectar y

67 VIOLLET-LE-DUC, Eugène Emmanuel, en SACHSSE, Rolf, op. cit., p. 18. 
documentar posteriormente sus pequeños hallazgos vegetales, lo convierten en un referente no sólo del mundo de la imagen, sino también del mundo de la escultura. Su particular mirada detenida en el detalle, es similar a nuestra admiración hacia todo aquello que consideramos parte de nuestra propia naturaleza humana. En esta mirada están presentes, tanto el discurso sobre la dicotomía entre Naturaleza y Cultura, como el discurso ecológico, todo ello matizado por la seducción -siguiendo a August Endell- que ejercen en nosotros, las mismas formas vegetales:

Quien no se ha sentido embelesado por las exquisitas curvaturas de los tallos de hierba, la maravillosa inexorabilidad de la hoja de cardo, la acre juventud de los capullos de hojas brotando; a quien nunca ha cautivado la forma maciza de una raíz, la fuerza inquebrantable de la corteza que ha estallado, la fina flexibilidad del tallo del abedul, la gran serenidad de las amplias masas de hojas, sintiéndose conmovido en lo más profundo de su alma, nada sabe de la belleza de las formas68.

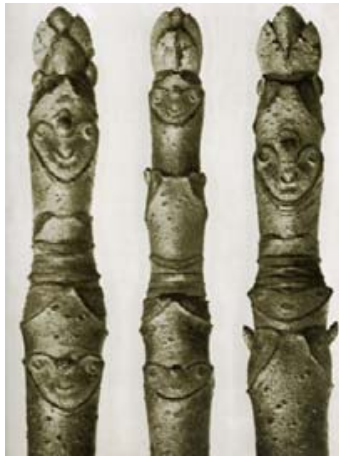

Karl Blossfeldt, Aesculus parviflora,

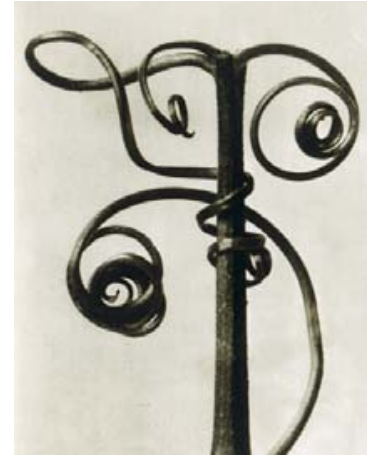

Karl Blossfeldt, Cucurbita calabacera, 1928.

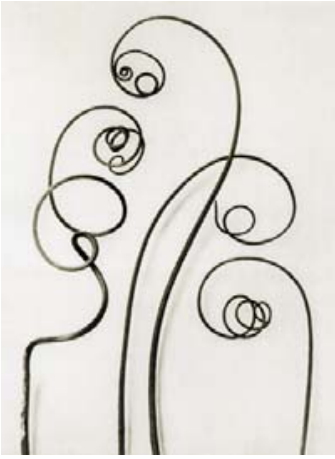

Karl Blossfeldt, Bryonia alba, 1928.

1928.

Interesante al respecto es el punto de vista de Cuauhtémoc Medina, para quien las imágenes de Blossfeldt están en concordancia, con el Jugenstil, o "estilo joven", propio del Art Nouveau. Su objetivo era propiciar la imagen de un nuevo tipo de hombre, libre de indagar, directamente en las formas naturales, intuiciones nuevas que, sin intermediarios históricos, lograran percibirse de manera independiente de las anteriores fases evolutivas de la ornamentación. Para Blossfeldt sus trabajos sobre plantas suponían una colaboración en la recuperación de una nueva relación con la Naturaleza. Estas imágenes debían despertar nuevamente el sentido por la Naturaleza, señalando la rica variedad de sus formas y ensalzando la observación individualizada de la flora y del patrimonio vegetal nacional69.

68 ENDELL, August, en SACHSSE, Rolf, op. cit., p. 32.

69 MEDINA, Cuauhtémoc, "Prototipos y últimos modelos: Blossfeldt y Fontcuberta (1994)", en FONTCUBERTA, Joan, et al., Ciencia y fricción: Fotografía, naturaleza, artificio, Colección Palabras de arte, $\mathrm{N}^{\circ}$ 4, Mestizo, Asociación Cultural de Murcia, Murcia, 1998, p. 71. 
Varios críticos y autores tanto de su época como actuales, coinciden en la insistencia casi espiritual con la que Blossfeldt se acercaba a sus modelos vegetales. Para Gert Mattenklott, Blossfeldt no era un entusiasta de la cámara, sino un amante de las plantas 70 .

Por mucha geometría, por mucha simetría, por mucho carácter de catálogo de plantas, repentinamente aparece algo impenetrable, algo misterioso ${ }^{71}$.

Estas fotografías revelan un tesoro de analogías y formas completamente inesperado en las plantas. Sólo la fotografía es capaz de ello. Pues se precisa una fuerte ampliación para que esas formas se quiten el velo que ha echado sobre ellas nuestra indolencia72.

Blossfeldt, quien normalizaría el estándar de la fotografía científica botánica, veía en sus humildes plantas verdaderos paradigmas, modelos a ser emulados y ejemplos de las leyes universales de la armonía y de la belleza. La finalidad didáctico-escultórica del origen de estas imágenes, derivaría posteriormente en la conversión de Blossfeldt en exitoso fotógrafo. Sus fotografías sobre plantas sin mayor ánimo creativo que el de servir de inspiración como modelos para sus clases de talla y forja ornamental ofrecían -frente a la austera economía de recursos- una elegante técnica. Sus imágenes recurren a la verosimilitud atribuida a la fotografía (método de convencimiento) para plantear una retórica de la Naturaleza, donde lo pequeño y lo grande se perciben como lo mismo o de igual magnitud, donde microcosmos y macrocosmos se vuelven equivalentes.

Cuando más adelante revisemos la obra de Yolanda Paulsen, de Naomi Siegmann o de otros artistas de México, podremos observar cómo este sentir es recurrentemente generador de muchas de sus propuestas. Las reflexiones que aquí referimos en torno a la obra de Blossfeldt, expresadas por varios autores, definen en gran medida nuestra hipótesis, por lo que estas visiones nos aportan luz para acercarnos a nuestros planteamientos con respecto a lo vegetal. Uno de nuestros enfoques es expresado con claridad por Vilém Flusser, quien identifica con la Naturaleza, y en particular con la naturaleza vegetal, una de las virtudes que más admiramos los seres humanos, la voluntad de seguir adelante o como él la llama, la "extraordinaria necedad" de las plantas:

[...] las nuevas informaciones genéticas nacen por error, debido a una trasmisión incorrecta de la información de una base a otra. La gran mayoría de tales informaciones es un absurdo sin importancia; sólo una ínfima parte de estas mutaciones engendra nuevas especies $y$ es responsable de la evolución biológica. Esto quiere decir que la "Naturaleza" (sea esto lo que

\footnotetext{
70 MATTENKLOTT, Gert, en SACHSSE, Rolf, op. cit., p. 84.

71 HEISSENBÜTTEL, Helmut, en SACHSSE, Rolf, op. cit., p. 90.

72 BENJAMIN, Walter, en SACHSSE, Rolf, op. cit., p. 42.
} 
fuere) es increíblemente necia, y lo que nosotros tanto admiramos en las plantas es precisamente esta extraordinaria necedad73.

La fotografía de plantas ha oscilado entre dos modalidades extremas: una descriptiva y científica (al servicio de biólogos y botánicos) y otra, más mística y poética (Edward Weston e Imogen Cunningham). Para Joan Fontcuberta, Blossfeldt aunando ambas, es uno de los más destacados autores de la Nueva Objetividad. Según Fontcuberta, Blossfeldt logró, sin pretenderlo expresamente, la sistematización más rigurosa hasta entonces conseguida, en relación a la documentación botánica. Todo ello, a pesar de utilizar recursos mínimos, como los cambios de escala o la ausencia precisa del contexto de lectura que conseguían sumergir al espectador "en un universo de formas fantásticas en el que se pierde la identidad del modelo"74. El mismo Blossfeldt refleja con sus propias palabras la intención específica de sus imágenes:

Pero la planta nunca cae en una configuración meramente objetiva; forma y conforma según las leyes de la lógica y la funcionalidad, y obliga, con una fuerza primigenia, a que todo tome una forma altamente artística75.

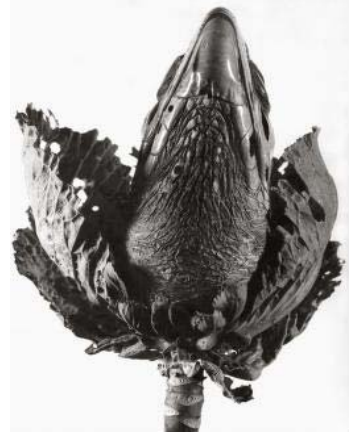

Joan Fontcuberta, Lavandula Angustofolia, 1984.

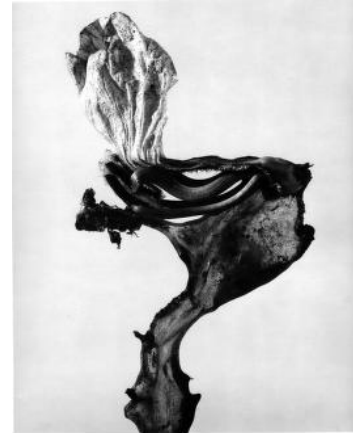

Joan Fontcuberta, Guillumeta Polymorpha, 1982.

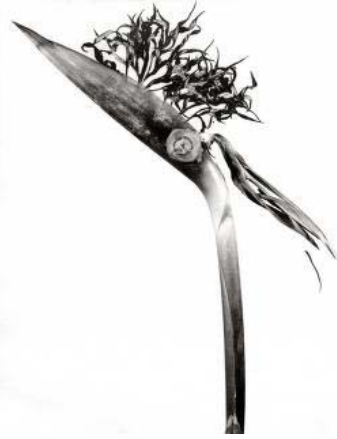

Joan Fontcuberta, Giliandria Escaliforcia, 1984.

Cabe destacar que, en contraposición al tratamiento otorgado a las plantas por Blossfeldt, en sus fotografías, Fontcuberta elaboraría su colección de fotografías Herbarium (1984), en la cual, paradójicamente, las plantas son consideradas en realidad como pseudoplantas, o pequeños assemblages, construidos en base a diferentes materiales orgánicos e inorgánicos. El artista aquí, haciendo pasar por verosímiles estas hibridaciones insólitas, no se erige como documentalista sino como visionario y diseñador genético, que aparentemente, recrea especies en concordancia con la nueva relación que el hombre establece con una Naturaleza y con un paisaje alterados por sus propias acciones. Con Herbarium,

\footnotetext{
73 FLUSSER, Vilém, en SACHSSE, Rolf, op. cit., p. 81.

74 FONTCUBERTA, Joan, "Contravisiones: la fotografía otra", en FONTCUBERTA, Joan et al., op. cit., pp. 33-55.

75 BLOSSFELDT, Karl (1932), en SACHSSE, Rolf, op. cit., p. 44.
} 
Fontcuberta realiza un trabajo similar al de Blossfeldt en tanto en cuanto que ambos, utilizan la fotografía como medio para hacer pasar por verosímiles sus composiciones híbridas. El mismo Fontcuberta declara el juego al que somete al espectador, mediante sus composiciones:

Herbarium hace pasar esos montajes por verdaderas plantas, mientras que Blossfeldt fotografiaba las verdaderas plantas de modo que pareciesen ornamentos arquitectónicos76.

Esta visión de Fontcuberta es importante, dado que con el escepticismo crítico de su obra propone un discurso alternativo con el que cuestiona tanto la objetividad de la fotografía como la validez del realismo en sí. Del mismo modo, algunos artistas (por ejemplo Sofía Táboas) actúan de forma similar, ya que con sus representaciones y presentaciones de lo vegetal, cuestionan los parámetros de los discursos establecidos sobre lo natural o lo artificial, sobre nuestra forma de vivir y nuestra Naturaleza como humanos.

Por último y respecto a la obra de Fontcuberta todavía, Castro Flores nos ofrece una visión que responde a parte de los cuestionamientos que realizan los artistas que trabajan con lo vegetal. Nos habla del carácter retórico de la verdad y cómo éste obsesiona a Fontcuberta, al punto de responder al mismo con una estrategia de producción de espejismos y simulacros. Castro Flores, siguiendo a Nietzsche, recuerda que las verdades al fin y al cabo, son ilusiones que se nos ha olvidado que lo son; metáforas que se han vuelto gastadas y sin fuerza y, junto con Baudrillard advierte sobre el uso de la seducción y del trompe l'oeil, no para confundir con lo real, sino para "producir un simulacro con plena conciencia del juego y del artificio: sobrepasar el efecto de lo real para sembrar una duda"77. Según Castro Flores y siguiendo a Craig Owens, habría que diferenciar el impulso deconstructivo característico del arte postmoderno en general, de la tendencia autocrítica del modernismo que presupone la mímesis o la adecuación de una imagen a su referente:

[...] puede ponerse entre paréntesis o suspenderse y que el objeto de arte en sí puede ser sustituido (metafóricamente) por su referente. El postmodernismo ni pone entre paréntesis, ni suspende el referente, sino que trabaja para problematizar la actividad de la referencia, para teatralizar la representación [...]78.

Hasta aquí hemos visto como el discurso en torno a lo vegetal no es algo novedoso sino que es una realidad recurrentemente vinculada con el hombre. Desde siempre nos hemos visto expuestos a la sorpresa que generan la contemplación y la curiosidad por el mundo de las plantas. Su persistencia y

\footnotetext{
76 FONTCUBERTA, Joan, “Contravisiones...", en FONTCUBERTA, Joan et al., op. cit., p. 53.

77 CASTRO FLÓREZ, Fernando, "Notas sobre el (d)efecto de la realidad, 1995", en FONTCUBERTA, Joan et al., op. cit., pp. 271-283.

78 CASTRO FLÓREZ, Fernando, "Notas sobre el (d)efecto...", en FONTCUBERTA, Joan et al., op. cit., p. 279.
} 
abnegada paciencia nos hacen percibirnos, en relación con la Naturaleza y con nosotros mismos, expuestos a nuestras propias e individuales características tanto como individuos, como seres que viven en sociedad. Salvando las distancias, Blossfeldt y sus coetáneos sintieron una suerte de nuevo Romanticismo que, al igual que en la actualidad, impulsa a nuestros contemporáneos a replantearnos cual es en realidad, nuestra relación con la vegetación que nos rodea, árboles, selvas, hierbas o flores.

Los artistas de hoy encuentran categorías que desarrollan a través de un coleccionismo de experiencias en el terreno de la creación de imágenes. Para entender la nueva mirada relacionada con la naturaleza vegetal y las nuevas relaciones entre Arte, ser humano y Naturaleza en los últimos años, el crítico de arte José Manuel Springer señala, dentro del contexto del arte contemporáneo mexicano, la manera por ejemplo, de actuar de la artista Perla Krauze, cuya obra veremos más adelante. Así, la específica topología del lugar y el interés por rescatar lo trivial en una de sus exposiciones: Topologías del paisaje mental, demuestra cómo la artista clasifica experiencias a la manera en la que Bourriaud define un semionauta79:

[...] recorre la ciudad registrando grietas en el pavimento, hendiduras en las banquetas, pequeñas erupciones de hierbas que nacen en las calles, mostrando que hay microcosmos en nuestros recorridos en los que apenas reparamos 80 .

En conclusión, el uso de lo vegetal en el arte y, en particular en la escultura presenta, amén de una extensa carga semántica, la persistente utilización de la retórica desde la metáfora, la alegoría o la metonimia -entre otras figuras lingüísticas- y, en relación directa con las propiedades características de los humanos, así como una estrecha relación con la simbología cimentada en el inconsciente colectivo fraguado a través de la experiencia cotidiana. Asimismo es importante considerar el factor del tiempo porque generalmente, el empleo de esta categoría, que afecta en particular al mundo vegetal, repercute paralelamente en el acontecer de ciertos caracteres de la obra artística. Por un lado, se presenta "lo procesual" (como todo aquello que necesita un tiempo y un espacio para desenvolverse) y por otro "lo efímero", como aquello que es temporal, transitorio o perecedero.

\footnotetext{
79 BOURRIAUD, Nicolás, Postproducción. La cultura como escenario: modos en que el arte reprograma el mundo contemporáneo, Adriana Hidalgo editora, Buenos Aires, 2009. p. 14. Semionauta: término usado por Bourriaud para definir el papel del artista contemporáneo y cuyo significado se acerca al de inventor de nuevos itinerarios al interior de un paisaje de signos, mismos que el artista proyecta sobre la cultura, considerada como el marco de un relato.

80 SPRINGER, José Manuel, "Topologías del paisaje mental. Un análisis a vuelo de pájaro de aquello que identifica al artista citadino de hoy", Disponible en red: <http://www.replica2 1 .com/archivo/articulos/s_t/345_springer_topo.html>, [Consulta 10, agosto, 2011].
} 


\subsection{E híbrido Arte y Naturaleza en México}

Por los múltiples restos arqueológicos sabemos que en el mundo prehispánico, el empleo de elementos vegetales en la representación tenía siempre una significación concreta y definida, que estaba vinculada directamente con la cosmovisión prehispánica. Tanto en el México antiguo, como en el actual, encontramos múltiples muestras plásticas de la importancia del mundo vegetal para las diferentes culturas. Doris Heyden, en su libro Mitología y simbolismo de la flora en el México prehispánico, nos habla de la importancia del mundo vegetal en el México prehispánico:

[...] la flora representaba la vida, la muerte, los dioses, la creación, el hombre, el lenguaje, el canto y el arte, la amistad, el señorío, el cautivo en la guerra, la misma guerra, el cielo, la tierra, y un signo calendárico. Acompañaba al hombre desde su concepción y nacimiento hasta su entierro. Evidentemente la flor fue uno de los elementos básicos en la comunicación simbólica prehispánica [...] era sinónimo de lo precioso ${ }^{81}$.

Asimismo, el antropólogo Guillermo Bonfill Batalla apunta cómo todo el territorio mexicano se ha visto profundamente marcado y transformado por la estrecha relación entre el hombre y la Naturaleza:

[...] todos los rincones del país, atestiguan la relación del hombre con esta Naturaleza desde un pasado remoto. Ese hacer incesante ha cambiado nuestro paisaje, a veces en forma espectacular, más comúnmente de manera sutil, lenta pero constante. La transformación de la Naturaleza incluye la creación de espacios adaptados para el desarrollo de la vida humana82.

Para el antropólogo, la interdependencia de estos vínculos son los responsables de que, en cierta manera, apenas se conserven paisajes vírgenes en México, puesto que los rastros del quehacer humano y del "antiguo transitar por estas tierras" del hombre mesoamericano, han dejado a lo largo de la historia, multitud de huellas de los lugares anteriormente habitados:

[...] desde las imponentes ruinas de las grandes ciudades hasta los vestigios más discretos de pequeñas aldeas bajo montículos que parecen naturales. Muchos poblados mexicanos hoy, han sido habitados continuamente desde siglos antes de la invasión europea ${ }^{83}$.

La necesaria sobrevivencia implica una inevitable relación que, sin duda determina las razones por las que la cosmovisión, el mundo sobrenatural y las fuerzas que escapan al control humano, adquieren un papel de primera

81 HEYDEN, Doris, Mitología y simbolismo de la flora en el México prehispánico, UNAM, Instituto de Investigaciones Antropológicas, México, D.F., 1985, p. 9.

82 BONFILL BATALLA, Guillermo, México Profundo. Una civilización negada, Grijalbo, México, D.F., 1994, p. 33.

83 BONFILL BATALLA, Guillermo, op. cit., p. 32. 
importancia. Para hacer comprensibles estas fuerzas, el ser humano les da cuerpo, encarnándolas en un repertorio de seres que simbolizan a las diferentes manifestaciones de la Naturaleza:

[...] los dueños de los manantiales, de los cerros, de las cuevas: los gobernantes de la lluvia y del relámpago; el animal cuya vida y suerte están indisolublemente unidas a la vida y suerte de cada recién nacido; los aires, la tierra misma. La relación con la Naturaleza se simboliza mediante el ceremonial destinado a propiciar a las entidades sobrenaturales que la representan 84 .

Todo ello se convertirá en rituales que darán la pauta para expresar simbólicamente $y$, de manera coherente, la participación del hombre en la unidad fundamental e indivisible del universo al que pertenece, una relación difícilmente escindible, en la que los límites se diluyen. Por otra parte, el sentido de pertenencia viene marcado por patrones de tiempo fuertemente vinculados con los ciclos agrícolas que describen espirales sin un fin determinado $y$, en los cuales, el adecuado comportamiento del ser humano es determinante para el correcto desarrollo de la vida.

La unidad con el cosmos se expresa también en otra dimensión trascendente: el tiempo. A diferencia de la concepción occidental, el tiempo en la civilización mesoamericana es un tiempo cíclico, no rectilíneo. El universo transcurre en una sucesión de ciclos que no son idénticos, pero que pasan por las mismas etapas, como en una espiral inacabable. Cuando un ciclo termina, otro similar comienza. El hombre cumple también su propio ciclo, que está en armonía con los demás ciclos del universo. Esa armonía necesaria se expresa ritualmente en las ceremonias del calendario agrícola que simboliza la renovación de la vida, en la que el hombre debe participar85.

Desde otro punto de vista como es la alimentación, podemos afirmar que las plantas fundamentales y características de la nutrición del hombre mesoamericano determinan también su modus vivendi. El maíz por ejemplo planta inventada por el hombre de estas tierras- ordena desde hace muchos siglos gran parte del territorio mexicano:

Una observación mínimamente alerta permite constatar la adecuación recíproca del maíz al hombre y del hombre al maíz en cualquier comunidad campesina de estirpe mesoamericana: la distribución de las casas, por ejemplo [...] en función de los requerimientos locales del cultivo del maíz [...]. Las casas mismas, en la distribución interna de los espacios, revelan la importancia central del maíz: siempre habrá un sitio para almacenar las

\footnotetext{
84 BONFILL BATALLA, Guillermo, op. cit., pp. 70-71.

85 BONFILL BATALLA, Guillermo, op. cit., p. 71.
} 
mazorcas, [...] un espacio para desgranar el maíz [...] el metate para elaborar las tortillas86.

Como podemos observar, siguiendo las referencias en las fuentes históricas del siglo XVI, desde entonces y hasta hoy, existe la creencia de que al igual que los hombres, las plantas en general, tienen alma; y de que los árboles, por ejemplo, fueron en otro tiempo hombres (razón por la que todavía existe la costumbre de saludarles y pedirles permiso para cortarlos o cualquier otra utilidad que los humanos les vayan a dar).

Culturalmente, Ilama la atención la metáfora que se establece en el mundo prehispánico en torno al tema de la flor y el canto (In xóchitl, in cuícatl), cuya traducción literal hace referencia a la poesía y el arte. La interacción de ambos conceptos se entiende como lo único verdadero en la tierra, lo que crea relaciones y acerca a los amigos: gracias a la flor y el canto, "sabemos que son verdaderos los corazones de nuestros amigos" 87 . Las relaciones entre la poesía, el arte y la flor están ampliamente documentadas por los historiadores mexicanos Ángel María Garibay y Miguel León-Portilla, quienes aluden directamente a esta metáfora -empleada en la rica lengua náhuatl- para designar lo que hoy conocemos como arte. En el calendario mexicano antiguo uno de los días se llamaba xóchitl (flor), signo, como veremos más adelante de la diosa de las flores y la primavera, Xochiquétzal 88 .

Anticipando ciertas soluciones que veremos posteriormente en el ámbito del arte contemporáneo mexicano, es de destacar la importancia del pensamiento analógico de las sociedades primitivas, puesto que esta forma de pensar es también la de los antiguos mexicanos, así como en general, de las antiguas culturas, es lo que habitualmente se conoce como pensamiento mágico. En este sistema de pensamiento, el procedimiento que seguían los humanos para obtener el favor de los dioses, era hacer ofrendas, mediante representaciones en miniatura de las cosas o favores que solicitaban -entiéndase una casa, animales, curaciones, etc.- y, elaborándolas en barro o de cualquier otro material, eran depositadas como ofrendas en los lugares habilitados para el culto. De aquí proviene la costumbre que se mantiene aún hoy en día, de los conocidos como exvotos, si bien estas pequeñas figurillas que se depositaban en los lugares de culto tienen su origen en las civilizaciones egipcias y mesopotámicas. Es de destacar que como un claro ejemplo de la interacción entre ser humano y las plantas, el sistema curativo entre los habitantes nahuas del Altiplano Central de México abunda en procedimientos curativos de este género. Siguiendo los procesos de la magia imitativa, numerosos ejemplos llegados hasta nuestros

\footnotetext{
86 BONFILL BATALLA, Guillermo, op. cit., p. 34.

87 LEÓN PORTILLA, Miguel, Los antiguos mexicanos a través de sus crónicas y cantares, Fondo de Cultura Económica, México, D.F., 2005, pp. 146-151.

88 L. VELASCO LOZANO, Ana M. a y NAGAO, Debra, "Mitología y simbolismo de las flores", en Arqueología mexicana. Las flores en el México prehispánico, Vol. XIII, № 78, INAH, CNCA, Raíces, México, D.F., marzo-abril, 2006, pp. 28-35.
} 
días, dan cuenta y pueden ser agrupados, de acuerdo con el principio de que lo semejante, atrae o produce a su semejante.

Todo tratamiento mágico se dirige a las entidades espirituales -que son la realidad última de los fenómenos- y nunca a los fenómenos en sí mismos, lo que implica que los elementos terapéuticos deben ser reunidos en épocas determinadas, así como por las personas adecuadas, siguiéndose toda una serie de pasos sucesivos en su recolección y preparación. En ocasiones, el aspecto o la forma de la planta son fundamentales en los procedimientos curativos de este tipo, ya que estas particularidades establecen una semejanza que, aunque reducida a los aspectos morfológicos, es sin embargo decisoria. Como ejemplo de ello, el parecido en la forma de la planta yolloxóchitl o flor del corazón, (Talauma mexicana), da pie a que esta planta se utilice para tratar las enfermedades del corazón. Otras plantas como el tzotzoca íhuit/ o hierba de las verrugas (Euphorbia helioscopal) por sus hojas llenas de excrecencias, sirve para curar las verrugas. En otras circunstancias, la semejanza se establece con respecto no tanto a la forma, sino a las cualidades propias del elemento terapéutico: el cuauhaláhuac o árbol resbaloso (Grewia Terebinthimacea), es utilizado para los partos difíciles; el tonatiuh íxiuh o hierba del sol, (Malvaviscus), en el tratamiento del miedo patológico con el fin de trasmitir las características solares de la planta al enfermo:

Propiedades adquiridas y después de ello trasmisibles serían las que se buscaban en las hierbas y fragmentos de árbol sobre los que había caído un rayo, para curar a los "asustados" por el propio rayo, o de hierbas reverdecidas en un jardín que se hubiera quemado, para las quemaduras por rayos 89 .

Condenadas a ser parte de supercherías y supersticiones, este tipo de creencias han sido superadas en la actualidad por la Ciencia y la medicina en la mayoría del mundo occidental, sin embargo, en muchas partes de México podemos observar todavía cómo estas relaciones siguen siendo utilizadas y forman parte de la cotidianeidad de la gente del pueblo. Con todo ello, concluimos que los vínculos entre la naturaleza vegetal y el ser humano, se evidencian a lo largo de toda la historia de la representación y hasta nuestros días, a través de analogías tanto visuales, como formales, presentes en la mayoría de las culturas.

En paralelo y, desde el punto de vista iconográfico, la figura vegetalizada, más allá de constituirse como elemento decorativo u ornamental, ha sido muy utilizada en todas las épocas. Entre otras, la planta del acanto ha servido desde la época clásica, para manifestar esta relación. Sus hojas generan ritmos y composiciones que podemos apreciar tanto en escultura como en pintura o en arquitectura, produciéndose en ocasiones, una suerte de elementos híbridos entre plantas y humanos. En Occidente encontramos ejemplos de hibridación en

89 MARTÍNEZ CORTÉS, Fernando et al., Historia General de la Medicina en México, Tomo 1 , México Antiguo, UNAM, Facultad de Medicina, Academia Nacional de Medicina, México, D.F., 1984, pp. 205-207. 
los roleos, motivos conocidos en el Mediterráneo antiguo, mezcla de elementos vegetales y partes humanas. Los roleos con formas humanas se difunden desde el románico italiano hasta la arquitectura gótica de Chartres y Nótre-Dame. La planta con torso humano se adapta a todo un sistema religioso y simbólico, el medieval, fusionando el aspecto decorativo y fabuloso de Oriente, con la corriente clásica. De esta manera, los herbarios de los siglos XIV y XV recogen estos arquetipos, así como las iluminaciones que aparecen en los textos manuscritos como el Hortus Sanitatis (Lübeck, 1492), Hortus Deliciarum (hacia 1205) y Maravillas de la Naturaleza (manuscrito supuestamente persa del s. XIV) ${ }^{90}$. Los cristianos armenios, los coptos, las miniaturas persas y sirias contribuyeron al renacimiento de estos híbridos que se introducen en Occidente desde los siglos VI al VIII. La supervivencia helenística de estos motivos se presenta en Italia durante el siglo VIII por la influencia de los tejidos mesopotámicos e iraníes, así como también en el arte celta que se inspiró en los tejidos coptos. En general, conocemos los elementos fitomorfos, de aspecto o forma vegetal, incluidos como decoración o adorno en diferentes textos impresos. Estas representaciones reproducen la forma de algún vegetal o planta como elemento compositivo. Pero también encontramos la reunión de ambos mundos en diferentes expresiones artísticas.

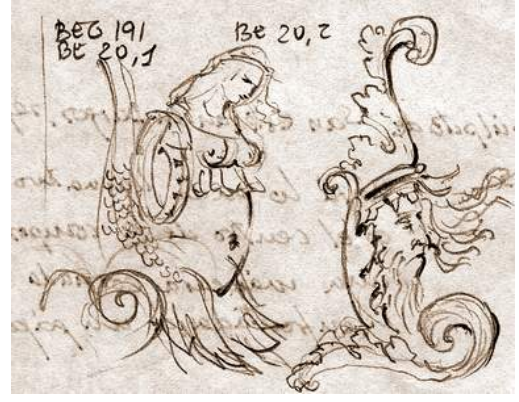

Zoan Andrea,

Transformación del acanto, 1500.

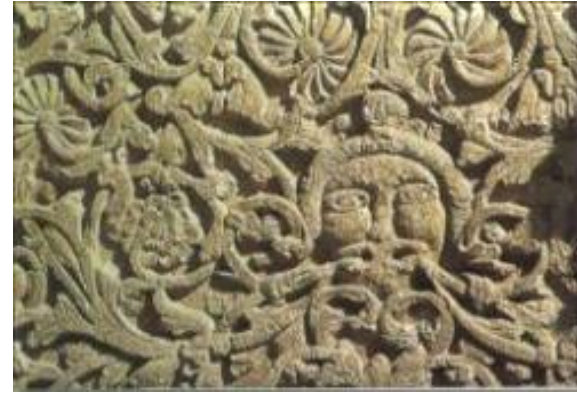

Anónimo, Trabajo indígena en la Iglesia de Santo Domingo en Oaxaca, 1608.

En México, durante la época posterior a la Colonia, podemos observar representaciones de este tipo de hibridaciones, en el meticuloso trabajo indígena realizado en la Iglesia de Santo Domingo en la ciudad de Oaxaca, ejemplo de la escultura barroca novohispana. Asimismo, y en general, podemos encontrar numerosos ejemplos de hibridación en la pintura de los grandes maestros. El cuadro El Jardín de las Delicias (1480-1490), tríptico del Bosco perteneciente a la colección del Museo del Prado de Madrid, está compuesto por una tabla central y dos laterales pintadas a ambos lados en óleo sobre tabla. Ésta es considerada una de las obras de arte de mayor simbolismo, cuya lectura se sustrae a cualquier clasificación iconográfica tradicional mostrando una

90 LORDA, Joaquín, "El repertorio a la romana: Las transformaciones del acanto", Departamento de Teoría e Historia, Escuela de Arquitectura, Universidad de Granada, Disponible en red en: <http://www.unav.es/teohistarq/histarq/MEb/romana/candelabro. html $>$, [Consulta 3, febrero, 2008]. 
interesante relación del ser humano con los vegetales. Si en el panel central apreciamos una relación armónica entre unos y otros, en la tercera parte del tríptico aparece curiosamente un híbrido de hombre árbol que representa al infierno.

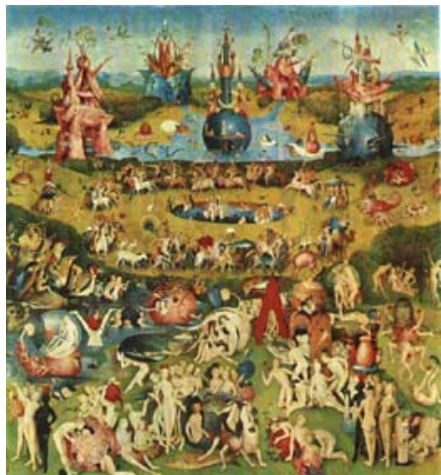

El Bosco, El Jardín de las Delicias, 1480-1490.

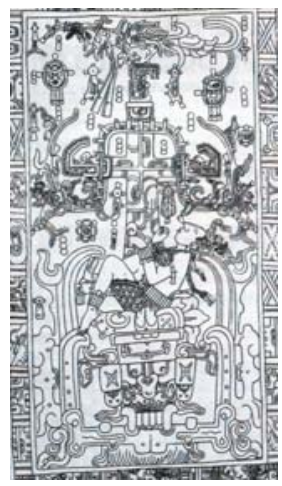

Cultura maya, Lápida de Pacal, 683 d. C.

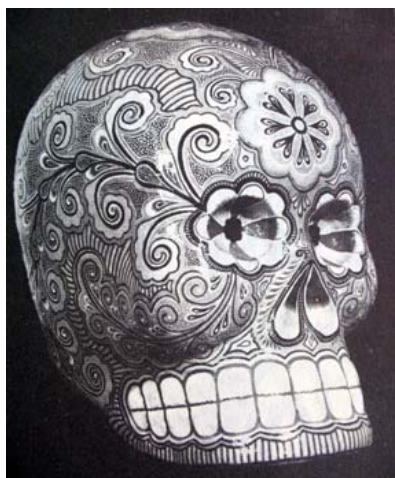

Cráneo de azúcar, decorado con motivos vegetales, 2007.

En Mesoamérica, México y en toda la Cultura prehispánica es común la iconografía de dioses y humanos que muestran rasgos botánicos en su configuración, tanto en la cosmovisión y mitología del origen de dioses y humanos, como en ciertos monumentos públicos. En la genealogía de los mixtecos representada en el Códice Vindobonensis se observan personas creciendo de las raíces de los árboles, ilustrando de esta manera, uno de los mitos origen de los mixtecos. Algo similar sucede en la Cultura maya, donde encontramos casos como por ejemplo, el relieve de Pacal. En la lápida esculpida que cubre el sarcófago del gobernante Pacal y que se encuentra debajo de la pirámide del Templo de las inscripciones (Palenque), podemos apreciar la representación del personaje Ilamado Pacal llegando al nivel terrestre, guiado por el tronco de un árbol sagrado como personificación del dios patrono de la agricultura, K'awiil.

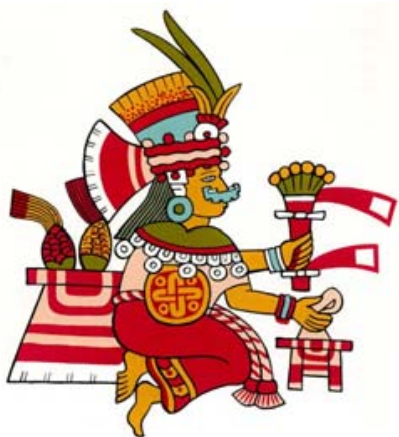

Xilonen, Códice Maglabecchiano, 1562.

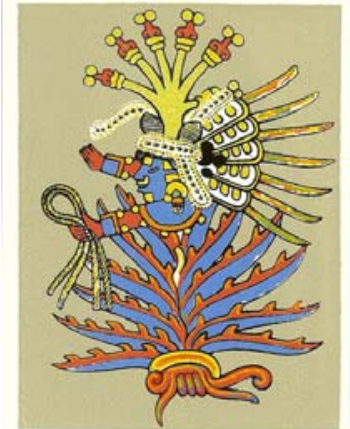

Mayáhuel, Códice Borbónico, 1562. 
Múltiples y variadas son las deidades mesoamericanas que muestran rasgos vegetales, entre ellas la diosa de la vegetación Chicomecóatl, que aparece representada con mazorcas de maíz. Centéotl es el dios del maíz en general, pero según las edades de la planta se representa en la iconografía prehispánica como semilla Xilonen, una mujer joven o como mazorca seca, Ilamatecuhtli, "la señora de la falda vieja"91, cubierta por las hojas secas y amarillas. Mayáhuel, diosa del pulque, originariamente representaba ciertas plantas que se ponían al pulque para ayudar a la fermentación. Se representa como creciendo de un maguey, del que los aztecas extraían las hojas y las espinas para la elaboración del pulque ${ }^{92}$.

Muy íntimamente relacionado con Centéot/ está Xochipilli, dios de las flores, del amor, de la primavera, de la música y de la danza, se le representa adornado con flores y mariposas. Xochiquétzal, diosa de las flores, "la flor de pluma rica", es la personificación de la belleza y del amor. Xochipilli y Xochiquétzal eran adorados principalmente por los xochimilcas quienes cultivaban en sus jardines flotantes flores y plantas para el consumo de templos y palacios de Tenochtitlán ${ }^{93}$. Tláloc, dios de la lluvia, está representado en el mural de Tepantitla en Teotihuacan-Tetitla94, rodeado de una exuberante vegetación en lo que es considerado el paraíso de los ahogados o de los que mueren por causas relacionadas con el agua.

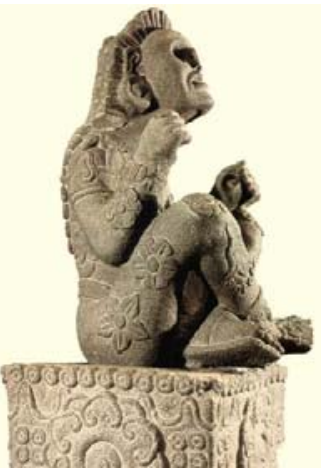

Xochipilli.

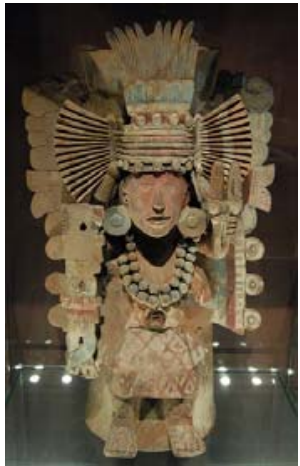

Xilonen.

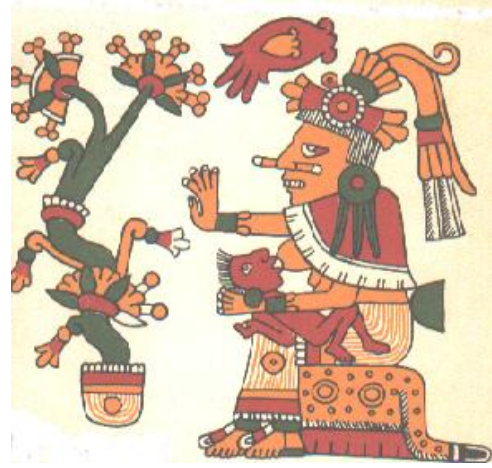

Xochiquétzal.

Podemos comprobar así, cómo la cosmovisión de los antiguos mexicanos está basada en la idea de que el cosmos es un todo unitario. En este todo, se incluyen todos los elementos que el hombre puede percibir, incluso aquellos que escapan a su entendimiento, desde el cielo, la tierra, el mundo inferior, los dioses, los hombres y la Naturaleza. Todos ellos se encuentran íntimamente

91 Véase CASO, Alfonso, El pueblo del Sol, Fondo de Cultura Económica, México, D.F., 1987.

92 Bebida alcohólica.

93 Capital del imperio mexica o azteca.

94 URIARTE, M. ${ }^{a}$ Teresa, "Flores en la pintura prehispánica", en Arqueología mexicana. Las flores en el México prehispánico, Vol. XIII, N 78 , INAH, CNCA, Raíces, México, D.F., marzo-abril, 2006, pp. 36-41. 
ligados mediante una infinita serie de relaciones. De la misma manera, el mundo vegetal está presente no sólo en sus aspectos alimenticios, curativos, medicinales u ornamentales, sino que también se nos presenta con vida y características mágicas. Por ejemplo el tabaco es una planta considerada mágica por tener la propiedad de hacer visible lo invisible: el aliento95. Posteriormente, el Virreinato Colonial en México ofrecerá numerosas imágenes en las que podremos constatar la relación humano-vegetal en imágenes que representan híbridos, procedentes de la tradición europea, como por ejemplo, los árboles genealógicos de la orden de los franciscanos y dominicos.

En la imaginería novohispana, los motivos vegetales son constantemente recurrentes, en parte, ello es debido a la gran importancia que plantas y flores tenían en el mundo prehispánico. En los tratados de herbolaria y medicina elaborados por los sabios indígenas apreciamos el gran conocimiento que éstos tenían del mundo vegetal. En un fresco de la Iglesia de Ixmiquilpan observamos dos figuras, una de ellas representa a un caballero jaguar, el cual como vencedor en la contienda sujeta con su mano derecha a un guerrero vencido, puesto que éste es llevado por los cabellos. Ambos personajes surgen de una planta en alusión probablemente a la guerra florida.
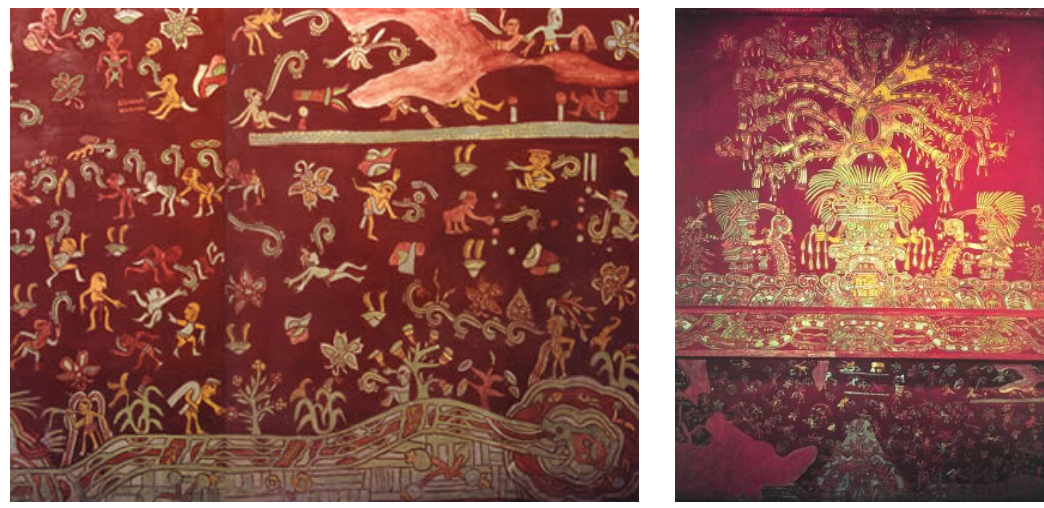

Mural de Tepantitla, El paraíso de Tláloc, o Tlalocan (100-700 a. C.).

Asimismo, en el interior del templo y Ex-Convento de Santo Domingo (Oaxaca), cuya construcción duró desde 1570 hasta 1666, encontramos el ejemplo más notable del barroco mexicano. En sus muros y bóvedas, adornados con yeserías realizadas en el siglo XVII, encontramos en la parte baja del coro, una abigarrada composición de personajes, representación alegórica del árbol genealógico de Santo Domingo de Guzmán. La representación de la familia en un árbol genealógico es un motivo bastante tardío, pero en el México novohispano podemos encontrarlo en numerosos ejemplos de los techos de las iglesias como en Santo Domingo, donde encontramos una representación barroca de la orden de los dominicos surgiendo de un árbol. Podríamos establecer un posible origen de esta iconografía en relación con ciertas

95 Véase WESTHEIM, Paul, Ideas fundamentales del arte prehispánico en México, Biblioteca Era, Serie mayor, México, D.F., 1986. 
representaciones alquímicas más antiguas, vinculadas posiblemente con el personaje mítico de Pandora.

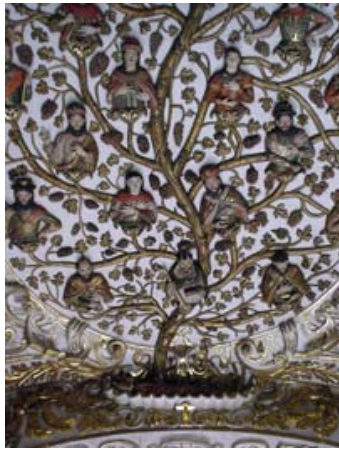

Iglesia de Santo

Domingo, Oaxaca,

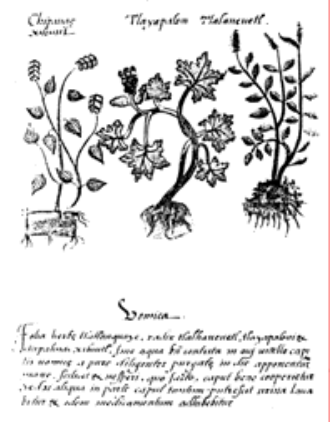

Fragmento del Códice de la Cruz-Badiano, 1552.

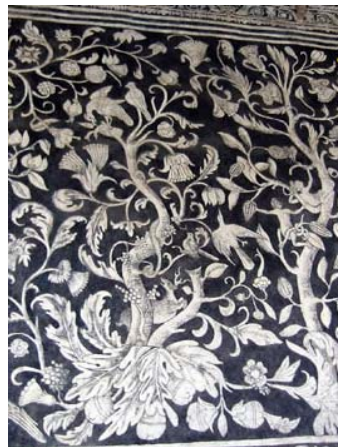

Frescos del Convento de Malinalco, 1540.

1570-1666.

En los siglos XIV y XV encontramos representaciones en las cuales la conexión entre lo humano y lo vegetal establece una suerte de analogías mágicas. En la visión del nacimiento de Adonis, que aparece en las Metamorfosis de Ovidio, éste surge del árbol de la vida. El árbol, muy representado en toda la historia del arte, tiene múltiples significaciones tanto en la Biblia y en el pensamiento pitagórico como en la tradición de las leyendas árabes. Este tipo de relaciones tiene una larga trayectoria en la imaginería tradicional y antigua de México. El prototipo de la mayoría de estas genealogías es el árbol de Jesé, que en la tradición mística europea es una representación simbólica de la genealogía o del linaje de Cristo, situándolo a éste como descendiente de la figura de Jesé. El árbol de Jesé representa la conjunción de los dos aspectos del simbolismo del árbol. Es un árbol macrocósmico, pero a la vez refleja la relación del hombre y el vegetal. El origen de este tema es un episodio que la Biblia no refiere directamente: el sueño en que Isaí o Jesé, padre del rey David, habría visto salir de su vientre un árbol -especie de árbol genealógico- de cuyos nudos surgían sus descendientes a manera de antepasados del Mesías. El fragmento del libro de Isaías da cuenta de que Yavheh sacude el ramaje del árbol de Jesé y que de su tronco surge un brote y de sus raíces, una flor. El tronco de Isaías no es otra cosa que el árbol de Jesé, de cuyo linaje real procede la rama que da origen a la Virgen María y a su retoño, Cristo. Olivier Beigbeder relaciona el origen de la fórmula del árbol tipológico de Jesé -si bien el motivo era conocido anteriormente por el Románico- con el Arte Gótico, cuando se codifican los atributos y aspectos iconográficos característicos de este motivo, alcanzando un desarrollo sin precedentes 96 . Beigbeder, minimizando la relación que en su momento estableció E. Mâler, - quien atribuía a Suger el descubrimiento de la fórmula iconográfica de Jesé- lo identifica, junto con el sacerdote Corblet, con la analogía de Dios -en el libro del Génesis- sacando a Eva de la costilla del dormido Adán.

96 BEIGBEDER, Olivier, op. cit., pp. 47-51. 


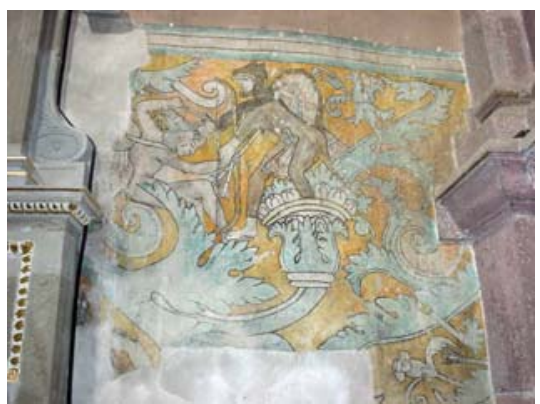

Frescos en la Iglesia de Ixmiquilpan, México, S. XVI.

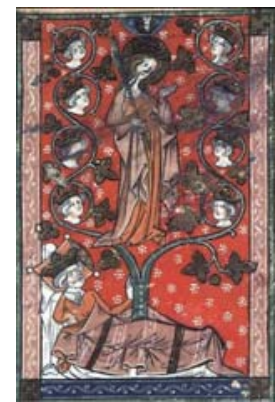

Guyart des Moulins, Árbol genealógico de Jesé, S. XIV.

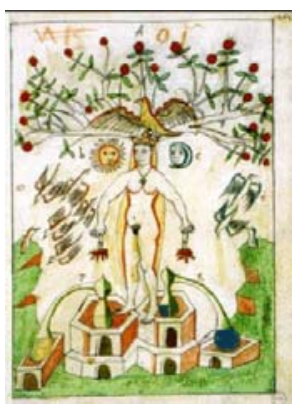

Manuscrito de alquimia,

Pandora, 1550.

En Occidente, desde la Edad Media, pasando por las imágenes de grutescos en las fachadas y el interior de las iglesias, hasta los artistas del siglo XX como Max Ernst, Salvador Dalí y Paul Delvaux el recorrido y la nueva visión que presenta este tipo de manifestaciones es sorprendente. Durante el siglo XX con los surrealistas, encontramos numerosas imágenes de híbridos entre humanos y plantas en las que podemos apreciar una cierta percepción de lo femenino vinculado estrechamente con la Naturaleza. Sin embargo casi todos los ejemplos presentan un hilo conductor que parece hablarnos de la continuidad de una misma ideología: la estrecha relación entre la Naturaleza y el mundo de la mujer. Podemos inferir que esta tendencia responde a una especial transferencia simbólica de cualidades en la que en ambas direcciones se asocia a la mujer con elementos vegetales.

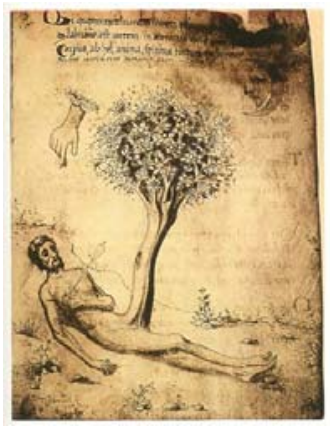

Árbol de Jesé, Códice Ashburnhan, S. XIV.

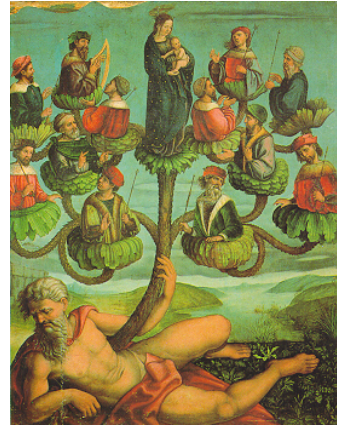

Árbol de Jesé y antepasados de la Virgen María, S. XV.

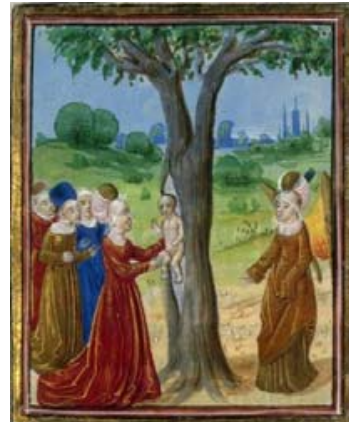

Nacimiento de Adonis,

Hoja 142, Metamorfosis de Ovidio, S. XV.

En 1931 Dalí por ejemplo, nos presenta un retrato en el que de la cabeza de Gala, su esposa, surge una espesa vegetación, hipotéticamente aludiendo al énfasis creativo. También, en la obra de Paul Delvaux, El descanso del día (1937), cuatro mujeres ensimismadas aparecen dialogando, pero sus cuerpos 
surgen de sendos árboles que se encuentran firmemente amarrados a la tierra por sus raíces, como habitualmente se identifica también a la mujer.

La investigadora Nancy Deffebach (Universidad de San Diego, Estados Unidos), nos presenta en un interesante artículo aparecido en la revista Curare ${ }^{97}$ un estudio - uno de los pocos dentro de la historiografía del arte en México- en el que se tratan este tipo de relaciones analizando estos aspectos y revisando las imágenes en las que se representan híbridos entre vegetales y humanos. El análisis está centrado en el contexto de la pintura y la literatura mexicanas de mediados del siglo XX, en particular, en ciertas obras de Frida Kahlo y Leonora Carrington. Se trata de obras específicas que representan seres con rasgos tanto humanos como vegetales. La autora estudia las cuestiones que estas imágenes proponen, localizando sus orígenes formales e históricos. Explora las similitudes y diferencias en la manera de abordar la cuestión entre ambas artistas. También compara estas imágenes con otras realizadas por dos artistas masculinos contemporáneos de ellas, el pintor Diego Rivera y el poeta Carlos Pellicer. Todos ellos fueron quienes utilizaron con mayor frecuencia el concepto de hibridación humano-planta en la pintura y la literatura respectivamente. En este ensayo la palabra híbrido se usa en el contexto de la historia del arte y no en su sentido botánico u otras acepciones del arte más contemporáneo. Se refiere en particular a las figuras en las que vemos representados elementos de dos o más especies de reinos, como por ejemplo la escultura Dafne y Apolo (1622-1624) de Gianlorezo Bernini, en la que la ninfa se transforma en árbol para refrenar los impulsos sexuales del dios.

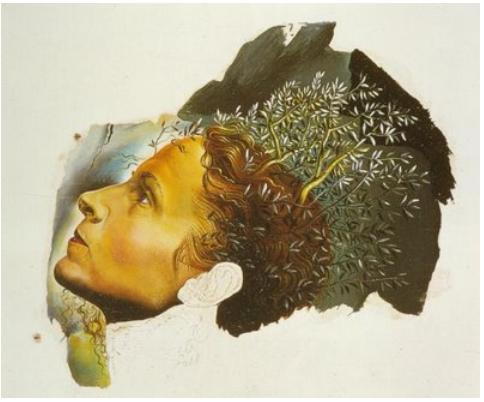

Salvador Dalí, Automatismo a partir de un retrato de Gala, 1932.

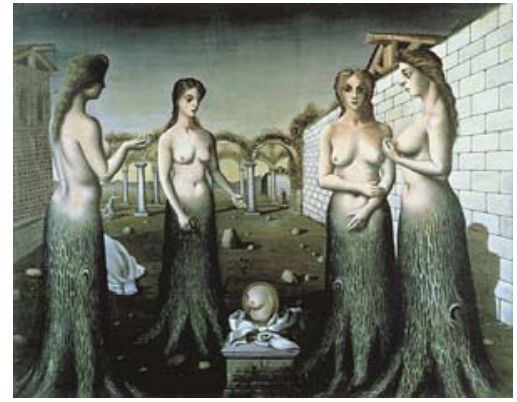

Paul Delvaux, El descanso del día, 1937.

La historiadora Deffebach examina con mirada incisiva, cada uno de los trabajos pero a la vez, como a vista de pájaro, mantiene una visión del concepto de híbrido, analizando las obras en conjunto. Las razones que nos plantea para llevar a cabo la investigación son por un lado, el fuerte impacto -afirma la investigadora- que las obras de cada uno de los artistas analizados tenían entre los otros artistas y, por otro lado, la relación entre género y Naturaleza que

97 DEFFEBACH, Nancy, "Images of Human-Plant Hibrids in the Art of Frida Kahlo and Leonora Carrington", en Curare, Espacio crítico para las artes, № 11 , México, D.F., 1997, pp. 95-129. 
presunta y frecuentemente, presentan los híbridos humano-planta. Estas apreciaciones se vuelven más evidentes al abordar el estudio de las obras de manera colectiva.

La autora afirma que este tipo de híbridos están muy presentes en general en las obras más importantes del modernismo mexicano. Los temas abordados en esta metáfora son la generación, el crecimiento, la transformación y el conocimiento. El artículo concluye que la mayoría de estos trabajos no buscan establecer directamente una relación entre género y Naturaleza de manera explícita, sino que sólo exteriorizan el modo en que cada artista enfoca la temática. Al parecer, en el México de esa época, la construcción de géneros y su relación con la Naturaleza se hacía desde diferentes enfoques. Según Deffebach, en el mural de Diego Rivera en Chapingo, el hombre es asociado con la Cultura, mientras que la mujer se relaciona con la Naturaleza, pero la manera en la que en otras imágenes, se presenta esta cuestión, ejemplifica que claramente hay otros artistas que abogan por una relación entre el ser humano y el reino vegetal no específicamente de género. Algunas de las imágenes comentadas en el artículo, en la actualidad, podrían parecernos sexistas, sin embargo la investigadora advierte de la existencia de otras que abordan la temática desde la igualdad de género. A su modo de ver, entre las imágenes de híbridos humano-vegetal que realizaban los surrealistas europeos contemporáneos, hay mayor afán por imponer estereotipos de género que en los artistas citados del arte mexicano de principios del siglo XX.

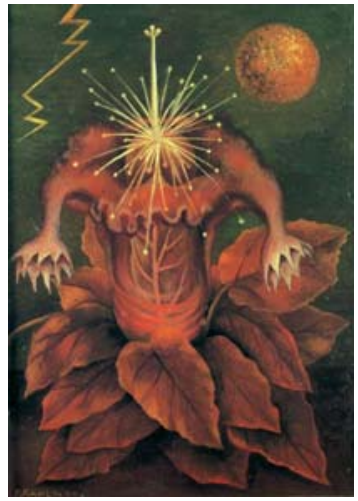

Frida Kahlo,

Flor de la vida, 1944.

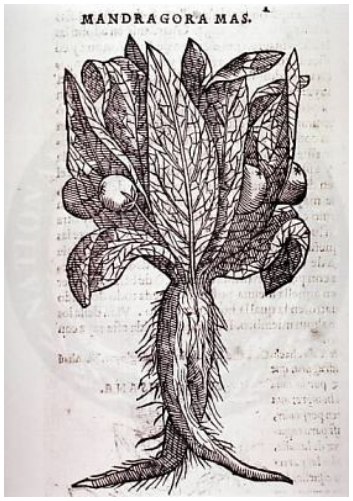

Teodor Clutius, Mandrágora, S. XVI.

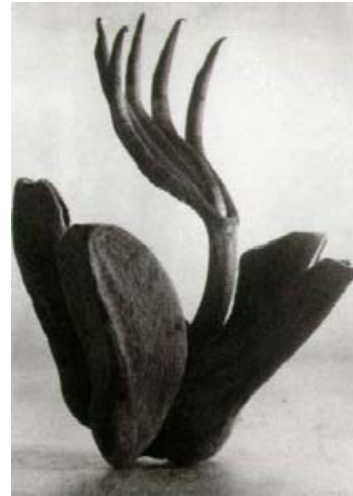

Tina Modotti,

Flor de manita, 1925.

Una planta la mandrágora, Mandragora officinarum, una de las más famosas plantas medicinales de la Antigüedad, conocida ya por los asirios, puede haber sido la fuente de inspiración para Frida Kahlo en el cuadro Flor de la vida (1944). La forma de la raíz bifurcada de esta planta, parecida a un cuerpo humano, favorecía que se le atribuyeran propiedades mágicas. Numerosas leyendas árabes conceden especial importancia al árbol de la vida, sobre todo bajo la forma de la mandrágora, raíz humana y vegetal a la vez, ya que se trata de un vegetal frondoso del que sale la vida en todas sus formas. En el México 
prehispánico tenemos un caso similar en la llamada flor de la manita, cuya forma antropomórfica le da nombre. Así, desde la perspectiva simbólica, las formas de las plantas son símbolos de los genitales masculinos y femeninos. Por ejemplo, en la obra Las tentaciones de San Antonio (1947), de Diego Rivera, los vegetales en este caso rábanos, muestran formas antropomorfas de ambos sexos.

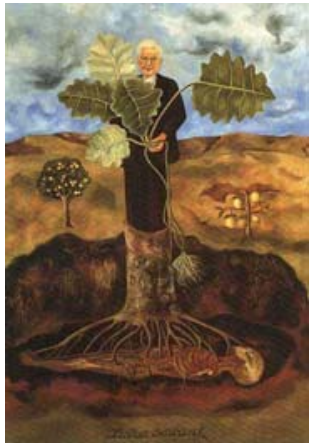

Frida Kahlo, Luther Burbank, 1931

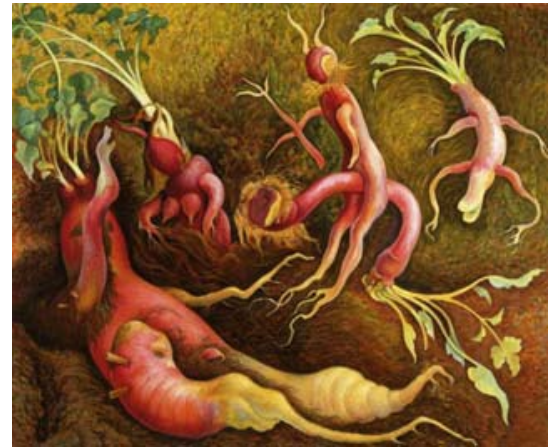

Diego Rivera, Las tentaciones de San Antonio, 1947.

En los murales de la Capilla de la Universidad Autónoma de Chapingo, (México), Rivera realiza un fresco en torno al ciclo Canto a la tierra (La revolución natural). Para ello, adapta su composición a una ventana circular que hay en el muro, haciendo que, de una especie de concavidades figuradas, aparezcan desnudos femeninos y un niño, en forma de fetos y en diversas posiciones, los cuales aparentan estar dentro de la tierra. Estos cuerpos, que representan tanto a las semillas de las plantas, como a las fuerzas germinativas de la Naturaleza, se encuentran en diferente grado de desarrollo.

De esta manera, Diego representó a las semillas con cuerpo de mujer, en virtud de que la mujer tiene la capacidad biológica de ser fecundada y, por ello, llevar en su seno el germen de la vida. Se subraya la idea de que al sembrar la semilla, ésta se desarrolla dentro de la tierra, lo cual quedó representado por la mujer del centro, como la planta elemental. Si se compara este tablero con el de enfrente, que corresponde al tercero del desarrollo de la sociedad, el líder campesino está señalando que la semilla de la nueva sociedad está sembrada. Por ello, para que se desarrolle la vida en la Naturaleza, se necesita la semilla, y para que se desarrolle la sociedad, es necesaria también la "semilla", representada aquí como símbolo social e idea del cambio.

En general $y$, siguiendo el artículo de Deffebach en lo concerniente a la imaginería que en el siglo XX relaciona humanos y plantas, la autora afirma que esta suerte de imágenes puede provenir de los surrealistas y de sus creencias en los procesos mágicos. 


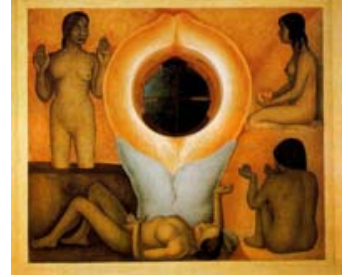

Diego Rivera,

Maduración, 1927.

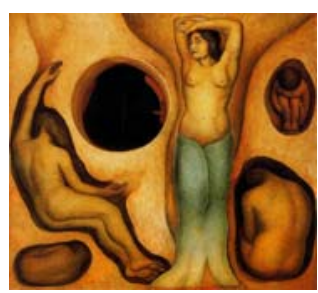

Diego Rivera,

Germinación, 1927.

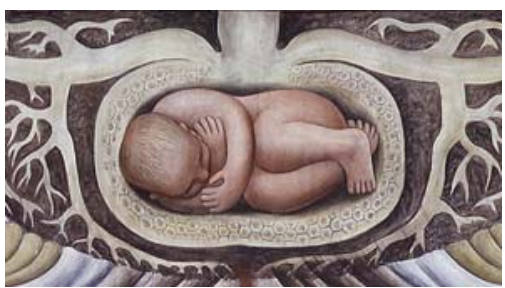

Diego Rivera, Niño naciendo del bulbo de una planta, 1933.

La idea de algunos surrealistas es que la mujer está más cerca de los procesos de la Naturaleza que el hombre, convirtiendo así la dialéctica en una cuestión de género. Sin embargo entre los surrealistas del siglo XX en México, esta relación no se manifiesta de la misma forma. A este respecto, la obra más significativa en torno a la relación entre género y vegetales, no vinculada específicamente con lo femenino, la encontramos en el retrato de Luther Burbank (1931) de Frida Kahlo, donde como contrapartida, podemos apreciar un hombre emergiendo de un árbol. Presumiblemente Frida tuvo conocimiento y admiración por la investigación botánica de este biólogo horticultor. El cuadro presenta al científico saliendo de un árbol en el cual se plantea el dualismo entre vida y muerte.

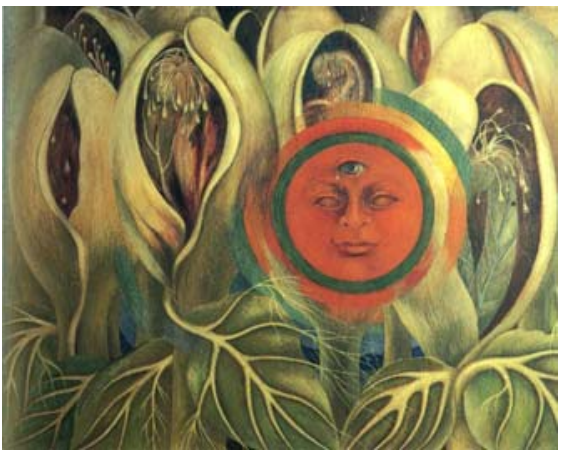

Frida Kahlo, El sol y la vida, 1947.

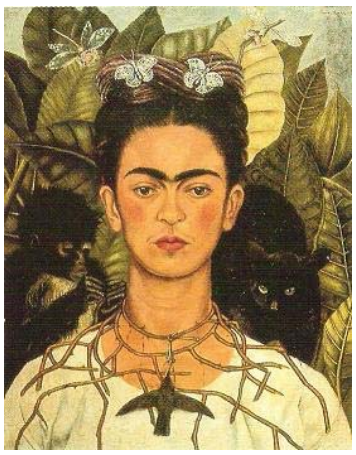

Frida Kahlo, Autorretrato

con collar de espinas, 1940.

En otros cuadros con temática similar como Raíces (1943) y Flor de la vida (1944), la artista presenta plantas de una manera antropomórfica, relacionando humanos con vegetales. En la obra Raíces (1943), se retrata a sí misma reclinada en un paisaje árido, las raíces emergen de su cuerpo como venas rojas, proclamando de esta manera, la continuidad de la vida. Esta imagen revela la necesidad de Frida de asumirse como Naturaleza y su reconocido deseo de tener un hijo. A través de su pintura, la artista quiere que el milagro de la Naturaleza se haga patente en el paisaje de su cuerpo. Con esta obra, Frida se acerca a un tipo de iconografía que funde imágenes de la iconografía indígena prehispánica, con la iconografía europea clásica. Estamos ante un planteamiento cultural híbrido, mitad indígena y mitad europeo. En Flor de la vida (1944), establece una asociación entre la parte reproductiva de la planta y el aparato reproductor femenino: el útero aparece rodeado de hojas. Estas analogías visuales plantean 
un paralelismo entre el macrocosmos y el microcosmos, estableciendo de esta manera vínculos entre la fertilidad humana y la vegetal.

Por otro lado, en las series realizadas por Diego Rivera en los muros de la Universidad de Chapingo en México, vemos que el mural de la Germinación (1927), presenta figuras femeninas, aunque también de niños y en opinión de Deffebach, se puede reconocer la figura de Tina Modotti saliendo de un árbol verde. En otras obras de Rivera observamos que el pintor no se ciñe nada más a una cuestión de género en la relación humano-vegetal. En sus murales, como hemos visto aparecen también niños, aunque éstos presentan una imagen embrionaria o de semilla, como por ejemplo en el mural Niño naciendo del bulbo de una planta (1933), realizado en Detroit.

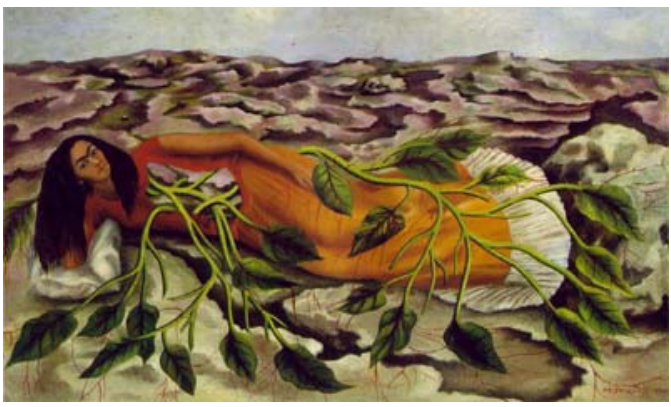

Frida Kahlo, Raíces, 1943.

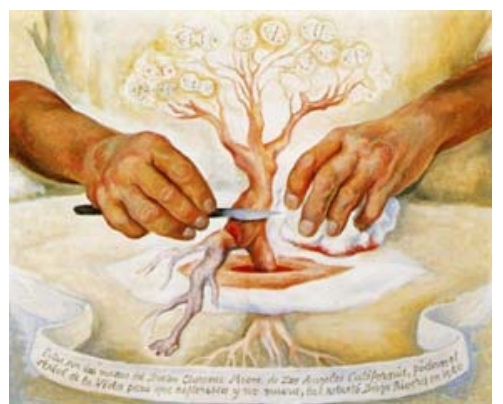

Diego Rivera, Las manos del Dr. Moore, 1940.

En este sentido, destaca también la obra Las manos del Dr. Moore (1940), realizada por Rivera en la que podemos observar en un primer plano, las manos del doctor Clarence Moore, en ella se puede observar un planteamiento sexista puesto que el árbol representado sugiere una forma femenina. En lugar de hojas, el árbol presenta células, indicando un tipo de crecimiento diferente. Una de las raíces o piernas de este árbol, en su carácter antropomorfo, está siendo cortada por las manos del cirujano. Con un color morado diferente al resto de la planta se nos muestra una parte enferma de la misma y la sección producida por el corte de la que mana, aparentemente sangre.

\subsection{La presencia de lo vegetal en el arte contemporáneo.}

El arte contemporáneo ha incursionado ampliamente en torno al binomio Naturaleza y Cultura. Sin embargo como dice el refrán "para que el árbol no te impida ver el bosque", antes de analizar el panorama de la escultura y los eventos escultóricos en México que han motivado esta investigación, hemos querido realizar un periplo no sistemático por diferentes ámbitos geográficos. Hemos encontrado que en diferentes lugares, el interés detectado por lo vegetal en el arte es fruto de una inquietud que los artistas manifiestan ante los cambios y vivencias que se están experimentando en los últimos años. Tras los grandes movimientos artísticos de Arte Povera, Land Art, Earth Works y sus 
subsiguientes manifestaciones, y fuera de los grandes circuitos de arte consagrado al respecto, en la actualidad se mueven un nutrido círculo de creadores que perpetúan ciertos conceptos instaurados por estos movimientos. Numerosos artistas tienen como referencia en su obra todas aquellas consideraciones que promulgaban estos movimientos. La inclusión de materiales desechables, efímeros o pobres en el Arte Povera, como en otro tiempo se denominaban todos aquellos que no fueran la piedra, la madera o el bronce, es una fuente de inspiración para muchos artistas, aunque con distintos planteamientos.

Debido a las circunstancias económicas actuales de migraciones y movimientos humanos, de tecnologías y economías globalizadas, llegan hasta nosotros información en torno a obras y productos que en otro tiempo no eran fácilmente accesibles a todos. Habitualmente se considera el Land Art como la culminación de los puntos de partida y de los pretendidos presupuestos históricos tanto del arte ecológico como del Arte Povera. Como puntos de partida, estas tendencias artísticas sirvieron para abrir el contexto del arte hacia una realización más conceptual, las obras que integran esta definición abandonan el marco del estudio, de la galería o del museo para materializarse en contextos naturales. La exposición Earthworks en la galería Dwan de Nueva York, en 1962, consolida esta tendencia como tal. El arte de la Naturaleza tiene sus antecedentes en el trabajo de artistas como Manzoni, Fautrier, Dubuffet o Tapies quienes anteriormente ya habían utilizado en sus obras materiales tales como arena, tierra, piedras y cantos rodados, como un claro referente al medio natural. Pero sería con la llegada del Land Art y del arte de la Naturaleza o Natur-Kunst (Arte de la Naturaleza) con Timm Ulrichs, cuando la obra sale del interior de la galería al medio ambiente, y cuando la Naturaleza, considerada tanto como material y como espacio de intervención, se reivindica como elemento conformador de la obra. Ulrichs realiza las obras Colores de camuflaje (1969) y Ataques quirúrgicos del árbol (1971), manteniéndose en la línea europea de un arte de la Naturaleza de pequeñas dimensiones.

Para Simón Marchán Fiz ${ }^{98}$ el Land Art es en general, la versión anglosajona del Arte Povera. Si el Land Art expresó el momento culminante de autoafirmación de la Cultura tecnoindustrial, por la grandeza de sus proyectos y la evidencia física de las formas, en contrapartida en la parte europea se desarrolla paralela y simultáneamente, lo que se ha denominado Intervenciones mínimas. La tendencia en este arte es intervenir en la Naturaleza prácticamente sin que se note, haciendo de la fragilidad un instrumento de defensa del lugar, proponiendo un nuevo modelo de intercambio ente la humanidad y el medio. En este contexto, reivindicar la debilidad presupone cuestionar las bases tradicionales de la Cultura hegemónica, rechazando con ello el dominio por la fuerza aplicado por el ser humano hasta el momento y reflejado en los grandes

98 MARCHÁN FIZ, Simón, Del arte objetual al arte de concepto (1960-1974), Epílogo sobre la sensibilidad "postmoderna". Analogía de escritos y manifiestos, Akal, Madrid, 1997, p. 217. 
símbolos monumentales de autoafirmación. Esto supone, siguiendo a José Albelda, cuestionar nuestro papel colonizador y reconsiderar con ello, la relación entre la potencia y la escala, ya que desde lo mínimo, se puede comunicar más intensamente cosas, y se asume que mediante lo leve y lo respetuoso, se renuncia a la autoría y al protagonismo en las intervenciones. En coincidencia con estos artistas encontramos en México a artistas como Yolanda Gutiérrez que, como veremos más adelante, explorarán en términos artísticos la fragilidad de la Naturaleza como entidad que hay que cuidar y respetar para nuestros semejantes. Finalmente todo ello nos llevará a reivindicar una nueva voluntad por equilibrar, mediante el arte como medio y símbolo fundamental de la Cultura, nuestra dinámica de intercambio con el medio, pasando éste a asumir un papel más protagonista, no sólo como escenografía, sino como origen y espíritu de las obras. Así estaremos frente a proyectos y obras tridimensionales que más que ubicarse en la Naturaleza, hunden sus raíces en ella, para explorar el elemento natural como entidad autónoma:

La coincidencia con aspectos del pensamiento ecológico confirma, no una dependencia o una militancia, sino la común expresión de un incuestionable signo de los tiempos 99 .

El arte no mediático apuesta por la diversidad: múltiples concepciones de lo natural que se expresan en posturas plásticas personales y diferenciadas, aunque manteniendo presupuestos conceptuales comunes. En general se trata de intervenciones en el medio que proceden de la tradición escultórica. Según Albelda, en este nuevo giro del trabajo con la Naturaleza, se confirman estereotipos ya señalados por él, como la identificación de la Naturaleza como el lugar de lo salvaje, lo verde, lo hermoso, que hay que recuperar como escenografía para manifestar un cambio de actitud. Estos artistas cuya obra revisaremos: Goldsworthy, Udo, Laib, Penone, etc., reconstruyen lo natural como sujeto, optando por una Naturaleza esencialmente vegetal y viva, en contraposición a otros artistas del Land Art (Heizer, De Maria, Smithson) que optaban por lugares, alejados y minerales, donde la Naturaleza era ante todo materia y territorio. Frente a estos últimos, los primeros, se decantan por moverse en un terreno entre la sutileza y la metáfora, reivindicando el lugar sea genuino o simulado- como metáfora de Naturaleza, renunciando al protagonismo del autor o la obra frente al medio. Para Albelda la obra de estos artistas muestra cierta nostalgia:

[...] la añoranza de un orden ahora excepcional y contribuyen a la construcción de una escenografía que tiende a renunciar a lo sublime, optan selectivamente por un tipo de belleza que descarta otros aspectos inherentes a lo natural, como el riesgo y la muerte, pero sobre todo la podredumbre, la fealdadioo.

\footnotetext{
99 ALBELDA, José y SABORIT, José, op. cit., p. 146.

100 ALBELDA, José y SABORIT, José, op. cit., p. 148.
} 
Podríamos cuestionar parte de la explicación de Albelda ya que algunos de los artistas que veremos a continuación, trabajan con la podredumbre, la fealdad $u$ otros procesos que pueden no estar bajo el control del artista y que implican una aceptación de una Naturaleza en transformación como parte de la obra. Es el caso de Anya Gallaccio o los suizos Steiner y Lenzlinger y, en el caso de México, algunas obras de Sofía Táboas. La obra de estos artistas nos obliga a pensar en torno a la función referencial del lenguaje, aquella que nos permite como hablantes, la posibilidad de designar los objetos que constituyen la realidad extralingüística y que, generalmente, suele ser el objeto de la comunicación lingüística. De esta forma, cada vez que un artista utiliza un vegetal, sea representándolo o sea presentándolo en vivo, este elemento se convierte en una referencia que yendo más allá del elemento presentado, alude a una realidad externa.

Ciertos enunciados lingüísticos se refieren a circunstancias extralingüísticas particulares: en ese caso se dice que denotan un referente. Por importante que sea, esta propiedad no es constitutiva del lenguaje humano: algunos enunciados la poseen, otros no. Pero también existe un tipo de discurso Ilamado ficcional donde el aspecto de la referencia se plantea de manera radicalmente diferente: está explícitamente indicado que las frases formuladas describen una ficción y no un referente reallor.

Como hemos visto, las plantas y, en general, la mayoría de las ideas que trasmiten los vegetales han sido en todos los tiempos motivo de inspiración para el arte. En la actualidad, artistas de diferentes culturas y de diversos ámbitos geográficos utilizan elementos vegetales como un recurso, no sólo representativo o formal, sino con toda la nueva carga semántica que conlleva la convivencia con una Naturaleza profundamente transformada por el ser humano. Así, en el arte contemporáneo en particular, los artistas cuyas obras se acercan desde diferentes perspectivas a esta temática, plantean numerosas cuestiones. ¿Cual es la razón para la utilización de lo vegetal en el arte contemporáneo? ¿Qué mensajes, ideas y conceptos transmiten? Si bien, la incorporación de plantas vivas en una obra de arte es, sin duda, un recurso contemporáneo, las estrategias empleadas por los artistas son innumerables. Con este estudio, como podremos ver, deseamos plantear estos interrogantes para, si no encontrar una respuesta definitiva, por lo menos acercarnos a las diferentes intenciones de los artistas.

Hace unos años, la Documenta XII de Kassel albergó en el espacio de la Friedrichsplatz, el proyecto Poppy Field (2007) de la artista croata Sanja Ivekovic (Zagreb, Croacia, 1949), el cual, una vez desarrollado, lograba modificar significativamente el uso público de la plaza. La obra planteaba -mediante la construcción paisajística de un frondoso campo de amapolas en flor- la imagen de un paisaje cuya finalidad no incidía fundamentalmente en su nivel de

101 DUCROT, Oswald y TODOROV, Tzvetan, Diccionario enciclopédico de las ciencias del lenguaje, Siglo XXI, México, D.F., 2005, p. 301. 
percepción estética. Las relaciones que la artista establecía entre la pieza, el entorno y la sociedad muestran cómo, desde un punto de vista artístico, se puede entender una obra en proceso, en la cual, una parte de la Naturaleza (la vegetal) interviene desde sus propios "tiempos", estableciendo la idea de una obra en proceso. Los transeúntes que llegaban a la Documenta quedaban sorprendidos al encontrar el espacio situado frente al Museo Friedriciano, en pleno corazón de la ciudad, invadido por este evocador campo de amapolas. Sin embargo el objetivo de la artista, más allá del horizonte poético que construye la obra, aborda el presente y la historia con un sentido crítico. Su obra remite al hecho de que desde los siglos XVIII, XIX y, en particular, durante el Nacionalsocialismo, esta plaza ha sido utilizada como lugar de desfiles militares.

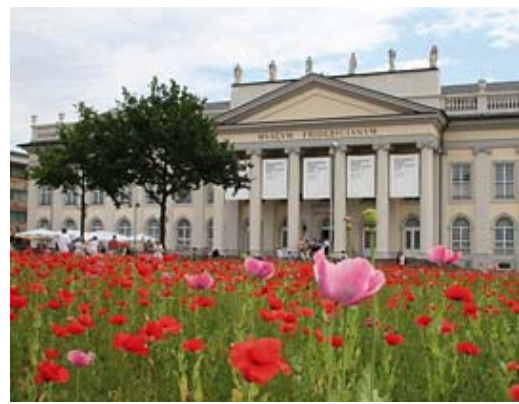

Sanja Ivekovic, Poppy Field, 2007.

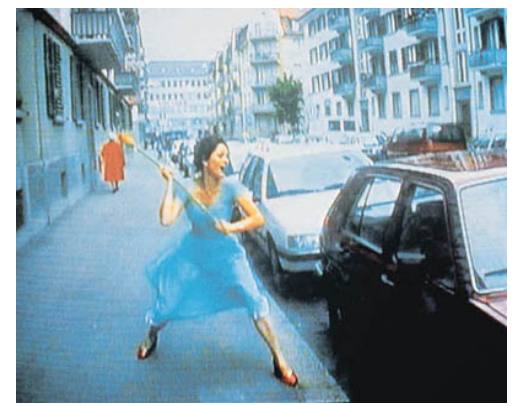

Pipilotti Rist, Ever Is Over A/l, 1997.

La artista propone así, recurrir a la tradición del uso público que aporta específicamente el lugar, para contraponerla con las referencias históricas y culturales de una flor, la amapola, que, si bien en la tradición cultural inglesa es considerada como símbolo de los soldados muertos durante las guerras, en los países de pasado comunista, simboliza el espíritu de resistencia y de la revolución. En esta dialéctica, Ivekovic recupera la tierra de la plaza y hace aparecer un campo en el que siembra semillas de amapola en un 90\%, sobre la superficie del mismo y un $10 \%$ de semillas de opio. Con ello, establece una crítica social que denuncia el cultivo masivo de droga en Afganistán, país que, tras la instauración por parte de EE. UU. de un gobierno democrático, se transforma paradójicamente en el mayor productor de opio. Asimismo, en una línea activista, la obra se complementa con las voces de mujeres croatas que cantaban en coro canciones revolucionarias, poniendo de manifiesto la tragedia de las mujeres afganas, que son víctimas directas de las atrocidades del comercio ilícito de las drogas.

El componente de denuncia social y la vía del arte como agente transformador del hombre no es nuevo, recordemos entre otras, la idea de escultura social y el concepto arte expandido que reivindicaba la acción de Joseph Beuys (Krefeld, 1921) al plantar en 1982, 7.000 robles en la Documenta VII de Kassel (Alemania), con la intención de reforestar la ciudad. A partir de esta obra, podemos rastrear los orígenes del énfasis de la mirada en torno a lo vegetal como motivo en la escultura contemporánea. El componente ecológico y social que plantea esta escultura tiene al árbol vivo como material principal de su 
proyecto, pero sin embargo, la carga semántica de la obra recae en las personas, sus vidas y sus trabajos cotidianos. Sus ideas en torno al concepto ampliado de arte, le permiten redefinir las relaciones poéticas entre la Naturaleza y el hombre ${ }^{102}$, despertando la conciencia ecológica durante los años ochenta, mediante acciones de gran alcance como El renacimiento de la agricultura (1978) y Difesa della natura (1984).
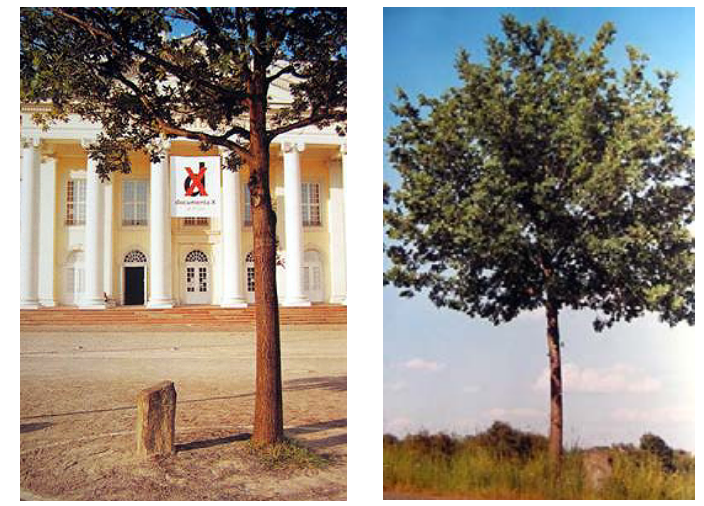

Joseph Beuys, 7000 robles, 1982.

Beuys utiliza el árbol como un elemento de regeneración que, en sí mismo presenta el concepto de tiempo. El roble es especialmente adecuado porque es un árbol de lento crecimiento que encarna la idea de tiempo y de vida prolongada, es, de hecho, una forma de escultura, un símbolo para este planeta, cuyo valor sagrado Beuys recupera. De esta manera, la acción de plantar siete mil robles se convierte asimismo en un principio simbólico. Junto a cada roble, el artista colocó un monolito de basalto que marcaba el paso del tiempo.

Esta confrontación entre el basalto y el árbol reproduce la típica polaridad beuysiana entre lo cristalino (la roca) y lo orgánico) y cálido (el árbol), entre escultura y plástica [...]. En los últimos años de su vida, Beuys manifestó públicamente su agradecimiento a los árboles porque-decía-sufrían por nosotros 103 .

Al plantar estos árboles, Beuys marca un punto de inflexión para la transformación vital de la ciudad, de la sociedad y del sistema ecológico y ambiental en el mundo. Estos siete mil árboles están considerados cada uno de ellos, como monumentos vivos en permanente transformación ${ }^{104}$. Si bien las piedras no crecen, al poner estos dos elementos en relación, el juego proporcional entre las dos piezas del monumento, con el paso del tiempo, se

\footnotetext{
102 MARTíNEZ MUÑOZ, Amalia, De Andy Warhol a Cindy Shermann, Colección Arte del S. XX, Universitat Politècnica de València, Valencia, 2000, p. 89.

103 BERNÁLDEZ SANCHís, Carmen, Joseph Beuys, Nerea, Guipúzcoa, 1999, p. 33.

104 HERNANDO, Javier, "Visiones de la naturaleza: El arte y la sensibilidad ecológica", en RAMÍREZ, Juan Antonio y CARRILLO, Jesús (eds.), Tendencias del arte, arte de tendencias, a principios del siglo XXI, Ensayos de Arte Cátedra, Madrid, 2004, p. 64.
} 
transforma. Al principio, por su tamaño, las piedras dominaban al árbol, pero ahora es el árbol el que domina la composición. La acción que permanece como un gesto de renovación urbana, continuaría durante los siguientes cinco años bajo la supervisión de la Universidad Internacional Libre que por consenso popular fue plantando robles, junto con los residentes y los consejos de vecindad, en diferentes espacios públicos (centro urbano, escuelas, jardines de infancia, asociaciones locales, etc.).
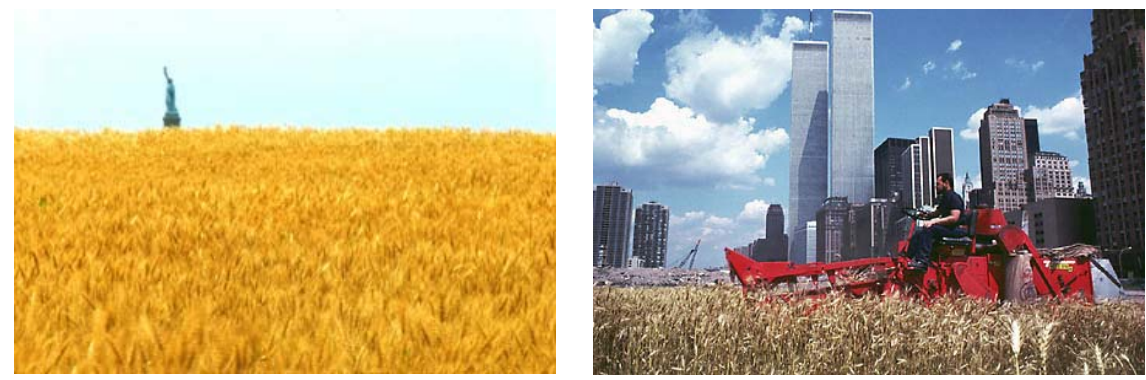

Agnes Denes, Wheatfield A Confrontation, 1982.

El resultado ofrecía nuevas y significativas oportunidades de utilizar el espacio público. Con estas intervenciones, el arte contemporáneo nos ofrece una alternativa y una continuidad en el uso de determinados elementos del mundo vegetal para despertar la conciencia ecológica en el mundo105. Tanto en las acciones agrícolas de Beuys, como en la intervención de Ivekovic, el significado de los términos que se citan en la obra se reinventa críticamente para poder dar cuenta del conflicto que, de forma cada vez más evidente, confronta Naturaleza y ser humano. Estas obras entran en relación y establecen un vínculo muy cercano entre sí. En particular la obra Poppy Field, 2007, de Ivekovic, recuerda la intervención en Nueva York de la artista norteamericana Agnes Denes (Budapest, 1931) quien en 1982, llevó a cabo un proyecto de arte medioambiental al plantar, entre los rascacielos del centro de Manhattan y cerca del World Trade Center, un campo de dos hectáreas de trigo, en un lote baldío junto a los vertederos de Battery Park. La obra Campo de trigo. Una confrontación, 1982, pretendía crear conciencia en torno al tergiversado sistema humano de valores. Ayudada por voluntarios, la artista limpió la basura de cuatro acres de tierra y extendió en ellos doscientos cincuenta camiones de tierra. De esta forma, Denes pudo revisar los ciclos naturales del crecimiento y la regeneración de las plantas. Durante cuatro meses se instaló un sistema de riego para sostener y regular el ciclo de crecimiento y finalmente, el grano de trigo cosechado viajó a veintiocho ciudades en el "Internacional Show de Arte para el fin del hambre en el mundo" y fue plantado simbólicamente en diferentes lugares del mundo.

Por su parte y, con estrategias de investigación diferentes, artistas como Pipilotti Rist (Grabs, Sankt, Suiza, 1962) y, mediante las nuevas tecnologías de la imagen y el video, plantean su visión de lo vegetal en torno al uso de estereotipos

105 D'AVOSSA, Antonio, "Joseph Beuys, Domani la terra", en Cimal. Arte internacional, N ${ }^{\circ}$ 41, Valencia, 1993, pp. 8-10. 
aplicados a lo femenino dentro de la sociedad contemporánea. Por ejemplo, en la video instalación Ever Is Over Al/, 1997, la artista aparece con un vestido azul y unas zapatillas rojas paseando por la calle junto a una fila de coches aparcados, llevando en la mano una flor gigante que balancea como en un juego inocente. La obra, acompañada de una melancólica melodía, envuelve al espectador con la proyección en cámara lenta de las imágenes sobre las dos paredes adyacentes. En una de ellas, la cámara se centra en un frondoso campo lleno de una vegetación con flores rojas. La aparente armonía de esta imagen, superpuesta en parte con la proyección de la izquierda, se ve alterada cuando la mujer en un arranque de inexplicable violencia destruye con sucesivos y agresivos golpes de la flor, los parabrisas de toda una fila de automóviles estacionados. Las imágenes presentan en una tensión caprichosa y anárquica, el reflejo de un vandalismo absurdo. La artista camina golpeando las ventanillas de varios coches, cruzándose con personas, entre ellas un policía que le saluda amablemente, mientras su acción destructora parece no tener repercusión alguna. La figura de este oficial de policía y de su sonrisa de aprobación, convierte en absurda, a la vez que minimiza el impacto de la acción de la artista. Con colores saturados, las proyecciones son una sofisticada combinación de ingenio, humor y de ironía. La ficción versus realidad es un tema importante para Rist, en cuyo trabajo observamos una extraña combinación de pesadilla y magia, prevaleciendo éstas sobre la lógica del sentido común. Una de las posibles lecturas de esta obra, podría involucrar una dialéctica de género, en torno a lo dañino que puede resultar en la sociedad, aquellos actos aparentemente considerados como benevolentes o creativos y que, sin embargo repercuten de manera perjudicial en ciertos sectores sociales. La flor, con su aparente fragilidad, nos presenta una metáfora de la mujer y de todos aquellos estereotipos preestablecidos con respecto al género. La artista nos propone, con la violencia ejercida a través de su misma fragilidad representada en la flor y, bajo el beneplácito de las instituciones (el policía), la ruptura con este tipo de convenciones.

El trabajo artístico en torno a la dialéctica Naturaleza y Cultura, teniendo el elemento vegetal como protagonista es prolífico. El escultor británico David Nash (Esher, Surrey, 1945) ha realizado desde los años setenta esculturas e instalaciones con árboles vivos en cuya concepción se involucra tanto el concepto del paso del tiempo como el de colaboración y autoría. A través de sus acciones, Nash ha redirigido el crecimiento de ciertos árboles, como es el caso de la obra Ash Dome (Cúpula de fresnos) 1977, en la que se observa un círculo formado por veintidós fresnos plantados en los alrededores de su casa, cuyas ramas siguen un ritmo común.

El árbol es un elemento vivo que puede trabajarse, que puede adaptarse $y$ manipularse. El énfasis se pone siempre en la intersección de la naturaleza y la cultura humana, que no están enfrentadas, sino que son simbióticas y están relacionadas entre sílo6.

106 GRANDE, John K., Diálogos Arte-Naturaleza, Fundación César Manrique, Madrid, 2005, p. 35 . 


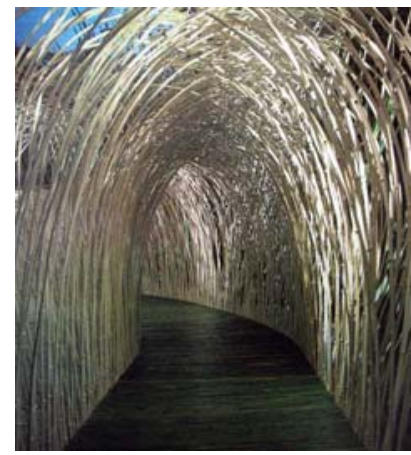

Hiroshi Teshigahara, Bamboo, 1995.

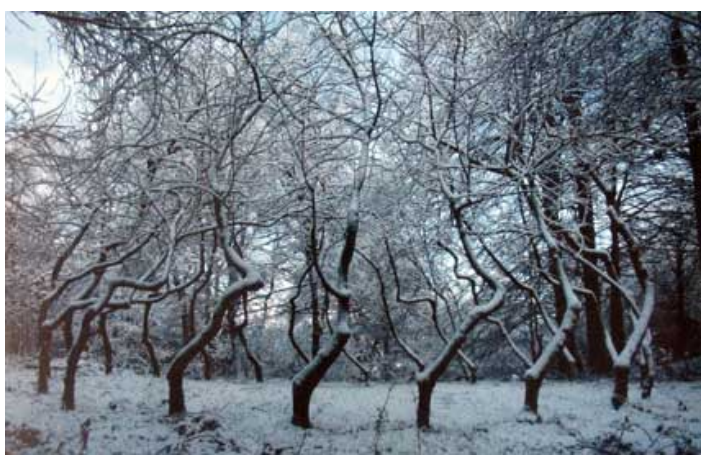

David Nash, Ash Dome, 1977.

Por su parte, el escultor Hiroshi Teshigahara (Tokio, 1927) quien posteriormente reorientaría su actividad artística hacía al cine, plantea en los orígenes de su obra escultórica una íntima relación del ser humano con la Naturaleza. En Bamboo (1995) reconstruye el hábitat de dicha planta, recurriendo, como en otras ocasiones a la práctica de realizar construcciones vegetales cuyos límites se insertan en la delgada franja entre Naturaleza y Cultura.

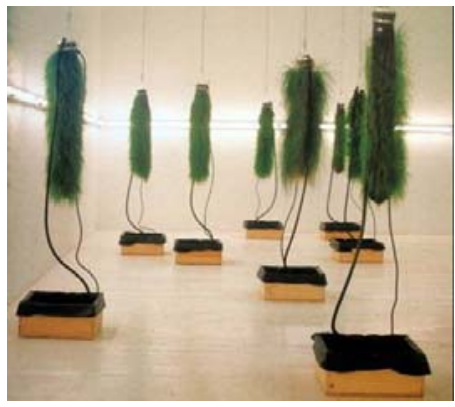

Samm Kunce,

Water Cultura, 1994.

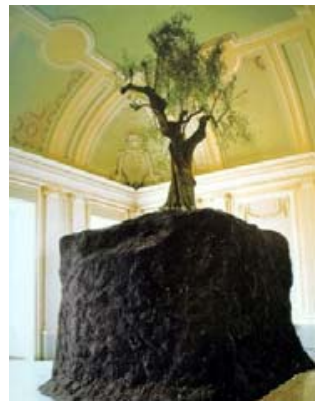

Maurizio Cattelan,

Sin título (Olive Tree), 1999.

Como podemos observar, en la selección de artistas que proponemos se consideran aspectos afines a los enfoques y la sensibilidad de las ideas que dieron origen al Land Art y a las estéticas relacionadas con la Naturaleza, pero más allá de las coincidencias puntuales, las obras marcan distancias cualitativas respecto a dicho movimiento107. La selección propuesta responde a la observación de determinadas coincidencias en la selección de un elemento específico de la Naturaleza, el vegetal, para generar planteamientos estéticos muy diversos. Se trata de un nuevo contexto artístico, determinado fundamentalmente por un deterioro intensivo de nuestro medio ambiente, y a la imposibilidad cada vez mayor de diferenciar entre lo natural y lo modificado por el hombre. Algunos otros artistas como Maurizio Cattelan (Padua, Italia, 1960)

107 PÉREZ LÓPEZ, Héctor Julio, La naturaleza en el arte posmoderno, Akal, Madrid, 2004, p. 10. 
transgreden los límites de la tolerancia del espectador al cuestionar las fronteras de la ética con ironía y humor. Cattelan, al combinar esculturas con performance, señala Taiyana Pimentel, ofrece "nuevas lecturas a ideologías, situaciones y símbolos establecidos"108.

Samm Kunce (Los Angeles, California, 1956) con Water Cultura (1994)109, Henrik Hakansson (Helsingborg, Suiza, 1968), con After forever (1998) o Yoko Ono (Tokyo, Japón, 1933) con su instalación en el Museo de l'Almodí de Valencia (Ex $i t$, 1997) son otros ejemplos de artistas que eventualmente recurren a lo vegetal para explicitar determinados simbolismos en torno al crecimiento, lo germinativo o la regeneración de la vida. Igual que ellos, muchos de los artistas mexicanos como Sofía Táboas o Jerónimo Hagerman, reflexionarán en torno a las plantas como personajes que nos ayudan a definir nuestra personalidad como humanos.

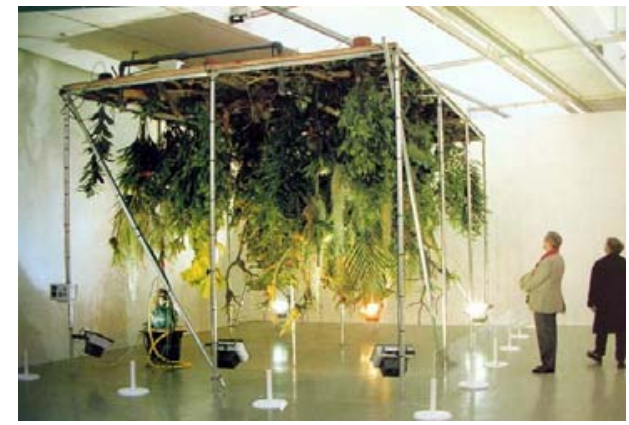

Henrik Hakansson, After forever, 1998.

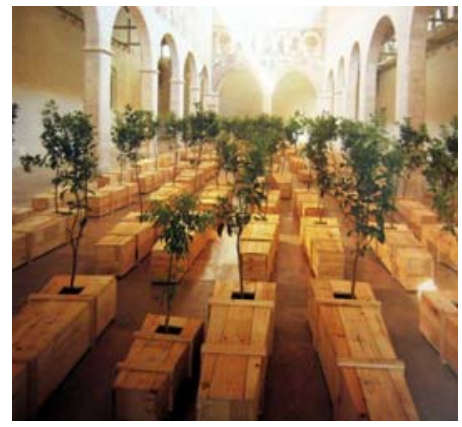

Yoko Ono, Ex it, 1997.

El artista Carsten Höller (Bruselas, Bélgica, 1961), biólogo de formación, explora el vínculo arte y Ciencia realizando construcciones que invitan al espectador a interactuar con sus obras. Su obra experimenta con las reacciones del público e, incidiendo en la naturaleza orgánica del ser humano, se centra en la respuesta humana a estímulos específicos. En la obra Solandra Greenhouse (2004) el artista presenta un receptáculo metálico, similar a un invernadero, donde cultivó la planta venenosa Solandra máxima - planta parecida al floripondio- la cual tiene propiedades alucinógenas y emite sustancias capaces de estimular sensaciones asociadas comúnmente a los síntomas que experimentamos en el sentimiento amoroso. La pieza, está provista de luces estroboscópicas con las que consigue desorientar a los visitantes e inducir en ellos una experiencia similar a los efectos físicos del enamoramiento que, según Rodrigo Zúñiga, es una parodia de la mitología en torno a este sentimiento 110. Más adelante, entre los artistas mexicanos, podremos observar la influencia que este tipo de obras

108 PIMENTEL, Taiyana et al., Las implicaciones de la imagen, Vol. I, Museo Universitario de Ciencias y Arte, Colección Isabel y Agustín Coopel, UNAM, México, D.F., 2008, p. 1966.

109 NEMITZ, Barbara, Trans Plant. Living vegetation in contemporary art, Hatje Cantz Publishers, Stuttgart, 2000, pp. 88-89.

110 ZÚÑIGA, Rodrigo, “¿Un Arte que trata con la vida?", en La Demarcación de los Cuerpos. Tres textos sobre arte y biopolítica, Metales Pesados, Santiago de Chile, 2008, pp. 43-82. 
pueden haber tenido en trabajos como los de Eduardo Rincón, Paola de Anda y Gustavo Gómez Brechtel.

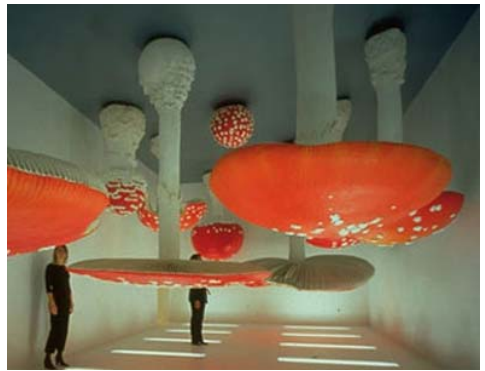

Carsten Höller, Upside Down Mushroom Room, 2000.

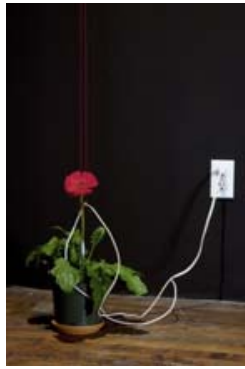

Carsten Höller, Suicide Gerbera, 2008.

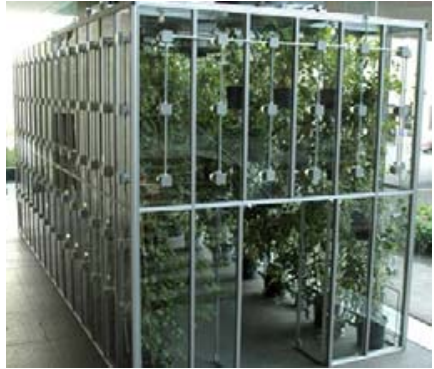

Carsten Höller, Solandra Greenhouse, 2004.

La obra Upside Down Mushroom Room (Sala de hongos al revés, 2000), consistía en una habitación, de cuyo techo colgaban setas gigantes blancas y rojas que giraban sobre sí mismas, en la que el artista intentaba recrear la confusión que se experimenta en las experiencias con drogas. Carsten Höller genera acontecimientos visuales, de forma que el verdadero material de sus obras es la propia experiencia de las personas que ven sus obras. Sus piezas describen estrategias que implican al público, estimulando las sensaciones y los pensamientos para dar lugar a experiencias compartidas 111 .

Podríamos considerar que uno de los artistas precursores en el uso del elemento vegetal fue Robert Smithson (Passaic, New Jersey, 1938), quien comenzó a trabajar en el diálogo entre el lugar/obra exterior y lugar/obra interior a partir de sus primeras superposiciones y estratificaciones de espejos y vidrios en las que investigaba las relaciones entre las formas geométricas, las culturales, las naturales y las sociales. Sus experiencias se concretaron en los términos de Site (lugar/obra exterior) y Nonsite (lugar/obra interior), extendiendo esta dialéctica a los conceptos de Sight (visión) y Nonsigth (no visión), y donde el Nonsite, como obra y como fragmento del Site es a un espacio interior o delimitado en la galería o el museo, lo que el Site es al espacio abierto sin connotaciones artísticas.

En la pieza Nonsite Mirror Displacementet (Desplazamiento de espejos) que realizó en 1969 en el Estado de Yucatán, México, Smithson aísla el componente conceptual de los Nonsites, colocando en los espacios abiertos de la selva espejos cuadrados que captaban tanto la vegetación del lugar como los desplazamientos efímeros de la luz, la atmósfera o el entorno del lugar. La voluntad de Smithson con estas obras, calificadas de arqueología metafísical12, era la de transferir la tierra, la realidad física en bruto, del exterior Site, al interior Nonsite, aunque en el caso de Mirror Displacement el proceso parece

111 BADER, Joerg, “Carsten Höller", en Lápiz, № 206, Madrid, 2004, p. 83.

112 MARCHÁN FIZ, Simón, op. cit., 2005, p. 59. 
producirse a la inversa, puesto que son obras que incorporan espejos $y$ estructuras hechas de elementos naturales temporalmente situados en el paisaje que convierten de una manera no figurativa, la realidad abstracta sujeta a la mirada del espectador (tierra-escultura-espacio-espectador) en piezas y sistemas descriptivos del lugar específico.

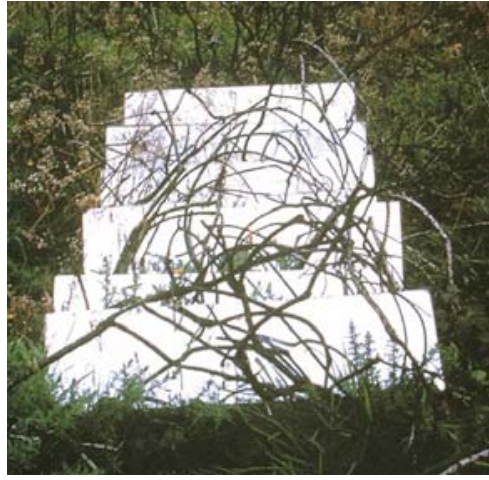

Robert Smithson,

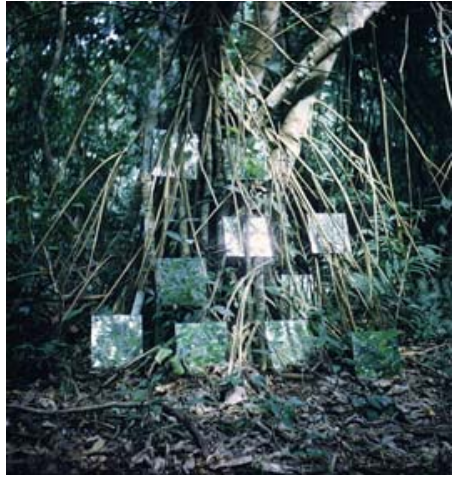

Robert Smithson, Séptimo

Mirror Displacement, Brambles, 1969. desplazamiento especular, 1969.

Smithson deconstruye los espacios que rodean al hotel Palenque en una especie de recorrido imposible, recogiendo documentos para la conferencia que impartiría en 1969 a los estudiantes de arquitectura de la Universidad de Utah. Las fotos y dibujos que realiza son evidencias de una ausencia, de aquello que está en otro lugar, un lugar sin lógica, en su opinión, memoria de tiempos pasados que se manifestaban en un presente. Smithson interroga a los espejos y éstos, a su vez, interrogan al lugar construyendo una arquitectura entrópica del arte de mirar, memorias de un pasado remoto que cuestionan nuestra incapacidad de ver.

En opinión de Fernando Castro Flórez: "Lo que atraía a Smithson del hotel Palenque era la superposición de procesos constructivos, la ruina contemporánea"113. En esta dinámica Smithson recupera el sentido del azar, evidenciando las limitaciones de la percepción, la imposibilidad de percibir lo intangible que nos rodea. Sin embargo para Tonia Raquejo, la importancia de la imagen especular en la obra de Smithson consiste en la capacidad de los espejos de ser simultáneamente lugar y no lugar. Por su naturaleza inmaterial, los reflejos pueden desintegrar el objeto que reflejan. De esta forma la obra Nueve desplazamientos de espejos, 1969 se constituye en una experimentación en torno a las falacias de la mímesis, "aprovechando para parodiar la práctica de la pintura, que entiende el arte como reflejo de la naturaleza, de la realidad" 114. Con todo ello Smithson recuperaba para el arte, la conciencia capaz de detectar

113 CASTRO FLÓREZ, Fernando, "El entropólogo deconstructor", en $A B C D$, Las Artes y las letras, 21, junio, 2008, $\mathrm{N}^{\circ} 855$, Disponible en red: <http://www.abc.es/abcd/noticia. asp?id $=10022 \&$ num $=855 \& \mathrm{sec}=36>$, [Consulta 8 , marzo, 2010].

114 RAQUEJO, Tonia, Land Art, Nerea, Madrid, 1998, pp. 76-81. 
la "falsedad en la apariencia" de la espesura de lo real, construyendo una visión crítica que favorece la percepción escéptica de nuestros sentidos.

Dentro de la dialéctica que los artistas del Land Art establecen entre la obra y el entorno donde ésta se sitúa, James Pierce nos remite a un diálogo con la Naturaleza propio de las culturas primitivas. Experimentando con los significados de lo primordial y desde el lado antropológico del arte, este tipo de trabajos resaltan por el aspecto telúrico de la fuerza geológica del azar, como autor propiamente dicho de la obra. Pierce con una técnica más propia del jardín paisajístico que del Land Art, experimenta con los materiales autóctonos del lugar, con materiales orgánicos en este caso, tierra y hierba, para elaborar una metáfora adecuada a la imagen figurativa que construye. Se trata de una serie de montículos a través de los que se percibe una mujer tumbada de bruces, surgiendo de la tierra misma y cubriéndose de hierba que crece en los alrededores. Es una intervención en el paisaje que está literalmente viva, habitada por insectos, pájaros e incluso mamíferos propios del territorio que la rodea.

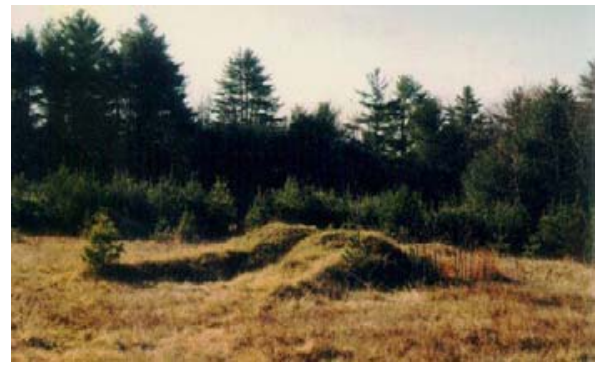

James Pierce, Pratt Farm, 1976-1977.

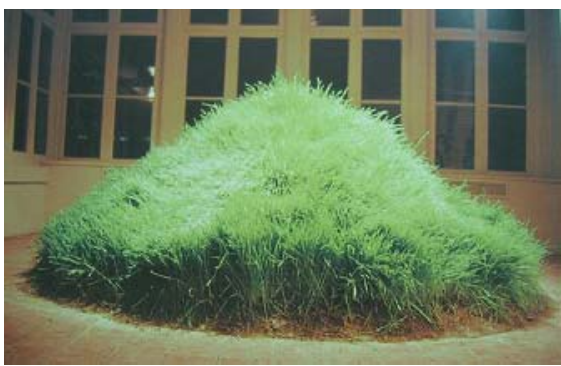

Hans Haacke, La hierba crece, 1965.

Valorando el poder intrínseco de estos materiales naturales, tanto por su economía como por su duración, Pierce los utiliza sin alterar su naturaleza básica, "trabaja con el paisaje, no contra él"115, adaptándose a las condiciones de la materia y el lugar. La asociación entre mujer primitiva y fecundidad de la tierra nos remiten a la célebre estatuilla del Paleolítico de la Venus de Willendorf. Sin embargo Pratt Farm, (1976-1977), no es una figura exenta, sino que se funde, a través de su rostro y de su sexo con la tierra en una simbología que permite que ambas se unifiquen en una misma entidad. Esta pieza forma parte de El Jardín de la Historia, que Pierce comenzó alrededor de 1970 en Maine, (EE. UU.), con la intención de reunir en un mismo espacio diferentes alusiones a las representaciones artísticas del pasado primitivo. El artista como algunos otros representantes del Land Art, superpuso en el mismo espacio, tiempo pasado y presente, queriendo situar su obra en un tiempo ahistórico y jugando así con las fronteras del antes, el ahora y el después.

115 BEARDSLEY, John, Earthworks and Beyond, Contemporary Art in Landscape, en RAQUEJO, Tonia, op. cit., p. 22. 
El lugar elegido por Pierce, responde -como en el caso del Observatorio (1971) de Morris y el señalamiento de los equinoccios mediante los rayos del sol en los cuatro vanos en forma de triángulo- al punto en el que el sol coincide en su puesta del solsticio de verano, con el centro de las nalgas de la mujer, superponiendo de esta manera, la consistencia biológica del material orgánico, perecedero y cambiante de las formas de la escultura a una existencia y un tiempo astronómicos y transcendentales en el que se confunden pasado y presente. De esta manera el artista convoca un tiempo cíclico fuera del devenir histórico, similar al de las estructuras míticas como Stonehenge, un tiempo circular que relaciona los ciclos de la Naturaleza con la imagen de su Mujer de la tierra (1976-77) y que propician que el espectador cuestione la idea de progreso como respuesta unidireccional frente al futuro.

Para entender las motivaciones y las estrategias discursivas de algunos de los artistas que aquí aparecen, revisaremos las concepciones de lo que hoy en día se entiende como trabajo con lo natural, haciendo una pequeña referencia a alguno de ellos. Alrededor de finales de los sesenta y principios de los setenta, proliferan los trabajos con ciertos estereotipos de Naturaleza. Así nos encontramos por ejemplo, con los visionarios trabajos ecológicos de Newton Harrison (New York, 1929)116, quien creaba ecosistemas, como Interfase aire, tierra, agua, (1971), realizado por encargo del Museo de Arte de Boston, donde hizo crecer hierba en el exterior del museo, siguiendo unas pautas particulares. De forma similar Hans Haacke, (Colonia, Alemania, 1936) artista conceptual y activista político de origen alemán, que más tarde cuestionaría el arte como sistema social, planteaba en sus primeras obras, cuestiones ecológicas que desempeñaron un papel importante en la historia del Ecoarte. En ellas, Haacke presentaba procesos naturales documentando sistemáticamente los mismos. Para la exposición de Arte de la Tierra (1969), de la Universidad de Cornell, Haacke hizo crecer hierba en el suelo de la galería, sobre un montón de tierra, sin ningún pesticida. La hierba crece, (1965) era una manera de vivir-en-eltiempo, una obra de arte efímero que reaccionaba a los cambios de temperatura y de luz, del ambiente que la rodeaba. Se trataba no sólo de materiales inusuales en el arte (suciedad, semillas), sino también de experimentar la Naturaleza como proceso cambiante. Todo ello propició un creciente interés artístico en los procesos y en los materiales afectados por el paso del tiempo ${ }^{117}$.

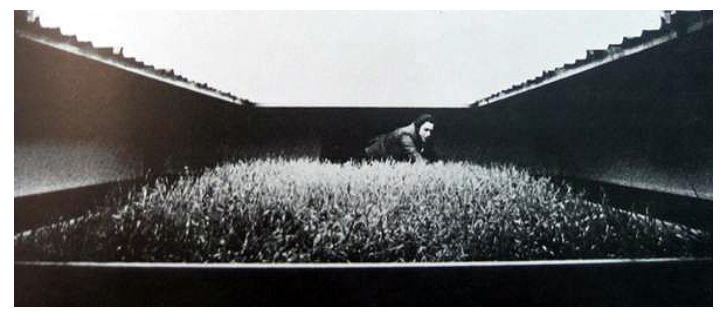

Newton Harrison, Interfase aire, tierra, agua, 1971.

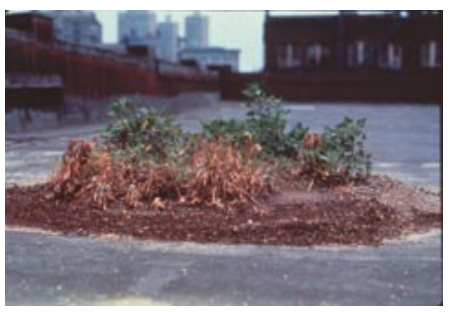

Hans Haacke, Bowery Seeds, 1970.

116 NEMITZ, Barbara, op. cit., p. 14.

117 WOOD, Paul, La modernidad a debate. El arte desde los cuarenta, Akal, Madrid, 1999, p. 222. 
Otro artista que por distintas razones utilizó lo vegetal en su obra fue Giovanni Anselmo (Turín, 1934) quien sería, junto con Mario Merz y Gilberto Zorio, uno de los protagonistas del movimiento povera italiano de finales de los años sesenta. En la obra Estructura que come (1968), Giovanni Anselmo profundiza en el tema de la precariedad y del paso del tiempo. Para ello, emplea dos bloques de granito, una lechuga y un montón de arena. El bloque pequeño de granito está atado al grande y, mientras el elemento vegetal no se deshidrate, no se cae. Después de unos días, el proceso natural de deshidratación hace que disminuya la presión entre las dos piedras y el bloque pequeño se desprende, cayendo sobre el montón de arena.

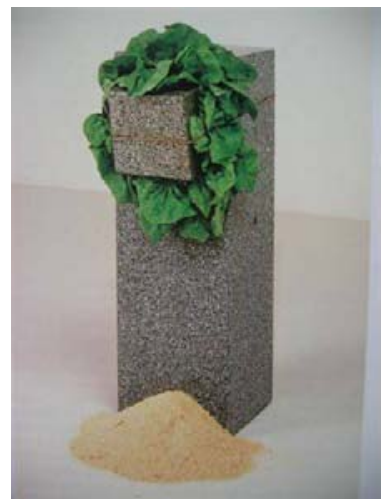

Giovanni Anselmo,

Estructura que come, 1968.

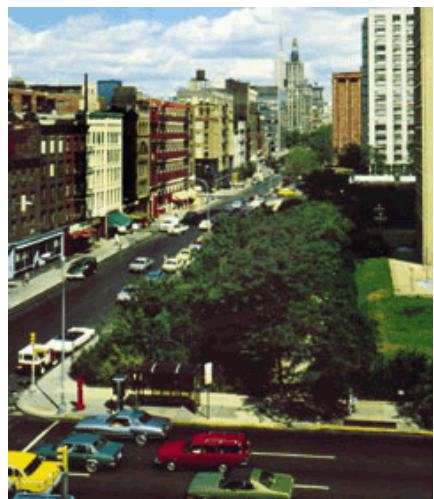

Alan Sonfist,

Time Landscape, 1965-1978.

Anselmo nos presenta aquí la obra considerada como un organismo vivo, un termómetro claro que nos permite experimentar eventualmente la temporalidad a la que estamos expuestos en este mundo, al desgaste y la erosión que inevitablemente hacen mella en todos los seres. Un mundo en el que el artista, como señala Aurora Fernández Polanco, nos sitúa frente a un sistema de oposiciones binarias entre lo duro y lo blando, la geometría de líneas puras y lo orgánico del elemento vegetal. En este sistema de estructuras binarias se desenvuelve de nuevo la batalla entre la Naturaleza -representada por la lechuga - y la Cultura, como la piedra tallada y el mundo del hombre, el arte, la arquitectura y lo racional en general. Sin embargo nada es inmutable, todo está expuesto al tránsito de las apariencias físicas que provoca el paso del tiempo, un discurso que equipara estas transformaciones al deterioro que los humanos experimentamos al envejecer. Como el mismo Anselmo dice, sus obras son energía que se transforma:

Yo, el mundo, las cosas, la vida, somos unas situaciones de energía y la cuestión es precisamente no cristalizar esas situaciones sino más bien mantenerlas abiertas y vivas en función de nuestro vivirl18.

118 FERNÁNDEZ POLANCO, Aurora, Arte povera, Colección Arte Hoy, Nerea, Madrid, 1999, p. 59. 
Giovanni Anselmo trabajará con diversos materiales cotidianos que van desde la tierra a la piedra en una personal búsqueda de liberar la energía que estos encierran, en un intento de desvelar las dinámicas internas que estos materiales experimentan. Este intento plástico de estrechar nuestra experiencia cotidiana con lo invisible confiere a la obra de Anselmo un carácter desorientador e indeterminado en el que la escultura se produce a sí misma. Los materiales, a partir de aquí, disponen de una autonomía sensorial y sensual que les confiere la misma realidad de los elementos (vegetal, animal o cultural), los cuales, ya no necesitan representar nada:

[...] aceptando la literalidad de lo real en su potencial significador; al tratar de comprender que combinar elementos reales y no reproducirlos ya tiene la suficiente carga compositiva para que en cierta manera representen en su sola presentación, en su puesta en evidencial19.

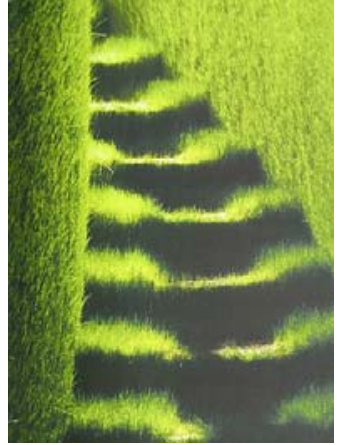

Heather Ackrroyd y Dan Harvey, Sin título, 1992.

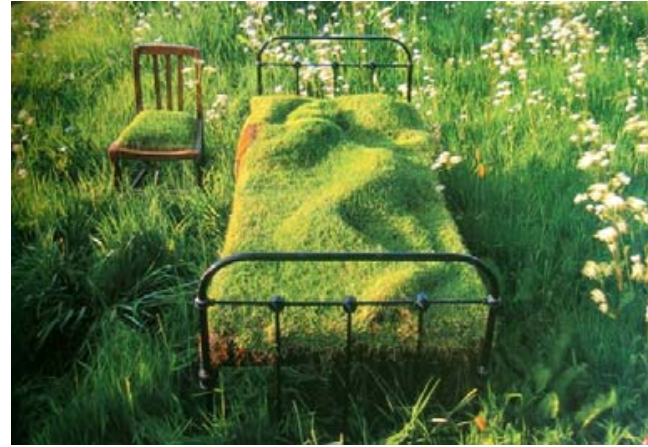

George Wright, Sin título, 1992.

El binomio Naturaleza y Cultura establece un discurso de larga trayectoria entre los artistas de todas las épocas. Los materiales orgánicos $y$, entre ellos las plantas, han sido empleados en defensa de lo considerado natural y, en diferentes circunstancias, para expresar conceptos frecuentemente opuestos a la idea de civilización como estandarte del progreso y de la Cultura. En este tipo de discursos subyace en el fondo la reflexión de "lo natural" versus "lo artificial", que en definitiva nos plantea las preguntas sin respuestas más recurrentes de la humanidad: ¿quién soy?, ¿dónde estoy?, ¿a dónde voy? El crítico Juan Bautista Peiró confirma cómo, en torno al binomio Arte y Naturaleza, constituido como una de las dialécticas fundamentales de la Cultura, se ha generado una amplia zona de interés estético:

Desde el tradicional género del paisaje hasta recientes aportaciones individuales, pasando por un significativo grupo de manifestaciones fundamentales en los setenta como el Povera, Land Art y Earthwork, la naturaleza ha sido fuente inagotable de investigación plástica. Como punto

119 FERNÁNDEZ POLANCO, Aurora, op. cit., p. 89. 
de partida, como referente visual, como escenario de actuación, como lugar de experimentación [...] hoy su indudable vigencia se amplia con matices de tipo social cuando no políticos [...]120.

Este espectro se amplia -como hemos visto con Giovanni Anselmo- tanto con el discurso en torno al tiempo, lo perdurable y lo efímero que conlleva tanto la vida del ser humano, como la obra de arte, como sobre el individuo y la colectividad. La mayoría de los casos que recurren a lo vegetal en sus procesos, se asientan en la capacidad innata de aquello que nos rodea -la realidad y, en este caso, lo vegetal- de reflejar nuestra condición humana, tal y como si aquello de lo que hacemos mención, aunque sea tangencialmente, fuera un espejo de nosotros mismos. En los procesos de nacimiento, crecimiento, maduración, plenitud y decadencia de todo lo vegetal existe una alegoría -metáfora del devenir de lo humano- inevitablemente relacionada con el ser humano.
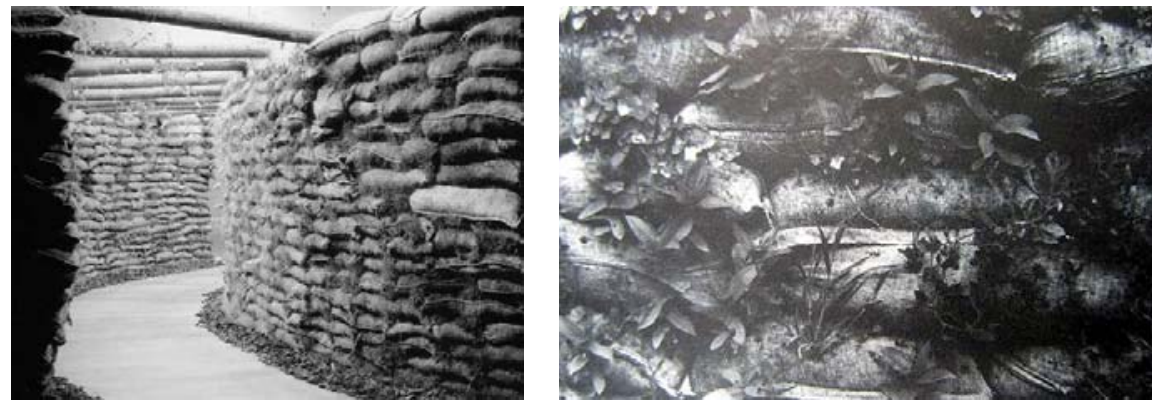

Charles Simonds, Casa que crece, 1975-1994.

Numerosos son los ejemplos en los que el tratamiento de lo vegetal queda patente en el arte y en la escultura. Desde los Crops, anteriormente mencionados, a los jardines públicos -México es un ejemplo claro de la pervivencia de las costumbres topiarias- hasta lo encuentros de escultura que se realizan especialmente con la intención de trabajar con elementos vegetales. Los trabajos realizados en el evento Les Arts Etonnants // (1992) de George Wright, Heather Ackrroyd y Dan Harvey, con respecto a los trabajos de Haacke o Newton Harrison, dan cuenta de este vínculo. El sentido del crecimiento y la idea de proceso recorren todas estas obras como anticipaban los trabajos de Charles Simonds (Nueva York, 1945) y su obra Casa que crece (1975-1994), instalación con sacos de arena, semillas y plantas ${ }^{121}$. Simonds realizó durante los años setenta, numerosas construcciones en miniatura con barro sobre su propio cuerpo que, con un sentido antropológico, hacían alusión al cuerpo, las ruinas y a la civilización. Más allá del efecto estético generado, es evidente el sentido metafórico con el que todos estos artistas utilizan el elemento vegetal. Aquí es la hierba, en otras ocasiones son árboles, ramas, y un sin número de presencias

120 PEIRÓ LÓPEZ, Juan Bautista, "Pamen Pereira: Huellas de luz, sombras de tiempo", en Cimal. Arte internacional. Arte y Naturaleza, № 51, Valencia, 1999, p. 80.

121 NEMITZ, Barbara, op. cit., pp. 14-15. 
verdes las que nos invocan a meditar sobre los diferentes aspectos de la existencia humana.

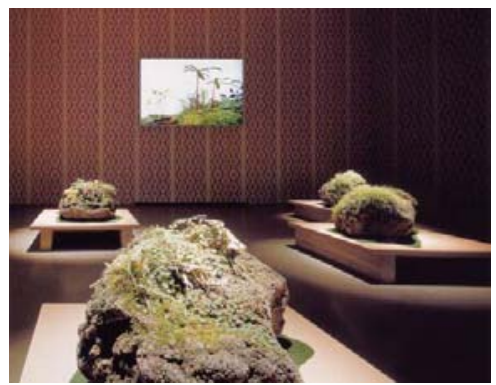

Olaf Nicolai,

Interieur-Landschaft, 1996-97.

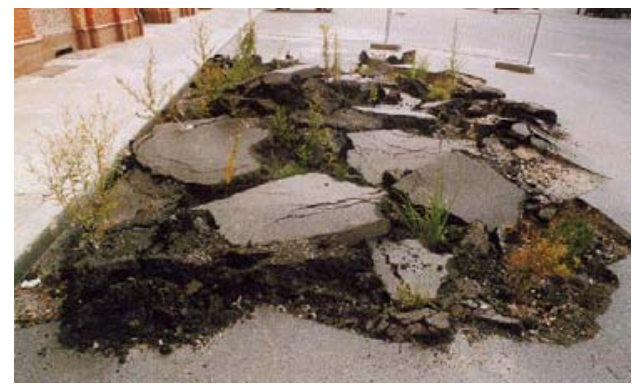

Lois Weinberger,

Asfalto levantado, 1992-1997.

Naturaleza, ser humano y arte, trilogía necesaria a la que los artistas nos remiten con sus obras. En referencia a esta cuestión cabe detenernos en la obra realizada para la Documenta X de Kassel (1997) de Lois Weinberger (Stams, Tyrol, 1947) quien investiga la articulación de la obra de arte en la sociedad y la Naturaleza, creando con todo tipo de materiales un sistema de alegorías sobre la vida real. En Asfalto levantado, (1992-1997) realiza una llamada a la recuperación de lo natural en el corazón de asfalto de las ciudades. Asimismo, obras como la del alemán Olaf Nicolai (Halle, 1962) quien, con la ayuda de un botánico, realizó en unas rocas volcánicas cinco paisajes miniatura que continuaban creciendo durante la exposición. Las paredes del recinto donde estaban las rocas aparecían empapeladas con la silueta repetida de una planta que no existe en la Naturaleza, sino que solamente es una representación idealizada de una planta. La fotografía que cuelga en la pared parece ser un follaje pero en realidad es de lava volcánica. Los estudios en filología y semiótica de Nicolai le permiten referirse en su obra a la relación entre la opinión y la identidad de la cosas que percibimos. De la misma manera que Olafur Eliasson, nos remite a la idea de que la percepción de todas las cosas está condicionada a la forma en que nosotros las percibimos.

La noción de identidad, señala Juan Bautista Peiró, es otra de las grandes cuestiones debatidas desde diferentes frentes, por los artistas que plantean el binomio Naturaleza-Cultura. La búsqueda de todo lo relacionado con el entorno menos manipulado por el hombre en cuanto a ecología, paisajismo o naturalismo es una vía de acceso complementaria a las indagaciones relacionadas con la identidad personal (física o espiritual) del artista que, en ocasiones convergen como podremos ver por ejemplo, en los trabajos de Yolanda Paulsen. Juan Bautista Peiró nos da la pauta para entender este tipo de manifestaciones:

Tras la fractura irreparable de los lazos que le convertían en parte indisociable de la naturaleza, el hombre ha construido múltiples caminos para intentar el imposible retorno. Volver a la naturaleza es reencontrar, o intentarlo al menos, la parte de nosotros que ya no somos capaces de 
escuchar, que tenemos adormecida, que obviamos todos los días y que es indispensable para recomponer los pedazos de nuestra identidad perdida [...] las formas orgánicas, las figuras poéticas que nos remiten una y otra vez a imágenes de nacimiento, de desarrollo, de evolución, de crecimiento [...] como la espiral, el árbol, el nido [...]122.

Otro de los usos de lo vegetal está estrechamente vinculado con el sentido de lo público. En este sentido, la opinión de Lucy Lippard es contundente al retomar las palabras de Donna Haraway para afirmar con ella, que el mejor medio que tendrían los artistas para reimaginar la Naturaleza, sería "negociar los términos en los que el amor por la Naturaleza podría formar parte de la solución en vez de ser parte de las imposiciones de la dominación colonial y de la destrucción medioambiental", creando un arte que trabajara en la línea de obras como Time Landscape:

[...] a favor de una toma de conciencia medioambiental y por la mejora y reivindicación de zonas baldías, centrándose en la historia natural, realizando parques y limpiando la contaminación. Un ejemplo de esto es el Time Landscape of New York City de Alan Sonfist ${ }^{123 .}$

Esta obra, precursora en cuanto a sus intenciones, afirmaba las ventajas ecológicas de los mini-paisajes, conocidos como Greenstreets que brotan alrededor de la ciudad de Nueva York. La intención de Alan Sonfist (New York, 1946) era reconstruir el espacio natural: el bosque original de la isla de Manhattan, recompuesto en una pequeña parcela junto a Broadway, de manera que preservó el perímetro de una manzana y transplantó y sembró en ella árboles y semillas seleccionadas específicamente del periodo pre-colonial. Se trata de un bosque urbano que nos ofrece la vegetación originaria del lugar. Su acción recoge la esencia de un auténtico activismo en el sentido de que se dirige como señala Javier Hernando, "más allá de la simple denuncia simbólica"124, hacia la intervención directa sobre el medio natural. Desde 1965, Sonfist defendió la construcción de monumentos dedicados a la historia de la contaminación atmosférica y a la emancipación del Arte Público de su concentración exclusiva en la historia humana125. Muestra de ello será un artículo publicado en 1968 con el título de Natural Phenomena as Public Monuments (Los fenómenos naturales como monumentos públicos). Este tipo de obras enlazarán en la actualidad, con los proyectos de Natalie Jeremijenko y su clonación de árboles, en cuanto a sus planteamientos públicos.

Este tipo de intervenciones públicas en pro de una recuperación de lo natural que se enfoca específicamente en un contexto vegetal tiene resonancias paralelas en la obra Herman de Vries (Países Bajos, 1931), quien con intenciones

\footnotetext{
122 PEIRÓ LÓPEZ, Juan Bautista, “Pamen Pereira...”, op. cit., pp. 80-81.

123 LIPPARD, Lucy R., "Mirando alrededor...", en BLANCO, Paloma et al., op. cit., pp. 51-71. 124 HERNANDO, Javier, "Visiones de la naturaleza...", en RAMÍREZ, Juan Antonio y CARRILLO, Jesús (eds.), op. cit., p. 62.

125 GRANDE, John K., op. cit., pp. 277-292.
} 
similares expresó la relación entre un concepto de Naturaleza salvaje y arquitectura en su pieza Santuario (1997), realizada en Münster y en la que construye un espacio arquitectónico para preservar y permitir que la Naturaleza se recupere a sí misma sin la intervención del ser humano. Aunque esta obra implica en definitiva, un concepto de Naturaleza artificialmente preservada, la idea latente es la de lugar sagrado, espacio de reflexión, revelación y contemplación. El artista, oponiéndose a las ideas de Descartes (1596-1650) y a su célebre frase, "cogito, ergo sum" (pienso, luego existo) así como al desarrollo de la filosofía mecanicista y de la Ciencia, nos ofrece las ideas de Gassendi (1592-1655) anteponiendo la frase "ambulo, ergo sum" (camino, luego existo), para defender la idea de movilidad y experimentación. Entre otras, la obra Natural relationships (1989) recopila parte de los intereses botánicos acumulados durante años por Herman de Vries. La colección de piezas, que consta de dos mil ejemplares entre hierbas, semillas, raíces, cortezas y sustancias vegetales de diferentes geografías, que el artista expone vinculándolos a la flora de la región donde vive, con la finalidad de mostrar las afinidades entre unas y otras especies 126. En el contexto mexicano, podemos relacionar estas obras con las recopilaciones realizadas por Jan Hendrix y Rosario García Crespo.

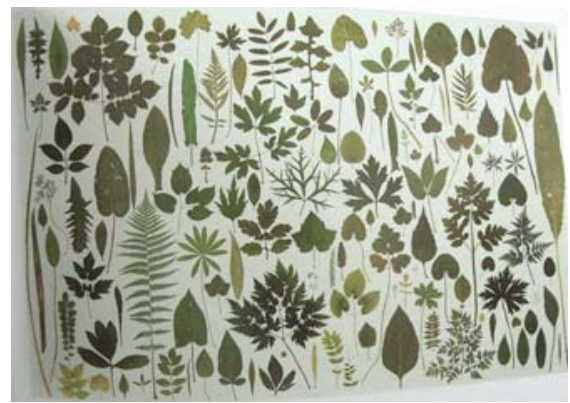

Herman de Vries, Natural relationships, 1989.

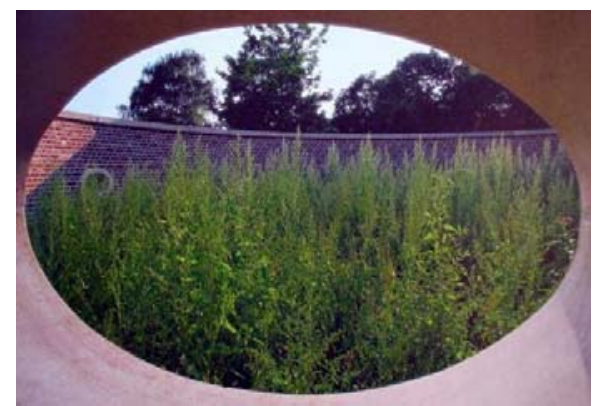

Herman de Vries, Santuario en Münster, 1997.

Por otro lado, cabe destacar cómo en nuestras ciudades y hogares, la Naturaleza se ha visto suplantada por representaciones artificiales de "lo natural". Como veremos más adelante, los trabajos de artistas como el colombiano Alberto Baraya, utilizan una metodología sistemática, al estilo de Alexander Von Humboldt o Linneo (primeros exploradores y biólogos del Nuevo Mundo) y recolecta ejemplares vegetales de plástico de diferentes partes del mundo. A la manera de las grandes colecciones científicas, el artista confecciona su personal herbario artificial, clasificando todo tipo de plantas artificiales que, rescata de los espacios públicos en los que estas plantas conviven cotidianamente con nosotros. No es el único, muchos otros artistas como Petah Coyne, Isa Genzken, M. ${ }^{a}$ Fernanda Cardoso, John Isaacs o Gerda Steiner y Jörg Lenslinger y, en el contexto mexicano, Sofía Táboas o Perla Krauze, en ciertas obras, ya no necesitan de elementos o materiales naturales, para hablar de la Naturaleza 
misma. La dicotomía entre lo natural y no artificial ya no se presenta como un enfrentamiento, sino que ofrece una vía alternativa de convivencia. Estas estrategias de coexistencia rescatan un mundo en el que se asume que todo es artificial, y donde resulta descontextualizado el pretender hablar de una Naturaleza que no esté mediatizada por nuestro propio concepto cultural de la misma. En estas circunstancias, es perfectamente coherente utilizar indistintamente, materiales naturales o artificiales, ya que, en la actualidad, el discurso en torno a la Naturaleza no se centra únicamente en la ecología, sino que las referencias se corresponden, como estamos viendo, con numerosos contextos sociales y existenciales.

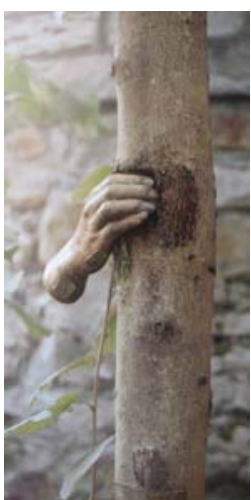

Giuseppe Penone, Continuará creciendo, excepto en aquel punto, 1968.

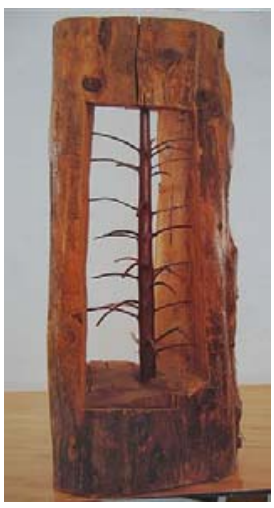

Giuseppe Penone, Árbol-puerta, 1993.

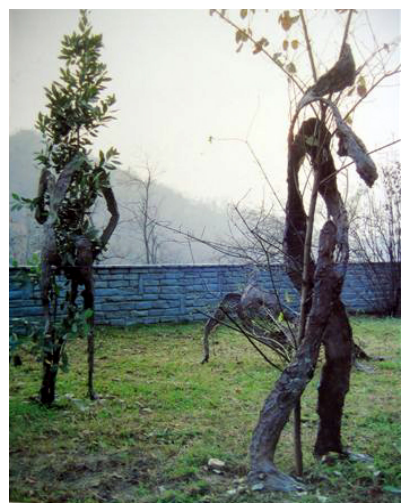

Giuseppe Penone,

El paisaje del gesto vegetal, 1983-1984.

Sin duda, un artista fundamental en la relación naturaleza vegetal y arte contemporáneo, es Giuseppe Penone (Garessio, Italia, 1947), artista identificado con el Arte Povera y para quien la Naturaleza no sólo es fuente de inspiración, sino que es el medio y el fin de su quehacer artístico. Albelda lo sitúa entre los artistas que plantean una poética de coautoría y disimulo, desde la metáfora de un nuevo modelo de relación con el medio. En estas circunstancias, el artista y sus trabajos declinan ser el centro de atención, de forma similar a las entidades híbridas de las que hablábamos en este capítulo, el artista prefiere fundirse con la Naturaleza:

[...] prefiere integrarse y disolverse en el paisaje, ser una parte más, equilibrada del ecosistema [...] Penone, suprime las fronteras que demarcan los límites entre lo vegetal y lo humano, haciéndolos partícipes de una sustancia común'127.

De forma que su obra, basada en la relación entre el hombre y su medio natural, defiende que la Naturaleza es arte y que el hombre, en tanto que es también Naturaleza, es artista por naturaleza, por tanto le corresponde repetir los comportamientos escultóricos de la misma. No se trata de imitar los resultados,

127 ALBELDA, José y SABORIT, José, op. cit., pp. 155-160. 
sino de acercarse a ella para entender los procesos de transformación. Así, el artista traza una morfología que establece paralelismos entre las formas de la figura humana -tronco, brazos, dedos-y las vegetales, buscando captar además la flexibilidad de movimientos de la hierba o de las ramas de los árboles y la figura humana, entre el interior y el exterior de ambas naturalezas, lo que fluye, la respiración:

Siento la respiración de la floresta, oigo el crecimiento lento e implacable de la madera, modelo mi respiración sobre la respiración del vegetal, percibo el deslizamiento del árbol alrededor de mi mano apoyada en su tronco. El cambio de relación temporal vuelve fluido lo sólido y sólido lo fluido. La mano se hunde en el tronco del árbol que por la velocidad del crecimiento y la plasticidad de la materia es el elemento fluido ideal para ser plasmado ${ }^{28}$.

Sus obras revelan las diferencias entre las escalas de tiempo y ritmo vitales entre los seres humanos y los árboles. Desde la perspectiva relativamente corta y el ritmo veloz de la vida humana, el árbol parece sólido, pero en realidad, la materia del árbol es también fluida, depende de nuestra percepción y del periodo de observación. La obra, concebida como una totalidad, es imposible, porque en rigor, la duración de una única vida no es suficiente para presenciarla en su estado acabado, como por ejemplo la obra Continuará creciendo, excepto en aquel punto, 1968.

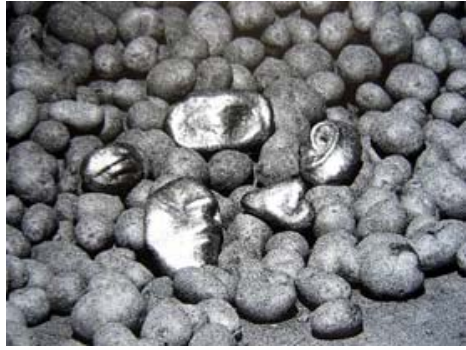

Giuseppe Penone, Patatas, 1977.

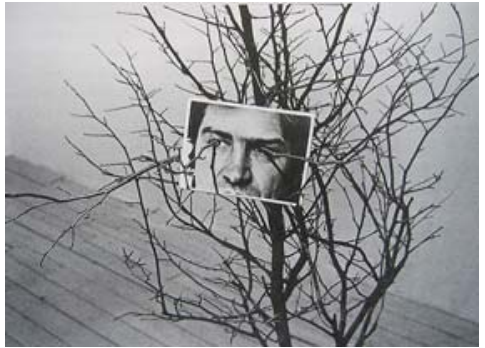

Giuseppe Penone, Mirada vegetal, 1991.

Son conocidos los árboles de Penone, en los que toma una viga de la construcción -un elemento natural, transformado en artificial- y con su gesto, el artista, rescata el árbol que hay en su interior, invirtiendo el proceso a partir de uno de los anillos de tiempo del árbol129. La acción de rescatar el árbol de la viga de madera no plantea en esencia un interés ecológico, su idea es hacer visible algo cotidiano que habitualmente no percibimos: lo invisible, lo que está en el interior. Es por esto, que Penone habla de resucitar el bosque contenido en

\footnotetext{
128 Véase AA. VV., Giuseppe Penone, 1968-1998, Centro Galego de Arte Contemporánea, Xunta de Galicia, Consellería de Cultura, Comunicación Social e Turismo, Santiago de Compostela, 1999, pp. 47-48.

129 HERNANDO, Javier, "Visiones de la naturaleza...", en RAMíREZ, Juan Antonio y CARRILLO, Jesús (eds.), op. cit., p. 64.
} 
mesas, suelos y travesaños: encontrando la memoria del árbol en la madera, la escultura en el río, el aire en la respiración y la Naturaleza en el árbol. Su empeño es mostrar lo que está delante de nuestra mirada, pero oculto. Volver la mirada o invertir la visión, ver desde el ser árbol, esa es la metáfora en la obra Mirada vegetal, 1991. El artista se convierte aquí en un espejo para el espectador, invitando a que el público se identifique con el artista. Para Penone, el hombre forma parte integral de la Naturaleza y, en esencia, no existen diferencias jerárquicas entre el ser humano y un árbol. En su obra, suprime las fronteras entre lo vegetal y lo humano, de forma que hace a ambos, partícipes de una misma sustancia común. El motivo recurrente en su obra es el vínculo entre Naturaleza, hombre y tiempo y, alejándose del antagonismo típico entre Cultura y Naturaleza, Penone concibe al hombre como fruto de ambos conceptos, de forma que el artista debe, a su vez, situarse entre ellos.

Esta singular operación, que consiste en revelar el árbol en la viga, en establecer un paralelo entre la edad del artista y la del vegetal, en oponer a la actitud clásica de negación del carácter intrínseco del material la actitud inversa orientada a convertir ese mismo carácter en escultura, conduce al artista a reanudar la estrecha y misteriosa relación entre la Naturaleza y la Cultura puesta de manifiesto por Malraux. A partir de ese momento se puede instaurar un diálogo silencioso entre las cosas del universo y los objetos de los hombres, entre los elementos naturales y el cuerpo del artista, entre el dibujo de los árboles y la forma de las estatuas. Un diálogo delicado y sutil en el que se pasará libremente de la genealogía de una viga a la memoria de los huesos, del impulso vertical de la linfa a la arborescencia exuberante de los tejidos de la piell30.

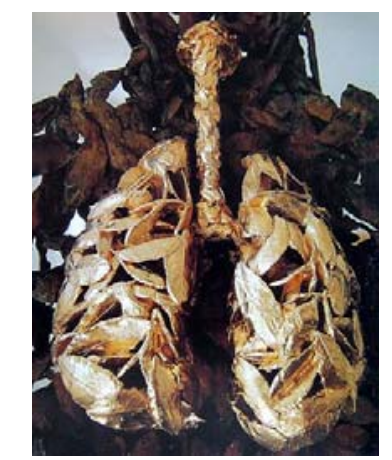

Giuseppe Penone,

Respirar la sombra, 1997-99.

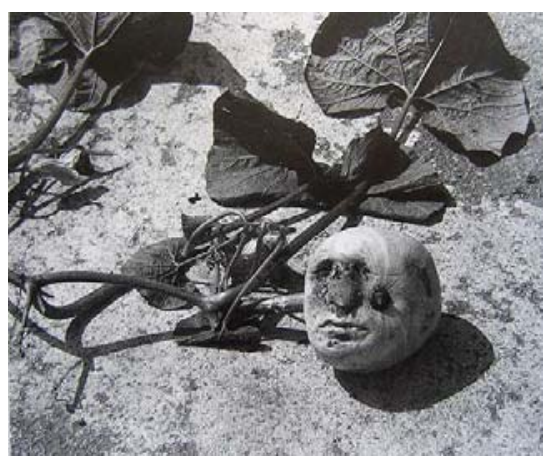

Giuseppe Penone, Calabazas, 1978.

A propósito de la temática vegetal que nos ocupa, cabe destacar que la obra de Penone, a pesar de su sensibilización hacia todo lo natural, no escapa en nuestra opinión, de imprimir una especie de huella antropomorfizada a la Naturaleza, de manera que, incluso sin proponérselo quizás, ejerce una cierta imposición, al obligar al vegetal a adquirir forma humana (acciones de abrazar al

130 Véase TOSATTO, Guy, en AA. VV., Giuseppe Penone, 1968-1998, op. cit., p. 149. 
árbol con su mano, pulmones humanos de hojas, mano de bronce sobre tronco, patatas con partes de su rostro, calabazas con rostro humano, etc.). En la filosofía artística de Penone encontramos vínculos con la obra de artistas mexicanos como Perla Krauze - piedras de resina y referencias en sus obras a la memoria y al tiempo- y en la obra de Yolanda Paulsen en torno al árbol que llevamos dentro y los árboles y nubes de silicón. Ambos trabajos plantean un discurso cercano al de hacer visible lo invisible de lo cotidiano y lo interno que habitualmente no podemos ver. Por su parte, formalmente Rosario García Crespo tiene en sus herbarios, paralelismos humano-vegetales similares a los de Penone.

Asimismo es imprescindible mencionar la obra de Andy Goldsworthy (Cheshire, Inglaterra, 1956), cuyo trabajo se caracteriza por la intervención en el entorno natural a partir de la sutileza y desde una posición de colaboración131, como así lo atestiguan los documentos que recoge en los libros que publica a posteriori y en los que mediante fotografías documenta todas las acciones llevadas a cabo en los diferentes lugares del planeta. Su labor reconstruye lo natural como sujeto, optando generalmente por trabajar con una naturaleza vegetal y viva.

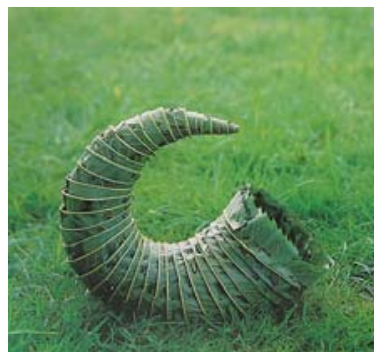

Andy Goldsworthy, Espiral-cuerno, 1987.

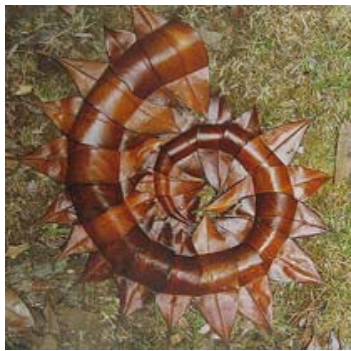

Andy Goldsworthy, Sin título, 1987.

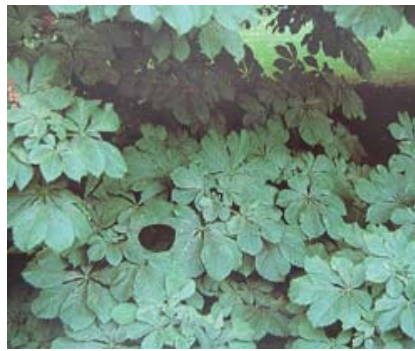

Andy Goldsworthy, Sin título, 1986

Las acciones que lleva a cabo este artista en el medio natural están vinculadas con una suerte de ritual contemporáneo. El sitio que el ritual ha ocupado en la Historia del hombre ha sido siempre muy importante si bien, como advierte Juan Bautista Peiró, el regreso a lo natural ya nunca será inocente, pensamos que el modo en el que algunos artistas realizan este tránsito, es mediante un nuevo ritual relacionado con el quehacer artístico:

Ahora bien, ningún regreso puede ser inocente. Ese camino se puede abordar desde la razón, cosa imposible, pues precisamente la razón concentra la parte más específicamente humana; o bien desde la intuición, la sensibilidad, el instinto adormecido por nuestra singular evolución 132.

\footnotetext{
131 CAUSEY, Andrew, "Environmental Sculptures", en Andy Goldsworthy, A collaboration with nature, Terry Friedmann and Andy Goldsworthy (eds.), Harry N. Abrams, Inc., Publishers, New York, 1990, pp. 37-44.

132 PEIRÓ LÓPEZ, Juan Bautista, Otras naturalezas, Cimal Arte internacional, Valencia, 2003, p. 14.
} 


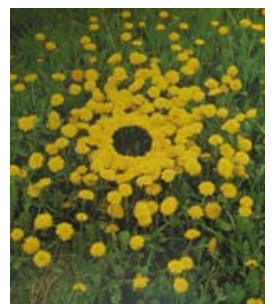

Andy Goldsworthy,

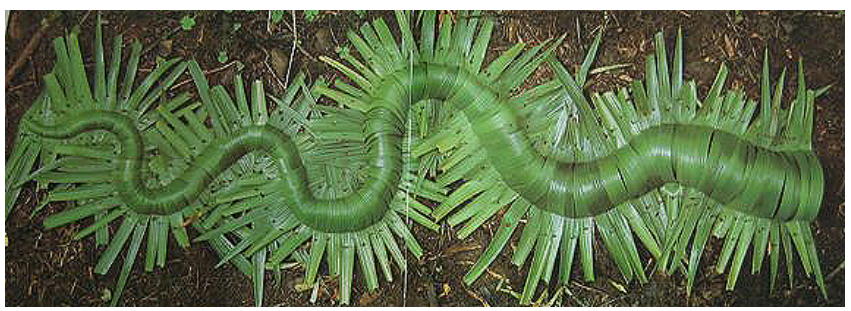

Andy Goldsworthy, Sin título, 1988.

Sin título, 1987.

En el ritual se redime parte de la conexión perdida. Al respecto el antropólogo Arthur Maurice Hocart señala que el ritual, para el género humano y desde los tiempos del hombre primitivo, es una herramienta necesaria y una estrategia vital:

[...] una técnica para dar vida, dando a entender que la inercia del hombre primitivo fue siempre la de tratar de controlar la vida, escapar de lo malo y de la destrucción de la naturaleza, hecho con todo tipo de ritual, incluso el sacrificio con toda su destrucción 133 .

Estamos ante un arte que funciona como un nuevo ritual mediante el cual se consigue generar vida y permanencia. Un ritual en el que el artista pretende comportarse de forma procesual de la misma manera que lo haría la propia Naturaleza. La ofrenda y el sacrificio se manifiestan aquí mediante el propio trabajo y el tiempo invertido en la obra. Las obras de Goldsworthy son ejemplos de este tipo de ceremonias creativas, en las que el sentido del ritual y el sacrificio de tiempo y trabajo requeridos se identifican con la recuperación de lo sagrado de la Naturaleza:

El sentido de estos sacrificios humanos debe buscarse en la teoría arcaica de la regeneración periódica de las formas sagradas. Evidentemente, todo rito o argumento dramático que persigue la regeneración de una "fuerza" es a su vez una "repetición" de un acto primordial de tipo cosmogónico que tuvo lugar ab initio [...]. El ritual rehace la creación, la fuerza activa en las plantas se regenera por una suspensión del tiempo y por le retorno al momento inicial de la plenitud cosmogónical34.

Mircea Eliade describe la importancia del ritual para el hombre primitivo, que vivió durante millones de años con la ansiedad de que se le acabaran los recursos, controlando el miedo a que el sol se apagara con el solsticio de invierno, de que no saliera más la luna por la noche o de que la tierra se convirtiera en un páramo sin vegetación:

133 FERNÁNDEZ ARENAS, José (Coord.), Arte efímero y espacio estético, Anthropos, Barcelona, 1988, p. 132.

134 FERNÁNDEZ ARENAS, José, op. cit., p. 136. 
La ansiedad es particularmente patética ante las manifestaciones periódicas del "poder", como la vegetación, cuyo ritmo conoce momentos de extinción aparente. Y la ansiedad es más aguda aún cuando la desintegración de la "fuerza" parece deberse a la intervención del hombre: la recolección de las primicias, la siega, etc. En este caso se ofrecen sacrificios Ilamados "de las primicias"; el ritual reconcilia al hombre con las fuerzas que actúan en los frutos y le otorga el permiso de consumirlos sin riesgos ${ }^{135}$.

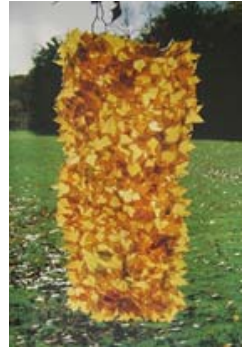

Andy

Goldsworthy,

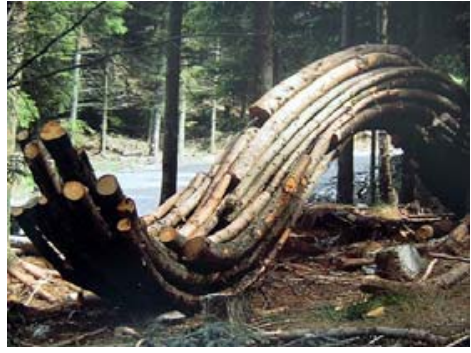

Andy Goldsworthy,

Sin título, 1985.

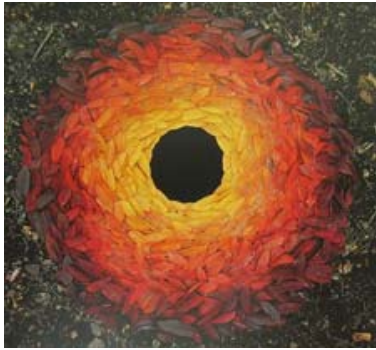

Andy Goldsworthy, Sin título, 1987.

Sin título, 1986.

El ritual que desarrollan los artistas que trabajan en colaboración con la Naturaleza conlleva una fuerte voluntad de integración. Estamos ante una fina sensibilidad que, como apunta Albelda, aprecia "la belleza más imperceptible de la Naturaleza, todo aquello que requiere rebajarse al nivel de lo pequeño y permanecer contemplando largamente para comprender todo su sentido"136. Siguiendo las directrices de imitar el orden natural imperante, las obras resultantes aportarán una renuncia voluntaria por parte del artista a la tradición imperante durante siglos, de la supremacía de lo artificial sobre lo natural. Goldsworthy forma parte de una serie de artistas que sin duda, comulgan con una nueva percepción de la Naturaleza:

[...] se ven influidos por una nueva sensibilidad expresada en sus obras por un conjunto de metáforas que inconscientemente ilustran las principales premisas del paradigma ecológico [...]. A partir de ahora la idea de naturaleza se relacionará con lo frágil y lo finito, convirtiéndose en un concepto que habrá que manejar con respeto y veneración137.

Otro de los artistas surgidos de la corriente del Land Art, es Nils-Udo (Baviera, 1937) pero, en contraposición a los artistas del Land Art americano -quienes en ocasiones, eran indiferentes a la vitalidad inherente a la Naturaleza- las estructuras de Udo desempeñan un papel relevante en la misma. Artista alemán relacionado con el arte medioambiental desde los años sesenta, su interés por

135 ELIADE, Mircea, en FERNÁNDEZ ARENAS, José, op. cit. pp. 136-137.

136 ALBELDA, José y SABORIT, José, op. cit., p. 64.

137 ALBELDA, J., "Intervenciones mínimas, poéticas de la preservación", en Cimal..., N ${ }^{\circ} 51$, op. cit., pp. 49-54. 
este tipo de arte surge frente al crecimiento del impacto destructivo de la actividad humana en el ambiente y la Naturaleza. Su trabajo in situ, íntimamente ligado con el paisaje en el que se inserta, presenta estructuras realizadas con materiales naturales del lugar. En sus obras en la Naturaleza recurre frecuentemente a la fotografía para registrar sus intervenciones efímeras. Sus esculturas y fotografías cuestionan nuestra manera de domesticar la Naturaleza, pero más allá de nuestras clasificaciones y representaciones, el artista sostiene que el mundo natural nos sobrepasa.

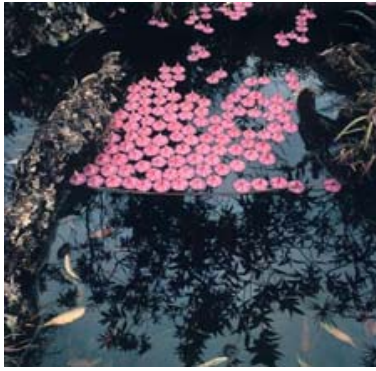

Nils Udo,

Lecho de arroyo, 1990.

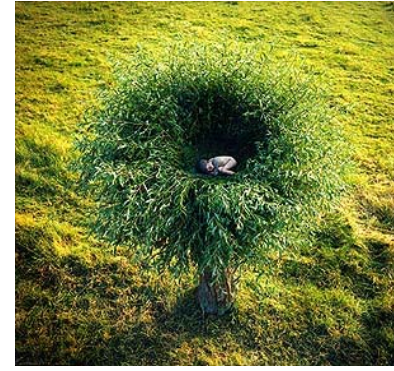

Nils Udo,

El sauce, 1999.

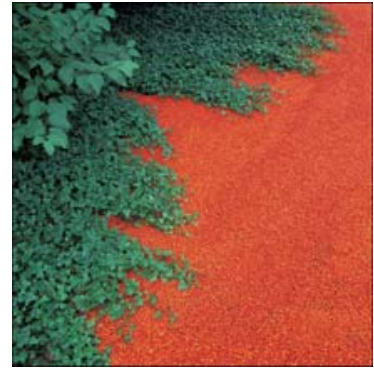

Nils Udo,

Casa de agua, 1982.

John Grande, en entrevista con Nils-Udo, nos acerca a algunas de las premisas de su trabajo. Según Grande, Udo establece relaciones entre horticultura y arte, creando con sus plantaciones e instalaciones vegetales, un "contrapunto visual entre elementos orgánicos e inorgánicos"138 y aportando una visión de una sensibilidad particular hacia la historia del paisaje y la tierra de los lugares en los que trabaja. El acercamiento de Nils-Udo al elemento vegetal es táctil y a menudo improvisado, con los árboles, plantas y los materiales naturales vivos que utiliza, pareciera que borda en la Naturaleza. En definitiva su obra plantea al ser humano como una parte de la Naturaleza, que para sobrevivir, debe actuar en conformidad con las leyes de la misma. A partir de 1972 Udo realiza plantaciones extensas de árboles, arbustos, hierbas y flores. Literalmente, la idea de plantar su trabajo en la Naturaleza y de trabajar en simbiosis con la misma, sometiéndose a sus ciclos y ritmos, le proporcionaría, además de un sentimiento de paz, nuevas e inagotables posibilidades de acción. Esto no implica que no use, en determinadas circunstancias, materiales no naturales como cemento, pero lo que cuenta para él son las acciones, la utopía de fusionar en uno, arte y vida.

En general su trabajo se caracteriza por un sentido ritual y procesual de la obra. En 1994, en el Château de Laás, (Francia), el artista realizó una gran espiral de diferentes especies de maíz para conmemorar el Quinto Centenario de la introducción de esta planta en Europa. Otro de los temas sobre los que versa su obra es la vulnerabilidad y la temporalidad de la existencia humana. Yolanda Gutiérrez, escultora mexicana de la que hablaremos más adelante, realizó

138 GRANDE, John K., op. cit., pp. 171-184. 
trabajos similares en unas milpas en México, aunque como nos comunicaría en entrevista informal, los resultados de las cosechas no fueron los esperados.

Consciente de la paradoja de sus intenciones naturalistas y, a la manera del libro de Nigel Barley en torno al antropólogo inocente139, Nils-Udo sabe de las consecuencias negativas que puede generar su trabajo, puesto que los seres humanos han demostrado ser constantemente destructivos al tratar incluso, de preservar los mismos sistemas naturales. Udo asume que, de la misma forma que el principio de incertidumbre de Werner Heisenberg implica que la intervención del observador transforma el resultado del experimento, las probabilidades de un artista de intervenir en los procesos naturales sin dejar ningún rastro son prácticamente nulas. Pese a todo lo cual, las obras de Nils Udo, junto con las de Goldsworthy se consideran metáforas de respeto, de restitución y de disolución y, junto con las obras realizadas por otros artistas en los últimos tiempos, expresan la voluntad de encontrar caminos para recuperar una Naturaleza diezmada. Sin embargo, como apunta Albelda, este tipo de obras constatan la muerte de una Naturaleza no artistificada, ya que si bien antes, la Naturaleza era un espacio definido, ahora se ha convertido en "un territorio conceptual de alto impacto y una gran capacidad de legitimar todo aquello con lo que se relacione, incluso el arte"140.

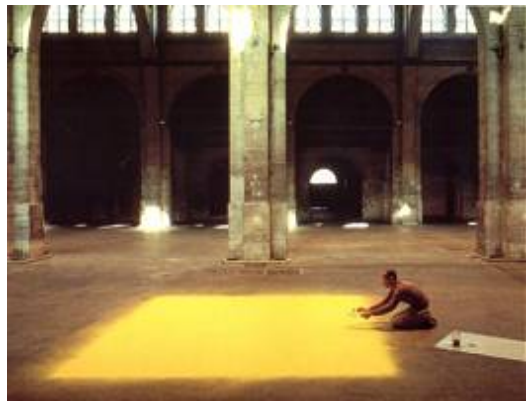

Wolfgang Laib,

Polen de avellano, 1991.

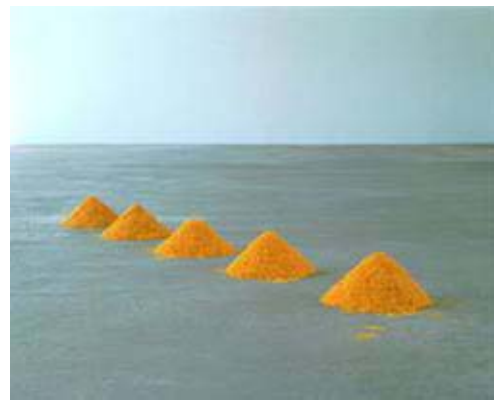

Wolfgang Laib, The Five Mountains Not to Climb On, 1984.

La recuperación de la Naturaleza como entidad con la que el artista trabajará a la par, coincide en artistas como Wolfgang Laib (Metzinger, Alemania, 1950) con la reivindicación por parte de estos artistas de los materiales como portadores de sentido y de expresividad. La no transformación de las materias primas y el escaso procesamiento de los materiales empleados dotan a la materia de un concepto esencial, naturalista y religioso que permite que el arte se manifieste en todo el proceso de creación, los materiales no modificados se convierten en sí mismos, en esencia de lo espiritual. En su obra, según Saborit y Albelda, "la materia recupera una entidad no transformada que se enuncia con la máxima intensidad, como arroz, cera, polen o mármol, con todo el simbolismo que el

139 BARLEY, Nigel, El antropólogo inocente. Notas desde una choza de barro, Anagrama Barcelona, 1989.

140 ALBELDA, J., “Intervenciones mínimas...”, en op. cit., pp. 49-54. 
autor -Laib, en este caso- le otorga"141. Esta actitud ante los materiales tiene como precedente claro ciertos trabajos de Beuys en los que el artista utilizaba el fieltro o la grasa y donde cada material era poseedor de una identidad propia que caracterizaba el discurso artístico. El interés de Laib por el elemento vegetal del polen no termina en la intensidad del color, sino que su importancia radica en la vinculación de su trabajo a los ciclos vitales de la Naturaleza como la observación de las estaciones, o al carácter ritual del proceso en cuanto a la lentitud y la dificultad de la recolección.

Los materiales que utiliza para sus instalaciones (leche, polen, arroz, cera de abejas...) son recopilados en los campos que rodean su casa y están ligados a la idea de nacimiento, crecimiento, muerte, ideas por otra parte, presentes en el misticismo de todas las culturas. Sus casi treinta años de trayectoria se han convertido en un trabajo continuo de presentación de la Naturaleza en su estado más puro. Toda creación para Laib se concibe como un proceso cíclico donde la premisa es la conservación de la pureza de los elementos. Desde la selección de las materias, la recolección del polen en las distintas estaciones, hasta el cuidadoso montaje de la exposición y el mantenimiento de las sustancias que son recogidas y vueltas a poner diariamente, presupone una serie de acciones que hacen del ritual el objetivo último de la obra de este artista.
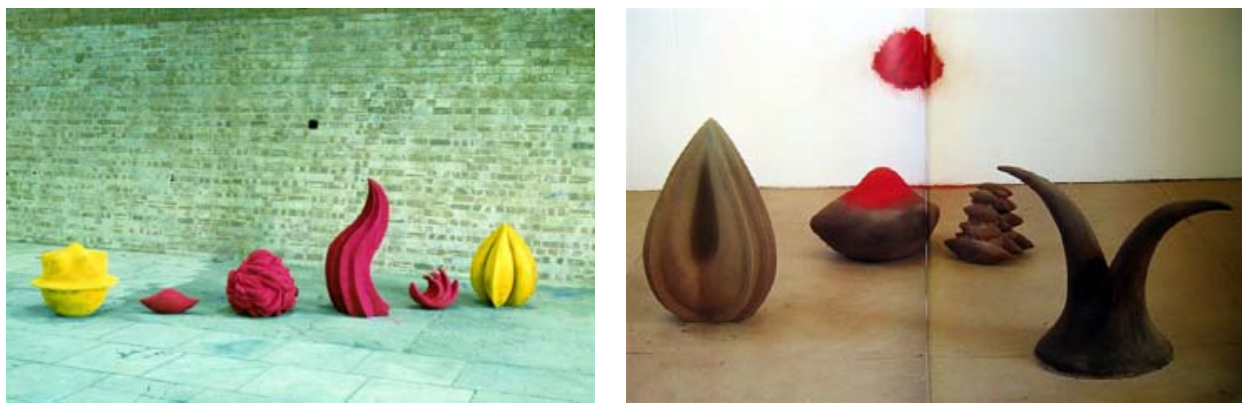

Anish Kapoor, Seis Lugares Secretos, 1983.

Frente a los artistas que han trabajado en su obra con elementos vegetales, recurriendo a procesos de coautoría con la Naturaleza, y a aquellos que establecen dichos procesos como partes de un ritual, otros han recurrido a detener su mirada en la naturaleza vegetal, como inspiración formal que redescubre una geometría generadora de connotaciones y de sentido. Así Anish Kapoor (Bombay, India, 1954) en la década de los ochenta, fusiona en su obra las influencias culturales de Oriente y Occidente explorando opuestos primordiales como lo masculino y lo femenino, lo abierto y lo cerrado, la luz y la oscuridad, apelando, sin una simbología precisa, a la idea de lo sublime. Después de su formación en el Reino Unido, Kapoor realizó en 1979, un largo viaje a su país de origen. En esta visita recuperó el fuerte sentido ritual de la vida cotidiana en la India, la constante presencia de lugares de culto y, como parte de las celebraciones religiosas, los coloridos pigmentos que se apilan a la

141 ALBELDA, José y SABORIT, José, op. cit., p. 154. 
entrada de los templos. Con esculturas de volumetrías cerradas, a medio camino entre lo orgánico y lo geométrico, Kapoor -quien formaría parte de la llamada Nueva Escultura Británica- se aleja del reduccionismo minimalista "insuflando a sus esculturas el sentido oriental de lo trascendente" 142 . Hechas de yeso y poliéster, estas primeras esculturas que parecen tener referentes vegetales (Seis Lugares Secretos, 1983), se caracterizaban por presentar colores intensos que desbordan de la superficie de las mismas, generando una aureola, mediante pigmentos en polvo aplicados directamente, lo que sería posteriormente una característica particular en la producción del artista. Inherente al pensamiento tradicional indio, la transformación de la Naturaleza en arte es retomada por Kapoor ${ }^{143}$ al emplear elementos con formas de origen orgánico mezclados con formas arquitectónicas y figuras geométricas básicas, junto a otras más enigmáticas y no desprovistas de cierto misticismo. De esta mezcla resulta un mundo en clave propia que no rehuye una filosofía del arte de gran complejidad. Para Kapoor, el uso del color y los pigmentos implica la unión de lo intangible con lo sensual desde una perspectiva que analiza el resultado estético como parte de una cosmovisión personal. En nuestra opinión, tanto a través de la forma como del color, las referencias de Kapoor a una naturaleza vegetal en estas obras, son claras. En su obra, tenemos una referencia interesante vinculada -a través del tiempo y del espacio- con trabajos como los de la escultora mexicana Ivonne Domenge o del polaco afincado en México, Xawery Volski, en cuyas obras aparecen formas que nos remiten a frutos, semillas y a la estrecha relación entre lo vegetal y lo humano.

La temática vegetal ha inspirado obras de carácter público como por ejemplo la escultura que encontramos en la ciudad de Buenos Aires, Floralis genérica (2002) de Eduardo Catalano (Buenos Aires, 1912) ${ }^{144}$. Esta monumental escultura cinética dispone de un sistema eléctrico y un control lógico programable que regula de forma automática, la apertura y cierre de la flor de acuerdo con una velocidad establecida y según horarios predeterminados. Sin duda su creador hace un homenaje a la Naturaleza interpretando una referencia floral, en la que la realidad se transforma en una abstracción geométrica que representa, más que a todas las flores, a la capacidad de renovación de un pueblo. En referencia

\footnotetext{
142 MARTíNEZ MUÑOZ, Amalia, op. cit., p. 173.

143 FERNÁNDEZ DEL CAMPO, Eva, Anish Kapoor, Nerea, San Sebastián, 2006, p. 29.

144 Eduardo Catalano fue profesor de arquitectura en el Instituto Tecnológico de Massachusetts (EE. UU.) y donó esta obra a la ciudad de Buenos Aires. La escultura está formada por seis pétalos de aluminio y acero, montados sobre una estructura cónica. Los movimientos se realizan a través de un sistema hidráulico-mecánico. La flor se abre durante el día y se cierra al anochecer. El tiempo de apertura es de veinte minutos. Su peso es de 18 toneladas y tiene una altura de veintitrés metros. Simultáneamente con el cierre de la flor durante la noche, doce proyectores con lámparas halógenas de color rojo, proyectan su luz en la superficie interior de los pétalos. Asimismo, cuando la velocidad del viento supera, por un tiempo mayor de sesenta segundos los $80 \mathrm{~km} / \mathrm{h}$., la escultura se protege automáticamente cerrando sus pétalos.
} 
al mensaje simbólico de la pieza, Catalano sugiere que la flor es una síntesis de todas las flores y es a la vez, una esperanza que renace cada día al abrirse.

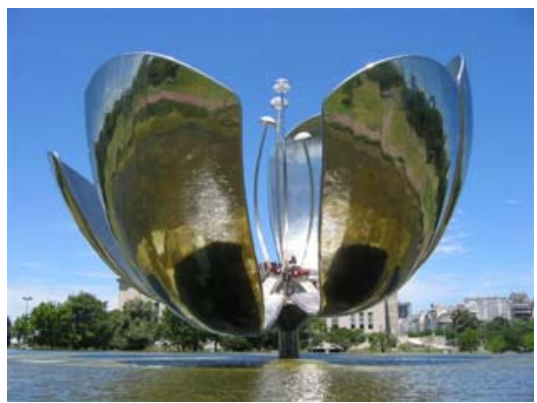

Eduardo Catalano,

Floralis Genérica, 2002.

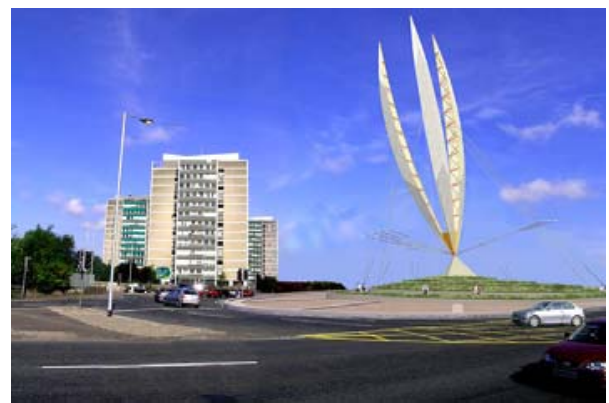

Ed Carpenter,

Proyecto para Belfast, 2005.

Además de la ciudad de Buenos Aires, otras ciudades han propuesto proyectos monumentales de Arte Público con este tipo de temáticas como por ejemplo la obra Trillian del artista Ed Carpenter (Los Angeles, California, 1946) que estaba proyectada para ser ubicada en la ciudad de Belfast. Se trataba de una flor de cuarenta y cinco metros, que en un principio, se planteaba como un símbolo de regeneración para la ciudad de Irlanda del Norte ${ }^{145}$.

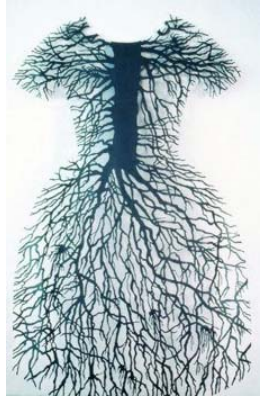

Barb Hunt,

Vestido de raíces, 1994.

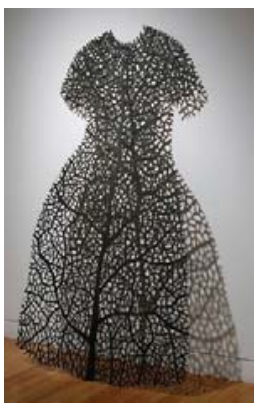

Barb Hunt, Leaf dress, 1994.

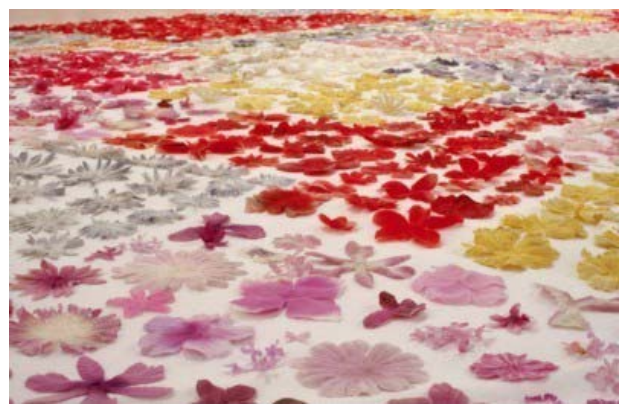

Barb Hunt, Shround, 2000.

La referencia formal a lo vegetal es una constante en numerosos artistas que, como veremos más adelante, generalmente alude a relaciones simbólicas externas, más allá de la forma de la obra en sí. En la práctica artística de Barb Hunt (Canadá, 1950) se investigan los prejuicios culturales con el fin de examinar cómo se construyen nociones respecto de los sexos. En la sociedad, el vestuario se asocia poderosamente con lo masculino o lo femenino. El duro

145 Véase "Belfast to bloom with new artwork. A humble flower is set to dominate the Belfast skyline in three years time", en $B B C$ News, 11, octubre, 2005, Disponible en red: $<$ http://news.bbc.co.uk/1/ hi/northern_ireland/4329710.stm >, [Consulta 30, octubre, $2011]$. 
metal de Vestido de raíces (1994) y su forma firmemente anclada, genera un fuerte contraste, a la vez que diferentes asociaciones que vinculan el vestido femenino -habitualmente con tejidos suaves y vaporosos-con cuestionamientos en torno a los estereotipos basados en las diferencias de género.

Utilizando imágenes de la Naturaleza y formas históricamente conectadas con feminidad, la artista plantea relaciones entre el material, la imagen y el proceso para revelar visiones diversas y alternativas de la identidad. En otras de sus piezas retoma la temática textil desde la deconstrucción. Para ello utiliza flores que desmenuza, esparce y clasifica siguiendo patrones de colores con los que realiza composiciones que invaden el espacio expositivo. En ambos casos, las referencias de género plantean significados alternativos.

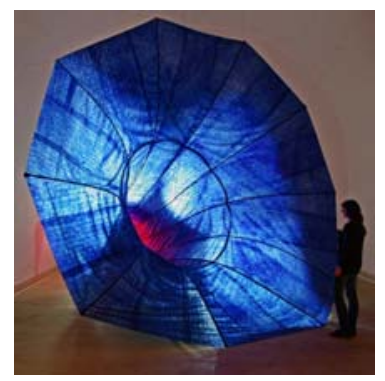

Monique Bastiaans, Gran Hermana, 2007.

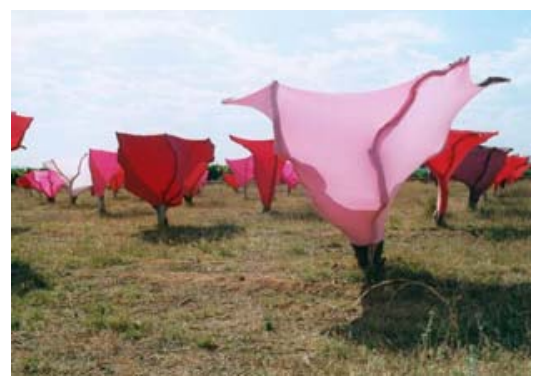

Monique Bastiaans,

Adeu Tristesa, 2000.

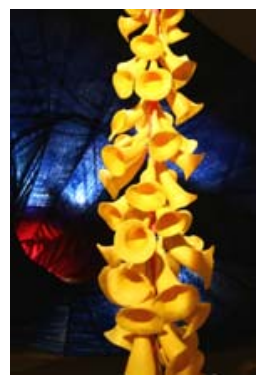

Monique Bastiaans, Alma de casa, 2007.

La escultora Monique Bastiaans (Jemappes, Mons, Bélgica, 1954) quien reside y trabaja en España, en una de sus múltiples intervenciones en la Naturaleza recurre a la transformación de doscientos setenta naranjos aquejados de un mal que ataca a los cítricos, para plantear un proyecto de vida. En unos naranjales privados en la localidad de Ribarroja (Valencia), después de podar los árboles, dejándoles el tronco y las ramas principales, la artista transformó los mismos en enormes flores de colores, mediante telas que dispuso sobre los troncos, dándole una segunda vida a los campos. En obras posteriores las referencias vegetales son usadas reiterativamente para expresar una sensualidad que, traspasando el mundo vegetal, alcanza la expresividad de lo humano para trasmitir cuestiones que van más allá del género y que nos hablan del gozo de vivir. El movimiento y la transformación como fuentes de la vida, así como la fecundación, la polinización y la fructificación son -en la obra de Bastiaansmetáforas de la vida que tiende a perpetuarse a sí misma. Como sugiere José Albelda, "La magia del deseo y del placer permite que la biosfera siga latiendo" 146 y, sólo la humildad y la capacidad de observación -una de las tareas del arte es la de enseñar a mirar- puede hacernos percibir la altura similar del hombre y la flor.

146 ALBELDA, José, "Las enseñanzas de natura", en Plaisir de fleurir, Monique Bastiaans, Sala Parpalló, Valencia, 2007, pp. 16-25. 


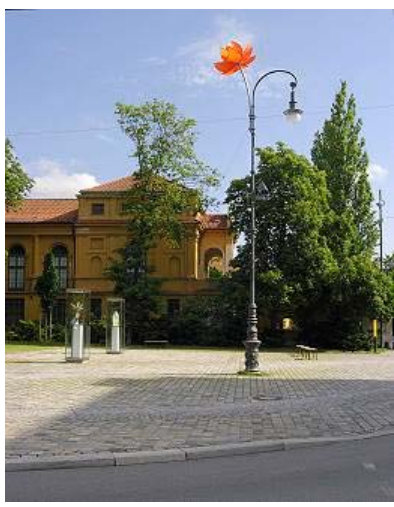

Isa Genzken,

Sin título, 2004

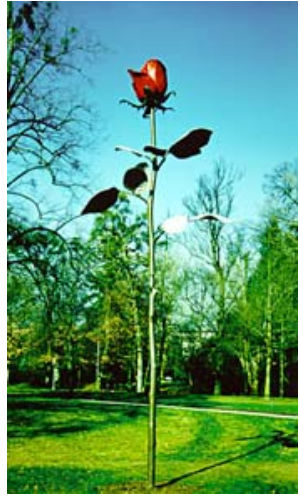

Isa Genzken, Rosa, 1993.

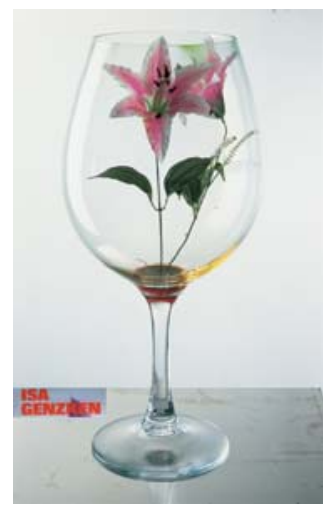

Isa Genzken,

Empire vampire, 2004.

La obra de Isa Genzken (Bad Oldesloe, Alemania, 1948) que vive y trabaja en Berlín, era fundamentalmente minimalista y centraba su interés en la arquitectura. El trabajo de esta artista es versátil, mientras que en los años ochenta realizaba formas arquitectónicas, ventanas en yeso, concreto y resina, en las cuales su discurso versaba en torno a los espacios interiores y exteriores como una forma de relación, a partir de los atentados terroristas del 11 de septiembre del 2001 a las Torres Gemelas de Nueva York, su obra dio un giro total con la realización de piezas que tienden a representar un naturalismo vegetal. Desde entonces, la artista trabaja con materiales baratos que rayan aparentemente en el kitsch. Se trata de obras abigarradas y coloristas, cargadas de materiales diversos, pero fundamentalmente vegetales y flores de plástico, con un cierto trasfondo apocalíptico. La pieza Rosa (1993) es un símbolo del amor que sin embargo revela un naturalismo tal que al mirarla adquiere, por su tamaño, un carácter casi amenazador. En 1988, Genzken había bosquejado para una autopista en Holanda, algo parecido a este trabajo con flores, se trataba de una obra que presentaba tulipanes enormes, que se inclinaban sobre el camino. Vemos cómo la artista utiliza lo vegetal desde una posición totalmente artificial, poniendo en un mismo plano todo tipo de artificios humanos.

Para algunos artistas la representación del mundo vegetal expresada a través de las partes componentes selectivas de este mundo como pueden ser las flores, parece haberse convertido en un campo fértil para su trabajo. El origen, la germinación y el crecimiento son temas recurrentes en Iraida Cano (Madrid, 1959) quien pareciera utilizar estas formas para establecer un nexo -a la manera de las representaciones occidentales- entre el pensamiento y la Naturaleza, exaltando de esta manera las virtudes de la vida hasta en la más sencilla de sus manifestaciones. Más que la paz, el amor o la unidad de los elementos naturales, las flores anuncian un estado espiritual, una plenitud que rebate la condición efímera de la flor. Iraida Cano plantea ${ }^{147}$ que sus esculturas se metamorfoseen con el entorno natural, haciéndonos sentir como Alicia en el país de las maravillas o como Gulliver en un nuevo paisaje reencontrado. El color

147 RAQUEJO, Tonia, op. cit., pp. 86-87. 
de los pétalos trasmite energía, convirtiéndose en elementos compositivos que resultan sorprendentes como el constante fluir de la vida natural pese a todas las adversidades. Más allá de la tradición occidental de las naturalezas muertas, las flores de Iraida Cano son meditaciones sobre lo material, lo perecedero y lo perenne.

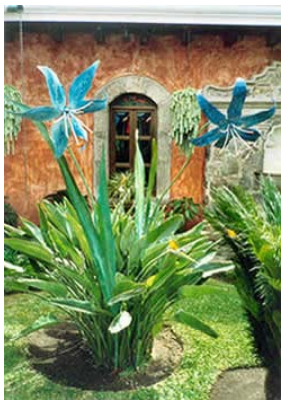

Iraida Cano,

Lirios azules, 2003.

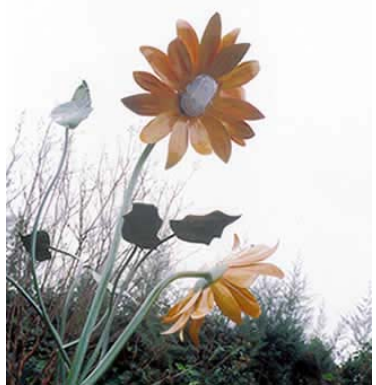

Iraida Cano,

Flores, 2002.

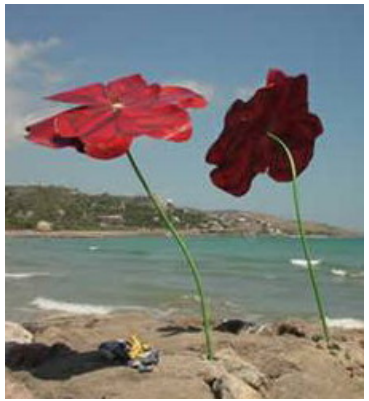

Iraida Cano,

Amapolas, 2002.

Por su parte, el artista Petah Coyne (Oklahoma, Ohio, 1953)148 genera obras pseudo vegetales con materiales artificiales. El poder transformador de la metamorfosis surge en la obra Dafne (2002), en la que el escultor utiliza la cera como material que unifica los diversos materiales que forman la pieza. Se trata de composiciones en las que la referencia vegetal se alía con el cuerpo humano, haciendo alusión a la fantasía de los tradicionales cuentos infantiles. A la manera de Louis Bourgeois, el artista exorciza los procesos de la memoria, el dolor de la pérdida y las emociones generadas por acontecimientos personales y dolorosos de su vida, en trabajos donde consigue dar a los recuerdos amargos del pasado, un lugar en el tiempo presente.

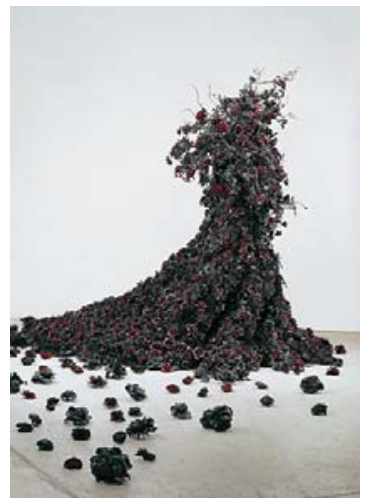

Petah Coyne,

Daphne, 2002.

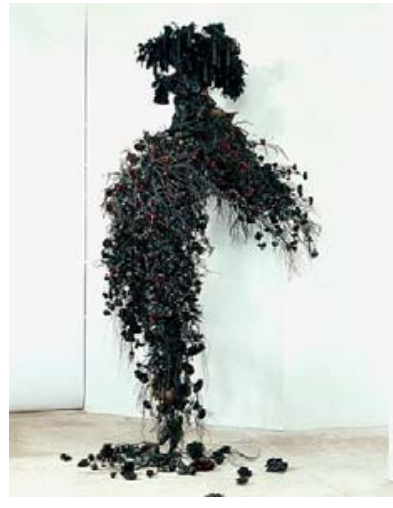

Petah Coyne, Sin título $1111,2003$.

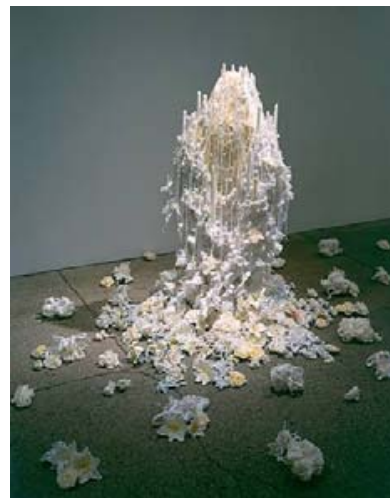

Petah Coyne, Sin título 978, 2001.

148 GoOdmAN, J., Petah Coyne, Sculpture, Galería Lelong, Washington, D.C., marzo, 1999, pp. 69-71. 
En su mayoría son obras realizadas con cera derretida, algunas suspendidas del techo por una amenazadora y elegante cadena metálica, en una especie de putrefacción suntuosa y decadente. Abrumadoras y barrocas, sus inquietantes esculturas desmienten el origen humilde de los materiales con las que están realizadas. Un barroquismo simulado por la acumulación de materiales como pelo humano y de caballo, cintas, pigmentos, pintura de aerosol negra, caucho fabricado, ramas de árbol, alambre, acrílico, flores de seda, cintas de plástico, plumas, borlas, pigmentos, perlas, velas, tinte del pelo, champú, acondicionador y tachuelas. El trabajo de Coyne presenta velas, reales o no, con fuertes connotaciones eclesiásticas y rituales. Combinando tradiciones figuradas y abstractas, los trabajos de Coyne poseen una extraña calidad antropomorfa que mezcla la vitalidad orgánica de lo vegetal con la belleza de la decadencia. Objetos tales como rosas y pájaros se envuelven en una capa de cera, convocando así a una elegancia gótica que resulta estéticamente inquietante.

En pos de la lógica de Baudrillard, Joao Pedro Vale (Lisboa, Portugal, 1976) se instaura en el simulacro como técnica para redimir la realidad y como una forma de la Cultura de tomar postura, frente a la sobrevaloración de los aspectos históricos. La trasgresión en cuanto a los materiales y tamaños de sus piezas nos hablan de un diálogo entre lo natural y lo artificial, surgido como en otros artistas de su generación, del término contemporáneo de Neobarroco.

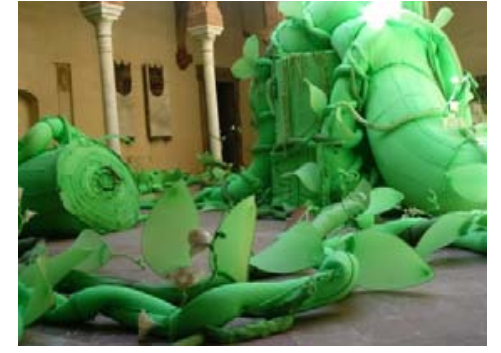

Joao Pedro Vale, Jardín secreto, 2004.

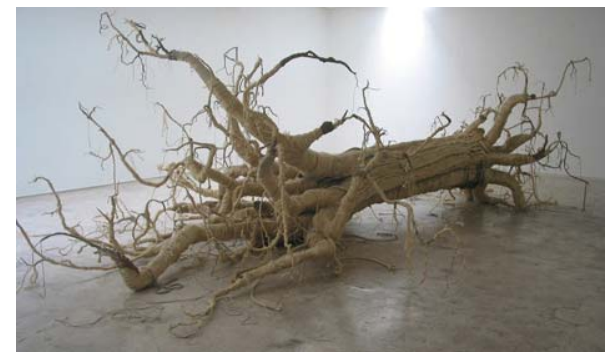

Joao Pedro Vale, La culpa es mía, 2003.

Su Jardín secreto (2004), expuesto en la I Bienal de Arte contemporáneo de Sevilla (España) generaba una fantasía épica que constataba el engaño de las apariencias y la realidad del simulacro ${ }^{149}$. Su obra construye una narrativa, utilizando la cita al pasado y al arte, como una representación de sí mismo a través del simulacro. La ironía expresada en sus obras funciona de forma similar a la clave humorística-kitsch, que retoman las obras de Jeff Koons. Joao Pedro Vale se apropia de iconos locales y de imágenes de la Cultura de masas, a fin de formular observaciones en torno a los valores mantenidos por la sociedad como verdaderos y relaciona los aspectos simbólicos que acompañan la existencia de estas creencias, oponiendo la ironía y el fetiche pop y exhibicionista, contra la

149 REIS, Paulo, "It is the truth that hides the fact that there is no truth", en Dardo Magazine, $\mathrm{N}^{\circ}$ 9, octubre-enero, 2008, Santiago de Compostela, Disponible en red: $<$ http:/ / www.galerialeme.com/artistas_textos.php?lang=ing\&id=42\&text_id=139>,

[Consulta 9, abril, 2010]. 
monotonía del arte conceptual. El autor exalta el carácter extravagante y fantástico que se esconde en nuestro imaginario, con un simple cambio de contexto. La culpa es mía (2003), es una alegoría en la que aparece el universo mítico de los niños relacionado con la temática vegetal de un árbol hecho de hierro y cuerdas, que crece como parásito de otro árbol-huésped. El árbol termina matando a los árboles circundantes, al estrangular sus raíces, de la misma manera que los monstruos carnívoros, aterrorizan a los niños en las películas. Siguiendo a José Luis Brea, este tipo de obras remiten a lo que el crítico denomina Efecto Neobarroco, término que le sirve para designar el fenómeno de cansancio de los sistemas de representación surgido en el ámbito artístico, frente a "la opulencia de las sociedades de la comunicación, la saturación de las escenas del discurso, la multiplicación de las estrategias de simulación, el triunfo del artificio, la Cultura del hiperconsumo y la sobreabundancia"150. Un neobarroco post-trágico que afirma la impotencia de las formas para enunciar la verdad de las cosas.

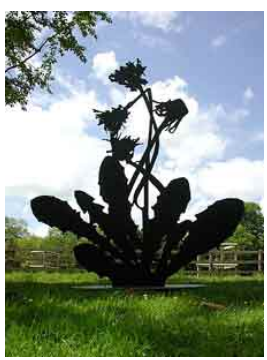

Paul Morrison,

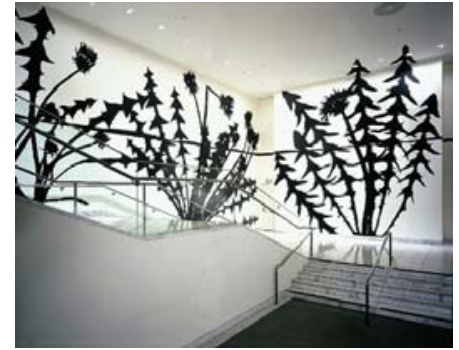

Paul Morrison, Cirque, 1999.

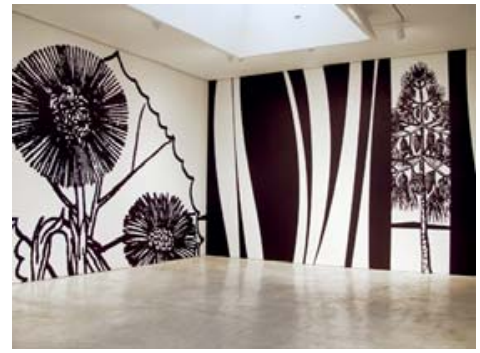

Paul Morrison, Harebell, 2004.

Sin título, 2005.

Las referencias botánicas en el trabajo de Paul Morrison (Liverpool, Reino Unido, 1966), son lo suficientemente relevantes como para citar a este artista, en cuya obra encontramos cierta afinidad con el trabajo de Jan Hendrix, de quien hablaremos más adelante. La observación exhaustiva de los fenómenos naturales y los términos botánicos le sirven al artista para describir el tejido celular que aumenta anualmente la circunferencia de los árboles y de otras plantas, confirmando la fascinación casi científica de Morrison por la Naturaleza.

Al eliminar el color de sus imágenes, la naturaleza serial de sus pinturas de plantas se expresan en un negro y blanco uniforme que habitualmente identifica su trabajo. Su inspiración recurre no sólo a los libros botánicos, sino también a las manifestaciones populares de la alta y baja Cultura, extendiéndose a los paradigmas de la Historia del arte y de los precursores del paisaje, Durero, Monet, etc., para crear visiones abstraídas y a menudo, magnificadas del paisaje. Su técnica consiste en el tratamiento infográfico de imágenes, para después proyectar las mismas en las paredes y, posteriormente siluetear cada elemento en lápiz, pintándolos con pintura negra. Sus representaciones de plantas -en ocasiones, repeticiones de una misma planta que representa bajo diversos aspectos- se complementan con videos de películas como las del 
personaje Bambi, a las que como a sus pinturas, les ha quitado el color, y con las que produce unas atmósferas inquietantes ${ }^{151}$.

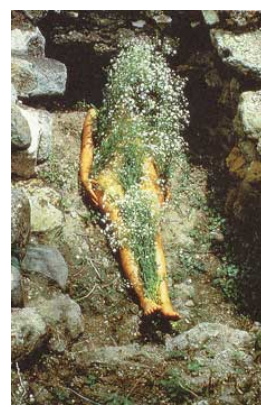

Ana Mendieta, Flores sobre el

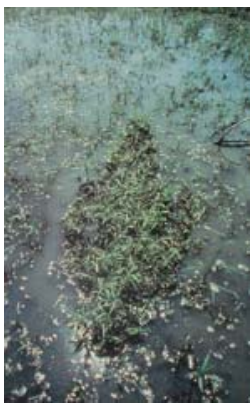

Ana Mendieta, Silueta, 1979.

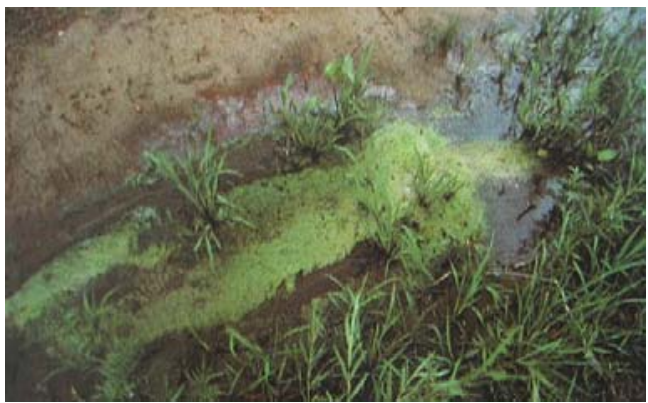

Ana Mendieta, Silueta, 1979.

cuerpo, 1973.

Frente al uso del referente vegetal en el arte contemporáneo desde una instancia formal o simbólica, artistas como Ana Mendieta (La Habana, 1948) plantean, como señala Gerardo Mosquera, una identificación directa de la naturaleza vegetal con el cuerpo físico de la artista:

Ella y su arte eran una sola pieza. Se trata de uno de los casos en que la creación artística ha estado más vinculada con la existencia individual. Su arte fue un rito compensatorio de su escisión personal, una solución imaginaria a su ansia imposible de afirmación mediante el regreso, a la vez en términos étnicos, freudianos, sociales y políticos [...]152.

Mendieta describía su obra como una vuelta al seno materno que consistía fundamentalmente en el gesto de fundirse en un acto místico, con el medio natural, la tierra y la vegetación. Estamos frente a una metáfora del regreso a lo primario, construida desde la propia sed individual de retorno al origen, una experiencia trascendental, a la manera de una hierofanía íntima. Una práctica artística que recupera una religiosidad pseudo primitiva, basada en la reactivación de los acervos tradicionales de América Latina. El trabajo de Ana Mendieta, a la manera de una ceremonia íntima con la Naturaleza, cargada de implicaciones antropológicas, se adscribe habitualmente y desde los años setenta, al Earth Art, pero en el caso de esta artista, los materiales naturales no se desplazan de su lugar de origen, sino que la artista, integrando su propio cuerpo, asume una actitud más modesta: es el ser humano quien se dirige hacia la tierra, para integrarse en el medio natural, en busca de una fusión íntima que

151 Véase "Arte en el mundo, Paul Morrison", en El Cultural, 25, septiembre, 2003, Madrid, Disponible en red:<http://www.elcultural.es/version_papel/ARTE/7875/Paul_Morrison>, [Consulta 30, octubre, 2011].

152 MOSQUERA, Gerardo, "Ana Mendieta", Disponible en red, Biblioteca virtual Luis Ángel Arango, Banco de la República:<http://www.lablaa.org/blaavirtual/letra-a/anam/anam23 a.htm>, [Consulta 30, octubre, 2011 ]. 
pretende, en última instancia, en lugar de transformar, formar parte del entorno. Se trata de un incipiente arte ecológico que preconiza la simbiosis entre mujer y paisaje y que plantea la colaboración entre la artista y la Naturaleza para romper las fronteras entre Naturaleza y Cultura.

La mayor parte de su producción es de carácter efímero y fue hecha en lugares apartados, exhibiendo sólo la documentación fotográfica. Mendieta se usó a sí misma como una metáfora, utilizando la huella de su propio cuerpo junto con el paisaje, la tierra y los elementos vegetales para experimentar la fusión de su cuerpo con la materia. Varios de los trabajos más significativos llevados a cabo mediante su propio cuerpo fueron realizados durante 1973, en México, donde recurrirá a la incorporación del ritual de la muerte, "desafiando los límites de dos estados que en nuestra tradición occidental son contradictorias y excluyentes"153. Con sus acciones, sugiere de una forma simple e inmediata las relaciones necesarias entre la muerte y el resurgimiento de la vida, construyendo de forma natural, el discurso arte-vida. Las imágenes aquí presentadas, forman parte de la serie Siluetas, en las que el cuerpo de la artista, al cubrirse con elementos vegetales, genera un híbrido humano-planta, que sugiere la regeneración de la vida, de forma similar a El árbol de la vida (1977), en el que la figura de la artista se metamorfosea en un árbol -que crece de la tierra y extiende sus ramas al cielo- y en el que la imagen convierte a la mujer en "parte mujer, parte planta, parte diosa"154.

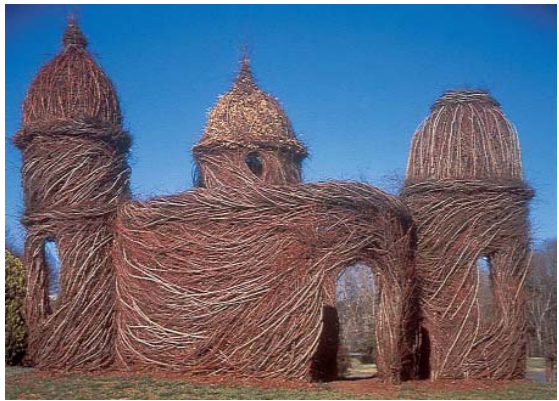

Patrick Dougherty's, Spittin Image, 2001.

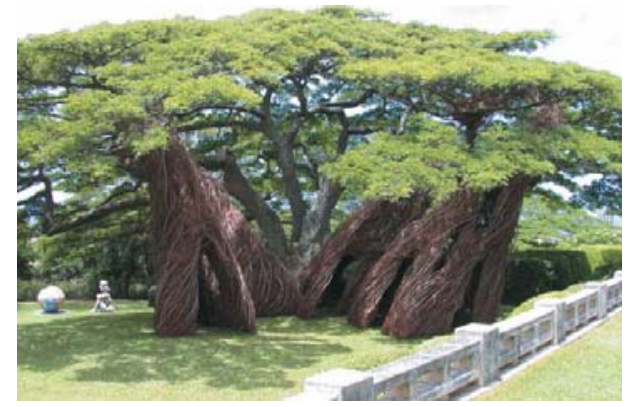

Patrick Dougherty's, Na Hale 'O Waiawi, 2003.

Como extensión de la necesidad del ser humano de habitar los espacios y, a manera de integración de esta necesidad en un hábitat natural, los trabajos de Patrick Dougherty's (Oklahoma, Ohio, 1945) concilian Naturaleza y arquitectura, haciendo referencia a capullos, colmenas y a las guaridas construidas por animales, así como las formas artificiales de chozas. Su instalaciones escultóricas están realizadas a la manera del trabajo artesanal de las cestas creadas a partir de entretejer y trenzar ramas de arbustos y árboles. Muchos de sus trabajos parecen más que hechos, encontrados como si fueran creados por la fuerza natural de un tornado que barriera el paisaje.

\footnotetext{
153 RUIDO LÓPEZ, María, Ana Mendieta, Nerea, San Sebastián, 2002, p.25.

154 RUIDO LÓPEZ, María, op. cit., p.98.
} 
Dougherty's es conocido por las instalaciones que realiza en parques y jardines o en el exterior de galerías y museos, explorando la tensión, la elasticidad y las cualidades de las ramas con las que trabaja. Como la de otros artistas que trabajan con materiales naturales, su obra tiene un carácter efímero, se trata de estructuras de formas arremolinadas que, con el tiempo, regresan a la Naturaleza. Para John K. Grande, sus trabajos nos remiten a la experiencia estética de una Naturaleza salvaje que todo lo invade.

Cuando me puse a hacer esculturas con pequeños árboles, parecía fácil asimilar las fuerzas de la naturaleza e imprimir una especie de flujo de energía a las superficies de las grandes formas que creaba ${ }^{155}$.

En algunas piezas trata de crear obras que se sustenten por sí mismas y que funcionen como arquitectura. En su obra se aprecia un cierto espíritu de fantasía infantil que le permite interactuar con los espacios públicos de manera rápida. Sus intervenciones, sin pretensiones ecológicas, expresan una Naturaleza antropomorfizada que tiene como finalidad acentuar el lugar específico en el paisaje, aportando huellas de la presencia humana.

Mi propia obra no intenta realmente cumplir una misión medioambiental [...]. Me gusta el hecho de que la naturaleza tenga su propia voluntad que nosotros no podemos controlar. Parece claro que a la gente le gustan los jardines y el césped, pero que desean desesperadamente una conexión con la naturaleza salvaje, a pesar de que ese concepto no está claramente definido ${ }^{156 .}$

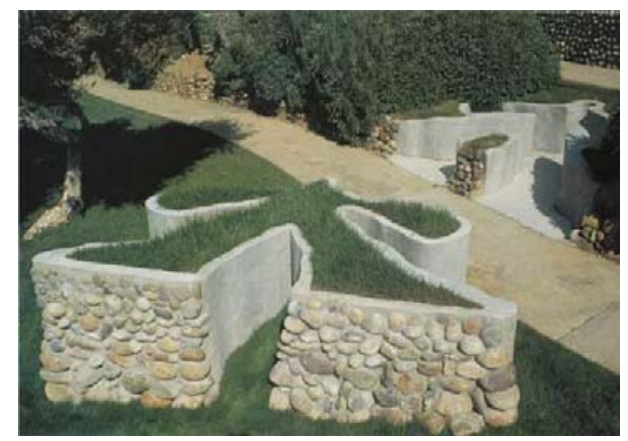

Vito Acconci, Persona desplazada, 1987.

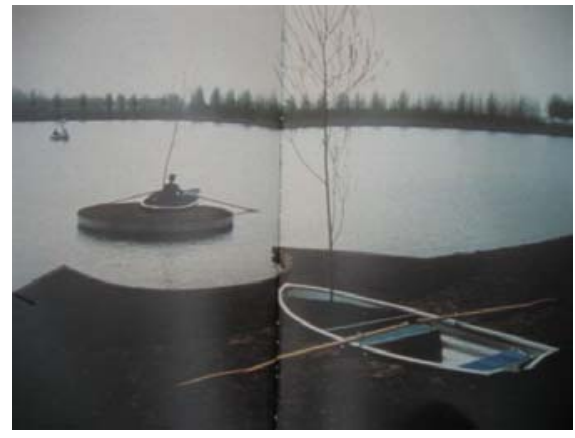

Vito Acconci, Is/a personal, 1992.

Un artista que se caracteriza por un uso particular del vegetal relacionado con el cuerpo y la forma humana es Vito Acconci (Nueva York, 1940). Hacia mediados de los años setenta, Acconci desarrolló la idea de que una obra podía utilizar el espacio expositivo para configurar el conjunto del espacio cultural. En 1969, Acconci inició un periodo experimental, realizando acciones y performances en

\footnotetext{
155 GRANDE, John K., op. cit., pp. 53-66.

156 GRANDE, John K., op. cit., p. 65.
} 
espacios expositivos, en los que reflexionaba en torno a su propio ser, tanto físico como psicológico. Su idea era redefinir la obra de arte, al borrar las fronteras tradicionales entre el artista y el público y su relación con un contexto espacial y/o social. A principios de los ochenta, su interés por el espacio evolucionó hacia intervenciones de tipo medioambiental y arquitectónico. El poder de las propuestas del Acconci consiste en su capacidad de repensar drásticamente el uso de los espacios públicos.

En Isla personal (1992) -instalación temporal que duró cuatro meses- realiza una isla portátil con la que el artista puede desplazarse. En esta obra podía observarse un bote hundido en el suelo, con la proa llena de tierra y hierba, en el que estaba plantado un árbol. Paradójicamente, los remos estaban anclados en la tierra, como si alguien estuviera remando sobre la misma. El espectador podía sentarse en la barca y sentir que podía navegar como si la tierra fuese agua. Frente a este bote, estaba la imagen especular de otro que, enclavado en una sección circular de hierba, tenía también la proa llena de tierra, recubierta de hierba y un árbol plantado en él. En la acción sugerida al público, éste podía coger la barca con la sección circular y remar, llevándose consigo la propia isla hasta el mar. Podemos considerar este tipo de obras como referentes de trabajos recientes como los de Sofía Táboas en el Bosque de Chapultepec.

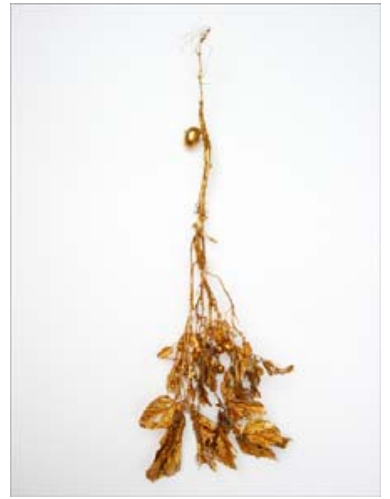

Anya Gallaccio, Till the

stars all burn away, 2003.

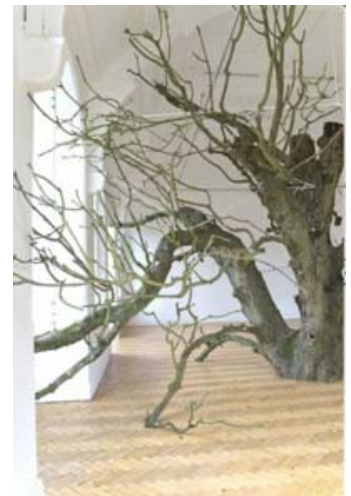

Anya Gallaccio, Dentro de ese espacio abierto, 2008.

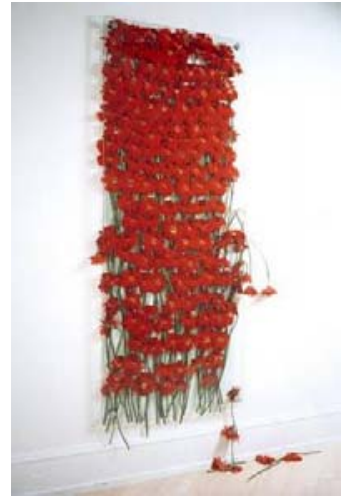

Anya Gallaccio, Belleza preservada, 1991.

En relación a los procesos como fuente de información en torno a la Naturaleza, nos interesa el trabajo de Anya Gallaccio (Glasgow, Escocia, 1963). Esta escultora es una de las principales artistas británicas de los años noventa. En sus obras, la mayoría instalaciones, los procesos de cambio constituyen la esencia de las mismas. Utilizando materiales naturales como flores, fruta, agua, hierba, chocolate, hielo, manzanas o plantas, la artista juega con procesos como la descomposición de los materiales, el derretido u otras alteraciones orgánicas. Anya Gallaccio explora la tensión entre los materiales orgánicos y los materiales tradicionales en la escultura157, como el azúcar, la cera y el bronce, el hielo y el

157 FORTNUM, Rebecca, Contemporary british women artist: in their own words, I.B. Tauris, Londres, 2007, pp. 1-7. 
plomo, generando trabajos en los que el carácter cambiante de la obra y el factor temporal son determinantes. Sus obras más que objetos, son eventos - cosas que pasan- marcando dos puntos de referencia: creación y destrucción. Como algunos artistas asociados al Art Povera, Anya Gallaccio controla la duración de sus proyectos, haciendo de su trabajo un acontecimiento casi teatral.

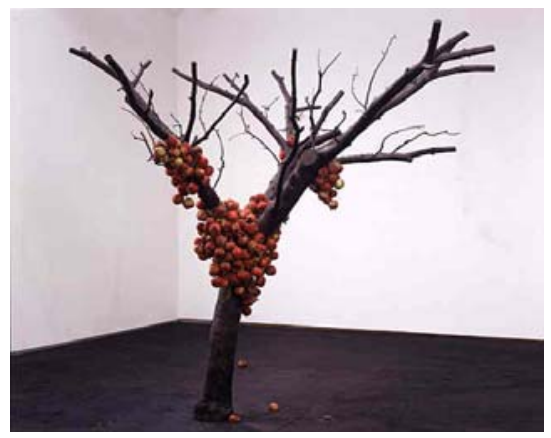

Anya Gallaccio, Because nothing has changed, 2000.

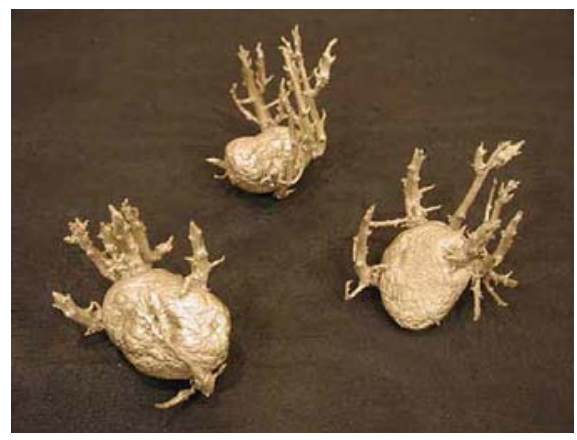

Anya Gallaccio,

Tres patatas, 2002.

La obra de Gallaccio rompe con el concepto de la obra de arte como mercancía, habitualmente relacionado con nuestra sociedad de consumo e introduce el factor del objeto artístico como algo temporal. Su trabajo, debido a la naturaleza imprevisible de los materiales con los que trabaja es una colaboración. Utiliza materiales cotidianos de maneras fantásticas e inesperadas, encubriendo su artificialidad bajo una capa del naturalismo. Sus instalaciones cambian con el tiempo, e interactúan con el espectador no sólo visualmente, sino también mediante otros sentidos como el olor y el oído. En una de sus obras (Repens, 2000) realizadas en Compton Verney, Gallaccio retomó el diseño de la decoración interior de los techos del palacio y lo transfirió al paisaje exterior, en el césped de los jardines exteriores. El patrón desapareció al crecer la hierba, acentuando el interés de la artista en la transformación continua. Siguiendo la tradición de la pintura británica del paisaje, Gallaccio comenzó a considerar las posibilidades de trabajo con el símbolo-arquetípico del paisaje británico: el roble. Así utilizó troncos de robles para llenar con ellos una galería. Con su corteza intacta, pero sin sus ramas, estos árboles eran como columnas que reflejaban la arquitectura clásica. En otra instalación Gallaccio crea una alfombra semi-transparente de azúcar, vertiendo una solución fundida de azúcar directamente sobre el piso. Esto se separará y endurecerá, en un gesto similar al del trabajo de La helada (1988) al verter plomo fundido y encendido en el piso de un almacén.

Gallaccio presenta experiencias sensoriales que van de lo auditivo a lo olfativo, de la percepción del olor de la putrefacción a la descomposición de la materia (cien mil rosas que se descomponen en el suelo o el olor del chocolate seco sobre las paredes). En otra ocasión, utilizó una tonelada de naranjas maduras extendiéndolas sobre el piso hasta que se pudrieron y llenaron el espacio con sus aromas acres y mohosos. También colocó ochocientas flores rojas (gerberas) 
en el escaparate de una galería, cubriéndolas con un panel de cristal. Imitando la técnica del arte tradicional del enmarcado, el cristal -que normalmente conservaría y protegería- aquí facilitaba la descomposición de las flores. Se trata de un arte en proceso constante, donde la descomposición crea la vida, donde los significados son ambiguos y la materia no puede ser controlada a voluntad. En sus proyectos, a los sentimientos de unicidad y de teatralidad, se suma el componente de riesgo ya que no se pueden garantizar los resultados. Algunos de estos trabajos nos acercan a obras de la mexicana Sofía Táboas.

En definitiva el trabajo de Gallaccio versa sobre la noción de permanencia, lucha y equilibrio entre el crecimiento y la decadencia. Los materiales pueden ser transitorios, pero el mensaje es constante: el cambio es inevitable. Aunque el concepto artístico de la decadencia de la belleza no es nuevo, Gallaccio lo trata de una manera innovadora, así, un manzano en bronce se adorna con manzanas verdaderas o una patata con brotes es fundida en bronce para ofrecer una visión de crecimiento y de vida duradera.

Para la Fundación Montenmedio Arte Contemporáneo de Cádiz, Gallaccio realizó una obra titulada Para Siempre (2001), compuesta por cien piñas de tamaño natural de bronce que fueron esparcidas en el bosque con el objetivo de confundirse entre el resto de piñas auténticas. Por otro lado, realizó la pieza Verde y Verdoso (2001), elaborada con diferentes especies autóctonas de hierba y flores. La artista escogió dos áreas rectangulares en el bosque de idénticas medidas y en ellas sembró semillas de hierbas y flores autóctonas para que crecieran y se mantuvieran como dos "tapices" en medio del bosque hasta que terminó la exposición, momento en el cual desaparecieron de forma natural.

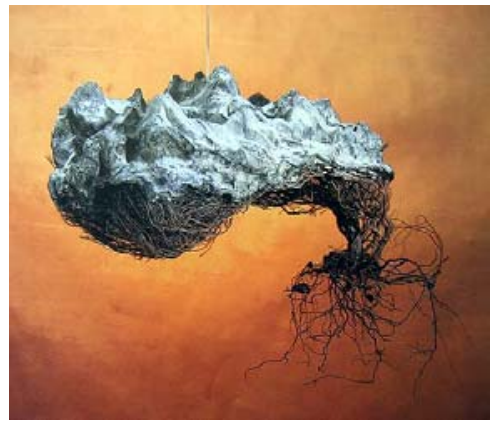

Pamen Pereira, No hay orilla, 1997.

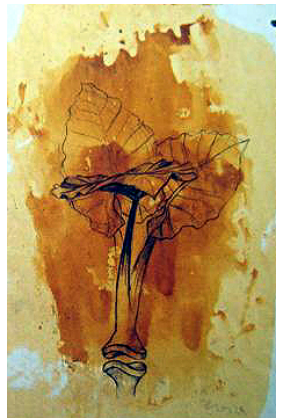

Pamen Pereira, Sin título, 1993.

La dialéctica Cultura y Naturaleza anima aspectos relevantes del trabajo de artistas como Pamen Pereira (Ferrol, La Coruña, 1963) cuyo interés en la Naturaleza, según Juan Bautista Peiró, no es tanto, una política de concienciación social, como un "proceso introspectivo de conciencia personal":

Sin embargo, no se debe caer en la reducción simplista de identificar tan compleja relación con el hecho de utilizar una serie de materiales tales como grasa, paja, pieles, arcilla, cera, raíces, chocolate, madera [...] estrechamente vinculados con la naturaleza entendida como aquello no 
manipulado por el hombre. [...]. Contrariamente a esa visión epidérmica por no decir paisajística: la montaña, el agua, la vegetación- el término naturaleza alude primera y sustancialmente a las esencias y propiedades características de cada ser. Es desde esta segunda perspectiva cuando adquiere sentido la profunda e intensa investigación plástica que viene desarrollando Pamen Pereira. El trasunto del viaje, del tránsito, del cambio de estado, como principios recurrentes en la obra de P. Pereira no es otro que el eterno debate entre el universo de las esencias y el mundo de las apariencias 158

En sus obras aparecen reiterativamente raíces unidas a casas de formas geométricas o a un templo japonés. La unión de conceptos alude a una espiritualidad, estrategias mediante las cuales Pereira experimenta en la idea de ambivalencia, transformación, movimiento, proceso y devenir.

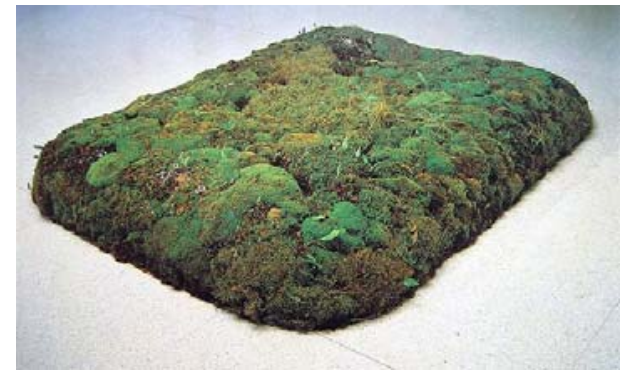

Meg Webster, Cama de musgo, 1986.

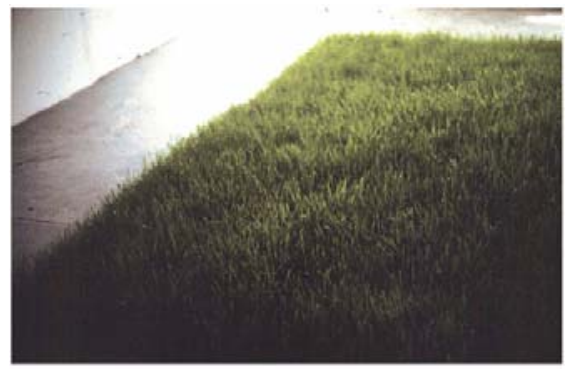

Meg Webster, Sin título, 1987.

El agua y la tierra, materiales en la obra de la escultora Meg Webster (San Francisco, California, 1944), "abarcan lo inmediato y lo elemental"159 como sustancias básicas en relación con la forma. La artista, quien participó en la exposición The new Poverty (1987), aborda la temática de la naturaleza vegetal desde el planteamiento de la real mortalidad de las cosas. Sus trabajos con materiales naturales, recurren a representaciones de lo que Ana M. ${ }^{a}$ Guasch denomina la utopía pastoril 160 con la que consigue infundir una vida nueva a los años sesenta. En cierta manera sus paisajes miniaturizados, realizados con sistemas vegetales que se plantan y necesitan de un tiempo para su crecimiento, podrían considerase Arte Mínimal. Se trata de paisajes conformados por sistemas ecológicos que generan la idea de una Naturaleza no virginal sino, manipulada por el hombre, partiendo incluso de la actuación de la misma artista.

\footnotetext{
158 PEIRÓ LÓPEZ, Juan Bautista, "Pamen Pereira...", op. cit., p. 81.

159 GUASCH, Ana M. ${ }^{a}$, Los manifiestos del Arte Posmoderno, Textos de Exposiciones (1980-1995), Akal, Arte contemporáneo, Madrid, 2000, pp. 152-153.

160 GUASCH, Ana M. ${ }^{a}$, Los manifiestos..., op. cit., p.198.
} 


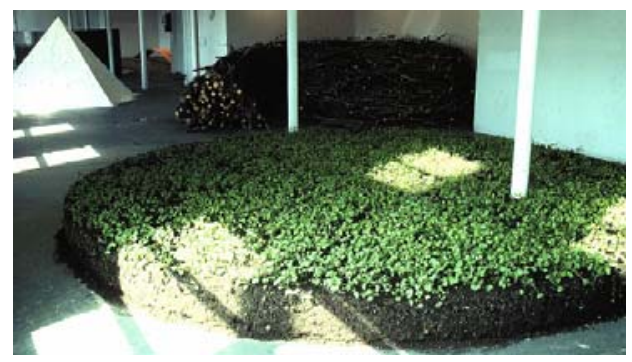

Meg Webster, Radish Disk ,1986.

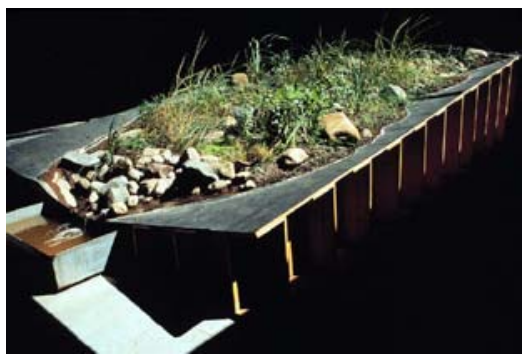

Meg Webster, Lifted Wetland, 1989.

Por otra parte, estas obras ofrecen la doble lectura de la omnipresencia de la Naturaleza en el entorno aparentemente doméstico de los humanos y el contexto cultural de la galería de arte. En lo que se refiere a nuestra investigación, podríamos encontrar ciertos paralelismos en algunas obras de la escultora Yolanda Gutiérrez.

En el panorama del arte latinoamericano, algunos artistas se han caracterizado por haber utilizado elementos vegetales artificiales para plantear diferentes cuestiones culturales en el ámbito social. Entre ellos, M. ${ }^{a}$ Fernanda Cardoso (Bogotá, Colombia 1963) realiza una serie de composiciones en cuyas formas podemos apreciar una idea necrológica. Jardín vertical (1992) es una especie de cementerio vertical, en el que la artista dispone flores de plástico que emergen de las paredes, sugiriendo una nueva, serena y extraña imagen de la Naturaleza, que recrea un estado contemplativo de la muerte. Su obra hace alusión a los rituales sociales a los que nos sentimos apegados.

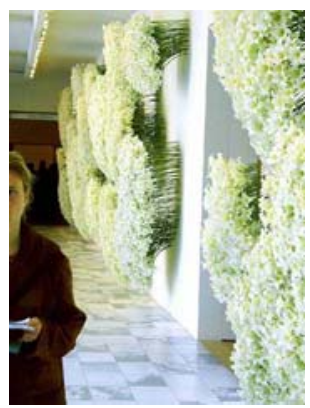

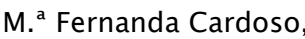
Jardín vertical, 1992.

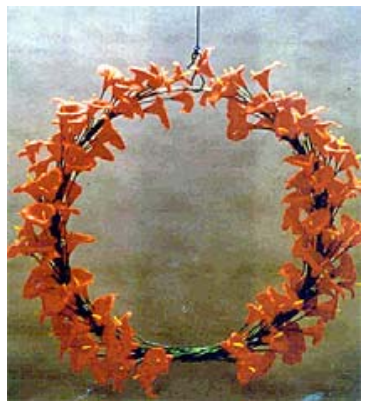

M. ${ }^{\mathrm{a}}$ Fernanda Cardoso,

Corona Plástico, 1992.

El jardín vertical y las coronas de Cardoso se conectan con la belleza del rito funerario y hacen consciente la forma en la que la repetición de ritos, símbolos y ceremonias conmemorativas provocan la pérdida de la memoria y de los valores significativos. La utilización de la flor como símbolo de la belleza y sustitución de lo natural por lo artificial -las flores de plástico no tienen vida- revierte por contraste, el proceso. En el contexto específico de Colombia -que sin duda, podríamos hacer extensivo a varias partes del mundo- la crudeza de las imágenes de violencia, de guerra y muerte han dejado de impactar al 
espectador. Al provocar una estetización de la idea de la mortalidad, las imágenes recobran su visibilidad.

La serie de obras con flores plásticas realizada por M. ${ }^{a}$ Fernanda Cardoso desde principios de los noventa [...] recurre al ready made -en las flores se trata de productos industriales- [...] subyace una reflexión en torno a la muerte. [...]. Lo mórbido no es el contenido de la obra, es el dolor y su manifestación en agrupaciones coloridas de flores, símbolo de la belleza, la fertilidad y la vida, para celebrar la muerte y el sentimiento de pérdida que ella conlleva", como ha anotado la critica Ana Sokoloff. En la tradición cristiana, las flores forman parte de los rituales de duelo, usualmente en forma de coronas que son enviadas como ofrenda póstuma a los familiares de alguien que ha fallecido. Como lo ha señalado José Hernán Aguilar, [...] la obra de Cardoso explora un tipo de agresividad que podría fundamentarse en la frustración de no poder salir del laberinto cultural que la original61.

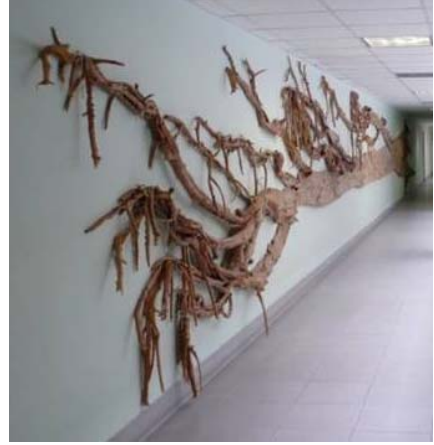

Alberto Baraya, Árbol Histórico, 2006.

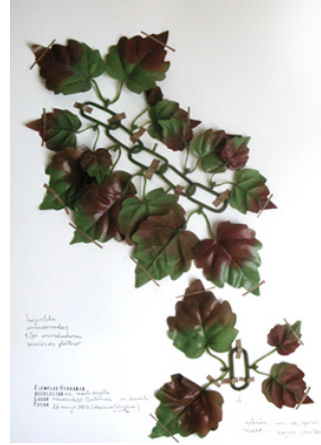

Alberto Baraya, Lucía, Madrid, 2002.

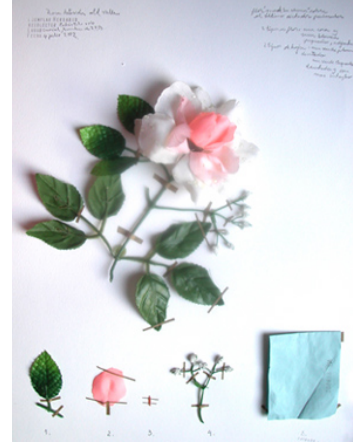

Alberto Baraya, Patric, Escorial, 2002.

El artista colombiano Alberto Baraya (Bogotá, 1968), recurre al universo plástico de una naturaleza artificial para explorar los usos de nuestra sociedad. En su obra Herbario de plantas artificiales (2003), a manera de las grandes expediciones botánicas del siglo XIX recolecta plantas que, en lugar de ser reales, son artificiales. Baraya recorre el mundo tomando muestras de la variada vegetación artificial que decora los espacios tanto públicos como privados del planeta, a veces en lugares tan contradictorios y exuberantes como el Amazonas, a donde sin lugar a dudas, también llegó la colonización de la artificialidad que nos envuelve. Con estas muestras, clasificadas y organizadas la presentación visual de estas plantas sigue la metodología de las expediciones botánicas- confeccionó durante cuatro años un herbario de plantas artificiales que fungía como activador de la memoria. En él, el artista documenta no sólo lo ejemplares sino también, las experiencias y anécdotas de la recolección y de la donación, estableciendo una taxonomía de los lugares donde encuentra las plantas o desde donde se las envían sus colaboradores. Baraya realizó en 2004

161 ROCA, José Ignacio, "Flora necrológica. Imágenes para una geografía política de las plantas”, en Lápiz, N 178, Año 2001, pp. 58-63. 
una muestra en el Museo Universitario de Ciencias y Artes de México, D.F., en la Colonia Roma, en donde tuvimos la oportunidad de ver una de sus colecciones. También en la Bienal de Valencia (España) presentó Árbol Histórico, (2006), un monotipo del árbol de Caucho, realizado en látex natural. El trabajo de Baraya, como una exploración en torno al generalizado gusto por el kitsch, nos habla de una naturaleza vegetal que nos acompaña alrededor de todo el mundo y que, fingiendo crear un ambiente natural, evidencia nuestra propia artificialidad. El espectador, inmerso en una sociedad de consumo aberrante, prefiere la imitación -la representación fiel- que no necesita de riego y cuidados, a lo real y perecedero, con el objetivo de prescindir del cambio y obviar la muerte.

Como señala Humberto Junca, "La caprichosa relación entre arte como representación, cultura como construcción artificial y naturaleza no podría ser más contradictoria"162. De esta manera, el artista cuestiona nuestras ideas en torno a la Naturaleza en general, como construcción cultural, junto con las ideas en relación a lo nativo o al descubrimiento del Nuevo Mundo de naturaleza eurocéntrica. La taxonomía de Baraya se centra, después del proceso de recolección y de clasificación de los ejemplares, en el uso que tenía la planta, con lo que reduce el elemento vegetal a la categoría de objeto decorativo. Para Baraya, es difícil que podamos conocer lo absolutamente natural, puesto que esta idea estará siempre contaminada por el punto de vista humano. Su estrategia, en definitiva, describe un paisaje cultural de intereses estéticos muy particulares.

Los proyectos de Ester Partegás (La Garriga, Barcelona, 1972) se relacionan con la implacable presencia del consumismo en los espacios públicos. Sus instalaciones escultóricas reproducen los elementos genéricos que conforman nuestro paisaje urbano -anuncios, cajeros automáticos, bolsas de basura, árboles o bancos para sentarse- para mostrarnos lo que normalmente se encuentra escondido. Partegás forma parte de las nuevas generaciones de artistas españoles, cada vez más cercanos a la cotidianeidad y al espacio público y, sumamente críticos con el poder y la institución 163. En sus trabajos, Partegás reproduce papeleras o contenedores de basura, rebosados de su propio contenido, identificándolos como objetos universalmente reconocidos en la vida urbana contemporánea. En la Cultura de la sobresaturación, estos objetos públicos se convierten en un signo del comportamiento del usar y tirar, que describen prácticas comunes y que identifican al individuo como ciudadano y como parte de un conjunto.

162 JUNCA, Humberto, "El jardinero infiel. Alberto Baraya, artista... plástico", en Arcadia, Periodismo cultural, № 9, Bogotá, junio, 2006, pp. 18-19.

163 GRACIA, Jordi y RÓDENAS DE MOYA, Domingo (eds.), Más es más. Sociedad y cultura en la España democrática 1986-2008), Iberoamericana, Madrid, 2008, p. 178. 


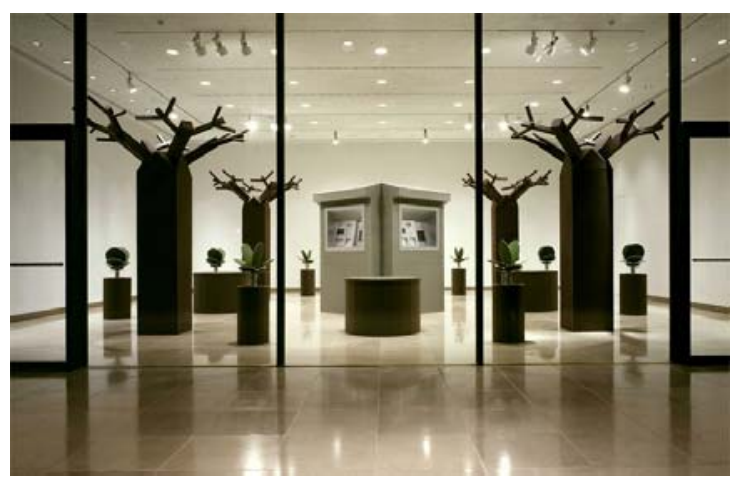

Ester Partegás, Samesation, 2002.

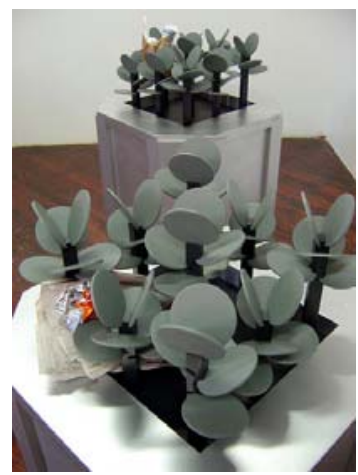

Ester Partegás, Los sueños son más poderosos que las pesadillas, 2003.

La escala de los objetos representados hace que el espectador sienta que físicamente forma parte de estos paisajes, sin embargo la asepsia con la que la artista configura sus escenificaciones -casi teatrales-concierten al público en vulnerable al considerar el exceso y el desperdicio que producen nuestras sociedades. A través de la reproducción de un paisaje urbano, la obra Los sueños son más poderosos que las pesadillas (2003) es una instalación de grandes maceteros grises con plantas que apela a la homogeneización del mundo contemporáneo, cuyas únicas notas de color vienen dadas, en contraposición, por la basura esparcida por el suelo.

Olafur Eliasson (Dinamarca, 1967) trabaja en torno a la Naturaleza y a los fenómenos naturales, como procesos de transformación y de interacción. Eliasson genera dispositivos productores de efectos que a menudo parecen reproducciones de la Naturaleza. Sus trabajos crean situaciones que desafían al espectador, cuestionando lo que suponemos que nos rodea y que requieren reordenar nuestra percepción del ambiente y de nuestro lugar dentro de él. Su obra se caracteriza por el estudio de la tensión entre Naturaleza y Cultura164, centrando su estudio en las leyes de la física y la percepción sensorial de las condiciones naturales. Sus trabajos cuestionan nuestro concepto de realidad, así como las ideas que habitualmente tenemos en torno a la Naturaleza y los mecanismos empleados por la Ciencia para el registro y la observación de ésta, convocando al espectador a reflexionar en torno a las experiencias que percibe. Su obra circula entre la Naturaleza y la tecnología, entre lo orgánico y lo industrial, interrelacionándose psíquica y emotivamente con los elementos utilizados.

164 GÓMEZ AGUILERA, Fernando, "La Naturaleza ya no será más la Naturaleza”, en El Cultural, El Mundo, Madrid, 1, junio, 2006. 


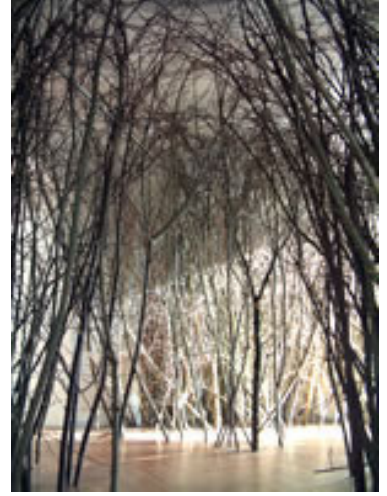

Olafur Eliasson,

The Forked Forest Path, 1998.

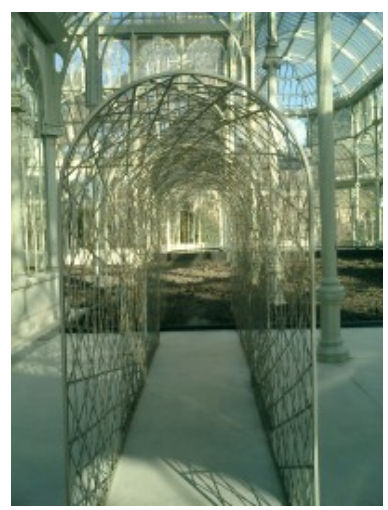

Olafur Eliasson, Fivefold Tunnel, 2000.

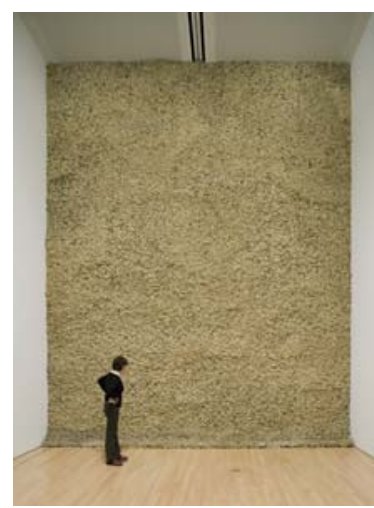

Olafur Eliasson,

Pared de musgo, 1994.

A lo largo de su trayectoria, el artista ha desarrollado dos bloques de trabajos independientes, pero fuertemente relacionados: instalaciones y registros fotográficos. En sus instalaciones, utiliza elementos que pertenecen siempre a la esfera natural: rayos de luz solar, vapores, corrientes de aire y agua, o elementos vegetales configurando escenografías que, en ocasiones, se basan indirectamente en investigaciones subatómicas o astrofísicas. El propósito del artista es mostrar cómo a lo largo de la historia, los diferentes modelos de percepción admitidos por la razón objetiva provocan cambios en las estructuras sociales e ideológicas, afectando nuestra visión del mundo. Eliasson crea, con una gran economía de medios y mediante diferentes dispositivos para la percepción de la realidad, conexiones entre la realidad y nuestra percepción de la misma.

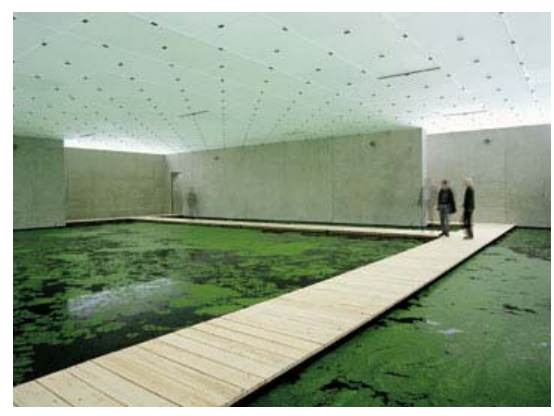

Olafur Eliasson,

The mediated motion, 2001.

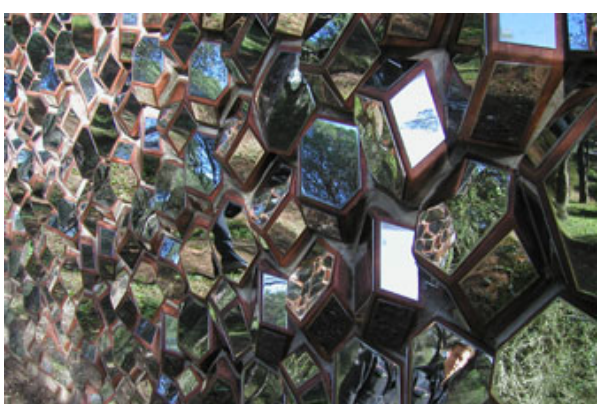

Olafur Eliasson,

Quasi brik wall, 2002.

En su obra fotográfica, el artista actúa como documentalista del paisaje natural. Sus series fotográficas presentan imágenes con temas repetitivos sobre glaciares, ríos, islas, cuevas, lagos o cataratas que se presentan montadas unas junto a otras, componiendo retablos monográficos. En estas composiciones, sin que aparezca directamente la presencia humana, vemos señales indirectas del ser humano que funcionan a modo de invitación para que el espectador se integre en la experiencia perceptiva que el artista plantea. Eliasson trata de 
apresar así las peculiaridades del entorno desde ángulos poco habituales, reflejando una Naturaleza diferente.

Para la realización de sus instalaciones y esculturas, utiliza materiales poco usuales como hielo, aire, musgo, lava o agua, que confieren a su trabajo un aspecto casi científico, provocando sutiles enfrentamientos entre el espectador y los fenómenos naturales. Los elementos naturales, la luz, el agua, el viento, la temperatura, el movimiento o el fuego se hacen presentes sin ocultar los sencillos procesos mecánicos por los cuales el artista ha generado esa presencia. Lo mecánico, lo natural y la experiencia perceptual se integran de un modo poético. Eliasson busca motivar la habitual pasividad del público, implicándolo en situaciones estimulantes, haciendo por ejemplo, que el espectador recorra el espacio de sus obras como en el caso de Lavafloor (2002), obra en la que el artista llenó el espacio de la galería con varias toneladas de lava que el espectador tenía que atravesar.
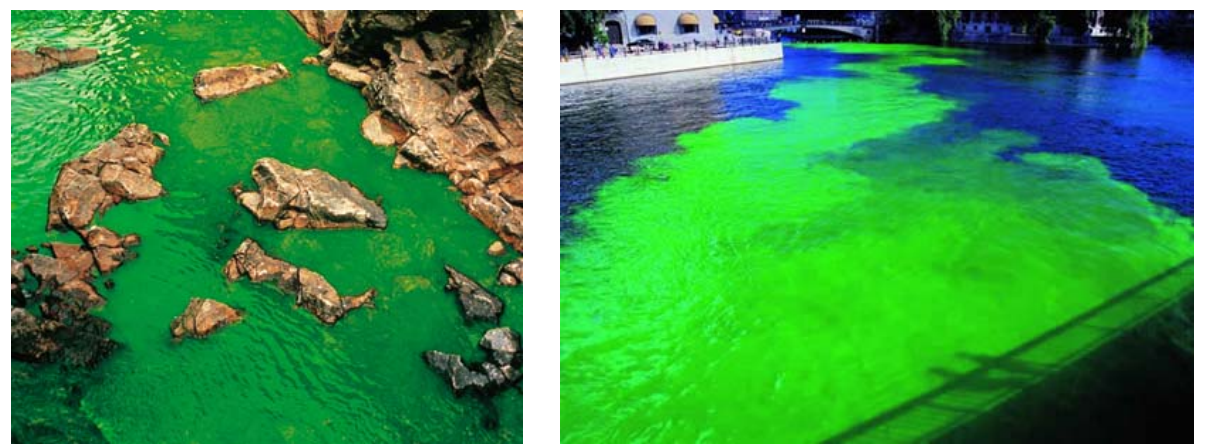

Olafur Eliasson, Green River Project, 1998.

En Green River (1998) el artista, sin previo aviso, vació en el río Norrström que corre a través de la ciudad de Estocolmo, un pigmento no tóxico usado comúnmente por los biólogos marinos. El agua, al contacto con la sustancia se volvió de un color verde luminoso y, a medida que el río atravesaba la ciudad, impactaba a los transeúntes que detenían su paso, percibiendo el río de una manera nueva y diferente. Esta intervención, transformó momentáneamente el paisaje, redirigiendo la atención de la ciudad a la realidad aumentada del río.

La obra Moss wall (1994) es un muro de musgo en tres dimensiones con texturas que parece una alfombra, pero que al acercarte se puede ver que es realmente musgo nórdico. Fue como tomar una parte del paisaje directamente del suelo y levantarlo en posición vertical, lo cual resultaba contradictorio a la forma en la que normalmente se encuentra este material orgánico. La pieza tiene mucho que ver con la relación de la Naturaleza con la Cultura. Los cambios que experimenta en el transcurso de la exposición, uno de ellos el color -una especie de gris verdoso que se va secando con el tiempo hasta volverse amarillento- la convierten en una obra procesual en continua metamorfosis. También permite percibir un olor particular y como tal, es un trabajo multisensorial. 


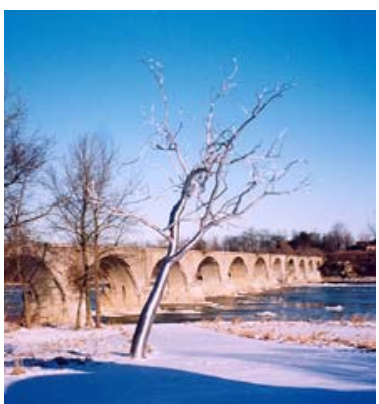

Roxy Paine, Replicante, 2000.

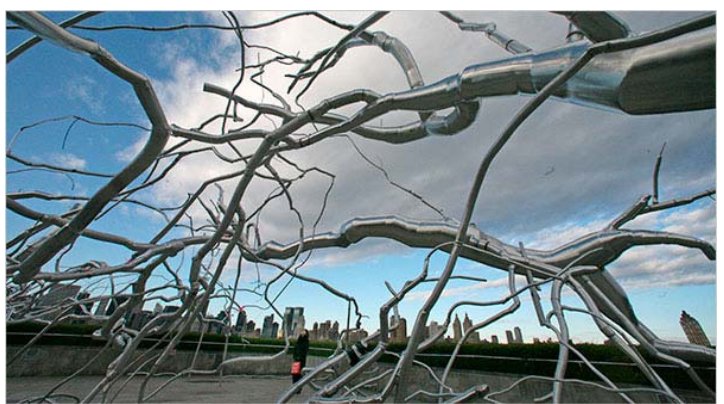

Roxy Paine, Inversión, 2009.

El artista Roxy Paine (Nueva York, 1966) genera naturalezas artificiales que se emplazan en espacios públicos. Se trata de esculturas con apariencia orgánica, específicamente vegetal: árboles de acero inoxidable que generan un fuerte contraste entre el material y lo representado. En la base de su trabajo encontramos la idea de manipulación de la Naturaleza para crear algo artificial. La gran mayoría de sus obras conllevan una realización técnica compleja y una precisión casi mecánica, donde la dificultad de la ejecución da vida al más mínimo detalle. Los fragmentos de paisajes de setas y amapolas de Paine ofrecen una apariencia de naturalidad, generando la paradójica ilusión de que existen sin manipulación humana.

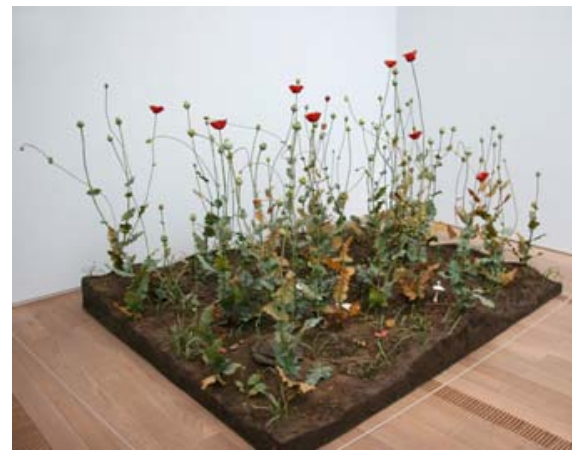

Roxy Paine, Cosecha, 1997.

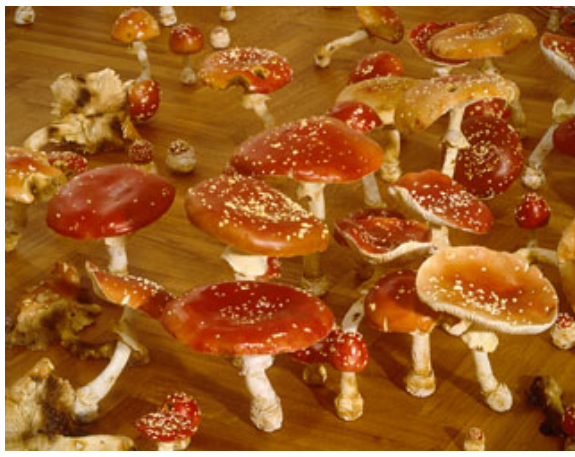

Roxy Paine, Campo de amanitas, 2002.

Psilocybe Cubensis Field (1999) es una obra que contiene 2.200 hongos alucinógenos pintados individualmente. Se trata de cultivos de hongos y amapolas, realizados meticulosamente con polímero thermoset -una clase de arcilla ligera, sintética- látex y resinas, con un carácter tan perfeccionista que hace difícil distinguir sus creaciones de la realidad. El artista declara su admiración por las plantas como productoras de vida, capaces de proveer su propio alimento. La vida se encuentra en animales y plantas; pero mientras que en animales se manifiesta claramente, en las plantas se oculta y no es tan evidente. Como argumenta una investigación botánica, las plantas tienen una velocidad diferente que acaso, podríamos percibir con el opio, única sustancia vegetal que según el poeta Jean Cocteau, es capaz de comunicarnos el estado vegetal. Por otra parte, los hongos, los más bajos en la escala ecológica de las 
plantas, funcionan incluso a velocidades más reducidas: son plantas que descomponen otros organismos del mundo natural después de que éstos hayan muerto. En este tipo de obras Paine se plantea la obra como un proceso, resultado del tiempo más el trabajo invertido en él. Cosecha (1997), es un arreglo de amapolas pintadas a mano -meticulosamente realizadas con látex y alambre- en todas las etapas de su ciclo vital, desde la semilla a la cosecha del opio. Campo de hiedra venenosa (Radicans de Toxicodendron, 1997) es un fragmento de campo, en el que se observa hiedra, dientes de león, basura, jeringuillas y malas hierbas, en una elegante vitrina de madera y cristal. En concordancia con los planteamientos de Paine, recordamos las palabras de Baudrillard en torno al concepto de simulacro y su poder de seducción afirmando que ésta obedece al artificio:

La seducción nunca es del orden de la naturaleza, sino del artificio -nunca del orden de la energía, sino del signo y del ritual. Por ello todos los grandes sistemas de producción y de interpretación no han cesado de excluirla del campo conceptuali65.

Las construcciones de Paine -tanto por sus formas como por sus temáticasproducen un trompe-l'oeil que nos seduce por conseguir sustraer de la realidad, la paradoja ilusionista que nos devuelve al mundo real:

Veleidad física de atrapar las cosas, pero veleidad suspendida y por ello convertida en metafísica -los objetos del trompe-I'oeil conservan la misma imposición fantástica del descubrimiento por el niño de su imagen, algo de alucinación inmediata anterior al orden perceptivo-. Si hay, pues, un milagro del trompe-l'oeil, nunca reside en la ejecución realista -las uvas de Zeuxis, tan verdaderas que los pájaros van a picotearlas-. Absurdo. Nunca puede haber milagro en el exceso de realidad, sino justo al revés, en la extinción repentina de la realidad y en el vértigo de precipitarse en ella. Esta desaparición del escenario de lo real es la que traduce la familiaridad surreal de los objetos 166 .

En definitiva la cuestión fundamental, como en muchos otros artistas, es cuáles son los límites entre la vida y el arte, pero como generalmente todos están más interesados en las preguntas que en las respuestas, sus obras funcionan como laboratorios de experimentación con los que provocar al espectador. Así también Gerda Steiner y Jörg Lenzlinger (Esttiswil, 1967 y Uster, 1964) han venido desarrollado desde 1997, una serie de proyectos comunes en los que construyen paradójicos sistemas aparentemente naturales. Gerda Steiner era conocida por sus pinturas murales de formas curvilíneas y fuertes colores, evocadores de los patrones psicodélicos de los años sesenta. Por su parte Jörg Lenzlinger, se había especializado en experimentar con sustancias químicas que se transformaban, mediante fertilizantes, en extraños paisajes de brillantes, coloridas y cristalinas formaciones.

\footnotetext{
165 BAUDRILLARD, Jean, De la Seducción, Cátedra, Madrid, 2007, pp. 9-10. 166 BAUDRILLARD, Jean, De la Seducción, op. cit., p. 63.
} 


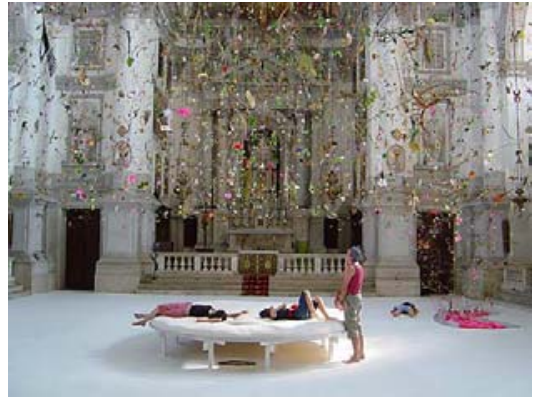

Gerda Steiner \& Jörg Lenzlinger,

Giardino calante, 2003.

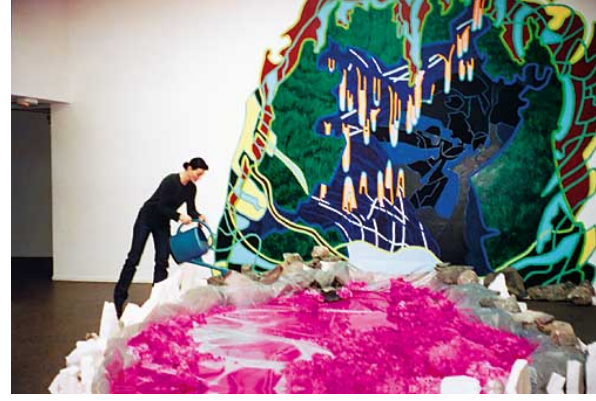

Gerda Steiner \& Jörg Lenzlinger,

Les maux de dents du Romantisme, 2001.

En su trabajo en común estos artistas realizan instalaciones de grandes dimensiones, con innumerables y diversas piezas, que ofrecen el aspecto lúdico de un metajardín, repleto de arreglos de flores artificiales, alambres, luces y vegetación, tanto viva como sintética. La experiencia del jardín se complementa con flores que cuelgan y pequeños estanques conectados por un sistema nervioso vegetativo, en el que una solución hidropónica fluorescente es el fertilizante que sirve para alimentar al entramado de plantas tanto artificiales como verdaderas. Al ambiente de la exposición se añaden sonidos de jardín y ruidos de las pulsaciones del cuerpo humano, así como mobiliario especial (camas) en donde el espectador puede reposar y dedicarse a la contemplación del espectáculo.

Tras la seductora apariencia de estos bucólicos escenarios, los artistas jardineros -como así les llaman- plantean los graves problemas ecológicos de nuestra época. Su intención, a manera de una extraña prueba de laboratorio, es presentar con ironía y humor, una especie de paisaje futurista, en el que poder observar las fuerzas del crecimiento, en el seno de una biodiversidad compleja y caótica. Esta circunstancia nos ofrece la posibilidad de ver qué sucede con elementos tan dispares y comprobar qué estrategias, alianzas y necesidades desarrollan entre ellos. En este panorama -las estructuras cohabitan con los mismos espacios en los que entran en descomposición- los límites entre lo atractivo y lo repulsivo se disuelven: el aloe vera crece en un lago de aceite usado en donde flota una isla de champiñones; plantas trepadoras escalan un cable, las raíces se transforman en tubos, las ramas muertas de un rosal florecen, hay una fuente en una cueva construida con ordenadores y basura de plástico, las malas hierbas se desarrollan a gran velocidad, etc. En estos jardines interiores, se confronta lo natural y lo artificial a través de la vegetación, evidenciando las relaciones entre el arte y la Naturaleza, mediante dispositivos heteróclitos de finalidad confusa, con los que se genera un retrato de la relación conflictiva entre la Naturaleza y la civilización contemporánea. En un proceso de cambio constante, las fuerzas elementales de la biodiversidad contratacan, transformando las instalaciones en el transcurso de la exposición, ya que los organismos vivos crecen, florecen o se pudren, recubriendo con cortezas de cristales coloreados su entorno. Sus instalaciones escultóricas parecen respirar, en ellas lo artificial y lo natural convive, generando un ecosistema en el que 
aparentemente máquinas y organismos vivos se relacionan. Si en 1950, Jackson Pollock declaraba "I am nature" (Yo soy naturaleza)167, a lo que Andy Warhol contrariamente proponía: "I am a machine" (soy una máquina)168 podríamos considerar que, en alguna parte, entre las afirmaciones aparentemente antagónicas de estas declaraciones, se encuentran las instalaciones construidas por estos artistas que invitan al espectador a la interacción y a la contemplación.

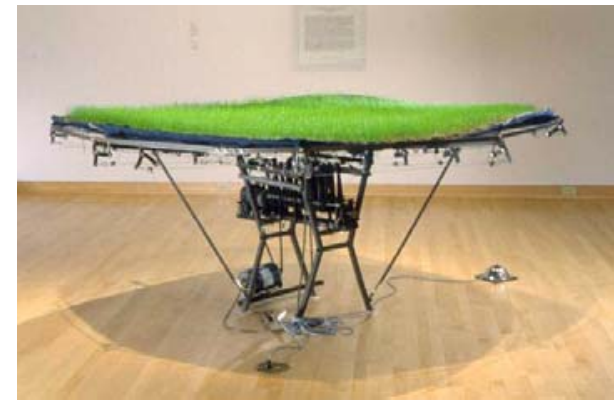

Doug Buis, Máquina con hierba, 2002.

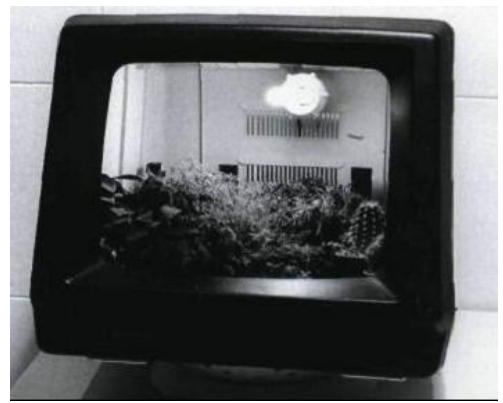

Doug Buis, Portable garden, 1994.

En la intersección entre Naturaleza y tecnología169, el trabajo de Doug Buis (London, Ontario, Canadá, 1957), consigue fusionar estética e ingeniería. El artista realiza instalaciones interactivas en las que implementa máquinas con componentes electrónicos (acero, motores eléctricos, piezas mecánicas) y elementos naturales (hierba, plantas, tierra) que, junto con otros elementos simbólicos (ordenadores portátiles, monitores), cuestionan nuestra relación con la Naturaleza. Máquina con hierba (2002) define la fenomenología de un paisaje de hierba, debajo del cual se observa todo un aparato mecánico. El conjunto deviene vivo al accionar un pedal que el espectador puede manipular con el pie. Con esta acción se genera una onda similar a los efectos que produce el viento sobre la hierba. Buis desenmascara así los escenarios políticamente correctos que, en torno a la ecología nos presenta el mundo de la imagen y las promesas de la publicidad170. Paradigmas ficticios que nos ofrecen un mundo de sustitución en el que la imagen se vuelve sustituto de lo real y en el que podemos prescindir tanto de selvas (Naturaleza), como de museos (Cultura). Sus microjardines -en ocasiones pequeños dioramas paisajísticos- ridiculizan la forma en la que la imagen sustituye a nuestra experiencia de la realidad. El artista propone la vivencia real, como actividad que rescata nuestro conocimiento en torno a los procesos vitales.

167 BLANCO, Alberto, Las voces del ver, 42 ensayos sobre artes visuales, Sello Bermejo, Consejo Nacional para la Cultura y las Artes, México, D.F., 1997, pp. 289-290.

168 FOSTER, Hal, El retorno de lo real. La vanguardia a finales de siglo, Akal, Arte contemporáneo, Madrid, 2001, p. 133.

169 GRANDE, John K., op. cit., pp. 121-136.

170 MOLTER, Michael, "Douglas Buis: home and Oasis", en Espace Sculpture, №31, Québec, Canadá, Primavera, 1995, pp. 22-24. 
Sin duda, los conocimientos científicos nos han llevado más allá de las leyes de la mecánica, así, ante un futuro de evolución imprevisible, la libertad de especular sin límites es Ilevada a diferentes extremos por la biotecnología. En este proceso y, partiendo de planteamientos artísticos, una serie de artistas han incursionado en la variación genética de organismos vegetales. Entre ellos, a Natalie Jeremijenko (Mackay, Queensland, Australia, 1966) podemos considerarla como tecnoartista que realiza proyectos en la intersección entre el arte contemporáneo, la Ciencia y la ingeniería.

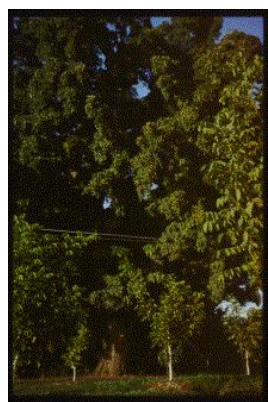

Natalie
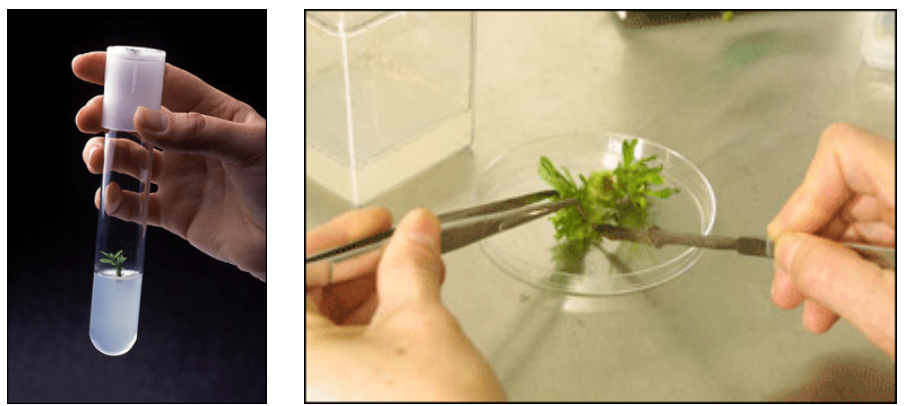

Natalie Jeremijenko, Tree cloning, 2004.

Jeremijenko,

One Trees, 2000.

En el año 1999 expuso en San Francisco un microcultivo con el que había conseguido la clonación de un "ejemplar arbóreo en 100 descendientes idénticos"171. Posteriormente, con el proyecto One Trees (2000), se ampliaría al ámbito público en el experimento público de plantar parejas de árboles genéticamente idénticos -clones- en diferentes zonas de la bahía de San Francisco. La artista planteaba que en su proceso de crecimiento, los árboles, a pesar de ser genéticamente idénticos, revelarían las variaciones específicas de los diferentes entornos sociales y ambientales en los cuales se encontraban, ayudándonos con ello, a entender nuestro lugar en el mundo. Esta experiencia hacía visible los resultados al público, que podía comparar los árboles clonados y sus homólogos biológicos, a la vez que abría el debate en torno al determinismo genético y su influencia ambiental. El proyecto usaba programas informáticos que incluían simulaciones del índice de crecimiento de los árboles, controlado por un medidor de anhídrido carbónico. Tree cloning (2004) es otra pieza de Jeremijenko en la que presenta un kit de microbiología para aficionados, que se vende en tiendas de mascotas y que ofrece todo lo necesario para poder clonar árboles, incluyendo las instrucciones. En el ámbito mexicano, podemos relacionar la obra de esta artista con algunos de los trabajos realizados por Daniel Rivera y por Eduardo Rincón.

171 PÉREZ LÓPEZ, Héctor Julio, op. cit., p. 68. 


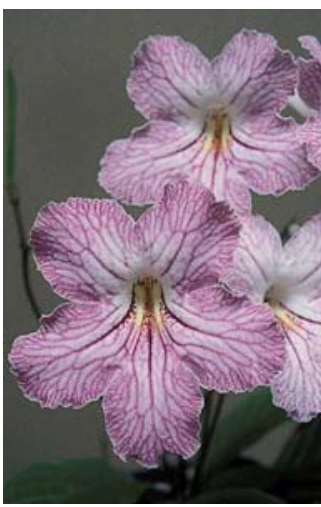

George Gessert, Streptocarpus hybrid 1028, 2003.

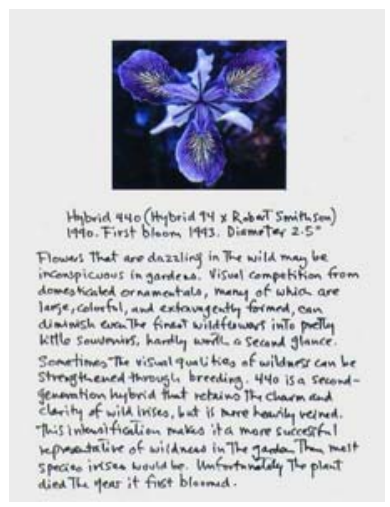

George Gessert, Hybrid 440, 1990.

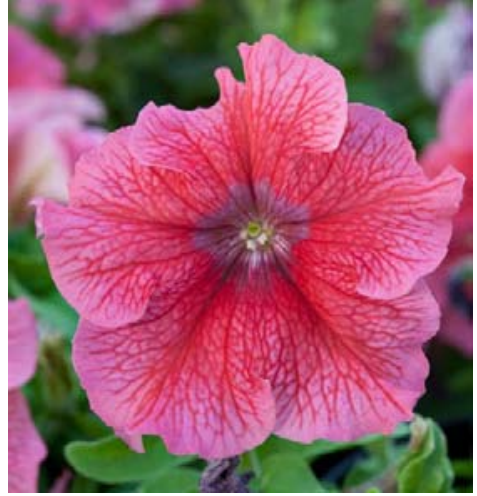

Eduardo Kac, Edunia, 2003-2008.

La obra del artista norteamericano George Gessert (Milwaukee, Wisconsin, 1944) destaca, entre una serie de artistas dedicados en exclusiva a la variación genética de organismos vegetales, por su grado de especialización en la obtención de flores híbridas, siendo uno de los primeros -como señala Héctor Julio Pérez- en explorar el arte transgénico:

[...] en 1985 realizó un polémico proyecto en que distribuyó semillas de varios de sus híbridos en zonas consideradas salvajes de USA. Gessert, pese a declarar su conexión con los métodos de hibridación tradicionales y su inspiración en las modificaciones genéticas puestas en marcha por el fotógrafo Edward Steichen en su Delphinium, fue uno de los primeros en explotar el potencial polémico del arte transgénico [...]172.

Tras sus estudios en horticultura, biología, química y entomología, sigue la inspiración de Edward Steichen quien en 1936, expuso híbridos de flores en el Museo de Arte Moderno de Nueva York. Interesado en las plantas tanto como seres vivos, como objetos estéticos, Gessert practica un arte biotecnológico cultivando, cruzando y seleccionando flores. Contrariamente a lo que afirmaba Walter Benjamin en torno a la pérdida del aura de las obras de arte reproducidas en serie, las plantas ornamentales prueban exactamente lo contrario. Explorando la alianza humano-vegetal, también Eduardo Kac (Río de Janeiro, 1962), ha desarrollado mediante la biología molecular, una nueva flor que tiene el ADN del propio artista. La floración de la Edunia (2003-2008) que no se encuentra en la Naturaleza, proporciona una "imagen viviente de la sangre humana circulando por las venas de una flor"173.

En un polo completamente opuesto, las plantas y las flores aparecen repetitivamente en las piezas de Jeff Koons (York, Pennsylvania, 1955). Su obra,

172 PÉREZ LÓPEZ, Héctor Julio, op. cit., p. 67.

$173 \mathrm{KAC}$, Eduardo, Telepresencia y bioarte. Interconexión en red de humanos, robots y conejos, Cendeac, Murcia, 2010, pp. 389-390. 
relacionada con el concepto del vacío, lo cursi y el kitsch, lleva a Duchamp y al dadaísmo a sus últimas consecuencias, integrando referencias al pop. Koons forma parte de una generación de artistas que, a mediados de los ochenta, exploraba el significado del arte en una era saturada por los medios de comunicación y la crisis de representación. Sus obras, inspiradas en el lenguaje visual de la publicidad, el marketing y la industria del entretenimiento, hacen una apología de la decadencia de nuestra sociedad. El artista, alejándose de la estética convencional explora los límites entre el arte y la Cultura popular, utilizando objetos de consumo como aspiradoras, balones de baloncesto 0 porcelanas, en homenaje a Michael Jackson o a la Pantera Rosa, mediante las cuales el artista funciona como mediador 174 que facilita el acceso al objeto de deseo. En sus obras abundan iconos familiares extraídos de la realidad cotidiana, de hecho, la recuperación del objeto recargado y kitsch -que responde al gusto de la Cultura dominante175- satisface el deseo del artista de acceder al público mediante los objetos característicos del entorno cotidiano del propio espectador. Realizadas en cerámica, en madera policromada o metalizadas y magnificadas por el tamaño (Tulipanes, 2004), una buena parte de sus esculturas retoma la temática del ornamento floral, en el afán de evidenciar el carácter mercantilizador del arte ${ }^{176}$.

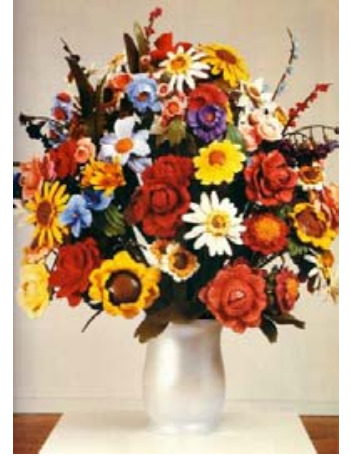

Jeff Koons, Gran vaso de flores, 1991.

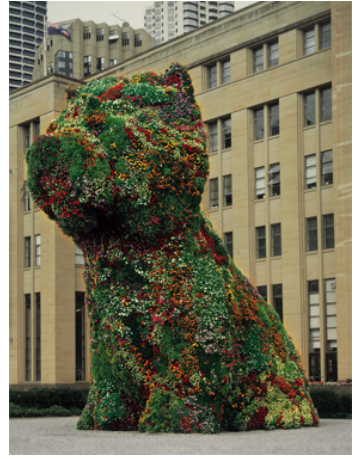

Jeff Koons, Puppy, 1992.

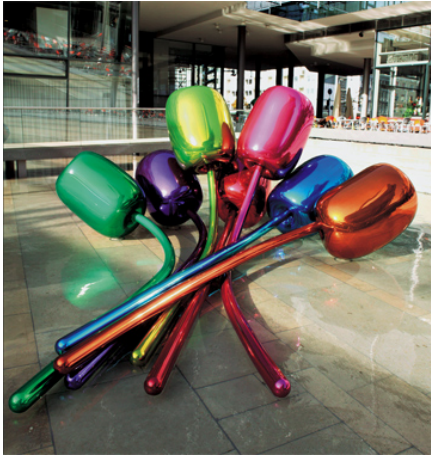

Jeff Koons,

Tulipanes, 2004.

La escultura Puppy (1992) -un cachorro de perro terrier que custodia la entrada al Museo Guggenheim de Bilbao- es uno de los jardines verticales contemporáneos, convertido ahora en referente turístico de la ciudad. Polémico, por su declarado culto al mundo de la apariencia y del consumismo, esta pieza se mantiene "viva", gracias a las 50.000 flores que se cambian dos veces al año. Koons presenta el mundo del fetiche consumista como una manera de recordar al espectador lo obsoleto del arte frente al dominio de lo cotidiano. Sin embargo, esta desacralizadora lectura del arte, se convierte en subversiva al entender el Puppy como obra en proceso que requiere cuidados $y$ mantenimiento. El artista, considerando la obra de arte como mercancía,

\footnotetext{
174 BOURRIAUD, Nicolás, Postproducción..., op. cit., pp. 24-28.

175 GREENBERG, Clement, Arte y Cultura, Gustavo Gili, Barcelona, 1979, p. 20.

176 KUSPIT, Donald, El fin del arte, Akal, Arte contemporáneo, Madrid, 2006, p. 74.
} 
propugna el acto de consumir como un acto creativo dentro de una Cultura en la que el arte depende de la sociedad del espectáculo -la misma que da a luz a museos como el Guggenheim- y, sin la cual, el planteamiento estético se torna absurdo. Siguiendo la lectura de Bourriaud en torno a Koons, por extensión, la naturaleza vegetal manifiesta en las obras de este artista, se cosifica como un condensador del deseo, hasta el punto de considerarse también un objeto de consumo.

La trasgresión del culto a la belleza y de la mímesis como representación, junto con la nueva e imprescindible necesidad de mantenimiento de la obra de arte, aparece en el trabajo de Marc Quinn (Londres, 1964) quien realizó unas series fotográficas (Winter Garden, 2002) en torno a naturalezas muertas de flores, conservadas en un congelador. Se trata de ocho fotografías tomadas a partir de la elaboración de un exuberante jardín dispuesto sobre una cama de hielo. El proceso de congelación de las plantas, combinado con el tratamiento digital de las imágenes, realzaba los colores, acentuando irónicamente la línea entre la vida y la muerte, regulada a partir de aquí, por el dispositivo técnico de un refrigerador.

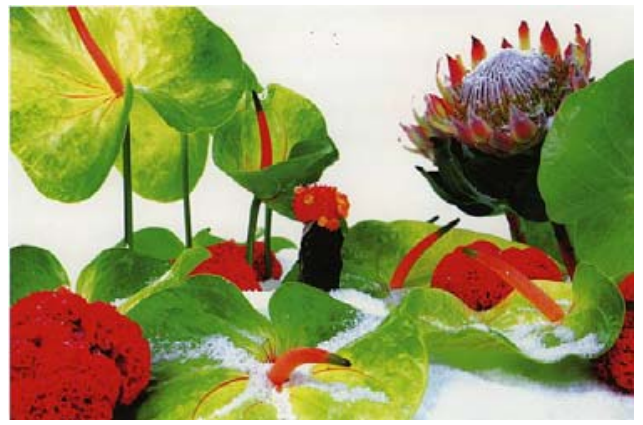

Marc Quinn, Garden, 2000.

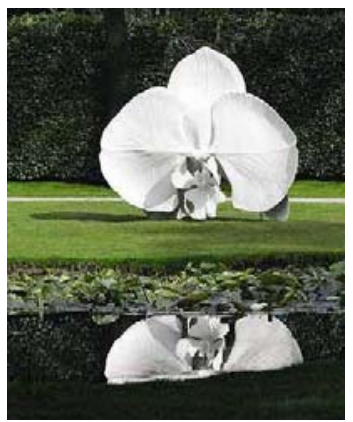

Marc Quinn,

Arqueología del deseo, 2009.

El planteamiento del artista gira en torno a la supervivencia de nuestra especie en la era de la manipulación genética, interrogándonos sobre la mortalidad y la fragilidad de la vida, en un mundo donde la criogénica parece una progresión casi natural en nuestra obsesión por la longevidad. Más conocido como escultor, Quinn emplea materiales no tradicionales como sangre como en el Autorretrato (1991) de su cabeza, en donde el artista presentaba cinco litros de su sangre que, para que la sangre estuviera sólida, permanecía congelada mediante una cámara frigorífica.

De la economía y el consumo como ejes sociales, a la política como motor del mundo, la artista Jane Benson (Thomburg, Inglaterra, 1971) utiliza el camuflaje como estrategia creativa, centrándose en la representación de la naturaleza artificial en ambientes interiores. El trabajo de esta artista se caracteriza por la utilización del elemento vegetal con un trasfondo político, para cuestionar nuestros conceptos en torno a lo natural y lo artificial. Sus obras se insertan en contextos no tradicionales para producir en el espectador una mirada diferente 
en relación a lo políticamente correcto de lo cotidiano. Como material, utiliza flores artificiales que son alteradas por la artista para parecer más artificiales todavía, lo que hace visible la artificialidad de los lugares en donde habitualmente se colocan este tipo de decoraciones.

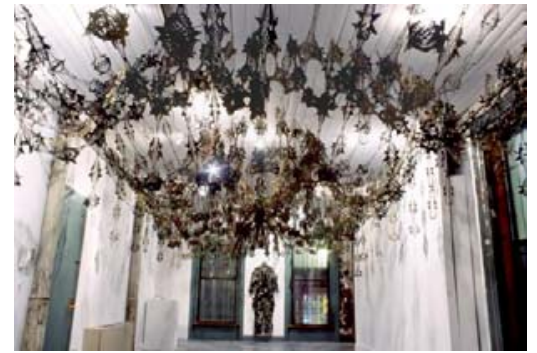

Jane Benson, Underbush (Camuflaje), 2004.

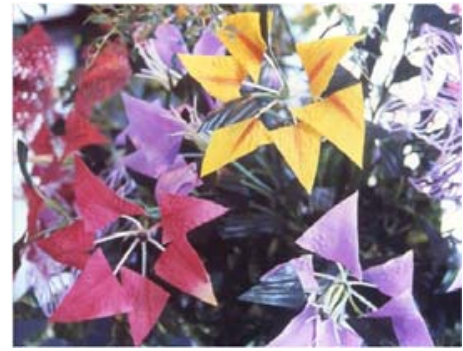

Jane Benson, Falsa Flora, 2002.

En la pieza Happy Faux Flora (Flora artificial, 2002) la artista cortó cada hoja de las plantas expuestas siguiendo formas geométricas (triángulos, rectángulos, etc.), de manera que las plantas ofrecían una forma antinatural creando la ilusión de fantásticas mutaciones genéticas producidas por la contaminación del medio ambiente. De esta forma, la artista cuestiona la artificialidad de nuestra percepción en torno a la experiencia de lo cotidiano177. En Underbush'78 (2004), una especie de de camuflaje-follaje ornamental evoca las antiguas pompas militares, colgando del techo a manera de adornos para una celebración. Al estar pintada con los colores del camuflaje militar, la inofensiva decoración adquiere el matiz de crítica política en torno al poder, la guerra, el terrorismo y las recientes políticas de Estados Unidos. Underbush (2004) transforma el espacio expositivo en un salón híbrido entre festivo y militar, evidenciando las relaciones actuales entre celebración, adorno y engaño. Sus plantas, estructuras que deberían ser agradablemente decorativas, se tornan agresivas, negándose a ser cómplices de este proceso de camuflaje. Con la identificación entre los ámbitos de la estética y la política, Benson plantea una resistencia a la mimesis, así como una necesaria y urgente reelaboración de patrones y formas. En Monument to Weeds (2006), uno de sus recientes trabajos escultóricos, Benson realiza un monumento conmemorativo a las malas hierbas indígenas que el Ministerio de Agricultura estadounidense consideraba nocivas, construyendo una metáfora de las políticas, cada vez más restrictivas de inmigración de los Estados Unidos.

La utilización de plantas, flores y en general, del referente vegetal en cualquier material, dentro del arte contemporáneo, otorga al elemento sobre el que se aplica, un valor simbólico añadido, capaz de transformar radicalmente el significado que el objeto tuviera anteriormente. Así lo demuestran los trabajos de Jerilea Zempel (Nueva York, 1947) quien, tras la liberación del poder soviético en Poznan (Polonia), recubre un tanque (Guns and rosettes, 1995-98), con una

177 BANAI, Nuit, "Excerpts from New Views-World Financial Center", Disponible en red:

$<$ http://janebenson.net> [Consulta 9, abril, 2010].

178 Underbush es el nombre de una empresa que fabrica trajes de camuflaje. 
funda de flores de ganchillo, convirtiendo éste en un "fantasma del militarismo" 179 recuperado por medio del sentido floral y feminista del trabajo textil.

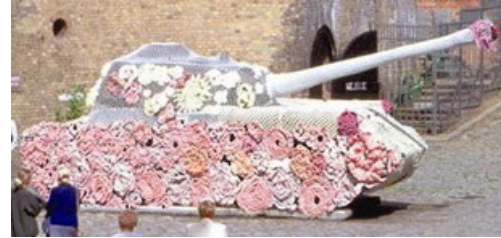

Jerilea Zempel, Guns and rosettes, 1995-1998.

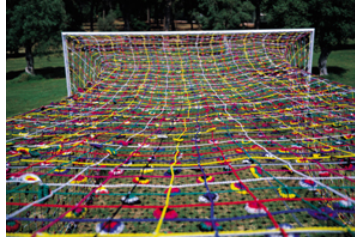

Joana Vasconcelos, Opio, 2003.

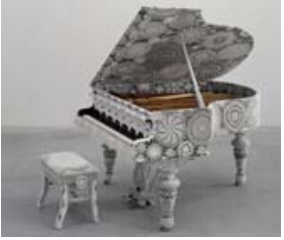

Joana Vasconcelos, Piano Dentelle, 2008.

Asimismo, la artista portuguesa Joana Vasconcelos (París, 1971) se caracteriza por la incorporación y articulación múltiple de objetos cotidianos de consumo en piezas que son objetos del mobiliario público, industrial o doméstico. Estas piezas como hemos visto, recuperan el discurso del arte pop y la ironía estética del kitsch, con el empleo de nuevos lenguajes y materiales. Estas obras, con un toque de humor mordaz, abordan problemas claves de la tradición escultórica.

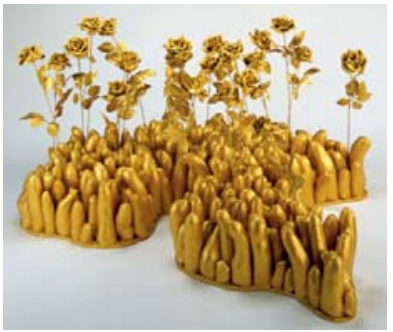

Yayoi Kusama, Rose garden, 1998.

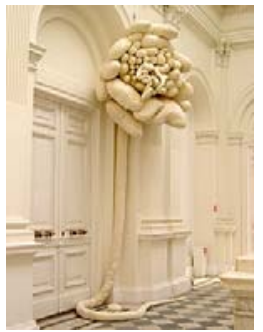

Yayoi Kusama,

Flor, 2001.

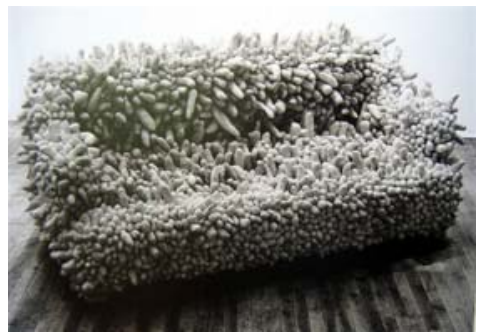

Yayoi Kusama, Acumulación $\mathrm{N}^{\circ} 2,1962$.

El vacío ideológico y espiritual provocado por la crisis de valores de la sociedad moderna se ha visto sustituido, como hemos estado viendo, por el consumismo, la frivolidad y la simulación ${ }^{180}$. Pero tras el aparente triunfo de un hedonismo voraz, la insatisfacción recorre el panorama de las artes multiplicándose formalmente, en busca de respuestas que recuperen el sentido vital. Entre ellas, algunas prácticas recurren a lo que Omar Calabrese denomina la "repetición como modo de producción de una serie con una matriz única"181. La categoría estética y formal del Barroco, denostada durante el siglo XIX, fue recuperada a partir de 1888, por $\mathrm{H}$. Wölfflin ${ }^{182}$, quien lo consideraba un sistema de

\footnotetext{
179 GRANDE, John K., op. cit., p. 89.

180 HERNANDO, Javier, "Energía convulsiva. Barrocos Neobarrocos. El infierno de lo bello", en El Cultural, El mundo, Madrid, Publicado 6-10-2005, Disponible en red: $<$ http://www.elcultural.es/version_papel/ARTE/12858/Energia_convulsiva/>, [Consulta 9, abril, 2010].

181 CALABRESE, Omar, La era neobarroca, Cátedra, Madrid, 1999, pp. 45-46.

182 WÖLFFLIN, Heinrich, Renacimiento y Barroco, Paidós, Barcelona, 2008.
} 
representación que aparece periódica y sistemáticamente, dentro de la Historia del Arte.

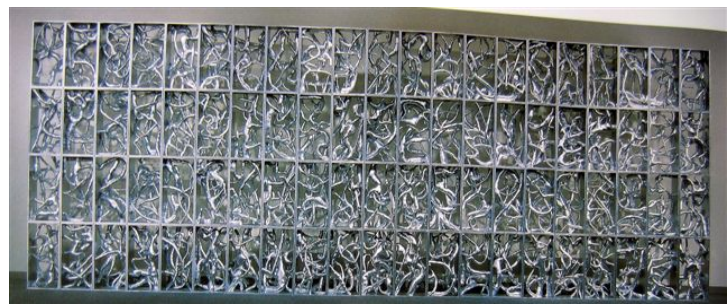

Yayoi Kusama, Acumulaciones, 1961.

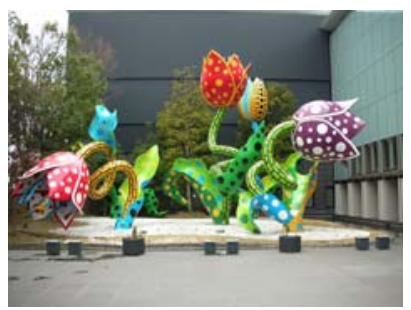

Yayoi Kusama, Flores, 2010.

Por su parte, Calabrese, alejándose de la concepción clásica del Barroco, acuñó en 1987, la expresión "neobarroco" para designar el "gusto predominante de nuestro tiempo"183, reflejo de las nuevas estéticas contemporáneas de la banalidad y, coincide con Baudrillard, en explicar de esta forma, la pulsión por la teatralidad de las nuevas prácticas artísticas y el gusto por el simulacro, como sustituto de la realidad en nuestra época. Estamos así ante formas Ilamativas, recargadas y con un dinamismo exacerbado, que fungen como soportes de discursos de temas intemporales: amor, placer, dolor o muerte u otros característicos de nuestro presente, como la inmigración, formando parte de la sensibilidad neobarroca. Uno de estos casos es por ejemplo, la obra de Yayoi Kusama (Matsumoto, 1929) en la que observamos una tendencia a la exageración y a lo recargado, con abundantes referencias naturales a un mundo orgánico que, por su exhuberancia formal, pueden considerarse como alusiones al mundo tanto animal como al vegetal. Kusama comenzó a realizar sus acumulaciones sobre objetos cotidianos, encontrados en la calle, en Nueva York, en 1961. La artista resuelve el conflicto de poder entre lo masculino y lo femenino, mediante la multiplicación reproductiva de trasfondo sexual, transformando las formas fálicas que aparecen en sus esculturas en elementos germinativos y vegetales. Su posterior interés por el camuflaje y, el deseo de camuflar sus objetos en un fondo desdiferenciado, la llevó a pintar puntos rojos en todos sus escenarios. El afán por confundir figura y fondo se materializó mediante el uso de espejos, de forma que la presencia del propio cuerpo de la artista lograba, en su inclinación hacia la indistinción, borrar la identidad 184 .

\footnotetext{
183 CALABRESE, Omar, op. cit., p.12.

184 FOSTER, Hal et al., Arte desde 1900, Modernidad, antimodernidad y Posmodernidad, Akal, Madrid, 2004, p. 502.
} 


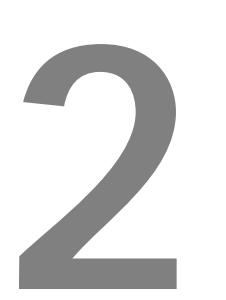

MÉXICO, ANTIECEDENTESY ESTADO DE LA CUESTIÓN 



\subsection{Contexto histórico}

México ha sido en términos de creatividad, desde sus orígenes y hasta nuestros días, un país profunda y vivencialmente creativo. Como pueblo eminentemente creador, desde los tiempos prehispánicos sus culturas han sido y siguen siendo de hecho, fuente inagotable de conocimiento. En todos los universos de su geografía esta inspiración nutre los diferentes ámbitos del presente. Todo hecho, todo objeto, todo rito ha generado un sinfín de manifestaciones y de posibilidades. De esta manera se han definido formas culturales que como un complejo entramado, manifiestan un particular sistema de valores, de creencias, de estilos y de símbolos que identifican y definen sus actos en el quehacer cotidiano.

En algunos países europeos se había seguido con mayor atención al arte latinoamericano a partir del folklore y del arte azteca y maya. En España el interés que México ha despertado en cuanto al arte moderno y contemporáneo es más bien reciente. Sin embargo últimamente se ha reconocido con énfasis el dinamismo artístico de las últimas décadas en México. Diferentes exposiciones dan buena cuenta de ello como tendremos ocasión de ver más adelante.

En esencia, podemos decir que exceptuando el movimiento del muralismo mexicano, con sus representantes más conocidos como José Clemente Orozco, Diego Rivera y David Alfaro Siqueiros, el arte moderno en México era, fuera de sus fronteras, un gran desconocido. Poco ha llegado aquí de los artistas que formaban la llamada Generación de la Ruptural85: Mathías Goeritz, Carlos Mérida, Rufino Tamayo, Gunther Gerzo, Remedios Varo, Manuel Felguérez, José Luis Cuevas, Francisco Zúñiga, Francisco Toledo entre otros. Pintores reconocidos todos ellos en la actualidad, quienes con su obra, perfilaron este movimiento y revolucionaron el arte en México.

Es en Madrid fundamentalmente, a partir de los años ochenta y noventa, donde se comienza a ver públicamente obra de Germán Cueto, Rufino Tamayo, Frida Khalo, Francisco Toledo, Juan Soriano, Gabriel Orozco, etc. y se abren nuevas vías de interés por ver qué está sucediendo en México en cuanto a arte contemporáneo. En el año 2005, México es el país invitado en la edición de la Feria Internacional de Arte Contemporáneo de Madrid (Arco). Esta circunstancia, unida a una mayor difusión a nivel internacional de los artistas mexicanos, permite que lleguen hasta nosotros diferentes muestras de arte contemporáneo, a través de las cuales podemos observar qué es lo que los artistas están haciendo actualmente en ese país. Generalmente, lo que nos llega es un arte cercano al mainstream ${ }^{186}$ que, como todos sabemos, se inscribe en una

\footnotetext{
185 Nombre por el que se conoce al grupo de artistas tanto mexicanos como extranjeros radicados en México, quienes en la década de los cincuenta reaccionaron contra los valores de los muralistas y la temática nacionalista y revolucionaria de la Escuela Mexicana de Pintura, que venía imponiéndose desde la Revolución mexicana de 1910.

186 ARRIOLA, Magali, "Cuando la (mala) fe mueve fronteras: Ocho puntos para analizar la representación de México en el extranjero”, en BENÍTEZ DUEÑAS, Issa M. ${ }^{a}$ (ed.), Crónicas
} 
corriente globalizadora. Los nuevos artistas mexicanos que están llegando son sin lugar a dudas creadores que tienen una sólida obra tanto en México como en el exterior. Pero no hay que olvidar que los factores que se involucran a la hora de sacar a un artista fuera del propio país oscilan en una maraña de intereses muy dispares sean tanto éstos comerciales, como curatoriales o de cualquier otra índole.

En general, el arte de las Américas 187 se ha visto siempre desde este lado del mundo como lo otro que, desde su otredad reivindica su especificidad étnica y cultural. El curso de la historia ha venido pautado desde la conciencia del devenir occidental, haciendo a un lado esas otras manifestaciones que escapaban a la lógica lineal de Occidente. Como resultado de este lineamiento, la tónica en la mayoría de los países de Latinoamérica, ha sido la de los nacionalismos a ultranza. Por otro lado, este sentimiento ha propiciado un rechazo hacia los aspectos destructivos de la globalización, preservando así la pluralidad de las tradiciones culturales autóctonas. Esto mismo es todavía más patente en el contexto artístico por su natural capacidad de integrar lo nuevo con la tradición. Si a este hecho sumamos la transculturalización que actualmente generan los nuevos medios de difusión de la información, nos encontramos con manifestaciones artísticas en países como México que, desde su especifidad y problemática particulares nos sorprenden por su frescura.

Todos estos factores confluyen en la obra de los artistas mexicanos contemporáneos. Nacionalismos, identidades políticas, culturales o sociales autónomas. Pero más allá de estereotipos eurocéntricos o anglosajones no podemos dejar de pensar que el mismo fenómeno se da en los países considerados occidentales, en los que se acusa marcadamente una identidad característica del mismo tipo. Lo que nos distingue finalmente, unido al registro de nuestros actos, es la posibilidad real de dejar huella.

No cabe duda que la realidad social y política en México es de características muy especiales y que la denuncia que desde su obra ejercen numerosos artistas mexicanos contemporáneos fluye con poéticas muy personalizadas. Memoria, política y arte han barajado el territorio de la Cultura en México generando estrategias que se han visto reflejadas en puntuales textos críticos. En este sentido la revista Curare 188 publica su primer boletín trimestral en octubre de

del paraíso. Arte contemporáneo y sistema del arte en México, México, D.F., 2007, pp. 5877.

187 Usamos aquí el término arte de las Américas, siguiendo a Jiménez y Castro Flórez, para reivindicar con estos autores la pluralidad y la gran diversidad de las creaciones de artísticas en Latinoamérica y el Caribe. Cfr. JIMÉNEZ, José y CASTRO FLÓREZ, Fernando (editores), Horizontes del arte latinoamericano, Tecnos, Colección Metrópolis, Madrid, 1999, pp. 9-15. En general hacemos referencia a todos los países del hemisferio occidental que se encuentran al sur de los Estados Unidos, incluyendo tanto los de habla española y portuguesa o francesa como los de habla no latina.

188 Curare: Veneno vegetal, de acción paralizante, con el que los indígenas del Amazonas cubren sus flechas. El curare fue utilizado como anestésico y analgésico a principios del 
1991. Curare se constituye en los años noventa como una asociación civil y sin fines lucrativos, un espacio crítico para las artes que, desde una perspectiva pluridisciplinaria se dedica a la investigación y al análisis de la Cultura visual en México. Integrada por un grupo de críticos e historiadores del arte de México, D.F., que previamente habían colaborado en varios proyectos curatoriales, se inserta en la tradición de espacios alternativos creados por -y para- artistas. La revista se convierte en un foro flexible y creativo, que permite incrementar el diálogo entre los artistas, los ensayistas y sus diversos públicos. Aunque mantienen relaciones con museos oficiales y privados, y con galerías, buscan ofrecer una respuesta a las actitudes sacralizadoras y dogmáticas de estas instituciones. Se consolidan también como una alternativa frente a las tendencias monopolizadoras del mercado del arte. En la década de los noventa en México, esta revista de arte ha sido fundamental para documentar los procesos historiográficos que ha vivido el arte contemporáneo tanto mexicano como internacional de las últimas décadas. Pero el tema que nos ocupa aquí no es redefinir ni concretar el panorama del arte actual en México. Sirva lo anteriormente expuesto como bosquejo para tratar de fundamentar genéricamente, las razones por las cuales no se ha prestado la suficiente atención a ciertas problemáticas que en la actualidad se han desmarcado de los magnos proyectos curatoriales.

Como anticipamos en el primer capítulo, tanto a nivel internacional como en España y en México, el interés despertado por la temática de Arte y Naturaleza es relativamente reciente. Sin embargo en los últimos años en España se han documentado diferentes eventos que han dejado constancia del panorama del arte contemporáneo al respecto. Numerosos centros, convocatorias y encuentros han marcado pautas fundamentales para hacer recuento de experiencias pasadas y presentes.

En los noventa, los encuentros de Arte y Naturaleza en Huesca, organizados por Javier Maderuelo constituyen un foro de discusión fundamental para entender la dinámica que se establece. También la Fundación César Manrique y su proyecto de conservación armónica de la isla de Lanzarote o la Fundación Montenmedio en Vejer de la Frontera, Cádiz se consolidan como plataformas culturales de reflexión entre las artes plásticas y el medio ambiente. Con inquietudes paralelas, Josep Ginestar y el Grup de Reüll con los encuentros de arte contemporáneo en espacios públicos y naturales en la zona de los pueblos de La Marina en Alicante, con Estiu-Art. Intervencions en Alicante; Arte, industria y territorio en Minas de Ojos Negros, Teruel, con Diego Arribas como organizador; la Isla de las esculturas en Pontevedra, Galicia; el Parque de las esculturas en las Tierras Altas de Lomas de Oro en la Rioja, por citar algunos de ellos, son en

siglo XX. Curare: Del latín curare, por cuidar o sanar. Curare: Nombre propio. Asociación civil fundada en 1991 en México, D.F., dedicada a la crítica, la investigación histórica y el apoyo al arte contemporáneo independiente que se realiza en México. Utilizando las diferentes connotaciones del término, su nombre se deriva de las dos definiciones anteriores, Disponible en red: <http://www.laneta.apc.org/curare/index.html>, [Consulta 2, febrero, 2008]. 
definitiva muestras palpables del interés despertado en cuanto a estas temáticas.

Sin embargo en México y hasta hace muy poco, el binomio Arte-Naturaleza no ha sido siquiera planteado y por consiguiente no se han podido desarrollar proyectos curatoriales de esta envergadura. Pero la ausencia no es total ni el silencio absoluto. Es evidente que en México no se dio un movimiento ideológico y artístico coetáneo al Land Art que en Europa y Estados Unidos se daba durante los años setenta. Si bien es cierto que la problemática inicial de este movimiento no tenía la misma intención que la relación Arte y Naturaleza tiene en la actualidad para los artistas que trabajan en ello. Sin embargo podríamos afirmar que la repercusión del Arte Povera sí tuvo y sigue teniendo, un impacto en el medio artístico mexicano, fundamentalmente desde la perspectiva de que es el común denominador del día a día en la producción de muchos artistas.

Poco se ha documentado al respecto y tampoco se ha reflejado en general respecto al panorama del arte mexicano más reciente. Si pensamos en particular en el medio de la escultura, la información es todavía más escueta. La carencia de registros, la falta de medios a la hora de realizar exposiciones ha hecho que siempre sean beneficiados los artistas que han podido desenvolverse o en un circuito político-mediático o en un circuito comercial de galerías. De cualquier manera pocas han sido las revisiones que se han hecho de la escultura en México.

Las exposiciones y la difusión de obras son generalmente de carácter individual, la impresión de catálogos que documenten las exposiciones pasa a veces, por la mera impresión de un tríptico que corre por cuenta del expositor. Los movimientos artísticos vienen dados por categorías excesivamente cerradas: la Academia, el Porfiriato, la escultura popular, la herencia del mundo prehispánico, los Surrealistas, la Ruptura, los Geometristas y los discursos actuales de difícil clasificación.

Sin embargo, en los últimos años, podemos apreciar el trabajo de una serie de artistas que reiteradamente trabajan con diversos elementos de la Naturaleza y que, formulando sus propuestas en base a diferentes estrategias creativas, mantienen una vivencia contemporánea con respecto a ella. Se trata, como veremos más adelante, de nuevos comportamientos artísticos en el arte contemporáneo, planteamientos que partiendo de la referencia formal o desde el plano conceptual y, con distintas visiones e intereses, reformulan nuevas categorías de la Naturaleza, misma que sigue siendo vital en nuestra experiencia cotidiana.

Cuestionándonos sobre los artistas que han trabajado anteriormente en México en el tema de nuestra investigación y que pudieran haber influido en las generaciones de artistas más jóvenes, encontramos algunos planteamientos cercanos a la temática que nos ocupa. Nuestro análisis comienza con una revisión previa de las intervenciones locales de carácter permanente que 
sentaron precedentes en los años setenta para pasar posteriormente a registrar las exposiciones más relevantes realizadas al respecto en México. A continuación revisaremos la obra de tres artistas que apuntan trayectorias a seguir en tiempos más recientes. En nuestra opinión, la obra de artistas como Helen Escobedo, Marta Palau y Jan Hendrix está directamente relacionada con una profunda experiencia vivencial y estética de la Naturaleza. Cabe plantearse la circunstancia de que curiosamente los tres tienen vínculos con otros países.

\subsection{Intervenciones pemanentes y exposiciones más relevantes celebradas en los últimos 30 años}

Al acercarnos al conjunto artístico de carácter público, llamado el Espacio Escultórico podemos leer la frase del político, pensador y escritor mexicano José Vasconcelos: "Al crear el hombre el jardín, de hecho separa lo bello de lo útil, en el tránsito del grano a la rosa hay el mismo salto que de la marcha a la danza y de la representación imaginada al dibujo que la plasma"189. Esta reflexión nos da una idea de cómo era, hacia 1979 -año en que fue inaugurado este espacio- la relación entre el conocimiento, el Arte y la Naturaleza en espacios públicos en esta ciudad. En ese año año, se conmemoraba el cincuentenario de la autonomía universitaria, para lo cual se decidió construir este lugar emblemático, único en México, que denota una lectura ambigua, de afán de dominio y de domesticación de la Naturaleza y una cierta idea bucólica de preservación y de respeto hacia las formaciones naturales de lava que allí se encontraban.

\section{El Espacio Escultórico (1979).}

Una de las piezas más destacadas en el panorama del arte en México, relacionada con el binomio Arte y Naturaleza, con la ecología y con la idea contemporánea de Arte Público, es la obra monumental denominada el Espacio Escultórico (1979). Situada en el Pedregal de San Ángel, al sur de la Ciudad Universitaria, forma parte del conjunto escultórico ubicado en el Centro Cultural de la Universidad Nacional Autónoma de México (México, D.F.). Aledaño al llamado Paseo de las Esculturas, e inmerso en el área ecológica de Cuicuilco, encontramos una construcción circular compuesta por diferentes módulos piramidales, por los cuales se accede a un círculo central, en el que se ha conservado el terreno volcánico y la vegetación características de la zona que rodea a toda la construcción. La obra, iniciada en 1977, fue concluida en 1979, constituyéndose a partir de entonces, en una de las primeras intervenciones humanas en México, relacionadas con el Arte Público contemporáneo, de carácter permanente y en un entorno natural.

Los autores conceptuales de la obra fueron seis artistas, Helen Escobedo, Manuel Felguérez, Mathías Goeritz, Hersúa, Sebastián y Federico Silva. Todos ellos eran y son escultores de gran trayectoria en México. En aquel entonces

189 Frase de José Vasconcelos, en TIBOL, Raquel, "Por mi lava hablará el espíritu", en Proceso, $\mathrm{N}^{\circ} 130$, México, D.F., 28, abril, 1978. 
crearon el Laboratorio de Experimentación en Arte Urbano, como un organismo universitario que se ocupaba de las prácticas teóricas y empíricas del Arte Público. El grupo fue conformado por los citados escultores, el 4 de noviembre de 1977.
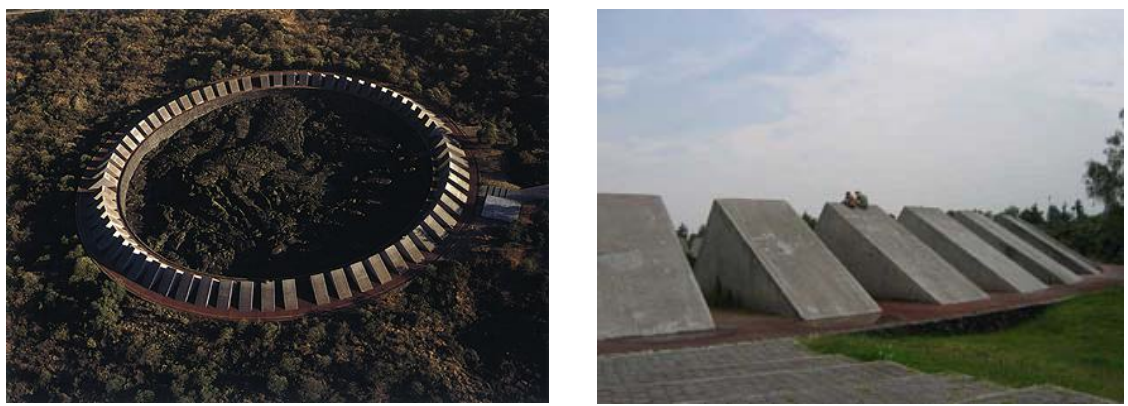

Helen Escobedo, Manuel Felguérez, Mathías Goeritz, Hersúa, Sebastián y Federico Silva, Espacio escultórico, 1979.

El historiador de arte Jorge Alberto Manrique, director del Instituto de Investigaciones Estéticas entre 1974 y 1980, fue quien dio un gran impulso a la escultura monumental contemporánea. Él sugirió a las autoridades universitarias qué tipo de obra debían patrocinar y fue quien orientó al entonces Rector de la UNAM (Universidad Nacional Autónoma de México), sobre la creación del Espacio Escultórico (1979), proponiendo que se invitara a los escultores que estaban relacionados con la Universidad. El encargado de coordinar el proyecto y convocar al grupo de los seis escultores fue Mathías Goeritz.

Este espacio se creó al sur de la ciudad de México, D.F., ante el acoso constructivo moderno a lo largo de los ochenta kilómetros del Pedregal de San Ángel. En su momento fue construido en el espacio entonces conocido como Cultisur área cultural de la UNAM y junto al Ilamado Paseo de las Esculturas. Su construcción estuvo a cargo de la Dirección General de Obra de la UNAM con la coordinación de la Comisión del Plano Regulador de la UNAM. En la misma zona encontramos otras grandes piezas realizadas por los escultores que participaron en esta obra colectiva. Así tenemos de Federico Silva la pieza Ocho Conejo, de Mathías Goeritz Corona del Pedregal, de Sebastián las esculturas Colotl y Tláloc, de Hersúa Ave dos; de Manuel Felguérez Variante de la llave de Kepler, de Helen Escobedo, Coatly de Rufino Tamayo La Universidad, germen del humanismo y la sabiduría, entre otras ${ }^{190 .}$

Los antecedentes de esta obra podemos encontrarlos en la corriente imperante durante la segunda mitad del siglo XX en México: la escultura geométricomonumental. Este movimiento, iniciado a fines de los años cincuenta busca su apoyo en la tradición y en la vanguardia del país para dinamizar la

190 AA. VV., El Espacio Escultórico, Museo Universitario de Ciencias y Arte, Centro de Investigación y Servicios Museológicos, UNAM, México, D.F., 1980. 
modernización de México. En este contexto los escultores mencionados trabajaron en coordinación con las autoridades de la Universidad.

Aunque la obra tiene de una manera fluida y coherente, una identidad propia en el contexto actual de la Cultura mexicana, y se inscribe también en el proceso de la Cultura y el mundo prehispánico, podemos establecer una cierta analogía formal con trabajos espaciales que, en otros ámbitos a nivel internacional la sitúan en un contexto cultural cercano a las intervenciones artísticas llamadas Earth Works y Land Art, concretamente nos referimos a la obra realizada por Robert Morris que lleva por título Observatorio (1971).

Robert Morris nos propone en esta construcción que refleja la utopía del espejo, un juego mental en el que somos a la vez constructores y observadores de nuestra propia realidad. El autor nos exige además del papel de espectadores, el de actores.

En esta obra Morris, exige al observador una participación activa, por eso ahora éste ya no puede limitarse a contemplar la obra pasivamente, ya que no la puede abarcar con su mirada de un sólo golpe de vista ni desde una posición fija; ahora tiene que recorrerla. Le exige, pues, que se mueva y altere sus puntos de vista, pero también que se transforme en ese recorrido, es decir, que tenga la capacidad de verse asimismo. O mejor, de constatar que su sistema perceptivo no es un instrumento que determina la realidad que ve $y$ conoce"19l.

De la misma manera la obra del Espacio Escultórico genera y delimita una extensión dentro del contexto histórico-artístico que invita a ser recorrido y percibido desde otros puntos de vista diferentes a los que nos plantea una escultura objeto. Juan Acha atribuye la paternidad proyectual de esta obra a Hersúa, quien interpretó en su momento el diseño teórico al que por unanimidad, había llegado el grupo de escultores. Hersúa "llevó la maqueta de módulos hechos en cartón" 192 a la oficina del Dr. Carpizo que, en aquel entonces, era Rector de la Universidad y el responsable de haber convocado al grupo de artistas que trabajaban como profesores y/o empleados de la UNAM, a los que les propuso construir una escultura en un área cubierta por lava petrificada, producto de las erupciones del extinto volcán Xitle.

\footnotetext{
191 RAQUEJO, Tonia, "Imágenes del lugar, leyendas del no-lugar", en MADERUELO, Javier (dir.), Arte público: Arte y naturaleza, Actas del V Curso, Diputación de Huesca, Huesca, 1999, pp. 178-179.

192 ACHA, Juan, Hersúa: Obras/Escultura, Persona/Sociedad, UNAM, Coordinación de Humanidades, México, D.F., 1983, pp. 14-20. Para hacer esta afirmación, Juan Acha se basa en un artículo de Joaquín Sánchez Mcgregor, publicado en el periódico Uno más uno de México, D.F., (3, junio, 1979) en el que Sánchez Mcgregor describe cómo ante él y otras personas, a principios de mayo de 1978, Hersúa llevó la maqueta, pudiendo ver "la propuesta fundamental: los módulos o prismas triangulares".
} 


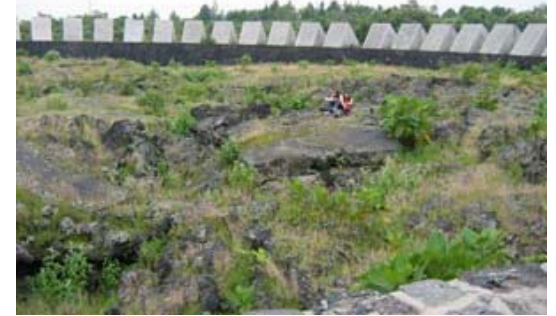

Helen Escobedo, Manuel Felguérez,

Mathías Goeritz, Hersúa, Sebastián y

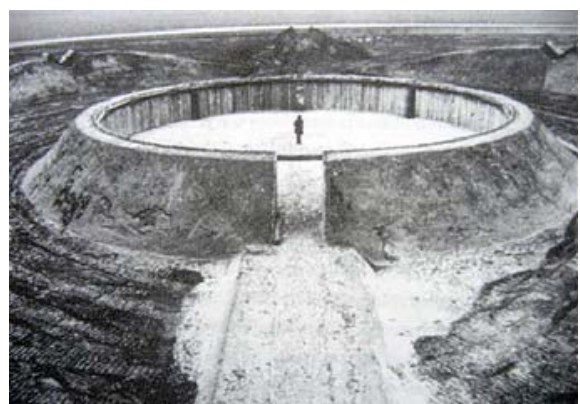

Robert Morris, Observatorio, 1971.

Federico Silva, Espacio escultórico, 1979.

Los artistas decidieron realizar una obra anónima que resumiera los conceptos de los seis participantes. El punto fundamental para lograr integrar el proyecto fue el acuerdo al que llegaron, basándose en que todas las decisiones tendrían que ser tomadas unánimemente. Establecieron un filtro conceptual y usaron el círculo como forma básica, también usada en las civilizaciones prehispánicas precisamente en la cercana pirámide de Cuicuilco (la más antigua del Valle de México).

Con el fin de establecer los módulos, seleccionamos el número 64, que significaba algo distinto para cada uno de nosotros. Luego pensamos en cuatro puertas o aperturas equidistantes, algo presente en virtualmente todas las civilizaciones del mundo. Por último, elegimos la forma de un módulo con el cual ninguno de nosotros había trabajado hasta la fecha, el triángulo isósceles'193.

La obra en cuestión consta de una superficie de lava rugosa de $92^{\prime} 78$ metros de diámetro que, libre de toda vegetación salvo ciertos arbustos autóctonos, se encuentra rodeada por un doble muro de piedra volcánica. Sobre esta plataforma se suceden radialmente 64 módulos poliédricos, de base rectangular de $9 \times 3$ metros con una altura de 4 metros de hormigón armado con un acabado de martelinado grueso ${ }^{194}$. La separación entre ellos es mayor en los cuatro puntos cardinales. Propiamente los módulos constituyen una suerte de pirámides, cuya cara interna se aleja del centro del círculo volcánico, mientras que la externa, que es más larga, se inclina en sentido contrario. Está construido

193 ACEVEDO, Alejandro, "Helen Escobedo: Artist and Promoter of the Mexican Avant Garde", Entrevista Disponible en red: <http://www.pintomiraya.com.mx/lapala nuevaweb/ingles/engentrevista4.htm>, [Consulta 24, febrero, 2005]. Alejandro Acevedo es crítico del arte y artista visual en México, D.F. (Traducción libre de la autora de la investigación).

194 ENCISO DE LA VEGA, Salvador, "Características del Espacio Escultórico", en AA. VV., EI Espacio Escultórico, op cit., pp. 27-30. 
sobre el basalto que cubre la zona de Cuicuilco y Copilco, al sur de México, D.F.195.

Juan Acha, quien siguiera de cerca el desarrollo de este proyecto, realiza un análisis incisivo de la pieza. Al respecto comenta que el Espacio Escultórico se encuentra - para aquellos que desconocen los cambios que se han producido en la escultura de los últimos tiempos- en los límites entre arquitectura y escultura. Acha describe la construcción escultórica como una obra antiinformalista y antiobjetualista, remitiéndonos a un análisis similar al que podríamos aplicar a la pieza de Robert Morris Observatorio (1971) aunque, sin hacer directamente referencia a dicha obra. Sus descripciones inciden en una lectura no sólo visual, sino también, corporal o visivo-táctil de la pieza, haciendo especial hincapié en la transitabilidad de la escultura. Acha sitúa los antecedentes formales y conceptuales del Espacio Escultórico en las construcciones megalíticas de la Prehistoria (dólmenes, menhires, cromlechs, etc.), pero a la vez, reconoce las actuales y en aquel momento, preocupaciones artísticas que los artistas se plantearon en la resolución del proyecto. Comenta asimismo la influencia de sentimientos cosmológicos y antropológicos, míticos y místicos inherentes a la sempiterna oposición entre Cultura y Naturaleza. Y lo que es más definitorio, en su descripción la presenta como una obra de arte integrada en los movimientos de transformación que por medio del arte se estaban dando en los espacios naturales, sin ir muy lejos, en EE. UU.

En su cinturón registramos el antiobjetualismo de las estructuras seriales del postminimalismo y el aún mayor del arte térreo que transforma la naturaleza, insertándole elementos culturales. Tampoco falta el conceptualismo que demanda el hecho de aislar un pedazo de realidad o naturaleza y presentarlo como obra de arte, obra que va dirigida a los conceptos más que a los patrones sensitivos y formales. Si ahora nos remitimos al espacio circunscrito, tendremos un pedazo de naturaleza que testimonia un espíritu expresionista de fruición matérica en quienes lo eligieron. El Espacio Escultórico se torna, entonces, en un altar idolátrico, mítico y agorafóbico de un magma petrificado que viene de las entrañas de la madre tierral96.

Una de las integrantes del grupo, Helen Escobedo, haciendo alusión al origen de sus instalaciones, cuenta cómo en 1969 todos los artistas hacían trabajos de este tipo porque no tenían dinero para hacer el trabajo que querían. Ese año se les proporcionó mucho periódico y todos los artistas hicieron instalaciones con él en el Museo Universitario de Ciencias y Artes. Después de esto, cada quien volvió de nuevo a sus intereses originales, pero, desde ese momento, ella nunca dejó de revisitar esta nueva forma de expresión. Como comenta Helen Escobedo

\footnotetext{
195 MARTíN DEL CAMPO, David, "Cinco torres, antes y después. Escultura Moderna en México", en MP Memoria de papel, Crónicas de la cultura en México, Consejo Nacional para la Cultura y las Artes, México, D.F., 4, octubre, 1992, pp. 5-27.

196 ACHA, Juan, "Otra Escultura Transitable en México", en AA. VV., El Espacio Escultórico, op. cit., pp. 83-84.
} 
en la entrevista realizada por Alejandro Acevedo, era un momento histórico en el que la creatividad estallaba en México $y$, de la misma manera que en el movimiento del Land Art, los artistas no deseaban estar encerrados en los museos o las galerías, donde su trabajo pudiera ser considerado como algo meramente decorativo o como objeto del consumo. Preferían espacios alternativos como la calle, el metro o los edificios abandonados que convocaban nuevas sinergias.

Dejando a un lado la obra al Espacio Escultórico (1979) como un hito en su concepción dentro de las intervenciones permanentes 197 en México, pasaremos a revisar algunas exposiciones que marcan también un punto de inflexión en la temática de nuestra investigación. En este terreno debemos considerar que si bien ha habido algunas que se han realizado con un intento de sopesar la cuestión de Naturaleza y ecología, vistas desde la perspectiva del arte, varias son las carencias que percibimos y que dificultan en gran manera, el seguimiento del proceso llevado a cabo. Por un lado, como indica Carlos Aranda, crítico y curador de arte, tenemos la falta en cuanto al registro documentado y secuencial de la información.

[...] no existe una tradición crítica para escribir una/la historia del arte en/de México en el siglo XX o sobre lenguajes como instalación, performance, video o arte en la red. Existe una bibliografía numerosa sobre Muralismo y la Escuela Mexicana de Pintura; de ahí se van adelgazando los títulos sobre los artistas de la generación de la Ruptura hasta llegar a ausencias graves sobre temas específicos de las últimas tres décadas. Este problema es una consecuencia directa del mundo académico que no otorga validez histórica, ni tiene el menor interés en un proceso que todavía está en efervescencial98.

Por otro lado, en el proceso de nuestra investigación y mediante entrevistas directas hemos observado, como veremos a continuación por los testimonios recavados, que algunos críticos coinciden en manifestarse en contra de esta temática, así como de su uso por parte de los artistas o por parte del sistema, alegando que desvirtúa los posibles campos de actuación del arte. Constatamos así que existe una tendencia a considerar que es un tema excesivamente proclive a la manipulación.

El problema [...] es que, si bien el término ecología es de una impresionante amplitud incluyente, sus cometidos y campos de acción han sido

\footnotetext{
197 En un contexto artístico contemporáneo, consideraremos intervenciones permanentes aquellas que permanecen en el tiempo en espacios públicos, convirtiéndose en parte del paisaje, sea éste urbano o natural.

198 ARANDA MÁRQUEZ, Carlos, "Los (h)usos de la Historia", septiembre, 2007, Disponible en red: <http://www.arteamerica.cu/14/dossier/aranda.htm>, [Consulta 12, febrero, 2008].
} 
gradualmente acotados desde hace unos 25 años, generando, de un lado del espectro, el activismo político y por el otro el sentimentalismo o las estrategias de relaciones públicas de las empresas transnacionales. Recientemente el ecologismo que critica la industrialización capitalista ha tenido como respuesta el término desarrollo sustentable, cada vez más utilizado por los estrategas económicos del neo-liberalismo. La palabra ecología se integra ahora al repertorio de un discurso de las sociedades democráticas, aparentemente concreto pero efectivamente vago, compartiendo un lugar junto a bienestar, federalismo o producto interno bruto ${ }^{199}$.

El crítico de arte Cuauhtémoc Medina, fue muy preciso al especificar que "desde la hegemonía del poder" -hablando en cuanto a crítica de arte se refiere- que, "por supuesto, él representaba, el tema de discusión no era qué artistas están vinculados o no a esta temática, sino más bien por qué el discurso de Arte y Naturaleza ha sido reprimido en México" 200.

Por otro lado, la crítica de arte Graciela Schmilchuk201, quien escribió en el año 2005 el libro Pasos en la arena sobre la artista Helen Escobedo, nos comentó que le resultaba sorprendente que hubiera una serie de artistas trabajando en la actualidad en torno a estos aspectos de la Naturaleza. Similares actitudes eran adoptadas por otros críticos a los que en su momento entrevistamos como José Luis Barrios, Francisco Reyes Palma, Jorge Juanes o Lily Kassner. Sin embargo, en nuestra opinión y, a pesar del rechazo y el ostracismo teórico, son varias las exposiciones en las que se pueden rastrear algunos parámetros del estado de la cuestión, en particular en lo que se refiere a la obra de cada uno de los artistas que serán estudiados en los siguientes capítulos.

\section{Xilitla, arquitectura vegetal (1962-1984).}

En México, existe un lugar cuya construcción, otorgando una particular atención al mundo vegetal, ha alimentado durante varias décadas el imaginario popular mexicano en la Cultura. Se trata de una de las arquitecturas o escultotecturas margivagantes, como las denominan Jesús Marchamalo y Damián Flores202, enclavada en la Sierra Madre Oriental de San Luis Potosí. Las Pozas de Xilitla aparentan ser un vestigio de una civilización milenaria, pero en realidad son un capricho, una arquitectura surrealista al aire libre y una suerte de jardín

\footnotetext{
199 REYNOSO POHLENZ, Jorge, "Estar y no estar", en Helen Escobedo, 15 instalaciones. Estar y no estar, Unam, Difusión Cultural, Dirección General de Artes Plásticas, México, D.F., 2000, pp. 22-23.

200 Entrevista realizada por la autora de esta investigación a Cuauhtémoc Medina, julio, 2006.

201 Entrevista realizada por la autora de esta investigación a Graciela Schmilchuk, agosto, 2006.

202 Véase MARCHAMALO, Jesús y FLORES, Damián, Escultecturas Margivagantes: La arquitectura fantástica en España, Siruela, Colección Biblioteca Azul, Serie Menor, Madrid, 2006.
} 
arquitectónico inmerso en la selva huasteca, que surge de la imaginación del aristócrata y poeta inglés, Edward James (1907-1984). Este laberinto-ciudad sin muros, es un lugar abierto a la espesura, que dialoga con la exuberante vegetación y, para cuya construcción Edward James tuvo que vender parte de su vasta colección de arte surrealista203. En medio de la selva y, en lo que tiempo atrás fue una floreciente zona cafetalera, este personaje, heredero de varias fortunas, decidió construir en el transcurso de veinte años (1962 y 1984) la experiencia insólita de un paraíso propio.
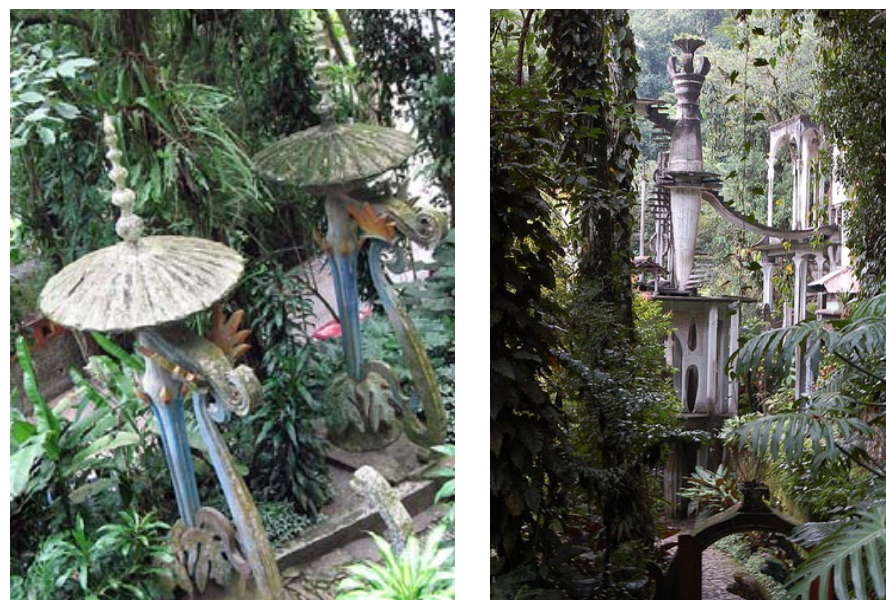

Edward James, Xilit/a, 1962-1984.

La leyenda inscrita en la entrada al espacio arquitectónico relata cómo el clima, los paisajes y lo pintoresco del lugar sedujo a Edward James quien compró los márgenes del arroyo (actualmente Las pozas). En aquella época llegaban a la zona las mariposas monarca y en este paraje se apareaban. Edward James emocionado ante este espectáculo eligió este lugar para realizar sus fantasías. En opinión de Lourdes Andrade, dos son los elementos fundamentales que "en una especie de convivencia promiscua", configuran el espacio creado en este lugar. Por un lado,

\section{[...] los elementos arquitectónicos desarticulados que forman un original laberinto y evocan diversos estilos de construcción -gótico, mesopotámico, egipcio, etcétera- y la naturaleza que se imbrica íntimamente con ellos; como si unos y otra intentaran confundirse, entremezclan sus esencias desiguales204.}

Lourdes Andrade, relaciona estas construcciones con los grabados de prisiones de Giovanni Batista Piranesi (1720-1778), considerando que la influencia piranesiana en las construcciones es incuestionable, ya que, afirma, es bastante

203 Véase HOOKS, Margaret, Edward James y Las Pozas: un sueño surrealista en la selva mexicana, Madrid, Turner, 2005.

204 ANDRADE, Lourdes, "Ruinas y bosques", en Saber ver lo contemporáneo del arte, №35, Fundación Cultural Televisa, México, D.F., julio-agosto, 1997, p. 8. 
probable que Edward James conociera estas obras de arte. La herencia cultural de Edward James está matizada sin duda, por una percepción del paisaje marcada por la asimetría y el elemento sorpresa. En su jardín, este patrimonio escultórico-arquitectónico está relacionado con un nuevo sentimiento ante los fenómenos naturales que, "aunque angustioso, resulta más auténtico y fructífero que la ilusión de creer en la posibilidad de controlar la naturaleza"205, pero especialmente por las experiencias vividas por James vinculadas al Surrealismo y a los artistas que conocía.
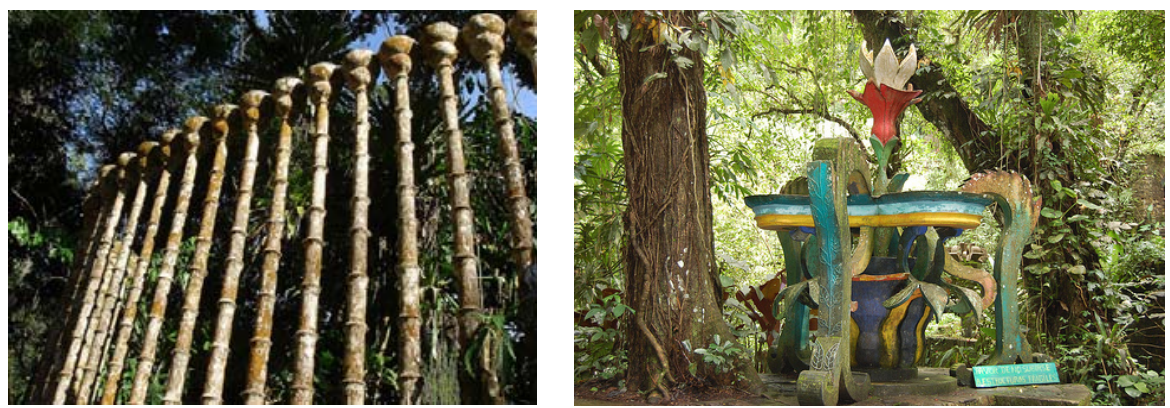

Edward James, Xilit/a, 1962-1984.

Con cierto aire surrealista cercano al de sus amigos artistas y protegidos entre los que se encontraban Salvador Dalí, René Magritte o Leonora Carrington, James construyó en las treinta hectáreas que había comprado, un prodigio arquitectónico, el Edén secreto que, probablemente, había imaginado en su niñez. Allí encontramos escaleras que suben al cielo, columnas que se asemejan a bambúes y que no sostienen más que aire, arcos que parecen plantas, flores, pájaros, manos, piernas y pies de cemento enmohecido y fuentes de las que manan flores. Estas delirantes construcciones influyeron en sus amigos al punto que artistas como Remedios Varo y Leonora Carrington realizarían obras en las cuales se puede apreciar cierta influencia de la leyenda generada por este lugar. La segunda de ellas visitó Xilitla pintando el fresco de El Minotauro (1965) en las paredes de la casa del aristócrata. Según Andrade, la importancia del mundo vegetal, tanto para Leonora Carrington, como para Edward James queda reflejada en la intensidad emotiva, irracional y onírica de sus obras: "La floresta semitropical, la oscuridad, la humedad crean un ambiente que remite a la tierra de origen"206 de ambos.

La casa de Edward James alberga un museo que recoge la documentación, los dibujos y bocetos de las piezas que James trazaba para dar indicaciones a sus empleados, así como algunos de los encofrados con los que se hacían las piezas de hormigón. En una de las paredes podemos encontrar un enigmático cuadro titulado El Subconsciente (1955), pintado por el mismo y firmado con su pseudónimo Edward Silence. En este cuadro, como pudimos constatar en nuestra visita a dicho museo, se observa una figura femenina ataviada con una

205 ANDRADE, Lourdes, "Ruinas...", op. cit., p. 19.

206 ANDRADE, Lourdes, "Ruinas...", op. cit., p. 26. 
túnica, de cuyo cuello en lugar de cabeza humana, brota una rosa, alegoría vegetal de la imaginación y del pensamiento creativo de su autor.

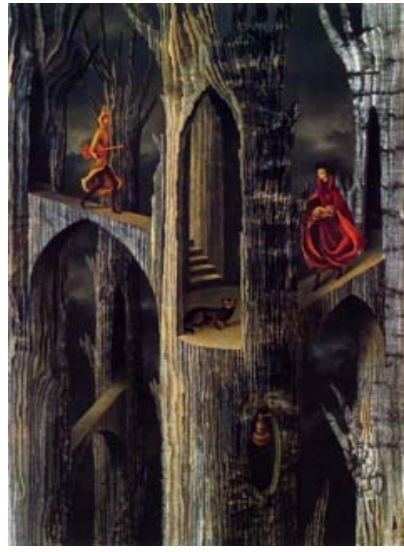

Remedios Varo,

Arquitectura vegetal, 1962.

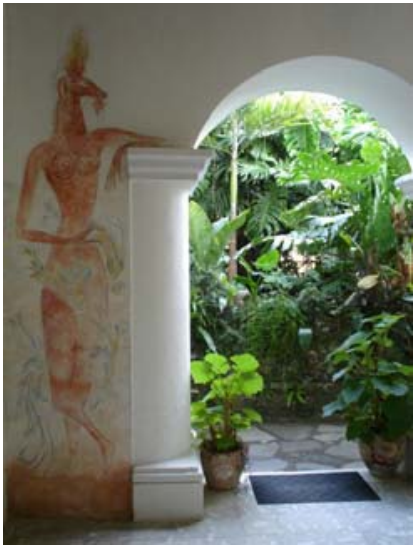

Leonora Carrington,

El Minotauro, 1965.

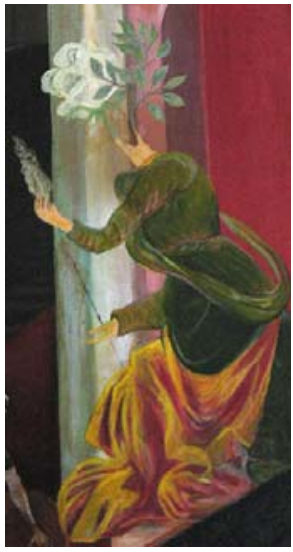

Edward James,

El subconsciente, 1955.

James, quien construiría este lugar idílico, especie de santuario para dar cobijo a sus quiméricas ideas, dotó a su jardín de una arquitectura fantástica en donde la utilidad se descarta en función de la belleza. Este azaroso juego arquitectónico es un homenaje a la Naturaleza circundante que, como por arte de magia, elude cualquier planificación premeditada. Las innumerables estructuras surgen en una especie de vértigo físico de la imaginación, en una suerte de mímesis selvática de cemento, una ciudad laberíntica, imposible y cercana al éxtasis. Los elementos arquitectónicos que integran estas estructuras, ignoran y se contraponen a una de las características esenciales de la arquitectura, la funcionalidad. En este sentido, se encuentran más cerca de las creaciones de los surrealistas, compartiendo con ellos uno de los aspectos más atractivos de esta estética, su antiutilitarismo207.

La Naturaleza y la humedad de la selva se encargan de que Las Pozas sea una obra en proceso. La escasa conservación de las construcciones, favorece que lo que en su momento surgiera con un principio antipragmático, fruto de la voluntad de su constructor, siga integrándose en la magia del entorno. Su constructor anhelaba que las construcciones se confundieran en el diálogo con la Naturaleza hasta el punto de que llegara alguien a Las Pozas años después y creyera estar frente a los restos de una civilización perdida, parte neogótica, parte egipcia, parte fruto del surrealismo en el que el propio James se vio envuelto.

La paradójica ciudad del inglés fue posible gracias a la colaboración de Plutarco Gastélum Esquer, un indio yaqui al que Edward James contrató en Cuernavaca en

207 ANDRADE, Lourdes, Arquitectura vegetal. La casa deshabitada y el fantasma del deseo, Artes de México, Consejo Nacional para la Cultura y las Artes, México, D.F., 1994, p. 12. 
los años cuarenta y a quien convirtió en su amigo y administrador. El hijo de Plutarco es en la actualidad el encargado de este museo al aire libre. El tallador local José Aguilar fue el que se encargaba de interpretar los bocetos que James enviaba vía postal desde sus múltiples viajes. Él los traduciría en los moldes de madera que se utilizaron para todas las construcciones y el arquitecto Carmelo Muñoz Camacho los trasladaría a cemento. Las Pozas representa asimismo y en parte, el genio artesanal de los artistas y albañiles de Xilitla208. Llama la atención la particular impresión de lo inacabado que se aprecia en este lugar, en donde "el desorden o la deconstrucción imponen su ley"209 de forma similar a como se aplican en la actualidad ciertos conceptos de la arquitectura postmoderna que permiten apreciar "el mismo desorden que tiene la naturaleza: la integración, la imitación de vegetales, plantas, flores, tanto en sus formas y colores" 210.

En Las Pozas, las fantasías escultóricas y arquitectónicas se integran de manera armónica con la vegetación razón por la cual, hacemos mención de esta escultotectura margivagante la cual, a pesar de no quedar circunscrita en los parámetros del arte contemporáneo, refleja parte del espíritu de integración entre Arte y Naturaleza que posteriormente se ha desarrollado como una tendencia artística. Uno de los poemas de James describe el sentimiento de cercanía que experimentaba hacia la fantástica vegetación de la que se rodeó:

Porque he visto tanta belleza como rara vez se puede ver,/estaré agradecido de morir en este pequeño cuarto,/rodeado de la floresta, de la gran penumbra verde de los árboles,/mi única penumbra -y del murmullo, el murmullo del verdor [...]211.

\section{A propósito. 14 artistas en torno a Joseph Beuys (1989).}

Con este título y un carácter bastante especial e innovador para la escena artística en México, el 15 de abril de 1989 fue inaugurada una exposición en el Parque cultural y recreativo Desierto de los Leones. La crítica de arte Raquel Tibol documentó dicha exposición en un artículo para la Revista Proceso, en el que se hace eco de las propuestas de los catorce artistas que participaron, nueve mexicanos: Rubén Bautista Guadiana, Mónica Castillo, Roberto Escobar, Silvia Gruner, Gabriel Orozco, Raúl Piña, Mario Rangel Faz, Manuel Rocha Iturbide, Juan Manuel Romero; una chilena: Eugenia Vargas Daniels; una

\footnotetext{
208 BRITO, Sara, "Casas que cantan en la selva. Edward James levantó en la mexicana Xilitla un onírico entramado constructivo", en El País, Madrid, 6, mayo, 2006, Disponible en red: $<$ http://elviajero.elpais.com/articulo/viajes/Casas/cantan/selva/elpviavia/20060506elp viavje_13/Tes $>$, [Consulta 19, febrero, 2008].

209 AUDEFROY, Joel, "Las Pozas, Xilitla. Arquitectura surrealista de Edward James", en Esencia y Espacio, Arte y cultura urbana, Año 3, $\mathrm{N}^{\circ}$ 19, Escuela Superior de Ingeniería y Arquitectura, Unidad Tecamachalco, Instituto Politécnico Nacional, Estado de México, marzo, 2004, pp. 40-44.

210 AUDEFROY, Joel, “Las Pozas...”, op. cit., p. 44.

211 ANDRADE, Lourdes, "El extraño paraíso de James", en Saber ver..., op. cit., pp. 33-72.
} 
argentina: María Causa; una inglesa: Melanie Smith y dos suecos: Michael Dag Willi Bode y Ulf Rollaf.

El promotor cultural de esta exposición fue Guillermo Santamarina quien, con la idea de organizar una actividad en torno al artista alemán Joseph Beuys a tres años de su muerte, convocó a artistas que estuvieran interesados en las aportaciones de Beuys. Las palabras de Santamarina en el texto de presentación de la exposición dan una idea clara del carácter visionario que supondría la muestra dentro del panorama de la plástica en México:

Esta exposición se ha dividido en dos partes. Una pretende la introducción al público mexicano de la vida y la obra de una figura trascendental en la historia del pensamiento y la expresión de nuestra especie: del maestro alemán Joseph Beuys. Otra se ha decidido con la representación de 14 obras (13 de ellas ejemplos de instalación in situ, y una más configurada en proyección sonora) que revisan las ideas expuestas por Beuys desde la década de los sesenta, especialmente sobre un arte constituido con materiales a la mano, dispuestos como centros energéticos o dispositivos que asimilan -metafórica y esotéricamente- compromisos de bien común, reiteraciones místicas, o comparecencias en la esfera de las tradiciones (locales y universales) del hombre, pero que a la vez no excluyen interpretaciones múltiples, equivocaciones [...]212.

Santamarina explica cómo algunas de las obras contradicen abiertamente los esquemas habituales de lo que se considera arte.

Para muchos de nosotros, Beuys representa algo más que la noción primaria de una posible expresión sustentada en el abandono a los materiales comunes del arte, y el acatamiento de "cosas" desacostumbradas [...]. Esta experiencia-creemos- abre para muchos de nosotros un potencial infinito, latente, que no puede yacer dormido. Para los que usualmente pintamos, ahora se abre la posibilidad de marcar distancias reflexivas y considerar soluciones con síntesis ahistórica. Para los escultores, el análisis de un lenguaje sincrético, desprovisto de pedestales, pero prolijo en su alcance espacial. Para todos, la evidencia de una realidad dinámica y de intención justa con las capacidades individuales de cada hombre-todo artista213.

Por su parte Raquel Tibol calificó la muestra de insólita, atractiva y profunda, indicando que todos los artistas, "se empeñaron en actos de creatividad dignos del impulso quimérico de Joseph Beuys" 214. En gran medida fue una exposición que repercutió en varios sectores de la comunidad artística desde la perspectiva

\footnotetext{
212 SANTAMARINA, Guillermo, "Panchito en Baviera (o un condensado de reflexiones sobre viejas y nuevas estrategias, internacionalismo y, desde luego, obligaciones en el arte mexicano", en Exit México, Olivares y Asociados, Madrid, 2005, pp. 79-80.

213 SANTAMARINA, Guillermo, "Panchito en Baviera...", op. cit., pp. 79-80.

214 TIBOL, Raquel, "Acercamiento a Joseph Beuys en México", en Proceso, № 652, 29, abril, México, D.F., 1989.
} 
no sólo de la propuesta museográfica que ocupaba todos los espacios, refectorio, celdas, capilla, patio y demás espacios del Ex-Convento carmelita en lo que Tibol calificó de ambientaciones, sino también por el despliegue biográfico y documental en torno a Beuys y la evolución de sus concepciones artísticas. A manera de seminario se llevaron a cabo durante la exposición una serie de reuniones.

La obra de Beuys (figura cumbre del Neodadaísmo europeo) y su concepto ampliado del arte, junto con sus acciones en Fluxus, su inclinación a convertir la disidencia social en estética tratando de borrar diferencias entre arte y vida, su escultura social con fuertes motivaciones ecologistas, su defensa de la paz, la democracia y la libertad del individuo, su anticapitalismo y su reconceptualización de la religión debieron resultar muy atrayentes para los artistas en México justamente desde la vivencia nacional de una política de estado autoritaria basada desde la época de la Revolución en una dictadura de partido.

En esta exposición, Mónica Castillo señala Tibol, realizó una instalación titulada Sala de recuperación en la que el verbo o la palabra eran destilados. Este proceso se materializaba mediante una serie de papeles atados y una patata que, como elemento de la Naturaleza, representaba el proceso de destilación por el cual un sujeto podría alcanzar un estado superior de conciencia. Silvia Gruner utilizó palomas en su obra, mientras que Gabriel Orozco, con unos troncos cortados y caídos, sitúa una cabeza de elefante a tamaño natural en una especie de llamamiento al derecho de las especies a existir sanamente en su propio ambiente.

A finales de los años ochenta la heterogeneidad de discursos formales se había diversificado al punto de que los límites entre las disciplinas artísticas específicas se habían borrado. Las instalaciones permitían -desde la toma de un espacio tridimensional- concretar y acercar los vínculos entre arte y vida y, a nivel cognoscitivo entre el arte como creación y como forma de conocimiento y de percepción. Al diluirse el objeto las relaciones espacio-temporales se expanden así como el concepto de escultura. Los procesos involucrados en la documentación de la obra comienzan a valorarse como forma intrínseca de arte, así como de nuevo la realización de las piezas ex proceso e in situ. En este sentido esta exposición fue de las primeras en realizarse de esta manera en México. La obra Luz de Joseph de Juan Manuel Romero, permitió un ejercicio de observación del recorrido de la luz en la arquitectura del recinto del viejo ExConvento. Partiendo de esta mirada, nos cuenta Itzel Vargas el artista, "dibujó la trayectoria lumínica en un camino de plantas y ramas secas"215. Esta acción define una relación más amplia entre la obra de arte y su entorno saliendo del

215 VARGAS, Itzel, "Disertaciones sobre el sentido de la práctica escultórica. Del geometrismo a los discursos actuales", en AA. VV., Escultura Mexicana. De la Academia a la Instalación, Instituto Nacional de Bellas Artes y Landucci Editores, México, D.F., 2000, p. 348. Itzel Vargas es Historiadora del arte, curadora y coordinadora de exposiciones. 
espacio expositivo y retomando el exterior, convirtiendo lo etéreo de una percepción visual en materiales manipulados pero naturales.

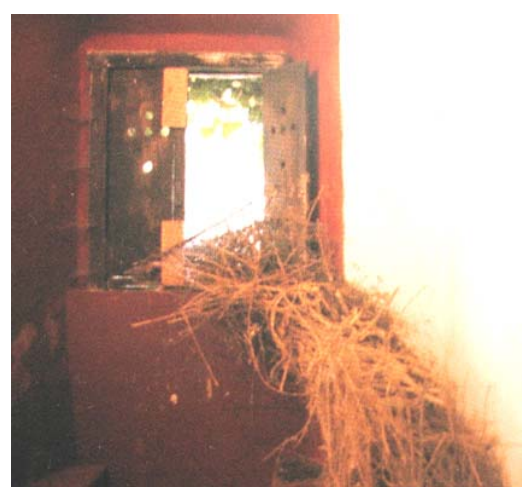

Juan Manuel Romero, Luz de Joseph, 1989.

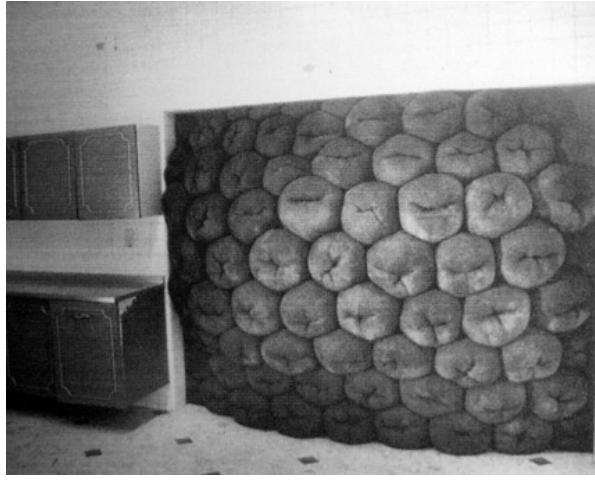

Héctor Velázquez, Polanco, 1993.

A partir de exposiciones como ésta varios son los artistas que comienzan a utilizar materiales nuevos en sus obras. Así, una pieza realizada con posterioridad y que incorporaba materiales naturales y efímeros como tierra, impresionó por su originalidad a la crítica de arte Karen Cordero. La obra de Héctor Velázquez (México, D.F., 1965), realizada en una galería de Polanco (Temístocles, 44), era un montón de bolsas de nylon rellenas de tierra que parecían salir de un orificio en la pared que en realidad, era un pasillo que llevaba a otras partes de la casa. Formas inesperadas que participan de la idea de la escultura como forma de apropiarse artísticamente del espacio. Posteriormente, el trabajo de este artista partirá de la relación del ritual del ser humano como ser social, del concepto de la piel y el cuerpo como símbolos de renovación emocional y psíquica, del poder de transformación de la Naturaleza y de la tierra. En piezas como Topografías (2003) construirá a partir de sus manos y sus brazos una modalidad de paisajes-plantas-cuerpos extendiendo de esta manera los límites físicos de su cuerpo, mezclándolos con otros entornos para sintetizar según el propio autor, cuerpo, montañas y plantas.

\section{Lesa Natura (1993).}

A poco menos de un año de su muerte, el candidato a la presidencia Luis Donaldo Colosio hace una presentación para el catálogo de la exposición Lesa Natura que se presentó en el Museo de Arte Moderno, con motivo del Día Mundial del Medio Ambiente. Consciente del deterioro, la contaminación y la degradación de la Naturaleza que ha llevado a cabo el ser humano, en su texto exhorta a un compromiso hacia un desarrollo sustentable, para lo cual entre otras cosas, se concretó dicha exposición. Ideada por Homero Aridjis y los artistas de la Quiñonera, comisariada por Carlos Ashida y Patrick Charpenel y, auspiciada por organismos tanto oficiales como independientes en el campo de la ecología en México, la muestra fue una de las pocas oportunidades de 
mostrar la confluencia de intereses entre arte e institución, en torno a la temática ecológica.

Es Homero Aridjis, reconocido poeta, quien se encarga de escribir la introducción, en la que apunta que después de la caída del comunismo, la ecología es la luz del nuevo humanismo en el mundo. En este sentido, Aridjis señala que es el hombre quien tiene la responsabilidad de acometer las acciones necesarias para preservar habitats y especies así como prevenir su propia desaparición como tal: "El hombre sabe que la Tierra es un organismo vivo y como tal puede morir [...]"216, añadiendo que la Naturaleza podría vivir sin el hombre, pero que el hombre no podría hacerlo sin la Naturaleza. La "nueva generación de artistas" que nombra Aridjis y a los que les da la bienvenida a la "Ecología" son algunos de los mismos que integraron la anterior exposición fruto del homenaje a Beuys. Claudia Madrazo, fundadora y directora de La Vaca Independiente, organización privada que apoyaba proyectos relacionados con el arte, destaca el tipo de obra exhibida "realizada bajo técnicas no convencionales y en defensa de la destrucción de la naturaleza", lo cual nos da una cierta idea del gran abismo y desconocimiento que a principios de la década de los noventa se vivía en México en cuanto a arte contemporáneo, con respecto al resto de geografías.

Los artistas que participaron en esta exposición fueron Francis Alÿs, Marco Arce, José Bedia, Thomas Glassford, Silvia Gruner, Eniac Martínez, Gabriel Orozco, Pablo Ortiz Monasterio, Kiyoto Ota, La Quiñonera, Ray Smith, Pablo Vargas Lugo y Germán Venegas. Puesto que la obra pictórica no es el objeto de nuestro interés en esta investigación, nos limitaremos a comentar la obra de los artistas con piezas tridimensionales o con instalaciones y de los conceptos que se manejaron, con la excepción de Francis Alÿs, cuya obra, de una perspicaz y sorprendente sutileza, trasciende la bidimensionalidad de la pintura.

Para esta exposición, Alÿs (Antwerp, 1959) presentó una serie de cuadros, de discreto formato y de mensaje polisémico, en los que por lo que se puede apreciar en el catálogo, la nota está puesta no sólo en los alegóricos contrastes entre la ausencia y la presencia y lo que todo ello conlleva, sino también en una cuestión espacio-temporal. Se trata, como él mismo señala a Teresa del Conde217, de una "maldita alegoría" sobre la destrucción forestal que aporta en nuestra opinión, una crítica en torno al preciosismo y la belleza, tanto la representada como la de los materiales empleados. En uno de los dípticos, Pájaros cruzados, una calcomanía de un pájaro rojo parece contemplar el incendio que arrasa metafóricamente toda la superficie del cuadro. El espacio flotante que ocupa este pájaro marca y hace hincapié en la ironía que el artista nos propone, puesto que en contraposición, el díptico presenta otro lienzo que

216 ARIDJIS, H., "Introducción", en AA. VV., Lesa Natura, Reflexiones sobre ecología, Museo de Arte Moderno/Grupo de los Cien/Cemex/Sedesol/La Vaca independiente, México, D.F., 1993 , p. 5.

217 DEL CONDE, Teresa, “¿Ecología? Miradas y propuestas”, en AA. VV., Lesa Natura,..., op. cit., pp. 9-12. 
representa un romántico bosque dieciochesco. Sin embargo el espacio que en el cuadro anterior ocupaba el pájaro ahora se ha transformado en una mancha blanca. El mismo pájaro con la misma forma recortada pero, en esta ocasión invertida. El fondo se convierte en figura, adquiriendo el papel de personaje principal y convirtiendo en protagonista a la sensación de ausencia y pérdida que se genera.
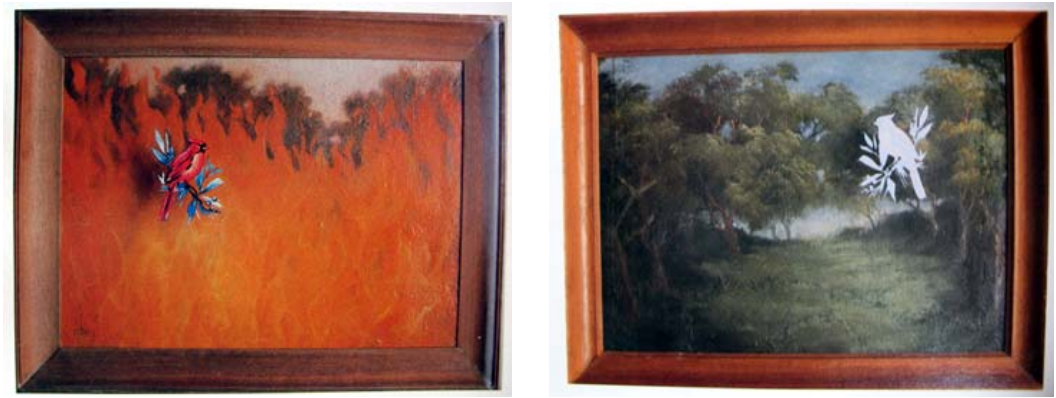

Francis Alÿs, Pájaros cruzados, 1992-1993.

La sugerencia es clara en un primer nivel, pero pensamos que más allá de la anécdota evidente de lo que puede hacer el hombre a nivel de destrucción, el artista cuestiona el valor y la manipulación de las imágenes. La imagen pintada, tanto del pájaro como de ambos ambientes, tiene implicaciones sociales que nos hablan de una forma de arte que también es inocentemente destructora, aquella que marca la ilusión de lo bello, el bello paisaje es la imagen que presenta la ausencia del pájaro, de la vida.

Tanto en ésta como en el resto de las obras, el acento está puesto en la pintura como espejo de ilusiones. El hecho de que todas ellas estén enmarcadas, nos parece una crítica al valor de lo institucional. En el resto de las piezas Alÿs recalca esta cuestión. En las obras que llevan por título Miss Amazonia y Miss Ecuador, la ironía se manifiesta en el hecho de que, en lugar de presentar paisajes idílicos, se representa el fuego que de nuevo ocupa la totalidad de la superficie del lienzo. Europa, otra de las piezas es, por el contrario, una idílica y exuberante selva. Paradigmáticamente Alÿs, acompaña la obra con la leyenda "Ecología: estudio del medio ambiente en el cual existen seres vivos y de las relaciones de esos seres con el medio ambiente". Parece que el artista sugiriera que precisamente aquellos que se preocupan por la ecología son los mismos que con sus economías perjudican aquello que quisieran preservar.

En el contexto peculiar del arte mexicano, Teresa del Conde cuestiona y pone en duda si hacer arte con el tema de la ecología como pretexto es válido, coherente y honesto tanto en lo que se refiere al propio arte y su relación con el ámbito comercial y privado, como en relación al hecho de poder cambiar con ello algún aspecto de la sociedad. Está de acuerdo con el artista Pablo Vargas Lugo acerca de la peligrosidad que pueden representar "las pseudomísticas que se han enganchado a la ecología para enarbolarla como una nueva moral", puesto que es cierto que la pseudomística puede llegar a redundar en actitudes fetichistas 
de "culto a lo verde, dañinas para la vida animal y sobre todo para la vida humana"218. Del Conde coincide con el artista, con Cuauhtémoc Medina y Roberto Tejada quienes apuntan las consecuencias del diluvio de buenas intenciones que esto puede llegar a generar.

Por su parte Cuauhtémoc Medina concreta que no se puede juzgar esta exposición como un señalamiento inequívoco y contundente de la situación, sino tan sólo como un síntoma de la incomodidad de la sociedad en México a finales del s. XX, acerca de las tensiones y peligros ante el vínculo existente entre civilización y Naturaleza. Puntualiza las reacciones irreconciliables, el carácter confuso y la falta de consenso respecto a términos como ecología, economía, civilización, política y el mismo con el que denominamos a la Naturaleza. Esta exposición es "una tentativa -contradictoria y difícil- que, saliendo al paso, articula la angustia que se ha apoderado de una sociedad y un tiempo cultural"219.

Medina, argumentando en favor de la temática ecológica como "algo más que un saber científico", señala que anteriormente otros artistas han trabajado de manera muy directa al respecto, entre ellos podemos citar a Eugenia Vargas Daniels, Jan Hendrix y Carlos Aguirre y, de forma implícita Marcos Kurticz, Jimmy Durham, Michael Tracy, Juan Francisco Elso, Gabriel Macotela, Magali Lara, Eloy Tarsicio, Miguel Ventura, Felipe Ehrenberg y Miguel Castro Leñero, entre otros. Sin embargo, para Medina, la exposición Lesa Natura es pertinente puesto que establece un estado de la cuestión, sienta unos parámetros críticos para el diálogo y propicia la participación social.

Así el crítico, parafraseando a Joseph Beuys como ejemplo y referencia más contundente de acción artística en el terreno de las relaciones políticas entre hombre y Naturaleza, recuerda la acción de Beuys en 1982, de plantar 7.000 robles en la Documenta de Kassel. Medina señala que en aquella ocasión Beuys pretendía que aquellos árboles sentaran nuevos lineamientos estéticos y que su acción planteara la necesidad de sembrar un nuevo concepto económico en el centro del pensamiento humano. Sin embargo, su postura es crítica, para él la palabra ecología en esos momentos (los años noventa) era un arma de doble filo, "un traje más de los intereses económicos y geopolíticos"220. En la actualidad y en el transcurso de la última década, las circunstancias han cambiado drásticamente, generalizándose un alza exponencial de los problemas que en aquellos momentos se vislumbraban. El cambio climático entre otros problemas, convierte la amenaza de la habitabilidad del ser humano en el planeta en un colapso inminente. Jorge Riechmann ${ }^{221}$ nos previene de que más

\footnotetext{
218 DEL CONDE, Teresa, “¿Ecología? ...”, op. cit., p. 10.

219 MEDINA, Cuauhtémoc y TEJADA, Roberto, "Lesa Natura”, en AA. VV., Lesa Natura,..., op. cit., p.13.

220 MEDINA, Cuauhtémoc y TEJADA, Roberto, "Lesa Natura", op. cit., p. 14.

221 Jorge Riechmann, poeta español nacido en Madrid en 1962. Licenciado en Ciencias Matemáticas, con estudios de Filosofía, Literatura alemana y doctorado en Ciencias Políticas. Es profesor de filosofía moral en la Universitat de Barcelona desde 1995. Desde
} 
allá de la era de la crisis ecológica global, estamos ante la era de la "crisis de la civilización"222. Para contrarrestar el afán materialista que los afanes de Medina auguran frente a la indefinición del problema, nos apoyamos en Riechmann quien define un cuarto sentido de Naturaleza más allá de los tres planteados por Savater en su diccionario filosófico ${ }^{223}$. Con los conceptos de biosfera224 y ecosistema225 Riechmann nos conduce a percibir la Naturaleza como un sistema estructurado de forma compleja en el cual la distinción entre natural y artificial no es una mera entelequia cultural y en la que dirimir estas diferencias es fundamental para la vida misma. El no considerar diferencia entre ambos conceptos, puede llevarnos a confundir biosfera con tecnoesfera (la Ciencia con la cual el hombre va conformando el mundo adaptándolo a sus necesidades y apetitos) y esta confusión, en la que el hombre comienza a adaptar la Naturaleza natural a esa tecnosfera, puede conducirnos al fin de la Naturaleza como hasta aquí la hemos conocido. Sería absurdo por nuestra parte el pretender que el papel del arte o del artista, inmerso en el devenir de la historia y de la sociedad fuera el de retrotraer este proceso, pero también lo sería el subestimar la función reflexiva, de conocimiento y de testimonio que en su origen y en el transcurso de la historia ha desempeñado, dejándole tan sólo el lugar de la ironía y el escepticismo.

Volviendo a la exposición, encontramos Mapa de climas de Pablo Vargas Lugo (México, D.F., 1968), un mapa situado en el piso hecho de linóleo y colocado a manera de un confuso ajedrez. El artista genera la ilusión óptica de un territorio con fronteras activadas que delimitan categorías geoclimáticas: tumdra, selba tropical, etc., mediante letreros de aluminio ortográficamente mal escritos. Como alegoría de lo vegetal, el artista sitúa pequeñas montañitas de gel dentífrico verde a manera de detritus. Con esta leve nota de color, Vargas Lugo hace hincapié en la parafernalia de las simbologías vegetales usadas como discursos higienizados en torno a una retórica sobre la Naturaleza. Observamos la utilización de una forma en particular (montaña) y del color verde para

1996 forma parte del Departamento Confederal de Medio Ambiente de CC.OO., donde es responsable de biotecnologías y agroalimentación.

222 RIECHMANN, Jorge, "La industria de las manos y la nueva naturaleza. Sobre naturaleza y artificio en la era de la crisis ecológica global", en DURÁN, A. y RIECHMANN, J., Genes en el laboratorio y en la fábrica, Trotta, Fundación $1^{\circ}$ de mayo, Madrid, 1998, p. 204.

223 SAVATER, Fernando, "Naturaleza", op. cit., p. 256.

224 Biosfera, es un término anticipado por el químico Jean-Baptiste Lamark o el geógrafo Eduard Suess y acuñado definitivamente por el geólogo ruso Vladimir Varnadsky, en su libro homólogo La biosfera (1926). Etimológicamente, se entiende por concepto de Biosfera o esfera de la vida, al sistema complejamente estructurado de los ecosistemas, el total de la biomasa o material vivo de la Tierra. RIECHMANN, Jorge, "La industria de las manos...", en DURÁN, A. y RIECHMANN, J., op. cit., pp. 204-205.

225 Concepto de ecosistema: término utilizado por el biólogo británico Arthur Tansley (1935), para definir al conjunto de poblaciones de seres vivos, junto con los factores no vivos asociados a estas poblaciones, RIECHMANN, Jorge, "La industria de las manos...", en DURÁN, A. y RIECHMANN, J., op. cit., p. 204. 
establecer una relación entre los discursos ecológicos y lo que usamos para limpiar nuestra boca: la pasta de dientes.

La retórica sobre la naturaleza que Vargas-Lugo explora tiene la calidad del aliento con sabor a menta. Es un discurso higienizado y perfumado [...]. El artista describe las expresiones de la buena intención ecologizante como un habla tramposa y reconfortante, como una exhalación de pretendida salud interior. Desnuda un discurso como mera estrategia ornamental, como autosatisfacción 226 .

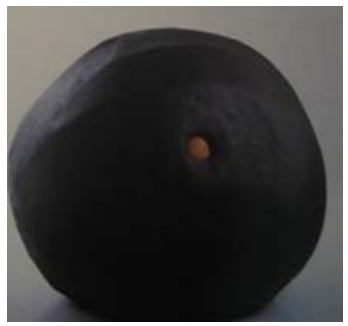

Gabriel Orozco, Naranja sin espacio, 1993.

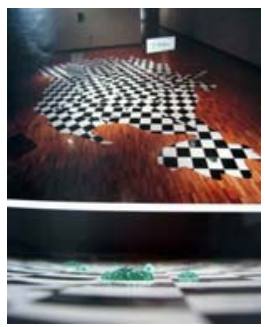

Pablo Vargas Lugo, Mapa de climas, 1993.

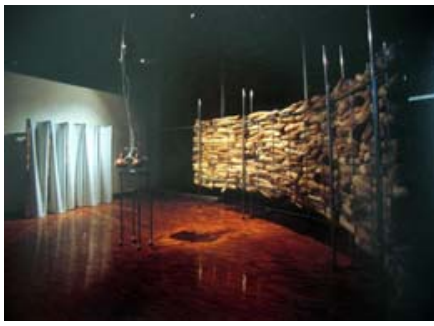

Thomas Glassford, Paisaje interno, 1993.

Para nosotros, lo interesante en este caso es la posibilidad de construir el referente vegetal partiendo de una forma ajena a las estructuras del reino vegetal usando la simbología del color. Sin embargo, para Medina las relaciones establecidas por el artista se corresponden con la lectura de que el peor peligro que corren los artistas al abordar temas como el de la ecología, es enmascarar el discurso de los políticos:

Dar lugar a obras propicias a estetizar la angustia ecológica, que también den la apariencia de una actividad bien intencionada pero que no tiene un propósito más allá de sumar una voz más al concierto de la buenas intenciones227.

Por otra parte, la obra de Gabriel Orozco (Xalapa, 1962) es un fruto, una naranja que está envuelta en una bola inmensa de plastilina que a su vez, casi la devora. Medina señala que esta pieza está enclavada en los procesos (la naranja sufre un proceso de putrefacción) y en la intención de negar el congelamiento de la obra terminada en el contexto de esta exposición, convirtiéndose en una metáfora de la mercancía moderna.

En la obra de Thomas Glassford (Laredo, 1963) encontramos una Naturaleza que fluye nítidamente entre lo humano y la tierra a través de una metáfora vegetal. En sus piezas la utilización de este elemento aparece tanto en forma de materia como de referente para establecer una analogía entre ambas entidades (tierra y ser humano). Los pulmones son los que se encargan de la respiración en el

\footnotetext{
226 MEDINA, Cuauhtémoc y TEJADA, Roberto, "Lesa Natura”, op. cit., p. 52.
}

227 MEDINA, Cuauhtémoc y TEJADA, Roberto, "Lesa Natura", op. cit., p. 52. 
hombre y el artista en esta obra, reconstruye unos pulmones a manera de prótesis biónica, con guajes 228 intervenidos (como en otros trabajos del artista). Esta construcción, junto con otra estructura pseudo alveolar realizada con zacates $^{229}$, es utilizada para revisar el concepto de lo natural.

Aquí, el museo se configura como un medio artificial, una especie de hospital de cuidados intensivos, un ambiente esterilizado política y socialmente que permite plantear la sanación de las relaciones entre ambos conceptos a través de la liturgia purificadora del arte. Esta sala de intervenciones nos remite a su vez al Bosque de Chapultepec, considerado en México, D.F., como uno de los pulmones de la misma.

Su Pulmón, construido con su lenguaje ya conocido de aprisionar guajes en mecanismos de flejes, tornillos u tubos de plástico [...]. Un biombo de "camillas" portátiles; un muro de estropajos manchados que recuerdan la masa esponjosa de los alvéolos pulmonares230.

El acento de la exposición está puesto en cómo la crisis ecológica acapara los medios de comunicación masiva y del vértigo que esto produce.

Para algunos de los artistas en esta exposición, se trata entonces de reconstruir, resignificar o criticar la verosimilitud de lo sublime como el legítimo interlocutor de su obra231.

Otros artistas como los del colectivo La Quiñonera (Claudia Fernández, Francisco "Taca" Fernández, Diego Toledo y los hermanos Néstor y Héctor Quiñones nacidos entre 1964 y 1967) plantean el diálogo entre Ciencia, experiencia, mística, Naturaleza y Cultura desde la realidad encontrada de su medio habitual, la ciudad como el cúmulo de los desechos con los que convivimos en una Naturaleza reinventada del residuo cotidiano.

[...] los artistas buscan revelar al público la imposibilidad de concebir a la naturaleza desnuda y desprovista de coordenadas culturales, o al margen de consideraciones morales o estéticas. Por tanto dejan abierta la puerta a las interpretaciones encontradas: la naturaleza como espejo del yo, como tierra prometida y mancillada, como instrumento, como mecanismo, como casa de la divinidad, como organismo de los organismos (Gaia), como mero artefacto cultural232.

\footnotetext{
228 Guaje: del náhuatl uaxin. En México se conoce por este nombre a la calabaza, planta de la familia de las Cucurbitáceas, de grandes frutos y flores amarillas.

229 Zacate: del náhuatl zacatl: En México, esponja vegetal natural extraída del esqueleto de un cactus, estropajo para fregar.

230 MEDINA, Cuauhtémoc y TEJADA, Roberto, "Lesa Natura", op. cit., p. 51.

231 MEDINA, Cuauhtémoc y TEJADA, Roberto, "Lesa Natura", op. cit., p. 15.

232 MEDINA, Cuauhtémoc y TEJADA, Roberto, "Lesa Natura", op. cit., p. 48.
} 
Por otra parte, la obra de Kiyoto Ota (Nagasaki, 1948) utilizando el material natural de la madera aspira a una reconciliación con la intuición a través de la textura y el tacto recuperando así otras formas de conocimiento. Germán Venegas, quien rehuyó recoger ninguna idea de carácter ecológico, plasma en su quehacer de escultor y a través de su obra realizada in situ, un momento de la historia cultural de los antiguos mexicanos en el que el artista percibía un mayor equilibrio entre el individuo y su universo material y espiritual.

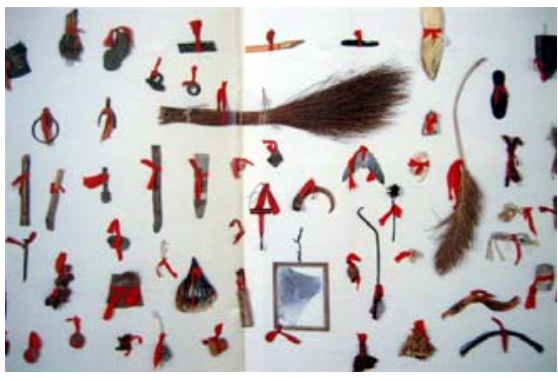

Silvia Gruner, Natura-Cultura, 1993.

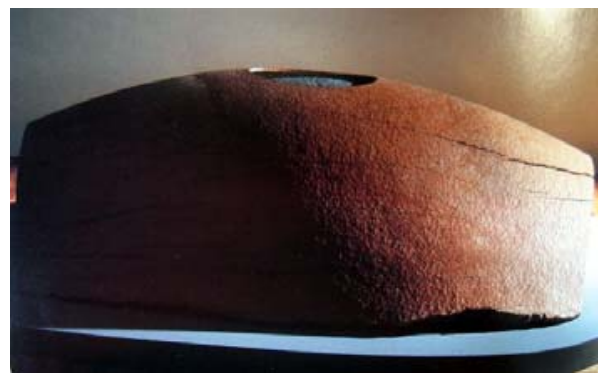

Kiyoto Ota, Océano primitivo, 1993.

Por último, de entre las obras de los artistas que hemos considerado pertinente comentar, mencionaremos la pieza Natura-Cultura (1993) de Silvia Gruner (México, D.F., 1959) quien presentó, a manera de nuevo altar de culto, una instalación de objetos encontrados, incorporando algunos elementos vegetales en una disposición taxonómica basada en la similitud de sus formas. Independientemente del origen de estos objetos, la intención de la artista pone en evidencia la fragilidad de los mismos sistemas de clasificación.

[...] a la manera de una arqueología de residuos culturales. En esta obra, creo un discurso de interrelación y de ambigüedad entre las categorías "naturales" y "culturales" que acompañan a dichos objetos, la mayoría de ellos, fragmentos arrancados de un contexto al que ya no pertenecen. Esta obra se ubica en el lugar donde las categorías se borran, se ridiculizan y mitifican. El valor de los objetos se reinstala y se equilibra a través de su presencia física y su ordenamiento artístico mágico. No son ni su lugar de origen ni su funcionalidad los que justifican su lugar. La arbitrariedad del lenguaje y la del trapito rojo son la misma cosa233.

A través de los textos que reseñan esta exposición parece leerse que es mayor el temor a caer en una discursiva estética que utilice la ecología como medio que, todos aquellos problemas que puedan derivarse de no hacerlo. Consideramos que en gran parte, la postura excesivamente crítica de los curadores propició el hecho de no contemplar como consistentes la mayoría de las propuestas que en tiempos posteriores se fueron dando al respecto.

233 GRUNER, Silvia, "Cédula informativa de la obra", en AA. VV., Lesa Natura,.., op. cit., p. 40. 
Dado que el objetivo fundamental en esta investigación es presentar un panorama de las estrategias utilizadas por artistas que han abordado el tema de Arte y Naturaleza a través de la perspectiva del elemento vegetal con recursos tridimensionales, no debemos pasar por alto una de las revisiones más importantes realizadas en el contexto mexicano con respecto a la disciplina de la escultura.

\section{Escultura Mexicana del Siglo XX: De la Academia a la Instalación (2001).}

Esta exposición, planteada en tres períodos sucesivos a lo largo de todo un año entre el 2000 y el 2001, se realizó en el Museo del Palacio de Bellas Artes. En el imaginario colectivo del mundo del arte y la sociedad en México, ostenta un gran reconocimiento. Con motivo de la misma, se llevó a cabo una muy necesaria revisión de la escultura en México durante el S. XX. La primera parte, titulada De la academia al objeto ofreció por primera vez un recorrido compartido por los escenarios de la escultura desde la última década del siglo XIX, hasta los años cuarenta con una visión lineal y cronológica de artistas y producciones que desde una perspectiva conceptual colocaba la escultura en el contexto de los intereses de la época.

La segunda, bajo el nombre De la ruptura al geometrismo, presentaba el desarrollo de la disciplina entre los años 1950 a 1970 incluyendo desde el movimiento de la Ruptura, a la corriente de la Geometría y la del Arte-Objeto. En la última y tercera parte con el título Nuevas Tendencias, se pudo observar el cambio producido en el concepto de escultura en los últimos años en México, desde los años ochenta hasta la actualidad. La exposición contó con la participación de cincuenta y ocho artistas entre los que se encontraban Perla Krauze, Manuel Marín, Francisco Toledo, Pablo Vargas Lugo, Germán Venegas, Reynaldo Velázquez Zebadúa, Paloma Torres, Laura Anderson Barbata, Carlos Aguirre, Francis Alÿs, Eduardo Abaroa e Inmaculada Abarca.

Dos son los textos que en el catálogo de esta exposición resumen el criterio de los curadores para seleccionar las obras. Itzel Vargas 234 realiza un recorrido histórico-artístico desde los movimientos políticos de la década de los sesenta y la repercusión que éstos tuvieron en México, en particular la matanza de Tlatelolco, entre la comunidad artística. Estos hechos marcaron el giro que el arte tomó en aquellos momentos. El descontento generalizado ante los acontecimientos propició que los artistas se organizaran de manera independiente, creando nuevos espacios alternativos donde expresar su malestar.

Los tres Salones Independientes que se llevaron a cabo en esos años sentaron un precedente en la utilización de medios experimentales, materiales alternativos y formas heterodoxas de producción y de trabajo en común. Esta situación favoreció un proceso de transición desde las tradicionales formas de concebir la disciplina de la escultura a las nuevas formas de expresión. Todo

234 VARGAS, Itzel, “Disertaciones...”, op. cit., p. 339. 
ello, en detrimento del arte objetual y hacia un progresivo desarrollo de la instalación ambiental y conceptual. La idea era sacar el arte a la calle que conectara más con el público, ampliar el sistema artístico que estaba muy limitado a los espacios oficiales de exhibición y al reducido y, por lo tanto cerrado circuito de galerías de arte. Entre este tipo de grupos organizados después del último Salón Independiente (1970) se encontraban Suma, Proceso Pentágono, Tepito Arte Acá, Marco, Taller de Arte e Ideología, Peyote y la Compañía, Taller de Investigación Plástica, No grupo, Arte Otro, Taco de la perra brava y Germinal. La mayoría de estos grupos desaparecieron en los ochenta, tiempos en los cuales una nueva generación de artistas tomaba el relevo, explorando nuevos discursos visuales de manera individual, con lenguajes heterogéneos más contemporáneos. Algunos de ellos eventualmente formaron colectivos como La Quiñonera, el Salón des Aztèques, Temístocles 44 o Zona en búsqueda de espacios alternativos donde exponer o vender sus obras y generando interesantes experiencias como La Toma del Balmori (Primer museo al aire libre, 1990). En opinión de Jorge Alberto Manrique, esta generación estuvo marcada por la recuperación de la imagen y del objeto artístico:

Después de la desconfianza y el desprecio de los grupos hacia el objeto, se le concede a éste un valor propio y un derecho a la existencia. Pero puede decirse que se trata, ahora, de un objeto "herido", en el que han quedado las huellas del trauma de los años setenta y su desprecio a la obra de arte235.

Manrique apunta que en cuestión de escultura todavía se importan y se asimilan estrategias formales y modelos conceptuales de otros lugares, procesos de creación que en México se transforman, ofreciendo resultados aparentemente imaginativos, inteligentes e incluso a veces autocríticos, situación que debería cambiar.

En 1988, en La Quiñonera, se realiza una exposición llamada Escultura viva, plantas, seres, agua. Esta iniciativa reúne a los artistas Héctor Alvarado, Benjamín, Lourdes Cué, Helen Escobedo, Martha Hellion, Arturo Hernández, Enrique Hernández, Juan Hernández, Illy, Francisco Moyao, Newton, Sindicato del Terror, Siro y Rubén Valencia. De este antecedente pocos documentos hemos encontrado, sin embargo en la exposición realizada en el Palacio de Bellas Artes participaban artistas como Sofía Táboas, Betsabée Romero, Yolanda Paulsen, Inmaculada Abarca, Francis Alÿs y Thomas Glassford que utilizaban materiales que tenían relación con algún aspecto de lo vegetal.

Así por ejemplo, la pieza de Francis Alÿs seleccionada para esta exposición fue una de las primeras que realizó en México, una muestra de la recuperación del valor intrínseco de los materiales unida a un tipo particular de construcción narrativa. Sobre una rudimentaria mesa metálica se reconstruye una ficción de la cotidianeidad mediante un interesante juego visual que remite por una parte, al vacío, la soledad y al absurdo del estado del bienestar contemporáneo y por

235 MANRIQUE, Jorge Alberto, Una visión de arte y la historia, Tomo IV, UNAM, Instituto de Investigaciones Estéticas, México, D.F., 2001, p. 190. 
otra, a la más fina tradición pictórica europea sobre la ilusión. Una simple maqueta de una casa en cuyo interior un individuo ve la televisión. A simple vista, el interior de la casa en donde se encuentra el sujeto no es visible al espectador pero a manera de bucle, el artista nos convierte en parte de la obra, como en Las Meninas de Velázquez o en el retrato del Matrimonio Arnolfini de Jan Van Eyck. El exterior es una planta viva, un elemento de ornato con lo que la realidad pasa a formar parte de la ficción.

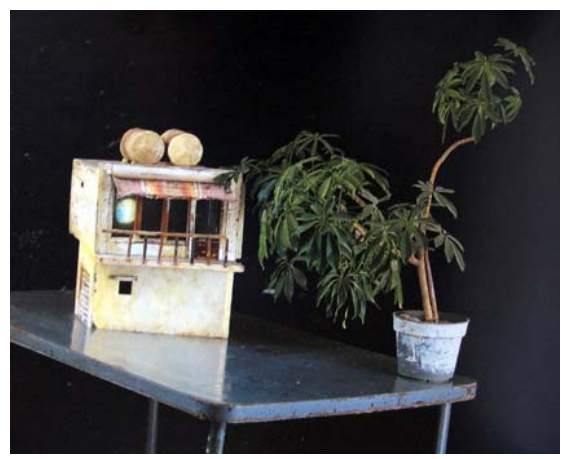

Francis Alÿs, Sin título, 1994.

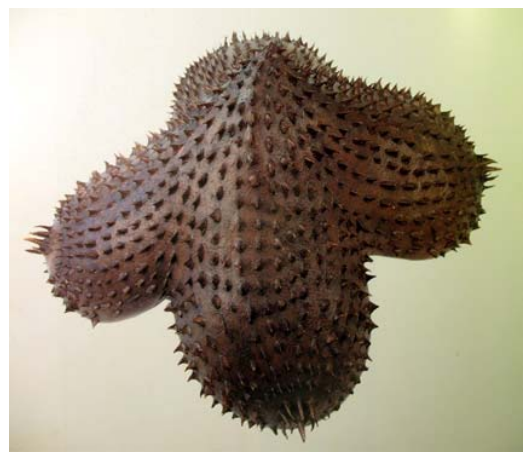

Inmaculada abarca, Fruto, 1998.

Con la escultura Fruto (1998) de Inmaculada Abarca la relación entre lo vegetal y lo humano se establece a través de una confluencia de procesos. La artista toma un molde de una parte de su propio cuerpo (senos) y realiza una pieza de cera sobre la que coloca espinas de rosas previamente recolectadas en numerosas sesiones. Finalmente el conjunto de cera con incrustaciones de espinas es fundido en bronce. El sentido de la protección que este elemento natural otorga a la flor-rosa se trasfiere a la forma humana que ya no son dos senos, sino cuatro conformando así una especie de fruto que aparenta ser posible. Tenemos una pieza que atrae a la mirada y al tacto como generalmente sucede con la escultura, sin embargo nos enfrentamos a una escultura que más que protegerse, se defiende y a pesar de la sugerente sensualidad, no se deja tocar. La metáfora establece una metamorfosis de las cualidades matéricas para entablar un diálogo entre dos tipos de naturalezas generando una conexión íntima entre ambas.

Por su parte Eloy Tarsicio utiliza una planta especialmente representativa de México el maguey236. El artista presenta las pencas u hojas de la planta, cortadas y amarradas con una cuerda llamada henequén. Sobre ellas vibran salpicaduras de chapopote y pintura acrílica de color rosa mexicano. En sentido simbólico, la

236 Maguey: nombre común de la planta originaria de México y perteneciente a la familia de los Agavecea o Agaves. Desde los tiempos prehispánicos, esta planta tiene múltiples usos, de ella se extrae el tequila, considerado bebida nacional de México. Sus pencas son utilizadas para techar casas, construir cercas; de las fibras de las hojas se extraen hilaturas para confeccionar cuerdas o henequén, etc. 
pieza nos habla de represión y violencia contenidas. De nuevo se trata de sentimientos y sensaciones humanas proyectadas sobre una materia a la que le son ajenas tales percepciones. Por contagio y extensión la planta junto con el color que se le aplica, trasmite un sentimiento de nacionalismo patrio.

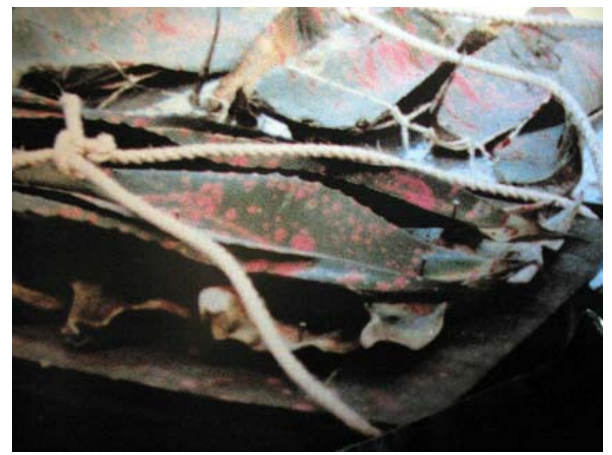

Eloy Tarsicio,

Vista de Sahagún, 1984-2000.

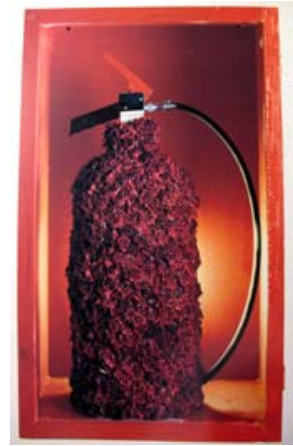

Betsabée Romero, Extinguidor, 1996.

En la obra Extinguidor (1993) de Betsabée Romero - pieza realizada con madera, alambre y rosas secas- la artista utiliza flores en lugar de las espinas, para convertir un objeto cotidiano en los edificios públicos, en una especie de bouquet. El objeto, recubierto de rosas asemeja un corazón, transformándose de extinguidor de fuego, en extinguidor de pasiones. Las poéticas de estos artistas están vinculadas al tipo de estética contemporánea que establece una reflexión entre hombre y Naturaleza si bien, cada una de ellas parte de diferentes premisas.

Por su parte, la artista Yolanda Gutiérrez lo hace desde la puesta en escena de una cosmogonía prehispánica vigente, un diálogo con la divinidad entendido como parte cotidiana de la vida. En la obra Los frutos del árbol de corazones (2000), pieza realizada con una rama de árbol, hojas de papalocahuite ${ }^{237}$ y espirales de caracol, arte y vida se entremezclan a partir de elementos naturales con lo que la artista consigue reanimar el espíritu ancestral que los convoca. En general se trata de obras como las de Yolanda Gutiérrez, Yolanda Paulsen, Thomas Glassford o Sofía Táboas en las que la fragilidad o lo efímero se contagian de lo cotidiano.

La pieza de Thomas Glassford presentaba un guaje o calabaza junto a una bata de carpintero ambos amarrados en el sillín de una bicicleta. El artista hace una apología de la ligereza transportando estos elementos en uno de sus viajes a manera de invitación a vivir la vida con menos problemas.

237 Papalocahuite: nombre náhuatl del comúnmente conocido como árbol del amor por la forma de sus hojas y el color de sus flores. El Cercis siliquastrum es una especie arbórea de la familia de las leguminosas. 


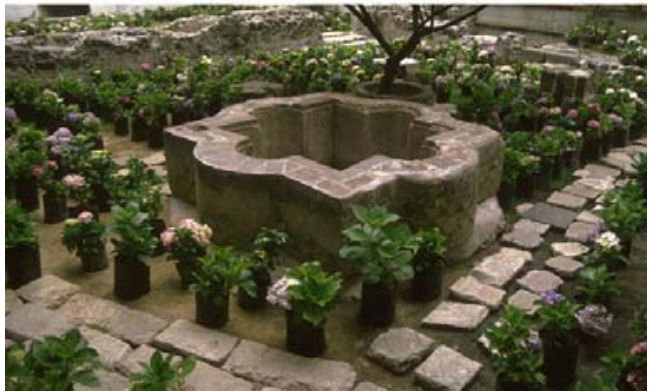

Sofía Táboas,

Jardín portátil, 2000.

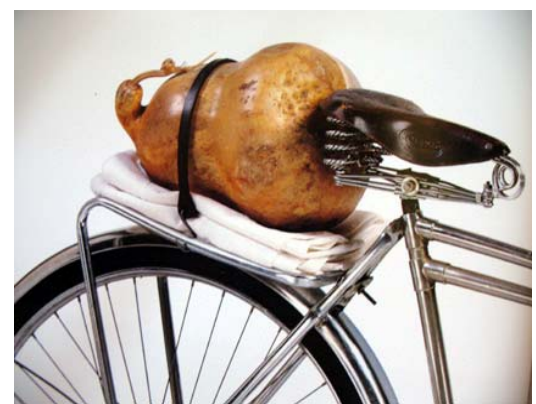

Thomas Glassford,

Invitation to portage, 1991.

Sofía Táboas coloca un jardín portátil hecho de madera, hule y plantas que se disponen en macetas de plástico en medio de la sala del Palacio de Bellas Artes. Lo natural y lo artificial dialogan en su pieza recontextualizando espacialmente las propiedades intrínsecas de las plantas convertidas ahora en arte, como tiempo atrás hiciera Duchamp con su urinario. Con esta pieza se introduce en el museo lo procesual, un ser vivo que se transforma, que necesita de lo humano para sobrevivir.

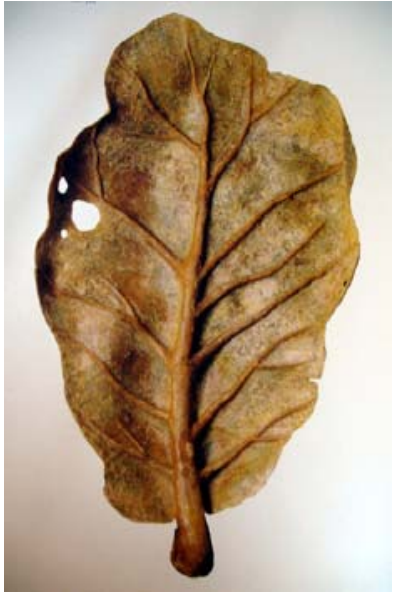

Yolanda Paulsen,

Hojas de encino, 1999.

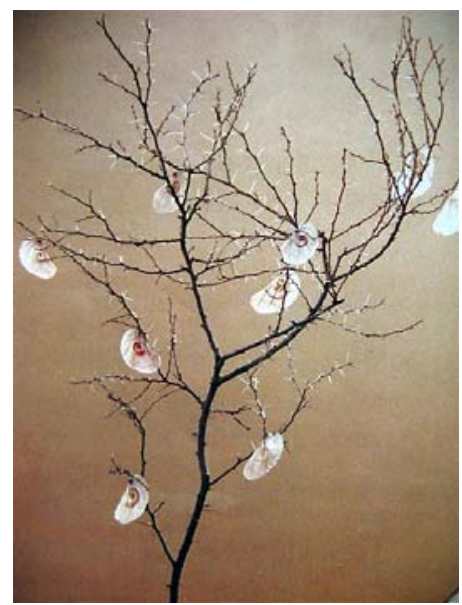

Yolanda Gutiérrez, Los frutos del árbol de corazones, 2000.

Yolanda Paulsen trabaja con la dimensión y los gradientes de tamaño haciendo aflorar la grandeza de lo pequeño en sus series de hojas hechas de resina y cera, colocadas sobre el suelo. En un mundo que contempla las sensaciones, su mirada va del interior al exterior. Como vemos, en todas estas piezas en las que se utilizan plantas sea como material o como referente formal o conceptual, se produce una puesta en escena en la que, independientemente de la intención final de cada artista se genera una dialéctica imprescindible entre Arte y Naturaleza, proyecciones de la naturaleza humana y usos apócrifos de la realidad. 


\section{Alter Natura (2004).}

Con motivo del primer aniversario del Museo Federico Silva (2004) en San Luis Potosí se realizó la exposición Alter Natura, montada al exterior del museo, en el Jardín de San Juan de Dios. Itzel Vargas, como curadora del Museo Rufino Tamayo fue la que hizo la selección de los escultores participantes. Si bien, esta exposición no representa una tendencia dominante, manifiesta una vez más la persistencia del vínculo y la necesidad que manifiestan los artistas por los conceptos que redefinen tanto su propia naturaleza como la Naturaleza que les rodea. El conjunto de obras iba desde la abstracción hasta la figuración en relación directa con la Naturaleza.

El punto de convergencia entre ellas tiene que ver con una herencia prehispánica y con la alteración/asimilación de la naturaleza como sistema de vida. Este grupo de obras tan heterogéneo plantea asociaciones al parecer arbitrarias pero fundamentalmente familiares en la búsqueda por el entendimiento del ser humano dentro del orden del Universo. La apropiación de elementos naturales para ser sustituidos por lo artificial es una de las facetas más interesantes de estas piezas. Pareciera que la naturaleza como referencia es intrínseca al móvil creativo de este conjunto. Ya sea desde las reminiscencias del geometrismo, del gesto emotivo estilizante o del impulso lúdico, el mundo natural no sólo es recreado sino alterado y transformado en un subsistema natural de reintegración al cosmos 238 .

Por otra parte la curadora, expresa que en esta exposición, la selección de materiales que van desde el bronce hasta el plástico inflable, pretende dar cuenta de la expansión en cuanto a las posibilidades espaciales, temáticas y técnicas que la escultura como disciplina ha desarrollado en los últimos años. Los escultores en esta ocasión fueron Mathías Goeritz, Fernando González Gortázar, Marina Lascaris, Jesús Mayagoitia, Yolanda Gutiérrez, Paul Nevin, Ricardo Ragazzoni, Jeannette Betancourt, Yvonne Domenge, Yolanda Paulsen, Perla Krauze, Gilberto Esparza, Ernesto Hume, Jorge Yázpick, Antonio Nava Tirado e Inmaculada Abarca239. Esta exposición supuso una afirmación frente a la inexistente dialéctica oficial en torno al binomio Arte y Naturaleza. Desde esta perspectiva se valoró la relación individual que cada escultor tuviera en torno a la temática. Ciertas piezas tenían una mayor relación con lo natural, aunque las múltiples diferencias entre épocas y artistas que se reunieron para esta ocasión muestran bajo nuestro punto de vista, un carácter confuso.

238 VARGAS, Itzel, Véase material de divulgación, Texto de presentación de la exposición: Alter Natura, en San Luis Potosí, septiembre, 2004.

239 Véase "El Museo Federico Silva le ha dado un nuevo rostro a San Luis Potosí", en El sonido 13, Portal digital de propuesta informativa en arte de San Luis Potosí, Disponible en red: <http://www.elsonido13.com/detalle-noticia.asp?id=14>, [Consulta 15, febrero, 2008]. 


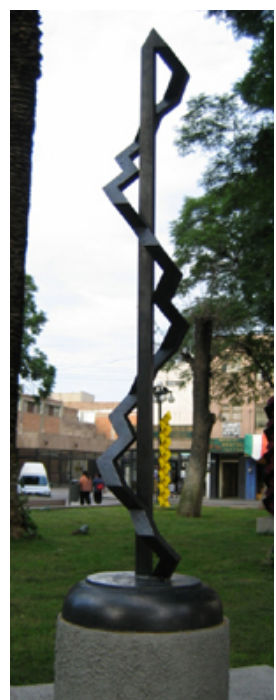

Ricardo Regazzoni,

Dispareja, 2004.

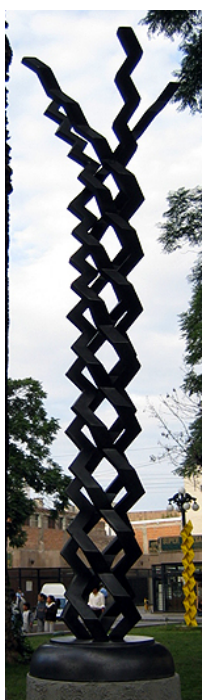

(1)

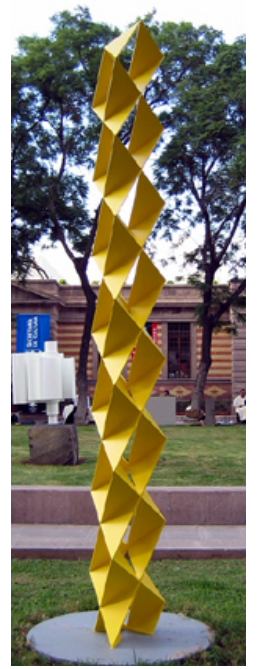

Jesús Mayagoitia, El arlequín, 2004.

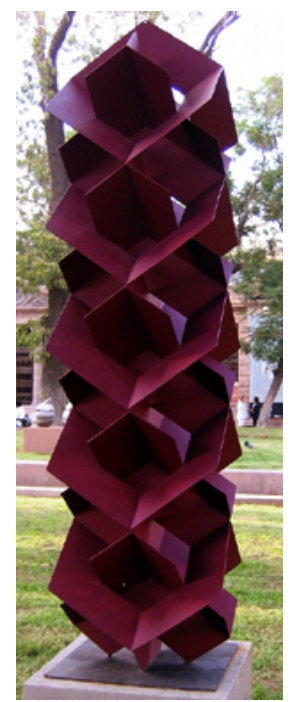

Ernesto Hume, Espiga

dodecarrombiédrica, 2004.

Por un lado, encontramos una tendencia geometrista que deriva de los planteamientos de los años setenta: Jesús Mayagoitia, Ricardo Ragazzoni, Ernesto Hume y la misma obra de Mathías Goeritz. Todas estas piezas presentan estructuras geométricas que nos remiten a nociones cósmico-simbólicas que, organizadas en una composición totémica, desarrollan procesos modulares a partir de la segmentación de cuerpos geométricos. Estas piezas encuentran en los juegos geométricos la posibilidad de aludir a los esquemas que rigen las formaciones naturales, manifestando en particular una fascinación por el cosmos a partir de un equilibrio físico que tendría su paralelismo en el mundo emocional.

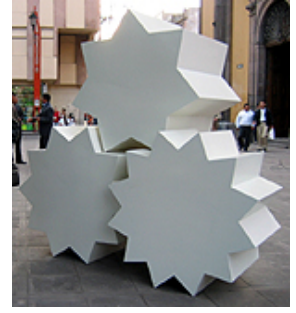

Mathías Goeritz, La vía Láctea, 1968.

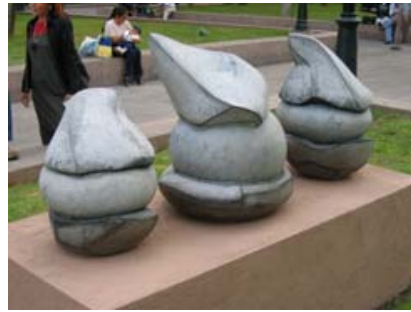

Marina Lascaris,

Rumorosa I, /I y III, 1999.

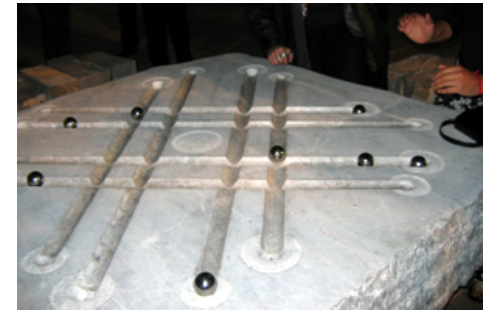

Antonio Nava,

Cosmos, 2004.

Algunas esculturas, como la de Marina Lascaris o Paul Nevin, establecen una conexión cercana con una naturaleza más orgánica. Sin embargo, ni unas ni otras escapan a la consideración de la escultura como un objeto cerrado en sí mismo, si bien hasta cierto punto transitable $\mathrm{y} / \mathrm{o}$ en relación con su entorno dadas las características mismas de la exposición que se emplazaba en un entorno público, al exterior del museo. 


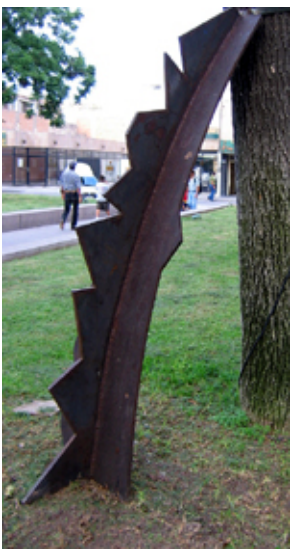

Paul Kevin,

Columna, 2003.

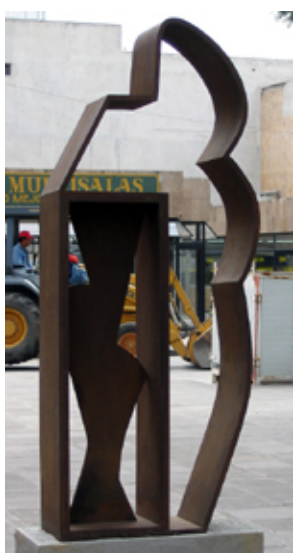

Paul Nevin, Escultura clásica, 2003.

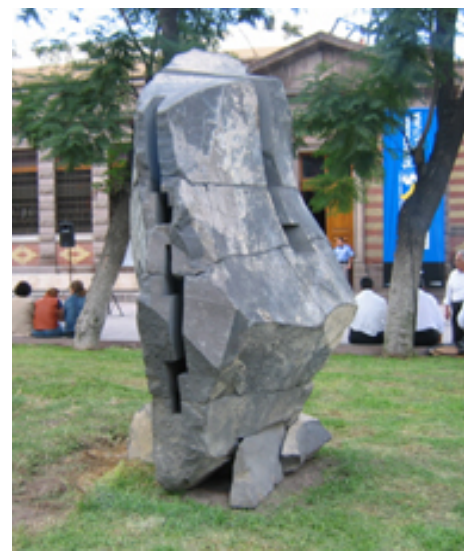

Jorge Yázpick,

Sin título, 2003.

La pieza de Jázpick, realizada en piedra, recupera una arquitectura antigua, construida con un cierto misticismo emparentado con los creadores de dólmenes, menhires y crómlechs. Aborda fundamentalmente la idea de la perdurabilidad de la piedra, anclada en la tierra, con la que construye desplazamientos volumétricos y espacios estratificados en los que siempre la salida hacia la luz se construye con un objetivo básico.

Por su parte Antonio Nava, quien directamente recurre en su obra a la rica tradición prehispánica, expuso un juego interactivo combinando la piedra con unas bolas de acero y propiciando la participación del espectador para generar los movimientos entrecruzados que aludían al tiempo mítico, al cosmos y a la tradición prehispánica.

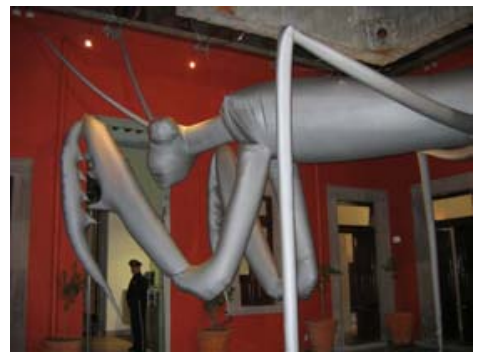

Gilberto Esparza, Mantis religiosa, 1999.

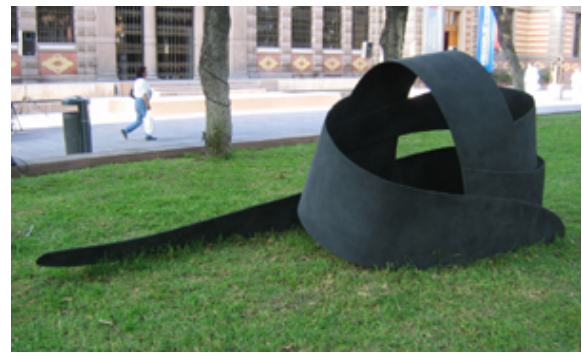

Jeannette Betancourt,

Túmulus, 2004.

Jeannette Betancourt elaboró una narración a partir de una forma abstracta con evocaciones orgánicas, conjugando con ello formas espaciales del macrocosmos/microcosmos e interrelacionándolas con los conceptos que definen nuestra interacción social. En una permanente experimentación matérica, la artista aborda ideas teológicas e históricas, explorando las formas rituales con las que éstas toman cuerpo. El reino animal también estuvo 
presente en esta exposición a través de la obra de Yolanda Paulsen y Gilberto Esparza. Paulsen tras la observación directa en sus estudios morfológicos con diferentes animales, presentó una obra en bronce que representaba a un sapo.

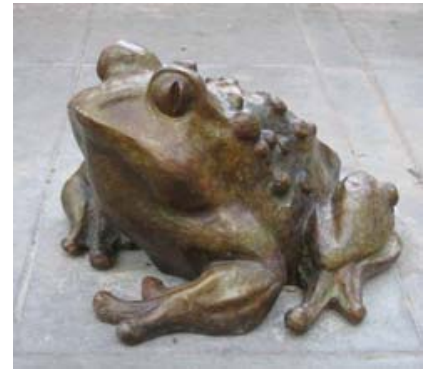

Yolanda Paulsen, Sapo, 1997.

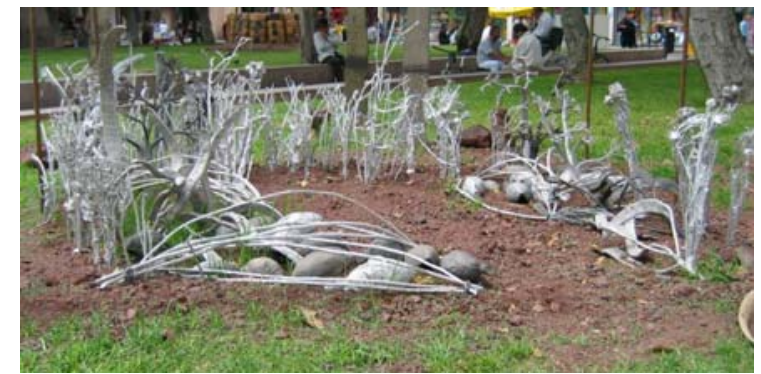

Perla Krauze, Paisaje artificial, 2004.

Gilberto Esparza, participaba con Mantis religiosa, pieza elaborada con polietileno termosellado, con la que el artista, proponía una intrusión orgánica en el espacio del museo, al invadir prácticamente todo el espacio del patio interior. El elemento animal descontextualizado por la distorsión de tamaño, funcionaba de manera invasora, desacralizando el espacio y pasando a formar parte del mismo. Por último, el elemento vegetal estuvo presente en la obra de otros artistas. Es el caso de Perla Krauze quien "siembra" un jardín de ramas y semillas fundidas en aluminio. Las piezas consiguen, pese a su elaboración artificial evocar un jardín real, tanto por la similitud de las formas de las esculturas como por el contexto en el que están situadas, en medio de un parque y sembradas sobre la tierra.

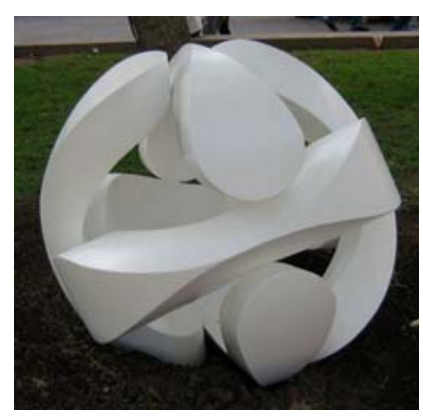

Ivonne Domenge, Flor de abril, 2004.

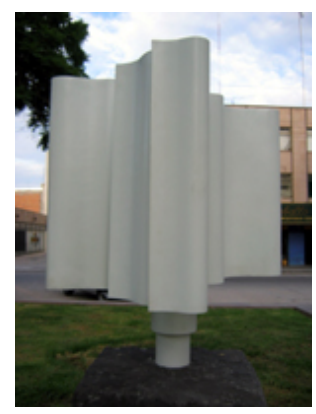

Fernando González Gortázar, Desconfines IV, 2001.

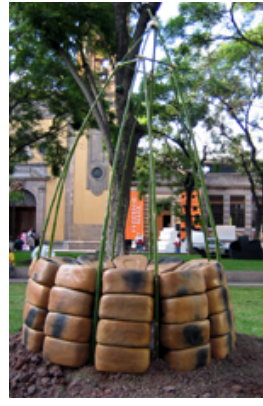

Yolanda Gutiérrez, 12 Mazorca, 2004.

Fernando González Gortázar a su vez, planta un árbol de acero pintado de blanco que crece desde su tronco, ofreciéndonos una serie de ondulantes superficies, extendidas al viento. Ivonne Domenge presenta una flor cerrada sobre sí misma que hace referencia a la simbología geométrica de la perfección de la esfera, insistiendo en conceptos que son capaces de transformar el nivel de la conciencia. 
Partiendo de la importancia del maíz y de su protagonismo tanto en la actual Cultura mexicana como en el mundo prehispánico, Yolanda Gutiérrez construye una mazorca cerámica cuyos granos se organizan en una construcción de hierro inconclusa, remitiendo al espectador a un pozo esencial al que habría que asomarse para recuperar la conciencia del alimento trascendental. Una escultura que propone la necesidad de las partes para conformar el todo. En esta obra, el acento está puesto en el gradiente de tamaño y la escala magnificada de los elementos empleados. Para finalizar la revisión de esta exposición, la obra de Inmaculada Abarca recontextualiza el elemento vegetal en dos piezas de bronce que se insertan en el contexto natural del parque, a manera de una heterotopía.

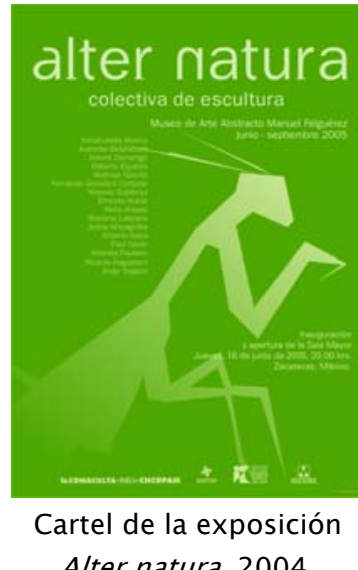

Alter natura, 2004.

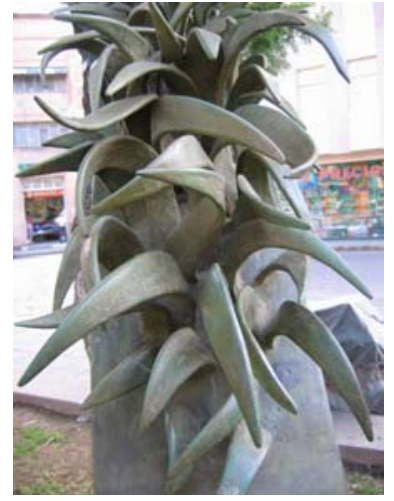

Inmaculada Abarca, Arco de pasto, 2001.

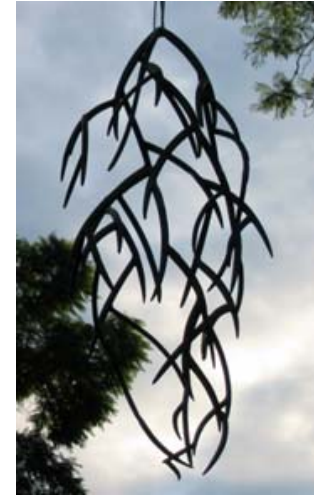

Inmaculada Abarca, Racimo, 2003.

En su propuesta, una de las piezas cuelga de un árbol como una metáfora de crecimiento y la otra se apoya en un árbol tratando de contaminarse de una naturalidad con la que no se busca la representación o la mímesis, sino la recreación de un proceso. Se trata de plantas que no remiten a ninguna especie en particular sino que buscan convertirse en la esencia de una forma de ser. Posteriormente, en junio del año 2005, la exposición se trasladó a Aguascalientes donde estuvo expuesta en el Museo Abstracto Manuel Felguérez, así como en el Instituto Cultural de Aguascalientes.

\section{El bosque de Naomi Siegmann (2005).}

En el mes de julio del año 2005, la escultora Naomi Siegmann realizó el proyecto de El Bosque/The Forest, convocando a diferentes escultores -que previamente habían trabajado con la idea de Naturaleza- a participar en una exposición colectiva con el propósito de reflexionar sobre el árbol como entidad representativa y valor fundamental de la misma. Así, además de participar con su propia obra, invitó a escultores como Helen Escobedo, Pedro Friedeberg, Yolanda Gutiérrez, Caroline Kaplowitz, Marina Lascaris, Robert Lobe, Bryan Nash Gill, Kiyoto Ota, Marta Palau, Beverly Pepper, Ricardo Regazzoni, Steve Tobin, Catherine Widgery y Jorge Yázpik a elaborar proyectos que, una vez realizados fueron expuestos tanto en México como en EE. UU. 
La compilación de obras constituía una intervención estética cercana al Arte Público. La exhibición configuraba un espacio heterogéneo en el cual -a través de un diálogo formal- se daban cita, la metáfora de la representación y el concepto de heterotopía. En la exposición, se podía apreciar árboles creados, expuestos en espacios urbanos que, a través del hecho de haberlos reunidos con una intención común, evocaban una red de relaciones y significados, construyendo lugares imposibles por los que circula el hombre contemporáneo. El planteamiento de esta exposición respondía al concepto de heterotopía, término acuñado por Foucault 240 en conferencia pronunciada en el Círculo de Estudios de Arquitectura (París, 14, marzo, 1967).

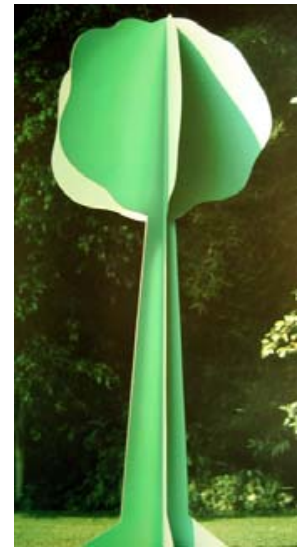

Naomi Siegmann, Suplente, 2004.

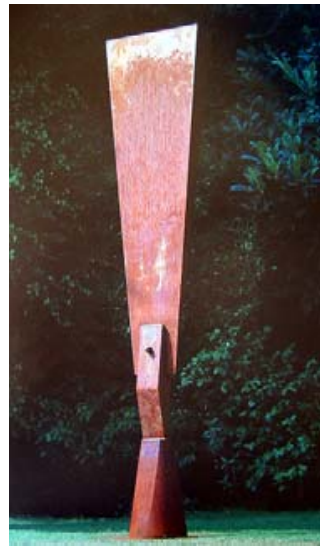

Beverly Pepper, Árbol cuña, 2004.

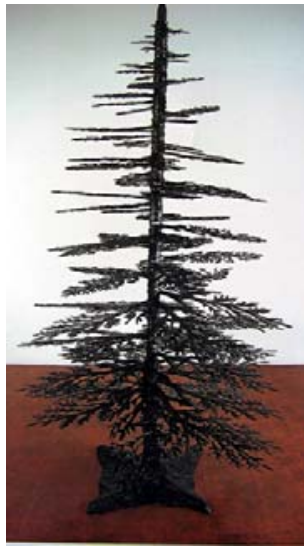

Marina Lascaris,

Aeternum, 2004.

Moviéndose entre los polos de lo compensatorio y la ilusión, la exposición retomaba la dosis de irrealidad, ficción y humor necesarios para construir una utopía posible. Una esperanza que convocaba a recuperar los espacios imaginados, aquellos lugares de la memoria que nos corresponden por vividos, aunque sea con la imaginación. Estamos en presencia de estructuras vegetales inmersas en el contexto de lo social, emplazadas en lugares no habituales. Lo artificial haciendo referencia a lo natural desplazado. En resumen, se trata de una alegoría de la Naturaleza volviendo a conquistar los espacios que en otro tiempo le fueron propios.

Cada uno de los artistas invitados elaboró un árbol en base a sus personales y diferentes planteamientos. Los materiales empleados fueron diversos, pero la media de las esculturas tenía una dimensión de dos metros de altura. Así, Naomi Siegmann con su árbol de acero pintado de verde, proponía una crítica a

240 FOUCAULT, Michel, "Des espaces autres. Hétérotopies", en Architecture, Mouvement, Continuité, $\mathrm{N}^{\circ} 5$, Paris, octubre, 1984, pp. 46-49. Foucault designa como heterotopías a aquellos otros lugares, reales y efectivos configurados por la sociedad, lugares de reubicación tanto permanentes como transitorios, que obedecen a la misma lógica inclusión/exclusión de "ese otro lugar" en un orden transformado. 
la realidad simplificada construyendo dos planos bidimensionales recortados que al interseccionarse perpendicularmente forman la silueta de un árbol. La escultora, frente a la destrucción que es capaz de acometer el ser humano frente a un bosque o a la Naturaleza en general, nos habla de nuestra facilidad para transformar en iconos visuales todo aquello que nos rodea, hasta el punto de poder prescindir de la realidad, suplantándola con elementos artificiales. Beverly Pepper, Bryan Nash Gill y Caroline Kaplowitz respectivamente, utilizaron en sus obras, las herramientas con la que el hombre arremete habitualmente contra el árbol. Hacha, serrucho y cadena de motosierra adquieren en sus esculturas el carácter y la identidad de un nuevo árbol, planteando un discurso sobre la agresividad que es capaz de ejercer el ser humano frente a los árboles y bosques.

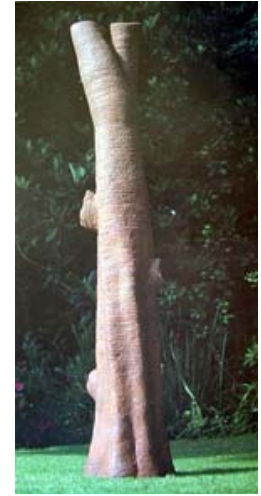

Yolanda Gutiérrez,

Tamoanchan, 2004.

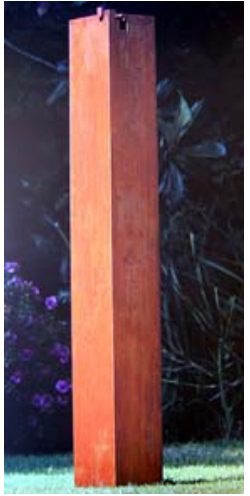

Jorge Yázpick, Sin título, 2004.

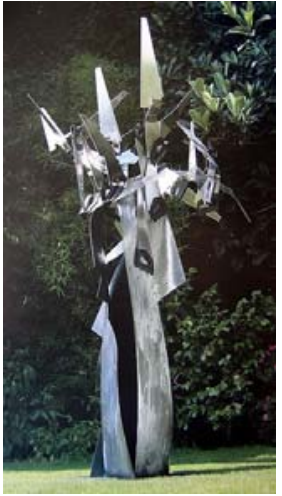

Caroline Kaplowitz, Árbol sierra, 2004.

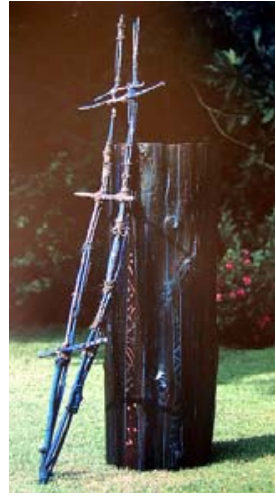

Marta Palau,

Árbol azul, 2004.

Marina Lascaris evocaba un icono creciente de tiempo horizontal en busca de la trascendencia de todo lo efímero. Jorge Yázpick planteaba el árbol como columna que, a manera de una arquitectura inaccesible nos obligaba a descubrir y, Yolanda Gutiérrez rememora en su Tamoanchan truncado -representado por un árbol seccionado- un tiempo en el que la conciencia de la Naturaleza formaba parte del ser humano.

La naturaleza de lo humano y lo vegetal se fusionan en la pieza de Kiyoto Ota ante una forma que sugiere la idea de incubación/germinación, un árbol a punto de nacer. En tanto que Catherine Widgery, Steve Tobin y Robert Lobe utilizan la forma visible de las raíces o de la corteza de un árbol, empleando diferentes materiales para materializar la epopeya de la destrucción, de una Naturaleza utilizada y descuidada por el hombre.

Helen Escobedo, con Árbol hulero, realiza una metáfora del reciclaje reutilizando neumáticos que cuelgan de una sombrilla, una forma crítica de sustitución. Marta Palau, plantea una metáfora de lo inalcanzable con un árbol de resina al que aparentemente se pudiera trepar con una escalera, pero que no lleva a ninguna parte puesto que el árbol está cortado. Pedro Friedeberg y Ricardo 
Regazzoni, partiendo de simbologías culturales y personales muy específicas, traducen en elaboradas geometrías las figuras de sus árboles.

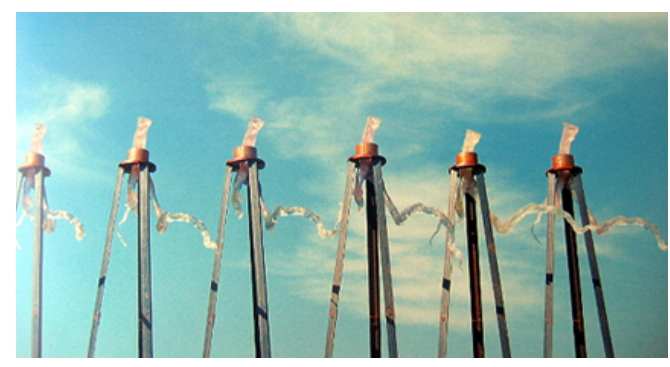

Catherine Widgery,

Enraizado arriba, 2004.

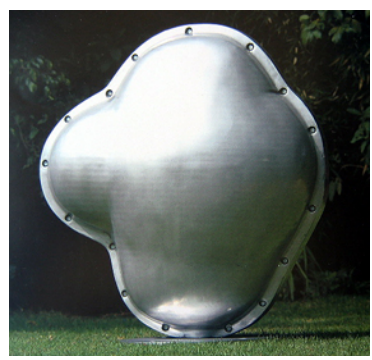

Kiyoto Ota,

Hola bebé árbol, 2004.

La muestra estuvo expuesta en México en las ciudades de San Luis Potosí, Zacatecas, México, D.F. y en Oaxaca. En el extranjero, en San Antonio (Texas), Santa Fe (Nuevo México), Los Ángeles y San Francisco (California) y aglutinó en su recorrido, tanto nacional como internacional, un bosque heterogéneo, nómada y portátil.

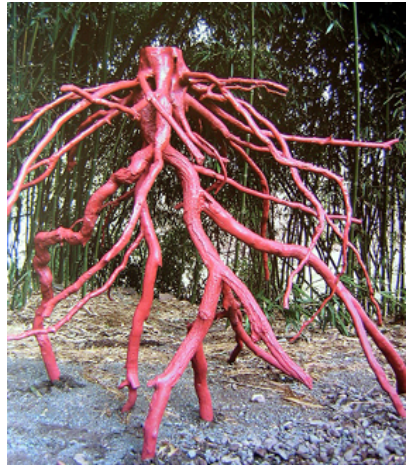

Steve Tobin,

Raíces, 2004.

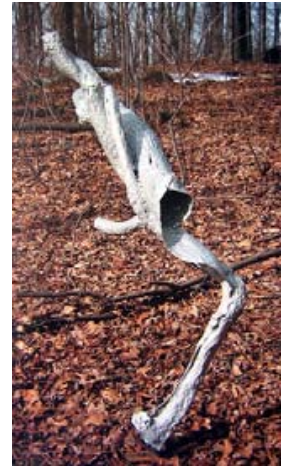

Robert Lobe, Blow Down, 2004.

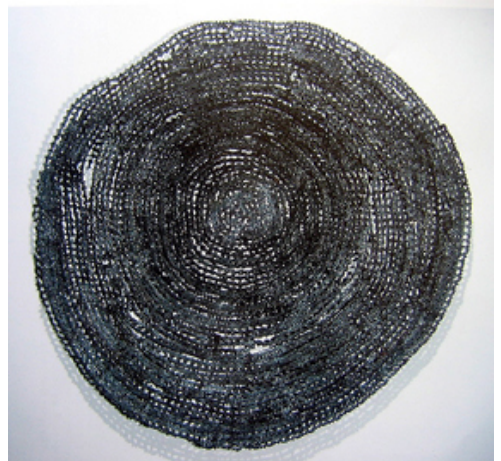

Bryan Nash Gill, Dendriform, 2004.

Un conjunto formado por las diferentes maneras en que los artistas piensan el árbol, el bosque y la repercusión de su desaparición, con el que desde esas "otras naturalezas" de materiales diversos e inertes se lanza una llamada de atención hacia la realidad vista, no desde su representación visual sino como un replanteamiento de la compleja situación contemporánea.

Así este bosque creado por tantos artistas siguiendo la iniciativa de Naomi Siegmann, se ha extendido de una montaña a la mente de los artistas y de ahí, como una planta trepadora, ha seguido creciendo hacia la nuestra, donde ha crecido el asombro y con él un merecido tributo al árbol"241.

241 RUY, Alberto, "Por las venas del árbol al bosque", en AA. VV., El Bosque/The Forest. Escultura/Sculpture, Naomi Siegmann, Buena Tinta, México, D.F., 2005, pp. 4-5. 
Mary Schneider Enriquez, quien escribiera un texto para el catálogo, señala la presencia física y estética con la que los árboles que conforman esta exposición, impresionan al público: "Con callada fuerza estas piezas confrontan al espectador con la presencia física y estética de los árboles en la vida del hombre" 242.

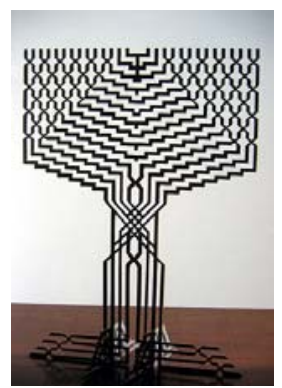

Pedro Friedeberg, Odnoposoff, 2004.

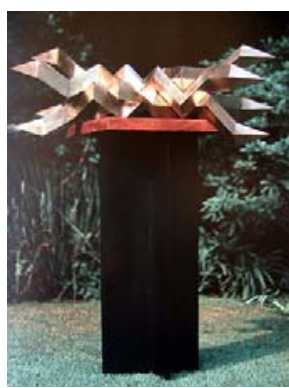

Ricardo Regazzoni, Branching Out, 2004.

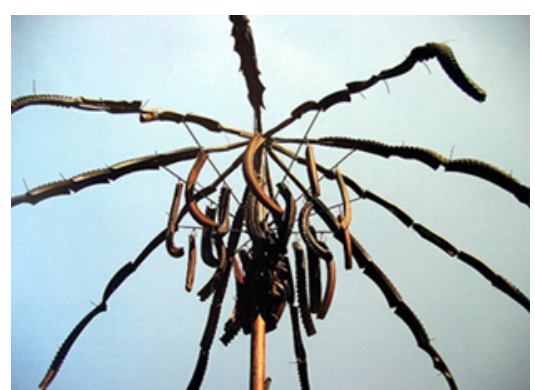

Helen Escobedo, El árbol hulero, 2004.

De esta manera, esta exposición se convierte en una evidente muestra del interés que despierta la representación de "lo vegetal" en la escultura a través del binomio Arte y Naturaleza. El árbol se transforma aquí en un icono representativo del equilibrio precario que el hombre ha impuesto a su entorno.

\subsection{La reivindicac ión del medio ambiente. Helen Escobedo.}

La larga trayectoria artística de Helen Escobedo (México, D.F., 1934) ha propiciado que su obra tenga protagonismo en diferentes ámbitos artísticos, tanto dentro de la historia del arte contemporáneo en México como a nivel internacional. En conjunto, la obra realizada por esta artista ofrece en gran medida, parámetros que nos sirven para referenciar las circunstancias de la aparición de la temática ecológica en este país.

Considerando el objeto de nuestra investigación -lo vegetal como referente temático- centraremos el análisis en aquellas obras en las que esta materia ha sido utilizada tanto física, como conceptualmente; tanto desde la óptica de su representación, como desde su utilización como material para la configuración de la obra o desde la referencia más conceptual, en la que sólo se percibe del vegetal alguna de sus características esenciales. Los trabajos de Escobedo tienen una importante vinculación con lo ecológico y, en este sentido, lo vegetal es empleado en sus obras como una experiencia estética capaz de comunicar las ideas de la autora a un extenso público de una manera clara, directa y eficaz.

Los temas abordados son aquellos que inciden en el deterioro del entorno y que afectan a la vida en general: la agresión a la existencia, las especies en

242 SCHNEIDER ENRIQUEZ, Mary, "Árboles: Formas esculpidas, presencia perdurable", en AA. VV., El Bosque/The Forest..., op. cit., pp. 8-11. 
extinción, las guerras y sus repercusiones, el menoscabo al medio ambiente y a los espacios considerados naturales, la contaminación del agua y del aire, los incendios provocados por la especulación del terreno, los desechos y el reciclaje, la falta de concienciación con respecto a la basura, en definitiva el derecho social a una calidad de vida, a la belleza y a la esperanza. En torno a estas problemáticas ecológicas y, en opinión de Schmilchuk243, Escobedo es una referencia $y$, sin lugar a dudas, la primera artista en México que trabajó sobre estas cuestiones. Por tanto, basándonos tanto en la opinión de Schmilchuk como en la de otros críticos 244 podemos afirmar que Escobedo con su obra, ha supuesto un referente importante para generaciones posteriores. Esta es la razón por la cual iniciamos la revisión de artistas con la trayectoria de esta artista.

En Helen Escobedo, confluyen una serie de influencias tanto en sus orígenes como en su formación. Hija del matrimonio entre un abogado de Aguascalientes y una inglesa, desde muy pequeña estuvo rodeada por diferentes artistas de la época, Remedios Varo, Leonora Carrington, Gunther Gerszo, Enrique Climent, Katy Horna, circunstancia que debió influir en sus intereses artísticos. Como estudiante se formó en México con Ramón Cueto y posteriormente en 1951 con Germán Cueto, quien introduciría en México la escultura moderna.

Posteriormente, obtiene una beca para seguir su formación en Londres en el Royal College of Art donde estudia con Henry Moore entre otros maestros. A su regreso a México en 1954, sus esculturas en bronce tienen referencias de Giacometti de quien conoció la obra en Europa. Por mediación de Gunther Gerszo, presenta su primera exposición individual en 1956 en la Galería de Arte Mexicano (GAM). En ese año conoce El Eco, de Mathías Goeritz con quien establecerá una relación profesional importante al ser éste quien le descubre las posibilidades y el alcance de la escultura urbana. Las ideas de Goeritz sobre el arte ambiental influyeron de manera determinante en sus obras posteriores.

La obra de Escobedo se vuelve rica en influencias y prolífica en realizaciones. Tras un breve período fuera de México, regresa para integrarse en la vida cultural del país, encargándose del departamento de artes plásticas de la UNAM, y concretamente de las galerías universitarias, lo que posteriormente será el Museo Universitario de Ciencias y Artes. De vuelta en México la artista tenía nuevas ideas. En cierta medida no es sólo su formación en el extranjero, sino también su permanente contacto y sus visitas a Europa y EE. UU. -para realizar sus intervenciones artísticas- lo que le permiten mantener una postura abierta a las nuevas influencias del arte contemporáneo. Como señala Marc Augé, volver

243 SCHMILCHUK, Graciela, Helen Escobedo. Pasos en la arena, Turner, Madrid, 2005, p.131.

244 REYNOSO POHLENZ, Jorge, op. cit., p. 22. Jorge Reynoso, en el texto introductorio a la exposición Estar y no estar se refiere a la artista de la misma manera: "Helen Escobedo es una de las primeras artistas mexicanas que integró a sus obras la preocupación por asuntos ecológicos y es natural que la crítica quiera frecuentemente identificar su obra con la ecología o le otorgue una interpretación desde la perspectiva ecológica". 
al lugar de origen es importante, "el retorno al lugar es el recurso de aquel que frecuenta los no lugares"245.

Desde 1961 hasta 1984 continuará en la dirección de museos. Fue directora del Museo Nacional de Arte (1981-1982) y del Museo de Arte Moderno (19821984). Con los años, el hecho de haber ocupado cargos públicos en el medio artístico, le harán abordar esta labor con la perspectiva de establecer y mantener una mayor comunicación con el público en general, circunstancia que puede apreciarse en la concepción de sus obras.

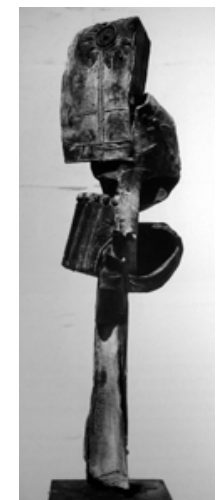

Helen Escobedo, Flor de cactus, 1965.

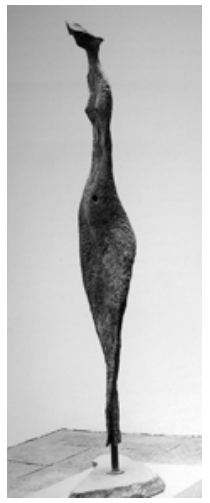

Helen Escobedo, Mujer hoja, 1964.

De los trabajos en bronce de Helen Escobedo comprendidos en este período, queremos hacer mención de Mujer hoja (1964) y Flor de cactus (1965) piezas de aproximadamente dos metros. Se trata de figuras entre humanas y vegetales o cactáceas en las que de una manera temprana, percibimos una cierta sensibilidad que unifica dentro de una abstracción figurativa, una morfología vegetal inventada y relacionada con lo humano. Este tipo de iconografía vegetal, junto con el árbol y el bosque, será retomada reiteradamente en varias de sus obras posteriores como en Biombo (1975), instalación realizada para el Museo de Arte Moderno y en algunos de sus Ambientes Totales (1971), como por ejemplo, en el despacho de los abogados Noriega y Escobedo.

Posteriormente contactará con la Generación de la Ruptura: Manuel Felguérez, Vicente Rojo, Roger von Gunten, Lilia Carrillo, Arnaldo Cohen. Será Mathías Goeritz quien la invita a participar en la Ruta de la Amistad para los Juegos Olímpicos celebrados en 1968, siendo integrante del grupo de escultores que realizarían el Espacio Escultórico que, como ya hemos dicho, es pieza clave en el entorno de Arte y Naturaleza en México. Siguiendo el plan para la modernización con el que la Universidad pretendía continuar la tradición del Arte Público, con el proyecto del Espacio Escultórico se propiciaba un diálogo entre el orden natural del terreno, la vegetación autóctona del lugar y la 
estructura cultural que marcaba la obra misma. El híbrido resultante será calificado como arte-ecología, arte-tierra ${ }^{246}$ y establecerá relaciones entre el arte y la ecología, el arte y la tierra o el arte de la tierra.

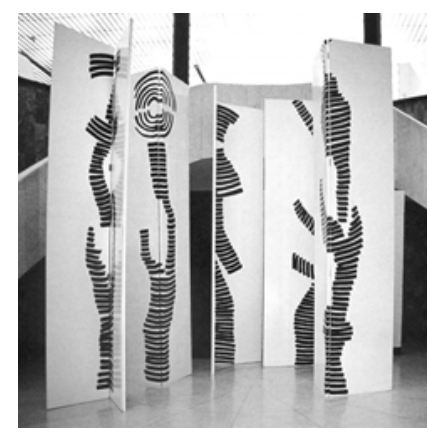

Helen Escobedo, Biombo, 1975.

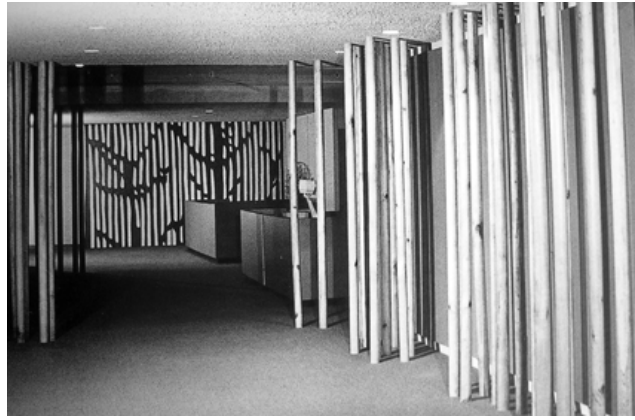

Helen Escobedo, Ambiente Total, 1971.

Su temprano interés por el concepto de Arte Público queda manifiesto alrededor de 1967 cuando sus obras plantean la ciudad como un escenario posible para el arte y su obra comienza a girar en torno al arte relacionado con el urbanismo y la mejora, tanto material como simbólica, de la calidad de vida. Las inquietudes que distinguen a la artista en este período están relacionadas fundamentalmente con el espacio como materia escultórica, con la alternancia de llenos y vacíos, la policromía y el uso de materiales básicos, baratos y sencillos; todo ello unido al carácter lúdico de las piezas y al juego entre apariencia y realidad. La utilización en México de materiales fácilmente accesibles y en ocasiones efímeros fue común entre los artistas de los años sesenta y setenta. Hacia 1970 en el III Salón Independiente, el Arte Povera prevaleció entre los participantes.

En 1971 Escobedo decide tomar la experiencia del lugar como premisa para la elaboración de sus piezas: "Perder peso, desplazarse libremente, comprometerse con cada lugar y adaptarse a sus posibilidades, será su regla de oro"247 a partir de entonces. Esta inclinación por la movilidad, la adaptación a diferentes circunstancias y la realización de obras in situ anticipan características propias del arte contemporáneo. En esta línea queremos recordar lo que el filósofo francés Perec alaba en referencia a la virtud de no aferrarse a las situaciones ni a las cosas:

Vivimos en alguna parte: en un país, en una ciudad de aquel país, en un barrio de aquella ciudad, en una calle de aquel barrio [...]. Hace tiempo que tendríamos que haber cogido la costumbre de desplazarnos libremente, sin que nos costara. Pero no lo hemos hecho [...]. No nos hemos preguntado por qué aquello estaba allí y no en otro sitio, por qué esto era así y no de otro modo [...]. Nos cuesta mucho cambiar, [...]. Tienen que ocurrir cosas

\footnotetext{
246 SCHMILCHUK, Graciela, op. cit., p. 104.

247 SCHMILCHUK, Graciela, op. cit., p. 35. 
extremadamente graves para que consintamos en movernos: guerras, hambre, epidemias. Es difícil aclimatarse [...]248.

Por el contrario, la realidad de Escobedo es muy distinta, ella se desplaza libremente entre países realizando obra y participando en eventos de arte contemporáneo. Como artista, está siempre en continuo movimiento, éste le es innato. Busca involucrarse con el espacio e interactuar con él, realizar piezas in situ, integrar el objeto en su propio ambiente. Por otro lado, respeta la escala humana y el paisaje tanto urbano como natural, en definitiva, su modus operandi es componer en base al entorno. Sus trabajos posteriores se diversificarán en multitud de inquietudes pero una característica constante en su obra será este interés por rescatar una visión más humana de la escultura, una dimensión de lo cotidiano, y una visión personal de la ecología. La capacidad para desplazarse y realizar trabajos efímeros en diferentes lugares, le permite considerar nuevos planteamientos, la convierten en una nómada que se mueve en diferentes mundos centrando su interés en la relación ser y entorno, arte y espacio. En sus obras y partiendo de estas problemáticas específicas, el concepto de la obra desplaza a la creación del objeto.

Helen conoce y admira las obras de Ana Mendieta, Michael Heizer, Robert Smithson, Yayoi Kusama, Louis Bourgeois y Joseph Beuys y, a través de su obra, Escobedo cuestiona los conceptos sacralizados del arte de la época. Valora el diseño y la decoración de ambientes por su implicación en un arte para la vida cotidiana no para el museo. Este tipo de ideas democratizadoras se conectan con las ideas de movimientos anteriores como el Muralismo de Rivera, Orozco y Siqueiros, así como con las tendencias a nivel internacional de encontrar nuevos espacios fuera de museos y circuitos comerciales de las galerías de arte.

Escobedo se interesa por lo que le rodea, los espacios urbanos, el crecimiento caótico y desorbitado de México, D.F., busca una relación más equilibrada entre el arte, la ciudad, la gente y la Naturaleza y, considerando la contaminación visual a la que estamos sobrexpuestos se decanta por realizar esculturasambientaciones-intervenciones efímeras. Considera que al contrario de las obras permanentes que necesariamente agreden e invaden el espacio público y los hábitos de las personas, una obra efímera deja una respetuosa y sutil estela estética en la memoria, una emoción. Con sus intervenciones, busca resignificar estéticamente espacios desocupados o baldíos, tierra de nadie, marcando hitos a la manera en la que Kevin Linch 249 considera los mojones, elementos que se integran sutilmente en los lugares con la finalidad de devenir paisaje o para establecer un contraste local con los elementos vecinos. Sus intervenciones varían en función de cada país, de cada localidad, su obra incita a ver la cotidianeidad de lo que nos rodea de una forma singular. Su tendencia nómada le ha permitido conocer otras problemáticas artísticas gestadas fuera de México. De ahí su rechazo por las intervenciones escultóricas permanentes y la

248 PEREC, Georges, Especies de espacios, Montesinos, Barcelona, 1999, pp. 110-112.

249 LYNCH, Kevin, La imagen de la ciudad, Gustavo Gili Reprints, Barcelona, 2001, pp. 6364. 
búsqueda de espacios alternativos en donde se pudieran realizar intervenciones efímeras y se diera una relación entre artista y sociedad de forma más cercana.

Graciela Schmilchuk, crítica de arte y autora del libro Helen Escobedo: Pasos en la arena 250 , reseña su trayectoria reconociendo tres períodos en la obra de Escobedo, estructurándolos por un lado según el tránsito de la obra permanente a la efímera, por otro atendiendo a los procesos evolutivos en los que toma más importancia la noción de espacio y la evolución del concepto de lugar y por último, la relación establecida con los materiales, técnicas y dimensiones. Así, sitúa entre 1954 y 1966 un período formativo, con esculturas realizadas en bronce. De 1967 a 1985 una etapa en la que prevalecen las ambientaciones, el diseño arquitectónico, gráfico y de objetos. Por último, una fase en la que la artista se decanta por las intervenciones efímeras.

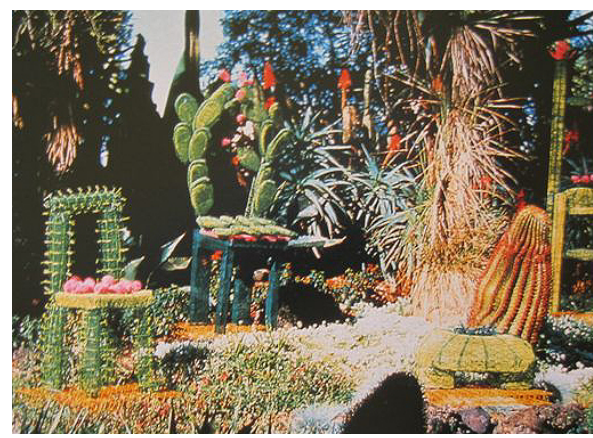

Helen Escobedo,

Sillas cactus, 1989.

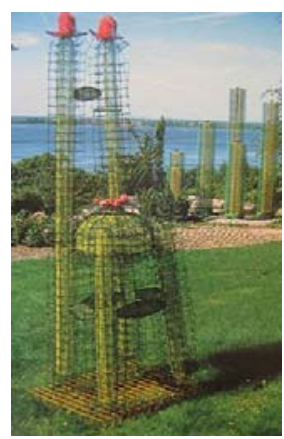

Helen Escobedo, Sillas cactus, 1989.

Entre 1968 y 1986 Escobedo realizara seis esculturas monumentales, entre las que se encuentra Coat/ (1980), obra en acero de 15 metros de largo. A partir de entonces, su preferencia por las instalaciones efímeras le llevará a diversificar su trabajo utilizando en muchas ocasiones materiales de reciclaje. En esta fase es donde encontramos una mayor tendencia a relacionarse con intervenciones en contacto con la Naturaleza aflorando con mayor consistencia sus preocupaciones ecológicas. La Naturaleza tiene un lugar preponderante en su producción, le resulta un marco interesante tanto como proveedora de materiales (ramas, paja, troncos, hojas secas, semillas...) y de formas, como fuente temática.

[...] tanto en espacios urbanos -el aire, el agua, la vegetación- como en zonas algo más campiranas: bosques, playas, parques [...]. La naturaleza no es solamente materia de contemplación, para una Escobedo ecologista del Grupo de los Cien; es asimismo su contrapartida, lo que destruimos 251.

250 SCHMILCHUK, Graciela, op. cit., p. 11.

251 SCHMILCHUK, Graciela, op. cit., pp. 129-130. 
Basándose en la idea de que la permanencia no existe, su quehacer creativo como artista tiene que ver con su identidad ecológica como ser humano. Busca el Genius Locci o espíritu del lugar para intervenirlo y conjugar sus dos presencias, visión y realidad y encuentra la solución para ese espacio en el momento preciso del tiempo en que vive. La trascendencia de la Naturaleza en sus obras, se ve reflejada entre otras formas, en el uso de materiales y elementos vegetales. Por un lado éstos son tomados en cuenta por la artista en su hábito de conjugar una pareja de opuestos. En la pieza Sillas Cactus (1989) la referencia vegetal es utilizada lúdicamente contraponiendo con ironía la forma con la función. La habitual utilidad del elemento silla para sentarse es relegada aquí a un segundo plano.
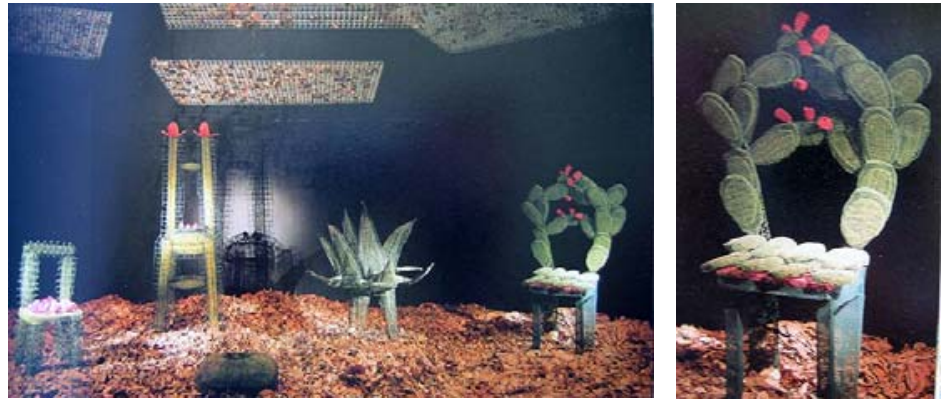

Helen Escobedo, El jardín de los ecólogos, 1989.

El impedimento que ofrecen estas esculturas-sillas para sentarse, debido al empleo de formas espinosas y cactáceas, genera un juego que nos lleva a considerar que la Naturaleza establece sus propias leyes y que aun lo bello puede ser incómodo. Así, la puesta en escena de la pieza El jardín de los ecólogos (1989), nos remite a la imposibilidad de tomar conciencia de la verdadera problemática ecológica, cuando este proceso se realiza únicamente desde la institución.
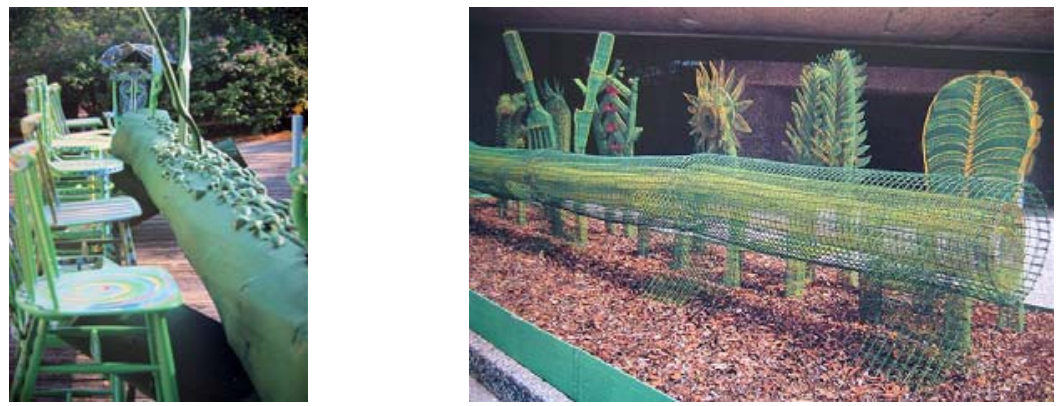

Helen Escobedo, El gran banquete o la Fiesta que se comió a sí misma, 1991.

Algo similar sucede en El gran banquete o la Fiesta que se comió a sí misma (1991) expuesta en Finlandia en el año 1991 y en 1992 en el Museo Rufino Tamayo de México. En una probable lectura, las sillas cactus se convierten en la invitación incómoda a devorar el árbol. La metáfora se establece -como sugiere 
el texto de la artista que aparecía en la invitación para esta ocasión- en el proceso de nuestra propia negligencia por cuidar aquello que nos rodea:

[...] está cordialmente invitado a comerse a sí mismo. Esperamos que los presentes no dejen nada de sí en sus platos. Por tanto no podremos levantarnos de la mesa porque no quedará nada de ella ni de nosotros para hacerlo252.

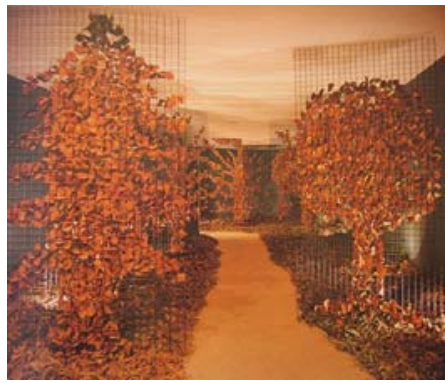

Helen Escobedo,

La muerte del bosque, 1990.

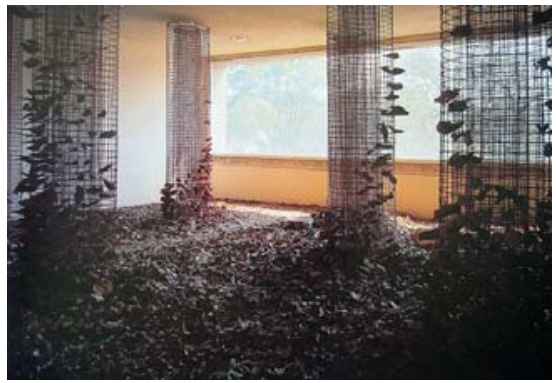

Helen Escobedo,

El Jardín de Orozco, 1987.

Otra manera en la que Escobedo utiliza lo vegetal es generando una ilusión mediante elementos naturales. En la intervención llamada La casa arde (1991) una maraña de ramas de diferentes colores sugieren la destrucción por el fuego de aquello que nos acoge, una casa que hace referencia a nuestro propio hogar: es la venganza de la Naturaleza quien ejerce en este caso, mediante el fuego, el daño que nosotros le infringimos. De igual manera ocurre con las ramas rojizas que insinúan sangre humana en Sangre de árbo/ (1991), intervención realizada en el Bosque de Tlalpan. Aquí, quince árboles son protegidos con vendajes blancos, excepto en una parte a manera de herida abierta, que nos deja ver ramas pintadas de rojo en su interior. El vínculo entre lo humano y lo vegetal es aquí evidente en el uso, junto con el rojo sangre, del elemento de las vendas.

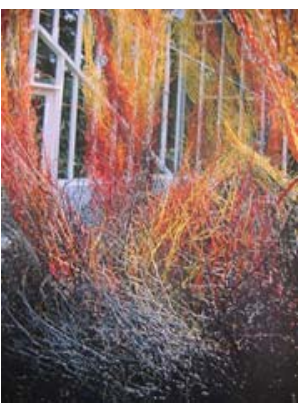

Helen Escobedo,

La casa arde, 1991.

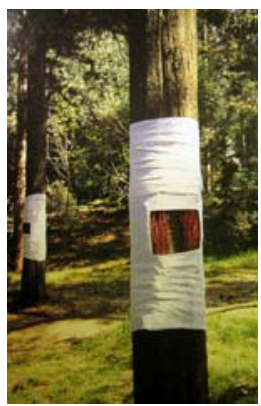

Helen Escobedo, Sangre de árbol, 1991.

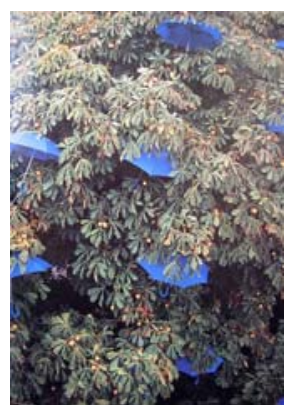

Helen Escobedo, Lluvia ácida, 1992.

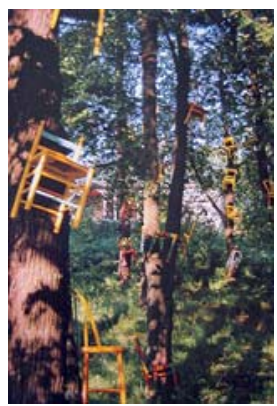

Helen Escobedo, Sillas trepadoras, 1991.

252 SCHMILCHUK, Graciela, op. cit., p. 175. 
En esta misma línea, Escobedo hace referencia a un tema social, el de los refugiados, pero lo hace utilizando paja o hierba. La artista colocó 101 figuras de dos metros de altura en el parque Moorweide, cerca del Campus de la Universidad de Hamburgo (Alemania) haciendo alusión a un tema que se debatía en esos momentos: la cantidad de refugiados que el país podría admitir. Las estructuras antropomorfas que colocó, están relacionadas con los sistemas que se usan en los campos de cultivo para poner a secar las mieses que se recogen.
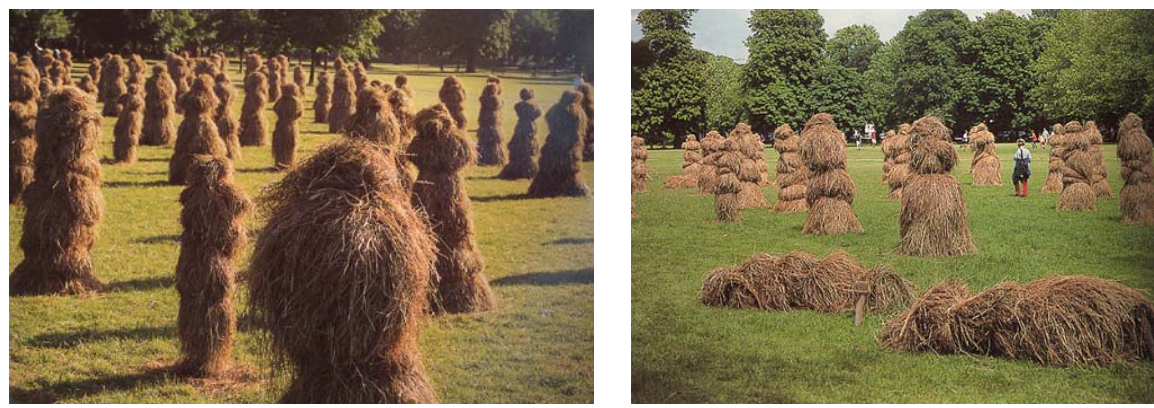

Helen Escobedo, Los refugiados, 1997.

También en Alemania participa en eventos en los que con otro tipo de intención, árboles y bosques son intervenidos con elementos que le son ajenos. Paraguas o sillas pueblan las masas vegetales, elementos humanos con los que el hombre, propone la artista, podría proteger a los árboles de la lluvia ácida, o sillas para devolverle al árbol lo que se le quitó, su propia carne, la madera con la que se elaboran las sillas.

El método de Escobedo en ambos casos es característico del Surrealismo, hacer coincidir dos ideas dispares mediante la aplicación de un llamativo contraste. Sentarse en un árbol sería una manera difícil, por no decir imposible, de ponerse a dialogar con él, lo que juega es la capacidad de recuperar el símbolo. El paraguas como símbolo de protección o la silla como instancia posible para un diálogo son en definitiva, elementos que forman parte de la esfera humana puesta a dialogar con aquello que aun siéndole ajeno aparentemente, un vegetal, es intrínseco también a la cotidianeidad del ser humano. Por último haremos mención de una de las quince instalaciones realizadas en el Museo Universitario de Ciencias y Artes (MUCA), en la exposición Estar y no estar (2000). En esta ocasión, Escobedo muestra una trágica, consumada y asfixiante realidad. Sin embargo la artista deja una vía libre, una alternativa para actuar sobre este panorama, al conducir al espectador hacia una toma de conciencia, incidiendo positivamente en su propio futuro. En la instalación Piso verde (2000), se observa la fachada de una habitación humilde y urbana, a través de una ventana podemos ver un trabajo de pintura de piso. El color de la pintura es verde, el pintor está ausente, ha dejado abandonados sus instrumentos de trabajo, un bote de pintura, la brocha y sus zapatos. 


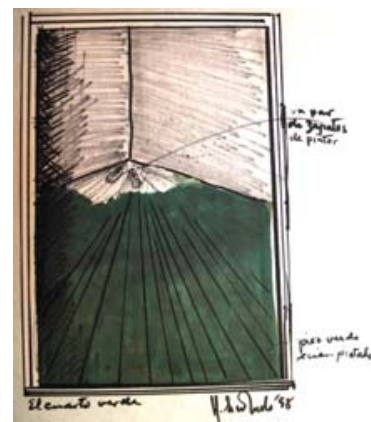

Helen Escobedo,

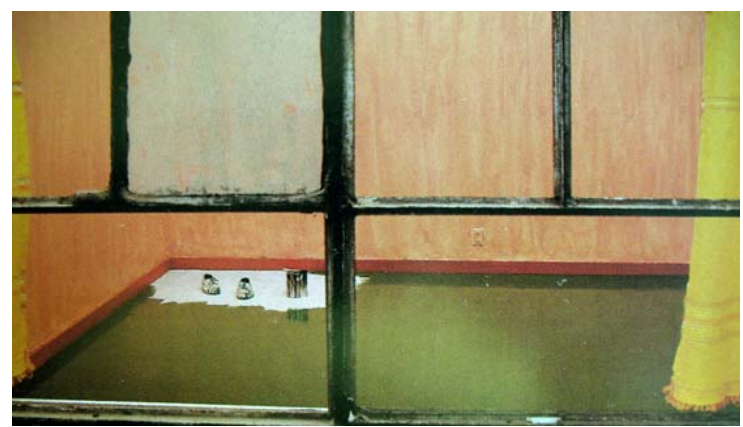

Helen Escobedo, Piso verde, 2000.

Piso verde, 2000.

En consonancia con el resto de instalaciones, los sujetos están, pero no están, su presencia se percibe a través de la ausencia o de los restos: "La masa de pintura verde acorraló al pintor". Esta anécdota "pequeño chiste" según la autora y como corrobora el crítico autor del texto, pasaría por un detalle de comicidad popular253. Sin embargo, pintar de verde un piso tiene unas connotaciones y al no encontrarse el autor de dicha acción, nuestra lectura es la de que la autora hace una crítica mediática al concepto de la aparente artificialidad que puede suponer el recurso a lo ecológico, así como a lo que el ser humano puede desencadenar sin ser capaz de prever las consecuencias de su acción.

\subsection{Una visión mágico-ancestral. Marta Palau}

Cuando Jorge Alberto Manrique 254 se refiere a las nuevas tendencias, modos, corrientes y actitudes de las últimas generaciones mexicanas de artistas a partir de los ochentas hasta 1995, nos habla de los llamados happenings, performances y otros modos diversos de arte, caracterizándolos como alternativos. En referencia a los años setenta, indica las grandes dificultades por las que tuvieron que atravesar las generaciones precursoras en estas tendencias. La situación en México estuvo marcada en esa década por la creciente pobreza y las represiones realizadas por el gobierno, encabezadas por la matanza de Tlatelolco. Al igual que en otras parte de América Latina, fluía la crítica al objeto artístico sobrevalorado, la desconfianza respecto a los habituales y endiosados grandes artistas y proliferaban los ataques a los grandes concursos y bienales.

Estas circunstancias generaron que durante esos años, surgieran los llamados Grupos, artistas que se organizaban para poder seguir trabajando. Estos colectivos, cuyo objetivo principal era acabar con la situación anteriormente descrita, estaban muy organizados y politizados, manteniéndose muy sensibles a todas las cuestiones sociales. Así, en respuesta al oficial Salón Solar organizado por el Instituto de Bellas Artes, surgió el Salón Independiente en

253 REYNOSO POHLENZ, Jorge, op. cit., p. 19.

254 MANRIQUE, Jorge Alberto, Un visión de arte y la historia..., op. cit., p. 189. 
1968, que dio origen a la llamada Generación de la Ruptura, en contra de la omnipresencia del Estado como promotor.

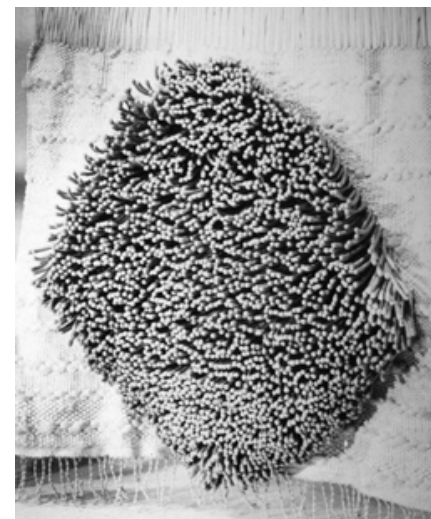

Marta Palau, El Aleph, 1978.

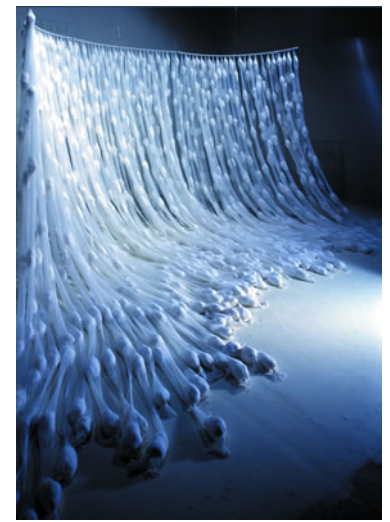

Marta Palau, Cascada, 1981.

Un hecho significativo es que a falta de recursos y bajo estas circunstancias, al amparo de la Universidad el Salón Independiente de 1969 convocó a los artistas a trabajar sobre papel periódico. Algunos de estos artistas realizaron un mural conjunto y efímero en las mamparas que cubrían el monumento a Miguel Alemán en Ciudad Universitaria. Estos movimientos tuvieron poca vigencia en el tiempo, dando paso al Geometrismo Mexicano donde confluirían procesos individuales diversos, unidos a ciertos antecedentes tanto europeos como estadounidenses y latinoamericanos.

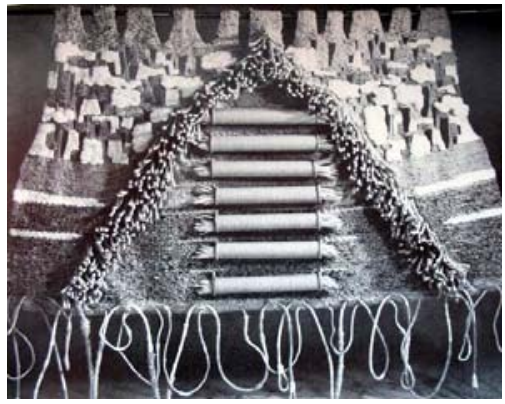

Marta Palau,

La guerra florida I, 1984.

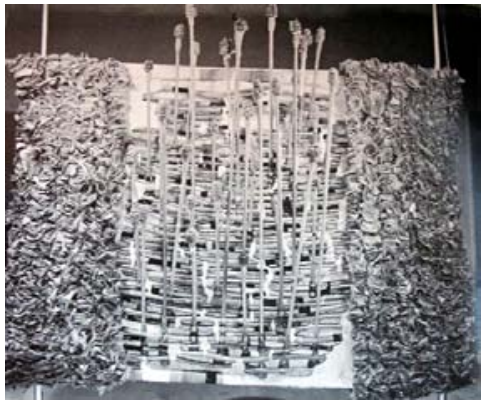

Marta Palau,

Mis Caminos son Terrestres XII, 1984.

A partir de 1968, con el precedente de las Torres de Satélite (1954) y la llamada Ruta de la Amistad (1968) será la escultura urbana la que tome el relevo como uno de los hechos más importantes en la plástica mexicana. Fuera de estos espacios, los artistas calificados como "de tránsito" por Manrique, son los que trabajan a partir de los ochenta con nuevos planteamientos de los que nos ocuparemos más adelante. Si bien artistas como Helen Escobedo, cuya obra acabamos de revisar, forma parte de estos grupos de los años setenta puesto que participó junto con los Geometristas en el Espacio Escultórico, la trascendencia -en cuanto a sus aportaciones- de la obra de otros artistas 
destacados en esas décadas como Marta Palau (Albesa, Lérida, Cataluña, 1934) está por redefinir.

En nuestra opinión y como demostramos en esta investigación, el germen surgido en México, en los años sesenta y desarrollado en los setenta es más relevante de lo que la crítica suele atestiguar. Debemos considerar decisivos y representativos estos años, no solamente por el surgimiento de los Grupos y de las principales figuras de la Ruptura y los Geometristas, sino también por la influencia de artistas como Marta Palau quien, junto con Helen Escobedo, desarrollará en este período, una obra singular y trascendente. Nos encontramos frente a nuevas tendencias que darán origen a nuevas poéticas que, a su vez posteriormente, serán retomadas por artistas más jóvenes a finales del s. XX.

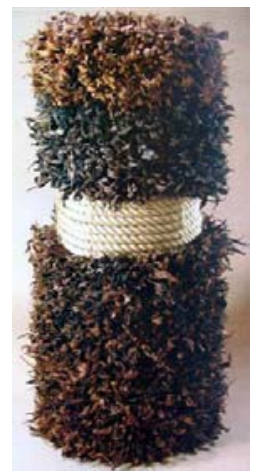

Marta Palau, Mis Caminos son Terrestres XIII, 1984.

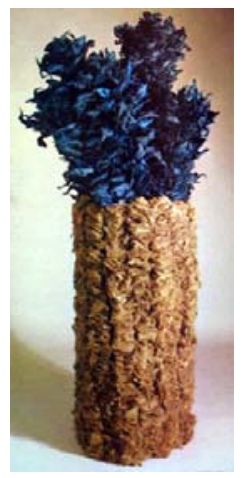
1.1.

Marta Palau, Empalizada de Chamanes, 1988.

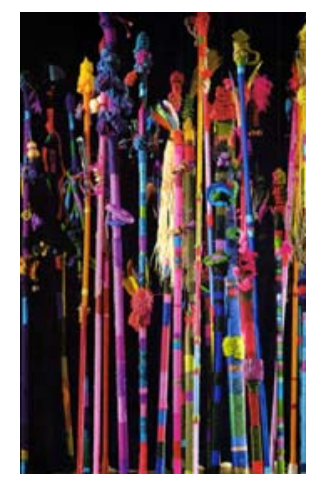

Marta Palau, Bastones de Mando, 1985.

Marta Palau desde muy joven, se trasladó a México junto con su familia donde desarrolló su trabajo creativo. La artista formaba parte de los españoles exiliados que enriquecieron de innumerables maneras, el contexto cultural mexicano. Los inicios en su carrera están marcados por la elaboración de textiles con fibras naturales.

En 1978 y después de haber participado en el Décimo Simposium Internacional de Escultores en Toronto (Canadá), expone individualmente en el Museo de Arte Moderno en México, D.F., bajo la dirección, en aquel entonces, de Fernando Gamboa. El catálogo de su exposición 255 exhibe en la portada la pieza Cascada (1981) en la que con tejido de nylon (medias femeninas blancas) introduce en México la noción de escultura blanda. De esta manera desafiará tanto al tradicionalismo de la escultura académica, como a aquella rotundidad heredada por la tradición de la escultura prehispánica. Su organicidad pone en tela de juicio las nuevas tendencias de los Geometristas instaladas en el formalismo e incluso los nuevos retos que por aquel entonces se gestaban en torno a la nueva escultura urbana.

255 Véase Marta Palau. 30 esculturas en materiales textiles, Museo de Arte Moderno, Bosque de Chapultepec, Instituto Nacional de Bellas Artes, México, D.F., 1978. 

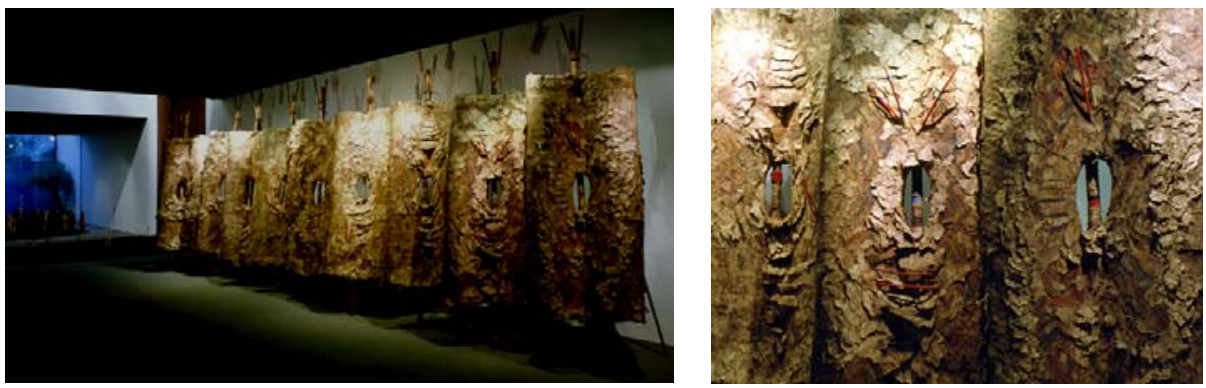

Marta Palau, Centinelas, Heráldica de Naualli, 1993.

Con su instalación o ambientación escultórica y efímera en el Salón Independiente de 1970, Marta Palau fue precursora en el afán de establecer un vínculo interactivo con el público. Al proponer que el espectador interactuara con la estructura espacial de la obra, se convierte en una artista con una de las obras más radicales en el arte experimental de América latina. Con la incorporación de nuevas fibras, coco y hojas de maíz entre otras y las ambientaciones con bastones de mando, elemento simbólico de la autoridad entre las antiguas culturas de México, Palau ancla su trabajo en conceptos relacionados con el pensamiento mítico, con la tierra y las raíces culturales de lo mexicano.

Lo que para críticos como Rita Eder, Renato González Mello, Cuauhtémoc Medina y Francisco Reyes Palma es una construcción lírica "afín a la poética de artistas contemporáneos como el brasileño Ernesto Neto"256, en Marta Palau es en nuestra opinión, una proeza en el tiempo y en el México de la época que no necesita revisiones extemporáneas o extraterritoriales para refrendar su valía.

A lo largo de su trayectoria, esta artista se ha caracterizado por aunar en su trabajo la exploración formal con la experimentación en cuanto a los materiales, acercándose a los planteamientos del Arte Povera y del Land Art. En sus viajes y recorridos a lo largo de todo el territorio mexicano ha cosechado sistemáticamente elementos y materiales que a través de su obra ha ido reelaborando y confeccionando como entrecruzamientos, relaciones, ataduras de fibras, ramas y de papel amate257.

Contemporánea de las tendencias en los años sesenta y como tejedora en sus orígenes, Marta Palau realizaba sus primeros tapices escultóricos con fibras diversas (lana, algodón, henequén, yute natural, nylon) y colores naturales.

256 EDER, Rita, et al., "Marta Palau a cuatro voces", Disponible en red en: <http:// www.martapalau.com/uploads/MartaPalaucuatrvoce.htm>, [Consulta 7, febrero, 2008].

257 El papel amate es un tipo de soporte de origen vegetal cuyo uso se remonta a la época prehispánica en Mesoamérica. Proviene de la manufacturación artesanal de la corteza del amate, árbol del género ficus. Aplastando la corteza y cociéndola en agua con cal, se obtiene una lámina vegetal fibrosa, de colores que van del marrón oscuro al amarillo paja. 
Desde aquel entonces, sus inquietudes están relacionadas con lo orgánico y las formas de la Naturaleza, buscan un origen místico anclado en signos de identidad cultural profundos que apuntan tanto a un sentido mágico como a un sentido de tiempo y Naturaleza. Todo ello unido a una visión también ancestral de la función de lo femenino como generador de vida. Desde esta óptica de lo femenino y con su obra, revaloriza uno de los oficios más antiguos, el de las tejedoras y todos aquellos oficios relacionados con la cestería, vinculando así el poder del ritual a través del proceso de trabajo con las mitologías populares más primitivas.

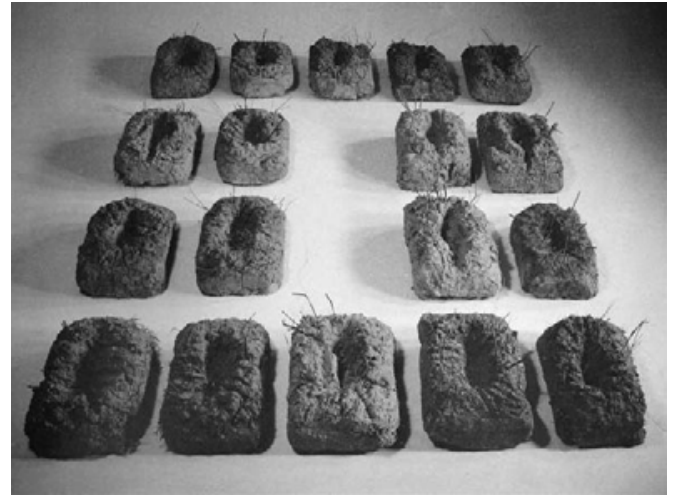

Marta Palau,

Nahualli IX, Gestación, 1991.

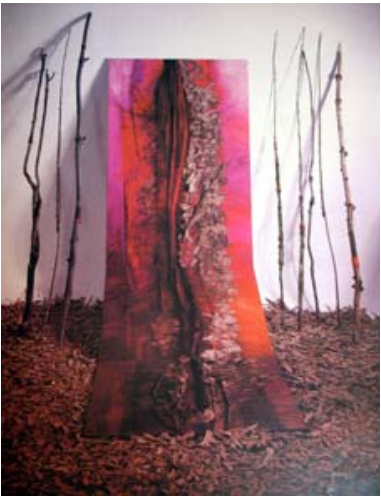

Marta Palau, Nahualli IV,

Protección de Otoño, 1991.

En esta búsqueda del origen y de la raíz recorre sus Caminos Terrestres 258 , título con el que en 1985 da nombre a su exposición individual en la Sala Nacional del Palacio de Bellas Artes de México. En este punto, la recolección de nuevas fibras que incorporar a sus obras se ha enriquecido con hojas, semillas, ramas, etc. Su relación con esta suerte de naturalezas está vinculada a un diálogo entre Naturaleza y Cultura desde la óptica del que redescubre el poder de los mitos y de la tradición. Una tradición de artesanos que ella sabe recuperar e instaurar en un sistema de arte con plena conciencia de que más allá del trabajo manual, estos oficios y estas tradiciones emanan de un saber ancestral repleto de conocimientos a descubrir. Pero a partir de este momento, la lectura remite a unas obras que se acercan a una vertiente ecológica. Para esta exposición a través de los textos introductorios que escriben Teresa del Conde y Rita Eder, entendemos que Palau realizó las piezas ex proceso para el lugar.

La inclusión de materiales orgánicos va más allá de una simple metáfora de evocación de la Naturaleza. Palau desarrolla una metodología para subvertir el orden establecido entre las diferentes artes en la búsqueda de un sistema de

258 Véase AA. VV., Marta Palau, Mis caminos son terrestres: muros, esculturas, ambientaciones en fibra, Sala Nacional del Palacio de Bellas Artes, Instituto Nacional de Bellas Artes, Secretaría de Educación Pública, México, D.F., julio-septiembre, 1985. 
integración de las mismas. Sus fetiches nahuallis 259 apuntan a una sensibilidad no sólo material sino cultural propiamente mexicana, mediante el rescate de las referencias a las culturas indígenas de las diferentes zonas de México y entre ellas en particular, la zona norte a la que aún sigue vinculada con sus evocaciones a las pinturas rupestres de Baja California (hombres de rojo y negro) y el nomadismo de los primeros recolectores cazadores.
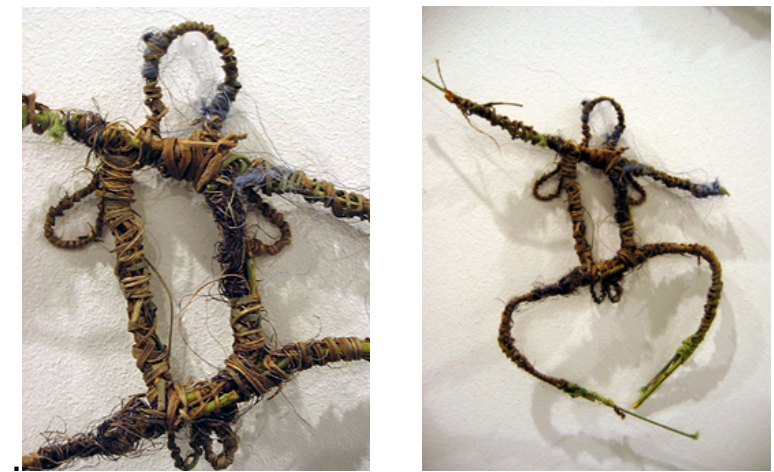

Marta Palau, Hombre de Baja, 2004.

Para Palau sus nahuallis son elementos constantes, referencias directas a los rituales de poder y erotismo femenino. Se trata de introducir el elemento femenino en forma de hechiceras, sacerdotisas, cuidadoras y protectoras de su comunidad, que son las que realizan los encantamientos y ofrecen protección contra las fuerzas externas. Son responsables de la creación del mundo, guerreras que están prestas a defender la Cultura propia, el "derecho a la tierra y la identidad como pueblo". Son las soñadoras, idealistas, constructoras que han heredado la fe y permiten la continuidad; "son sexo-semilla, creación y gestación"260. Así, la misma artista se funde con sus personajes adquiriendo ella misma la identidad de chamana. Estas actitudes mediáticas entre la obra de arte y el ritual mágico aparecerán de nuevo en el panorama del arte de los ochenta con la obra de artistas como Rosario Crespo, Yolanda Gutiérrez o Elizabeth Ross.

259 Nahualli es un término polisémico utilizado habitualmente para denominar a los sabios nahuas, conocedores de los saberes y las formas más antiguas en la tradición nahua. Fue un término mal entendido por los transcriptores coloniales que lo interpretaron como los brujos o hechiceros. También se refiere a la facultad-que desde la época prehispánica, se atribuye a los dioses- de tomar la forma de un animal (nahual) como una especie de doble, para de esta forma, interactuar con los humanos. Asimismo, se identifica como la afinidad entre un ser humano y un animal vivo en particular, cuyos destinos y suerte están enlazados. Véase LÓPEZ AUSTIN, Alfredo, Cuerpo humano e ideología. Las concepciones de los antiguos mayas, Vol.1, UNAM, México, D.F., 1984, pp. 416-418.

260 RODRÍGUEZ, Dunia, "Los nahuallis y erotismo mexicano, cubren las obras de Marta Palau", Disponible en red:<http://www.cimacnoticias.com/noticias/01 oct/01103101.

html $>$, [Consulta 1, septiembre, 2011]. 


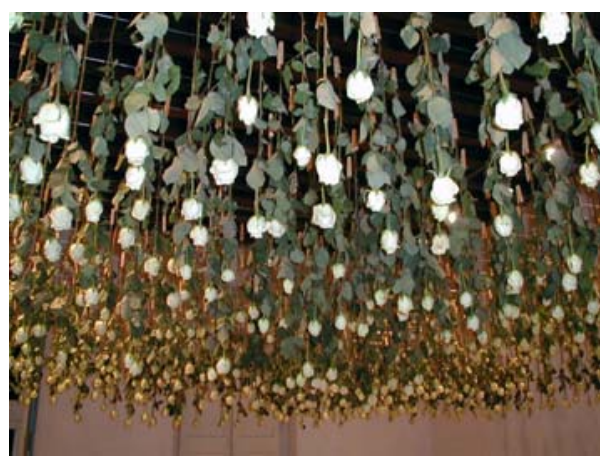

Marta Palau,

Lluvia de Rosas para el General, 2004.

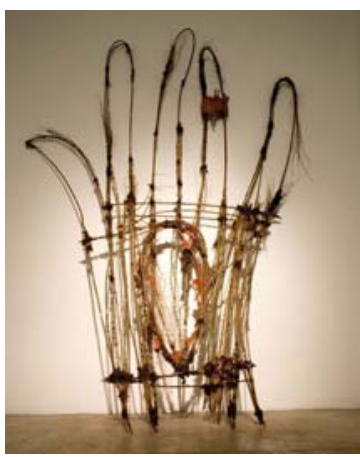

Marta Palau,

Naualli mano poderosa, 2005.

Como podemos apreciar, la relación que a través de su obra Marta expresa en relación a lo vegetal es de un sentimiento ecológico vinculado a una cuestión de género en donde lo femenino está relacionado con el poder de creación, tanto de la tierra como de la mujer. Las constantes alusiones a la sexualidad recrean la mística de lo femenino erótico desde la sexualidad innata en este sexo. Sus formas remiten a sexos que crecen, que protegen, guardianes y umbrales de otro tipo de conocimiento. Templos, escudos y corazas protectores que mediante la alusión al mito, establecen el ritual, la ceremonia de la razón mágica. En este sentido su recurrencia a lo natural es una construcción cultural desde el pensamiento ancestral y la magia. En 1963 Margarita Nelken escribe de ella que es la primera en recrear esos viejos mitos261. Por otra parte, la utilización de materiales vegetales y orgánicos le permiten establecer un diálogo entre lo efímero y lo cíclico, su tiempo evoca constantemente el ritual. Se trata de procesos vinculados con lo humano y su relación con la Naturaleza, en su manifestación de lo divino.

A principios de los ochenta, la artista desarrolló un taller en la ciudad de La Habana, en el que animaba a los participantes a usar materiales naturales propios de su entorno inmediato. Este trabajo inspiró a varios artistas de la vanguardia cubana, entre ellos al ya fallecido Juan Francisco Elso, con quien tiempo después, en 2005 y, en una exposición realizada compartiendo espacio con Helen Escobedo, entablará un diálogo virtual y formal, con su obra Naualli mano poderosa. Esta instalación realizada con ramas de árbol, fibra de tule tejida, papel amate y barro negro, de 260 centímetros de altura, dialogaba a través del tiempo con la misma estructura formal de una mano, como la escultura de Elso, La mano creadora (1987-88).

Artistas como Magalí Lara, Ana Quiroz y Laura Anderson Barbata, cercanas a ella en este tipo de concepciones y trabajo, se refirieron también a ella como

261 Véase AA. VV., La razón mágica de Marta Palau. Nahualli, instalaciones, escultura, collage, Galería Expositum, México, D.F., 1991. 
"enraizada en el orden de la naturaleza"262 que nos acerca a una mirada de la Naturaleza a través de lo ancestral, no sólo como visión sino desde la construcción cosmológica de las antiguas culturas263.

Por último, cabe destacar su labor como promotora cultural, con la que ha contribuido a expandir el campo creativo en México. La organización entre otras cosas, de la actualmente Bienal Internacional de Estandartes de Tijuana, es un claro ejemplo. También ha ostentado un papel clave en el diálogo artístico global iniciado con las exposiciones Cinco continentes y una Ciudad (19982000), evento nacido por su iniciativa y que puso en contacto a los artistas y las concepciones curatoriales más destacadas del ámbito mundial, con públicos y creadores mexicanos.

\subsection{Contemplación y denunc ia de la devastación. Jan Hendrix.}

Un árbol es un paisaje para una hoja (2001)264 es el título de una de las obras de Jan Hendrix (Maasbree, Holanda 1949) y podríamos considerar que ésta, en nuestra opinión, es una de las máximas que dan origen a la obra de este artista quien, más que interesado en la Naturaleza, la reconstruye muy de cerca. Hendrix, artista holandés afincado en México desde los años setenta, es uno de los grandes maestros contemporáneos de la gráfica y amante confeso del paisaje. Sin ser de nacionalidad mexicana, su obra es importante para el contexto de México y el diálogo entre Arte y Naturaleza que nos ocupa. Sus recientes incursiones en la escultura, derivan de su trabajo gráfico y fotográfico que implica una búsqueda constructiva más allá de lo bidimensional.

Para Santiago Espinosa de los Monteros la obra de Hendrix es una investigación sólida que emprendió hace ya más de tres décadas "cuando comenzó a mirar el paisaje como el espacio posible para una planta, un árbol o los discretamente luminosos espacios que existen entre una rama y otra" 265 . Por otra parte, en una entrevista realizada en verano de 2006 por la autora de este texto, el artista nos condujo por un recorrido conceptual de su obra, afirmando que su trabajo tiene un cierto vínculo de continuidad con la estética de Arte y Naturaleza que él mismo se trajo de Europa.

262 Véase QUIROZ, Ana, "Añoranzas de tierra. Cruzando fronteras", en Marta Palau. Nómadas II. Arte ritual, Material divulgativo de la exposición, Kunsthaus Santa Fe, San Miguel de Allende, 1999, p. 2.

263 LARA, Magali, "La tierra y el cuerpo", en Marta Palau, Nahualli, esculturas y dibujos, Galería Juan Martín, México, D.F., 2001, p. 3.

264 HENDRIX, Jan, "La naturaleza como metáfora", en AA. VV., Botánica, Miguel Ángel Blanco-Jan Hendrix, Museo Nacional de la Estampa, CONACULTA, México, D.F., 2003, p. 3. 265 ESPINOSA DE LOS MONTEROS, Santiago, "Botánica: Exposición gráfica de Jan Hendrix y Miguel Ángel Blanco", Disponible en red: <http://www.replica21.com/archivo/articulos /e_f/331_espinosa_botanic.html >, [Consulta 8, marzo, 2004]. 


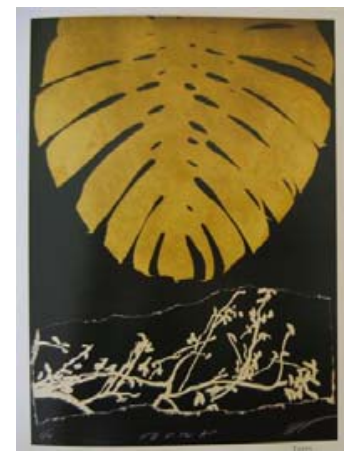

Jan Hendrix, Tierra, 1992.

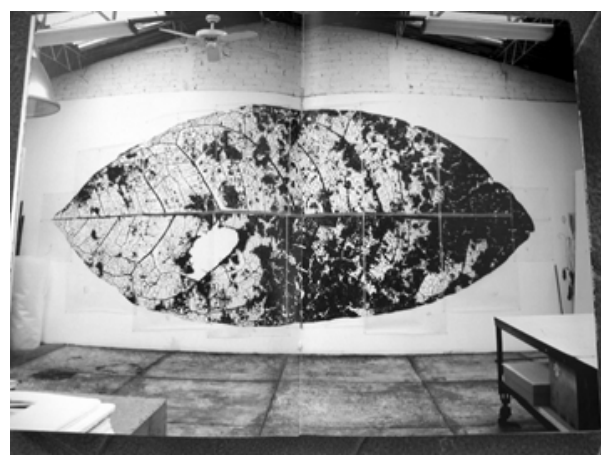

Jan Hendrix, Sin título, 2002.

Se trata de un tipo de estética relacionada con un particular modo de hacer, algo que él mismo llamó tru-tru o la estética del macramé, encaje o filigrana relacionada con lo femenino, con las tejedoras, una estética volcada en la distracción de la mirada y las horas dedicadas al trabajo y a la contemplación del hacer. Esta estética nos dice, tuvo su continuidad en Europa, sin embargo al llegar a México en 1978, se encontró que su trabajo no seguía las tendencias predominantes en este país, con lo cual tuvo que continuar en solitario sus peregrinajes en este ámbito y nos habla de su terquedad al encontrarse trabajando un tema que no era común en México en esos momentos. Declara que su obra tiene conexiones con el paisaje como tema, así como con la obra de Richard Long y la organicidad de Diter Roth, cuya obra se basa en el principio de la transformación efectiva mediante la destrucción casual del objeto.

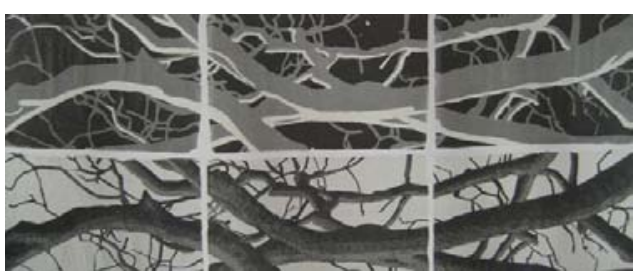

Jan Hendrix, Albán, 1991.

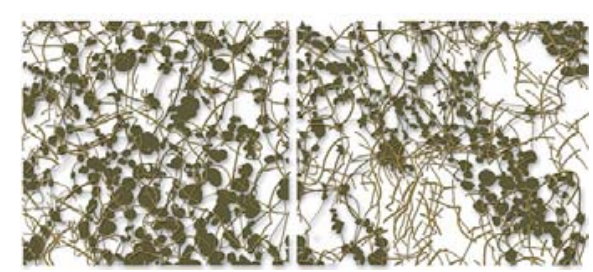

Jan Hendrix, Eclipse 8, 2007.

Remitiéndose a la Historia del Arte, Hendrix señala que si bien en el siglo XIX, surgieron los primeros artistas en abordar el tema del paisajismo como tal, éste fue abandonado por casi tres cuartos de siglo y no fue sino hasta 1970 aproximadamente, que comienza de nuevo el interés por la Naturaleza. A su modo de ver, la ausencia de una adecuada valoración crítica en la sociedad mexicana ha impedido percibir de una manera más inminente ciertas cuestiones al respecto, razón por la cual este tipo de sensibilidad diferente es rechazada y percibida en México como algo lírico o femenino.

Su trabajo se vertebra en la metáfora que relaciona lo humano con lo vegetal, considerando las plantas como elemento fundamental en el que éste se basa. Como ejemplo, propone la obra en la que podemos ver estampada sobre papel nepalés una sola hoja, el artista indica que ésta podría considerarse una cartografía de la selva misma. Con un golpe de ojo, podemos ver que la 
superficie en la que la hoja ha perdido su corporeidad representa fehacientemente, según los biólogos que lo acompañan en sus paseos por la selva lacandona, un reflejo real de la destrucción que el hombre ha provocado en la misma.

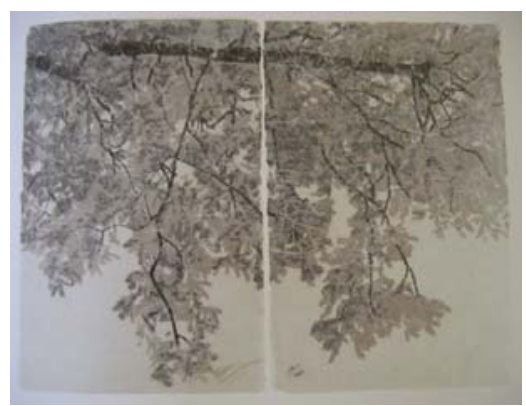

Jan Hendrix, Hortus, 1992.

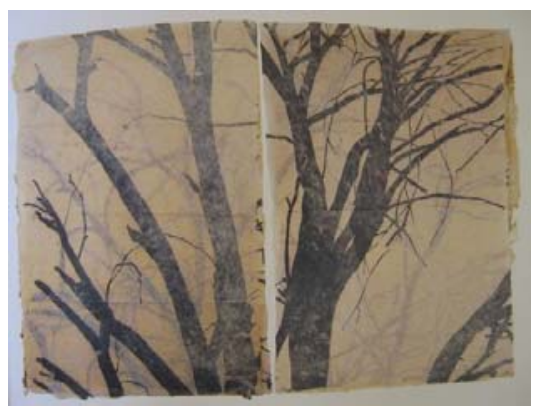

Jan Hendrix, Aguascalientes, 1993.

Una vocación de incansable viajero y naturalista lo ha llevado a realizar su obra en diferentes partes del mundo, realizando a su vez numerosos libros de artista. Compagina su labor gráfica con una profunda mirada como fotógrafo que le permite recavar la información necesaria para sus composiciones. Su trabajo se diversifica mediante la investigación de los materiales que utiliza, así como en los procesos en los que se ve involucrado como productor. Es interesante su continua colaboración con trabajadores y ciertos equipos de trabajo, que entraña una recuperación de procedimientos antiguos como el peltre266 que curiosamente, fue un material utilizado por Niepce para tomar la primera fotografía, lo cual tiene relación con el propio proceso de sus obras.

Podemos vincular la lectura de la obra de Hendrix a uno de los primeros filósofos en apuntar la experiencia estética en el terreno de la apreciación del arte y las corrientes estéticas desligada del sentido religioso como fue Anthony Ashley Cooper, Conde de Shaftesbury (1671-1713), quien junto con Edmund Burke son los representantes de la estética de lo sublime. Sus escritos propugnan la configuración de una ética humana partiendo de la creencia en la unidad y la armonía del universo, considerando necesario para el desarrollo de la virtud, el seguir la observación de la Naturaleza. La característica fundamental que da sentido a esta filosofía moral, por otra parte, común a todas las éticas humanistas, es el sentimiento de vida unitaria, la creencia en la existencia de un vínculo espiritual entre el individuo, la humanidad y el cosmos. A partir de este sentimiento de unión, el ser humano es pensado como un reflejo del todo, como un microcosmos en correspondencia directa con el todo de la sociedad y del universo. Así, las primeras obras de Hendrix remiten a una necesidad por proteger ciertas zonas de la devastación que el hombre realiza. A partir de esta premisa y de la confianza fundada en este sentimiento de unidad, de cohesión,

266 Peltre: Aleación de zinc, plomo, estaño y antimonio. Metal maleable, blando y de color blanco generalmente utilizado para adornos. Popularmente también se llama peltre a los utensilios de metal bañados con una capa cerámica o esmalte cerámico. 
de vida en común de todos los seres, adquiere pleno sentido y se llena de contenidos una ética basada en la responsabilidad y la colaboración. La estética y ética del paisaje en los Moralistas 267 presupone que de acuerdo con este ideal de armonía, la apreciación estética de la Naturaleza a través del paisaje, posee una eminente función ética: conduce al descubrimiento del sistema de correspondencias entre el ser humano y el mundo.

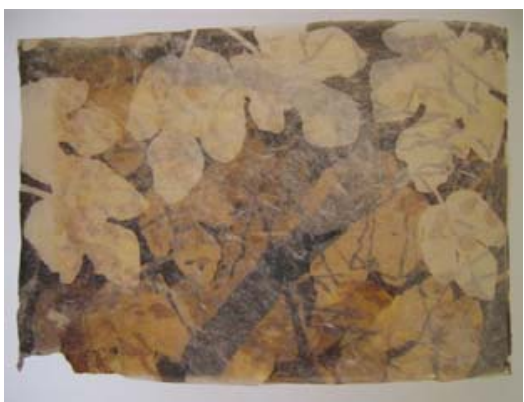

Jan Hendrix, Hortus, 1992.

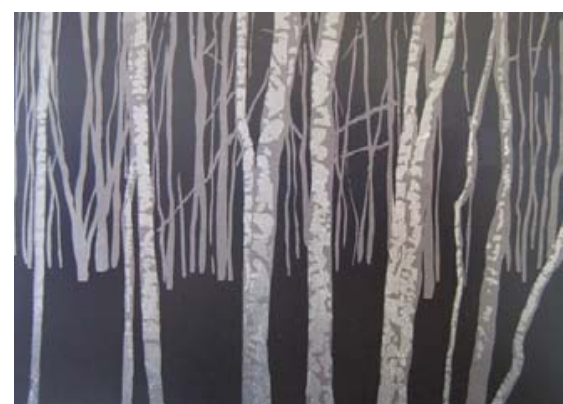

Jan Hendrix, Sin título, 1994.

Shaftesbury pone en boca de un personaje Teocles, la reflexión sobre el paisaje convertida en un himno al mundo natural, convocando al genio del lugar en los diversos mapas de la naturaleza268. Esta filosofía, implícita en el trabajo de Hendrix, nos trasmite la idea de los Moralistas de que lo salvaje agrada y nos acerca a una estética romántica de lo sublime. Hendrix al igual que Shaftesbury, antepone su idea de Naturaleza original a los laberintos artificiales y a las naturalezas fingidas, así las intervenciones arquitectónicas en las que ha participado, como veremos más adelante, muestran un afán por acercar su visión entrópica de la Naturaleza a la urbanidad de las ciudades.

Asimismo, cabe destacar cómo Hendrix utiliza la imagen en su obra, planteando la idea fotográfica de la imposibilidad de abarcar el todo. Ante la utopía de la imagen absoluta, el creador desgrana la realidad en instantes que son fragmentos intercambiables, que en su mutabilidad, permiten comprender la paradoja y la estructura del todo. Ya hemos hablado del proceso creativo del artista, de sus viajes y del registro fotográfico, sus dibujos y la recolección de materiales. Posteriormente, durante su trabajo en el taller, utiliza estos registros para hacer serigrafías. Desde la fragmentación de la realidad, la percepción de las sensaciones se disecciona para luego recomponer el todo, que no es posible sino a través del código. Un mapa hecho de partes. Este aspecto racional, de simplificación en su obra, ha sido relacionado con la estética oriental. Sin embargo, en opinión del autor, el factor de reducción que aplica en su obra es más parecido y más cercano a la obra de Mondrian que a la estética china.

267 Los Moralistas propugnan la base de una ética material que es el sentido moral innato en el hombre, sentido que no parte de la inteligencia, sino de una vivencia interior que arranca del sujeto mismo. El hombre es bueno por naturaleza.

268 LLORENS, Nuria, "Estética y ética del paisaje en Los Moralistas", Disponible en red en:

< http://ddd.uab.cat/pub/locus/11359722n8p349.pdf>, [Consulta 5, febrero, 2008]. 


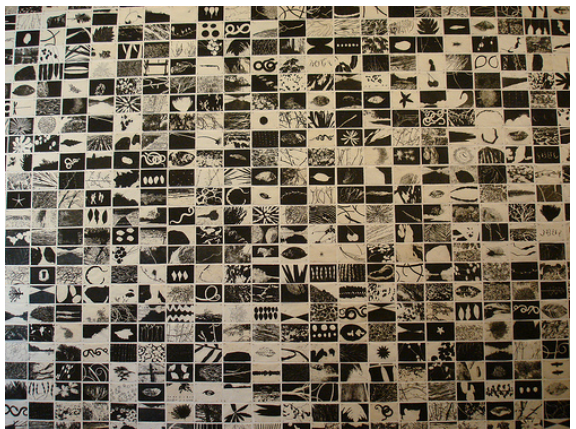

Jan Hendrix, Script, 2006.

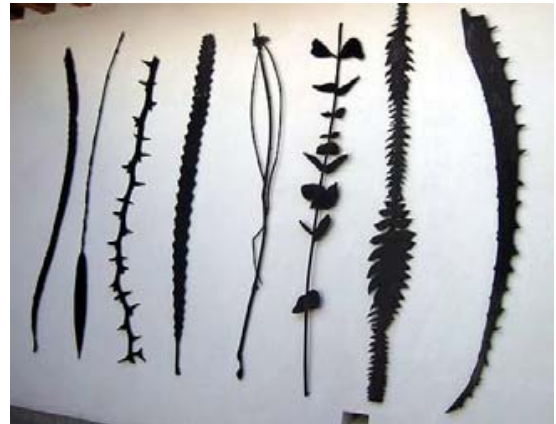

Jan Hendrix, Sin título, 2006.

Este es el origen de la obra Script (1989-2006), recopilación de una amplia serie de visiones, de momentos, de presentes y de pasajes que funcionan como instrumento de la memoria. Se trata de impresiones de imágenes sobre papel traslúcido cuya forma tanto al exhibirse, como al guardarse, recuerda a una colección de especimenes valiosos. En entrevista realizada con Hendrix por la autora de esta investigación en 2006, el artista declara que esta obra podría considerarse su disco duro, un registro en proceso que él mismo está nutriendo continuamente. Así la obra se convierte, no en una declaración cerrada, sino en un proceso infinito, como la vida misma. Es una fuente de información fragmentada que recoge todos los momentos e investigaciones que su autor ha ido compilando.

Utilizando las cualidades epistemológicas de las que goza el proceso gráfico, originado en el dibujo y con una economía de medios, el artista consigue usar la representación como un proceso de análisis de aquello que observa detenidamente. En Script cientos de pequeñas imágenes a una tinta y con un formato uniforme, se convierten en algo más que un álbum o una colección de estampas. El origen de esta pieza lleva en sí su propio proceso de gestación y de resignificación que, a manera de bitácora de viaje recoge las experiencias vividas y los viajes emprendidos. La composición -apunta Issa M. ${ }^{a}$ Benítez Dueñas- responde a la geografía de los lugares recorridos y no a una clasificación botánica.

En esta pieza el artista ha construido un espacio virtual donde todo está sucediendo todo el tiempo y en donde cada fragmento es a la vez la visión amplificada y parcial de un fragmento del mundo, [...]. Script es en lo que se ha convertido la Tierra después de que Hendrix la ha recorrido. Es su muy personal versión del mapa del mundo269.

En el año 2005 expuso en España en la Sede de la Calcografía Nacional junto a Miguel Ángel Blanco. En la muestra conjunta, titulada Botánica, se conjugaba arte, Ciencia y Naturaleza en obras que eran síntesis de historias personales. En

269 HEANEY, Seamus y BENÍTEZ DUEÑAS, Issa M. ${ }^{a}$, Jan Hendrix, Diario de fatigas, Turner, Fundación Cultural Artención, México, D.F., 2002, p. 18. 
esta exposición se hacía patente cómo el acto de mirar y de crear está ligado a la historia de la interpretación, de los símbolos y de los códigos. Hendrix transita por las plantas del mundo, por sus hojas, por sus venas, tallos y raíces, generando con sus reinterpretaciones múltiples asociaciones.

Hendrix empezó trabajando hace treinta años con paisajes realizados en pequeño formato que se han convertido en detalles de paisajes en gran formato, convirtiendo su trabajo en una especie de atlas de la Naturaleza. Esta circunstancia podría venir motivada porque de niño vivió en contacto cercano con la Naturaleza, tema central en su obra desde siempre y esta manera, casi infantil de observar hasta los más mínimos detalles del entorno, ha gestado una obra a la vez con mirada de bisturí y aliento fresco. Su forma de trabajar es como si hiciera un zoom en los elementos de la Naturaleza en busca de detalles, para crear con éstos un mapa del paisaje que represente otra manera de acercarse al mundo. En opinión de Cuauhtémoc Medina:

Decir que Hendrix es un artista que se ocupa de la naturaleza puede ser verdad, pero resulta insuficiente. Sus obras [...] muestran en efecto los rasgos del paisaje [...]. La naturaleza y los estados de la naturaleza: el tiempo y los fenómenos [...]. La naturaleza está sí, pero como materia. Lo que destaca de la obra de Hendrix es más que lo observado, la condición de quien observa270.

Asimismo, habla del registro de la Naturaleza como experiencia sensible. La obra gráfica de este artista-viajero es la mirada sensible a un paisaje o a un detalle de la Naturaleza. La forma no tiene realidad sin el espíritu, no hay fragmentos sin el todo. La reflexión de Jan Hendrix es innata, una especie de cualidad filosófica interior sobre la armonía de lo efímero y la transformación continua. Con una visión insaciable ante la Naturaleza, Hendrix se deja seducir por las formas puras y sus infinitas combinaciones, por los contrastes y por el movimiento dentro del extenso espectro visual. Su trabajo es un mapeo que recrea la nueva geografía del mundo ordenado a través de su mirada. El minucioso registro de un viajero, la precisión del observador, la investigación, el dibujo y la codificación de los seres que encuentra a su paso, son procesos integrados a su método, que revierten siempre en la creación de nuevos lenguajes. Cabe resaltar cómo el artista traduce tridimensionalmente, el alto contraste al que llega en su gráfica vegetal, en esculturas que persiguen la implicación del observador.

La pieza $X X L X X S$ (2004) tiene su origen en la exuberancia de la Selva Lacandona de Chiapas, cuya diversidad biológica es muy particular. Las visitas del artista a esta zona le permitieron trabajar en torno a diversos conjuntos de la extensa vegetación de este territorio. La recuperación de las sinuosas formas de las semillas de esta región chiapaneca a través del dibujo de Hendrix se convierte en volúmenes de bronce y juegos de luz. Estas pequeñas plantas recortadas en

270 MEDINA, C. y STELLWEG, C., Jan Hendrix, Consejo Nacional para la Cultura y las Artes, Eindhoven, 1994, pp. 11-12. 
metal se vuelven presencias de la problemática específica del entorno selvático. Una amalgama de siluetas con formas vegetales cuyas sombras proyectadas asumen igual o mayor importancia que el metal recortado, creando una tridimensionalidad en la bidimensionalidad de la obra.

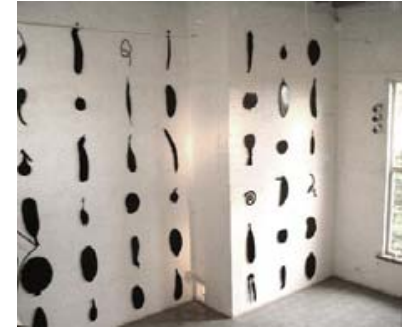

Jan Hendrix, XXL XXS, 2004.

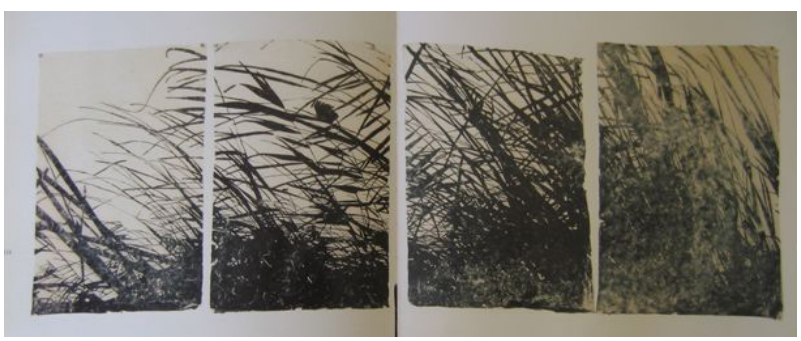

Jan Hendrix, Ezdná, 1992.

La aparente sobriedad y la nitidez de contornos es una constante en la obra de Hendrix, una característica que se repite en las obras presentadas en la Galería de Arte Mexicano (2002), a raíz de los recorridos realizados por Hendrix a través de los paisajes de la Italia mediterránea, donde los altos y austeros cipreses proyectan sus siluetas hacia una verticalidad infinita, a la vez que hacia la horizontalidad de sus propias sombras. En estas obras, los vacíos recrean presencias que reclaman su propio espacio y las líneas de fuga hablan de recorridos comunicantes a la vez que de zonas de relación y de vínculos de pertenencia. Los juegos de luces y sombras son una constante en sus obras, los guiños que la luz del sol provoca en nuestros ojos a través de las hojas de los árboles se convierten en el aire necesario para la existencia de cada ser, algo parecido a la idea del vacío que nos describe Cirlot, como realidad informal en la que se encuentra todo germen ${ }^{271}$. Así, Hendrix se desliza entre las transparencias de su obra gráfica y las masas y los vacíos de sus esculturas planas que, en ocasiones para ser, deben dejar de ser. Conexión entre positivo y negativo de las fotografías que usa para el registro de sus trabajos.

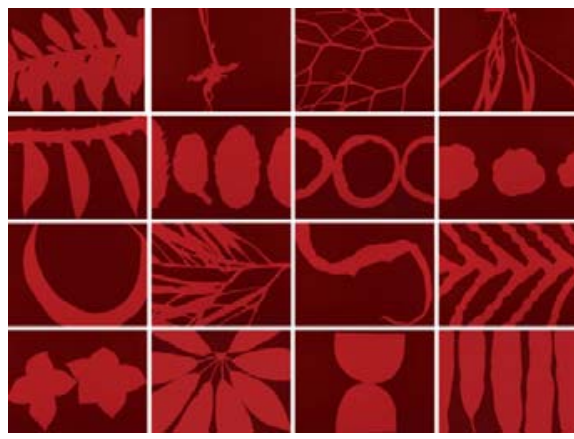

Jan Hendrix, After Nature I, 2003.

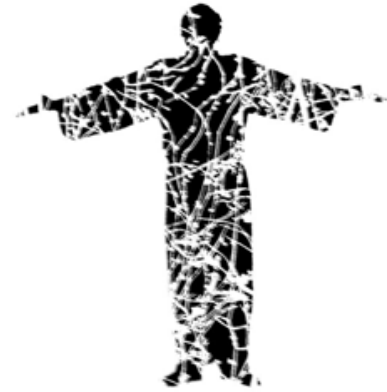

Jan Hendrix, Sin título, 2006.

Uno de los objetivos de esta investigación es descubrir la conexión entre lo vegetal y lo humano y, para ello, la obra Sin título, 2006, fotografiada en el taller

271 CIRLOT, Juan Eduardo, op. cit., p. 455. 
del artista, nos ofrece una pauta de interpretación. En ella, podemos observar una silueta negra de un hombre con un kimono o hábito de monje. La figura del personaje, llenando toda su superficie, es atravesada por formas vegetales blancas que destacan sobre el fondo negro de la vestidura, lo vegetal define el espacio de lo humano. La relación es nítida, no hemos encontrado entre las obras documentadas de Hendrix, otro ejemplo similar a éste, sin embargo, esta pieza explica en parte, la constante conexión con lo vegetal que el artista siente.

Por otra parte y específicamente en cuanto a la problemática ecológica, en entrevista concedida a Marta Carrasco 272 , Hendrix declara -en su posición de creador- que en relación con la Naturaleza, la coincidencia de su trabajo con la contemporánea denuncia de la destrucción de la Naturaleza remite, más que a una intención declarada por su parte a una mera coincidencia. Dentro de estos planteamientos las sensaciones de paz y armonía que su obra trasmite es a la vez una reivindicación por los temas que efectivamente son su interés como la selva tropical, pero desde un formato extemporáneo, nunca desde la contemporaneidad instantánea. Cuauhtémoc Medina señala una relación con lo sereno y lo equilibrado, pero también con la denuncia de la continua violación y devaluación del entorno.

En las serigrafías de Hendrix el detalle se reduce a una simple gradación de tonos, transparencias, masas y vacíos [...] estas serigrafías buscan ser serigrafías sin más. En el sentido en que despojan la ilusión del tema y nos hacen conscientes de la creación y los valores propios del medio: la homogeneidad del continuo del plano, la gama de tonalidades $y$ transparencias 273 .

La repetición de patrones vegetales parece obedecer a la recomposición de una estructura a la vez imaginaria y real.

Las hojas minuciosamente vistas, recorridas y viajadas son casualmente los mapas utópicos de la persona. Son un reflejo puntual de todos los esquemas de conocimiento previos al momento en que son devueltos con la técnica, la escala y el material más preciso. A su vez, representan una mitología personal de un orden secreto donde, además de la botánica y la técnica, tiene cabida, por suerte, la poesía ${ }^{274}$.

Además de la temática, otra de las características por las que su trabajo es fundamental para nuestra investigación es por las intervenciones arquitectónicas en las que Hendrix ha colaborado con arquitectos. En estas ocasiones, su obra plantea un juego de escalas y un cambio de perspectiva, no sólo a nivel de

\footnotetext{
272 CARRASCO, Marta, "Jan Hendrix, pintor. El arte ha quedado para la élite", en $A B C$ de Sevilla, Sección Cultura, 12, mayo, 2005, p. 62.

273 MEDINA, C. y STELLWEG, C., op. cit., p. 28.

274 CLARK, Kenneth, Material divulgativo exposición: Botánica, Miguel Ángel Blanco-Jan Hendrix, Museo Nacional de la Estampa, CONACULTA, México, D.F., 2003.
} 
dimensión, sino también de imagen y función de la obra en el contexto arquitectónico.
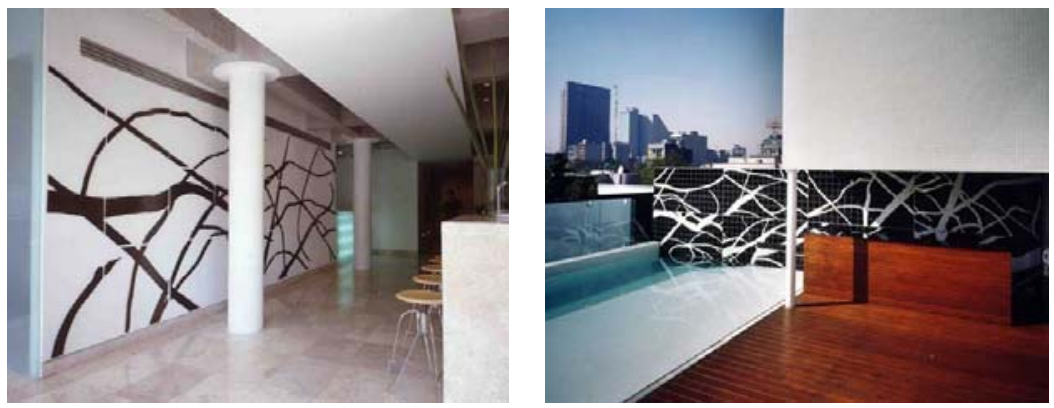

Jan Hendrix, Hotel Habitat, 1996-2000.

En entrevista con Guadalupe Alonso, Hendrix relata sus recientes incursiones en la escultura y sus colaboraciones en diferentes proyectos arquitectónicos. En este tipo de trabajos, la obra del artista visual ya no es considerada como un objeto aislado, sino que se incorpora desde el inicio de la concepción del proyecto, como parte integral del mismo. Su idea actual en cuanto a estos proyectos, completamente alejada de la retórica que en relación a estas prácticas imperaban durante la Revolución Mexicana, consiste en redefinir la funcionalidad del arte en relación con la arquitectura:

Lo que me interesa es la colaboración real, el hecho de que el arquitecto invite al artista a su espacio y viceversa [...]. Gracias a la arquitectura, se me ha presentado un catálogo de materiales que no son los que se usan en el taller, sino en la construcción. Estos nuevos soportes me han permitido ampliar la escala, algo que ya había experimentado con los papeles grandes, pero ahora esa escala la puedo llevar a los metales, los cristales, las mallas y otros materiales que son muy propios de la arquitectura [...] con la técnica que utilizo en la serigrafía, se puede imprimir sobre cualquier superficie plana: puede ser triplay, madera, piso, techo, pared, cristal, etcétera275.

En esta línea ha construido diferentes visiones de paisajes, piezas que se superponen al paisaje urbano o al arquitectónico en el que se encuentran las obras, generando una experiencia diferente del espacio. En este tipo de proyectos podemos destacar entre otros, el mural en bronce realizado en el Hotel Habitat, en México, D.F. Allí podemos encontrar en el vestíbulo y en el restaurante de la planta baja, una serie de murales. El mural realizado en la piscina está compuesto de mosaicos de cerámica blanca y negra hechos especialmente para el lugar. En esta ocasión Hendrix colaboró con los arquitectos Enrique Norten y Bernardo Gómez Pimienta.

Así también, el plafón para el techo de la Librería Rosario Castellanos del Fondo de Cultura Económica, realizado en 2006 en el Centro Cultural Bella Época, en

275 ALONSO, Guadalupe, "Entrevista con Jan Hendrix. Storyboard", en Revista de la Universidad de México, UNAM, N²46, México, D.F., diciembre, 2007, pp. 61-64. 
México, D.F., resulta del trabajo conjunto con el arquitecto Teodoro González de León. Esta pieza está compuesta por doscientos cincuenta paneles de cristal esmerilado de $260 \times 170$ centímetros cada uno, pintados con tinta epóxica y horneados. La composición reproduce a escala ampliada el dibujo de una rama de bambú.

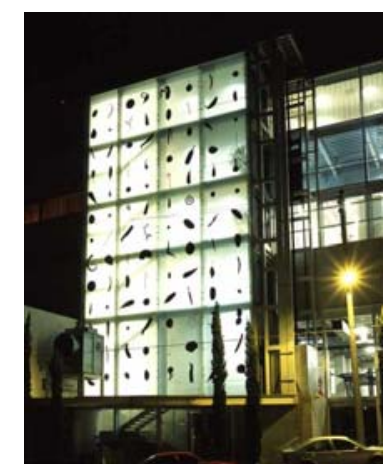

Jan Hendrix, Centro de Diseño, Cine y Televisión, 2004.

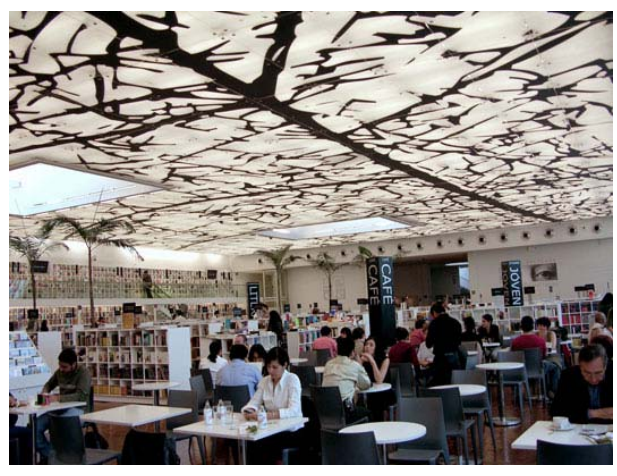

Jan Hendrix,

Librería Rosario Castellanos, 2006.

En el año 2004 Hendrix, en colaboración con Uzyel Karp y los arquitectos Alejandro Hernández y Carlos Tello, realizó el diseño de la fachada del Centro de Diseño, Cine y Televisión en México, D.F. El proceso aquí consistió en aplicar tinta cerámica sobre cristal templado, con una cara esmerilada. En esta obra, las siluetas contundentes se convierten en presencias evocadoras, en una especie de tatuajes que marcan el lugar como huellas. La dialéctica entre llenos y vacíos, luces y transparencias provoca un juego dinámico en el espacio. Presencia de la ausencia, ausencia de la presencia. Naturaleza observada y reinventada, ampliada y construida. El concepto de naturaleza vegetal de Hendrix en esta obra es una reflexión sobre la belleza estética. Este trabajo está concebido como si de ideogramas 276 se tratara, como la elaboración de un alfabeto de semillas con el que se busca hablar generalmente de otra cosa. Aquí la multiplicación de imágenes diversas y similares de semillas en un soporte arquitectónico, se convierte en una afirmación taxonómica y simbólica. La esencia de las formas, la similitud y diversidad de las muestras vegetales proyectan una promesa de futuro sobre los elementos del paisaje arquitectónico, sobre el futuro promisorio de los estudiantes y en lo que a los procesos de germinación se les puede

276 Un ideograma es una representación gráfica de una idea. La escritura en ciertos idiomas, como el chino o el japonés, está fundamentada en determinados símbolos que representan palabras o ideas completas. Los ideogramas suelen formarse por la combinación de pictogramas, o sea caracteres que indican una idea mediante una representación gráfica de la misma. Así en chino el pictograma que significa "persona", es una representación del perfil de un hombre; la forma de un árbol o cuando se dibujan dos árboles, se lee como "bosque". 
remitir como individuos. Siluetas que funcionan como un código legible de referencias coherentes entre sí277.

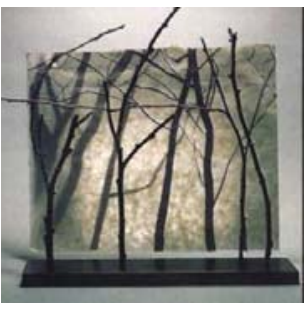

Jan Hendrix, Klein bos, 1992.

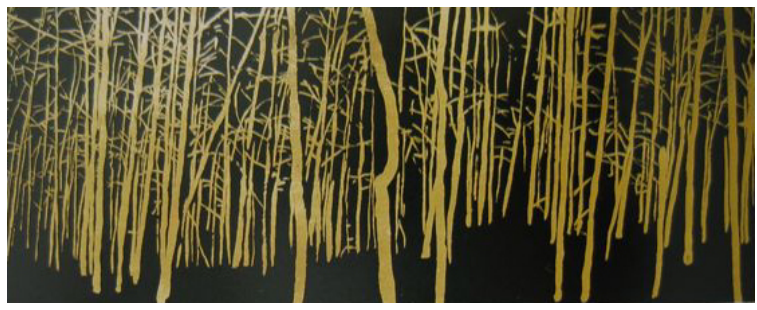

Jan Hendrix,

Bosque, 1993.

En 2006, en la Fundación César Manrique, Hendrix hace un homenaje a la vida vegetal de Lanzarote. En su exposición titulada Malpaís, además de su habitual trabajo gráfico, realiza una pieza escultórica que cierra el recorrido expositivo. Una espiral de $4 \times 4 \times 4$ metros situada en un espacio circular de siete metros de diámetro, que funciona como una linterna mágica de metal recortado (aluminio lacado en blanco). Esta pieza, como si de un evocador sueño se tratara, nos remite como el resto de su obra a un fino encaje o filigrana.

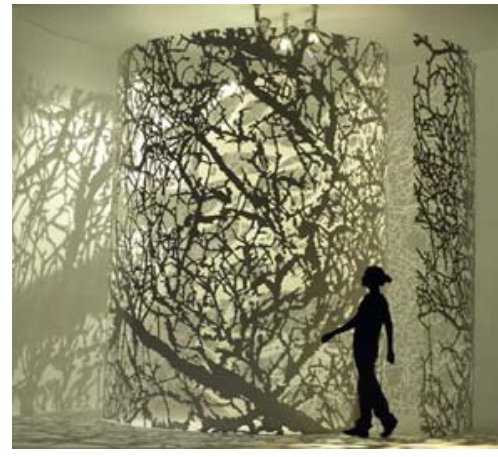

Jan Hendrix, L O (maqueta), 2008.

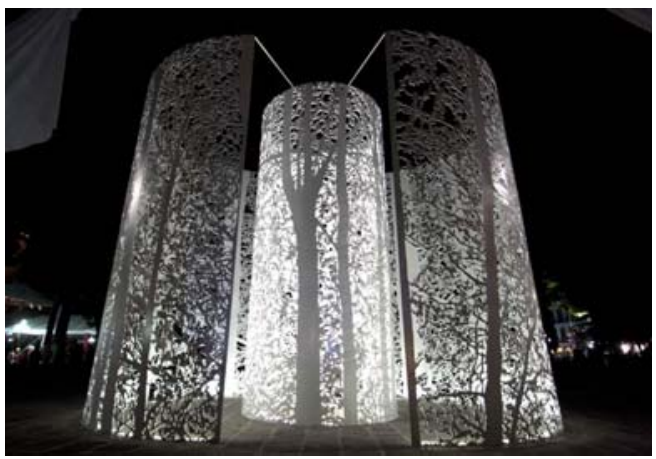

Jan Hendrix, Refugio, 2009.

Como hemos podido apreciar, las proyecciones de sus grafías en el plano tridimensional son frecuentes. Con el proyecto de la escultura Refugio (2009), en homenaje a Ángeles Espinosa Rugarcía realizada en la ciudad de Puebla, en el Estado de Puebla, Hendrix recurre a una estructura relacionada con los parques y las plazas públicas en México, el kiosco que funciona como aglutinador de actividades públicas. Así, diseña un espacio que con el tipo de llenos y vacíos que le caracteriza permite a la obra fusionarse con el entorno de los árboles.

Por todos los aspectos que hemos revisado en torno a cada uno de los artistas aquí tratados y para finalizar este capítulo, podemos concluir que la obra tridimensional $-y$ en particular en lo que a su aspecto vegetal se refiere- de

277 BENITEZ DUEÑAS, Issa M. ${ }^{a}$ et al., Signos de origen, Centro de Diseño, Cine y Televisión, México, D.F., 2006. 
estos tres artistas debe considerarse un antecedente importante en las reflexiones en torno al binomio Arte y Naturaleza en México. La obra de Helen Escobedo es precursora y un referente histórico en México por su interés en la temática ecológica, así como por sus intervenciones efímeras en espacios públicos específicos. Destacamos su afán por acercar la obra de arte a un mayor número de espectadores. Resaltamos la labor de Marta Palau por su apuesta por los materiales alternativos, pobres y orgánicos y por su visión mítico-mágica de la Naturaleza que descubre una manera alternativa de recuperar la tradición cultural de México. En cuanto a Jan Hendrix, cabe subrayar la traducción tridimensional que de una concepción particular del paisaje redunda en beneficio de una grafía que se percibe escultórica y que tiene como fuente fundamental de inspiración, el mundo vegetal. 


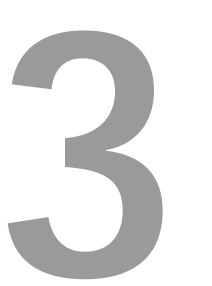

LAS PLANTAS COMO REFERENIE FORMAL 

El arte necesita de la mirada del otro para existir278. En este acto de reconocimiento, toda realidad atraviesa por el tránsito de la mirada entendida ésta, no sólo como el vínculo con lo visual, sino también con todos aquellos sentidos tanto físicos como intelectuales que nos identifican como seres humanos. En el contexto artístico de esta investigación, hablamos del otro como del receptor, observador, espectador o público que capta con su mirada la obra de arte, aquel cuya mirada nos es indispensable para descifrar el mensaje.

El otro por definición, es un sujeto extraño, externo, distinto de uno mismo. El otro es lo incógnito, pero sólo hasta cierto punto, ya que nos resulta indispensable para constituirnos como seres humanos: en cierta manera, somos desde la mirada del otro [...] 279.

Para Félix Duque "toda obra de arte está destinada a la contemplación"280. Si bien, aceptado este principio, el comentario de Duque apunta hacia la posibilidad de arrebatar el arte de la tiranía de la contemplación privada para entregársela al público. Podemos decir entonces que, sólo cuando la obra es contemplada por el espectador se concluye el carácter maleable o plástico de la misma.

Al igual que la obra, debemos considerar que también el público es materia dúctil y, que a su vez se transforma, tanto en el proceso de percepción, como en aquellas obras que requieren su participación. La participación del espectador más allá de la contemplación, es fundamental. Como afirma Frank Popper en relación a determinados artistas, es de hecho, "no sólo deseable, sino esencial, pues vitaliza la relación objeto/entorno"281. Duque participa de esta idea al afirmar que el carácter "plástico de las obras, o sea la capacidad moderna de moldear ab libitum un material dócil, se extienda igualmente al espectador" 282.

Por otro lado, debemos tener en cuenta que tanto desde la perspectiva del receptor, como desde la del hacedor o creador, el arte está habitualmente relacionado con el artificio. Bajo esta perspectiva podríamos decir que es el artificio el que nos configura como humanos. Para Clément Rosset quien defiende la concepción del mundo como artificio 283 , no hay otra estética que la del artificio $^{284}$ y sólo cuando el hombre, renunciando a la idea de Naturaleza

278 ABARCA, Inmaculada, "Del simulacro a la magia de la realidad", en $D[X] I$ Magazine. Cultura \& Post-diseño, $\mathrm{N}^{\circ} 30$, Valencia, 2008, p. 40.

279 CEREIJIDO, Marcelino et al., El otro, el extranjero, Zorzal, Buenos Aires, 2003, p. 50.

280 DUQUE, Félix, "El arte (público) y el espacio (político)", en MADERUELO, Javier (dir.), Arte público..., op. cit., pp. 109-110.

281 POPPER, Frank, Arte, acción y participación, El artista y la creatividad de hoy, Akal, Arte y Estética, Madrid, 1989, p. 187.

282 DUQUE, Félix, "El arte (público)...", en MADERUELO, Javier (dir.), Arte público..., op, cit., p. 110.

283 ROSSET, Clément, La antinaturaleza, Taurus, Madrid, 1974, pp. 9-10.

284 ROSSET, Clément, op, cit., p. 93. 
como una de las sombras de lo divino, asuma plenamente el artificio, será capaz de entender su propia esencia.

En relación a la creación de obras de arte, Dorfles señala la fina membrana que separa artificio de Naturaleza, sosteniendo que artificio es todo lo hecho de manera artificial, pero también, todo aquello para lo que se emplea un método o un medio 285 , o sea un arte. En definitiva, estamos rodeados de artificio, puesto que la mayoría de cosas que rodean al ser humano están realizadas según estos criterios. Así tanto los objetos cotidianos como las obras de arte son parte de nuestra existencia.

Sin duda, en el mundo consumista en el que vivimos, es difícil ignorar la trascendencia de los objetos:

[...] la importancia asumida por los objetos que nos rodean se ha vuelto casi tan grande como la de la naturaleza que nos ha creado y de la que está constituido nuestro planeta286.

A lo largo de la Historia del Arte varios son los movimientos que han resaltado el carácter cotidiano de los objetos en nuestras vidas, convirtiéndolos a su vez, en protagonistas de nuestra experiencia estética. Históricamente, Marchán Fiz reivindica el "Principio Collage"287, como detonante de la preponderancia del objeto que, trascendiendo el límite histórico de su origen cubista, traza un recorrido que va desde Duchamp y los primeros Ready-Mades, hasta al Dadaísmo, el Surrealismo, pasando por el Pop Art, hasta llegar al Arte Objetual. Éste último se hace eco del valor de los objetos en la sociedad moderna e, identificando los niveles entre la representación y lo representado, borra las diferencias que hasta entonces establecían los principios tradicionales ilusionistas. La reflexión se desplaza hacia las relaciones asociativas que los objetos convocan a nuestra percepción.

El arte objetual alcanza su plenitud en sus posibilidades imaginativas y asociativas, libres de imposiciones, en el preciso momento en que el fragmento, objeto u objetos, desencadenan toda una gama de procesos de dacción de nuevos significados y sentidos en el marco de su banalidad aparente 288 .

Concretando, puesto que la necesidad del artificio es uno de los pilares sobre los que se asienta nuestra destreza para sobrevivir, en la búsqueda y realización de nuestro locus existencial hemos desarrollado toda una gama de procesos que nos identifican como seres humanos, entre los cuales se encuentran los objetos y la realización de obras de arte relacionadas con ellos. En el tránsito del locus como hogar (domus) al locus amoenus, el hombre -como artesano- y el artista -

\footnotetext{
285 DORFLES, Gillo, op, cit., p. 16.

286 DORFLES, Gillo, op, cit., p. 56.

287 MARCHÁN FIZ, Simón, op. cit., 2001, p. 159.

288 MARCHÁN FIZ, Simón, op. cit., 2001, p. 168.
} 
por extensión- manipula todas las herramientas, tanto físicas como conceptuales que están a su disposición para acercarse a ese lugar idílico del que cree provenir.

Desde esta perspectiva, la mirada del artista contemporáneo recorre su entorno configurando a su alrededor toda una suerte de construcciones que van desde la concepción del lugar como casa (lugar donde habitar, donde sentirse protegido, donde poder crecer...), hasta la experiencia de su propio ser. Con ello aprehende las múltiples facetas del espacio que le rodea para después, desplazar su visión fuera del hogar en que vive y se desarrolla. Al considerarlo como propio, va construyendo poco a poco hacia el exterior, hacia el mundo, la realidad circundante, apropiándose mediante la experiencia, del espacio en el que vivimos, integrándolo a nuestro ser. Así, nuestra concepción actual del hogar se ha expandido hasta considerar como tal, todo el mundo que nos rodea, la Naturaleza ha entrado a formar parte del hogar del hombre occidental, de aquello que le corresponde y a lo que debe respetar y cuidar. Como veremos más adelante, en nuestra investigación, la escultura como disciplina de reflexión, encuentra diferentes modos con los que acercarse a este planteamiento.

Constituyendo una de las maneras de reflexionar sobre la existencia, la mirada contemporánea del arte se caracteriza por analizar el devenir de lo cotidiano, partiendo de un proceso de desconstrucción. El término desconstrucción fue acuñado por el filósofo del lenguaje Jacques Derrida para describir un método de lectura de textos en el cual, los elementos conflictivos del mismo, se utilizan para cuestionar toda interpretación o significado considerado inamovible o fijo. Para Derrida la desconstrucción es:

[...] la operación de desmontar un edificio o artefacto, para que puedan aparecer sus estructuras a la vista, [...] y al mismo tiempo, pueda observar la precariedad formal [...]. No es algo meramente negativo ya que junto a la operación del desmontaje va implícita la afirmación de una propuesta constructiva289.

Bajo estas premisas y, tras haber esclarecido algunos antecedentes en la obra de los artistas que vimos anteriormente como iniciadores de estas preocupaciones, seguiremos la trayectoria de artistas que en México han desarrollado una fina trama de reflexiones sobre el valor del espacio y del lugar que ocupamos, desde diferentes planteamientos.

En este tercer capítulo, revisaremos la trayectoria de aquellos artistas que, dentro del objeto de nuestro estudio, han utilizado lo vegetal como un referente formal para explorar el mundo que les rodea. Así, artistas como Naomi Siegmann, Federico Silva Lombardo, Ivonne Domenge, Betsabée Romero o Maribel Portela, entre otros, nos permitirán entender cómo lo vegetal canaliza la

289 DERRIDA, Jacques, El tiempo de una tesis. Desconstrucción e implicaciones conceptuales, Proyecto A, Biblioteca Universitaria, Barcelona, 1997, p. 7. 
posibilidad de conceptualizar nuestro entorno, desde una perspectiva antropológica y desde una visión excéntrica.

\subsection{Lo cotidiano como natural. Naomi Siegmann}

La escultora Naomi Siegmann (Nueva York, 1933) comenzó tardíamente en la escultura, iniciándose en el taller de la escultora Tosia Malamud entre 1963 y 1968 y posteriormente formándose con Enrique Miralda, de 1968 a 1970290. Alejándose de los postulados de los Geometristas y de las corrientes experimentales del momento, así como de sus primeros escarceos con obras organiformes, a partir de 1976 desarrolló una vertiente figurativa basada en la poética del objeto cotidiano.

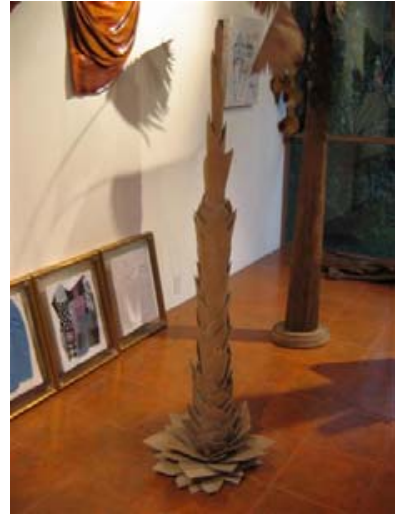

Naomi Siegmann,

Quiote, 2005.

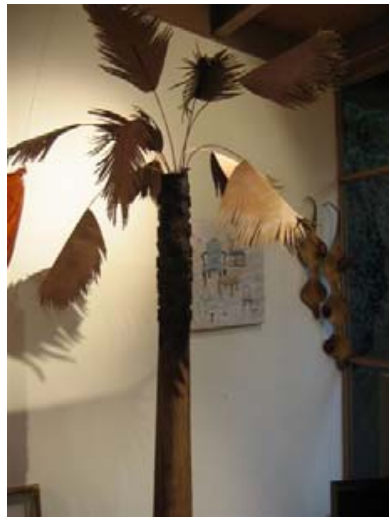

Naomi Siegmann,

Palmera, 2003.

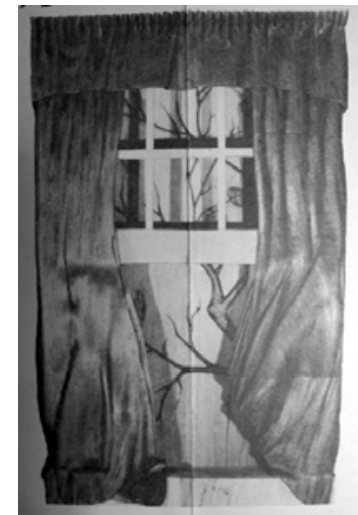

Naomi Siegmann, Ventana II, 1979.

En su obra, todos aquellos objetos que en su momento la rodeaban cobran una nueva vida latente y trascendental, sus realizaciones recuperan la existencia de esa cotidianeidad para enfrentarnos a un nuevo objeto ensimismado; objetos recubiertos en su fisicidad, de una nueva espiritualidad. Más que de una poética del objeto recreado, podríamos hablar de una mística del entorno cercano. Esculturas como Sofá (1979), una talla directa en caoba ensamblada de tamaño natural, expuesta en el mismo año en el Museo de Arte Moderno de México, D.F. confrontan tanto al objeto recreado como a la mirada del que contempla la obra.

En su dilatada trayectoria, Siegmann ha trabajado con numerosos materiales pero es con la madera, con la que la intimidad de los objetos encuentra una nueva y tersa piel con la que llamar nuestra atención y acercarnos a su existencia próxima y real. Se trata de una nueva realidad trasmutada en coloquial que establece un diálogo entre sus rotundas presencias y el silencioso

290 MANRIQUE, Jorge Alberto, "Escultura viajera", en AA. VV., México en el mundo de las colecciones de arte. México Contemporáneo, Tomo I, Conaculta, Unam, Secretaría de Relaciones Exteriores, México, D.F., 1994, p. 163. 
alboroto de la ausencia de personajes. Ausencias y miradas palpables que invitan e incitan al espectador a apropiarse de la sustancia de la obra.

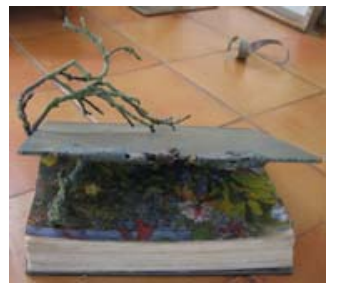

Naomi Siegmann, Libro, 2001.

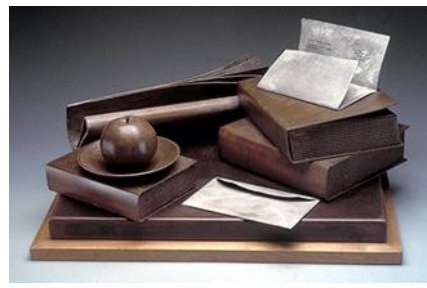

Naomi Siegmann,

Libros con manzana, 1999.

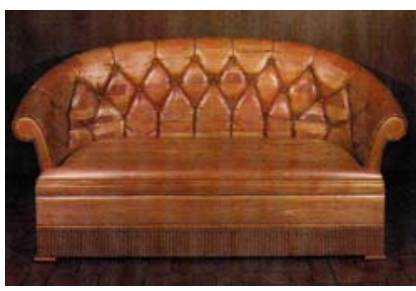

Naomi Siegmann, Sofá, 1979.

Para el crítico Jorge Alberto Manrique el trabajo de Siegmann se centra en un naturalismo puntilloso que, rallando en la neofiguración Neovanguardista se inscribe en el Hiperrealismo, apuntando a una "representación verista, exageradamente detallada, de escenas que existen en la realidad tangible"291 y que consiguen un fuerte impacto. Podemos afirmar con Manrique que cualquier elección temática evidencia la mirada personal del artista así como un concepto particular del arte mismo y de la realidad circundante. Pero en nuestra opinión, el caso de Siegmann describe una representación que no se ancla ni en el Surrealismo ni en el Hiperrealismo como movimientos. Sin lugar a dudas sus obras no persiguen la mímesis como objetivo final, sino que se inscriben en planteamientos conceptuales más contemporáneos. Más allá del virtuosismo y de los recursos técnicos, las soluciones formales que plantea Siegmann rebasan el ilusionismo como efecto, para anclarse como recurso estético, en la seducción de la mirada del observador.

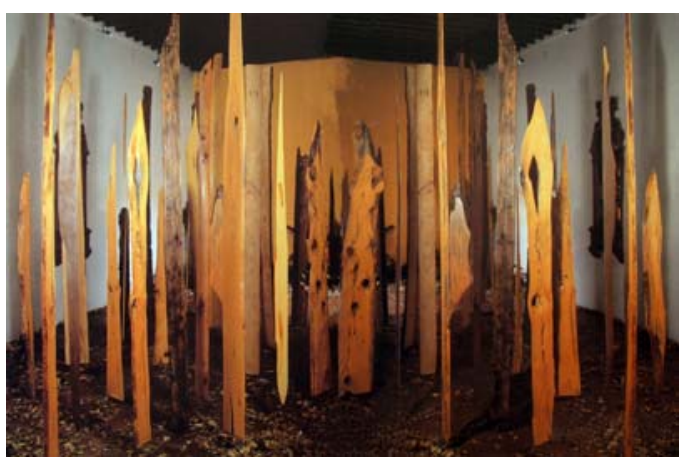

Naomi Siegmann,

Bosque, 2003.

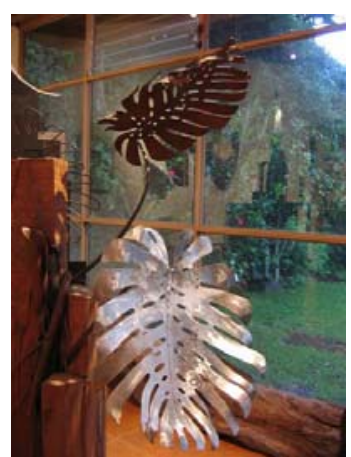

Naomi Siegmann, Philomena deliciosa, 2003.

En torno a la recreación de objetos cotidianos y respecto a la obra realizada por esta artista, Teresa del Conde comentaba que con Naomi Siegmann, "Ios "fantasmas" de la ropa, el jabón, la cortina de baño, el pan que está sobre la mesa, se introducen a un material orgánico: la madera o [...] el mármol; para

291 MANRIQUE, Jorge Alberto, "Escultura viajera", op. cit., p. 164. 
crear analogías que reproducen ciertos usos cotidianos de la vida burguesa actual"292.

Asimismo, Manrique opina que Siegmann, por su filiación hiperrealista, registraba con esos objetos, testimonios de los hábitos de la burguesía del momento. En nuestra opinión, si bien es cierto que estos objetos nos remiten a un contexto social particular, su singular existencia se inscribe en un universo colectivo y nostálgico que da sentido al concepto de hogar. Entendemos el concepto de hogar como el lugar donde nos encontramos con nosotros mismos, el espacio donde se genera y se comparte la intimidad, donde la convivencia se nutre del diálogo. Esta conversación pausada con la materia, es la que mueve a Siegmann a recorrer los hitos que marcan la dimensión humana del habitar a través de la metáfora que concurre en los objetos que representa. Porque efectivamente, todos y cada uno de sus objetos en gran medida, manifiestan la cercanía de un ser humano que los ha intervenido, utilizado o tocado. Con ello, la escultura de Siegmann inicia el tránsito de la mirada al tacto, incitando a una de las mayores provocaciones de la escultura: la necesidad de ser tocada ya que las superficies y texturas de sus obras, nunca son fruto de la casualidad sino de una austera seducción de las formas.

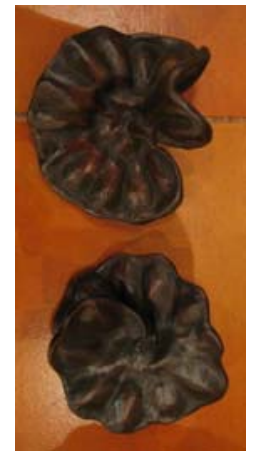

Naomi Siegmann,

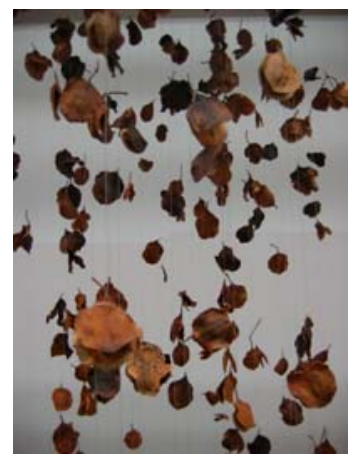

Naomi Siegmann,

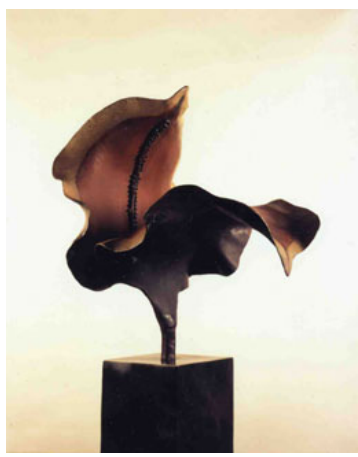

Naomi Siegmann, Vainas de parota, 2003. Lluvia de Jacaranda, 2003.

Jacaranda abierta, 2003.

En su aspecto más provocativo, su obra juega a seducir la mirada del espectador, constituyendo un guiño sutil que nos convoca a diferenciar entre los objetos verdaderos y la creación aparentemente mimética de la artista. Estos trabajos hablan de la línea ambigua que separa realidad de arte. En esta óptica Donald B. Goodall apunta:

Siegmann insiste en el carácter distintivo e individual de sus objetos que se tornan en iconos de nuestra existencia actual y que surgen como nuevas

292 CONDE, Teresa del, "Analogías cotidianas de Naomi Siegmann", en Esculturas. Naomi Siegmann, Artista mexicano-norteamericana, Museo de Arte Moderno, Instituto Nacional de Bellas Artes, septiembre-octubre, 1979, p. 3. 
unidades frente a todo aquello que antes $y$ simplificadamente denominábamos nostálgico293.

En la búsqueda de esta nueva resignificación del objeto cotidiano sus piezas cobran un fuerte poder expresivo, un poder evocador que nos empuja a descifrar su discurso. En el conjunto de la obra subyace una narrativa por la elección del momento decisivo, un espacio para la vida suspendida, generando así una dinámica de escenarios posibles. Se hace patente una disposición escénica en la que la escenografía creada, convoca a una sobria teatralidad. Este escenario se impregna de momentos puntualmente vívidos que muestran una frágil, pero contundente existencia entre la solemne seriedad de la puesta en escena y el devenir lúdico de los objetos creados. Así, estos objetos se caracterizan por tejer una fina red entre su existencia inmóvil y una potencial movilidad impresa en cada una de las texturas con las que la artista trabaja las superficies de sus piezas: arrugas, vestimentas y telas están imbuidas de una suerte de aliento humano.

Sus esculturas están ubicadas en un puente peculiar entre lo quieto y lo móvil, entre lo serio y lo risible, entre lo real y lo idolizado, entre lo obvio y lo secreto, entre tiempos detenidos y tiempos pasados, entre lo real y la evocación mnémica, entre lo personal y lo ajeno, entre lo experimentado y lo visto en otros, entre lo deseado y lo realizado, entre lo formal y lo informal, entre lo conservado y lo desechado, entre lo poético y lo evidente, entre lo surreal y lo cotidiano, entre lo abstracto y lo biológico, entre lo hiperrealista y lo abstracto, entre una parodia y una verdad294.

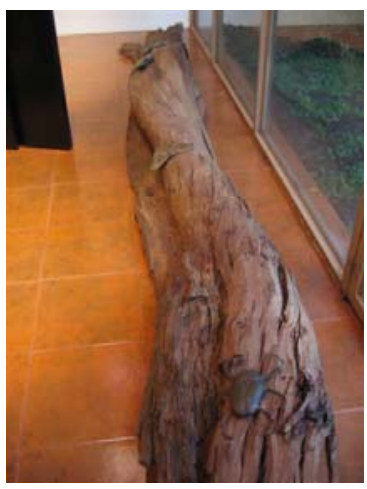

Naomi Siegmann, Tronco con insectos, 2003.

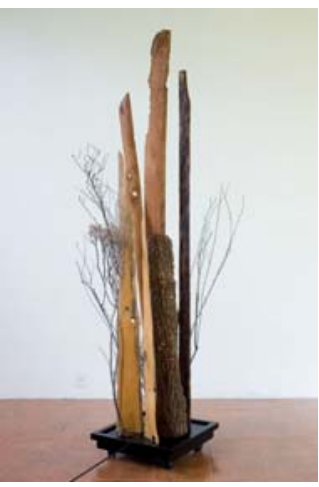

Naomi Siegmann, Bosque portátil, 2007.

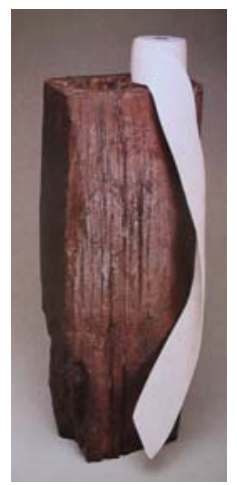

Naomi Siegmann, Viga 2-C con rollo de papel, 1988.

Los objetos de Siegmann lejanos por su manufactura a los ready made de Duchamp, describen una trayectoria de la forma a la idea, de la misma manera

293 GOODBALL, Donald B., Esculturas Naomi Siegmann, 1971-1992, Véase material divulgativo de la exposición, Museo Universitario del Chopo, México, D.F., marzo, 1992. 294 KARTOFEL, Graciela, Naomi Siegmann, Katún, Serie Artelibro 1, México, D.F., 1985, p. 33. 
que las prácticas creativas de Claes Oldemburg o el tránsito posible que Meret Oppenheim realiza en su pieza Objet (Objeto) 1936, en donde la teatralidad se vuelve trasgresora y supera los principios de la ortodoxia del Arte Minimal enfatizando la desviación de la percepción, hacia el componente vitalista y sensual de los objetos295.

Si observamos la obra Viga I/ con rollo de papel (1988), veremos que en esta escultura, el rollo de papel blanco está realizado en madera mientras que la viga que, aparentemente es de madera está realizada paradójicamente en bronce. Siegmann no trata de confundirnos con esta técnica ni de trasmutar el material real de los objetos. Su profundo respeto a la madera como materia viva le hace conceptualizarla como lo que es, un material en constante evolución y por esto mismo la artista requiere de nuestra mirada para hablarnos de esa vida de la que nos hace partícipes. Así consigue Siegmann que en obras posteriores de sus vigas, sean éstas de madera o no, comiencen a emerger plantas que utilizan la paradoja como retórica para construir metáforas de crecimiento y de belleza.

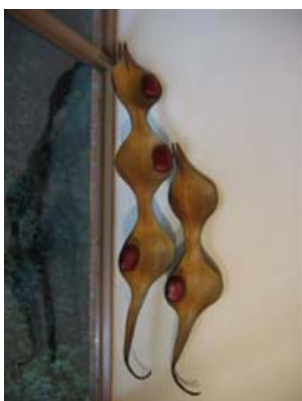

Naomi Siegmann, Colorines, 2004.

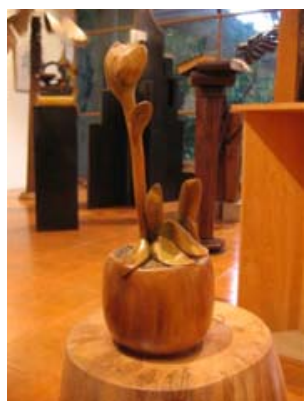

Naomi Siegmann, Flor antigua, 2005.

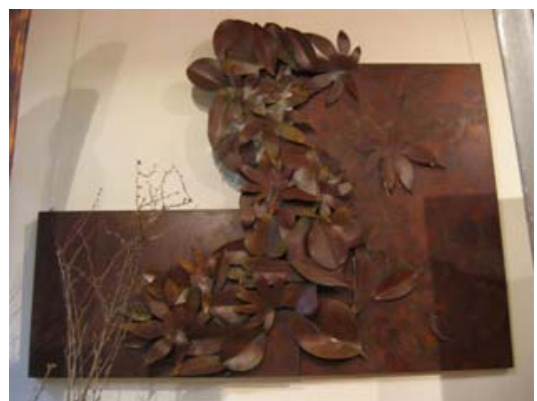

Naomi Siegmann,

Florium, 2004.

El principio ante el que nos sitúa la obra de Siegmann diluye la barrera entre lo privado y lo público, descontextualizando los objetos para situarnos en parajes en los que en algún momento, todos nos hemos sentido inmersos. Su relato plástico nos hace creer en la posibilidad real de una comunión con la vida. $Y$ aunque la realidad nos demuestra que el arte se nutre más del mismo arte que de la Naturaleza misma, la persistencia de ciertas iconografías nos demuestra que éstas forman parte de nuestro ser social.

Las imágenes constituyen, desde siempre pero especialmente en la actual sociedad de la información, un imaginario complejo que nutre nuestro mundo, al punto de convertirse en un éxtasis de la mirada, casi en una perversión. El reverso de esta mirada pervertida nos introduce en el mundo de la seducción a través del simulacro. En términos antropológicos, Alfredo López Austin, eminente historiador mexicano, nos ilustra respecto al simulacro y los procesos medicinales. El recurso de la simulación nos reconduce, en virtud del

295 GUASCH, Ana M. ${ }^{a}$, El arte último del siglo XX. Del posminimalismo a lo multicultural, Alianza, Madrid, 2000, p. 30. 
pensamiento mágico o de la magia imitativa, a la creencia de que todo lo semejante atrae o produce lo semejante.

El mayor número de ejemplos que han sido trasmitidos por distintos caminos hasta nuestros días, pueden ser agrupados de acuerdo con el principio de que lo semejante atrae o produce a su semejante, es decir, de la magia imitativa. [...]. Entre los habitantes nahuas del Altiplano Central abundan los procedimientos curativos de este género abarcando todo tipo de intenciones y modalidades en la acción 296 .

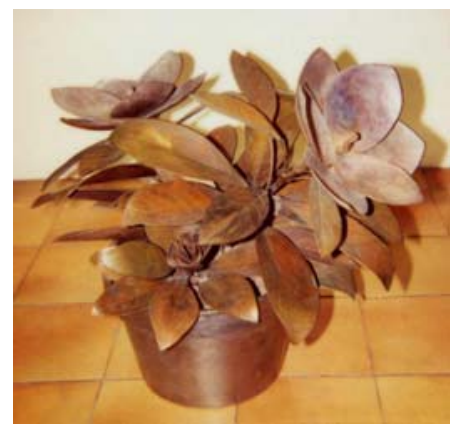

Naomi Siegmann, Magnolia, 2000.

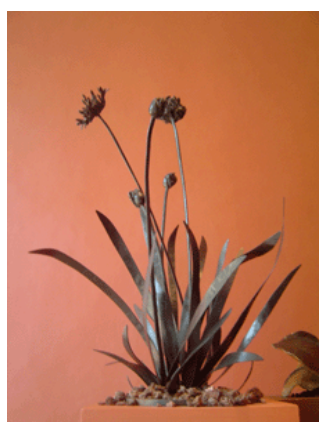

Naomi Siegmann, Agapando, 2004.

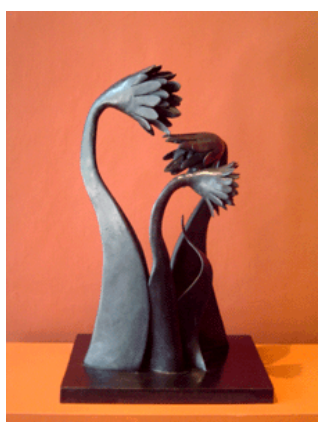

Naomi Siegmann, Aconitum, 2006.

Las verdades, al fin y al cabo, son ilusiones de las que nos hemos olvidado que lo son, metáforas que se han vuelto gastadas y sin fuerza. Jean Baudrillard en su tratado sobre la seducción apunta sobre el uso de la misma como estrategia, relacionándola con el trompe /'oeil. Para Baudrillard, la seducción es "el artificio del mundo" 297 y repara en su utilidad, no para confundirnos con lo real, sino para "producir un simulacro con plena conciencia del juego y del artificio" 298 , todo ello con la finalidad de desbordar el efecto de lo real y sembrar la duda.

Siegmann en una clara actitud postmoderna, no pone entre paréntesis ni suspende el referente al que remiten sus piezas, modelos perfectos generadores aparentes de felicidad. Sus obras trabajan por un lado, teatralizando la representación para polemizar la realidad de referencia y por el otro, reconstruyendo la posibilidad del ritual mágico para así, recomponer las múltiples y calidoscópicas caras de esa posible y productiva convivencia con nuestro entorno.

No estamos ante una serie de objetos prefabricados que respondan al juego de la seducción desde la frivolidad, ni tampoco al juego lúdico del gusto por lo kitsch. El desdoblamiento de la realidad, pasa por la resemantización de la cotidianeidad doméstica proyectando más allá de las apariencias, una verdad

296 MARTÍNEZ CORTÉS, Fernando et al., op. cit., pp. 205-207.

297 BAUDRILLARD, Jean, De la seducción, op. cit., p. 9.

298 BAUDRILLARD, Jean, De la seducción, op. cit., p. 64. 
que devela299 el aspecto más íntimo de nuestras pequeñas y diarias muertes. En lenguaje poético, podríamos permitirnos la licencia de concebir esta percepción de la cotidianeidad, como el río constante de la vida que fluye a través de los goces del amor, del dolor y por extensión, del hogar y de la familia.

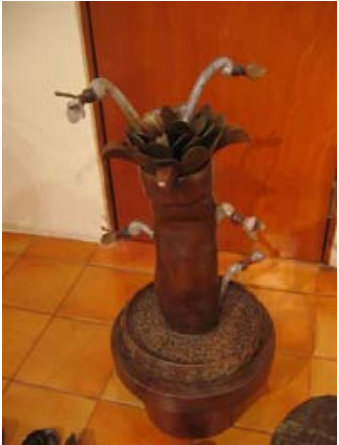

Naomi Siegmann,

Planta azteca, 2005.

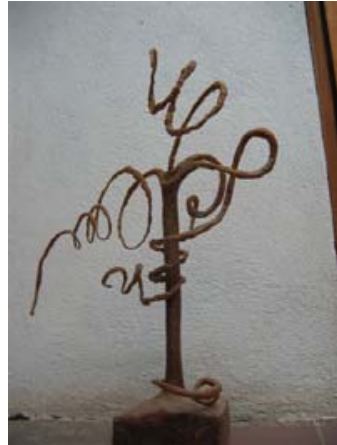

Naomi Siegmann,

After Karl Blossfeldt, 2004.

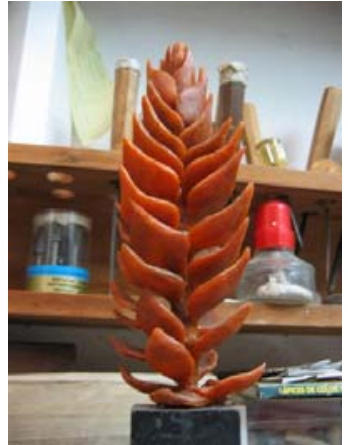

Naomi Siegmann,

Cera, 2004.

Con esta nueva mirada sobre el trabajo escultórico de Siegmann podemos entender mejor el devenir de su obra hacia una concepción más amplia del concepto de hogar. Así, la iconografía que describían sus esculturas durante las décadas anteriores, se ha reconfigurado en una nueva idea del hogar como mundo circundante. De la meticulosa artificiosidad de sus objetos impregnados de las presencias de la casa, ha desviado su mirada hacia el exterior de la misma $y$, a partir de aquí, la naturaleza vegetal se ha convertido en eje de sus esculturas, evidenciando el concepto de entorno natural cercano. Así, aparecen nuevos materiales en su obra: hierro, caucho, cartón, yeso, metacrilato que generalmente, se interrelacionan con los anteriormente usados madera, bronce, etc., procedimiento por otro lado nada novedoso en esta artista, quien anteriormente ya había abordado la integración de técnicas y disciplinas plásticas, con impresiones de fotografía en sus esculturas o con diferentes tipos de collage y pintura sobre las superficies de las mismas.

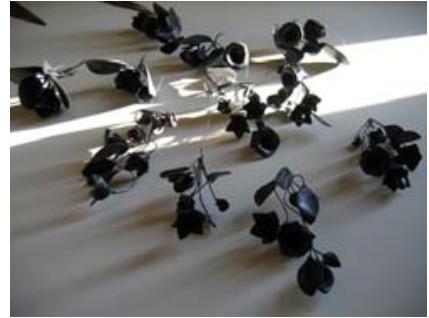

Naomi Siegmann,

Hiedra Cobaea Scaneus, 2004.

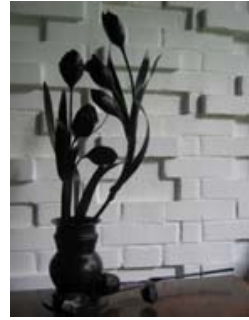

Naomi Siegmann

Iris Foetissima, 2004.

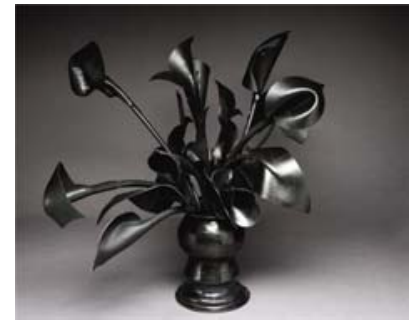

Naomi Siegmann, Calalillies, 2009.

299 Develar. del latín develare, hace alusión a la acción de quitar o descorrer el velo que cubre alguna cosa. En este texto el concepto de develar se utiliza para significar la acción mediante la cual, la obra de arte, más allá de lo racional, nos permite acceder al conocimiento. 
Partiendo de la cercanía e inspiración creativa de las plantas de su jardín hasta llegar a desarrollar los proyectos de El Bosque de Naomi Siegmann (2005)300 y el espacio transitable Bosque de sombras (2007)301 -instalación realizada con DM, hojas naturales y gasa, expuesta en el Museo Federico Silva (San Luis Potosí) -la obra de Siegmann ha ido configurando un nuevo universo que Jeannette Betancourt califica de producción centrífuga:

Su constante intervención en diversos contextos de lo real es una acción que asume indistintamente, algo sorprendente en una artista con una carrera consolidada como la de Siegmann [...]. En el ejercicio de separar lo esencial de lo demás para crear obras que exhiben técnicas y artificios de la duda, la artista conjuga una visión integradora de las estructuras simbólicas de los mundos de la vida (cultura, sociedad y personalidad), con una sensible relación con la vida misma y las cosas vivas. Es por ello que mediante la ausencia de enunciaciones afirmativas, como es el caso de Bosque portátil, la artista manifiesta una poética ocupada con las fracturas de su tiempo donde lo único cierto, es la incertidumbre302.

Ante su actual obra nos encontramos con el mismo proceso de figuración entre el simulacro y la reivindicación del momento, un momento que transcurre, como para todos los artistas que recopilamos en este trabajo y como anticipamos en el primer capítulo, por la identificación y resignificación de nuestra relación como humanos con nuestro entorno.

La mirada de Siegmann se proyecta hacia el exterior en obras anteriores. En Ventana // (1979), la artista traspasa el espacio del interior -el hogar recreado mediante sus objetos intimistas- para dirigir su mirada hacia lo externo. El exterior se configura como una Naturaleza-árbol que se insinúa a través de las cortinas de madera $y$, mediante su característica mezcla de técnicas, en la recreación escenográfica intrínseca a la pieza. Este asomo de naturaleza vegetal aparece frecuentemente en otras obras, véase por ejemplo Libro pintado (2001), donde una Naturaleza exuberante, representada por una rama, desborda los límites de las cubiertas del libro. Podemos considerar por tanto que este interés por lo natural ha acompañado en un continuum las piezas de Siegmann emergiendo en su último trabajo en una producción constante. Así, un bosque contemplado, transitable, distante pero no ajeno, reaparece veinte años después, en una instalación. Bosque (2003) presentaba en la exposición Plantae, una serie de tablones de madera que ocupaba el espacio del Centro Cultural Isidro Fabela en Coyoacán. Se trataba de una serie de finas tablas de madera, seccionadas de troncos que colgaban del techo, constituyendo un frágil y nuevo bosque vertical rodeado de un manto de hojas secas.

\footnotetext{
300 Véase AA. VV., El Bosque/The Forest..., op. cit.

301 Véase RIUS CASO, Luis, Naomi Siegmann, Des-ilusiones, Museo Federico Silva, Escultura Contemporánea, San Luis Potosí, marzo-junio, 2007, pp. 10-13.

302 BETANCOURT, Jeannette, "La certeza de lo incierto", México, D.F., 2007, Disponible en red en: <http://www.arteven.com/naomi_siegmann.htm>, [Consulta 13, abril, 2009].
} 
Previamente, otras piezas le acompañaban en este camino de salir al exterior. Ejemplos de ello son Bosque portátil (2007), una composición resuelta con tablas de madera, ramas, troncos y una base de metal con ruedas que permite desplazar la pieza y Tronco con insectos (2003), una pieza en la que la corteza de madera de un tronco real está colonizada por insectos de bronce. Palmeras, sábilas y otras plantas comienzan literalmente a crecer en su taller, primero tímidamente, como surgiendo de las hojas del Libro pintado del que hablábamos antes, para llegar a una Naturaleza que se desborda para comunicar el mismo taller con el jardín contiguo.

Libros que se escapan de aquellos anteriores bodegones y naturalezas muertas con frutas que ahora comienzan a cobrar vida fuera ya del marco de sí mismas. De ahí al encuentro explosivo con el jardín sólo serán unos pasos, un pequeño recorrido similar al del fotógrafo Karl Blossfeldt, entornos cercanos, intimidades desatadas en una nueva mirada sostenida que la llevan a plasmar semillas de jacaranda o de parota, hasta generar su propia Lluvia de Jacaranda (2003) y expandir sus esfuerzos en el proyecto internacional de El Bosque de Naomi Siegmann (2005), del que hablábamos en el capítulo anterior.

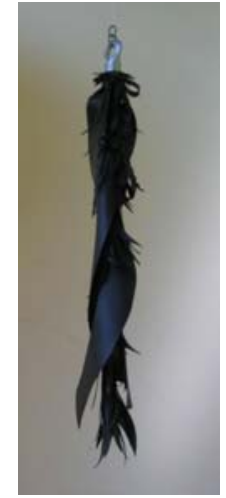

Naomi Siegmann, Sin título, 2004.

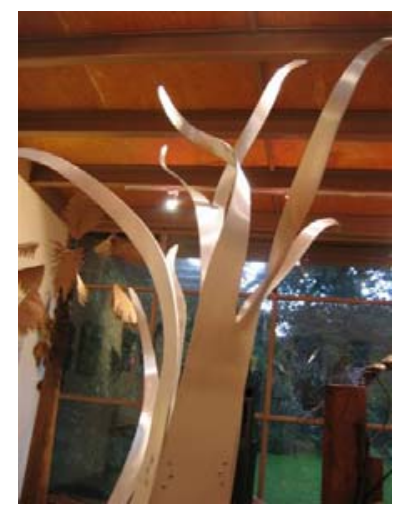

Naomi Siegmann, Árbol, 2003.

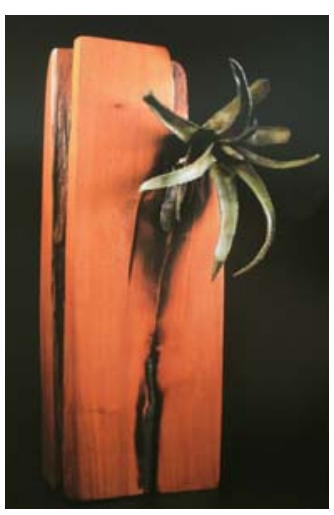

Naomi Siegmann, Sábila naciente, 2003.

Con este proyecto itinerante, Siegmann, preocupada por la deforestación mundial y la desaparición del material con el que tanto ha trabajado (la madera), decidió generar este proyecto expositivo para aumentar la sensibilización en torno a este controvertido tema. Para ello invitó a quince artistas a crear árboles con la única directriz de que el material empleado no fuera madera. Su pieza Suplente (2005), una abstracción en acero pintado de verde es un árbol quasi naif que sitúa una realidad convertida en un icono simplificado, en ausencia de la verdadera Naturaleza a la que en principio estamos acostumbrados.

En entrevista realizada en 2005 , por la autora de esta investigación, las palabras de la artista explican su interés por la Naturaleza y las plantas: 
Durante muchos años mi trabajo consistió en re-crear objetos de uso cotidiano: una mesa, una bolsa de piel, un saco colgando de una silla [...]. Pero de un tiempo a esta parte, mi atención se ha dirigido hacia la naturaleza: tan imponente, tan grande y a la vez, tan frágil. Mi interés por trabajar árboles y plantas en general, nace de un deseo de inspirar pensamientos sobre la vulnerabilidad de la naturaleza y su tenue balance con el hombre. Nuestra supervivencia depende de una sabia interacción con ella. [...]. Recordemos que la naturaleza no depende de nosotros, nosotros dependemos de ella. "El hombre pertenece a la tierra y no la tierra al hombre» cuando entendamos esta sencilla verdad, atribuida al Jefe Seattle, entonces comenzaremos a vivir en armonía con nuestro entorno y, quizá, podamos confiar en el futuro. Las fuerzas de la naturaleza nos muestran que si queremos perdurar debemos respetar a todos los elementos de nuestro entorno con nuestra protección. Tenemos que cambiar la forma de pensar para sostener lo que aun queda de la naturaleza que nos dio vida. Mi interés es inspirar y provocar pensamientos sobre la vulnerabilidad de la naturaleza y su tenue balance con el hombre. Nuestra supervivencia y la preservación de la naturaleza dependen de nuestra interdependencia303.

En una de sus más recientes instalaciones, Bosque de sombras (2007), la artista nos hace participar de su mirada hacia el exterior. La obra genera un espacio que, como en un espejo, refleja la imagen de una Naturaleza que podemos perder. Una serie de paneles recortados con formas de árboles generan un espacio transitable. Siegmann hace una invitación al viaje, trasportándonos físicamente desde el exterior de la pieza hacia el interior, para guiarnos hacia las entrañas del bosque.

No hay engaño en las obras de Siegmann, si acaso, la seducción inteligente que producen sus piezas se corresponde de forma espontánea, con una evidencia fulgurante, con aquella que representa el dominio del universo simbólico, siguiendo a Baudrillard, con el exceso de realidad que nos acontece:

En el trompe-l-oeil no se trata de confundirse con lo real, se trata de producir un simulacro con plena conciencia del juego y del artificio - remedando la tercera dimensión, sembrar la duda sobre la realidad de esta tercera dimensión- remedando y sobrepasando el efecto de real, sembrar una duda radical sobre el principio de realidad, pérdida de lo real a través del mismo exceso de apariencias de lo real. Los objetos se parecen demasiado a lo que son, este parecido es como un estado secundario y su verdadero realce, a través de este parecido alegórico, a través de la luz diagonal es el de la ironía del exceso de realidad304.

303 Texto inédito proporcionado por la artista a la autora de esta investigación, febrero, 2008.

304 BAUDRILLARD, Jean, De la seducción, op. cit., p. 64. 


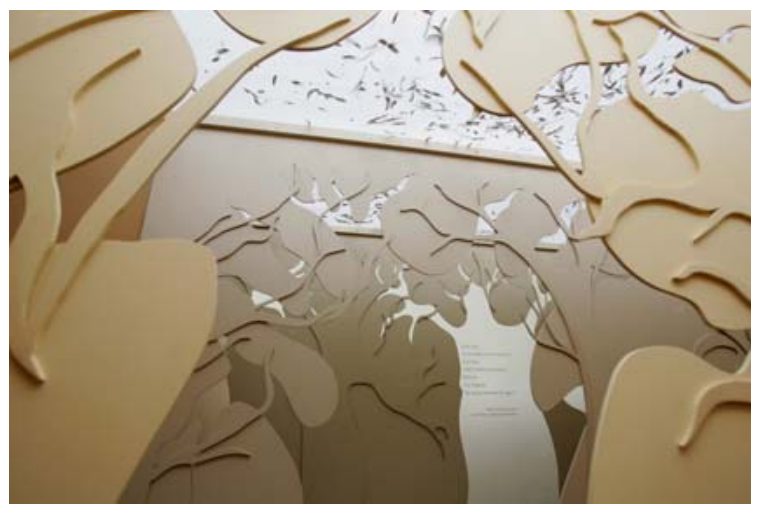

Naomi Siegmann,

Bosque de sombras, 2007.

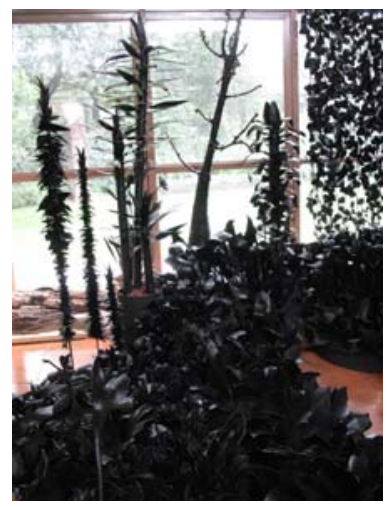

Naomi Siegmann, Jardín negro, 2009.

Estamos ante una forma de ir más allá de la simulación, Siegmann genera espacios que no remiten a las apariencias simples sino que, por refracción y no por reflexión de espejo, nos hace conscientes de la ausencia a la que pudiéramos estar destinados. Uno de los escenarios posibles sería aquél invadido por una Naturaleza en desmaterialización. Jardín negro (2009) es una muestra evidente de esta denuncia: un frondoso jardín, todo él realizado en caucho negro y cuya visión se convierte en una prognosis del futuro. El juego que proponen estas formas vegetales es el principio de incertidumbre, el simulacro irónico, la seducción y la ambigüedad así como el testimonio radical de la misma. No es una seducción blanda la que aquí se nos presenta, sino una forma de romper la inercia, la seducción como "desafío"305, la única vía en opinión de Baudrillard, según la cual las cosas funcionan. La seducción no es lineal, sino oblicua; la seductora, en este caso, la artista, deja flotar los signos, sabe que dejarlos en suspenso es favorable y apunta a una estética de la ironía, en la que la desilusión del artificio no termina con las posibilidades de la percepción sino que deja abierto el campo estético:

Su única estrategia es: estar/no estar ahí, y asegurar así una especie de intermitencia, de dispositivo hipnótico que cristaliza la atención fuera de todo efecto de sentido. La ausencia seduce a la presencia306.

La propuesta de Siegmann nos conciencia de la urgencia de actuar, y para concluir citamos de nuevo a Baudrillard, "El original se ha perdido, sólo la nostalgia puede restituirlo como auténtico"307.

305 BAUDRILLARD, Jean, De la seducción, op. cit., p. 167.

306 BAUDRILLARD, Jean, De la seducción, op. cit., p. 83.

307 BAUDRILLARD, Jean, De la seducción, op. cit., p. 161. 


\subsection{Habitar el espacio urbano. Femando González Gortázar y Federico Silva Lombardo}

En relación con la obra de Naomi Siegmann, hablábamos de la seducción como estrategia para la representación escultórica y la vinculábamos con un ejercicio de desafío por parte de la artista, frente al espectador. Asimismo, la mirada era enlazada con la experiencia de lo cotidiano como una forma de reconocimiento fuertemente vinculada a la visión. Más allá del espacio vital, otra práctica en torno a la mirada es aquella que nos permite recurrir a la misma para comprender la forma y la complejidad de un lugar, algo similar a la lectura de un paisaje. A este respecto Massimo Venturi, apunta sobre el poder de la mirada para captar indicios culturales:

El espectador gracias a la mirada puede descubrir, cuando la calidad de la lectura lo permite, todo lo que pertenece a la época presente, a la vida actual, oculto o evidente en las formas del paisaje [...]. En el contexto paisajístico, la vista, el espectáculo y la apariencia indican [...] el poder de la mirada y remiten a la capacidad de observar lo contingente para bien o para mal308.

En esta mirada expandida que todo lo abarca, los límites entre arte y arquitectura se han ido diluyendo cada vez más, definiendo una relación de intercambio de experiencias entre artistas y arquitectos. Abandonando el habitual espacio de los museos, este encuentro se ha desarrollado fundamentalmente en el espacio público. Así, la arquitectura se ha visto considerada como una entidad susceptible de generar transformaciones en el entorno de nuestras ciudades. Algunos arquitectos actualmente, de forma similar a los artistas de finales de los años sesenta, se introducen en el paisaje, trabajando con sus aspectos más significativos, desarrollando un vocabulario híbrido:

El paisaje se ha convertido en el nuevo campo de acción, donde los destinatarios dejan de ser simples observadores $y$ se convierten en elementos indispensables del espacio que los alberga [...]. Los arquitectos de hoy [...]. No representan el paisaje, sino que se implican en él309.

Este tipo de preocupaciones han alentado siempre las investigaciones formales de algunos arquitectos que profesionalmente han incursionado de una manera constante en el mundo de la escultura. Podemos considerar que entre los escultores contemporáneos de México que han basado su obra con firme convicción, en las estructuras vegetales encontramos a dos artistas, de formación arquitectos, que han trabajado en la frontera entre arquitectura, escultura y diseño con una mirada dirigida en particular al entorno. Por un lado,

308 VENTURI, Massimo, "Mirada", en COLAFRANCESCHI, Daniela, Landscape +100 palabras para habitarlo, Gustavo Gili, Barcelona, 2007, pp. 132-133.

309 GALOFARO, Luca, Artscapes. El arte como aproximación al paisaje contemporáneo, Art as an approach to contemporary landscape, Gustavo Gili, Barcelona, 2003, pp. 27-28. 
Fernando González Gortázar, considerado uno de los arquitectos más decisivamente influyentes en la investigación arquitectónica, a la vez que urbanista, paisajista y escultor. Su labor dentro del campo de la escultura pública es relevante en este país para la comprensión de la analogía formal relacionada con los vegetales. Por otro lado Federico Silva Lombardo, de formación arquitecto y escultor, quien ha desarrollado una visión importante dentro de este ámbito formal y está vinculado muy de cerca con la esfera del diseño funcional.

Fernando González Gortázar (México, D.F., 1942) expuso en el Palacio de Bellas Artes en 1970. Ya en aquel momento articulaba un lenguaje propio, prefigurando las nuevas prácticas estéticas en México. González Gortázar, desde temprana edad se ha dedicado a estudiar el espacio, el desarrollo urbanístico y la Naturaleza, para lo que viajó por selvas y desiertos, redescubriendo relaciones en un vivero tropical con cactus y flores del desierto que él mismo cultiva. En 1973 cofunda y preside Pro-Hábitat, asociación que desde entonces aboga por la conservación no sólo del patrimonio arquitectónico sino también del paisaje, la flora y la fauna, en definitiva del patrimonio tanto cultural como natural.

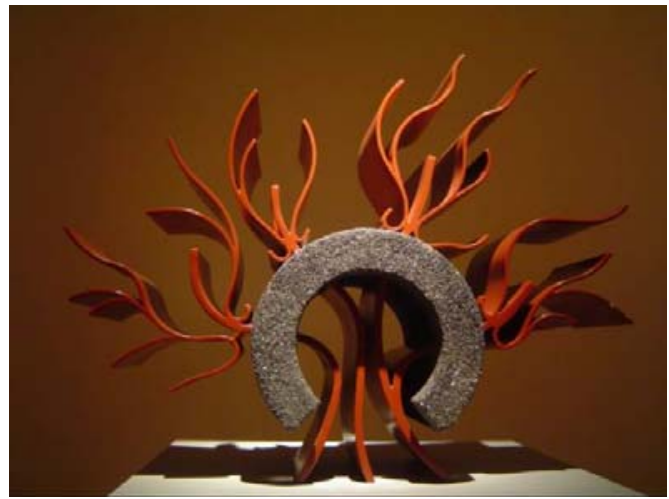

Fernando González Gortázar, Arbolito secreto, 2005.

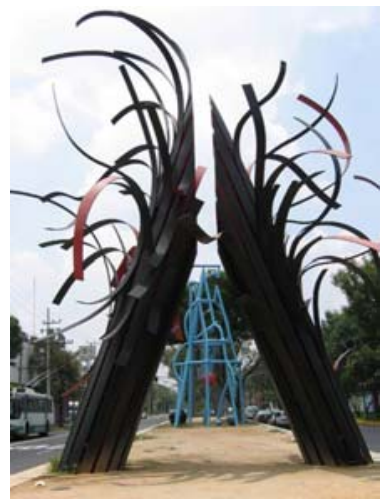

Fernando González Gortázar, Árbol de Coyoacán, 2003.

En contradicción con las tendencias estéticas de la segunda mitad del S. XX en las que todavía imperaba siguiendo a Carlos Ashida, "un tratamiento nostálgico e idealizado del arte oficial, apoyado en una visión ensimismada e hipócrita, de la historia y de la realidad"310, González Gortázar se propuso un cambio orgánico en la relación entre arte, Cultura y sociedad. Rechazando los valores de una revolución que dejaba de ser efectiva socialmente, sentó las bases de su obra en torno a problemáticas urbanas. Consolidaba así, las primeras raíces para un Arte Público, un arte en concordancia con las nuevas necesidades del nuevo ciudadano mexicano. Sus obras se convierten de esta manera, en importantes ejemplos de la escultura pública monumental, hitos dentro de la ciudad con un claro elemento de identificación comunitario. Configurando una

310 ASHIDA, Carlos, Fernando González Gortázar. Sí, aún, Consejo Nacional para la Cultura y las Artes, México, D.F., 2000, p. 10. 
abstracción alejada de contenidos panfletarios y, desde un austero lenguaje formal, sus esculturas se configuran como un nuevo Arte Público, buscando:

\section{[...] propiciar la experiencia artística en el transeúnte o en la persona común} que quizá jamás llegue a poner los pies en una galería o en un museo [...] las propuestas de González Gortázar dejan de lado la condición narrativa y sacralizada de la obra de arte. Su trabajo responderá, con un vocabulario de formas primarias o mínimas, a la razón, a la lógica de la geometría y la construcción, atemperadas por la emoción y la propia subjetividad ${ }^{311}$.

En este sentido, las esculturas de González Gortázar responden a ciertas características contemporáneas de lo que consideramos Arte Público. Varios son los autores que han escrito en torno a estas cuestiones, por lo que revisaremos algunas opiniones para poder determinar hasta qué punto la obra de González Gortázar, a pesar de situarse en otro contexto geográfico, puede observarse desde la óptica de un arte considerado como público.

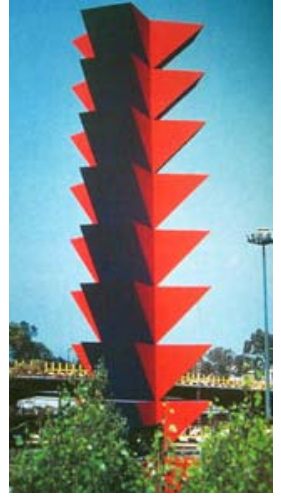

F. González Gortázar, La gran espiga, 1973.

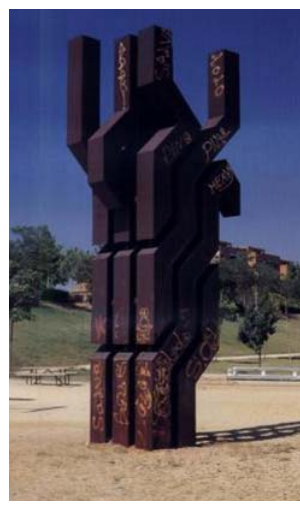

F. González Gortázar, La palmera, 1987.

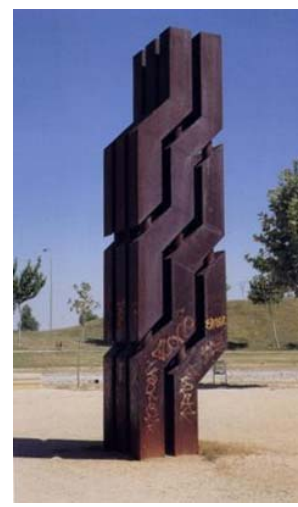

F. González Gortázar, El ciprés, 1987.

Según Javier Maderuelo el origen moderno del Arte Público surge con la nueva gestión del espacio público que, tras la segunda guerra mundial y con la reconstrucción de Europa propician la necesidad de "dotar de carácter a los lugares sobre los que se actuaba"312. En términos generales podemos afirmar que dos son las premisas para considerar una escultura como Arte Público, por un lado, debe de percibirse "la interacción de la obra de arte con el espacio urbano donde va a ser emplazada y la segunda, su integración con la arquitectura circundante" 313 . Alberto Ruiz de Samaniego concibe el Arte Público fundamentalmente como objeto de participación, capaz de interpelar al observador:

\footnotetext{
311 ASHIDA, Carlos, op. cit., p. 14.

312 MADERUELO, Javier, "Introducción: Arte Público", en MADERUELO, Javier (dir.), Arte público..., op. cit., p. 10.

313 GENER, Mónica, "Arte en lugares públicos", en Cimal, Arte internacional, Arte Público, $N^{\circ} 54$, Valencia, Año 2001, p. 48.
} 
El arte público, como la prostituta, no configura ningún espacio sagrado, religioso o político; no se da a contemplación inmóvil como si ante una representación se tratase, sino que interpela al transeúnte, solicita al que pasa en una temporalidad social, en el recorrido diseminatorio de la experiencia caminante, viajera, movilizada, de la cotidianeidad contemporánea. El arte público, como el cuerpo público, no ofrece un sentido de antemano, no promete trascendencia, pone más bien en entredicho lo que pasaba y a quien pasaba hasta ese momento para enfrentarlo con una experiencia trastornante, tantas veces molesta, otras gratificante. Lo público es el lugar de una inscripción donde el individuo se vuelve a lo(s) otro(s) [...]314.

Desde nuestro punto de vista, el Arte Público se acerca bastante a la concepción del arte como reunión o como detonador de efectos sociales que postula Siah Armajani. Este artista enfoca la creación artística como algo distinto a un vehículo de expresión personal y, siguiendo las directrices de John Dewey315, propone en cambio, un arte como experiencia316. Antonio Remesar en torno al Arte Público, nos remite a la propuesta del artista Siah Armajani, según el cual, un arte de estas características debe analizarse en base a contextos concretos, otorgándole la función social de transmitir y formalizar contenidos sociales. Debemos entenderlo como una producción social y cultural basada en necesidades concretas, dotándolo así de un carácter cooperativo317.

Si bien, "la lógica de la escultura era inseparable, en principio, de la lógica del monumento"318, la dirección que apunta González Gortázar se corresponde con la dinámica que seguirá la escultura contemporánea en las últimas décadas, en materia de abandono del discurso figurativo y en función de la desaparición de su, hasta entonces, misión conmemorativa.

En términos históricos, la modernidad vanguardista en la escultura comienza a finales del siglo XIX, en lo que Rosalind Krauss denomina el desvanecimiento de la lógica del monumento. Se trata de una circunstancia en virtud de la cual cambian las cualidades de la escultura. Asistimos a una pérdida del pedestal como el elemento que institucionaliza el poder. Maderuelo puntualiza como se manifiesta el cambio de valores en estos momentos en la escultura, en diferentes aspectos. Por una parte, hay un cambio en cuanto a los aspectos formales y al uso de materiales distintos, por otra, los procedimientos utilizados

\footnotetext{
314 RUIZ DE SAMANIEGO, Alberto, "Arte público: Enemigo público", en Cimal. Arte international. Arte Público, N 54, Valencia, 2001, p. 29.

315 A partir de las conferencias publicadas en 1931, con el título El Arte como Experiencia, los escritos de John Dewey son muy apreciados por artistas y críticos.

316 PRINCENTHAL, Nancy, "Congregación: Siah Armajani y el arte de reunir a la gente", en MADERUELO, Javier (dir.), Arte público..., op. cit., p.21.

317 REMESAR, Antonio, "Repensar el paisaje desde el río", en MADERUELO, Javier (dir.), Arte público..., op. cit., p. 194.

318 KRAUSS, Rosalind E., La originalidad..., op. cit., p. 292.
} 
por los escultores en el repertorio temático de las esculturas, sufre también una transformación 319 . Coincidiendo con estas opiniones $y, a$ partir de este momento, la escultura cae en lo que Krauss denomina la "condición negativa" o lo que es lo mismo, "[...] una especie de deslocalización, de ausencia de habitat, una absoluta pérdida de lugar" 320 .

La escultura contemporánea, a pesar de sus constreñimientos técnicos y discursivos excepcionalmente fuertes, procede a reconstruirse a partir de dos evidencias negativas: una es la pérdida de la función representativa, que afecta al conjunto del arte, y la otra alude a la desaparición de la servidumbre conmemorativo-narrativa, de la mano de la evolución funcional y racionalista de la arquitectura y del urbanismo321.

Como afirma Paloma Blanco, la intervención en el espacio público no se asienta en el tópico de "hacer cosas en la calle", y tampoco se ancla en la dicotomía maniquea entre lo público y lo privado, lo interior y lo exterior,

[...] sino que más bien plantea ejemplos, situaciones, emplazamientos, intenta hacer real un arte del lugar [...] unas prácticas en las que el concepto de contexto, de espacialidad, va estando más y más acabado para llegar incluso a incluir las conflictualidades políticas, sociales, económicas [...] del lugar con el que interactúa322.

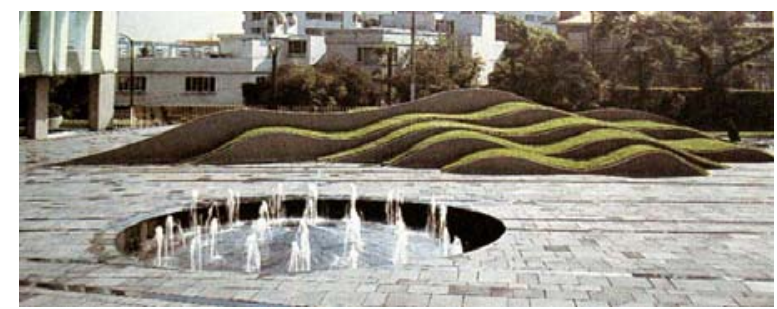

Fernando González Gortázar, Plazuela Palmas, 1996.

Así, en el caso particular de la obra de González Gortázar, observamos un énfasis en el tratamiento del territorio sea éste público o privado, para transformarlo en una percepción comunitaria del espacio que, a su vez redunde en un beneficio común. Por ejemplo, las ondulaciones presentes en la obra Plazuela Palmas (1996), realizada en el edificio construido por los arquitectos Augusto H. Álvarez y Augusto F. Álvarez, en México, D.F., contrastan con la rigidez del inmueble. El dinamismo impreso al espacio por el artista genera un

\footnotetext{
319 MADERUELO, Javier, La pérdida del pedestal, Cuadernos del Círculo, Círculo de Bellas Artes, Madrid, 1994, p. 16.

320 KRAUSS, Rosalind E., La originalidad..., op. cit., p. 293.

321 CASTRO FLÓREZ, Fernando, Esther Pizarro, Mapificar, Ayuntamiento de Granada, 2003.

322 BLANCO, Paloma et al., op. cit., p. 32.
} 
contraste de formas que "integra el diseño entre edificio y plaza, y se convierte en la principal imagen del corporativo" 323 .

Con todo ello podemos concluir que más que crear objetos plásticos, la propuesta escultórica de este artista genera ambientes urbanos, espacios para la sensibilización estética, con la característica particular y reiterativa del elemento vegetal. Así, también la mayoría de sus esculturas de pequeño y mediano formato son eficaces laboratorios de experimentación y ensayo, en donde las alegorías giran siempre en torno a elementos de la Naturaleza, una inspiración de la que tanto el arquitecto como el artista, no han dejado de nutrirse. En Desconfines (2001), el artista presenta una flora de formas en movimiento con ondulaciones que simulan pétalos o ramas al viento.

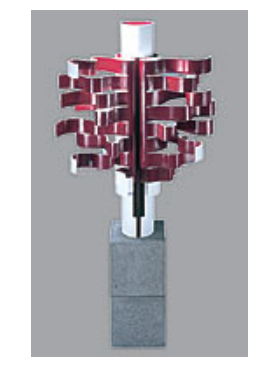

F.González Gortázar, Desconfines III, 2001.

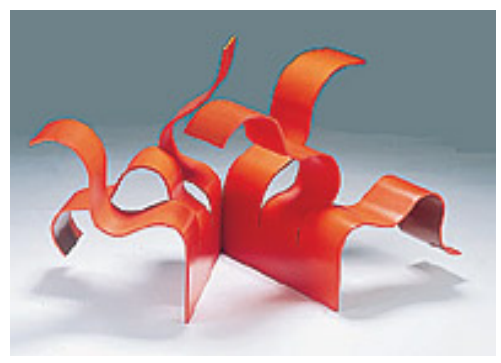

F. González Gortázar, Desconfines VIII, 2001.

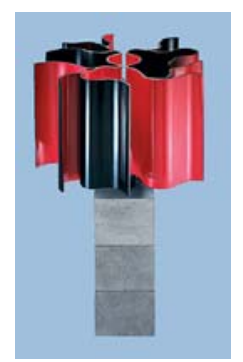

F. González Gortázar, Desconfines V, 2001.

Desde la Fuente de la Hermana Agua (1970), realizada en Guadalajara, (Jalisco), hasta la constante referencia al elemento vegetal en sus homenajes al árbol (ciprés, palmera, espiga, etc.) como estructura básica, sus piezas irradian una fuerza que proviene de la relectura de los elementos naturales para hacerlos coincidir con los elementos de la Cultura. La gran espiga (1973), en el cruce de Tlalpan y Taxqueña con una altura de casi treinta metros es una clara metáfora de crecimiento, estableciéndose como un icono de la simbiosis entre Naturaleza y Cultura.

Para el escritor Juan Villoro, el arquitecto González Gortázar no se dedica a construir edificios, su trabajo se enfoca hacia una labor de dinamización social y no sólo eso, sino que como muchos otros escultores lo hace desde una mirada hacia la Naturaleza:

González Gortázar ama tanto la naturaleza que la manda de vacaciones a sus edificios: colocó palmeras subterráneas en la Estación Juárez del tren ligero y jardines aéreos en las columnas interiores del Edificio San Pedro. En la Plazuela Palmas, de la Ciudad de México, creó un monumento de pasto, que sube y baja en ondas de surfing y alude de modo juguetón al inquieto subsuelo de la capital. Su mirada orgánica lo lleva a planear casas en 
relación con el crecimiento de las plantas. Sus balcones tienen una cita con los bambúes que llegarán ahí dentro de quince años. A contrapelo de quienes piensan que la arquitectura es un arte quieto, diseña rutas para moverse entre sus obras 324 .

La mirada orgánica y vegetal a la que nos remite González Gortázar no es nueva. $\mathrm{Si}$ en sus inicios las esculturas con reminiscencias vegetales apuntaban a volúmenes cúbicos, abstracciones que extraían su movimiento de la deconstrucción del cubo o del rectángulo, en general formas verticales, con el tiempo, esas piezas se fueron trasformando en volúmenes y líneas curvas que sugerían, lejos del hieratismo del principio, un movimiento más desenvuelto.

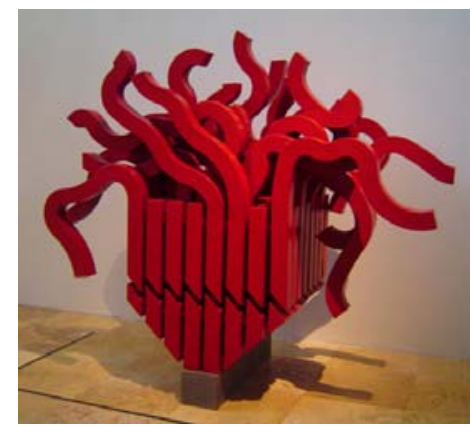

Fernando González Gortázar, Homenaje, 1993.

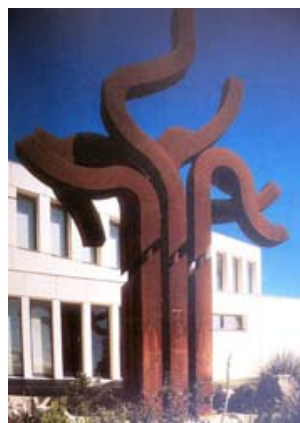

Fernando González

Gortázar,

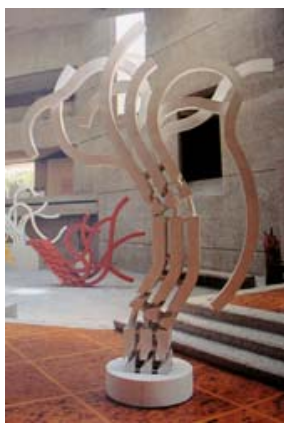

Fernando González

Gortázar,
Árbol de El Escorial, 1995. Homenajes, 1990-95.

También sus edificios presentan una minuciosidad particular por respetar la configuración de los emplazamientos, cuidando por ejemplo, la vegetación autóctona. La atenta observación de las plantas se manifiesta formalmente en ellos, confiriéndoles un carácter de organismos vivos y aspirando a mimetizar sus intervenciones arquitectónicas con el paisaje. Tanto en el Museo del Pueblo Maya (1973), realizado en la zona arqueológica de Dzibilchaltún (Yucatán), como en el Centro de Seguridad Pública (1993), sito en Guadalajara, Jalisco y dotado de una gran pérgola vegetal que simula las nervaduras de las hojas, podemos observar muestras del respeto al lugar que siguen las directrices marcadas por parámetros vegetales. Sus esculturas presentan un claro referente en ese contexto, como dice Castillero,

[...] un ramillete de flores y una vegetación de ríos y montañas, procedentes de las confusas mezclas, para ser materia cambiante con la máxima plétora de posibilidades, pues sus formas se sitúan en las zonas del umbral, en la indecisión de los límites, logrando encarnar el adentro del afuera y el afuera

324 VILLORO, Juan, "La mente del arquitecto", en La Jornada Semanal, Domingo breve, México, D.F., 26, diciembre, 1999, Disponible en red en: <http://www.jornada.unam. $\mathrm{mx} / 1999 / 12 / 26 /$ sem-villoro.html $>$, [Consulta 14, abril, 2009]. 
del adentro. Son y no son, y vuelven posible la duplicidad del sentir, simulan y se ocultan: se transfiguran 325 .

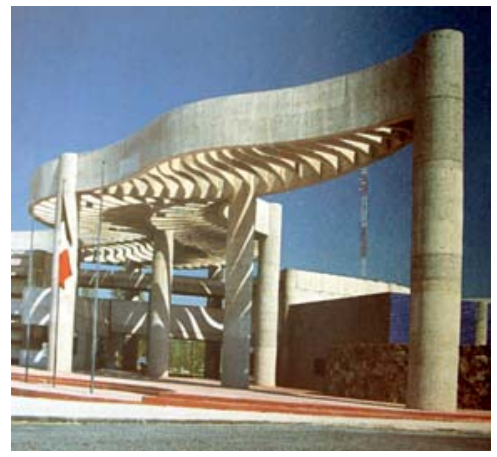

Fernando González Gortázar, Centro de Seguridad Pública, 1993.

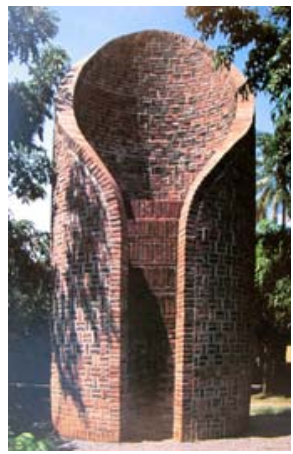

Fernando González Gortázar, Homenaje a la amistad, 1997.

Hasta aquí, en una clara tendencia formal hacia la abstracción y mediante una austeridad radical y un comedimiento característico, hemos tratado la obra de Fernando González Gortázar cuya propuesta fundamental es demostrar, con sus creaciones tanto arquitectónicas como escultóricas, que el ser humano puede convivir respetando su entorno, encontrando un equilibrio justo entre su realidad contemporánea, la tradiciones culturales y la Naturaleza circundante.

Al principio de este apartado nombramos la labor relevante de Federico Silva Lombardo (México, D.F., 1953) cuya visión está muy próxima al ámbito del diseño funcional. Desde la perspectiva de la relación entre escultura y Naturaleza y, revisando la idea de convivencia viable entre el hombre y el lugar que ocupa, su entorno habitable y su necesidad de habitar los espacios, la reflexión que presentan las obras de Silva Lombardo muestra una relectura del referente vegetal partiendo de una sensualidad en movimiento.

Sus esculturas oscilan entre la sencillez de la forma estética -bella, agradable, funcional y sintética- y un cierto barroquismo formal. Para el escultor Silva Lombardo, la estructura constructiva, la estática y la dinámica de los materiales que las mantienen es fundamental. Sus piezas, adoptadas por diferentes instituciones y espacios expositivos se desplazan de un lado a otro, en respuesta a la necesidad del artista de llevar su discurso a diferentes ámbitos. Así, las esculturas viajan desde su taller al Instituto de Investigaciones Biológicas de la UNAM o al Tepozteco (montaña mítica cerca de Tepoztlán, Morelos) en una suerte de movimiento migratorio similar al de los humanos o las plantas en la búsqueda de un lugar propio.

325 CASTILLERO, Silvia Eugenia, "Desconfines: La ciénega y la flor", Disponible en red en:<http://www.arte-mexico.com/lopezquiroga/FernandoGonzalezGortazar/texto.htm>, [Consulta 12, abril, 2009]. 


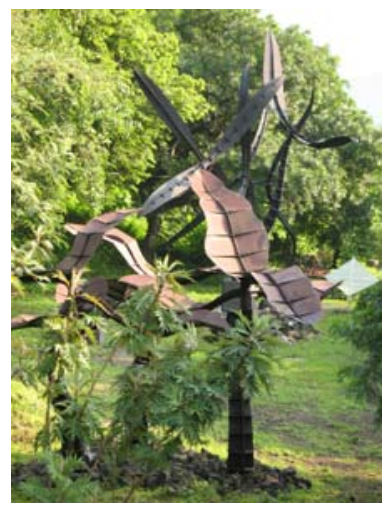

F. Silva Lombardo,

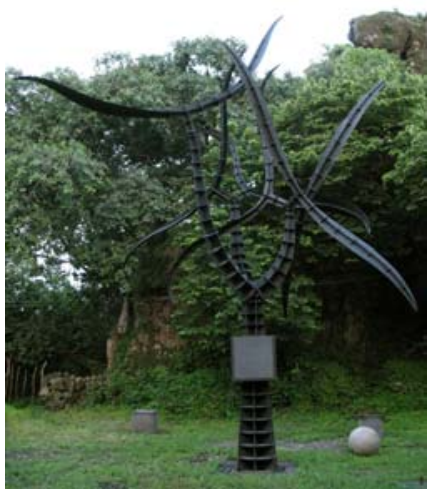

F. Silva Lombardo,

Plantas que curan, 2004. Bromelia Có Flor de Lito, 2007.

Silva Lombardo trabaja básicamente en dos líneas temáticas de investigación: una relativa a los sistemas cósmicos de equilibrio y otra ligada a los comportamientos vegetales. En sus esculturas de hierro soldado con hibridación en algunos casos, de otros materiales, los volúmenes sólidos son sustituidos por líneas vertiginosas y formas sutiles que logran transformar el material inerte en formas orgánicas.

Mi obra actual se encuentra ligada directamente al lugar geográfico donde vivo, el paisaje meteorológico y el universo vegetal, es primordialmente la influencia directa en mi trabajo. Las plantas, las piedras y el firmamento son el bagaje del que me nutro, me estimula y me permite producir326.

Preocupado por la dinamicidad y el cinetismo, sus piezas, en particular aquellas que hacen referencia a lo vegetal, plantean investigaciones formales que buscan un equilibrio en movimiento, y como consecuencia de ello propone geometrías y mecanismos optimizados en la búsqueda de una posible aplicación en el entorno humano. Entiende que ejercer la disciplina de la creación es un acto de vanguardia y para él la relación entre arte y Ciencia es un vínculo imprescindible en todo proyecto. De esta manera mediante la experimentación, el uso de materiales avanzados y técnicas accesibles, genera estructuras superligeras de en grandes dimensiones, capaces de ser construidas con relativa facilidad.

Es así el caso de su Sombrilla-Hoja gigante (2006), en la que apreciamos lo que se conoce habitualmente como Diseño de producto aplicado ${ }^{327}$, en esta pieza la estructura de sombrilla sigue literalmente la inspiración de las hojas. El énfasis en la función de los objetos -común por otra parte en la Historia del Arte y del

326 SILVA LOMBARDO, Federico, Página personal, Disponible en red:<http://www.silva lombardo.com/obra_actual.html $>$, [Consulta 14, abril, 2009].

327 Entendemos por Diseño de producto aplicado, la actividad creativa o el proceso proyectual por el cual -mediante la síntesis de la tecnología- los productos de uso humano, se adaptan a productos manufacturables (de fabricación industrial), respondiendo a necesidades tanto físicas como psíquicas de los usuarios. 
artificio humano- y el desarrollo del Diseño como disciplina, han propiciado en la actualidad que una gran cantidad de artistas y diseñadores desarrollen sus proyectos tomando la Naturaleza como fuente de inspiración. En este tipo de proyectos y siguiendo a Fabiola Reyes, apreciamos generalmente una "clara función estética" 328 pero sin lugar a dudas, la finalidad fundamental es lograr una óptima eficiencia, amén de generar comunicación, trasmitir un mensaje y entablar un diálogo. Se trata de piezas en las que forma y función van estrechamente ligadas, pero que conceden cierto margen a la retórica estética del espacio.

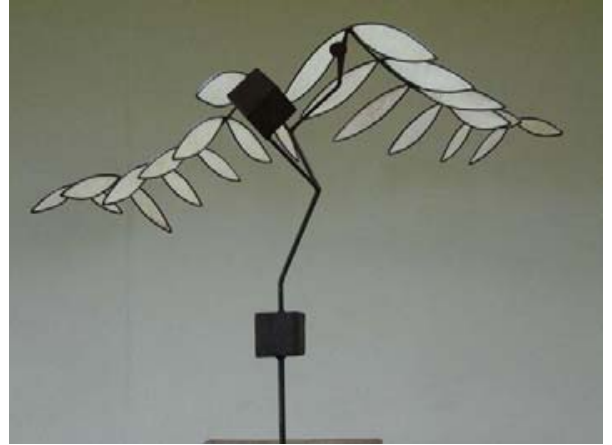

F. Silva Lombardo,

Helecho habla, 2006.

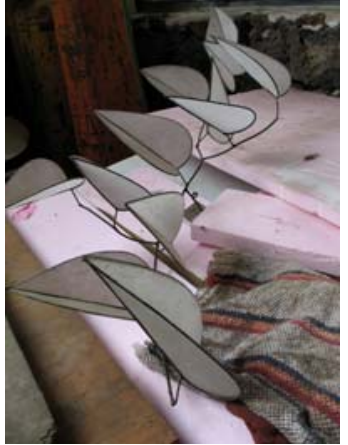

F. Silva Lombardo, Sin título, 2006.

La metodología de Silva Lombardo se corresponde con algunos de los procesos de la Naturaleza: para construir sus sistemas de equilibrio utiliza el principio de contrapesos así como diferentes recursos de estructurales (a los que él mismo denomina de nudo y barra). Fruto de sus experimentaciones en torno a la Naturaleza, la idea del equilibrio es una constante mecánica y temática en su trabajo, una búsqueda permanente de armonía entre el todo y sus partes. En una sutil pero fundamental interrelación entre ellas, cada parte depende de la otra para su estabilidad. Podemos afirmar que Silva Lombardo parte de la Biónica, como disciplina que estudia los sistemas vivientes y que tiende a detectar "procesos, técnicas y nuevos principios aplicables a la tecnología" 329 y, tomando los estudios sobre los fenómenos naturales como punto de partida, desarrollar soluciones proyectuales.

También en este caso la estrategia de la seducción a la que nos referíamos con anterioridad, se torna un hecho destacable en cuanto a la elección de las formas. Donald A. Norman señala, junto a los diseñadores Julie Khaslavsky y Natahn Shedroff, que sin duda, el secreto para mantener la efectividad de un diseño estriba en la seducción. Así, el poder seductor que nos ofrece el diseño

328 REYES, Fabiola, Nature, Inspiración para el arte y el diseño, Instituto Monsa, Barcelona, 2008, p. 7.

329 MUNARI, Bruno, ¿Cómo nacen los objetos? Apuntes para una metodología proyectual, Gustavo Gili, 2008, p. 338. 
de algunos objetos reales o virtuales, trasciende en ocasiones su fisicidad, su presentación o su precio.

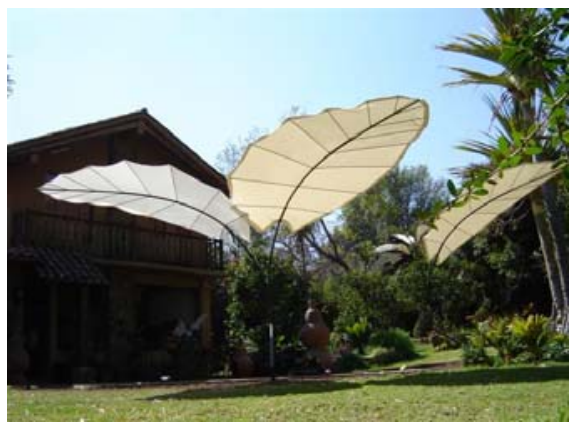

F. Silva Lombardo,

Sin título, sombrillas hoja, 2006.

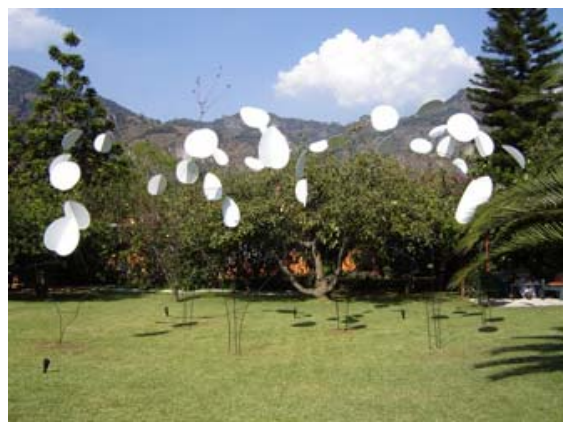

F. Silva Lombardo, Sin título, 2006.

El aspecto externo de un producto puede ser el responsable de su venta mayoritaria. Poniendo como ejemplo el exprimidor de cítricos modelo Juicy Salif, diseñado por Philippe Stark, para la marca Alessi, la causa es la habilidad que estos objetos desarrollan al crear un vínculo, casi una necesidad emocional, con su público.

La seducción, tal y como la sostienen Khaslavsky y Shedroff, es un proceso. Da lugar a una experiencia rica y cautivadora, que perdura en el tiempo [...] los tres pasos básicos son la atracción, la relación y el cumplimiento: hacer una promesa emocional, cumplir continuamente lo prometido y culminar la experiencia de un modo memorable330.

Así, las esculturas de Silva Lombardo tanto por su forma como por su función, trasfieren la sensación de habitar un entorno de comunicación con el mundo natural, nos hacen sentir como habitantes de espacios vegetales redescubiertos y nos permiten participar en la experiencia de sus creaciones. Otra constante de su técnica es el desarrollo de un módulo versátil que se repite y que, mediante la participación interactiva del espectador, encuentra una forma de relacionarse con la totalidad de la pieza misma. En el caso de Espacio peludo (2003), el módulo viene dado por una serie de alambres unidos por una pequeña anilla, que crean un conjunto de hierro y acero, de dimensiones variables formado por 94 fracciones de dos tipos diferentes. La repetición de esta pieza permite que la obra conforme un todo de forma similar a la de algunos elementos vegetales, en los que por su estructura y características particulares, los elementos se enlazan unos con otros, sin necesidad de otros aditamentos.

En su trabajo recurre al experimento como método de análisis y concreción de las ideas. Los modelos físicos, numéricos o geométricos le permiten experimentar y proponer nuevos comportamientos formales y estructurales en

330 NORMAN, Donald A., El diseño emocional. Por qué nos gustan (o no) los objetos cotidianos, Paidós Transiciones, Barcelona, 2005, pp. 135-137. 
sus piezas. En la base de éstas encontramos como norma, la dimensión antropológica en relación con el entorno natural.

La escultura que construyo en mi taller, es por sí misma un objeto terminado que no requiere de contexto específico o escala en particular, pero casi siempre alude a los ambientes donde la dimensión antropométrica es definitiva y lo público aparece como vocación propia. El paisaje urbano y natural es el ámbito donde mi escultura se desarrolla, parto de ese paisaje y regreso a él trastocándolo plásticamente con la nueva presencia, evidenciando lo existente y proponiendo un nuevo ambiente 331.

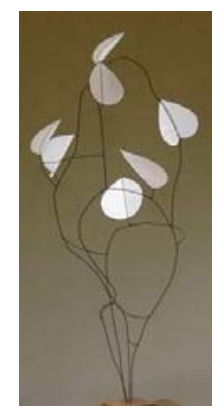

F. Silva Lombardo, Hr. 1, 2007.

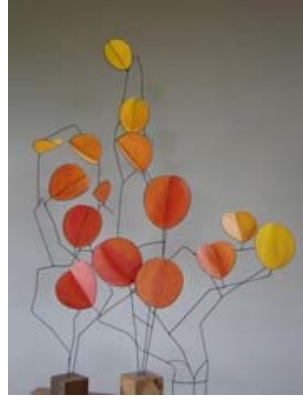

F. Silva Lombardo, Sin título, 2007.

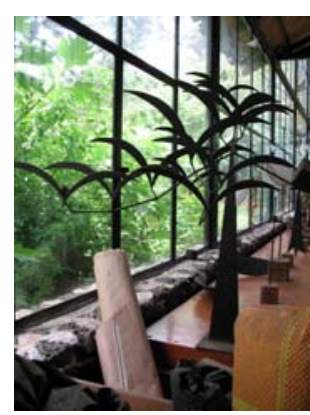

F. Silva Lombardo, Sin título, 2006.

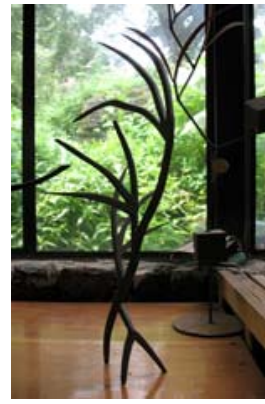

F. Silva Lombardo, Sin título, 2006.

La estructura que sostiene la obra de Federico Silva Lombardo se sustenta en un punto de apoyo, un fugaz y cambiante punto de equilibrio. Por su formación de arquitecto y su larga práctica académica, el artista define un punto como la intersección de dos líneas que provoca a la vez, convergencia y contradicción, confluencia y divergencia. Sus esculturas dan pie a que su pensamiento se desarrolle bajo la forma de binomios que suponen contrarios: afirmación y negación, peso y contrapeso, elevación y descenso, suma y resta. Estos opuestos proporcionan al artista la construcción retórica con la que imprime significados metafóricos a sus esculturas. En el funcionamiento y la mecánica de las esculturas de Silva Lombardo, radica su significado y, si bien sus interrogantes formales surgen de dicha ciencia, se dirigen de manera poética hacia una perplejidad ontológica.

En ciertas piezas el punto de equilibrio resulta, a la vez, un delicado punto de encuentro y desencuentro entre la Physis y el Nomos (ley), entre la Naturaleza y la Cultura, simbolizadas casi siempre, la primera por un elemento sin procesar como una piedra sin labrar, una rama, una espiga o una hoja aprehendida en su propio ritmo y, la segunda por una estructura rectilínea de metal -materia que proviene de la metalurgia, de un proceso en el que interviene el hombre y el fuego es decir, de la civilización-.

331 SILVA LOMBARDO, Federico, Disponible en red en: <http://www.silvalombardo.com /obra_actual.html>, [Consulta 14, abril, 2009]. 
En entrevista personal con el artista en su taller, realizada por la autora de esta investigación en agosto de 2008, pudimos observar numerosas de sus obras. Entre ellas, la pieza Ejército Zapatista (2006) que está compuesta por cien piedras volcánicas colocadas sobre sutiles estructuras de alambre en la cual, el equilibrio es tan precario que si uno de los elementos cae, puede llegar a derribar todo el conjunto. El módulo básico está formado por una pequeña estructura de hierro que sostiene una piedra volcánica. El conjunto está formado por cien unidades, se asienta sobre una superficie de metal recubierta de piedra volcánica y tierra. Pese a esta fragilidad, la obra se sostiene participando de un movimiento grácil con el espacio. Pieza, por otro lado interesante -en cuanto al uso de la metáfora se refiere- ya que cada uno de los elementos representa a la vez tanto a un arbolillo como a un ser humano.

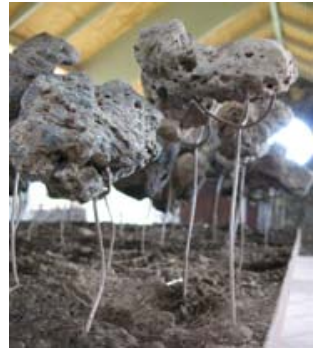

F. Silva Lombardo, Ejército Zapatista (Detalle), 2006.

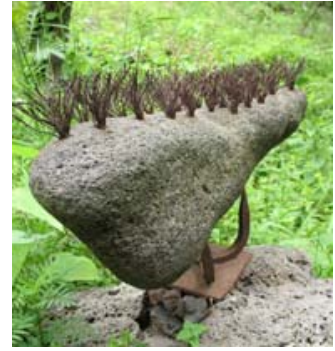

F. Silva Lombardo, Lengua, 2003.

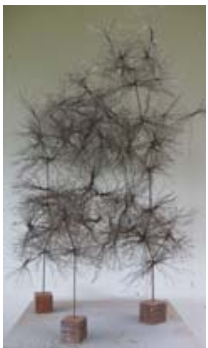

F. Silva

Lombardo, Espacio

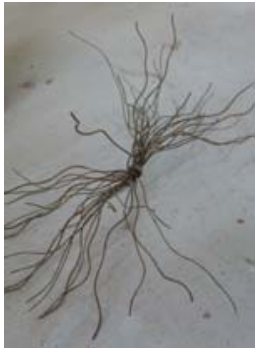

F. Silva Lombardo, Módulo peludo, 2003.

Peludo, 2003.

Si en sus piezas Naturaleza y Cultura se contrarrestan, resultando una el contrapeso de la otra y resolviéndose finalmente en un equilibrio precario e inestable, este procedimiento escultórico podría simbolizar el reinicio de un camino olvidado, donde la Naturaleza y la civilización no se opusieran, sino que confluyeran en una utopía de la armonía. Dentro del diálogo entre arte y filosofía, Silva Lombardo explica cómo la Naturaleza forma parte de nosotros mismos y nuestra mirada es fundamental para entender su comportamiento. El artista expone su proceso de trabajo en torno al estudio de la Naturaleza:

La disciplina de la escultura se convierte en un sistema de análisis para estudiar el comportamiento de la misma, convirtiéndose en un espejo analítico de aquella. Para el artista hacer escultura no es sólo un ejercicio formal o conceptual, sino eminentemente constructivo y en esta práctica, la naturaleza y sus modelos de comportamiento son ejemplos de los que parte para la invención de los nuevos modelos o sistemas constructivos 332.

332 Disponible en red en: http://www.silvalombardo.com/obra_actual/estructu ras/index.htm, [Consulta 25, enero, 2005]. 


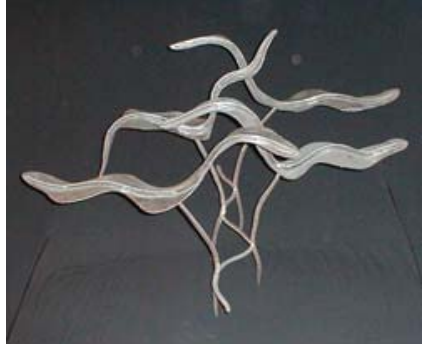

F. Silva Lombardo, Sin título, 2003.

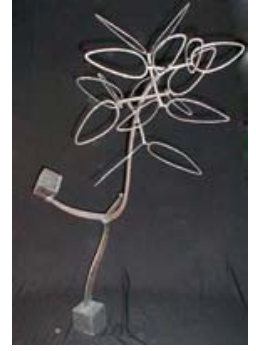

F. Silva Lombardo, Sin título, 2003.

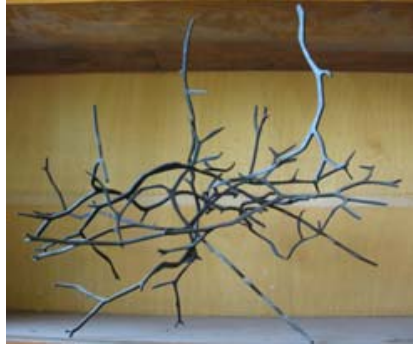

F. Silva Lombardo,

Ramas Secas, 2003.

En paralelo a sus reflexiones y a los procesos naturales observados, su obra, como en un contraposto, oscila entre la aparente liviandad de las formas y la pesadez de las estructuras y de los materiales que utiliza, resolviendo en esta dicotomía el binomio Arte y Naturaleza. Para el artista, Bromelia C (2007) parte de la incapacidad del hombre de proteger su medio ambiente, representa a una planta que ha sido extraída de un mar contaminado de aceite y petróleo, pese a lo cual, en una especie de réquiem estético, el artista se ve obligado a rescatar su belleza para con ello realizar un urgente llamamiento a sus coetáneos. Por el contrario, Espiga mutilada (2005), con una altura de seis metros, muestra una posible relación de la naturaleza vegetal con el hombre de la gran ciudad. Para ello en un proceso de adaptación al medio urbano y, a manera de mutación que le permite sobrevivir, la escultura crece y aumenta prodigiosamente su tamaño.

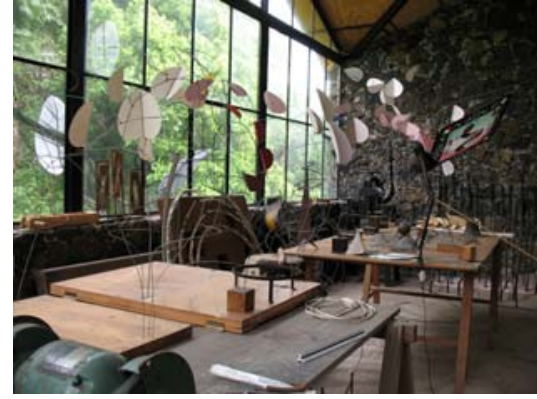

F. Silva Lombardo,

Vista al taller del artista, 2008.

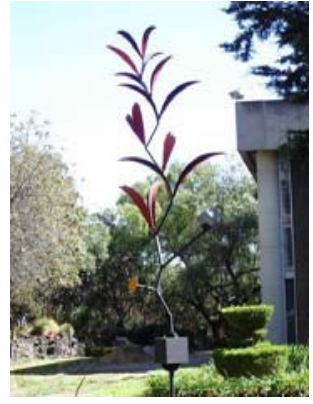

F. Silva Lombardo,

Espiga mutilada, 2005.

En resumen, rescatando la forma de operar de los vegetales, el artista asume en su obra la capacidad de las plantas para adoptar aspectos o condiciones plásticas no previstas previamente en el mapa genético natural del organismo. De esta manera, estamos ante una obra cuya propuesta escultórica se aleja fundamentalmente de lo decorativo y que, si bien en ocasiones, la coincidencia y el análisis formal permiten establecer relaciones amables con el contexto paisajístico, urbano o arquitectónico, la intención del artista no es embellecer el entorno, sino propiciar el discurso crítico y reflexivo en términos poéticos y filosóficos con el paisaje. 


\subsection{La semilla como referente formal y simbólico. Ivonne Domenge, Xawery Wolski y Miriam Medrez}

Dentro de las consideradas estrategias analógicamente formales que configuran gran parte del objeto de análisis de los trabajos escultóricos analizados en este capítulo, estudiamos aquí la obra de algunos artistas en cuyo modus operandi, no siendo específicamente la recurrencia al referente vegetal una constante en la elección de sus temáticas, opera sin embargo la selección prospectiva que ciertas formas vegetales generan en el inconsciente colectivo.

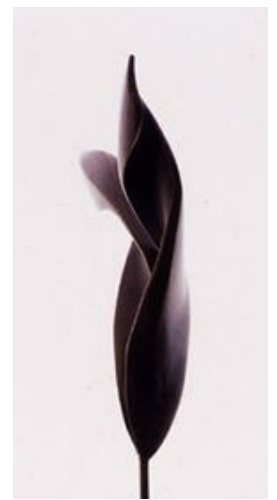

Ivonne Domenge,

Semilla de divergencia, 2003.

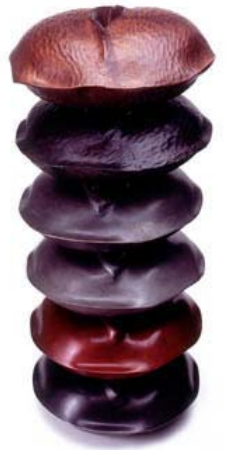

Ivonne Domenge,

Torre de semillas de Temporal, 2003.

En este apartado revisaremos la obra de escultores y escultoras como Ivonne Domenge, Xawery Wolski y Miriam Medrez en quienes queremos hacer hincapié por su recurrencia formal específica a desarrollar propuestas que remiten a la idea de origen, transformación y en particular, germinación vegetal, partiendo de la semilla como concepto. Así, las semillas como símbolo de origen primordial, de proceso inicial, de futuro nacimiento, de crecimiento y de las subsiguientes etapas del mismo (floración, decadencia y muerte de una planta), ofrecen una iconología significativa para explicar las razones simbólicas de su utilización como referente en el ámbito artístico.

El animal y la planta se desarrollan a partir de una semilla que, en un proceso de interacción diversa con el medio por el que su forma adquiere una complejidad progresiva, se nutre y termina por alcanzar el estado de organismo adulto333.

Una posible teoría para la elección de este tipo de simulaciones del objeto "natural" está relacionada con el desarrollo de una fuerza ligada a la expresión tanto de la autoafirmación de la obra como de la identidad del artista. Estamos ante una manera creativa de acercarse tanto a las razones físicas de los fenómenos naturales como a la religión o a la supuesta moral "natural" que 
comentábamos en el apartado anterior y cuyo principio nos lo ofrece la historia agraria del ser humano. En torno a estas ideas Mircea Eliade apunta:

Lo que el hombre vio en los cereales, lo que aprendió en el trato con ellos, lo que le enseñó el ejemplo de las semillas que pierden su forma bajo tierra, ésa fue la gran lección decisiva [...]. En la mística agraria prehistórica está anclada una de las raíces principales del optimismo soteriológico334: que el muerto, igual que la semilla sepultada en la tierra, puede esperar la vuelta a la vida bajo una nueva forma335.

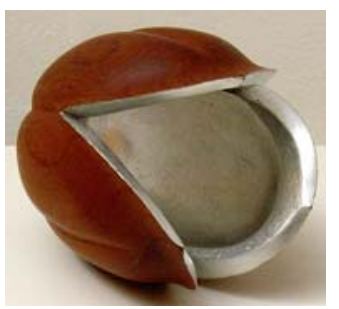

Ivonne Domenge,

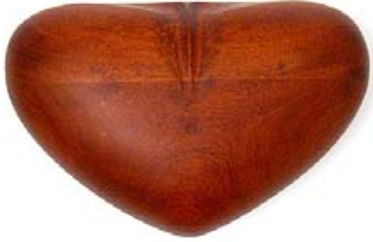

Ivonne Domenge,

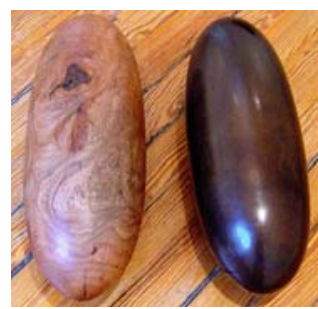

Ivonne Domenge,

Semilla de misterio, 2000.

Semilla de cielo-tierra, 2004.

Por tanto, la magia que envuelve al concepto de semilla parte del poder que antecede a la misma336, de la idea de considerarse como un ser vivo en potencia cuya naturaleza es la causa u origen de otras formas de vida. Este proceso a su vez, lleva emparejado el concepto de transformación, de metamorfosis que es intrínseco a su ser esencial. Como en la mayoría de diseños y construcciones realizadas por el ser humano, las metáforas biológicas y orgánicas se configuran partiendo además de una observación formal, de la relación que esta forma tiene con su función primordial.

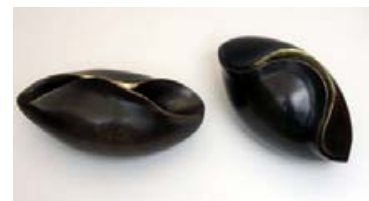

Ivonne Domenge,

Stupa II, Pétalo de semilla, 2004.

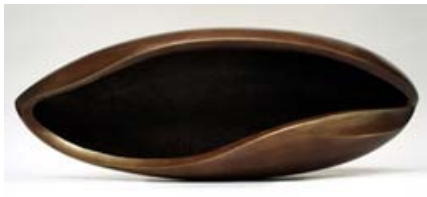

Ivonne Domenge, Semilla nueva, 2004.

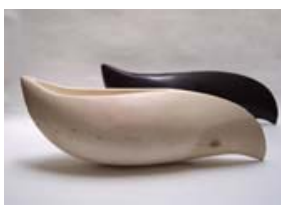

Ivonne Domenge, Semilla de los opuestos, 2004.

334 Soteriológico: referente a la salvación en el sentido de la religión cristiana. Nota de la autora de esta investigación.

335 ELIADE, Mircea, en CIRLOT, Juan Eduardo, op. cit., p. 53. Lo soteriológico en el sentido de la religión cristiana hace referencia aquí a la doctrina de la salvación.

336 La semilla, en Botánica, según el Diccionario de la Real Academia Española, es el fragmento vegetal, que forma parte del fruto de las fanerógamas. Contiene el embrión de una futura planta, protegido por una testa, derivada de los tegumentos del primodio seminal. Grano que en diversas formas producen las plantas y que al caer o ser sembrado produce nuevas plantas de la misma especie. 
La analogía orgánica según Steadmann permite dos interpretaciones distintas, aunque interrelacionadas, una que hace alusión a la apariencia visual o la composición y la otra funcional. Con respecto a la primera, la elección de este tipo de formas-función prevé la recepción de la misma como el logro de una relación equilibrada y proporcionada de las partes con el todo y viceversa, lo cual a su vez pronostica una percepción de placer estético ante lo que entendemos como fuente de perfección y belleza.

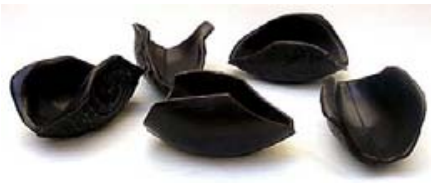

Ivonne Domenge,

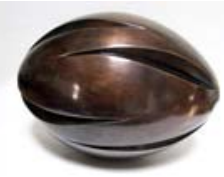

Ivonne Domenge,

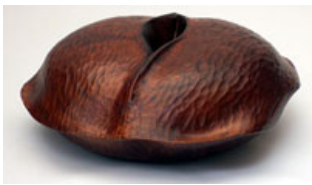

Ivonne Domenge,

Eslabón de semillas, 2003. Semilla de fuego, 2004. Semilla de Temporal, 2003.

Con respecto a la segunda interpretación vinculada a lo funcional, ésta admite en nuestro ámbito, una relectura simbólica que amplia el contexto en el que se utilizan este tipo de representaciones a la promesa de algo que crece y se desarrolla a partir de la propuesta del artista. En este sentido, en términos arquitectónicos y retomando la retórica como proceso de significación metafórica, el arquitecto Frank Lloyd Wright señala que: "El principio de vida interior es un regalo hecho a toda semilla" 337 y la elección por tanto de este referente orgánico indica en principio, una clara alusión a los procesos vitales.

Con una sólida trayectoria tanto nacional como internacional y a vueltas entre la belleza libre o intrínseca, -aquella que nos pueden proporcionar las matemáticas o la perfección de la geometría- y la belleza dependiente, relativa o belleza funcional debida a la adaptación al uso o función, la obra de Ivonne Domenge (México, D.F., 1946) se ha caracterizado por una búsqueda estética que oscila en diferentes direcciones, si bien todas ellas incidiendo en el concepto de lo universal.

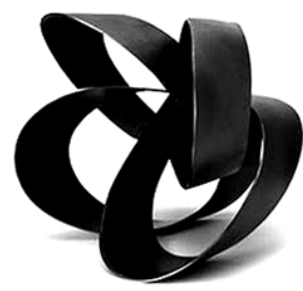

Ivonne Domenge, Mandala floral, 2003.

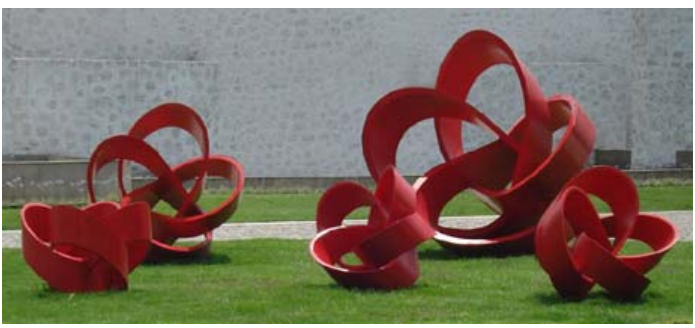

Ivonne Domenge, Mandala floral, 2004.

337 STEADMAN, Philip, op. cit., p. 191. 
Por un lado ahonda en una exploración formal inspirada en diferentes aspectos científicos relativos a la observación de la geometría de las moléculas. Esta búsqueda de la perfecta armonía, impregnada en cuestiones de orden ontológico y con la premisa de una estrecha correspondencia entre forma, armonía y orden, le han llevado a concretar un conjunto de obra de una cuidada factura, cuya tridimensionalidad recuerda a la música de las esferas. Su obra establece diálogos comunicantes entre los llenos y los vacíos de las formas respondiendo a inquietudes sobre los límites, las fronteras entre el interior y el exterior, sean estos espacios tanto físicos como espirituales, todo ello materializando en sus obras la captación de una energía en constante movimiento, generalmente envolvente y dinámico.

Después de unos inicios figurativos, sus inquietudes se concretan en la esfera, como el sólido, ontogénicamente hablando, más perfecto. Éste se presenta en sus esculturas como el lleno más completo, consiguiendo con el tiempo autorreferencialmente, multiplicarse en las infinitas caras que la geometría le ofrece para finalmente conseguir vaciarse de materia. Estamos ante un proceso de liberación a pesar del cual la artista consigue que las formas se comporten como contenedores concentrados de energía. Muestra de este proceso lo constituyen sus mandalas que remiten a un concepto particular de la filosofía Zen y de la espiritualidad contemplativa, mediante los cuales, provoca un movimiento cíclico que sugiere como Mandala de unidad en armonía (2003), el eterno devenir de las cosas.

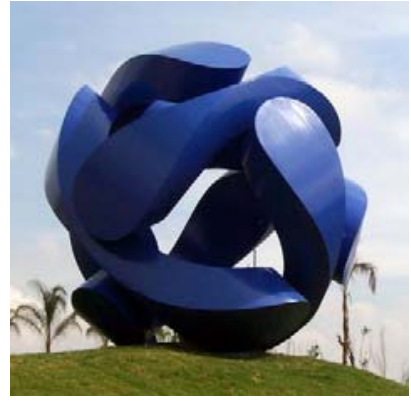

Ivonne Domenge, Flor de abril, 2003.

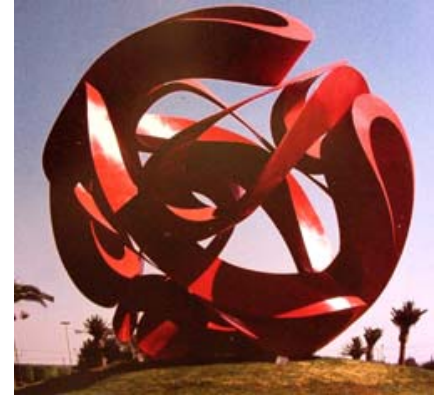

Ivonne Domenge,

Listón de tabachín, 2003.

Los mandalas han sido en diferentes culturas un símbolo que como continente, apelan a la trascendencia de la conciencia. Estos diagramas geométricos-rituales son imágenes arquetípicas que representan la totalidad de la persona, un ejercicio geométrico que funciona simbolizando el fenómeno de la divinidad percibida por el hombre338. Relacionados con la cuadratura del círculo, los

338 LEÓN DEL RÍO, M. ${ }^{a}$ Belén, "El símbolo como despertador del interés intelectual o estético en la escultura”, en SIGLER, Gerardo et al. , ¿Qué es la escultura hoy?, $1^{\circ}$ Congreso Internacional de Nuevos Procedimientos Escultóricos, Grupo de Investigación Nuevos Procedimientos Escultóricos, Universitat Politècnica de València, Valencia, 2002, pp. 63-64 
mandalas -como señala Juan Eduardo Cirlot- se convierten en una imagen sintética del dualismo entre unidad y variedad, diversidad y concentración, de forma que, excluyendo la posibilidad del desorden, estructuran el caos y la multiplicidad, en el anhelo de unidad y retorno a la condensación original 339. Aun cuando no se presenta de forma explícita, la concentricidad de las figuras alude siempre a la idea de centro.

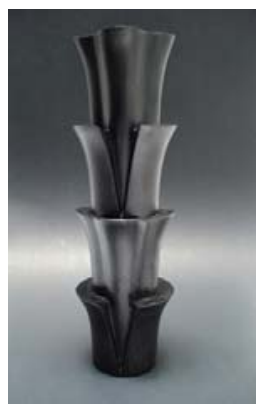

Ivonne Domenge,

Naturaleza extranjera, 2008.

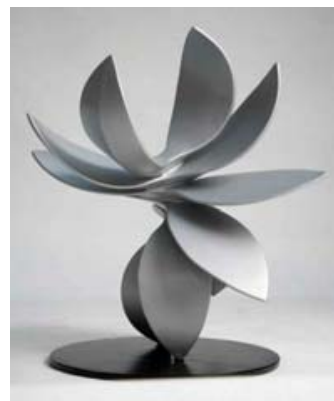

Ivonne Domenge, Lily, 2008.

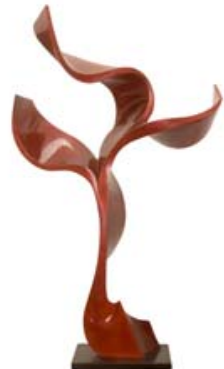

Ivonne Domenge, Árbol de vida, 2008.

Esta inclinación hacia el estudio de la geometría y la armonía universal deriva en una relación con el mundo y con la Naturaleza que nos circunda. Dentro de esta tendencia Domenge nos presenta lo orgánico como el reflejo y la manifestación del macrocosmos en el microcosmos y a la inversa y así, pese a que no utiliza constantemente lo vegetal como referente, los planteamientos en los que se basa muestran reiterativamente una profunda vinculación con el mismo.

Mi obra está basada en valores absolutos como el amor, la muerte y el erotismo. La naturaleza es la mejor maestra para un escultor, porque nos enseña la armonía de las formas y nos conecta con la perfección. Algunas piezas de mi trabajo, sobre todo las elaboradas en madera, son una interpretación a nivel personal de lo que observo en el hábitat natural 340 .

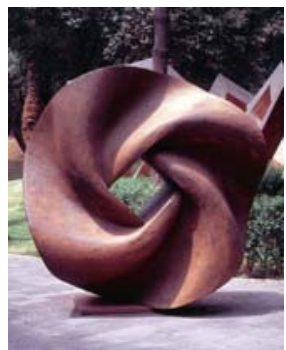

Ivonne Domenge, Mandala de unidad en armonía, 2003.

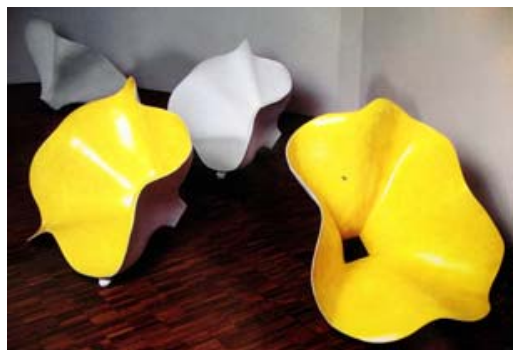

Ivonne Domenge,

Flores móviles, 2002.

339 CIRLOT, Juan Eduardo, op. cit., pp. 292-295.

340 DOMENGE, Ivonne, Disponible en red: http://www.cnca.gob.mx/saladeprensa-archivo, [Consulta 14, julio, 2009]. 
En cuanto a los materiales y técnicas de sus esculturas, Domenge ha experimentado en su obra con los más variados, desde la talla directa en madera como material fundamental, vivo y en transformación, hasta la piedra, bronce, acero, plata, resinas, barro, vidrio, jabón o hielo. Varios son los núcleos temáticos en los que habitualmente se clasifican sus piezas: la esfera, los soles, las estructuras moleculares, los relojes solares, mandalas, laberintos, semillas y flores, pero formalmente sus elecciones se decantan como ya hemos dicho, por el estudio de la esfera como el sólido geométrico más perfecto: la artista la analiza, a través del microscopio observando las estructuras moleculares de la misma para abrirla, generarle oquedades, fracturarla y así realizar sus obras escultóricas de gran formato.

Una de las constantes que podemos percibir en su obra es la fascinación por el orden, la simetría, el equilibrio, leyes que por la física y la mecánica conforman la estructura perfecta del cosmos. En la ley puramente geométrica, en la abstracción pura, en la forma absoluta y suprema el hombre encuentra "la mayor posibilidad de dicha" ${ }^{411}$, evitando así la arbitrariedad, caprichosidad y confusión de los fenómenos orgánicos.

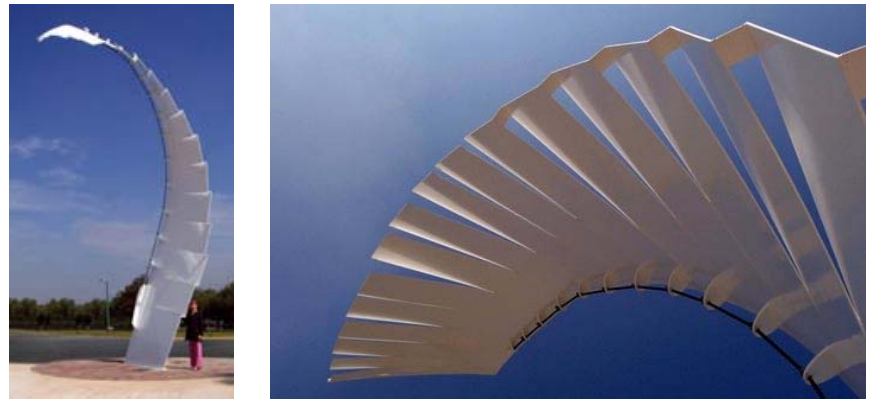

Ivonne Domenge, Palma, 2004.

Su intención es buscar, a través de la experiencia viva de la realidad, la esencia de las cosas, lo que la ha llevado a traducir en volúmenes y de forma simplificada sus estudios sobre la geometría. Fundamentalmente su interés por el cosmos y el universo parten del hecho de sentirse interrelacionada con todo lo que existe, tanto física como anímica e intelectualmente: considerarse parte de la creación, en la sorpresa ante la armonía, la elegancia, la sutileza de la belleza, ante la matemática y la geometría perfectas.

Yo siento que mucha de mi obra parte de la esfera [...]. Y esa esfera se fue abriendo. De ser monolítica, pasó a tener oquedades donde pasaba la luz. Empezó a abrirse como empecé a abrirme o también a la vida. Y empezó a geometrizarse, a crear un pentágono, que es la sección áurea de la esfera. $Y$ de allí, el pentágono se volvió flor. $Y$ todos son valores absolutos: es el

341 WORRINGER, Wilhelm, op. cit., p. 34. 
origen, es el orden, es la belleza [...], la continuidad [...], es la vida [...], es la espiritualidad 342 .

Considerando su escultura como una búsqueda espiritual, explora la posibilidad de propiciar con la contemplación de sus piezas, un cambio de conciencia en el espectador. De ahí que las estructuras moleculares observadas mediante el microscopio sean transportadas proporcionalmente a otras dimensiones de tamaño, en miras a una dimensión pública y urbana, con el objetivo de que el transeúnte pueda no sólo ver la belleza de la pieza, sino sentirse además partícipe de la belleza del universo de la que todos formamos parte. Este sistema constructivo nos habla de la minuciosa observación con que la escultora construye una suerte de traslación formal entre el microcosmos y el macrocosmos.

Cuando Domenge decide representar una estructura molecular, la cadena de ADN, un árbol o una semilla está aludiendo a una misma realidad compleja y viva, única y múltiple que ella concreta en la propuesta de una escultura [...]. Hay que contemplar sus semillas, sus hojas y vainas por las que resuena la estructura geométrica que la forma orgánica atempera. Es como si hubiera asumido el valor que entraña el cuerpo perecedero: la contingencia de una hoja o los avatares de las semillas como elementos necesarios $o$ connaturales al orden cósmico, no obstante que Domenge las aprehende con su mirada escrutadora de geómetra343.

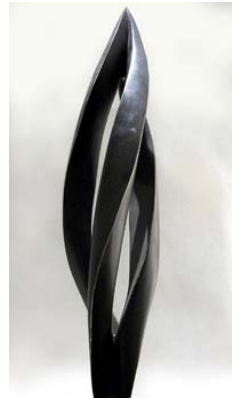

Ivonne Domenge,

Algas I, 2005.

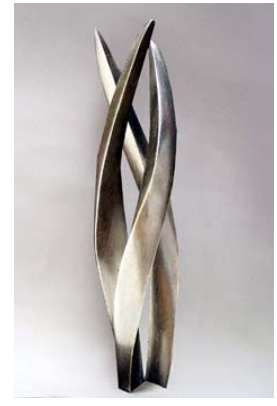

Ivonne Domenge,

Algas II, 2005.

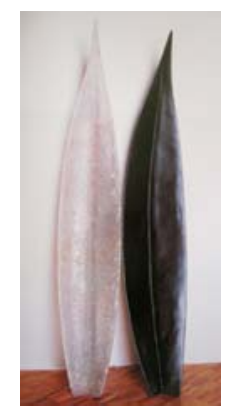

Ivonne Domenge,

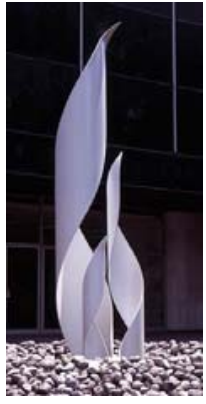

Ivonne Domenge,

Semilla Principia, 2005. Cumela, 2005.

En las piezas de gran formato, la escultora ha estado muy vinculada a un proceso de retroalimentación con diferentes arquitectos como Agustín Hernández, Legorreta y el francés Jean Stergou. Sus piezas en estos casos deben considerarse como acertadas intervenciones permanentes en el espacio público.

\footnotetext{
342 LARA ELIZONDO, Lupina, "Yvonne Domenge, Búsquedas profundas en el terreno de lo espiritual", en Resumen, Pintores y pintura mexicana. Irma Palacios, Yvonne Domenge, Promoción de arte mexicano, Año 10, № 76, México, D.F., julio-agosto, 2005, p. 37. 343 URIBE, Eloísa, "Yvonne Domenge Escultora. El uno y sus resonancias", en Yvonne Domenge, Escultora. Visión antológica, Museo de Arte Moderno de México, ConacultaFonca, México, D.F., 2005, pp. 17-25.
} 
Si bien deberíamos clarificar la diferencia entre arte en lugares públicos y Arte Público, puesto que éste no es el objetivo de esta tesis, únicamente haremos mención de la opinión al respecto de Mónica Gener ${ }^{344}$, la cual hablando de las premisas que presupone una actuación de Arte Público, comenta que una de ellas es la interacción de la obra de arte con el espacio urbano donde va a ser emplazada y la segunda, su integración con la arquitectura circundante, por lo que podemos considerar que las piezas realizadas por Domenge en este sentido se corresponden con la idea de obras en entornos públicos que interactúan con el espectador generando nuevos espacios de atención, espacios para el disfrute y la reflexión que permiten una mayor comunicación entre sociedad y entorno.

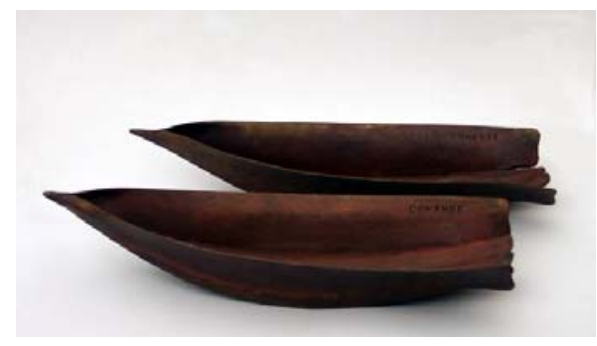

Ivonne Domenge,

Semilla, 2005.

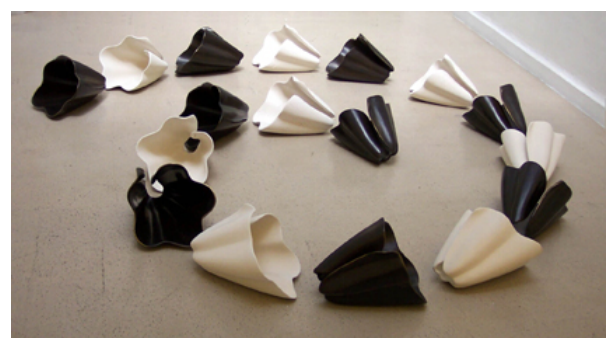

Ivonne Domenge, Instalación Flores, 2006.

Mediante estas premisas se establece un compromiso social que permite concretar y afirmar una identidad local, la demarcación de una zona urbana con un nuevo uso del espacio. No se trata de llenar un vacío, sino de generar un lugar de encuentro, social o individual. Esta democratización del espacio incita al espectador a acercarse, a participar de alguna manera. Las esculturas de Domenge, fieles a estas inquietudes, reflejan el espíritu, las necesidades y las inquietudes de nuestra época, sintetizando las relaciones existentes entre el entorno arquitectónico, el social y el natural. En una dinámica poético-participativa reclaman un espacio más democrático, no se convierten en escenarios políticos, ni conmemorativos, ni ególatramente artísticos sino que, como apunta Armajani, participan de una reflexión en la que la Ciencia se alía con la poesía.

El lenguaje esencial del ser es la poesía. Es el lenguaje de la teología secular y no sectaria. La poesía de nuestro tiempo es abierta y realza la presencia. Al otro lado de lo abierto está la muerte, que se halla en la cara oculta de la poesía, [...] la poesía es un rechazo sistemático de toda lógica y de toda razón. Podemos simplemente aceptar a la poesía tal y como es y evitar cuestionarla, moviéndonos hacia la vida cotidiana. Para interrogar al arte público necesitamos el lenguaje poético345.

${ }^{344}$ GENER, Mónica, "Arte en lugares públicos", en Cimal..., № 54, op. cit., p. 48.

345 ARMAJANI, Siah, "El arte público en el contexto de la democracia americana", en CUESTA, Salomé et al., op. cit., p.122. 
Contextualizado tradicionalmente como escultura urbana y relacionado con aspectos medioambientales, el Arte Público no agota aquí su propia definición. Antonio Remesar reivindica el concepto de Arte Público como un arte realizado en y para los espacios públicos, concibiendo al artista, cual demiurgo, como intermediario entre el espacio, el ciudadano y el arte. Siguiendo a Armajani, Remesar puntualiza lo que significa Arte Público y recuerda que éste debería analizarse en contextos específicos. Si le otorgamos como debiéramos, la función social de transmitir y formalizar contenidos sociales, debemos entenderlo como una producción social y cultural basada en unas necesidades concretas a la vez que "dotarlo de un carácter cooperativo" 346.

En conclusión, las piezas de Arte Público no deben configurarse como espacios sagrados, religiosos o políticos, ni deben tampoco propiciar la contemplación inmóvil por parte del espectador, como si se tratase únicamente de una representación. Estas obras tienen que, como señala el filósofo y crítico de arte Alberto Ruiz de Samaniego, "interpelar al transeúnte en su experiencia como caminante, como viajero, como ser en movimiento por la cotidianeidad contemporánea" 347 , comprometiéndose con él entre otras cosas, a transformar y mejorar el presente.

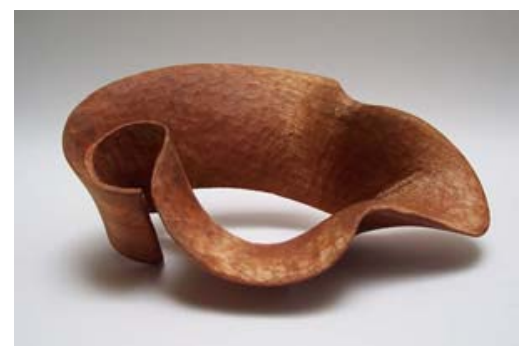

Ivonne Domenge, Fragilidad, 2005.
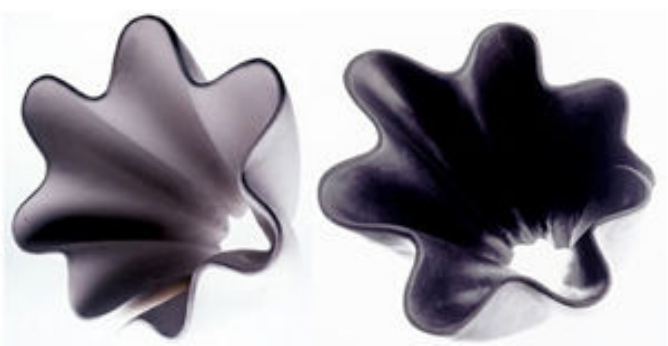

Ivonne Domenge, Eros y Ágape, 2005.

De entre las piezas de Ivonne Domenge que presentan un claro referente formal relacionado con lo vegetal y que podemos considerar cercanas al concepto de Arte Público, cabe destacar Palma (2004), escultura de doce metros de altura, realizada en acero dulce y situada en el Centro Comercial Las Palmas, en León (Guanajuato). En ella podemos apreciar el contraste entre la rigidez del material y la delicadeza de las articulaciones que la componen. Ambos aspectos confluyen en la plasmación sutil del movimiento de una hoja de palmera.

Otra escultura Cumela (2005) fue colocada en el Museo de Arte Moderno de México, D.F. con ocasión de la exposición de la artista en este recinto. Las formas de la pieza ubicada al exterior del museo, conectaba el territorio del mismo con los espacios ajardinados de los alrededores.

346 REMESAR, Antonio, "Repensar el paisaje desde el río", en MADERUELO, Javier (dir.), Arte público..., op. cit., pp. 193-194.

347 RUIZ DE SAMANIEGO, Alberto, "Arte público..." op. cit., p. 29. 
La serie Semillas (2005) aborda el misterio de la vida y surge en la obra de Domenge como un viaje de introspección a los orígenes. Si bien las esferas son concebidas por la artista como contenedores de múltiples posibilidades, estas nuevas piezas describen una vuelta hacia el centro de la geometría misma recuperando el punto inicial del código, allí donde el espacio se genera. El centro existencial se convierte en una semilla que representa el germen de todas las formas. La artista elabora semillas que se nos presentan como contenedores llenos de significados; semillas abiertas a un único vacío posible, aquel dispuesto a recibir todas las posibilidades de vida.

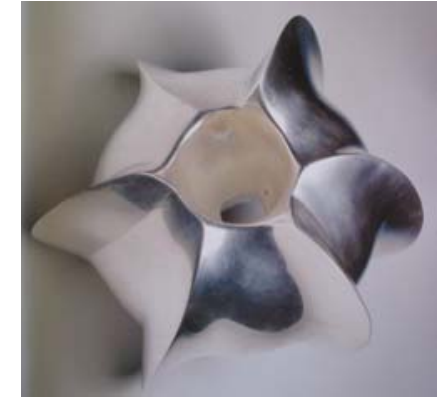

Ivonne Domenge, Flor de Mar, 1995.

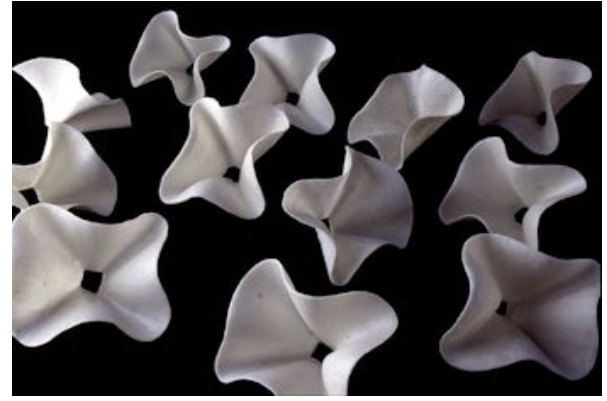

Ivonne Domenge, Flores, 2001.

En torno a la potencialidad del vacío como idea generatriz, Cirlot señala una lectura concreta:

Vacío. Es una idea abstracta, en contraposición a la "nada mística» que es la realidad inobjetiva, informal, pero en la que se encuentra todo germen. En el sistema jeroglífico egipcio, el vacío se representa como «lugar que se produce por la pérdida de la sustancia necesaria para formar el cielo», asimilándose así al espacio [...]348.

Esta idea, en nuestra opinión, nos acerca a la experimentación positiva del vacío como el complemento necesario e imprescindible de la presencia de lo lleno. Luis Rius Caso atribuye esta noción del vacío a la tradición del pensamiento occidental que bebe de las culturas orientales, en concreto de aquellas representaciones ligadas a la filosofía Zen, en las que fundamentalmente el vacío opera como un elemento positivo e iluminador vinculado a su vez con todo aquello universal e infinito ${ }^{349}$. La relación semántica entre forma y materia que establece el elemento semilla en estas esculturas se concreta entonces en un proceso de síntesis que recupera la potencia contenida en el símbolo, reflejando nuevamente la armonía inicial del universo.

348 CIRLOT, Juan Eduardo, op. cit., p. 455.

349 RIUS CASO, Luis, “Yvonne Domenge: La Aventura del Centro", México, D.F., 2004, p. 18. Texto inédito -en proceso de publicación- proporcionado por el crítico de arte, a la autora de esta investigación. 
Estableciendo un paralelismo, el poder representativo de estas obras se acerca a las ceremonias adonisias, rituales propiciatorios de los jardines de Adonis, en las que las representaciones del dios con formas vegetales funcionaban como encantamientos para promover el crecimiento o la reviviscencia de la vegetación entre las primeras civilizaciones agrarias 350.

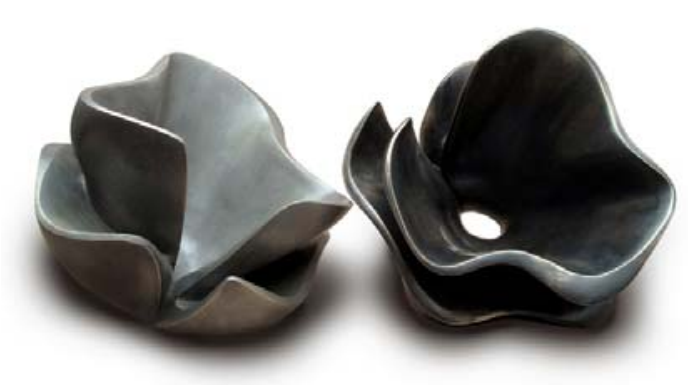

Ivonne Domenge, Flores caídas, 2003.

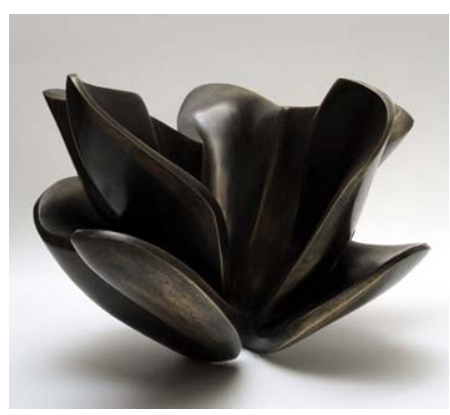

Ivonne Domenge, Flor al viento, 2003.

La artista, involucrándose en el misterio de la creación, de la transmisión de la vida y de la fecundidad busca trasmitir con estas esculturas la mágica ligereza de las líneas y las formas, todas ellas envolventes, protectoras y siempre a punto de germinar. Cuando se trata de madera, rescata las vetas del material acentuando con pigmentos las características propias del origen del material. En ocasiones, estas semillas se presentan en una simetría perfecta y en pares de materiales aparentemente opuestos, en donde la oposición se produce por el cambio de material: madera y bronce en la pieza Semilla de los opuestos (2004) y Semilla de cielo-tierra (2004) o resina y plomo en Semilla Principia (2005).

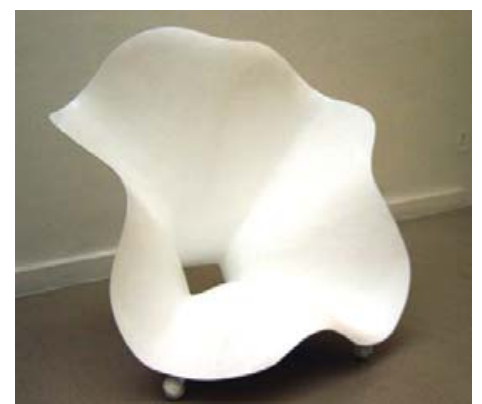

Ivonne Domenge, Flor móvil, 2005.

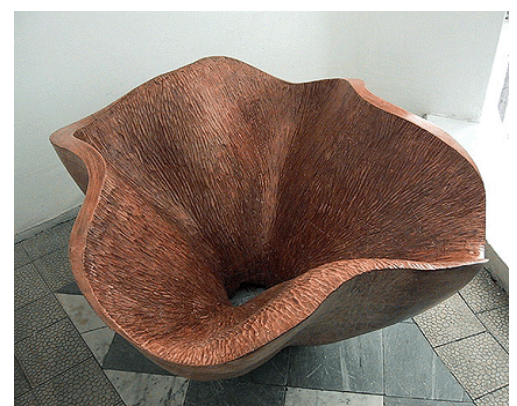

Ivonne Domenge, Floración, 2001.

Con el cambio, tanto del material como del color, la artista convoca el sentido del tacto, una de las instancias más significativas de la escultura y lo tridimensional. Los acabados de sus piezas, de manufactura muy pulida y con

350 FRAZER, James George, La rama dorada. Magia y religión, Fondo de Cultura Económica, México, D.F., 1986, p. 396. 
texturas de sandblasteado ${ }^{351}$ producen un efecto sinestésico ${ }^{352}$. El tacto como vehículo de reconocimiento e identidad es una fuente primordial tanto en el proceso de elaboración de sus piezas, como en la recepción de las mismas.

A lo largo de su desarrollo profesional, la artista ha experimentado constantemente con técnicas y destrezas que se corresponden con la fragilidad efímera producida por la estructura molecular de la madera, logrando así transparencias que se suman al concepto de semilla y permitiendo, por ejemplo, que en ellas penetre la luz y pueda metafóricamente surgir el concepto de vida.

Domenge se apropia de las formas que nos da la naturaleza y las transforma. Sus semillas, de origen minúsculo, alcanzan dimensiones de universos circundantes a manera de contenedores o refugios en los que igual puede uno recrear un espacio interior que una llave para abrir un nuevo deseo escondido353.

Además de las semillas, el interés por lo vegetal de esta artista se ha manifestado en diferentes esculturas: Floración (2001), Flores caídas (2003), Flor al viento (2003), Flor de abril (2003), Listón de tabachín (2003)354, Flores móviles (2002), etc. Al igual que en otros tantos escultores, la flor aparece como una de las partes de la planta, así como hojas o árboles que de nuevo nos remiten a la importancia de este referente dentro de la escultura contemporánea. Con Lily (2008), pieza que representa a un lirio, la artista ganó el primer premio del Concurso Olympic Landscape Sculpture Design Collection en Beijing, China. Las soluciones mecánicas para esta pieza fueron realizadas por el arquitecto José de Silva Rioseco. Otras especies vegetales han sido objeto de su atención. Algas / y Algas // (2005) son ejemplos del movimiento envolvente e implícito que asigna a las estructuras geométricas con referente vegetal. En todos los casos con un léxico visual que, como señala Itzel Vargas "siempre ha sido cercano al erotismo y la sensualidad" 355 , Domenge consigue trasmitir a sus esculturas una sensación de armonía no estática y en constante transformación.

351 El sandblasteado (anglicismo) también Ilamado Sand Blast es el término que se utiliza en México para la técnica de proyección de chorro de arena mediante aire comprimido a presión, sobre diferentes superficies y con la finalidad de obtener una textura particular.

352 Llamamos sinestesia a la relación o confluencia entre los sentidos. Imagen o sensación subjetiva, propia de un sentido, determinada por otra sensación que afecta a un sentido diferente.

353 CHÁVEZ SILVA, Eduardo A., "La Escultura de Yvonne Domenge", Disponible en red: $<$ http://www.domenge.com/artman/publish/escultura_214.shtml>, [Consulta 2, noviembre, 2004].

354 Tabachín común, flamboyán o árbol de fuego de nombre botánico, Delonix regia, árbol exuberante, frondoso, muy florido y de vistosos colores, propio de climas tropicales, cuyas vainas recuerdan una especie de espadita roja.

355 VARGAS PLATA, Itzel, Yvonne Domenge, Escultora. Visión antológica, Museo de Arte Moderno de México, Conaculta-Fonca, México, 2005, pp. 27-34. 
Paralelamente a los escultores y escultoras hasta aquí revisados, otros artistas han explorado también estructuras tridimensionales que, partiendo del concepto de semilla y con el objetivo de poner de manifiesto las semejanzas entre las formas vegetales y las humanas, presentan diferentes formas de acercarse a la Naturaleza mediante la transcripción del elemento vegetal. Entre ellos se encuentra Xawery Wolski (Varsovia, Polonia, 1960) quien ha vivido y trabajado en México durante varios años, y cuya obra en particular es relevante en el periodo de tiempo que nos ocupa. Sus piezas presentan formas orgánicas, sintéticas y tendentes a una geometría reduccionista.

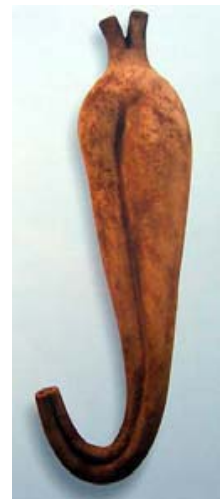

Xawery Wolski, Sin título, 1998.

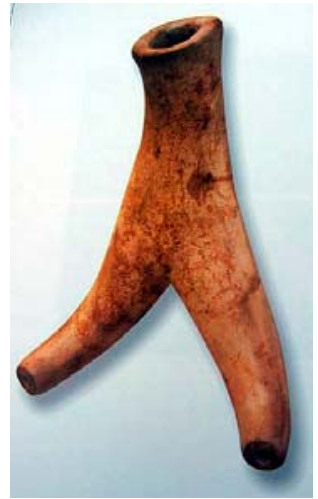

Xawery Wolski, Sin título, 1998.

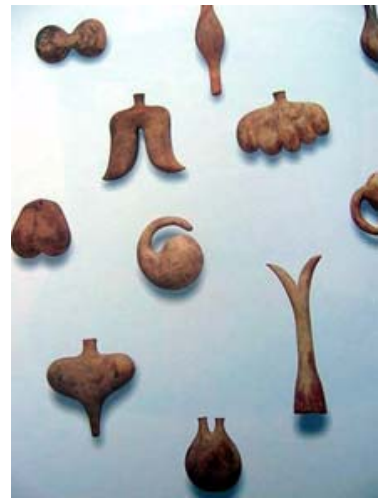

Xawery Wolski,

Órganos blancos, 1995.

Se trata, en ocasiones de fragmentos del cuerpo humano tanto a nivel interno (entrañas) como externo (miembros) con un gran predominio de círculos, curvas y formas redondeadas. Son creaciones de una limpieza extraordinaria elaboradas en terracota, cerámica y bronce. Estos fragmentos de cuerpo humano (huesos, dientes, pechos o torsos), como en el caso de Órganos blancos (1995), establecen una analogía formal con ciertas partes de plantas como semillas, tallos, frutos o raíces. La misma indefinición formal genera una reflexión sobre la ambigüedad ontológica puesto que incluso, cuando en las obras aparecen fósiles o conchas, éstas recuerdan a vainas y semillas.

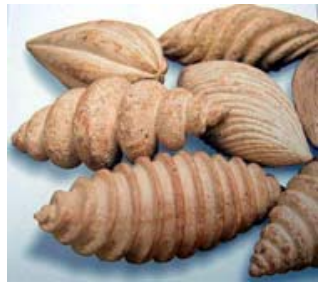

Xawery Wolski, Fósiles, 1995.

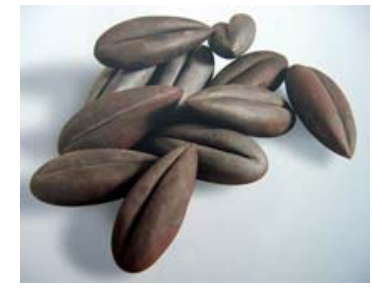

Xawery Wolski, Granos, 1988.

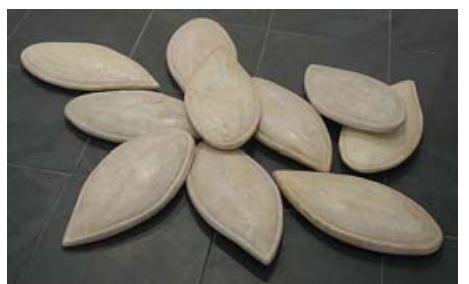

Xawery Wolski, Pepitas, 1996.

Estamos ante un proceso de fragmentación y desmaterialización del cuerpo humano, como una de las características de la postmodernidad. Uno de los 
núcleos temáticos principales en la obra de este artista parte de la representación de la figura humana y tiene que ver con las metáforas y las transcripciones del cuerpo en otro material, de manera que establece nexos entre la fragilidad del cuerpo y la del material utilizado.

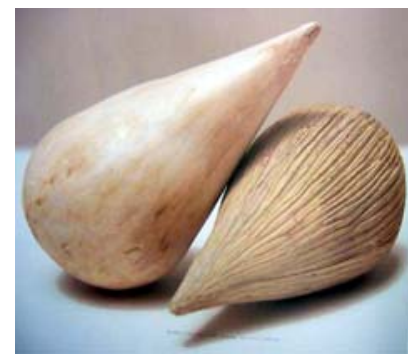

Xawery Wolski, Semilla, 1996.

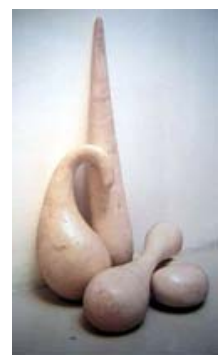

Xawery Wolski, Sin título, 1998.

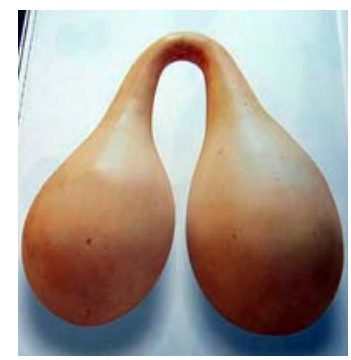

Xawery Wolski, Hueco doble, 1998.

Para José Miguel García Cortés, quien ha tratado a fondo la representación del cuerpo en el arte contemporáneo, las obras fragmentarias, parciales y mutiladas concentran precisamente la atención en aquello que falta. Los fragmentos tienen históricamente una importante impronta simbólica y, como parte de un todo, sugieren ausencia, muerte o el fin de algo. Sin embargo, la esencia del fragmento es la resistencia y no la fragilidad pues al provocar la imaginación del espectador ejercen un especial magnetismo que convierte al mismo en creador:

La vida es frágil, es fácil acabar con ella, fragmentarla; sin embargo nada es tan arduo de crear. El fragmento se convierte en el punto de partida de una reconstrucción material por parte del espectador [...] incita a proseguir, invita a investigar, a completar el abanico de hipótesis y de posibilidades que ofrece [...] ejerce una atracción indudable356.

La disposición ordenada de los fragmentos que nos ofrecen las obras de Wolski, no responde a una ausencia determinada, ni a mutilaciones específicas. En nuestra opinión se trata de la persistente reconstrucción de un cuerpo mayor, en tanto que siempre incompleto o imposible de abarcar, que incluiría todas las posibles analogías formales y que a su vez, más allá de órdenes anatómicos, permitiría una lectura transversal del conocimiento del todo universal. Las estructuras y las formas se autoafirman como una energía que fluye entre los diferentes seres, generando vida que a su vez, se manifiesta a través de la multiplicidad.

356 GARCÍA CORTÉS, José Miguel, El cuerpo mutilado. La Angustia de Muerte en el Arte, Direcció General de Museus i Belles Arts, Conselleria de Cultura, Educació i Ciència, Colección Arte, Estética y Pensamiento, Valencia, 1996, p. 53. 


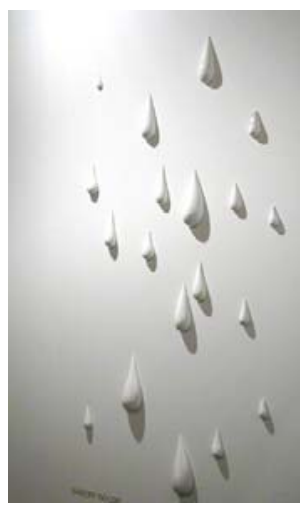

Xawery Wolski, Gotas, 2004.

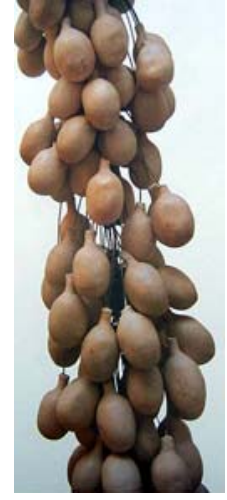

Xawery Wolski,

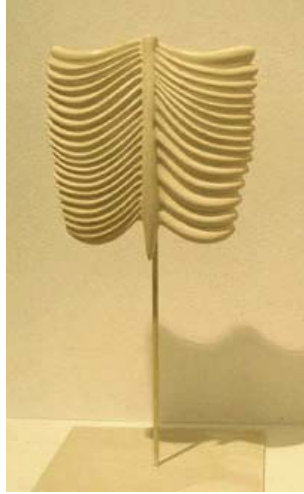

Xawery Wolski, Costillas, 2008.

Este proceso de trabajo en Wolski nos aproxima a la sinécdoque357. La metonimia formal empleada como recurso y la aceptación de una parte por el todo, ha sido una recurrencia constante a lo largo de la Historia del Arte. Desde tiempos remotos se conoce la existencia de fragmentos anatómicos en la escultura, de manera que en la retórica del cuerpo, un fragmento puede designar la totalidad orgánica del mismo. Pensemos por ejemplo en la tradición de los exvotos religiosos que presentaban, tanto en la Cultura occidental como en otras culturas, fragmentos de cuerpos colgando en las paredes de los santuarios 358 .

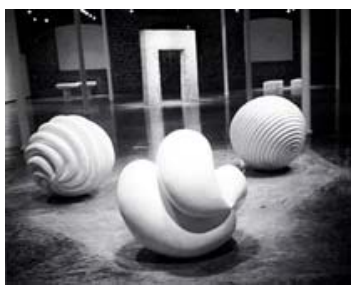

Xawery Wolski,

Esferas Grandes, 2002.

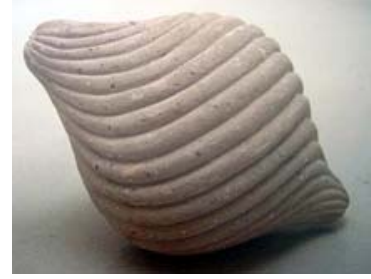

Xawery Wolski, Espiral cono, 1996.

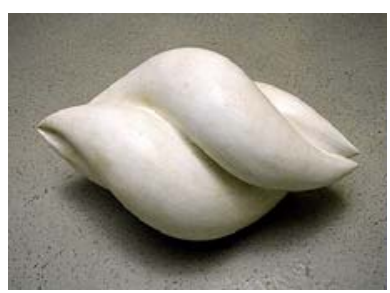

Xawery Wolski,

Cono doble grande, 1996.

A comienzos del siglo XX, Rodin utilizaba partes del cuerpo con un profundo contenido literario y psicológico359. Este escultor en un claro sesgo innovador, usaba este tipo de prácticas, -la mutilación, el injerto y los ensamblajes- para potenciar tanto la significación del cuerpo humano, como la expresión de sus pensamientos y sentimientos (El hombre que camina, 1877, La figura volante, 1890). De esta manera creaba seres antropomórficos e híbridos que, en un claro

357 Sinécdoque: dentro de la rama de la lingüística es un tropo consistente en extender, restringir o alterar de algún modo la significación de las palabras para designar un todo con el nombre de una de sus partes o viceversa.

358 RAMÍREZ, Juan Antonio, Corpus solus. Para un mapa del cuerpo en el arte contemporáneo, Siruela, Madrid, 2003, p. 226

359 GARCÍA CORTÉS, José Miguel, op. cit., p. 58. 
proceso de metamorfosis anunciaban lo efímero de la existencia, la mutabilidad del ser y la ambivalencia de la identidad, mostrándonos la visión que Rodin tenía del ser humano360.

Durante las últimas décadas del siglo XX, muchos otros artistas han roto con la tradición escultórica que hacía del cuerpo humano, entendido como totalidad, "un lugar de santidad, intocable en su apariencia externa y completa"361, para representarlo a partir del fragmento, dando soluciones completamente novedosas y componiendo discursos interminables con todo un repertorio nuevo de metáforas y sinécdoques. Sería Jean Tinguely quien introduciría por primera vez fragmentos de figura humana en su obra, interrelacionándola con sus máquinas cinéticas, (Dissecting machine, 1965). Pero la fragmentación entendida como sinécdoque corporal alcanzará posteriormente en las obras de Kiki Smith, Annette Messager, Judy Chicago o Robert Gober un despliegue irónico que ofrecerán en conjuntos más o menos ordenados, detalles corporales en los lugares más insólitos ${ }^{362}$.

En este sentido, la pieza Los pulmones de Barranco (1994) realizada por Wolski en Lima, Perú, funciona como un contenedor-purificador de aire, y genera un nuevo híbrido que establece una relación de identificación entre el cuerpo humano (pulmones) y el cuerpo de la tierra (semilla-fruto), haciendo de ambos un sólo cuerpo interdependiente. Esta exhibición de fragmentos procedentes del interior del cuerpo humano revela una intimidad que, al tiempo que se hace pública, relaciona estos objetos con una suerte de religiosidad o misticismo, similar al que procede de la magia simpática que dio origen a los exvotos u ofrendas votivas.

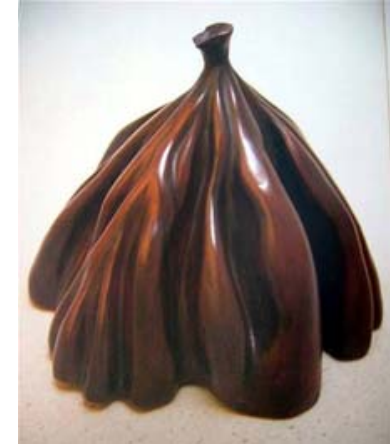

Xawery Wolski,

Sin título, 1998.

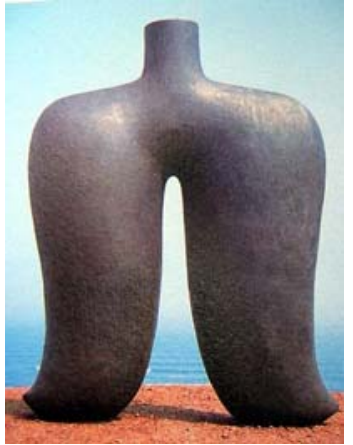

Xawery Wolski, Los pulmones de Barranco, 1994.

Esta tipología de objetos con una clara función polivalente, tiene su origen en el tipo de respuestas relacionadas con el ritual propiciatorio que las diferentes culturas han dado a la relación entre enfermedad y curación y está

360 GARCÍA CORTÉS, José Miguel, op. cit., p. 61.

361 GARCÍA CORTÉS, José Miguel, op. cit., p. 56.

362 RAMÍREZ, Juan Antonio, op. cit., pp. 227-229. 
fundamentada en una relación contractual que varía según las diferentes concepciones y creencias basadas en conocimientos empíricos sobre la naturaleza del mundo, tanto natural como sobrenatural. Conectada con la tradición de los exvotos, podemos observar un paralelismo en la recreación y exposición de vísceras y fragmentos del cuerpo humanos dentro del arte contemporáneo en la obra, entre otros artistas, de Annette Messager 363. Asimismo la obra de Penone constituye una metáfora similar en la que la utilización del órgano de la respiración humana, los pulmones, se asimila al medio natural, suprimiendo las barreras entre ambos y haciéndolos partícipes de una misma sustancia común.

En la obra de Wolski, esta temática aunada a la idea de repetición de elementosmódulos simples y repetitivos, pequeñas esferas con las que elabora infinitos collares, le permiten introducir el concepto de multiplicidad en lo orgánico. Así, sus Granos y Pepitas nos hablan de manera intrínseca de la exuberancia formal de lo orgánico y de la capacidad reproductora de lo múltiple.

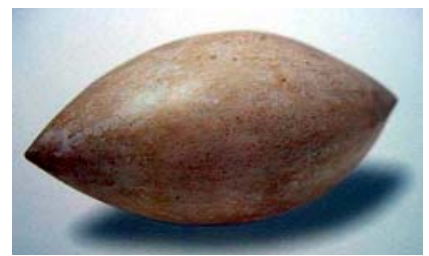

Xawery Wolski, Semilla l, 1996.

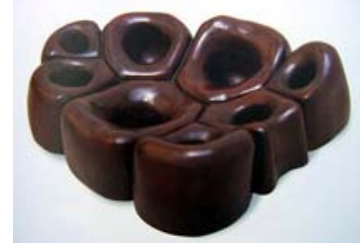

Xawery Wolski, Flor, 1998.

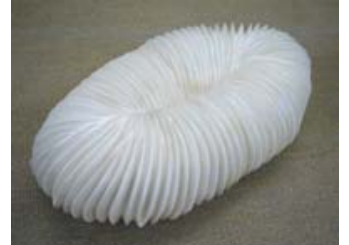

Xawery Wolski, Raia blanca, 1999.

Wolski trabaja sus esculturas de forma muy sutil, utilizando una gama monocromática en blanco, tratando las superficies generalmente pulidas, de manera que producen sensaciones muy poéticas. Interesado por el contacto con el material, incide en las capacidades expresivas de la arcilla, experimentando con diferentes procedimientos e investigando antiguas mezclas y milenarias técnicas tradicionales utilizadas por civilizaciones pasadas como las de los antiguos mexicanos y los incas, estudiando su uso y pervivencia de las mismas en la actualidad. En su obra, este interés está relacionado con la necesidad de vincular el pasado y el presente frente a las nuevas tendencias globalizadoras en las que predominan las tendencias occidentales, y que tienden a obviar todas aquellas manifestaciones autóctonas, restringiéndolas a todo lo relacionado únicamente con el folklore y las manifestaciones artesanales de la Cultura. En su opinión, la conciencia sobre lo universal debe manifestarse de manera inclusiva, dando cabida a todo lo plural. En este sentido, el artista comenta364 la

363 RAMÍREZ, Juan Antonio, op. cit., p. 226.

364 HOBLER, Martin, "La globalización en las Artes", entrevista con Xawery Wolski, Zürich, 2008, Instituto de Política de Europa Oriental, Universidad de Berlín, Disponible en red:<http:// www.xwolski.com>, [Consulta 13, enero, 2005]. 
importancia que ciertas exposiciones como la Magiciens de la terre 365 , organizada por el Centro Georges Pompidou en 1989, en París, han tenido en la revisión de estos conceptos y en la creación de nuevos paradigmas.

En cierta manera, la intención de las esculturas de Wolski, esas figuras geométricas básicas no desprovistas de cierto misticismo y basadas en elementos de origen orgánico, nos remiten también a la obra inicial de Anish Kapoor quien formó parte de la Ilamada Nueva Escultura Británica, en la década de los ochenta, fusionando las influencias culturales de Oriente y Occidente y explorando los opuestos primordiales de lo masculino y lo femenino, lo abierto y lo cerrado, la luz y la oscuridad. Si bien y en contraposición a Wolski, en su obra escultórica utilizó el color intenso de pigmentos aplicados directamente, cuya utilización es una seña de identidad dentro de la producción del artista. En ambos casos se percibe la unión de lo intangible con lo sensual desde una perspectiva que analiza el resultado estético como parte de una cosmovisión personal.

Por otro lado, tal como apunta Soledad Vilar, las nuevas representaciones fragmentarias del cuerpo están también relacionadas con los movimientos sociales y las grandes migraciones forzadas que experimenta en la sociedad contemporánea el ser humano366. Como apunta Deleuze, la filosofía, al igual que el arte crea nuevas relaciones con el mundo y en este sentido y, siguiendo a Bateson, es la vida la que transita en estas representaciones de Wolski que parecen tanto extensiones vegetales como fragmentos de órganos humanos. Su temática está relacionada con el cuerpo humano pero sus búsquedas relacionan a éste con otros organismos vivos. La vida es algo que pasa entre los sujetos, es lo que está entre los seres humanos, las plantas y los animales, es la lógica del "devenir". Tanto los seres humanos, como los animales o las plantas poseen un territorio que no se delimita por contornos fijos sino que está en continua transformación. No se trata de crear territorios cerrados sino de poner estos territorios en movimiento, emprender líneas de fuga y desterritorializarse para definir una identidad sin contornos fijos. Esta actitud de desterritorialización es característica del nómada que como Wolski, en su devenir por los diferentes países en los que ha vivido después de salir de su natal Polonia, ha conseguido expresar en sus obras esa experiencia de tránsito.

Lo que torna uno a descubrir son vínculos, lazos, más que lugares, fenómenos reflexivos [...] más que relaciones, sistemas de obligación recíproca, "pequeñas veneraciones", por decirlo así de la vida cotidiana367.

\footnotetext{
365 Véase AA. VV., Magiciens de la terre, Centre Pompidou, Paris, 1989. En esta exposición, organizada por Jean-Hubert Martin, se expusieron obras de cien artistas procedentes de más de cuarenta países. El particular concepto expositivo logró establecer un diálogo con el arte contemporáneo no occidental.

366 VILAR GARCÍA, Soledad, "La fragmentación del cuerpo en las instalaciones y la escultura contemporánea”, en SIGLER, Gerardo et al., op. cit., pp.103-106.

367 ISAAC, Joseph, El Transeúnte y el espacio urbano. Sobre la dispersión y el espacio urbano, Gedisa, Colección El mamífero parlante, Barcelona, 2002, pp. 25-31.
} 
La circunstancia de vivir en varios países le ha llevado a definir un discurso que nos habla de la fragilidad. Esta característica podemos percibirla tanto a través de los materiales que utiliza, como de la temática híbrida de sus esculturas, en las que la vida o el cuerpo humano se manifiestan como materia de múltiples posibilidades. Lo híbrido se percibe en sus formas, como una de las consecuencias probables de la vida. Podríamos decir que para Wolski, el retorno al lugar es el recurso de aquel que frecuenta los no lugares, y sobre este aspecto nos recuerda Augé la definición propuesta por Vincent Descombes sobre la noción de país retórico a partir de un análisis de la "filosofía" o de la "cosmología" de Combray sobre dónde en realidad está el personaje en su casa. La pregunta no hace tanto alusión a un territorio geográfico como a un territorio retórico:

El personaje está en su casa cuando está a gusto con la retórica de la gente con la que comparte su vida. El signo de que se está en casa es que se logra hacerse entender sin demasiados problemas, y que al mismo tiempo se logra seguir las razones de los interlocutores sin necesidad de largas explicaciones. El país retórico de un personaje finaliza allí donde sus interlocutores ya no comprenden las razones que él da de sus hechos y gestos ni las quejas que formula ni la admiración que manifiesta368.

Wolski, a través de su obra, hace referencia a las dificultades de adaptación vividas en el transcurso de sus estancias en varios países, a los obstáculos por hacerse entender, las diferencias sociales de percepción, políticas o a las concepciones religiosas.

Hasta aquí y, con este artista, introdujimos la obra de artistas mexicanos que relacionan fragmentos del cuerpo humano con partes de vegetales. En una línea similar, en la obra de la ceramista-escultora Miriam Medrez (México, D.F., 1958) la relación entre el cuerpo humano y las plantas cobra en la representación, un sentido de vinculación e interdependencia.

En su obra Miriam Medrez ha recurrido a la figura antropomorfa y a la recreación de imágenes "reales" como estructura de un discurso poético y reflexivo sobre la condición del ser humano369.

En algún momento, su obra se relaciona con ciertos aspectos de la artesanía tradicional mexicana, en concreto con los trabajos de cestería, los tejedores de petates, canastas, mimbres y bejucos. Con este trabajo formal sus esculturas se conectan también con la textura y la estructura del material. Ambas se exteriorizan en su obra generando una conexión con la misma naturaleza vegetal de los materiales a los que alude formalmente, apreciándose esos

368 AUGÉ, Marc, op. cit., pp. 110-121.

369 ARTEAGA, Agustín, "Vertientes en la escultura cerámica contemporánea", en AA. VV., Cuerpos terrenales. Escultura en barro. Azcúnaga, Margáin, Marín, Medrez, Portela, Torres Vargas, Boris Hirmas, México, D.F., 2003, p. 56. 
encuentros en su obra. En diferentes exposiciones a lo largo de los últimos años, esta escultora que trabaja en Monterrey, ha experimentado tanto con los materiales como con las formas. Generalmente su trabajo, situándose a caballo entre la figuración y la abstracción, se relaciona fundamentalmente con la representación del cuerpo humano con sutiles referencias de género, sin embargo las imágenes de sus obras más recientes muestran una clara relación del ser humano con la vegetación.

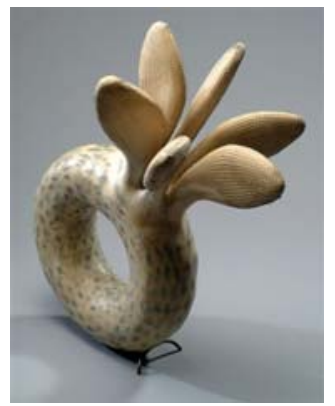

Miriam Medrez, Sin título, 2002.

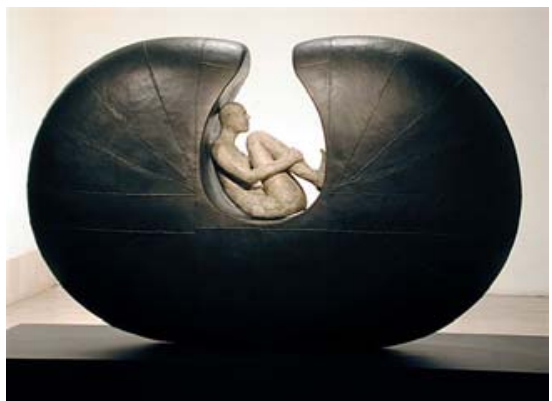

Miriam Medrez, Sin título, 2002.

Siempre me he considerado figurativa, aunque también he hecho escultura abstracta. Hace un par de años -una época desértica, en que me preguntaba: ¿qué expreso, cómo lo expreso, qué materiales utilizo, cómo lograr aquello que traigo dentro?- tuve que ponerme a investigar la forma, los acabados y las texturas, y esto me llevó al camino de la abstracción. Partí de las plantas por sus formas orgánicas, sus texturas, ritmos, movimiento y crecimiento; principalmente por la sensación que me provocan al sentirlas en mis manos 370 .

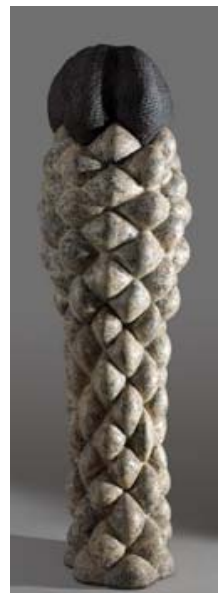

Miriam Medrez,

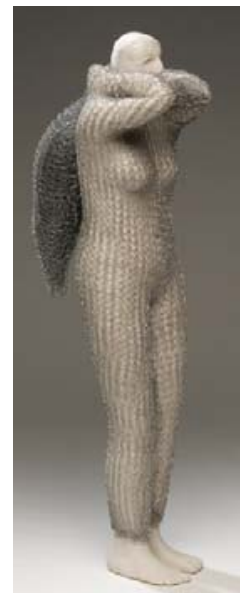

Miriam Medrez, Sin título, 2002.

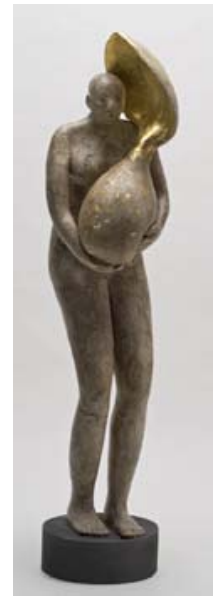

Miriam Medrez, Sin título, 2002.

370 ARTEAGA, Agustín, "Vertientes...", op. cit., p. 56. 
En las piezas relacionadas con la vegetación, podemos apreciar que la figura humana aparece en estrecha relación con formas orgánicas que recuerdan granos, semillas, frutos y en actitudes de protección mutua, sea la semilla protegiendo a la figura o a la inversa, siendo la semilla cuidada por la figura humana. Independientemente de la conexión autorreferencial al cuerpo de la misma escultora y al mismo proceso de trabajo de la artista al realizar las piezas, el cuidado con que éstas son realizadas y que requiere el material, cerámica, el hecho es que esas figuras evidencian un diálogo formal con la naturaleza vegetal y una alegoría de crecimiento conjunto.

Con firmes cualidades formales e impecable uso de diversas técnicas cerámicas, Miriam Medrez exhibe piezas que hablan de la naturaleza y de lo importante que es hacer conciencia de nuestra manera de interactuar con ella. Lleno de belleza estética, el trabajo de Medrez señala la trascendencia capital del medio ambiente y, cual arborescencia semántica, también llama a percatarnos de la vida como experiencia de compromiso37i.

Las nuevas formas que recoge su iconografía hablan de plantas, del desierto, de jardines y macetas que se vuelven fértiles a pesar de las condiciones extremas. Nuevos materiales aparecen en su obra, rafia, papel de arroz, fotografías, metal, cera, una nueva piel que cubre y redibuja la texturada piel del barro. El referente vegetal en estos casos remite a plantas cactáceas, especies que por sus características intrínsecas concentran atributos particulares y esenciales de la vida vegetal.

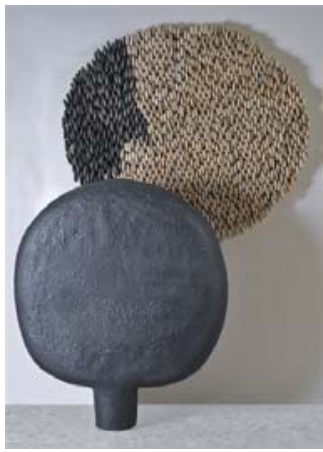

Miriam Medrez,

Sin título, 2002.

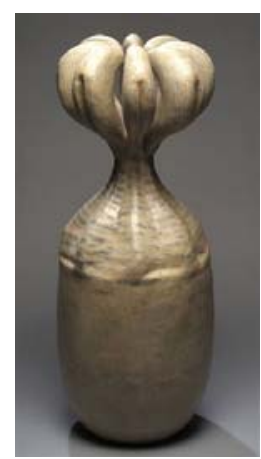

Miriam Medrez, Sin título, 2002.

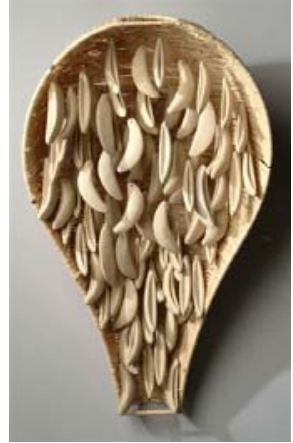

Miriam Medrez,

Sin título, 2002.

La vida en el desierto se protege a la manera del rizoma y se multiplica dispersándose por el interior de las arenas. Así, la pieza Guardando un pedazo de tierra (2003) tiene una estructura de crecimiento horizontal basada en módulos que se constituyen como contenedores de tierra y plantas de cactus

371 SUCKAER, Ingrid, "Desde la tierra reúne a cinco escultores que trabajan el barro", en $\mathrm{La}$ Jornada, 7, octubre, México, D.F., 2007, Disponible en red: <http://www.jornada. unam. $\mathrm{mx/}$

$2007 / 10 / 07 /$ index.php?section $=$ cultura\&article $=a 06$ n2cul $>$, [Consulta 25, julio, 2009]. 
vivos. En estas formas multiplicadas, el referente al cuerpo no es olvidado, al contrario estos cactus se configuran siguiendo el ritmo exigido por los materiales empleados, en orgánicos crecimientos que de nuevo simulan ciertas formas antropomorfas. El desarrollo diseminado sugiere un organismo vivo que crece indiscriminadamente con protuberancias bulbosas que recuerdan pechos femeninos y que, como el desierto, no tiene aparentemente finitud.

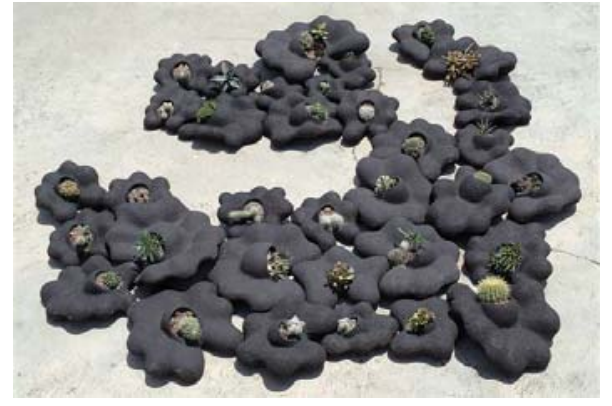

Miriam Medrez,

Guardando un pedazo de tierra, 2003.

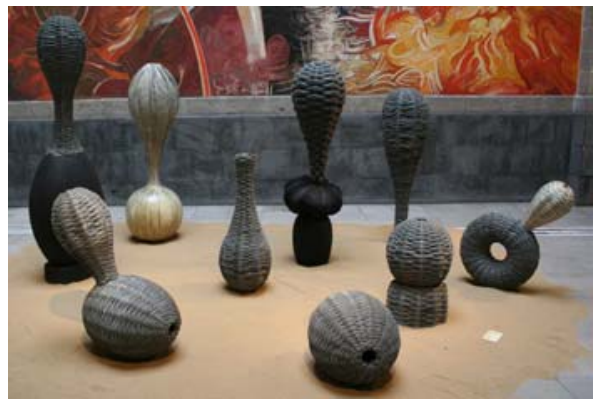

Miriam Medrez, Sin título, 2003.

La vida vegetal sigue en general, una pauta rizomática, se multiplica en relaciones colaterales, ocupando el espacio y extendiéndose hasta donde le permita su propia potencia, conquistando un territorio que no conoce límites. El rizoma es "una multiplicidad que cambia a medida que aumentan sus conexiones" 372 . Medrez conoce esta capacidad expansiva de la vida vegetal y la recrea dejándose invadir ella misma para que sus creaciones se fundan con el paisaje que la rodea. Imbuida del sentimiento de lo esencial, al igual que para los habitantes del Norte cercanos al desierto, como los indios yaquis de Sonora, la idea de paraíso creado por Dios tiene que ver con las tierras de los desiertos que habitan. En ellas uno se da cuenta de lo que realmente sirve y de lo que es prescindible. El desierto es un escenario para poner a prueba las cosas, no es el lugar en donde la Naturaleza, la exuberancia y la experimentación sean eficientes en el sentido habitual, es el lugar en el que lo secundario es accesorio, lugar de renovación y de retorno a los propósitos primeros, aquellos que por probados, sabemos que funcionan. Puesto que hablar de voluntad de la materia requeriría nociones de orden teleológico, entendamos que al hablar de propósitos, aquí nos referimos a las configuraciones y organizaciones características que dan origen a pautas y estructuras definidas por el mismo ecosistema.

En el ámbito de las artes y el diseño, a los propósitos y a las variantes que emergen del proceso suele llamárseles: proyecto y diseño. El proyecto quiere satisfacer un propósito principal: el diseño busca hacerlo, de la mejor manera, con los recursos que conoce y cuenta. El proyecto es el proceso que

372 LARRAURI, Maite, op. cit., p. 59. 
jerarquiza, vincula y equilibra los principios generadores u organizadores; el diseño es su adaptación a cierto contexto ${ }^{373 .}$

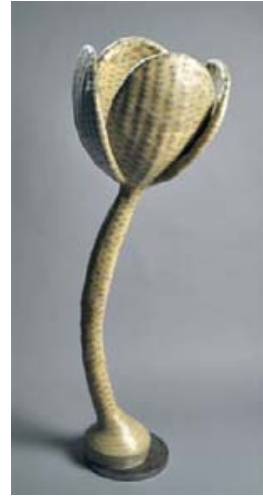

Miriam Medrez, Sin título, 2003.

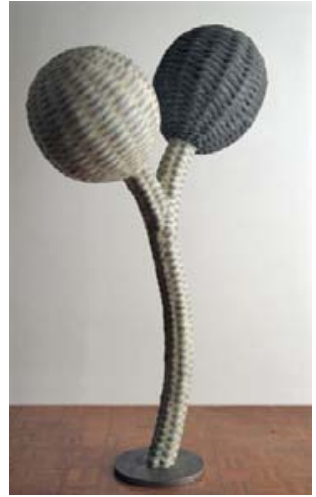

Miriam Medrez, Sin título, 2003.

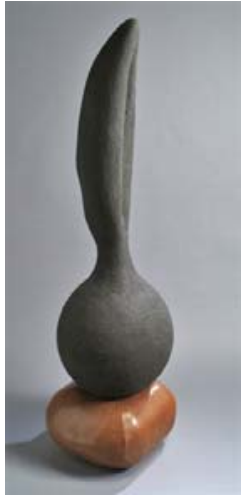

Miriam Medrez, Sin título, 2003.

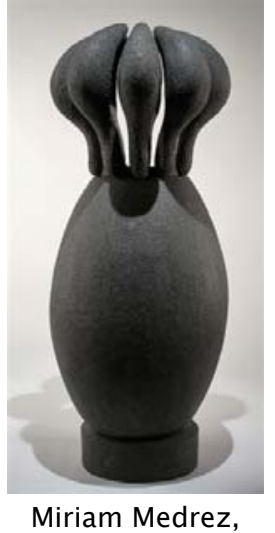

Sin título, 2003.

Las estructuras que Medrez explora tienen que ver con estas dinámicas de selección austera. El desierto es un lugar enigmático y peligroso, marca el reto de las fronteras sin fronteras, espacio errático en donde los límites se desplazan constantemente y nos hace perdernos. Pero es a la vez, un lugar de encuentro, tanto con uno mismo como con formas insospechadas de vida. Lugar de culto e iniciación de las antiguas tradiciones, los parajes desérticos se relacionan con el tránsito espiritual. Austeridad, soledad, silencio, sacrificio, privaciones, ayuno, son algunas de las sensaciones que se pueden relacionar con el viaje al mismo. Luis Racionero apunta que según la visión del mundo chino, el universo es un sistema armónico de resonancias en donde las partes se corresponden unas a otras y se armonizan en el todo del cosmos:

El objetivo del artista es revelar estas armonías que subyacen en la realidad y que no pueden percibir los sentidos, porque tales armonías están hechas de materiales más sutiles que las partículas $u$ ondas electromagnéticas que excitan los cinco sentidos374.

Desde contextos lejanos físicamente, la empatía que el arte taoísta busca respecto a la capacidad de penetrar los significados secretos de las cosas, está vinculada con la búsqueda mística de Medrez. Ambas a su vez se conectan con la visión del hombre prehispánico en el México antiguo.

373 MARTín JUEZ, Fernando, "El lugar de la bifurcación”, en PÉREZ-TAYLOR, Rafael et al., Antropología del desierto. Paisaje, naturaleza y sociedad, UNAM, Instituto de Investigaciones Antropológicas, México, D.F., 2007, p. 17.

374 RACIONERO, Luis, Textos de estética taoísta, Alianza, Madrid, 2002, p. 40. 
El desierto está en todas partes, la ruina está en todas partes, el chiste, el sentido está en que a pesar del desierto se den tres briznas de inmenso pasto 375 .

En la obra de Medrez, el material (arcilla) comparte con el espacio, el anhelo de encontrar una forma: "construir, figurar, convertirse en estructuras que llevan la cerámica a los límites de lo orgánico, ofreciéndonos claves para descifrar la secreta disposición del espacio" 376 .

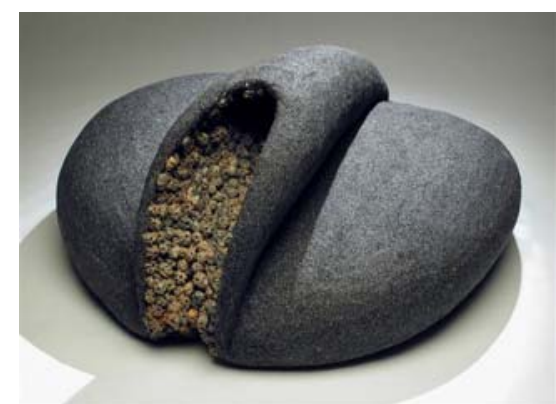

Miriam Medrez, Semilla, 2002.

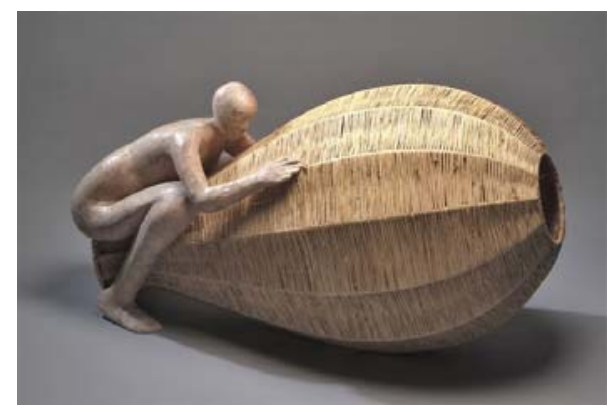

Miriam Medrez, Sin título, 2002.

Frente a las nobles bondades que representa el locus amoenus que otros artistas reflejan en su obra mediante la exuberancia de la vegetación, en una de sus últimas exposiciones Medrez se decanta por adentrarnos en su opuesto, el locus eremus o desierto, el cual representa el prototipo de todas aquellas condiciones extremas y difíciles para el desarrollo de la vida.

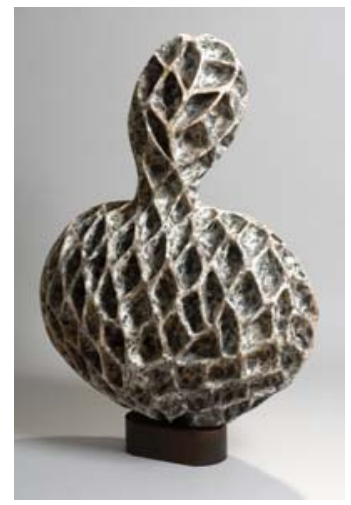

Miriam Medrez, Sin título, 2006.

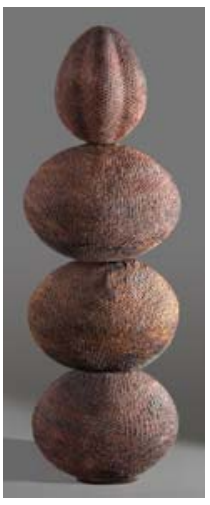

Miriam Medrez, Sin título, 2006.

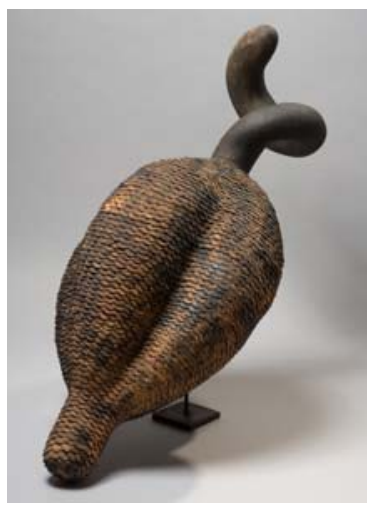

Miriam Medrez, Sin título, 2006.

375 ROSENZWEIG, Carmen, Simone, el desierto, Simone, el huerto, Gobierno del Estado de México, FONAPAS, Serie Juana de Asbaje, Colección Letras, Nº 14, Toluca, 1979, p. 91. 376 Véase nota de prensa y material de divulgación de la exposición, "La estructura de la piel", Museo Marco, Monterrey, 2008, Disponible en red, <http://www.marco.org.mx/ exposiciones/expo_anteriores /expo_miriam_medrez.htm>, [Consulta 26, julio, 2009]. 
Desde el punto de vista geográfico, el desierto es considerado como un ecosistema caracterizado por tener poca vida orgánica, debido fundamentalmente a la escasez de agua y a las temperaturas extremas. Sin embargo también es un lugar que presupone una necesidad de adaptación mayor por parte de las especies que en él cohabitan.

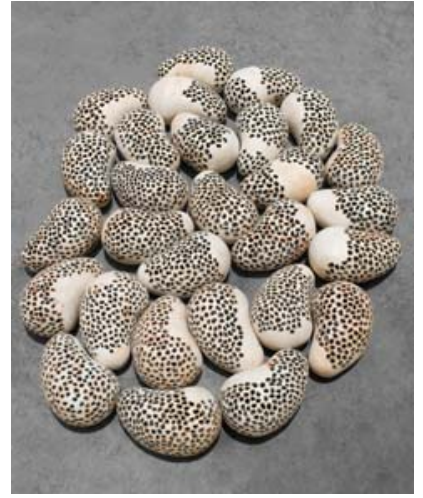

Miriam Medrez,

Sin título, 2008.

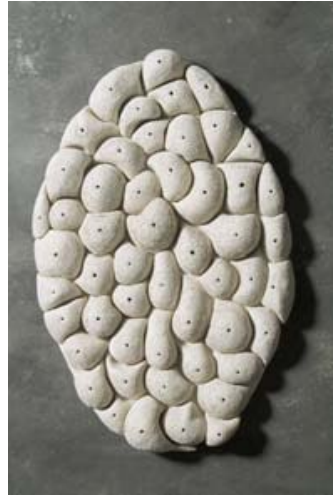

Miriam Medrez,

Sin título, 2008.

Tradicionalmente, y en diferentes culturas, se ha considerado desde siempre que el desierto es el lugar propicio para el sacrificio. Mediante los duros y difíciles retos que éste imprime al ser humano en contrapartida, le concede, desde el punto de vista de la religiosidad, el logro de la purificación y la redención. Espacio para la búsqueda espiritual, en la tradición judeocristiana es el lugar en donde Dios se dirigió a su pueblo a través de Moisés y a donde se retiró Jesús a meditar, siendo tentado por el diablo. Ante la adversidad surge el sentimiento de lo sublime377. Esta circunstancia conlleva que a pesar del rigor, la soledad, el silencio y el horizonte vasto y vacío, por su condición de nada y absoluto, el hombre se vea reflejado también en este paisaje. Un espacio y un lugar con ocultas posibilidades de sobrevivencia, más sin embargo, propicio para el desarrollo de una sabiduría particular, lugar de reencuentro con uno mismo, de riquezas escondidas y de acceso a la divinidad. Un ámbito para hacer frente a los espejismos y de esta manera, crecer y desarrollarse espiritual y físicamente hablando.

Las esculturas de Medrez presentan así unas construcciones orgánicas en barro de alta temperatura en las que la ambigüedad plástica revierte en una trascendente metáfora de la vida. En ellas, la diferenciación entre apariencia y realidad, al igual que en arte, desmienten los espejismos que nos confunden.

\footnotetext{
377 La categoría de Sublime explorada por Burke enfrenta al hombre a su insignificancia ontológica. Sin embargo, a través de la razón y de los sentidos éste puede superar su impotencia y frente al caos y, por medio de la estética, obtener una sensación placentera. Véase BURKE, Edmund, Indagación filosófica sobre el origen de nuestras ideas acerca de lo sublime y de lo bello, Tecnos, Colección Metrópolis, Madrid, 1997.
} 


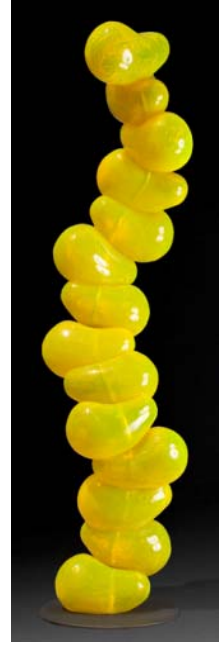

Miriam Medrez, Sin título, 2008.

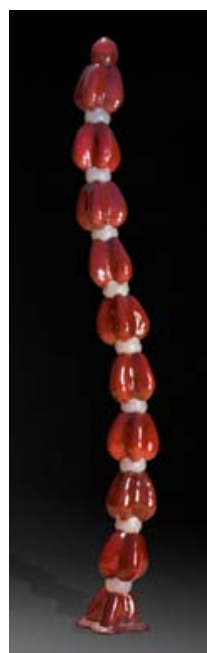

Miriam Medrez, Sin título, 2008.

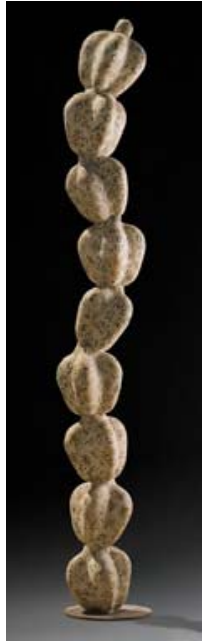

Miriam Medrez, Sin título, 2008.

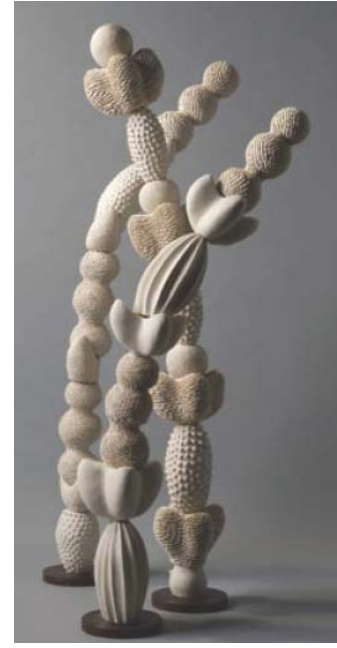

Miriam Medrez,

Sin título, 2006

Entre la experiencia estética y la racionalidad del arte, la obra de Medrez se despliega de manera polisémica con medios simbólicos que abren nuevos espacios de sentido. Además de la arcilla, utiliza otros materiales como resinas y a todos ellos les transfiere calidades orgánicas híbridas, de plantas, de piel, de huesos. Atributos casi sexuales vulvas, senos o penes. Con diferentes texturas genera cicatrices, heridas, laceraciones, tatuajes.

Pasa de la sutileza y pasividad a la confrontación agresiva. Esta forma de trabajo la encontramos también en el de otras mujeres artistas como Louise Bourgeois, Kiki Smith, Eva Hesse, Judy Chicago, Mónica Castillo, a las que la necesidad de explorar su identidad, su intimidad, las lleva al uso de una iconología metáfora del cuerpo femenino, cavidades vaginales, imágenes circulares, penetrables, formas turgentes. Logrando generar representaciones alternativas a las que por norma se le habían asignado al cuerpo femenino, tanto como mostrando la experiencia de ser cuerpo378.

Las columnas orgánicas de gran formato que presentó en la exposición en el Museo de Arte Contemporáneo de Monterrey construyen su verticalidad partiendo de la acumulación de módulos cuya ambigüedad se sitúa en la representación de órganos humanos y vegetales y cuya estructura recuerda, tanto a la diversidad de los cactus del desierto de México llamados órganos, como a la posición erecta del hombre que camina. Formas orgánicas con resonancias y connotaciones antropomórficas que despiertan al mismo tiempo sensaciones de atracción y resistencia, que exploran múltiples texturas y contrastes y con las que logra superficies aparentemente frágiles y delicadas.

378 LEAL, Esther, Miriam Medrez: Cuerpo y superficie, Fondo Editorial de Nuevo León, Monterrey, 2009, p.12. 


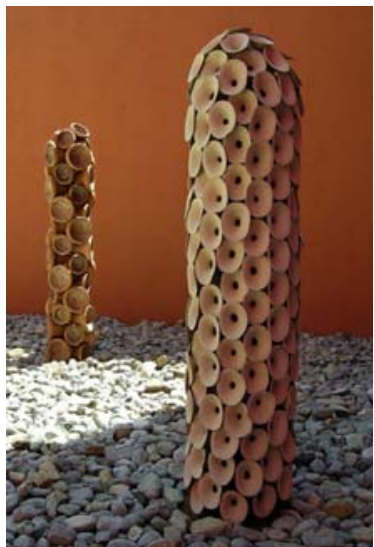

Miriam Medrez, Sin título, 2007.

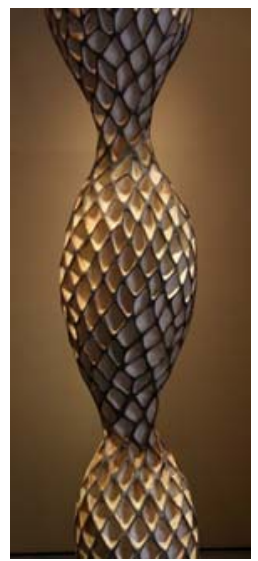

Miriam Medrez, Sin título, 2007.

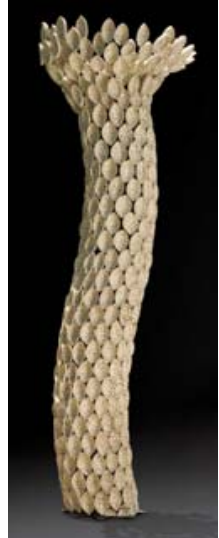

Miriam Medrez, Sin título, 2007.

En resumen, se trata de un proceder cercano a las leyes de la Naturaleza: creación de juegos repetitivos que se traducen en esculturas que a su vez, se configuran en procesos similares a los que realizan los organismos vivos. De la misma forma que, biológicamente hablando, la unión de células sirve para formar organismos cada vez más complejos o cuerpos más grandes generados por la repetición de estructuras pequeñas, la escultora busca trasmitir una armonía perfecta filtrada, entre formas, ritmos, movimientos y patrones, por los requerimientos del frágil material. Como apunta la escultora, las formas del mundo orgánico son puntos de partida para generar juegos creativos, aunque en definitiva el producto final no se parezca al motivo o fuente original.

Mi interés no es desarrollar una narrativa, sino un punto de confluencia, y expresar con materiales físicos ideas abstractas de lo orgánico hacia lo escultórico. Los materiales y los procesos empleados crean sensaciones y ánimos diferentes, desde lo onírico hasta lo concreto, cada escultura propone un ámbito emocional particular, una exploración singular sobre la estructura que da origen a la piel de cada obra379.

Como artista, la búsqueda de la propia identidad es una constante que se conecta con el viaje romántico, una travesía interior que devela la multifacética estructura de la piel, como límite de los sentimientos y de las sensaciones.

Puede ser una búsqueda de la identidad por medio del ahondamiento del dolor, una aventura a través del propio sufrimiento, ingreso en el territorio del riesgo 380 .

\footnotetext{
379 Disponible en red: http://www.marco.org.mx/exposiciones/pdf/Miriam_\%20Medrez. pdf, [Consulta 27, julio, 2009].

380 CASTRO FLÓREZ, Fernando, "Apuntes y visiones del desierto", en MADERUELO, Javier (dir.), El paisaje: Arte y naturaleza, Actas del II Curso, Diputación de Huesca, Huesca, 1996, p. 58 .
} 
Podríamos decir que, para no perderse en estos territorios Medrez, siguiendo a María Zambrano ${ }^{381}$, encierra poéticamente dentro de sí el desierto y con su obra, nos convoca a recorrer los nuestros. Para ello, los módulos-mantras repetitivos que utiliza, recorren las superficies de las esculturas que irguiéndose como serpenteantes columnas-estelas, nos recuerdan que el desierto está en todas partes y en cada uno de nosotros.

\subsection{Tradición y problemática social. Betsabée Romero y Maribel Portela}

Entendemos la noción de Cultura como aquello que reúne todas las características comunes a un grupo social. Dentro de este concepto englobamos tanto al lenguaje y las prácticas sociales como todos aquellos objetos materiales creados, así como sus significados y los numerosos rasgos que sostienen en común los miembros de una sociedad. En este sentido, los símbolos, dibujos, emblemas, etc. y todos los sistemas de creencias que están presentes en las construcciones y deconstrucciones de una realidad espacial concreta forman también, parte de la misma.

La Cultura presupone valores que sirven para guiar las acciones humanas, inscribiéndolas en cuadros normativos que dan sentido tanto a la vida individual como a la colectiva. En este ámbito de interacciones se construyen las concepciones sobre el mundo, la sociedad y la Naturaleza cobrando éstas sentido y consiguiendo así que las personas de una colectividad desarrollen un sentido de pertenencia.

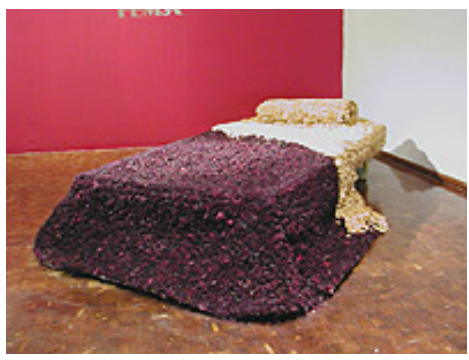

Betsabée Romero, Refugio de lecho de rosas, 1994.

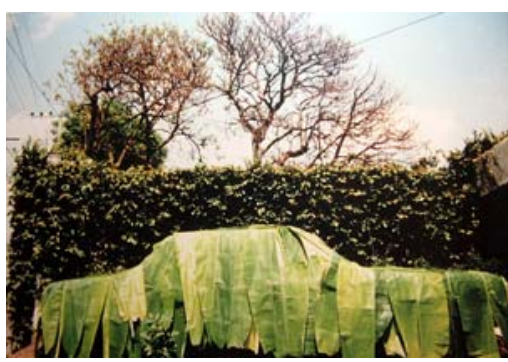

Betsabée Romero, El que nace para tamal... del cielo le caen las hojas, 2000.

Dentro de este rubro y frente al concepto más elitista de Cultura diferenciamos la Cultura popular como aquella que está relacionada con el pueblo o con la Cultura de masas. En México y el resto de América Latina generalmente, se asocia con cuestiones de identidad nacional íntimamente ligadas a sectores

381 María Zambrano habla del desierto como el lugar del exilio: "Para no perderse, enajenarse, en el desierto hay que encerrar dentro de sí el desierto. Hay que adentrar, interiorizar el desierto en el alma, en la mente, en los sentidos mismos, aguzando el oído en detrimento de la vista para evitar los espejismos y oír las voces", en ZAMBRANO, María, Los bienaventurados, Centenario del nacimiento de María Zambrano (1904-1991), Siruela, Madrid, 2004, p. 41. 
sociales, que se identifican con las raíces indígenas y con las costumbres y usos derivados de la lógica del mestizaje. En este contexto podemos entender cómo la artista Betsabée Romero (México, D.F. 1963) utiliza la representación de lo vegetal como símbolo nostálgico y a la vez presente de una tradición ancestral siendo una de sus intenciones la denuncia de la pérdida y la recuperación de estas tradiciones, al aplicarlas sobre el imaginario de la Cultura más reciente de México.

Los símbolos del folklore mexicano y los ornamentos característicos de la Cultura guadalupana, las flores, las espinas y nopales, junto con imágenes y técnicas de las artesanías tradicionales aparecen en su obra entrelazados con los símbolos representativos de la Cultura popular y transurbana mexicana. Así el Volkswagen, conocido popularmente como vocho o vochito y sus partes neumáticos, vidrios o espejos retrovisores- se trasforman en lienzos experimentales de una nueva forma de transmisión cultural y siguiendo a Olivier Debroise, forman parte del interés de la artista por una"cultura automotriz" 382.

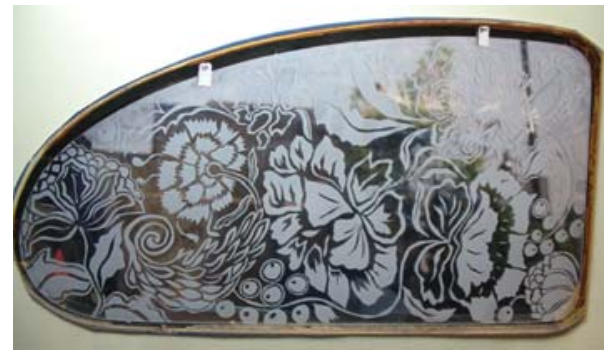

Betsabée Romero, Del otro lado del espejo, 1999.

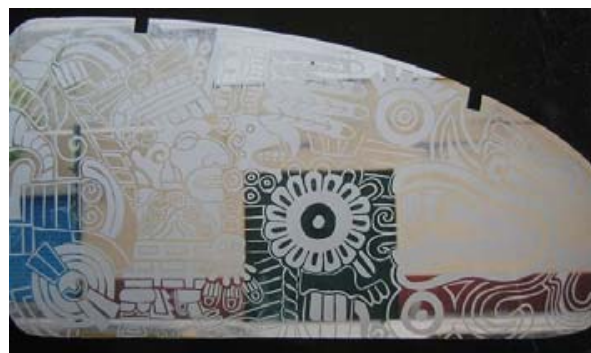

Betsabée Romero,

Trama Transurbana, 1999.

Si bien desde 1996 ya utilizaba materiales no convencionales, telas y plásticos industriales, petates tejidos o encortinados fue al acercarse a una realidad conflictiva (los talleres mecánicos, las accesorías y las tiendas de autopartes de la Colonia Buenos Aires) inmersa en las profundidades de México, D.F., cuando halló los soportes que le permitirían trasladar sus nuevas inquietudes a un plano de mayor implicación social. De esta manera logra reconfigurar una semiótica de lo utilitario, del auto como objeto de deseo, trasladándola a las problemáticas sociales recién exploradas.

Anteriormente había realizado instalaciones a manera de altares en los que diferentes materiales, rosas secas, tierra, coronas de espinas, cirios y veladoras suponían una suerte de conmemoración de ciertos rituales inmersos extemporáneamente en el contexto urbano. Costumbres y prácticas arraigadas no sólo en zonas marginales y proletarias de la ciudad, sino actuales y presentes

382 DEBROISE, Olivier, "Accesorias y autopartes", en Pecho tierra, Betsabée Romero, obra reciente, Galería de arte mexicano (GAM), México, D.F., diciembre, 2001-enero, 2002. 
todavía en diferentes contextos profesionales, en zonas tanto rurales como urbanas.

En el marco de un arte contextual383, la obra de Romero abandona los perímetros sagrados de la mediación artística, anteponiendo la realidad explícita como referente sobre la que establecer un diálogo más allá de la estética; arte en el que para la artista, la prioridad de la creación es que ésta se haga cargo de la realidad, más que trabajar en torno al simulacro, de la descripción figurativa o del fenómeno de las apariencias. Se establece entonces una relación directa entre la obra y la realidad, se utilizan los símbolos públicos para revitalizar el potencial crítico de las prácticas estéticas, enfocándose más que a la representación, a la presentación de las contingencias de la vida presente.

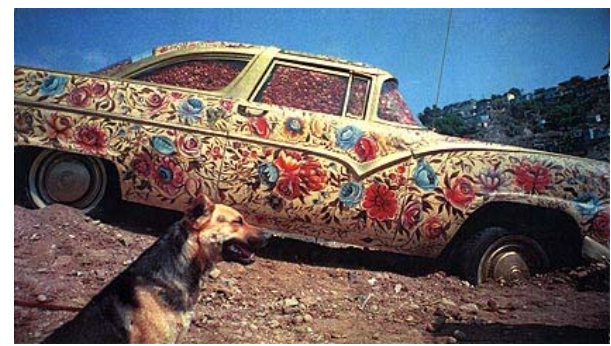

Betsabée Romero, Ayate Car, 1997.

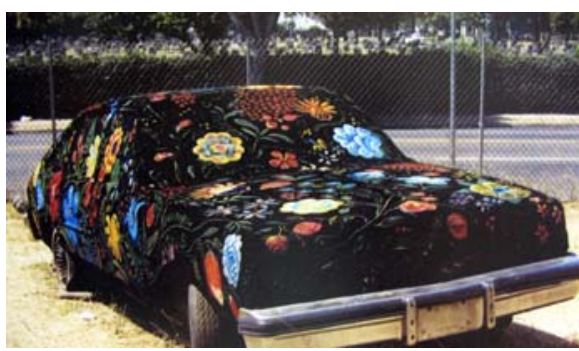

Betsabée Romero, Aterciopelado, 2002.

En el marco del Proyecto Insite realizado en Tijuana, México, en el año 1997, Betsabée entra en contacto con el movimiento chicano y sus problemáticas y, redefiniendo los rasgos característicos de los conflictos de identidad de estos grupos sociales, experimenta con estas nuevas temáticas. El Ayate car (1997) es un automóvil intervenido, lleno de rosas y pintado a mano que la artista situó en los altos de la Colonia Libertad, en Tijuana, cerca de la valla fronteriza con San Diego. Recontextualizando la típica representación colonial de la flor, la obra se convirtió en un símbolo de la iconografía mexicana con la que se identifican estos grupos, al recrear en el auto el perpetuo deseo de retorno a la patria de los inmigrantes que han cruzado a EE. UU. Se trata de una pieza en la que toda la carrocería de un Ford Victoria del año 55 se encuentra entelada y pintada al óleo con flores que hacen referencia a las pinturas populares de las vírgenes del Siglo XIX.

Con esta pieza mi postura es más bien irónica, parte de un descrédito hacia la política e incluso al arte como vehículo de alguna solución para una

383 Entendemos el arte contextual como el conjunto de formas de expresión artística que difieren de la obra de arte en el sentido tradicional. Arte de intervención y arte comprometido de carácter activista, que se apodera del espacio urbano o del paisaje, haciéndonos partícipes de una estética participativa o activa en el campo de la economía, la política, los medios de comunicación o el espectáculo, en ARDENNE, Paul, Un arte contextual. Creación artística en un medio urbano, en situación, de intervención, de participación, Cendeac, Murcia, 2006, p. 10. 
situación límite como la que vive mucha gente en la frontera. Para mi, la única posibilidad de salida es un milagro, pues en un sitio donde ambos gobiernos están coludidos para que las cosas pasen y sigan de cierta manera conveniente, principalmente para los poderosos de allá pero también para los corruptos e ineficientes negociadores de acá 384 .
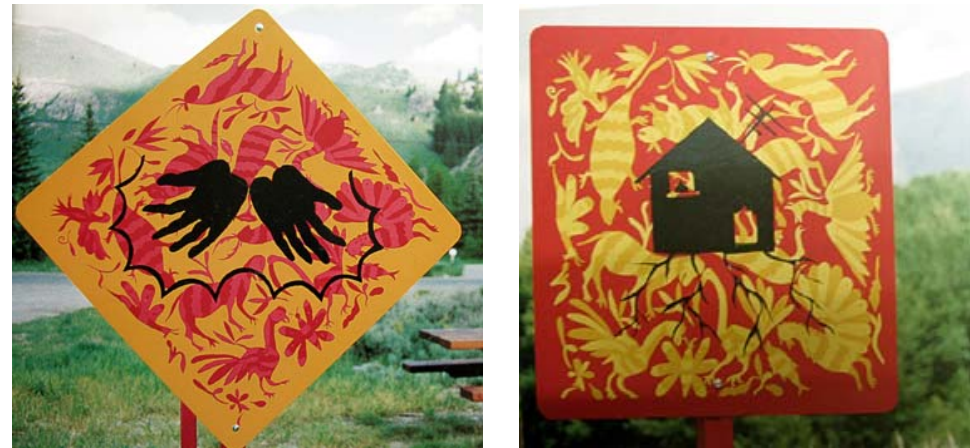

Betsabée Romero, Señales intervenidas, 2004.

Obras como Señales intervenidas (2004), que parten de símbolos reconocibles de la Cultura mexicana, se caracterizan por ofrecer soluciones a la desorientación sufrida por los migrantes en sus desplazamientos. Así también la obra Aterciopelado (2002), realizada en California (EE. UU.) presenta un coche Buick con toda su superficie forrada de terciopelo negro y pintada al óleo. El uso del automóvil en la obra de Betsabée Romero parte de una reflexión acerca de las contradicciones de la sociedad de consumo en países como México. El automóvil, como objeto típico de la producción en serie, de la industrialización, de la alta tecnología y las corporaciones globalizadoras está muy vinculado a la american way of life. En este sentido, la artista elabora un discurso acorde a una forma diferente de ver el coche. El auto varado, se convierte en una herramienta inútil que no se desplaza. Un automóvil que ni nos mueve, ni nos sirve para cambiar nuestro nivel económico pero que se configura como un refugio, pasa a ser como una segunda casa. A partir de este momento es también el lugar de la intimidad y, a manera de extensión del cuerpo, representa además un espacio polisémico de fragilidad, de iniciación a la sexualidad, el lugar del accidente o del secuestro.

La maceta ecológica (2001), denuncia evidente de una situación conflictiva y del olvido políticamente generalizado respecto a una problemática urbana difícil de resolver, se convierte también en un símbolo de una identidad eternamente irredenta, en espera de un águila que nunca llega385. En esta obra podemos apreciar un cactus o nopal, sembrado con tierra, sobre un coche abandonado,

\footnotetext{
384 ROMERO, Betsabée, Disponible en red en: <www.arteven.com/betsabee_romero_05 .htm>, [Consulta 26, abril, 2009].

385 El águila, la serpiente y el nopal forman parte del escudo nacional como iconografía que identificó para los mexicas el lugar marcado por los dioses y hacia el que debían dirigirse en la búsqueda de la propia tierra.
} 
un Thunderbird con un letrero pintado con óleo con el mismo título de la obra. Todo ello se sitúa en el corazón de la Colonia Buenos Aires ${ }^{386}$ de México, D.F.
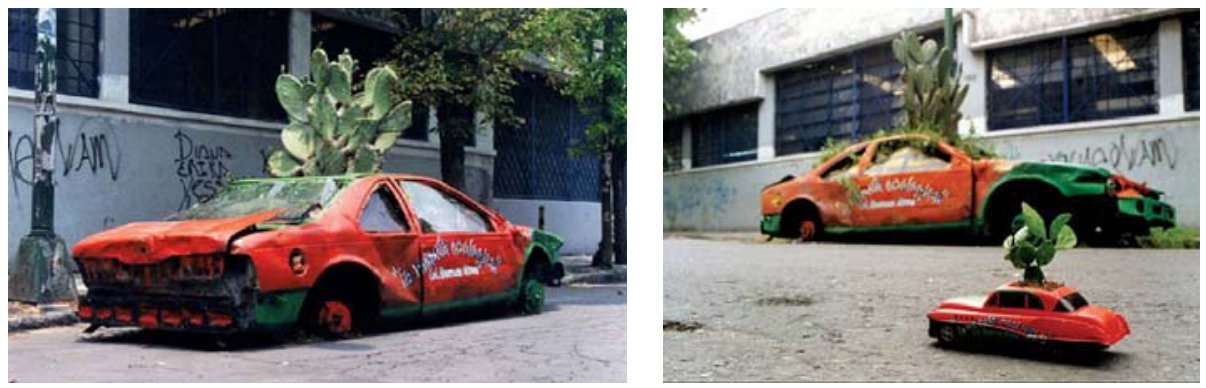

Betsabée Romero, Maceta ecológica, 2001.

Esta poética del coche florido empleada en estas obras por la artista, resulta del doloroso, pero necesario tránsito humano entre fronteras. Sus plantas-flores prehispánicas o coloniales, envuelven o quedan grabadas a manera de nuevos rituales propiciatorios buscando en esta dinámica, identificarse con los millones de mexicanos que, en detrimento de su propia vida, cruzan al otro lado de la frontera con Estados Unidos. La metáfora del tránsito queda plasmada en el uso del automóvil como símbolo de una movilidad truncada. Se trata en general, de coches que se encuentran en estado de inmovilidad, varados en el desierto, abandonados en una calle de la Colonia Buenos Aires o colocados en una sala de exposiciones.

Esta práctica artística de apropiación convierte al objeto utilitario en sí, el coche o carro, como popularmente se denomina en México al automóvil, en una especie de fetiche estetizado y lo lleva, en palabras de la crítica Corinne Sacca Abadi, a un grado que "ralla en el absurdo saturado hilarante y festivo" 387.

Sin embargo, el auto como objeto escultórico y sus partes como componentes parciales de una totalidad fragmentada, son capaces de recuperar las microhistorias de realidad social que, a manera de utopías posibles, nos narra Romero en su obra. Las piezas De reojo (2006) o Rosetones urbanos (2005) composición de 44 espejos de seguridad esmerilados y con hoja de oro- son microrrelatos. En ellos, la imagen se configura como reflejo de las miradas de tantas y tantas mujeres que, sorteando múltiples peligros, realizan cotidianamente trayectos peligrosos entre su casa y el trabajo o la escuela. Mujeres que, sea en Ciudad Juárez o en Guatemala, en las fronteras norte o sur, utilizan los transportes colectivos mirando de reojo, con una mirada tatuada,

${ }^{386} \mathrm{La}$ Colonia Buenos Aires es conocida por ser una de las colonias más peligrosas y conflictivas en cuanto a delincuencia $y$ al robo de autopartes o piezas de coche. 387SACCA ABADI, Corinne, Betsabeé Romero, Lágrimas negras, Museo Amparo, Puebla, 2008 
como la misma artista nos dice, grávida "de rezos y plegarias" 388 , temiendo por su seguridad o la de sus hijas.

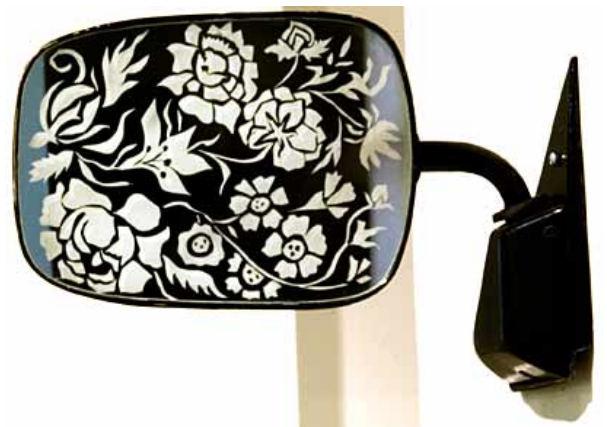

Betsabée Romero, De reojo, 2006.

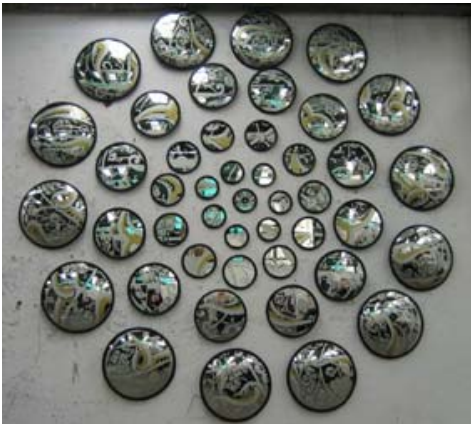

Betsabée Romero, Rosetones urbanos, 2005.

Si bien, no sería adecuado situar su obra dentro del movimiento llamado Neomexicanismo389, puesto que como artista se inscribe en una tendencia más postmoderna, sí podemos reconocer ciertas afinidades a este movimiento. Una de las características de esta tendencia es la recuperación del concepto de identidad nacional a través de la utilización de iconos recuperados de la Cultura popular. Romero, como tantos otros artistas más, utilizaban elementos de la vida cotidiana. Sin embargo no se limitaban al entorno de lo doméstico, sino que en una sociedad inmersa en un sistema mediático y globalizado, transportaban los iconos a un medio artístico que ofrecía una nueva relectura. Esta nueva visión se hacía tanto desde la revalorización y la crítica, como desde la ironía y el cinismo.

[...]. El trabajo artístico por tanto, formó parte de los fenómenos sociales y la cultura popular, $y$ no se mantuvo en una esfera ajena $y$ sublime, representante de lo bello de la producción social [...]390.

\footnotetext{
388 Cédula informativa, textos de Betsabée Romero, Exposición El cielo al revés, Centro Cultural Español, México, D.F., 2006.

$389 \mathrm{El}$ controvertido término de Neomexicanismo fue acuñado por la crítica de arte Teresa del Conde. En esta tendencia integraba a artistas como Francisco Toledo, Julio Galán, Nahum B. Zenil, Néstor Quiñones, Germán Venegas, Graciela Iturbide, Adolfo Riestra, Eloy Tarcisio, Thomas Glassford, Silvia Gruner, Adolfo Patiño, entre otros. En su obra recuperaban los símbolos autóctonos, históricos y religiosos tradicionales. Este tipo de obras que tal vez mediaban frontera con el kitsch, se anclaban en una cultura popular, propiciando el resurgir de un nuevo nacionalismo mexicano.

390 MACÍAS, Vania, "Espacios alternativos de los noventa", en MEDINA, Cuauhtémoc et al., La era de la discrepancia. The age of discrepancies, Arte y cultura visual en México. Art and visual Culture in Mexico, 1968-1997, UNAM, Instituto de Investigaciones Estéticas, Turner, México, D.F., 2007, p. 370.
} 
En esta línea, Betsabée Romero se lanza con su obra, a una relectura de los significados culturales resemantizándolos dentro del contexto actual. $Y$ lo hace mediante un acercamiento a la nueva realidad urbana de México y desde un entorno cotidiano en el que aún hoy prevalecen la mayoría de las imágenes que forman parte de la iconografía de una supuesta identidad popular. En su obra, lo cotidiano se transforma en extraordinario y establece diálogos inesperados entre la tradición artesanal, la herencia ornamental barroca y los conceptos más vanguardistas del arte contemporáneo internacional.

La fiebre neomexicanista se desentiende de la discusión sobre la modernidad cultural, acepta el carácter híbrido de la cultura y encuentra en la historia, el folklore, la cultura popular urbana un depósito de incalculable riqueza iconográfica dispuesto para ser apropiado: ídolos prehispánicos, calaveras, nopales, vírgenes, santos [...]391.

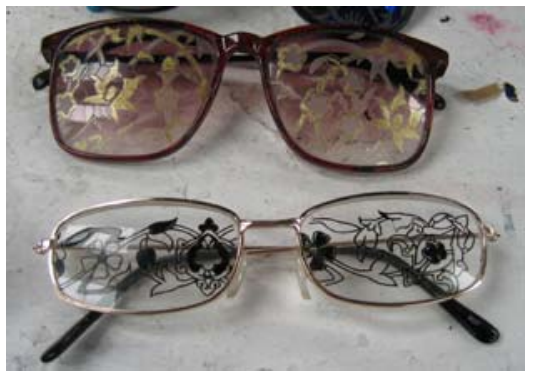

Betsabée Romero, Lentes, 2006

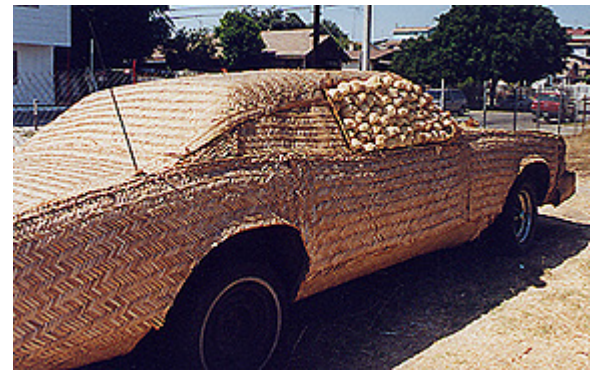

Betsabée Romero, El petate justiciero, 2001.

Recontemporaneizando las imágenes que caracterizan este sistema de valores, la artista construye prototipos de Cultura que a su vez relatan, como ya hemos dicho, escenas de problemáticas sociales particulares del México actual como es el de la migración. En su obra plantea el fenómeno transfronterizo entendiendo la frontera como un concepto que transgrede las dimensiones geográficas y trabajando sobre el concepto de migración como un canal que fluye entre las acciones sociales y las prácticas culturales. Fenómeno que por otro lado, a la vez que reivindicativo, presupone la reproducción endémica del sistema mismo que produce la problemática.

Por medio de metáforas, se vuelve cómplice de los migrantes, de los mecánicos, de los hombres y mujeres colocados en situaciones límite. Con exvotos pintados sobre cofres de auto, en espejos retrovisores esmerilados, en llantas de coche grabadas con grecas y flores, Betsabée explora las condiciones complejas de la identidad, el sentido de pertenencia, las raíces ${ }^{392}$.

391 GUTIÉRREZ GALINDO, Blanca, "Las artes visuales en México: 1960-2004", en Exit México, op. cit., p. 32.

392 ABELLEYRA, Angélica, "Betsabée Romero: el arte, única forma de resistencia", en $L a$ Jornada Semanal, México, D.F., 28, octubre, 2007, Disponible en red en <http:// www.jornada.unam.mx/2007/10/28/sem-angelica.html>, [Consulta 20, abril, 2009]. 
En un proceso de apropiación de la memoria colectiva y mediante la recuperación de este imaginario popular la artista construye una mirada postmoderna sobre el teatro de la memoria, configurando un horizonte común. La representación -mediante un proceso de simplificación- se convierte en un modelo social que utiliza la flor reiconizada, como herramienta capaz de moldear, subvertir y trastocar las representaciones sociales a partir de un vasto repertorio de mitos, leyendas y creencias sedimentado durante siglos. En definitiva, el objeto-auto, revestido así de estos nuevos tatuajes florales y de una nueva identidad nacional, junto con las llantas recicladas con huellas recuperadas de un pasado presente y cotidiano, se convierte entonces en el escenario posible para un relato. Algunas llantas aparecen con incrustaciones de chicle de colores en las que la temática vegetal se corresponde de nuevo con una metáfora de lo social, de lo doblemente utilizado, reciclaje más que de objetos usados, del significado de los mismos para el inmigrante contemporáneo.

Aunque la migración ha estado presente a lo largo de la historia, las formas que adopta actualmente; lejos de representar la búsqueda natural por mejores formas de vida, basadas en el equilibrio o en una ecología humana, se ha convertido, en el caso de México, en un problema político, cultural y económico que cuestiona profundamente la propia capacidad humana para construir sociedades 393 .

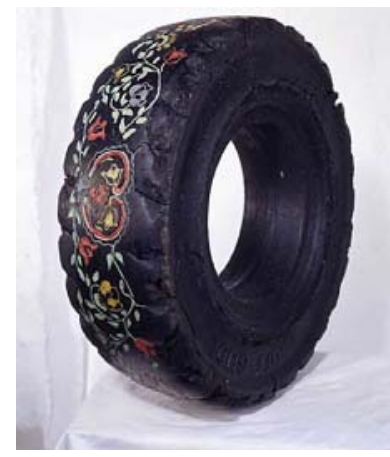

Betsabée Romero, De Tutti-Fruti, 2004.

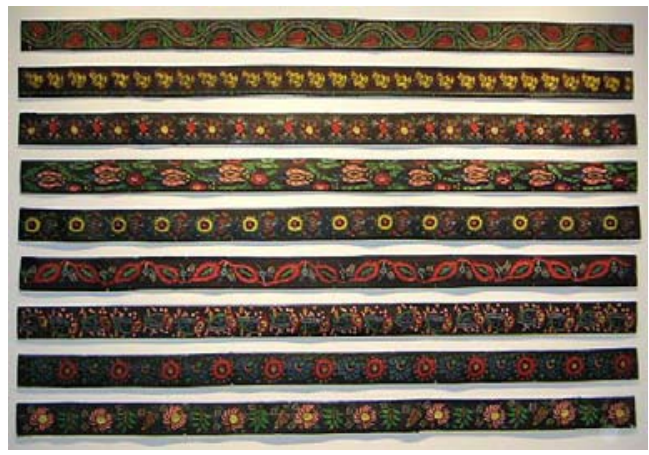

Betsabée Romero,

Cicatrices bloqueadas, 2004.

Estos neumáticos, reconvertidos en nuevos sellos, se equiparan a aquellos con los que los antiguos mexicanos impresionaban la cerámica, se vuelven narradores de las nuevas migraciones, similares a las huellas que los tlacuilos mexicas utilizaban en sus códices. La artista se sirve de los neumáticos para

\footnotetext{
393 LÓPEZ CUENCA, Alberto, "El desarraigo como virtud: México y la deslocalización del arte en los años 90", en Revista de Occidente, $\mathrm{N}^{\circ} 285$, febrero, 2005, Disponible en red en $<$ http://www.revistasculturales.com/articulos/97/revista-de-occidente/260/2/eldesarraigo-como-virtud-mexico-y-la-deslocalizacion-del-arte-en-los-anos-90.html $>$, [Consulta 20, abril, 2009].
} 
impresionar con ellos diferentes superficies (papel, barro, etc.). Son como códices contemporáneos que trazan una línea de conexión entre el presente y el pasado. En relación a la reutilización de los neumáticos, Romero señala:

Cuando dejan de ser útiles, son un desecho indeseable, cuando no tienen dibujo y todo se ha borrado es cuando me interesa volver a dibujar y grabar en ellas la memoria arquitectónica y cultural que han dejado en el camino. Son también el prototipo de la velocidad y la potencia, y en mi trabajo, por el contrario, son símbolo arqueológico de la memoria. En lugar de buscar la velocidad, se crean lenta y artesanalmente, con las manos. En lugar de sus dibujos, que nadie interpreta y que sólo pisan, dejan atrás y accidentan, esta nueva forma busca recordar lo atropellado, lo que se dejó atrás sin atención 394 .

El discurso visual de las instalaciones creadas por Romero, a partir de piezas sueltas de vehículos y otros materiales, plantea una crítica social. Estas obras nos hablan del choque entre la Cultura tradicional mexicana y esa otra inherente a nuestra contemporaneidad globalizada, una sociedad de la velocidad y del consumo que propicia paulatinamente la pérdida de toda una serie de valores. Entre ellos la artesanía de herencia prehispánica o colonial, significando ésta, más allá de la desaparición de una pieza con valor utilitario, artístico o ritual, la pérdida del legado de múltiples conocimientos tecnológicos y de dominio del medio ambiente. Sabiduría heredada y trasmitida por generaciones de artesanos, conocimientos que generalmente han fomentado la conservación de los recursos naturales nutriendo a su vez, la producción artesanal.

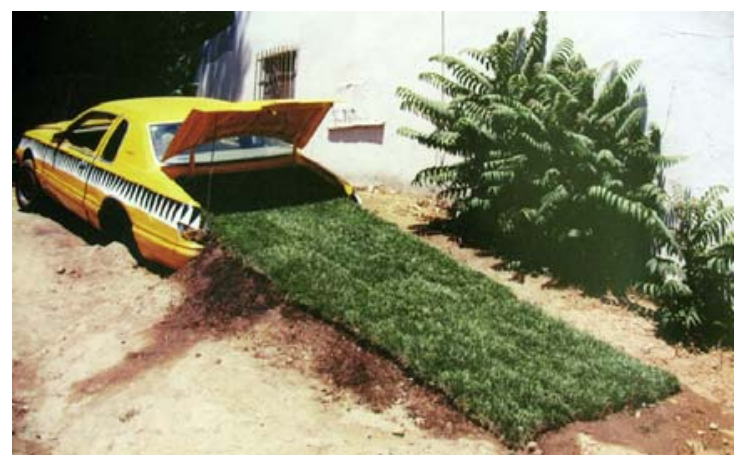

Betsabée Romero, Taxi verdor, 2001.

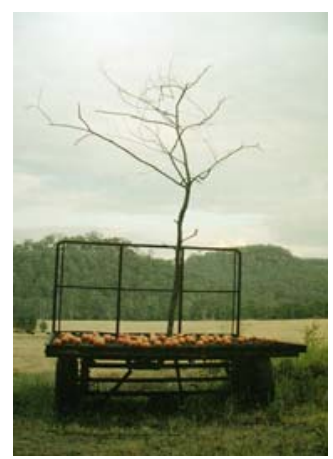

Betsabée Romero, Orange Tree-ler, 2002.

Técnicamente la obra de Romero transitó de la pintura, con referencias a los tradicionales exvotos de la Cultura popular mexicana, hacia la aplicación de flores-rosas secas sobre diferentes objetos. Posteriormente recurre a fotografías, trabajos sobre papel y esculturas en cerámica hasta llegar a las instalaciones en las que se percibe una mayor alusión a la modernidad

394 ROMERO, Betsabée, Disponible en red: <www.arteven.com/betsabee_romero_05.htm> [Consulta 19, abril, 2009]. 
tecnológica, materializada fundamentalmente en la imagen del automóvil, mediante todo lo cual Romero nos habla de la Cultura del atropello y el olvido. Las Ilantas o neumáticos responden a una reflexión sobre la forma en que este objeto se convierte en cronista de los trayectos devastadores del hombre contemporáneo.

A través de la observación de los entornos urbanos y su interés en las dinámicas sociales, Betsabée toma imágenes prestadas del caos de toda esta realidad y construye un sistema de identidad que aglutina diferentes comunidades tanto urbanas como no urbanas. Su trabajo muestra las tensiones existentes en el mundo moderno entre lo natural y lo artificial, la tradición y el progreso. Al utilizar el automóvil como símbolo por antonomasia de la modernidad, éste se convierte en un instrumento. Por un lado nos proporciona un supuesto bienestar y al mismo tiempo plantea la idea de nuestra lucha por mantenernos dentro de una noción de progreso evolutivo, aunque éste genere basura, contaminación, degradación y accidentes. Sin embargo, el automóvil nos transporta, permite el conocimiento y la relación con otras personas, lejanas o cercanas. Con sus escenificaciones, relatadas en ocasiones mediante el dibujo secuencial característico del lenguaje del cómic, Betsabée consigue que estos coches revestidos, recubiertos o repintados, expresen una nueva y evidenciada cotidianeidad. En sus formas y funciones, el auto se acerca cada vez más -a manera de una evidente prosopopeya o personificación- a un ser viviente, una extensión de nuestro cuerpo un objeto-ser que tiene alma o vida propia.

Desde el punto de vista social y político, sus temáticas exploran la problemática de las consecuencias del movimiento de miles de emigrantes que cruzan la frontera entre México y Estados Unidos. Con ellos llevan las imágenes, hábitos y costumbres propias de las que son, culturalmente hablando hereditarios. De esta forma, se asumen como parte de una misma identidad nacional. En esta línea, la obra de Romero establece mediaciones entre lo territorial y lo simbólico, lo político y lo religioso procedente del espacio comunitario. Frente a la xenofobia, su obra genera nuevas formas de convivencia simbólica abriendo brechas a la tolerancia. Una forma de proceder que se relaciona con las nuevas maneras de concebir tanto el espacio como el Arte Público.

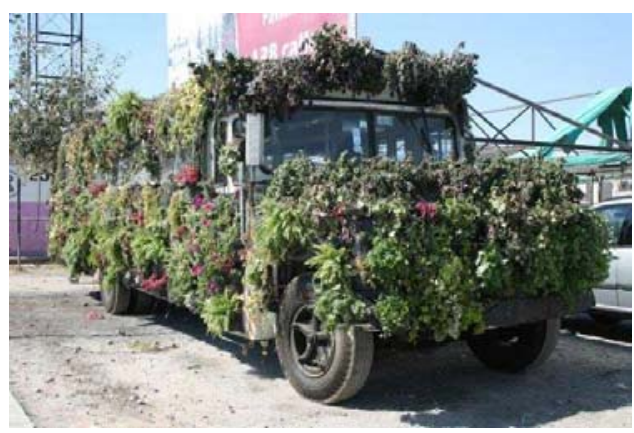

Betsabée Romero, Como un jardín en un pajar, 2009.

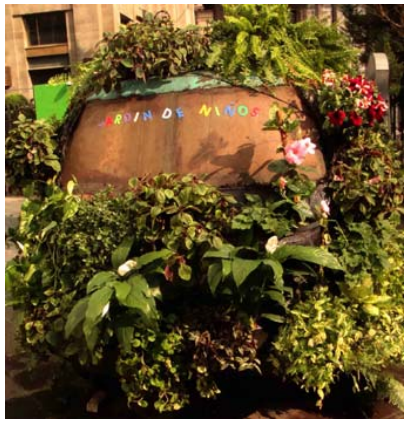

Betsabée Romero, Jardín de niños, 2009. 
Así, vemos cómo se puede tener la posibilidad de disponer rápidamente de un eventual taxi jardín, Taxi verdor (2001), que lleva jardines adonde no hay o una guardería disponible para todos, Jardín de niños, (2009). En esta última obra un pesero 395 cubierto de una exuberante naturaleza vegetal, nos habla de una accesibilidad democrática, sin fronteras, movible.

[...] a partir de esta premisa, encontramos que Romero, ha sido capaz de construir un amplio sistema mnemónico, desde el cual se traducen los conceptos y significados de su particular interés para intervenir $y$ desmaterializar el "arte como territorio" a partir de los contenidos simbólicos del espacio396.

En la obra $A$ orillas del paisaje o Ponchadas por el paisaje (2005), realizada en Francia, interviene sobre el paisaje francés con otros pequeños paisajes. Reinterpreta la utopía de la Naturaleza y su poder regenerador, situando en el paisaje tres llantas de tractor abandonadas de donde brotan pequeños arbolillos. Se trata de la apropiación de todo por parte de la Naturaleza, incluso de aquello que le es, en principio y por artificial, ajeno.

Las llantas degradadas son conquistadas en su material y formas por plantas que en su desarrollo se apropian de un terreno que nos parece infértil e inútil. Una esperanza postindustrial que nos hace voltear, para mirar y retomar, algunos supuestos de los artistas románticos cuando planteaban la escala humana frente a la fuerza y grandiosidad de la naturaleza. No se trata aquí de una visión postapocalíptica, sino de maquetas para la construcción de nuestro futuro, del futuro que no existe y se puede enquistar sobre lo que hoy es cotidiano 397.
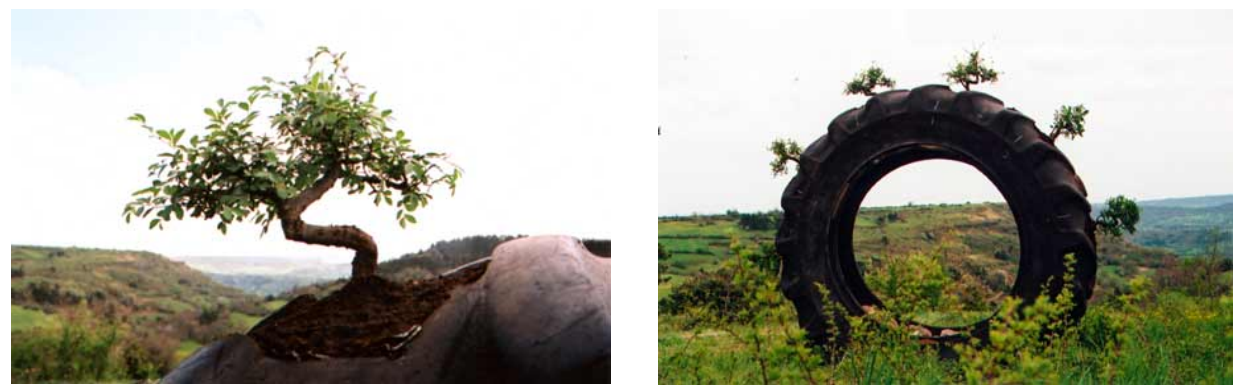

Betsabée Romero, A orillas del paisaje, 2005.

395 El pesero es un minibús o microbús, un vehículo pequeño de ruta fija que se emplea como transporte urbano y público en México.

396 BLANDINO, Bayardo, "Betsabée Romero, ciudades habitadas", en Lágrimas negras, Museo Amparo, Puebla, 2008, Disponible en red: <http://textoblanco.blogspot.com/>, [Consulta 26, julio, 2011].

397 GANADO KIM, Edgardo, "Ponchadas por el paisaje o El paisaje como vía de construcción de la utopía”, México, D.F., junio, 2005, Disponible en red:<http://www.arte-mexico.com/ betsa/texto.htm >, [Consulta 25, julio, 2011]. 
La artista, quien conociera a Nils Udo y ciertas tendencias asociadas a la temática de Arte y Naturaleza, declara que sus intereses por el andar o el movimiento, asociados a las migraciones y al cruce de fronteras, no tienen relación con los artistas del Land Art. Su reflexión conlleva un concepto más urbano, algo parecido a los ejercicios colectivos con los que se manifiesta la Cultura popular, allí donde hay un trabajo a realizar, algo que ofrendar, algo que ofrecer, algo relacionado con los ritos y las tradiciones colectivas que se realizan en común. Así, en declaraciones realizadas a la autora de esta investigación, en una visita a su taller, la artista declara que la utilización de flores como motivo dentro de su obra, refiere a estos rituales colectivos.

Formas de identidad que se generan y se alimentan a través de ritos colectivos, en específico de la devoción popular, creo que la sensibilidad además de lo festivo, es como un sentimiento social en sí, que existe en forma particular en México. Todo esto me llevó a que el leiv motif fuera la flor. La flor es el objeto de la ofrenda, de la devoción, el intermediario de todos los ritos, el intermediario cotidiano de la relación con lo divino, de la relación con lo colectivo, pero esa flor es un icono. Mi actitud hacia las flores es referencial, retomo las flores pintadas, las flores resemantizadas por el rito, las recojo y las trabajo398.

En estas palabras subyace la necesidad de dar voz a las imágenes de los inmigrantes quienes, para explicar sus movimientos necesitan construir, como apunta Néstor García Canclini, narraciones y metáforas, a fin de entender los procesos de globalización en los que se ven inmersos. Las metáforas les ayudan a imaginar lo diferente, mientras que las narraciones ritualizadas de las que Romero nos habla, les permiten ordenarlo.

[...] las migraciones, las fronteras permeables y los viajes hablan en sus desgarramientos de lo que en la globalización hay de fracturas $y$ segregaciones. También por eso en los relatos de migrantes y exiliados irrumpen narrativas y metáforas 399.

En la idea de Naturaleza a la que Romero nos acerca, y que se manifiesta a través de la representación de flores, observamos una noción híbrida que subsiste entre lo simbólico, lo natural - planta con raíces que no se mueve- y lo urbano -auto- un enfrentamiento entre la tradición, lo inmóvil y lo móvil. Después de trabajar en torno a los conceptos de frontera y de tránsito, surge la imagen de lo que se va, el inmigrante que se desplaza. Junto con él, la artista plantea una noción ampliada de ciudad que se mueve, pero que sin embargo permanece inmóvil, desbordada por la acumulación de coches parados que invaden las áreas públicas por todas partes. Enfrentando al elemento auto con

398 Entrevista inédita, realizada a la artista en visita a su taller, por la autora de esta investigación, en México, D.F., julio, 2006.

399 GARCÍA CANCLINI, Néstor, La globalización imaginada, Paidós, México, D.F., 1999, p. 11. 
elementos sedentarios y domésticos como los jardines que recrea, y usando las plantas como lo inmóvil, o el auto como maceta, se produce el proceso utópico y personal mediante el cual la planta vence al auto:

Culturalmente hablando hay una iconografía en peligro de extinción. El arte puede tener la intencionalidad de dar refugio a una memoria y en ese sentido, favorecer líneas de conexión con el pasado. En las ofrendas de muertos de mis abuelas en las fiestas populares de los pueblos, que cada vez son menos ricas menos frecuentes, menos colectivas. De ahí es donde entiendo lo efímero, la instalación. Me planteo no un rescate pero sí hacerle un espacio, un refugio a un significado, a otro tipo de entender el tejido de las cosas. La flor como el hilo conductor que aparece en objetos en la búsqueda de la esencia de lo humano, el arte en sí como el poder de contener la memoria y el sentido de la realidad. En especial la rosa que es difícil de trabajar porque como icono es un lugar común que ha tenido tantas y diferentes recurrencias culturales 400.
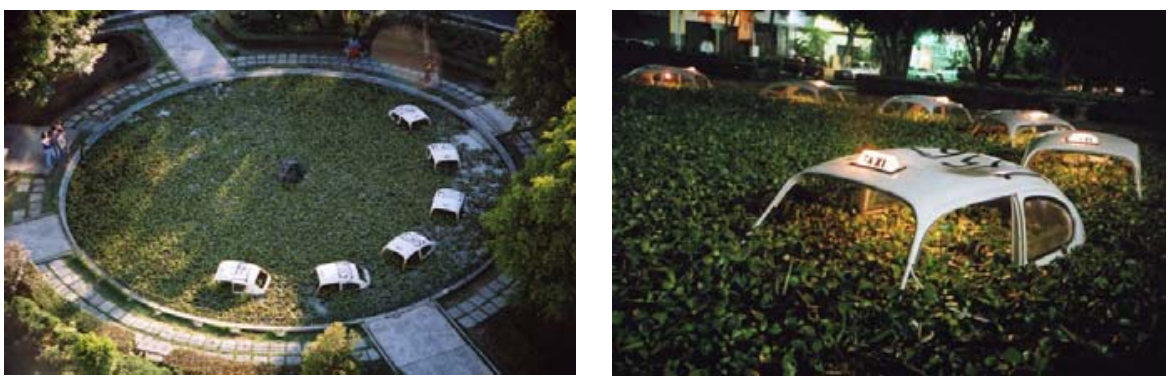

Betsabée Romero, No todo lo que brilla es verde, 2007.

En No todo lo que brilla es verde (2007) 401 , una hilera de taxis varados aparece en una fuente de la Colonia Condesa. La artista, en un bucle semántico, convierte ahora el auto en símbolo de toda una ciudad y con la doble referencia al color verde de los taxis, supuestamente ecológicos, que circulan por México, D.F., denuncia la imposibilidad de un cambio. Estamos ante la utopía del desplazamiento, del movimiento. La imagen es la de que nos movemos, pero finalmente no vamos a ninguna parte, como los inmigrantes que cambian de geografía cargando con ellos sus símbolos para en última instancia, recrear los hábitos de su lugar de origen. Un caos automovilístico que se presenta geométricamente ordenado, pero un orden a la fin, que es devorado por una especie de lirio acuático que se propaga fácilmente y que ahoga todo tipo de buenas intenciones. Aquí la artista se introduce físicamente en el paisaje para modificarlo y resignificarlo. Utiliza el elemento vegetal (el lirio acuático) en

400 Entrevista inédita, realizada a la artista en visita a su taller por la autora de esta investigación, en México, D.F., julio, 2006.

401 Instalación realizada en el Parque México, en el marco de la exposición colectiva de arte urbano generada por Neuronal y Edgardo Ganado Kim. Véase AA. VV., Usted está aquí: Arte contemporáneo mexicano. Intervenciones a la ciudad, Colonia Condesa, Neuronal Laboratorio + Creativo, S.C., México, D.F., 2007, pp.43-45. 
representación de la idea de desbordamiento, de una Naturaleza abrumadora y, con esta acción artística in situ, enfrenta a la Cultura urbana que se apodera paulatina y caóticamente de la ciudad 402 .

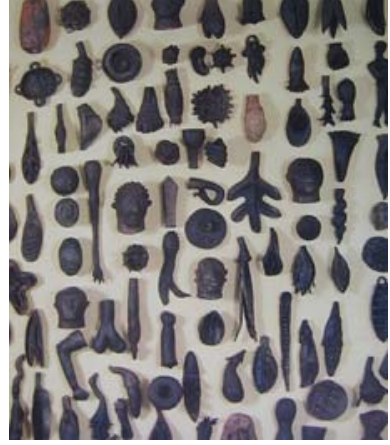

Maribel Portela,

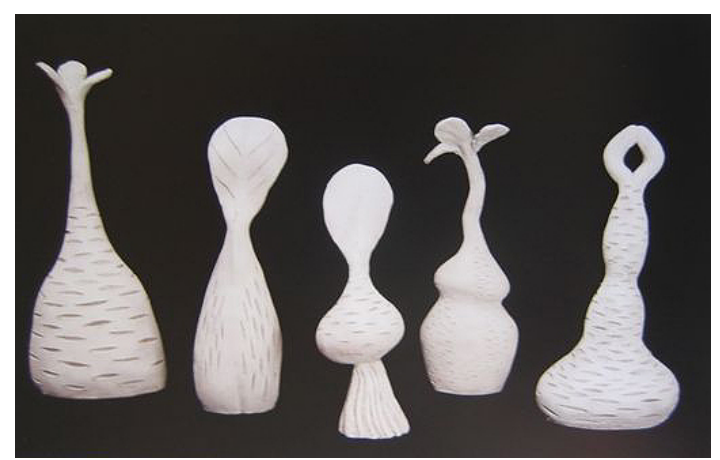

Maribel Portela, Frutos prohibidos, 2003.

Símbolos, 2003.

En este apartado estamos revisando la obra de artistas que utilizan el referente vegetal como apropiación artística de una realidad con implicaciones sociales que por su trascendencia nos concierne. En este sentido y con un material distinto de claras reminiscencias ancestrales, -el barro- encontramos en México obras escultóricas como las de Maribel Portela (México, D.F., 1960), quien realiza una simbiosis entre lo humano y lo vegetal, materializando un diálogo entre arte y naturaleza vegetal. En una imagen similar, Gaston Bachelard nos trae a la memoria la obra literaria de John Milton quien con su poema Paraíso perdido (1667) dio origen a uno de los tópicos más difundidos en la literatura universal. En él, el poeta nos ofrece a manera de sublimación vegetal, una serie de alimentos cada vez más etéreos con los cuales aparentemente podríamos nutrirnos:

Así de la raíz se alza más ligero el verde tallo; de éste salen las hojas más aéreas; por último, la flor perfecta exhala sus esencias fragantes. Las flores y su fruto, nutrimento del hombre, volatilizadas en una escala gradual, aspiran a los espíritus vitales, animales, intelectuales; procuran a la vez la vida y el sentimiento, la imaginación y el entendimiento, de donde el alma recibe la razón [...]403.

402 Con esta pieza, Betsabée Romero hacía alusión a dos plagas: una, la de las mafias de los taxis y otra, la de la invasión de una Naturaleza perjudicial. Colocó seis techos de taxis del servicio público (vochos) en la fuente de la glorieta de Citlaltépetl (la planta del lirio inundaba la fuente, ahogando a los taxis). De esta forma, la artista utilizaba tanto el color verde de los taxis, como la idea de que los mismos son un elemento peligroso que prolifera descontroladamente en la ciudad. Todo ello de forma similar a como actúan las plantas/plaga conocidas como lirio, que invaden los lagos y canales y que colonizan sin freno zonas lacustres como Chapala, Xochimilco o Valle de Bravo.

403 BACHELARD, Gaston, El aire y los sueños. Ensayo sobre la imaginación del movimiento, Breviarios del Fondo de Cultura Económica, México, D.F., 2002, p. 52. 

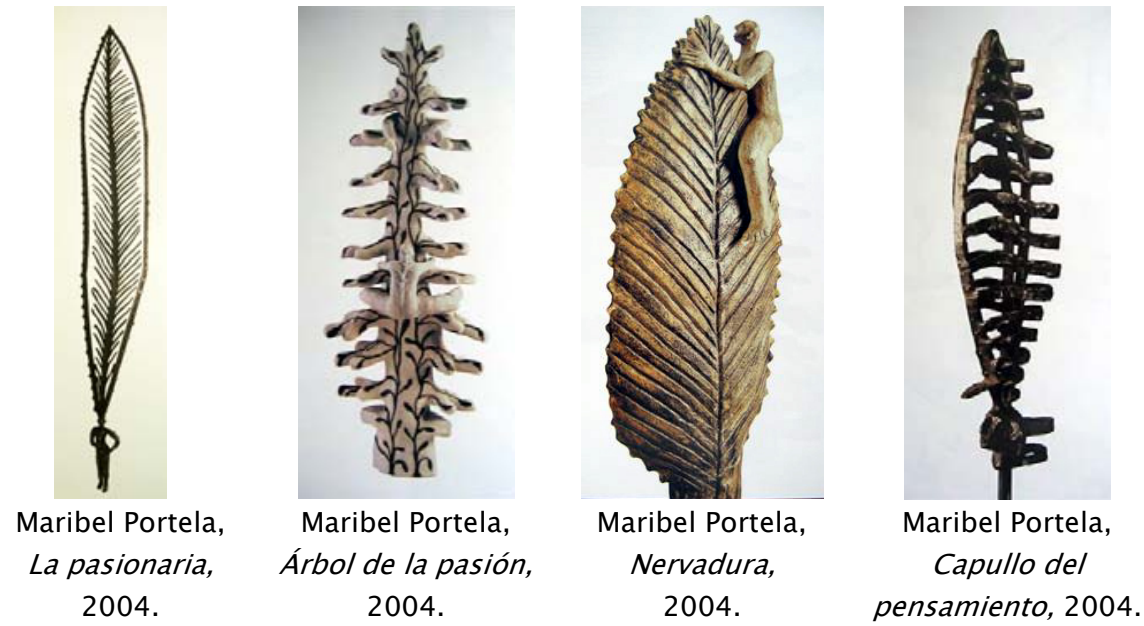

De nuevo, no estamos aquí ante la utilización de lo vegetal como una mera representación o un ornamento, ni ante el posible origen de la dicotomía, como diría a principios de siglo Worringer, entre la abstracción del motivo y el naturalismo del ornamento. Lo que recuperan los artistas contemporáneos con el uso del referente vegetal se corresponde con un simbolismo que tiene que ver no tanto con la estructura vegetal, como él mismo sugiere, sino con su ley constitutiva, la misma que el artista transfiere a sus obras de arte.

[...] el ornamento vegetal no reproduce originalmente la planta misma sino la ley a que está sujeta su formación exterior. Así es que ambos estilos ornamentales carecen propiamente de modelo natural, aunque sus elementos se encuentran dentro de la naturaleza [...] la sujeción a la ley orgánica, que se nos manifiesta de la manera más pura y evidente en la configuración de las plantas. Todos los elementos de la formación orgánica: regularidad, disposición en torno a un centro, compensación entre fuerzas centrífugas y fuerzas centrípetas [...], equilibrio entre los factores de carga y sostén, proporcionalidad de las relaciones y todos los otros prodigios que nos impresionan al contemplar el organismo de la planta, llegan a constituir el contenido y valor viviente de la obra ornamenta/404.

Frente a la aparición del ornamento vegetal únicamente como resultado de una tendencia imitativa de tipo naturalista, Worringer antepone el valor simbólico de estos motivos para su utilización dentro del contexto artístico. Así es como en la obra escultórica de Maribel Portela, artista integrante de la generación de escultores en barro que se dio a conocer en la década de los noventa, se materializa un universo posible en donde la relación del ser humano con los vegetales entronca con las teorías aristotélicas sobre la estética de la representación. Al igual que en los casos anteriores, no debemos confundir el concepto de representación con el de mímesis. No estamos frente a un proceso

404 WORRINGER, Wilhelm, op. cit., pp. 68-69. 
de copia de la realidad circundante, como en ciertas teorías del pasado se pone de manifiesto.

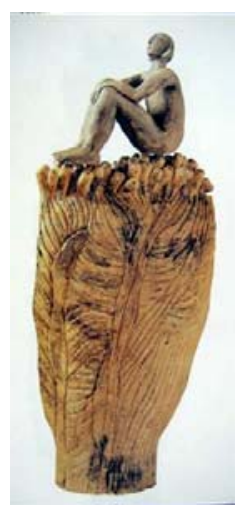

Maribel Portela,

Flor de una

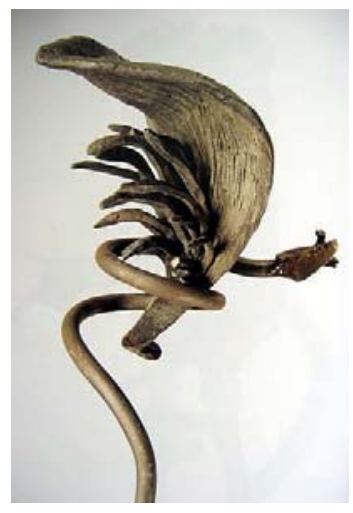

Maribel Portela, Pistilos, 2003.

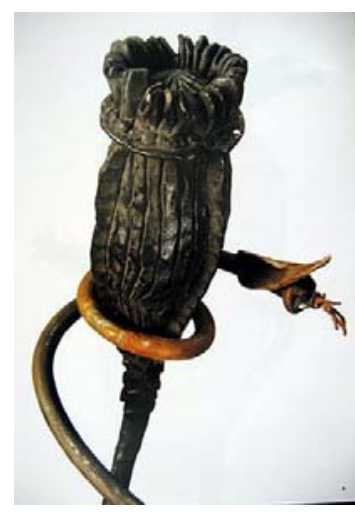

Maribel Portela, Flor negra, 2003.

noche, 2003.

Desde el punto de vista histórico, ante esta Representatio o representación de las cosas, debemos entender la libre interpretación de las mismas, es decir, los artistas plasman la realidad sin pretender una escrupulosa fidelidad 405. Tatarkiewicz apunta hacia el origen griego del término posthomérico de mímesis y señala que en dicha Cultura, este concepto se utilizaba fundamentalmente para designar los actos de culto que realizaban los sacerdotes. La imitación o imitatio, término utilizado posteriormente en latín, no tenía que ver con la acción de reproducir la realidad externa, sino con la posibilidad de expresar una realidad interior.

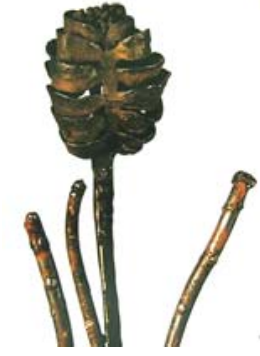

Maribel Portela,

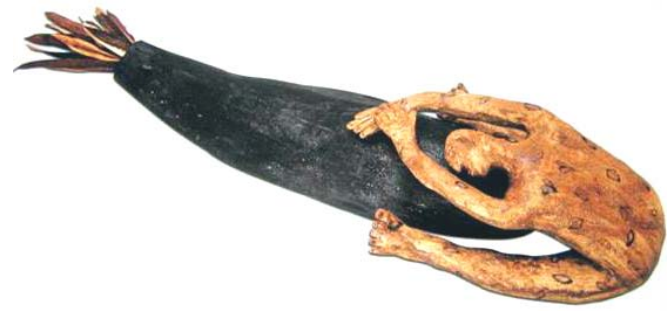

Maribel Portela, Semilla del interior, 2004.

Flor del espíritu, 2003.

Antiguamente $y$, en primera instancia, el término se asociaba más a la música que a las artes visuales. Fue Sócrates quien primero lo utilizó con el significado de copiar la apariencia de las cosas. Más tarde esta idea se desarrollará con Platón y Aristóteles. Finalmente éste último fue quien fusionó ambos conceptos, el ritualista y el socrático, que aunado al concepto de Demócrito (imitación de

405 TATARKIEWICZ, Wladyslaw, op. cit., pp. 301-324. 
los procesos naturales), atraviesa la Edad Media llegando hasta el Renacimiento en donde alcanza su mayor apogeo en la teoría de las artes visuales.

Para entonces la imitación no es tampoco un acto pasivo, la Naturaleza, como decía Durero tiene que descifrarse y su contenido extraerse, acercándose más a la alegoría o a la metáfora. Así, el concepto de imitación llega hasta la Edad Moderna, con Piero de la Francesca y más tarde con Leonardo, quienes incorporan la idea innovadora de que el arte no imita la realidad sino que la estudia. Posteriormente, será el tratadista barroco Emanuel Tesauro (15921675), quien en sus tratados sobre retórica desarrollará la idea, análoga a nuestros tiempos, de que las obras de arte no son una imitación, sino una metáfora y se constituyen únicamente, como símbolos de la realidad. En este devenir histórico sobre el concepto de mímesis situamos la obra de Portela asociada a la idea creativa de imitatio como conexión de ficciones que nos acercan a una realidad necesaria. Sus esculturas juegan con la capacidad objetual de producir nuevas escalas de relaciones y, en la línea de la antigua agudeza o perspicacia - de la que hablaba Tesauro- Portela se torna hábil en penetrar las cosas pequeñas, modificando los sistemas perceptivos y cognoscitivos del espectador.

El crítico Juan Rafael Coronel Rivera califica la obra de Portela como figurativa 406. Esta descripción es acertada en anteriores piezas de la artista de características fundamentalmente antropomórficas. En ellas, Portela utiliza el referente humano y lo transforma en emblemáticas figuras de dioses y diosas practicantes de rituales místicos y paganos, símbolos renovados de antiguas prácticas. Pero específicamente la obra escultórica de Maribel Portela está relacionada con la vida. En anteriores exposiciones (Cazadores y recolectores, 2001, Galería de Hacienda y Crédito Público), su obra presentaba enigmáticos personajes humanos que llevaban tatuados en su piel de terracota, fragmentos de narrativas, exploraciones sobre la vida primigenia del ser humano, glifos y pictogramas que tejían un diálogo con un pasado evocador de mundos míticos y rituales ancestrales. Estas piezas ofrecían implícitas referencias vegetales que hacían alusión a la íntima relación entre la vida humana y la vida vegetal, (Hombre en semilla, 1999 y Diosa de la abundancia, 2002) en donde la conjunción de exuberancia y ritos propiciatorios establecían una alegoría en común.

En estas piezas se descubren mitos, imágenes y leyendas primigenias que trasforman su trabajo en un mundo misterioso, aparentemente reconocible y cercano, a la vez que, paradójicamente, lejano. En sus últimas exposiciones aquellos rituales se centran en una exploración del sentimiento del placer tomando como referente específico la vida vegetal. La visita a la Hacienda San Gabriel de las Palmas, Morelos, (lugar donde el contacto con la Naturaleza es inevitable y el visitante recorre caminos de Naturaleza exuberante) propicia en la

406 CORONEL RIVERA, Juan Rafael, "Yin-Yang de terracota", en AA.VV., Construyendo con la mirada, Museo Carrillo Gil, México, D.F., 2004, pp. 2-4. 
artista la concepción de un proyecto para el cual crea piezas de barro y de bronce que establecen un juego visual con la vegetación (Enredadera, 2004). Adaptándose a cualquier área verde, las piezas tienen la capacidad de mimetizarse con el entorno circundante asombrando de esta manera al espectador.
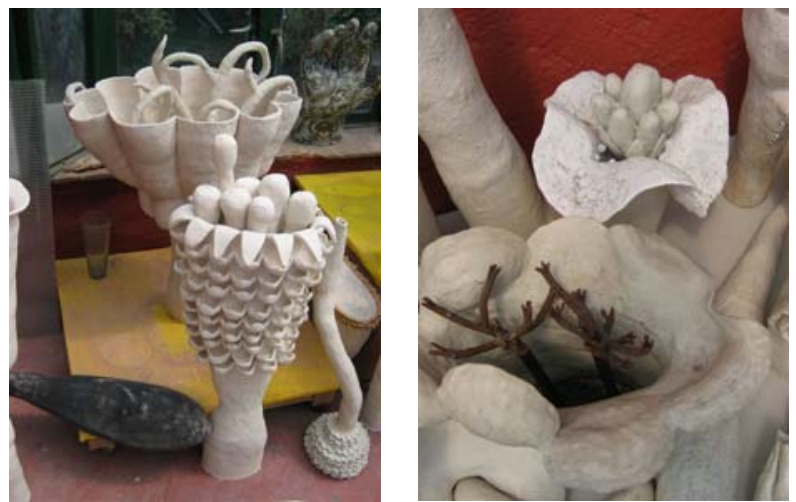

Maribel Portela, Sin título, 2006.

Para el crítico José Manuel Springer, el tema de la obra de Portela evidencia la relación del ser humano consigo mismo y con el universo. En sus obras, señala, prima la trasmisión de valores humanos básicos, pero como artista ha recorrido diferentes etapas:

Las diferencias de género, la forma en que los principios masculino y femenino se integran y se separan es uno de estos aspectos que aparece constantemente en su obra. En las semillas, enredaderas de bronce y frutos que presenta en esta exhibición encontramos un mundo natural resignificado. La naturaleza que rodea el entorno de la Hacienda de San Gabriel ha servido de motivo para crear una ofrenda, en el sentido populary tradicional del término, a las fuerzas invisibles que proveen y enriquecen nuestras vidas [...]. Siendo una mujer apegada a la tierra, Maribel no podría dejar de infundir a su obra el gusto por el ornamento y por la sensualidad [...]. La pasión por lo natural es esencial en el trabajo de Maribel Portela407.

Probablemente derivada de esta ulterior experiencia y con la intención de crear un espacio donde la violencia y la hostilidad no existan, en su última exposición titulada Jardín onírico (2008), la artista retoma la idea de propiciar un recorrido a manera de paseo natural y ofrece al espectador un jardín por el cual seguir un camino iniciático. Para ello, explora el reino vegetal, ámbito vital que es complemento y contrapartida del humano, y elabora una auténtica selva constituida por ciento veinte piezas de terracota. Se trata de plantas míticas, troncos esbeltos y gráciles de los que brotan ramas de vida, flores y follajes que emergen con la corporeidad del barro y sugieren al espectador la imagen de una

407 SPRINGER, José Manuel, en AA. VV., Construyendo con la mirada..., op. cit., pp. 27-28. 
tierra voluptuosa habitada por plantas curvilíneas que parecen contonearse al ritmo del viento.

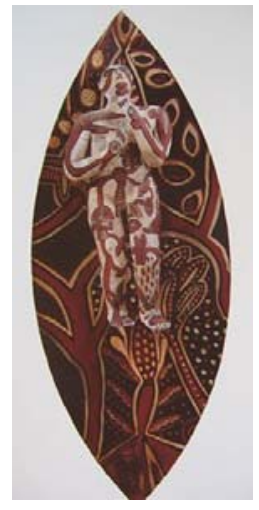

Maribel Portela,

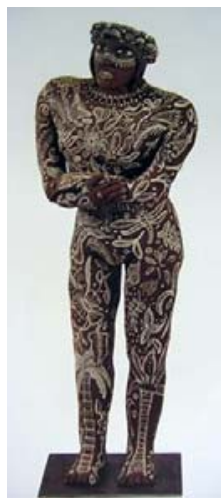

Maribel Portela,

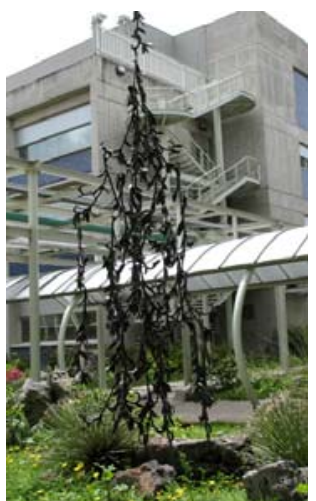

Maribel Portela,

Hombre en semilla, 1999. Diosa de la abundancia, $2002 . \quad$ Enredadera, 2004.

Flores, árboles y diversos tipos de vegetación, piezas en su mayoría de gran formato (dos metros de altura) forman un ambiente natural dentro de las salas del Antiguo Palacio del Arzobispado. Un jardín escultórico que invita al espectador a pasear entre sus formas orgánicas, una flora exuberante o como señala Germaine Gómez Haro, "un paisaje de ensoñación hecho realidad [...], jungla de formas vegetales rebosantes de energía"408. Portela crea un jardín imaginario con piezas hechas en barro de color blanco, sin brillos, ni esmaltes.

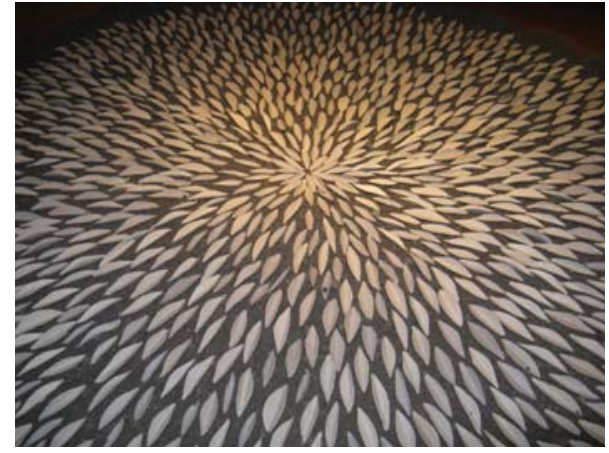

Maribel Portela,

Jardín Onírico, Pétalos, 2008.

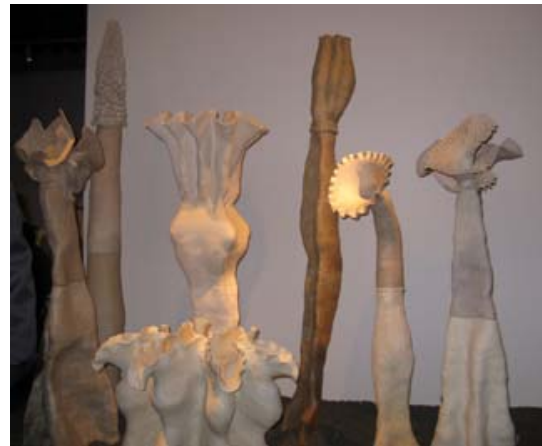

Maribel Portela, Jardín Onírico, Flores, 2008.

Figuras imaginarias y oníricas que ofrecen al espectador la sensación de transitar por un espacio de paz. Inspirándose en la novela Los jardines secretos

408 GÓMEZ HARO, Germaine, Maribel Portela (II y Última), Artes visuales, La Jornada Semanal, № 722, México, D.F., 4 enero, 2009, Disponible en red: <http://www.jornada. unam.mx/2009/01/04/sem-haro.html>, [Consulta 27, julio, 2011]. 
de Mogador409, la artista no copia planta o flor alguna existente en la realidad, sino que hace una versión íntima y personal de cada planta, de cada flor, de la esencia de todos los jardines.

Tanto en sus obras anteriores como en la más reciente, Portela destaca 410 su tendencia a recrear el hacer de las culturas ancestrales. Este tipo de proceder, aunque de muy distinta forma, se conecta con el trabajo de la artista Yolanda Gutiérrez, de la que hablamos en el capítulo cuarto. Ambas escultoras obtienen de su entorno cultural más próximo -la Cultura prehispánica- la inspiración necesaria que, matizada por la contemporaneidad, da luz a sus obras escultóricas.
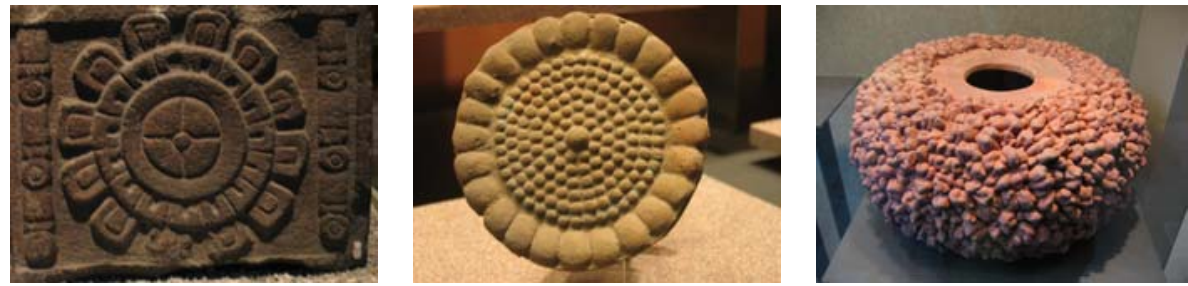

Piezas de cerámica prehispánica, Museo de Antropología, México, D.F.

También podemos asociar la obra de Portela con ciertos aspectos de la artesanía popular. Como en el caso de Betsabée Romero, aunque de forma muy diferente, en sus obras confluyen tradición y arte contemporáneo, en un proceso que revela una continuidad desde los tiempos prehispánicos hasta la actualidad. Siguiendo la ancestral tradición de la cerámica tanto prehispánica como colonial, Portela realiza una obra que, en sus últimos trabajos, se caracteriza por acercarse a los motivos vegetales en un intento de trasmitir a través de estos modelos, conceptos en torno al "placer y la sensualidad".

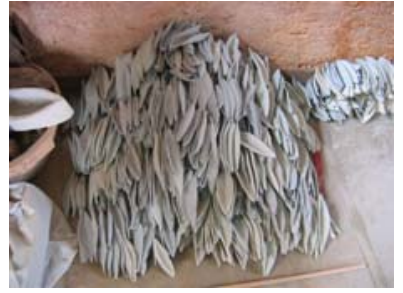

Maribel Portela, Sin título, 2005.

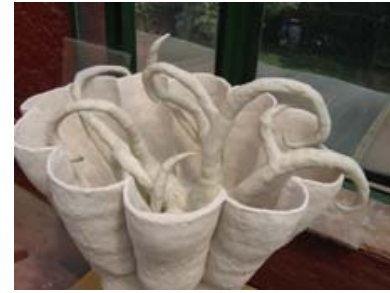

Maribel Portela,

Sin título, 2005.

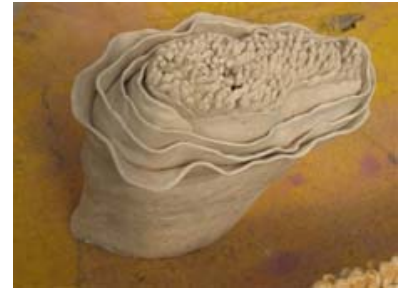

Maribel Portela, Sin título, 2005.

En el Museo de Antropología e Historia de México, D.F., así como en muchos otros museos de México, encontramos piezas de piedra y de cerámica de las

409 RUY SÁNCHEZ, Alberto, Los jardines secretos de Mogador, Alfaguara, Voces de tierra, México, D.F., 2001.

410 Entrevista inédita, realizada a la artista en visita a su taller, por la autora de esta investigación, en México, D.F., septiembre, 2005. 
diferentes culturas que han poblado y aún hoy habitan este país. En ellas podemos apreciar un hacer inspirado en el referente vegetal, similar al de algunos escultores contemporáneos. Se trata de esculturas, relieves y vasijas como las que podemos observar en algunas de las imágenes que aquí se muestran.

Más contemporáneos, la artesanía popular en cerámica de los árboles de la vida de Metepec ${ }^{411}$ o la alfarería vidriada de fuerte color verde de Michoacán es un claro ejemplo de estas tradiciones. Todas ellas dan buena cuenta, como dejamos entrever en el capítulo primero, de la trascendencia de las plantas para el hombre prehispánico. Ahora bien, si artistas como Maribel Portela y otros, construyen y trabajan esta suerte de jardines escultóricos debemos analizar cuales son los motivos que les mueven a realizarlos y desde qué diferentes enfoques.

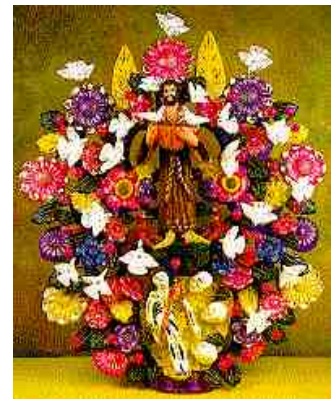

Árbol de la vida de Metepec.

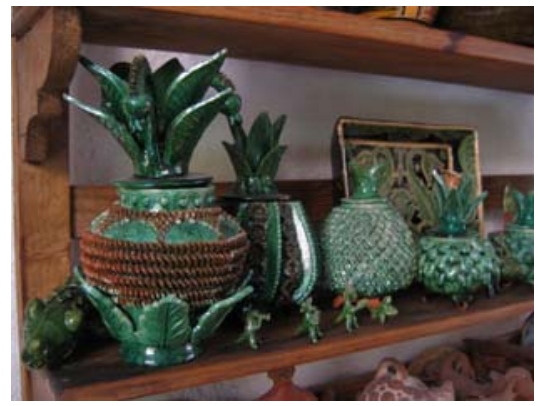

Cerámica de Michoacán.

Por un lado, el jardín según Cirlot 412 es el ámbito en que la Naturaleza aparece sometida, ordenada, seleccionada y cercada constituyendo un símbolo de la misma frente al caos de una Naturaleza exuberante. Lugar que como atributo es asociado con lo femenino en los emblemas de los siglos XVI y XVII en Occidente, en donde se producen acciones de conjunción o se guardan tesoros. Por sus características formales, orden y orientación el jardín se relaciona con el paisaje -espacio fértil para todo tipo de simbolismos relacionados con las plantas- pero también con los elementos (tierra, agua, etc.), la cerca y el jardinero. Maderuelo413, a su vez, nos dice que el jardín es tanto una construcción física como intelectual. Sus elementos constitutivos responden a modelos culturales e históricos, por lo que debe ser entendido además de como una forma de

411 El municipio de Metepec, en el Estado de México, se caracteriza por la artesanía típica de los llamados Árboles de la vida. Son esculturas con forma entre árboles y candelabros, pintados en vivos colores y cuya abigarrada iconografía, repleta de figuras, objetos y motivos vegetales, está relacionada con el tema bíblico del Jardín del Edén.

412 CIRLOT, Juan Eduardo, op. cit., p. 258.

413 MADERUELO, Javier, "Introducción. El jardín como arte", en MADERUELO, Javier (dir.), El jardín como arte: Arte y naturaleza, Actas del III Curso, Diputación de Huesca, Huesca, 1997, pp. 9-12. 
arquitectura, como el reflejo de una idea y como tal, debe considerarse también dentro del ámbito de la filosofía.

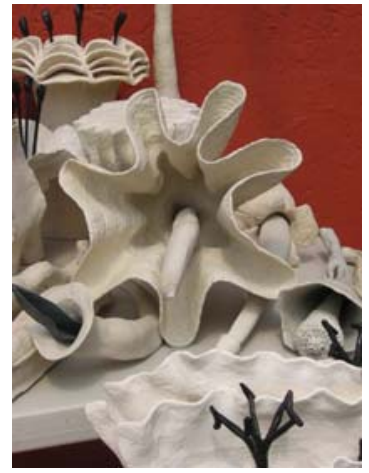

Maribel Portela, Sin título, 2005.

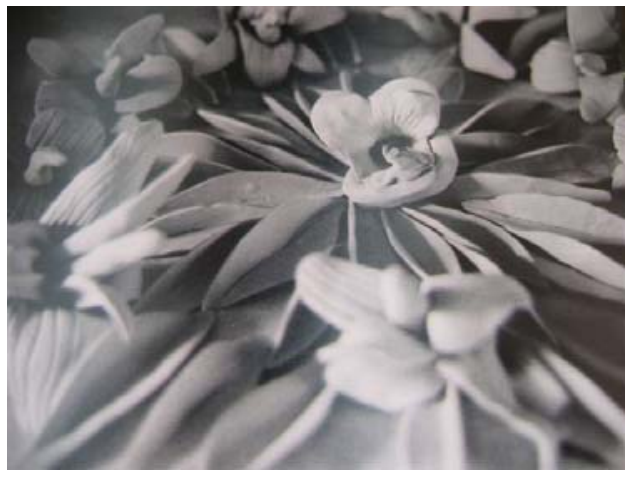

Maribel Portela, Sin título, 2005.

En general la idea de jardín está unida a la recreación de un mundo edénico, al anhelo por parte del hombre de habitar un mundo mejor. Aparece así, una dislocación entre idea y realidad de manera que frente al jardín, como utopía alcanzable y sinónimo de lugar de felicidad y quietud, el mundo se percibe como una realidad difícil. Pero oportunamente, Cereceda nos advierte de las pueriles trampas que puede esconder una falsa idea de vida natural:

La idea de naturaleza que habitualmente se maneja no es sólo la de algo que existe en sí $y$ por sí $y$ evoluciona en sí $y$ por sí antes $e$ independientemente de nosotros (los humanos), sino que es también la idea de algo orgánico, organizado y dotado de vida, de algo que crece y se reproduce espontáneamente, de un modo vegetal. De ahí también la relación usual entre la planta y la naturaleza. Pero ni una planta es la naturaleza, ni la naturaleza son plantas y vegetales 414 .
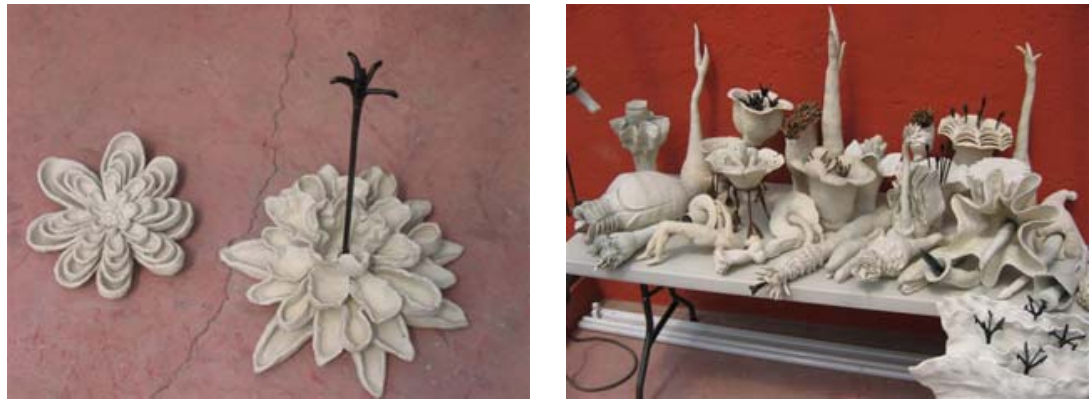

Maribel Portela, Sin título, 2005.

414 CERECEDA, Miguel, "Filosofía del jardín y filosofía en el jardín", en MADERUELO, Javier (dir.), El jardín como arte..., op. cit., p. 50. 
Pero Portela no nos engaña: nos sitúa en un jardín que no sólo se contempla sino que se recorre y se vive, en el mismo sentido en el que Carmen Añón plantea un recorrido histórico por las concepciones filosóficas que vierten cada uno de los jardines que el ser humano ha creado:

[...] porque en el jardín la belleza no sólo se contempla sino que se vive. Porque en el jardín realmente se vive el arte, en cuanto el acto de contemplar y el acto de vivir forman uno sólo415.

Añón nos trae a la memoria las teorías de Rosario Asunto, gran filósofo de la Naturaleza, quien planteaba el sentido y la esencia del jardín como la unidad entre Arte y Naturaleza. Asunto señala cómo, en la historia del ser humano, el jardín se constituye como el paradigma de la necesidad de la relación hombreNaturaleza, como respuesta a una búsqueda de lo bello, de lo estético y como la necesidad a su vez de una espiritualidad. Esta tendencia parte del contacto con lo natural y de forma aparentemente contradictoria, se concreta en la recreación de una suerte de jardines artificiales que, sin embargo, nos devuelven el sentimiento contemplativo de lo natural. Estamos ante un jardín que se inscribe en la tradición de la simbología que entiende lo vegetal como metáfora de Naturaleza.

[...] que sobrepasa la caducidad del tiempo. Jardín de la memoria y de la imaginación. Jardín hecho de una naturaleza reelaborada a través de la cultura, la tradición, la historia y el arte. Jardín donde la fantasía y realidad se integran en un todo. Jardín de la imaginación y del conocimiento, del saber y la técnica4t6.

Portela, siguiendo el modus operandi de las intervenciones artísticas contemporáneas, ha integrado sus jardines construidos (Enredadera, 2004 y Jardín portátil, 2008), en determinados lugares que permiten una mayor interactividad con el público:

El lugar más frecuente para acoger intervenciones artísticas que reflexionan sobre la Naturaleza serán parques, jardines, bosques turísticos, lugares creados o controlados por el hombre en una correcta escenificación de lo natural como lo verosímil. Este será el espacio más frecuente, un lugar no urbano donde las esculturas permanecen más o menos agazapadas para que el paseante las descubra, sin que su artificialidad influya en una percepción de lo natural que se encuentra cómoda con el concepto de Naturaleza como jardín417.

415 AÑÓN FELIÚ, Carmen, "El jardín como arte y sentimiento de la naturaleza", en MADERUELO, Javier (dir.), Huesca: Arte y naturaleza..., op. cit., pp. 39-40.

416 AÑÓN FELIÚ, Carmen, "El jardín...", en MADERUELO, Javier (dir.), Huesca: Arte y naturaleza..., op. cit., pp. 42-43.

417 ALBELDA, José y SABORIT, José, op. cit., p. 149. 


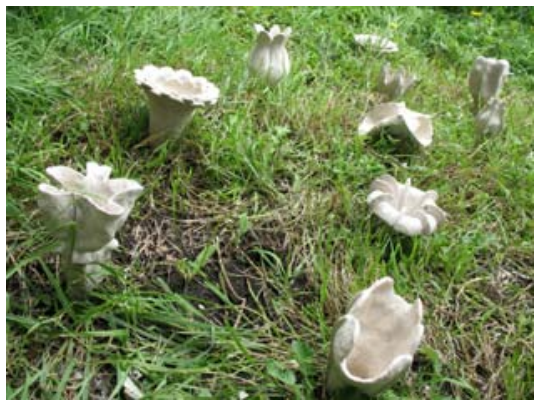

Maribel Portela, Jardín portátil, 2008.

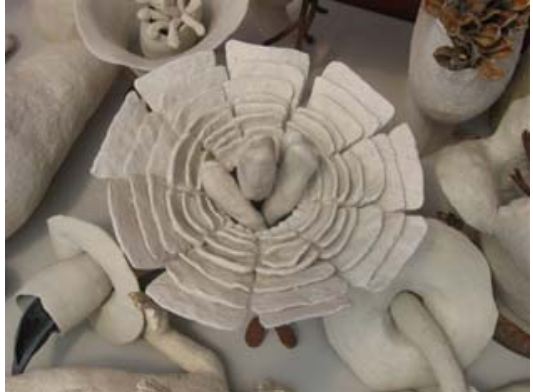

Maribel Portela, Sin título, 2005.

La configuración de estos jardines nos acerca a los jardines prehispánicos -tanto a los reales (Chapultepec, los jardines de Nezahualcóyotl en Texcoco, los señoríos de Iztapalapa y Huaxtepec) como a los figurados (Tlalocan de Tepantitla)- y más tarde, a las representaciones postcoloniales (Malinalco). Como ya hemos comentado en los primeros capítulos, dentro del mundo prehispánico y de la cosmovisión de los antiguos pobladores de México, el mundo vegetal es fuente constante de recreación. Son notorias las múltiples y complementarias caras que de él podemos encontrar: la cultivada y la silvestre, el huerto y el bosque, la milpa y el monte, el jardín y la selva. Pero todas ellas constituyen pilares imprescindibles para la comprensión de un mundo basado en los aspectos sensibles y míticos de la Naturaleza. El jardín era, sin lugar a dudas, un lugar privilegiado dentro de la Cultura de los nahuas, quienes tenían varios vocablos para designar las diferentes clases de los mismos, lo que muestra la prolongada familiarización que los indígenas tenían con la horticultura 418 .

Ante el descubrimiento de las grandes ciudades prehispánicas, los españoles quedaron muy sorprendidos al encontrarse un mundo en donde la integración entre animales, plantas, agua y construcciones se manifestaba de una manera natural en el paisaje, algo que anteriormente, nunca habían visto. Se trataba de la sublimación del mundo natural domesticado en un universo no silvestre, refinado y planeado, todo construido de forma armoniosa en el que las plantas se situaban en parcelas prescritas según los cánones estéticos de cada grupo étnico y ordenadas de acuerdo a la clasificación propia de su cosmovisión. La analogía entre estos jardines y otros, probablemente diseminados en todo el territorio mesoamericano, permite considerar la existencia de un entorno culto, un modelo explicativo de la idea de paraíso similar a la del mundo occidental. La necesidad de recrear este tipo de espacios nos acerca a una posible interpretación de su existencia: la creación de jardines urdidos para la contemplación activa.

418 Xochitla: lugar de flores; Xochitepanyo: jardín amurallado; Xochiteipancalli: jardines de placer para las clases gobernantes o palacio de flores; Xochichinancali: humilde jardín del indio, sitio de flores rodeado por una barda hecha de flores o de ramas. NUTTALL, Zelia, "Los jardines del antiguo México", en Arqueología mexicana. Antiguos jardines mexicanos, Vol. X, N 57, INAH, CNCA, Raíces, México, D.F., septiembre-octubre, 2002, pp. 16-17. 

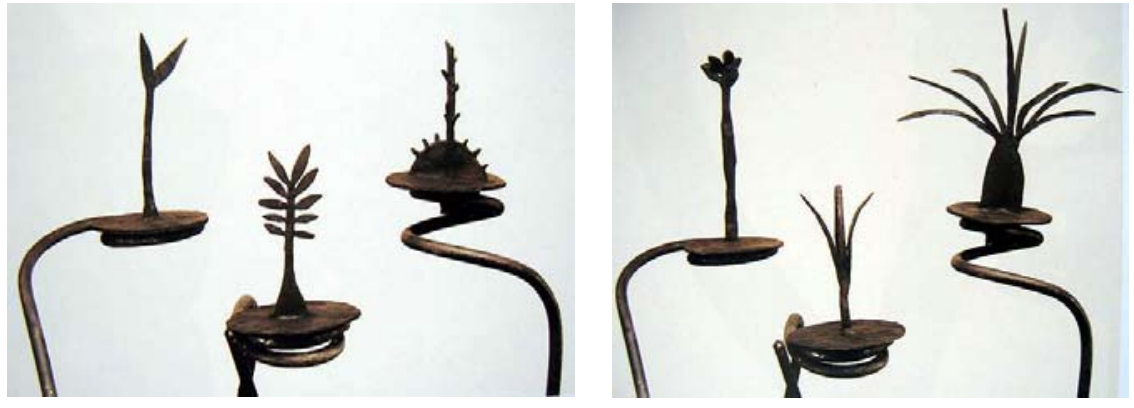

Maribel Portela, Lotos, 2003.

Si consideramos todo ello, en tiempo presente y, en una Cultura, la actual que, mudada por la idea de progreso, el deterioro y el desecamiento de las condiciones lacustres naturales de ciertas zonas de México, olvida la necesidad de un entorno natural para la contemplación y el sosiego, entenderemos la urgencia de construir espacios para La reflexión. En este sentido, los jardines que Portela propone se conectan con aquellos del pasado, posibles ciudades ajardinadas que, sin pretender detener la devastación generalizada que sufre no sólo México sino el planeta en general, ofrecen un respiro para la reflexión. Lugares en los que nos queremos incluir con una responsabilidad compartida, como seres humanos íntegros. Bozal lo expresa de la siguiente manera:

No es lo mismo decir que las cosas se presentan que decir que hay cosas presentes. El "se» introduce un matiz inicialmente débil, [...] matiz que atribuye protagonismo a la cosa que se presenta, de tal modo que este presentar-se es un llamar la atención y significarse, salir del horizonte en que todas están presentes y hacerlo para alguien, ante el que se presentan [...]. Es el gozo que nos invade cuando contemplamos las cosas de forma nueva, porque ese es un gozo estético, inscrito en la representación estética419.

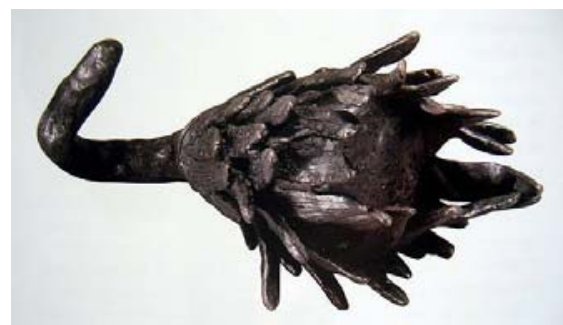

Maribel Portela, Planta, 2003.

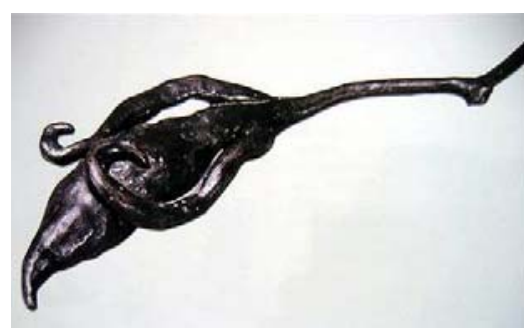

Maribel Portela, Flor secreta, 2003.

En este horizonte, el cambio perceptivo en torno al mundo natural radica en la posibilidad del arte, de fijar y alterar definitivamente nuestra visión sobre las

\footnotetext{
419 BOZAL, Valeriano, Mímesis: las imágenes y las cosas, Visor, Colección La balsa de la Medusa, Madrid, 1987, p. 28.
} 
cosas. Los personajes vegetales que integran la flora de Portela, flores ficticias o reales, imaginadas o recreadas, se insertan tanto en la estrecha relación con la tradición del mundo mesoamericano como en la dialéctica tramada a lo largo de la relación histórica entre las plantas y los humanos.

El gozo estético se asienta sobre un triángulo: el objeto estético, el sujeto y el mundo naturalizado que veo de otra manera a partir de las exigencias de aquel. También la tradición tiene fórmulas retóricas para aproximarse a este fenómeno: el arte nos permite ver la belleza del mundo 420 .

Respecto al motivo floral, sabemos que tradicionalmente, las flores se han considerado un medio para la expresión de los sentimientos más nobles del ser humano. Símbolo de la belleza, de la alegría, del placer, así como del color e incluso del amor, generalmente están asociadas con todo aquello efímero y vulnerable. Se trata de un signo dual que por su esencia y por su forma, hace referencia tanto a la vida más exuberante como a la muerte y la posibilidad de renacimiento o de permanencia. Fieles, como tantos otros elementos de la Naturaleza, al principio declarado por el filósofo Heráclito, "la única realidad de la Naturaleza radica en el cambio, todo se transforma, todo fluye y al mismo tiempo permanece" 421 , las flores han desarrollado, dentro de la Cultura de todos los pueblos, patrones que aún siendo confusos establecen un lenguaje, una forma de comunicación capaz de trasmitir valores. Tan cercanas a la manifestación de la pureza más prístina como a la pulsión del deseo más carnal, se encuentran como tales, inevitablemente ligadas por su propia naturaleza a todo aquello que tiene que ver con lo sexual y reproductivo y por lo tanto con lo tabú.

Dentro del arte contemporáneo el uso de las flores ha encontrado diferentes nichos con los cuales seguir exhibiendo la obscena capacidad sexual que representan, tan aceptada según Rosa Olivares, como indecente 422 . Recordemos en particular a artistas como Karl Blossfeldt, Imogen Cunningham o más contemporáneamente, Joan Fontcuberta o el enigmático Marc Quinn y su extásico Jardín del Edén congelado (Garden, 2000). También Isa Genzken y sus instalaciones con flores artificiales o Gerda Steiner \& Jörg Lenzlinger con sus jardines gigantes llenos de flores colgantes. En ellos, el colorido y el entramado sonoro entre plantas artificiales y vegetación viva mantienen una extraña pugna por la sobrevivencia.

\footnotetext{
420 BOZAL, Valeriano, op. cit., p. 30.

421 STEVENS, Peter S., Patrones y pautas en la naturaleza, Salvat, Serie Biblioteca Científica Salvat, Barcelona, 1986, p. 63.

422 OLIVARES, Rosa, "Dígaselo con flores", en Exit, $\mathrm{N}^{\circ} 28$, Flores/Flowers, Olivares y Asociados, Madrid, 2007, pp. 14-15.
} 

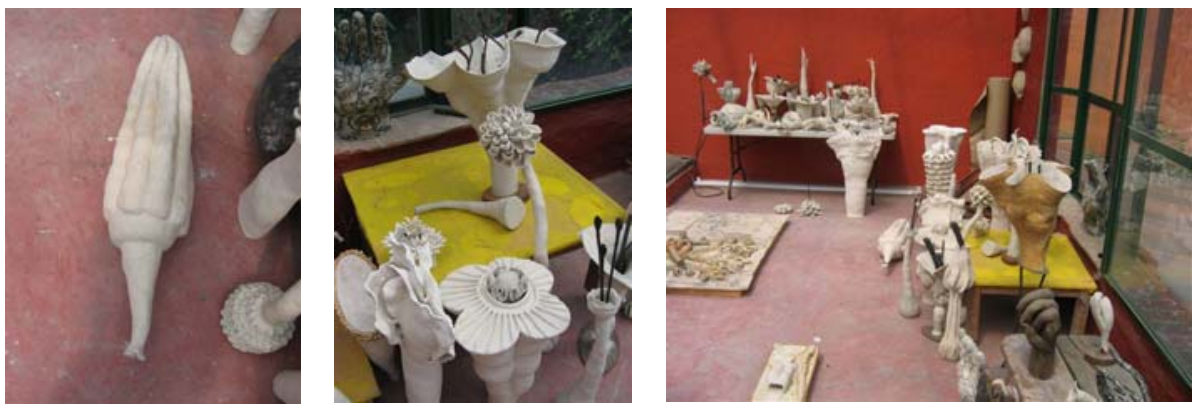

Maribel Portela, Sin título, 2005.

Podríamos decir que nuestra fascinación por las flores radica en su poder de metamorfosis, así como a las connotaciones asociadas a la fertilización,

La fascinación por las flores, más allá del atractivo de sus colores y formas, radica en su capacidad de transformación, en especial, en la rapidez con que se abre el capullo, la flor se expande y luego se marchita, vívida metáfora del ciclo de la vida humana y de la fugacidad de la belleza, el vigor y la vitalidad [...]. Los hombres han vinculado el esplendor de las flores con sus sentimientos amorosos porque, en ambos casos, se trata de un fenómeno previo a la fertilización ${ }^{423}$.

Para Georges Bataille la visión de una flor, no sólo revela esta parte esencial de la planta, sino que fundamentalmente provoca reacciones mentales mucho más significativas, "porque la flor expresa una resolución vegetal oscura" 424 y sus cualidades simbólicas van más allá de la apariencia seductora que las flores ejercen sobre los seres humanos, así como sobre otros animales. Bataille nos previene de la capacidad que hemos desarrollado para realizar la sustitución de elementos yuxtapuestos que las flores nos ofrecen: si bien los órganos reproductores de las flores son los que le conceden su verdadera razón de ser en la escala reproductora vegetal, son por el contrario esos otros atributos como los pétalos y la corola, los que nos cautivan por su belleza y su fragilidad.

En esta metáfora y a la vez metonimia sexual, en este movimiento entre lo que se expone como bello -la parte externa de la planta- y lo que se oculta -raícessurge una dirección de arriba hacia abajo que define imprescindiblemente implicaciones de carácter moral y significaciones que se asignan a los fenómenos naturales de manera causal. Este contexto es definitivo para que todas aquellas estructuras formales y representaciones que siguen una pauta vegetal, despierten en nuestra percepción un eco emocional.

423 SAUNDERS, Gill, "De especímenes a símbolos sexuales: flores en fotografía”, en Exit, $\mathrm{N}^{\circ}$ 28, op. cit., p. 27.

424 BATAILLE, Georges, "El lenguaje de las flores", en Exit, № 28, op. cit., pp. 108-117. 


\subsection{La metamorfosis de los materiales. Gabriela León, Verónica Sahagún, Alfredo De Stéfano, Hisae Ikenaga y Sergio Rodríguez}

El artista más que un creador es un receptor. Sus obras, aquello que como materialización de su arte pareciera ser una creación, no es más que el acto de dar forma a lo que se ha recibido. De esta manera, el artista se convierte en un filtro a través del cual se transforma la percepción de la realidad sensible. Por este principio de colaboración entre la realidad percibida y los objetos que resultan de este proceso de interacción, el artista nos ofrece una nueva visión calidoscópica de aquello que percibíamos originariamente desde un punto de vista fijo. Entre la relación del modelo o referente y la obra de arte solía haber un parecido. Para John Berger "un parecido es algo que se deja atrás sin ser visto" 425 , una especie de esencia fugaz que logramos percibir. Pero lo que nos importa aquí es la constancia de las formas, la repetición de un ritmo vital que expresa su razón de ser en la recuperación del equilibrio de la armonía presente en la Naturaleza y en el universo, para la cual la empatía con aquello que se registra resulta condición previa.

Hemos visto hasta aquí un relevante grupo de artistas que en algún momento de sus trayectorias han resuelto enfrentar las problemáticas con respecto al binomio Arte y Naturaleza decantándose por una dialéctica con lo vegetal en sus múltiples concepciones y significaciones. Los casos que pudiéramos ejemplificar son todavía numerosos. En este apartado revisaremos algunas otras obras que, por sus características específicas, mantienen una relación con los materiales empleados en las esculturas.

Es así como la artista Gabriela León426 (Cuautla, Morelos, 1973) -invitada a participar en el Simposium Internacional de Escultura y Poesía en Varanasi, India- decide reinterpretar el proyecto de escultura que tenía pensado y realiza una pieza para el contexto específico (Specific site, Specific time) en el que iba a participar. Respondiendo a la complejidad del contexto y en atención a la situación, desarrolla una pieza que podemos inscribir dentro de la categoría de Arte Público definida por Dani Karavan como "aquel trabajo que es creado para un lugar determinado independientemente del carácter permanente o la duración limitada de la obra en sí". Se trata de un trabajo cuya génesis, desarrollo y existencia se vinculan a un lugar determinado que, en la mayoría de las ocasiones, destacan por su capacidad para suscitar el debate social y cuya significación final desaparece tan pronto como el lugar le es ajeno. En estas circunstancias, la intervención implica aspectos tanto visibles como invisibles. En cuanto a los materiales, ninguno es mejor que otro y se deben tener en cuenta tanto aquellos tangibles como los intangibles tales como la memoria y la conciencia personal e histórica. Ello implica una responsabilidad por parte del

425 BERGER, John, Algunos pasos hacia una pequeña teoría de lo visible, Ardora, Madrid, 2002, p. 45.

426 Página personal de Gabriela León, Disponible en red en <http://www.gabrielaleon. com>, [Consulta 28, julio, 2009]. 
artista hacia el arte y hacia la sociedad427, estableciendo una relación de compromiso social con los otros, trabajando con ellos incluso en acciones colectivas. El crítico Ramón Almela encuentra en el modo de actuar de esta artista las características propias derivadas del encuentro con la situación y el contexto específicos.

Su obra no se conforma al giro etnográfico imperante en la práctica artística actual que podría delatar su actitud nómada con los viajes. El método antropológico utilizado por el arte busca observar y mapear al otro, convirtiéndose el individuo en intérprete artístico del texto cultural. Al contrario, Gabriela se siente impactada por sentimientos contradictorios ante las divergencias que se viven en las calles de la India a cada paso, Se involucra por completo en el espacio, en la situación [...]. La realidad vivida impactaba su psique, y lo percibido encontró una síntesis escultórica en dos piezas: Una flor y una semilla, sin pretensión formal o intención de insertarse en el discurso contemporáneo del arte 428.
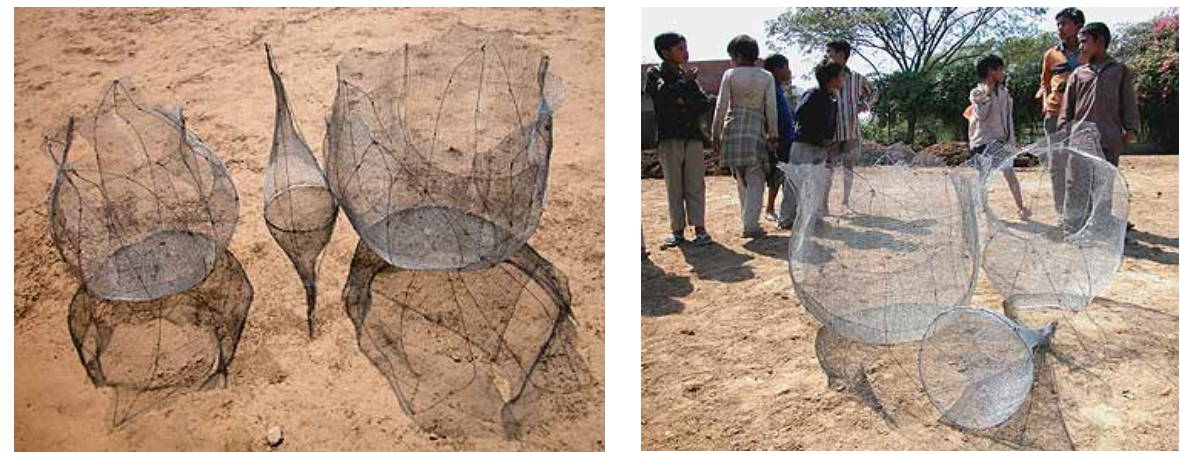

Gabriela León, Flor de Loto, 2005.

Los recorridos que la artista hizo para desplazarse a su lugar de trabajo le permitieron ser consciente de la situación en la que vivían los campesinos, lugares rodeados de excrementos de vaca, producto sagrado. Esta materia es recolectada por las castas más bajas y pobres cuyo oficio es amasarla y aplanarla, dejándola secar para luego venderla como combustible para cocinar. Ante esta realidad la artista realiza dos piezas. Una de ellas es una flor elaborada con estructura de tela metálica y alambre, recubierta de esa masa y otra, una semilla hecha con moldes de su propio cuerpo y cenizas de los crematorios hindúes. La artista rescata de la crudeza de la vida cotidiana una circunstancia habitual para los habitantes del lugar y la convierte en una ocasión para la reflexión. El excremento de vaca como materia adquiere en este proceso

427 KARAVAN, Dani, "Reflexiones sobre arte público", en CUESTA, Salomé et al., op. cit., p. 141 .

428 ALMELA, Ramón, "Gabriela León en la India. Arte de contexto y situación", Disponible en red: <http://www.criticarte.com/Page/file/art2005/GabrielaLeon.India.html>, [Consulta 14, julio, 2009]. 
estético de transformación una calidad ontológica que, mediante la forma conferida por la artista se resignifica.

La flor de loto crece en aguas contaminadas y echa raíces en el fango, pero al florecer realiza una especie de alquimia, una transición de lo escatológico a lo bello. La intención de establecer un paralelismo entre este específico elemento vegetal y las posibilidades de un cambio social para gentes del lugar queda patente cuando la artista traslada la estructura de alambre realizada hasta los campos de excremento de vaca, Ilamando de esta manera la atención de los trabajadores sobre su propio trabajo. Una niña de doce años Nilham, fue su maestra y asistente en la labor de amasar y aplanar el excremento para recubrir finalmente con él la estructura de la flor. Si bien, la pieza terminó expuesta en una galería, la experiencia de realizar la misma in situ, supuso un fuerte impacto entre los lugareños.

La visión del ritual de los crematorios de cadáveres y de las cenizas esparcidas en el río sagrado del Ganghes, lugar donde los hindúes van a morir y a esparcir sus cenizas, inspiró a la artista la pieza que lleva por título Semilla (2005). Aquí utiliza su propio cuerpo como materia para extraer fragmentos de moldes de escayola y posteriormente, realizar positivos con cenizas de los crematorios. Se trata de una acción en la que de nuevo la idea de semilla se constituye como facilitadora del tránsito hacia otra vida.

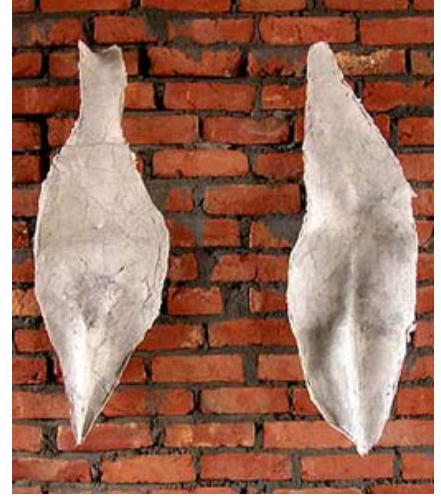

Gabriela León, Semilla, 2005.

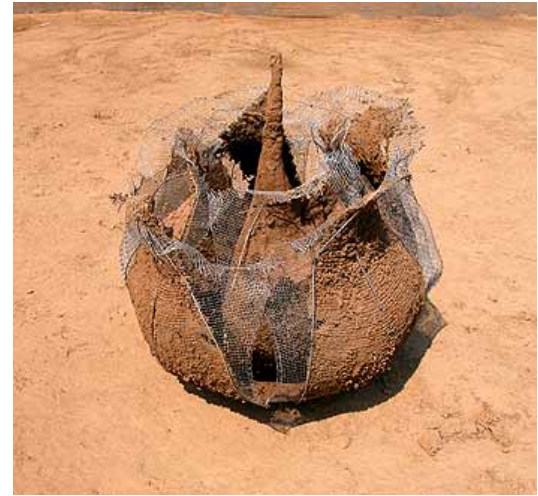

Gabriela León, Flor de Loto, 2005.

Esta producción artística, en línea con la reflexión en torno al cuerpo en la obra de Gabriela León, enlaza con la tradición colectiva de la reencarnación en la Cultura hindú. El proceso de transformar la carga emocional de un material en algo renovador y lleno de vida como la flor, le permite a la artista elaborar una particular estrategia de situación. La artista experimenta con el contexto y, comprometiéndose socialmente con el lugar, desentraña costumbres y condensa las conductas y los materiales que marcan una Cultura.

Por otra parte, cabe destacar que la artista, interesada en la trasmisión del conocimiento sobre las plantas y de la sabiduría de la medicina tradicional, 
estableció contacto con un grupo de jóvenes Atekokolli, en Amatlán, Estado de Morelos. Fruto de estas investigaciones surge el libro El secreto de las plantas (2007), del que la artista es coautora y del que recopilamos la información proporcionada por uno de los componentes del grupo que en esta población Ilevan a cabo la recuperación de esta sabiduría ancestral. Observamos aquí que la relación con la Naturaleza, dentro de la cosmovisión prehispánica que comentábamos en capítulos precedentes, sigue presentando parámetros similares y por otro lado, nos aproxima a la relevancia que en México tiene la visión sobre el mundo vegetal, la misma que la artista tuvo en cuenta en la realización de las piezas anteriormente comentadas. Aurelio, uno de los informantes describe las antiguas creencias que el grupo quiere trasmitir.

Lo que yo he pensado es que nosotros somos parte de la naturaleza; la naturaleza no es nuestra. Tenemos que estar en equilibrio y en paz con ella. Si nosotros la tratamos bien, nos da todo; pero si no hay ese contacto directo, pues no nos ayuda, no nos da nada [...] y lo que hacemos nosotros, tradicionalmente, es eso, cuidarla. Como nos decían nuestros abuelos, ellos tenían el conocimiento de las plantas, el secreto de las plantas. Yo sé que cada planta tiene su propiedad curativa, pero no se trata nada más de que la agarre, la corte y me la tome. También es muy importante hablar, platicar con la planta, pedirle permiso para usarla429.

Tanto en la obra de esta artista como en la expresión de estas ideas podemos observar que subyace la creencia de que las plantas, incluso únicamente su forma, tienen una especie de voluntad y con ella, la propiedad de trasmitir simbólicamente vida a otros elementos.

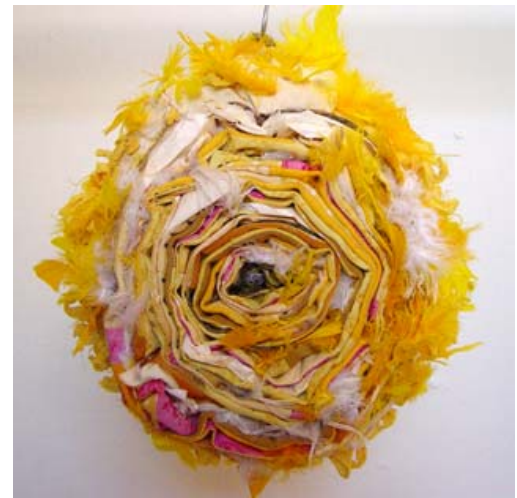

Verónica Sahagún, Serpiente, 2004.

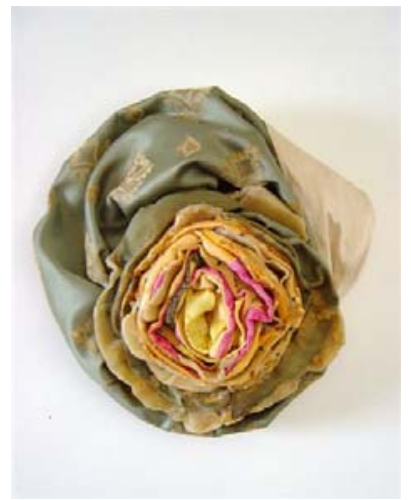

Verónica Sahagún, Centro, 2005.

En el proceso de trabajo de otros creadores mexicanos, encontramos referentes vegetales vinculados con cuestiones particulares relativas al proceso de la obra. Para Verónica Sahagún (Tepexpan, Estado de México, 1976) es fundamental la

\footnotetext{
429 DEL ANGEL, Varinia y LEÓN, Gabriela, El secreto de las plantas, Castillo, México, D.F., 2007, p. 37.
} 
trasformación metamórfica que la materia imprime a su obra430. Como una alquimista transforma materiales, aparentemente insignificantes (pedazos de hilo, alambre, telas, cuentas) y de desecho, en esculturas que dialogan tanto con la dimensión corporal (corazones) como con el ritmo que lo vegetal imprime a las formas. Este aspecto subyace en piezas como Serpiente (2004) o Centro (2005) que siguen un patrón de crecimiento en espiral similar al de una rosa.
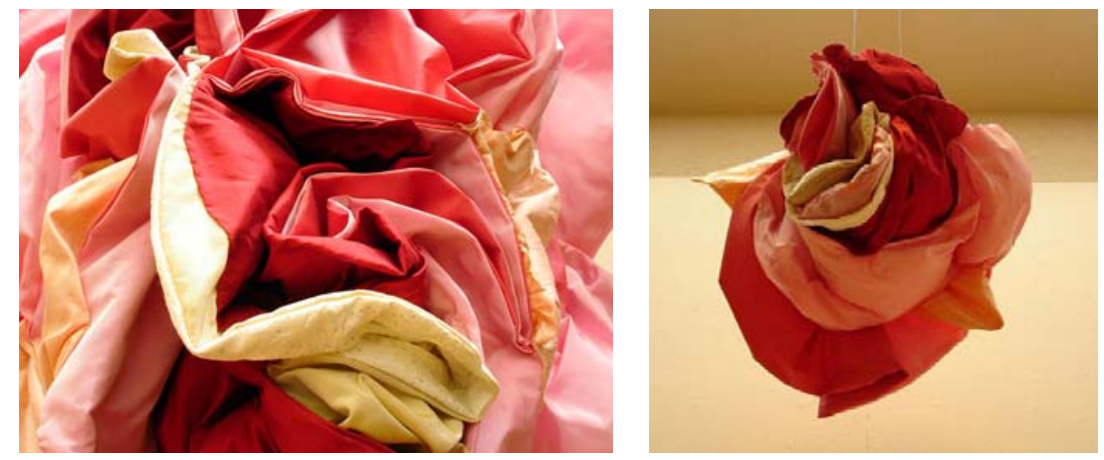

Verónica Sahagún, La rosa es la rosa, 2006.

Una de las características fundamentales del mundo vegetal, que más atrae al hombre y por lo tanto también influye en el mundo de la plástica, es su poder de transformación. De las fases que experimenta la planta en su proceso vital desde su ser semilla al brote pasando por el tallo, el rizoma, la rama o la flor, lo que asombra en mayor medida es su capacidad para adoptar formas tan diferentes. De manera intuitiva, en cada uno de estos procesos, el hombre ha encontrado una proyección simbólica que le permite explorar su propio ser esencial como humano. Con respecto a este poder metamórfico, Sahagún experimenta este proceso de cambio en cada una de sus piezas. En su trabajo, el tiempo es un elemento clave. Aborda el trabajo sin ideas preconcebidas, ajustando sus proyectos a la disciplina de manipular el material y analizando minuciosamente los procesos de intervención que realiza sobre el mismo. Frente al trabajo, su punto de partida no es la obra como sujeto o fin último del proceso creativo, sino el verbo que la transforma. Para la artista, lo que define a la obra son las acciones que realiza sobre ella de manera intuitiva: cortar, rasgar, doblar, enrollar, acumular, torcer, coser, etc. El proceso que Ileva a cabo, a manera de ejercicios metodológicos para un nuevo vocabulario formal, nos remite a las listas de pensamiento que redacta Georges Perec, para aludir dados los innumerables matices del lenguaje- a la necesidad de utilizar diferentes palabras para describir la misma acción:

¿Cómo clasificar los siguientes verbos: acomodar, agrupar, catalogar, clasificar, disponer, dividir, distribuir, enumerar, etiquetar, jerarquizar, numerar, ordenar, reagrupar, repartir?431.

430 Página personal de Verónica Sahagún, Disponible en red: <http://www.veronica sahagun.com/>, [Consulta 28, julio, 2009].

431 PEREC, Georges, Pensar-Clasificar, Gedisa, S. A. Barcelona, 1986, p. 110. 
En esta línea, Perec recuerda la frase de Stephen Leacock: "Dividimos las plantas en árboles, flores y hortalizas" 432 , pero las apariencias engañan y como apunta el filósofo, nuestra tendencia a dividir el mundo en categorías, en clasificar el mundo como un rompecabezas siempre falla. Como veremos, en este proceso abierto de mutación, los materiales empleados por Sahagún adquieren múltiples identidades.

De forma similar podemos relacionar su proceso de trabajo con el procedimiento creativo de Richard Serra quien, mediante su lista de acciones particularmente ejecutables sobre materiales no especificados: laminar, arrugar, plegar, torcer, cortar, etc., permite que sean éstas en definitiva, las que construyan la obra.

La obra de Serra parece habitar el reino de los verbos transitivos, con su imagen de actividad y efecto, [...]. En lugar de un inventario de formas, Serra propone una lista de actitudes en el comportamiento [...] uno se da cuenta de que esos mismos verbos generan las formas artísticas [...] ${ }^{433}$.

Con estos parámetros como norma, si bien con materiales muy diferentes, las obras de Sahagún crecen y se desarrollan en su propia dialéctica. Una vez que han adquirido el peso, la dimensión o el volumen adecuado, la artista añade un agente catalizador que suele ser orgánico (cera de abejas) a manera de elemento mágico con el que se aglutina el proceso de transformación. En el siguiente paso integra aromas de aceites esenciales (esencia de geranio, de limón o de clavo) y luz con la que nutre a sus esculturas de brillos y de colores. Con estos elementos consigue reactivar la materia anteriormente inerte y convertirla en fuente de sugerentes experiencias multisensoriales implicando a la subjetividad y la complicidad estética y emocional del espectador.

En cuanto al referente, podemos observar que las imágenes de las obras aquí presentadas tienen apariencia de flores y de rosas. Pero se trata de flores que parten de una metáfora sobre el corazón, el corazón como motor-pulsión de la vida del hombre, como alambique de esencias para explorar sentimientos y sensaciones, un portal que como nos dice la artista "comunica mundos y abre posibilidades". La rosa como símbolo representativo del corazón que, al igual que en la mística sufí es el órgano que nos permite alcanzar, a través del amor, la esencia de la vida. Con estructuras formales (espiral/torbellino) que se cierran sobre sí mismas en una especie de retorno al centro, estas esculturas textiles y blandas generan una atmósfera sensual llena de erotismo, un intimismo que recuerda por un lado, a las esculturas flexibles de Ernesto Neto y, por otro a la reivindicación de una sensualidad específicamente femenina como en las obras de Judy Chicago (Dinner party, 1974-1979).

432 PEREC, Georges, op. cit., p. 110.

433 KRAUSS, Rosalind E., Pasajes de la escultura moderna, Akal, Arte contemporáneo, Madrid, 2002, pp. 268-270. 


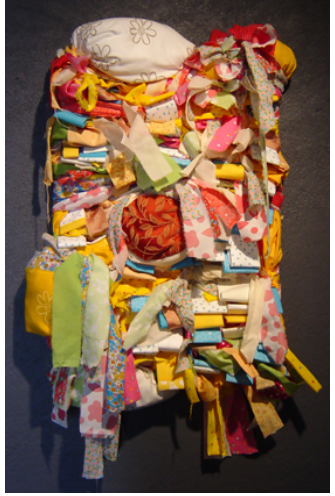

Verónica Sahagún,

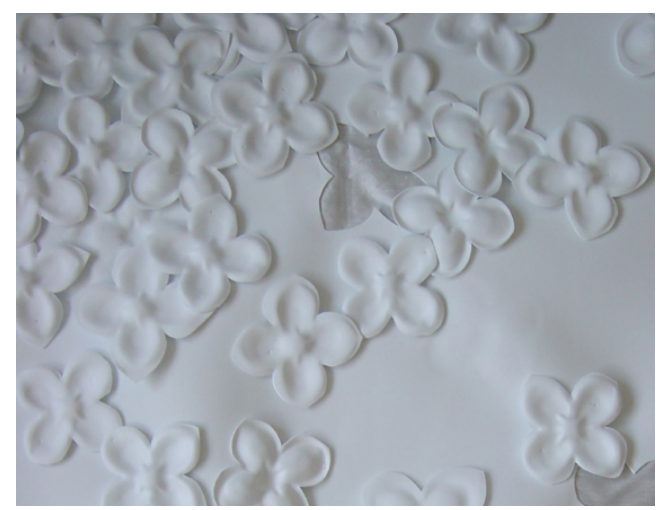

Verónica Sahagún, Sin título, 2007.

Espectros, 2007.

Respecto a, Ana M. ${ }^{a}$ Guasch comenta que tanto en su libro autobiográfico como en las piezas de esta artista, se puede reconocer el intento de reapropiación positiva de la feminidad en torno al núcleo del sexo femenino. Verónica Sahagún, de forma similar a Judy Chicago materializa estas ideas a través de la representación de flores 434 .

El reencuentro con el tema de la flor, en otro tiempo alegórico, recurrente y cercano a la belleza femenina, se retoma en la obra de Sahagún de manera tangencial. Las formas y materiales textiles de sus esculturas se repliegan cuidadosamente sobre sí mismas, guardando un secreto aroma que se percibe al acercarse a las piezas. A través de los sentidos, la seducción del artificio retoma la historia exuberante de la vestimenta femenina envuelta en la calidez sugerente de la cera y la promesa suculenta de la miel. En la muestra Espectro (2007), realizada en el Centro Cultural el Ágora de Xalapa (Veracruz), Sahagún hace referencia específica a la intención de sus piezas. Nos habla de la imperceptible pero innegable presencia de la vida en los sucesos y movimientos cotidianos, como el abrir de una flor a las emanaciones solares.

La acumulación de materiales, plumas, papel, cera, telas remite a una exuberancia cuasi mística. Pero en esta ocasión no es sólo la vista la que es llamada a interactuar con la pieza. Las sedas, telas, hilos, plumas y otros sutiles materiales mueven al espectador de la vista al tacto. No obstante la diferencia que Sahagún imprime a su trabajo viene marcada por el sentido del olfato, ya que cada una de las obras están impregnadas de diferentes esencias: flores como el geranio, frutos como el limón, plantas como la citronela o especias

434 Judy Chicago publicó su autobiografía en el libro Through the Flower: My Struggle as a Woman Artist (A través de la flor: mi lucha como mujer artista), Garden City, Nueva York, Doubleday, 1975 (Penguin, Nueva York, 1993). En este texto, Chicago escribe: "Desplazarse a través de la flor es un proceso útil a todas nosotras, un proceso que puede conducirnos a un lugar donde podamos expresar nuestra humanidad y valores como mujer a través de nuestro trabajo", en GUASCH, Ana M. ${ }^{a}$, El arte último del siglo XX..., op. cit., p. 531. 
como el clavo. Se trata de una cualidad sinestésica que, en el campo expandido de la percepción 435 , la artista aplica a sus esculturas. Así, frente a la supremacía de la vista y al olvido al que generalmente han estado sometidos los otros sentidos en la expresión artística y en la estética clásica, estas piezas obligan a una mayor implicación corporal por parte del espectador. Más allá de la representación objetual, las piezas se erigen como trozos de vida y laboratorios de experiencia para un ejercicio estético realizado en tiempo presente y real.
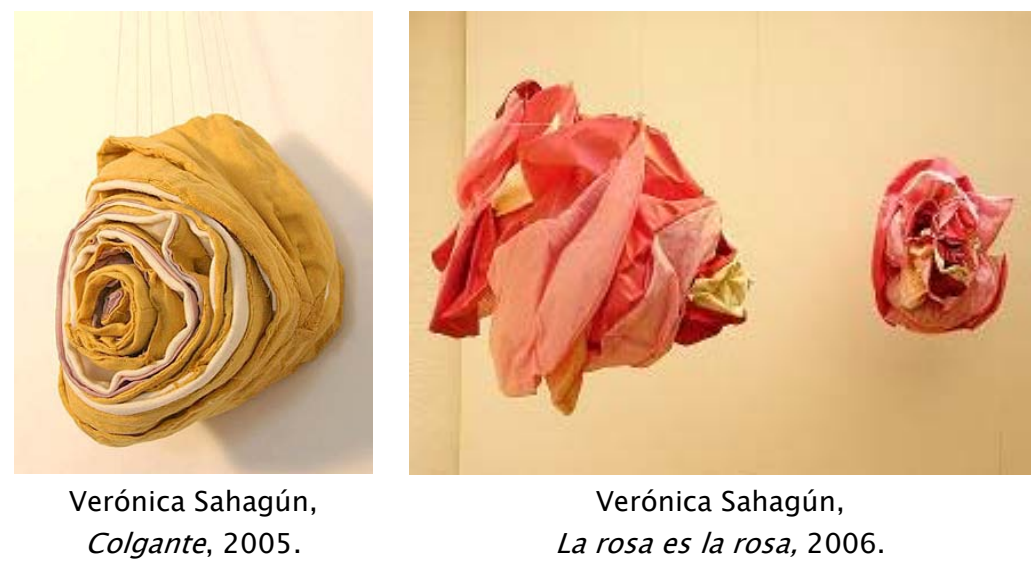

Con autores como Novalis, el Romanticismo experimentó con la idea de la sinestesia para mostrar el orden misterioso que hay detrás de todas las cosas. También Goethe sentía una profunda veneración por la Naturaleza y, en la búsqueda de una estética de lo invisible pasaba horas observando y registrando las diferencias morfológicas entre unas hojas y otras, pero su manera de afrontar el conocimiento de la Naturaleza consistía fundamentalmente no en separar y analizar, sino en unir y ordenar.

Los fenómenos visibles no son reductibles a conceptos. Éstos tan sólo podían ser ordenados según una familiaridad interna en series constantes de tal manera que las series más complicadas se derivarán de las más sencillas 436 .

En la búsqueda de las correspondencias entre Arte y Naturaleza, Goethe emplea la imagen de la metamorfosis de las plantas para explicar el fenómeno que él entendía como la unidad de la Naturaleza. En el ámbito de la plástica, anteponía la supremacía de la escultura frente a la de las otras artes por lo que ésta ofrece de sensible y palpable en su representación artística, considerando la utilización

\footnotetext{
435 Según el Diccionario de Estética de Henckmann y Lotter la sinestesia es el fenómeno psicofísico por el cual, una excitación de los sentidos provoca simultáneamente -además de la reacción primaria correspondiente- percepciones y representaciones en el ámbito secundario de los sentidos, en HENCKMANN, Wolfhart y LOTTER, Konrad (eds.), Diccionario de estética, Crítica, Barcelona, 1998, pp. 220-221.

436 SALMERÓN, Miguel, Escritos de arte, J.W. Goethe, Síntesis, Madrid, 1999, pp. 11-12.
} 
del símbolo como el territorio adecuado para la comprensión total de la realidad.

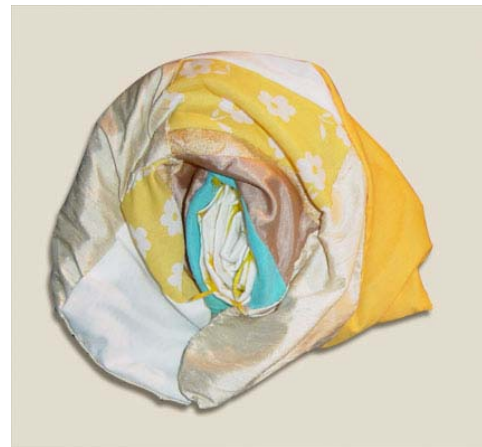

Verónica Sahagún, Múltiples, 2005.

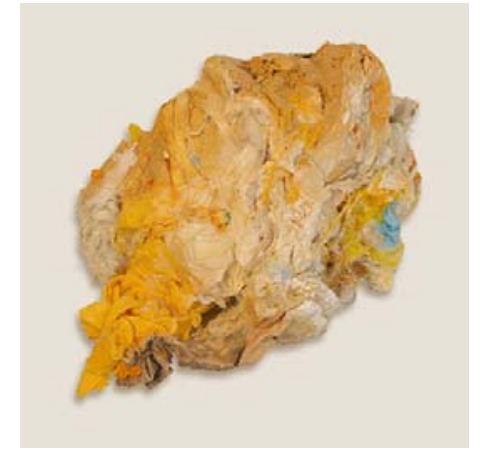

Verónica Sahagún, Germinal, 2003.

Siguiendo a Miguel Salmerón, para Goethe lo verdadero era lo fructífero, aquello que conduce a un aumento de la vitalidad y que estimula la percepción de los fenómenos. A esto último, contraponía la teoría de las causas que conduce a un punto de vista orientado hacia la finalidad y la utilidad de la Naturaleza en favor del hombre. En 1783 Goethe afirmaba en un artículo:

¡Naturaleza!, estamos rodeados por ella, sumidos en ella, empujados a conocerla sin poderla llegar a comprenderla plenamente, ni mucho menos a servirnos de ella, incapaces de salir de su seno y de adentrarnos más en su interior 437 .

Sin la contigüidad de la causa y efecto y, guiadas por los parámetros marcados previamente por la artista, las piezas de Sahagún evocan el sentimiento de ser parte de una Naturaleza que hay que exteriorizar. Si analizamos el proceso creativo de algunas de sus piezas, percibimos las dinámicas ejercidas. En obras como Germinal (2003), la disciplina fue trabajar dos horas diariamente durante dos meses. La artista parte de un pedazo de tela enredado a un alambre. En cada sesión de trabajo los elementos se van acumulando en capas sucesivas (tela, cuentas, flores artificiales, etc.) y utilizando la cera de abeja y la encáustica como aglutinante, consigue generar una forma viva que evoca al corazón humano. Esta pieza, presentada en el contexto de la exposición colectiva Rizoma (2003), fue concebida específicamente para el Museo Universitario Leopoldo Flores (Toluca). De la misma manera, Viaje Adentro // (2005), creada para la misma exposición, es una referencia directa al cuerpo de la artista. La pieza que tiene la misma altura de la artista (160 centímetros), adquiere nuevos significados al incorporar el cambio de escala y de contexto.

437 SALMERÓN, Miguel, op. cit., pp. 12-13. 


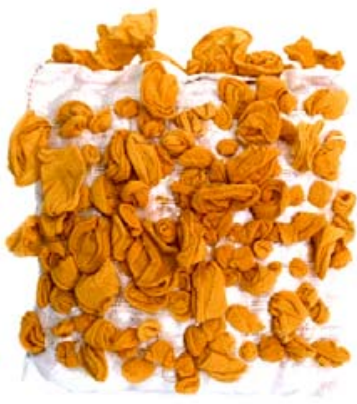

Verónica Sahagún, Viaje Adentro I, 2003.

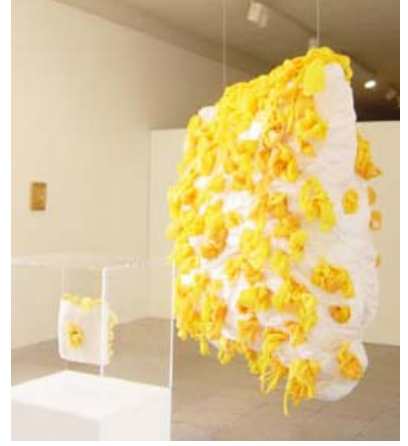

Verónica Sahagún, Viaje Adentro II, 2005.

La pieza Múltiples (2005), se compone de cinco esculturas blandas impregnadas con aroma de clavo. Se trata de una pieza específica para el Ágora de la Ciudad de Xalapa, inspirada en los rosetones que originalmente decoraban la fachada del Ex-Convento franciscano. Viaje Adentro / (2005) es una propuesta tridimensional creada originariamente para ser fotografiada y distribuida 0 regalada como postal o imagen, en museos y galerías de la ciudad de San Francisco. Esta pieza se compone de una bolsa de seda o cojín relleno de telas de nylon, completamente sellado. Las acciones de trabajo efectuadas para elaborarla fueron rasgar y estirar deliberadamente, extrayendo o haciendo aflorar el material que se encontraba en su interior.

En la observación de la obra de los artistas mencionados en este apartado, hemos podido reflexionar en torno a la transformación que sufren los materiales cuando con ellos se representan elementos vegetales. Otro artista más nos proporciona un ejemplo diferente de cómo esta transformación puede ejercerse también sobre la totalidad de un paisaje y tomar éste, como materia susceptible de ser transformada.

En la obra de Alfredo De Stéfano438 (Monclova, Coahuila, 1961), podemos encontrar un tratamiento del paisaje conceptualizado como escenario. En este marco, la Naturaleza deviene espectáculo con el que el artista interactúa. Este artista visual trabaja con el paisaje característico de la zona desértica de la que es originario. Sin embargo, en sus últimos proyectos ha ampliado su radio de acción trabajando sobre los desiertos de otras partes del mundo como el desierto de Atacama o en el Sahara. En el año 2004, expuso en la Embajada de México en España la muestra de fotografías Breve crónica de luz.

\footnotetext{
438 Página personal de Alfredo De Stéfano, Disponible en red: <http://www.adestefano. com>, [Consulta 28, julio, 2009].
} 


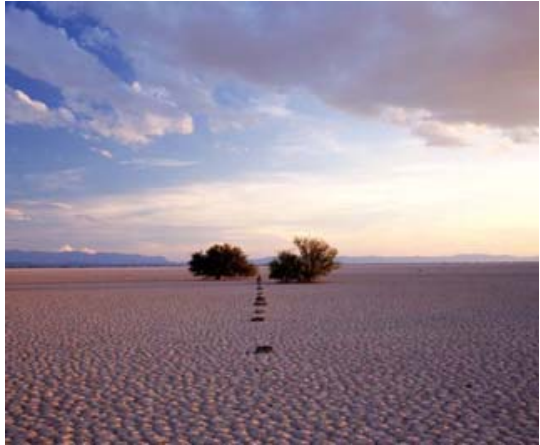

Alfredo De Stéfano, Línea Walter, 2004.

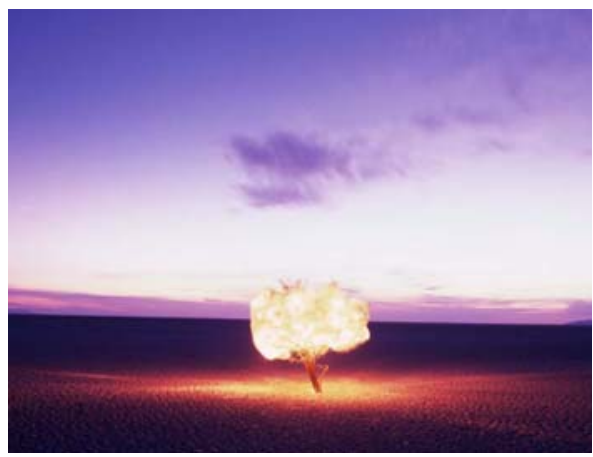

Alfredo De Stéfano, Árbol de Luz, 2004.

Desde la óptica contemporánea, el paisaje del desierto en la obra de este artista es entendido como una construcción cultural de la cual el autor deviene un intérprete emocional del mismo. Para Maderuelo, el paisaje no es un lugar físico, sino "una serie de ideas, sensaciones y sentimientos que elaboramos a partir de un lugar"439. El territorio se configura como idea para la representación de la Naturaleza. El paisaje será entonces un constructo cultural, en contraposición a lo otro: la ciudad, escenario del artificio humano. La noción moderna de paisaje no ha existido desde siempre, en Europa data del Renacimiento, pero es en China donde surge la idea de que el paisaje no está en la forma exterior u objetiva de las cosas, sino en la relación que une su naturaleza a la de nuestro corazón 440 . El proceso que permite concebir el territorio como paisaje pasa por la conversión del mismo -realizada por el espectador-, en elemento capaz de focalizar el goce estético. Es entonces cuando, abstrayéndose de la vinculación directa con las exigencias vitales de sobrevivencia de la persona con respecto al territorio, éste se convierte en un escenario posible de ser percibido como ente estético 441 .

En este contexto y desde la visión del arte contemporáneo, la fotografía es una de las artes por las cuales el territorio, como representación visual, deviene paisaje. A la reconstrucción de esta idea contribuyeron notable e históricamente el Land-Art y el Earth-Art 442 , punto de partida del interés del artista por el territorio físico como motivo y lugar de intervención. Revisando estos movimientos y, partiendo de la óptica de la percepción específica del lugar, la obra de De Stéfano se inserta críticamente en el discurso del territorio como un ámbito emocional. Su obra está íntimamente relacionada tanto con las intervenciones y acciones mínimas de Richard Long, Hamish Fulton, Andy Goldsworthy, Giuseppe Penone, Ana Mendieta, Wolfgang Laib, Nils Udo o

439 MADERUELO, Javier, "Introducción: El paisaje", en MADERUELO, Javier (dir.), El paisaje: Arte y naturaleza..., op. cit., pp. 9-12.

440 BERQUE, Agustín, "El nacimiento del paisaje en China", en MADERUELO, Javier (dir.), El paisaje: Arte y naturaleza..., op. cit., pp. 15-20.

${ }^{441}$ CARBÓ, Enrique L., "Paisaje y fotografía: Naturaleza y territorio”, en MADERUELO, Javier (dir.), El paisaje: Arte y naturaleza..., op. cit., pp. 25-53.

442 Véase RAQUEJO, Tonia, op. cit. 
Charles Simonds como con las grandes intervenciones y desplazamientos de tierra y materiales de Walter de Maria, Michael Heizer o James Pierce. Las construcciones-intervenciones que realiza en el desierto, en el específico paisaje de su propia tierra, son el medio por el cual revisa y actualiza la obra de algunos de aquellos artistas. Su trabajo fotográfico se origina a partir de la relación estética del ser humano con el ambiente que le rodea, haciéndolo dialogar subjetiva y estéticamente con él.

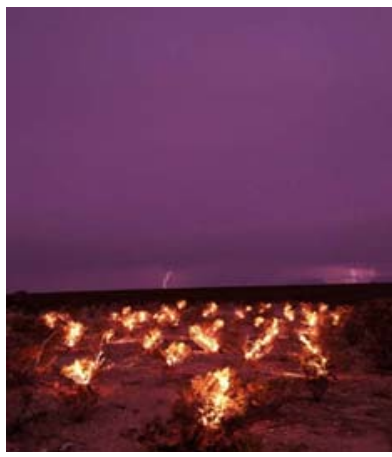

Alfredo De Stéfano, Matorrales de fuego, 2004.

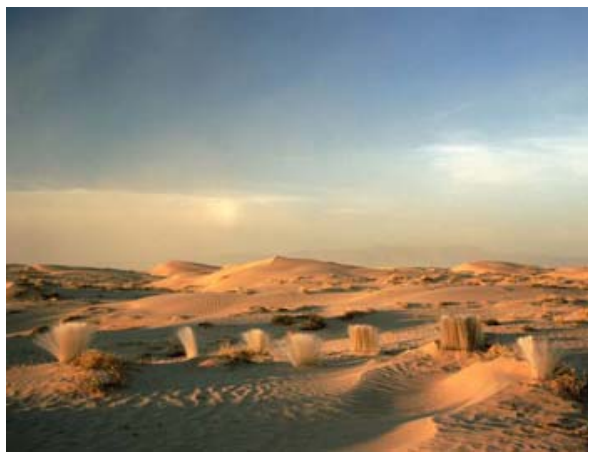

Alfredo De Stéfano, Zacatal óptico, 2004

Estas representaciones-reconstrucciones no formulan el paisaje como una entidad pasiva sino como un espacio-tiempo en constante transformación. Acción que el mismo artista provoca mediante sus acciones $\mathrm{y}$, a través de las cuales ofrece al espectador su propia visión. Con diferentes recursos tanto físicos como metafóricos, en sus imágenes De Stéfano genera ficciones, trastocando el concepto de verosimilitud y convirtiendo en simulacro la realidad, así como a la inversa. Si bien, los procesos y estructuras previamente realizadas a la toma de estas imágenes tienen autosuficiencia y pueden funcionar autónomamente como esculturas o instalaciones reflexivas sobre la percepción del paisaje, la documentación fotográfica juega un papel especial. En estas obras las imágenes se convierten y transforman, actuando a su vez como medio y canal para establecer el vínculo entre lo pintoresco y lo sublime del espacio representado, provocando el desplazamiento de la razón a la sensación más íntima, directamente relacionada con lo espiritual o con el ámbito de lo ritual simbólico.

En este sentido, la necesidad del acto fotográfico funge de forma similar que en las prácticas artísticas del Land-Art. En la mayoría de los casos, la experiencia directa de la obra es minoritaria debido a la imposibilidad de acceder a ellas fácilmente. En consecuencia, toda la documentación que las obras generan tanto previamente como a posteriori, -bocetos, fotografías, catálogos, revistas, postales, etc.- es en definitiva, a lo que el gran público puede acceder. Para el público de la ciudad, estos documentos serán el registro palpable de la obra, referencias de una obra que no existe más que en un espacio-tiempo concreto, que recalcan el papel de la misma y del paisaje, como percepción efímera de la realidad. 


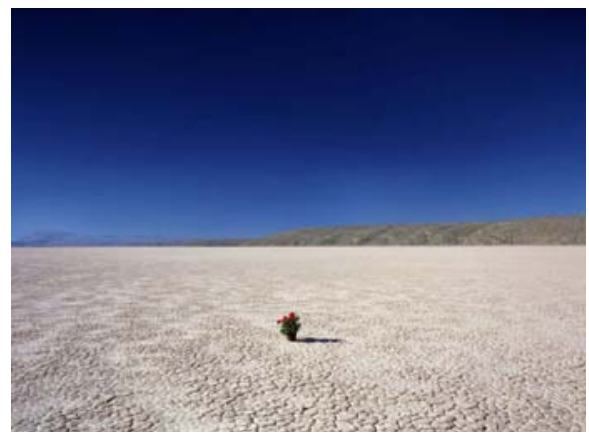

Alfredo De Stéfano, ¿Necesita el desierto una flor para ser paraíso?, 2005.

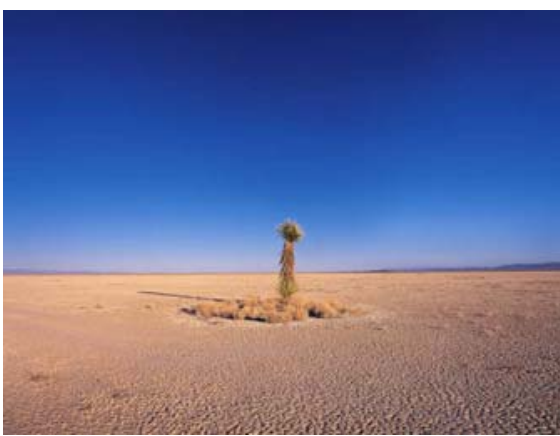

Alfredo De Stéfano, Yuca extraviada, 2006.

En algunas de sus obras, Matorrales de fuego (2004) y Árbol de luz (2004), De Stéfano usa la luz como componente específico de la fotografía, de forma que ésta se torna protagonista de las imágenes. En estos casos, el artista incorpora luz artificial al elemento vegetal como huella de la relación y la presencia humana. Este hecho permite leer metafóricamente la estructura lumínica remitiéndonos al poder destructor y purificador de uno de los cuatro elementos: el fuego. En opinión del crítico de arte y comisario independiente cubano Juan Antonio Molina, podríamos encontrar incluso, rasgos de violencia en alguna de las imágenes en las que vemos aparentes incendios existentes tan sólo en la imaginación:

Eso nos ayudaría también a matizar el discurso ecologista que a menudo se imprime sobre las fotos de Alfredo De Stéfano, y que se ha hecho fuerte, sobre todo a partir de su exposición Habitar el vacío, del 2002. De hecho, yo tiendo a considerar su obra, no tanto como soporte de un planteamiento ecologista, sino como estímulo para una reflexión sobre el paso del tiempo443.

En general, este tipo de interferencias humanas en la aparente visión virginal del espacio alude a la dicotomía entre Naturaleza y Cultura, entre natural y artificial, sin embargo lo que confiere un matiz diferente en cuanto al tratamiento de estas imágenes es la decidida pero sutil intervención del artista sobre el paisaje. En piezas como ¿Necesita el desierto una flor para ser paraíso? (2005) y Yuca extraviada (2006), la alusión por ausencia al elemento vegetal, atribuye a éste la idea de espejo de una acción social y de un sentimiento humano. El artista, con este trabajo, denuncia las intervenciones agresivas que de hecho se realizan en el medio natural del desierto y muestra el deterioro que éstas conllevan. De esta manera sus obras son una respuesta reivindicativa a una Cultura que ejerce de manera implícita y constante el abuso.

443 MOLINA, Juan Antonio, "Inscripciones en el paisaje", Disponible en red en: <http://static.scribd.com/docs/g5Ir00ajnrr5s.pdf>, [Consulta 29, julio, 2009]. 
Todo ello se resumiría en la comprensión del entorno, de su estructura, como inspiración de una obra que adquiere su razón de ser en el diálogo respetuoso con el medio en el que se ubica, reivindicando su valor $y$ permanencia444.

En el imaginario colectivo la ausencia de una vida exuberante tal y como la imaginamos habitualmente, no presupone la no existencia de una biodiversidad, aunque ésta no esté a la vista y, de igual forma, merezca respeto y cuidados. Alejándose de los estereotipos simbólicos dominantes que hacen coincidir nuestra concepción de una Naturaleza verde y exuberante con aquellas construcciones mediáticas que responden a estos parámetros, la visión de De Stéfano responde menos a una revisión del concepto de ecología, que a la concepción del desierto como un paraíso no antropizado. Con estas imágenes el artista propone un camino simbólico de reequilibrio donde el arte actúa como metáfora de la relación entre el medio físico y la Cultura dominante.

En el ámbito artístico, los discursos se plantean en ocasiones como dualidades conceptuales, convirtiendo éstas en motor para la creación. Así los binomios natural/artificial, público/privado, interior/exterior, manual/industrial, cuerpo/objeto o creación/destrucción dan lugar a espacios de discusión que proponen la revisión de los estereotipos creados por la sociedad. La escultura en el campo expandido se caracteriza por la diversidad y la no discriminación en la utilización de materiales. Dentro de este rubro, artistas jóvenes como Hisae Ikenaga (México, D.F., 1977) investigan el valor metamórfico que se produce sobre el material original en un proceso de transformación conceptual. Trabaja los géneros escultóricos del ensamblaje, el ready-made y la instalación. Sus prácticas, centradas en el objeto, resultan cercanas a Duchamp, iniciador de las prácticas de apropiación del objeto manufacturado. Dos son las estrategias fundamentales en su producción, por un lado transforma y manipula muebles ya elaborados. Se trata de mobiliario procedente de las cadenas de producción global, en relación directa con la producción en masa y la tendencia contemporánea del hágalo usted mismo. Con un cierto grado de ironía, IKenaga descontextualiza los objetos asignándoles funciones diferentes para las que han sido creados. Estos objetos cotidianos se convierten en herramientas con un poder de transformación, todo ello con la finalidad de cuestionar las cosas que suceden a su alrededor.

El procedimiento incluye la deconstrucción de los textos que guían la correcta función y obtención adecuada de los muebles. IKenaga recrea un nuevo proceso que permite articular las partes de manera distinta. El resultado que se obtiene al seguir las nuevas instrucciones proporcionadas por la artista -manual para la obtención última del objeto escultórico- reivindica el absurdo del acto creativo, en contraposición al diseño ortodoxo. En este proceso, la artista, al contar con la hipotética participación del espectador, convierte al objeto en un instrumento de participación artística.

${ }_{444}$ ALBELDA, José, "Arte y Naturaleza, evolución de un vínculo", en Exitbook, № 7, Madrid, 2007, p. 54. 

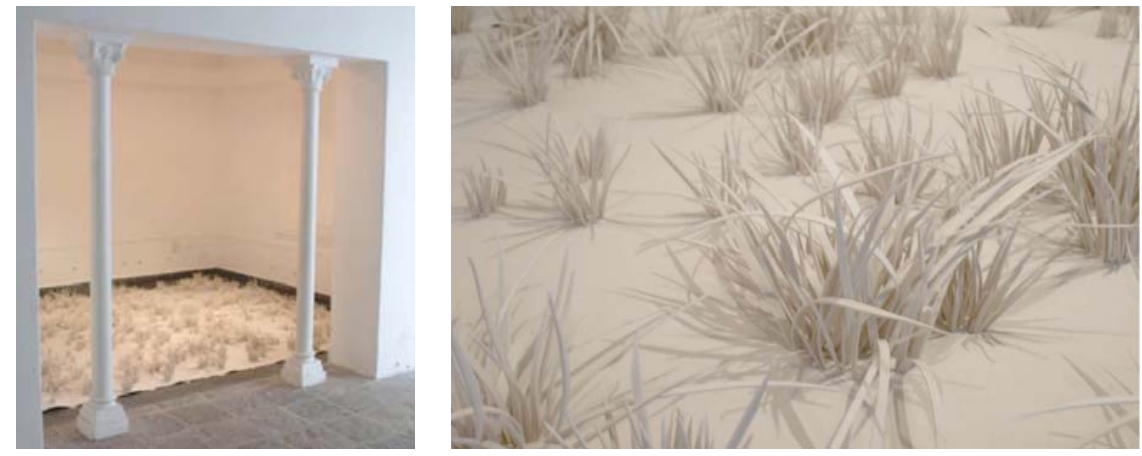

Hisae Ikenaga, Pasto Foami, 2003.

En algunos de sus dibujos la repetición lineal de prototipos tomados de los manuales de instrucciones siguen patrones orgánicos que simulan, paradójica y aparentemente, patrones de misteriosas plantas observadas a través del microscopio. La segunda de las vías exploradas por Ikenaga en torno al objeto 445 y la que aquí nos interesa, procede a una relectura de algunos aspectos de la Naturaleza relacionados con el valor y los usos que el hombre moderno infringe a la misma. A tal fin emplea técnicas artesanales con una elaboración de tendencia naturalista, que incluye elementos y materiales marcadamente artificiales, cuyos referentes proceden de la Naturaleza como es el caso de Pasto foami (2003) y Planta azul(2005).

En la primera de estas piezas el referente vegetal de la hierba sigue la estructura de crecimiento y el comportamiento de la misma. Está realizado con un material artificial llamado foami, e insertado sobre una superficie bidimensional del mismo material. La asepsia con la que se presenta el referente vegetal en Pasto Foami convierte a la misma en una especie de alfombra utilitaria que cuestiona los usos que la sociedad contemporánea ejerce sobre los espacios naturales. Por otra parte, el meticuloso proceso de trabajo es importante para la artista quien recorta y reconstruye el material minuciosamente.

Tampoco hay que olvidar que el tema del trabajo manual frente al acabado industrial, es otro de sus campos de acción, [...] desarrollando delicadas operaciones de tijera y recorte, que requieren filigranas conceptuales, y que Hisae revisita según la tradición del plegado japonés, casi en un "origami extendido" [...]. Es el caso de las flores artificiales pintadas e incorporadas en entornos naturales, como Planta Azul (2005) y sus conjuntos de "flores raras" que tomadas en tiendas de baratillo renacen glamurosas y altivas después de sus aderezos446.

445 ABAD VIDAL, Julio César, "Los desplazamientos del objeto de Hisae Ikenaga", en Formato Cómodo, $\mathrm{N}^{\circ}$ 001, Exposición: Objetos perdidos, Galería Formato Cómodo, Contemporary Art, Hisae Ikenaga, mayo, 2008.

446 BLAS, Susana, "Instrucciones para adentrarse en la obra de Hisae Ikenaga", en Muestra de Artes Visuales Creación InJuve Madrid, 2007, p. 80. 


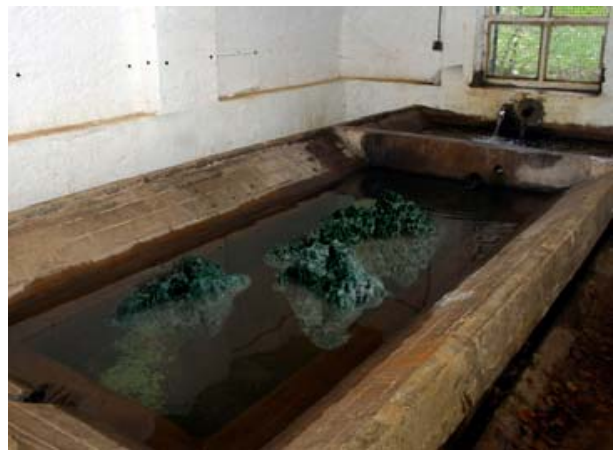

Hisae Ikenaga, Sin título, 2005.

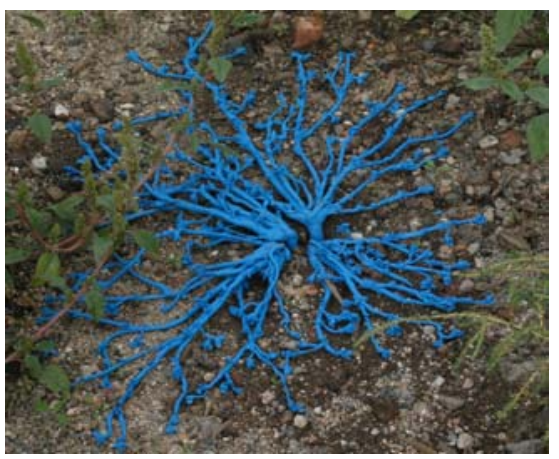

Hisae Ikenaga, Planta azul, 2005.

Ikenaga transita entre una poética postminimalista y un misticismo ritualista en el que predomina el tiempo de trabajo invertido, como una de las formas de configuración del espacio estético. Lo uno y lo múltiple requiere de ese espacio de meditación que nos sitúa en el proceso que media entre la obra, su creador y el que la percibe como experiencia directa de una realidad diversa.

En esta línea, Jardín de piedras de plastilina (2003) nos remite según Javier Hontoria447 al jardín japonés. Una puesta en escena austera, una simulación de espacio infinito y sin vegetación, una ausencia de distracciones que nos enfoca hacia la meditación. Diálogos entre la ausencia y la presencia que transforman la dureza material de las piedras en límites moldeables y flexibles de plastilina. Podemos ver aquí una alusión directa a la concepción elástica de la Cultura japonesa448. Una alusión a la intimidad del hogar japonés, en donde la casa no presenta una división clara entre lo externo y lo interno, donde no hay una determinación funcional precisa y el centro de la casa se configura en estrecha relación con el jardín y por extensión, con la Naturaleza. En nuestra opinión, esta pequeña extensión artificial se ancla también en la tradición de los jardines que se mueven y desplazan, relacionados como aquellos que en el mundo prehispánico en el México antiguo, se cultivaban en las chinampas 449 y se trasladaban en trajineras (canoas) hacia las casas de los nobles.

Con la repetición y la multiplicidad de sus piezas, Ikenaga diluye las fronteras entre realidad y representación. Hace partícipe al espectador cuestionando la veracidad de su percepción y tendiendo puentes entre lo natural y lo artificial, que nos ayudan a convivir con la realidad.

447 HONTORIA, Javier, "Hisae Ikenaga, productora de ironías", en El Cultural, El Mundo, Madrid, 1, mayo, 2008.

448 SCOTINI, Marco, "El jardín de Abeona, Una conversación con Nagasawa a cargo de Marco Scotini”, en MADERUELO, Javier (dir.), El jardín como arte..., op. cit., pp.163-174.

449 Chinampa: Del nahua chinamitl, seto o cerca de cañas. Terreno de corta extensión en las lagunas vecinas a la ciudad de México, donde se cultivan flores y verduras. Antiguamente estos huertos eran flotantes. 

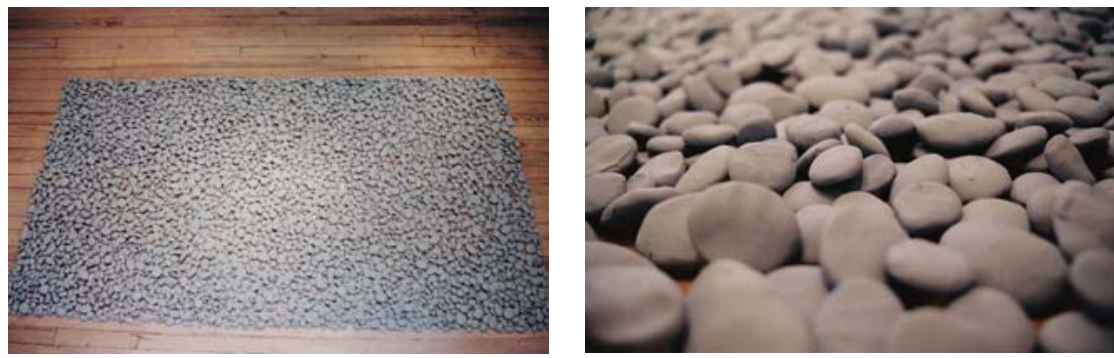

Hisae Ikenaga, Jardín de piedras de plastilina, 2003.

Las relaciones entre el arte y las formas del capitalismo aunadas a un tratamiento lúdico, sutil y acertado de los materiales, consiguen que piezas como Aislados / (2007) nos remitan a márgenes poéticos en donde se hace referencia a la masificación de las grandes ciudades. La incomunicación de las personas en la sociedad contemporánea presenta situaciones como las que sugiere esta pieza. En ella, la alusión a un territorio sirve para describir irónicamente una situación de aislamiento social. Sobre la numerosa cantidad de nombres que suelen aparecer en una guía de teléfonos se recorta la silueta de una isla. A este respecto la artista declara:

Quería trasladar la sensación de soledad que provocan a veces las ciudades grandes, donde a pesar de la cantidad de gente que existe en ellas casi no hay comunicación 450 .

Los objetos que nos rodean se inscriben en el imaginario personal mediante su uso particular o a través de su significado de pertenencia. Ikenaga trasciende la autonomía del objeto individual y lo transfiere al imaginario colectivo mediante procedimientos que remiten a procesos que tienen su origen en el mundo orgánico. En general, la transformación que el artista realiza sobre la materia prima favorece que los objetos se carguen de un significado añadido que a la vez, como en el caso de los ready-made, cuestiona su funcionalidad. La pérdida de su función o debilitamiento, como lo llama San Martín451, de los ready-made, tiene relación con la vida social de los objetos. El artista los convierte en objetos que ya no sirven para lo que habían sido creados, su condición artística los priva de su funcionalidad anterior. Este tipo de estrategias trasparentan procesos y desenmascaran el artificio frente a lo presuntamente natural. En este proceso de descontextualización, la artista proporciona a los objetos que transforma, una forma de humanización, dotándoles de actitudes humanas y de una vida propia, con las que acerca el objeto a un plano más íntimo relacionado con la experiencia estética de los mismos.

450 LANDA, Isabel, "Vaivén de objetos globalizados. La artista mexicana Hisae Ikenaga expone sus últimos trabajos en Madrid", en El país, Madrid, 30, abril, 2007, Disponible en red en <http://www.elpais.com/articulo/cultura/Vaiven/

objetos/globalizados/elpvidcul/20070430elpepucul_1/Tes>, [Consulta 30, julio, 2011 ].

451 SAN MARTín, Francisco Javier, "La escultura en la época de las vanguardias, un objeto fuera de lugar", en RAMíREZ, Juan Antonio y CARRILLO, Jesús (eds.), op. cit., p. 45. 


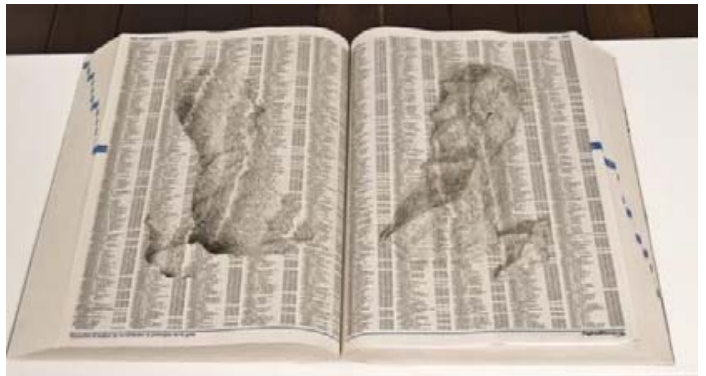

Hisae Ikenaga, Aislados I, 2007.

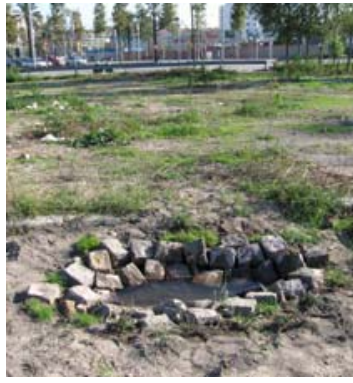

Hisae Ikenaga, Estanque, 2005.

Este tipo de procesos mediante los cuales los objetos experimentan la pérdida de funcionalidad, encontrando una nueva percepción estética, es realizado también por el escultor Sergio Rodríguez (Monterrey, Nuevo León, 1962)452. Este artista incursiona en la instalación y en el arte-objeto utilizando diversos materiales, principalmente botellas de vidrio, pero también tazas, platos y otros objetos domésticos. En sus obras encontramos la referencia a lo natural y en particular a lo vegetal, en construcciones que se presentan redimensionadas respecto a su tamaño original. Son objetos y propuestas lúdicas con las que el artista nos invita a percibir las cosas desde una óptica diferente. Objetos cotidianos que como la obra Manzana (2002), pierden su anterior funcionalidad para convertirse en módulos de hiperobjetos pseudonaturales.

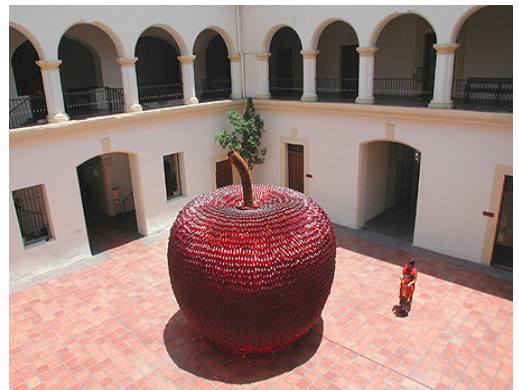

Sergio Rodríguez, Manzana, 2002.

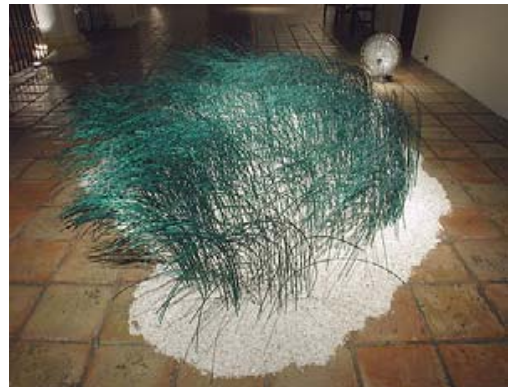

Sergio Rodríguez, Aire, 2002.

Sus objetos atraviesan la línea que convierte la pericia del reciclaje en una celebración festiva, una estética del desperdicio que se relaciona con las estrategias del Dadaísmo y el Constructivismo de Schwitters. Más allá del arte pobre (arte con materiales de desecho), el artista plantea una economía social basada en el residuo, como un ejercicio lúdico de humor, y con el objetivo de sorprender al espectador y construir nuevos escenarios de convivencia con la basura. Más allá de la disciplina escultórica, la complejidad técnica y el ensamblado de botellas de colores buscan la reutilización de estos objetos para obtener nuevos significados. Se trata de una invitación a explorar, sentir y tocar

452 Página personal de Sergio Rodríguez, Disponible en red en: <http://www.sergiorodriguez.com.mx/com>, [Consulta 30, julio, 2011]. 
estas creaciones artísticas en una sociedad, cuya actitud frente a los objetos de desecho es habitualmente deshacerse de ellos sin plantearse, que este tipo de posturas convierte nuestro entorno en una especie de basurero sin posibilidades de recuperación.

La mutación o recreación de un objeto en otro transforma materiales, anteriormente insignificantes, en espacios para la reflexión, buscando dar otro sentido a la realidad y aportando nuevas visiones que actúen como generadores de pensamiento y actitud. Así, estos objetos naturales del escultor regiomontano compuestos de innumerables objetos artificiales no buscan insertarse en un circuito comercial sino trastocar la percepción de nuestro entorno cotidiano. En Aire (2002), la sugerencia remite a una pradera de altas hierbas, pero éstas están hechas de alambre. El aire de un ventilador pone en movimiento a las mismas y crea en el espectador, la ilusión de percibir el viento, una forma de incorporar el público a la obra.

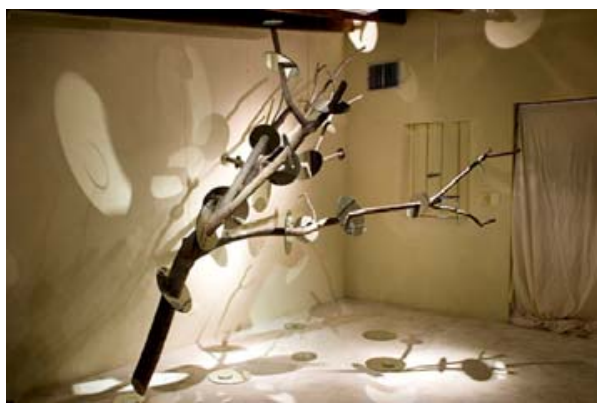

Sergio Rodríguez, Reflexión, 2006.

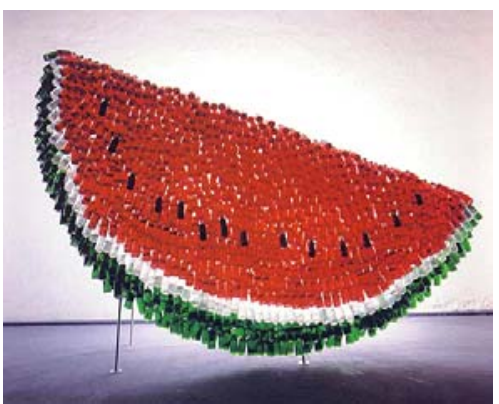

Sergio Rodríguez, Rebanada de sandía, 1998.

El reciclaje creativo es en la actualidad, un fenómeno multicultural y global que estuvo en relación con el arte popular y la artesanía en todas las sociedades del mundo. Cabe destacar que México en particular, es un país que, por sus características intrínsecas (economías precarias), ha reutilizado tradicionalmente todo tipo de objetos, por una necesidad básica de consumo mínimo, generando con ellos, innumerables y nuevas formas de artesanía popular.

En el mundo occidental fueron las vanguardias artísticas de principios del siglo XX las que introdujeron la técnica como procedimiento para la creación, entrando en el ámbito del diseño posteriormente. El lenguaje del Object trouvé como crítica social fue utilizado tanto por los dadadístas como por los surrealistas, el Pop Art, el Ate Povera e incluso Fluxus, quienes incorporan en sus obras objetos encontrados y desechos aparentemente sin valor. En la actualidad, este tipo de propuestas son más una herramienta relacionada con el desarrollo de ideas para una economía y un mundo más sostenible, un interrogante abierto sobre nuestra forma de explotar los recursos, pero también nuestra forma de pensar, de trabajar y de percibir la realidad. 


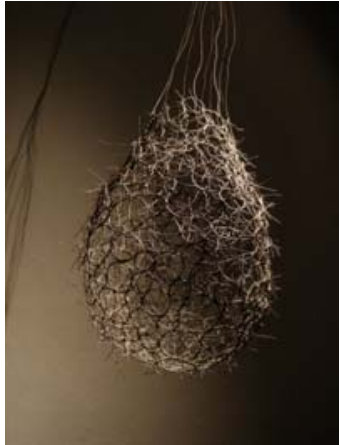

Sergio Rodríguez, Capullo, 2005.

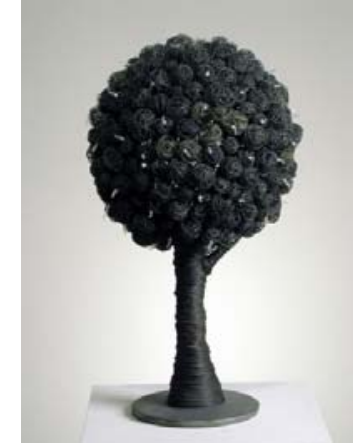

Sergio Rodríguez, Las garras del árbol, 2002.

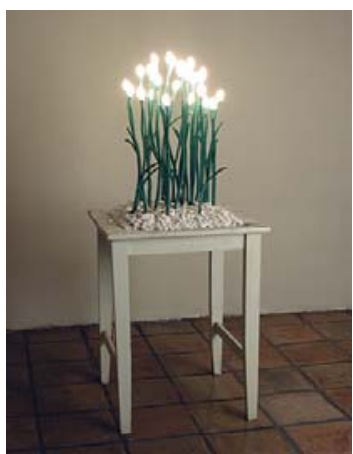

Sergio Rodríguez, Mesa con lirios, 2001.

En la obra de Sergio Rodríguez este procedimiento recurre a formas orgánicas, algunas de las cuales tienen específicamente lo vegetal como referente. Desde otra perspectiva y dentro del arte contemporáneo, la frecuente tendencia a recurrir a objetos de uso cotidiano como materia formativa de nuevas experiencias deriva en ocasiones, en una banalización del kitsch, sin tener en cuenta que este sentido de la apropiación tiene aspectos que son interesantes por lo que presupone de recuperación de transformaciones significativas e incluso de diversos rituales.

En la hipersensibilidad por lo vulgar no se trata de una glorificación, sino de una inversión de sus notas alienantes, asumiendo el «kitsch» en lo que puede poseer de sentido crítico, satírico o existencial453. 


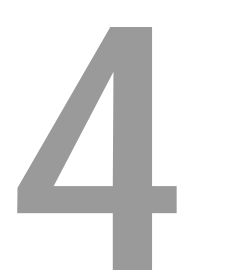

ECOARIE Y MISTICISMO 

Además de la renovación formal, una de las aportaciones más importantes de las vanguardias artísticas del siglo $\mathrm{XX}$, fue el cambio experimentado en relación al sujeto o artista quien, entre otras cosas, comenzó a formar parte de la propia manifestación artística. Esta circunstancia, sumada a la pérdida del lugar del objeto artístico, favoreció cierta actitud que propiciaba la integración de la obra con la propia vida del artista, con sus circunstancias ideológicas, sociales y políticas. En relación directa con el surgimiento de estas problemáticas colectivas, el artista de la postmodernidad se hace eco de uno de los aspectos más característicos y preocupantes de nuestros días: el deterioro del entorno.

En la actualidad, los problemas heredados de la revolución industrial y el cambio en los usos y costumbres, así como en los comportamientos económicos, políticos y sociales, han provocado graves consecuencias. Entre ellas, la vertiginosa transformación del territorio, la excesiva antropización del mismo, la degradación del medio ambiente y el consumismo indiscriminado han generado actitudes que, desde el punto de vista social denominamos ecológicas y en cuanto a las tendencias artísticas, siguiendo a María Novo, podemos llamar Ecoarte454. Todo ello propicia posturas que derivan en una especie de misticismos individuales. Estas manifestaciones funcionan partiendo de la conciencia de que el ser humano es susceptible de interactuar con la Naturaleza, ya no en detrimento de su propia seguridad -como hasta ahora se ha venido haciendo- sino contemplando la posibilidad de una convivencia más respetuosa con la misma.

El término ecología fue acuñado en 1873 por Haeckel, un naturalista que lo utilizó para denominar el estudio de las relaciones de los seres vivos con su medio. Sin embargo será en pleno siglo XX, cuando esta conciencia ecológica cobre mayor intensidad con el surgimiento de grupos activistas que con el tiempo, serán el germen de colectivos como Greenpeace. Podríamos decir que en realidad, no existe una relación directa entre los movimientos de Land Art y Arte Povera con las actuales tendencias de Ecoarte. También podríamos afirmar que no existe una directa reivindicación ecológica por parte de todos los artistas que en estos momentos trabajan o han trabajado en contacto o en referencia a la Naturaleza, tanto en el plano internacional como en México. Los artistas que usan la Naturaleza como eje argumental de sus obras, incluso los que lo hacen mediante la apropiación de materiales naturales o en los espacios que la propia Naturaleza les ofrece, participan de un compromiso ecológico, pero esto no representa per se y únicamente, tal compromiso 455.

454 NOVO, María (coord.), Ciencia, arte y medioambiente, Mundi-Prensa, Madrid, 2002, p. 98. María Novo define el Ecoarte como un "arte de los ecosistemas", una "línea de pensamiento y acción" que "reconoce la interdependencia que se establece entre las dimensiones biofísicas y socioeconómicas (analizadas por las ciencias) con las estéticas (interpretadas por las artes) para la comprensión global de la realidad de la naturaleza. 455 HERNANDO, Javier, "Visiones de la naturaleza...", en RAMíREZ, Juan Antonio y CARRILLO, Jesús (eds.), op. cit., p. 58. 
En general se trata del uso de una serie de poéticas o como hemos dicho anteriormente, misticismos individuales que rescatan tanto la antigua vinculación del ser humano con la Naturaleza, como una relación más sana con el entorno circundante. Estamos hablando más bien, de una serie de intervenciones sutiles realizadas por artistas contemporáneos. Estas obras y acciones, se orientan de forma clara y directa a un reconocimiento explícito de la amenaza de la destrucción y, por consiguiente, de la necesidad de una preservación de la Naturaleza. Dentro de este panorama, la suerte de estrategias empleadas por los artistas es muy diversa. Se trata de diferentes procesos de pensamiento que, más allá de una manifestación del impulso romántico, reflexionan sobre nuestra propia existencia y nuestra naturaleza como seres humanos. Entre los artistas que en México han vinculado su actividad artística con estos aspectos de la Naturaleza, encontramos escultores que lo hacen con la intencionalidad de recuperar una mística personal. Entre ellos podemos hablar del trabajo de Yolanda Gutiérrez, Yolanda Paulsen, Laura Anderson Barbata y Rosario García Crespo.

El espíritu de las obras de estas artistas evidencia la profunda relación que une a la Naturaleza con el ser humano. A pesar de la fortaleza de estos vínculos, en estas esculturas, la elección de determinados materiales procedentes de la misma, refuerzan el carácter efímero y la fragilidad. Relacionados con la obra de Giuseppe Penone, Andy Goldsworthy, Nils Udo o Wolfgang Laib, este tipo de obras retoman el concepto de intervenciones mínimas456. Acciones y piezas que pretenden interferir lo menos posible con el espacio en el que interactúa el artista. Sin embargo, en el caso de México, este tipo de intervenciones son más bien esporádicas y parecen, tal y como veremos a continuación, concentradas en determinados artistas.

\subsection{Simbolismo y herencia c ultural. Yolanda Gutiémez}

Yolanda Gutiérrez (México, D.F., 1970) es una de las artistas mexicanas que con más asiduidad ha revisado el concepto de Ecología, desarrollando un trabajo muy prolífico al respecto 457 . Para introducir la obra de esta artista debemos referirnos a la relación entre Naturaleza y misticismo con la que la artista, parece encontrar una forma para restablecer lo que podríamos caracterizar como el equilibrio perdido. En este sentido y, en términos de actividad artística, la artista deviene un configurador de rituales, generando un espacio para el diálogo entre el público y la problemática sobre el entorno. Cabe puntualizar que ya en el mundo prehispánico, la concepción del artista respondía a una particular consideración en torno al mismo y a sus capacidades. El Toltécat/ o el verdadero artista, según Fray Bernardino de Sahagún, era un personaje capaz de dialogar con su corazón:

456 ALBELDA, José y SABORIT, José, op. cit., pp. 146-147.

457 Gran parte de la información aquí recogida procede de la documentación proporcionada por la artista, así como de la reciente edición de KASSNER, Lily S., Yolanda Gutiérrez: el arte de divinizar la naturaleza, Consejo Nacional para la Cultura y las Artes, CONACULTA, México, D.F., 2006. 
Toltécatl: el artista, discípulo, abundante, múltiple, inquieto. El verdadero artista: capaz, se adiestra, es hábil; dialoga con su corazón, encuentra las cosas con su mente. El verdadero artista todo lo saca de su corazón; obra con deleite, hace las cosas con calma, con tiento, obra como tolteca, compone cosas, obra hábilmente, crea; arregla las cosas, las hace atildadas, hace que se ajusten 458 .

En la traducción de Miguel León Portilla, esta cita de Sahagún, sitúa el quehacer del artista o mejor dicho, del artífice prehispánico, en un lugar que difiere de las concepciones en las que se ha desarrollado el arte occidental. Más allá de considerar al artista como poseedor de habilidades y destrezas, nos lo presenta como aquel cuya sabiduría emana, no de la lectura visual de las cosas de este mundo, sino como aquel que lee, dialoga y transcribe con el corazón.

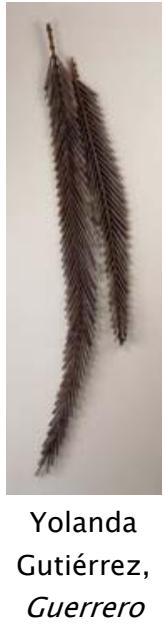

Quetzal, 1997.

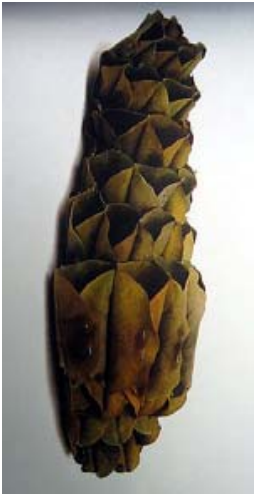

Yolanda Gutiérrez, Hábitat, 1998.

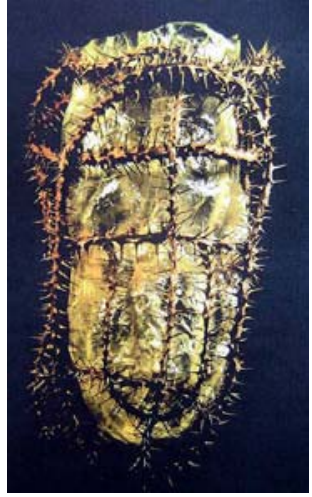

Yolanda Gutiérrez, Máscara, 1998.

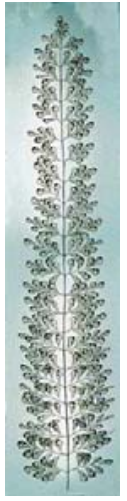

Yolanda

Gutiérrez, El sueño de la oruga, 1999.

Desde sus inicios como escultora, una parte fundamental de la obra de Yolanda Gutiérrez ha estado inspirada, como ella misma indica459, por la filosofía náhuat/ como fuente de motivación. Heredera, estudiosa y amante de esta gran tradición prehispánica cursó estudios de Artes Visuales en la Escuela Nacional de Artes Plásticas (ENAP) de la Universidad Nacional Autónoma de México. Fue alumna, entre otros maestros, de Kiyoto Ota 460 , con quien se inicia en la búsqueda de la esencia a través de la escultura. Con su quehacer contemporáneo recupera parte de aquellas creencias y mitos del mundo

\footnotetext{
458 LEÓN PORTILLA, Miguel, La Filosofía Náhuatl estudiada en sus fuentes, UNAM, Instituto de Investigaciones históricas, México, D.F., 1983, p. 261.

459 GUTIÉRREZ, Yolanda, "Un proceso de encuentros", en El final del Eclipse. El arte en América Latina en la transición al Siglo XXI, Fundación Telefónica, Madrid, 2001, pp. 157161.

460 Escultor de origen japonés afincado en México desde 1972.
} 
prehispánico, lo que conocemos por cosmovisión 461 . Su obra da testimonio de las creencias y costumbres de un presente vivo y todavía, como ella lo presenta habitable, en tanto en cuanto sea percibido con el corazón como la cita de Sahagún nos recuerda.

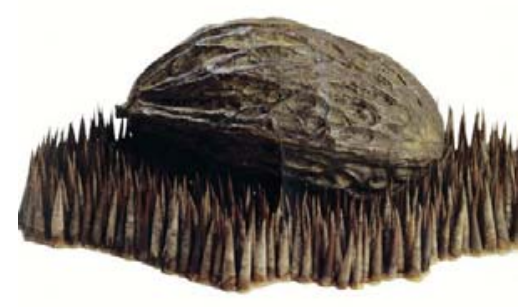

Yolanda Gutiérrez, Semilla de artista, 2002.

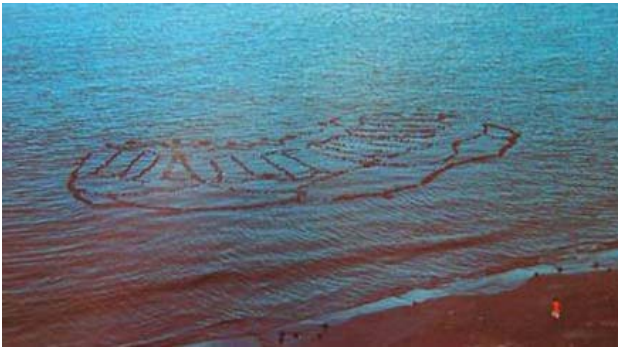

Yolanda Gutiérrez, Su falda ondulante como espuma preciosa, 2001.

Todo su trabajo está impregnado del sentimiento animista que se manifiesta en cada una de sus obras. El animismo, palabra derivada del latín anima, nos refiere al ser vivo, ya que alma es sinónimo en cierta medida, de soplo o hálito vital. El concepto de animismo, desde el punto de vista de la arqueología y la antropología, está todavía presente en algunas culturas indígenas. Este principio se entiende como la creencia en que tanto los objetos como los seres animados e inanimados, están habitados por seres y fuerzas sobrenaturales, espíritus y almas que, en definitiva, están dotados de razón, inteligencia y voluntad. En este tipo de concepciones, los seres sobrenaturales gobiernan y determinan la existencia de los seres de este mundo.

Estamos ante una sobrenaturaleza que entiende que todo está vivo, todo es consciente o todo tiene alma. Este pensamiento, aparentemente arcaico, es explicado con exactitud por Alfredo López Austin, uno de los más eminentes historiadores del área de Mesoamérica, quien en su tratado sobre el cuerpo humano y la ideología nahua apunta:

Algunos de los seres sobrenaturales tenían para el hombre náhuatl una realidad tan presente, tan inmediata, tan cotidiana, como aquellos que podían captar plenamente a través de los sentidos. La sobrenaturaleza se imaginaba material, potencialmente visible, tangible, audible. Era remota para el hombre por las limitaciones del hombre; pero éste se hallaba inmerso en ella. Cuando el ser humano creía romper sus propias barreras de percepción, sentía que el mundo se le mostraba más cabalmente ${ }^{462}$.

\footnotetext{
461 "Por cosmovisión puede entenderse el conjunto articulado de sistemas ideológicos relacionados entre sí en forma relativamente congruente, con el que un individuo o grupo social, en un momento histórico, pretende aprehender el universo", en LÓPEZ AUSTIN, Alfredo, op. cit., p. 20.

462 LÓPEZ AUSTIN, Alfredo, op. cit., pp. 441-442.
} 


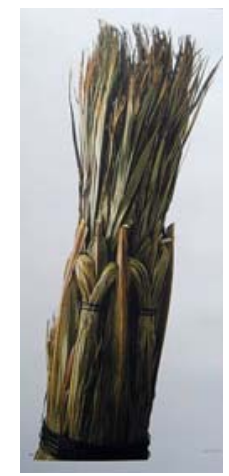

Yolanda Gutiérrez, Inaprensible, 1997.

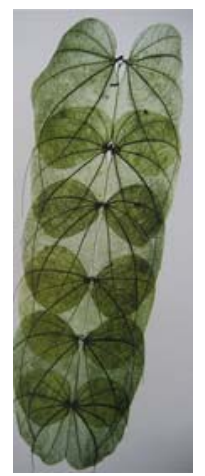

Yolanda Gutiérrez, El refugio de la oruga, 2000.

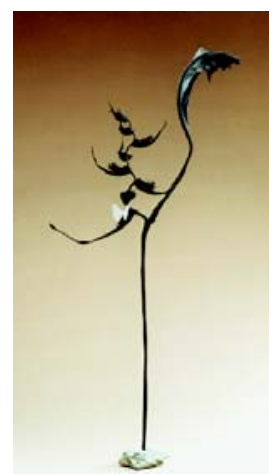

Yolanda Gutiérrez, Yolanda Gutiérrez, La Visita, 2000.

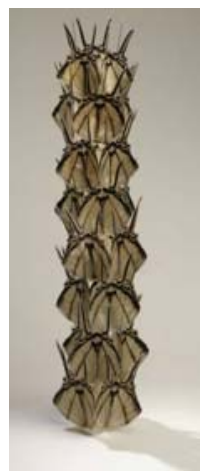

Vertebral, 2002.

Sin embargo, no todos los mortales tienen la capacidad de percibirlos, estas facultades están reservadas tan sólo a unos cuantos. Según la cosmovisión prehispánica, el individuo común debe vivir entre seres invisibles y está a la intemperie frente a fuerzas que no puede controlar. Para el hombre prehispánico, la sobrenaturaleza de la que nos habla López Austin está presente en todas aquellas formas visibles e incluso invisibles de la Naturaleza, las montañas, los ríos, las piedras, los instrumentos de trabajo e incluso, dentro de nuestro propio organismo. Para poderse proteger de ellos, el hombre debía de recurrir a medios y rituales muy precisos.

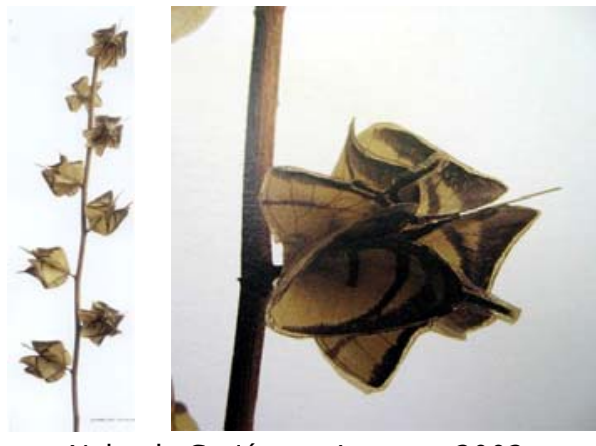

Yolanda Gutiérrez, La rama, 2002.

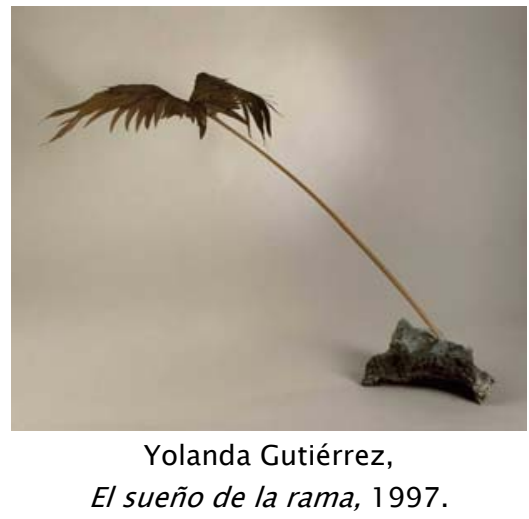

El sueño de la rama, 1997.

Yolanda Gutiérrez a través de sus obras nos revela parte de este íntimo sentir que, todavía hoy pervive entre la mayoría de las comunidades indígenas de México así como también en la gran mayoría de la población de este país. El lenguaje, en gran medida, es una buena muestra de este dato: en el entorno cotidiano mexicano, las cosas y los fenómenos se convierten en sujetos que adquieren el predicamento de un verbo para manifestar una cierta voluntad. Así 
por ejemplo se dice, de un objeto que se ha perdido, que no quiere aparecer, del clima que quiere llover o de la salsa que quiere más chile 463.

Gutiérrez a través del conjunto de su obra, nos desvela esta sobrenaturaleza y lo hace con medios muy precisos: convoca diferentes realidades, aparentemente inconexas, de esa Naturaleza que le rodea, estableciendo relaciones muy íntimas entre las diferentes características de los elementos. Su forma de proceder, sin duda muy cercana a la poesía, crea vínculos que nos remiten a realidades presentidas, con la diferencia de que ella nos las muestra convertidas en arte. En sus obras son fundamentales los conceptos de simbiosis y de analogía; en definitiva, de metamorfosis entre los seres de los diferentes reinos. En la mayoría de los casos, los materiales a los que recurre son naturales y presentan una fragilidad extrema aunado a un sentido de lo efímero derivado del paso de tiempo.

Así, nos presenta flores y motivo vegetales, hechos con alas de mariposas como en las piezas La Rama (2002), Efímeras (2002) o ¿Puede la oruga volver a la rama? (2002). También a la inversa utiliza este recurso con obras que son mariposas hechas con hojas de plantas como en la instalación De noche un viento frío las trajo (2000) o Tlalocan (2000). ¿Cuál es la razón de este modus operand? Podemos encontrar un posible razonamiento en la forma en la que los primitivos llevaban a cabo su encuentro con los procesos propios de un entorno natural.

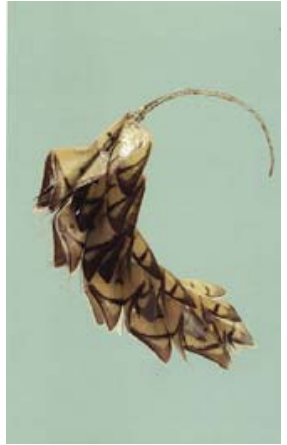

Yolanda Gutiérrez, ¿Puede la oruga volver a la rama?, 2002.

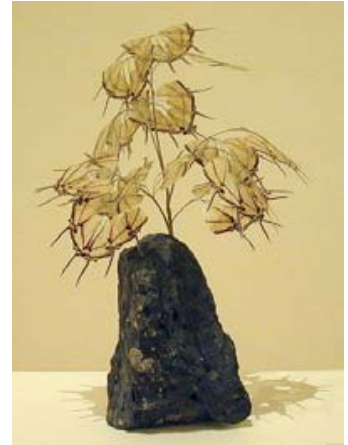

Yolanda Gutiérrez, Amate, 2002.

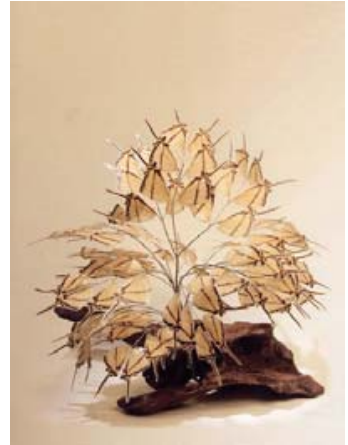

Yolanda Gutiérrez, Infantil, 2002.

[...] la naturaleza adquiere significado y se transforma en recurso para el hombre, sólo a través de la cultura, y ésta varía en el transcurso de la historia. [...] Persisten mitos, cuentos y leyendas en los que la naturaleza figura como un ente vivo, $y$ se mantienen prácticas propiciatorias $y$ creencias en torno a seres sobrenaturales de clara estirpe india ${ }^{464}$.

$463 \mathrm{El}$ chile es una especie de pimiento picante muy utilizado en México como condimento culinario.

${ }^{464}$ BONFILL BATALLA, Guillermo, op. cit., pp. 74-77. 


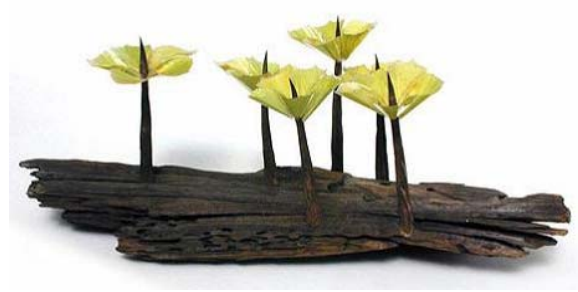

Yolanda Gutiérrez, Silvestres, 2002.

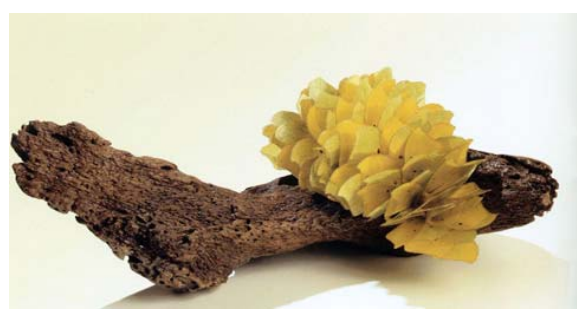

Yolanda Gutiérrez, Oruga, 2002.

Los ciclos de las estaciones provocan cambios muy perceptibles en la Naturaleza y dentro de ella, la vegetación evidencia, a ojos de los hombres, una serie de transformaciones, particularmente visibles. Para el hombre primitivo estos cambios debían ser favorecidos con su actuación personal. El punto que aquí nos interesa resaltar es aquel a partir del cual este hombre, totalmente involucrado e identificado con la posibilidad o no de estos cambios, se sentía empujado a enfocar su vida como actor básico en estos procesos. En este sentido, los rituales, las ofrendas y todas las acciones humanas estaban encaminados a favorecer el correcto desenvolvimiento de los procesos de la Naturaleza. Esta conducta se traduce en un sentimiento de identificarse como un sólo ser con la misma.

El origen de esta idea puede verse reflejado de forma similar y desde el punto de vista de James Frazer, en otros contextos sociales primitivos. En concreto Frazer hace referencia a la relación entre el reino vegetal y animal hecho que, en pleno siglo XXI percibimos -atendiendo a la estrecha y persistente relación simbiótica entre todos los organismos vivos- no tan distante de la realidad.

[...] las dos series de la vida, la animal y la vegetal, no estaban disociadas en la mentalidad de los que ejecutaban las ceremonias. Claro está que ellos creyeron por lo general que los lazos entre el mundo animal y el vegetal eran aún más estrechos de lo que en realidad son: por esto combinaban muchas veces la representación dramática de la reviviscencia de las plantas a una unión real dramática de los sexos con el propósito de reforzar, al mismo tiempo y por el mismo acto, la multiplicación de los frutos, de los animales, de los hombres. Para ellos el origen de la vida y la fertilidad, animal o vegetal, era uno e indivisible 465 .

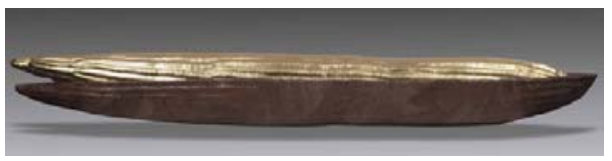

Yolanda Gutiérrez,

La promesa, 2002.

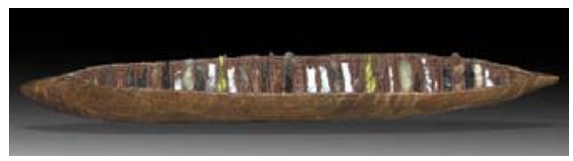

Yolanda Gutiérrez, Recuerdos del viaje, 2002.

465 FRAZER, James George, op. cit., p. 378. 
Esta visión relaciona la idea anteriormente expresada de animismo con la doctrina filosófica del panteísmo466, la cual predica que si todo es uno e indivisible, las ideas Universo, Naturaleza y Dios son equivalentes. Tenemos aquí nuevamente una cierta creencia en que "Dios es todo" y "todo es Dios" por lo tanto, cada criatura es una manifestación de lo divino. Estas ideas que se han visto modificadas en la actualidad con la pérdida de poder por parte de las religiones y con la experiencia del ateísmo, parecen haberse trasformado con los movimientos ecologistas. En relación a esta temática, Saborit comenta la importancia del nuevo catecismo ecológico de Leonardo Boff, quien sostiene que las recientes aportaciones de la Ciencia favorecen una cierta recuperación de todo lo sagrado. Se trata de una especie de Teosfera: "Todo en Dios, Dios en todo" 467 , que supera a la antigua biosfera y que nos revierte a un panteísmo naturalista, es decir, a la Tierra vista como un organismo vivo.
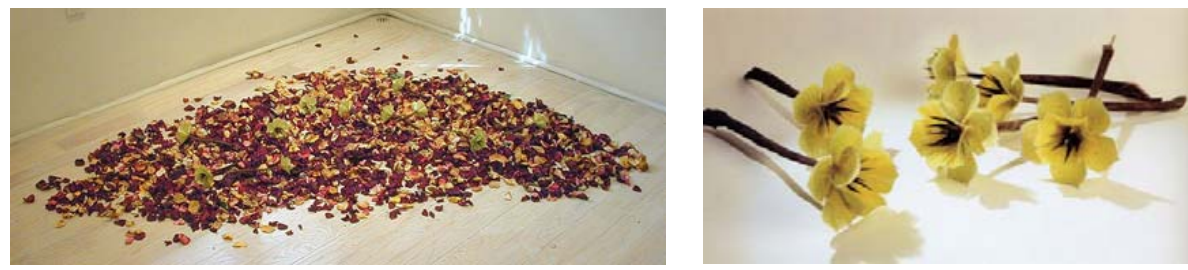

Yolanda Gutiérrez, Efímeras, 2002.

Para Yolanda Gutiérrez éste parece ser el hilo conductor de su trabajo, "todo es uno" y así lo manifiesta en la mayoría de sus proyectos. La artista se hace eco de este sentir y produce, en una especie de ritual místico artístico, flores con alas de mariposas, libélulas y mariposas con esqueletos de hojas o pájaros con escápulas de res. En todas estas piezas, las diferencias entre lo animal y lo vegetal se diluyen y se reconstruyen, conformando un nuevo ser cuya realidad y unidad se percibe en la obra de arte. Así, por deducción la artista se ve reflejada, como por ejemplo en la obra Semilla de artista (2002), en donde podemos observar una semilla con forma de nuez colocada sobre una cama de espinas de henequén. La obra como metáfora directa entre la artista y la idea de semilla, trasmite el dolor de la creación y de la transformación, a través de las puntas de la planta del henequén.

El origen del trabajo de esta escultora debemos buscarlo en una diferente concepción de la Naturaleza tanto en el México prehispánico como, aún hoy en día, en el México actual. Esto es debido a una conciencia de la Naturaleza, por parte del hombre de estas tierras, que difiere en gran medida de la del mundo occidental. Hacemos mención al mundo prehispánico puesto que el conocimiento de esta diferente forma de concebir el mundo es básico para la comprensión de la obra de esta artista.

466 Panteísmo: Del griego $\pi \alpha v$ (pan), "todo" y $\theta \epsilon o \varsigma$ (theos), "dios".

467 ALBELDA, José y SABORIT, José, op. cit., p.37. 


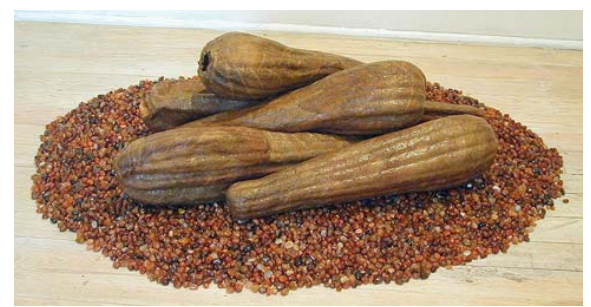

Yolanda Gutiérrez,

Frutas del reino mineral, 2002.

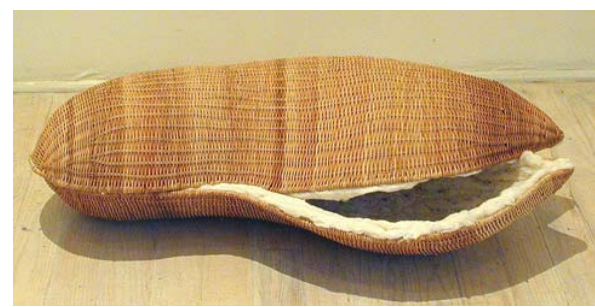

Yolanda Gutiérrez, Mitológico, maíz, 2003.

En el exhaustivo e imprescindible estudio de la multifacética sociedad mexicana, Bonfill Batalla nos orienta en la comprensión de la visión trascendente del hombre y del universo en el México actual. Según su concepción:

[...] la naturaleza, de la que forma parte el hombre, está regida por un orden cósmico al que deben ajustarse todos los seres. Por eso el hombre no se enfrenta a la naturaleza: ésta no es enemiga ni objeto de dominación, sino un todo inmediato con el que debe armonizarse la vida humana. El trabajo adquiere entonces el sentido de vehículo de relación con la naturaleza viva y esa relación, como entre los hombres, es de reciprocidad $[\ldots] 468$.

Esta suerte de mitologías enlaza en el caso de Yolanda Gutiérrez con su proceso formativo. Como ya hemos dicho fue alumna de Kiyoto Ota cuya obra a su vez, con una fuerte influencia de la filosofía y Cultura de Japón -su país de origenestá inmersa en la búsqueda de la esencia. Las filosofías de la Cultura oriental y náhuatl tienen ciertos puntos de convergencia, esta circunstancia sumada a su afición por las lecturas taoístas, chinas y al haikú japonés, enriquecieron sus motivaciones iniciales.

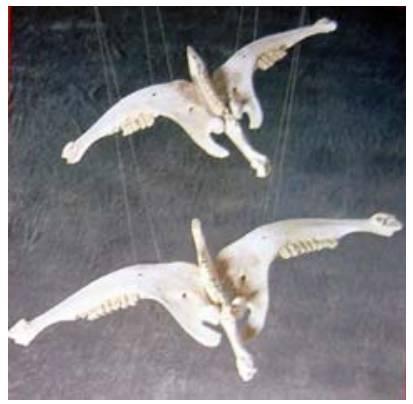

Yolanda Gutiérrez, Umbral (Detalle), 1992.

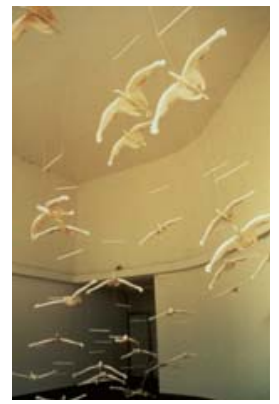

Yolanda Gutiérrez, Umbral, 1992.

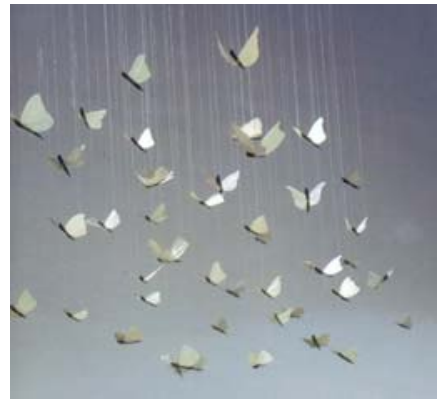

Yolanda Gutiérrez, De noche un viento frío las trajo, 2000.

En un libro proporcionado por la artista, encontramos algunas de las ideas que están en el origen de sus propuestas. Su autor, Fernando Rodríguez Izquierdo, equipara el haiku en la poesía, con la creación artística. La comparación pone de

468 BONFILL BATALLA, Guillermo, op. cit., p. 70. 
manifiesto cómo este tipo de poesía, -tan visual- es capaz de hacer reales las cosas en nosotros mismos. El artista en general, nos dice Rodríguez Izquierdo, debe penetrar en la vida de las cosas para captar así el sentido inexpresable de los acontecimientos aparentemente cotidianos:

El haiku es la aprehensión de una cosa por una "realización" de nuestra propia unidad original y esencial con la cosa misma. La palabra "realización" tiene aquí el significado literal de "hacer real "en nosotros mismos. [...] como el doctor Suzuki explica en sus obras sobre el Zen, cuando se toma una cosa, todas las cosas se toman con ella. Una flor es la primavera; una flor que cae contiene la totalidad del otoño, del otoño eterno [...] Haiku es la creación de cosas que ya existen por su propio derecho, pero necesitan del poeta para poder llegar a la plena estatura del hombre. [...] El poeta es el hombre que sabe ver y tiene como misión transmitir ese poder de ver. Su papel es así doblemente creativo, en un nivel más profundo [...] crea en las cosas una supernaturaleza divina por medio de su intuición expresada en un poema, y crea también en sus lectores una potencia divinizante 469.

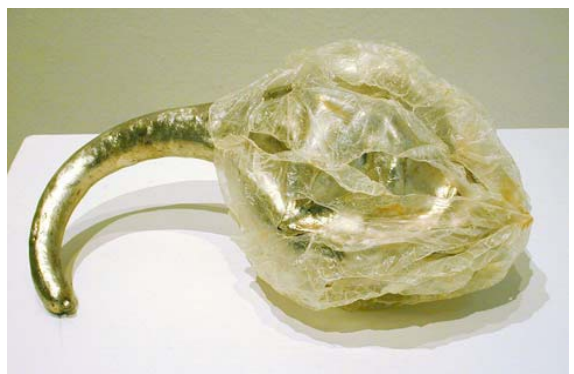

Yolanda Gutiérrez, Lunar, 2003.

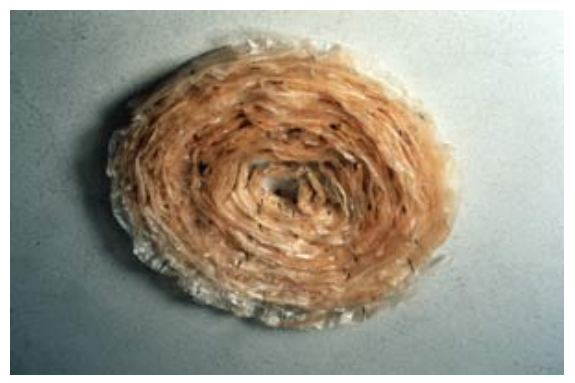

Yolanda Gutiérrez, Entrañablemente, 1996.

En este mismo sentido, la artista Yolanda Gutiérrez devela la verdadera naturaleza de lo que con dificultad percibimos a simple vista. La obra de Gutiérrez destaca en el panorama de los últimos años en México por ser una de las artistas que desarrollan un sistema propio, íntimo y personal, casi podríamos denominar autóctono. Su trabajo artístico proyecta una mirada contemporánea sobre las creencias y los mitos pertenecientes a la Cultura heredada del mundo prehispánico. De esta manera, se inserta en la tendencia a definir la obra de arte como patrón de pensamiento más que como un objeto artístico o un acto meramente visual. Respecto al uso de lo vegetal como referente en muchas de sus obras consideramos que este elemento, entre los otros muchos que usa, le proporciona la dialéctica necesaria para asentar los principios que trata de transmitir.

469 RODRIGUEZ IZQUIERDO, Fernando, El Haiku Japonés. Historia y traducción. Evolución y triunfo del haiku, breve poema sensitivo, Hiperión, Madrid, 1994, pp. 27-30. Material bibliográfico proporcionado por la artista en entrevista realizada por la autora de esta investigación, en Oaxaca, septiembre, 2005. 


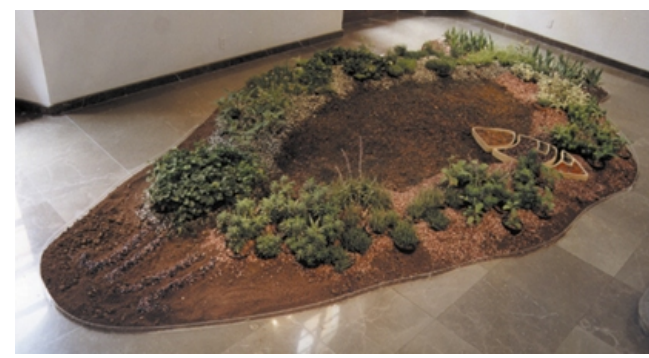

Yolanda Gutiérrez, Tlalocan, 2000.

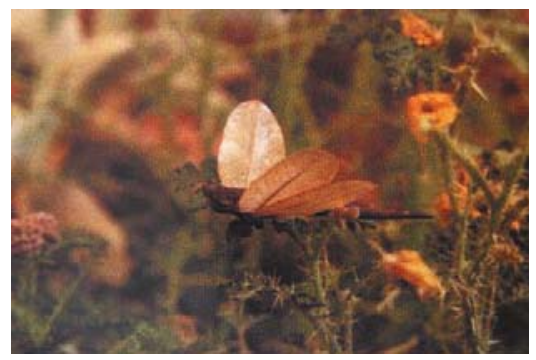

Yolanda Gutiérrez, Tlalocan (Detalle), 2000.

Así por ejemplo podemos ver en la pieza Tlalocan (2000), un jardín compuesto por plantas medicinales, semillas en germinación y animales hechos con granos de maíz y esqueletos de hojas, todo ello evocando el paraíso de Tlaloc o Tlalocan. La obra está realizada con tezontle, ceniza animal, granos de maíz rojo y azul, y plantas medicinales y rituales. Sobre tres plataformas de cerámica en forma de pedernal, se disponen semillas germinadas de cacao, de ayacote, colorín y toloache. Junto a ellas, podemos apreciar, arañas realizadas con granos de maíz y alambre, así como libélulas y mariposas hechas con hojas secas, alambre y espinas de maguey. Las plantas, que necesitan riego y cuidado, presentan una composición en forma de dos serpientes opuestas entrelazadas, simbolizando la vida y su dependencia del agua. Todo ello, emula un cuidadoso ritual propiciatorio de fertilidad que favorece la continuidad del ciclo vidamuerte-vida.

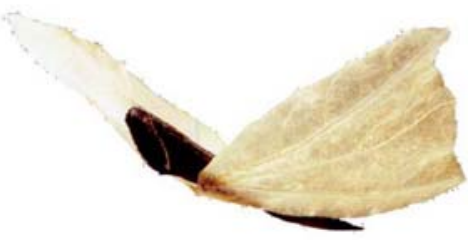

Yolanda Gutiérrez, Tlalocan (Detalle), 2000.

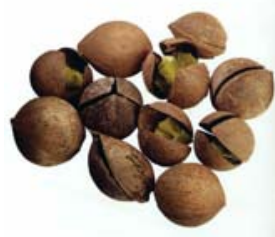

Yolanda Gutiérrez, Ofrenda de familia, 2002.

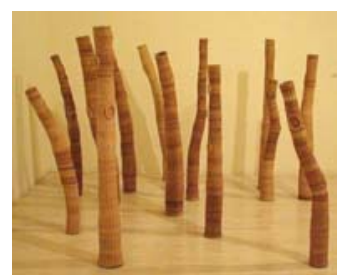

Yolanda Gutiérrez, Palos de lluvia, 2003.

Para Agustín Arteaga, la obra de Yolanda Gutiérrez se inscribe con naturalidad en la corriente ambientalista heredada de las tendencias de los años sesenta, de los emergentes grupos ecologistas y las posturas que trataban de abrir nuevas puertas a la búsqueda de una alternativa nueva que reconciliara al ser humano con su entorno. Movimientos como el Land Art y los Earthworks surgidos en esos años en otros contextos culturales, ponen en entredicho la necesidad de objetualidad de la creación estética, propiciando la posibilidad de lo efímero, lo transitorio y el valor de la documentación, del proceso y de su resultado. Estas circunstancias, aunadas a las herramientas proporcionadas por el arte Mínimaly el arte Conceptual, favorecieron el desarrollo de las líneas de investigación en relación a la conciencia ecológica. 
Sus primeros trabajos se insertan directamente en el Land Art, como lo muestran las obras presentadas en su primera exposición individual en 1992, titulada Númenes [...]470.

Como vemos, si bien es cierto que en esos años en México, no se produjeron movimientos similares, Arteaga adscribe la obra de Yolanda a este tipo de corrientes. Dadas las circunstancias y a pesar de que Yolanda nació en 1970, difícilmente se podría encontrar paralelismo alguno, salvo aquel derivado del estudio de dichas corrientes en los años ochenta y noventa, por parte de la misma artista. A nuestro parecer, su obra se decanta por las nuevas corrientes que si bien es cierto, están en deuda con aquellos movimientos, se pueden enmarcar más adecuadamente en lo que podríamos llamar Ecoarte, una forma de arte basada en planteamientos ecológicos que hace de su propia condición efímera, su virtud.

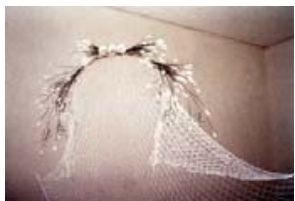

Yolanda Gutiérrez, Cauda, 1999.

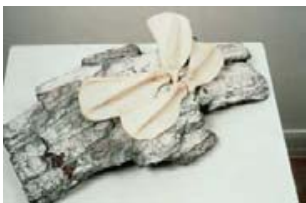

Yolanda Gutiérrez, Mariposa Nocturna, 1994.

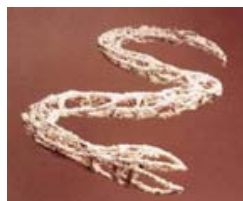

Yolanda

Gutiérrez, Malaire, 2000.

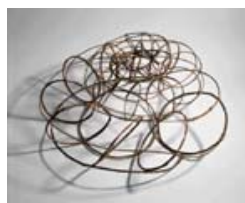

Yolanda

Gutiérrez, Arquitecturas /I, 2000.

Los artistas de esta tendencia se encuentran en la actualidad revisando nuestro concepto de Naturaleza, pero no lo hacen desde la necesidad de encontrar espacios fuera de las galerías, como los artistas americanos de los años setenta. Su búsqueda tiene que ver más con la armonía entre arte y vida que, anclada en el binomio Naturaleza/Cultura plantea la capacidad del ser humano de vivir en armonía con su propio entorno. En esta labor contemporánea, Yolanda rescata de su contexto cultural, de la arqueología y la antropología todas aquellas vivencias que pueden aportarnos luz sobre otros modos de percibir la vida con mayor armonía y con una actitud de mayor respeto hacia nuestro medio ambiente. Sus declaraciones giran en torno a estas ideas: "mi intención es, por una parte, hurgar en lo que perdimos (en lo que aún somos) y aprender de eso"471. De esta manera, la artista confiesa su forma de entender el arte, la cual nos aporta una nueva visión sobre una Cultura que está viva, una observación que se acerca a la forma en la que los mexicanos actuales recurren a los elementos de la civilización mesoamericana:

[...] las múltiples formas en que los mexicanos recurrimos a elementos de la civilización mesoamericana para establecer una relación armónica y benéfica

470 ARTEAGA, Agustín, "Nuevas cadenas", en Yolanda Gutiérrez, Galería Espace d’Art Yvonnamor Palix, México, D.F., 1999, pp. 32-45.

471 MARTÍN LOZANO, Luis, "Yolanda Gutiérrez: una artista con serios compromisos estéticos", en Atl-Agua, Yolanda Gutiérrez, Museo Amparo, México, D.F., pp. 9-14. 
con la naturaleza que nos rodea, revelan algo mucho más complejo y rico que lo que aparenta a primera vista: no es la simple "supervivencia" de tecnologías aisladas, obsoletas que existen solamente por causa -o como causa- del atraso; y no es así, porque la persistencia de esas tecnologías está vinculada a un acervo de conocimientos que son resultado de experiencias acumuladas y sistematizadas durante siglos, y que son consistentes con maneras propias de ver el mundo y entender la naturaleza, con esquemas de valores profundamente arraigados, con formas particulares de organización social y con el universo correspondiente de la vida cotidiana. Es decir: son parte de una cultura viva472.

Yolanda desarrolla un sistema íntimo de comunicación con el mundo natural, fruto como ella misma dice, de una muy cercana relación con el medio rural y de las frecuentes visitas que, durante su niñez realizó a la casa de sus abuelos paternos en Xochimilco 473 y de sus abuelos maternos en Toluca, quienes se dedicaban a las labores agrícolas. En su trabajo, se vale de la materialización de imágenes poéticas para acercar al espectador a otra manera de ver las cosas, una forma ideal de vida y sociedad basada en una equilibrada y estrecha relación entre hombre, Naturaleza y espiritualidad, en armonía con el medio ambiente.
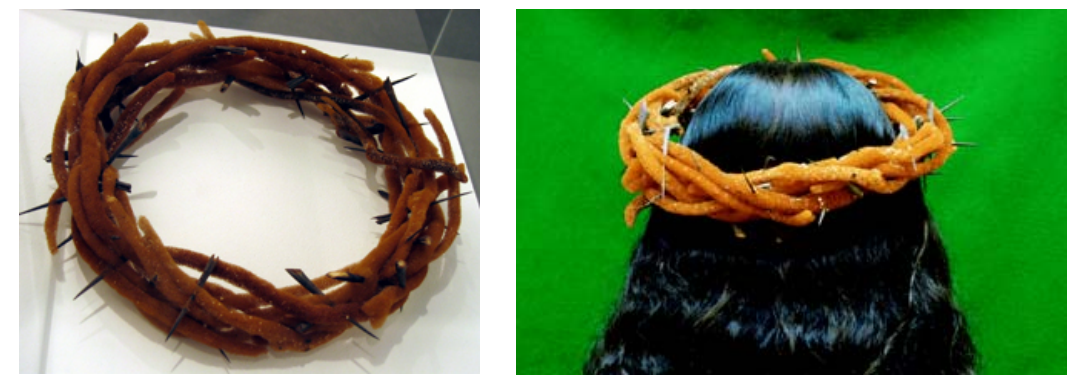

Yolanda Gutiérrez, Reina Madre, 1997.

La constante utilización de elementos naturales en su obra es un fiel reflejo de su relación con las culturas autóctonas del país. Los trabajos de campo realizados con diferentes comunidades indígenas, le han permitido entender los múltiples y estrechos vínculos que estos grupos étnicos tienen con la Naturaleza. La intención de su obra es hacer del arte un medio para divinizar lo natural como fuente de vida, origen y reflejo de nuestro propio ser. Asimismo, las intervenciones en áreas naturales le han permitido utilizar el arte como herramienta para transmitir ideas y colaborar en la conservación del medio ambiente.

472 BONFILL BATALLA, Guillermo, op. cit., p. 36.

473 Zona lacustre de la ciudad de México, considerada una de las Reservas naturales más importantes de México, D.F. Se distingue por la existencia de las chinampas, antigua técnica agrícola mesoamericana. 
En cuanto a los materiales empleados por Yolanda, la artista, desmarcándose desde sus inicios del panorama mercantilista mediático-artístico, realiza una obra cuya principal característica radica en el uso de materiales aparentemente efímeros y en definitiva, no tradicionales. Con ellos consigue crear un diálogo de contrarios y provocar reflexiones en la dirección que ella misma nos plantea. Hojas, ramas, huesos, intestinos de animales, tierra, carrizos, bambúes, todo en función de clarificarnos sus propuestas de lectura.

Si bien es cierto que su escultura sigue siendo representacional y mimética, la creación de sus metáforas se mece en ese difícil arco entre la idea y el objeto representado; los materiales mas disímiles dan vía a flores, aves, capullos, serpientes o nidos y no nos debe sorprender, que ahora Yolanda Gutiérrez sea una pionera de la escultura ecológica en México, con resultados tan admirables como prácticos 474 .

Como hemos visto en el recorrido de la obra de esta artista muchas son las piezas que utilizan lo vegetal como referente, como sujeto o como material. A continuación desglosaremos la poética que ha inspirado alguna de ellas.

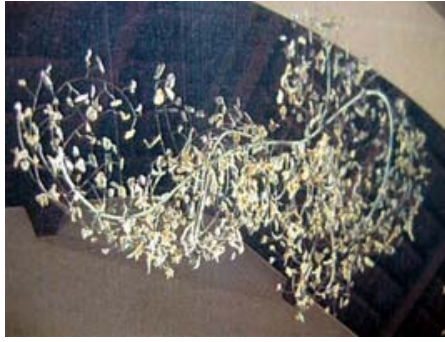

Yolanda Gutiérrez, De paso, 1994.
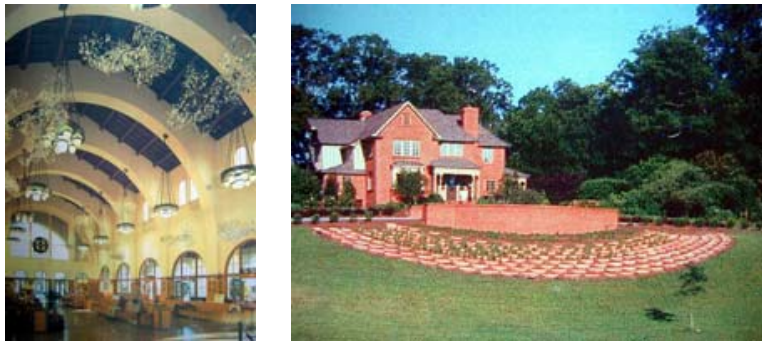

Yolanda Gutiérrez,

La devoción del Girasol, 2003.

En la instalación permanente La devoción del Girasol (2003), pieza realizada en el Jardín Botánico de la Universidad de Clemson, Carolina del Norte, el sol recibe un homenaje como una de las principales deidades de las culturas que fundamentan su sabiduría en el conocimiento de la Naturaleza. La intervención consistió en la transformación del paisaje mediante losas de barro compactado, en forma de semicírculos que seguían la forma de la espiral radial y del patrón geométrico del corazón de los girasoles. Entre las losas, la artista, junto con un equipo de estudiantes, sembró plantas aromáticas, medicinales y de ornato, como romero y orégano, todo ello en una superficie de 400 metros cuadrados.

474 ARANDA MÁRQUEZ, Carlos, "Yolanda Gutiérrez", en AA. VV., Por mi raza hablará el espíritu, Intercambio artístico México-Colombia, Museo Universitario del Chopo, UNAM, México, D.F., 1995, p. 25. 

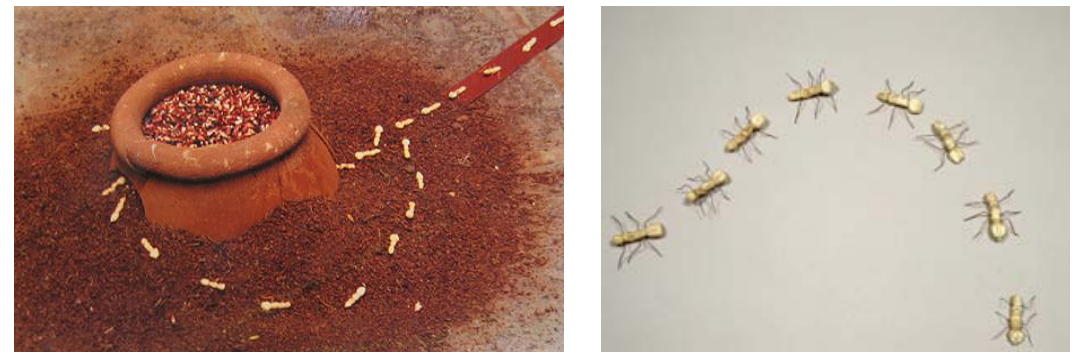

Yolanda Gutiérrez, Los ayudantes de Quetzalcóatl, 1999.

Reina Madre (1997) es una escultura-objeto realizada con esponjas de mar engarzadas en una corona por espinas de maguey, cuyo título "no hace alusión a la Virgen, sino a la madre Naturaleza"475. En el caso de la pieza Los ayudantes de Quetzalcóat/ (1999), el mito de este dios prehispánico se utiliza para hacer un recordatorio del origen divino del maíz, base de la alimentación de los mexicanos. Quetzalcóatl, símbolo de la dualidad y de todo lo creado, descendió al mundo de los muertos convertido en hormiga, en busca de los huesos humanos, los cuales trituró y mezcló con su propia sangre. Según el mito, este sacrificio daría nueva vida a los hombres, que posteriormente serían alimentados con los granos del maíz que Quetzalcóat/ robó a las hormigas. De esta manera, las hormigas que son las que conducen al dios hasta el lugar en donde, según la tradición, estaba el maíz, están hechas con el mismo material que Quetzalcóatl se encargó de proporcionarles a los hombres.

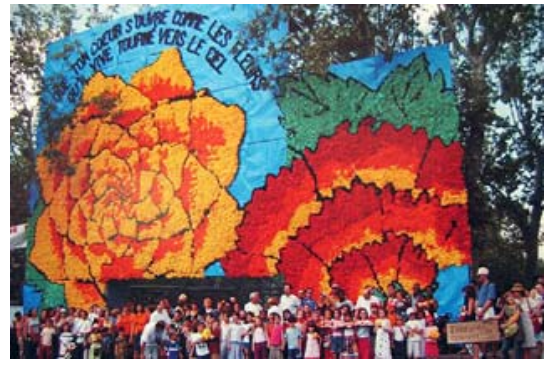

Yolanda Gutiérrez, "Que se abra tu corazón como las flores, que viva vuelto hacia arriba tu corazón", 2004.

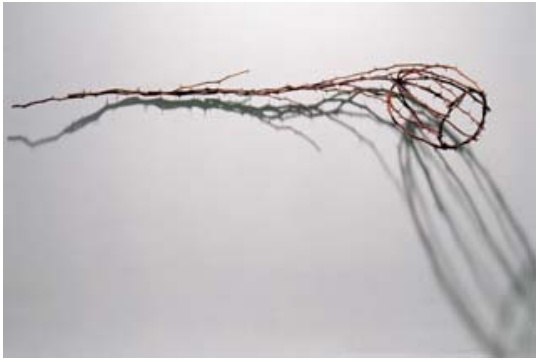

Yolanda Gutiérrez, Capullo, 1997.

En el proyecto Que se abra tu corazón como las flores, que viva vuelto hacia arriba tu corazón (2004), la artista toma un verso de los Cantares mexicanos 476 para titular la obra que realizó en el Festival de Garonne, en Río Loco (Toulouse, Francia). El título sintetiza el sentir y la sensibilidad de los nahuas quienes veían en las flores un elemento sutil, símbolo de la manifestación de Dios en la tierra y la presencia del mismo en nuestras almas, cuando la poesía, la música y los

475 BORRÁS, M. ${ }^{a}$ Luisa, "Yolanda Gutiérrez, vivencias, metáforas y mitologías", en ArtNexus, $\mathrm{N}^{\circ} 39$, Miami (Florida), 2001, pp. 56-61.

476 LEÓN-PORTILLA, Miguel, Trece poetas del mundo azteca, Serie Cultura Náhuatl, Monografías 11 , UNAM, Instituto de Investigaciones Históricas, México, D.F., 1984. 
cantos se elevaban en su honor477. Para esta obra, realizada en plástico de colores, alambre y malla metálica, de dieciocho metros de altura, Yolanda Gutiérrez se basa en la rica tradición de los textiles utilizados por las mujeres, los días de fiesta, en las comunidades oaxaqueñas.

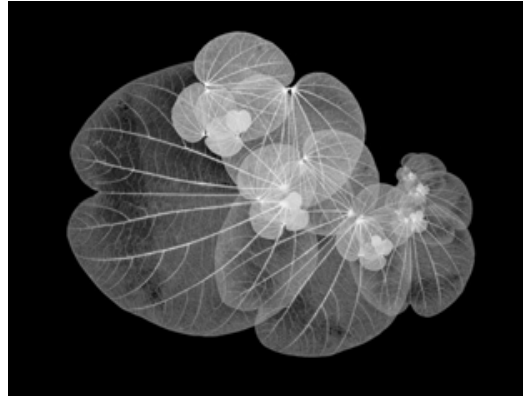

Yolanda Gutiérrez, Aura, 2004.

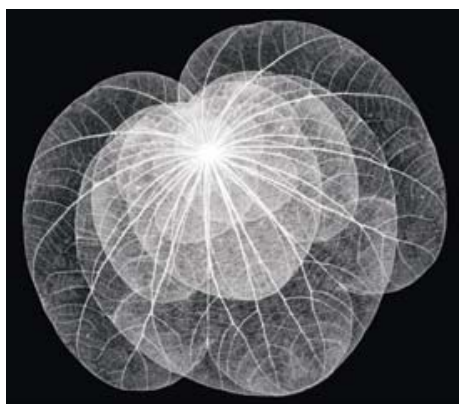

Yolanda Gutiérrez, Fibonacci, 2004.

Fibonacci (2004) y Aura (2004) son piezografías, técnica basada en la impresión digital con tintas al carbón. Aquí, la artista recurre a la repetición, a través de la fotografía, de una hoja del árbol de corazones (Cercis siliquastrum). Esta obra refleja el antiguo sentir náhuatl en el que la flor era un elemento sublime, utilizando la geometría sagrada basada en la serie de Fibonacci, forma de crecimiento orgánico universal que expresa el interés de la artista por la manera en la que lo divino se manifiesta en la Naturaleza.

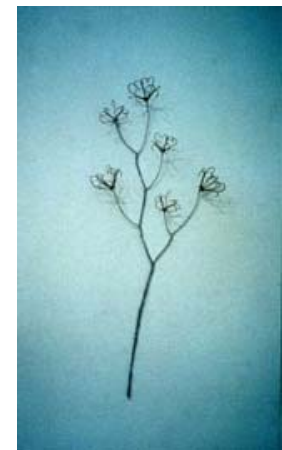

Yolanda Gutiérrez, Botánica, 1998.

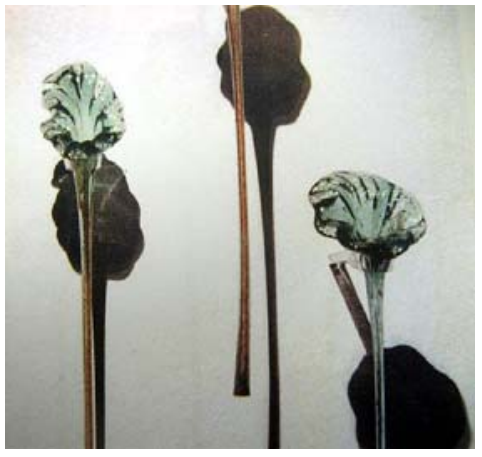

Yolanda Gutiérrez, Flores (Detalle), 2000.

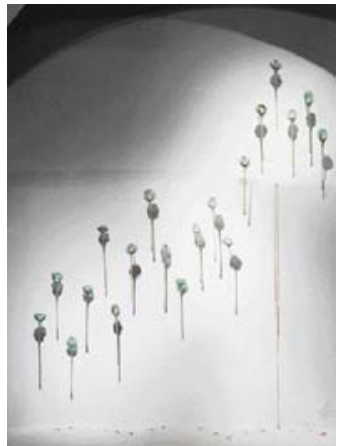

Yolanda Gutiérrez, Flores, 2000.

Con Flores (2000), la metáfora se expresa mediante una serie de alcatraces de vidrio que surgen de un muro blanco. En su interior, un líquido rojo similar a la sangre gotea proyectando hilillos sobre una cama de polvo de ónix. La obra simboliza la renovación de la vida emulando la capacidad de la Naturaleza de reciclar sus desechos, de guardar -como la tierra- el germen de la vida, aún

477 LEÓN-PORTILLA, Miguel, "Las flores en la poesía náhuatl", en Arqueología mexicana. Las flores en el México prehispánico, Vol. XIII, N 78 , INAH, CNCA, Raíces, México, D.F., marzo-abril, 2006, pp. 42-45. 
cuando ésta parezca estéril. La sangre, el líquido más sagrado y preciado que el hombre puede ofrendar a la tierra, se destila a través de unas flores que, como el agua o el semen, líquidos sagrados en la cosmovisión prehispánica, alimentan y fecundan la tierra.
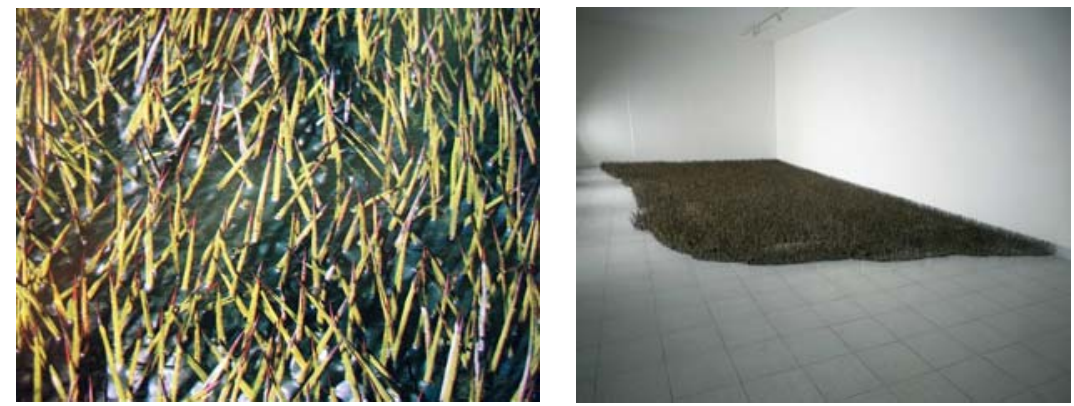

Yolanda Gutiérrez, La tormenta, 1997.

El protagonismo que tienen en su trayectoria los materiales naturales como bejucos, palmas, ramas espinosas, hojas y caracoles, y que utiliza para representar los fenómenos naturales, se explica por la manera en la que trata de mostrar cómo las fuerzas, en constante tensión, se pueden encontrar en una realidad armónica. Estas tensiones se manifiestan sin oponerse entre sí, sino al contrario complementándose de la misma manera que el bien y el mal, la vida y la muerte, o el crecimiento y la decadencia. La artista utiliza espinas de maguey o agave -dispuestas sobre una lámina de plomo- en La tormenta (1997), en alusión a las víctimas humanas por las inundaciones.

La obra Los frutos del árbol de corazones (2000) sincretiza varios símbolos, por un lado representa a un árbol, hecho de ramas secas y hojas de papalocahuite o mariposa, símbolo del alma. Estas hojas encapsulan espirales de caracol marino, símbolo del agua y del seno materno, representando así, la fuente de la vida. En referencia tanto a la mitología maya y mexica, tenemos una obra que genera la metáfora del renacimiento a través de la caída de las semillas.
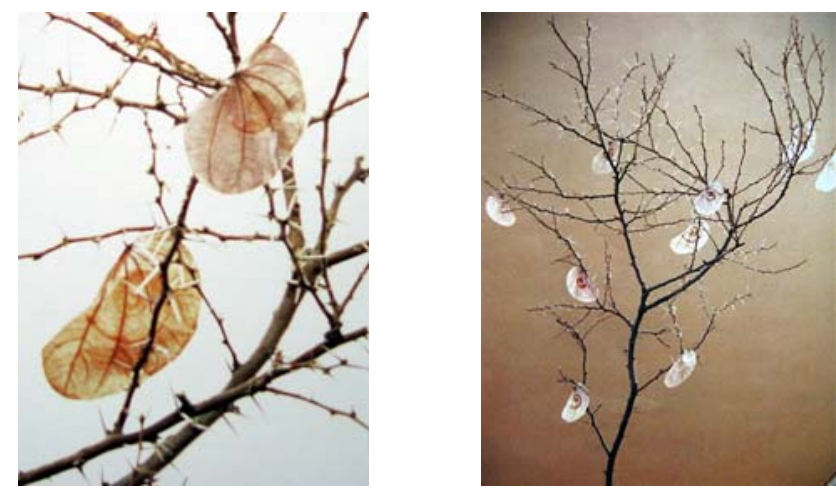

Yolanda Gutiérrez, Los frutos del árbol de corazones, 2000. 
En La Visita (2000) observamos una pieza realizada con una rama pintada de negro, escápulas de gato y piedra. En ella, una flor negra representa el estado actual de la Naturaleza y la vida. En contraposición, una mariposa blanca hecha con huesos simboliza, al igual que en la época prehispánica, el alma de un muerto que ha regresado a visitarnos como cada dos de noviembre, para recoger nuestras ofrendas y pensamientos. Aunque la mariposa se posa en una realidad artificial y cercana a la muerte, la posibilidad del reencuentro genera una sutil metáfora.

Con respecto a las esculturas realizadas con alas de mariposas plastificadas: Vertebral (2002), Efímeras (2002), ¿Puede la oruga volver a la rama? (2002), Enredados (2003), La rama (2002), Silvestres (2002), Oruga (2002), Infantil (2002), etc., cabe destacar que las mariposas provienen de la reserva de la Biosfera de Montes Azules478. Con este tipo de trabajos, la artista consiguió recuperar el excedente de alas de mariposas que allí se concentran y realizar con ellas numerosas piezas, generando además, toda una serie de trabajos que apoyan el desarrollo de las artesanías de los indígenas de la zona. El recurso de utilizar la flor como elemento simbólico de regeneración es utilizado por la artista desde sus inicios, como lo demuestra la obra En esencias (1993), donde reutilizó fragmentos de huesos para conformar varias flores que se disponían, en una especie de misticismo zen, sobre una cama de cenizas.

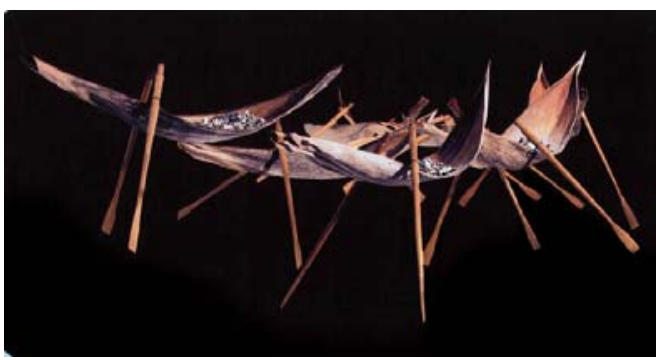

Yolanda Gutiérrez, La Corriente, 1998.

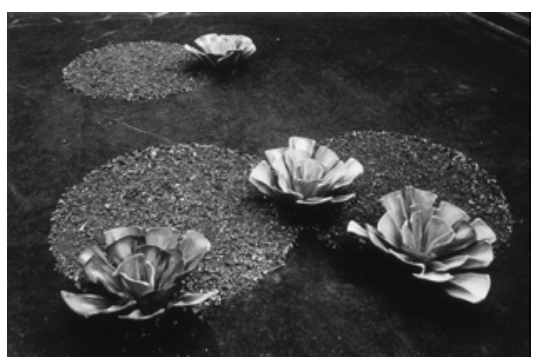

Yolanda Gutiérrez, En esencias, 1993.

El afán de Yolanda por incidir en la importancia del agua como elemento básico para la vida no sólo humana y vegetal, sino de todo ser vivo, se ve manifiesto también en numerosas piezas a través de las cuales la artista hace patente su interés. La forma en la que nos acerca a esta problemática ha sido también muy variada. En La Corriente (1998), el fluir imaginario en el aire de un río toma forma a través de la sucesión de pequeñas canoas vegetales que transportan cenizas de animales en dirección hacia una nueva vida, en un ciclo interminable de regeneración. Cenizas símbolo de muerte y canoas que revelan la presencia humana en relación íntima y armoniosa con la Naturaleza. Metáfora de creencias ancestrales como el viaje de los espíritus a través del río Nilo de los egipcios; el agua como fluir de las fuerzas y elemento siempre adaptable del taoísmo o la

478 La Reserva de la Biosfera Montes Azules forma parte del ecosistema conocido como Selva Lacandona, en el Estado de Chiapas. 
interacción de opuestos del yin y el yang chinos y del at/-tlachinol/j479 náhuatl. Esta instalación se realizó en homenaje a todas las culturas antiguas que no olvidan sus vínculos con lo natural, para recordar que aunque somos entes culturales, nuestros orígenes están en la Naturaleza.

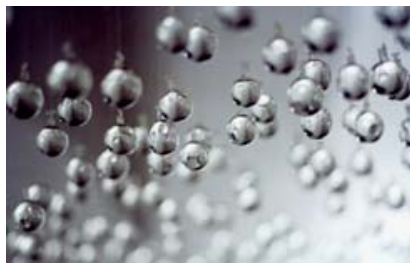

Yolanda Gutiérrez, El Espejo, 1999.

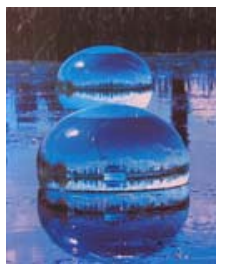

Yolanda Gutiérrez, Gotas vírgenes, 1994.

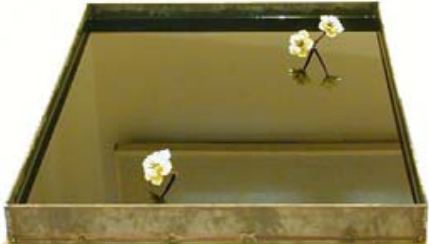

Yolanda Gutiérrez,

Acre, 2002.

Gotas vírgenes (1994), fue según la artista la primera pieza con la que representó de manera poética sus inquietudes con respecto al problema ecológico. La transparencia y brillantez de las esferas de vidrio que conformaban la instalación, generaban un contraste sorprendente al flotar aparentemente, sobre las aguas turbias y contaminadas de la zona lacustre de Xochimilco, en donde estaban instaladas. Estas esferas de vidrio soplado estaban rellenas de agua y se disponían sobre columnas inmersas en el agua, de forma que no estaban a la vista del público. Su finalidad era hacer reflexionar sobre lo positivo y lo negativo de nuestras civilizaciones respecto a la armonía de la Naturaleza.

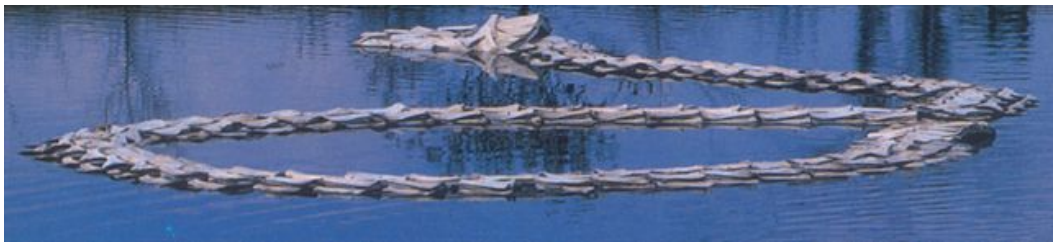

Yolanda Gutiérrez, Cóatl, 1994.

En Cóatl (1994), una enorme serpiente de 25 metros, compuesta de huesos de res engarzados a manera de escamas, flotaba sobre las aguas deslizándose en mística dimensión. Serpiente de materia muerta que pide prestada al viento y a las corrientes de agua la esencia de vida para moverse y vibrar zigzagueante. La serpiente, por su alta capacidad reproductora, fue sagrada para los nahuas y considerada como símbolo de la fertilidad. En este caso es una imagen de la relación entre los polos de la vida y la muerte, del ciclo generador de todos los seres vivos. Con esta y las anteriores piezas, la artista pretendía en general, sensibilizar al público sobre el deterioro del agua.

479 Atl-tlachinolli: concepto mexica relacionado con el acto ritual de la Guerra sagrada o florida. Basado en la unión de dos elementos opuestos: agua y fuego. 
Durante el evento Festival Cumbre de Tajín480 (Veracruz, México), Yolanda participó con la instalación Los dueños del monte están aquí (2003). Se trataba de una ofrenda compuesta por doce figuras de silueta redondeada que insinuaban el perfil de personas. Construidas mediante una estructura tejida de bejuco o mimbre, estaban cubiertas de flores frescas y follaje de diferentes colores. Toda ella estaba dedicada, según las creencias totonacas de la sierra, a los dueños ${ }^{481}$ de las plantas, de los animales y del monte en general. Las figuras se presentaban de pie, de la misma manera que los indígenas totonacas conciben la acción que realizan las deidades creadoras.
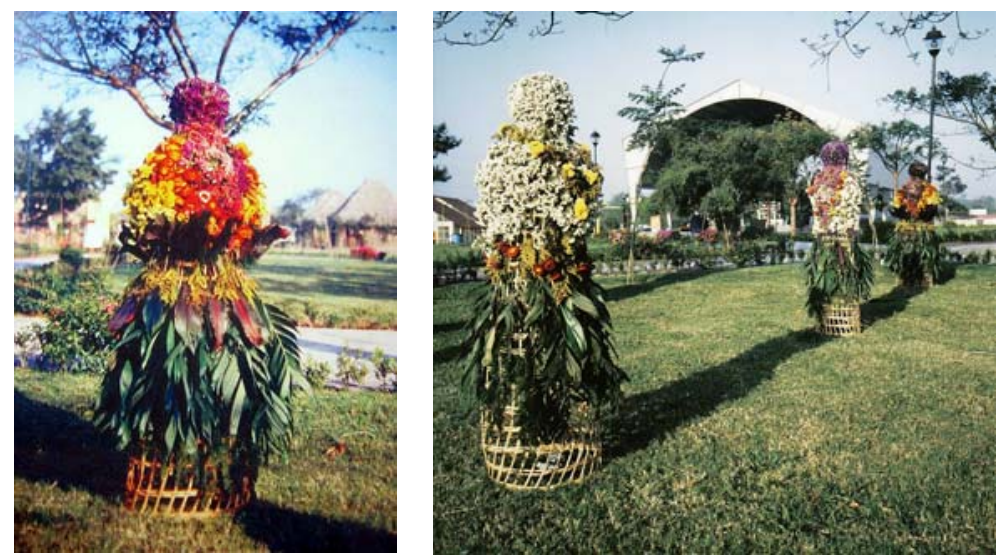

Yolanda Gutiérrez, Los dueños del monte están aquí, 2003.

En el proyecto Conviviendo con aves y mariposas (2004), Yolanda Gutiérrez construyó esculturas-comederos ${ }^{482}$. En esta pieza la artista conjugó el quehacer escultórico con las herramientas que proporciona la biología. Estas obras no eran objetos aislados o ejemplos de la estética que sólo puede observarse. El fin es que los resultados artísticos, las esculturas, tengan un necesario complemento en la utilización que de ellos harán los seres vivos. Los objetos producidos ejemplifican la interdependencia de los seres vivos en la Naturaleza, base de cualquier ecosistema, y proporcionan alternativas para la conservación de los seres vivos en hábitats manejados por el hombre, ayudando a la preservación de algunas especies que se encuentran amenazadas. Las esculturas

480 Tajín: zona arqueológica cercana a Papantla, Veracruz.

481 Estos dueños, no son deidades creadoras, sino una especie de patronos menores que juegan el papel de ayudantes o guardianes de las deidades superiores. Estos últimos delegan en ellos su autoridad para representarlos en cada elemento de su dominio: cielo, agua, tierra cultivada, monte o cerca, sean seres animados o inanimados. El Dueño del Monte o Stiku wa kakiwi es el dueño de todos los árboles, dueño de la parte no labrada, del monte. Se le llama Aksanjan que es una deformación lingüística de San Juan. A él se le pide permiso para cortar los árboles o desmontar. Se le llama también el Perdedor porque confunde a los cazadores para que éstos pierdan el sentido de la orientación en el bosque. 482 Este proyecto fue realizado en la Estación Chaju/ de la Reserva de la Biosfera de Montes Azules, a orillas del río Lacantún, en tierras de la comunidad Lacandona. 
ubicadas en los árboles ofrecen frutas y semillas, funcionando como fuentes de alimento y refugio para algunos animales e insectos.
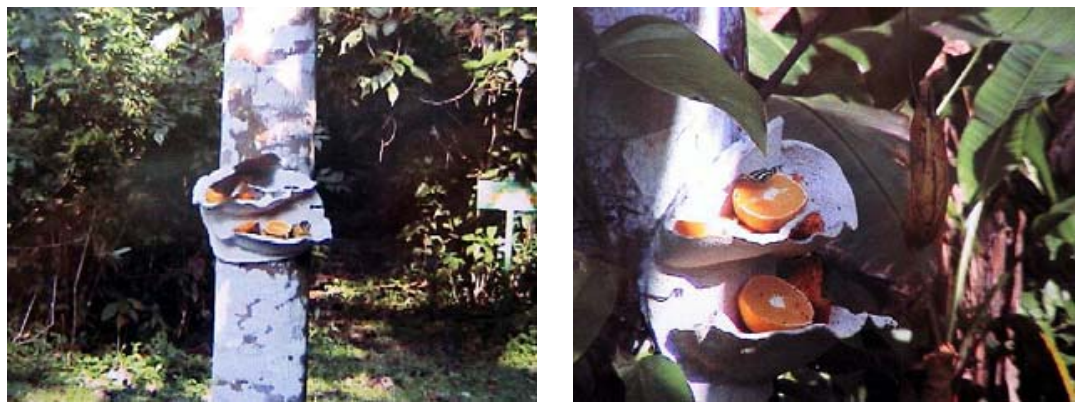

Yolanda Gutiérrez, Conviviendo con aves y mariposas, 2004.

La presencia de los animales alrededor de las esculturas, permite disfrutar de su belleza sin la triste presencia del cautiverio, con lo que se promueve la interacción con la Naturaleza de manera amistosa, sin destrucción o alteración violenta de la vida. Hoy en día, esto se constituye en un atractivo más para el visitante de la estación, y en el futuro será un ejemplo a seguir para atraer turismo ecológico en otras áreas protegidas, dándole al arte la oportunidad de ser un medio para los mensajes de conservación y armonía con la Naturaleza.

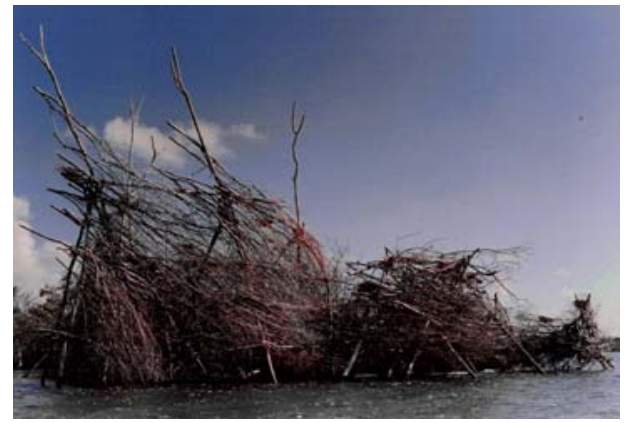

Yolanda Gutiérrez, Retoño, 1995.

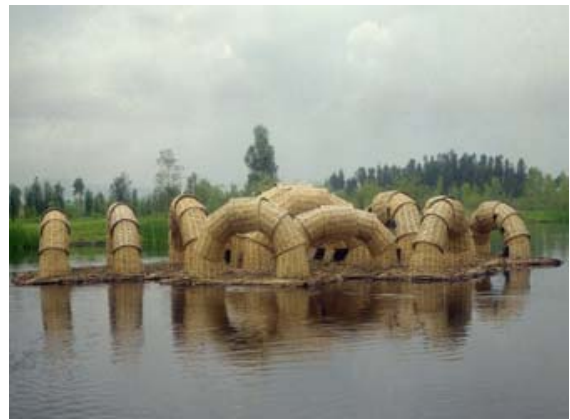

Yolanda Gutiérrez, Santuario, 1995.

La artista ya había realizado otras piezas site specific. Santuario (1995) en Xochimilco, fue una de sus primeras intervenciones realizadas en colaboración con biólogos especializados en la flora y la fauna específicas de un lugar. Las estructuras de gran formato que tenían forma de arco, estaban configuradas con cestos entrelazados que se situaban sobre una estructura flotante y fueron concebidas en su origen, como albergue para aves migratorias. Así también Retoño (1995), realizada con ramas y cestos, hojas y materiales orgánicos, se concibió para permitir que las aves de la región anidaran en ella. En esta ocasión se trataba de una instalación en la laguna de Colombia (Cozumel) para la anidación de aves marinas en cautiverio. La obra estaba instalada en la jaula de vuelo del aviario Xaman-Ha en Playa del Carmen (Quintana Roo). 


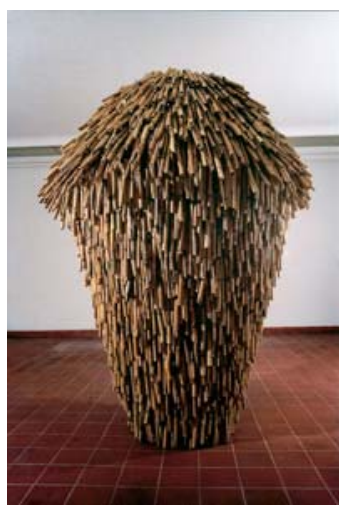

Yolanda Gutiérrez, El señor de la Lluvia, 1994.

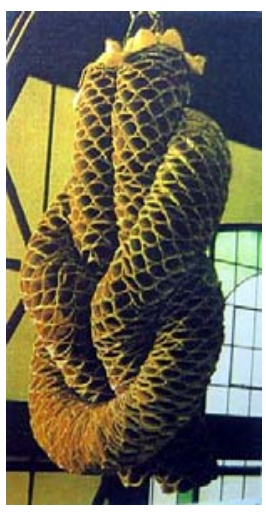

Yolanda Gutiérrez, Reconciliados, 1995.

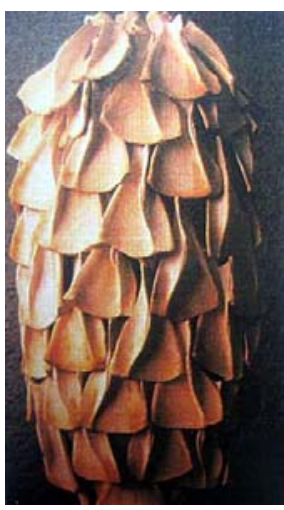

Yolanda Gutiérrez, Ánima latente, 1992.

Finalmente, queremos destacar que en ocasiones el patrón repetitivo y modular con el que trabaja en ocasiones la artista, procede de las estructuras orgánicovegetales. Si bien su intención última no es hacer un alarde geométricoconstructivo, la utilización de materiales sencillos y cotidianos, así como la reutilización de huesos, intestinos y desechos orgánicos, generan parámetros formales de pensamiento que rescatan la repetición como expresión de un ritmo generador. El señor de la Lluvia (1994), Ánima latente (1992) y Reconciliados (1995), son ejemplos de ello. Esta última pieza ofrece la imagen de un nudo elaborado mediante dos estructuras tubulares que, a su vez, están conformadas por pequeños cestos. La escultura fue expuesta en el Museo Universitario del Chopo (México, D.F.) donde la artista proyectaba que las aves que habitaban en el interior del museo, pudieran anidar en esta pieza colgante. Como hemos observado hasta aquí, gran parte de la obra escultórica de Yolanda se configura mediante las instalaciones, el arte objeto y las intervenciones en espacios públicos. Todo ello unido a su interés ecológico, vital y honesto por la recuperación de la convivencia entre los diferentes seres, tanto en su obra como en el mundo, nos permiten concluir que el carácter de sus piezas y su obra en general definen una inclinación hacia lo público. Esta actitud tiene un sentido no sólo presencial, perceptual y místico, sino que ilustra una profunda inclinación a desarrollar a través de sus esculturas, un proceso educativo primordial.

\subsection{E discurso de la identidad, entre el interior y el exterior. Yolanda Paulsen}

La relación entre el macrocosmos y el microcosmos no es una reflexión ni reciente, ni postmoderna, sino una de las más antiguas correspondencias de la Humanidad.

El primer aspecto de la teoría de las correspondencias es cosmológico. Se trata de la teoría según la cual el universo está estructurado por toda una red de correspondencias, en particular, entre el macrocosmos (es decir, el 
conjunto del mundo) y el microcosmos (especialmente, el cuerpo humano) 483 .

Este ancestral correlato entre el universo como marco y el hombre considerado hasta ahora, como la medida de todas las cosas, es en nuestros días valorado como un delicado entramado que el hombre contemporáneo necesitaría tener más presente. La época de la interdependencia está en crisis y en este contexto, seguimos encontrando en el arte uno más de los axiomas que nos permiten reflexionar sobre la dimensión humana, partiendo de los valores de aquello que percibimos más próximo. Esa naturaleza visceral, que nos identifica cercanos a otros seres vivos, es la tabla de navegación de los artistas que buscan en la Naturaleza la suerte de resonancias y empatías que nos pueden permitir recuperar todavía una forma de vida coherente con nuestro entorno.

En ese sentido Yolanda Paulsen (México, D.F., 1963) recupera los registros que nos identifican como humanos y construye imágenes en las que hace converger ideas que nos permiten desarrollar el pensamiento intuitivo. A través de sus propuestas, estas imágenes materializan y canalizan lo que el poeta, filósofo y escritor literario de la imaginación, Gaston Bachelard identifica como todas aquellas sensaciones muy alejadas de la realidad presente, pero que nos hacen percibir "que hubiera todo un universo sensible en potencia dentro de la materia imaginada" 484 .

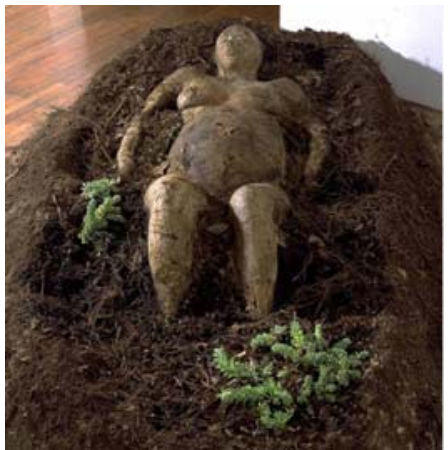

Yolanda Paulsen, Bajo tu piel, sobre tu piel, 1998.
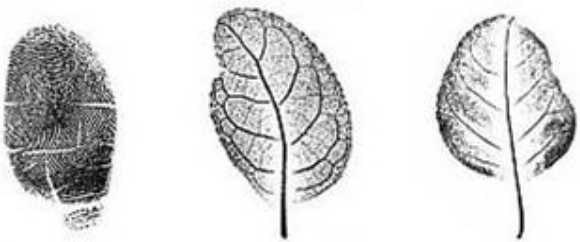

Yolanda Paulsen, No es por azar que estamos juntos en el universo infinito, 2002.

Para Bachelard, es entonces cuando el antiguo dualismo entre Cosmos y Microcosmos -universo y hombre- no basta ya para traducir la dialéctica de las ensoñaciones sobre el mundo exterior y es necesario concebir -como sugiere el autor- "un Ultracosmos y un Ultramicrocosmos, para soñar más allá del mundo y más acá de las realidades humanas mejor definidas"485. Las imágenes primarias

\footnotetext{
483 SOURIAU, Etienne, Diccionario de Estética, Akal, Madrid, 1998, pp. 374-375.

484 BACHELARD, Gaston, La tierra y las ensoñaciones de reposo. Ensayo sobre las imágenes de la intimidad, Breviarios del Fondo de Cultura Económica, México, D.F., 2006, p.14.

485 BACHELARD, Gaston, La tierra y..., op. cit., p. 14.
} 
así consideradas, favorecen una metafísica de la imaginación. Su poder radica en despertar los arquetipos sepultados en el inconsciente de todas las razas. Estas metáforas de potencia múltiple nos llevan -en su simplicidad y claro entendimiento- hasta el nivel más alto del pensamiento abstracto y a la parte más clara de nuestro espíritu. En esta línea de pensamiento la obra de Yolanda Paulsen sugiere imágenes como en la escultura Bajo tu piel, sobre tu piel (1998), con las que la artista parece querer decir -al igual que el poeta Lucien Becker: "nadie sabe si su cuerpo es una planta que la tierra ha hecho para darle un nombre al deseo"486 que nuestro ser físico es una manifestación de una magnitud mucho más trascendente que la materia misma. Con esta pieza se establece el paralelismo Tierra/Ser humano: una mujer a punto de dar a luz representante de la capacidad de fertilidad del ser humano- es equiparada a la Tierra misma y la prodigalidad con la que ésta ofrece sus frutos. La artista nos sitúa frente a dos materias físicas diferentes -tierra y carne, lo inerte y lo animado-. Ambos materiales, siendo distintos, comparten -en el imaginario cultural (polvo eres y en polvo te convertirás)- una misma esencia, la de dar vida.

El elemento vegetal que observamos en la instalación escultórica se convierte aquí en el contrapunto que otorga la posibilidad de vida a aquello -el elemento tierra- sin lo cual, la lectura de la obra podría ser confusa trasmitiéndonos la sensación de estar frente a un cuerpo yacente y, por lo tanto, carente de vida. En particular observamos aquí una clara metáfora entre el cuerpo de la mujer y la Madre Tierra. Si bien es cierto que como apunta Bachelard, siempre se ha relacionado la fecundidad femenina con el modelo cósmico de la Terra Mater o la Genetrix universal487, en esta obra, lo sagrado vincula lo femenino con la Tierra y, por extensión, con los mitos de la partenogénesis488. Haciendo alusión al predominio social de la mujer y al descubrimiento por parte de la misma del cultivo de las plantas alimenticias, la obra en cuestión, a nuestro parecer, hace un guiño al fenómeno social y cultural conocido como matriarcado, a las diosas de la autosuficiencia y los ocultos poderes mágico-religiosos que influyen decisivamente sobre la vida de las plantas. Por extensión, la imagen simbiótica de tierra, mujer y plantas se identifica con Naturaleza. De esta forma, la artista unifica el sentido de regeneración de la vida vegetal con la idea de renovación creativa expresada en las formas y los materiales empleados en la obra. Esta idea aparece también en obras como por ejemplo, No es por azar que estamos juntos en el universo infinito (2002), en la que una huella del pulgar de la artista -y por extensión, del nuestro- se coloca paralelamente a las huellas dejadas por la impresión de unas hojas. De nuevo aquí, el elemento vegetal se hace presente en una relación de igualdad y paralelismo con lo humano.

\footnotetext{
486 BECKER, Lucien, en BACHELARD, Gaston, La tierra y..., op. cit., p.324.

487 ELIADE, Mircea, Lo sagrado y lo profano, Paidós Orientalia, Barcelona, 2003, pp. 107108.

488 La partenogénesis hace referencia a la reproducción asexuada de algunos organismos, partiendo únicamente de células femeninas no fecundadas.
} 
Preocupada por el lugar que ocupa todo lo que está vivo en nuestro planeta, la artista recurre a mostrar en sus proyectos, la vulnerabilidad de todas esas pequeñas cosas que nos rodean y a las que con dificultad prestamos atención. Cosas, tan intangibles como el aire que nos rodea, invisible y sin embargo, imprescindible, a través de su obra, Paulsen lo hace visible mediante registros en silicón de ciertas partes de animales. Estas reverberancias directamente orgánicas, generan ecos simbólicos en nosotros ya que, por analogía formal, nos permiten observar las formas internas de nuestro propio organismo y las correspondencias con otros seres vivos, en particular, del mundo vegetal.

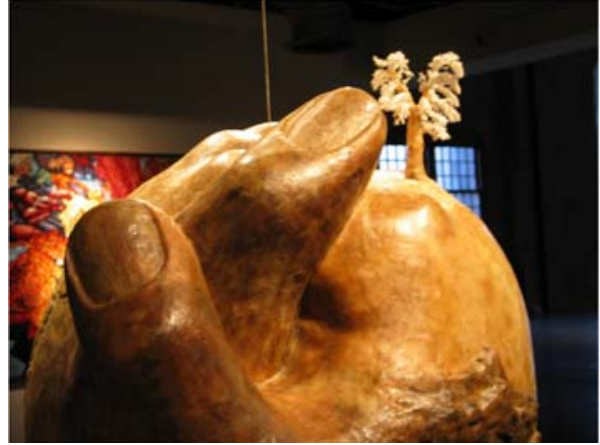

Yolanda Paulsen, Planeta, 2003.

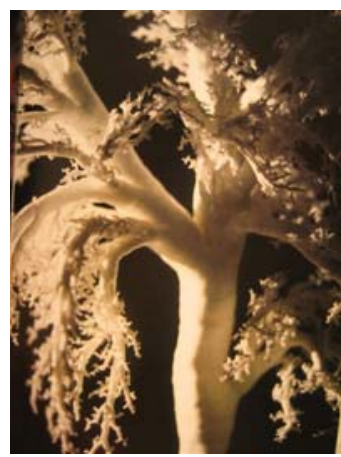

Yolanda Paulsen,

Planeta (Detalle), 2003.

La artista, para imponer respeto hacia el mundo natural, nos conduce de la conciencia de la animalidad hacia un -como diría Bachelard- vegetalismo nauseabundo 489 que permite entender la metamorfosis extraña de lo duro en blando, de lo oscuro en luminoso. El rescate de esta complicidad nos acerca a una percepción de la Naturaleza en la que el mundo que nos rodea, ese microcosmos en el que habitualmente, nos desenvolvemos, es a la vez un reflejo del macrocosmos. Nuestro interior es tan similar a todo lo que nos rodea nuestro exterior- que sólo después de esta compresión de magnitudes nuestra realidad cobra sentido. Todo aquello que percibimos es sólo un juego, un simple reflejo a través del cual fluye nuestro ser. Lo verdaderamente esencial son las correspondencias, lo que atraviesa a todos los seres vivos y permanece. Ese fluido, para Yolanda Paulsen y, en opinión de Teresa del Conde, es el aire:

Sus productos tienen que ver con el silencio, con la naturaleza, con la idea del baobab, el planeta que Saint Exupéry creó para su principito cuando deambulaba en el aire [...]. El aire es lo que vincula las instalaciones de Yolanda Paulsen y lo que más llama la atención es mirar una especie de bosque $[. .]$.490 .

\footnotetext{
489 BACHELARD, Gaston, La tierra y..., op. cit., pp.336-337.

490 CONDE, Teresa del, "Dos exposiciones", en La Jornada, México, D.F., 9, mayo, 2000, <http://www.jornada.unam.mx/2000/may00/000509/delconde.html>,

[Consulta 25, marzo, 2004].
} 


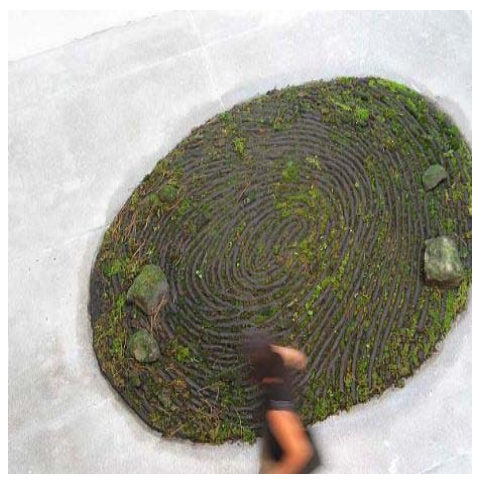

Yolanda Paulsen, Paisaje aéreo, 2003.

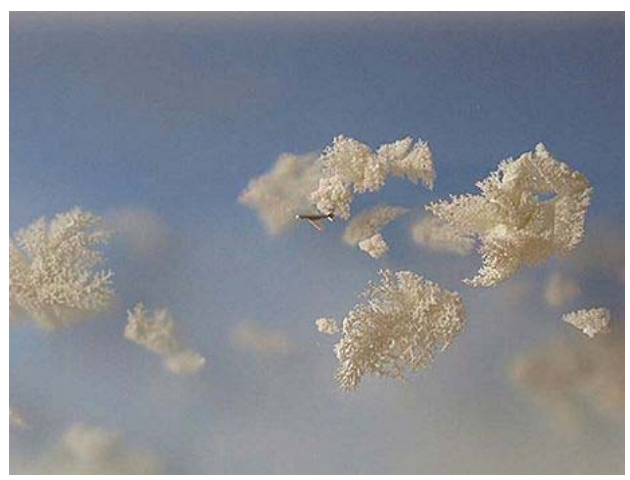

Yolanda Paulsen, Cielo X con avión, 2003.

La artista movida por intereses espirituales cercanos al Zen y al ascetismo, nos remite en la exposición Te escucho (2000), a los versos de Juan Carlos Zamora, que acompañan las imágenes del catálogo y que son testimonio de sus ideas: "te escucho, cuando escucho, trato de seguir el camino, el camino del aire que respiro, el aire en el árbol, el aire en las hojas. El aire en el árbol de las hojas. Así, si habito en el espacio vacío"491. Estos versos nos hablan de la necesidad de retomar el camino ancestral de los hombres primitivos, en cuanto a prestar una mayor atención hacia lo natural. Con este objetivo, la artista presenta una instalación en la que se puede observar un bosque formado por pequeños árboles de silicón colocados en el suelo. Con ayuda de luces puntuales y estratégicamente dirigidas, estos arbolillos proyectan sombras. De manera que, la imagen de este pequeño bosque se redimensiona en un espacio natural, un bosque virtual conformado por enormes sombras de árboles por el que podemos pasear y desplazarnos. La idea es plantear, de forma similar al sentido de la caverna platónica, un no-lugar en donde la Naturaleza y los seres humanos pueden, en algún momento de la historia, haber vivido en armonía.

Con el elemento aire como protagonista, en la serie El cielo que Ilevamos dentro (2003), Yolanda Paulsen presenta una de las más claras analogías formales entre lo interior y lo exterior. Sumergido entre dos placas de metacrilato transparente, un prístino cielo de color celeste, conformado por nubes blancas ramificadas, está contenido en una caja-ventana que genera la ilusión de un espacio aéreo atravesado por un pequeño avión plateado. Esas esponjosas y alveolares nubes son en realidad, como ya hemos advertido, el vaciado en silicón del interior de los bronquios-pulmones de diferentes animales. En una referencia a la respiración como función vital de la Naturaleza, ese cielo inmaculado es contaminado por la acción del hombre. La artista nos presenta así, una ventana abierta a la reflexión. En relación a esta serie Gonzalo Vélez señala la impresión que causan las piezas, más allá de la sorpresa ante la factura o el material de las mismas:

491 ZAMORA, Juan Carlos, Yolanda Paulsen, Material divulgativo exposición, Galería OMR, México, D.F., Fonca, OMR, 2000. 
[...] las piezas apelan con gran carga poética a una mirada distinta al mundo natural que nos rodea. El material de estas nubes, que son una imagen del aire externo, parte del contenido de un pulmón, que es aire interior, y asíla atmósfera del planeta equivale a la superficie interna, igualmente frágil y vulnerable de este asombroso órgano vita/492.

Con la recreación de este tipo de paisajes la artista pone en entredicho el mismo término de paisaje, que siguiendo a Maderuelo, no es tanto lo que está frente a nuestros ojos, sino un concepto inventado, una construcción cultural: "El paisaje no es un lugar físico, sino una serie de ideas, sensaciones y sentimientos que elaboramos a partir de un lugar"493. Partiendo de estos parámetros, el paisaje construido por Paulsen reclama nuestra mirada y nuestra complicidad para resolver la interrogación que la artista nos plantea. La necesidad de la mirada del otro: aquella que redimensiona la pieza y le concede el carácter que, más allá de lo que el artista vuelca en su obra, traspasa los límites de la intención del autor y confiere a la misma, una existencia expandida.

No cabe duda de que la percepción de la naturaleza como paisaje y no sólo como mero fondo escenográfico de narraciones ha estado en relación directa con la capacidad de observación del entorno y de la valoración de la naturaleza como un ámbito de contemplación, disfrute y reflexión. La noción de paisaje conlleva pensar la naturaleza como un ente autónomo con el que el hombre establece relaciones, pero a la vez que se convierte en objeto adquiere la calidad de sujeto, tanto pasivo como activo, al generar emociones y efectos capaces de conmover494.

Coincidiremos pues, tanto con Santiago Olmo, como con Maderuelo en que el paisaje, sea éste pintado, esculpido, descrito o real, "es para los practicantes del Arte una visión interiorizada, subjetiva y, si se quiere, ritual de ese medio"495.

En cuanto a la relación entre autor y receptor de la obra, Luis Racionero496 indica que el primer canon según la estética taoísta, consiste en conseguir resonancia entre el perceptor y la cosa percibida. En nuestro caso, hablamos del vínculo entre la obra de arte y aquel que la percibe, como de una armonía estética que en occidente, es llamada empatía. Dentro del contexto artístico, entendemos por empatía, la capacidad de sentir en, una propiedad que,

\footnotetext{
492 VÉLEZ, Gonzalo, "Yolanda Paulsen y la vulnerabilidad de lo que está vivo", en Boletín de información técnica [de] AITIM (Asociación de investigación técnica de las industrias de la madera), $\mathrm{N}^{\circ} 241$, Madrid, 2006, pp. 42-47.

493 MADERUELO, Javier, "Introducción: El paisaje", en MADERUELO, Javier (dir.), El paisaje: Arte y naturaleza,..., op. cit., p. 10.

494 OLMO, Santiago B.: "Naturalezas artificiales. El paisaje fotografiado" en Los géneros de la pintura, Centro Atlántico de Arte Moderno, 1994, p. 121.

495 MADERUELO, Javier, "Paisajes descritos: un paseo por la literatura", en MADERUELO, Javier (dir.), El paisaje: Arte y naturaleza,..., op. cit., p. 135.

496 RACIONERO, Luis, op. cit., p. 38.
} 
extendida al objeto de arte, presupone la posibilidad de que éste nos proporcione una identificación instantánea con nuestro ser íntimo. Se trata de una circunstancia que nos permite sentir adentro aquello que percibimos. Así, la obra de Paulsen permite el encuentro con esas sensaciones mediante un mundo de resonancias orgánicas.
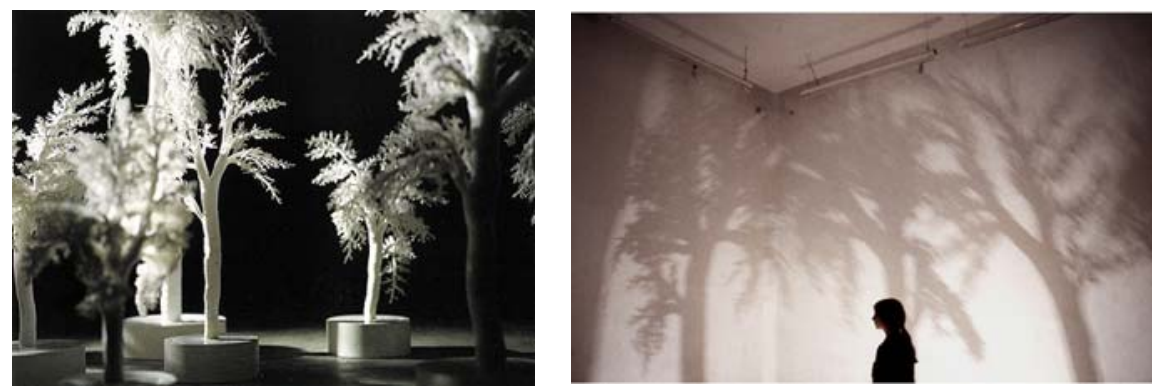

Yolanda Paulsen, Bosque, 2002.

La artista nos invita a redimensionar las cosas guiándonos a través de un recorrido desde lo más pequeño a la magnitud mayor, aquella que nos sitúa en medio de un bosque elaborado con la intangibilidad de las sombras. De lo romántico a lo sublime, la artista nos envuelve en este paisaje de formas bronquiales de animales, reconfiguradas en formaciones vegetales que llenan de forma intangible un vacío lleno de concordancias. La ambivalencia de utilizar una forma orgánica animal, en sustitución de otra vegetal, nos habla de una suerte de metáfora poética de clarividencia. Como en los proyectos de Yolanda Gutiérrez, la idea que prevalece es la de que todo es uno y uno está unido a todos los seres vivos y con ello, la idea más romántica de Naturaleza se impone para hablarnos de respeto.

Sus esculturas e instalaciones exploran los más variados materiales, desde los tradicionales como el bronce, el silicón, la cera o la resina de poliéster con fibra de vidrio, a la utilización de materiales más naturales como la tierra, los vegetales. De esta manera la artista explora las capacidades expresivas de cada uno de ellos, profundizando en las cualidades matéricas y en los significados de los mismos a través de lo blando, lo duro, lo transparente o lo opaco.

Su obra, estrechamente vinculada, como hemos visto hasta ahora, con la Naturaleza, produce sorpresas ante el cambio de escala, llevando al límite la cualidad escultórica de los elementos que la conforman. En Paisaje aéreo (2003), la huella dactilar que configura la obra se construye con barro, tierra, musgo y piedras. El correlato se realiza de forma evidente entre lo humano y la tierra: nosotros como parte de ella y ella, tan frágil como nuestra piel. Se trata de una huella de cuatro metros, que pareciera estar impresa en el barro por el índice de la Naturaleza misma. Los pliegues de esta instalación en proceso, se van transformando con la ayuda del sol y el agua, adquiriendo la calidad de pequeños jardines, cubiertos de hierbas y flores. 


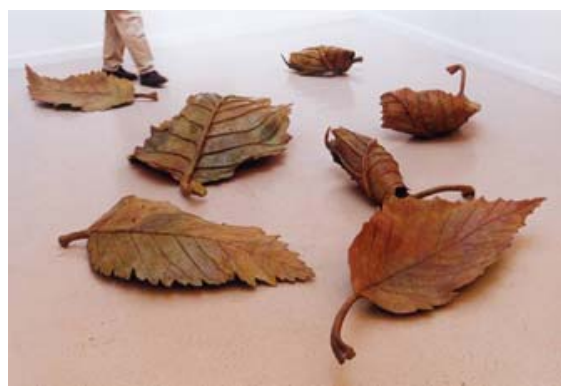

Yolanda Paulsen,

Con su silencio hablan, 2000.

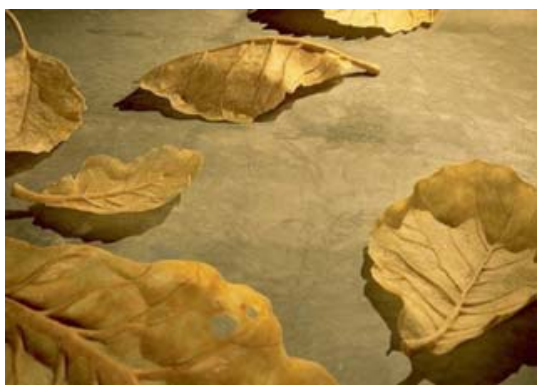

Yolanda Paulsen,

Hojas sobre el suelo, 2002.

En otras de sus obras Hojas sobre el suelo (2002) y Con su silencio hablan (2000), la artista realiza una serie de hojas gigantescas que, esparcidas caóticamente por el suelo de la sala de la exposición, inciden en su condición específicamente vegetal, de hojas caídas. En este tipo de obras la artista trastoca las proporciones de los objetos, transformando la habitual dimensión de las hojas pequeñas, frágiles y quebradizas, en hojas que por sus proporciones, sorprenden al espectador. De esta manera, alude a nuestra pequeñez y hace patente nuestra propia fragilidad como seres humanos, haciéndonos sentir como pequeños insectos en búsqueda de cobijo. Esta manera de involucrar al espectador es una forma de interactuar con el público, a través de la percepción del aire. El aire de dentro y el aire de fuera, el que inspiramos y el que expiramos, el aire que desplazamos al caminar y el aire que mueve las hojas de los árboles y las hace caer a nuestro alrededor.

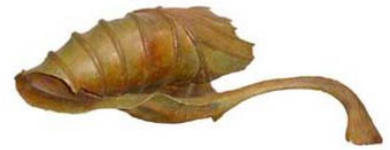

Yolanda Paulsen, Hoja del patio cerrada, 2002.

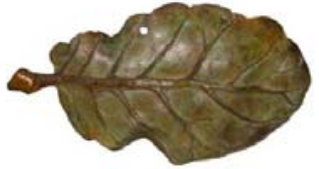

Yolanda Paulsen, Serie Hojarasca No 40, 2002.

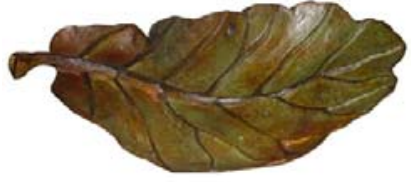

Yolanda Paulsen, Serie Hojarasca $N^{\circ} 43,2002$.

Yolanda recoge las hojas y las transforma, en virtud de una nueva magnitud recuperada tras nuestra propia respiración interior, en aquella que alimenta nuestras sensaciones y nuestro espíritu. La simplicidad de la verdad percibida pone en evidencia todas aquellas analogías que nos remiten a la esencia de que los cuatro elementos que antiguamente conformaban la Tierra: aire, tierra, fuego y agua, están también en nuestro interior. En nuestra opinión, estas esculturas trascienden su condición objetual, para convertirse en una especie de ambiente similar a los primeros ambientes neodadaístas y pop de mediados del siglo XX. Algo que, siguiendo la definición de Marchán Fiz, podríamos llamar ambiente natural contemporáneo:

[...] el «ambiente» es una forma artística que ocupa un espacio determinado y envuelve al espectador, el cual ya no está frente a, sino en la obra. Ésta, 
por su parte, está compuesta de todos los materiales posibles: visuales, táctiles, manipulativos, auditivos, etc. 497.

Tanto con estas hojas descomunales dispersas por el suelo como con las sombras arbóreas proyectadas por los árboles de silicón, la artista nos sitúa en un plano en el que la obra se expande hasta llenar el espacio, modificando la percepción y la vivencia de la misma. De una manera sutil se nos es permitido penetrar en estos ambientes naturales, estamos y nos movemos dentro de ellos.

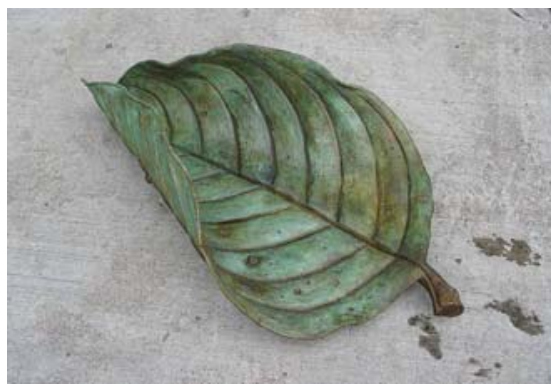

Yolanda Paulsen,

Hoja de Guayabo, 2004.

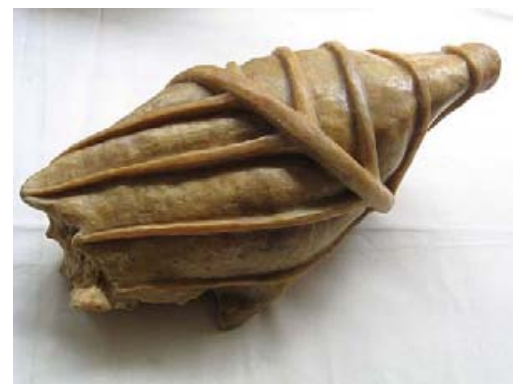

Yolanda Paulsen,

Capullo, 2004.

De manera similar a los ambientes neodadaístas aunque con una intención y factura completamente diferentes, los espacios generados por la obra de la artista, denuncian principios recurrentes partiendo de la aceptación literal de los fragmentos de la realidad. Elementos naturales que no son elegidos al azar y que conservan notas de una fragilidad física y una cierta expectativa de obsolescencia. $Y$ como en la anterior referencia histórico-artística, en estas obras se consolidan las tesis sobre la identidad ambivalente entre arte y vida.

Si tomamos en cuenta el carácter simbólico de las hojas, conviene señalar también su vinculación con los seres humanos, hecho que, por varias razones (multiplicidad, caída, etc.), se halla inscrito en el inconsciente colectivo. Debemos tomar en cuenta que según Cirlot, la representación de las hojas nos remite a una conciencia de entidad, algo parecido a un cierto aspecto social de la Naturaleza:

Hoja: Uno de los ocho «emblemas corrientes» del simbolismo chino, es la alegoría de la felicidad. Cuando aparece en grupo en un motivo representa personas, lo cual coincide con el significado de las hierbas como símbolos de seres humanos 498 .

Ésta sería entonces por parte de la artista y a nuestro modo de ver, una manera de establecer una relación entre el elemento vegetal hoja y todo lo relacionado con lo humano, vinculando de forma existencial a ambos elementos. En piezas

497 MARCHÁN FIZ, Simón, op. cit., 2001, pp. 174-175.

498 CIRLOT, Juan Eduardo, op. cit., p. 242. 
como Rama (2005) o Quiote (2005), el acento vertical y ascensional se corresponde con una devoción hacia lo místico que, de nuevo y por paralelismo, nos habla no sólo de una cuestión vegetal o de una Naturaleza deteriorada, sino de la vinculación de esta precariedad con todas aquellas necesidades espirituales que nutren el espíritu humano.

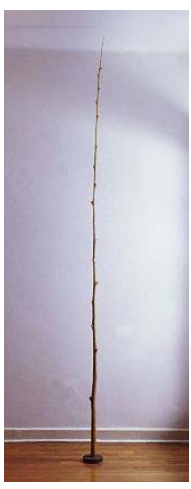

Yolanda

Paulsen,

Rama, 2005.

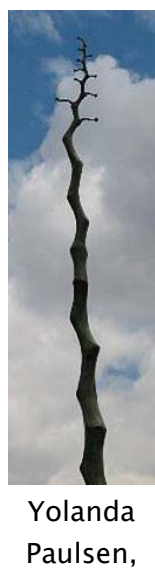

Quiote, 2005.

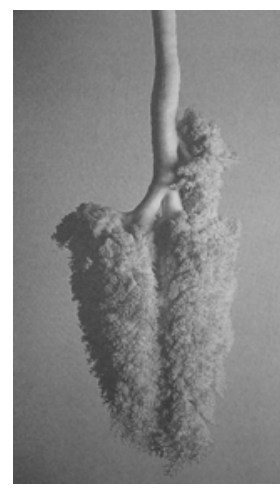

Yolanda Paulsen, Sobre una misma tierra, 2000.

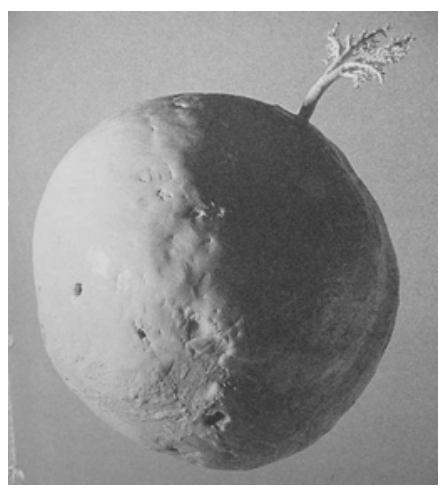

Yolanda Paulsen,

El árbol que llevamos dentro, 2000.

Más allá de la sobriedad y elegancia de sus piezas, o de la manera sencilla de transmitir la vulnerabilidad de la vida, Yolanda Paulsen se dedica a su trabajo como si de "un acto de fe" 499 se tratara, un acto de voluntad que implica un proceso vital de conocimientos por encima o por debajo de las palabras, intuiciones que se configuran como chispas de comunión cósmica. Los elementos grandes se representan como pequeños y los pequeños como grandes. Ritmos, armonías, escalas, reflejos y sombras que cuestionan los contornos y perfiles de las cosas que nosotros damos por descontado.

\subsection{La aproximación a otras culturas. Laura Anderson Barbata.}

En un proceso de pensamiento similar al desarrollado por las dos artistas anteriormente mencionadas, basado en la idea de que el universo es un sistema armónico de resonancias, el trabajo de Laura Anderson Barbata (México, D.F., 1958)500 se ha desarrollado desde la segunda mitad de los años ochenta y durante los noventa, en un ir y venir en torno a los conceptos de Naturaleza y Cultura. Después de realizar estudios de escultura y grabado en la Escuela de Artes Visuales de Río de Janeiro, de arquitectura en la Universidad Motolinía (México, D.F.) y de sociología en la Universidad de San Diego, (California), ejerció durante un tiempo la docencia en México para posteriormente fijar su

499 VÉLEZ, Gonzalo, "Yolanda Paulsen...”, op. cit., p. 47.

500 Página personal de Laura Anderson Barbata, Disponible en red: <http:// www. lauraandersonbarbata.com>, [Consulta 2, marzo, 2008]. 
residencia en Nueva York, desde donde viaja con frecuencia para estudiar las culturas primitivas (en Venezuela, el Caribe o Canadá).
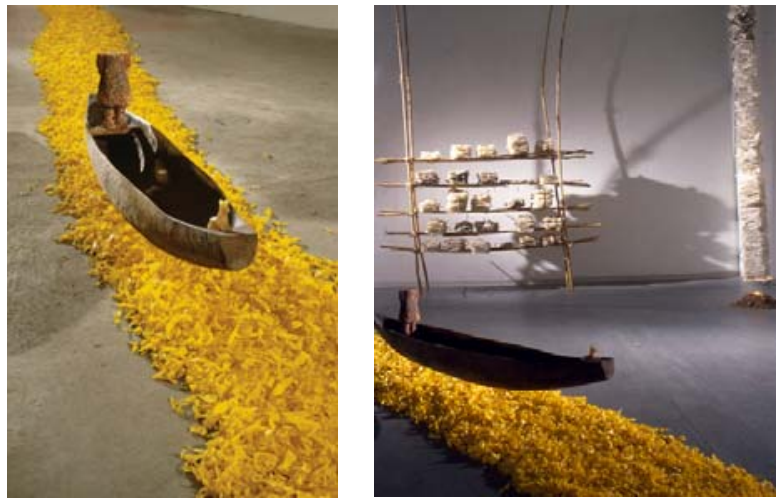

Laura Anderson Barbata, El viaje (Autorretrato), 1996.

Desde 1984 cuando vivía en Brasil y posteriormente, a través de sus periódicos encuentros con la selva, la artista logró establecer un sistema ético y estético que se puede vislumbrar a través de sus trabajos. Estos viajes a la selva, representaron para ella un impacto tan fuerte, que decide generar proyectos que logren rescatar la esencia vital de los pueblos que habitan en ella. Era su propia forma de mostrar respeto y reciprocidad a la selva y a las gentes que allí habitaban y, de esta manera, reivindicar el derecho de estas comunidades, a conservar su idiosincrasia, frente a la hegemonía del poder mediático del mundo occidental.

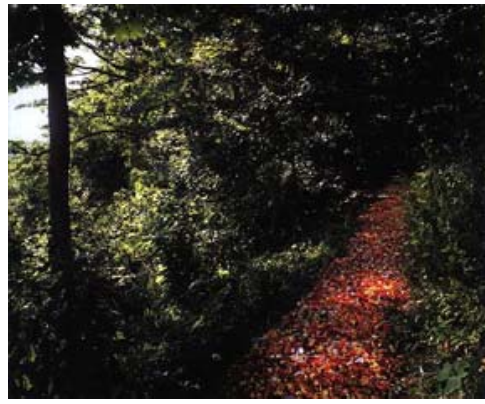

Laura Anderson Barbata, Trazos del Infinito I, 1999.

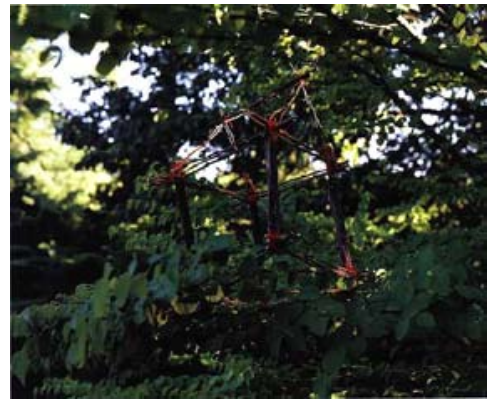

Laura Anderson Barbata, Huellas de las Migraciones, 1999.

Actualmente, como declara la artista501, la razón de ser de su obra, más allá de la búsqueda de estética, se basa en la práctica social y colectiva del arte. Si bien

501 ANDERSON BARBATA, Laura, "Sin lo uno no hay lo otro", Conferencia pronunciada en el Forum TEDxDF, $x=$ Independently organizad TED event, Teatro de la Ciudad, México, D.F., (27, octubre, 2010), Disponible en red: <http://www.youtube.com/watch?v=zRzYfa UCCXI $>$. Su charla abordaba el tema de la reciprocidad en el trabajo como herramienta 
anteriormente, trabajaba obras cuyo motivo principal era la Naturaleza como espejo simbólico del ser interior. El punto de partida eran semillas que dejaba germinar y a las que observaba a la espera de que las mismas le ofrecieran la receta mágica que las transformaba en algo vivo, para posteriormente, aplicarla a su trabajo y a su vida.

Mediante sus prácticas, la artista consigue reelaborar una nueva serie de relaciones en base a opuestos sobre las diferentes concepciones de la existencia. Para ello toma en cuenta no sólo a las diferentes comunidades con las que ha colaborado y con las que tuvo la oportunidad de convivir en la selva brasileña y venezolana (los Ye'Kuana, los Yanomami, en la reserva CotocachiCayapas de Ecuador y con los Piaroa), sino también a nuestra Cultura contemporánea y la propia visión de ella misma como artista. En estos contactos la influencia de la selva como entidad está profundamente omnipresente:

Para mi la selva es un Templo. Es donde existe el origen de nuestra vida, de nuestro espíritu y el mundo y, a la vez, también es donde se encuentran los secretos del futuro de la humanidad502.

Parte de su proceso creativo consiste en integrarse durante un tiempo en estas comunidades para realizar junto con ellos diferentes proyectos de cooperación. Propiciando generar procesos de autogestión que favorezcan el desarrollo en dichas comunidades, su trabajo se constituye de esta manera, como una búsqueda de modelos de intercambio e interacción con las poblaciones marginadas, contribuyendo así a promover, frente a otros grupos vecinos y ante el extranjero, un sentimiento de orgullo étnico entre los miembros de la comunidad.

De entre estos proyectos destaca la enseñanza para la elaboración de papel y libros a partir de los vegetales autóctonos. La idea surge con el planteamiento de colaborar con los grupos autóctonos para que con su ayuda, aprendieran a fabricar el papel necesario para la confección de libros con los que poder documentarse y para usarlos en sus escuelas. La artista consiguió que las comunidades indígenas asumieran este proyecto como suyo. De hecho, el proyecto fue iniciado en realidad por la comunidad de $Y e^{\prime}$ kuana, quienes, desde un principio habían pedido que "ella les enseñara algo a cambio de aprender su oficio"503.

que eleva a los individuos a un nivel superior, dentro de la comunidad, y que simultáneamente, beneficia a nuestro entorno.

502 ESPINOSA DE LOS MONTEROS, Santiago, "Entrevista a Laura Anderson", en AA. VV., Laura Anderson Barbata. La piel de la tierra, Museo de Arte Moderno, Consejo Nacional para la Cultura y las Artes, México, D.F., 1995, p. 26.

503 KATZEW, Ilona, "Laura Anderson Barbata y el Amazonas", en AA. VV., Laura Anderson Barbata, Terra incógnita, Proyecto Intervenciones Sociales, Ex Teresa Arte Actual, Instituto Nacional de Bellas Artes (INBA), México, D.F., 2003, pp. 24-49. 
Con la intención de alejarse de la homogeneización de la sociedad occidental actual y con la participación de las comunidades involucradas, Laura Anderson Barbata comenzó la búsqueda de las fibras más accesibles para la elaboración de los primeros papeles fabricados en la Amazonia. Para el proceso de fabricación empleó sistemas muy rudimentarios al alcance de sus manos, combinando las fibras para obtener variedades en textura y color, secando los papeles sobre planchas de arcilla y hierro y, una vez terminado el proceso de producción, elaborando los primeros cuadernos cosidos y reforzados con fibras naturales. Sobre dichos papeles, los niños de las comunidades pintaron con extractos de plantas diferentes motivos como el río, sus chozas y otros temas que suelen representar en la escuela comunal.

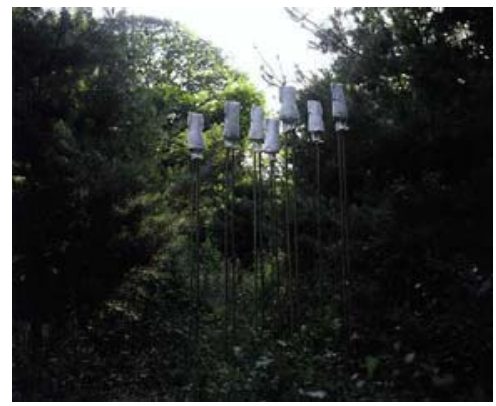

Laura Anderson Barbata,

Trazos Infinitos de Luz, 1999.

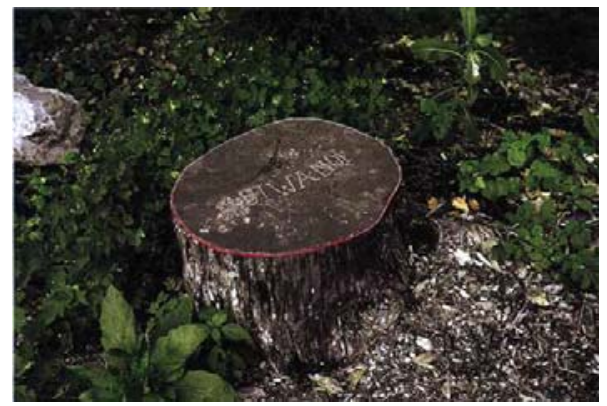

Laura Anderson Barbata, Aquel cuyo nombre no es pronunciado, 1999.

El objetivo final era que las comunidades recuperaran, recrearan y publicaran su historia mítica utilizando un método ecológico que con el tiempo, se ha convertido en una fuente de ingresos para la comunidad sin por ello, menoscabar ni su Cultura, ni su entorno. Si originariamente tenía por objeto fomentar la autosuficiencia de la comunidad así como enseñar a hacer papel a partir de las fibras vegetales, más tarde esta idea se transformó en una realidad. A partir de una industria artesanal, se puede recuperar un uso de los recursos vegetales, para revertir en una necesidad social: la educación y la pervivencia de la tradición oral. Ésta a su vez revierte en un interesante compromiso social de la artista con respecto a los procesos de biodiversidad y de multiculturalización. La utilización de materiales reciclados que estuvieron a su alcance permitió asimismo desarrollar la técnica del grabado en madera y de cuanto pudiera facilitarles hacer sus propios libros, fundamentalmente aquellos que fueran de utilidad escolar. Con esta finalidad educativa el compromiso social y económico por parte del objeto artístico queda profundamente asentado en la obra de la escultora.

La iniciativa plástica de la artista era el primer proyecto de tales características que se daba en aquella zona y acabó convirtiéndose para los más mayores de las comunidades en una especie de revelación, casi una herramienta de poder, puesto que sobre los papeles elaborados se comenzaron a escribir en 1996, las primeras palabras impresas. Las palabras elegidas por los miembros de mayor 
jerarquía de la comunidad fueron lo que ellos Ilaman Watunna, la historia de su propia creación o el mito del origen de los Ye'Kuana.
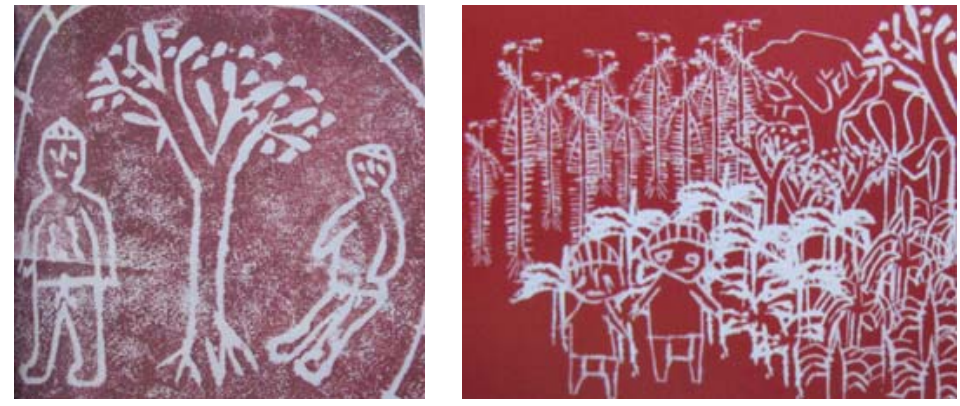

Laura Anderson Barbata, Shapono, 2001.

Fruto de estas experiencias comunitarias de reciprocidad la artista publicó el libro Shapono504 que, a posteriori, se convertiría en video. En él se materializó el proyecto realizado con los indígenas Yanomani, en el cual describen su historia con sus propias palabras y dibujos, relatando también la experiencia de la elaboración de papel junto con Laura Anderson Barbata o "Laura Papel"505 como la llamaban los ye'kuanas.

La primera vez que la artista estuvo en Venezuela fue a raíz de resultar ganadora del concurso Eco Art. La participación en este evento, propició que la artista se acercara a las comunidades del Amazonas, por el parecido formal entre su obra trabajada en madera y los objetos utilitarios realizados por los indígenas de estas comunidades. La historia comienza cuando la artista al llegar a la selva, establece contacto con la familia Ortiz, de la etnia ye'kuana quienes estaban en esos momentos enseñando a los Yanomami a hacer canoas o curiaras, partiendo de un tronco. Sorprendida por el uso y la optimización de los recursos naturales, así como por la participación grupal en la realización de las canoas, la artista pide integrarse en el proceso, para aprender con ellos a realizar canoas, disciplina que podría más tarde integrar a su trabajo escultórico. Los miembros de la comunidad, después de consultar entre ellos, le propusieron enseñarle a hacer una canoa a cambio de que ella también les compartiera algún conocimiento. De manera que, para ser aceptada como alumna en la comunidad, la artista les ofreció enseñarles a fabricar papel hecho a mano. En este proceso de retroalimentación, Anderson Barbata aprendería a vaciar un tronco, abriéndolo con un machete, y aplicarle fuego para conseguir que la canoa fuera eficiente 506 .

504 ANDERSON BARBATA, Laura, Shapono, Proyecto: Yanomami Owë Mamotima, libro encuadernado artesanalmente con papel hecho a mano por la Escuela Intercultural Bilingüe Yanomami, Platanal, Amazonas, Venezuela, 2001.

505 KATZEW, Ilona, "Terra incógnita”, en AA. VV., Laura Anderson Barbata, Terra incógnita, op. cit., pp. 29.

506 STEIN, Axel, "Cuentos del Orinoco y otros relatos", en AA. VV., Cuentos del Orinoco y otros relatos, Laura Anderson Barbata, Sala Mendoza, Caracas, 1999. 
Toda esta secuencia -al tiempo de ser una interesante metáfora del proceso de aprendizaje - es en sí, en una especie de sugerencia Zen, uno de los objetivos primordiales de la artista, o lo que es lo mismo, una manera de hacer del arte el espejo de su propia vida. En Anderson Barbata confluyen la mezcolanza de inquietudes fruto de la multiplicidad cultural que ha configurado la visión de la artista entre la Cultura oriental (meditativa), la occidental (expresiva) y la indígena mexicana (vivencial) y aquella que deja a un lado sus preocupaciones personales y dedica una buena parte de su tiempo a programas que tienen que ver con la biodiversidad, tanto ecológica como cultural. Esta forma de actuar se relaciona con todos aquellos artistas que utilizan la Naturaleza en ese proceso vital que intenta acercar arte y vida. Estas y otras ideas quedan reflejadas en la práctica escultórica de esta artista en algunas de sus obras que analizaremos a continuación.

En la pieza Epítome o modo fácil de aprender el Idioma Náhuatl (1996), observamos sesenta y dos elotes o mazorcas dispuestas sobre repisas o estructuras construidas de carrizo y mecate. De lejos, aparentan ser únicamente mazorcas puestas a secar, en la proximidad, la pieza revela ser truculentamente morbosa. Las mazorcas están recubiertas de cera y conformadas con dientes y cabellos humanos - cinco mil dientes humanos incrustados en un tipo de cera de abejas Ilamada cera de Campeche-.
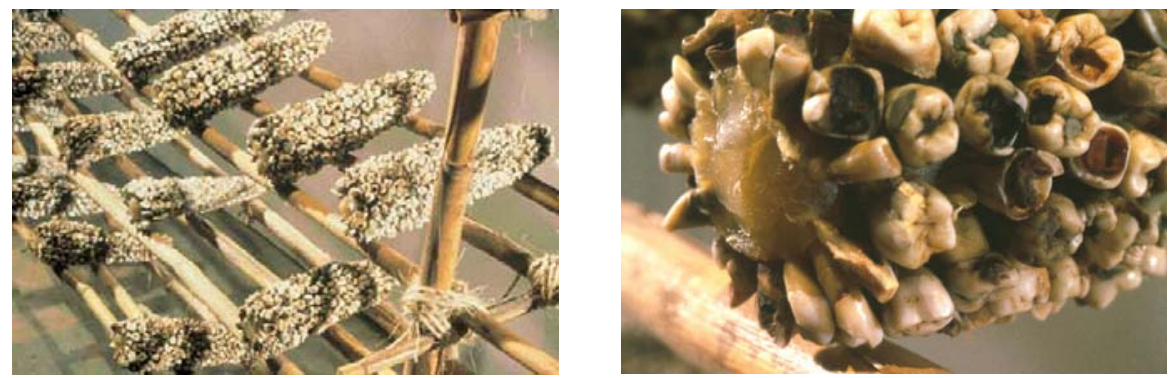

Laura Anderson Barbata, Epítome o modo fácil de aprender el Idioma Náhuatl, 1996.

Aquí, Anderson Barbata presenta una de las más claras analogías conceptuales y formales en lo que se refiere al trabajo realizado con las comunidades. Importante es hacer notar que el elemento seleccionado es de nuevo un vegetal -el maíz- que por otro lado es la base de la alimentación de muchos indígenas en México, América Central y Sudamérica. Con esta obra, la artista hace visible la dureza de los procesos de aculturación vividos en general en toda América. El tema de la obra está en relación con la barbarie provocada por la Inquisición española y las matanzas de indios que ésta propiciaba, apoyándose en el remanente cultural arrastrado desde Europa. Con la llegada al Nuevo Mundo de la tortura inquisitorial practicada en Europa en el siglo XIII, el indígena fue despojado no sólo de sus hábitos y costumbres culturales sino también de su manera de hablar. Aunque la época de los inquisidores ya pasó, la manera en la que se perpetúan sus estrategias continúa prevaleciendo. Con esta obra, Anderson Barbata plantea que la Cultura dominante se empobrece cuando las 
minorías son marginadas y aboga por un mayor respeto hacia un mundo de amplios conocimientos, hoy empañado por la globalización y el progreso. El conjunto de la obra de Laura Anderson es como apunta lona Katzew "un espacio seductor e inquietante, a la vez que obliga a reflexionar sobre cuestiones de apropiación e intercambio cultural en el mundo poscolonial"507.

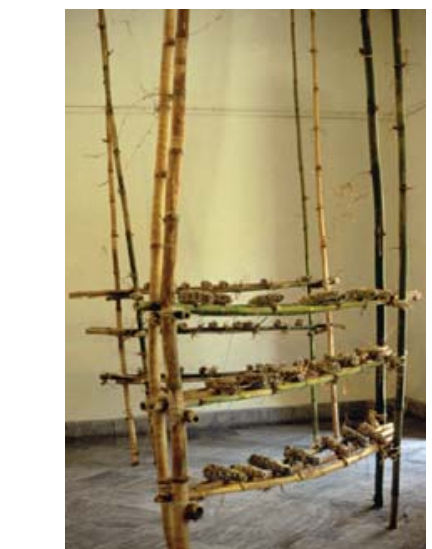

Laura Anderson Barbata, Epítome o modo fácil de aprender el Idioma

Náhuatl, 1996.

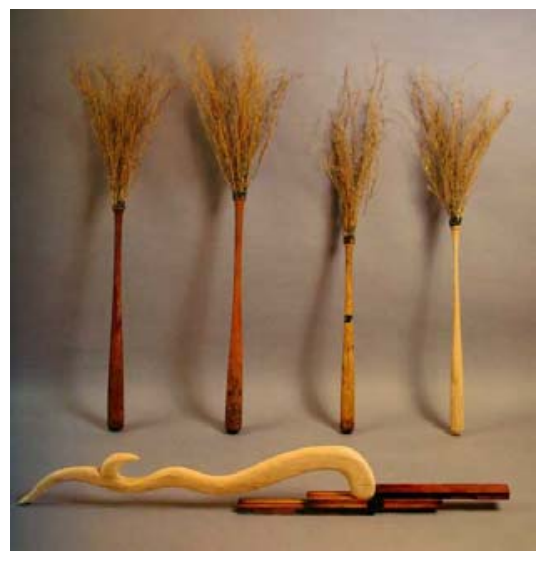

Laura Anderson Barbata, Lluvia en el río, 1994.

La obra, según la artista, constituye una base para la recuperación del idioma propio de las comunidades, de sus tradiciones y de su historia. En este contexto cada diente extraído significa en el tiempo, una palabra muerta. La instalación de las mazorcas sobre una estructura de cañas remite por otro lado, a una de las construcciones mexicas Ilamadas zomplant/i508, con lo que formalmente la artista se conecta con las antiguas tradiciones artísticas de su país de origen, rememorando en su pieza los monumentos aztecas levantados en la plaza pública para mostrar sus trofeos de guerra (las cabezas del enemigo recién sacrificado). Los zomplantli, dentro de la sociedad autoritaria de los mexicas, eran un claro ejemplo del arte oficial tenochca, permitían visualizar formalmente la hegemonía de los mexicas:

[...] se puede decir que el arte oficial tenochca fue significativo en su comunidad porque desempeñó funciones sociales, mediatas e inmediatas,

507 KATZEW, lona, Disponible en red en <http://www.esay.edu.mx/directorio/ficha.php?ld Personal $=6>$, [Consulta 15, noviembre, 2004]. Iona Katzew es comisaria asociada del Latin American Art, Los Angeles County Museum of Art.

508 El zomplantli es una construcción arquitectónico-escultórica prehispánica realizada en piedra en la que se acumulaban de forma característica, los cráneos y los huesos de los vencidos en la Guerra Florida. Esta estructura es característica del arte Tenochca, producido en Tenochtitlán (ciudad capital del imperio mexica, actualmente México, D.F.). 
explícitas e implícitas, que satisfacían necesidades humanas básicas, tanto de orden físico como mental509.

De la misma manera que el arte oficial tenochca no desempeñó funciones estéticas sino sociales, para la artista esta forma simbólica de representación convertida en arte, desempeña una función no individual, sino social. Buscando una forma de significación similar recupera un recurso plástico que conecta con las necesidades de las comunidades con las cuales interactúa.

Me di cuenta de que hay hilos invisibles que conectan mi vida con mi país, desde el México prehispánico hasta el actual, hilvanándose con historias y migraciones que conforman el árbol de mi país, el de mi vida y el de mi familia. Es una referencia de quienes nacen, viven y habitan la tierra de México, pero también de los caminos transitados, de las migraciones, voluntarias o forzadas 510 .

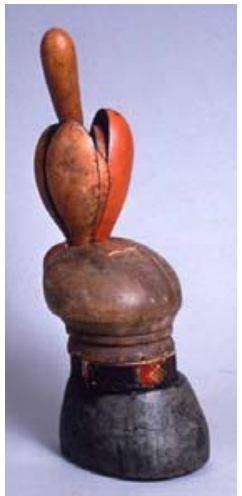

Laura Anderson Barbata, Flor de río, 1994.

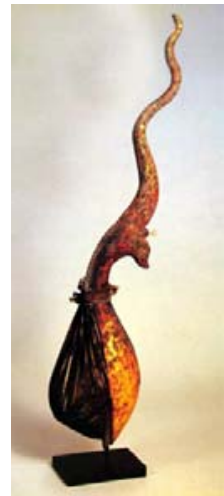

Laura Anderson Barbata, Este es mi cuerpo, 1999.

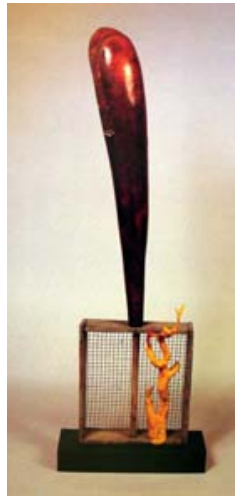

Laura Anderson Barbata, Ritos de pasaje, 1995.

En la apreciación de su obra no nos enfrentamos al mito del buen salvaje511, reelaboración de un mito tan antiguo como el hombre: el del paraíso terrenal, sino que por el contrario estamos ante una realidad, la de unas comunidades relegadas por el progreso de nuestra Cultura occidental y a las que Anderson Barbata con su arte, consigue acercarnos. La artista, a través del modo en que procesa la madera en su obra, nos transmite una sensibilidad estética en la que, al igual que en las comunidades de la selva, el trabajo se vuelve un ritual relacionado con el lugar.

509 AGUILERA, Carmen, El arte oficial tenochca. Su significación social, UNAM, Instituto de Investigaciones Estéticas, Cuadernos de Historia del Arte, México, D.F., 1985, p. 154.

510 BORRAS, M. ${ }^{a}$ Lluisa, "Laura Anderson Barbata. Entre la poesía y el compromiso", en ArtNexus, № 36, Miami (Florida), 2000, pp. 48-55.

511 ELIADE, Mircea, El mito del buen salvaje o el prestigio de los orígenes, Mitos, sueños y misterios, Kairós, Barcelona, 1999, p. 38. 


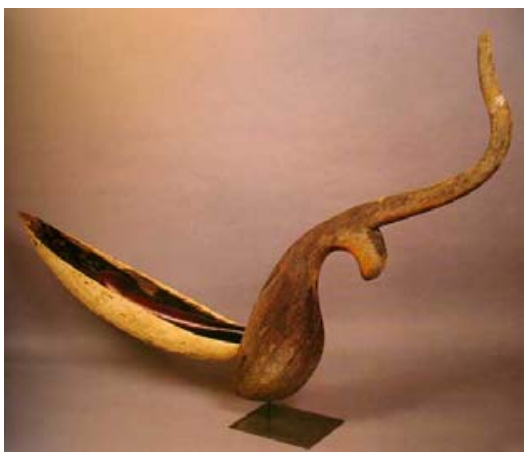

Laura Anderson Barbata, El sonido del agua, 1994.

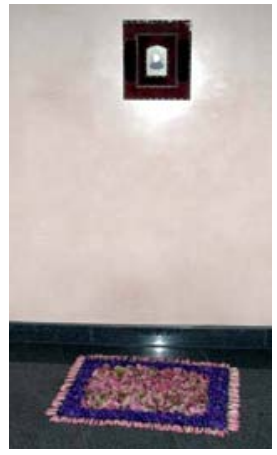

Laura Anderson Barbata, La sombra que protege, 1999.

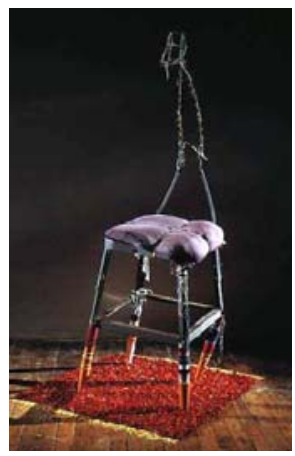

Laura Anderson Barbata, Sin título, 1999.

Pero ésta no es la única ocasión en la que la artista utiliza elementos extraídos específicamente del mundo vegetal para establecer un paralelismo entre aquello que se identifica como vegetal, con lo que parece tener un cierto sentido místico y sociológico del empleo del mismo.

\section{[...] en la exposición Cinco continentes y una ciudad, sustituía los rostros de} sus retratos anónimos por grandes hojas de orquídea, silueteadas por pespuntes blancos evocando iconos religiosos, rituales indígenas [...]512.

La serie Cuentos del Orinoco y otros relatos (1999) 513 es parte de una obra que Laura Anderson Barbata ha realizado como muchas más, a posteriori de cada uno de los viajes al Alto Orinoco. Siempre vuelve cargada de hojas, semillas, lianas y condimentos que de inmediato ordena, califica y guarda. La recolección de estos materiales junto con los registros de voces y sonidos captados en la selva, permiten a la artista combinar su sensibilidad con el uso de materiales poco comunes en la escultura tradicional: papeles, hojas, ceras, carrizos, perlas, dientes, mecates, flores, etc. En sus experimentaciones utilizó plantas que sólo conocía por su nombre indígena: Tavari, Haruru, Yamaa, Yamaa pigmentado además con semillas de Onoto, Curata, Shiki, Curawa, Tutappa y otras como el Bambú, Moriche y el Plátano. El uso de este tipo de materiales orgánicos traídos desde las profundidades de la selva amazónica, para integrarlos en una obra contemporánea, nos permite situar su obra en un punto que podríamos considerar como una encrucijada entre Cultura y Naturaleza.

En otra de sus obras, la artista trazó con hojas de orquídea, siguiendo los límites establecidos por los mismos indígenas, un mapa del territorio Ye'Kuana para con ello, reclamar la posesión de la tierra ante las autoridades de

512 MAC MASTER, Merry, "Laura Anderson trae del Amazonas a Chiapas su proyecto para hacer papel", Disponible en red en:<http://www.fundacion.telefonica.com/at/mexico/

paginas/03.html $>$, [Consulta 8, agosto, 2011 ].

513 STEIN, Axel, "Cuentos del Orinoco...", en AA. VV., Cuentos del Orinoco..., op. cit. 
Venezuela. En esta búsqueda de su voz y su propia personalidad como artista, a través de otras culturas, la escultora encuentra en la Naturaleza, la ecología, la antropología y la etnografía, la circunstancia mediadora para que la tecnología no atropelle la Cultura.

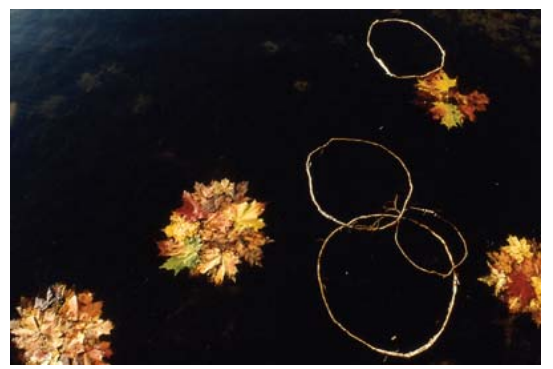

Laura Anderson Barbata,

Buscando el lugar donde nuestras lenguas se encuentran, 2000.

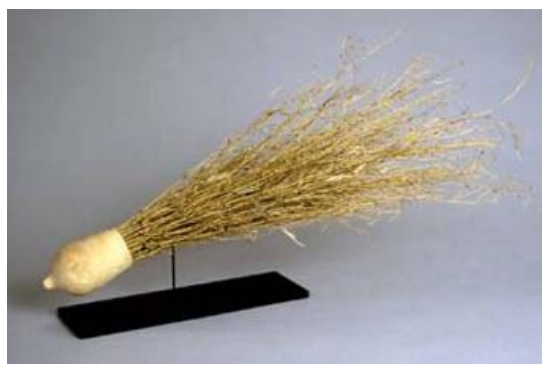

Laura Anderson Barbata, Autorretrato como Daphne, 1991.

Para Anderson Barbata los materiales que utiliza tienen una cualidad intrínseca que nos habla directamente al espíritu: las fibras vegetales, los hilos de algodón silvestre o los canutillos de bambú son materiales que contienen escrita una historia que habla de los orígenes. Desde esos primeros caminos haciendo mapas con hojas de orquídeas, la artista utiliza diferentes tipos de elementos vegetales tanto de su Cultura como de culturas ajenas, para buscar un acercamiento a otras formas de vida más en concordancia con la esencia vital del ser humano.

Así por ejemplo, en Desplazamiento temporal (1999), intervención realizada en el parque Wave Hill (Bronx, Nueva York), la artista parece hacer referencia al Séptimo desplazamiento especular (1969) realizado en Yucatán (México) por Robert Smithson. En dicha intervención, la artista coloca sobre un camino recubierto con pétalos de flores de papel, un espejo de doble cara que interrumpe el camino y nos devuelve duplicada la imagen del mismo. Esta especie de bucle confronta nuestra creencia en la confusa idea de progreso, todo ello con la finalidad de hacernos reflexionar sobre la pérdida de la capacidad de contemplación y sobre los procedimientos utilizados en el mundo contemporáneo. Esta obra, junto con Sendero desde el pasado (2000), realizada en el Parque Dante de la ciudad de Nueva York en la que también cubre con pétalos de rosas y flores azules algunas zonas del parque, se plantean como intervenciones efímeras que marcan espacios especiales en los que generar un diálogo Naturaleza/Cultura. Sin embargo, también nos remite a ciertas prácticas rituales con las que los artistas contemporáneos sitúan su trabajo en un plano quasi mítico, tal vez por su proceso de trabajo intenso, repetitivo, metodológico y cíclico. Un ejemplo de estas prácticas lo encontramos en la obra de Wolfgang Laib con sus trabajos de recolección del polen en las diferentes estaciones de año. 


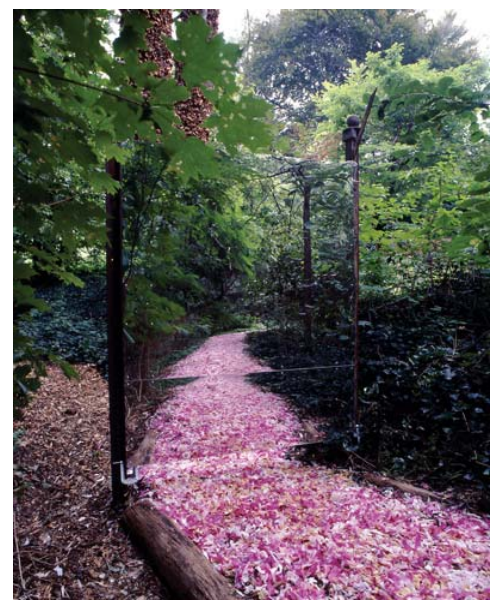

Laura Anderson Barbata,

Desplazamiento temporal, 1999.

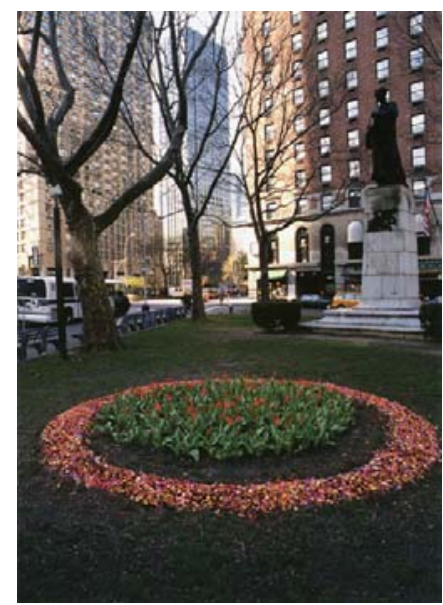

Laura Anderson Barbata,

Sendero desde el pasado, 2000.

El montaje cuidadoso y el mantenimiento cotidiano de sus piezas y exposiciones se inscriben de forma similar en el proceso orgánico natural de la vida que estas intervenciones de Laura Anderson Barbata tienen. La crítica de arte M. ${ }^{a}$ Lluisa Borras, describe este proceso de la siguiente manera:

[...] un largo proceso duro y agotador que comienza pidiendo a mayoristas de flores y floristas en general que le hagan graciosa donación de las flores marchitas, no aptas ya para la venta, que acumulará en cantidades industriales en su taller; que después aún Laura Anderson Barbata habrá de proceder a deshojar las flores y retirar los tallos, a disponerlo todo sobre estructuras metálicas confeccionadas para tal fin, en un espacio hermético provisto de deshumidificadores, y aun después deberá cargar en sacos los pétalos que transporta una vez por semana desde Nueva York hasta el Bronx. No se trata pues de un acto puntual, sino de todo un proceso minucioso, repetido una y otra vez ${ }^{514}$.

Estos caminos de flores funcionan más allá de la experiencia poética que su visión nos puede ofrecer. Se trata de un proceso que reúne diferentes culturas y comunidades, similar a una especie de recuperación de las tradiciones ancestrales de carácter religioso que se celebran aún hoy en día en muchos países. Ejemplo de ello son por ejemplo, las alfombras florales que, en las festividades importantes, se realizan para las procesiones típicas de la religión católica o las confeccionadas a la salida de sus casas, para los niños que van a tomar la primera comunión. En la misma dirección, en las instalaciones El que yace entre tiernas raíces (1999) y No, no es que yo sueño (1999), se remite al mundo prehispánico de los mayas y los aztecas, recurriendo a elementos como muebles viejos o una canoa desvencijada, a modo de altares de un culto

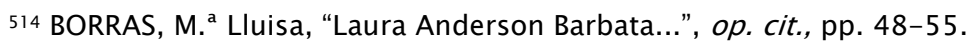


desconocido en el que se entremezclan imágenes religiosas con trigo verde, fotografías y libros, una manera en definitiva de convocar a la convivencia entre diferentes culturas anteponiendo el respeto a la diversidad de cada una.

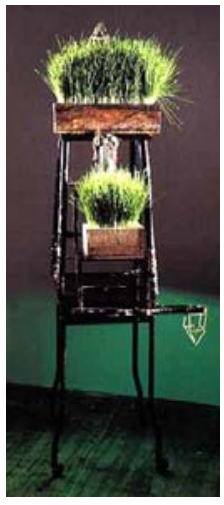

Laura Anderson Barbata, El que yace entre tiernas raíces, 1999.

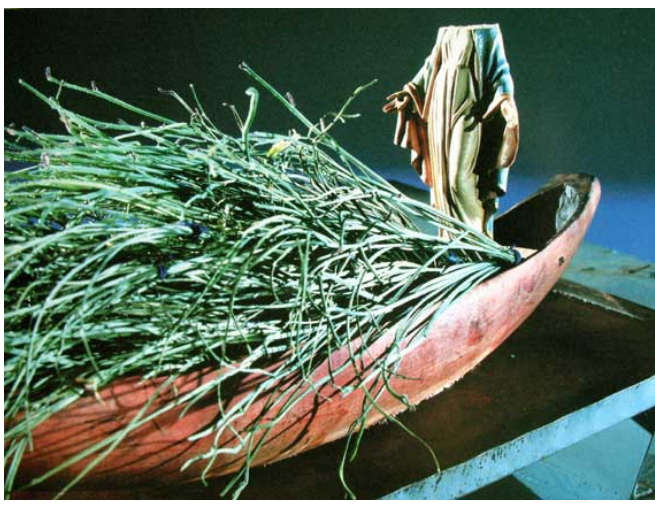

Laura Anderson Barbata,

No, no es que yo sueño (Detalle), 1999.

En resumen, el trabajo de Laura Anderson Barbata muestra la erosión cultural que ha ido mermando el rico patrimonio de creencias, mitos y tradiciones que muchos pueblos habían ido construyendo previamente a la conquista y que, tras la destructiva imposición con la que el hombre occidental cambió su visión del mundo, debemos aprender a rescatar.

\subsection{Cuenpo y ritual como proceso de intervención. Rosario García Crespo}

El diverso conjunto de artistas que vinculan sus producciones artísticas a la Naturaleza partiendo de un sentimiento entre ecológico y místico tienen en común la idea de ésta, como una entidad sagrada que necesita de nuestra atención y de nuestro cuidado. Debemos entender que a pesar de que sus prácticas se circunscriben a un ámbito contemporáneo, también es cierto que sus obras se emplazan en un punto que comunica al hombre con el cuerpo mítico de las religiones, sean éstas las que sean. Lo que aquí llamamos ritual no está en relación directa con ninguno de los hábitos religiosos que en la actualidad se puedan practicar. La mitología individual que cada uno de estos artistas desarrolla tiene que ver tanto con las cualidades intrínsecas de los materiales utilizados y las acciones llevadas a cabo, como con la posibilidad de comunicación y por lo tanto, de transmisión de los sentimientos experimentados. En este sentido no existe un ritual mágico sino un uso del sentido común, aquel que llama al cuidado de todo aquello que nos rodea y de lo que debemos sentirnos parte integrante.

En el ámbito social y, en cuanto a las prácticas artísticas estas circunstancias se manifiestan en un desplazamiento de la atención hacia entornos menos explorados y explotados por el hombre como bosques o espacios naturales. En 
un entorno urbano son los jardines y parques públicos los que funcionan como escenario para declaraciones de índole interactiva con el público potencial. En todos los casos la llamada está apuntando no sólo a la preservación, sino al cuerpo de lo social-humano del cual forma parte cada una de nuestras individualidades. De esta manera podemos apreciar que la Naturaleza aún y en el contexto polisémico que este concepto nos transmite, es un camino que, no por ampliamente recorrido por el hombre, ha perdido su capacidad de sorprendernos. En la actualidad, como actores de los cambios que estamos produciendo en el planeta, el arte se replantea su capacidad de interferir en contextos más amplios que el entorno cerrado de un taller, las galerías o los museos.

No cabe duda de que cada una de las acciones desarrolladas por los artistas involucra un más allá que la mera expresión estética y con este compromiso, muchos de los artistas exploran no sólo la percepción de la Naturaleza como ente físico y social sino con la perspectiva intimista de un crecimiento personal. De entre los planteamientos constatados por este tipo de artistas podemos observar tipos de procedimientos artísticos que conllevan el andar como práctica artística. Esta acción, como hábito, no es específicamente contemporánea. Desde tiempos inmemoriales la trashumancia nómada está inscrita en nuestra historia como el arquetipo de cualquier recorrido. Éstos se originan en las interminables batidas de caza del paleolítico cuyos significados simbólicos fueron traducidos por los egipcios por medio del $k a$, el símbolo del eterno errar. El errar primitivo ha perdurado a través de las religiones (el recorrido en tanto que mito) y en las formas literarias (en tanto que narración), transformándose de esta manera en recorrido sagrado, danza, peregrinación o procesión.

La obra de la artista Rosario García Crespo (México, D.F., 1953), se ha caracterizado por manifestar en lo procesual de sus recorridos la base de su encuentro con la Naturaleza. La artista usa el caminar como parte de un proceso o procedimiento para realizar su obra. Asimismo, en el camino y en los lugares que va encontrando, se vale de una serie de acciones programadas o no, en comunión con la Naturaleza. Aunque a lo largo de su trayectoria ha andado en diferentes entornos, tanto naturales como urbanos, últimamente se ha decantado más por un viaje hacia su propio yo interior. La artista parece seguir al pie de la letra las palabras de Marcel Réja, "Viajo para conocer mi geografía"515 rescatadas del Libro de los Pasajes por Walter Benjamin para describir al flâneur contemporáneo. Así, a manera de escritura con su propio cuerpo, utiliza el recorrido y la recreación de símbolos en el paisaje, para descifrar en este mismo proceso, la esencia de sí misma y de su propia obra.

515 RÉJA, Marcel, "Un loco" L’Art chez les fous: dessins, la prose, la poésie, El arte de los locos: dibujos, prosa, poesía, en BENJAMIN, Walter, "El Flâneur", El libro de los Pasajes, Edición de Rolf Tiedemann, Akal, Madrid, 2004, p. 421. 


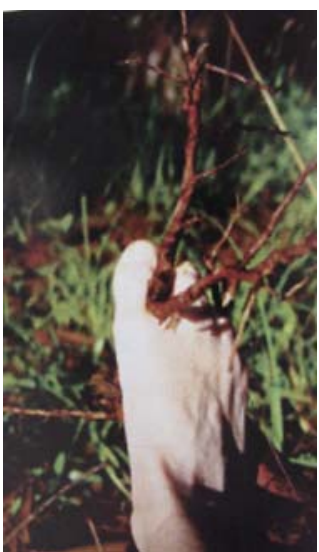

Rosario García Crespo, Mimetismo, 1997.

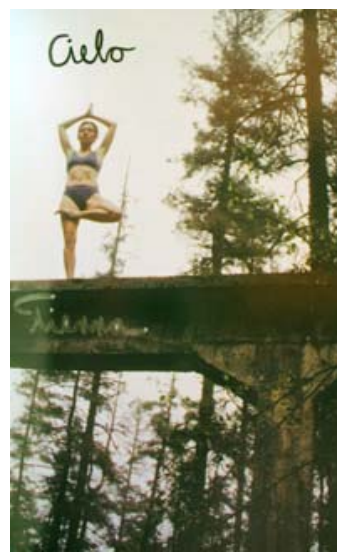

Rosario García Crespo, Desierto de los Leones, 1998.

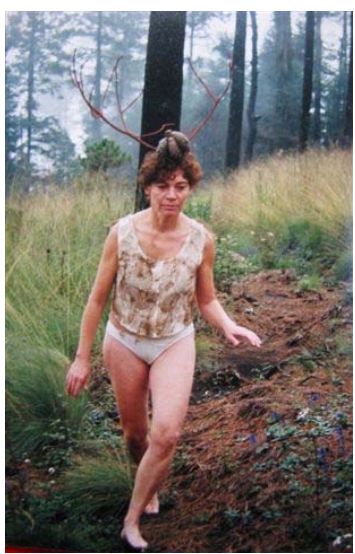

Rosario García Crespo, Caminata por el bosque, 1999.

Sirviéndonos como directriz de la investigación realizada por Francesco Careri, El andar como práctica estética516, podemos acercarnos a la comprensión de la obra de esta artista. Careri más que considerar la acción de andar como una herramienta crítica, la entiende como una manera obvia de mirar el paisaje. Para explicar su teoría, el autor en su estudio traza un recorrido crítico por la historia de la humanidad desde la trashumancia de los primeros cazadores recolectores y la colocación de los menhires, pasando por Egipto y Grecia Antigua, hasta los artistas del Land Art.

Hemos escogido el recorrido como una forma de expresión que subraya un lugar trazando físicamente una línea. El hecho de atravesar, instrumento de conocimiento fenomenológico y de interpretación simbólica del territorio, es una forma de lectura psicogeográfica del territorio comparable al walkabout de los aborígenes australianos 517.

Careri nos señala la idea de que en todas las épocas el andar ha producido arquitectura y paisaje y que esta práctica, olvidada por los arquitectos, ha sido reactivada por poetas, artistas y filósofos, quienes han sido capaces de mirar de manera diferente en los intersticios de la realidad, generando mediante esta reflexión, nuevas pautas de pensamiento. Acuña el término de Walkscapes para referirse al poder dinamizador del andar que pone en movimiento todo el cuerpo, el individual pero también el social. Al andar se manifiestan con mayor claridad los lugares que transitamos, y no sólo éstos, sino los contornos indefinibles, los espacios intermedios y las fronteras interiores de la ciudad. Es

516 Francesco Careri (Roma, 1966) es arquitecto. Desde 1996 desarrolla en Nápoles una investigación sobre el "El recorrido". Es miembro del Laboratorio de Arte Urbano Stalker (estructura abierta e interdisciplinar que realiza investigaciones sobre la ciudad a través de experiencias de transurbancia por los espacios vacíos y de interacción con los habitantes). 517 CARERI, Francesco, Walkscapes. El andar como práctica estética/Walking as an aesthetic practice, Land \& Scape Series, Gustavo Gili, Barcelona, 2003, pp. 10-17. 
una manera de trasformar el espíritu de quien a partir de ese momento ya sabe mirar, dilucidando con acierto los vacíos que nos son tan necesarios para una existencia plena. El hombre, a través del andar como una práctica natural pero a la vez consciente, va construyendo el paisaje que lo rodea.

El término recorrido se refiere al mismo tiempo al acto de atravesar (el recorrido como acción de andar), la línea que atraviesa el espacio (el recorrido como objeto arquitectónico) y el relato del espacio atravesado (el recorrido como estructura narrativa)518.

Siguiendo a Careri, el errar primitivo, el desplazamiento humano o el recorrido en tanto que mito, ha permanecido vivo en la religión y en las prácticas literarias, transformándose en recorrido sagrado, peregrinación o procesión. En la actualidad, se podría trazar una historia del andar como forma de intervención urbana. En paralelo, dentro de la historia del arte, Careri marca tres momentos fundamentales en la historia del siglo XX en donde podemos seguir la importancia y el significado de la acción de andar. Estos tres puntos de inflexión son la transición del Dadaísmo al Surrealismo (1921-1924), el paso de la Internacional Letrista a la Internacional Situacionista (1956-1957) con la Teoría de la deriva y la del Minimalismo al Land Art (1966-1967). Estos tres periodos nos permiten comprender la vivencia urbana de las diferentes formas de entender la ciudad.

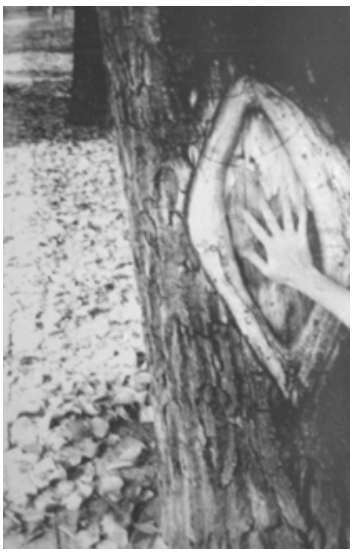

Rosario García Crespo,

Pasarse de la raya, 1995.

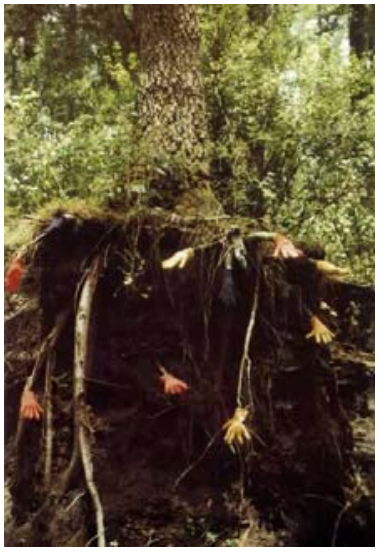

Rosario García Crespo, Sin título, 1997.

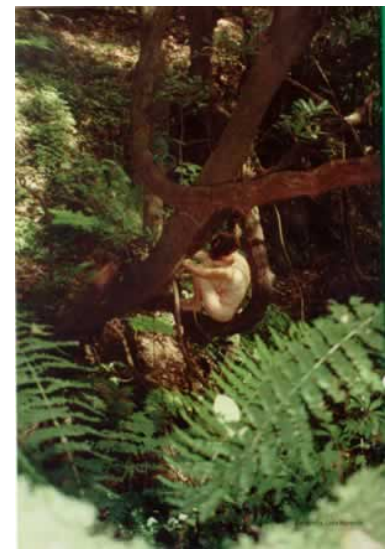

Rosario García Crespo, Desierto de los Leones, 1997.

El recorrido es una forma estética disponible tanto para la arquitectura como para el paisaje, el andar como un instrumento estético es capaz de describir y de modificar aquellos espacios urbanos que deberían comprenderse y llenarse más que de cosas, de significados. La reflexión de Careri nos conduce a entender el andar como una forma estética que, habiendo alcanzado el estatuto de disciplina autónoma permite considerar el vagabundeo o el errar como un valor más allá del error. 
La revalorización del recorrido durante el siglo XX se originó en el terreno de la literatura con Tristán Tzara, André Bretón y Guy Debord. Posteriormente en el campo de la escultura fueron Carl André, Richard Long y Robert Smithson quienes rescataron el término y la acción de andar, del camino hacia el anti-arte y el absurdo, al que los escritores lo habían conducido.
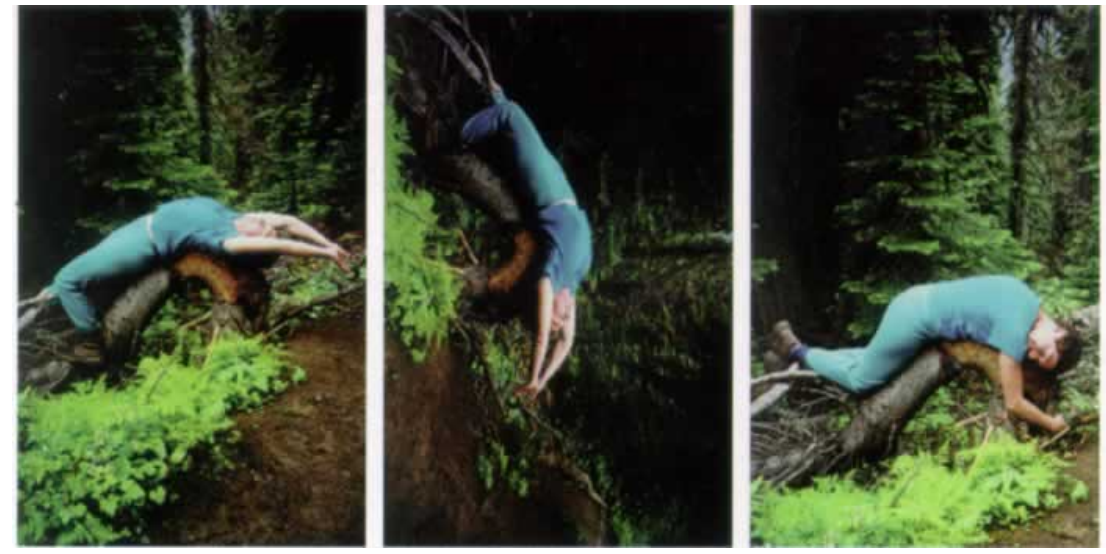

Rosario García Crespo, Caminata en el Parque Nacional Yoho Lake, 1999.

Enlazando con el significado de recorrido aportado por Careri, y volviendo a la obra de García Crespo, podemos observar que el concepto de recorrido, fundamental para esta artista, se centra en el cuerpo, el mundo vegetal y la escritura. De sus primeros recorridos en ciudades, la artista se centra en los grandes recorridos por los bosques. La génesis de este trabajo puede ubicarse en la exposición Caminata (1996) que Rosario realiza en el Museo Carrillo Gil. A través de la obra de García Crespo vemos la idea de recorrido ampliada con otra faceta del mismo: el caminar como proceso de transformación interior. La artista al caminar, articula una serie de relatos conformados por los recuerdos, signos y símbolos encontrados en el camino. Se trata del recorrido o viaje como herramienta de conocimiento interior. Así, los viajes que emprende esta artista nos remiten a Erich J. Leed, quien reflexiona sobre las relaciones que vinculan las palabras viaje, experiencia y peligro para evidenciar cómo en el origen del viaje late fundamentalmente, el deseo de mutación existencial:

Viajar es la expiación de una culpa, una iniciación, un acrecentamiento cultural, una experiencia: La raíz indoeuropea de la palabra experiencia es per, que ha sido interpretada como intentar, poner a prueba, arriesgar, unas connotaciones que persisten en la palabra peligro [...]. Esta concepción de la experiencia en tanto que cimiento, en tanto que paso a través de una forma de acción que mide las verdaderas dimensiones y la verdadera naturaleza de la persona o del objeto que lo emprende, describe también la concepción más antigua de los efectos del viaje sobre el viajero. Muchos de los significados secundarios de per se refieren explícitamente al movimiento: atravesar un espacio, alcanzar un objetivo, ir hacia fuera [...]. Una de las palabras alemanas que significan experiencia, Erfahrung, proviene del alto 
alemán antiguo, irfaran: viajar, salir, atravesar o vagar. La idea profundamente arraigada según la cual el viaje es una experiencia que pone a prueba y perfecciona el carácter del viajero aparece claramente en el adjetivo alemán bewandert, que actualmente significa sagaz, experto 0 versado519.

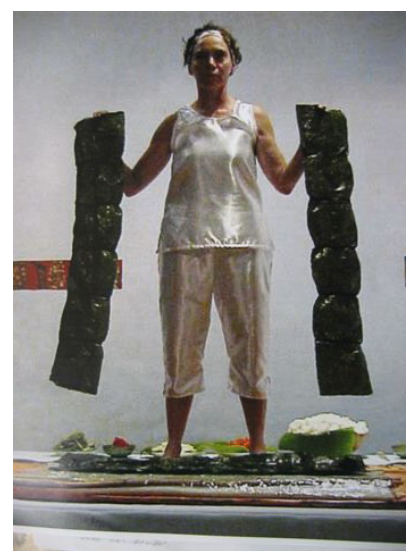

Rosario García Crespo,

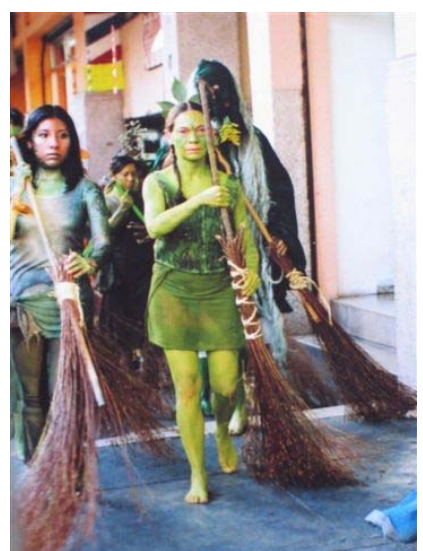

Rosario García Crespo,

Armonizar, dar y recibir, 2000. Los árboles limpian la ciudad, 2005.

Es en este sentido en el que Rosario García Crespo nos hace partícipes de sus experiencias. Retomando el concepto de peligro, la artista relata cómo en una de sus caminatas, pasaba sobre una tubería elevada -varios metros por encima del nivel del suelo- y sintió cómo ésta se cimbraba. Estaba sin proponérselo poniendo en peligro su vida, pero logró, mediante la respiración y el autocontrol, recuperar el equilibrio y cruzar al otro extremo. La artista, siguiendo al filósofo y novelista alemán Ernst Jünger, en su libro $L a$ emboscadura, nos remite a la experiencia y sentir de que si bien el bosque es un hábitat abrigado, es también la "morada de un peligro aniquilador" 520 que nos ofrece en contrapartida, la oportunidad de dialogar con nuestros propios miedos.

Ante a esta experiencia solitaria del peligro, cabe destacar aquí que las imágenes que sugieren ideas de puentes y pasajes peligrosos son frecuentes en rituales y mitologías iniciáticas relacionadas con el autoconocimiento y la sabiduría absoluta. Simbólicamente, estos elementos equivalen a la idea de tránsito de un estadio del ser a otro, operando como una especie de "mutación oncológica" 521 . Esta manera de entrar en contacto con el peligro es una forma, a la vez, de experimentar la sensación de lo sublime ${ }^{522}$, idea que simultáneamente

519 ERICH J. LEED, The Mind of the Traveller. From Gilgamesh to Global Tourism, en CARERI, Francesco, op. cit. p. 40.

520 JÜNGER, Ernst, La emboscadura, en GARCÍA CRESPO, Rosario, Caminar para descifrar, Consejo Nacional para la Cultura y las Artes, México, D.F., 2002, p. 35.

521 ELIADE, Mircea, Lo sagrado y lo profano, op. cit., p. 132.

522 BURKE, Edmund, op. cit., p. 42. 
se corresponde con la experiencia de magnificencia provocada por el espectáculo de la Naturaleza a la que García Crespo nos acerca.

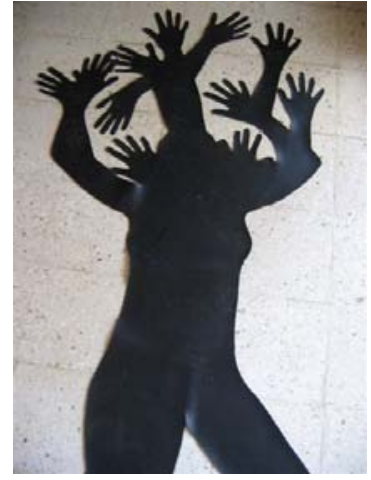

Rosario García Crespo, La sombra de los árboles transita la ciudad y el bosque (Detalle), 2006.

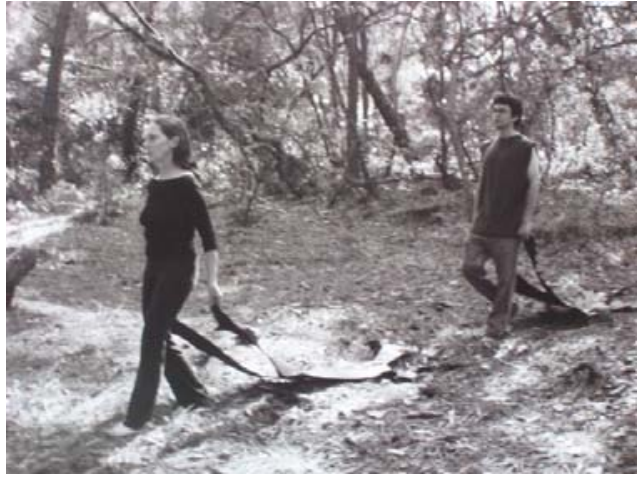

Rosario García Crespo,

La sombra de los árboles transita

la ciudad y el bosque, 2006.

En su libro Caminar para descifrar, la artista asume el andar como una forma nutritiva de existir: "Caminar es una manera de estar en el mundo, de pensar, de sentir diferente a la vida sedentaria" 523. A través de este habitar el mundo y mediante ciertas disciplinas de las que hace uso, reconoce que ha sido capaz de moverse de acuerdo a los cambios de la vida. En este libro, la artista registra fotográficamente sus acciones realizadas en varios lugares y durante largas temporadas, como son las realizadas en el Parque Nacional Desierto de los Leones, México (1997-1999), Canadá (1999) y en el Antiguo Camino a Chalma, Cuernavaca, México (2000-2001). En sus reiterativas caminatas, percibe los cambios que sufre el paisaje debido a los efectos de las estaciones, a la acción del ser humano e incluso a los accidentes (incendios). La artista nos habla del cuidado y la concentración necesarios al caminar: en determinadas circunstancias, la caminata debe adecuarse a las irregularidades del terreno o debe volverse más lenta, apoyando cuidadosamente el talón o la punta de los pies, para no perder el equilibrio o para no lastimar el propio cuerpo, hay que, en definitiva, "encontrar otras formas de andar" 524.

La búsqueda de equilibrio, entre otras, es una constante en sus acciones. Para estas ocasiones la atención se centra en los pies y la conexión de éstos con las raíces y las piedras. El proceso de registro fotográfico de las acciones da paso a la selección y composición de las mismas para lograr con ellas expresar el recorrido y la intención de las acciones. Como norma, el encuentro con los diferentes paisajes motiva la manera de intervenirlos.

523 GARCÍA CRESPO, Rosario, op. cit., p. 18.

524 GARCÍA CRESPO, Rosario, op. cit., p. 19. 


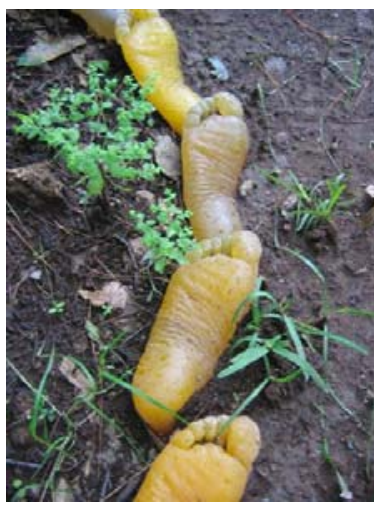

Rosario García Crespo, Sin título, 2002.

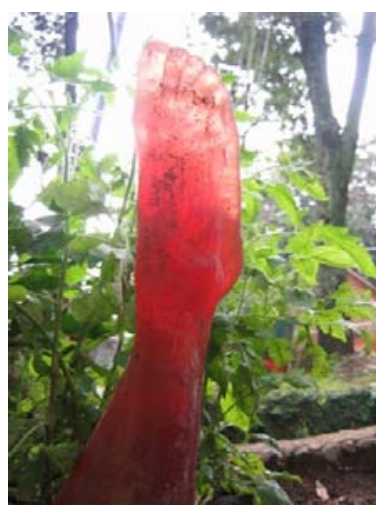

Rosario García Crespo, Sin título, 2002.

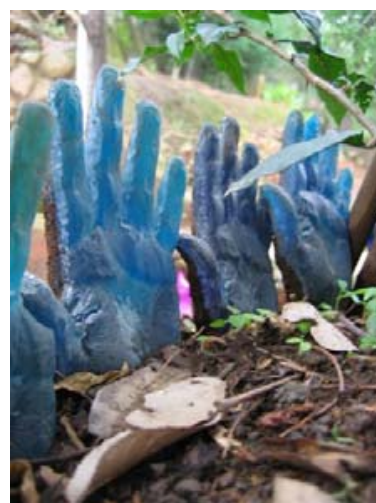

Rosario García Crespo, Sin título, 2002.

En opinión de José Manuel Springer, las fotografías del libro de García Crespo son el registro de una meditación sobre la Naturaleza al interior de la misma "que abren una posibilidad para el habitante promedio de la urbe" 525 . Con ellas la artista nos presenta más que representaciones de la Naturaleza o del cuerpo femenino, una actitud con la que unifica vida y arte. Sus series de rituales ofrecen metáforas o alegorías de la presencia de la Naturaleza en el propio cuerpo, sea éste el de la artista o el nuestro.

Para García Crespo el bosque representa simbólicamente un lugar espiritual que nos ofrece la posibilidad de reencuentro con lo místico así como con todos aquellos mitos relacionados con él y con los seres mágicos que lo pueblan en el inconsciente cultural de todas las civilizaciones. En él, el individuo debe enfrentarse a ciertas pruebas de sobrevivencia física y espiritual con la ganancia de adquirir un mayor conocimiento sobre sí mismo. Al tratarse de un ambiente que a los habitantes de la ciudad ya no nos es natural -todo aquello inesperado nos obliga a generar nuevas formas de respuesta - la opción que la artista propone es:

[...] deshabituarnos de los pasos-ciudad, para aprender pasos-montaña, pasos-caída, pasos-equilibrio, pasos-calor, pasos-frío, pasos-humedad y pasos-sequedad. [...]. El regreso diario al bosque, pese a las caídas, los golpes, el cansancio y la exposición a cambios de temperatura, nos renueva. Para las personas que nacimos y hemos vivido en la ciudad, el gesto de irse al bosque es un gesto nuevo y, los gestos nuevos expresan una nueva forma de existencia. El gesto de irse al bosque tiene que ver con el gesto del

\footnotetext{
525 SPRINGER, José Manuel, "Un recorrido cifrado", en Réplica 21. Obsesiva compulsión por lo visual, México, D.F., Fecha de publicación: 01.04.03, Disponible en red en <http://www.replica21.com/archivo/articulos/g_h/163_gardea_gcrespo.html>,

[Consulta 9, agosto, 2011]. José Manuel Springer es crítico de arte y comisario de exposiciones, además de fundador de la revista digital Réplica 21.
} 
acecho, el ser humano acecha la naturaleza porque personalmente no está en ella526.

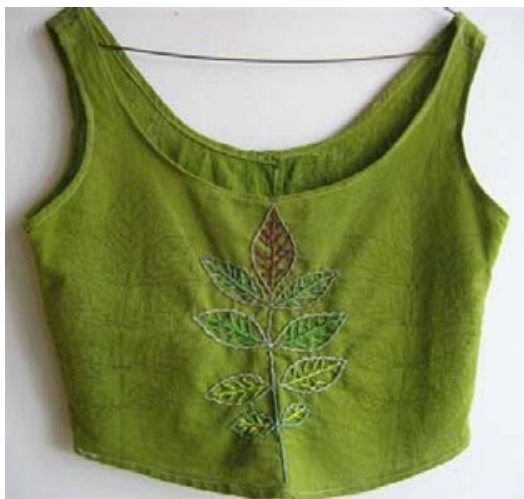

Rosario García Crespo, Camisa bordada, 2005.

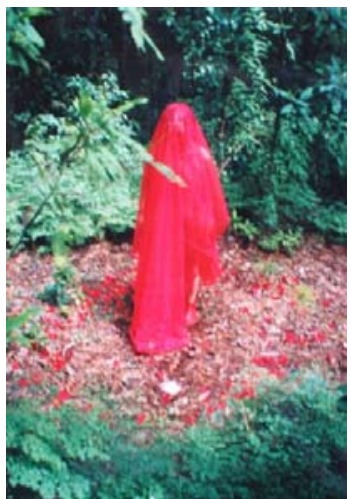

Rosario García Crespo, Acción de fuego, 2002.

Como veremos más adelante, su obra muestra conscientemente, una interesante intersección entre el mundo vegetal - se ha inclinado además de a la observación, a la recolección de ciertos vegetales- y el acto de desplazarse en el espacio. Para Rosario la experiencia de caminar cotidianamente le permite concebir el espacio de una manera diferente. Su relación con el espacio es escuchar y atender a lo que éste le va pidiendo para poder transitarlo. Esta acción, que le permite abrir espacios peculiares que no son perceptibles a simple vista sino en el transcurso de recorridos cotidianos por el mismo lugar, se asemeja a una experiencia religiosa. El bosque es el escenario de un acontecimiento: el cuerpo en el espacio. La reflexión en torno al tránsito de la experiencia religiosa -típica del ser humano primitivo- al recorrido como experiencia estética es referida por Careri de la siguiente manera:

La acción de atravesar el espacio nace de la necesidad natural de moverse con el fin de encontrar alimentos e informaciones imprescindibles para la propia supervivencia. Sin embargo, una vez satisfechas las exigencias primarias, el hecho de andar se convirtió en una acción simbólica que permitió que el hombre habitara el mundo. Al modificar los significados del espacio atravesado, el recorrido se convirtió en la primera acción estética que penetró en los territorios del caos527.

En este contexto, la artista genera acciones y utiliza simbolismos universalmente conocidos que devienen concepciones de lo sagrado. De la noción de espacio sagrado, Rosario destaca la importancia particular en su obra del centro. Remitiéndonos de nuevo a las culturas primitivas y para explicitar su propia búsqueda y encuentro consigo misma, la artista concibe diferentes rituales para llegar al centro a través del viaje místico.

526 GARCÍA CRESPO, Rosario, op. cit., pp. 36-37.

527 CARERI, Francesco, op. cit., p. 20. 
En la simbología del centro se considera que cualquier lugar puede significar el centro del universo por efecto de un ritual que conecte la tierra con el cielo. En diversas culturas se considera el símbolo de una montaña, de un árbol o de un pilar como el centro del mundo, como inserción del espacio sagrado en el espacio profano528.

En su obra aparecen mandalas o círculos mágicos trazados en el bosque en una acción sinérgica con el espacio y en pos del efecto benefactor de estos símbolos sobre la propia autora quien, con una cita de Jung, aclara su uso.

Según Jung el símbolo mandálico no sólo es una expresión sino también tiene efecto benefactor sobre su autor. Las prácticas mágicas son proyecciones del alma que le facilitan a la persona la vivencia de su centro espiritual, donde puede reencontrarse con su alma y curarse529.

A través de la investigación sobre los mandalas y su significado, la artista desarrolla acciones, movimientos circulares, arriba-abajo, adentro-afuera en las que involucra la acción de su propio cuerpo, así como ciertos colores con los que identifica los conceptos sobre los que trabaja y quiere trasmitir. Jaime Moreno Villarreal en la introducción al libro Caminar para descifrar nos dice, "ponerse en camino es comenzar de nuevo la vida", así nos presenta a la artista quien habiendo elegido como disciplina espiritual y artística la caminata, especialmente a través de los bosques, encuentra en ellos santuarios que le permiten abrir nuevos senderos.

[...] el camino del bosque no consiste de una sola senda sino de la multiplicidad de rumbos que se abren y que hay que ir librando, inventando electivamente en un recorrido. En el cruce de esta invención con la naturaleza surgen encuentros únicos. [...]. Algo tiene su práctica artística que recuerda los peregrinajes que, durante ciertas estaciones, grupos de romeros realizar en todo el mundo hacia lugares sagrados. Los recorridos y acciones de García Crespo, como los de los peregrinos, se alientan mediante el uso de símbolos añadidos a la vestimenta, se nutren de una comunicación con la naturaleza y el paisaje, y se pueblan de episodios simbólicos530.

Este recorrido, búsqueda mítica y mística a través de los bosques es una indagación, como en el caso de muchos otros artistas, en torno a la propia identidad -el yo como persona y el yo como artista- que encuentra en estos desplazamientos el espacio adecuado para efectuar una suerte de rituales, de toma de contacto con el medio natural. Es un viaje hacia el interior de uno mismo, una búsqueda de la propia naturaleza. Mediante los ritos que prescribe, la artista se funde con los elementos del paisaje, las piedras, la tierra, los

528 GARCÍA CRESPO, Rosario, op. cit., pp. 86-87.

529 GARCÍA CRESPO, Rosario, op. cit., p. 88.

530 MORENO VILLARREAL, Jaime, "En camino", en GARCÍA CRESPO, Rosario, op. cit., p. 11. Jaime Moreno Villarreal es poeta, escritor y editor. 
árboles, las aguas, el paisaje. Esta fusión es un acto de purificación y de investidura:

[...] la artista se lava o se unge, se alinea en equilibrio o se somete a los ritmos del viento, adopta los colores mimética o diferenciadamente, 0 despliega una acción que la convierte en un puente entre los elementos [...]. El viaje que la artista ha emprendido implica una progresión espiritual531.

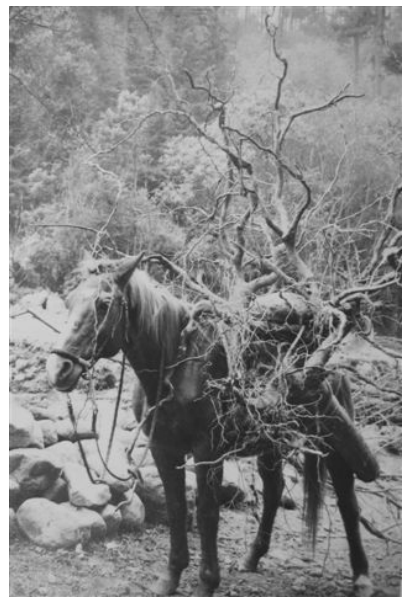

Rosario García Crespo, Árbol Caído, 1998.

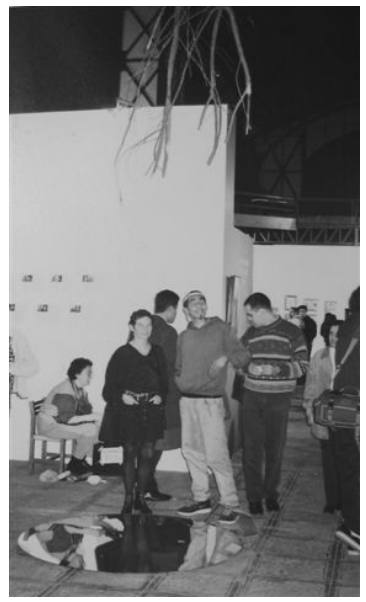

Rosario García Crespo, Árbol Caído, 1998.

El mundo vegetal, objeto de nuestra investigación, es fundamental en su inspiración. De la ciudad al bosque, el hábito de caminar amplió el radio de contacto y de vivencia con los elementos del paisaje, así como con sus integrantes, sean éstos personas, animales o plantas. El paso de la representación del cuerpo a la acción con él y del uso del fragmento a la totalidad del cuerpo de forma natural, la hace transitar de lo objetual de la obra al concepto de actitud.

La pregunta sobre el camino y el viaje no puede responderse con la pura razón, es necesario emprender el viaje. Caminar significa aceptar la vida como un viaje, no acostumbrarse a quedarse en ninguna parte, porque la vida es un fluir constante [...]. Caminar es una manera de estar en el mundo, de pensar y sentir diferente a la vida sedentaria. La vida se traduce en pasos y los pasos en signos que están aún por descifrar [...]. A partir de 1997 mis caminatas se trasladaron de la ciudad al bosque532.

\footnotetext{
531 MORENO VILLARREAL, Jaime, "En camino", en GARCÍA CRESPO, Rosario, op. cit., p. 12.

532 GARCÍA CRESPO, Rosario, op. cit., pp. 18-19.
} 


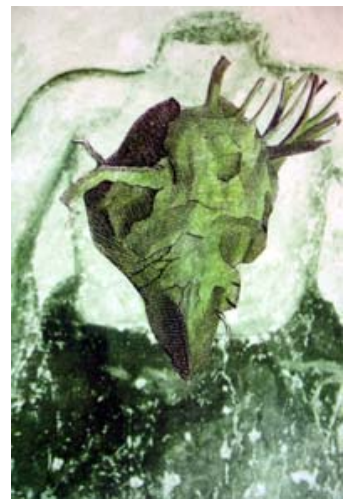

Rosario García Crespo,

Caminar, 2003.

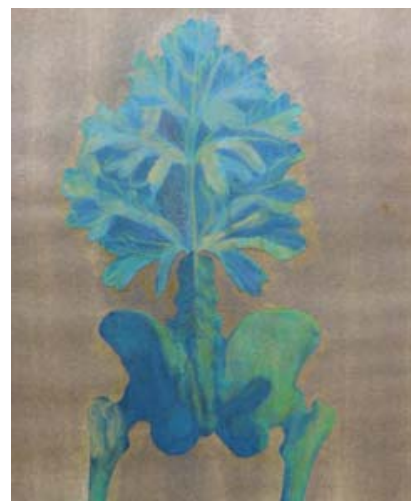

Rosario García Crespo, Herbario imaginario, 2005.

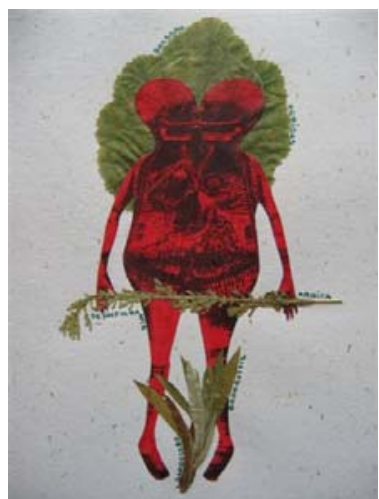

Rosario García Crespo, Gordolobo, 2005.

Con todo ello la artista encuentra y practica otras formas de andar. Pasa de poner su atención en aquello que estaba al alcance de sus manos a prestar atención a sus pies para controlar mejor los pasos o a percibir de manera más amplia el entorno que la rodea para a partir de él generar su trabajo. Así, la artista abraza un árbol cuyo tronco torcido crece en curva contradiciendo la verticalidad y, ante la carencia de corteza del mismo, ella adopta la postura junto con el árbol, en actitud de protección. En otras ocasiones, caminando al lado de un río respira al ritmo de las corrientes acuáticas que se encuentra y realiza un rito de simulación en el que el agua fluye desde sus pies hasta sus brazos o utiliza su cuerpo, para acostarse en forma de cruz sobre la sombra proyectada de un árbol. Sin lugar a dudas, sus acciones involucran un proceso de mimetización con el paisaje.

Rodearse de verde, de flores, de hongos, hasta sentir que empiezan a salir ramas por los pelos, por los dedos de los pies y de las manos. Mimetizarse con el entorno, ser piedra, árbol, tierra. Perderse en el todo para encontrarse un poquito más adentro533.

Al igual que el proceso que desarrollan ciertos animales que cambian de color adquiriendo el de su entorno, la artista inicia su recorrido con un plan trazado, amén de con una vestimenta diseñada por ella misma, de un determinado color. En el transcurso del viaje pasa de sentirse una extraña en el bosque, a incorporarse a él. Después de un día completo de caminar, con las hojas pegadas al cuerpo, las ramas a los cabellos, la tierra a los pies; de sudar, arrastrarse, mojarse y llenarse de lodo, finalmente se consuma la metamorfosis y se produce la alquimia de los colores. Se trata fundamentalmente de sensaciones físicas, pero también espirituales; tras este proceso, los pensamientos se desvanecen y ciertamente uno adquiere otra actitud frente a la vida, "ya no sentía humedad, olores a plantas y a tierra, sentía como vegetal y me movía como animal" 534 .

533 GARCÍA CRESPO, Rosario, op. cit., p. 19.

534 GARCÍA CRESPO, Rosario, op. cit., p. 45. 


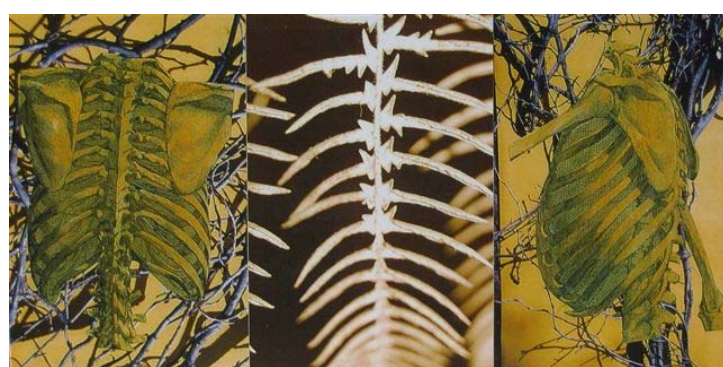

Rosario García Crespo, Sin título, 2005.

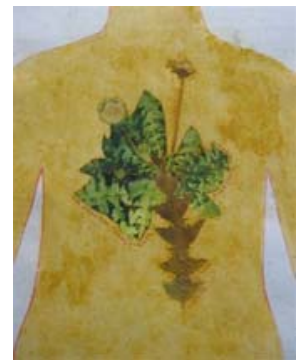

Rosario García Crespo, Diente de León, 2005.

Este anhelo de Naturaleza y su utilización en las artes plásticas, está en consonancia con la sensación de pérdida que, a su vez, se corresponde directamente con nuestra vida cosmopolita. Para la artista, a partir de la década de los años sesenta, se verifica en el arte un retorno a los elementos, debido en particular a la problemática ambiental. Encontramos que en algunos de sus planteamientos García Crespo se acerca a la obra de otros artistas que han utilizado el caminar como práctica estética en México535. Todos ellos se identifican con la idea de la acción de caminar como proceso creativo y como generador de nuevas visiones para la sociedad.

El interés artístico por el acto de deambular, está en relación directa con los recorridos de la Internacional Situacionista (1956-1957) así como con la Teoría de la deriva de Guy Debord. La idea de perderse por la ciudad se reconocía como una posibilidad expresiva concreta de anti-arte, a la vez que, como un medio estético-político subversivo contra el capitalismo. Haciendo un poco de historia, en México, encontramos noticias de estas tendencias por el Situacionismo en Manifiesta II, Cábula situacionista (1997). En este evento, que se llevó a cabo en el Centro Histórico de México, D.F., García Crespo junto con un grupo de muchachos vestidos de blanco, arrastraron la pieza Aya con tres pechos, enfrente del Palacio Nacional y alrededor del Zócalo, repartiendo "panes del deseo" en la esquina de las calles Moneda y Seminario. También en esta ocasión Juan José Gurrola -autor de teatro y artista polifacético- quien fue el responsable del marco teórico del encuentro, realizó la obra Asalto situacionista, describiéndola como un Neosituacionismo, en un intento de retomar el movimiento internacional fundado en 1957536.

535 Nos referimos en particular, al artista mexicano-belga Francis Alÿs, quien destaca, entre otras cosas, por sus recorridos erráticos sea, arrastrando un artefacto como en la obra The Collector (1991), desplazando un trozo de hielo como en Algunas veces el hacer algo no lleva a nada (1997), dejando caer una línea de pintura verde como en The green Line (2004), Zapatos magnéticos (1994), Duet (1999), Walking a painting (2002), The Modern Procession (2002), The Leak (2002), Railings (2004) o en otras muchas piezas realizadas en torno al concepto de recorrido como generador de nuevas experiencias.

536 VARGAS, Ángel, "Incursión en el performance de la Jornada Semanal. La cábula situacionista y lo insólito en el Centro Histórico", en La Jornada, Sección Cultura, México, 
En exposiciones anteriores, como Caminata (1996), el proceso de caminar no es en sí el cuerpo de la obra expuesta. Se trata fundamentalmente de dibujos, pinturas, fotografías y collages, fruto de sus experiencias en varios de sus viajes como becaria del Fondo Nacional para la Cultura y las Artes, con el proyecto $\mathrm{La}$ letra como imagen. A pesar de exponer obra gráfica, la artista, en una entrevista realizada a raíz de esta exposición, declara servirse del caminar como forma de pensamiento para, mediante su obra, llevar al espectador por los lugares que ella ha visitado. Su intención al mostrar y exponer los caminos que ella ha recorrido, es motivar al espectador a que encuentre el suyo:

Al ir caminando -dijo- vas encontrando tu propio ritmo y tienes mucho más cercanía con el entorno urbano o con la naturaleza que si viajaras con un medio de transporte [...]. Elegí el caminar como una forma de pensar y de ir construyendo mis imágenes, así realicé varias series de polípticos en pequeño formato [...] y les fui integrando las figuras que fui encontrando537.

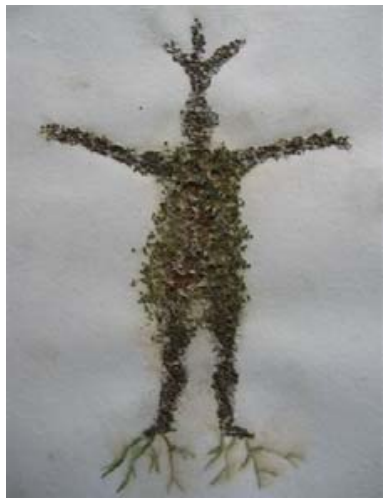

Rosario García Crespo, Sin título, 2005.

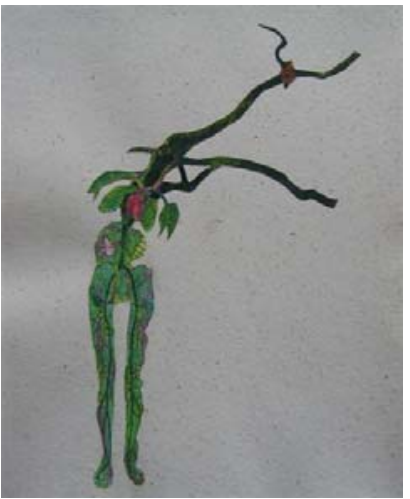

Rosario García Crespo, Sin título, 2005.

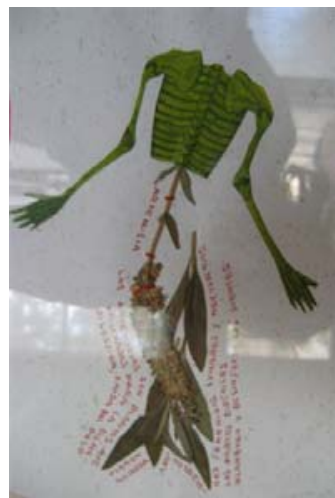

Rosario García Crespo, Artemisia, 2005.

Estamos frente a una mirada detenida en el entorno que nos propone la posibilidad de una gramática de imágenes. Esta lectura implica una atención particular a la marcha, una singular manera de andar pendientes del paso y de todo aquello que nos circunda. De esta manera, la artista encuentra señales que registra y que a modo de escritura, nos deja su testimonio, a manera de relato de su propio paso.

Esta unidad de lectura y escritura en acto, en marcha, puede llamarse un texto: esto es lo que se halla en la obra plástica de Rosario García Crespo. La intención de la artista es hacer relatos a partir de la yuxtaposición de su

D.F., 26, abril, 1997, p. 26. De esta exposición se editó un catálogo: AA. VV., Manifiesta 2. Cábula situacionista, Instituto Nacional de Bellas Artes, Ex-Teresa Arte Alternativo, México, D.F., 1997.

537 PALACIOS GOYA, Cynthia, 'El caminar, una forma de pensamiento. Exposición pictórica de Rosario García Crespo", en El Nacional, Sección Cultura, 15, marzo, 1996, p. 32. 
paso sobre estructuras preexistentes [...]. Su atención sobre el propio paso revela un modo de estar en viaje por el mundo: al apropiarse de lo pasajero, la artista ha encontrado en la fotografía y en el souvenir modos de marcar el rastro y recolectar el tránsito538.

La recolección de pequeñas experiencias se convierte en una metáfora de la búsqueda de dirección, de equilibrio y de armonía, en una manera de reunir camino y vida. Podemos situar la trayectoria de esta artista, de forma tentativa y salvando las distancias, en un punto cercano a los procesos de trabajo de algunos de los artistas agrupados bajo la denominación de Land Art. Durante la segunda mitad del siglo XX, estos artistas experimentaron con el andar como una manera para intervenir en la Naturaleza. La experiencia (en apariencia insignificante, publicada en 1966 en la revista Artforum) del relato del viaje realizado por Tony Smith por una autopista en construcción, desencadenó en que algunos escultores incursionaran por aquel entonces, en la idea de recorrido. Algunos como Carl André, lo hicieron reelaborando la visión de Smith del recorrido por la autopista como presencia cada vez más ausente en el interior del espacio real y realizaron esculturas sobre las que se podía andar. Otros como Long o Fulton, realizaron un arte que se materializaba andando. Si cada uno de estos artistas generó su propia interpretación del tema desde el recorrido como objeto, al recorrido como experiencia, podemos argumentar que en la obra de Rosario el paso del objeto a la experiencia fluye de la misma manera.

En 1967 Richard Long realiza A Line Made by Walking, una línea dibujada hollando la hierba de un prado. Su acción deja una traza en el suelo, el objeto escultórico se encuentra completamente ausente, el hecho de andar se convierte en una forma artística autónoma. El mismo año, Robert Smithson termina A Tour of de Monuments of Passaic. Se trata del primer viaje a través de los espacios vacíos de la periferia contemporánea539.

La obra-acción de Long ha sido considerada, por su absoluta radicalidad y simplicidad formal, un episodio fundamental del arte contemporáneo. Esta pieza, que genera una sensación de infinitud, situada a medio camino entre la escultura, el performance y la arquitectura del paisaje, inaugura el concepto de lo efímero en el arte. Tras el paso del artista, la hierba crecerá de nuevo y, de esta manera, su toma de contacto con la Naturaleza primordial y con su recién inaugurada nueva religiosidad, lo alejarán del resto de los artistas del Land Art. Su trabajo, como él mismo reconoce, va acompañado de una preocupación ambiental y ecológica: "Los espacios abiertos están desapareciendo cada vez más [...]. Para mí, estar en la naturaleza es una forma de religiosidad inmediata [...], la naturaleza produce mucho más efecto sobre mí que yo sobre ella" 540 .

538 MORENO VILLARREAL, Jaime, "Caminata por la vía", en Caminata. Rosario García Crespo, Museo Carrillo Gil, Consejo Nacional para la Cultura y las Artes, México, D.F., 1996, p. 3.

539 CARERI, Francesco, op. cit., p. 23.

540 WHITE, Kenneth, en CARERI, Francesco, op. cit., p.148. 


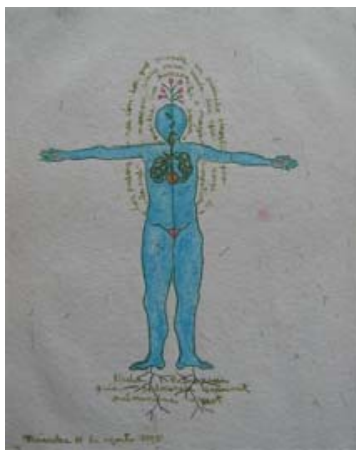

Rosario García Crespo,

Hierba pulmonaria, 2005.

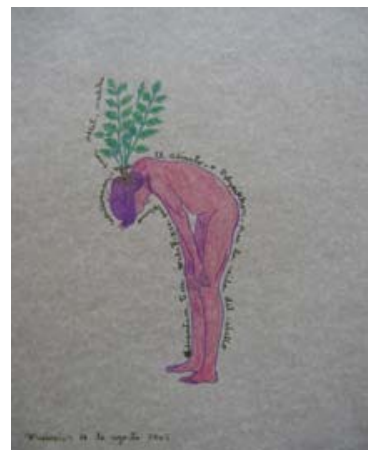

Rosario García Crespo,

El adianto para la caída del cabello, 2005.

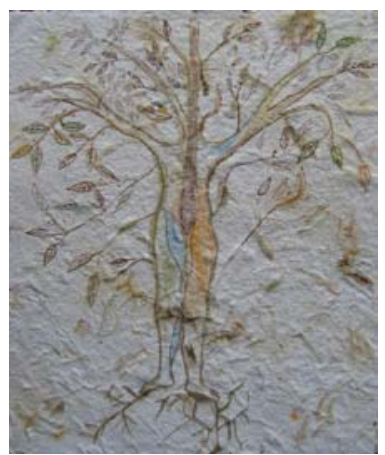

Rosario García Crespo,

Sin título, 2005.

De forma similar García Crespo, en consonancia con la lógica de Pierre Gassendi (1592-1655) -quien formulara la frase ambulo ergo sum (camino, luego existo) $y$, en contraposición a la de Descartes (1956-1650) cogito ergo sum (pienso, luego existo) - nos recuerda con su trabajo que los recorridos por el bosque permiten alcanzar una toma de conciencia que afecta directamente al actor de los mismos. El bosque se configura así, como una especie de santuario que permite acceder y consolidar el conocimiento. Esta idea relacionada con un cierto concepto de animismo, se apoya en las creencias de determinadas culturas antiguas para las cuales, los árboles -en ciertos rituales de paso y de cambio de las estaciones- son seres animados. Cabe destacar que, entre los celtas, es conocido el culto de los druidas al roble y que la palabra antigua usada para santuario -en latín nemus- significa bosque ${ }^{541}$.

El culto a los árboles se fundamenta en la idea primitiva de que en ellos habitan ciertos espíritus y de que por lo tanto, todo en este mundo está animado. De hecho, esta idea pervive en diferentes comunidades primitivas $y$ ha ido transformándose conservando a lo largo del tiempo, la estrecha relación entre plantas, árboles y humanos. En los cuentos populares, la vida de una persona está ligada a la de las plantas de tal manera que su marchitamiento o su prosperidad está en relación directa con la del humano con la que se relaciona542. Entre ciertas culturas, esta idea se repite en la costumbre de conferir género a los árboles y en las cualidades que se les atribuye a éstos, al realizar ceremonias que vinculan árboles y personas. En esta misma línea y, mediante su capacidad creativa, la artista se configura en una especie de mediadora o chamán capaz de dialogar y establecer puentes entre las distintas fuerzas de la Naturaleza, con sus capacidades y propiedades tanto beneficiosas como destructivas para el ser humano. Los procesos de deambular y de apropiarse de signos y símbolos de diferentes culturas han llevado a García Crespo a una relectura de su convivencia personal con su entorno actual, el bosque de Cuernavaca, a donde cotidianamente dirige sus pasos para seguir

\footnotetext{
541 FRAZER, James George, op. cit., p. 143.
}

542 FRAZER, James George, op. cit., p. 764. 
preguntándose, en la actitud de un nómada543 que interpreta las señales que tanto el medio como su cuerpo le trasmiten.

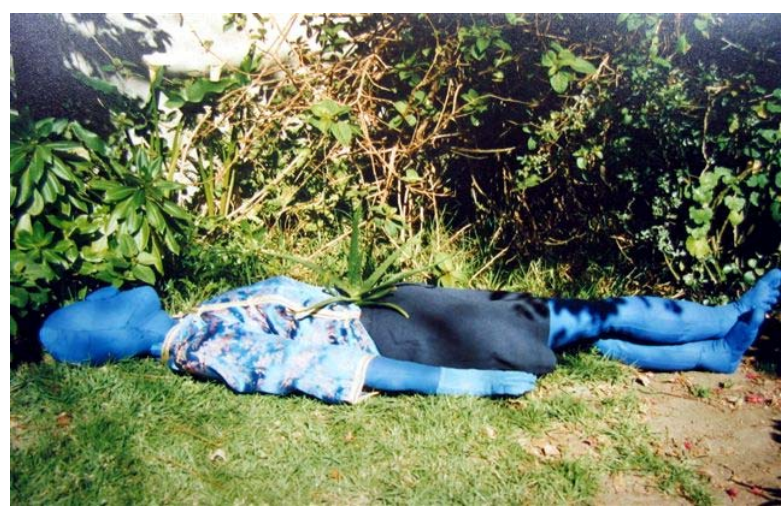

Rosario García Crespo, Morti Vita Datur, 1998.

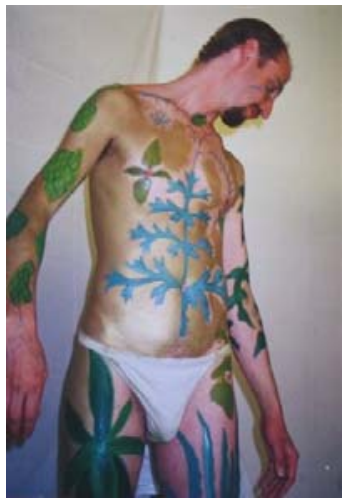

Rosario García Crespo, Arcano curativo, 2003.

A partir del 2002, su labor se ha ido ampliando con la recolección de diferentes especies del mundo vegetal, en particular aquellas que se encuentran vinculadas a ciertos aspectos curativos o medicinales. En su obra, García Crespo ha dibujado, pintado, fotografiado, bordado, cultivado y observado las plantas. Como antecedente, en 1998 realizó una instalación compuesta por cuerpos humanos conformados con ropa rellena de tierra. En el vientre de cada uno de estos cuerpos la artista sembró una planta de sábila con la idea de propiciar con ello -a través de las propiedades sanadoras de esta planta- un cierto beneficio curativo en esas personas. Más tarde participaría junto con un grupo de artistas, en el proyecto Arte y Medio Ambiente en la Reserva Natural de Sian Ka'n (Quintana Roo). La idea de la obra surge con el planteamiento de intervenir el espacio con los mismos materiales del lugar. En esta ocasión, García Crespo realizó un pequeño jardín con forma de una silueta de mujer a la que Ilamó $L a$ curandera (2002).

En esta pieza -seis veces más grande que el tamaño de su propio cuerpo- la artista sembró plantas específicas que curan cada una de las partes del mismo cuerpo humano que representaba la obra. Para elaborarla, García Crespo caminó por los alrededores del lugar con un curandero maya quien le explicó las cualidades medicinales de cada una de las plantas que luego utilizó.

543 "Nómada: En griego nomos significa pasto, y el nómada era un jefe o un anciano del clan que dirigía la distribución de los pastos [...]. El verbo nemein -pasturar, pacer, disponer o esparcir- tiene desde los tiempos de Homero otro significado: distribuir, repartir, dispensar, referido sobre todo a las tierras, los honores, la carne y la bebida", CHATWIN, Bruce, en CARERI, Francesco, op. cit., p. 31. 


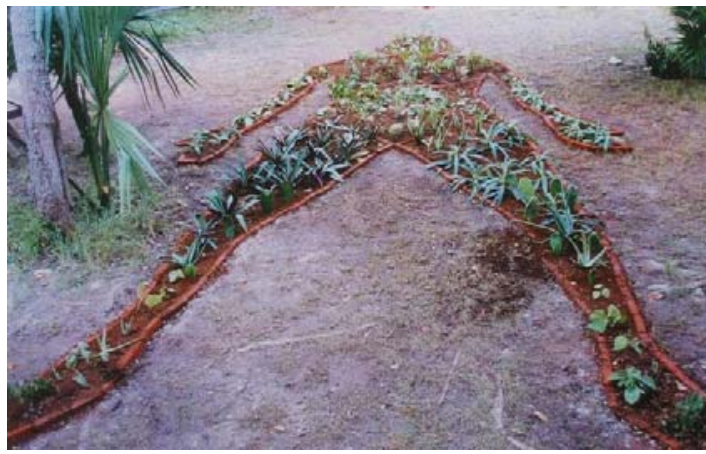

Rosario García Crespo, La curandera, 2002.

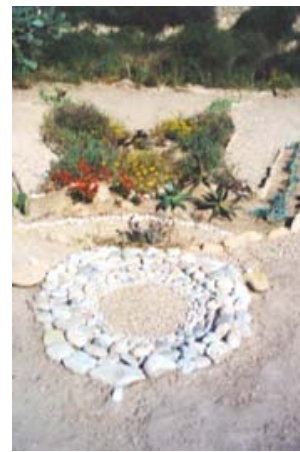

Rosario García Crespo, La mujer del desierto, 2004.

La artista recupera con esta intervención escultórica parte de la historia del lugar puesto que en la época prehispánica, ese mismo lugar era un jardín de plantas curativas. Con estas acciones relacionadas con las plantas, sus propiedades curativas y su específica vinculación con las diferentes partes del cuerpo humano, la artista se acerca a la idea del médico indio y ejerce a la manera de éste quien, como especialista diagnostica y prescribe a partir de síntomas naturales corporales, pero interpretándolos en el marco de una significación simbólica más amplia, en juego con los elementos de la Cultura.

Tampoco en el ejemplo de la medicina india es posible establecer límites estrictos con otras áreas del pensamiento y las vida social: la conducta condiciona la salud; el conocimiento de las propiedades curativas de las plantas forma parte de la concepción total de la naturaleza y se expresa en el simbolismo correspondiente; lo que llamamos religión y lo que llamamos medicina, se entrelazan por muchas fronteras, hasta borrarlas 544.

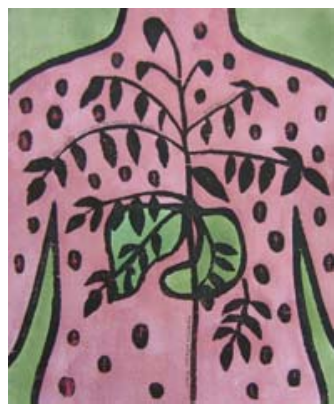

Rosario García Crespo, Coffea arábica. Herbario Imaginario, 2006.

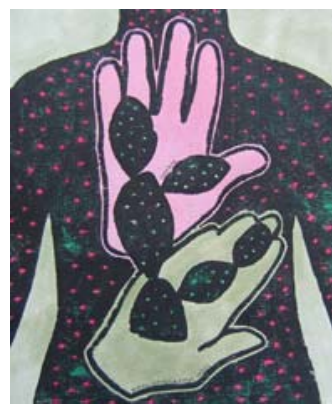

Rosario García Crespo, Nopal. Heridas, Herbario Imaginario, 2006.

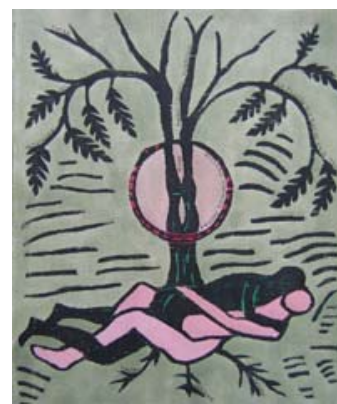

Rosario García Crespo, Árbol cósmico. Herbario Imaginario, 2006.

En el año 2003, dentro del Encuentro de Pintura Corporal en México, en el Museo del Chopo, México, D.F., la artista pinta sobre el cuerpo de una persona algunas de las plantas que curan las partes específicas sobre las que son

544 BONFILL BATALLA, Guillermo, op. cit., pp. 65-66. 
pintadas esas plantas en la piel de la persona. Desde entonces y hasta la fecha, la artista ha estado aprendiendo herbolaria con una de las viejas curanderas de Amatlán, Morelos. Con ella ha descubierto que las hierbas de los caminos tienen en la tradición de los pueblos y en las ciencias naturales, nombre y poderes curativos.

Este trabajo de campo ha derivado en la creación de un Herbario Imaginario (2006), con el que la artista ha ampliado el horizonte de sus recorridos. Su práctica de caminar se ha enriquecido con la recolección y el secado de estas plantas para su conocimiento y utilización, lo que implica asimismo un andar siguiendo las estaciones del año, por los diversos caminos en donde crecen las plantas a recolectar. Este nuevo proyecto consiste en realizar un herbario imaginario en el cual se relacionan las formas y las estructuras de las plantas con las de los huesos y otras partes del cuerpo humano, según la zona que curen dichas plantas. La creación de estas imágenes elaboradas mediante pintura, fotografía, collage y otras técnicas mixtas, parte del estudio de la herbolaria mexicana y de la investigación bibliográfica al respecto. De nuevo, la artista construye un sistema de signos. En esta ocasión establece una relación directa entre el ser humano, su representación y el mundo vegetal, a través del estudio de los mitos y los ritos que ancestralmente han estado unidos a las plantas, creando de esta manera una nueva cosmología especulativa a través de la cual dialoga con su obra:

Los mismos principios del orden universal parecen encontrarse en los sistemas clasificatorios con los que se entiende la naturaleza; las clasificaciones indias del mundo vegetal, hasta donde han sido estudiadas, emplean frecuentemente términos que provienen de una manera ancestral de concebir el mundo; en la nomenclatura botánica se asocian frecuentemente ciertas características propias de las plantas con los colores que simbolizan los rumbos del universo, y éstos corresponden a su vez a deidades que están ligadas al destino de los hombres. Los principios de clasificación se aplican también, hasta donde se sabe, para distinguir las partes, los órganos y los elementos del cuerpo humano; se conectan así con las concepciones sobre salud y enfermedad y con la práctica terapéutica y rituales correspondientes 545 .

En resumen y recapitulando, consideramos que las estrategias de las cuatro artistas cuya obra hemos revisado en este capítulo, nos ofrecen el común denominador de un panorama en el que la Naturaleza es vista en relación a un concepto estético vitalista que vincula al artista con la fusión entre arte/vida desde un planteamiento místico. En esta relación del hombre con su medio natural, el artista se establece como mediador/chamán quien a través de su búsqueda refleja una indagación sobre su propia identidad como artista y como persona. Este proceso conlleva la concepción de la Naturaleza como una entidad viva, Naturaleza igual a Ser vivo, en una especie de panteísmo que sustituye la religiosidad común por una ideología o conciencia ético-mística que más allá de

545 BONFILL BATALLA, Guillermo, op. cit., p. 70. 
cualquier simbolismo, se muestra también como la toma de conciencia de un compromiso ecológico.

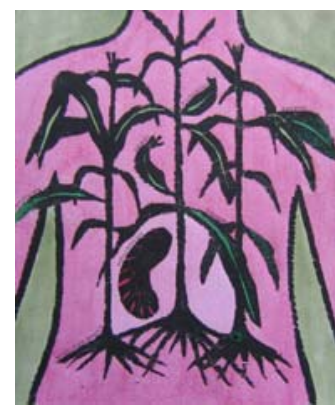

Rosario García Crespo, Maíz, Herbario Imaginario, 2006.

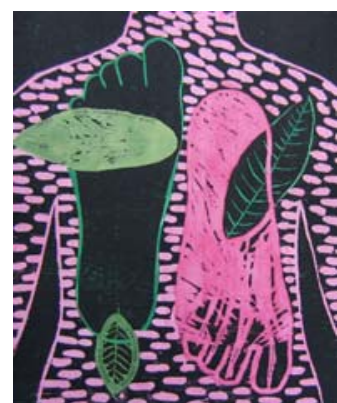

Rosario García Crespo, Salix Humboldtiana Willd, Herbario Imaginario, 2006.

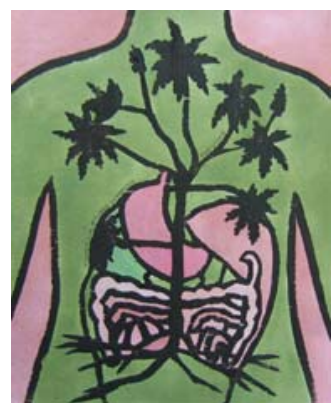

Rosario García Crespo, Higuerilla Ricinus

Communis, Herbario

Imaginario, 2006.

En esta forma de pensamiento, la Naturaleza y sus procesos se convierten en sujeto fundamental que interviene en la obra en colaboración con el artista. Éste conserva un papel secundario frente a la Naturaleza. El aspecto procesual de algunas de estas obras involucra un concepto de espacio y tiempo similar al de la Naturaleza misma, en consonancia con concepciones de lo efímero. Por lo tanto, todos aquellos elementos capaces de transmitir las ideas de creación/destrucción y todos los procesos de transformación están involucrados, cuestionando la noción de permanencia e instaurando el de trascendencia. La lucha por la vida, por el equilibrio, por la armonía y la oscilación entre el crecimiento y la decadencia son vitales para establecer lo ritmos entre vida y muerte, los mismos que podemos observar en las obras. 



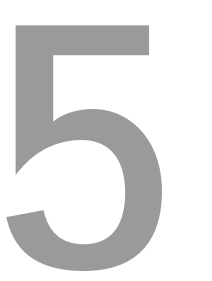

DE LA REPRESENTACIÓN A LA PRESENTACIÓN:

PLANTAS VIVAS EN ELARIE CONIEMPORÁNEO 

Los capítulos anteriores nos han permitido trazar un esbozo del panorama del arte contemporáneo en México, a partir de la obra de escultores y escultoras que, entre sus estrategias, utilizan diferentes aspectos del mundo vegetal. Hasta aquí, lo vegetal ha sido empleado como un referente que permite traducir las inquietudes del artista usando como medio básico la representación tridimensional. En este capítulo, nos ocuparemos de aquellos artistas que han usado o usan plantas vivas y reales, para realizar sus obras y para quienes, los procesos que experimentan las plantas como seres vivos, son fundamentales en la transcripción de los significados de sus obras.

En contraposición a lo que hasta aquí hemos analizado, en la obra de estos otros artistas, destaca la sustitución de la necesidad de representar el referente vegetal por una nueva estrategia, que se corresponde con la presentación del elemento original, es decir, la planta viva. En torno a esta problemática relacionada con la desaparición de la pulsión por la representación, Juan Bautista Peiró López ${ }^{546}$ nos acerca a la visión de Paul Virilio, quien en su ensayo La máquina de la visión, apuntaba hacia el "agotamiento de una lógica de la representación pública" 547 , como la causa del declive de la modernidad a finales del siglo XX. Antes de esto, en los años sesenta, el artista Douglas Huebler decía no querer producir más, argumentando en torno a la excesiva saturación de objetos en el mundo. A este respecto Nicolás Bourriaud, para explicar las nuevas formas de producción artística, describe esta sintomatología como un proceso en transformación:

Si la proliferación caótica de la producción conducía a los artistas conceptuales a la desmaterialización de la obra de arte, en los artistas de la postproducción suscita estrategias de mixtura $y$ de combinaciones de productos. La superproducción ya no es vivida como un problema sino, como un ecosistema cultural 548 .

Este proceso es un tránsito de la simulación -sea ésta en pintura, escultura, instalación, performance $u$ otras disciplinas- a la presencia real en espacio y tiempo, del motivo anteriormente objeto de la representación. Estas estrategias de presentación, tienen en el ámbito de las artes enormes resonancias: "el arte de pintar intenta sobrepasar toda re-presentación, para ofrecer la presencia misma del acontecimiento" 549 . Tenemos entonces que todas aquellas relaciones vinculadas a un referente, son ahora planteadas en directo mediante objetos y materia, reconocibles y palpables. La experiencia de la figuración ha sido sustituida por la experiencia del concepto.

Marchán Fiz sitúa el origen del arte de concepto en la práctica del desplazamiento del objeto (tradicional y objetual) hacia la concepción de la idea.

\footnotetext{
546 PEIRÓ LÓPEZ, Juan Bautista, "Dos notas sobre El objeto mismo", en AA. VV., El objeto mismo, cuatro propuestas, Universitat Politècnica de València, Valencia, 2004, p. 10.

547 VIRILIO, Paul, La máquina de la visión, Cátedra, Madrid, 1989, p.82.

548 BOURRIAUD, Nicolás, Postproducción..., op. cit., p.52.

549 VIRILIO, Paul, El procedimiento silencio, Paidós, Buenos Aires, 2005, p. 59.
} 
Todo ello se da, a partir de una mayor atención al planteamiento teórico del arte por el arte y del desentendimiento de los artistas hacia la obra como objeto físico. En este movimiento, la culminación de la estética procesual son los procesos formativos y de constitución de la obra, los cuales importan más que la obra terminada y realizada. Debido a la posibilidad por parte del espectador de percibir diferentes configuraciones de la obra, ésta deviene un proceso abierto. El concepto según Marchán Fiz,

[...] en la acepción filosófica más común y coincidente con la idea, es el resultado de una acto de generación de la mente en su alejamiento de la inmediatez de las impresiones sensibles $y$ de las representaciones particulares, en su elevación a una significación universal550.

En este sentido, el arte conceptual elimina el objeto artístico como eje modular de la obra, pasando a ser la concepción y el proyecto de la misma, aunados a la conducta perceptiva e incluso creativa del receptor, los que generan el hecho artístico. En el desplazamiento de la importancia de la estética del objeto hacia el proceso, la ejecución tradicional y el virtuosismo en la obra, así como incluso la realización manual de la misma -como se habían considerado hasta entonces-quedan relegados a un segundo término.

El proceso de desmaterialización del objeto y de autorreferenciabilidad de la obra de arte, se desarrolla originariamente en Estados Unidos y Gran Bretaña, propagándose rápidamente desde finales de los años sesenta y mediados de los setenta, enfrentándose con la estética formalista que hasta entonces había dominado el panorama artístico. Si bien Ana M. ${ }^{a}$ Guasch ${ }^{551}$, sitúa los orígenes del arte conceptual, a partir de las aportaciones de Marcel Duchamp y sus cuestionamientos sobre lo visual, en la corriente más reflexiva del Arte Minimal que ya privilegiaba los componentes conceptuales de la obra por encima de los procesos de ejecución/fabricación. A partir de estos hechos, será Sol LeWitt quien en 1967, señala la supremacía de la idea sobre la materialización de una obra de arte, al afirmar que "la idea es una máquina que genera arte" y que más que a la mirada del espectador, el arte debía dirigirse a la mente del mismo. Estos planteamientos derivaron en una necesidad de un arte emocionalmente neutro, desligado de todo sentimentalismo que delatara cualquier relación con el autor. Si durante generaciones el estilo personal del artista se había considerado la verdadera esencia de la creación artística, ahora éste se percibía como un signo de debilitamiento del mensaje verdadero de la obra.

Por su parte, también Joseph Kosuth cuestionó la Naturaleza misma del arte asumiendo el papel de crítico de la misma y proporcionando a través de sus escritos e investigaciones, las bases teóricas que afianzaron el arte conceptual, diferenciando entre estética (como belleza o gusto) y arte. Kosuth indica que la diferencia es ahora entre percepción y concepto, y llega a la conclusión de que

550 MARCHÁN FIZ, Simón, op. cit., 2001, pp. 249-252.

551 GUASCH, Ana M. ${ }^{a}$, El arte último..., op. cit., pp. 165-194. 
la desvalorización de todo componente estético redundaría en una adecuada recepción mental. Según Kosuth, la función del nuevo artista radica en la capacidad de formular nuevas proposiciones dentro del contexto del arte, que sean reflexiones analíticas y que, a su vez, no repitan en absoluto las formas del pasado. Independientemente de la realidad, el arte, como forma de pensamiento, se convierte en un instrumento capaz de reemplazar a la filosofía o a la religión como forma vivencial que permite acotar las fronteras entre arte y vida, reivindicando disciplinas del conocimiento no específicamente artísticas como las matemáticas, la lógica, la Ciencia, la sociología, la antropología o la biología, etc.

En este contexto, los artistas configuran propuestas tendentes a la desmaterialización del objeto, prescindiendo de la manufactura de los mismos, pero no del objeto mismo que se utiliza para configurar escenificaciones o procesos naturales sin la intervención del artista con la finalidad de trasmitir conocimiento o experiencias trascendentales. Este fenómeno es llamado por Karl Schawelka la "escenificación del objeto mismo": "Los artistas prescinden más y más de su papel ancestral de creadores o productores de obras y se limitan a mostrar objetos y sucesos que no han sido producidos por ellos" 552.

En este punto nos parecen interesantes las ideas de Schawelka, quien siguiendo a Richard Wollheim ${ }^{553}$, sugiere la teoría de la doble Naturaleza de los objetos por la cual éstos, además de ser cosas físicas poseedoras de un soporte material, tienen una realidad ficticia que se corresponde con lo que los escolásticos llamaban qualitates occultae, aquellas que no pueden percibirse mediante los sentidos y que suelen ser generalmente, de naturaleza social. Asimismo Schawelka, sin pretender establecer comparaciones racionales, explica la presencia de objetos y de organismos vivos en las nuevas perspectivas del arte, en relación con los dos tipos fundamentales de magia descritos por Frazer en su libro La Rama Dorada (1890). Estas dos variantes son, por un lado la magia imitativa y por el otro, la magia del tacto o del contacto. En el primero y, siguiendo la ley del parecido, la importancia recae en una imagen, representación o simulacro de la persona, para que se produzca el efecto requerido por la magia; en el segundo caso, la importancia reside sin embargo, en un objeto que haya estado necesariamente en contacto con la persona. Esta última condición requiere la presencia material del objeto, del contacto o de la presencia del mismo, aunque sea desplazada en el tiempo. Esta independencia de interpretación o de manipulación es la que Schawelka considera fundamental en el lenguaje de los fenómenos mismos y en las nuevas presentaciones del arte contemporáneo. Ambos tipos de magia son básicos y se corresponden en el pensamiento humano y en las formas de su expresión retórica, con lo que

\footnotetext{
552 SCHAWELKA, Karl, "Magia del tacto y la escenificación del mismo", en AA. VV., El objeto mismo, op. cit., pp. 14-27. Karl Schawelka es Doctor y Profesor en la Bauhaus Universidad de Weimar.

553 Richard Wollheim (Londres1923-2003), de quien volveremos a hacer mención en el capítulo seis, es considerado filósofo del arte. Sintetizó la filosofía analítica, el psicoanálisis y el estudio de la pintura para realizar análisis estéticos.
} 
conocemos como metáfora y metonimia. La idea de poder presentar algo en lugar de representarlo, no ya como un simulacro o una acción mágica sino como un hecho discursivo, parece hacer más real la dialéctica y la compresión de las ideas o por lo menos plantear realidades sociales y situaciones que pueden, en opinión de Schawelka, dinamizar la reacción del observador. En resumen podemos decir que, como fruto de la experiencia de la vida, el poder real residente en los objetos genera un impacto espontáneo y de efecto más directo que la representación de los mismos.

Los materiales que se emplean en estos casos, tienen que ver con el lenguaje de los procesos y los fenómenos que acontecen en la vida, independientemente de la influencia humana. La actividad artística se redefine mediante tipologías, categorías, clasificaciones y, a la manera de Goethe, estableciendo analogías. La dinámica a seguir será entonces llamar la atención sobre algo, provocar y mostrar fenómenos naturales o registrar fielmente huellas de fenómenos físicos que se producen al margen de la intervención del artista. En este sentido, las obras de Hans Haacke El cubo de condensación (1963), La hierba crece (1965), la Planta purificadora de agua (1972) o Semillas de Bowery (1970) exponen procesos físicos como hacer crecer la hierba sin ningún pesticida en una galería, en un museo o en la calle a la vista de todo el mundo. Todas ellas son un claro ejemplo de las formas que tomaron en su momento estas nuevas metodologías creativas que, mostrando sistemas anteriormente ajenos al mundo del arte y evidenciando nuevos significados e interdependencias entre ellos, amplifican la comprensión de los mismos y mediante su autenticidad, consiguen establecer vínculos más directos con lo social.

De esta forma, numerosos artistas trabajaron en la materialización de proyectos que incluían procesos relacionados con vegetales. Entre ellos, Alan Sonfist (Time Landscape, 1965), Newton Harrison (Interfase aire, tierra, agua, 1971), Charles Simonds (Growth House, Casa que crece, 1975), Lois Weinberger (Brennen und Gehen, Arder y Caminar, 1992), y Herman De Vries (Santuario, 1997) recuperan espacios en la ciudad para exponer fenómenos de la Naturaleza como por ejemplo, dejar crecer las plantas libremente. Muchas también son las motivaciones de este tipo de proyectos, pero en general la tipología de estas obras está relacionada con la idea de que el trabajo con plantas ofrece la posibilidad de experiencias reales, sensuales y tangibles que los espectadores, en teoría, tienen la oportunidad de observar por ellos mismos en un contexto cotidiano.

La artista y profesora de la Bauhaus Universidad de Weimar Barbara Nemitz ${ }^{554}$ ha difundido ampliamente la labor de artistas con estos planteamientos. Las investigaciones llevadas a cabo por Nemitz desde 1993, derivaron en el proyecto Kunstler Garten, realizado en colaboración con la Bauhaus Universidad de Weimar. El proyecto ofrece a los artistas, la posibilidad de elaborar piezas en

\footnotetext{
554 Página personal de Barbara Nemitz, Disponible en red:< http://www.barbaranemitz. de>, [Consulta 15, agosto, 2011]. 
el entorno de la Villa Haar (Weimar)555 que incluyen vegetales vivos en su desarrollo. En el libro Trans Plant. Living vegetation in contemporary art (2000)556 Nemitz recoge varios de estos proyectos que utilizan la vegetación como fenómeno y medio para la creación de obras en el marco del arte contemporáneo. El libro, que ofrece una amplia visión de los trabajos realizados, contempla los interesantes aspectos de las relaciones del arte en los lugares públicos, en relación con el paisaje, la arquitectura y el diseño. Estos proyectos muestran diferentes concepciones pero en general, tratan de mostrar lo vegetal como un elemento vivo cuyo desarrollo y aspecto final, no sólo está determinado por la intención del artista, sino también por las estructuras genéticas de las plantas y las condiciones específicas del lugar.

En torno a estas propuestas, Nemitz explica las afinidades que surgen entre arte y vida, a través del trabajo con vegetales, parte de las cuales transcribimos aquí en forma de traducción libre. Nemitz expone cómo el ser humano ha sido incapaz de encontrar respuestas lógicas sobre su propia Naturaleza y, en cierta medida, la tendencia histórica a buscar en la Naturaleza estas respuestas es la base para acercarse no sólo al conocimiento de la misma sino también al del ser humano. En su opinión, el trabajo con plantas dentro del arte contemporáneo, es un esfuerzo visionario e íntimo que abre nuevas perspectivas y construye nuevas estructuras connotativas y metafóricas. A pesar de la diversidad en cuanto a las intenciones, los estilos o los materiales empleados la inclusión de plantas vivas en el medio artístico evidencia las nuevas motivaciones de los artistas de hoy en día.

La diferencia esencial que Nemitz encuentra en los trabajos realizados con plantas vivas, en comparación con los artistas que usan materia inanimada, es que los primeros reflejan un sistema de vida y presuponen una dinámica, que se desarrolla en el tiempo y que, por lo tanto, tiene una dimensión temporal diferente. Ya desde su concepción, estas obras implican un plan vivo: a diferencia de la materia inerte, las plantas muestran relaciones de dependencia vital en relación a ciertas constantes y condiciones básicas necesarias para su desarrollo. Se trata de un proceso interactivo que evidencia un sistema de comunicación entre la planta y el humano. El vínculo entre estímulo y respuesta es similar a los eslabones de una cadena, el trabajo, las intervenciones y las acciones del artista deben ajustarse a las condiciones de la Naturaleza, esto provoca una retroalimentación sine qua non el proceso de la obra no puede realizarse. De todo esto se deduce que en una época dominada por la realidad virtual, la experiencia de sentir -aunque sea mediada por estos pequeños fragmentos de realidad vital que ofrecen la plantas- se convierte en una vivencia especial para el hombre urbano y en una vía de interacción con la propia Naturaleza.

555 Fue en el entorno, paisajes y parques de Weimar en donde Goethe realizó sus experimentos botánicos y en donde todavía se conserva desde 1820 la disposición de los jardines que él mismo cultivaba.

556 Véase NEMITZ, Barbara, op. cit. 
Si bien las plantas, en términos históricos y geológicos, han existido por mucho tiempo independientemente de nosotros, visualmente forman -en el imaginario colectivo- una parte inherente a nuestra concepción del paisaje: la vegetación con un aura de ambivalente exotismo nos es a la vez, familiar y ajena. En general los humanos tenemos la tendencia a percibir la vegetación con una apariencia suave y amable, además de inmersa en un paisaje en el que suele predominar la vegetación misma. Por otro lado, los vegetales estimulan a menudo en nuestro cuerpo respuestas palpables. A través del cuerpo, percibimos esencias, olores, colores, formas y estructuras en una llamada que desafía a nuestros sentidos.

La capacidad expresiva de las piezas elaboradas mediante estos procedimientos alcanza al espectador generando respuestas que presentan diferentes grados de complejidad y sofisticación. El conocimiento de la Naturaleza cambiante, de los procesos inherentes a la vida, incrementa la posibilidad de percibir y comprender relaciones formales en la obra de arte, no simplemente como estímulos estáticos sino de una manera más participativa. Las obras que incorporan plantas vivas tienen la ventaja de establecer vínculos por proximidad emocional, trasmitiendo generalmente contextos positivos: las plantas nos proveen de alimento, nos adornan y nos gustan. Generalizando, la vegetación nos trasmite un cierto sentido de paz. Los profundos cambios metamórficos que experimentan las plantas extendidos en el tiempo de la germinación, el crecimiento, su desarrollo y muerte se producen en una progresión continua, con lo que lejos de sorprendernos, nos confieren una apacible sensación de seguridad que, tal vez encuentre su razón de ser en nuestra mutua domesticación.

Otra de las características significativas en nuestra percepción de las plantas es la que las identifica como sujetos que están enraizados firmemente en la tierra. A diferencia de otros seres vivos, como los animales o nosotros mismos -que dependemos del desplazamiento para nuestra sobrevivencia- el movimiento en las plantas está restringido a la expansión. Esta es la razón por la que tendemos a percibir las plantas como pasivas y por lo tanto inanimadas, circunstancia que abre la posibilidad de usarlas como material. Sin embargo a pesar de esto, el viento, la lluvia u otros agentes atmosféricos nos permiten percibirlas en movimiento convirtiéndose en eco de los sonidos de sus hábitats. Por otra parte, como signo de vida que son y por la relación tan cercana que mantienen con sus hábitats, las plantas reflejan claramente las características de éstos, indicando las condiciones que presentan y proporcionando indicaciones precisas sobre la calidad de la vida en esos lugares.

Todas estas percepciones que el ser humano tiene en contacto con la vegetación, nos permiten entender cómo las plantas -empleadas como material o medio para la obra de arte- son capaces de transmitir efectos significativos y duraderos en nuestra conciencia, convirtiéndose en una forma de expresión. La información producida por este tipo de trabajos crece en densidad y profundidad, entre otras cosas, porque presenta no únicamente lo que un humano ha pensado y producido sino que, en última instancia, manifiesta 
también lo inexplicable, lo otro como valor añadido que es inherente a la propia Naturaleza y que se convierte en el componente complementario del trabajo. Con estos prolegómenos este tipo de trabajos constituyen una obra abierta que se desarrolla en el tiempo.

Por último es importante considerar que, en general, a la mayoría de la gente le gusta el tan habitual color verde de la Naturaleza y debido a este alto grado de popularidad, la vegetación -por la obviedad de su apariencia visual- es un material capaz de causar cierta irritación en el ámbito ortodoxo del arte. Por esta razón -apunta Nemitz- la belleza de la Naturaleza presentada abiertamente es inusual en el arte del siglo XX. En consecuencia, podemos concluir que el uso de plantas en el arte contemporáneo trae a la memoria cuestiones fundamentales largamente descuidadas, como la tensión entre Naturaleza y Belleza, favoreciendo así una nueva manera de acercarse a este tema -en primera instancia- tabú.

\subsection{E referente vegetal como agente y proceso. Sofía Táboas, J erónimo Hageman, Gabriel Orozco, Colectivo Tercenunquinto y Sebastián Romo}

Las ideas que aporta Nemitz en torno al uso de vegetales en el arte contemporáneo, nos ayudan a acercarnos a las creaciones de los artistas que en México, utilizan plantas en sus obras. Un claro ejemplo de estas prácticas podemos encontrarlo en la obra de Sofía Táboas (México, D.F., 1968), la cual se ha caracterizado por enfrentarnos a un discurso perceptual con el que la artista construye y recontextualiza objetos para enfatizar sus cualidades matéricas 557. Táboas selecciona los materiales que utiliza en función de las propiedades intrínsecas de los mismos, potenciando que sea el propio espectador el que perciba éstas a través de los sentidos. La artista deja a la imaginación y a la percepción del público, la posibilidad de completar el proceso de recepción de las obras. Como integrante y miembro fundador del colectivo de artistas Temístocles 44558 sus búsquedas, al igual que las del resto de los artistas del grupo 559 , se alejan de lo popular y lo mágico mexicano imperante en la época de los ochenta para centrarse más en las estéticas de la disolución y de la simulación de los años noventa560.

557 VARGAS Itzel, "Disertaciones...", op. cit., p. 345.

558 Temístocles 44 fue un espacio de arte alternativo surgido en 1993 en México, D.F., integrado por artistas y promotores privados quienes en una casa del residencial barrio de Polanco, realizaban proyectos curatoriales destinados a la difusión del arte con planteamientos contemporáneos.

559 MEDINA, Cuauhtémoc, "De la intemperie...", en MEDINA, Cuauhtémoc et al., La era de la discrepancia..., op. cit., p.402.

560 BARRIOS, José Luis, "Los descentramientos del arte contemporáneo: de los espacios alternativos a las nuevas capitales (Monterrey, Guadalajara, Oaxaca, Puebla y Tijuana)", en BENÍTEZ DUEÑAS, Issa M. ${ }^{a}$ (Coord.), Hacia otra historia del arte en México, Disolvencias (1960-2000), Arte e imagen, Conaculta, México, D.F., 2004, pp. 163-164. 
En uno de los primeros jardines artificiales realizados por Táboas, encontramos una alfombra de césped artificial sembrada de pequeños cristales que simulan el rocío esparcido al amanecer sobre la hierba. Este juego de artificio al que nos convoca Jardín artificial (1993) es una trampa y una locución a la percepción del espectador. En esta tónica, en la obra de Táboas, la utilización de materiales se sucede y varía según las percepciones a las que nos emplaza la artista. La constante en su obra no es pues, un material específico sino la subversión del unívoco significado que solemos atribuirles a los materiales en general. De esta forma, materiales como caramelo líquido, algodón de azúcar, fuego, plásticos, champú, píldoras, materiales para la construcción, pintura reflectante, muebles, luces especiales así como plantas invasoras, sean éstas naturales o artificiales, se alternan paulatinamente siempre en función de la intervención específica para un lugar en concreto. La artista retoma la problemática ontológica de los materiales, perturbando al mismo tiempo el sentido y la función del objeto, para así generar confusión y desconcierto.

Hay en ella un interés por llevar los materiales al máximo o, como ella lo expresa, "volverlos obscenos" al punto de la ostentación y del desperdicio, exagerar su cantidad, invertir su función o develar su nombre. El artificio está en la evocación de lo real, de lo natural -aun considerando la polivalencia de sentidos de los términos "real" y "natural"-, para lo cual Sofía usa elementos, ya sean naturales o sintéticos, como medio561.

En esculturas de períodos anteriores su trabajo se caracterizaba por apelar a una crítica del sistema mercantilista de consumo y a la creación de imaginarios de género, clase y raza. En esta línea, la maleabilidad tanto de los materiales como del discurso mismo, eran importantes en su obra. Junto a estos parámetros, la artista valora la capacidad de transformación de una situación o de un espacio, concibiendo propuestas en las que desde su postura como mujer, dentro del panorama de las artes plásticas en México, apostaba por el enfrentamiento constante ante al típico cliché concebido socialmente, en torno a la femineidad.

Pruebas de esto son obras a base de materiales como anillos provenientes de la bisutería comercial, contenedores de maquillaje, zapatos coloridos de acrílico a manera de fetiche, etc. Táboas rebasó, a través de la seriación, el carácter artificial de la construcción pre-establecida de lo femenino. Estas primeras series provienen del planteamiento conceptual que caracterizó a una parte de los artistas activos en la ciudad de México hacia comienzos de la década de los noventa: la búsqueda del readymade, y con ella la posibilidad de reactivar mecanismos de re-lectura de lo circunstancial, del espacio y tiempo cotidianos, de posicionarse hacia fuera de lo establecido562.

\footnotetext{
561 Véase PÉREZ GAVILÁN, Ana Isabel, "La distancia del deseo", en Origina, Año 11, № 132 , marzo, 2004.

562 PIMENTEL, Taiyana, "Otras implicaciones de la imagen", en PIMENTEL, Taiyana et al., op. cit., p. 57.
} 
Posteriormente, la artista conceptualizaría obras como Azul madera (1995), Azul soplado // (1997) y Azul Acapulco (1999), en las que la intención era crear una forma determinada cuyo único referente fuera el título mismo de la obra, creando una tautología563 sobre los materiales de las que éstas estaban compuestas. De forma paralela, Táboas trabaja explícitamente en la transformación de la percepción del espacio:

[...] en un inicio a través de objetos para disolver el binomio tangible-intangible. Pero con el paso del tiempo, las posibilidades maleables y corruptas del material en sí mismo le permitieron trastocar no sólo la percepción, sino la noción de deseo en el espacio: el volumen colapsado de una alberca en Azul Acapulco (2000), algodones de azúcar que se desintegran por completo en Algodón degenerado (2004), o varias instalaciones de piso hechas de caramelo sedimentado con diamantina ${ }^{564}$.

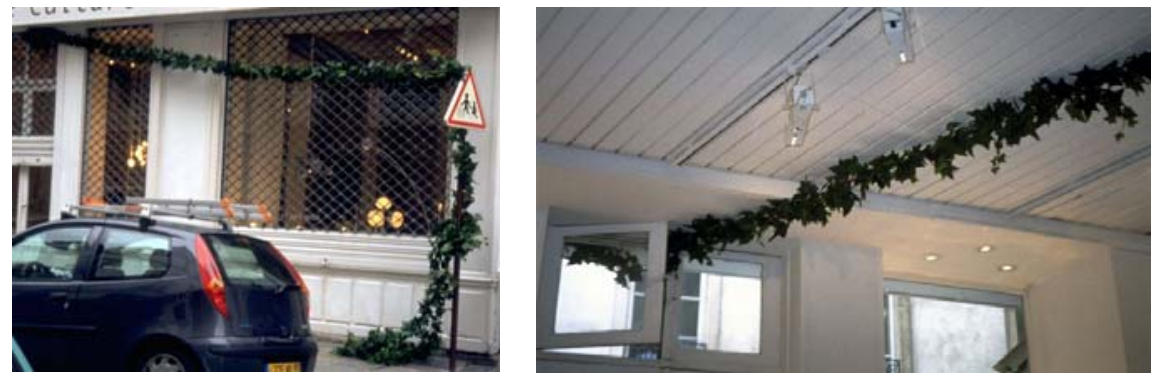

Sofía Táboas, Hacer tierra, 2002.

En esta dinámica, a principios de los noventa comenzó a incorporar plantas vivas en su discurso estético con la intención de reflexionar sobre la naturaleza artificial o natural de la materia utilizada. En 2001 la pieza Sin título (2001), expuesta en el Centro Cultural Mexicano en Berlín y posteriormente en Francia, en el marco de la exposición colectiva Un lugar en otro lugar. Ici, ailleurs (2002) consistía en una enredadera de hiedra artificial que colgaba del techo a manera de guirnalda, desbordándose incluso del espacio expositivo.

De esta forma, desde el techo del interior de la galería y en un aparente crecimiento, la planta trepadora -haciendo referencia a los límites y a las fronteras establecidas por hombres y países- atravesaba fronteras tan artificiales como las mismas plantas de plástico, descendiendo y escapándose por la ventana hasta salir a la calle. Finalmente el vegetal ficticio se enredaba en una señal de tráfico que indicaba un cruce de peatones y llegaba al suelo de la calle. La simplicidad evidente de esta propuesta sorprende por el contraste marcado entre su belleza y por el resultado que logra.

563 Tautología: Repetición de un mismo pensamiento expresado de distintas maneras.

564 PIMENTEL, Taiyana, "Otras implicaciones...", en PIMENTEL, Taiyana et al., op. cit., p. 57. 

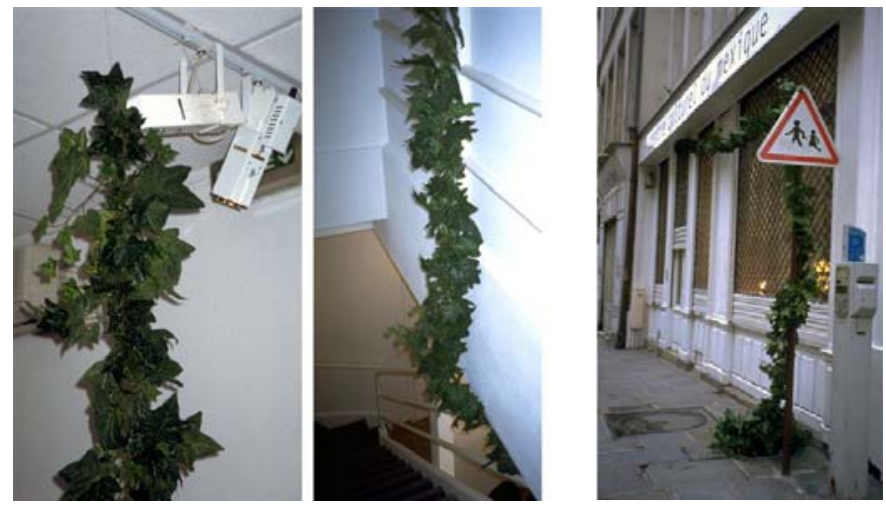

Sofía Táboas, Hacer tierra, 2002.

La pieza hace referencia -en un planteamiento claramente social- a la problemática de la emigración forzada que sufren muchos mexicanos debido a la precaria situación económica del país. Las plantas de plástico utilizadas, en su materialidad artificial, remiten a la situación forzosa en la que viven miles de personas, debido a los desplazamientos y a las migraciones globales de la sociedad actual. La necesidad, tanto individual como colectiva, de enfrentarse a esta problemática empuja a la hiedra que la artista coloca en el Centro Cultural de México, a salir de este acogedor entorno específico, para-como reza en el título "hacer tierra" -al igual que una toma de luz- y adaptarse a las nuevas tierras y a las nuevas circunstancias.

Táboas, con esta pieza que aborda el tema de la extensión territorial, transforma el espacio de la galería consiguiendo definir y resignificar esta zona que, intensificada por la acción de la artista, delimita una zona imaginaria, convirtiéndola a la vez -escultóricamente hablando- en materia maleable. La hiedra falsa recorre los techos y las paredes del Centro Cultural de México antes de salir a territorio de Alemania o Francia. Si bien la planta crece y se desarrolla hacia el exterior, sus raíces se quedan conectadas en México565.
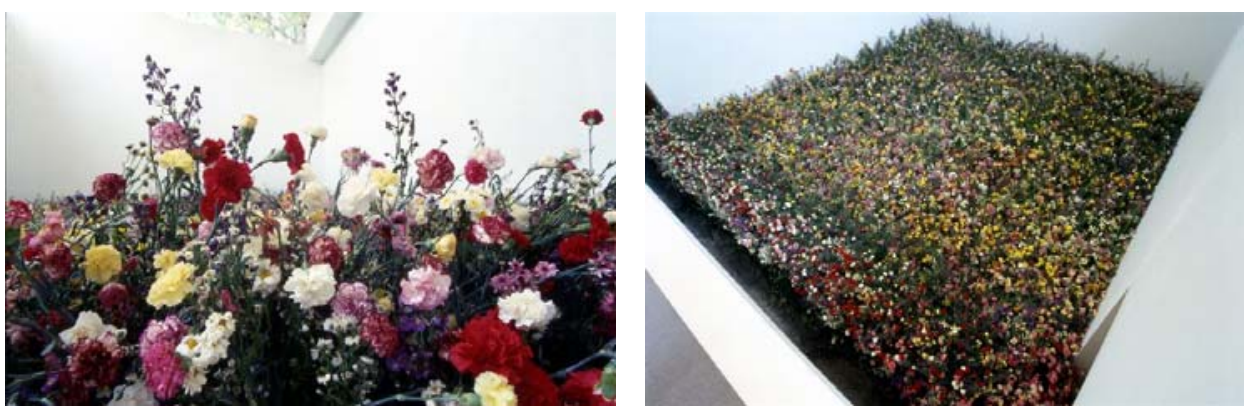

Sofía Táboas, Silvestre, 2002.

565 Véase AA. VV., Un lugar en otro lugar, (Comisarios: Vanessa Fernández y Patrick Charpenel), Centro Cultural de México en París, Francia, 2002. 
Posteriormente, en la intervención Silvestre (2002), realizada en la Sala de Arte Público Siqueiros (SAPS) la artista recrea la atmósfera natural que alguna vez formó parte de la casa-habitación del muralista David Alfaro Siqueiros, hoy convertida en museo. En esta instalación, en donde la materia prima la constituían elementos naturales, Táboas nos remite a la condición original del cubo de la galería, reinterpretando el jardín que inicialmente albergaba este espacio, con la finalidad de elaborar un discurso sobre la mutación de la realidad. La obra consistía en la creación de un paisaje cerrado, concebido mediante la completa saturación de una variedad particular de flores silvestres en un espacio de cien metros cuadrados. La acumulación masiva de este elemento vivo generaba un nuevo organismo, una totalidad que se modificaba progresivamente con el paso del tiempo traduciéndose en un continuo cambio. Como la misma artista declara, la transformación del material está contemplada como parte de la obra misma:

El material lleva implícita la perversión añorada: Algunos de los materiales con los que trabajo tienen una vida temporal o limitada: quien adquiera la obra debe relacionarse con ella en pos de evitar su deterioro566.

Con estas particulares características, la obra presentaba una multiplicidad de paisajes que permeaban la experiencia efímera e in situ de la misma, confrontando escultóricamente el espacio del desaparecido jardín y privilegiando, de una manera subversiva y contradictoria, la experiencia de este nuevo paisaje.

La creadora se valió del proceso contráctil del material para aludir, nuevamente, a la memoria; su desafío, a través de los sentidos, es una apuesta a la reacción visceral del espectador: su vestigio provoca repulsión, duda, asco, inquietud. [...]. El recuerdo -y el tiempo que lo transforma- se vuelve la materia prima con la que ella trabaja [...]. También lleva a un millar de flores a semejar un campo Silvestre (Sala de Arte Público Siqueiros, 2002) dentro de un cuarto cerrado al que no se puede acceder sino sólo mirar desde el umbral. Sin luz natural, sin agua, las flores mueren. La crueldad de este acto inútil, señala la propia artista, fue reprochada por custodios y visitantes del lugar, iy para un fin tan inútil como es el arte! -concluye. Táboas marchitó el aroma de las flores, empujando el deseo al extremo: eros $y$ thanatos, inseparables y desalmados amantes, erotismo de la trasgresión que toca lo sublime sólo para acercarse a la muerte567.

Para crear este jardín, Táboas utilizó en lugar de macetas ramos de flores sin tierra ni agua para que la vegetación no creciera. Obviamente, con el paso del tiempo y, en el transcurso de la exposición, el aspecto de las flores fue cambiando progresivamente, convirtiendo la pieza en una intervención orgánica susceptible de transformación. El comisario y conservador del MOMA Christian Rattemeyer describía cómo la pieza - un bloque de flores y hierba que ocupaba

566 PIMENTEL, Taiyana, “Otras implicaciones...”, en PIMENTEL, Taiyana et al., op. cit., p. 57. 567 Véase PÉREZ GAVILÁN, Ana Isabel, op. cit. 
todo el espacio de la galería- se fue secando lenta y dramáticamente, cambiando la percepción visual y olfativa, tanto de la galería como del paisaje creado, proyectando de esta forma, una sombra de decadencia sobre la instalación, que acabó adquiriendo una apariencia mortecina568.

Por otra parte, cabe destacar el recorrido forzoso que tenía que hacer el espectador para observar la pieza, ya que éste solamente podía acceder al espacio expositivo atravesando un estrecho pasillo pegado al muro. El bloque de vegetación estaba ligeramente elevado un metro de altura por el lado de la entrada de los visitantes. A partir de aquí, la altura de la pieza decrecía física y visualmente, obligando a percibir la obra desde un punto de vista fijo que convertía la perspectiva en un horizonte florido que se alejaba. Esta ubicuidad del espectador y la obligatoriedad de una mirada distante ponen de manifiesto el juego entre la percepción y el deseo que ocupa un lugar central en la producción de la artista. Se trata de ejercer la seducción para propiciar un deseo que sin embargo está condicionado a la presencia de un objeto, tangible o intangible, a alcanzar. En Silvestre (2002), la Naturaleza sencillamente muere, enfrentándonos a su total decadencia.

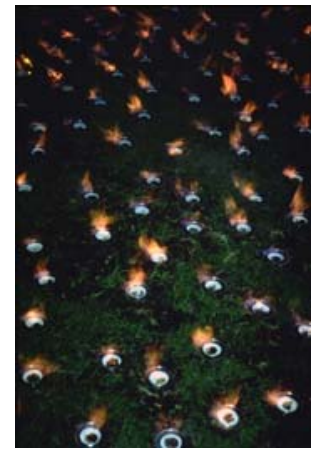

Sofía Táboas,

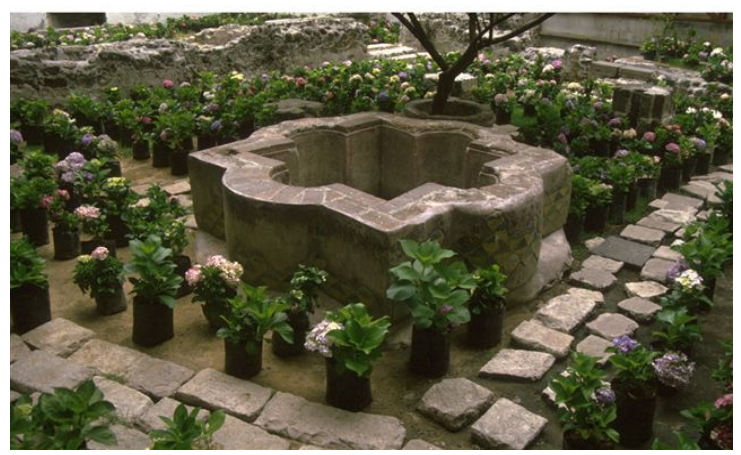

Sofía Táboas, Jardín, 1995.

Fuego envasado, 2001.

El escultor y crítico Enrique Jézick apunta una característica, sin duda muy particular, de esta obra de Táboas. Jézick, aludiendo al olor de la pieza en descomposición, comenta que en esta obra lo visual no lo es todo, puesto que se involucran en ella -como en otras obras de Táboas- varios sentidos, entre los cuales uno de los protagonistas es el olfato:

[...] el olor emanado de unas cuantas toneladas de flores puede ser particularmente evocativo. El intenso aroma de este jardín de flores cortadas, sin tierra ni agua, acaso recordaba el hedor de un cementerio, con lo que se ampliaban las posibles lecturas de la instalación. Desde otra perspectiva [...] daba la sensación de fragmento trasladado y a la vez de artificio que no escondía su propia, inherente, falsedad. El falso fragmento

568 RATTEMEYER, Christian, "Complicación de la Naturaleza" (Traducción libre), Disponible en red: <http://www.culturebase.net/artist.php?718>, [Consulta 8, marzo, 2005]. 
de falso prado, el falso sendero en el supuesto paisaje fragmentario [...]. El juego de las contradicciones está planteado desde el título de la obra, Silvestre, alusión a un mundo natural569.

Jézick apunta en esta obra a una lectura en la que las connotaciones se amplían, sugiriendo y alentando una reflexión en torno a varios aspectos de nuestra relación con la Naturaleza. En particular Jézick habla sobre el proceso convocado aquí por Táboas para llegar a la sublimación de una flora domesticada y fragmentada, que funciona como parte subsidiaria de la arquitectura o reducida a su mínima expresión en las ciudades, como breve detalle urbanístico.

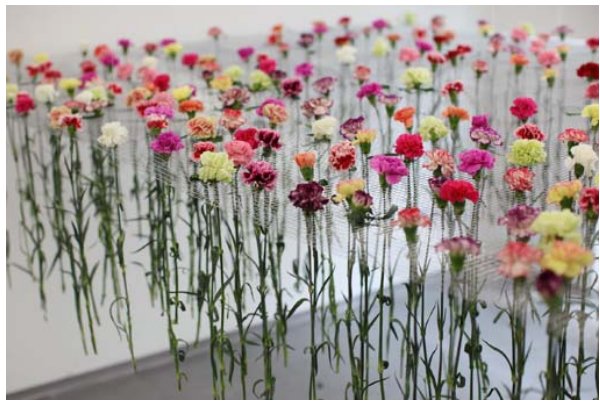

Sofía Táboas, Código horizontal, 2011.

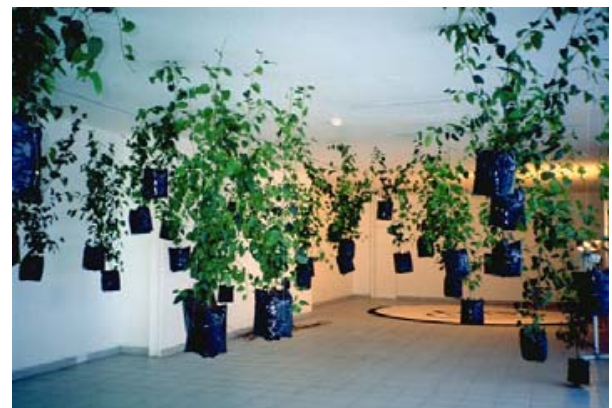

Sofía Táboas, Sin título, México, 2001.

En anteriores trabajos de la artista, las plantas experimentaban un proceso de transformación, debido a su propio crecimiento, como es el caso de Jardín (1995), pieza en la que la artista generó un espacio perceptualmente nuevo al transformar el patio del Convento Ex-Teresa Arte Alternativo (Centro Histórico), en un jardín con setecientas cincuenta macetas de hortensias. Sin embargo, contrario a lo que pudiera parecer, Táboas afirma no remitirse a ningún simbolismo en concreto. Se trata asegura, como de percibir "algo que cambia, se metamorfosea, se modifica"570, algo, como explica Cecilia Aguilar o la misma artista, a lo que se nos enfrenta, con la fuerza de una experiencia en directo:

Mi obra -explica Sofía- no es algo que pueda hablarse, más bien es una pieza a la que el espectador tiene que enfrentarse para que su sensibilidad se despierte 571 .

Para sus instalaciones a menudo site-specifics, Táboas utiliza como ya hemos visto, una amplia gama de materiales orgánicos pero también, inorgánicos. Mantos de hierba artificial o flores en numerosas cantidades se combinan para

569 JÉZIK, Enrique, "Silvestre, Sofía Táboas", en SCHMELZ, Itala (Coord.), Memorias, 20012002, Sala de Arte Público Siqueiros, Instituto Nacional de Bellas Artes, México, D.F., 2002, p. 28.

570 MAC MASTERS, Merry, "Silvestre recrea un jardín que había en la sala Siqueiros", en La Jornada, México, D.F., 25, mayo, 2002.

571 AGUILAR, Cecilia <http://www.conaculta.gob.mx/saladeprensa/2002/06may/taboas.ht $\mathrm{m}>$, [Consulta 9, marzo, 2005]. 
crear sensualidad, siempre con el ingrediente de una crítica a las instituciones, así como a todo lo establecido, aunque sin perder de vista la belleza inherente a los materiales empleados. En varias ocasiones la pauta a seguir era colgar macetas en el interior de una sala, tanto en México como en Berlín o Los Ángeles. En todos estos lugares el espacio expositivo se llenaba de verde hasta formar una maraña de pequeñas plantas trepadoras vivas cuyo crecimiento, a través de invisibles hilos, enfatizaba la transformación paulatina de la obra que flotaba en el techo, cada planta con su correspondiente porción de tierra que -demandando siempre los cuidados necesarios- debía de ser regada periódicamente.

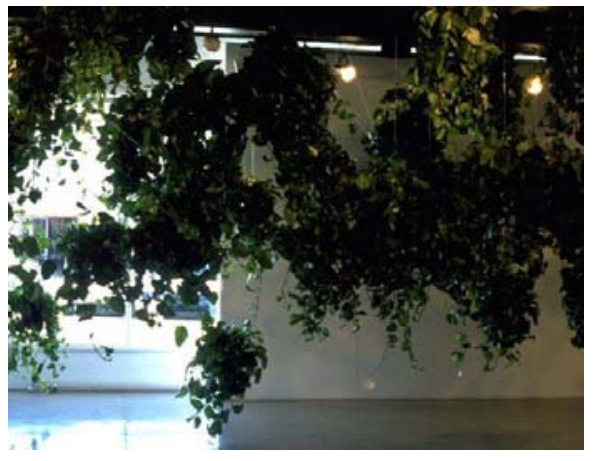

Sofía Táboas, Sin título, Los Ángeles, 2002.

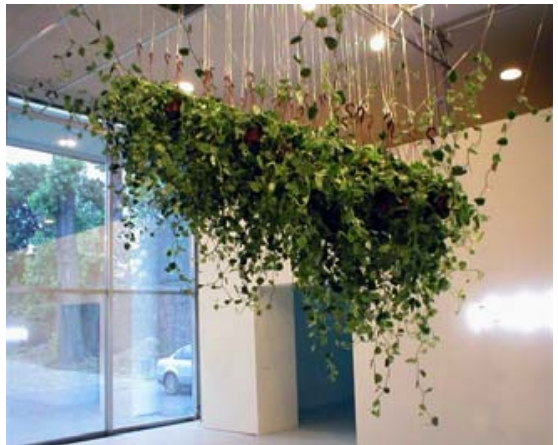

Sofía Táboas, Sin título, Berlín, 2002.

En estos casos, las macetas no estaban provistas de ningún material habitual como barro o plástico. Muy al contrario, se presentan tal y como se venden en los viveros -con bolsas negras de plástico- para subrayar el alto grado de artificialidad inherente a la costumbre doméstica de cultivar plantas que se encuentran fuera de su medio habitual. En estas ocasiones, la necesaria implicación del propio espacio expositivo en la conservación de las plantas, fuerza la lectura de una situación de interdependencia entre las plantas como Naturaleza dependiente, estrechamente vinculada con el ser humano.

Un jardín representa una forma de cuidado y acicalamiento que, antes que mantener vivas a las plantas y animales que lo habitan, se ocupa de mantener viva una idea [...] el jardinero impide el florecimiento del caos572.

Táboas plantea un doble bucle entre lo natural y lo artificial, sus propuestas juegan a seducir, a la vez que a confundir, para introducir una grieta en nuestra percepción, un interrogante frente a las apariencias. En Jardín portátil (2000), presentado en la muestra antológica Escultura mexicana del siglo XX, de la Academia a la instalación (2000), realizada en el Palacio de Bellas Artes de México, D.F., utiliza de nuevo plantas vivas. Éstas se hayan separadas de la superficie del piso por una sencilla pero artificial plataforma de madera con

572 VARGAS LUGO, Pablo y MARTïN, Patricia, "Edén”, en AA. VV., Edén, La colección Jumex, México, D.F., 2004, p. 13. 
unas pequeñas ruedas que refuerzan no sólo la idea del desplazamiento y la necesaria manipulación humana, sino también una distancia de la superficie horizontal básica, que en otras circunstancias sería la tierra. El artificio redunda aquí, al igual que en otros espacios expositivos, al introducir estas plantas en el recinto legitimador del Palacio de Bellas Artes.

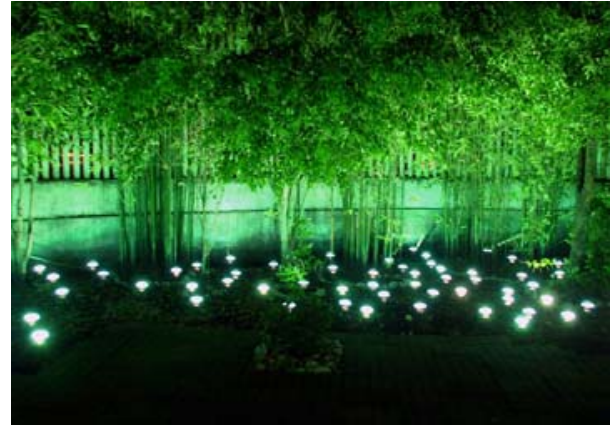

Sofía Táboas, Pasto artificial, 2003.

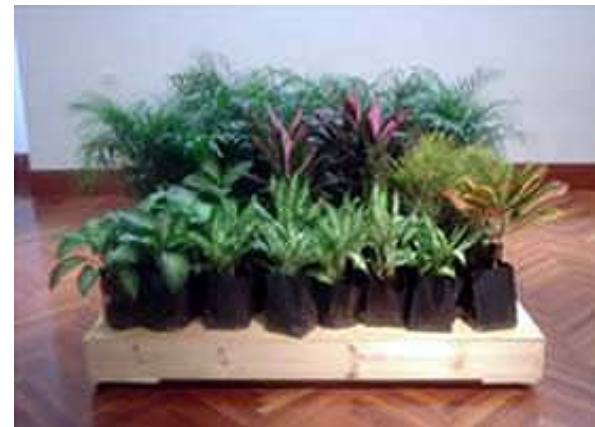

Sofía Táboas, Jardín portátil, 2000.

Por el contrario, en la intervención Pasto artificial (2003), realizada en el Museo Carrillo Gil, los planteamientos se invierten. En una de sus características estrategias de trastocar el deseo invirtiendo el orden común de las cosas, la artista coloca una numerosa cantidad de focos en el suelo del patio del museo, iluminando intensamente de color verde los tallos de bambúes que crecen en el jardín, como parte habitual del museo. En este caso, la instalación eléctrica funciona como señalamiento a la vez que crea una especie de ambiente artificial. De esta manera, la artista consigue subvertir e invertir los procesos de percepción entre aquello que es natural y aquello que puede parecer artificial, pero no lo es.

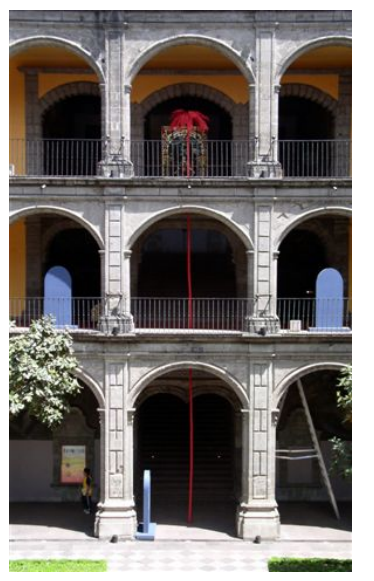

Sofía Táboas, Palmera roja, 2003.

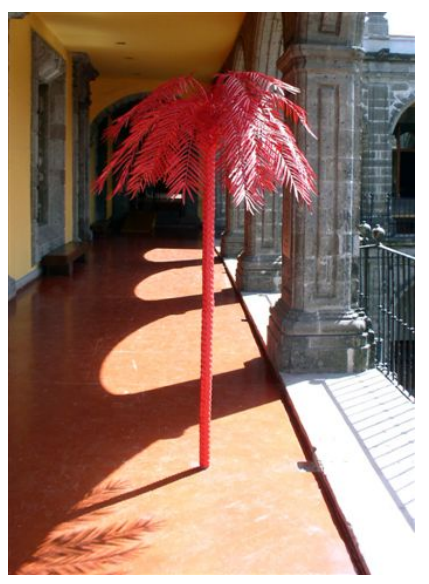

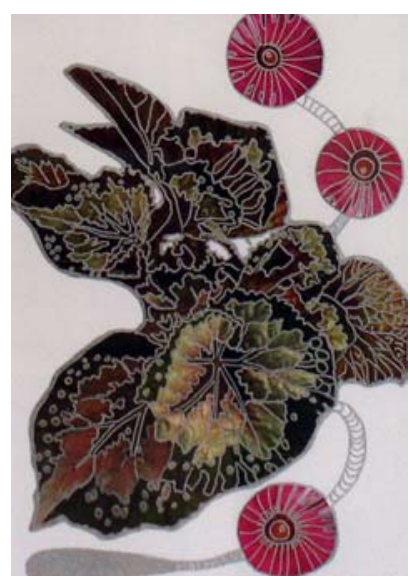

Sofía Táboas, Plantas intervenidas, 2006. 
En la exposición Edén (2003)573, la Naturaleza es según Michel Blancsubé, "imitada" 574 por algunos artistas, entre ellos Sofía Táboas, quien aborda la recreación del mito del paraíso perdido y su imposible recuperación mediante la representación de una alta palmera de un artificial color rojo, elaborada en plástico. Este elemento actúa aquí en la tónica de la tendencia natural de la vida -y su interpretación vegetal en este caso- a desbordar todo límite, atravesando las tres plantas del edificio, con una omnipresencia que simula el poder de lo vegetal más allá de las estructuras culturales de la arquitectura.

Para la exposición Giro espacial (2005), en la Galería Kurimanzutto, la artista reinterpreta a través de la manipulación de diferentes materiales como madera, plantas de plástico, neón y muebles pintados, la configuración de espacios geométricos que se materializan en la abstracción de diferentes simbologías míticas.
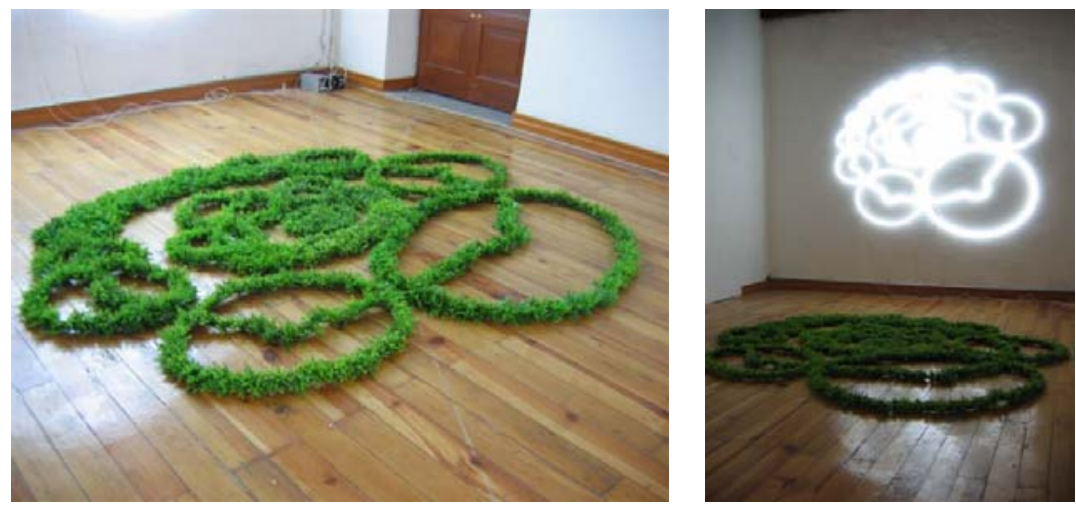

Sofía Táboas, Cosecha espacial, 2005.

Estructuras y caligrafías exóticas se multiplican y desbordan para plantear, con lenguajes nuevos, diálogos combinatorios sobre el anónimo e indescifrable manuscrito Voynich del siglo XVII y sus inexistentes vegetales o sobre los famosos y exóticos crops (extraños círculos en sembradíos) cuya autoría es supuestamente extraterrestre. La pretendida intervención de seres de otros planetas produce cambios genéticos y variaciones arbitrarias que son registrados en los herbolarios de la artista, para cuestionar, mediante sus reflexiones, las falsas creencias sobre el hecho perceptual en el que suelen caer todos aquellos que se dejan llevar por las apariencias.

El misterio en estas obras se toma prestado casi como una afirmación del escepticismo, prefiriendo el gatillo irónico o humorístico que provocan los

573 Edén (2003), exposición organizada por la Colección Jumex en el Antiguo Colegio de San Ildefonso, dentro del marco del Festival del Centro Histórico.

574 BLANCSUBÉ, Michel, "Padre nuestro que estás en el cielo, quédate allá, y nosotros nos quedaremos en la Tierra que a veces es tan hermosa", en AA. VV., Edén, op. cit., pp. 3953. 
enigmas "laterales" de la civilización a su respetable repertorio de soluciones 575 .

Con estas obras la artista pone en evidencia las creencias esotéricas de las que nos rodeamos, por encima de cualquier razonamiento, validando todo tipo de postulados con el único apoyo de la fe como verdad última. De esta forma, la realidad y la ficción se entremezclan en la obra, generando una productiva ambigüedad con la que incursiona en la percepción de las construcciones y de sus materiales.
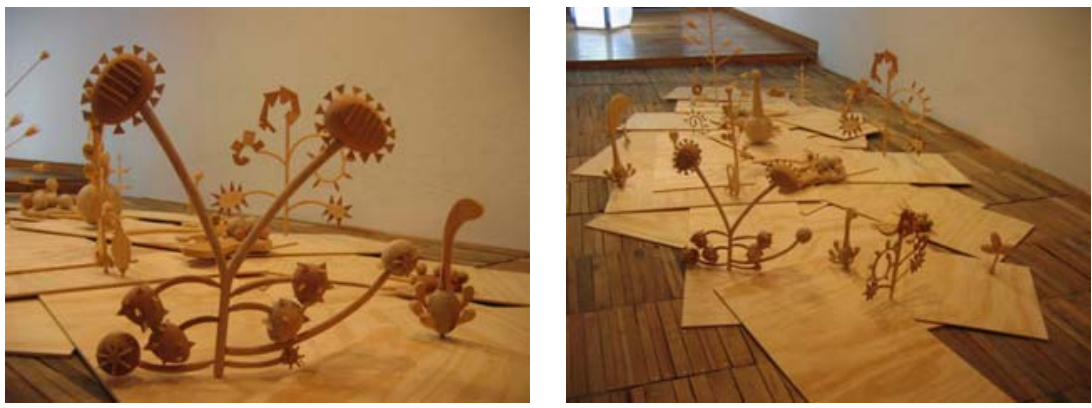

Sofía Táboas, Germen Voynich, 2005.

La artista reinterpreta en madera las imágenes del manuscrito Voynich y, transcribiéndolas tridimensionalmente las esparce sobre el suelo a manera de un jardín-puzzle de juguete. En la exposición se observaban cinco construcciones transitables de mediano formato realizadas en madera, metal, plantas verdes de plástico, acrílicos de colores y formica. En esta ocasión, el espectador no es invitado a utilizar sus sentidos a través de los materiales, sino que los espacios propuestos por la artista generan signos que, a su vez, se convierten en un nuevo tipo de material sobre el que reflexionar. Los signos se organizan en círculos concéntricos entrelazados a manera de elaborados sistemas planetarios que, como en un juego especular se duplican en el piso sobre vegetales verdes (imagen artificial y terrestre de una Naturaleza reconstituida), y después en un eco que se repite, sobre una estructura de luces de neón. La ciencia ficción como trampa o espejo visionario de ocultas redes de conocimiento, la artista combina significados y juega con nuestra percepción que en ocasiones, engañosamente, proyecta espejismos sobre la realidad.

Para la exposición colectiva Germinal (2006)576, Táboas como artista invitada, mandó detalladas instrucciones para la construcción de un jardín con plantas naturales que posteriormente pasaría a formar parte de la colección de fondos

\footnotetext{
575 Nota de prensa para la exposición Giro espacial, proporcionada por Gaby de la O, directora de la Galería Kutimanzutto.

576 La exposición Germinal (2006), se realizó en la galería del Vicerrectorado de la Universitat Politècnica de València con la mediación como co-comisaria de la autora de esta investigación. Véase AA. VV., Germinal. Arte y Naturaleza, Vicerrectorado de Cultura, Universitat Politècnica de València, Valencia, 2006.
} 
de la UPV. En esta ocasión la estructura principal era, una intersección de tres plataformas cuadradas, lisas y de madera, sin pintura ni barniz alguno, de un metro y medio cada una, más una plataforma circular de iguales características de 75 centímetros de diámetro. Las superficies debían constar de ruedas giratorias y ser lo suficiente resistentes como para soportar el peso de las plantas naturales que se colocaron sobre ellas. Las plantas, con diferentes alturas y de diferentes variedades eran todas de interior (Táboas las elige en función del lugar o ciudad en donde se presenta la pieza) y la cantidad de las mismas viene determinada por las dimensiones de las plataformas.

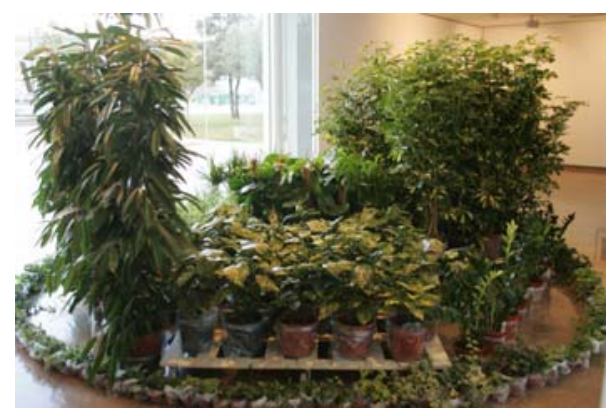

Sofía Táboas, Jardín portátil con plano extraterrestre, 2006.

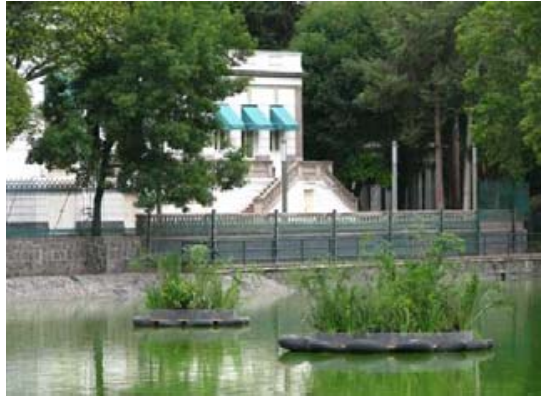

Sofía Táboas, Cinco jardines flotantes para cinco piedras, 2009.

Entre las últimas piezas en las que la artista ha utilizado plantas podemos citar Jardín flotante (2008) realizado en la ciudad de Puerto Vallarta, en donde una barca llena de diferentes plantas surcaba las aguas marítimas. Posteriormente, la artista retomará el ejercicio romántico y poético de una Naturaleza a la deriva en Cinco jardines flotantes para cinco piedras (2009). En ambos casos, las instalaciones con plantas vivas abandonan el espacio cerrado de la galería o el museo y permiten a la artista hablar de la idea de un jardín que se desplaza y de una Naturaleza huidiza que -en su recorrido- interactúa con el entorno y el paisaje circundante. En el último caso, la construcción de estas pequeñas y exuberantes islas flotantes, presenta un doble bucle, Táboas nos habla del artificio dentro del artificio, de la Naturaleza dentro de la Naturaleza. El colocar plantas en el lago aun cuando éste, de por sí, está rodeado de vegetación, convierte esta acción en una redundancia cuya finalidad es dirigir la mirada y señalar, con un atípico acento verde sobre el agua, un cambio en el paisaje cotidiano del lugar. Las plantas aunque autóctonas son procedentes del jardín botánico y nos hablan de su desarrollo en un espacio protegido por el hombre. Los pequeños recintos vegetales -cinco plataformas circulares de diferentes tamaños- aparentemente vírgenes, están construidos sobre bases de madera, con tela metálica a su alrededor. Unos flotadores de plástico consiguen la ilusión de permanencia sobre el agua.

Ante la visión de estas islas que se desplazan por las aguas del lago, el público podría percibirlas como aquellos jardines que llegaban en chinampas por los lagos que comunicaban el Valle de México desde Xochimilco hasta el mismo corazón de Tenochtitlán. Esta remembranza histórica resulta un lugar común 
frente al planteamiento de la artista de elaborar un juego de resonancias en el que el tamaño de las plataformas remite a la construcción artificial de una Naturaleza a un tiempo cercana y distante. Para la artista, la inaccesibilidad de islas - por su situación en el centro del lago- está directamente relacionada con la intención de la obra. La lectura a trasmitir tiene que ver con la acción de lanzar una piedra al agua y la repercusión que esta acción genera sobre la superficie de la misma, provocando una onda expansiva en círculos concéntricos. La idea es definir una escritura y una lectura que se traduzcan en un movimiento de fuga. Esta acción -que se encuentra en el origen mismo de la obra- fue realizada por la artista, la cual lanzó cinco piedras al agua, que fueron las que determinaron el lugar de ubicación de cada uno de los jardines. Estos se mantienen unidos y alejados de las orillas del lago mediante un sistema de sujeción. Al igual que en la pieza Silvestre (2002), el espectador es obligado a percibir la Naturaleza desde una perspectiva lejana. El encadenamiento de formas, signos e imágenes se multiplica dentro de la obra, permitiéndonos entender como señala Bourriaud, que "la cualidad de una obra depende de la trayectoria que describe dentro del paisaje cultural"577. Casi cuarenta años después las pequeñas islas artificiales de Sofía Táboas enlazan conceptualmente con proyectos como el de Robert Smithson Floating island to travel around Manhattan Island (1970)578.
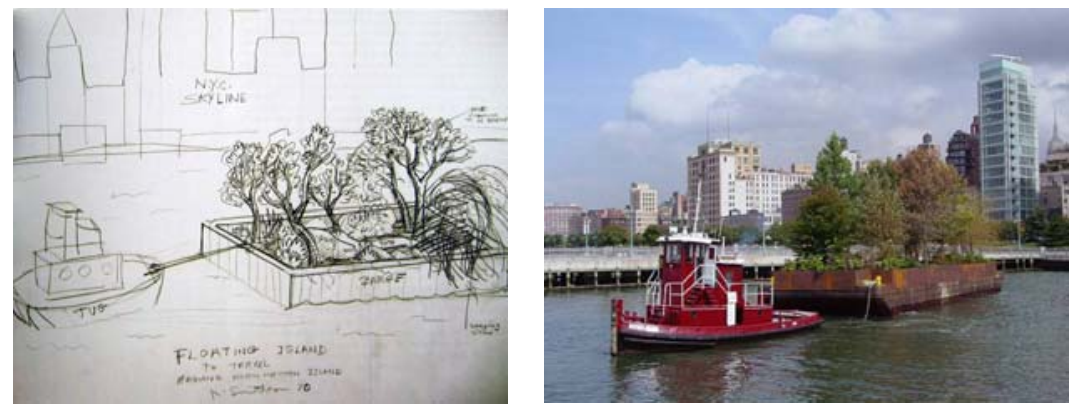

Robert Smithson, Floating is/and to travel around Manhattan Is/and, 1970.

En todo caso, el jardín se convierte en la obra de Táboas, en un sistema con una dinámica propia, un material vivo que conlleva un proceso de crecimiento en permanente cambio, en donde los factores externos son los que alteran o procuran el desarrollo de la pieza. Esta constante de no tener todo el control sobre la obra es para la artista un factor altamente significativo, tanto como la seriación y el desplazamiento, elementos que se conjugan en este proyecto.

Dentro de la tendencia a utilizar elementos vegetales en la línea, que comentábamos al principio de este capítulo, de Barbara Nemitz y, como una

\footnotetext{
577 BOURRIAUD, Nicolás, Postproducción..., op. cit., p. 46.

578 Proyecto basado en un dibujo del artista, en el que se aprecia una barca-isla ajardinada, remolcada por un barco. Para este proyecto (producido póstumamente en 2005, por el Whitney Museum of American Art y la productora Minetta Brook) se reconstruyó una isla flotante con la que se podía viajar alrededor de Manhattan.
} 
nueva forma de presentación y de reflexión en arte contemporáneo, encontramos en México otros artistas que utilizan la dimensión vegetal como principal medio de investigación. Para ellos, las plantas son una plataforma para explorar las posibilidades de relacionarse personal y emocionalmente con una naturaleza no humana y con las maneras de resolver este innato impulso en el ser humano de convivir con ellas y a través de ellas, con la Naturaleza579.
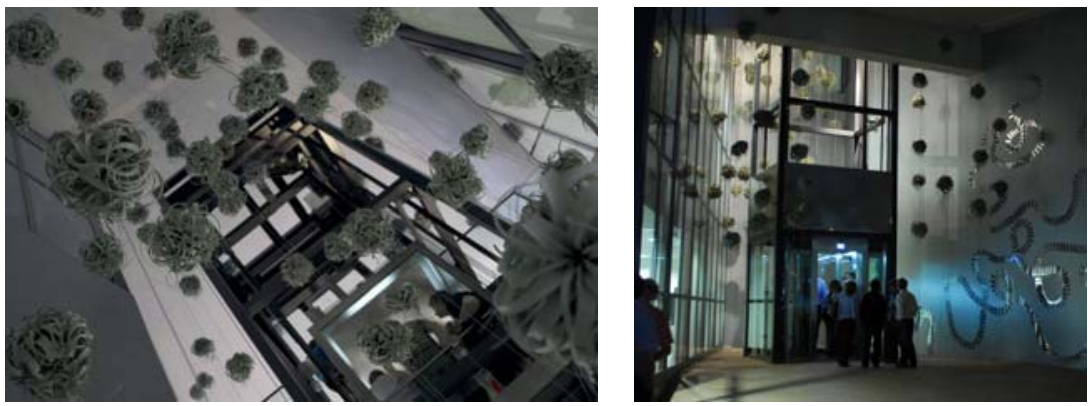

Jerónimo Hagerman, Jardín suspendido de Xerographicas, 2008.

Además de su trabajo como artista visual Jerónimo Hagerman (México, D.F., 1967) ha desarrollado, en colaboración con diferentes arquitectos, una extensa trayectoria como arquitecto del paisaje. De entre estas colaboraciones destaca por lo que nos aporta al conocimiento de su trabajo- la participación con el arquitecto Mauricio Rocha, en la construcción del Centro para la atención de gente invidente (2002), en México, D.F. En este proyecto se buscaron nuevas formas de estimular otros sentidos como el olfato o el tacto, que minimizaran las diferencias entre el ver y el no ver. La selección de plantas aromáticas como jazmín, romero, té limón y cedrón, así como espacios intercalados de silencio con plantas sin olor, sembradas en el entorno del centro, establecían un ritmo de olores que conseguían intensificar ciertas áreas. El lugar presenta zonas plantadas con diferentes cactáceas sin espinas y resistentes al tacto como echeverias, sábilas, kalachoes y espadas en los niveles más bajos de los taludes, de manera que los visitantes pueden tocar algunas de las especies, provocando así el sentido del tacto y generando referencias de localización. El planteamiento conceptual de este proyecto fue, más allá de vibrar con el capricho formal o visual, concebir el edificio y su entorno como una experiencia sensual y paulatina entre el olor de las plantas y las sensaciones percibidas frente a los ritmos de luz y sombra580.

En función de la naturaleza de estos trabajos y probablemente por su propia formación, el artista declara que en su trabajo, más que un interés estético-

579 Véase entrevista: "Arte: Jerónimo Hagerman", Tomo. Arte Arquitectura y Diseño, Suplemento Excelsior, México, D.F., 23, junio, 2009, Disponible en red: <http://tomo.com.mx/2009/06/fresco-jeronimo-haggerman/>, [Consulta 10, agosto, 2009].

580 Véase "Entrevista a Mauricio Rocha. Vista aérea y zonas de vegetación", en Cambio, 10, noviembre, México, D.F., 2002, pp. 79-81. Material proporcionado por el artista. 
formal en las obras que realiza con plantas y jardines, lo que prima es la idea de concebir el mundo vegetal y las plantas en particular, como un laboratorio de relaciones que nos permite intensificar la experiencia de vivir a través de los sentidos. El artista plantea la construcción de jardines como una experiencia sea ésta pública o privada- que potencia la capacidad de tomar conciencia plenamente de todo aquello que nos rodea. Todo ello desde el punto de vista de la complejidad de la dimensión universal que, como el mismo artista comenta, no tiene que ver específicamente con la escala humana.
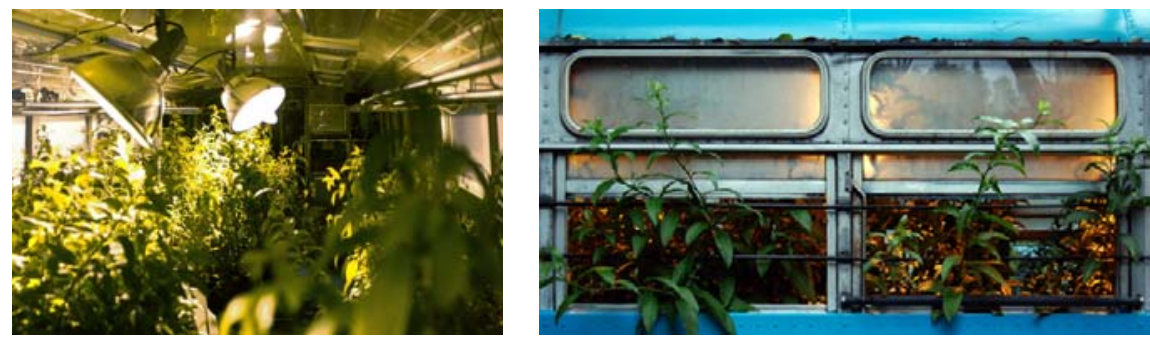

Jerónimo Hagerman, Cámara de sodio para Cestrum Nocturnum, 2008.

La referencia humana del tiempo es una variante muy pequeña en la escala del universo físico. Hasta el mismo artista, se muestra sorprendido ante la limitación con la que, habitualmente el ser humano, piensa exclusivamente en función de esta perspectiva. La intención de sus obras es tratar de pensar e hilar la conciencia alrededor de otras formas de medir el tiempo. Como ejemplo, Hagerman pone la vida de un árbol que puede tener tres o más veces los años de una vida humana. Le impresiona la vida, su significado, lo que quiere decir y, su trabajo se orienta a tomar conciencia de la importancia y la complejidad de la misma. El determinismo de permitir que todas nuestras referencias sean habitualmente en función de la escala y el género humano -debido a las necesidades y a la propia historia del hombre- nos ha limitado mucho, por ello considera que la relación con el reino vegetal manifiesta formas particularmente diferentes de intensificar nuestra percepción del mundo. El trabajo realizado con ciegos -anteriormente comentado- y todas las otras percepciones que nos trasmiten otros sentidos como el olor o el tacto son experiencias a destacar en sus obras. Mediante ellas, el artista busca explorar nuevos canales que nos acerquen a esa parte de Naturaleza que, dentro de las ciudades, las plantas nos pueden transmitir a los habitantes urbanos ${ }^{581}$. Parece que Hagerman siguiendo a Zenón de Elea (490-430 a.C.) -quien fuera discípulo de Parménides- afirma y demuestra en su trabajo con plantas que "el ser es múltiple y se mueve en el no-ser" 582 , y que el movimiento en definitiva, no es más que una mera ilusión de los sentidos.

581 Entrevista inédita, realizada por la autora de esta investigación con Jerónimo Hagerman, agosto, 2006.

582 FEYERABEND, Paul, La conquista de la abundancia, Paidós, Barcelona, 2001, p. 225. 

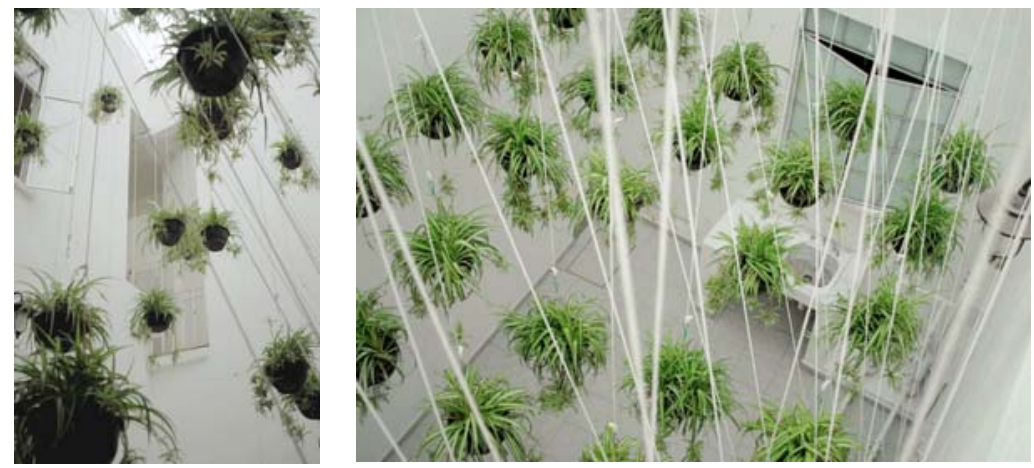

Jerónimo Hagerman, Malas Madres, 2007.

A través de su obra plástica y formal, así como de los jardines que ha diseñado, Hagerman reflexiona sobre las concepciones en torno a la temporalidad característica del reino vegetal, estableciendo relaciones entre lo natural y lo artificial. Sus trabajos establecen constantemente un diálogo con el contexto, haciendo un comentario poético sobre la manera en la que percibimos nuestro entorno y el tiempo que transcurre en él. Con la intervención Contemplando la invasión (2004), realizada en la fachada de la Sala de Arte Público Siqueiros (SAPS), el artista expandió el espacio expositivo del museo con la presencia real de enredaderas de hiedra. Hagerman proponía, frente al caótico dinamismo urbano, la idea de contemplar una enredadera de hiedra y su crecimiento sobre la superficie del museo, como una medida diferente de percibir el tiempo.

Para desplazarse a esta exploración del reino vegetal hay que acceder a otro tiempo, en apariencia mucho más lento pero capaz de invadir espacios insospechados y alcanzar proporciones fuera de la escala humana. Tan sólo hay que pasearse por las calles que rodean la SAPS para encontrar torres $y$ cascadas de hiedra descontrolada invadiendo todo tipo de estructuras 583.

El público que transitaba frente a la sala podía así observar una pieza que tomaba en cuenta las características físicas de los alrededores de la calle de Tres Picos en donde se encuentra la SAPS. En este barrio residencial de Polanco muchas otras casas ofrecen una panorámica similar: largas enredaderas se descuelgan ornamentalmente de los muros que protegen las mansiones. Con su acción real pero a la vez retórica, Hagerman generó una metáfora con la que transfería las características vitales de las plantas y su crecimiento, al edificio del museo y a lo que éste representa como ente vivo dentro de la Cultura. De esta forma se podía percibir una nueva imagen del museo como un organismo dinámico y en continuo crecimiento, un nuevo espacio por lo demás habitable

583 HAGERMAN, Jerónimo, "Contemplando la invasión", en SCHMELZ, Itala (Coord.), Memorias, 2004, Sala de Arte Público Siqueiros, Instituto Nacional de Bellas Artes, México, D.F., 2004, pp. 43-48. 
pues la disposición particular de las plantas en el exterior daba sensación de cobijo.
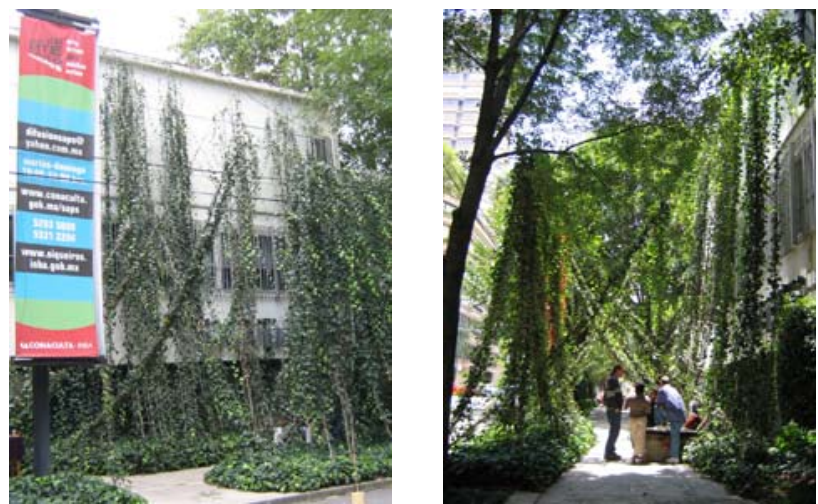

Jerónimo Hagerman, Contemplando la invasión, 2004-2009.

La intervención se materializó mediante guías que a manera de trazos, como lo expresa el artista, servían para dirigir las plantas, establecer relaciones y conectar circunstancias, pero en definitiva el azar y la movilidad de las propias plantas son las que construían la pieza. Al igual que en algunas de las obras de Sofía Táboas, Hagerman reconoce no controlar el resultado de las suyas puesto que por sus características, se consideran obras en proceso en las que, en definitiva, uno nunca sabe lo que va a pasar. Como podemos observar, uno de los intereses fundamentales de este artista es la relación temporal que el artista pretende que el espectador entable con su obra, a través de la observación y la convivencia con el mundo vegetal:

A diferencia de la rapidez con que se experimenta la vida moderna, marcada por la tecnología y la movilidad. La observación del mundo vegetal implica otro ritmo, las plantas no son estáticas, pero su movilidad, que es la de la expansión y el crecimiento corresponde a otro tiempo paralelo al de la civilización. Las predicciones en cuanto al tiempo y el desarrollo de esta obra de arte viviente no son más que eso, predicciones. De hecho, para realmente poder apreciar esta obra, el espectador tendrá que volver a visitar la sala, pues los cambios en este mural vegetal (abstracto y concreto a la vez) tardarán semanas o incluso meses en ser visibles. Además de esto esta pieza será particularmente disfrutable para quienes cohabitan con este entorno cotidianamente584.

584 HAGERMAN, Jerónimo, "Contemplando la invasión", Disponible en red: <http://www. artesvisuales.com. $\mathrm{mx} /$ museos/temporales/museo.php?TMP_CONSECUTIVO=1623>, [Consulta 10, marzo, 2005]. 
En el mismo año y en coordinación con la revista Espacio, Arte contemporáneo, Hagerman realiza la pieza Azotea Jardín (2004) ${ }^{585}$, intervención en la que el artista dispone una serie de camas de olor, como parte del proyecto Espacio/localismo/azotea jardín, realizado en un edificio de la calle de Correo Mayor, en México, D.F.
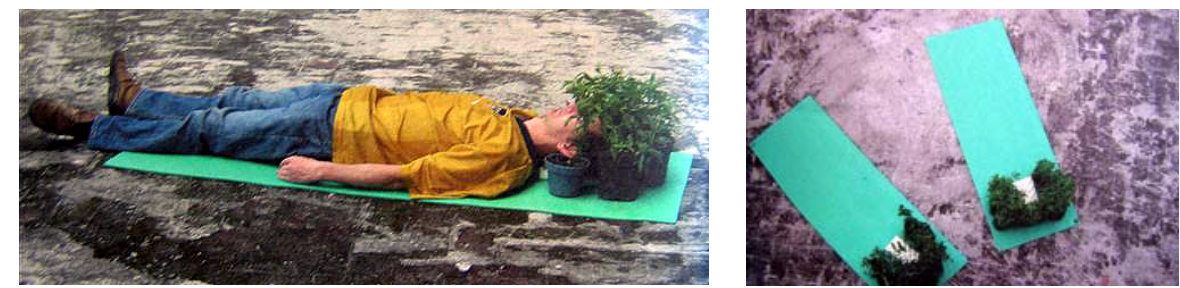

Jerónimo Hagerman, Acuéstese-Inhale-Disfrute, Azotea Jardín, 2004.

La génesis de esta obra plantea la idea de refugio íntimo proporcionado por las plantas, junto con la posibilidad de abstraerse del ruido, de la saturación y del bullicio cotidiano de la ciudad; la idea es la de acostarse a oler.

Las características de este lugar son determinantes para cualquier intervención. Estar tan expuesto al cielo es increíble. Trabajar con la idea de las camas que huelen te da la sensación de refugiarte estando al ras del suelo. El lugar, a pesar del bullicio que hay abajo, te relaja y te da conciencia de tu posición [...]. A veces las sensaciones son mucho más claras que los discursos intelectuales 586 .
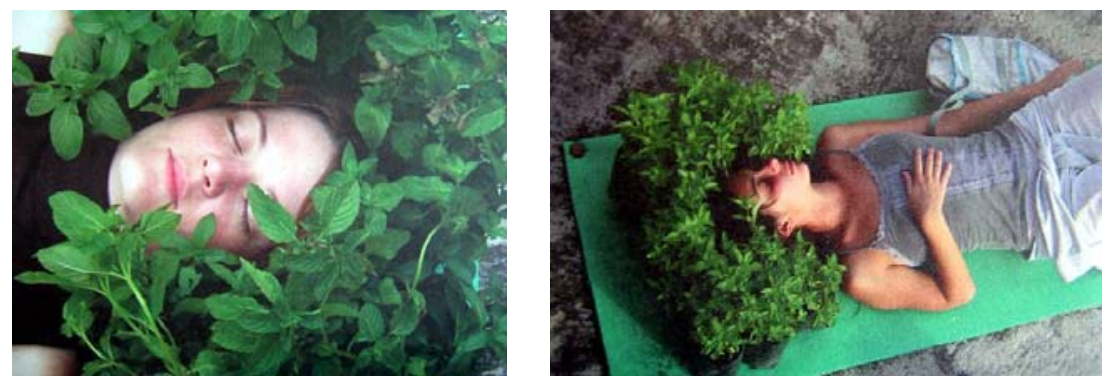

Jerónimo Hagerman, Acuéstese-Inhale-Disfrute, Azotea Jardín, 2004.

Como podemos percibir, Hagerman crea situaciones, en el sentido de propiciar la intervención de un público que interactúe con su pieza. La pieza, compuesta por unas colchonetas verdes y una serie de macetas de plantas aromáticas romero, albahaca, hierbabuena, etc.- no está completa, hasta que el espectador

585 AGYEMAN, Julian et al., "More gardens", en Down the Garden Path: The Artist's Garden After Modernism, Capítulo 5, Queens Museum of Art, Nueva York, 2005, p. 99.

586 HAGERMAN, Jerónimo, "Acuéstese-Inhale-Disfrute, Azotea Jardín/Lie Down-Breathe Deeply-Enjoy. Roof Garden", en [ESPACIO], Arte contemporáneo, № 1, Diamantina, México, D.F., mayo, 2005, pp. 58-65. 
se recuesta y participa de la vida vegetal, interactuando con ella a través de sus sentidos. Las plantas entonces se convierten en una especie de pelucas verdes que, con su frescura y olor, son capaces de proporcionarnos una experiencia fundamentalmente estética por el contexto en el que se realizó la pieza, pero también terapéutica por la posibilidad de detener el tiempo y la comprensión de la noción de relax que pueden llegar a trasmitir. Este tipo de desarrollo conceptual de la obra nos remite al sistema de creación de lo que Nicolás Bourriaud Ilama Postproducción, en donde "el consumidor extático de los años ochenta desaparece en favor de un consumidor inteligente y potencialmente subversivo: el usuario de formas" 587 , que se involucra, consume y disfruta.

Con un planteamiento similar, Hagerman realiza la pieza Mina (2006) para el proyecto Pink Not Dead (El rosa no muere) de Maurycy Gomulicki, en la Galería Garash, México, D.F. y en el Centro de Arte Ujazdowski Castle, en Varsovia (Polonia). Formalmente la obra hace referencia tanto al objeto "bélico" artificial que le da nombre, como a otro tipo de formaciones orgánicas y microscópicas como los virus. Hagerman deconstruye el significado conceptual de estas estructuras formales elaborando un espacio penetrable, visual y sensualmente atractivo, repleto de azucenas que se conservan vivas en unas probetas rellenas de espuma rosa y agua.

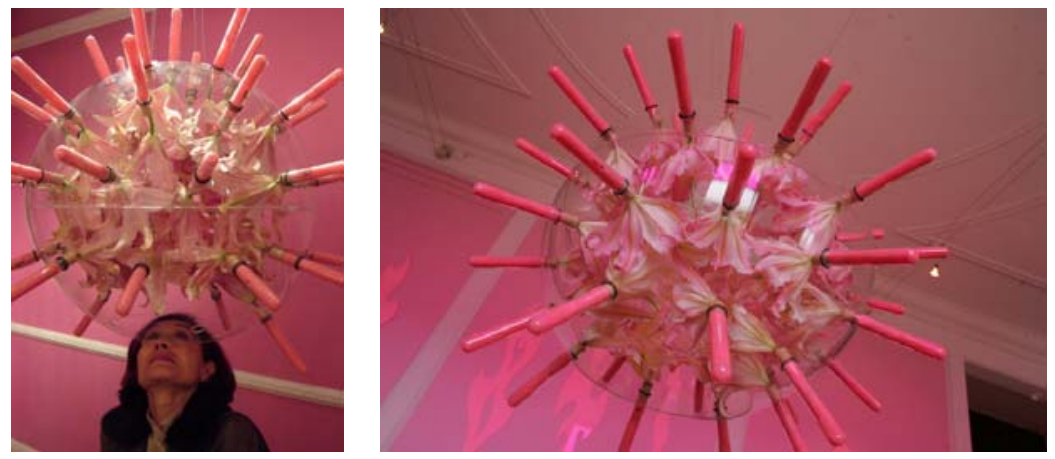

Jerónimo Hagerman, Mina, 2006.

En general las flores son el órgano más sensual de las plantas y, como elemento reproductivo, con su belleza y aromas atraen a los insectos. Con la creación de este pequeño recinto de cristal -en el que puedes meter la cabeza y embriagarte con el olor de las azucenas- el artista seduce al espectador al hacerle experimentar la sensación de poder acceder a esos otros lugares que, según Hagerman, existen en la realidad, aunque no a nuestra escala.

En otro de sus trabajos, Bosque (2006), realizado en el Centro Cultural Muros de Cuernavaca (Morelos), la dimensión viene dada por la pequeña construcciónmirador desde la cual, una pequeña figura humana contempla un simulacro de paisaje recreado con macetas de arbolillos de diferente altura. El espectador de la pieza es convertido por la escala y la proporción de su propio tamaño, en un

587 BOURRIAUD, Nicolás, Postproducción..., op. cit., p. 45. 
nuevo Gulliver, sin embargo el observador se siente identificado y se personaliza en la pequeñez del personaje del mirador que absorto, contempla la inmensidad de este paisaje artificial. Situándonos en la concepción romántica del paisajismo, la conexión con la obra de Caspar David Friedrich es inevitable.
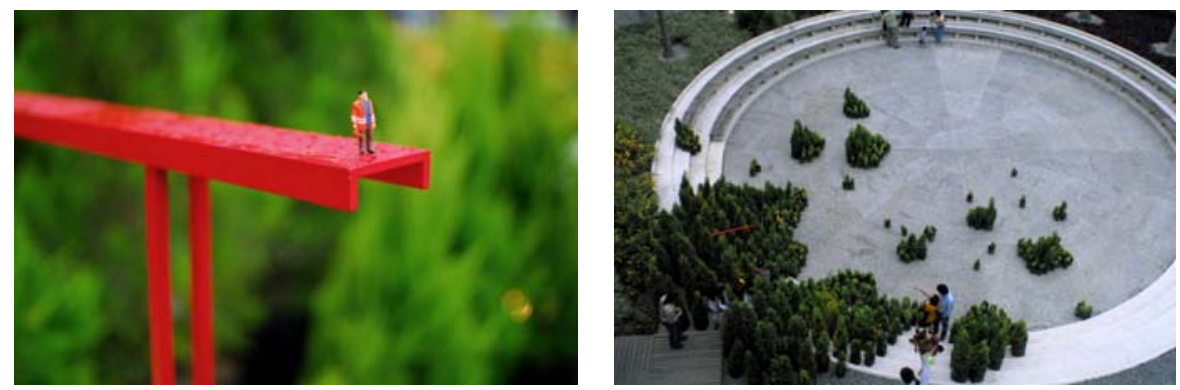

Jerónimo Hagerman, Bosque, 2006.

Hagerman nos presenta aquí una concepción escenográfica y romántica del paisaje que, no por usar plantas naturales y vivas convierten esta imagen en una percepción menos artificial. Aquí, al igual que los maestros de la pintura de paisaje en la Europa del siglo XIX, el artista busca situarnos ante una experiencia vivencial intensa y directa de una Naturaleza ilimitada que nos desborda frente a la percepción de lo sublime y de su inasibilidad588, sin embargo esta idea es un recurso cuestionado por Hagerman ante la imposibilidad misma del concepto. Como señala Argullol:

La contemplación romántica de la Naturaleza, no es una visión directa de la realidad sino una contemplación de la contemplación. El artista romántico no se limita a la percepción sensitiva y consciente y, por el contrario, recurre, no como un elemento secundario sino como la fuerza principal, a la indagación de su propio subconsciente589.

No se trata como en aquellos casos, de una Naturaleza radical o temible que nos enfrenta a nuestro último destino, sino tan sólo de un espectáculo, una visión armónica en la cual el personaje es espectador desde fuera590, como quien contempla un lugar en el que a pesar de todo no habita. Finalmente, la imagen percibida desde la atalaya por esta pequeña representación del espectador, es un interrogante a lo otro, una apreciación estética que media la distancia cultural y física del habitante de las ciudades con la percepción de esa Naturaleza que observa en la distancia. Ya en el siglo XVIII el término sublime, de connotaciones estéticas y metafísicas, tenía que ver con la percepción de la escala y el tamaño591. El sentimiento de inmensidad se escenificaba con

\footnotetext{
588 BURKE, Edmund, op. cit., p. 43.

589 ARGULLOL, Rafael: La atracción del abismo, Bruguera, Barcelona, 1983, p. 61.

590 ALBELDA, José y SABORIT, José, op. cit., p. 64.

591 LITVAK, Lily, El tiempo de los trenes: el paisaje español en el arte y la literatura del realismo: (1849-1918), Serbal, Barcelona, 1991, p. 30.
} 
escenarios de montañas, y se asociaba con el temor, el silencio, las tinieblas, la majestuosidad y todo lo que la visión de estas escenas provocaba en el espectador. De la misma manera, en esta pieza el público se enfrenta a un sentimiento romántico en donde el juego de escalas de su propio tamaño es un juego de reflejos que lo convierte en espectador de un espectador que a la vez contempla y es contemplado.
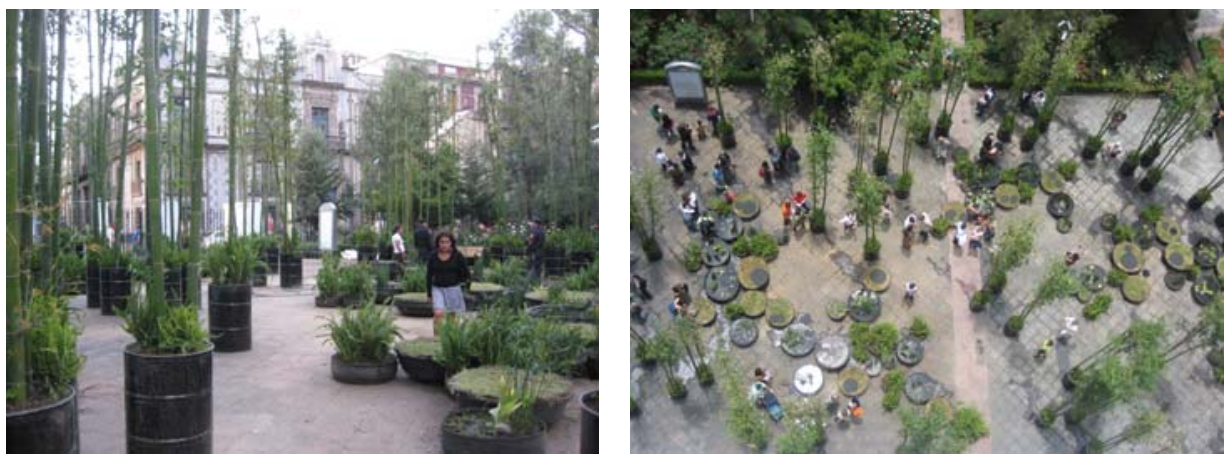

Jerónimo Hagerman, Aquí y ahora. Jardín Radial, 2009.

En uno de sus más recientes trabajos, Aquí y ahora. Jardín radial (2009), realizado en el Atrio de San Francisco del Centro Histórico de México, D.F., Hagerman, partiendo de la vida vegetal, vincula diferentes dimensiones espaciales y temporales, con la finalidad, como comenta el poeta, escritor y periodista Juan Carlos Bautista, de que la obra de arte suceda. Lejos de convocar un lugar ficticio, a manera de un contacto irreal, con una falsa Naturaleza, el artista hace real algo que crece y se recrea constantemente, devolviéndole al jardín,

Su calidad de experiencia estética y de espacio reflexivo [...]. Jardín radial sucede. Si uno se adentra en él, la intervención vegetal, ordenada en grupos de macetas redondas, moleculares, parece proliferar, suceder [...]. Jardín radial es una versión pervertida de lo paradisíaco592.

Se trata de una experiencia que nos invita a pensar la ciudad de otra manera y nos proporciona una visión ajena a cualquier idea anacrónica del paraíso. En esta obra, el espacio y el contexto arquitectónico del lugar determinan el aquí, a partir de este punto, el artista remite a un ahora con texturas temporales que se incorporan a la vivencia del jardín como un presente irrepetible y fugaz. De la misma manera, el espectador puede percibir los procesos de cambio que los elementos vegetales experimentan con el paso del tiempo.

592 BAUTISTA, Juan Carlos, "Dos notas a propósito del Jardín Radial de Jerónimo Hagerman”, en Galleta China. Revista de Arte \& Propaganda, № 1, Casa Vecina, Espacio Cultural y Fundación del Centro Histórico de la Ciudad de México, México, D.F., 2010, pp. 8-11. 
Las dos nociones -espacio, tiempo- se manifiestan solamente a partir de una presencia, de la vida: la vegetal que transcurre encadenando múltiples cambios sutiles y la humana que se inserta en la historia y que crea historias. El jardín de Jerónimo Hagerman está concebido como una intersección de instantes irrepetibles que se generan en el encuentro con diferentes escalas y formas de ver, habitar y vivir en el espacio593.

El artista, al utilizar diferentes tipologías de elementos vegetales (nenúfares, bambúes, etc.) juega con distintas escalas entre lo micro y lo macro, dirigiendo nuestra mirada tanto hacia la verticalidad como hacia la horizontalidad. Desde una vista aérea, el jardín ofrece una perspectiva de estructuras moleculares como las que se aprecian en un microscopio (colonias de líquenes, moho, etc.) en la cercanía, la distribución de los elementos circulares -contenedores de plantas elaborados con neumáticos reciclados y toneles metálicos- favorece un diálogo real, con el centro de la ciudad y la gente que lo circunda.

En definitiva, dentro del contexto del arte contemporáneo, la obra de Hagerman, cercana en nuestra opinión a las nuevas teorías sobre el estudio de las propiedades de los sistemas biológicos, nos sugiere desconfiar de la tendencia a imponer explicaciones sobre la Naturaleza, basadas únicamente en experiencias antropocéntricas. Enfrentándonos a la observación directa de la vegetación y sus procesos, así como a la morfología del ambiente exterior y de la experiencia sensorial externa que es la que determina la forma y estructura de nuestro cerebro ${ }^{594}$, propone propiciar la percepción de otra clase de conocimientos.

Entre los artistas que en México han utilizado plantas en su obra haciendo un uso explícito de la vida vegetal, con claras y significativas implicaciones sociales, podemos citar a Gabriel Orozco (Jalapa, Veracruz, 1962) cuya obra se inserta en el análisis de la realidad cotidiana, describiendo y codificando el accidente y los encuentros casuales. Partiendo del relato de la precariedad, de la sorpresa y del descubrimiento de lo imperceptible, en algunas de sus imágenes fotográficas aparecen plantas, haciendo alusión a una Naturaleza en crisis. El jardín del mundo (1998) presenta una bola del mundo colgada de una horca en el marco incomparable de una Naturaleza exuberante. La oficina /-// (1992) es un cibachrome donde se aprecian unos muebles en una habitación tomada por las plantas. En ambos casos, el gesto del artista elabora una nueva situación significativa, construyendo alegorías de un mundo y de una vida social en decadencia, debido al cansancio de las acciones y a las caducas concepciones del mundo moderno.

\footnotetext{
593 BRAUNŠTAJN, Helena, "Intervención artística de Jerónimo Hagerman en el Atrio de San Francisco", Disponible en red: <http://www.lugarcero.com/index.php/atrio-de-sanfrancisco/aqui-y-ahora-jardin-radial-jeronimo-hagerman >, [Consulta 10, agosto, 2009]. 594 ALBERCH, Pere, "Jardines internos: Orden y caos en las formas orgánicas", en MADERUELO, Javier (dir.), Huesca: Arte y naturaleza..., op. cit., pp.21-35.
} 


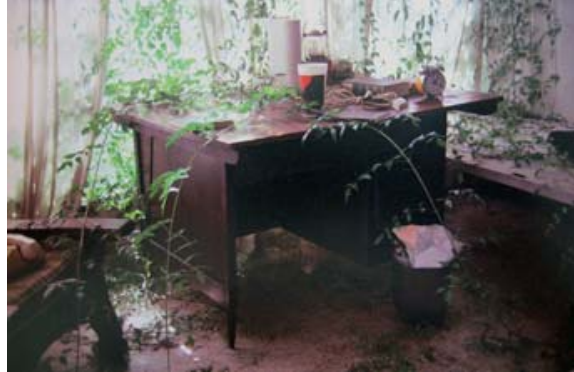

Gabriel Orozco, La oficina I-II, 1992.

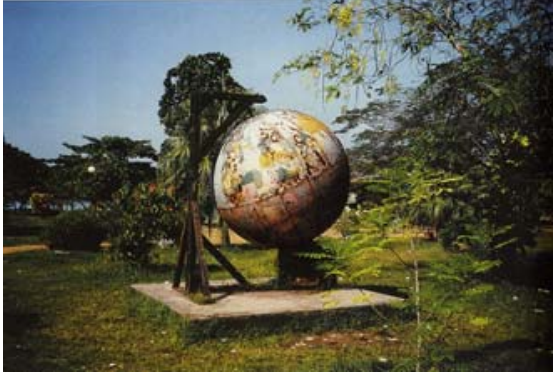

Gabriel Orozco,

El jardín del mundo, 1998.

Aquello que se refiere al conocimiento humano y a la Cultura es convertido en reflejo de una crisis total de valores, en una naturaleza muerta a merced de la fugacidad del tiempo595. El artista cuya obra es una vivencia oblicua de la Cultura, se vuelve testimonio mimético del anima viva afectada y del cuestionamiento producido por un modelo humanista. En sus trabajos, son importantes las referencias al mundo de los objetos en relación con el mundo natural. Estas piezas permiten al artista crear situaciones que podríamos considerar escultóricas. Así se puede apreciar en su exposición Un paisaje en tiempo de secas (2009), donde el artista interviene quiotes de maguey para construir paisajes del agotamiento.

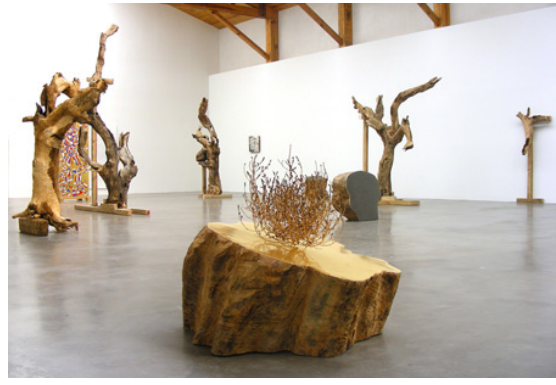

Gabriel Orozco,

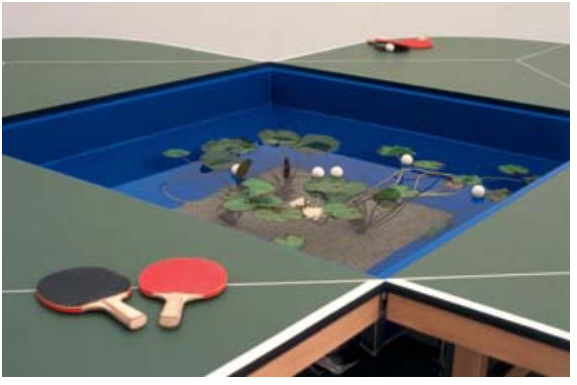

Gabriel Orozco,

Un paisaje en tiempo de secas, 2009. Mesa de ping-pong con estanque, 1998.

Si bien entre las motivaciones de este artista no encontramos la intención de establecer ninguna declaratoria específica que vincule la necesidad de utilizar lo vegetal como representativo de la relación entre Arte y Naturaleza, lo destacable es que, en determinados momentos de su trayectoria ha recurrido específicamente a este material orgánico para plantear su discurso respecto al binomio Naturaleza/Cultura. En Mesa de ping-pong con estanque (1998), el artista parte de una división (la separación de campos en la mesa normal de ping-pong) para abrir un espacio nuevo y generar un comportamiento espacial diferente: al transformar geométricamente el trazado, se genera un cuadrado en

595 RUÍZ DE SAMANIEGO, Alberto, "El tiempo de un bodegón", en Exit, Nº 18, Naturaleza muerta/Still.life, Olivares y Asociados, Madrid, 2005, p. 26. 
el centro, y lo que antes era una línea divisoria entre dos zonas, ahora se convierte en un espacio tridimensional formado por cuatro mesas, en cuya intersección el artista construye un estanque de agua con lirios. Esta circunstancia se convierte en un rasgo característico de que cuando el arte contemporáneo quiere establecer una dialéctica entre el ámbito de la Cultura y lo natural, frecuentemente utiliza como pretexto la vida vegetal.

También el Colectivo Tercerunquinto (1998) formado por Julio Castro (1976), Gabriel Cázares (1978) y Rolando Flores Tovar (1975) todos ellos de Monterrey (Nuevo León), desarrollaron un proyecto artístico en Miermaigne (Francia) en el que, como parte de una actividad agrícola social, cultivaron un pequeño espacio, en el que aparecen vegetales. Este grupo desarrolla proyectos -a manera de interrupciones en el sistema del orden urbano- que revelan la conexión entre arquitectura, escultura, urbanismo y espacio público. Su trabajo se basa en el cuestionamiento del orden de los sistemas urbanos o arquitectónicos así como en los efectos que éstos provocan dentro de la sociedad, la Cultura y la política. Sus obras cuestionan los límites entre el espacio público y el espacio privado, examinando las fronteras socialmente establecidas que definen dichos límites. Tercerunquinto utiliza la negociación con las instituciones y los grupos sociales como elemento de cohesión colectiva y considera estos trámites como una estrategia discursiva clave dentro de su propio proceso artístico. De esta manera, su concepción del espacio en términos semánticos, les permite manipular y recomponer los fragmentos del lenguaje, en función de la necesidad del mensaje.

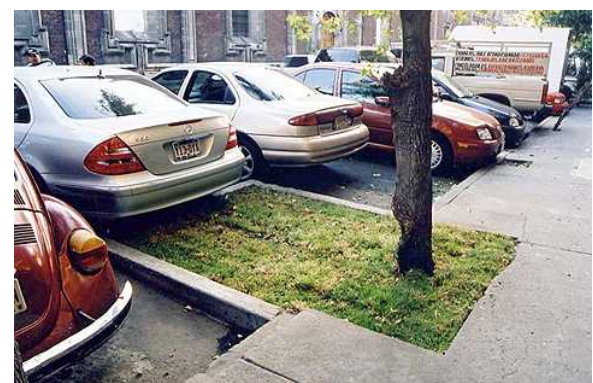

Colectivo Tercerunquinto,

Ampliación de un área verde, 2004.

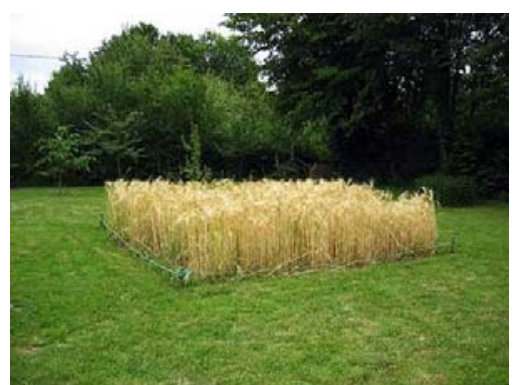

Colectivo Tercerunquinto,

16 metros cuadrados para cultivo, 2002.

Para la realización de la obra 16 metros cuadrados para cultivo (2002), Tercerunquinto propuso a una familia de la citada región agrícola, acotar un pequeño campo de cultivo de $4 \times 4$ metros, en el jardín privado de su casa particular, con la finalidad de integrarse de esta manera, en la actividad económica de la región. Con la acción de sembrar esta pequeña parcela con los granos característicos de cada estación en esa zona (trigo, colza y cebada), el colectivo pretendía demostrar la sentencia de que aprender una regla no es seguirla: 
[...] no existen reglas como hechos objetivos separados de las actividades que realizan los hombres, demostrando que aprender una regla no es seguirla, sino ser introducido por adiestramiento a actividades sociales establecidas donde las concordancias son las que determinan las condiciones de aceptabilidad596.

En este sentido el proceso mimético de lo natural como actividad económica cobra sentido al actualizarse en su dimensión social. Por ejemplo, en otra de sus obras, Ampliación de un área verde (2004), la acción consistía en la ampliación intencional de dos metros de un área verde o jardinera en una calle de México, D.F., que estaba utilizada casi en su totalidad como aparcamiento para vehículos. Con esta pequeña, pero significativa acción, el colectivo buscaba modificar la forma de entender el paisaje urbano, otorgándole más espacios a los transeúntes. Una evocación poética que plantea incidir en la necesidad de una mejor gestión de las infraestructuras en las ciudades, para entender y construir el paisaje urbano de una manera más armónica. Si bien la intervención puede pasar desapercibida por los peatones, en el contexto artístico, ejerce como detonante capaz de evocar "un lugar mejor"597.

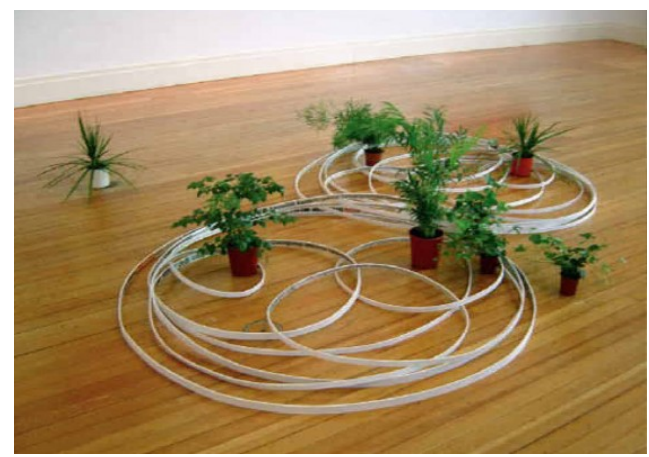

Sebastián Romo, ¿Cómo ser los mismos siendo diferentes?, 2009.

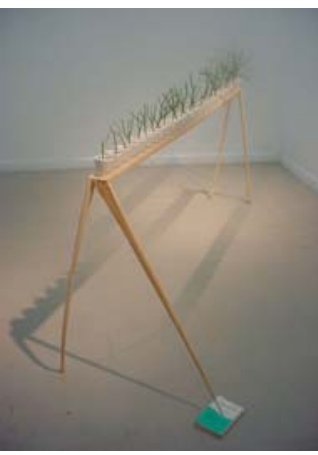

Sebastián Romo, La Voluntad en la Naturaleza, según Schopenhauer, 2002.

Por último, queremos ejemplificar el uso de plantas vivas en el arte mexicano contemporáneo con una obra que refleja una de las características fundamentales de la vida vegetal que, a nuestro entender, es la voluntad de existir, y que en parte de sus trabajos escultóricos Sebastián Romo, México, D.F. (1973), pone de manifiesto. En el inicio de su trayectoria, sus trabajos estaban vinculados a preceptos estéticos y a soluciones formales cercanas al Land Art de la década de los setenta. Se trataba de obras efímeras elaboradas con materiales encontrados in situ y en espacios abiertos, donde el contexto específico de la

596 ORIARD, Andrés, "Los críticos hacen sus apuestas", en Exit Express, № 18, Olivares y Asociados, Madrid, marzo, 2006, p.13.

597 MARCíN, Mauricio, "El colectivo regiomontano Tercerunquinto altera con su arte el paisaje urbano", Disponible en red: <http://cronica.com.mx/nota.php?id_nota=158867> [Consulta 16, agosto, 2011]. 
Naturaleza y el paisaje, eran protagonistas, materia prima y fuente de reflexión sobre el arte mismo. Posteriormente, su obra se dirige a la experimentación con materiales y medios más próximos a debates y estrategias del arte posconceptual de los noventa. La práctica artística de Romo se ha caracterizado por generar procesos de investigación y producción a largo plazo en los que destaca un interés por conjugar disciplinas, soportes y métodos constructivos. En su trabajo escultórico su punto de partida es la conjunción de distintos objetos, ideas y materiales.

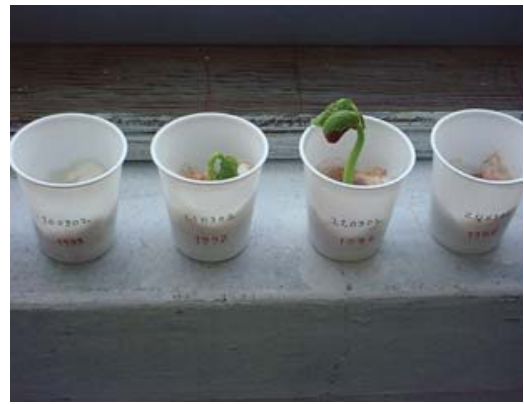

Sebastián Romo,

La Voluntad en la Naturaleza, 2002.

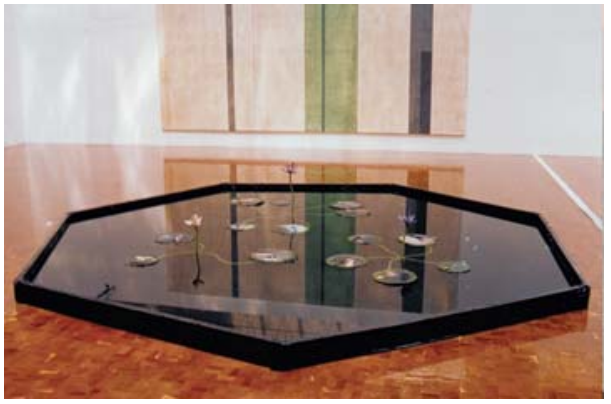

Sebastián Romo, Victorias ferox, 1999.

La Voluntad en la Naturaleza, según Schopenhauer (2006), es una pieza escultórica que consiste en la seriación de una planta en diversas fases de crecimiento. Cada una de estas pequeñas plantas representa un año de la vida del artista. Las plantas están sembradas en unas pequeñas tazas blancas y alineadas sobre una inestable estructura de madera. Esta estructura reposa sobre cuatro patas en un, aparentemente, precario equilibrio, ofreciendo una sutil imagen de la fragilidad tanto por la estructura que presenta la pieza como por las connotaciones que conlleva. Significativamente, una de las patas se apoya en el libro The world as Will and Representation 598 de Schopenhauer. La obra fue expuesta en la exposición La voluntad de las cosas (2009) en el Centro Galego de Arte Contemporánea. Con tal motivo, Víctor Palacios, comisario de la exposición, señalaba que en esta obra -tomando como base el pensamiento kantiano, las ideas platónicas y su profundo estudio de la Cultura hindú- el filósofo alemán plantea una metafísica de la moral en la que argumenta detalladamente cómo la voluntad es la clave para explicar, desde nuestro fuero interno, los grandes enigmas del universo ${ }^{599}$.

A su vez, en esta instalación escultórica que está viva, el proceso del paso del tiempo y la magia del crecimiento de las plantas, nos convocan a reflexionar no

598 The world as Will and Representation (El mundo como voluntad y representación), la obra cumbre del filósofo alemán Arthur Schopenhauer (1788-1860) fue publicada por primera vez en 1819.

599 PALACIOS, Víctor, "Sebastián Romo. La voluntad de las cosas", Centro Galego de Arte Contemporánea, Disponible en red: <http://www.cgac.org/index.php?id=65\&idn=582>, [Consulta 13, agosto, 2009]. 
sólo sobre la transformación de la pieza en sí y la representación de estos conceptos, sino también sobre nuestras propias vidas. El artista, siguiendo a Schopenhauer -quien abre su libro con la frase "el mundo es mi representación"- toma a su vez, el mundo como representación y se representa a sí mismo como una planta, identificándose con ella. Al presentar la voluntad como idea de la existencia, establece una analogía entre el objeto (plantaescultura) y el sujeto (el artista) que se identifican en una misma unidad:

La idea implica tanto al objeto como al sujeto, pues éstos son una forma única y exclusiva (las formas subordinadas de las cosas particulares quedan suprimidas); en la idea, sujeto y objeto se mantienen en perfecto equilibrio [Gleichgewicht]: el objeto (como siempre) no es otra cosa que la representación del sujeto; y el sujeto, en la medida en que se sumerge en el objeto contemplado, llega a confundirse con él, pues la conciencia entera no tiene entonces otra cosa que su imagen clara y precisa: es el siempre medium de la entrada del objeto en el mundo de la representación600.

Este proceso de identificación -individual o social- establece un símil que se constituye como una de las razones básicas del uso del elemento vegetal en la mayoría de obras de estos artistas. En la pieza Victorias ferox (1999) realizada años antes, el artista crea una naturaleza artificial elaborada como presencia absoluta de una Naturaleza en donde fantasía y realidad se conjugan para hablar de pensamiento y sentimiento.

\subsection{Naturaleza y memoria. Perla Krauze, Antonio Ortiz Gritón y Ander Azpiri}

Los artistas que trabajan en torno a la Naturaleza, sea con materiales naturales o artificiales, presentan también una especie de tendencia a recuperar algo que nuestra sociedad consumista tiende a perder. En este sentido, obras como la de Perla Krauze (México, D.F., 1953) parecen querer evidenciar las huellas601 del paso del tiempo y su manifestación en nuestro entorno cotidiano, mediante la memoria como eje de constatación. Cercana en sus reflexiones, a la estética del Arte Povera, su estrategia plantea que sean los propios materiales los protagonistas principales de sus obras.

[...] lo que en el arte tradicional era la composición de la obra, aquí se reduce a un acto de elección de materiales encontrados sin voluntad rígida de configuración, presentados como antiforma. Es decir, el azar sustituye al orden formal602.

600 SCHOPENHAUER, Arthur, Lecciones sobre metafísica de lo bello, Universitat de València, Valencia, 2004, p. 106.

601 DRIVEN, Lelia, Landscapes. Perla Krauze, Gallery Iturralde, Los Ángeles, California, pp. 19-22.

602 ESPINOSA, César y ZÚÑIGA, Araceli, La perra brava. Arte, crisis y políticas culturales, UNAM, México, D.F., 2002, pp. 216-217. 
A diferencia del arte matérico, en el que las propiedades físicas del material son presentadas como ingredientes estéticos y transformadas artísticamente (Tapies), el Arte Povera603 se limita a presentar la materia seleccionada por la forma de manifestarse de cada elemento. El artista pobre se sitúa junto al biólogo o el ecólogo, acercándose al mundo natural para redescubrirlo en algunas de sus potencialidades físicas y energéticas, así como investigando el crecimiento vegetal, las reacciones químicas y físicas o las propiedades de los minerales. El carácter energético de los materiales ${ }^{604}$ se manifiesta en la obra de Krauze, presuponiendo la potencialidad transformadora de los mismos que pasan a convertirse de receptores pasivos, artísticamente hablando, a agentes activos, orientando su poder hacia el mismo proceso de transformación. Si bien, la vía de recuperación llevada a cabo por Krauze, involucra una meticulosa manipulación técnica del accidente encontrado -en cuanto a la reproducción y seriación mediante moldes- la esencia de su trabajo no busca la reconstrucción del objeto sino, como en el Arte Povera, la presentación de un acontecer cotidiano a manera de una colección heterogénea de circunstancias, sustancias y formas del campo tanto visual como emocional.
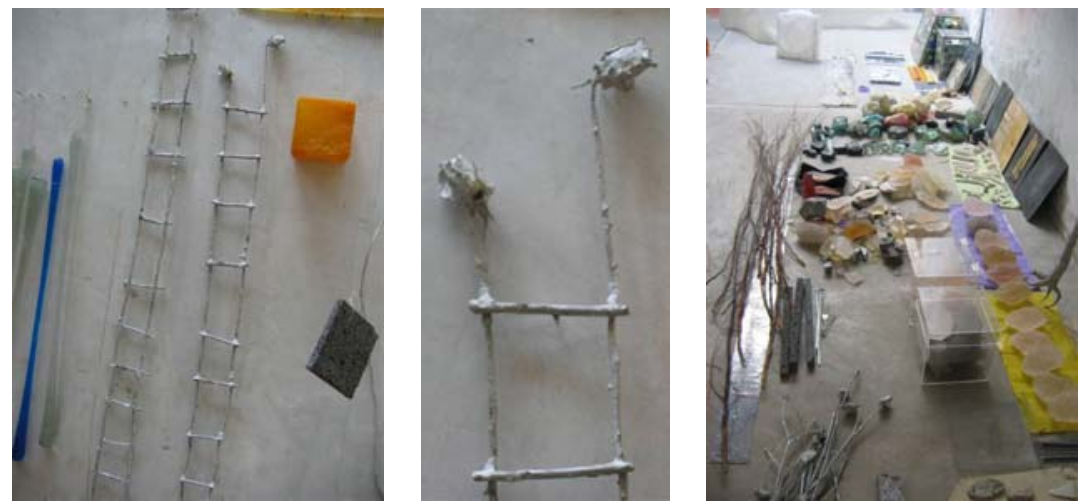

Perla Krauze, Sin título, 2005.

En este contexto la obra de Krauze se acerca a la de Giuseppe Penone605, uno de los artistas exponentes del Arte Povera, para el cual la Naturaleza no es sólo fuente de inspiración, sino medio y fin de su quehacer artístico. Basando su obra en la relación entre el hombre y su medio natural Penone afirma que la Naturaleza es arte y el hombre es artista en tanto que es Naturaleza y como tal, repite los mismos comportamientos escultóricos de la Naturaleza. No se trata de imitar los resultados, sino de acercarse, de entender los procesos de transformación. En la obra Ser río (1981), Penone trabaja en torno a la idea del artista que deviene río, copiando minuciosamente piedras recogidas del mismo y realizando el mismo proceso de desgaste que el río hizo anteriormente -

603 FERNÁNDEZ POLANCO, Aurora, op. cit., p. 34.

604 PORRAZ FRASER, Paloma, "Naturalezas", en Perla Krauze, naturalezas, Galería Nina Menocal, 1998, pp. 2-5.

605 Véase AA. VV., Giuseppe Penone, 1968-1998, op. cit. 
después de haber localizado el punto de donde proviene esa piedra y elegir un bloque de piedra para tallarlo con la misma forma-.

En otras piezas como Líneas de contorno (1989), Penone obtuvo moldes de las escaleras de piedra de una fábrica de alfombras del siglo XIX, destinada en la actualidad a salas de exposiciones, en la ciudad de Halifax (Gran Bretaña). En los huecos de los escalones deformados durante años por el paso de los trabajadores, su obra recupera la huella de la acción humana y el efecto del tiempo transcurrido. El vacío producido por los trabajadores es ahora el lleno de la escultura, huella sedimentada que memoriza el contacto con la materia. En cuanto autor de un gesto significativo, el artista no crea la escultura sino que señala. En estas obras, la idea da forma y expresión al roce mínimo de un tiempo dilatado manifiesto en la Naturaleza o en la sociedad. El artista traduce el efecto de la erosión anónima del paso del tiempo, haciendo del arte un mecanismo capaz de condensar la acción difusa de la Naturaleza en una serie de gestos muy eficaces606.
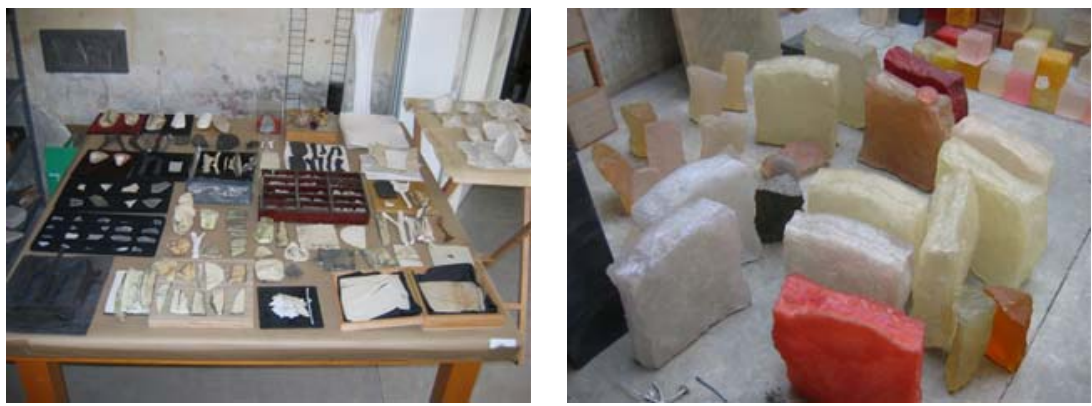

Perla Krauze, Sin título, 2005.

En este sentido y considerando a la Naturaleza como parte integrante de la Cultura, el Arte Povera une Cultura y Naturaleza. De forma similar Krauze, utiliza sus recorridos por diferentes zonas de México, D.F. como estrategia para evidenciar con sus obras, las huellas que los agentes de la Naturaleza y el paso del tiempo han dejado en el entorno. La utilización tanto de diversas técnicas y materiales, le permiten que sea la propia materia de cada uno de éstos la que ponga en evidencia sus cualidades y lenguajes propios: la maleabilidad, el peso, la toxicidad, la atemporalidad o la permanencia, etc.

En sus últimas obras, su trabajo se ha centrado en la Naturaleza y sus apariencias, llevándole a explorar la tensión entre la misma y aquellos materiales artificiales que adoptan la misma imagen, elaborando discursos formales sobre la veracidad de lo que observamos. Ya en sus proyectos en el Centro para las Artes en Banff (Canadá, 2002) exploraba la fosilización, la memoria y el tiempo, recreando en procesos seriados y con materiales artificiales, formas del reino vegetal y mineral.

606 SAN MARTíN, Francisco Javier, "Entrevista con Giuseppe Penone", en Lápiz, N 152 , Madrid, 1999, pp. 34-45. 
[...] logré hacer piezas en porcelana, barro de alta temperatura y en papel hecho a mano, de dos elementos, una rama y una piedra. Llevé los moldes de estos objetos desde México y logré repetir muchas piezas diferentes de ambas formas. En ocasiones les añadí esmalte u otros materiales para hacerlas diferentes cada una. Se convirtieron en una especie de «fósiles» de hoy607.
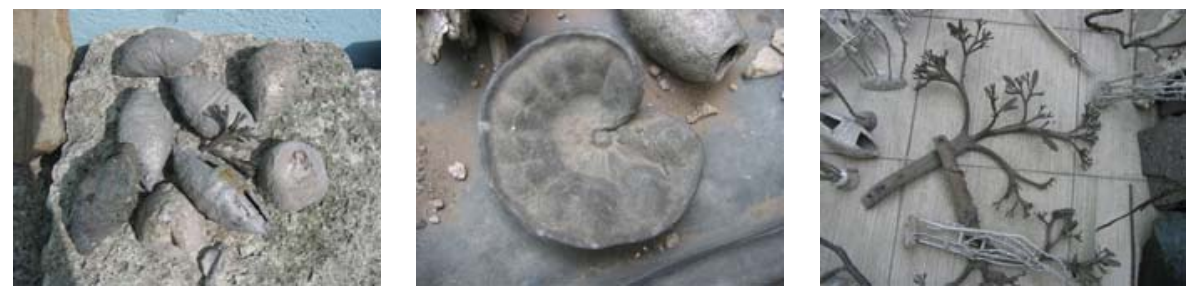

Perla Krauze, Sin título, 2005.

Su obra, en permanente diálogo con el espacio, ha oscilado entre lo bidimensional y lo tridimensional, entre el dibujo, la pintura, la escultura y la instalación, investigando las dualidades y las contradicciones entre lo natural y lo artificial, entre lo racional y lo intuitivo, lo permanente y lo efímero. Interesada en la idea de preservar las formas de la Naturaleza, utiliza materiales (diferentes tipos de moldes y positivados en resina o vaciados en aluminio o azúcar) que le ayudan a fosilizarlos, logrando que lo efímero se torne permanente.

En esta dinámica ha reproducido en aluminio, de forma directa -por baño de inmersión en cera- innumerables rosas naturales, así como otras plantas y semillas. Al tratarse de vaciados directos de las plantas, una extremada similitud plantea cierta ambigüedad, pero no hay confusión posible puesto que, la artificialidad de la reproducción queda patente no sólo debido al material, sino también en la forma de presentar las reproducciones. Las piezas de aluminio mantienen las coladas típicas de la técnica del vaciado, tal cual como salen de la fundición. La artista, al no prescindir del artificio propio de la técnica de la escultura, evidencia la sutil unión entre Naturaleza y Cultura, entre natural y artificial.

Krauze, incursiona también en la fotografía y el video, trabajando temas que hablan de la huella del tiempo y documentando en sutiles y mínimas intervenciones urbanas, la memoria de un lugar. A través de estas obras trata de registrar la ciudad en base a recorridos: la ciudad como un libro abierto que le encanta recorrer, caminar, encontrar y mirar, descubriendo sus detalles más pequeños. El mirar hacia abajo se convierte en una forma de prestar atención a los pasos: fijarse en el suelo, observando la capacidad de éste de preservar la

607 KRAUZE, Perla, Texto inédito proporcionado por la artista, a la autora de esta investigación, octubre, 2004. 
memoria, todo aquello que nos encontramos forma parte de nuestra propia historia.
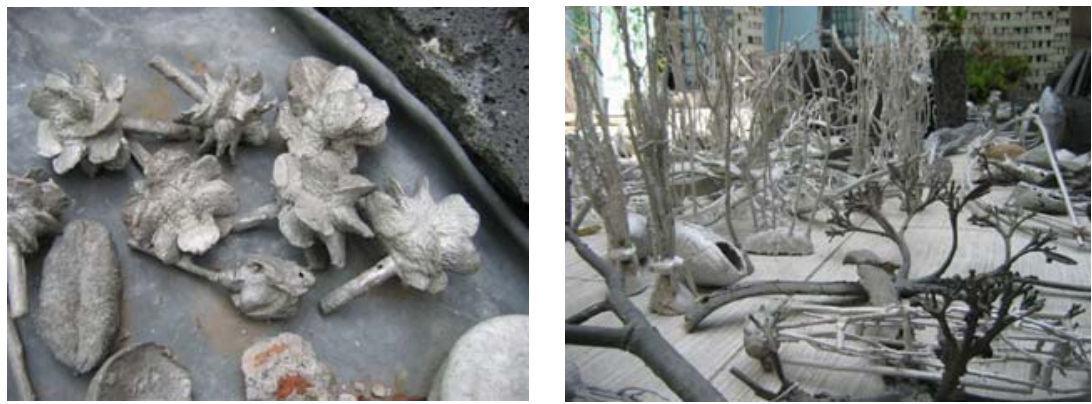

Perla Krauze, Sin título, 2005.

Así, mediante improntas, fotografías o videos, registra en cada sitio las huellas de todo lo que el tiempo ha dejado a su paso, encontrando en las aceras la memoria de lo que ha sucedido. Cada ciudad tiene un vocabulario distinto, por lo que una de las labores del artista debe ser hacer visible lo sutil, lo que está ahí de antemano, lo casi imperceptible o lo que no se ve al paso de lo cotidiano. En esta dinámica, una de sus estrategias fue dejar constancia y evidenciar las grietas en el suelo (la grieta como registro y memoria de la evidencia del paso del tiempo en nosotros mismos). En su exposición Paisajes, huellas y recorridos (2005)608, en la Galería Nina Menocal, Perla Krauze exploraba y reproducía las huellas de los cambios producidos por la Naturaleza en algunos espacios urbanos, aprehendiendo la memoria de un sitio mediante improntas, moldes y registros de accidentes o huellas (grietas de las aceras en las calles) que posteriormente vaciaría en resina. Estas acciones artísticas constatan el deseo de Krauze de replicar y presentar la acción y las formas de la Naturaleza en el propio gesto de reproducir, convertido por la artista en una lucha contra lo efímero del paisaje urbano cotidiano. El carácter del accidente vaciado y reproducido en resina traslúcida capta a manera de reflejo, lo habitualmente desapercibido en el paisaje urbano cotidiano.

En ocasiones, la intervención de la artista enfatiza el accidente-grieta aplicando varias capas de barniz sobre las grietas originales de la calle para evidenciar su presencia. Las reproducciones de grietas capturan el paisaje exterior del espacio de la galería y al ser exhibidas en el interior de la misma, la piel de la ciudad se introduce en la galería a través de un proceso en el que lo de afuera (grietas de la calle), se traslada al interior de la galería para convertirse en un paisaje nuevo, otra Naturaleza, una topografía transformada, clonada y reemplazada en resina.

608 JANKA, J. Frederick, "Perla Krauze. Paisajes: huellas y recorridos", en Perla Krauze. Paisajes: huellas y recorridos, Material divulgativo de la exposición, Galería Nina Menocal, México, D.F., 2005. 


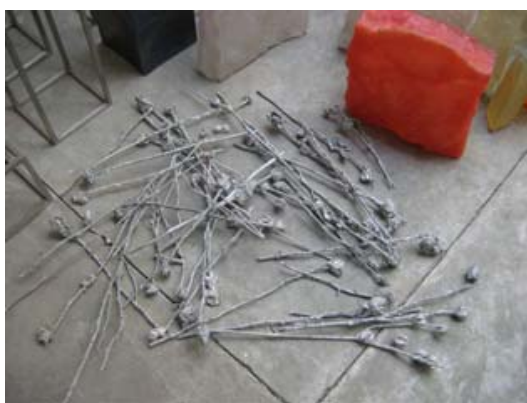

Perla Krauze, Sin título, 2005.

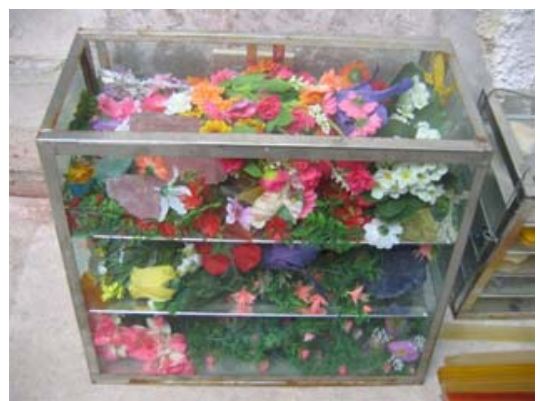

Perla Krauze, Caja de gelatinas con flores artificiales, 2005.

El traslado de las superficies es inmediato ya sea con el uso de silicona para los moldes de las grietas en la acera o con la utilización del video, en ambos casos, la impronta obtenida aparece como natural y fresca. Como resultado de estos procesos, la escultura que se obtiene es un encuentro, un extra que permite recrear la Naturaleza, haciendo visible el efecto del tiempo sobre la memoria de lo que uno ha visto y experimentado. Los videos de flores de jacarandas, grabados durante sus caminatas sin rumbo fijo por México, D.F., devuelven la mirada de la artista en sus recorridos cotidianos. En torno a la trasgresión sobre las formas que efectúa la artista, el comisario y crítico de arte, Edgardo Ganado Kim escribe:

Para Perla, la apropiación de la apariencia transgredida de las cosas naturales es un recurso válido de enfrentamiento con nuestra propia realidad, siempre artificial, efímera y contradictoria. Parecería pretender perpetuar las formas particulares y accidentadas de lo natural, como si la resina no fuese a desaparecer, como si las piedras no se fueran a transformar también. Su fin, utópico e ideal, es una manera de suspender en el tiempo las estructuras de la naturaleza través de lo que definimos como artificial609.

Por tanto, el registro de los accidentes del terreno encontrados en las caminatas no tiene la intención de recrear un ambiente artificial urbano sino, en todo caso, permitir que cada cosa conserve su objetualidad particular. Tras los procesos realizados, cada nuevo elemento reproducido se ha convertido en una versión distinta de su antecesor natura/610.

El accidente no es ya identificable por sus consecuencias funestas, por sus resultados prácticos -ruinas y restos esparcidos- sino más bien por un proceso dinámico y energético, una secuencia cinética y cinemática que no

609 GANADO KIM, Edgardo, "Naturaleza y apariencia", en Naturaleza suspendida. Perla Krauze, Galería Menocal, México, D.F., 2001, pp. 22-25.

610 KRAUZE, Perla, Texto inédito..., op. cit., octubre, 2004. 
podría parecerse a las reliquias de los objetos destruidos, escombros y cascotes de todo tipo611.
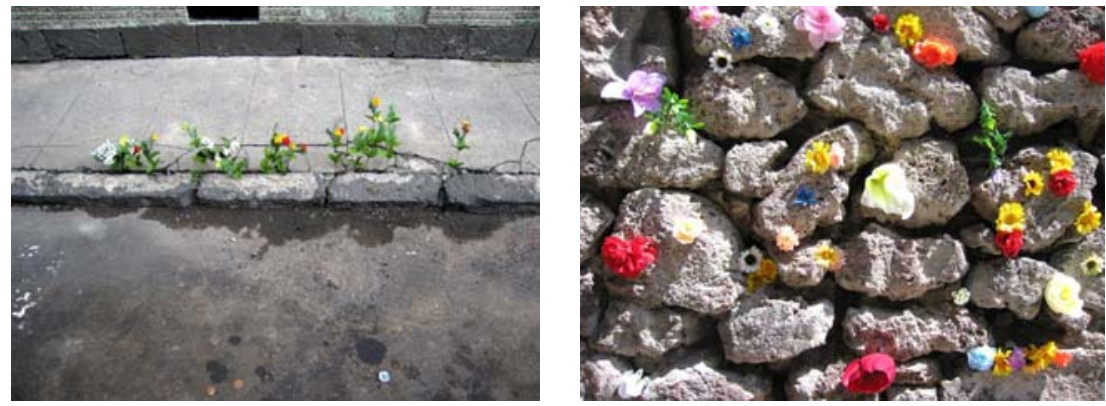

Perla Krauze, Flores de asfalto, 2005.

Mediante estos encuentros la artista se torna viandante consciente a la vez que nos emplaza a nosotros mismos -espectadores- a redescubrirnos como pasajeros en tránsito, capaces de reconocer y tomar conciencia del espacio que nos rodea. En torno a esta forma consciente de conocer la ciudad en la que vivimos, Paul Virilio apunta:

¿Encontrar o reencontrar? ¿Conocer o reconocer? En el intervalo entre esos términos, la unidad perceptiva ha desaparecido, la Ciudad devino una aglomeración, suerte de "Metaciudad, memorial de los trayectos del objeto pasajero en que me he convertido repentinamente, yo el sujeto, ese ciudadano programado por su motricidad tanto como por el sistema de las arterias de los barrios [...] cada ciudadano es un urbanista que se ignora"612.

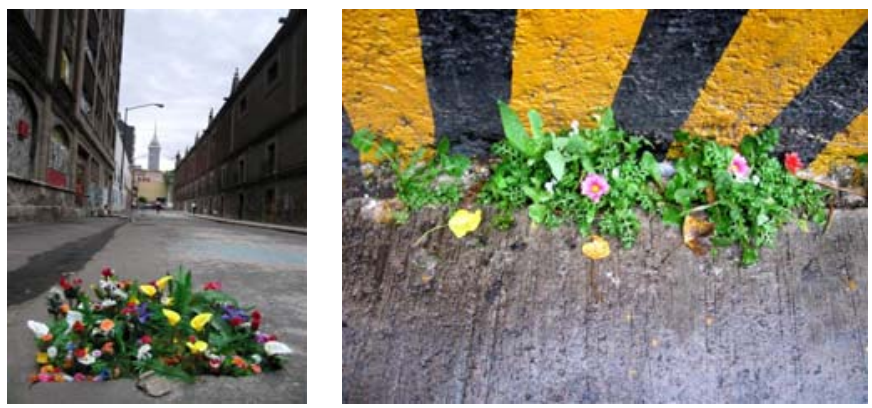

Perla Krauze, Huellas de la Santa Veracruz, 2005.

La forma de exponer los registros, a manera de colección o gabinete, es parte del proceso de recuperación con el que la artista busca generar una duda sobre su posible origen natural o manufacturado, planteando así una ambigüedad en el espectador:

611 VIRILIO, Paul, "El museo del accidente", en Un paisaje de acontecimientos, Paidós, Buenos Aires, 1997, p.123.

612 VIRILIO, Paul, Ciudad Pánico. El afuera comienza aquí, Libros del Zorzal, Buenos Aires, 2006, pp.17-19. 
Esta es una colección de objetos manufacturados, hechos por mi en su mayoría, de materiales diversos y que parecen objetos encontrados, quizás fósiles de otras culturas, de algún hallazgo arqueológico [...] no se sabe de cuál cultura, ni de cuando, sólo se percibe lo arcaico y el ser vestigios suspendidos en el tiempo [...] hay un intento de categorización o catalogación, aunque no hay números ni etiquetas [...] No hay un orden perfecto, ni clasificación exacta por tamaño, ni forma. La intención es hablar del tiempo, además de estar en un sitio ambiguo entre la Cultura y la Naturaleza. [...] La noción del tiempo es muy importante, los procesos de elaboración son lentos, básicos, no involucran una gran tecnología. $A$ veces parecen objetos comunes encontrados, piedras, ramas, huesos, fragmentos de vasijas, restos o vestigios de alguna cultura actual o ancestral. Son de barro, porcelana, aluminio, resina, papel, materiales a veces contrastantes, que "viven el tiempo" de manera diferente613.
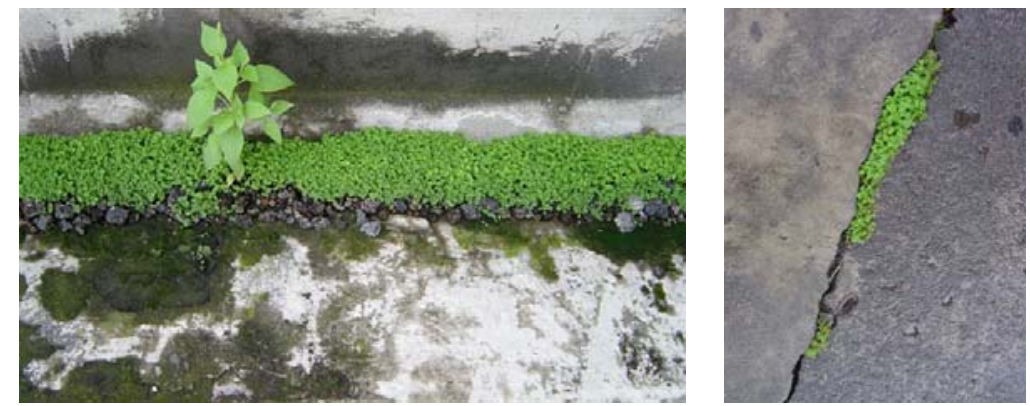

Perla Krauze, Sin título, 2005.

El deseo de interactuar con el espectador está presente en toda su obra. La idea es generar diferentes dinámicas de ambigüedad de forma que, según el sitio y la forma de instalar sus piezas, éstas pueden presentar diferentes lecturas y significados. Su intención consiste en buscar diferentes espacios alternativos de exposición, museos de historia natural, de geología, de arqueología, museos y galerías, en cuyas vitrinas se puedan exponer sus colecciones aparentemente encontradas. La confusión surgiría en el espectador, al no saber dónde o cuándo fueron hechas estas piezas, si son actuales o son fósiles. Otra idea, declara la artista, era colocarlas en plazas públicas, a la manera de puestos informales, "tomo de los puestos de mercados ambulantes la estructura y manera informal, nómada de disponer sus objetos para ser expuestos y vendidos". De esta forma, como en los mercados ambulantes, la instalación parecerá un puesto más en la plaza o en el mercado, "quizás una serie de objetos recién encontrados en algún encuentro arqueológico apenas comenzado a catalogar", en definitiva, la idea es propiciar diferentes tipos de encuentros del espectador con la obra, incluso el retorno de la colección a la Naturaleza, como una especie de hallazgo arqueológico sobre la tierra misma.

613KRAUZE, Perla, Texto inédito..., op. cit., octubre, 2004. 
De sus intervenciones en sitios específicos, destacamos sus acciones efímeras en el Centro Histórico de México, D.F., en donde, siguiendo el procedimiento de evidenciar el accidente, la artista coloca flores, ramas y plantas artificiales, en las grietas del pavimento, haciéndolas de alguna forma, permanentes, a la vez que evidenciando lo efímero de las mismas. En estas obras, Krauze genera a manera de metáforas, imágenes muy poéticas de una naturaleza artificial que condena la ausencia de Naturaleza en las urbes. Por otra parte, también sembró en las grietas semillas reales que germinaron, de manera que el trabajo adquiría la noción de proceso en cambio constante.
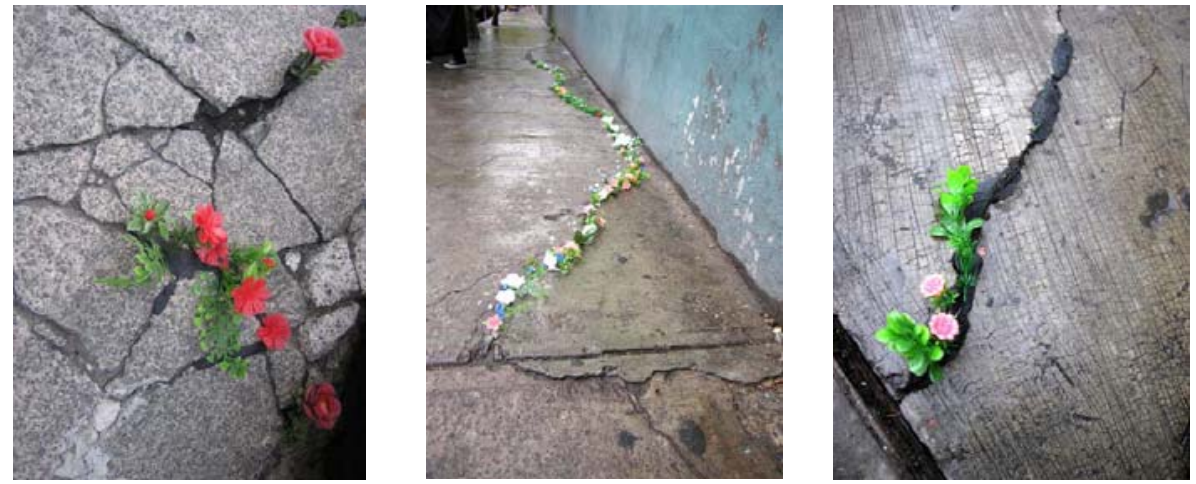

Perla Krauze, Flores de asfalto, 2005.

Krauze apuntaba614 que antes de extraer con silicona el molde de las grietas de las aceras, la gente no percibía las mismas, de alguna manera -por cotidianasparecen ser invisibles. Sin embargo, al colocar en ellas flores artificiales, las grietas no sólo se hacían visibles y patentes, sino que la gente interactuaba con ellas, llevándose las flores. La lectura de la obra ofrece varias connotaciones. Por un lado, como en la tónica de varios otros artistas contemporáneos -Penone por ejemplo- es una manera a los ojos del espectador, de hacer visible lo invisible615; por otro, la intervención recoge el significado profundo y la carga simbólica de renacimiento que ofrece el vegetal florido, creciendo en las grietas de la ciudad. Se percibe una reconquista, una vuelta a tomar posesión por parte de la Naturaleza de aquellos lugares que en otro tiempo le correspondían. En el año 2004, Krauze realiza una intervención con plantas para la Revista Espacio616, en un proyecto realizado en la azotea de un edificio, en el Centro Histórico de México, D.F., donde también participó Jerónimo Hagerman. En este caso, la artista crea una serie de mini-paisajes en las grietas y en los accidentes que surgen en el suelo de la terraza.

614 Entrevista realizada por la autora de esta investigación, octubre, 2005.

615 GUASCH, Ana M. ${ }^{a}$, Arte y archivo, 1920-2010. Genealogías, Tipologías y discontinuidades, Akal Arte contemporáneo, Madrid, 2011 , p. 239.

616 KRAUZE, Perla, "Correo Mayor, 109, Azotea Jardín, Roof Garden, 07.2004", en [ESPACIO], op. cit., pp. 80-95. 

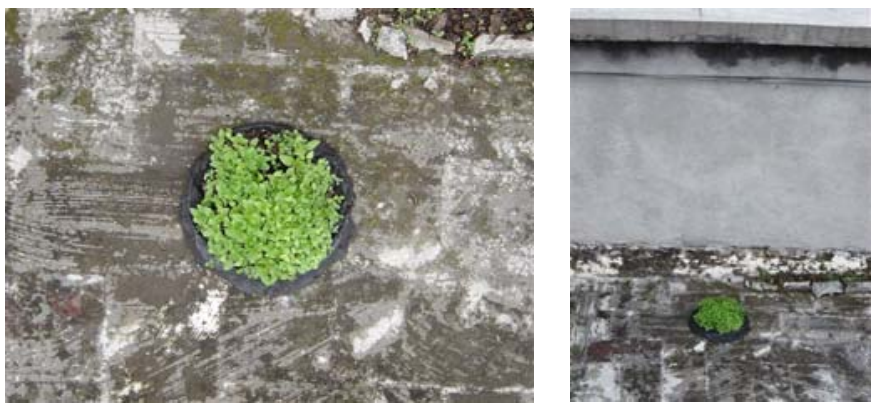

Perla Krauze, Correo Mayor 109, 2004.

La idea es hacer perceptible aquello que pasa habitualmente desapercibido, para ello, la artista mezcla elementos naturales con artificiales. Para la intervención depositó granos-semillas que posteriormente germinaron, ofreciendo la imagen de hierba surgiendo de entre las grietas. La artista con esta acción mínima, enfoca nuestra mirada hacia lo menos obvio, -espacios diminutos que proyectan un guiño al espectador-. Para esta ocasión, la primera en la que la artista trabajaba con materia viva y con una pieza procesual, se dejó influir por la arquitectura del sitio, la altura, la luz, los cambios a lo largo del día, creando con elementos tanto artificiales como naturales -la hierba real se alternaba con palmeritas de plástico, pequeñas islas flotantes, sobre charcos reales- paisajes en miniatura que trastocaban la escala natural del observador:

El concepto de naturaleza existe en mi trabajo desde hace tiempo pero principalmente a través de representaciones artificiales. El proceso es diario, con los cuidados que las plantas requieren $y$ sus reacciones que son inesperadas. Yo partí de lo que existía aquí, de las grietas, hacerlas más patentes con elementos artificiales. Juego con la escala interna y externa, las pequeñas filas de árboles se pueden ver como paisajes en sí mismas. Trabajar con algo vivo es impredecible, dependiendo de lo que va sucediendo, la pieza me va "indicando" lo que debo hacer. El proceso cotidiano de algo que crece o se muere, me pide y me dice cómo continuar. Yo he sido como una escucha, mi pieza nunca ha permanecido estática. Partí de lo existente en el sitio, de las grietas y de las plantas que nacen solas. El objetivo era hacer más visible lo que casi no es perceptible, ya sea a través de medios naturales o artificiales. Experimenté con la escala pequeña, más íntima, paisajes casi en miniatura. Algunas grietas existentes se convirtieron en pequeños paisajes artificiales, al igual que las islas flotantes en el lago617. 

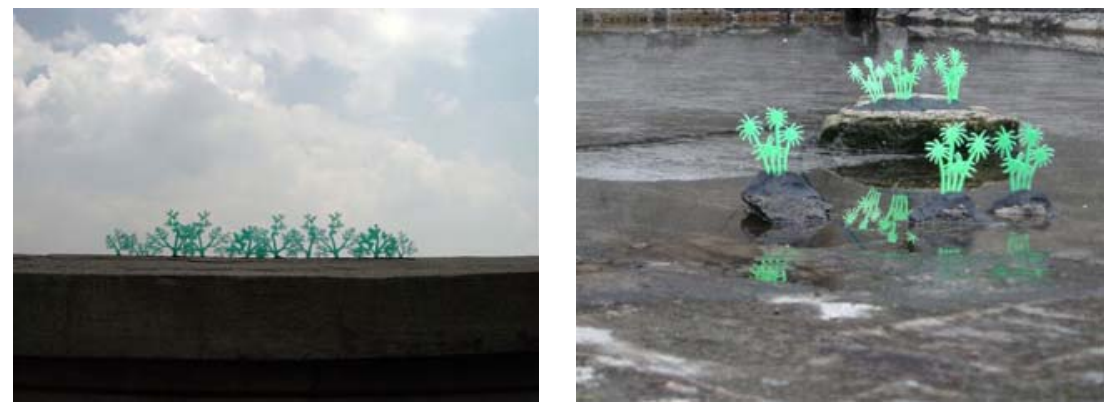

Perla Krauze, Correo Mayor 109, 2004.

En su taller, pudimos ver la elaboración de una de las últimas piezas Jardín portátil (2005), que la artista estaba realizando cuando fue entrevistada por nosotros. Se trataba de una estructura metálica en la que la artista iba acomodando flores multicolores de plástico. Este evocador jardín vertical delimita un espacio si bien artificial, tan íntimo como tantas otras piezas de la artista. Esta pieza enlaza con otras de Krauze como Caja de gelatinas con flores artificiales (2005) que nos habla de la ambivalencia en la utilización de lo vegetal por parte de los artistas que, desde una artificialidad evidente parecen querernos hablar de lo natural como de todo aquello que finalmente desborda nuestra experiencia.
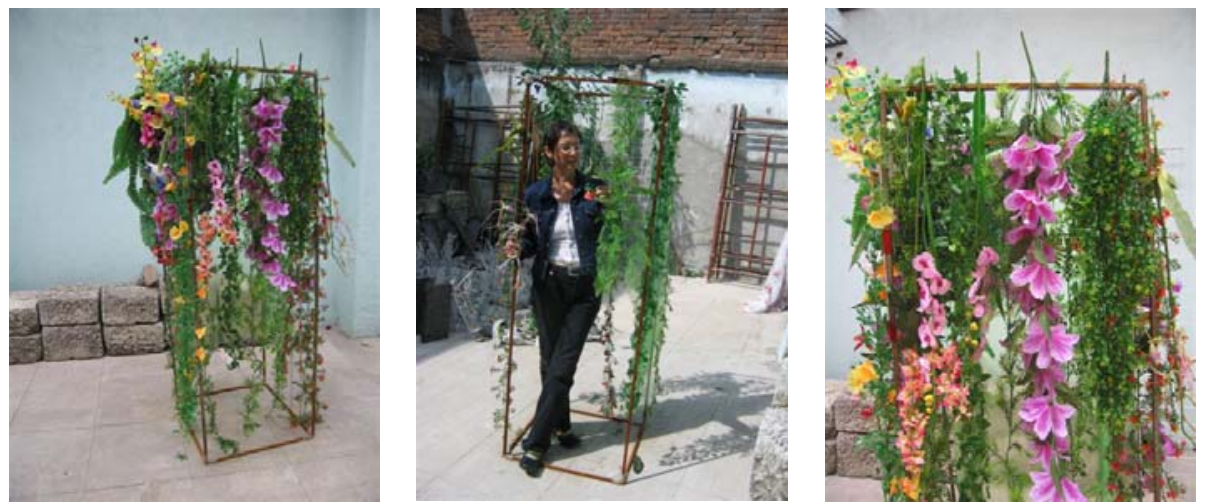

Perla Krauze, Jardín portátil, 2005.

Obras como las anteriores, nos recuerdan las prácticas de los suizos Gerda Steiner y Jörg Lenzlinger, quienes crean conjuntamente jardines interiores, colgantes y portátiles a manera de dispositivos heteróclitos. En ellos y, mediante una vegetación exuberante, se confronta la vida natural (plantas vivas) con la artificial (plantas de plástico) experimentando con las fuerzas del crecimiento, en una diversidad compleja y caótica.

Hemos visto cómo para la mayoría de los artistas que establecen un fuerte vínculo entre arte y vida, la representación de la Naturaleza se orienta a evidenciar el estrecho vínculo entre lo humano y lo vegetal. Esta tendencia los conduce, en la mayoría de ocasiones, a la necesidad de utilizar elementos orgánicos o vivos -en este caso, entiéndase plantas-como material procesual 
para la configuración de sus obras. Sin embargo estamos viendo cómo esta relación se hace extensible dentro del mismo sistema de la obra de arte, a la idea del vegetal aún cuando la materialidad de éste sea evidentemente artificial. De esta manera si la presentación de vegetales vivos de la que hablábamos al principio de este capítulo, sustituye a la representación (sea bidimensional o tridimensional del elemento) llegamos al punto de que esta nueva presentación o nueva objetividad es utilizada por diferentes artistas independientemente de si el material originario es natural o artificial. Las connotaciones que asume la presentación de un vegetal, sea éste real o de plástico, no afecta al entendimiento de la obra en la perspectiva de su vinculación con el hecho vegetal y su capacidad de trasmitir una esencia vital, relacionada con la experiencia estética del ser humano.

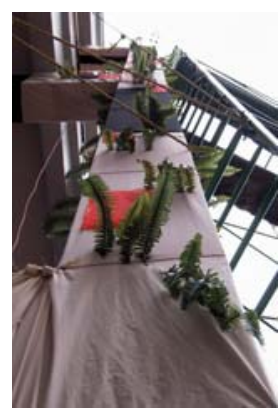

Antonio Ortiz Gritón, Realidad II, 2004.
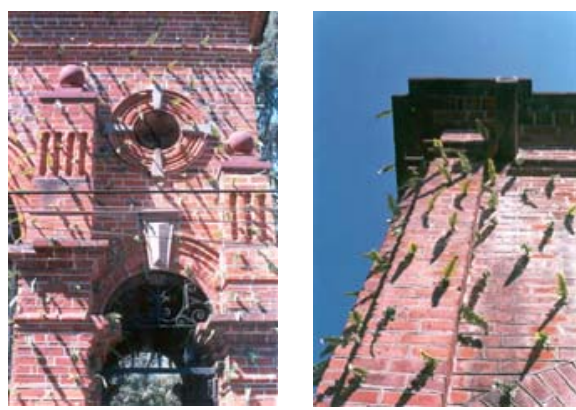

Antonio Ortiz Gritón, Instrucciones recibidas, 2004.

En el año 2004 por ejemplo, Antonio Ortiz Gritón (México, D.F., 1953) quien ya había integrado en varias ocasiones plantas de plástico en sus obras, realizó dos intervenciones en México, D.F., en las que utilizó helechos de plástico aplicándolos sobre diferentes contextos arquitectónicos. En la intervención Instrucciones recibidas (2004), el artista colocó estas plantas en los arcos de la Casa Frisac, en el Zócalo de Tlalpan. Si revisamos la trayectoria de Antonio Gritón vemos que ésta abarca tanto la producción artística, como el activismo cultural enfocado a encontrar nuevos espacios para la exhibición y la divulgación del arte. En este sentido, ha desarrollado proyectos de autogestión en torno a temas de interés comunitario y ha articulado acciones ciudadanas encaminadas a construir infraestructuras artísticas y sociales, más allá de las institucionales. Su producción artística es extensa en cuanto a temática y experimentación en distintos medios y técnicas. En pintura y escultura inserta elementos y objetos de la estética popular y del mercado de consumo masivo, para resignificarlos y articular con ellos una poética visual híbrida entre lo fantástico y lo real, abordando temas vinculados a los fenómenos sociales de la globalización (migraciones, derechos humanos y medio ambiente).

En esta dinámica y, como continuación de la acción realizada en Tlalpan, Gritón intervino algunos meses después las rampas exteriores del espacio arquitectónico de la Facultad de Medicina de la UNAM. El proyecto Realidad /I (2004), contemplaba la utilización de tres mil helechos de plástico que fueron 
adheridos con silicón a uno de los arcos de la Facultad, en las columnas que dan soporte a las rampas que unen los edificios A y B. La obra es una reflexión en torno a la posibilidad de modificar creativamente la realidad cotidiana. Con la inclusión de estos elementos el artista, buscaba transformar la presencia habitual del edificio, estableciendo un nuevo vínculo entre lo cotidiano y toda la comunidad de estudiantes, profesores y personal laboral, de la Facultad de Medicina. La estructura paradigmática y sujeta a multiplicidad de explicaciones y reflexiones conseguía el efecto de trasmitir un significado de nueva vida al complejo. Esta experiencia fue transplantada en 2005, a Madrid (España), en donde cubrió las ventanas del edificio del Teatro Español con helechos que se proyectaban hacia el exterior.
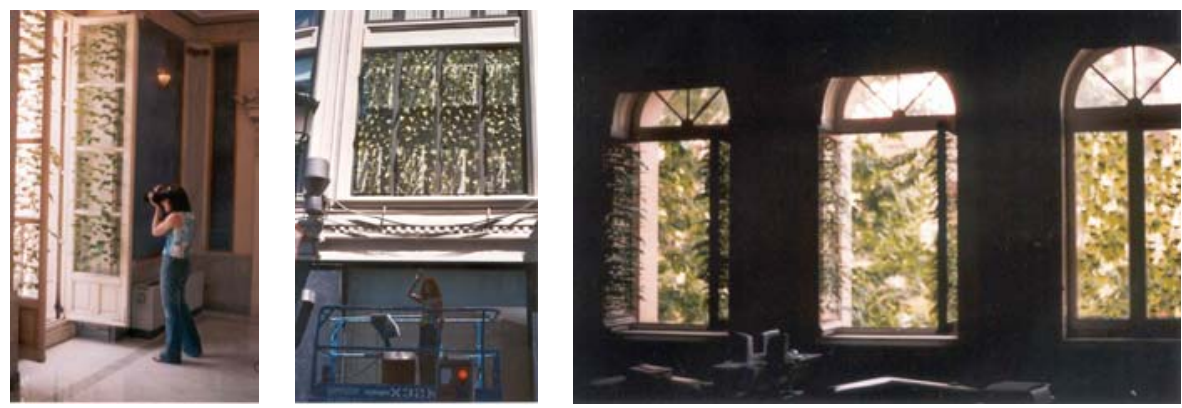

Antonio Ortiz Gritón, Sin título, 2005.

Como una forma de descentralizar la creación y la difusión cultural y con la finalidad de acercar las diversas creaciones artísticas contemporáneas al medio rural, el artista gestó en Navarra (en donde vive en los últimos años) uno de sus últimos eventos. Emari 09, Primer Ritual Internacional de Arte Actual de la Zona de la Ultzama618 es un proyecto en el que diversos artistas a nivel tanto local como internacional, realizaron diferentes intervenciones artísticas en fincas particulares y en espacios públicos, a manera de ofrenda a Mari619, diosa de la mitología vasca.

En sus trabajos más recientes el artista integra las nociones culturales sobre el paisaje, a partir del acto de observar y reelaborar desde diversas perspectivas, el medio rural. La obra-intervención rural que Antonio Gritón presentó en Emari '09 se encontraba emplazada en el bosque aledaño a Guelbenzu. Paseo (2009) consistía en un numeroso grupo de bultos envueltos con telas estampadas con motivos florales y dispersos en un área de 500 metros cuadrados en el bosque. Los bultos recubren sencillamente hojarasca, pero en la percepción del espectador la obra se torna inquietante al tener la impresión de encontrarse ante personas dormidas o muertas envueltas con estas telas. En este caso, el

618 Véase "Emari 09, Primer Ritual Internacional de Arte Actual de la Zona de la Ultzama", Disponible en red: <http://colectivoelpuente.com/emari_09/proyecto_emari_09.html>, [Consulta 20, agosto, 2009].

619 Mari es una antigua divinidad de la mitología vasca, relacionada con la tierra y el cosmos, habitualmente se identifica como una personificación de la Naturaleza. 
elemento flor ha quedado relegado a su representación únicamente mediante la impresión textil industrial en las telas, pero la relación con el bosque y a la vez con la ambigüedad de los bultos humanos explícita la relación de la Naturaleza con el hombre y con la idea de paisaje.
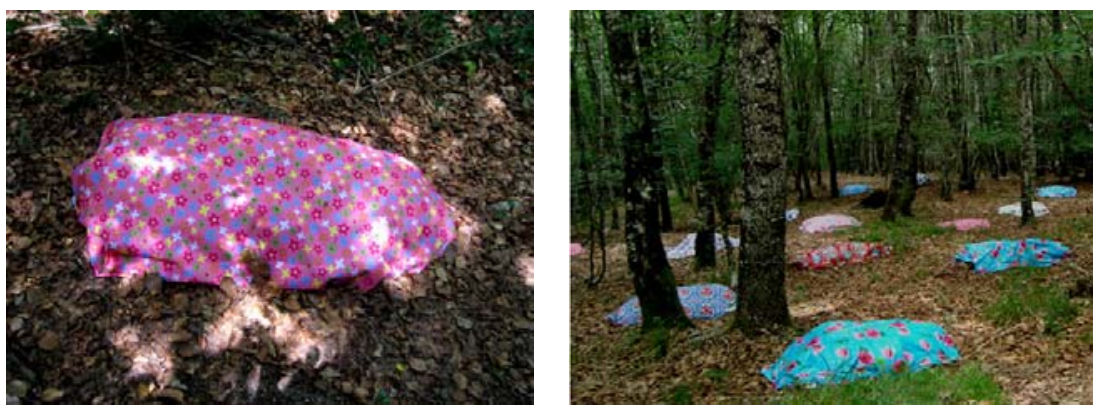

Antonio Ortiz Gritón, Paseo, 2009.

Otro artista que entabla una interesante dialéctica con el paisaje circundante es Ander Azpiri (Guadalajara, Jalisco, 1971) quien aborda la práctica de la escultura en obras que son una especie de organismos vivos. En los últimos años, sus piezas crecen y se diseminan en función tanto de las características de cada una de ellas, como del medio o del espacio en el que se desenvuelven. Estableciendo un paralelismo similar al que hemos estado observando en otros artistas, Azpiri, tanto en sus esculturas, como en su obra fotográfica recurre a estructuras del mundo vegetal con las que el artista reproduce ritmos de crecimiento de la Naturaleza.

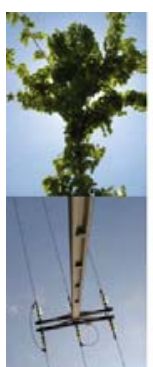

Ander Azpiri, Luz y raíz, 2009

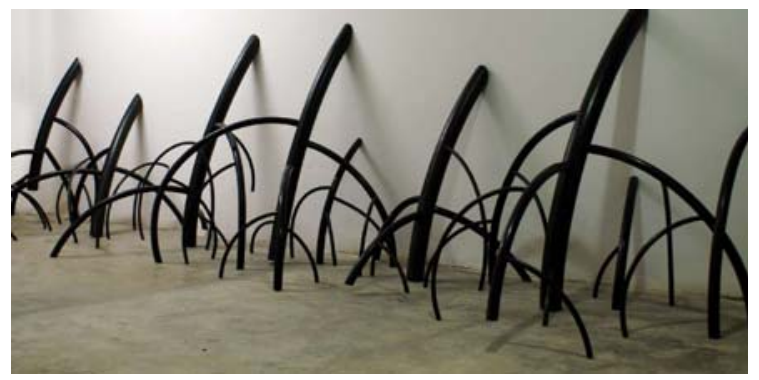

Ander Azpiri, Mangle, 2009.

Además de vegetales, diversos organismos son tomados como modelo y pretexto para reflexionar sobre el comportamiento de los seres humanos. En este sentido, la forma en la que las obras conviven y se relacionan entre sí en entornos específicos, tiene particular importancia en sus exposiciones. De forma similar a las plantas y a los humanos, estas piezas se desarrollan siguiendo diferentes pautas para mantenerse funcionando, revelando una analogía entre las tácticas empleadas por las plantas y las formas de adaptación que los humanos siguen frente a las diversas circunstancias vitales y a los diferentes medios sociales en los que nos desenvolvemos. Desde la discreción de las formas, hasta la dominación por acumulación de las mismas, Azpiri crea 
sistemas transitorios, en donde mediante distintos grados de adaptación -transgresión, hibridación, simbiosis, convivencia o parasitismo- unas formas dependen de las otras para propagarse y seguir existiendo. Todas ellas se nutren de lo que el medio les ofrece, volviéndose más o menos especializadas según el caso, y recorriendo los distintos ciclos vitales hasta alcanzar su propio deterioro o fin.

Las obras pueden surgir y habitar en los lugares más inesperados y, al igual que las plantas, pueden brotar en grietas o tejados, dando lugar a todo un ecosistema vegetal.

[...] en los materiales que le sirven a Azpiri para dar forma a una idea, a la elaboración conceptual de un espacio, a la transformación perecedera de una habitación en manglar, ramaje, animal, selva de lianas, raíz infinita clavándose en el parqué, habita una vez más el convencimiento de que nuestros objetos, los iconos llamados del progreso que siempre nos han acompañado, no se pueden desprender ya del ser del mundo620.

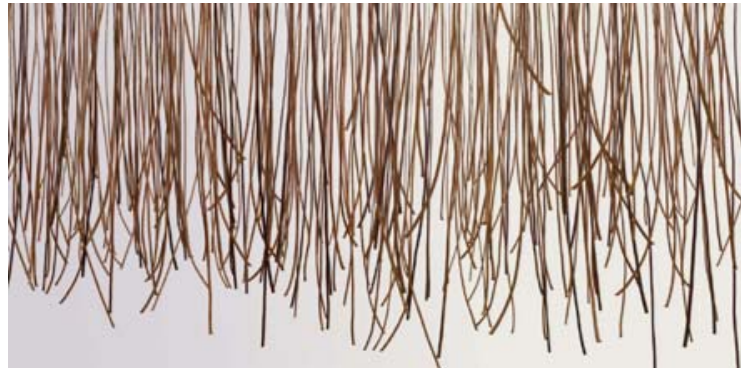

Ander Azpiri, Subterránea, 2007.

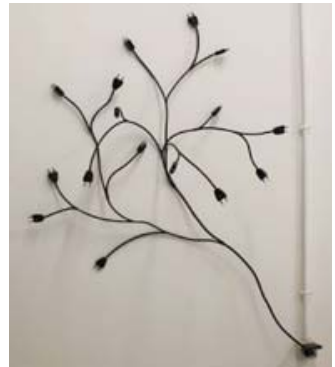

Ander Azpiri, Arraigada, 2010.

Cabe destacar que para Azpiri, los materiales que utiliza en sus esculturas son definitorios de las mismas. Entre ellos podemos encontrar desde madera, luz y motores eléctricos, a plumas, raíces, zacates, pelo humano, mangueras de riego y lianas, hasta chupones de látex o serpientes. En muchas de estas esculturas se produce una simbiosis formal, como ya pudimos observar anteriormente en las obras de Yolanda Gutiérrez o de Yolanda Paulsen, mediante una sustitución de funciones. En Retoño (2006), las ramas que salen de la pared están resueltas, además de con ramas de madera reales, con plumas que encajan a la perfección en el discurso formal. Sin embargo en el caso particular de Azpiri, los elementos que utiliza forman parte frecuentemente, de un sistema de objetos utilitarios que provienen del mundo de la funcionalidad. Por ejemplo en las obras Arraigada (2010) y Hiedra (2010), el artista nos presenta una configuración formal ramificada de plantas en desarrollo, pero los materiales empleados en ambas, son cables eléctrico y enchufes, conexiones o tubos aislantes que nos permiten mutar la función original de estos materiales, trastocando el sistema de los objetos. En ocasiones las lianas que cuelgan son reales, pero en piezas

620 MATEO, Regino, "La casa de la Esfinge", en Azder Azpiri. Hábitat. Entorno y morada, Centro Municipal de las Artes y Alcorcón y Fundación ArtSur, Madrid, 2010, pp. 3-4. 
como Mangle (2009), el material empleado es manguera de riego para el uso agrícola. Estos procedimientos nos acercan al mundo de lo cotidiano, consiguiendo que estas estructuras naturales formen parte de nuestro mundo de una manera más íntima.

Un dibujo de formas duales que se enredan en tramas capaces de crecer $y$ germinar en nuevas inflorescencias, como una metáfora viva y en perpetua mutación, espíritu y carne, pasión y raciocinio. Y que como nosotros definen la medida del espacio que nos envuelve $y$ de nuestra necesidad de conquistarlo621.

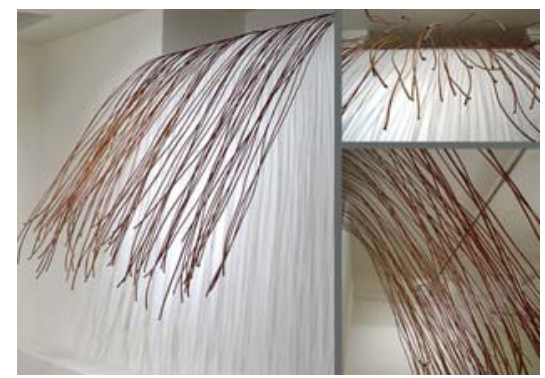

Ander Azpiri, Refugio, 2007.

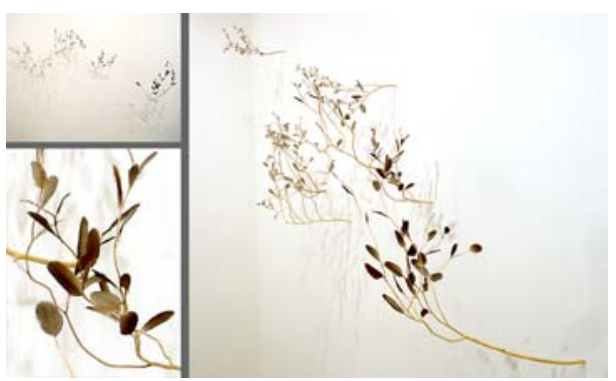

Ander Azpiri, Retoño, 2006.

En estos casos, el artista parece seguir el discurso de Jean Baudrillard en torno a la funcionalidad de las cosas. Como señala Baudrillard, la connotación de Naturaleza está implicada en el discurso de las formas. Estamos rodeados por doquier de objetos en los que la forma ofrece una solución contradictoria a la de su propia esencia, sin embargo, esta naturalización otorga a los objetos referencias morales y psicológicas que nos permiten compartir con naturalidad, su significado.

[...] la naturaleza, en todas sus formas, es a la vez significada y negada en los signos mismos. [...] "funcional" no califica de ninguna manera lo que está adaptado a un fin, sino lo que está adaptado a un orden o a un sistema: la funcionalidad es la facultad de integrarse a un conjunto. Para el objeto, es la posibilidad de rebasar precisamente su "función" y llegar a una función segunda, convertirse en elemento de juego, de combinación, de cálculo en un sistema universal de signos. [...]. El orden de la Naturaleza (función primaria, pulsión, relación simbólica) se halla por doquier presente, pero sólo como signo622.

Según Baudrillard estamos en definitiva, ante una Naturaleza elaborada y rescatada del tiempo y de la angustia que pasa a convertirse por virtud del signo, en Cultura, de manera que ambas ya no se oponen, sino que pueden por fin convivir en los ambientes creados por el artista.

621 MATEO, Regino, "La casa de la Esfinge", en Azder Azpiri, op. cit., pp. 3-4.

622 BAUDRILLARD, Jean, El sistema de los objetos, Siglo XXI, México, D.F., 2004, pp. 70-73. 


\subsection{Participación y percepción del espectador. Aurora Noreña y Pedro Reyes}

Hemos visto cómo una de las razones por las que el elemento vegetal -sea como representación o presentado directamente- es utilizado dentro de la retórica del arte contemporáneo, por su capacidad de evocación de la totalidad, identificada ésta con la imagen o el constructo cultural de Naturaleza que el hombre ha elaborado a lo largo de su historia. También hemos visto que su uso es, entre otras cosas, fruto de la creciente sensibilización global acerca del medio ambiente y de la preocupación en torno al precario equilibrio ecológico que rodea la existencia del ser humano en la actualidad. Uno de los discursos que con su obra plantean los artistas, se corresponde con aquel que tiene que ver con el exceso, dentro de nuestra sociedad de consumo. En este contexto y dentro del ámbito artístico, el desgaste de los recursos naturales y la acumulación de desperdicios que todo ello conlleva, se contrarrestan con estrategias que presuponen una observación minuciosa de todos estos procesos, aunada a la recuperación física de materiales procedentes del abuso, para propiciar con ello, políticas y economías del reciclaje. En algunas de estas obras, la participación creciente del espectador es fundamental. Este fenómeno en general, "ha contribuido a la desaparición del objeto de arte tradicional [...] Lo esencial no es ya el objeto en sí mismo, sino la confrontación dramática del espectador con una situación perceptiva"623. Éstas no tan nuevas, pero sí más consolidadas prácticas, refuerzan la secuencia protagónica en los procesos artísticos, descrita por Néstor García Canclini: "Espectáculo-espectacularizaciónespectador", en donde "los proyectos creativos acaban realizándose en el reconocimiento de quienes los ven" y "lo artístico no estaría contenido en la obra sino en el movimiento que completa la mirada del receptor"624. Desde la perspectiva de algunos artistas y teóricos la pregunta no es "qué es el arte, sino qué puede hacer625" el arte, para cambiar la sociedad. A ello debemos añadir la importancia de un público cada vez más amplio que participa en los procesos artísticos, es el "espectador comprometido" como lo llama Donald Kuspit, el espectador que desea sentirse parte integrante y necesaria del momento creativo de la obra artística:

El espectador comprometido no puede emitir ningún juicio definitivo sobre el arte porque quizás tenga una nueva reacción crítica a éste -una nueva transferencia creativa que comporte una nueva experiencia e interpretación y nuevo sentido de la personalidad que lo informa, así como un nuevo sentido de su propia personalidad y profundidad-que lo haga parecer más fresco que en el momento de la reacción inicial [...] el coeficiente artístico personal del espectador crítico desempeña un papel imprescindible en el desciframiento y la interpretación del arte[...]. El espectador, como el artista,

623 POPPER, Frank, op. cit., p. 11.

624 GARCÍA CANCLINI, Néstor, La sociedad sin relato. Antropología y estética de la inminencia, Katz, Madrid, 2011 , p. 211.

625 POPELARD, Marie Dominique, Ce que fait I'Art. Approche communicationnelle, en CANCLINI GARCÍA, Néstor, La sociedad sin relato..., op. cit., p. 211. 
desempeña un "papel de médium", lo cual significa que sus juicios estéticos tienden a ser racionalizaciones de sus sentimientos subjetivos, como las "explicaciones racionalizadas" que el artista hace con la esperanza de ser aprobado [...]626.

En este sentido las ideas de Aurora Noreña (México, D.F., 1962) en torno a los límites entre lo natural y lo artificial se constituyen como una praxis de la participación consciente del público y del reciclaje, no sólo de los materiales de desecho de la sociedad contemporánea, sino también del concepto de usuario del medio ambiente. La artista a través de sus obras, reflexiona y convoca al análisis sobre el hombre como observador y manipulador de su propio entorno. En esta dinámica, presentó la obra Corrientes Invisibles (1999) en la estación del metro Copilco en México, D.F. Se trataba de un conjunto de cinco árboles naturales procedentes de la tala de bosques, a los que la artista proveyó de unas plataformas metálicas con ruedas industriales y que estaban intervenidos con planchas metálicas, cinchos y transferencias de pintura natural de fresno y de pintura vinílica. Todo ello se disponía sobre una tela colocada en el piso que fungía como plataforma horizontal y límite para los desplazamientos.

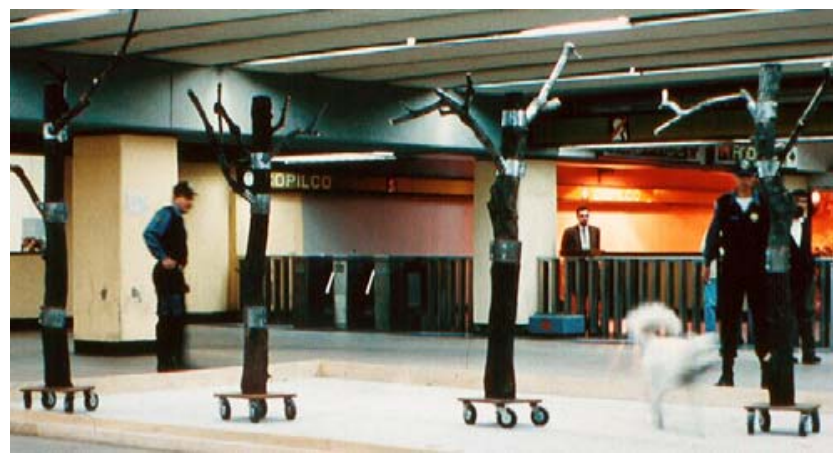

Aurora Noreña, Corrientes Invisibles, 1999.

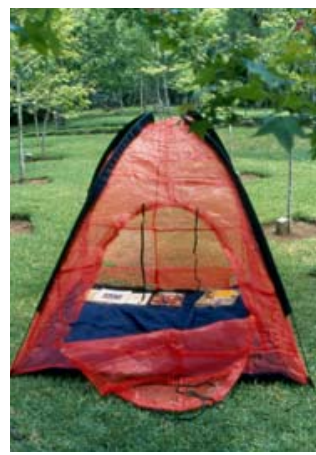

Aurora Noreña, Observatorio, 2004.

Siguiendo las instrucciones que la artista dispuso junto a la pieza, durante el período que duró la exposición, los usuarios del Sistema Público de Transporte pudieron desplazar y recolocar las estructuras, a su libre albedrío. De esta manera, los espectadores participaban activamente en la disposición y el diseño de los nuevos paisajes que se configuraban en el interior del metro, con este sorpresivo bosque dispuesto bajo la superficie de la ciudad. El conjunto, que era de configuración y medidas variables, funcionaba en la estación del metro como un espacio real de participación colectiva, pero también como foro biológico, ideológico y de comportamiento social. Debido al carácter público, masivo y anónimo de la intervención, la artista registró sistemáticamente las múltiples configuraciones que la pieza adoptaba diariamente. Con estos datos, la artista podía valorar las reacciones del público, la intensidad de participación y los hechos tanto insólitos, como inesperados que sucedieron. 
Los árboles fueron desplazados por los usuarios del metro según las instrucciones que acompañaban a la instalación, pero también funcionaron como vehículo de juego, mojones territoriales para perros o simplemente para que fueran ignorados o vandalizados por un público desconsiderado, lo que trasfiere la reflexión al uso irracional no sólo del medio ambiente sino del arte como manifestación creativa. Si bien el espectador contemporáneo es usuario de una mirada acelerada, el pasajero-espectador usuario del metro, es poseedor, como sugiere Susana Rey Crespo, de una visión doblemente apresurada que puede revertir negativamente en aquello que ve involuntariamente en este tipo de espacios públicos627. En estas obras escultóricas Noreña parte de su interés por el movimiento y la manipulación de elementos como vía para la comprensión del tiempo. En este caso, el referente vegetal (árboles intervenidos) y con él, la idea de paisaje posible, adquiere un significado de objeto de uso. La artista planteó en esta acción una paradoja irónica. Por un lado, la finalidad era concienciar al espectador de tomarse el tiempo de detenerse y observar y, por otro, brindar al público la posibilidad de percibir que tanto el paisaje que nos rodea como el arte, pueden ser instrumentos que nos sirven para involucrar la mente y el cuerpo y que son capaces a su vez, de trastocar los aspectos más convencionales de una sociedad. En este sentido, Noreña desde su formación de arquitecta y artista visual, no concibe la Naturaleza o el paisaje, como un objeto o un escenario, sino que lo configura -siguiendo a Luca Galofaro- como un sistema activo, directamente relacionado con la acción y con el tiempo, donde los destinatarios son indispensables para la definición de la obra628.

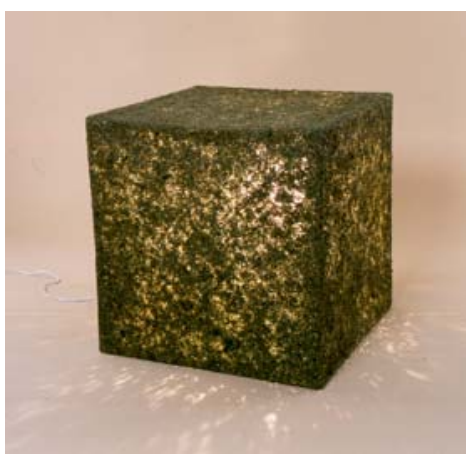

Aurora Noreña, Paisaje, 2004.

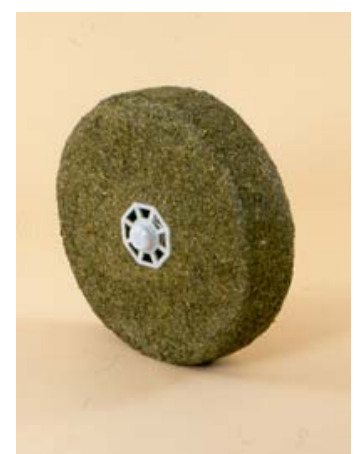

Aurora Noreña, Rueda, 2004.

En varias exposiciones posteriores como Reciclando el tiempo y el paisaje (2001), Desperdicio de tiempo (2004) y De naturaleza artificial (2005) la artista utiliza objetos derivados del diseño industrial (empaques de desecho) junto con ramas y raíces naturales con los que propone una vía alternativa de transformación y de convivencia posible, entre la Naturaleza y el artificio humano. La dimensión poética y el concepto de temporalidad hasta entonces

627 REY CRESPO, Susana, "La ecuación espacio-tiempo: el espectador es un pasajero", en SIGLER, Gerardo et al., op. cit., pp. 218-224.

628 GALOFARO, Luca, op. cit., pp. 27-28. 
plasmados en sus piezas se transforman en propuestas estéticas con narrativas más legibles vinculadas a preocupaciones sociales y problemas reales. Su preocupación en torno a la problemática con respecto a la basura que generamos en la sociedad de consumo, la llevó a trabajar con desechos:

Empecé juntando basura de mi casa, sobre todo aquella de la industria del empaque de plástico, y a partir de ella articulé materiales [...] en torno al binomio: consumo- desperdicio. Utilicé los detritos plásticos con materiales tan diversos como la tierra y el concreto para construir a partir de una función que me sugiriera el mismo desperdicio, objetos reconocibles: por un lado conectados irónicamente a la idea contemporánea de que el tiempo no empleado con fines productivos es tiempo desperdiciado [...] y por otro lado asociados a ideas ecológicas[...]629.

Estos planteamientos generaron nuevos resultados en los que la artista bajo el nombre De Naturaleza artificial, aglutina piezas que articulan el desperdicio, ya no para señalar las contradicciones entre consumo y desperdicio sino más bien, para mostrar la condición híbrida del paisaje contemporáneo y su condición paradójica.

Aceptar que el arte es un mundo artificial desde su concepción hasta su consumo y si bien, son muchos los artistas que han querido borrar la frágil línea entre el arte y la vida, lo cierto y absoluto es que el arte es un campo de producción de objetos, acciones o ideas, cuyas cargas simbólicas son innegables y que se opone a cualquier otro campo de producción humana630.

Estas piezas con una apariencia de plantas dispuestas en macetas, reproducen la idea de paisaje natural mediante envases de plástico, rellenos con resina de poliéster. Fresa (2004), Manzano (2004) y Mango (2004) entre otras, evidencian la ambivalente y paradójica relación entre lo artificial y los elementos naturales empleados. Otro procedimiento empleado por la artista es imitar el artificio humano utilizando basura natural. Para ello crea objetos aparentemente utilitarios, como es el caso de Rueda (2004), o Paisaje (2004), ambas hechas con césped cortado y amalgamado con claras de huevo. Esta última es una lámpara cúbica que emite luz y que a su vez, nos remite a los rayos luminosos que atraviesan el follaje tupido de un bosque o una selva. Aurora Noreña plantea en estas piezas una re-configuración del paisaje partiendo de un mejor aprovechamiento de los recursos tanto naturales como artificiales.

629 NOREÑA, Aurora, Texto inédito proporcionado por la artista a la autora de esta investigación en entrevista personal, noviembre 2004.

630 ARANDA MÁRQUEZ, Carlos, “De naturaleza artificial”, Texto inédito proporcionado por la artista a la autora de esta investigación, octubre, 2004. 


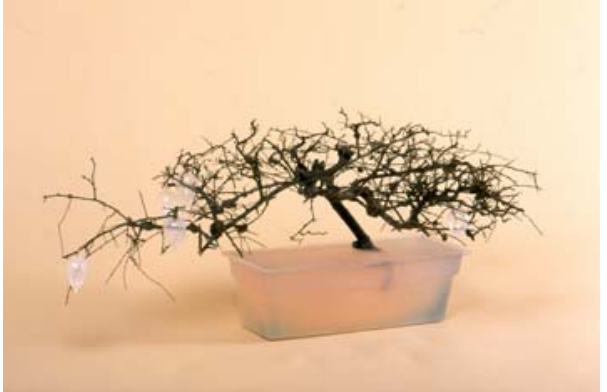

Aurora Noreña, Fresa, 2004.

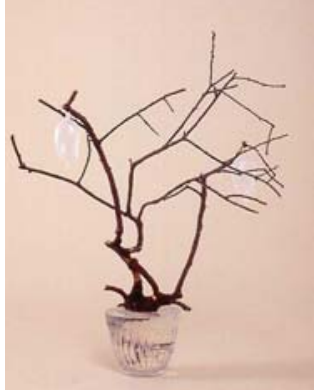

Aurora Noreña, Mango, 2004.

El componente ecológico implícito en el reciclaje del desperdicio se une a un cierto afán naturalista en la pieza Observatorio (2004), que promueve la observación y el estudio empírico del mundo que nos rodea. Esta pieza, pensada específicamente para el Jardín Escultórico de Jalapa (Veracruz), se constituía como un espacio no permanente y destinado a la contemplación y el estudio de las especies vegetales del jardín. En torno a las prácticas escultóricas de Aurora Noreña, el crítico de arte Luis Rius Caso apunta la consistencia como objetos reales que la artista les transfiere a sus piezas.

Hechos de material y tiempo desperdiciados, los objetos de Aurora Noreña proponen un régimen de significación que transgrede las nociones de orden y temporalidad que marcan nuestra relación cotidiana con el mundo. Esta trasgresión, este sutil desplazamiento de los límites, no se verifica únicamente en los confines de la dimensión artística (como sí sucede con la mayoría de tendencias emparentadas con el arte del reciclaje); sus alcances involucran a la conciencia de realidad que el pensamiento instrumental ha conseguido imponer en nuestra época631.

La instalación Observatorio (2004), realizada con sacos de naranjas reciclados, lona, postes de fibra de vidrio y metal, era una tienda de campaña. Si bien, por la misma naturaleza del material empleado (redes), la pieza no cumplía la función originaria como recinto para guarecerse de la intemperie, convertía el espacio delimitado por su forma, en un observatorio privilegiado. Un lugar desde el cual, a manera de filtro, el espectador al situarse en su interior, podía dirigir la mirada hacia el exterior. En el interior de la tienda de campaña podían consultarse tanto catálogos impresos de herbarios de la zona, como libros de botánica, de árboles y de herbolaria. La idea del observatorio activo convierte el acto de mirar, en una posibilidad dinámica que modifica nuestra visión haciéndonos más conscientes. Modificar la mirada implica cargar de nuevos significados a la acción misma de mirar y como consecuencia de ello, también a los objetos o ámbitos sobre los que se proyecta la misma.

631 RIUS CASO, Luis, "Aurora Noreña, entre la dicha inicua y la consagración del desperdicio", en AA. VV., Desperdicio de tiempo/De Naturaleza Artificial, Museo Tridimensional M-3D, Azcapotzalco, México, D.F., 2003 y Jardín de las Esculturas, Jalapa (Veracruz), 2004-2005. 
La idea de expandir la reflexión sobre Arte y Naturaleza, partiendo de la posibilidad de dinamizar la mirada del espectador para con ello, lograr encontrar nuevos sistemas participativos, aparece también en piezas tempranas del artista visual y arquitecto Pedro Reyes (México, D.F., 1972), cuya obra está relacionada con las representaciones a escala de utopías arquitectónicas. En sus proyectos, destaca el carácter propositivo y lúdico de sus propuestas que permiten al público interactuar con ellas tanto a nivel corporal, como conceptual e interpretativo. Como comisario artístico o curador independiente, inicia el proyecto Arte in situ (1996), en un importante espacio considerado como un icono modernista de México, D.F. Reyes, dado a la creación de nuevos usos para todo tipo de espacios, logra concebir un espacio de arte alternativo que se desarrolla en La torre de los vientos632, escultura que llevaba abandonada casi 25 años $y$ en donde numerosos artistas y arquitectos realizaron puntuales intervenciones con el afán de dialogar con el espacio físico y simbólico de la torre. Importante para nuestra investigación es el hecho de que conjuntamente a su primera exposición individual en este lugar en el año 2000, Reyes realizó un seminario Ilamado Psicohorticultura633, con el que buscaba concebir modelos de pensamiento derivados del mundo vegetal.

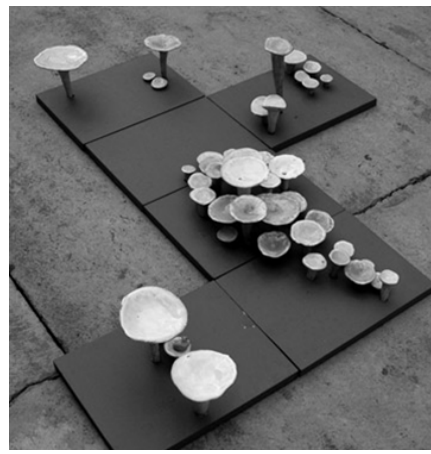

Pedro Reyes,

Fungusia, 2005.

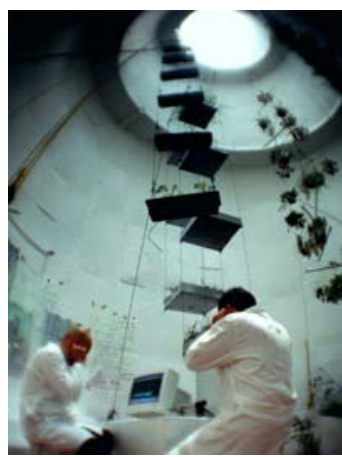

Pedro Reyes,

Jardines colgantes, 2000.

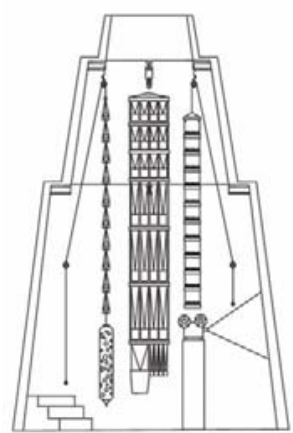

Pedro Reyes, Estudio para jardines colgantes, 2000.

La Torre de los Vientos se convirtió durante dos meses, en un laboratorio con jardines colgantes, en donde Pedro Reyes llevó a cabo un seminario con especialistas en plantas634. A la vez que se cuidaban los jardines, los participantes en el seminario realizaban actividades periféricas enfocadas a

632 La torre de los vientos (1968), escultura del escultor Gonzalo Fonseca, que forma parte del complejo escultórico de La Ruta de la Amistad, al sur de México, D.F.

633 Véase AA. VV., Escultura social. A new generation of art from Mexico City, Museo of Contemporary art, Chicago, 2007, pp. 194-203.

634 CUEVAS, Tatiana, "Pedro Reyes's functional utopias", en Bomb, No 94 (Invierno 20052006), Gary Indiana et al. (eds.), Brooklyn, NY, pp. 20-27. La mayoría de la información aquí vertida son fragmentos de la entrevista realizada por Tatiana Cuevas y es una traducción libre realizada por la autora de esta investigación. 
"desarrollar las áreas verdes del cerebro" tales como "trepar árboles, visitas al jardín botánico, catalogación de hojas, etc.". También se llevaban a cabo actividades tan peregrinas como estudiar los "posibles vínculos entre la cinematografía y la fotosíntesis; la música como estímulo del crecimiento vegetal y comparaciones entre los relojes biológicos de las plantas y los de la especie humana"635. La simulación de jardines colgantes estaba realizada mediante la reutilización de objetos domésticos (fuentes o charolas), tela de gallinero y envases de refresco, en donde se recreaba un posible sistema de cultivo de plantas mediante hidroponía636.

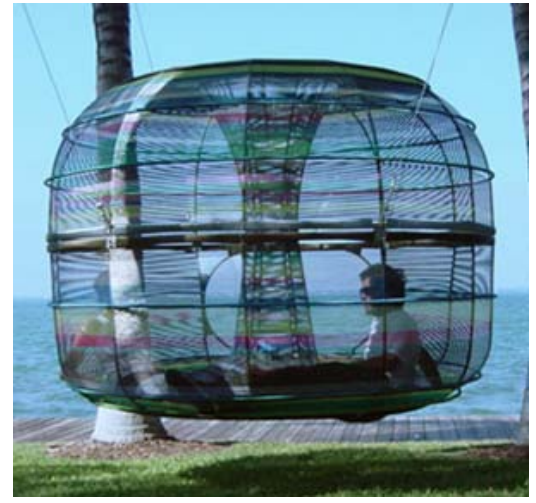

Pedro Reyes, Cápula X Torus, 2003.

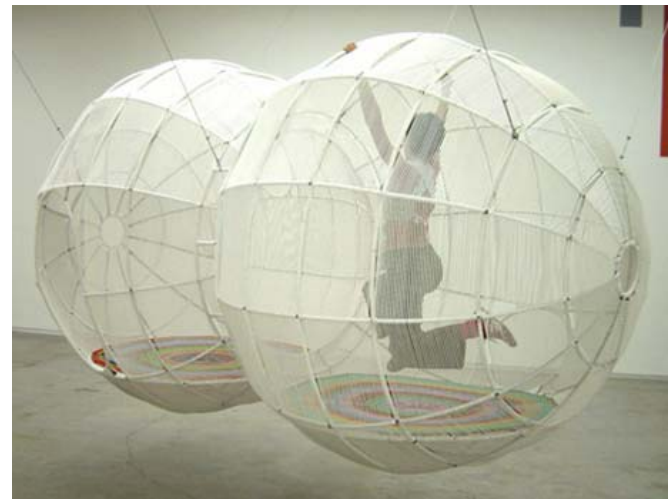

Pedro Reyes, Cápula V, 2002.

Si bien el crítico Cuauhtémoc Medina describía la intervención como tangencialmente ecologista, lo cierto es que para el objetivo de nuestra investigación, la propuesta de Reyes resulta sin lugar a dudas, interesante porque establece similitudes entre el sistema creativo de las prácticas artísticas y el desarrollo físico y orgánico de las plantas. La crítica de Medina apuntaba:

La tónica del Macramé en Psico-Horticultura es el tono tangencial, seudo utópico, espuriamente ecologista y vagamente doméstico con que el proyecto orienta sus investigaciones [...]. La idea del jardín como símbolo de felicidad forma parte de la intención de Reyes de conducir un

635 REYES, Pedro, “Jardines colgantes", Disponible en red en: <http://www.torredelos vientos.org/\#667857/2000-Pedro-Reyes >, [Consulta 15, agosto, 2011]. Dada la específica vinculación con el elemento vegetal de este proyecto, es importante citar aquí, el tipo de reflexiones y definiciones que se desarrollaron durante el seminario, entre las cuales Pedro Reyes apunta: "Pensamiento Dicotiledóneo: desdoblamiento centrífugo; Pensamiento Epifito: enlaces tangenciales a un tema; Pensamiento Fungiforme: cultivar umbroso; Pensamiento Rizomático: asociaciones polidireccionales; Pensamiento Fototrópico: iluminación; Pensamiento Tubérculo: cavilaciones profundas; Pensamiento Suculento: carnosidades digitales; Pensamiento Florido: el olvidado arte de sonreír lentamente; Pensamiento Osmótico: la sabia savia; El Pensamiento Caducifolio: ideas que caen; Pensamiento Arborescente: andarse por las ramas; Pensamiento Xilemático: crónicas concéntricas".

636 Cultivo de plantas en soluciones acuosas. 
seminario/laboratorio sobre el tema de las asociaciones libres que surgen de tejer horticultura y mente. [...] se propone investigar [...] la relación entre el efecto psicológico de «elevación» que produce arreglar plantas y la verticalidad que sugiere el espacio interno de la escultura. Así, sugiere la fantasía de una reflexión arborescente que debería ser capaz de proyectar ideas «audaces» a partir de las resonancias psicológicas de la jardinería: la desaparición del vegetarianismo, el uso de joyas vegetales y la instauración de cursos de «superación vegetal», etc.637.

Entre otras cosas, los procesos descritos por Reyes dieron como resultado ideas como Arquímica638, concepto con el que planteaba fusionar el lenguaje y la arquitectura con la química. Las obras presentadas junto con los textos, los diagramas y algunos ejemplos de los especimenes que estudiaba esta nueva ciencia, recordaban un museo de historia natural. Las reflexiones del artista en torno a estas posibilidades tuvieron continuidad en su exposición Nomenclatura arquímica (2002), realizada en la Sala de Arte Público Siqueiros así como en otros proyectos en los que el artista buscaba expandir la relación entre el hábitat humano y el mundo vegetal con la intención, no de formar imaginarios o realidades utópicas, sino para generar posibles vías de convivencia y de relación comunitaria, formas de vida y modelos de acción que funcionen dentro de la realidad actual. En nuestra opinión, estos proyectos abren potenciales vías de investigación para conseguirlo.

Con su trabajo, Reyes propone un idealismo activo que, dentro de un sistema complejo de asociaciones -que desafía nuestros supuestos sobre las formas en las que el conocimiento es habitualmente categorizado y legitimado- es sin embargo capaz de concebir nuevas maneras de mejorar el mundo. Sus ideas utópicas sobre arquitectura aluden a un lugar que no existe o cuya existencia es sólo temporal. Mediante el uso de medios simples y escenarios ocasionales, combina los reinos de la utopía y de la función, las fantasías y las aspiraciones colectivas. Su trabajo opera estableciendo una red de conexiones entre el mundo de las ideas, el de las personas y el de los colectivos humanos, entre lo histórico y lo formal. Entiende la ciudad moderna como el nuevo paisaje romántico. Pero no le interesa en sí lo que es o fue la modernidad, sino en lo que se está convirtiendo o lo que puede llegar a ser. Para él, la modernidad es una caja de herramientas con la que trabajar. La circunstancia de algo en decadencia, como puede ser la modernidad misma, puede ser el abono y la oportunidad de asociaciones totalmente nuevas cuya mezcla puede generar un vasto catálogo de soluciones diferentes.

637 MEDINA, Cuauhtémoc, "Artesanías alegóricas. Arte In Situ/La torre de los vientos", en Reforma, México, D.F., 2, agosto, 2000, p. 4c.

638 Disciplina imaginaria inventada por el artista, definida por él como la ciencia de las sustancias psíquicas, que tiene entre sus múltiples aplicaciones, el estudio de las reacciones que ocurren entre el sistema límbico, la corteza cerebral y los materiales externos que el hombre utiliza para la construcción de su hábitat. 
Una parte de sus prácticas están en el terreno de la neología, abarcando la creación de nuevos términos y conceptos, a manera de una nueva forma de abrir el pensamiento, con la que el artista aborda la creación de nuevas topías639. Así, el nombre dado a sus esculturas habitables como Cápula (2002), es la denominación que adjudica a una especie de hábitat particular, cuya interpretación es una combinación de diferentes palabras: cúpula, capilar, cópula, cápsula, etc. Cápula habla de la posibilidad de crear espacios habitables que son a la vez confortables para cualquier pasajero en tránsito, o extranjero de paso. Es la antítesis de un modelo de construcción: si un espacio habitualmente tiene habitáculos, la cápula es esférica, si las paredes son sólidas y rígidas, la cápula es suave y elástica, si una pared divide el interior del exterior, la cápula es permeable, si una habitación se basa en sus cimientos, la cápula está suspendida en el aire, si una pared produce una imagen estable, cápula crea una interferencia óptica por lo que parecerá siempre cambiante. En definitiva, se trata de un espacio como dice el propio artista, en donde lo más maravilloso de todo es, "no lo que uno hace, sino lo que los demás sienten, la construcción de una experiencia para los otros":

[...] un tipo de espacio construido para desencadenar experiencias que tienen que ver con el cuerpo, que sirven como extensión de éste y como manifestación de esas redes intangibles que determinan nuestra imaginación [...]640.

Si en la arquitectura hay mobiliario, la cápula aparece como algo intermedio, una idea que podría existir entre los muebles y la arquitectura, una especie de espacio en el que se puede flotar. Este espacio no puede ser definido a través de una narrativa simbólica, sino que debe ser definido por la experiencia. Reyes afirma que entre forma y función debería haber una tercera categoría correspondiente a un arte ad usum ${ }^{641}$, un arte para ser utilizado, concepto que es ligeramente diferente a un arte útil, de manera que la pieza o la obra de arte funcionaría como una herramienta, un dispositivo, una táctica o un recurso. La idea fundamental es construir una experiencia.

El ser humano -dice-genera tejidos, extensiones del cuerpo de los que se rodea para su supervivencia. La ropa, los vehículos, la arquitectura lo son. Las cápulas funcionan como una especie de placenta, de ectoplasma en el cual tú experimentas otro estado [...]. Es el hombre que conecta territorios

639 Reyes habla de psychotopía, como de un lugar mental; de neotopía, como de un nuevo lugar; prototopía, casi un lugar; ecotopía, un lugar sostenible; hypnotopía, el lugar de nuestros sueños; teotopía, un lugar sagrado; infratopía, menos de un lugar, etc., afirmando que toda situación o cosa nueva necesita un nuevo nombre.

640 HERRERA, Adriana, "Pedro Reyes, el conexionista. Las esculturas para usar del artista mexicano sorprenden a los espectadores en The Americas Society, en Nueva York", en Poder y negocios, México, D.F., 27, marzo, 2007, pp. 2-6.

${ }^{641}$ Ad usum: para ser usado. 
del conocimiento que aparentemente no tienen conexión. Es un "conexionista"642.

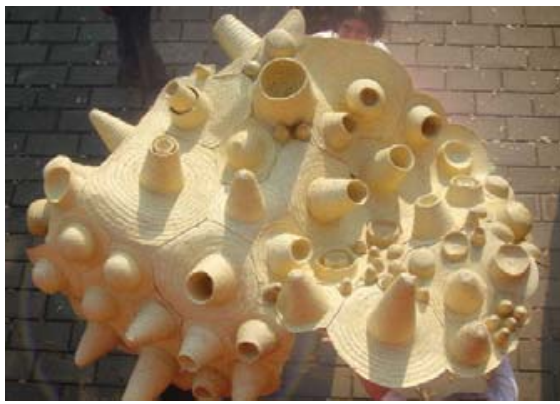

Pedro Reyes, Sombrero colectivo, 2004.

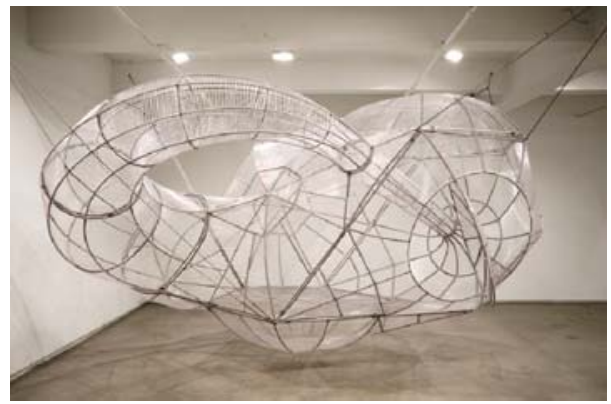

Pedro Reyes, Cápula botella de Klein ${ }^{643}, 2007$.

Podemos observar estos procesos de conexión en otro de sus proyectos que puede ser interpretado como un intento de crear nuevos cultivos a partir de estructuras en decadencia. Jardín o Parque vertical (2002) es un proyecto destinado a realizarse en uno de los edificios más emblemáticos de México, D.F., la Torre Insignia644, en Tlatelolco. Dicha construcción es un ejemplo de la arquitectura moderna de México que se convirtió en inoperante e inhabitable a través de los años, en particular tras el terremoto de 1985. El artista considera interesante revisar la historia de este tipo de edificios modernistas que han sido privados de su función inicial, con el fin de rehabilitarlos o más exactamente, revitalizarlos con nuevas ideas. El objetivo no es tanto, cómo cambiar el mundo, sino la posibilidad de concebir la creación de un mundo nuevo, aunque éste durara unas pocas semanas o incluso unos pocos segundos.

En este edificio, Reyes propone la idea de crear un parque vertical, una finca urbana en donde los vecinos pudieran cultivar sus propios alimentos con hidroponía. La idea del artista de publicar el proyecto en periódicos y revistas, de presentarlo y anunciarlo como algo que requeriría una inversión relativamente pequeña o como factible, un nuevo Centro de educación ambiental, forma parte de una estrategia concebida por el autor, más que como la creación de un rumor, como una serie de planteamientos con los cuales lograr una masa crítica que pudiera permitir que el proyecto se llevara a cabo. En la compleja tarea de la sobrevivencia, se requiere una Cultura de la permacultura.

642 REYES, Pedro, en HERRERA, Adriana, "Pedro Reyes, el conexionista", op. cit., pp. 2-6.

643 La botella de Klein es el modelo descriptivo de una superficie topológica tridimensional que no tiene ni interior ni exterior. Desarrollado por el matemático Christian Felix Klein, se forma al insertar el extremo más pequeño de un tubo cónico abierto a través de la misma superficie del tubo, de manera que al ensanchar el tubo, éste pasa por dentro de sí mismo uniéndose a la base.

644 Torre Insignia o Torre de Banobras construida en 1962 por el arquitecto Mario Pani en el parque del mismo nombre (Conjunto urbano Nonoalco-Tlatelolco) en el centro de México, D.F. 
Este concepto es, según Reyes, una mezcla de permanencia y agricultura. La idea es mantener la vida en un circuito de retroalimentación de fuentes y residuos.

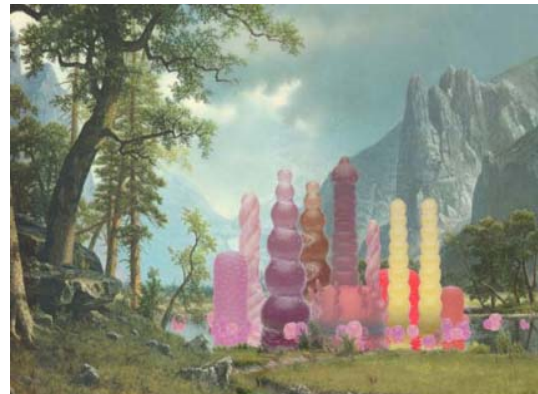

Pedro Reyes,

Orgonic, 2003.

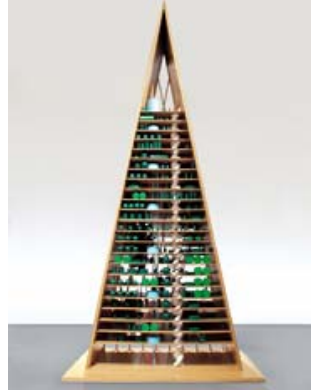

Pedro Reyes,

Parque Vertical, 2002.

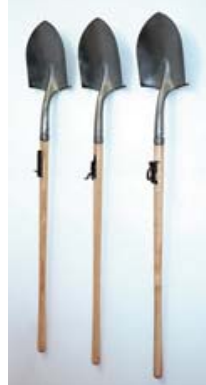

Pedro Reyes,

Palas por

pistolas, 2008.

Otro de sus proyectos presentados en la Galería Enrique Guerrero fue su muestra individual titulada Nuevas terapias grupales (2004), en la que si bien el artista había trabajado anteriormente creando espacios destinados a la interacción social, en esta ocasión, abordó el problema del diseño a una escala menor, creando esculturas que son activadas por el uso. La condición de la escultura como objeto es aquí relegada a un segundo plano, privilegiando la experiencia real de uso que ésta posibilita y valorando la implicación de los posibles espectadores que incidentalmente quedan involucrados en los eventos como Catarsis (2004) y Trabajo de Equipo (2004), terapias propuestas por el artista y llevadas a cabo en diferentes puntos de México, D.F. Ésta última utilizaba la escultura Sombrero colectivo (2004), compuesta de varios sombreros estilo zapatista, que formaban una suerte de tejido celular soportado por todo el grupo. La colaboración en esta acción generaba un espacio orgánico que podía desplazarse con el común acuerdo en cuanto a la dirección a seguir, de los usuarios de la pieza. La "participación creadora"645 del espectador es contemplada por muchos artistas como una forma de inflexión política capaz de generar resonancias en el ámbito público, de ahí la importancia de estas prácticas trasformadoras del imaginario colectivo, capaces de propiciar la participación colectiva del receptor y transformar la conciencia social, más allá de las expectativas artísticas. La incorporación del espectador en estos casos, es lo que permite que la obra cobre existencia.

Ejemplo de ello es también, el proyecto realizado por Reyes para el Jardín Botánico de Culiacán, evento comisariado por Patrick Charpenel en el que participaron artistas contemporáneos mexicanos. No se trataba de convertir el jardín en un lugar para ver obras de arte, sino en complementar la experiencia del recorrido del mismo con proyectos escultóricos específicamente diseñados para el lugar que reforzaran la misión científica del jardín. Aquí, Reyes realizó la 
pieza Palas por pistolas (2004), con la que dialogaba con el contexto natural del jardín y el contexto social de Culiacán -ciudad al oeste de México con el mayor número de muertes por armas en el país-. El artista, relacionando problemáticas específicas de la zona, vincula entidades como el ejército, la industria de las herramientas y la de las armas, con la sociedad específica del lugar. Finalmente, con la ayuda del gobierno de la ciudad, Reyes consiguió juntar una tonelada de armas decomisadas a delincuentes y fundió el metal obtenido, para con él fabricar herramientas de jardinería con las que plantar árboles en la región. La retirada de la circulación de esa cantidad de armas y su utilización dentro del proyecto concebido para el Jardín Botánico funge como un alegato posible para la metamorfosis de la convivencia social entre ambos mundos: el de armonía del jardín y el del entorno conflictivo de la ciudad que rodea al mismo. La trasformación de un agente de muerte en un agente de vida, convierte al material de trabajo -instrumentos que anteriormente fueron de "violencia y muerte"646- en algo maleable capaz de absorber la idea de transformar el conflicto en acto de vida favoreciendo a su vez, la relación entre el ser humano y la naturaleza vegetal.

Sacar estas armas fuera de la circulación podría salvar algunas vidas, pero en realidad el propósito de la pieza consiste en añadir una historia al mundo -la historia de que este hecho pudiera ser cierto en Culiacán-. Afirma el artista que añadir historias al mundo puede ser un arma para el cambio pacífico. En este sentido, sus proyectos de arte se basan en la idea de que es posible dar soluciones reales a los problemas sociales. Si bien sería bastante ambicioso y romántico afirmar que el arte va a cambiar el mundo, puesto que en realidad estos problemas requieren un enfoque más complejo y el esfuerzo conjunto de diferentes instancias sociales y políticas, de alguna forma es viable el hecho de que el arte puede y debe participar construyendo situaciones para el cambio. El poder de este trabajo pertenece al ámbito de la simbología, pero su eficacia reside en la elaboración de la parábola.

\subsection{Naturaleza como moneda de cambio e imagen de mercado. Thomas Glassford, Melanie Smith y Máximo González}

En el contexto del arte contemporáneo mexicano podemos encontrar, en cuanto a los materiales de las obras se refiere, piezas que reinterpretan la relación del hombre con su entorno natural, con la característica particular de presentar un proceso de hibridación. Se trata de obras hechas a partir de materiales tanto orgánicos como inorgánicos, que responden a la conciencia de asumir este vínculo, como un efecto inevitable de la contemporaneidad. Podemos observar este fenómeno de transformación de la Naturaleza en un entorno cotidiano que difiere mucho del estereotipo del lo natural en artistas como Thomas Glassford, Melanie Smith y Máximo González. Las múltiples lecturas que el escenario físico,

646 MUNGUÍA, Jorge, "Jardín Botánico. Entrevista a Patrick Charpenel”, en Tomo. Arte, arquitectura y diseño, Suplemento Excelsior, $\mathrm{N}^{\circ} 10,2008$, Disponible en red: <http://tomo.com.mx/2008/10/25/jardin-botanico/>, [Consulta 19, agosto, 2011]. 
el paisaje urbano, la contingencia y la contaminación que las condiciones de México, D.F., ofrecen al ciudadano, son vistas por ellos como el efecto de una Naturaleza-paisaje fruto de la Cultura acumulativa asumida a partir del exceso. En este sentido sus trabajos reflejan el efecto de estos síntomas construyendo imágenes y recreando símbolos que denuncian las prácticas desbordantes de nuestra sociedad.

Thomas Glassford (Laredo, Texas, 1963) llegó a México en 1990 y se integró en el ámbito conceptual del arte emergente mexicano. En el capítulo segundo dimos cuenta de su participación en esa época, en la exposición Lesa Natura (1993). En el libro Round de sombra, Abraham Cruzvillegas relata que como tantos otros artistas contemporáneos suyos, Glassford deja de lado la preocupación "generalizada hasta entonces, de la representatividad asociada a la identidad nacional o cultural, como una selección del arte producido en un lugar específico"647. Si bien, Glassford selecciona ciertos elementos del imaginario colectivo mexicano y los asume como característicos de su propio lenguaje conceptual, otorgándoles una nueva identidad. Paralelamente a la elección del guaje648 como una especie de icono conceptualmente revisado de la mexicanidad y de la relación entre las acciones humanas y la Naturaleza, su interés por el concepto de paisaje se manifestaba en su obra, a través de una aséptica tipología de paisajes conceptuales elaborados con alfombras verdes. Alguna de estas apocalípticas apologías del paisaje fue presentada en la $\mathrm{V}$ Bienal de la Habana (1994), dando una idea de una Naturaleza parca y verde, pero instrumentalizada como objeto de consumo.
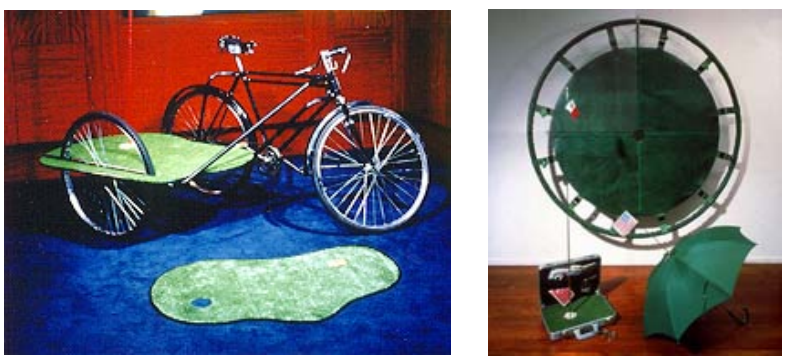

Thomas Glassford, Ciudad de verdes, 1997.

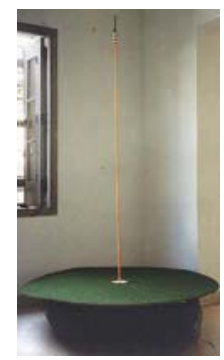

Thomas Glassford, Is/a vacía, 1997.

En estas obras, el elemento vegetal fungía únicamente como anclaje metafórico de una superficie horizontal, caracterizada por la simbología del color y la artificialidad del material empleado. Glassford, dedica la obra Ciudad de verdes (1997), a manera de ironía, a la ciudad de San Diego - una de las ciudades con más circuitos de campos de golf en el mundo-. En esta pieza, se vislumbra un concepto de Naturaleza totalmente utilitario, como ejercicio crítico al exceso de

647 CRUZVILLEGAS, Abraham, Round de sombra, Consejo Nacional para la Cultura y las Artes, México, D.F., 2006, p.141.

648 Especie de calabaza que, una vez seca y vaciada, se utiliza en México para transportar agua. 
una Naturaleza uniformemente domesticada en favor del comercio. Estas piezas esculturas-paisajes, en una especie de paráfrasis del Arte Povera, estaban realizadas con materiales pobres, hechas de papel, piel o plástico, como en el caso de Cinturón verde (1997). Se presentaban estiradas mediante dispositivos industriales -tensores metálicos- e incorporaban elementos insólitos como cremalleras, hebillas o broches. Isla vacía (1997) era una especie de austero paisaje flotante, con una superficie circular y un palo en el centro que, a manera de boya, parecía que fuera a ser lanzada a la bahía. A pesar de que la pieza remitía de manera muy simple a una versión muy reducida del paisaje de la isla, la aparente alusión a los balseros cubanos debió parecer a las autoridades demasiado evidente y la acción fue censurada.

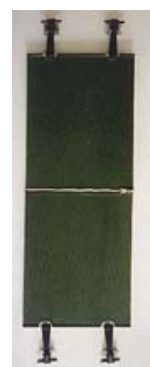

Thomas Glassford, Cinturón verde, 1997.

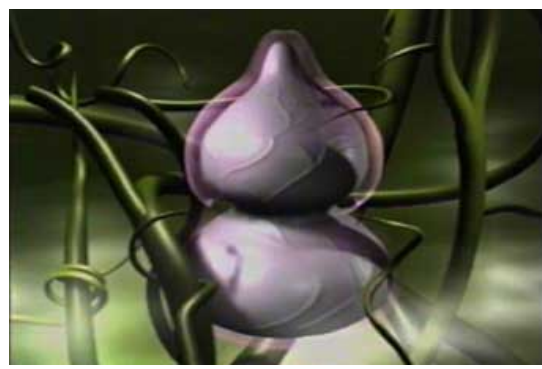

Thomas Glassford, Guaje electrónico, 2004.

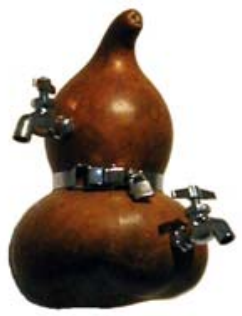

Thomas Glassford, Fuente, 1990.

La mayoría de su obra posterior se inscribe en una estética minimalista, en la que las ambivalencias del objeto primitivo y sus implicaciones en intervenciones postmodernas con materiales plásticos, cremalleras, tuercas y cadenas desaparecerán paulatinamente. Entre 1990 y 1994, Glassford realizó una serie de piezas cuyo motivo principal era el guaje. Estos objetos, recubiertos de piel y con las cremalleras características de los trajes sadomasoquistas, conservaban en ellos una fuerte carga fetichista, una simbología fría e inquietante con la que lograban trasmitir un erotismo voluptuoso. Todo ello, transformaba este objeto tradicional de raigambre rural y de origen natural -primitivo en su forma $y$ artesanal por su elaboración manual- en objeto de deseo sexual649. Si bien, la presencia del guaje en esos momentos en el panorama artístico introdujo en el arte contemporáneo mexicano una revisión particular de la Cultura tradicional. El uso del guaje como cuerpo, recipiente o medio para transportar agua, hablaba tanto de la falta de la misma en muchas zonas de México, como de la idea del cuerpo humano como contenedor de fluidos, estableciendo una suerte de paralelismo entre ambos.

Durante años empleaba calabazas secas para crear ensamblajes barrocos, sexualmente provocativos, incorporándolas a otomanas, espejos, luces de arañas y piezas de joyería. Ahora las resonancias simbólicas que dieron impulso a su obra anterior han sido superadas por intereses de eficacia

649 DEVROISE, Olivier, en "Puertos de entrada: el arte mexicano se globaliza 1987-1992", en MEDINA, Cuauhtémoc et al., La era de la discrepancia..., op. cit., p.334. 
óptica [...]. Sin embargo, en la recreación de Glassford el objeto especifico se convierte, de forma deliberada, en un elemento decorativo al que no le importa ser considerado una mercancía650.

Una de las acciones que llevó a cabo en la Bienal de la Habana de 1994 fue Invitación al acarreo (1994) "donde a caballo, en bicicleta, a pie y con paracaídas plateados soltados a volar desde el faro del Morro, homenajeaba al guaje como primer instrumento de la cultura trashumante" ${ }^{651}$. A esta acción corresponde la pieza del mismo nombre, en la que se puede apreciar la bicicleta que el artista usó, cargada con un guaje atado sobre una bata de carnicero.

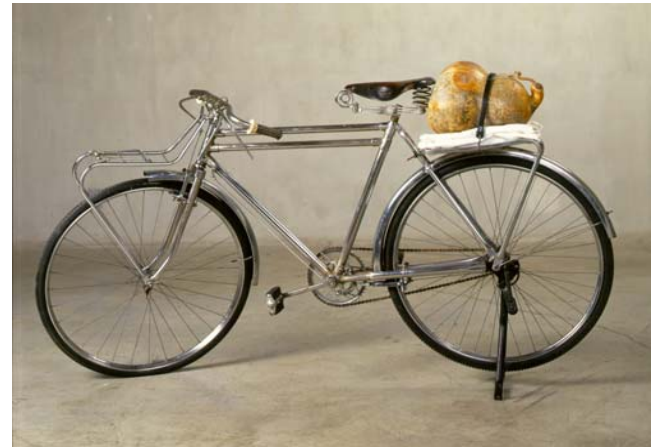

Thomas Glassford, Invitación al acarreo 3, 1991.

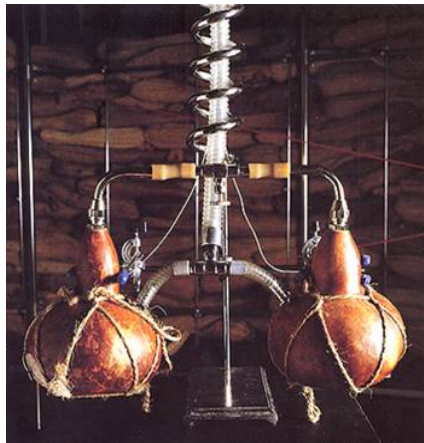

Thomas Glassford, Pulmones, 1993.

Mirar la tradición y la identidad mexicana desde una óptica diferente, le permiten al artista inscribir en lo urbano este objeto utilitario y rescatarlo del olvido. Es una nueva forma de plantear el contacto característico de la gente humilde con el mundo natural y tangencialmente, de la interdependencia del ser humano con el mundo vegetal.

Podríamos considerar que lo que el autor pretende mediante una disfrazada y sutil ironía es poner en evidencia y criticar el esquema del mercado del arte. Estas piezas se aproximarían, en su preciosismo y voluptuosidad, a lo que Thomas Crow llama "fetichismo de la mercancía", en donde "lo que la mayoría de los compradores persigue no es el valor de uso específico" de una obra en particular, "sino el valor genérico de cambio652" representado por su autor, sea éste quien sea. En una defensa de lo valores y creencias insertos en la Cultura de lo cotidiano, el artista reniega de ser adversario del ciudadano corriente. Lo

650 BORRÀS M. ${ }^{a}$ Lluïsa et al., "Thomas Glassford, Ciudad de México. Torre de los Vientos. Galería OMR", en México, Identidad y ruptura, Fundación Telefónica, Madrid, 2003, Disponible en red en: <http://www.fundacion.

telefonica.com/es/at/mexico/paginas/05.html>, [Consulta 20, agosto, 2011].

651 MEDINA, Cuauhtémoc, "La real Habana", en MEDINA, Cuauhtémoc et al., La era de la discrepancia..., op. cit., p.400.

652 CROW, Thomas, El arte moderno en la cultura de lo cotidiano, Akal Arte contemporáneo, Madrid, 2002, p. 87. 
que el artista hace con estos objetos populares, es rescatarlos de su uso tradicional, cultural e histórico, para problematizar su habitual recepción, y de esta manera convertirlos en objetos absurdos, a la vez que en objetos de culto: "El momento en que un objeto de uso revela su ineficiencia puede ser también el que nos hace verlo por primera vez"653. Es una manera de poner en tela de juicio la diferencia establecida entre el reconocido y establecido arte de los museos, del que, siguiendo a Thomas Crow:

[...] está excluido el carácter de mercancía de la producción cultural moderna. Aquí el pretexto agresivamente reiterado es que las formas tradicionales han sobrevivido inalteradas y permanecen como una experiencia fuera de la historia. Las subculturas marginales del tiempo de ocio niegan más o menos del mismo modo la condición de mercancía utilizando los objetos a su conveniencia. Careciendo de instituciones legitimadoras, su transformación de la mercancía debe ser activista e improvisadora: de ahí su continua inventiva en el desplazamiento de los bienes culturales recibidos a nuevas constelaciones de significado654.
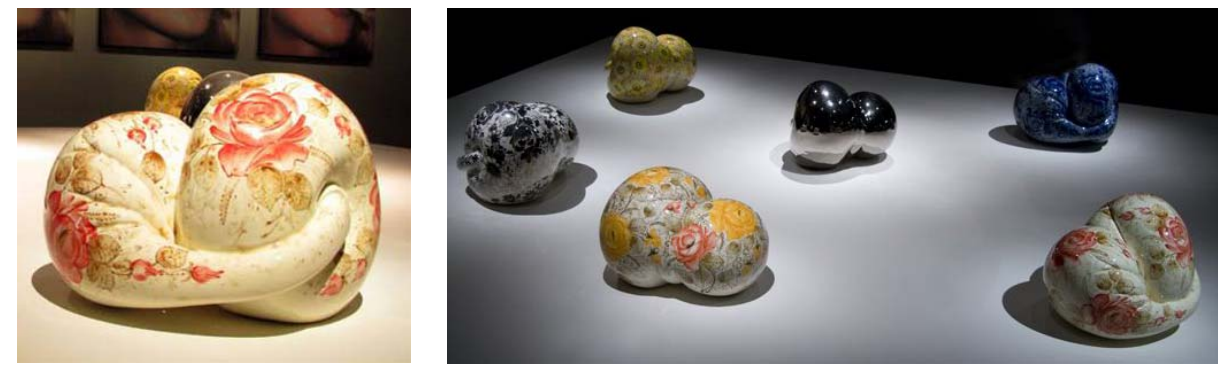

Thomas Glassford, Autogol, 2009.

Con todo ello -como apunta James Oles- entre el diseño funcional y el objeto absurdo, Glassford no fabrica objetos utilitarios para alguna utopía doméstica en donde la forma sigue rígidamente la función, sino que tras la apariencia de perfección y exclusividad y, "privilegiando lo industrial (lo perfecto) sobre lo natural (lo imperfecto)"655, se desliza entre los intersticios de nuestra Cultura del consumismo, en donde la comercialización, lo superficial, la posición social y el diseño, lo son todo, y nos traslada a un mundo donde impera la inutilidad más decadente. Glassford admira y utiliza los materiales producidos a gran escala, sin embargo la paradoja de sus objetos, en ocasiones minuciosamente hechos a mano, nos remite a una cotidianeidad real, pero imposible. El objetivo final es concienciar al espectador, explicitando la absoluta frivolidad de nuestras obsesiones, para evitar que éste caiga ciegamente en la seducción de la comercialización y en la venta de simbolismos aunados a las imágenes que te

653 ABAROA, Eduardo, "Moving", en AA. VV., Eco: arte contemporáneo mexicano, Museo Nacional Centro de Arte Reina Sofía, Conaculta, Madrid, 2005, p. 190.

654 CROW, Thomas, op. cit., p. 32.

655 OLES, James, "Thomas Glassford", en Poliester, № 26, octubre, México, D.F., 1999, pp. 40-45. 
vende el consumo indiscriminado y feroz. Como apunta Simón Marchán Fiz, el arte objetual

\section{[...] alcanza su plenitud en sus posibilidades imaginativas y asociativas,} libres de imposiciones, en el preciso momento en que el fragmento, objeto u objetos desencadenan toda una gama de procesos de dación de nuevos significados y sentidos en el marco de su banalidad aparente656.

Podemos concluir que el uso que Glassford hace de este tipo de objetos está cargado de significaciones que advierten al espectador en torno a los usos incorrectos del arte. La utilización de este objeto específico de origen vegetal, ha perdurado en su obra convirtiéndose, de forma deliberada, en un elemento decorativo al que no le importa ser considerado una mercancía como se puede apreciar en la pieza Autogol (2009)657, donde retomó el símbolo del guaje y utilizando una característica decoración artesanal lo convirtió en un objeto de lujo, desplazando intencionalmente su original función.

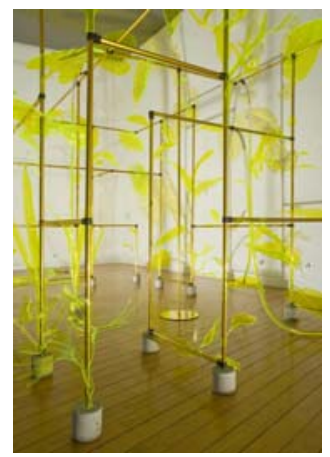

Thomas Glassford, Afterglow, 2010.

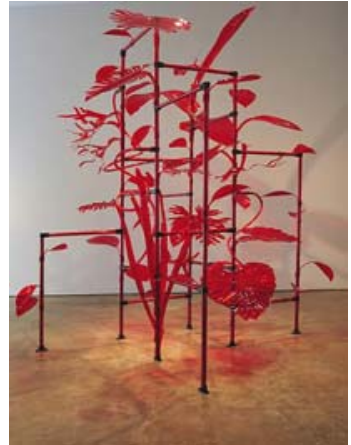

Thomas Glassford, Jungala, 2011.

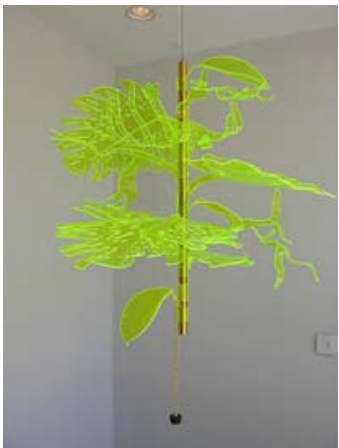

Thomas Glassford, Afterglow Hybrid Pendant 1, 2010.

Para el Museo Experimental El Eco (México, D.F.) Glassford realizó la instalación Afterglow (2010), donde recrea una Naturaleza paradójicamente artificial. Se trata de una especie de exuberante jardín futurista en el que, mediante la combinación de diferentes materiales artificiales, el artista consigue generar un ambiente natural y exótico, que invita al espectador a caminar alrededor -0 al interior- de la obra. Compuesta por hojas de plexiglás o acrílico verde y tubos de aluminio dorado, esta pieza remite a la obra anterior del artista -más enfocada en los materiales y en las composiciones de orden industrial-. En esta construcción neobotánica, el artista continúa formulando cuestiones de decadencia, de clasismo y de transfiguración de materiales industriales en objetos estéticos. En ella, aparecen tuberías que forman estructuras características de los juegos infantiles y que el artista utiliza como soporte para

656 MARCHÁN FIZ, Simón, op. cit., p. 168.

657 Véase material divulgativo de la exposición Cerámica Suro, diálogo y producción, realizada en la Galería Jesús Gallardo (León, Guanajuato), 2009. 
presentar una invasión de formas orgánicas, específicamente vegetales, una jungla con grandes hojas de acrílico y tubos transparentes rellenos de líquido. Todo ello con un color verde fosforescente, de manera que los materiales atraen la luz y permiten una especie de narrativa de ciencia ficción.

Por medio de este juego entre lo orgánico y lo industrial, el artista hace referencia al periodo histórico de la época victoriana, cuando las imágenes de helechos abundaban en las artes decorativas. Este espacio cercado, recuerda tanto a los invernaderos victorianos y a los jardines interiores creados por las adineradas nuevas clases industriales, que poseían colecciones de plantas tropicales importadas, como a los jardines del Medio Oriente o de la India, que significaban riqueza, lujo e industria. La instalación de Glassford recuerda también las formas y los patrones del Art Nouveau, movimiento artístico que intentaba -como el mismo artista- reconciliar los materiales industriales con las formas orgánicas. Estas formas evocan la nostalgia de una Naturaleza que, finalmente sólo se puede representar artificialmente y que, como el arte, se convierte en un objeto de cambio.

La idea de una Naturaleza clasificada y cosificada por la sociedad de consumo, combinada con la resignificación de objetos, aparece también en las primeras obras de Melanie Smith (Poole, Inglaterra, 1965). Esta artista llegó a México en 1989 y su discurso se orientó a reflejar la textura visual contemporánea de la México, D.F. Su estética está relacionada con las acumulaciones de los "nuevos realistas" de los años sesenta. Según Marchán Fiz, la acumulación

[...] es una modalidad objetual, próxima al assemblage, en la que los objetos de uso de igual o de distinta naturaleza son amontonados en una disposición en relieve o son coleccionados [...]"658.

Marchán denomina a estas prácticas, los Nuevos Realismos, ejemplificándolos con la obra de M. Rayse, quien trabajaba en torno a la "purificación y la sensibilización de la capacidad visual"; con las expansiones y la industria de los plásticos, en las obras de César y las multiplicaciones-acumulaciones típicas de Arman. En el caso de Melanie Smith, aún cuando esta artista sigue las pautas formales de los acumulacionistas en la elaboración de algunas piezas, su obra estaría más cercana, en nuestra opinión, a prácticas más recientes, que como afirma Marchán, proponen "la sustitución del arte privilegiado por un arte de uso reproducible que podría ser comprendido por los no iniciados, como un sociograma de la situación política y social [...]"659. Por su parte, Cuauhtémoc Medina describe la obra de Smith como una:

[...] estructura apretada de referencias internas entre fotografías, pinturas, videos, proyectos conceptuales e instalaciones hechas de objetos encontrados, que se refieren a la tensión entre un vocabulario 
pseudo-abstracto de patrones visuales básicos y de la estética dominante de una interpretación local de la contemporaneidad660.

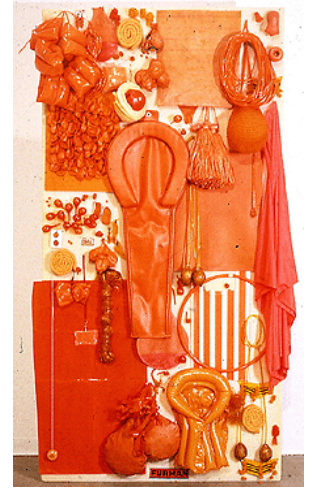

Melanie Smith, Orange lush, 1994.

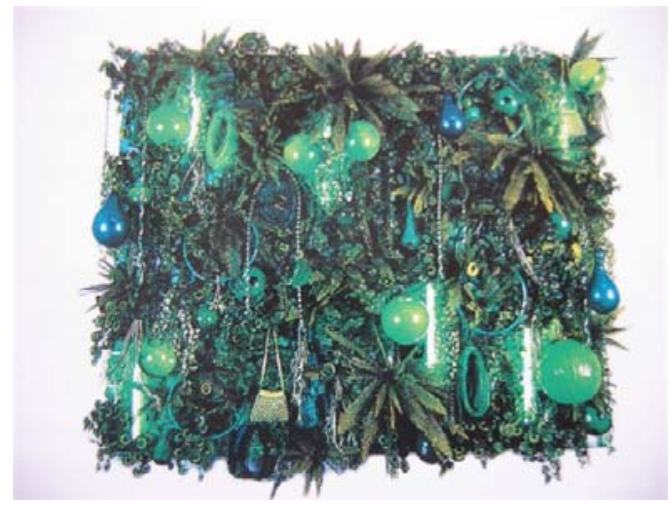

Melanie Smith,

Green lush sub tropicana jungle mix I, 1998.

Como intérprete de una estética localista, Smith convierte en su estudio los mercados y las calles del centro de México, D.F., centrando sus investigaciones plásticas en la plasmación de la acumulación visual, el impacto de los objetos y su entorno, así como en las nociones de lo que se define como buen gusto/mal gusto. Su período anaranjado (1994-1996) fue una especie de lectura arqueológica de la Cultura de lo sintético y de cómo ese color es utilizado para atraer la atención del consumidor. Esta serie de obras incluía todo tipo de artefactos anaranjados, con los que conseguía neutralizar la individualidad de los objetos y la atracción tiránica que habitualmente éstos ejercen sobre el espectador, para construir una nueva presencia. Smith no representa la caótica y exuberante vida de la ciudad sino que, a manera de inmersión en el caos visual del entorno -como una forma productiva de repetirlo- hace un registro material de los procesos sociales de la misma, reproduciendo pequeñas metonimias de la realidad urbana, con fragmentos que rayan sutilmente en la banalidad661. Como diría Pirson no se trata aquí de describir, sino de decir662. No se plantea la belleza, sino la presencia real del objeto que es lo que produce el impacto por la existencia de las fuerzas contenidas en él.

Así, en Green lush sub tropicana jungle mix I, Verde y exuberante selva subtropical (1998), Smith nos presenta una imagen de una Naturaleza urbana totalmente artificial, esa que asumen como propia los habitantes de las megalópolis. La selección de objetos y plantas artificiales de color verde

660 Véase MEDINA, Cuauhtémoc, "20 Million Mexicans can't be wrong, 20 millones de mexicanos no pueden estar equivocados", en 20 millones de mexicanos no pueden estar equivocados, South London Gallery, London, 2002.

661 Véase GUERRA, María, "Arqueología del Futuro", en Orange Lush. Melanie Smith, Instituto Anglo Mexicano, México, D.F., 1997.

662 PIRSON, Jean-François, La estructura y el objeto. Ensayos, experiencias y aproximaciones, Promociones y publicaciones universitarias, Barcelona, 1988, p.11. 
demuestran a través del interés de la artista por el artificio, la sustitución de la Naturaleza por su simulacro, presente constantemente en la amalgama citadina.

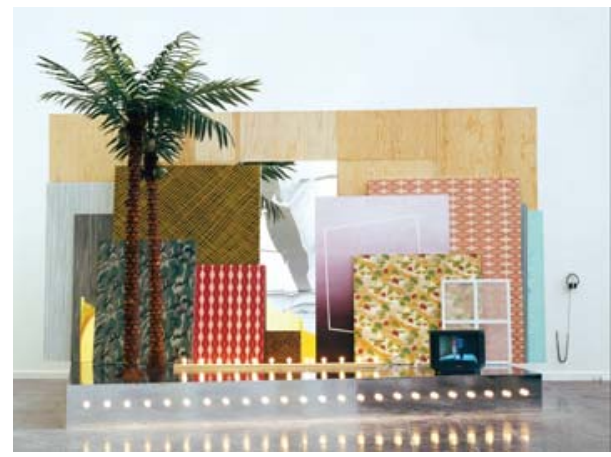

Melanie Smith, Farsa y artificio, 2006.

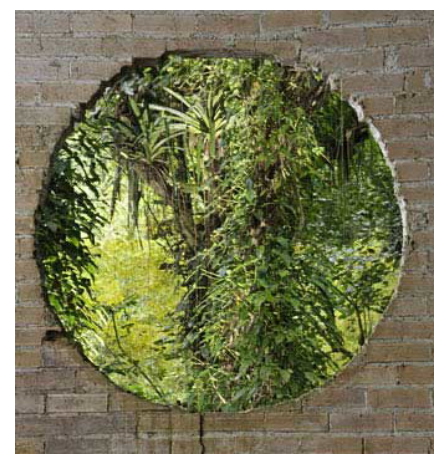

Melanie Smith, Xilitla, 2010.

Años más tarde, Smith convoca la desaparición del paisaje, reproducida en Farsa $y$ artificio (2006), mediante la construcción de un escenario ordenado en donde la Naturaleza queda convertida en un reducto artificial, de la misma manera que lo hacía la tradición paisajística de la pintura663. Con la sublimación del kitsch y la banalidad, sus abigarradas y coloridas composiciones repletas de objetos baratos, no hacen sino dialogar con la misma realidad que rodea cotidianamente al espectador, registrando fielmente como apunta Cuauhtémoc Medina:

\section{[...] la manera en la que el Tercer Mundo malinterpreta creativamente el encanto del consumo y las dificultades del subdesarrollo, ironizando a la vez que validando, esta nueva Naturaleza en la que habitamos664.}

En su último video, la artista realiza un ejercicio de fantasía retórica en torno a la Naturaleza, en referencia justamente, a uno de los lugares naturalesartificiales más emblemáticos de México - del que ya hemos hablado en el capítulo segundo- el jardín surrealista creado en la Huasteca potosina por el inglés Edward James. Xilitla (2010) es un filme experimental realizado en 35 milímetros, en el que Smith explora los múltiples significados de este espacio, casi mítico en México:

Se trata de estrategias de distanciamiento por medio de las cuales Melanie Smith desmonta la mirada moderna, que hace del paisaje exótico pantalla e imagen donde proyecta su deseo, produce su utopía. En suma, se trata de un juego crítico sobre el reflejo como pliegue que permite mostrar el

663 Véase AA. VV., Melanie Smith, Ciudad espiral y otros placeres artificiales/Spyral City and other artificial pleasures, MUCA, UNAM, A \& R Press/Turner, México, D.F., 2006.

664 MEDINA, Cuauhtémoc, "Melanie Smith", en AA. VV., Eco: arte contemporáneo..., op. cit., p. 64. 
mecanismo de la mirada que hace de la naturaleza un paisaje onírico de la modernidad665.

En este filme, en lugar de utilizar el convencionalmente apaisado formato cinematográfico, la artista elige un formato vertical para relacionarse con el entorno y como estrategia para desestabilizar la mirada. El elemento protagónico es un gran espejo que la artista usa a manera de cita directa a la obra Mirror Displacements (1969), que realizó Robert Smithson durante su viaje a la península de Yucatán, y con quien la artista entabla un diálogo en torno a las relaciones complejas entre las poéticas y los imaginarios exóticos que la historia ha producido en torno a la exuberancia del trópico. La artista mediante diferentes estrategias pretende desmantelar la mirada que inventó la exuberancia onírica del paisaje. Para José Luis Barrios este video es "una operación de extrañamiento de la imagen que muestra la estructura moderna de la fantasía romántica y surrealista con la que se construye ese lugar"666.

Después de los ejercicios de desmantelamiento del artificio y las fantasías en torno a la Naturaleza, por último, abordaremos un paso más allá en la utilización del referente vegetal como recurso para reflexionar sobre una civilización en la que todo vale y que hace uso de la Naturaleza como objeto de lucro. Una sociedad que antepone los valores del dinero y de la comercialización, a la necesidad de convivencia armónica con el entorno. Constatamos este tipo de reflexiones en la visión mediatizada sobre el intercambio y el comercio, que se percibe en la obra de Máximo González (Paraná, Entre Ríos, Argentina, 1971). En una exposición bajo el nombre de Efecto invernadero (2004), este artista expuso una serie de piezas relacionadas con la Naturaleza y diferentes elementos vegetales. Según la definición de los organizadores667, en esta muestra, el concepto de invernadero se planteaba como:

[...] un pequeño jardín en donde el horticultor juega a ser un verdadero creador [...] todo invernadero impone un orden y al mismo tiempo busca disimularlo bajo una apariencia de "naturalidad». La idea regulativa es que, en la medida de lo posible, los productos logren una simulación de lo fértil escondiendo precisamente el sistema de relaciones de producción que haría

\footnotetext{
665 SANTOSCOY, Paola, "Xilitla", en AA. VV., Melanie Smith. Cuadrado rojo, imposible rosa, 54 Bienal de Venecia, Turner/ Instituto Nacional de Bellas Artes, México, D.F., 2011, pp. 47-55.

666 BARRIOS, José Luis, "Cuadrado rojo, imposible rosa. Marco y afecto: de las alteraciones de la Modernidad", en AA. VV., Melanie Smith. Cuadrado rojo, imposible rosa..., op. cit., pp. 15-21.

667 Exposición Efecto invernadero (2004), comisariada por Laboratorio curatorial 060, entre cuyos miembros se encontraban Gabriela Gómez Mont, Sol Henaro, Lourdes Morales, Javier Toscano y Daniela Wolf.
} 
evidente su funcionamiento como mercancía. La naturaleza creada de esa forma esconde el artificio de su origen668.

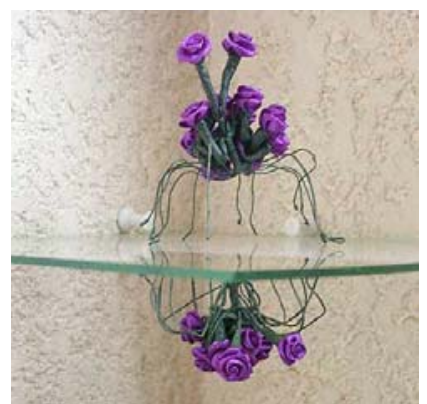

Máximo González, Itsy Bitsy araña, 2003.

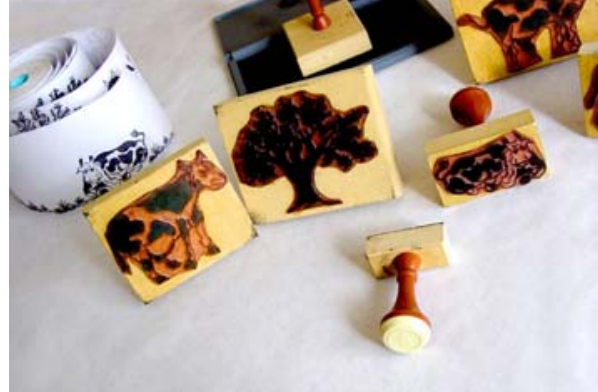

Máximo González, Máquina para hacer paisaje por metros, 2004.

Un invernadero construido por el hombre define conceptualmente, la recreación de un pequeño mundo hecho a la medida del mismo, en el que la reducción de las variables y la injerencia directa del ser humano lo configuran como una biosfera artificial hecha a su propia imagen y semejanza. La construcción de un ecosistema en el que el hombre se erige como pequeño dios, imponiendo su propio orden y eliminando el caos, es una ironía. En base a este tipo de planteamientos, la exposición agrupaba obras que trasmitían la idea de atmósferas reguladas que, generando una estructura de significados 0 semiósfera, revelaban las analogías entre las macroestructuras sociales y políticas, y el micromundo cotidiano, donde el artificio deviene poco a poco un proceso natural. Efecto invernadero es un término de nuestro tiempo que evoca una situación irreversible y trágica, creada por el artificio del hombre y al cual rebasa por extensión. Este fenómeno se puede aplicar a todo el aparato artificial que rodea a las estructuras sociales y económicas. La elaboración de analogías presentes en la obra de González da pie a relacionar dichas estructuras con el mundo del arte en el cual se insertan, mediante una resignificación formal, semántica y simbólica de los materiales. Por ejemplo en la obra Máquina para hacer paisaje por metros (2004) se observan una serie de sellos, a los que el artista llama objetos-acción, que se usaban durante la exposición para estampar y vender paisajes confeccionados con ellos.

Por medio de objetos de desecho, cotidianos y naturales, el artista explora la equivocidad de sus significados a partir del tropo retórico de la ironía [...]. Explorar la condición de esta "sarna especulativa» de los valores y los

668 TOSCANO, Javier, "El efecto invernadero o la impostura del sentido. Reflexiones en torno a una curaduría", Véase material divulgativo de la exposición Efecto Invernadero (2004), Galería Art \& Idea (Colonia Condesa, México), Disponible en red: <http://www.lc060.org/invernadero/>, [Consulta 25, agosto, 2009]. 
objetos para restituirles un sentido de materialidad es la estrategia estética y discursiva de los trabajos de Máximo González669.
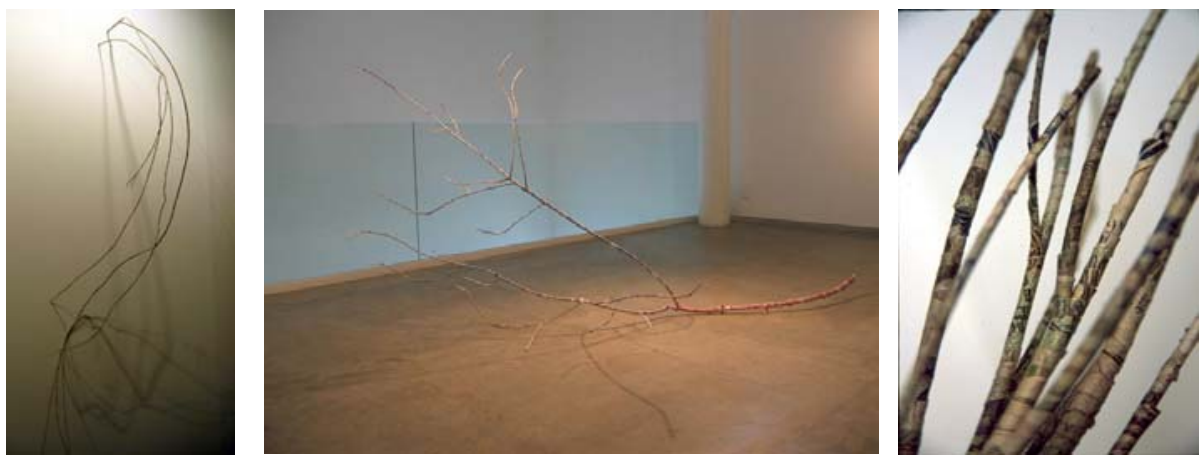

Máximo González, Cara y seca, Efecto invernadero, 2004.

Otra de las piezas que se podían observar en la exposición Efecto Invernadero (2004), era una serie de ramas de árbol recubiertas con billetes devaluados y recortados. Estas esculturas hechas de simples ramas, envueltas con billetes fuera de circulación, hacen que el dinero -que ha perdido su función originariaregrese a la circulación económica, convertido en arte. Parafraseando a Jean François Lyotard, el artista parece querer mostrar la banalidad enquistada en los procesos de globalización. Sus obras ilustran que cuando es el capital el que concentra el poder, la solución postmoderna asume el eclecticismo del todo vale, con el que el gran público contento, goza de lo ecléctico a través del kitsch. A falta de criterios estéticos, parece decirnos el artista, el arte asume el realismo del dinero, haciendo posible y útil medir el valor de las obras, por la ganancia que se puede sacar de ellas670.

[...] la obra de Máximo González, con su aparente estética decorativa y fragilidad corpórea, también apunta hacia la creciente complejidad que se teje entre los sistemas naturales y aquellos creados por el hombre: un mundo que no es ni una cosa ni la otra, sino que reside en la relación dialéctica entre ambos671.

González parte de la idea de que en la actualidad, el artificio es evidente, tanto si uno piensa en las oscilaciones de la economía como en los cultivos transgénicos. En un futuro cercano la interdependencia absoluta entre unos y otros factores, debería implicar una nueva civilización neo-biológica en la que los sistemas creados por el hombre necesitarán importar la lógica y las leyes de

669 BARRIOS, José Luis, "Efecto Invernadero: Humor y Restitución”, en Curare, $\mathrm{N}^{\circ} 23$, México, 2004, pp. 6-10.

670 LYOTARD, Jean François, La postmodernidad (explicada a niños), Gedisa, México, 1986, pp. 17-18.

671 Véase material divulgativo de la exposición Efecto Invernadero, Galería Art \& Idea, México, 2004, Disponible en red: <http://www.art-idea.com/_mexico/maximoimagenes /maxi.html $>$, [Consulta 9, agosto, 2005]. 
lo natural para funcionar de manera adecuada en su creciente complejidad, haciendo que la vida, a su vez, sea cada día más manipulada por la tecnología. En este escenario en el que los límites entre lo natural y lo artificial son tan cuestionables, la forma en la que el artista mezcla materiales orgánicos y fabricados por el hombre, como el dinero, se convierte en una interesante forma de manejar realidades y símbolos.

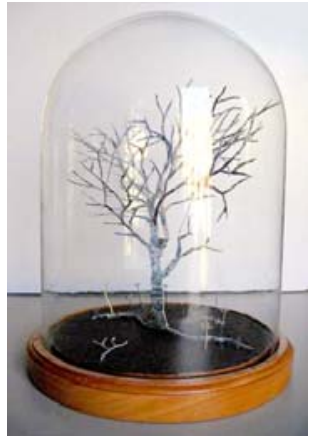

Máximo González, Árbol 3D, 2008.

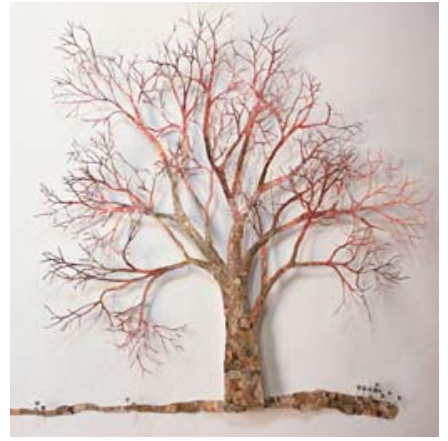

Máximo González, Árbol rojo y marrón, 2008.

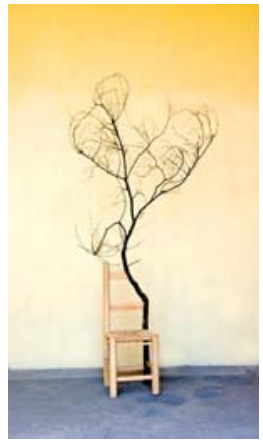

Máximo González, Silla-árbol, 2009.

En su obra Paisaje con basura (2006), el artista expone y critica el concepto habitual de paisaje y el de Naturaleza, al recortar un billete y desdoblarlo en una panorámica que incluye en su horizonte un basurero municipal. La pieza traza una línea visual que denuncia a la economía como la verdadera fuerza que dibuja el paisaje contemporáneo. La rama Cara y seca (2004), deriva su título de la condición de estar forrada de billetes, la rama-objeto adquiere su valor no sólo por su manipulación, sino como resultado de su condición de obra de arte dentro de una galería: lo que se comercializa es una rama seca, enfatizando así el cinismo de la obra.
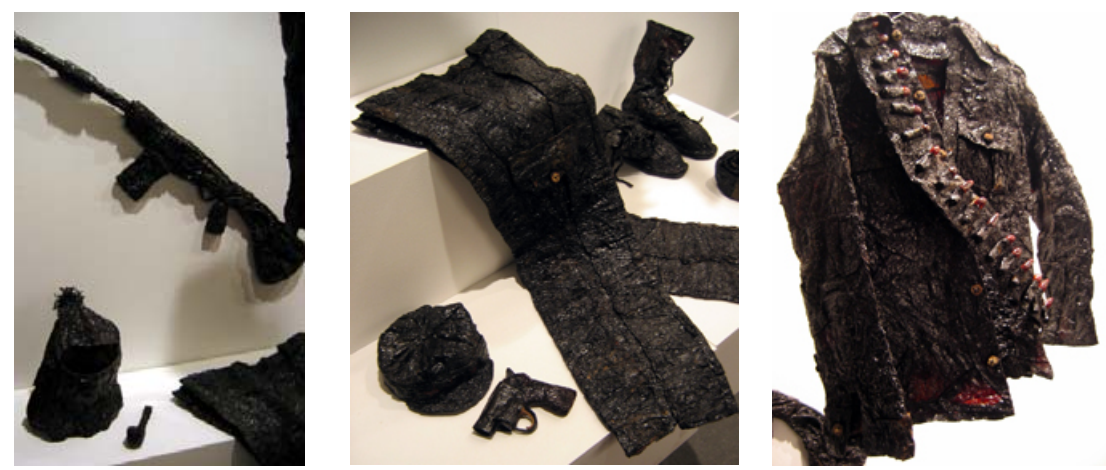

Máximo González, Subconjunto, 2005.

En la Feria Internacional de Arte Arco en Madrid, el artista expuso la obra Subconjunto (2005) en la que utilizaba chiles secos para criticar al sistema 
sociopolítico y económico del país672, elaborando todo un kit de guerrillero. La pieza realizada con chile mulato y chile cascabel cosidos, simulaba las prendas del uniforme y la iconografía del subcomandante Marcos, pipa incluida. El material empleado aquí trastoca su origen vegetal y su función alimenticia transformándose en material inerte que puede ser cosido, usado o vendido al mejor postor. La transferencia del valor de uso pone el dedo en la llaga porque los chiles aunque secos, siempre pican, al igual que la revolución zapatista (surgida el 1 de enero de 1994) que reaparece continuamente velada -a pesar de haberse diluido entre los avatares sociopolíticos- y que es convertida aquí en objeto de consumo.

En la exposición, Proyecto para la reutilización de vehículos obsoletos después de la extinción del petróleo (2006), proponía con una ironía que se sabe ingenua, la reutilización como maceteros de plantas de una serie de vehículos obsoletos (barcos de guerra, aviones de combate, tanques y cascos) artilugios que, como anticipa el artista, caducarán en un futuro por la falta de combustible. La de González, nos indica el periodista Mariano Navarro, es una "estética o una cultura del desecho"673, de los restos, de la mercantilización y de la conversión en dinero de todo lo obsoleto.

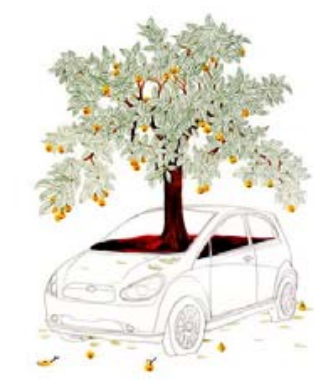

Máximo González, Membrillo Toyota, 2007.

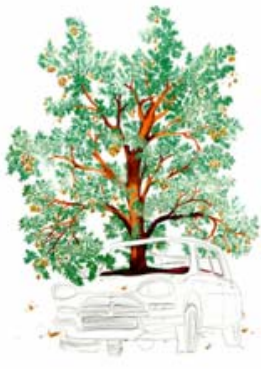

Máximo González, Peral en Citröen, 2007.

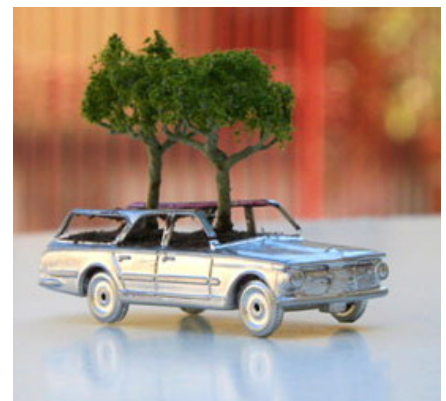

Máximo González, Miniatura $N^{\circ} 2,2011$.

Se trata de una serie de acuarelas en las que González pinta con colores lo orgánico -el árbol- mientras que la materia inerte está dibujada sólo con líneas. Los textos explicativos que acompañan a cada una de las obras dan noción del artefacto del que se trata y de la planta que se propone: una plantación de limones sobre la proa de un barco, nopales en una barcaza, verduras, chile, maguey, tomate, etc. en diferentes contenedores inutilizados, todos ellos cobrando vida de nuevo mediante el elemento vegetal de regeneración. Posteriormente esta idea se materializaría en pequeñas miniaturas que muestran los árboles sembrados sobre coches. Estas piezas formalmente recuerdan las

\footnotetext{
672 Además de emplearse como condimento alimenticio, el elemento vegetal del chile, por su forma tiene fuertes connotaciones masculinas convirtiéndose en un símbolo representativo de identidad de la Cultura mexicana.

673 NAVARRO, Mariano, "Máximo González. Letal macetero de vida", en El Cultural, El Mundo, Madrid, 8, marzo, 2007, p. 33.
} 
intervenciones de Betsabée Romero en la Colonia Buenos Aires, que comentábamos en el capítulo cuatro. Como vemos, Máximo González utiliza la metáfora vegetal para aludir a un efecto de vida que cobra terreno, vida que tarde o temprano regresará convertida en vegetal y que se instalará en los huecos de estos artefactos inútiles.

\subsection{E conoc imiento c ientífico y la pulsión entre lo natural y lo artific ial. Daniel Rivera y Eduardo Rincón}

Tomando como referente la temática particular del mundo vegetal y su manifestación dentro del campo de la escultura en México, hemos podido confrontar hasta aquí la evidencia del marcado interés por la relación entre Arte y Naturaleza. Mediante la revisión de las diferentes poéticas de los artistas que anteceden, hemos visto cómo las fronteras entre ambos campos del conocimiento se diluyen, en el afán de definir y/o transgredir los límites entre todo aquello considerado como natural o artificial. La sinergia que surge entre ambos ámbitos, deriva constantemente hacia un acercamiento entre todo lo humano y su ambiente. La idea de interdependencia y la comprensión de que todo está íntimamente relacionado excede con mucho las posibilidades de cambio que el arte puede ejercer en la sociedad contemporánea. Algunos artistas, como acabamos de ver, aluden al predominio de los valores económicos sobre los ecológicos y cómo los primeros se han constituido en una de las principales causas de los graves desequilibrios y de la crisis ambiental que padece el planeta.

La problemática de carácter ecológico relacionada con la sobrevivencia de ser humano, nos demuestra que la lógica del conocimiento -entendida como dominio por éste- se ha convertido en una lógica de la dominación como destrucción. La preponderancia de los valores económicos sobre los criterios éticos hace surgir nuevas fronteras entre la Naturaleza y el desarrollo humano. Ante la imposibilidad de trazar límites claros entre la propia Naturaleza, la Ciencia y el desarrollo tecnológico, las sociedades contemporáneas -más allá de criterios morales- deben establecer un nuevo concepto de frontera. Hemos visto aquí como el mundo del arte no es en absoluto ajeno a estas problemáticas, más bien al contrario, el artista contemporáneo -más allá de abogar por la recuperación de un paraíso perdido- se convierte en el portavoz de un discurso visionario que pretende hacer visibles las delicadas relaciones que vinculan al ser humano con una realidad que se torna espejo de sus propias acciones. En este sentido, las prácticas artísticas abarcan la realidad circundante y sus campos de acción, interrelacionando los diferentes campos del conocimiento humano en la dinámica de generar interferencias productivas entre el arte y la conciencia social que, por otro lado, han acompañado constantemente nuestro desarrollo.

Con los nuevos paradigmas científicos y, en la paulatina injerencia del conocimiento tecnológico, la reflexión en torno al binomio Arte y Naturaleza ha expandido su discurso, viéndose en la necesidad de ampliar sus límites para 
considerar el trinomio arte, Ciencia y vida. En este segmento, el artista colombiano radicado en México, Daniel Rivera (Bogotá, 1961) ha realizado diferentes investigaciones en torno a estas problemáticas desarrollando proyectos en los que aglutina el pensamiento científico y el estético en un objetivo común. Como artista, Rivera defiende que ambas formas de conocimiento deberían volver a trabajar en común, como era en la Antigüedad:

Las dificultades para entender la organización contemporánea radican en que el pensamiento estético y científico fueron separados hace unos 300 años, con la agudización del racionalismo y la implantación de una ideología denominada humanismo [...]. Hoy, la interdisciplinariedad es más que imprescindible. El conocimiento científico adquiere un territorio finito, del arte, no se sabe si podrá mantenerse en un territorio propio. Quizás hayamos llegado a eso que Einstein denominaba "el territorio del arte y de la ciencia”, sin la imaginación necesaria para asimilarlo674.

La convergencia de esas disciplinas tiene varias implicaciones, una de ellas en particular, refleja la despedida paulatina del antropocentrismo. La reflexión de Karin Ohlenschläger en torno a la obra del artista brasileño Eduardo Kac -quien en el año 2006 estuvo en México, D.F.675- nos acerca al planteamiento actual de la cuestión:

En la actualidad, la conexión entre arte y naturaleza sigue impregnada por dos grandes discursos: el ecológico y el tecnocientífico. Lo que distingue básicamente el uno del otro, es la diferente relación que establecen con la naturaleza. En general, el pensamiento tecnocientífico actúa desde una concepción jerárquica basada en la supremacía del ser humano sobre la naturaleza. En cambio, el pensamiento ecológico plantea un contexto dinámico y una relación circular de convivencia y coevolución, considerando a la persona como parte integrante de un ecosistema global de recursos limitados676.

Como podemos percibir en las opiniones de Ohlenschläger, el discurso ecológico, de forma obligada y contrariamente a la posición marginal de años atrás, habla de límites y, actualmente se ha convertido en punta de lanza del debate político y económico actual. Sus argumentos priorizan la sostenibilidad, la preservación y la recuperación del medio ambiente en contraposición al discurso tecnocientífico que sigue confiando en el progreso ilimitado.

674 RIVERA, Daniel, "A propósito de la ciencia y el arte", en La Jornada, México, 22, noviembre, 1999, Disponible en red: <http://www.jornada.unam.mx/1999/nov99

/991122/cien-rivera.html>, [Consulta 18, noviembre, 2005].

675 BUSTAMANTE, Maris, "Un artista de hoy: Eduardo Kac en Cahctas", en Arte al Día News Mex, Año 3, N 27, Manifiestos, México, D.F., 2006, p. 6. Eduardo Kac fue invitado por Cahctas y Casa Vecina de la Fundación del Centro Histórico.

676 OHLENSCHLÄGER, Karin, "Eduardo Kac y la Interacción Arte Ciencia Vida" en Cuadernos del IVAM, $\mathrm{N}^{\circ} 10$, Valencia, 2007, pp. 44-57. 
Como decíamos, en el caso concreto de México, uno de los artistas que ha incursionado en la relación entre arte, Ciencia y Naturaleza es Daniel Rivera quien, además de artista visual, es miembro del laboratorio de Visualización Matemática de la UNAM y se ha especializado en la convergencia entre arte y Ciencia. Consideramos fundamental incluir en esta investigación sus propuestas por la injerencia directa que sus trabajos nos ofrecen en torno a la relación del mundo del arte con el vegetal.

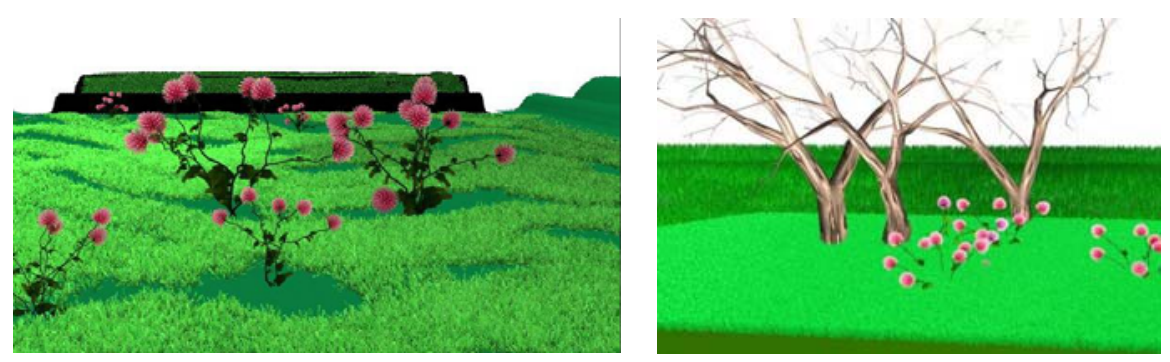

Daniel Rivera, Sin título, 2003.

Desde su primer proyecto El Jardín de las Delicias-El riesgo del arte (1999), Daniel Rivera trabaja con proyectos transgénicos. En este proyecto proponía la creación de geografías urbanas a partir de la reformulación de los espacios públicos ocupados por las zonas denominadas jardines. La historia del proyecto surge cuando a mediados del año 2000, el artista esboza la idea de reformular la jardinería pública en México, D.F., a partir del césped. Utilizando este elemento vegetal como materia prima y potenciado el sentido del olfato con olores a gardenia, acacia y jazmín, logra en coordinación con el Cinvestab677, generar con éxito, hierba fluorescente como parte de un proyecto artístico. La colaboración con científicos 678 como parte esencial del trabajo en algunos artistas es representativa del arte de hoy. Esta nueva forma de proceder implica un cambio sustancial en la forma tradicional de intervenir en la Naturaleza: "al dominar la estructura de la materia y los procesos de la vida, se borran definitivamente las fronteras que todavía se mantenían", entre el artificio y aquello verdaderamente natural, en lo que nuestra intervención no participaba:

Este giro implica un cambio sustancial [...] puesto que la apariencia de un vegetal transgénico o de una oveja clónica es idéntica a aquellos ejemplares en los que no se ha producido ninguna intervención de ingeniería genética. Se ha terminado de vencer lo que se podría calificar como "el reconocible estilo de lo artificial", fácilmente distinguible del "inconfundible aspecto de lo natural". Así, las últimas aparentes seguridades que todavía permanecían

677 Centro de Investigación y Estudios Avanzados. Laboratorio Nacional de Genómica para la Biodiversidad (LANGEBIO) de Guanajuato, México.

678 Daniel Rivera ha colaborado con científicos como Isaac Rudomín, Luis Herrera y Marissa Díaz. El trabajo realizado por Rivera pudo llevarse a cabo gracias a la aceptación, en uno de sus laboratorios, del Dr. Luis Herrera-Estrella, director del Cinvestav (Unidad Irapuato), quien realizó el primer reporte de transgénicos en plantas en la revista Nature, destacando especialmente sus trabajos en biología molecular de plantas. 
firmes, se van desmoronando ante una definitiva disolución de "Naturaleza" $y$ "artificio" como conceptos claramente diferenciados 679 .

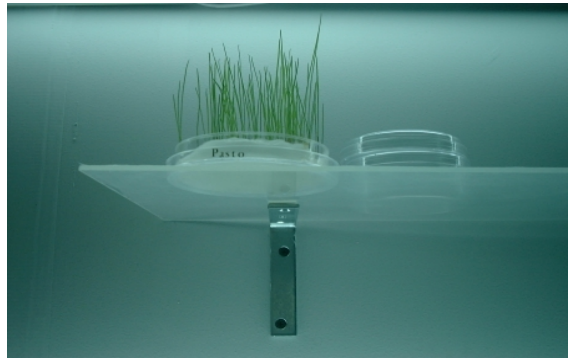

Daniel Rivera, El riesgo del arte, el arte del riesgo, 2000-2001.

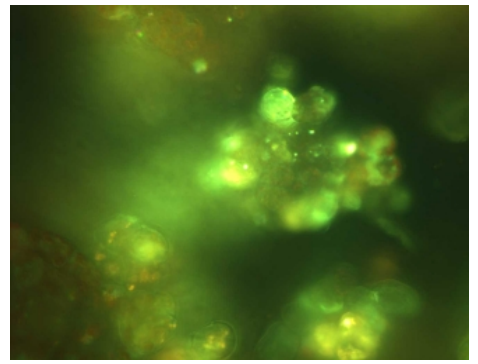

Daniel Rivera, Fotografía microscópica de los callos con la GFP, 2001.

En torno a esta temática, la exposición más importante realizada en México según Daniel Rivera, fue la de Arte Tecnológico, propuesta por Rafael LozanoHemmer y comisariada por Karin Ohlenschläger, en el extinto Museo de Monterrey entre noviembre de 1997 y febrero de 1998680. El artista, como creador o manipulador de vida, abre una de las polémicas más interesantes en torno al movimiento emergente conocido como Bioarte. Según M. Jesús Buxó Rey, quien nos ofrece las pautas para definir este nuevo movimiento, actualmente el Bioarte es:

[...] una práctica artística que implica la introducción de los artistas en el laboratorio con actuaciones dedicadas a la reproducción celular y reparación de células vivas. Como indica Jens Hauser (2003) el Bioarte no es un híbrido, es un término mutante proliferante que se propone transgredir los procedimientos de representación y metáfora mediante la manipulación de la vida misma681.

Superada la instancia representacional del arte, en esta nueva disciplina vinculada a los avances de la biotecnología y de la medicina, los modernos bioartistas son una simbiosis de científicos y artistas que trabajan generalmente en laboratorios, en colaboración con universidades y centros de investigación que contemplan el Bioarte como un instrumento muy útil de reflexión crítica, de trascendencia cívica y de interacción entre arte, sociedad, Ciencia e industria. El

679 ALBELDA, José y SABORIT, José, op. cit., p. 98.

680 DÍAZ INFANTE, Juan José, "Todavía, la magia. Los nuevos soportes, el arte, México, los independientes", en Revista virtual de arte contemporáneo y nuevas tendencias, 08/01/2009, Basado en un ensayo publicado en la Revista $A R C O$, por Juan José Díaz Infante, artista independiente y curador en Jefe de Transitio $m \times 3$, septiembre, 2003, México, D.F., Nueva edición, julio, 2009, Disponible en red $:<$ http://revista.escaner.cl /node/1441>, [Consulta 27, agosto, 2009].

681 BUXÓ REY, M. ${ }^{a}$ Jesús, "Pró/tesis del cuerpo: claves estéticas para una antropología androide y biónica", en CIRLOT, Lourdes (Coord.), Arte, Arquitectura y Sociedad Digital, Universitat de Barcelona, Barcelona, 2007, p. 21. 
origen del Bioarte tal como se entiende actualmente se remonta a los años treinta, cuando el fotógrafo y pintor de origen luxemburgués Edward Steichen 682 -quien postuló lo que hoy se conoce como Arte Transgénico- expuso en el Museo de Arte Moderno de Nueva York unas fotografías gigantes de plantas de jardín, que él mismo había alterado con semillas seleccionadas mediante productos químicos. El resultado de estos procesos fueron unas imágenes extrañas e innovadoras 683 .
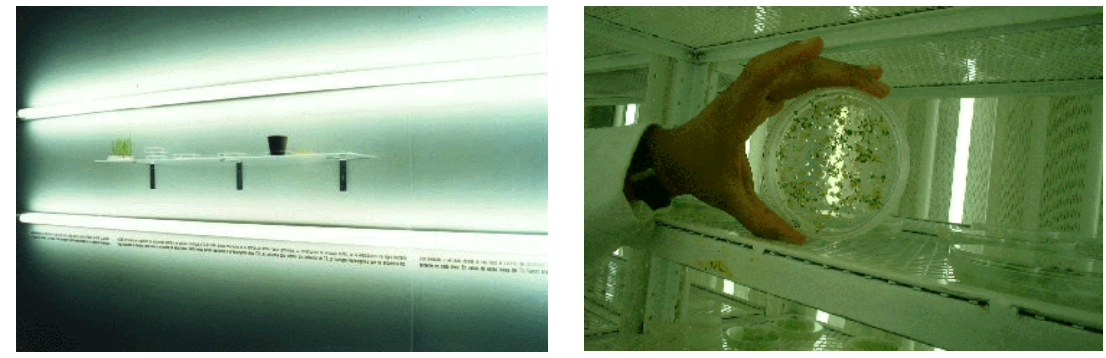

Daniel Rivera, El Jardín de las Delicias, 1998.

Frente a los descubrimientos y avances vertiginosos de la tecnología, el Bioarte se convierte en una herramienta para, si no predecir el futuro, acercarse a la experiencia de experimentarlo de una manera aproximada. En este contexto, la obra El jardín de las delicias (1998) de Daniel Rivera, exploraba la relación entre el arte y la biología molecular, proponiendo como proyecto a futuro, la generación de un pasto ornamental transgénico que al ser cortado oliera a jazmín. La pieza de Rivera, en referencia directa a la obra del fotógrafo Steichen, sugiere la recreación de geografías urbanas basadas en la hierba y en la reescritura del sentido del olfato. En su proyecto, Rivera retoma este sentido que según los recientes resultados de la biología evolucionista, ha estado minimizado por razones desconocidas. De esta forma, el artista genera un césped ornamental transgénico, factible de ser utilizado en diferentes entornos urbanos.

Relacionada con la obra de El Bosco684, la instalación recorre los paisajes - generados por la biología molecular-implicados hoy en la posibilidad real de transformar la Naturaleza de los seres vivos. El artista apela a la secuenciación de genomas, a la transgénesis o la clonación, como tecnologías paradigma, directamente comprometidas con el diseño de las especies convocando, a través

682 Según Rivera, Steichen pensó que el mundo de los seres vivos, especialmente el mundo de las plantas, podía ser transformado mediante la ingeniería, revelando de esta forma, que el acto estético podía estar comprometido con la generación de las formas naturales.

683 VAL, Eusebio, "La última revolución creativa. Llegan los artistas de laboratorio. El bioarte se hace un espacio usando bacterias y genes como expresión estética" en $L a$ Vanguardia, Madrid, 16, agosto, 2005, p. 26.

${ }^{684}$ Recreando la obra de El Bosco, el proyecto de Rivera, ofrece un resultado que redefine la noción de jardín y actualiza los parámetros de relación entre el humano y las especies vegetales involucradas en la ornamentación. 
de ellas, la participación irrevocable del arte. Mediante la presentación de una maqueta de lo que podrían ser los jardines futuros -tecnológicamente asistidos, científicamente controlados y artísticamente diseñados- y, más allá de la confluencia entre biotecnología, nanotecnología y realidad virtual, Rivera convoca a la re-escritura de las ciudades, de la arquitectura y de todas las especies (incluyendo la humana) como tarea imprescindible para el futuro:

El Jardín de las Delicias es un concepto-dispositivo que mapea las ciudades, apropiándose de las zonas verdes, para re-escribir los futuros jardines públicos. La lenta desaparición del olor industrial dará vía libre a la recuperación de las fragancias que han acompañado a los jardines desde su aparición en la cultura685.

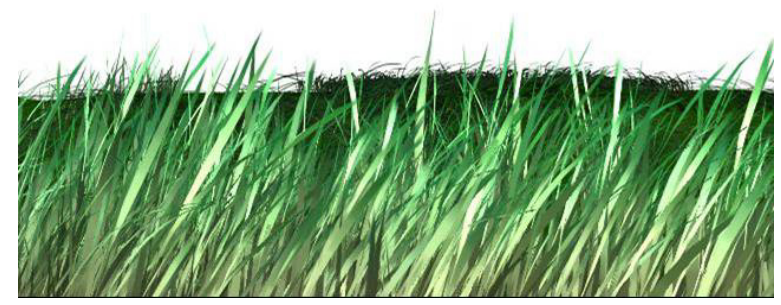

Daniel Rivera, Desarrollo infográfico del proyecto, 2003.

Según el artista, el mundo ha quedado sumergido en la convergencia entre el arte y la Ciencia, siendo la estética, en la sociedad actual, un requisito imprescindible para la vida productiva. Por otra parte, debemos tener en cuenta que la biología molecular es una de las disciplinas de la Ciencia que trabaja directamente con el azar y éste es a la vez, el algoritmo tradicionalmente usado por el arte. La transgénesis según Rivera, vendrá dada por la inserción en el proyecto, de genes de plantas que aporten fragancia, como por ejemplo, la magnolia, así como en la aportación de mejoras genéticas en el césped para que pueda soportar distintos niveles de estrés en las ciudades en donde se apliquen.
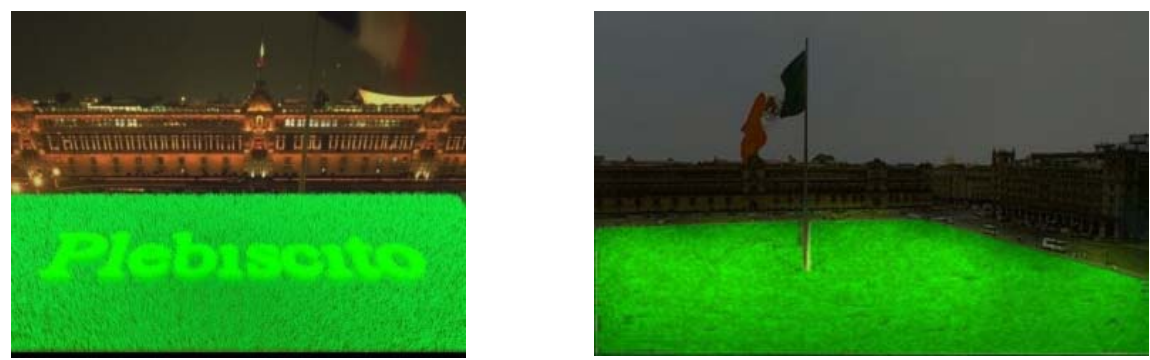

Daniel Rivera, Boceto-fotomontaje del Zócalo intervenido con pasto GFP, 2003.

La aplicación en su proyecto de las ciencias genómicas traslada el formato de investigación científica, al medio del arte tecnológico insertándose de esta

685 RIVERA, Daniel, "Naturaleza controlada", texto inédito en español, proporcionado por el artista a la autora de esta investigación, agosto, 2004. 
manera, en la cultura y el arte contemporáneo. El proyecto fue presentado en la Fototeca de Monterrey, bajo la curaduría de Juan José Díaz Infante y meses mas tarde, fue analizado en el Cinvestav (Departamento de Biotecnología e Ingeniería Genética de Plantas, Unidad de Irapuato, Guanajuato, México). La propuesta inicial tuvo que posponerse indefinidamente debido al escaso conocimiento genético del jazmín, y al estado de las investigaciones genómicas en rutas metabólicas de plantas. No fue hasta el año 2001 que comenzaría la transformación de una gramínea ornamental que ofrecía las condiciones necesarias 686 . El desarrollo biotecnológico fue gracias a la ingeniería genética ya que ésta ofrecía una posibilidad de transformación basada en la GFP (Proteína Verde Fosforescente).

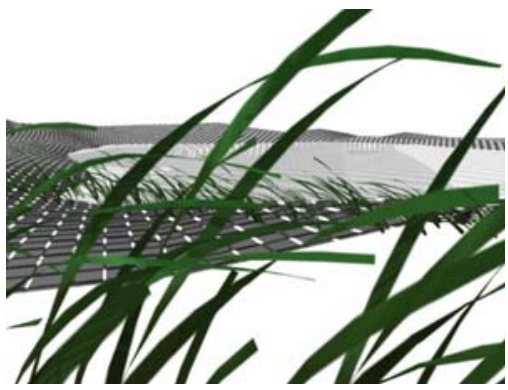

Daniel Rivera, Sin título, 2003.

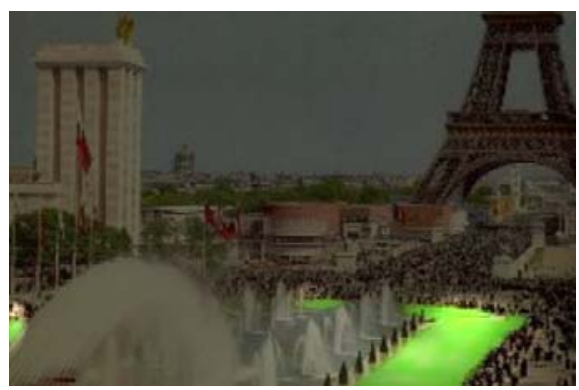

Daniel Rivera, Boceto-Fotomontaje del

Trocadero intervenido con pasto GFP, 2003.

Otro de los proyectos del artista, el denominado Planta-Chat (2003), apunta a la formulación de un sistema doméstico de comunicación que permita a las plantas informar sobre su situación, enviando directamente correos electrónicos, mediante un dispositivo instalado en su propia maceta, lo que favorecería tener constantemente monitoreada a la planta687.

686 RIVERA, Daniel, "Naturaleza Controlada", op. cit., En el texto, el artista explica el proceso llevado a cabo para obtener el gen fluorescente: 'La transformación genética del pasto se hizo tomando el cultivo de callos -o clonas-, un conjunto de células idénticas que se obtienen por inducción del germoplasma. Se utilizó la biobalística, una tecnología basada en el disparo de ADN sobre las células a transformar, en este caso las clonas del pasto. El bombardeo de helio se realiza en una pequeña cámara al vacío, siguiendo un estricto protocolo. El experimento consistió en insertar el gen GFP, junto al promotor 35S, que es parte de un gen del virus mosaic de la coliflor, y se encarga de expresar la GFP en toda la planta. El cultivo de los callos estuvo varios meses en un medio de kanamicina, un antibiótico que selecciona las células genéticamente modificadas. Las células fueron observadas en microscopio con un haz de luz ultravioleta cuya frecuencia nos permitió registrar la expresión de la GFP, como se puede apreciar en la imagen. Cabe resaltar que esta proteína es visible en verde, amarillo y azul, dependiendo de la frecuencia de luz ultravioleta".

687 RUDOMIN, Isaac et al., "Plant Lab: an AR plant laboratory for the typical home", en DE ITA LUNA, Guillermo et al., (eds.), Universidad Autónoma de Puebla, Cholula, noviembre, 2004, pp. 453-460. La cita, como indicamos a continuación, nos informa en torno a los detalles del proyecto: "Este mecanismo altera el PH del medio donde se encuentran, 
Planta-Chat explora la proxémica telemática de las plantas metaforizando los datos químicos involucrados en la comunicación. Establece que si aumentamos su mundo, mediante la relación humano/planta y planta/planta, podemos entrar en el mundo vegetal: los seres vivos más complicados que habitan el planeta688.
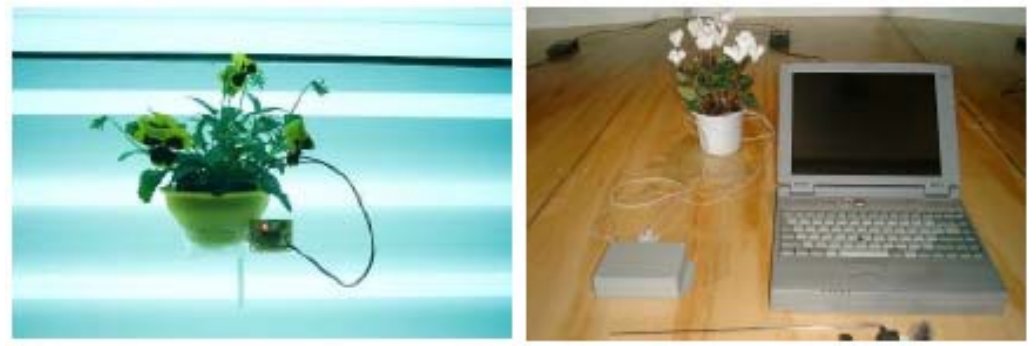

Daniel Rivera, Planta chat, 2003.

Rivera parte de que las plantas, utilizando el ácido salicílico, pueden comunicarse entre sí. Mediante la potencialidad de la expresión química se pueden inferir datos del comportamiento de las plantas mismas. Si bien a lo largo de la historia, el ser humano basándose en sentimientos de cercanía, ha experimentado algún tipo de comunicación con las plantas, lo cierto es que no ha hecho sino ignorar la realidad bioquímica de ese comportamiento. El sistema creado por Rivera, genera tanto una base de datos útil para el biólogo de plantas, como una forma amigable de compartir información científica con un amplio sector de la población que se encuentra muy distante de la Ciencia amas de casa o coleccionistas empíricos de plantas-con lo cual se diversifica el radio de acción del proyecto. La elección en particular por parte del artista del entorno del mundo vegetal para este tipo de piezas virtuales -donde se establece una comunicación con otros seres vivos- obedece a la condición primigenia de las plantas cuyos cloroplastos son las moléculas responsables de la producción del oxígeno, elemento sin el cual no podríamos vivir. La

permitiendo que su nivel se detecte y por lo tanto se capturen señales de comunicación. Este fenómeno lo hemos aumentado para darnos cuenta que es parte de una realidad virtual referenciada. La virtualidad es también una experiencia que puede ser imaginada sin ser vista, que puede ser oída sin la materialidad del sonido externo, pero que hoy puede ser implementada por una simple tecnología basada en alambres de cobre. El mecanismo utilizado para este desarrollo cuenta con dispositivos que automatizan el riego, desestresa las plantas conectadas al sistema, informa a los humanos sobre el estado en que se encuentran las plantas, y mediante señales electrónicas, establecen un "chat" que no es mas que un texto escrito a manera de diálogo activado por los sensores". 688 RIVERA Daniel y RUDOMIN, Isaac, "Naturaleza Aumentada. La ciencia es el arreglo ordenado que de momento, se parece a los hechos", texto inédito en español, proporcionado por el artista a la autora de esta investigación, agosto, 2004. 
experiencia de carácter artístico se enmarca en la posibilidad de ampliar tanto el conocimiento como las motivaciones de la percepción estética.

Tener un registro de la percepción durante el acto estético de contemplación y/o apreciación, abre un campo de investigación para determinar que factores podrían estar involucrados en la mecánica de la adaptación. Sobretodo para acercarse a los mecanismos de selección que tienen que ver porqué nos gustan unas cosas y otras no689.

La motivación de Rivera para utilizar la agricultura transgénica como contexto, surge con la idea de que nuestro tiempo está indefectiblemente marcado por el asentamiento de la misma en nuestras sociedades industrializadas. De cualquier forma, la agricultura en sí, es ya una actividad nociva para el medio ambiente, puesto que sustituye la diversidad por un determinado número de plantas. Asimismo, en opinión de Rivera, la jardinería y la estética selectiva en la que derivan, son también un arreglo social con el cual se sustituye el paisaje natural por un sistema controlado. El césped como elemento característico de estos sistemas, es la gramínea con mayor injerencia en un jardín. Habitualmente, constituye una figura "ecológicamente correcta", ya que simula una alfombra o un algoritmo altamente calificado por el establishment que, se exporta en el paquete democrático de las sociedades industrializadas del mundo. Al igual que en la actualidad nos parecería inconcebible una sociedad sin agricultura, sin el cultivo sistemático de alimentos; Rivera apunta que, de la misma manera, nuestras ciudades no podrían prescindir de los jardines públicos y privados a los que estamos visual y utilitariamente habituados.

Desde la perspectiva de la Bioética, cualquier transformación genética dentro de nuestra propia cadena alimenticia causa pánico, tanto en los circuitos ecologistas como en los políticos y financieros. Sin embargo es conocida y entendida por todos, como natural, la transformación y alteración genética que los humanos hemos ejercido desde los principios de la agricultura, sobre diferentes especies (maíz, soja, tomate, etc.). Así también, podemos afirmar que debido a la condición emergente de la Naturaleza, toda transformación hecha por humanos o por cualquier otra especie, estará siempre condicionada a fenómenos imposibles de predecir. En definitiva, tanto la humanidad como la Ciencia están pendientes de todo lo que tenga que ver con organismos genéticamente modificados puesto que éstos constituyen un excelente mercado para transnacionales agrícolas y ecologistas. Lo que aquí nos interesa, y éste es el punto en el que Rivera insiste, es que dentro del campo de las prácticas artísticas, la transferencia de genes de una especie a otra, sigue una ruta imaginaria trazada por la Cultura, pero una Cultura basada en las posibilidades del naturalismo, puesto que todo lo que va más allá nos causa temor.

Cabe añadir que una nueva geografía política se escribe con un gen como el de la GFP, que en nuestro caso, pudiera censar eventos como radiación ultravioleta, a veces causada por la contaminación de ozono; reportar armas 
químicas y fenómenos atmosféricos. Argumentos que podrían derrumbar cualquier conjetura ética en un momento dado. [...]. El arte transgénico, es un tipo de arte que se hace con la transferencia de material genético de una a otra especie, o con la implantación de un gen sintético, con el propósito de obtener seres comprometidos con expresiones de belleza. La creación está asociada a la idea de belleza [...] el arte biotecnológico se define como la ingeniería que garantiza el encadenamiento de resultados creativos en función de los sentidos y el entendimiento690.

Por un lado, una de las tareas políticas más importantes del arte biotecnológico debiera ser en opinión del artista, la de desmantelar la realidad montada específicamente por las transnacionales -enfocadas en el desarrollo de monocultivos- y por otro debería ser un requisito imprescindible en la planeación de las instituciones oficiales $\mathrm{y} / \mathrm{o}$ privadas que subvencionan las investigaciones genéticas y la creación de contenidos. La idea de Rivera de presentar una Naturaleza controlada parte de la forma en la que en la actualidad, se entiende el trabajo interdisciplinario entre la Ciencia y el mundo de la computación. Sus proyectos pretenden sintetizar el razonamiento demostrativo y -usando la imagen y la estética como herramientas- relacionar conceptos científicos para lograr descifrar la encriptada manera de la Ciencia de relacionarse con el mundo.

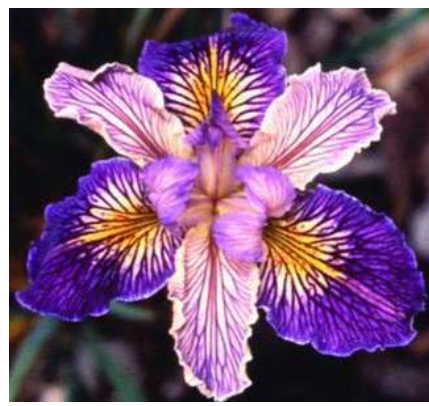

George Gessert, Flor Híbrida 703, 1992.

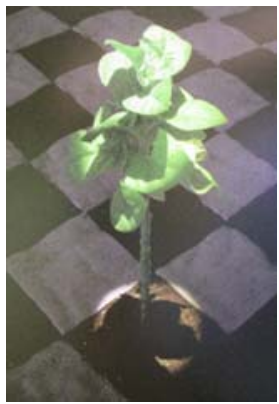

Eduardo Kac, Movimiento 36, 2002.

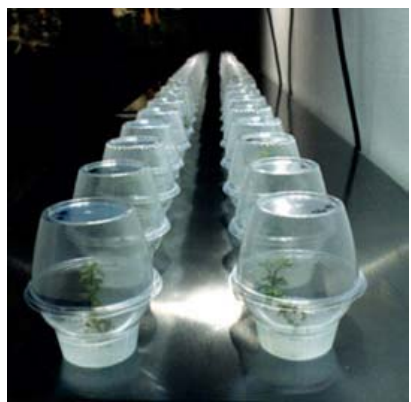

Natalie Jeremijenko, One Trees, 2000.

Las investigaciones artísticas y exposiciones realizadas en torno a esta temática son a estas alturas, numerosas. Encontramos ejemplos de trabajos similares en los experimentos sobre variaciones genéticas en organismos vegetales, del artista norteamericano George Gessert quien reivindica en su obra, la voluntad de mostrar la independencia del artista en estos campos, frente a las prácticas de cultivo y tendencias artísticas en el mercado. Su trabajo, que podría parecer puramente estético, evidencia la polémica contemporánea en cuanto a la manipulación de elementos vegetales y aporta una reflexión sobre la muerte, el tiempo y la utilización siniestra que se ha hecho de la genética durante el siglo XX691.

690 RIVERA Daniel y RUDOMIN, Isaac, "Naturaleza Aumentada...", op. cit.

691 PÉREZ LÓPEZ, Héctor Julio, op. cit., pp. 67-74. 
También destacan las investigaciones de la artista e ingeniera Natalie Jeremijenko cuyo proyecto One Trees (2000), es un experimento público en el que se plantaron pares de árboles genéticamente idénticos -clones-en diversos microclimas y contextos sociales del área de la bahía de San Francisco. Como los árboles son genéticamente idénticos, revelaban en su crecimiento, las diferencias sociales y ambientales a las cuales están expuestos. Otro artista Eduardo Kac, en su obra Move 36 (2002), reconstruye el movimiento hecho en 1997, por el ordenador Deep Blue contra el campeón mundial de ajedrez Gary Kasparov. La instalación presenta un tablero de ajedrez hecho de tierra y arena blanca, pero sin las piezas de ajedrez. Únicamente hay una planta cuyo genoma incorpora un nuevo gen creado por el artista, el ASCII692, con la idea de expresar en genética la máxima de Descartes: Cogito ergo sum (pienso, luego existo). Con la modificación genética, las hojas de las plantas ofrecen rugosidades, causadas por el gen Cartesiano, de modo que el público pueda ver a simple vista los efectos del gen693.

Como vemos, las interferencias entre Ciencia y arte no son cosas de ciencia ficción. Conviene aquí recordar que anteriormente situaciones similares llevaron a los teóricos a conjeturar sobre el poder y las técnicas de manipulación de los medios de masas. Si ahora las reflexiones son en torno a cuestiones éticas respecto a nuestra injerencia en los procesos entendidos como naturales, no podemos esperar sino que las cosas sigan, de nuevo, su curso, puesto que la investigación humana no tiende a detenerse:

Durante los años treinta Orwell, Mann, Adorno, Benjamin y otros veían en el desarrollo de los grandes medios de comunicación (de Formación) de Masas, técnicas temibles para dominar e imponer el pensamiento administrado. Con Un mundo feliz, Huxley conjeturó el modo en que desde la cuna es posible domesticar a los niños, superponiendo a lo innato 10 mediáticamente adquirido. Actualmente, estas obras proféticas siguen leyéndose como literatura fantástica, como ciencia ficción. Mientras tanto, las profecías se han quedado cortas: la biogenética, la manipulación de genes, se va desarrollando (no sin resistencia) como un método infalible para la normalización y homologación de los futuros ciudadanos, desde antes de su nacimiento. Nuevas dimensiones o extensiones mediáticas no del cuerpo, sino de la propia vida, antes del nacimiento: la naturaleza mediatizada del surgimiento de la vida694.

Estamos viendo cómo en arte contemporáneo, la relación entre la vida humana y la vegetal se estrecha trazando, mediante el conocimiento científico, un recorrido que fluye más allá de la representación e incluso de la presentación de

\footnotetext{
692 Código informático universal para representar números binarios como caracteres romanos.

693 Véase AA. VV., Eduardo Kac, IVAM Institut Valencià d'Art Modern, Valencia, 2007. La obra fue expuesta en Valencia en una exposición sobre el artista.

${ }^{694}$ ALBELDA, José y SABORIT, José, op. cit., p.199.
} 
organismos vivos. La retórica y sus tropos, se reinventan también a través de las nuevas formulaciones entre arte, Naturaleza y Ciencia. En este panorama de artistas que trabajan en México con materiales y conceptos asociados a aquellos procesos relacionados con lo natural-vegetal, encontramos también la obra de otro artista que fundamenta su trabajo en sus conocimientos científicos.

Eduardo Rincón (Cuernavaca, Morelos, 1964) es un artista y biólogo, tanto de formación como de profesión, que ha encontrado la manera de hacer germinar el paisaje para hacérnoslo llegar de nuevo, real y físicamente, haciendo patente, mediante su trabajo y su obra, la dialéctica entre lo natural y lo artificial. Como apunta Francisco Hinojosa, el arte "se relaciona aquí con la naturaleza, ya no como modelo a reproducir en un paisaje" 695 sino como un proceso que refleja la complejidad de la misma y en donde cada semilla es un cosmos, un espejo a descifrar con el cual, el artista nos invita a hacer un viaje, semilla adentro, del aparente caos al que nos enfrentamos. Dentro del marco de una filosofía de la Naturaleza y en la alquimia de recuperación de los ecosistemas locales propios de la zona en donde vive (Morelos), Rincón ha generado un prototipo de arte ecológico con fuertes raíces en la recuperación de "lo público".

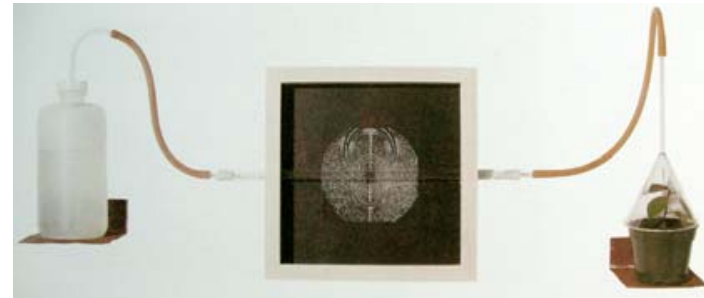

Eduardo Rincón, Spagyria $N^{\circ} 13,2001$.

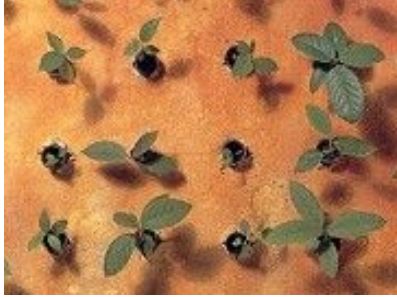

Eduardo Rincón, Stela Natura, 2002.

El artista identifica la Naturaleza, en particular la que encarna el reino vegetal, con el conjunto de la realidad objetiva, a manera de principio vital que entraña una "experiencia polimorfa traducida en la invención de las imágenes"696. Su universo, caracterizado por una investigación sobre la topografía específica del lugar, sea éste bosque, selva o jardín y la recurrencia a los cuerpos que ahí habitan: árbol, planta, fruto o semilla, se convierte en un ámbito capaz de expresar la metamorfosis primordial del universo. Siendo como es la ecología en México, un tema acallado por las políticas en curso que enmascaran una actuación flexible y sin planteamientos radicales, su forma de trabajar es un llamado a la recuperación de una riqueza natural que no por exuberante, deja de estar en peligro de extinción. Sus logros y planteamientos van más allá de la generalizada utilización de materiales naturales como materia prima de sus

695 HINOJOSA, Francisco, "Semilla adentro", en AA. VV., Eduardo Rincón. Via Sativa, Casa Lamm, Centro de Cultura, México, 2004, pp. 3-4.

696 ECHEVERRÍA, Adolfo, "Musa paradisíaca", en AA. VV., Eduardo Rincón. Musa paradisíaca, Casa Lamm, México, 2006, pp.4-5. 
instalaciones. Bajo esta clara vertiente ecológica se hace patente una crítica social a las políticas de devastación.

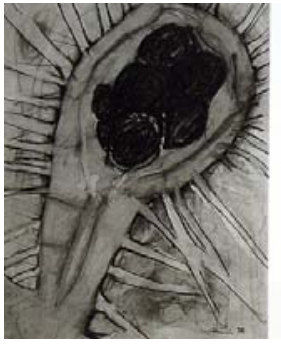

I, II y III Serie Unión, 1998.

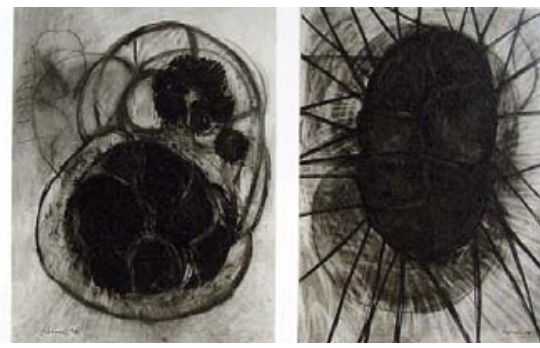

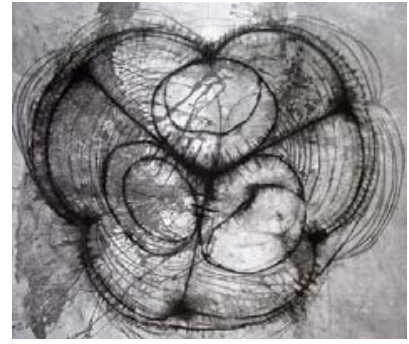

Eduardo Rincón, IV Serie Dos, 1998.

La importancia del Land Art, el Arte Povera o el Arte Procesual influyen en su obra, pero más allá del empleo del elemento simbólico y, rozando con cuestiones históricas, políticas, antropológicas y sociológicas, sus obras plantean -como diría el poeta Octavio Paz- un programa de vida. Para Octavio Paz, la Naturaleza es:

[...] ese conjunto de objetos y procesos que nos rodea y que, alternativamente, nos engendra y nos devora- no es nuestro cómplice ni nuestro confidente. No es lícito proyectar nuestros sentimientos en las cosas ni atribuirles nuestras sensaciones o pasiones. ¿Tampoco lo será ver en ellas una guía, una doctrina de vida? Aprender el arte de la inmovilidad en la agitación del torbellino, aprender a quedarse quieto y a ser transparente como esa luz fija en medio de los ramajes frenéticos - puede ser un programa de vida697.

De la misma manera, en la obra de Rincón, las fronteras entre obra y vida constituyen un programa de vida en el que el recurso del naturalismo se confronta con el método científico: el artista encuentra y desarrolla un modo de cultivar in vitro una determinada especie de árbol autóctona, el conocido amate amarillo698. No nos encontramos ante un mago ilusionista o un chamán misterioso que nos muestra aquello que desconocemos, sino frente a un científico biólogo que conoce la materia sobre la cual trabaja, desarrollando nuevos procedimientos para acercarnos a aquello que con su método, pone al alcance de nuestras manos. Un arte que podría parecer producto de un impulso

697 PAZ, Octavio, en ALBELDA, José y SABORIT, José, op. cit., p. 28.

698 Los amates son árboles, pertenecientes al género Ficus que, al hacer cortes en sus ramas, hojas, corteza o frutos derraman un líquido lechoso. En el mundo hay cerca de 750 especies, de las cuales veinticinco son nativas de México. Tienen un crecimiento muy peculiar, ya que se desarrollan sobre piedras o sobre otros árboles, a los cuales eventualmente estrangulan y matan a medida que ensanchan sus raíces. El papel amate es una tecnología muy importante en la cultura mexicana que fue desarrollada por los pueblos prehispánicos. Del amate Ficus petiolaris, extraían la corteza para, tras varios procesos, elaborar el papel con el cual se escribían los códices. 
romántico y contrario a lo tecnológico, aparece así íntimamente ligado a las más sofisticadas manifestaciones de la Ciencia y la tecnología.

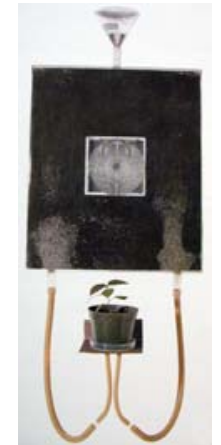

Eduardo Rincón, Spagyria $N^{\circ} 11,2001$.

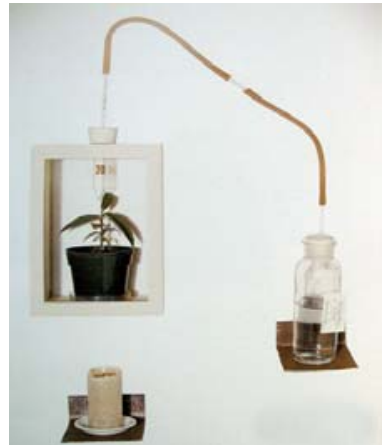

Eduardo Rincón, Spagyria $N^{\circ} 12,2001$.

Eduardo Rincón inicia su educación formal dentro de la Ciencia, trabajando en la investigación de plantas tropicales. En 1992 comienza a exponer artísticamente dejando la biología tradicional para dedicarse de lleno al estudio de la Naturaleza a través del trabajo plástico. En los últimos años ha hecho confluir los resultados de sus investigaciones sobre plantas en propuestas de instalación y escultura en las que compagina las disciplinas de las que se ha nutrido. Incursionado en el conocimiento arqueológico e histórico del árbol del amate, realizó una serie de proyectos en los que relaciona los conocimientos antiguos sobre este árbol, con los descubrimientos obtenidos en sus estudios sobre biología.

Históricamente, los pueblos tlahuicas699 pagaban anualmente a sus dominadores los aztecas, un tributo de cuarenta y seis mil rollos de papel de la corteza de este árbol. De esta información brindada por los cronistas del Virreinato, se puede deducir la presencia abundante de estos árboles en el valle de Tepoztlán y en general, en todo el estado de Morelos700. En la actualidad los amates, característicos por su color amarillo y por la belleza inusitada y sugerente de sus raíces, se encuentran con cierta dificultad. Presentan raíces expuestas al aire que crecen sobre rocas en las que se enraízan, mismas que sugieren con sus formas entrelazadas y sinuosas, fantásticas formaciones que nos recuerdan siluetas humanas abrazadas en posiciones sensuales. En el paisaje característico de esta zona, en las barrancas o suspendidos de las rocas, se pueden encontrar ejemplares que son bien conocidos por los habitantes del

699 Los tlahuicas fueron uno de los grupos aztecas que habitaban el centro de México antes de la llegada de los españoles (específicamente el área conocida actualmente como Estado de Morelos).

700 RINCÓN, Eduardo, Amate, Eduardo Rincón, Museo y Centro de Documentación histórica del Ex-Convento de Tepoztlán, Morelos. Proyecto realizado y editado con el apoyo del Fondo Estatal para la Cultura y las Artes de Morelos, el Instituto de Cultura de Morelos y el Fondo Nacional para la Cultura y las Artes, México, D.F., 2001. 
lugar quienes conocen sus diferentes nombres y especies. También se les otorga valores curativos, emblemáticos e históricos, siendo objeto de veneración en las plazas de los pueblos.
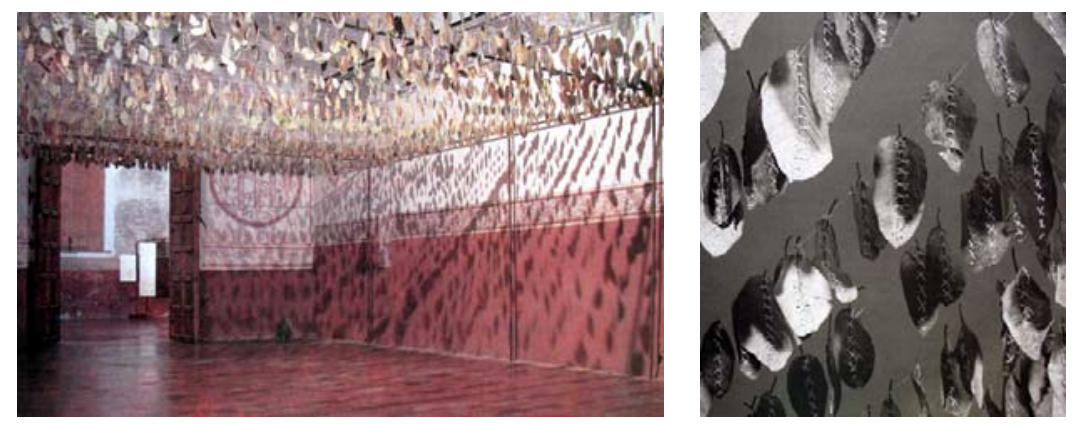

Eduardo Rincón, Sin título, 2001.

Así, los amates que encontramos en diferentes tipos de terrenos, creciendo sobre las copas o troncos de otras plantas, las rocas o las orillas de los ríos, juegan un papel fundamental en el entorno, no sólo por su belleza sino fundamentalmente porque sus frutos alimentan a miles de especies. Gran parte de la obra de Eduardo Rincón, siguiendo las tradiciones de la mitología universal, cuya simbología se expresa frecuentemente en la vida vegetal, recoge la importancia emblemática del amate y se basa en la dualidad árbol-vida. El amate, al que le confiere la calidad de representante del mundo natural, es el eje de su trabajo. La experiencia de vivir en un entorno natural, rodeado de la vegetación exuberante característica de la zona de Morelos y, que parte de su trabajo sean las mismas plantas, influye de manera decisiva en toda su obra.

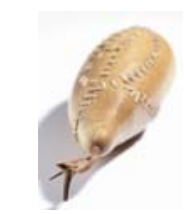

Eduardo Rincón, Semilla / e hilo, 2001.

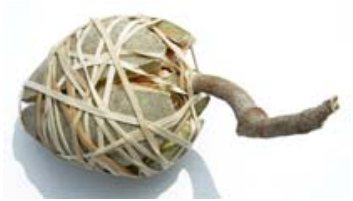

Eduardo Rincón, Semilla // con elásticos, 2001.

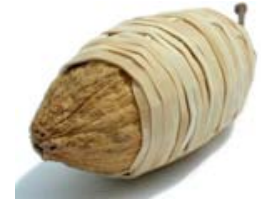

Eduardo Rincón, Semilla III con elásticos, 2001.

Una de las características más importantes de estas plantas para Eduardo Rincón y sobre la que ha fundamentado el proceso de su obra sobre los amates, es su fruto o higo, porque en él ha encontrado la posibilidad de reproducir estos árboles y hacer posible una reforestación de los mismos. En realidad este fruto más o menos esférico y casi completamente cerrado, es un conjunto de muchos frutos. En su interior se encuentran flores diminutas, masculinas y femeninas. Estas últimas producen después de la polinización, semillas muy pequeñas.

Debido a la particular característica de su "fruto" casi cerrado requieren, para la polinización de sus flores femeninas y la consecuente producción de 
semillas, de la actividad de avispas muy pequeñas [...] para entrar al higo, lo hacen a través de una pequeña abertura localizada en su ápice [...]7or.

Estas observaciones propiciaron que Eduardo Rincón en su laboratorio de arbolaria, encontrara la manera de detener la extinción de estos árboles. Y no sólo de detenerla, sino de conseguir - cosa que no se había hecho anteriormente- reproducirlos mediante el cultivo en vitro. Rincón ha subsanado la dificultad para reproducir el amate, recolectando los higos maduros del árbol, mezclándolos con agua y moliéndolos. Después de una serie de laboriosos procesos -entre los que se encuentran el realizar una especie de mermelada, colar la pulpa y provocar que las semillas se separen de la misma, hasta conseguir por fricción y erosión quitarle a la semilla una delgada capa que la cubre y que impide su germinación- la semilla puede ser secada al sol y guardada para ser almacenada.

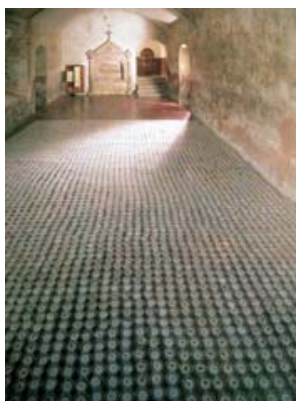

Eduardo Rincón, Germinación, 2001.

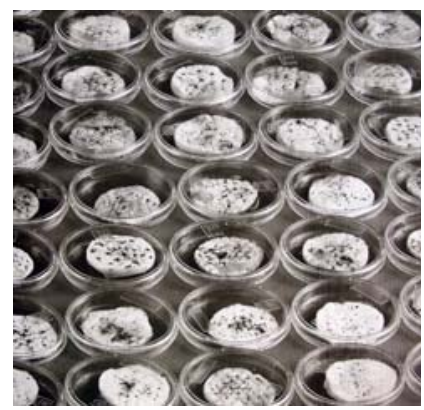

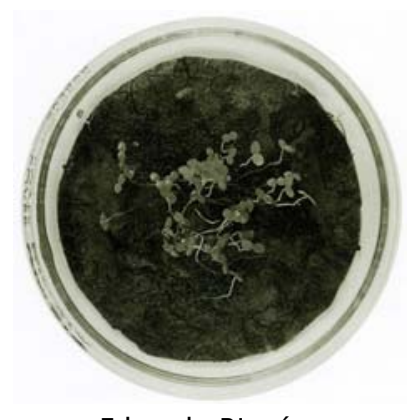

Eduardo Rincón, Caja de Petri, 2001.

Posteriormente podrá sembrarse directamente o hacerla germinar en tierra fina o sobre algodón muy húmedo en bolsas de plástico o cajas de Petri. Utilizando un modo místico de conocimiento, Rincón consigue fundirse con el objeto estudiado702 y a la vez, a la manera de un alquimista, recuperar el alma de las plantas para después de haberlas analizado minuciosamente, reconstruirlas mediante el método científico. La vida natural transcurre en casi toda la obra del artista, de forma que en cada visita al campo, encuentra los materiales necesarios para seguir formando el programa de su vida:

Eduardo Rincón deduce el tiempo vegetal del amate, como una manera de recomenzar otra historia, la suya, y se adueña de una pequeña parte del árbol: a veces de una hoja, otras de una semilla. Partes con las que va tejiendo la urdimbre de su obra. Es decir, su tentativa es repetir lo que la tierra otorga: renovación y regeneración ${ }^{703 .}$

\footnotetext{
701 RINCÓN, Eduardo, Amate, Eduardo Rincón..., op. cit. p. 29.

702 ISAAC, Claudio, "La partitura secreta", en AA. VV., Eduardo Rincón, Donde se origina el arte en el aire centro de arte, México, 2001, pp. 3-4.

703 BARANDA, María, “Amate, de Eduardo Rincón”, en La Jornada Morelos, 18, febrero, 2001.
} 

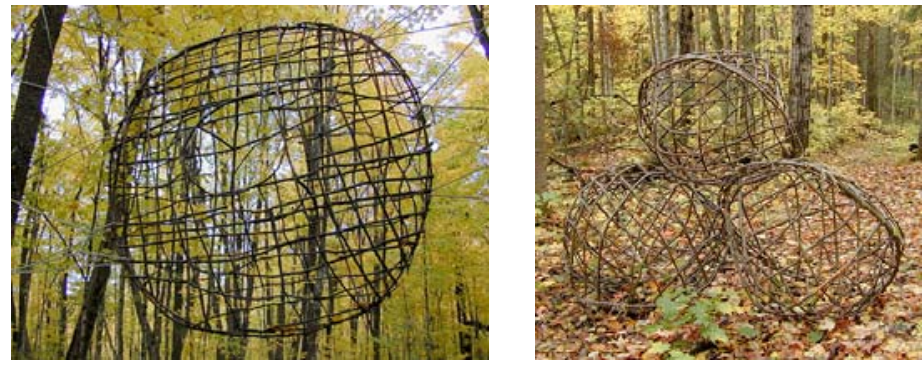

Eduardo Rincón, Sin título, 2000.

En función del tiempo habitado por el tiempo, de la semilla como contenedora del ser, fecundidad y germinación son palabras que determinan su trabajo. De forma ritual, recoge minuciosamente cada episodio de la vida vegetal para restablecer una dialéctica de contrarios entre lo natural y el artificio: hojas y cajas, semillas e hilos, frutos y tintas se entremezclan para recomponer el paisaje fracturado, y de esta forma volvernos a situar en la línea en la que se perdió la conexión.

\subsection{E mensaje de los materiales. Paola de Anda y Gustavo Gómez Brechtel}

La presencia de organismos vivos utilizados como material artístico es común en la obra de numerosos artistas contemporáneos. La característica fundamental en este tipo de piezas es que en ellas convergen los procesos naturales propios de los organismos vivos, junto con las condiciones predispuestas por el artista para la recreación de, en algunos casos, pequeños ecosistemas regidos por el mismo azar de la Naturaleza. La recreación de estas condiciones pone de manifiesto de forma más evidente, la contraposición entre el mundo natural y el mundo creado por el hombre. Este tipo de prácticas, obligan tanto a una redefinición de la obra de arte, como del proceso artístico que plantea ahora, un desarrollo fenomenológico de la creación artística. A mediados del siglo pasado, Maurice Merleau-Ponty define la fenomenología como:

[...] el estudio de las esencias y, según ella, todos los problemas se resuelven en la definición de esencias: la esencia de la percepción, la esencia de la conciencia, [...]. Pero la fenomenología es asimismo una filosofía que re-sitúa las esencias dentro de la existencia y no cree que pueda comprenderse al hombre y al mundo más que a partir de su fisicidad704.

Por lo tanto, es una forma de pensar el mundo como lo que "está ahí" como una presencia inajenable, el mundo como facticidad. Su aportación fundamental

704 MERLEAU-PONTY, Maurice, Fenomenología de la percepción, Península, Barcelona, 2000, p. 7. 
consiste en la "compresión de las naturalezas verdaderas e inmutables"705. Los materiales obligan a pensar la obra de determinada manera, en función de sus propias características. Así, algo importante a tener en cuenta en esta variante de productos artísticos, es que los materiales naturales hablan por sí mismos de forma que las obras adquieren una doble capacidad de resignificación semántica, anteriormente atribuida únicamente a la acción del artista. Todo ello obliga asimismo al espectador a cuestionar su propia presencia frente a este nuevo lenguaje artístico. Así, el objeto artístico deja de ser un mero elemento de contemplación, para formar parte de un arte capaz de transmitir un mensaje con múltiples resonancias, proponiendo al espectador una reflexión filosófica en torno a su propia existencia tanto como ser individual, social y como individuo insertado en un determinado espacio físico y conceptual.

Hemos visto cómo en gran parte, los proyectos concebidos mediante el uso de elementos vegetales para la representación de la Naturaleza, se constituyen como una metáfora del proyecto social de nuestras sociedades contemporáneas, cuestionando la viabilidad de nuestros sistemas de valores. Los resultados obtenidos se configuran como elaboraciones que evidencian la fragilidad tanto del sistema social como de nuestra actual relación con el medio natural. La reivindicación fundamental que se argumenta en este tipo de trabajos tiene que ver con la idea de la obra de arte como un proceso que se relaciona con el carácter cambiante de la Naturaleza. Estas obras, aludiendo a Merleau-Ponty, cuestionan la pérdida de relación con la fisicidad de las cosas y con todo aquello que nos rodea, así como las consecuencias de nuestras acciones, replanteando nuestra propia presencia en el mundo como humanos y haciendo tangible la conexión con el entorno. En realidad, no es tanto la preocupación por transmitir un mensaje ecológico específico, como el hacer perceptibles los lazos entre el hombre y los procesos de la Naturaleza.

La idea de no separar ni segregar la Naturaleza de la actividad humana implica un arte cuyo lenguaje integra los procesos vivos de la misma en el propio objeto del arte, a modo de considerar ésta como algo endémico y no separado de nosotros. El sentimiento de formar parte de la Naturaleza, de vivir en ella, ilustra el compromiso de estos artistas de convertir su actividad artística en un reflejo de la misma, un actuar conforme a sus leyes como algo obvio y necesario para sobrevivir. El interés en los materiales orgánicos y en los ciclos vitales de la Naturaleza está asociado a la observación de los procesos cambiantes e inestables de la Naturaleza.

A diferencia del arte realizado en un entorno natural, las piezas de este tipo que se exponen en espacios artísticos, implican una especial fragilidad de montaje. El artista se torna un mediador de las acciones que regularmente se han de llevar a cabo para conservar las piezas. Esto implica además un intercambio mutuo, la reflexión sobre el trabajo y los cuidados efectuados sobre la obra en proceso, repercuten en la resolución de los objetivos propuestos. La idea de utilizar la Naturaleza como punto de partida, en el proceso creativo, conlleva 
también la preocupación por la previsión de las condiciones y los elementos medioambientales necesarios: nutrientes, agua, luz, materia viva y todos aquellos cuidados específicos que requieren las obras instaladas fuera de su contexto natural.

John K. Grande describe en entrevistas realizadas directamente, los planteamientos que han desarrollado artistas de diferentes nacionalidades en torno al tema de Arte y Naturaleza, algunos de ellos vinculados a procesos semicientíficos o tecnológicos. La diferencia con respecto a las iniciativas artísticas basadas en el Land Art es que sus proyectos suponen como característica, rediseñar lo construido en nuestros entornos urbanos mediante la integración de la Naturaleza. La mayoría de los artistas que cita en su investigación como David Nash, Patrick Dougherty's, Bruni Babarit, Jerilea Zempel, Alfio Bonanno, Doug Buis, Michael Singer, Bob Verschueren, Nils-Udo, Alan Sonfist, Reinhard Reitzenstein, Mike MacDonald y Herman de Vries, utilizan el elemento vegetal para introducirnos en una especie de laboratorio vivo en el que se deja que las esculturas medioambientales entren en el proceso cotidiano de la vida.

En el panorama actual del arte contemporáneo, estas prácticas se inscriben dentro de las mismas transformaciones que han impuesto sobre las nuevas definiciones del arte y la producción artística de los últimos años tanto en México como en el mundo. En un principio, Marchán Fiz relaciona este tipo de prácticas con el Arte Povera, basándose en la utilización de materiales humildes y en el sentido del intento de restablecimiento de las relaciones arte-vida con el objeto de reinstaurar la unidad del hombre, más allá de los sistemas basados en el consumo y el desarrollo tecnológico. Desde el punto de vista sintáctico el empleo del material como protagonista principal de las obras es común en este tipo de piezas, recordemos que, en el caso que nos ocupa, es todo lo vinculado con el mundo vegetal lo que consideramos como material. Hay que tener en cuenta que en estas obras también es relevante la posibilidad de revalorización que los materiales ofrecen por sí mismos, subrayando el poder energético de éstos y su potencialidad transformadora -en cuanto a los cambios que se producen en su apariencia- y sin que medie la intervención del artista. Ya hemos apuntado en ejemplos anteriores cómo el artista se alía con el biólogo o el ecólogo, para acercarse al mundo natural a través del conocimiento científico y redescubrirlo en algunas de sus potencialidades físicas y energéticas, investigando el crecimiento vegetal, las reacciones químicas y físicas o las propiedades de los materiales. Marchán Fiz señala cómo el carácter energético de la materia natural da lugar a un arte simbiótico que surge en la necesidad de evidenciar los modos de manifestarse de cada elemento: "Tanto en las obras como en los testimonios se afirma el carácter energético y activo de los materiales"706.

En este sentido es importante considerar el componente azaroso y de indeterminación que las piezas pueden llegar a adquirir, como un aspecto 
fundamental de la existencia de las mismas. En el Ilamado arte ecológico707, precisamente es este aspecto procesual el que más destaca, en el sentido de que es un tipo de arte que se relaciona con los procesos vitales y la transformación de energía, evidenciando las relaciones entre las comunidades de plantas, animales y de la Naturaleza inanimada. Marchán Fiz utiliza esta denominación para calificar a algunas manifestaciones americanas del arte que acentúan el carácter procesual de las piezas de manera más contundente que en el Arte Povera europeo. La noción de simbiosis, integrada por los procesos y transformaciones en el tiempo, tendría su origen en las acciones de Hans Haacke (1936) y en sus sistemas biológicos, físicos y sociales. En 1965 Haacke escribía que entre sus planteamientos se encontraba la idea de crear algo que experimentara y reaccionara con su ambiente y cuya forma no pudiera predecirse con exactitud: "hacer algo que reacciona a los cambios de luz y temperatura, está sujeto a las corrientes de aire y depende en su funcionamiento de las fuerzas de la gravedad"708. Hans Haacke emplearía y construiría en un principio estos sistemas naturales o tecnológicos afectados por los cambios en el ambiente, aunque posteriormente se dedicaría a presentar trastornos ecológicos, sociales y políticos.

Desde el punto de vista semántico, los significados en este tipo de obras vienen dados no por una iconografía en particular ni por su narratividad, sino por la noción misma de obra en proceso, desplegándose en cada una de las secuencias del mismo, una heterogeneidad de contenidos. Como obras en proceso ofrecen asimismo una lectura procesual que cambia con cada una de las posibles presentaciones. Pero conviene no perder de vista las connotaciones simbólicas que, de cualquier manera, ofrecen estas piezas procesuales que no manifiestan una interpretación lineal y que valoran el proceso, por encima del producto final o la obra de arte como un objeto acabado. En este sentido, estas manifestaciones artísticas se insertan en la tendencia a concebir la obra de arte no como un fin en sí mismo, sino como una herramienta capaz de concienciar al espectador sobre la situación estética, social o ambiental de las cosas, provocando con ello reflexiones o tendiendo a desenmascarar situaciones que provoquen una toma de postura crítica ante las situaciones actuales que generan las sociedades desarrolladas.

Todos estos procesos creativos inciden en un cambio de la percepción artística, en situar la experiencia creativa como proclive a ser desencadenada en todo tipo de situaciones y con los medios más insignificantes. La forma de representación

\footnotetext{
707 Marchán Fiz sitúa la primera exposición de arte ecológico (Ecological Art) en 1969 en la Galería Gibson de Nueva York, en donde participarían André, Christo, Dibbets, Hutchinson, Insley, Long, R. Morris, Oldenburg, Oppenheim y Smithson. Hans Haacke es una de sus figuras más destacadas. Su resonancia ha llegado incluso en la actualidad a diversos países, asociándose generalmente a temas ricos en connotaciones sociales como la polución, la superpoblación o la supervivencia. Véase MARCHÁN FIZ, Simón, op. cit., p. 213.
}

708 HAACKE, Hans, en LIPPARD, Lucy, Six years, The desmaterialization of the art objet, en MARCHÁN FIZ, Simón, op. cit., p. 214. 
cambia porque cambia la visión del mundo, el artista así crea y recrea un nuevo sistema espacio-temporal, fruto de la nueva visión del mundo.

Las conexiones entre Arte y Naturaleza que podemos observar en la actualidad, derivadas del Arte Povera, del Land Art y del Arte Ecológico de los primeros tiempos, con sus posteriores desarrollos, se encuentran alejadas de las reivindicaciones del lugar como campo de acción, concretándose más bien en presentaciones de procesos que acentúan determinados aspectos vitales relacionados con el ser humano. Ante el uso de ciertos materiales y la importancia de la presentación de los mismos, volvemos a la frontera que sitúa a la obra lejos de la representación, desplazando la percepción del objeto artístico como entidad cerrada en sus propios significados, hacia el objeto de arte como indicador de problemáticas definidas. Las estrategias estilísticas diferentes cambian la forma de la representación.

La obra de arte se presenta así como la mediadora privilegiada entre la mirada y el mundo externo, de donde se derivan diversas estrategias de interpretación que intentan descifrar de un modo $u$ otro las motivaciones que originan estos cambios de visión 709 .

Podemos así encontrar artistas que utilizan como estrategia preferida el desencadenamiento de acciones o situaciones relacionadas con la estética procesual y con las formas efímeras del arte, obras que privilegian el aspecto temporal del arte en la medida en que se trata de intenciones que subrayan la fluidez de lo efímero. Los cambios producidos en este sentido pueden verse materializados ya no necesariamente en entornos naturales, parques o jardines públicos sino que el trabajo con organismos vivos y plantas en concreto, se ha insertado en muchos otros campos de la Cultura. En torno a la concepción de lo efímero en el arte, José Fernández Arenas define el arte efímero como:

El arte efímero es el resultado de una serie de técnicas que, más que fabricar objetos, genera producciones; su valor, como obra reside precisamente en ser consumido, literalmente, en una experiencia comunicativa que agota la obra. Y el arte de relación es per se, paradigma de lo efímero y, en última instancia, efímero él mismo. No existen en él experiencias inmutables, porque sus significados cambian con el tiempo 710.

Fernández Arenas señala $-y$ a todos nos consta- que en la historia de la Humanidad, este tipo de prácticas, como podemos observar en multitud de culturas, no son ni tan nuevas ni tan extravagantes, si bien, no formaban parte del ámbito artístico. Pensemos en las enormes piedras desplazadas por la antigua civilización de los olmecas -que podemos observar en el sitio de la Venta (Veracruz)- para realizar las ofrendas que posteriormente eran enterradas, a veces sin que nadie las viera; las pinturas de arena de los indios

709 BENÍTEZ DUEÑAS, Issa M. a , "Del arte contemporáneo y sus territorios: artistas nómadas y arte in situ", en BENÍTEZ DUEÑAS, Issa M. ${ }^{a}$ (Coord.), op. cit., p. 218.

710 FERNÁNDEZ ARENAS, José, op. cit., p. 34. 
navajos, hechas para que se las lleve el viento o sin ir más lejos, los juegos pirotécnicos, las fallas de Valencia o las alfombras de flores que se realizan durante las procesiones religiosas tanto en España como en otros países.

Por otra parte, también ha influido la percepción del arte ambiental que ha entrado en el entorno urbano y se ha involucrado en edificios tanto públicos como privados. Así, el arquitecto y botánico francés Patrick Blanc por ejemplo, ha diseñado muros vegetales con un sistema patentado con el que -aunando tecnologías específicas y plantas ligeras- cubre las fachadas de los edificios $u$ otros espacios arquitectónicos. Sus jardines verticales o muros vegetales como el del Museo Quai de Branly (París) o el de Caixa Forum (Madrid) tejen un entramado hecho con materiales tanto artificiales como naturales que permite a las plantas crecer en forma vertical, obteniendo sus nutrientes mediante un sistema inventado por el mismo arquitecto.
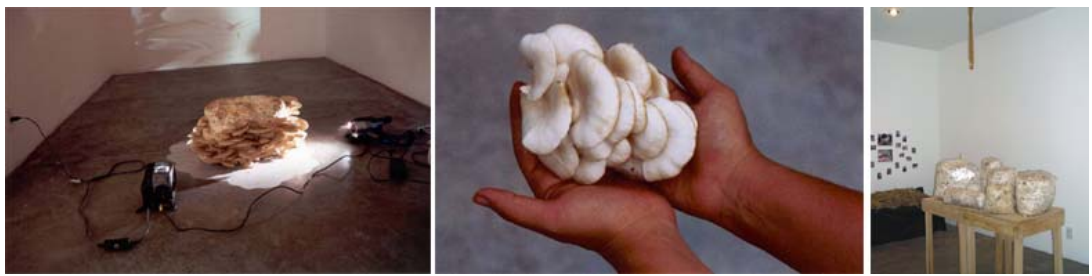

Paola de Anda, Eventos Fungi. Lo visible apunta a lo invisible. Sinergia, 2005.

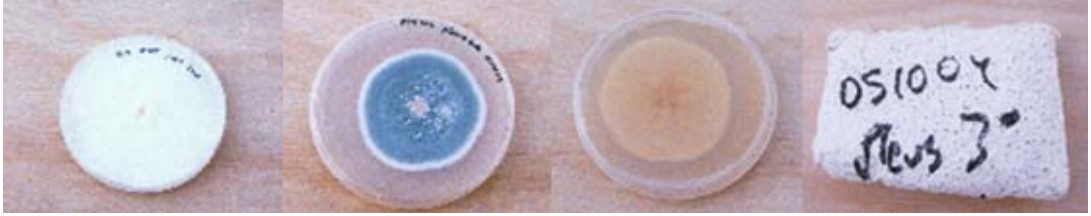

Paola de Anda, Eventos Fungi. Lo visible apunta a lo invisible. Sinergia, 2005.

Volviendo nuestra mirada al escenario mexicano, descubrimos que artistas más jóvenes, nacidos ya en la década de los setenta, como Gustavo Gómez Brechtel o Paola de Anda, se mueven en este tipo de dinámicas procesuales. Sus obras exploran las relaciones entre el arte y la Naturaleza, en conexión con ciertas disciplinas semicientíficas que les permiten a su vez, dentro del contexto artístico, la recreación de ámbitos naturales. La utilización de plantas en estos casos, vuelve a ser una forma de plantear procesos creativos que parten de los conceptos de crecimiento, expansión y estructura, específicos del mundo vegetal, buscando evidenciar con ellos, las posibles relaciones metafóricas que se establecen entre sí. Dejando a un lado la noción de perennidad del objeto artístico, estos jóvenes artistas mexicanos, retoman algunas instancias del Arte Ecológico, el Land Art, del Arte Povera y del desarrollo procesual de los proyectos y se decantan por la utilización de materiales efímeros. Todo ello, sumado al componente simbólico del empleo de materiales naturales les lleva a generar proyectos que tienen resonancias dentro del campo social, provocando experiencias reflexivas en el espectador. Así, uno de los proyectos de Paola de Anda (México, D.F., 1979) tiene que ver con la elaboración de biotipos formados 
por organismos que crecen asociados a pequeños pero complejos ecosistemas que se anclan entre muchas otras, en las referencias mencionadas.

El proyecto Eventos Fungi (2005), se realizó con hongos, organismos que pueden crecer en diferentes espacios y objetos. La construcción de un biotipo dentro del ámbito artístico, implica una fragilidad de montaje especialmente complicada, que se puede percibir en el conjunto de la obra. Por otro lado, esta obra realizada en colaboración con organismos vivos y todos sus posteriores desarrollos como el registro sobre papel del proceso de las esporadas 711 o esporografías, los registros fotográficos y los videos, implica un arte interactivo que integra en ocasiones la colaboración asimismo de los espectadores.

En la imagen podemos observar el cultivo a base de hongos, del cual derivan los demás. Los hongos sanos, los contaminados y la semilla de sorgo se esparcen en el sustrato elegido para la siembra. Este cultivo hace posible la siembra en los diferentes sustratos. El proyecto Eventos Fungi o Sinergia estaba basado en el cultivo doméstico de hongos macroscópicos (setas). La intención del mismo era concretar mediante el trabajo colectivo y el desarrollo procesual (a partir de la materia orgánica y su transformación), el cruce o desplazamiento de conocimiento con una disciplina distinta del arte, en concreto con la biología.
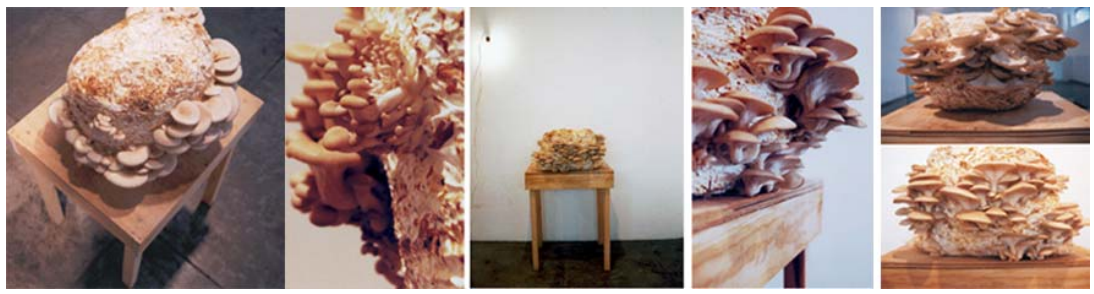

Paola de Anda, Eventos Fungi, Sinergia, 2005.

La artista utiliza un elemento orgánico -los hongos-como material, herramienta y soporte de trabajo, para reconocer mediante diferentes estrategias de aproximación, sus características estéticas y conceptuales. En este proyecto hace referencia a lo estético en relación a las cualidades plásticas, sensoriales y perceptuales contenidas en aspectos como la forma, el color, el olor, la temperatura, etc., del elemento orgánico, mientras que en el plano conceptual, la pieza se centra en aspectos que se encuentran en un plano abstracto y que se refieren a las características esenciales de su forma de vida. Los hongos a pesar de tener una estructura muy similar, no son plantas puesto que no contienen clorofila ni realizan la fotosíntesis, pero tampoco son animales, aunque se nutren de un modo secundario partiendo de alimentos orgánicos, así que están situados entre ambos mundos. Una de sus características principales es que son capaces de transformar la materia, alimentándose de los desechos o parasitándose en otros individuos, realizando una síntesis de sustancias muy parecida a la de los animales. De estos organismos llama la atención tanto la

711 Conjunto de esporas liberadas por los hongos que se depositan sobre una superficie y cuyo color es importante en la identificación de ciertas especies. 
forma de reproducción por esporas como la prolongada capacidad de vida latente, cuyas estructuras son capaces de soportar las condiciones más adversas de medio ambiente.

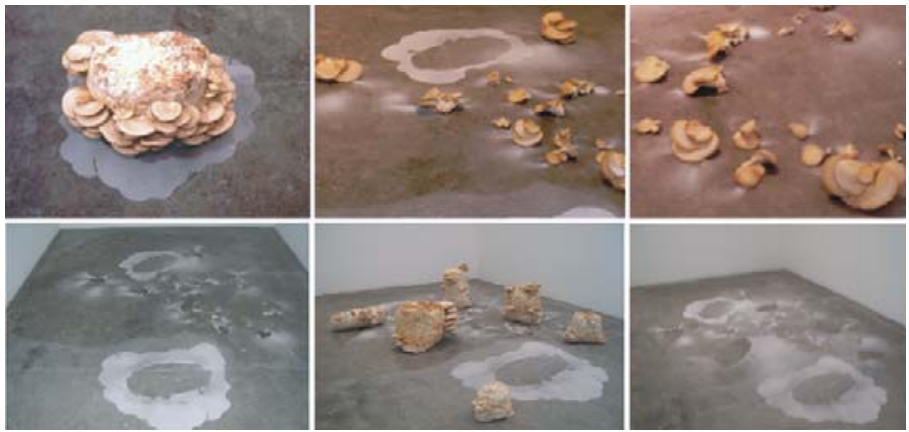

Paola de Anda, Eventos Fungi, Sinergia, 2005.

Para el desarrollo de este proyecto, la artista improvisó un pequeño laboratorio de cultivo en la azotea de su casa. Esta primera etapa de los preparativos para el cultivo se realizó de forma colectiva, en colaboración con otros compañeros. La intención era generar un espacio viable para la experimentación desde la práctica artística, de una situación inusual que fuera capaz de producir un aprendizaje, una vivencia en la que estuviera involucrado el esfuerzo y el disfrute de los participantes como parte de la construcción de la obra. Este pequeño laboratorio improvisado en la azotea de su casa fue trasladado posteriormente para su exposición al espacio de la galería. Allí los cultivos continuaron su proceso de crecimiento. El proceso de realización de esta obra viva, a manera de un evento que trascurre, permitió apreciar su transformación y generar una escultura hecha de tiempo y energía.
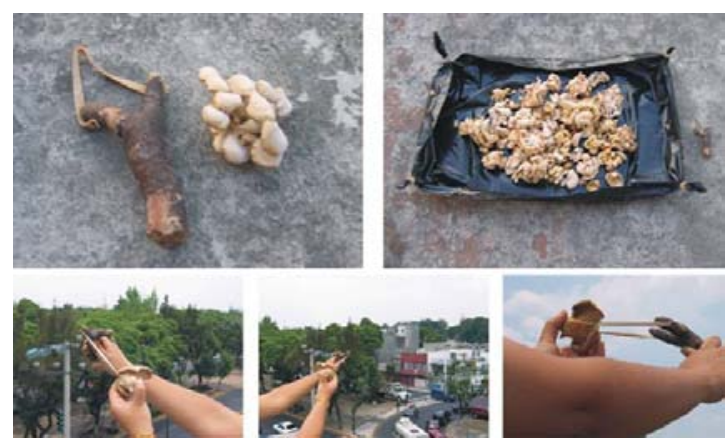

Paola de Anda, Sistema de reproducción por azar / y /I, 2005.

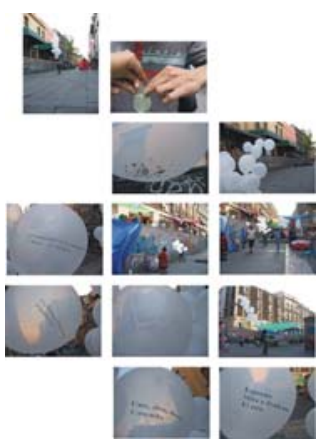

En una segunda etapa del proyecto, la artista desarrolló piezas en las cuales la contemplación y la observación del crecimiento de los hongos y de su forma reproductiva, juegan un papel importante dentro y fuera de las piezas. Es el caso 
de Sistema de reproducción por azar / y // (2005) y de los videos Expulsión y Dibujo con esporas (2005)712.
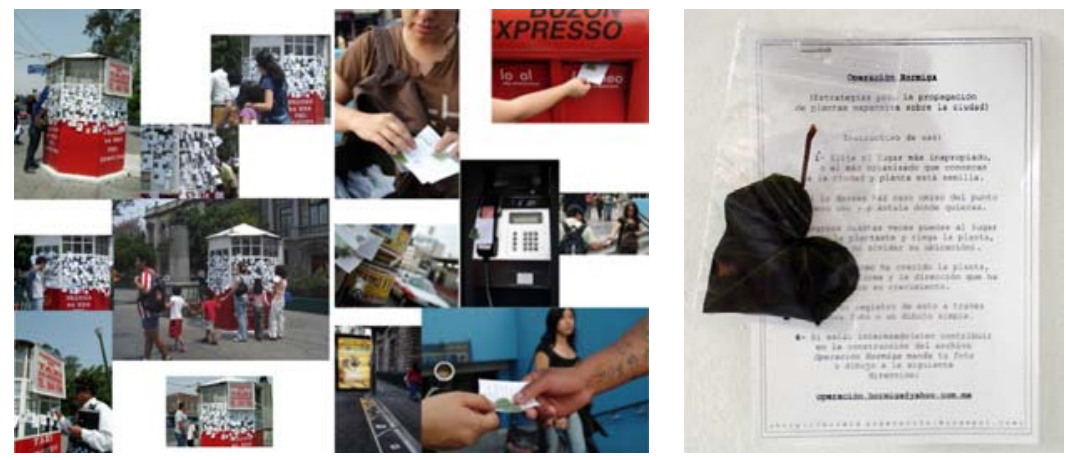

Paola de Anda, Operación hormiga, 2005.

En ellos, Paola de Anda realiza diferentes procesos en los cuales mediante la acción directa de la artista y la intervención del público, se llevaron a cabo diferentes procesos similares a los que desarrollan los hongos para su reproducción. En Sistema de reproducción por azar // (2005) la artista, en una acción similar a la realizada por los hongos con sus esporas, lanza al aire hongos secos con un tirachinas, propiciando que éstos se reproduzcan en diferentes lugares. En Sistema de reproducción por azar / (2005), las esporas son introducidas en globos blancos grabados con diversas frases como: "La humedad en la coincidencia y luego... ¡El tiempo!, o Esporas: Mire a donde mire. El otro", que hacen alusión tanto a la reproducción de los hongos como a un cierto sentido de relación social. Otra de sus piezas, Operación hormiga, estrategias para la propagación expansiva de plantas sobre la ciudad (2005), se distribuía en un puesto de taxis públicos, lo que le permitía a la artista contar con la posibilidad de tener numerosos potenciales colaboradores.

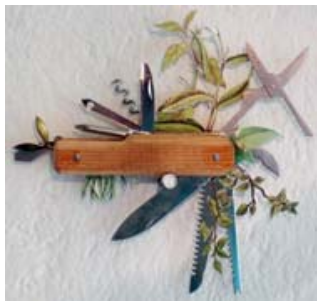

Paola de Anda, Sin título, 2006.

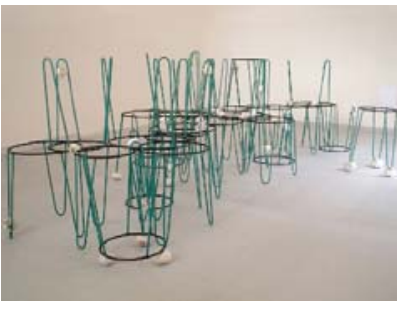

Paola de Anda, Sin título, 2006.
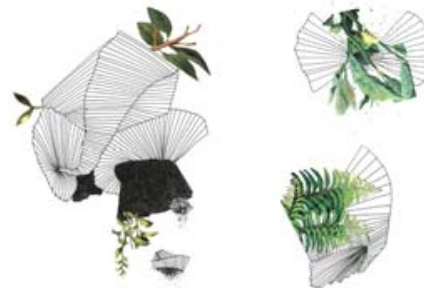

Paola de Anda,

Exploraciones orgánicas, 2006.

La obra consistía en una semilla o planta que iba acompañada de un instructivo de uso en el que se pedía al espectador y nuevo propietario de la planta enredadera, elegir el lugar más apropiado para plantar la semilla o en su

\footnotetext{
712 Información proporcionada por la artista a la autora de esta investigación en entrevista personal, septiembre, 2009.
} 
defecto, elegir un lugar al azar. Con posterioridad, el usuario debe recordar este lugar para volver a él cuantas veces quiera y regar la planta, observando su crecimiento. El requisito que la artista solicitaba era registrar, mediante fotografías, los cambios que mostrara la planta en el transcurso del tiempo y enviarlas por mail para contribuir así a la construcción del archivo de la pieza. En obras posteriores, tanto en instalaciones como en dibujos o en arte objeto, la artista elabora diferentes reflexiones en torno a los procesos de crecimiento del reino vegetal en relación con sus capacidades asociativas y establece comparaciones con los sistemas empleados por el ser humano para relacionarse.

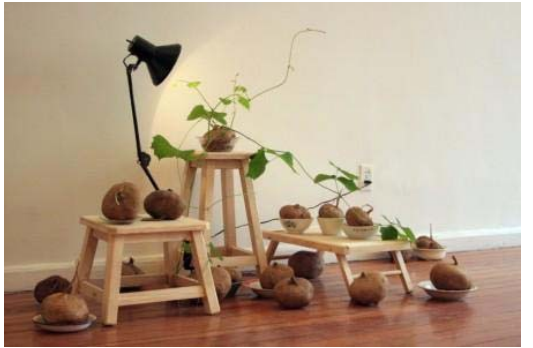

Paola de Anda, Already alive, 2010.

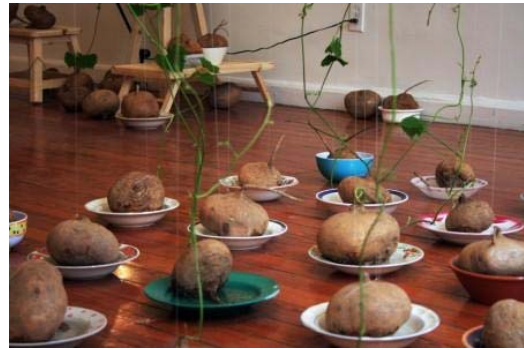

Paola de Anda, Already alive, 2010.

En referencia a la exposición Already Alive (2010) de Paola de Anda, realizada en la galería Alterna y Corriente, Verónica Gerber Bicecci comenta713 el proceso de realización de la obra, en el que implicó la colaboración de amigos y conocidos a través del correo electrónico y de las redes sociales como Facebooksolicitándoles un plato hondo para germinar jícamas en agua y transformar el espacio de la galería en un vivero. Gerber Bicecci comenta los resultados, relacionándolos con las implicaciones del género de las naturalezas muertas que, implican la construcción de un microcosmos en miniatura, en el que podemos observar una transformación en forma paralela a la del mundo, de "una imagen que nos hace testigos de la temporalidad irrevocable de las cosas". En este sentido, apunta Gerber Bicecci, el trabajo de Paola de Anda es una observación minuciosa de la Naturaleza en su interacción cotidiana con nuestro entorno. Sus piezas se convierten en una especie de plaga que puede invadir tanto el espacio de una habitación, como el de una sala de exposiciones o una ciudad. La manera de conseguirlo es recurriendo a dinámicas colectivas que se visibilizan en su obra mediante dos estrategias que se combinan. La primera es una apropiación artística de los sistemas y de los ciclos naturales que le permiten expandir las posibilidades poéticas de lo cotidiano. Esto ocurre por ejemplo en Sauna (2004), una obra en la que la artista sella las salidas de una habitación y la convierte así en una sauna mediante el vapor que se genera al hervir agua en varias ollas.

713 GERBER BICECCI, Verónica, "Naturaleza muerta con jícamas", en Letras Libres, México, D.F., 29, octubre, 2010, Disponible en red: <http://www.letraslibres.com/beta/blogs/ naturaleza-muerta-con-jicamas $>$, [Consulta 2, agosto, 2011]. 


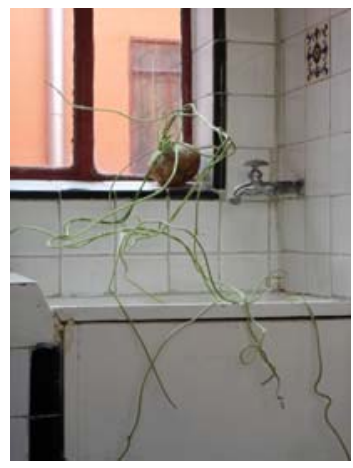

Paola de Anda,
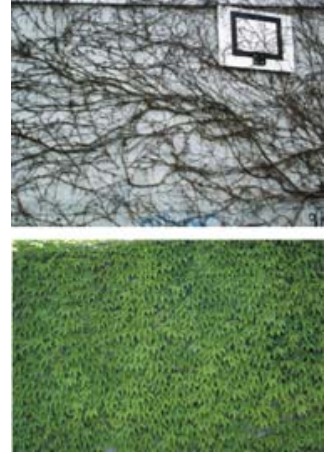

Paola de Anda,

Crecimiento acelerado, 2005. Juego estacional, 2005.

Lo mismo sucede en la acción anteriormente comentada, Sistema de reproducción por azar / (2005), en la que la artista soltó durante varias caminatas en el Centro Histórico de México, D.F., globos inflados que contenían semillas y esporas. Estos globos al reventar por azar generaban la posibilidad de que un hongo o una planta creciera en el lugar donde cayeran; también en Heliotropismo (2008), una instalación en la que un foco gira alrededor de un helecho aludiendo al movimiento de traslación del sol. La segunda estrategia de la artista incluye piezas que son resultado de un ejercicio de contemplación de la Naturaleza: Expulsión (2005), video en el que un hongo (cultivado por ella misma) emite esporas, o Exploraciones orgánicas (2006), serie de dibujos en la que se combinan recortes de monografías de plantas con estudios de esporas y elementos orgánicos trazados con estilógrafo negro. Already Alive (2010) es una alteración de la concepción conocida como still life (naturaleza muerta) así como un gesto al estilo ready made (lo ya hecho) duchampiano. Mientras la naturaleza muerta es una imagen inanimada en la que aquello que estuvo vivo se suspende entre el pasado y el presente, Already Alive es un desplazamiento de lo "vivo" al espacio de exhibición para atestiguar el proceso en que se transforma el presente. La pieza, considerada una pieza en proceso, parte del ejercicio empírico de la artista, quien espía e interfiere en la vida de los tubérculos durante un determinado periodo de tiempo. Después de ponerles agua, acercarlas al sol y cuidarlas, de las jícamas brotan raíces y enredaderas, algunas de las cuales se pudrieron y se llenaron de moscas. La instalación sucede en un tiempo que no podemos apreciar en disciplinas como la pintura, sino que implica el paso de un tiempo y de un devenir en transformación que ocurre y donde, en contraposición a la pintura de naturalezas muertas, según Gerber Bicecci, el modelo está en modificación perpetua.

Por su parte Gustavo Gómez Brechtel (México, D.F., 1976), centra su trabajo en la capacidad de aprender, comprender y utilizar métodos diferentes para la generación del conocimiento con el fin de ampliar las posibilidades de entendimiento de una extensa variedad de fenómenos. El artista está interesado en la idea de generar un híbrido entre los conocimientos de la Ciencia y el arte, que como él mismo reconoce son las bases que han construido su propio proceso cognitivo. Así, a través de sus proyectos, todos aquellos procesos que 
forman parte de ambas disciplinas son analizados y explorados por él. La observación empírica, el orden y la metodología; la certidumbre, los resultados y el control y -por otra parte y en contrapartida- el desorden, la incertidumbre, lo intrincado, lo amplio, lo vago o la metodología no lineal y la observación artística, se observan como una confluencia de sistemas que se complementan para la obtención de resultados. En alguna de sus piezas se puede apreciar una relación formal entre las estructuras humanas -partes componentes del cuerpo humano- y los desarrollos vegetales, como en Sin título, 2004 (mano), donde la tierra que se dispone para el crecimiento de la hierba tiene forma de mano humana y donde las connotaciones simbólicas alimentan la idea de crecimiento paralelo entre el vegetal y el ser humano.

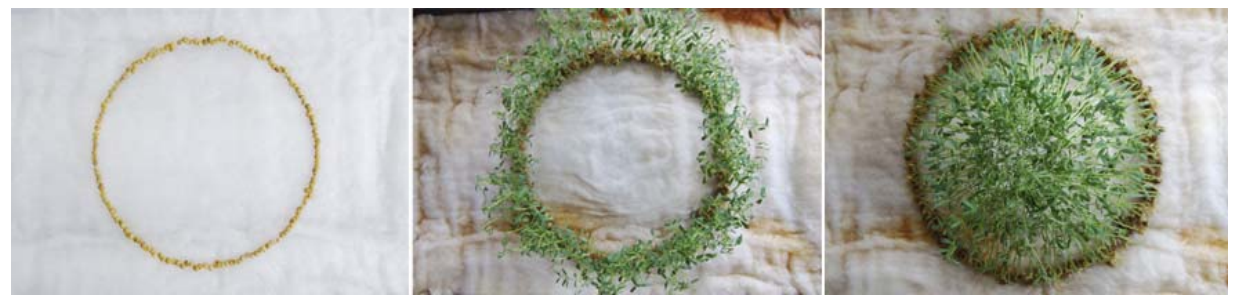

Gustavo Gómez Brechtel, Sin título (Círculo creciente), 2008.

En otras piezas, las estructuras creadas hacen referencia a objetos y útiles humanos como la cama hecha con paja en donde se reproducen colonias de hongos. En su obra, el artista desarrolla una serie de dicotomías horizontales de formas suaves y duras para entender los temas y los fenómenos que le interesan. Su trabajo se ha centrado en la exploración de los metabolismos naturales para jugar con los conceptos de aprendizaje, experiencia, adaptación e incertidumbre.

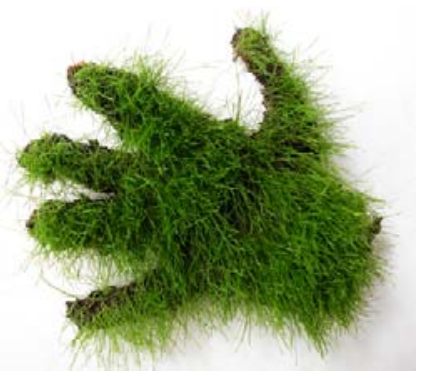

Gustavo Gómez Brechtel, Sin título, 2004.

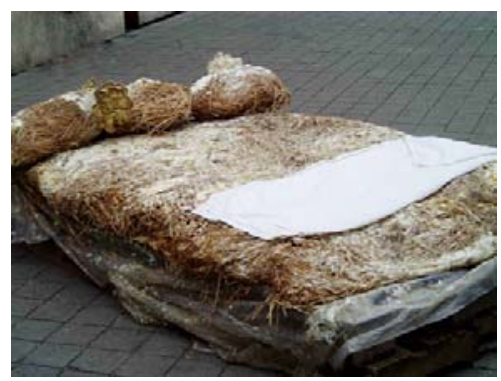

Gustavo Gómez Brechtel, Sin título, 2004.

Su interés por trabajar con organismos vivos, parte de la posibilidad de concebir piezas en cuya concepción está implícita la idea de cambio y de transformación constante. Sus procedimientos se basan en el concepto de entender el arte, y la escultura en particular, como una forma de percibir la presencia inevitable del tiempo. Debido a las condiciones de exhibición y de construcción de este tipo de piezas, el artista pone énfasis en la importancia de que éstas se modifiquen con el tiempo. Esta concepción de elaborar objetos con lo que está vivo le 
ayudan a investigar en torno a la relación compleja entre el creador, la obra y el espectador.

En la obra Sin título (sistema cerrado) (2006) observamos unos árboles plantados en el interior de unas sólidas estructuras de madera que funcionan a manera de grandes maceteros. La configuración formal de las estructuras -cajas cerradas con rejas horizontales, que simulan jaulas, a la vez que cárcelessugiere que el crecimiento de estas plantas terminará por romper las mismas estructuras que las contienen o por lo menos, desbordar estos contenedores. Así, el proceso de protección, aislamiento e incomunicación de ambas estructuras, se solapa y devela la potencia del elemento natural que tarde o temprano desbordará al artificio humano. Frente el carácter diferente y la posibilidad de dinamismo de este tipo de creaciones, las características, capacidades y responsabilidades del artista se modifican, generando una alteración en la relación de vínculos entre el exterior y el interior de la pieza.

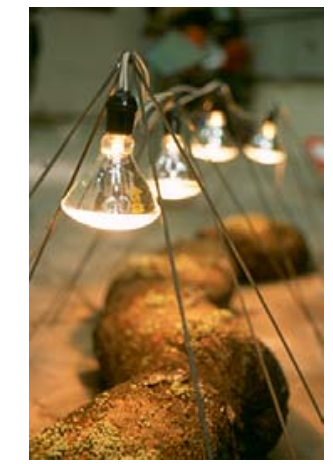

Gustavo Gómez Brechtel, Sin título, 2004.
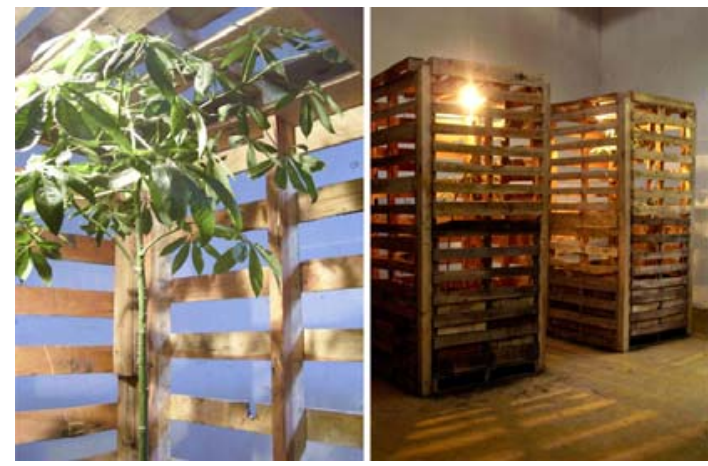

Gustavo Gómez Brechtel, Sin título (sistema cerrado), 2006.

El proceso es similar en su efecto, nos dice el artista714, a la acción lingüística en la que a una oración se le cambiara constantemente una palabra, modificando así su forma y significado. El artista provoca una reacción que afecta tanto al mismo creador como al espectador, ambos se ven de esta manera colocados en una situación de espera y observación constante. Debido a la intervención de los procesos de la Naturaleza en la pieza misma, ésta evidencia la acción de los ciclos naturales que a su vez transforman la estructura de la obra, convirtiéndose ésta entonces en provisional y provocando como resultado, un cambio en la relación artista-obra-espectador.

\footnotetext{
714 Información proporcionada por el artista en entrevista personal con la autora de esta investigación, septiembre, 2009.
} 

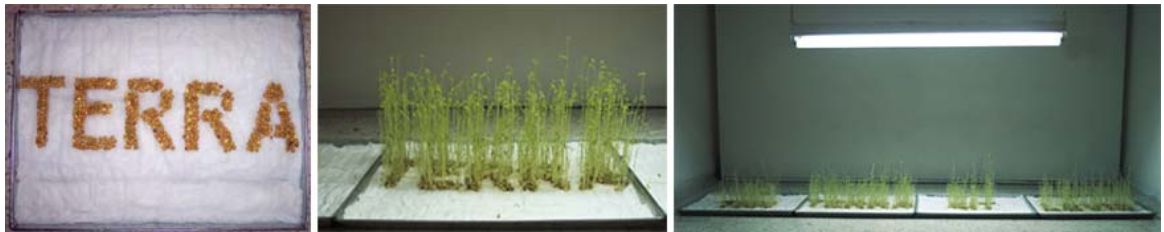

Gustavo Gómez Brechtel, Sin título (Sit tibi Terra Levis, Que la tierra te sea leve), 2008.

En la obra Que la tierra te sea leve (2008), el artista se centra de nuevo en la utilización de elementos vivos, como materia prima, para la producción no de objetos, sino de procesos. En este caso se trata de semillas que, dispuestas sobre una cama de algodón, crecen formando una frase con un fuerte sentido de trascendencia. La oración Sit tibi Terra Levis, se corresponde con la locución latina utilizada en el mundo romano precristiano como epitafio, que evoca poéticamente, la angustia del ser humano ante la muerte y el pensamiento de imaginar el peso de la tierra sobre el cuerpo del difunto. El hecho de que las semillas germinen reivindica un sentido de renacimiento, de vida latente, que supera a la muerte, vinculando de esta manera las potencialidades del mundo vegetal con los deseos humanos.

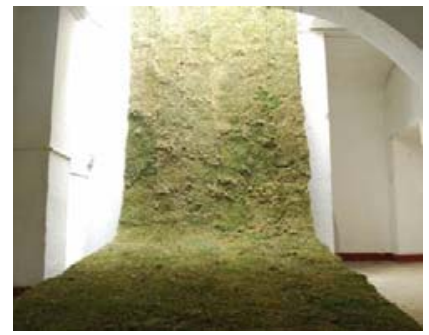

Gustavo Gómez Brechtel, Sin título (Castañeda, 44), 2007.

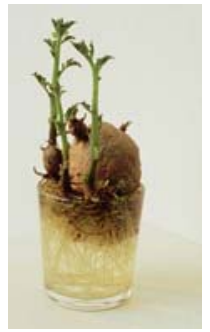

Gustavo Gómez

Brechtel, Sin título, 2007.

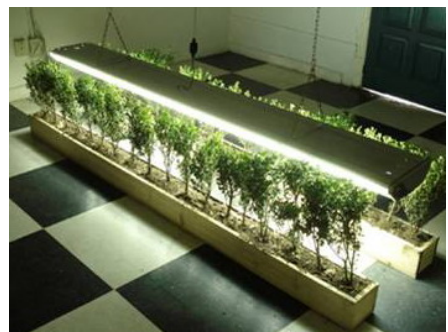

Gustavo Gómez Brechtel, Sin Título (Tragaluz), 2008.

El interés del artista de trabajar con la vida vegetal, radica en la posibilidad de crear obras en cuya concepción estén implícitas las ideas del cambio y de la modificación constante. Se trata de que las obras cumplan ciclos, que se modifiquen debido a las condiciones de exhibición y de construcción de las mismas. Todo ello, con la intención de entender el flujo del tiempo y la influencia de éste en los objetos y en los individuos. 



\section{NATURALZAS IMPUCADAS. OBRA PERSONAL}





\subsection{Primeras hierbas: vegetales y propiedades proyectivas}

Hemos visto hasta aquí cómo, en la actualidad, son muchos los artistas que de una $u$ otra manera, utilizan conscientemente el elemento vegetal para comunicar una suerte de integración entre la naturaleza humana y la vegetal. Tanto a nivel internacional, como dentro del panorama artístico de México de finales del siglo XX y principios del XXI, esta tendencia se inserta en un discurso vitalista que integra múltiples conceptos. Así, las nociones de Naturaleza y Cultura, conciencia y rescate ecológico, simbolismo y retórica o los conceptos de natural y artificial, discurren por caminos paralelos, desde el estudio de las formas y las estructuras, hasta la búsqueda de una identidad propia, sea ésta individual o social. En el ámbito artístico, múltiples y de diferentes formas son las propuestas que se presentan, pero todas ellas marcan pautas, plantean y dan respuesta a necesidades y cuestiones específicas del ser humano, sean éstas ecológicas, espirituales, formales y/o estructurales.

En este último capítulo, queremos complementar la información recopilada con las obras que a lo largo de los años de dedicación a la escultura, expresan nuestra propia visión en torno a los conceptos sobre los que hemos investigado. A partir de aquí, abordaremos una revisión de la obra personal realizada entre 1990 y 2011 , incidiendo en aquellos proyectos cuyas motivaciones registran específicamente, los conceptos en torno a lo vegetal que explora la presente investigación. Utilizando nuestra obra personal como medio, observaremos contextos artísticos diferentes en donde la escultura, usando el elemento vegetal como referente, ofrece la posibilidad de proporcionarnos una experiencia estética de la Naturaleza.

Como punto de partida, tomaremos las reflexiones de uno de los principales especialistas en estética, Richard Wollheim ${ }^{715}$ quien, en referencia a los procesos artísticos de creación, explica la capacidad de expresividad emocional que tiene el arte, vinculada directamente con las similitudes entre los aspectos relevantes del ser humano y la obra de arte:

Cuando envolvemos un objeto natural o artefacto con un significado expresivo, tendemos a verlo corporalmente; es decir, tendemos a otorgarle un aspecto particular que guarde una estrecha analogía con algún aspecto del cuerpo humano [...] $]^{716 .}$

Según comenta el investigador Héctor Julio Pérez López en su libro La naturaleza en el arte posmoderno7l7, las teorías de Wollheim se caracterizan por observar minuciosamente nuestro comportamiento estético frente a las relaciones con el

\footnotetext{
715 El filósofo Richard Wollheim (1923-2003) es conocido por haber acuñado en 1965 el término Minimal Art para designar a aquellos objetos derivados de la naturaleza o de la industria, cuyo contenido en elementos significativos o emocionales fuera mínimo.

716 WOLLHEIM, Richard, El arte y sus objetos: introducción a la estética, Seix Barral, Barcelona, 1972, p. 56.

717 PÉREZ LÓPEZ, Héctor Julio, op. cit., pp. 20-31.
} 
ambiente. Así, como paso preliminar a una nueva concepción de la expresión artística y con el objetivo de proponer una nueva definición de la asociación entre sentimientos y paisaje, Wollheim propone la existencia de una correspondencia entre ciertas propiedades del objeto externo y los sentimientos humanos. De esta manera, llama propiedades proyectivas a las cualidades del objeto por las que un ser humano proyecta sus sentimientos sobre dicho objeto. Según Pérez López, Wollheim establece el marco teórico según el cual, ciertas partes de la Naturaleza pueden llegar a corresponderse y percibirse como fenómenos psicológicos cercanos al ser humano puesto que, de alguna manera, encajan en un estado psicológico similar que provoca que, de forma casi automática, proyectemos sobre ellos nuestro propio estado emocional. Wollheim aplica el concepto de propiedades proyectivas al ámbito del arte, destacando el hecho de que estas propiedades son las que forman parte de la propia condición interna de una obra de arte y las que desencadenan el hecho psicológico de la expresividad.

Si la estética ambientalista 718 trata de poner al hombre y a la Naturaleza en el mismo plano, la postura de Pérez López defiende que aunque aparentemente los planteamientos de Wollheim diferencian entre expresión artística y Naturaleza, es posible que lo natural permanezca intacto como elemento expresivo primordial, sin convertirse únicamente en medio de transporte de las propiedades proyectivas del fenómeno psicológico. Frente al riesgo de que la fragilidad de lo natural se rompa con la intervención humana, la intención de Pérez López es responder a la pregunta de si el artista puede dar o no, una presencia a la expresión de lo natural en su creación. Para ejemplificar este proceso nos habla del complejo termal construido por Peter Zumthor a principios de los años noventa en la localidad de Vals (Suiza). En estas termas Zumthor, utiliza el elemento natural (piedra, agua) como poseedor de un valor esencial que, en el "juego de dar y recibir"719, se pone de manifiesto a través de la creación artística.

[...] Zumthor nos refiere precisamente una evolución durante el proceso constructivo de las termas, una evolución que podríamos considerar como una parte de aquel proceso por el cual la "condición interna", es decir, la condición de expresividad que depende de unos sentimientos, sensaciones y comprensiones del artista se va conformando en el mismo proceso artístico 720 .

Pérez López insiste en que, si bien en este caso concreto, la experiencia de lo natural requiere y se manifiesta a través de la presencia de elementos naturales, pudiera ser que la experiencia originaria de la Naturaleza derivara también en la

\footnotetext{
718 Teoría estética que aboga por expandir la experiencia estética a contextos mucho más amplios que los del terreno de las obras de arte, museos o galerías, considerando que la realidad circundante, el entorno o el ambiente pueden permitir al sujeto estético una vivencia igualmente gratificante.
}

719 ZUMTHOR, Peter, Atmósferas, Gustavo Gili, Barcelona, 2006, p. 7.

720 PÉREZ LÓPEZ, Héctor Julio, op. cit., p. 25. 
percepción de la condición interna de la misma, pudiendo el artista desarrollar la correspondencia entre las propiedades proyectivas y lo natural desde otras posiciones. Para ello diferencia entre dos tipos de propiedades proyectivas, las naturales (cualidades perceptivas de los materiales: piedra agua, aire, etc.) y las que dependen del trabajo de artista, aquellas que aportan además del material, su particular disposición, localización y combinación de todo ello que es en definitiva, lo que consigue generar una creación artística.

Lo que la aplicación de la terminología del profesor Wollheim implica es profundizar en la diferencia entre una acción que permita experimentar la naturaleza sin más ni más y un proceso de creación que parte de la naturaleza y permite que en él juegue un papel protagonista721.

En la arquitectura de Zumthor confluyen tanto propiedades proyectivas naturales como artísticas para permitir experimentar al espectador la conciencia de vivir algo natural. El sujeto asocia y percibe el beneficio de esta vivencia desde el punto de vista emocional, a través de un placer tanto físico como estético. Por otra parte la experiencia corporal específica del baño, intensifica la asociación con la percepción del entorno y el encuentro con la Naturaleza.

De todo ello, podemos deducir que existen una serie de características asociadas a ciertos materiales e incluso a ciertas estructuras que, independientemente de su esencia o disposición natural, pueden favorecer ciertas percepciones que, sin duda, nos ayudan a construir un entorno conceptual en el que la Naturaleza -y con ella, el tema que nos ocupa: la percepción de los vegetales- sea considerada como un espacio de reflexión en el campo de la actuación del ser humano. Así, en un mundo invadido por la artificialidad del ser humano, el artista encuentra -mediante la creación y este tipo de asociaciones- un contexto en el que, más allá de la aparente imposibilidad de considerar la coexistencia respetuosa de lo natural con lo humano, generar propuestas que denoten esta tendencia como viable.

Reflexiones similares a éstas dieron origen en nuestra obra a lo que hemos dado en llamar pensamiento vegetal722. Una de las primeras obras realizadas en este sentido fue la titulada Lo único auténticamente ecológico que el hombre podría hacer por la tierra sería desaparecer (1990). En esta escultura, construida dentro de una acción urbana en La Galería El Teatro en la provincia de Córdoba (Veracruz), se observa la forma de un hombre cuya estructura recuerda la de un tronco de árbol quebrado por su parte media, punto de donde surge un fuego real. El título de esta pieza denuncia con ironía la incapacidad del hombre de respetar su entorno y de convivir de manera integradora con él. La escultura hecha con cemento armado, está partida en dos, sus formas se parecen a las de un tronco real, similar al que emerge por debajo de la figura de cemento que, aunque cortado, simula estar resurgiendo (pintura verde como símbolo de

\footnotetext{
721 PÉREZ LÓPEZ, Héctor Julio, op. cit., p. 26.

722 Término empleado por nosotros para describir la influencia del reino vegetal en la génesis de nuestras esculturas.
} 
renacimiento) y que es el causante de partir en dos al humano. A la vez, en un proceso de inversión recíproca, el fuego -que habitualmente y por causa de la acción humana, es el que destruye el bosque y los árboles- surge en la escultura, sobre la forma humana rota en dos partes.

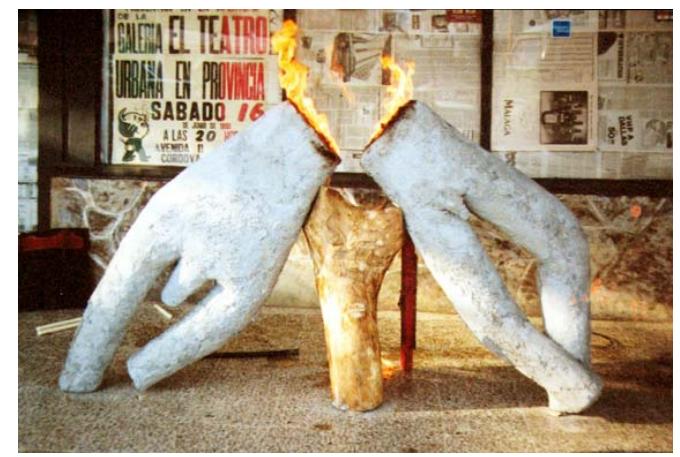

Inmaculada Abarca, Lo único auténticamente ecológico que el hombre podría hacer por la tierra sería desaparecer, 1990.

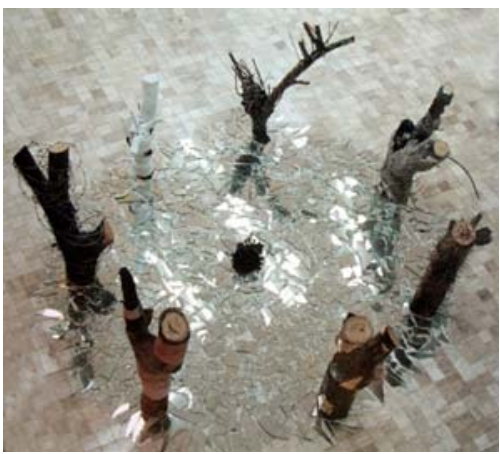

Inmaculada Abarca,

Tomando cartas en el asunto, 1991.

El artista Eduardo $\mathrm{Kac}^{723}$ nos recuerda que este tipo de paralelismos entre humanos y plantas, entre las formas antropomórficas y las botánicas no forman parte únicamente del ámbito de la historia del arte. En la historia de la filosofía y de la Ciencia contemporánea encontramos casos como el de Julien Offray de La Mettrie724 (1709-1751), médico y filósofo materialista de la llustración que en 1748 escribió, entre otros, el tratado de L'homme plante (El hombre planta), en el que dejaba constancia de las analogías entre los brazos, las piernas o los pulmones de los hombres y las hojas, ramas y tallos de las plantas o las ramas de los árboles, insinuando que al principio, los hombres pudieran haber sido un árbol, una planta o una flor. En nuestro caso, la pieza descrita es una de las primeras alusiones a la naturaleza vegetal en nuestra obra personal.

Posteriormente, en las instalaciones Las cartas sobre la mesa (1991) y Tomando cartas en el asunto (1991), realizadas para la exposición Volumen en la Casa de la Cultura de Tlalpan (México, D.F.), se usaron nuevamente troncos de árboles, para reivindicar la incipiente idea de autodefensa de la Naturaleza, a través de su manifestación vegetal. Para esta ocasión, el montaje presentaba siete troncos cortados de diferentes árboles, intervenidos cada uno de ellos con diversos elementos y materiales artificiales.

723 KAC, Eduardo, op. cit., p. 391.

724 Los escritos La Mettrie se caracterizan por un culto al hedonismo así como por exaltar los valores del placer y de los sentidos como vías alternativas frente al determinismo teológico. 


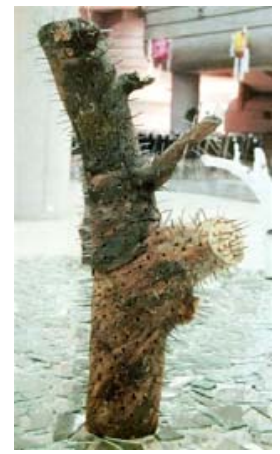

Inmaculada Abarca,

Agresión, 1991.

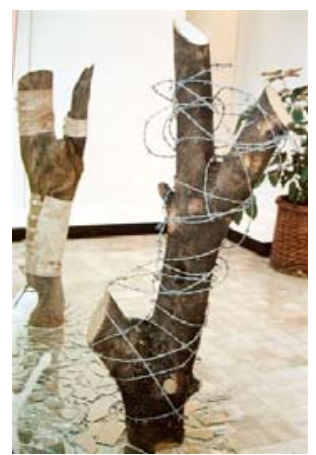

Inmaculada Abarca,

Trinchera, 1991.

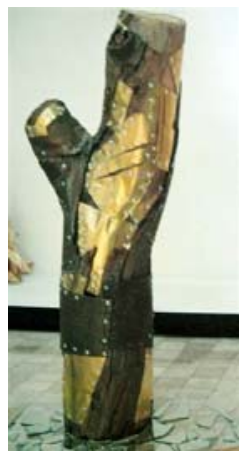

Inmaculada Abarca,

Armadura, 1991.

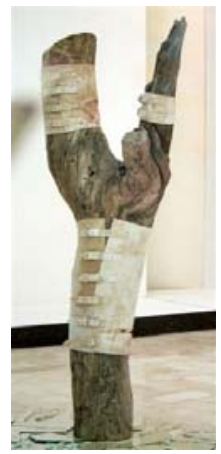

Inmaculada Abarca

Artrosis, 1991.

Los troncos estaban dispuestos en una estructura circular a manera de defensa, haciendo evidente el acoso y las agresiones de las que los árboles son objeto, generalmente en el entorno urbano. Los troncos, cortados y dispuestos sobre un círculo-mar de espejos-ilusiones rotas, defendían a un pequeño árbol vivo situado en la parte central del círculo. Ante las continuas agresiones del ser humano, los árboles presentaban actitudes de defensa. Cada tronco tenía un título que hacía referencia a la metafórica agresión o defensa en la que intervenían: Trinchera (1991) era un tronco recubierto con el alambre de púas con el que se protegen propiedades, límites o fronteras para que nadie pase; Agresión (1991) tenía toda la superficie del tronco cubierta con clavos colocados al revés, es decir, exponiendo sus puntas al espectador a manera de ataque y defensa personal del propio árbol.

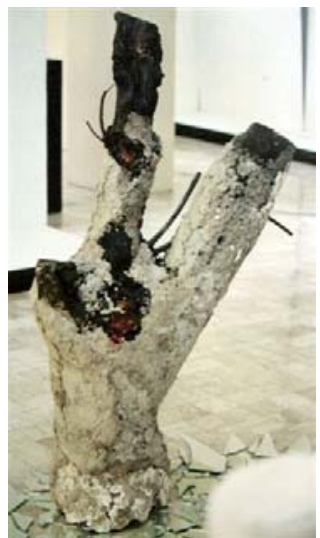

Inmaculada Abarca, Asfixia, 1991.

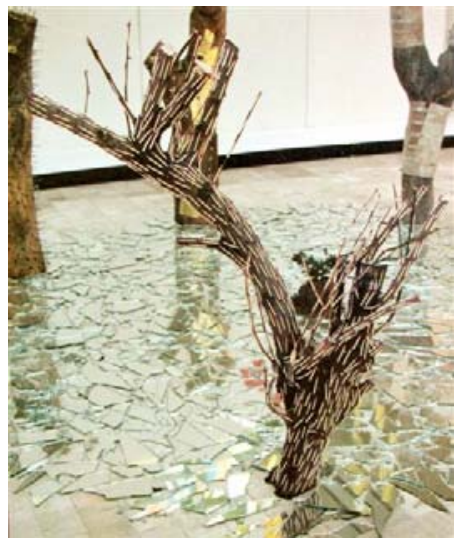

Inmaculada Abarca, Provocación, 1991.

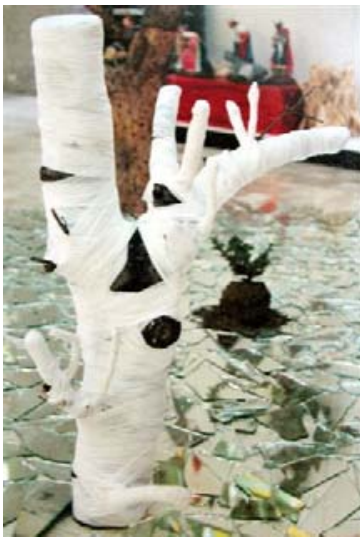

Inmaculada Abarca, Árbol herido, 1991.

Piezas como Armadura (1991), presentaban una especie de coraza de hierro, latón y remaches; Artrosis (1991) tenía varias fajas de cuero con correas, remaches y hebillas, como aquellas que usan las personas que tienen problemas con la columna vertebral. Otros eran árboles seccionados que mostraban actitudes de indefensión como Asfixia (1991), que se encontraba recubierto de 
cemento al igual que los árboles de las ciudades a los que apenas les dejan lugar para crecer. Provocación (1991) ofrecía su superficie cubierta de cerillas de madera en una clara alusión a la falta de precaución humana que ha provocado tantos incendios en los espacios forestales y por último Árbol herido (1991), nos hablaba de una agresión consumada.
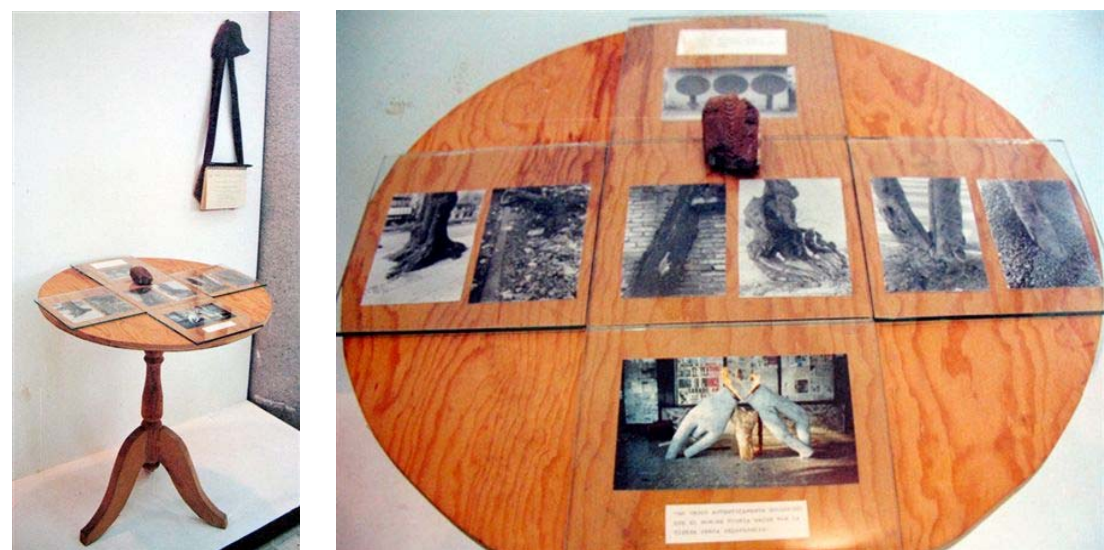

Inmaculada Abarca, Las cartas sobre la mesa, 1991.

A manera de réplica, otra parte de la instalación, Las cartas sobre la mesa (1991) presentaba una sencilla mesa de madera -el árbol procesado como objeto de uso- en la que se colocaban varias fotografías de árboles que constataban la agresión contra los mismos en un entorno urbano. Asimismo, había diversas fotos de árboles pintados en los muros de las calles, pinturas murales con las que, a principios de los años noventa se paliaban en ciertas colonias, los desastres provocados por la pobreza y el terremoto de 1985. Entre las fotografías, una piedra -un fósil real de madera- nos hablaba de la debacle, del paso del tiempo, de la arqueología del recuerdo a la que nos puede abocar la desidia de no cuidar aquello que deberíamos proteger.

En el conjunto de imágenes se observaba una fotografía de la pieza de la que anteriormente hablamos, Lo único auténticamente ecológico que el hombre podría hacer por la tierra sería desaparecer (1990) haciendo una alusión referencial a la propia obra y a la manera de enfocar la temática. Acompañando toda la instalación un cuaderno con tapas de corcho natural colgaba de un listón morado, invitando al espectador a dar su opinión sobre el juego de relaciones que generaba la pieza en torno al cuidado de los árboles. La pieza construía la figura retórica de una prosopopeya en donde el conjunto de árboles en círculo cerrado, se erigía como guardián y abanderado, en defensa de la vida del más pequeño de ellos -el único vivo- situado en el centro sobre un túmulo de tierra.

Unos años después, la idea vegetal vuelve a resurgir en una obra basada en la antigua creencia grecorromana de la correspondencia y la coexistencia paralela de dos mundos. En Pasto (1997) y A/ viento (1998), ante la necesidad de evidenciar la exuberancia característica del elemento vegetal, optamos por una 
nueva solución técnica: la reproducción en serie y la repetición de elementos que representan a la hierba, mediante la técnica de la fundición en bronce.

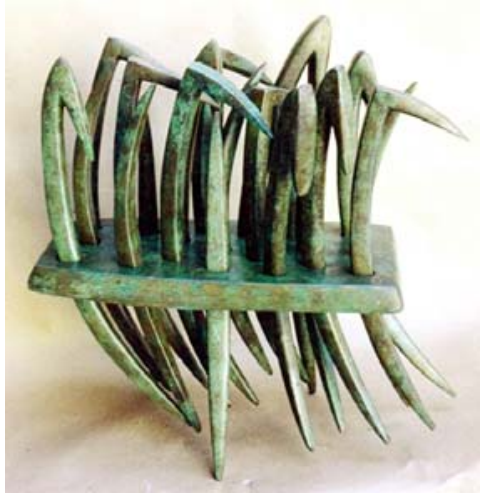

Inmaculada Abarca, Pasto, 1997.
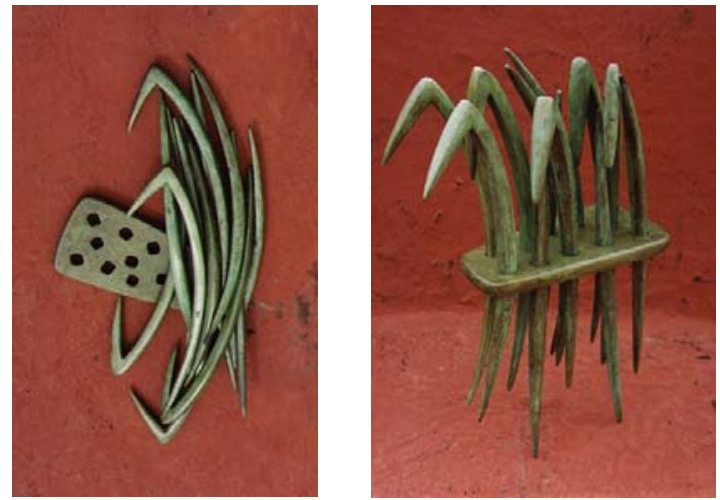

Inmaculada Abarca, A/ viento, 1998.

Estas esculturas parten de la conciencia originada en la analogía del macrocosmos-microcosmos 725 , de que lo que hay debajo es lo mismo que lo que hay arriba, o de que, lo que hay afuera y lo que hay adentro es similar. Como apunta metafóricamente Giuseppe Penone, las propiedades proyectivas de la hierba como referente se manifiestan como un reflejo psicológico en el ser humano: "Si se pudiera recoger la energía ascendente de los hilos de hierba de mi jardín podríamos también conservar la luz726.

Este tipo de piezas presentan una serie de puntas que se acoplan sobre un plano horizontal. Este plano rectangular funge como límite físico y simbólico entre ambos mundos (arriba y abajo) y se sostiene, a manera de trípode, únicamente por tres piezas que entran por la parte inferior del mismo. A pesar de presentar puntas bastante agudas, la pieza se percibe como la abstracción de una planta. La diferente curvatura de las piezas y la manipulación de cada una de las mismas permiten considerarla como armas, sin embargo la escultura no trasmite agresividad. La primera pieza realizada tenía unas dimensiones de $60 \times 60 \times 30$ centímetros, mientras que $A /$ viento, con un tamaño menor $38 \times 23 \times 13$ centímetros, nos permite percibirla de forma más íntima.

El perfecto acoplamiento (realizado mediante pequeños moldes) de cada una de las piezas sobre el plano, alude metafóricamente a la idea del lugar propio de cada ser vivo en el mundo, poniendo de manifiesto la correspondencia entre las partes y el todo.

725 Como ya hemos observado en el capítulo 4: Ecoarte y misticismo, aunque la analogía macrocosmos-microcosmos es un elemento básico del pensamiento medieval y renacentista (Cfr. LINDBERG, David C., Los inicios de la ciencia occidental. La tradición científica europea en el contexto filosófico, religioso e institucional (desde el 600 a. de C. hasta 1450), Paidós Ibérica, Barcelona, 2002, p. 187), podemos afirmar que continua vigente en el inconsciente colectivo de muchos pueblos y culturas.

726 Véase TOSATTO, Guy, en AA. VV., Giuseppe Penone, 1968 - 1998, op. cit., p.. 15. 


\subsection{Híbridos cuepo humano-cuepo vegetal}

En la exposición individual de la Galería Kim727 1997 otra pieza además de Pasto (1997), anticipaba en nuestra obra la intersección de elementos vegetales con rasgos y características humanos. En la escultura Familia (1997), podemos observar un hombre que camina abrazándose a sí mismo, a la vez que protegiendo en su abrazo, a una serie de pequeños hombrecillos que surgen de sus miembros y que atraviesan o recorren todo su cuerpo. Estos elementos son exentos y pueden extraerse de la pieza principal, acoplándose de nuevo a ella. En su mayoría, se perciben como pequeños humanos con los brazos o las piernas al aire, saliendo de un cuerpo que acusa en sus deformaciones la presencia de estos elementos sobre su superficie. La ambivalencia se hace evidente puesto que, a la vez que humanos, estos elementos parecen pequeños brotes o germinaciones que surgen del cuerpo principal, a la manera de un sistema de reproducción vegetal o de forma similar al proceso de reproducción llamado mitosis 728 .

Ese mismo año, recibimos el encargo del Ayuntamiento de Xàtiva (Valencia), de realizar una escultura-fuente en homenaje a los Hermanos Villanueva en una plaza pública de esta ciudad. La escultura Raíces (1997), realizada en bronce, fue modelada en cera directa y consta de veintidós piezas.

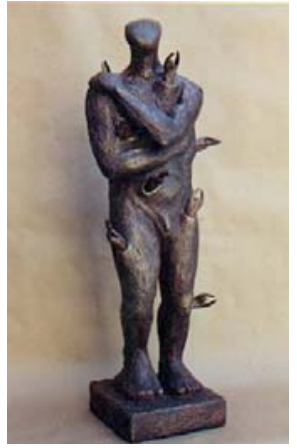

Inmaculada Abarca,

Familia, 1997.

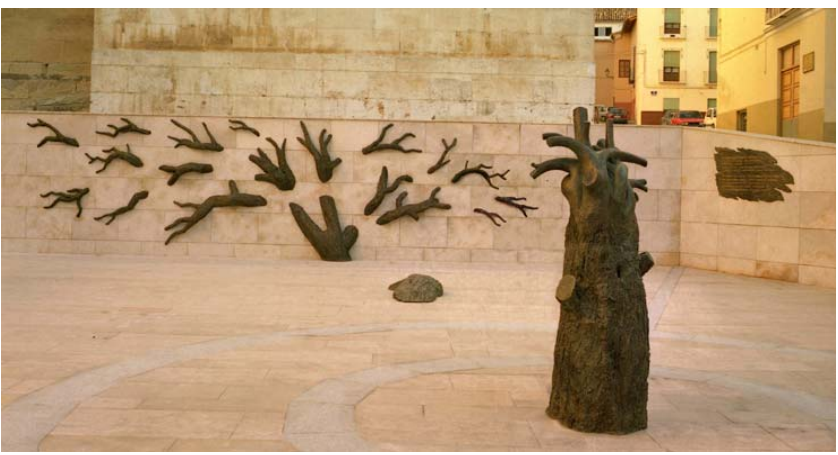

Inmaculada Abarca, Raíces, 1997.

La textura que configura todos los troncos está tomada directamente, mediante un molde de silicona, de la corteza de un árbol llamado pirul729. La fuente tiene unas medidas aproximadas de $142 \times 60 \times 60$ centímetros. Este elemento enlaza visualmente con una raíz ( $21 \times 103 \times 50$ centímetros) que, a cierta distancia y en altorrelieve, emerge ligeramente sobre el suelo. La continuidad compositiva con

\footnotetext{
727 Véase material divulgativo de la exposición Inmaculada Abarca, Galería Kin, México, D.F., 4, junio, 1997. Texto JUANES, Jorge, "Lo riguroso/ Lo abierto".

728 Proceso de reproducción sexual de las células, por el cual una célula se parte en dos y así sucesivamente.

729 Nombre común por el que se le conoce en México. Originario del Perú, el Schinus molle es conocido en España como el árbol de la pimienta falsa.
} 
el árbol-fuente, se concreta finalmente en la arborescencia de una serie de raíces que afloran a la luz para develarnos la intención última de la pieza (raíces al aire). En el muro que enmarca la fuente, observamos diecinueve raíces distribuidas en un espacio de $175 \times 640$ centímetros de ancho y con un espesor de 25 centímetros. En la placa conmemorativa (120x64 centímetros), realizada con la misma textura del árbol, se puede leer la inscripción que recuerda cómo, por mediación del diputado Joaquín Lorenzo Villanueva, la ciudad de Xàtiva recupera su nombre originario, del cual había sido privada durante ciento cuatro años por el rey Felipe $\mathrm{V}$.

Saetabis urbs pristino nomine quo per CIV annos ira victoris expoliata fuerit restituta ex comitiorum hipaniae decreto die xxi septembris anno mdcccxi.

La ciutat de Xàtiva ha recobrat el seu primer nom del qual havia estat privada durant 104 anys per la ira del vencedor pel decret de les corts d'espanya el dia 21 de septembre de l'any 1811730.

Insertándose de lleno en el discurso del arte contemporáneo dentro del binomio Arte y Naturaleza, en esta escultura de bronce se conjugan metafóricamente los intereses humanistas por la búsqueda de los orígenes de los personajes a los que está dedicada, con al espíritu creador de la Naturaleza. Este proyecto nace con la idea de realizar un homenaje al espíritu de verdad que inspiró tanto la vida del diputado Joaquín Lorenzo Villanueva como la de sus hermanos. Con este propósito en la escultura se hace presente el simbolismo que unifica el énfasis creador de la Naturaleza (representado en el muro con las raíces al aire de un árbol), con todo aquello que hace referencia a lo humano (forma de corazón en el tronco principal del árbol-fuente). Asimismo se relaciona el corazón de la tierra (corazón en el tronco del árbol) con las raíces del ser humano y del propio sentir como humano del personaje homenajeado, arraigado en una tierra y en un espacio vital. Esta referencia específica de pertenencia a un lugar evidencia los vínculos profundos que unían a este personaje con su ciudad natal a la que tanto quiso y a la que tuvo siempre presente, incluso en los momentos más inhóspitos de su propia vida.

Encontramos en esta escultura-instalación-fuente, dos elementos básicos, por un lado las raíces de un árbol que aparecen al descubierto sobre un muro -a pesar de que generalmente éstas permanecen ocultas a la mirada superficial- y creciendo al margen de límites, obstáculos y circunstancias naturales o artificiales. En este contexto, las raíces de esta escultura son una metáfora que representa el interés de nuestro personaje por la búsqueda de las raíces, no sólo de la Iglesia primitiva o de los cánones más ortodoxos, sino también en los orígenes del lenguaje. Así lo demuestran sus intereses tanto por la etimología como por la arqueología y otras múltiples inquietudes por las que destacó este gran humanista, víctima a nuestro modo de ver, del tiempo que le tocó vivir y sufriendo en su propia persona (exilio en Londres) el conflicto de la escisión entre el poder político y el poder eclesiástico.

730 Inscripción en latín y valenciano que aparece en la placa conmemorativa. 
Su interés por la verdad, lo llevaron a mantener posturas que personalmente le perjudicaron, como por ejemplo su defensa por la traducción en lengua vulgar de los textos sagrados, lo cual sin embargo, permitió desmonopolizar el poder verticalizante de los eclesiásticos sobre el pueblo. A pesar de sus múltiples responsabilidades, nunca perdió de vista la intención de beneficiar a sus semejantes, como lo demuestra el hecho de haber abogado por recuperar para su ciudad natal su nombre auténtico, del cual fue desprovista por tanto tiempo por el afán vengativo de un rey sin escrúpulos ni criterio. En esta misma dirección destacan también sus esfuerzos por convertir a Xàtiva en capital de provincia y Seo episcopal. Todas estas ideas quedan reflejadas en este proyecto mediante la fuerza de las raíces las cuales, en el simulacro de atravesar el muro, afloran de forma intermitente buscando constantemente la luz y el espacio necesario para alimentarse en la propia tierra y cimentarse en la historia.

Respecto al elemento del corazón, éste nos remite en lenguaje metafórico, a la nobleza de los sentimientos que impulsaron a estos personajes. Su humanidad ilustrada presenta fisuras a la razón de su tiempo, ante la que sin embargo, oponen sus verdaderos sentimientos, construyendo así los orígenes de un pensamiento social que posteriormente dio origen a la sociedad moderna y a la soberanía del pueblo sobre otros estamentos anacrónicos.

Cabe destacar que la hibridación en esta escultura, de elementos humanos y vegetales combinados, estableciendo un diálogo común, plantea una relación entre las propiedades proyectivas a las que hacía referencia Richard Wollheim, y las formas representadas en la escultura. En este caso, fue una manera de que las propiedades proyectivas de la idea de raíces, transmitieran sus cualidades a los sentimientos humanos relacionados con la pérdida de identidad de la ciudad. Estas representaciones de la Naturaleza se perciben como algo cercano al ser humano puesto que de alguna manera, encajan en el estado psicológico que provocan. La escultura hace a la vez, un guiño al poeta y cantautor de Xàtiva, Raimon, cuyos versos de la canción Jo vinc d'un silenci: "qui perd els orígens perd identitat"731, resuenan en todos y cada uno de los habitantes de esta ciudad.

Como ya indicábamos en el capítulo cuatro, las imágenes primarias favorecen una metafísica de la imaginación, ya que despiertan en nosotros arquetipos sepultados en nuestro inconsciente. La metáfora de las raíces, de potencia multiplicadora, nos lleva aquí, a través de su simplicidad y fácil entendimiento, hacia el pensamiento abstracto que clarifica nuestro espíritu. La imagen funciona de forma similar a la del personaje de Virginia Woolf, a quien le basta sostener un tallo en las manos para convertirse en raíz:

731 RAIMON (Ramón Pelegero Sanchis), Canción (traducción): Yo vengo de un silencio: Quien pierde los orígenes, pierde la identidad, en ARACIL, Rafael et al. (eds.), Memòria de la Transició a Espanya i a Catalunya, Els jovens de la Transició, Universitat de Catalunya, Barcelona, 2003, p. 276. 
Tengo en la mano un tallo. Soy yo mismo el tallo. Mis raíces se hunden en las profundidades del mundo, a través de la arcilla seca y de la tierra húmeda, a través de las venas de plomo, de las venas de plata. Mi cuerpo no es ya más que una fibra. Todas las sacudidas repercuten en mí, y el peso de la tierra presiona mis costillas. Allá arriba, mis ojos son ciegas hojas verdes732.

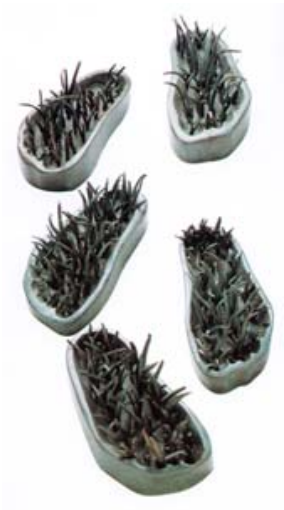

Inmaculada Abarca, Camino, 1998.

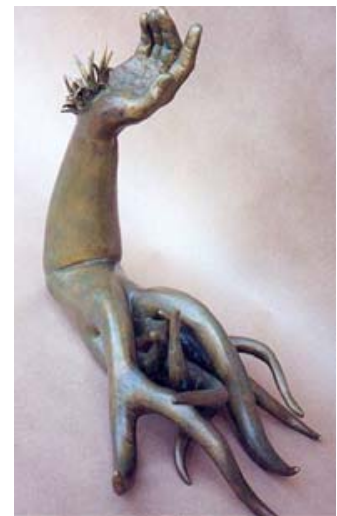

Inmaculada Abarca, Brote, 1998.

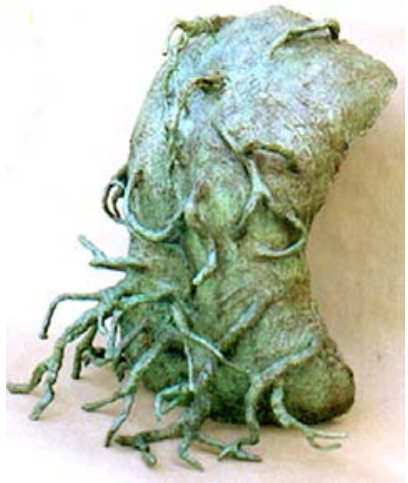

Inmaculada Abarca, Raíces, 1998.

Para el periodista y cineasta Gibrán Bazán la exposición Re-encuentros (1998)733 reunía una serie de piezas que exploraban la paradoja visual entretejiendo la duda entre lo interno y lo externo. El crítico nos habla de piezas cuyos títulos evocan una nueva realidad posible, en donde las re-lecturas y los re-encuentros son aceptados de manera natural. Entre las piezas encontrábamos huellas de pies humanos de los que afloraban, parafraseando al periodista, "hierbas metálicas" (Camino, 1998); una invitante mano "libre cual serpiente del paraíso e impulsada por raíces tentaculares" (Brote, 1998) y una Gorgona (Medusa, 1998), "cuyos rasgos son delineados por bulbos y canales líquidos y mercúreos". Una posibilidad, en resumen, de percibir "un orden propio dentro del caos" y de crear una "realidad empática capturando sentidos y percepciones":

El mundo estético de Inmaculada Abarca es peligroso. Impone la fuerza de las formas y niega cualquier verdad de carácter absoluto. [...]. En cada una de sus obras, Abarca nos hace partícipes de una realidad alterna. Nos conduce a la deriva por un limbo óptico que, conjuga forma y figura dentro de una ambivalencia tan cotidiana como insólita. [...] traducida en "evolución sostenida"; concepto que a manera de némesis bergsoniano cuestiona el centro y significado de todo lo inteligible y traduce la "realidad" en configuraciones de forma-base; unidas éstas umbilicalmente a arquetipos

\footnotetext{
732 WOOLF, Virginia, Les Vagues [Las olas], en BACHELARD, Gaston, La tierra y..., op. cit., p.329.

733 Véase material divulgativo de la exposición: Inmaculada Abarca, "Re-Encuentros", Galería de Arte Misrachi, México, D.F., 12, noviembre, 1998.
} 
que deambulan entre formas femeninas; algunas de ellas con espinas protectoras, otras con variantes de alusión clorofilica y etérea [...]734.

El crítico anticipa nuestra intención híbrida. Camino (1998) surge con la idea de tomar el registro de unas huellas de pies humanos, cuyo progresivo deambular genera una senda distinta, una noción de camino productivo, unas huellas que a su paso, en lugar de describir destrucción o desolación, permiten el renacimiento cíclico que anticipa la naturaleza vegetal, una hierba que renace ante las condiciones óptimas. Frente al hábito humano de dejar a su paso destrucción, desierto o contaminación, la pieza insinúa simbólicamente un camino de esperanza.

Este sentido de renovación, como hemos venido observando a través de esta investigación, se conecta, más allá de las experiencias naturalistas de la primavera, con el impulso religioso genérico que, en definitiva, enlaza más con la experiencia mística y con el mito que con la realidad del despertar de la vegetación. Recordemos lo que Mircea Eliade apunta al respecto:

Los llamados cultos de la vegetación no dependen de una experiencia profana, "naturalista", en relación, por ejemplo, con la primavera y el despertar de la vegetación. Antes bien, es la experiencia religiosa de la renovación (recomienzo, recreación) del mundo lo que precede y justifica la valoración de la primavera como resurrección de la naturaleza. Es el misterio de la regeneración periódica del cosmos lo que ha fundamentado la importancia religiosa de la primavera. Por otra parte, en los cultos de la vegetación no es siempre el fenómeno natural de la primavera y de la aparición de la vegetación lo que importa, sino el signo prenunciador del misterio cósmico. Grupos de jóvenes visitan ceremonialmente las casas del pueblo y enseñan una rama verde, un ramo de flores, un pájaro. Se trata del signo de la inminente resurrección de la vida vegetal, el testimonio de que el misterio se ha cumplido, de que la primavera no tardará en venir. La mayoría de estos ritos tiene lugar con anterioridad al "fenómeno natural" de la primavera735.

La escultura Brote736 (1998) parte de la idea de que el arte (en este caso, la escultura) es un medio capaz de transformar física y realmente el propio cuerpo del artista737. En este caso observamos, una mano reptante dispuesta en el extremo de un brazo seccionado y con brotes bulbares que da cuenta de estas

\footnotetext{
734 BAZÁN, Homero Gibrán, "El mundo estético de Inmaculada Abarca", en Exce/sior, México, D.F., 19, noviembre, 1998.

735 ELIADE, Mircea, Lo sagrado y lo profano, op. cit., p. 112.

736 La escultura Fruto (1998), junto con la de Brote (1998), pasaron a formar parte, por adquisición, de la colección del Fondo de Arte Contemporáneo de la Universitat Politècnica de València, en los años 2003 y 2006, respectivamente.

737 Con el tiempo, los esfuerzos físicos que requieren algunos procesos escultóricos han producido en nuestro cuerpo ciertas huellas -operación del túnel del carpo en ambas manos- que han inspirado formal y conceptualmente esta pieza.
} 
transformaciones, presentando una cicatriz realizada en la muñeca de la que brota lo creativo -representado por el elemento vegetal (hierba)-. Como apunta José Miguel García Cortés en relación con algunas culturas primitivas, en este tipo de piezas se vislumbra una fusión entre el medio y el sujeto que borra los límites entre ambos:

Los pueblos Canacos ligan su cuerpo al universo, entrelazan su existencia a los árboles y a la naturaleza. El cuerpo aparece como otra forma vegetal, o el vegetal como una extensión natural del cuerpo. Así encontramos que existe una misma palabra (Kara) para designar la piel del hombre y la corteza del árbol, y otra (Pié) con la que se refieren a la unidad de carne y músculos, y a la pulpa y hueso del fruto. La misma palabra sirve para nombrar el esqueleto humano y el corazón del bosque738.

La dimensión del ser va más allá de los límites del cuerpo, una idea en la que como en la tradición taoísta -afirman Albelda y Saborit739- se percibe la disolución del ser en la Naturaleza para construir un ser único y no escindido. Por último, los desplazamientos, la migración y la pérdida del sentimiento de pertenencia a una tierra dan origen a la escultura llamada Raíces (1998) en la cual podemos observar un bronce que simula como si de la espalda de la artista surgen raíces que hipotéticamente nos anclan a un lugar para permitirnos seguir creciendo. La fragmentación del cuerpo humano enlaza -dentro del arte postmoderno- con la tendencia a considerar el cuerpo humano como un campo de batalla en el cual se revisionan, tanto la concepción del mismo, como su relación con todo lo que le rodea. Como apunta José Miguel García Cortés, la unidad del cuerpo considerada como tal hasta hace poco, se ha resquebrajado, dando lugar a un sentir "esquizofrénico y fragmentario incapaz de recuperar la unidad perdida":

A finales del siglo XX los fragmentos del cuerpo humano han adquirido una profunda carga metafórica, se han convertido en asaltos psicológicos, sociales, políticos y físicos a la integridad del ser, a su identidad. El desazonante aislamiento de los órganos corporales enfatiza la vulnerabilidad de nuestros cuerpos 740 .

Para este tipo de esculturas se tomaron registros, mediante moldes de escayola, de fragmentos del cuerpo de la autora. Estas piezas ofrecían dificultades técnicas específicas: la mayoría de ellas, a pesar de tratarse de un procedimiento de reproducción escultórica (moldes) presentaban cierta complejidad. De los moldes se obtenía una o varias ceras con las que se trabajaba, incorporando elementos vegetales naturales incrustados (raíces, espinas y hojas). Finalmente, después del trabajo de modelado en cera directa, las piezas se fundieron en bronce. La paradoja de trabajar en bronce -sistema de reproducción en seriecon la finalidad de obtener una pieza única, nos remite a la idea fundamental de

738 GARCÍA CORTÉS, José Miguel, op. cit., p. 28.

739 ALBELDA, José y SABORIT, José, op. cit., p. 63.

740 GARCÍA CORTÉS, José Miguel, op. cit., p. 237. 
la escultura como proceso y al concepto de arte efímero ya que, en el proceso de la quema de las ceras cabía la posibilidad de que se perdiera la totalidad del trabajo realizado sobre ellas.

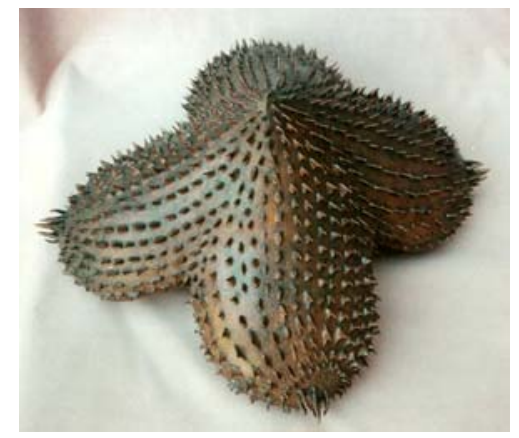

Inmaculada Abarca,

Fruto, 1998.

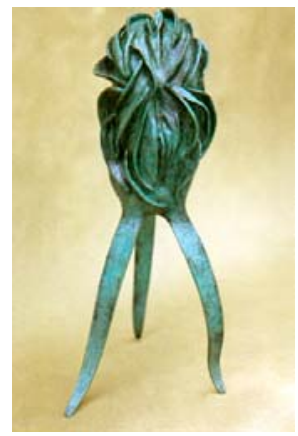

Inmaculada Abarca, Flor, 1998.

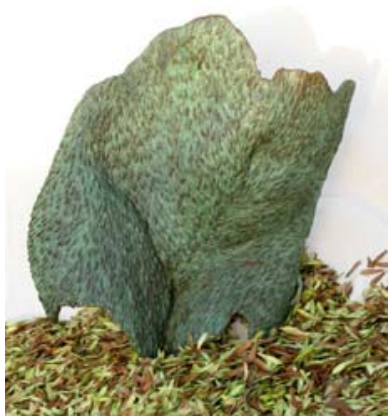

Inmaculada Abarca, Piel, 1998.

La experiencia, nueva para nosotros, de observar la superficie de nuestro cuerpo fuera de nosotros mismos, acaricia la idea de transgredir la bidimensionalidad del registro fotográfico y la lejanía de la imagen que nos devuelve el espejo. Es la idea de Alicia en el país de las maravillas de Lewis Carroll, atravesando el espejo: la imagen de verse a uno mismo más allá del espejo, de forma tridimensional. Se trata de un procedimiento similar al de Penone quien con las impresiones de la piel de sus párpados reproducidas en dibujo sobre la pared, instala una distancia entre sí mismo y la realidad para observarse mejor. Aquí estamos ante una obra, en la que fue necesario alejarse y tomar distancia desplazando la línea de horizonte, para descubrir los espacios y saltos temporales que llevamos en nuestro interior ${ }^{741}$. Penone describe el proceso de realización de los frottages de párpados realizados en 1978, de la siguiente manera:

La imagen se formaba por presión y proyectaba la imagen obtenida, la retrazaba en el espacio, repitiéndola para constituir una serie de acciones, serie que me envolvía por completo. No era sin embargo una imagen encontrada afuera. Mi cuerpo la creaba, y yo creaba el gesto de tocar. Una acción banal, insignificante, sin valor. Además, cuando recorría nuevamente la imagen, no me fiaba de ninguna de las proyecciones. A medida que avanzaba aprendía más sobre mi propio cuerpo que sobre la superficie del muro. Era como caminar en mi piel y caminar en la piel del espacio ${ }^{742}$.

Con parámetros semejantes se produjo la pieza Fruto (1998) en la que, a partir del molde de unos pechos femeninos, se extrajeron dos ceras iguales que al ser pegadas una frente a la otra, conformaron una imagen nueva: cuatro pechos

741 Véase AA. VV., Giuseppe Penone, 1968 - 1998, op. cit.

742 DIDI-HUBERMAN, Georges, Ser cráneo. Lugar, contacto, pensamiento, escultura, Universidad Nacional de Colombia, Facultad de Bellas Artes, Colección Sin condición 17, Bogotá, 2008, p. 72. 
enfrentados, dos a dos, con una apariencia de semilla o fruto diferente: una realidad inventada recubierta de espinas de rosas y de bugambilias que, al ser fundidas proporcionaban a la pieza una cualidad paradójica. Por un lado la pieza, tanto como entidad escultórica (que convoca al tacto) como por el motivo sensual utilizado (pechos) incita a ser tocada y acariciada. Por otro lado, la escultura adquiere ciertas particularidades a causa de las espinas de rosa que, incrustadas en ella y convertidas en bronce, ofrecen la apariencia de que la escultura se protege a sí misma y de que no se deja tocar. En la parte inferior de la pieza -confluencia de los cuatro pechos- se puede observar una encrucijada de formas que de forma íntima hace -por su posición oculta- una referencia sexual.

La escultura Pie/ (1998) presenta una vista frontal y hueca de la superficie de unas caderas, un vientre y un pubis femenino, desplegados, a manera de una nuevo recubrimiento o piel sembrada de vibrantes semillas de fresno. La pieza de bronce se expone sobre un lecho de este mismo tipo de semillas naturales que tienen una simbología específica743. Por último, en el caso de la escultura Flor (1998) encontramos la reproducción de unas vulvas femeninas recubiertas con hojas de eucalipto, fundidas en bronce y todo ello sobre un trípode con forma de hojas. El aspecto y la disposición de estas hojas recuerdan a su vez, los labios que configuran esta parte del cuerpo femenino. En apartados anteriores, hicimos alusión a las flores como órganos reproductivos de las plantas y de cómo por analogía con los órganos humanos, se convierten en elementos de seducción.

Las palabras del crítico de arte Springer, comentan el proceso y la experiencia de percibir el placer, el dolor y el éxtasis transmitido a través de la disección del cuerpo de la artista. Springer describe las esculturas como formas que ven la luz mediante un acto semejante al de parir, y que acaban por convertirse en "esculturas tangibles y sensuales", fraguadas en un encierro interior, donde "la seducción de la superficie del bronce no siempre lleva al placer". Sólo si uno puede entrar en la piel de la tierra o en el fantasma del cuerpo adolorido, se encuentra el sentir femenino de la artista:

Sentir, engañando al ojo, para dar una vuelta completa hasta llegar a la verdad. Salir de si y verse reflejada en el bronce, vestida con espinas, raíces y hojas de pasto. [...]. No estamos ante una escultura que termine en la superficie del bronce, en las curvas convexas de sus torsos o en las concavidades de sus huellas, éstos son tan sólo los datos sensibles que

743 FRAZER, James George, op. cit., p. 786. Las semillas del fresno volador o flögrönn (Sorbus Aucuparia) al ser transportadas muy fácilmente por el viento y los pájaros, crecen en lugares no ordinarios. Están relacionadas con mitologías y supersticiones paralelas a las del muérdago -considerado la Rama Dorada por conservar la vida del árbol al preservarse verde, cuando aquél se seca en invierno-. En algunas culturas como en Suecia, Noruega y Dinamarca relatan que estas semillas son especialmente beneficiosas contra la brujería pues se estima que el hecho de no crecer en el suelo, sino sobre el ramaje de otro árbol, evita que las brujas puedan acceder a él. 
forman el puente hacia el interior. [...]. Cada parte de su propio ser se funde con el entorno poético de la naturaleza. [...] la obra se enlaza con el reino vegetal. El pasto es una extensión del pie, la raíz prolonga el brazo y el busto se cubre de espinas de rosa. Quien pudiera encontrar placer en el tacto tendría que engañarse [...] $]^{744}$.

La estrecha relación que la mujer ha mantenido históricamente con la Naturaleza ${ }^{745}$, ha sido reconocida universalmente en muchas culturas. La antropóloga Sherry Ortner, subraya que esta relación más cercana en la mujer que en el hombre, se produce en virtud de su papel reproductivo en la especie, lo cual la sitúa en los márgenes a veces peligrosos entre la Naturaleza y la Cultura.

La hoja no es la generadora de la hoja, sino que todas las hojas son progenie colectiva del tronco. Así sucede con la raza humana según la concepción del Derecho materno. En ésta, el padre no tiene otro significado que el de sembrador, que cuando esparce la semilla en el surco, desaparece de nuevo. Lo engendrado pertenece a la materia materna, que lo cuida, que le ha dado el ser, y ahora lo alimenta. Pero esta madre es siempre la misma, en última instancia la tierra, cuyo lugar ocupa la mujer terrenal con la sucesión de madres a hijas. Lo mismo que las hojas no surgen unas de otras, sino del tronco, así también los hombres no nacen uno del otro, sino todos del poder originario de la materia, [...] del tronco de la vida ${ }^{746}$.

Como podemos observar en estas referencias, el imaginario colectivo, tiende frecuentemente a visualizar el vínculo mujer-Naturaleza, mediante imágenes que recurren a la naturaleza vegetal. Sin embargo, debemos aclarar que, a pesar del estrecho vínculo entre la Naturaleza y lo femenino, la motivación última de estas piezas, no es reforzar específicamente este nexo, sino hacerlo extensible a todo el género humano, sin distinción de sexo.

\subsection{Hierbas altas y sombras que redimensionan el significado}

Los anteriores planteamientos en torno a la expresión de sentimientos, cuerpo humano y simbología vegetal, desembocan en una proliferación masiva de hierbas que afloran en las siguientes esculturas. La tónica será ahora sustituir formalmente el rastro humano por el elemento vegetal de la hierba, pero estableciendo sin embargo, el mismo discurso sobre los sentimientos humanos. Se trata de una vegetación que se desborda simbolizando la abundancia, la fertilidad, la regeneración cíclica de la vida y que, como sugiere el mismo título

\footnotetext{
744 SPRINGER, José Manuel, Texto inédito proporcionado por el crítico de arte a la autora de esta investigación, México, D.F. 1999.

745 ORTNER, Sherry, "Is Male to Female as Nature Is to Culture?, en QUANCE, Roberta Ann, Mujer o árbol. Mitología y modernidad en el arte y la literatura de nuestro tiempo, A. Machado Libros, S. A., Colección La balsa de la Medusa, Madrid, 2000, p. 213.

746 BACHOFEN, Johann Jakob, op. cit., p. 80.
} 
de la pieza Aires de hierba (2003) genera, como diría el poeta, pequeños "jardines en donde el mismo viento se demora" 747 , trasmitiéndonos una sensación de formar parte de algo, de estar en el mundo.

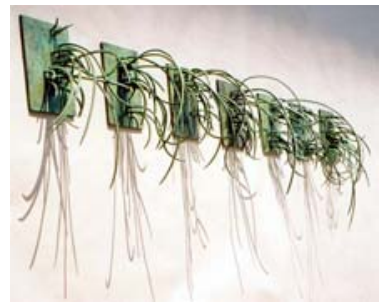

Inmaculada Abarca,

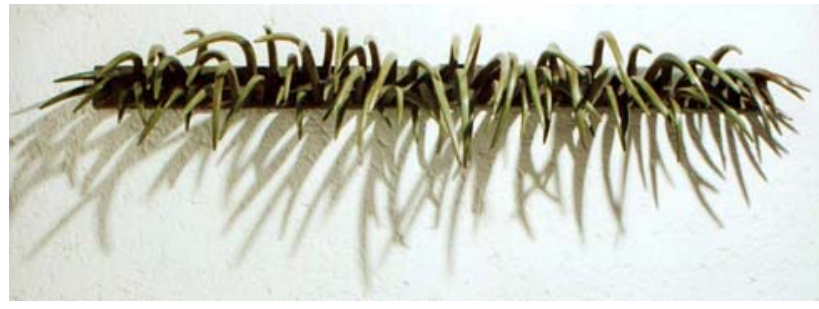

Inmaculada Abarca, Hierbas Altas, 2001.

Aires de hierba, 2003.

Piezas de gran tamaño -dos metros- como Arco de Hierba (2001) y Hierbas A/tas (2001) formaron parte de exposiciones itinerantes tanto en México, como a nivel internacional en EE. UU. y en Puerto Rico. Los textos del catálogo fueron escritos por los críticos de arte Lily Kassner y Antonio Espinoza. Éste último escribe en relación a nuestra obra:

Dueña de un gran oficio y diestra en el manejo de sus materiales, la escultora española Inmaculada Abarca (con 15 años de residencia en México) ha transitado por varios caminos en su aventura tridimensional. Su producción más reciente (de 1997 a la fecha) se centra en la representación del reino vegetal, en un afán de involucrar al ser humano con la naturaleza. Para esta artista, recrear en bronce la hierba y el pasto no es un ejercicio formal de intenciones preciosistas, sino una tarea que rebasa con mucho las dimensiones estéticas para alcanzar la reflexión existencialista748.

En el año 2003, participamos en una exposición colectiva en la Galería de la Secretaría de Hacienda y Crédito Público en México, D.F., con piezas que seguían la misma línea de trabajo en torno a las estructuras vegetales. Una de

\footnotetext{
747 PAZ, Octavio, El fuego de cada día, Seix Barral, Barcelona, 1989, p. 54.

748 ESPINOZA, Antonio y KASSNER, Lily, "Escultura mexicana", en Cuarto Creciente/ Escultores contemporáneos, Museo de la Ciudad, Puerto de Veracruz, México, 2001, p. 11. Véase material de difusión: se editaron varios catálogos, según los lugares en donde se expusieron las piezas. An expression of the New Millenium: Mexico's presence. 11 mexicans sculptors, fue la versión del catálogo que se imprimió para EE. UU., editado por el Instituto Nacional de Bellas Artes, Secretaría de Relaciones Exteriores, Conaculta, México, D.F., 2001. Las esculturas de este proyecto conjunto en el que participaban once escultores, estuvieron expuestas entre 2001 y 2002, en la Biblioteca Nacional de Educación (Centro Cultural del Sindicato de Trabajadores de la Educación); en el Museo de la Ciudad, Puerto de Veracruz; en el Museo de Arte Contemporáneo de Puerto Rico (Estado Libre Asociado de Puerto Rico) y en EE. UU. en el State Trade An Convention Center (Seattle, Washington) y en el Houston Center (Houston, Texas).
} 
las comisarias, Cristina Torres, haciendo alusión al poeta Novalis 749 , equipara estas esculturas con el misterio del arte de la poesía considerado como un hecho cotidiano de la vida. Sus palabras apuntan que la artista, tras desarrollar obras en donde la anatomía humana era el centro de sus planteamientos plásticos, sustituye ésta por la organicidad de estas nuevas piezas que reflejan los necesarios ciclos biológicos de la Naturaleza. Un camino que discurre por la senda de la abstracción figurativa, donde la representación no es de una planta o de un tipo de planta en particular, sino de la esencia de todas ellas, de la fuerza, a la vez que de la delicadeza de la vida, manifestada a través de la esencia del reino vegetal. Torres hace alusión a la pujanza de la vida a través de estas formas:

Los descubrimientos científicos que especialmente en materia de biotecnología sobrecogen y cimientan los dogmas del hombre contemporáneo, confirman la validez del ancestral principio de que la vida se abre paso a como dé lugar, aún contra todo orden sistémico. De igual manera, Abarca impregna sus piezas con una magia vital que tensa cada una de las formas exploradas. Gracias a ello, sus estructuras gozan de una ligereza que libera a la forma para dar paso a una alegoría de las calidades del cuerpo humano: fragilidad, modificación temporal, sensibilidad perceptiva, generosidad. Dicha energía transmutadora no es más que poderosa poesía alterando la naturaleza de las cosas: el bronce es desollado de su densidad para trocarse en material etéreo. Así, un conjunto de sencillas hojas de pasto o una sensual rama de palmera devienen en extractos de mundos alternos donde la percepción se dilata con una fuerte carga emotiva750.

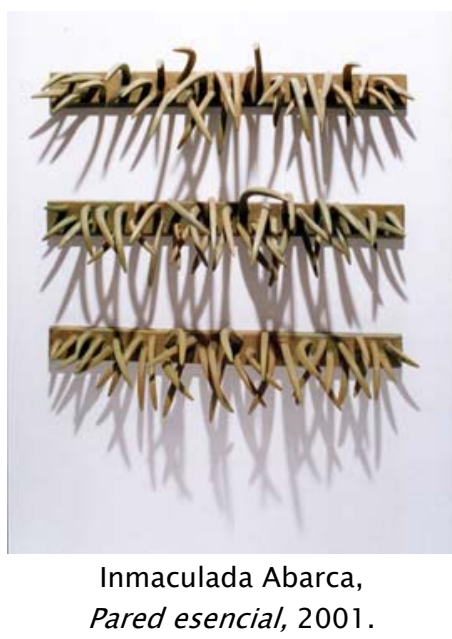

Pared esencial, 2001.

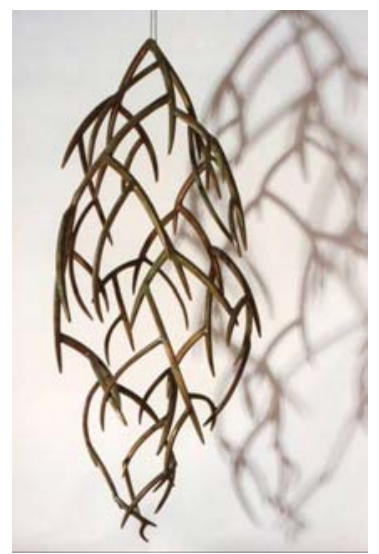

Inmaculada Abarca, Racimo, 2002.

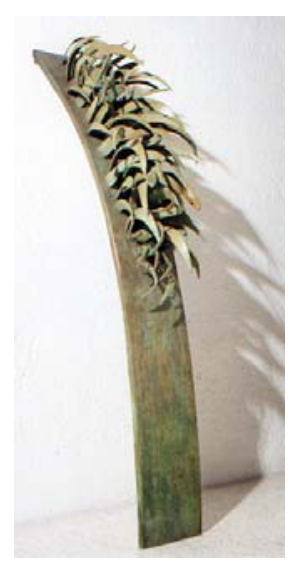

Inmaculada Abarca, Arco de Hierba, 2001.

749 NOVALIS, Granos de polen. Himnos a la noche. Enrique de Ofterdingen, SEP, Colección Cien del mundo, México, 1987, p. 177.

750 TORRES, Cristina, en AA. VV., Tridimensión actual. Inmaculada Abarca, Erik Bächtol, Selma Guisande, Laura Rosete y Shiori Chi, Galería de la Secretaría de Hacienda y Crédito Público, Guatemala, Nº 8, México, D.F., 2003. 
Si la exuberancia es la tónica en todas estas piezas, la idea de crecimiento físico que trasmiten -repetición de patrones y ritmos que se bifurcan- busca equipararse, en el plano humano con el desarrollo espiritual. Esculturas como Hierbas Altas (2001), se vuelven inaccesibles por su colocación -la obra se coloca en la pared, a más de dos metros de altura, lo que le proporciona un sentido de elevación que remite a la aspiración de crecimiento infinito de la vida-. Siguiendo a Torres, estas esculturas estimulan "el espacio creativo de cada uno de los espectadores" y, en su rizomatismo se quieren equiparar al desarrollo humano. Arco de Hierba (2001), Racimo (2002) o Pared esencial (2001), nos hablan del principio vital que se abre paso contra todo orden sistémico. Una geometría orgánica o una matemática biológica, según se quiera ver, que se expresa mediante crecimientos y ritmos expansivos.

En varias ocasiones, algunas de estas piezas, al margen de galerías o museos, se han exhibido en espacios alternativos. Así, formaron parte entre otros, de conceptos expositivos como la muestra colectiva El jardín de las delicias añoradas. Seis escultoras (2001)751, realizada en el jardín central de la Secretaría de Desarrollo Social, en México, D.F. Posteriormente, Racimo (2002) y Arco de Hierba (2001), participaron en la exposición Alter Natura (2004) -de la que hacemos mención en el capítulo segundo- que se ubicó en la plaza exterior del Museo Federico Silva (San Luis Potosí). En este lugar, al apoyarse y colgarse de los árboles de la plaza, las esculturas participaban en un concepto más postmoderno de la escultura, con planteamientos cercanos a una estética de camuflaje.
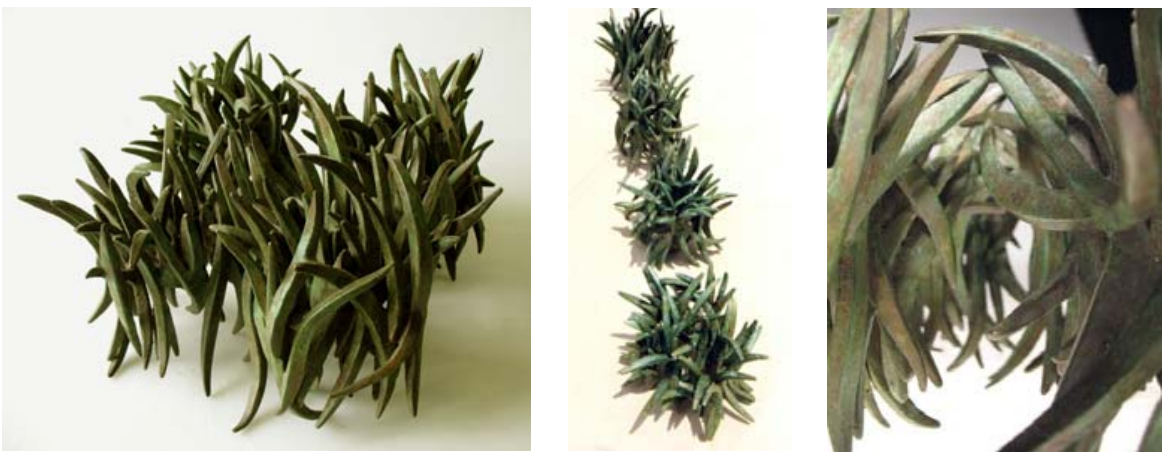

Inmaculada Abarca, Homenaje, 2002.

En un principio, todas estas piezas se elaboraban directamente, explorando las posibilidades del modelado en cera directa, para su posterior fundición como pieza única, con los consecuentes riesgos que este procedimiento conlleva. La investigación en este tipo de piezas tiene su origen en el planteamiento técnico

751 Véase material divulgativo de la exposición El jardín de las delicias añoradas. Seis escultoras, Jardín central de la Secretaría de Desarrollo Social, México, D.F., 20, marzo, 2001. Participantes: Inmaculada Abarca, Ivonne Domenge, Edna Pallarés, Maribel Portela, Naomi Siegmann y Paloma Torres. 
de realizar piezas que, por su específica estructura formal, tuvieran que ser elaboradas directamente en cera. En otros procesos se recurría a la combinación de reproducción y repetición de un molde parcial, del que se extraían sucesivas ceras, así como también, a la inclusión de diferentes elementos naturales como mimbre, henequén o elementos vegetales secos (ramas, raíces, hojas...) y cartón, que pudieran utilizarse en el mismo proceso de quemado de la cera perdida, sin hacer estallar el horno y que fungieran, mediante sucesivos baños, como alma para la cera.

En general, se trata de piezas como Homenaje (2002) a las que por su complicada configuración, no se les podría sacar un molde, y que requieren un procedimiento de modelado directo en cera. Esta manera de experimentar en las diferentes posibilidades de la técnica de fundición en bronce, nos permitió concebir el trabajo en dicho material, partiendo de perspectivas inusuales. La escultura Homenaje (2002), se concibe originariamente, como una superficie de hierba de aproximadamente $3 \times 3$ metros, realizada en bronce, donde parte de la hierba estuviera ausente. Este hueco definiría la forma de un ser humano extendido en el suelo, con los brazos y las piernas abiertas. Si bien esta pieza, por dificultades técnicas, no llegó a realizarse, marcó la pauta, para la forma que tiempo después, tomaría Hombre vegetal(2006), en la exposición Còrpora $i$ natura (Museo de I’Almodí, Xàtiva).

Desde 1990, habíamos estado experimentando en la maleabilidad de la disposición de las partes de una escultura, para configurar diferentes formas de la misma752. Homenaje (2002) se configuró mediante cuatro bloques de hierba de bronce que podían intercambiarse entre sí formando, según las necesidades expositivas y la intención del montaje, un cuadrado de hierba o una hilera de pequeñas matas que podían disponerse tanto en horizontal, como en una pared de la que parecían surgir. Sobre la complementariedad de las partes en una escultura, Jean-François Pirson recuerda la importancia de la relación ente las partes y el todo:

El análisis estructural considera el objeto como un conjunto de elementos interdependientes, un sistema donde todo se entrelaza. Cualquier modificación que afecte a una de las partes del sistema repercute en su totalidad e, inversamente [...]753.

Todas estas piezas tenían ya entonces el marco referencial, de la observación del mundo vegetal en relación a sus propiedades proyectivas. Frente a la deshumanización de las grandes ciudades y la falta en ellas, de zonas verdes libres o no domesticadas y, por el contrario, la aparición de zonas verdes perfectamente delimitadas por un urbanismo despótico, este tipo de proyectos giraba en torno a la conceptualización de un Jardín interior que nos permitiera

752 Véase material divulgativo de la exposición Inmaculada Abarca, Galería Kin, México, D.F., 4, mayo, 1994. Texto de SPRINGER, José Manuel, "El espejo de piedra".

753 PIRSON, Jean-François, op. cit., p. 18. 
ejercer una relación entre el mundo vegetal y el humano, invitándonos a concebir una convivencia más equitativa entre ambos.

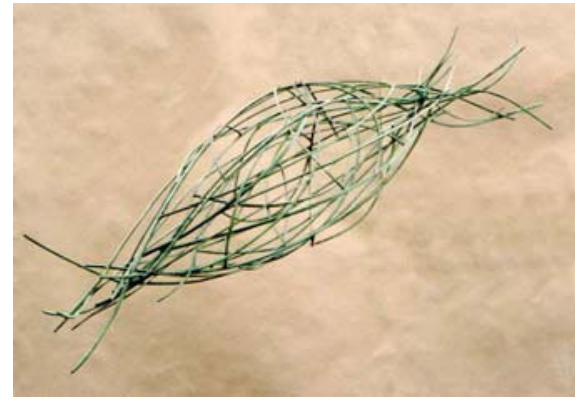

Inmaculada Abarca,

Tejiendo brisas, 2003.

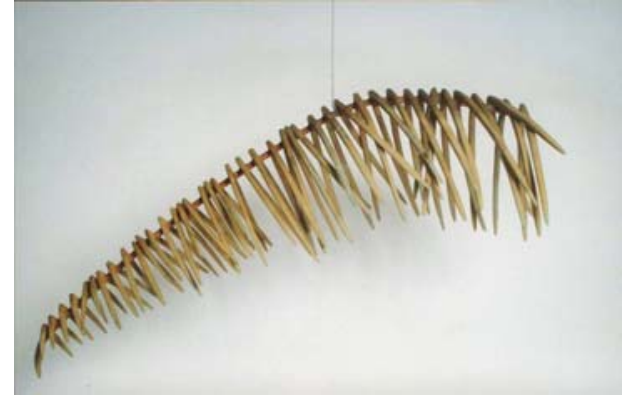

Inmaculada Abarca,

Recuerdo del Paraíso, 2001

Como apuntábamos en el primer capítulo, una de las características principales del mundo vegetal es la búsqueda de la luz, de forma que en este rubro, las esculturas reclamaban también para sí, la alegoría del uso de la luz para poder ser percibidas en su totalidad. En general, se trataba de esculturas como Racimo (2002) o Pared esencial (2001) que utilizan las sombras y la específica incidencia de la luz sobre ellas, para redimensionar la percepción de las mismas, así como el espacio físico circundante. Este espacio se maximiza con la luz proyectada sobre las piezas al generar sombras amplificadas de las mismas, de manera que la materia interactúa con el espacio a través de la luz, generándolo, transformándolo y redimensionando no sólo la escultura, sino la idea vegetal y expansiva que daba origen a la misma.

Algunas esculturas, a pesar de su peso, se presentan colgadas del techo con un cable de acero, de manera que el espectador puede transitar entre ellas. Siguiendo a Maderuelo, podemos relacionar estas nuevas formas de exponer la escultura con las ideas en torno a la pérdida del pedestal en la historia de la escultura. Pero, por otra parte, formalmente nos llevaron a la conceptualización de un jardín que, como ya sabemos, es el producto depurado de nuestra historia cultural. Siguiendo a Maderuelo, el jardín es una "heterotopía, un lugar fuera de la realidad, es un lugar donde se encuentran todos los lugares"754, imagen representativa del eterno anhelo de paraíso del ser humano.

Las alusiones a este profundo afán humano se traducen en piezas como Recuerdo del paraíso (2001) o Tejiendo brisas (2003) que se convierten en metáforas poéticas de acciones humanas que, a su vez, tienen su eco forma en el mundo vegetal. La primera nos hace viajar a la idea de un paraíso perdido en donde metafóricamente, hubiéramos podido apropiarnos de un fragmento del mismo, trayendo con nosotros a la vuelta de este hipotético viaje, el souvenir o recuerdo de una hoja de palmera. 


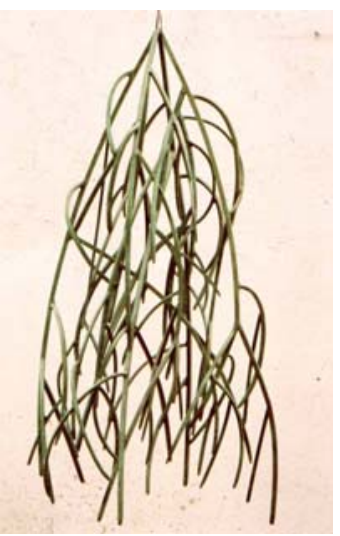

Inmaculada Abarca,

El romance del manglar, 2003.

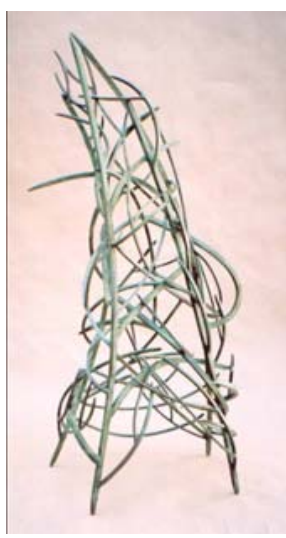

Inmaculada Abarca,

Tálamo, 2003.

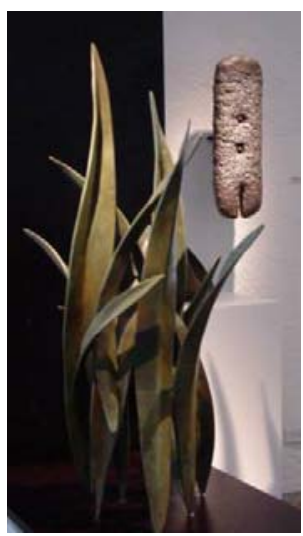

Inmaculada Abarca, Nostalgia, 2001.

Tejiendo brisas (2003) nos habla de uno de los oficios del hombre, atribuidos generalmente a la mujer, más antiguos: el de tejer, coser, urdir y con ello, sinestésicamente hace corresponder la acción humana, con la acción del viento sobre la hierba, de manera que siguiendo a Francisco Calvo Serraller, "el andamiaje de nuestra sensibilidad es de naturaleza sinestésica y funciona por correspondencias"755, se recrea la sensación de libertad que nos produce la percepción de la brisa fresca sobre nuestro cuerpo y en general, en nuestras vidas, para construir una metáfora vegetal del movimiento.
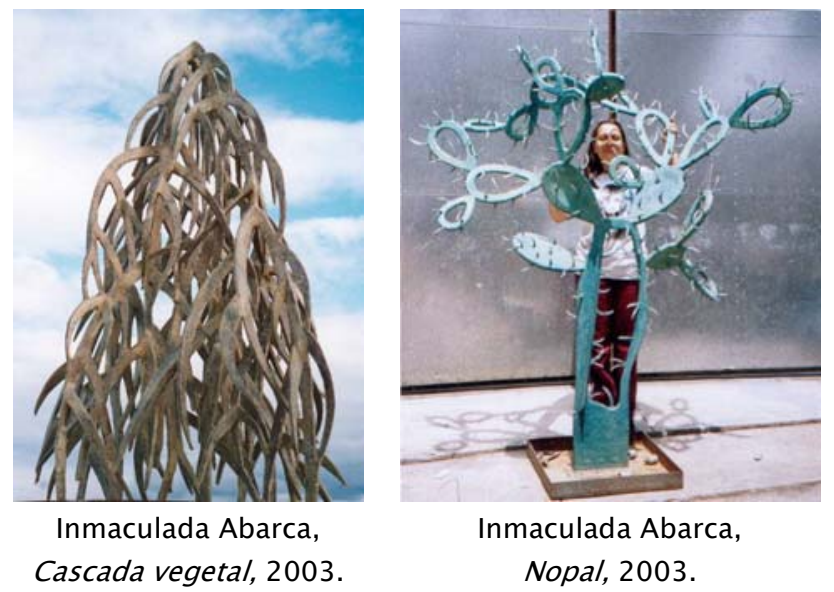

En esta línea vemos cómo, de nuevo las propiedades proyectivas se perciben en piezas como Nostalgia (2001), donde la representación de una simple planta756 -su forma aparentemente cortante, su estructura repetitiva y su textura

755 CALVO SERRALLER, Francisco, La senda extraviada del arte, Ensayos sobre lo excéntrico en las vanguardias, Mondadori, Madrid, 1992, p. 22.

756 Planta llamada Espada de San Jorge o Sansevieria trifasciata de la familia de las Agavaceae, una planta crasa con hojas largas y verticales en forma de espada. 
consistente- se convierten en recurso para hablar del dolor que puede producir la ausencia, hablando tanto del sentimiento humano, como de la totalidad de la Naturaleza.

Las ramas que crecen en configuraciones vegetales exuberantes, típicas de los manglares conforman desarrollos que nos hablan del fluir constante de la vida en piezas como El romance del manglar (2003), Cascada vegetal (2003), Nopal (2003)757 y Tálamo (2003). Este sentir vegetal consigue contaminar también objetos relacionados directamente con usos humanos. Así, unos zapatos de tacón, elemento prototípico de la feminidad, se cubren en Cenicienta o Los malos pasos (2005), de hierbas puntiagudas que nos hablan con irónica ambivalencia de la bondad o de la maldad de este tipo de complementos, apuntando en la denuncia del fetiche, a una cuestión de género.

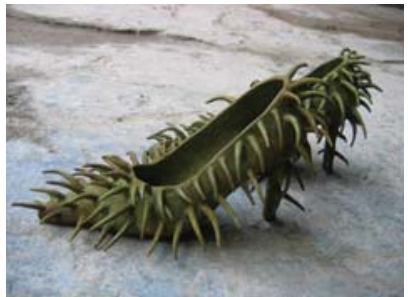

Inmaculada Abarca,

Cenicienta o Los malos pasos, 2005.

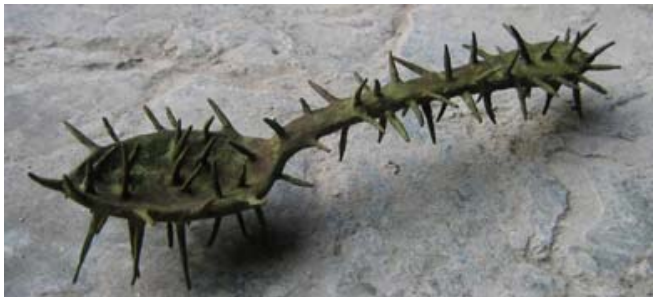

Inmaculada Abarca,

De alimentos y otros menesteres, 2005.

En De alimentos y otros menesteres (2005) observamos una gran cuchara recubierta de espinas. En principio podría tratarse únicamente de un objeto absurdo puesto que la cuchara no puede utilizarse con la función para la cual está habitualmente pensada. Su intención es hablarnos de acciones y actitudes humanas que, si bien aparentemente se consideran beneficiosas, como el necesario acto de alimentarse o comer, podrían sin embargo llegar a ser perjudiciales: no siempre te nutre aquello que comes o aquello de lo que te alimentas, refiriéndonos a ocupaciones humanas que, en realidad no desarrollan ni a la persona, ni al espíritu. Observamos cómo la naturaleza del elemento vegetal nos permite utilizar tanto sus cualidades intrínsecas como las propiedades proyectivas para construir discursos poéticos en donde ambas se extrapolan y entremezclan.

\subsection{Rizomas y epífitas que se reproducen en el tiempo.}

Desde 1997, hemos desarrollado proyectos y realizado piezas que tienen relación con lo vegetal, analizando la relación que este elemento tiene con lo humano. Como ya hemos visto, de estos proyectos, varios son los que muestran estructuras únicamente vegetales sin embargo, no hay que olvidar el vínculo y la metáfora que en estas esculturas, relaciona a este elemento con lo humano. La

757 Véase AA. VV., Nopal urbano. Visión de 78 artistas, Impronta editores, México, D.F., 2004, p. 11. 
mayoría de las piezas estaban realizadas en bronce, pero a partir de la intervención artística758 Homenaje (2004) realizada en el castillo de Denia (Alicante), se utilizó un material plástico (bridas o abrazaderas de electricista), que generó un nuevo discurso formal y conceptual entre la hierba, lo vegetal y lo humano, entre lo natural y lo artificial.
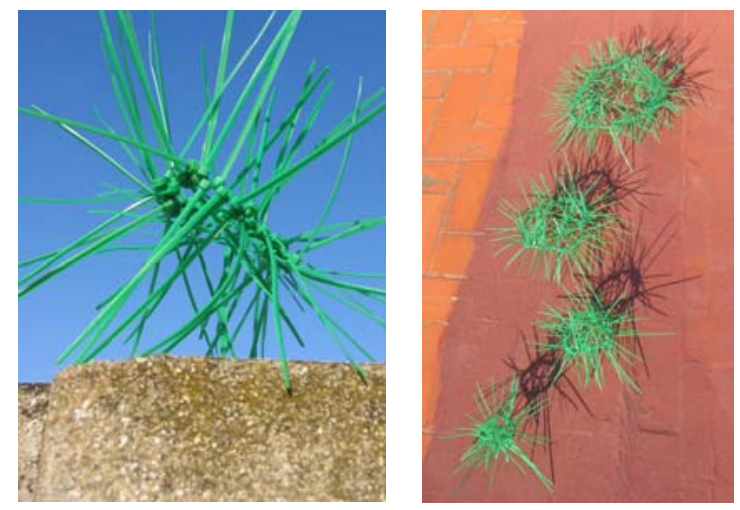

Inmaculada Abarca, Homenaje, 2004.

En este caso, la relación formal del material con la hierba se potenciaba por el color y la multiplicidad de elementos. La importancia del uso de este material radicaba en que establecía interesantes conexiones entre el arte y la industria de elementos manufacturados. Esta vía, permitía explorar formas de transgredir la función habitual de un objeto o elemento y encontrarle una nueva utilidad al punto que, una vez realizada la pieza, es inevitable no relacionar el material con el proceso artístico y la idea vegetal desarrollada. La superficie a ocupar era aproximadamente de sesenta metros cuadrados, para los que se realizaron doscientos treinta y nueve círculos de pasto artificial hecho con bridas, sujetas unas con otras con alambre plastificado. En total se usaron casi cien mil bridas de diferentes longitudes, lo cual daba un mayor dinamismo a los círculos que aparentaban ser de hierba real.

La propuesta de intervención estética estaba concebida para interactuar específicamente con el paisaje mediterráneo del castillo de Denia. Se trata de una reflexión poética, formal y simbólica sobre la hierba que, desde su sencillez, nos habla de todo aquello que crece y se reproduce aún en las condiciones más inhóspitas. Así, en un túmulo de piedras que, de alguna manera nos remite a las ruinas de un pasado y a cierto concepto de pérdida, deterioro y demolición, este nuevo verdor aunque artificial, nos habla de la voluntad de renacer, de ser y existir contra todas las dificultades.

758 ABARCA, Inmaculada, "Homenaje", en AA. VV., Intervencions plàstiques a la Marina, Consorci de museus de la Comunitat Valenciana, Generalitat Valenciana, 2004, pp. 196-199 


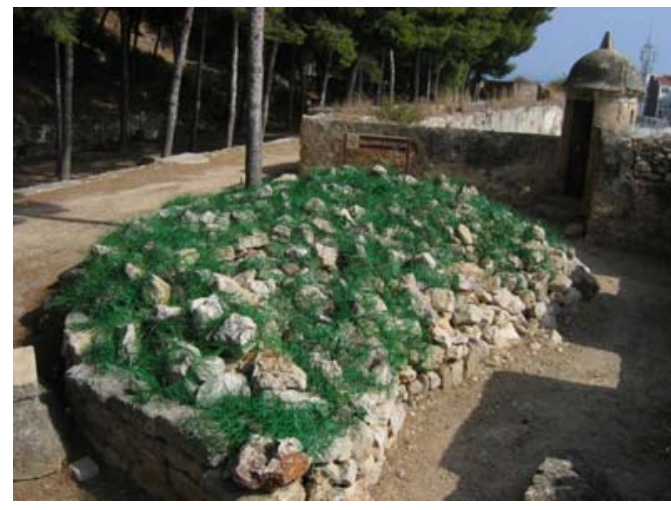

Inmaculada Abarca, Homenaje, 2004.

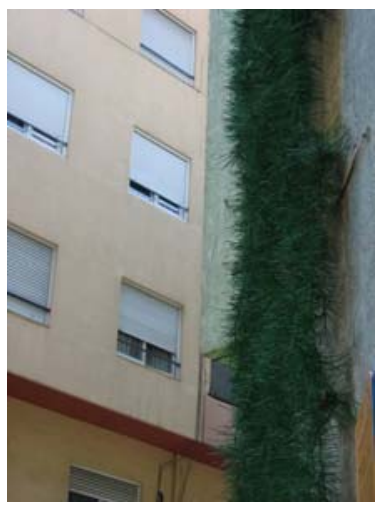

Inmaculada Abarca,

Pared vertical, 2005.

La idea retoma el diálogo formal con la hierba, con las hojas de los pinos circundantes, con el color y el olor al que éstos nos remiten, convirtiéndose en una metáfora-simbiosis: la hierba como metáfora esencial de la relación entre la Naturaleza y el hombre, entre lo vegetal y lo humano. Para Fernando Castro Flórez la intervención tiene una percepción dual:

El túmulo de piedra e hierbas de Inma Abarca remite tanto a la conciencia de que estamos en demolición cuanto a la esperanza depositada en la capacidad expansiva (nombrada por ella como crecimiento rizomático) de la naturaleza759.

La hierba como elemento vegetal que recubre y que aparece en cualquier lado, tiene en sí todas las reminiscencias de la vida. Mediante su característico crecimiento rizomático nos habla de la exuberancia, de la capacidad de expandirse de una manera creativa, de fertilidad, de renacimiento, de sobrevivencia, de camuflaje. Por todo ello, en definitiva, la pieza es un homenaje a todo lo pequeño, a todo aquello aparentemente intrascendente y sin embargo imprescindible, una metáfora analógica de una necesidad.

La utilización de un material artificial sobre un paraje natural construye una paradoja. Así, la pieza se asienta en la tríada natural-artificial-natural, es decir que, partiendo del paisaje y del entorno natural, se trabaja mediante lo artificial (recordemos que toda intervención humana es artificial), generando el recuerdo de lo natural y construyendo la memoria del tiempo en nuestras vidas. La específica época estival en la que se realiza la pieza, permite que el verdor artificial de la pieza destaque sobre el resto de la hierba que crecía en los alrededores que estaba seca y amarilla. Esta obra, como otras realizadas posteriormente en las que se han utilizando materiales procedentes de la industria, se inserta conscientemente en la tendencia actual de reconstruir lo natural a partir del artificio, aceptando el mismo, como parte irrenunciable y

759 CASTRO FLÓREZ, Fernando, "Escándalo es un escándalo. [Con una entonación sobradamente conocida]", en AA. VV., Intervencions plàstiques..., 2004, op. cit., p. 40. 
característica del ser humano. Este procedimiento, como metáfora de "la liberación de lo natural desde el fondo mismo del artificio" tiene la voluntad de eliminar las fronteras entre ambos conceptos -natural y artificial- haciendo alusión a las denominadas poéticas de la restitución de las que nos habla Albelda. Recordemos lo que señala Albelda en referencia al árbol desbastado (Albero di dodici metri verticale, 1982) presentado por Giuseppe Penone en el vestíbulo del Museo Guggenheim:

[...] este árbol supone un valioso ejemplo de nuestra tendencia a reconstruir lo natural a partir del artificio -una obra de arte que aparenta ser Naturaleza, es un nuevo guiño a la disolución de las fronteras- y que, por tanto, es digno de ser considerado como un gran símbolo760.

De forma similar en Homenaje (2004), podríamos percibir lo que Albelda denomina, "una renuncia metafórica a la autoría", expresada en el "deseo manifiesto de confundir la obra con el natural clásico, ser lo mismo, una forma de participar de la misma esencia". Dado el carácter de intervención en el espacio comunitario, esta obra, en opinión de la escultora Jeannette Betancourt, se contextualiza en el territorio de lo público:

\section{[...] es una apropiación que marca cambios fundamentales en la continuidad temática de esta escultora abocada por años a la recreación del mundo vegetal. Primero adopta un nuevo soporte: cinchos de plástico que se utilizan para amarrar cables eléctricos. Segundo, rapta el espacio para proponer una nueva realidad temporal mediante un acto de humanización de la naturaleza761.}

Siguiendo el mismo patrón y concepto, la obra Pared vertical (2005) fue colocada en una de las paredes exteriores del parking de Canalejas, en la ciudad de Alicante, dentro del evento In urbe, Intervenciones urbanas762. Aquí, se plantea de nuevo la metáfora de la relación entre lo humano y lo vegetal, y su vinculación dentro del entorno público de la ciudad. La intervención en el entorno de la ciudad propone un cambio de perspectiva en la mirada: de la habitual imagen de la hierba sobre un plano horizontal a su percepción en la inusual vertical del edificio, la sorpresa convierte esta alegoría de la Naturaleza en una nueva forma de percibir lo natural, lo verde o lo vegetal que, de esta manera vuelve a conquistar los espacios que en otro tiempo le fueron propios.

\footnotetext{
760 ALBELDA, José y SABORIT, José, op. cit., pp. 160-161.

761 BETANCOURT, Jeannette, "El campo expandido: tridimensión y su geografía de transgresión. Naturaleza incierta”, en Milenio, Vol. 12, Puerto Rico, 2008, p. 84. Ponencia presentada en la Escuela de Artes Plásticas de Puerto Rico (1, septiembre, 2005), Disponible en red: <http://www.uprb.edu/milenio/milenio-XII.htm>, [Consulta 22, julio, 2010].

762 Véase AA. VV., In urbe, Intervenciones Urbanas, Ayuntamiento de Alicante, Concejalía de Juventud, Alicante, 1, julio-12, septiembre, 2005.
} 
Construimos así una suerte de heterotopía763. Una metáfora del tejido social de las migraciones sociales contemporáneas se hace visible en la invasión vegetal del edificio. Planteando la paradoja de natural y/o artificial, este verdor artificial en el entorno también artificial de nuestras ciudades mostraba la voluntad de renacer, de ser y existir contra todas la dificultades.

Esta pieza recurre, como en la obra de los artistas Perejaume764 o de Penone, a la metáfora de volver a poner-acción simbólica de devolver al mundo natural aquello que le fue robado-. En gran manera, este tipo de elaboraciones conceptuales, muy alejadas de las metáforas de dominio765 tienen su origen en la diferente conceptualización de la Naturaleza. Si en otro tiempo, la Naturaleza y su representación eran fundamentales para establecer la relación del ser humano con su entorno, en la actualidad, tras los excesos de antropización del territorio, la crisis ecológica y el cambio climático, este vínculo se ha modificado, pasando necesariamente a conformar un compromiso de unicidad con la misma. Esta interdependencia ha llegado a ser imprescindible en todos los aspectos de la vida, en particular, en el contexto artístico, estos nuevos nexos han transformado profundamente la representación habitual de la Naturaleza, generando una concepción diferente de la misma.

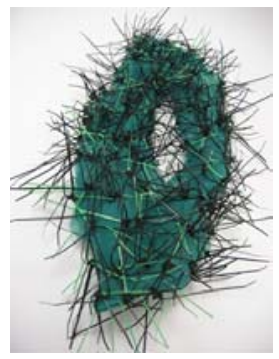

Inmaculada Abarca,

Hoja-Vulva,

2005.

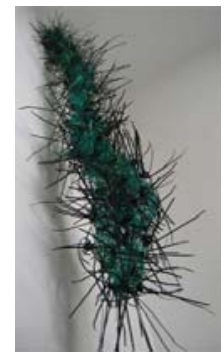

Inmaculada Abarca,

Gusano-Falo, 2005.

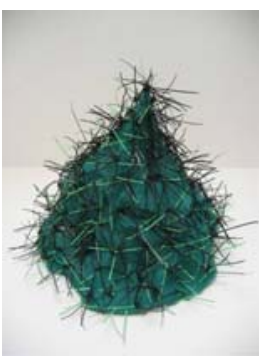

Inmaculada Abarca,

Montaña-Pecho, 2005.

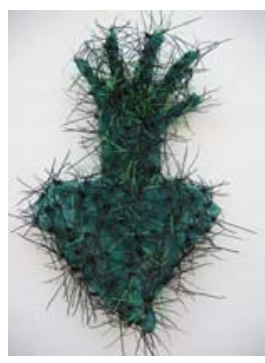

Inmaculada Abarca,

Mano-Corazón, 2005.

En el año 2005, nuestra obra participó en la exposición colectiva Revisioning Nature en la SAC Gallery de la Universidad de Stony Brook, (Nueva York). Comisariada por Keith Miller, esta muestra exploraba la importancia que, a lo largo de la historia del arte, ha tenido la relación entre Arte y Naturaleza. Las diferentes obras expuestas daban cuenta de la variedad de enfoques de los artistas participantes. En opinión del comisario, en cada caso lo que se observaba era un pequeño ejemplo de lo que podría entenderse como un "retorno a lo natural después del exceso de la modernidad"766.

763 Formación de tejidos u órganos normales en lugares no habituales, presencia de un tejido en un lugar distinto del que le corresponde.

764 PEREJAUME, "Parques interiores: La obra de siete despintores", en MADERUELO, Javier (dir.), El paisaje: Arte y naturaleza..., op. cit., pp. 165-171.

765 ALBELDA, José y SABORIT, José, op. cit., p. 86.

766 MILLER, Keith, "Revisioning Nature", Disponible en red <http://www.keithmiller.com/curatorial/nature/index.html>, [Consulta 28, agosto, 2011]. 
En nuestro caso, participamos con una serie de iconos tridimensionales (mano, corazón, gusano, vulva, montaña...) que interrelacionaban de manera aparentemente irracional, la abstracción naïf de fragmentos humanos, con la proliferación de elementos vegetales. Todos ellos estaban realizados con red de plástico y bridas de electricista, de manera que trasmitían una sensación de reproducción masiva y de crecimiento natural, una especie de hibridación entre seres, tanto humanos, como animales y vegetales.
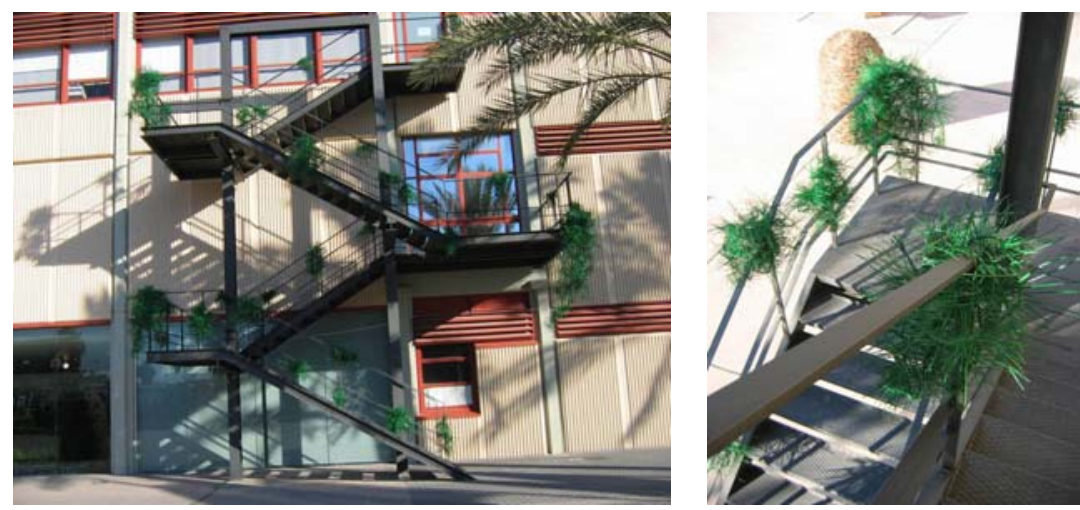

Inmaculada Abarca, Epífitas, 2006.

En 2006 y, entre otras circunstancias, como fruto de la presente investigación, se llevó a cabo en la galería del Vicerrectorado de Cultura de la Universitat Politècnica de València la exposición Germinal767, donde además de participar como artista, ejercimos como co-comisario de la exposición, invitando a participar en la misma a las artistas mexicanas Yolanda Gutiérrez y Sofía Táboas. Para esta ocasión y, siguiendo la exhortación de Deleuze y Guattari, materializamos la idea de expandir el uso y la repercusión de una pieza haciéndola maleable y confiriéndole capacidad de transformación. Las bridas empleadas en Homenaje (2004) y Pared vertical (2005), se transformaron en varias piezas posteriores en el proceso de concebir la escultura, no como una entidad cerrada, sino como una obra relacional que muda, se conecta y se reconfigura en diferentes proyectos. Este planteamiento dio paso a la reutilización de los elementos básicos de la pieza para convertirla en otro tipo de invasiones que, evitando la fotografía, el dibujo o el calco como dice Deleuze, la desterritorializaran, permitiéndonos utilizarla con la fuerza generadora de la conjunción, en un discurso en el tiempo que aún ahora identifica a la pieza:

Haced mapas, y no fotos ni dibujos. Sed la Pantera Rosa, y que vuestros amores sean como los de la avispa y la orquídea, el gato y el babuino [...]. Un rizoma no empieza ni acaba, siempre está en el medio, entre las cosas, inter-ser, intermezzo. El árbol es filiación, pero el rizoma tiene como tejido

767 ABARCA MARTíNEZ, Inmaculada, "Germinal: Arte y Naturaleza", en AA. VV., Germinal. Arte y Naturaleza, op. cit., pp. 25-30. 
la conjunción «y... y... y...». En esta conjunción hay fuerza suficiente para sacudir y desenraizar el verbo ser768.

En este proceso, la pieza Homenaje (2004) fue seleccionada en la Segunda Bienal de Artes Visuales de Mérida (Yucatán, 2004)769, donde se llamó Rizoma. Más tarde se trasformó en Epífitas (2006), en la Universitat Politècnica de València, formando parte de la exposición Germinal e invadiendo en esta ocasión, la escalera exterior de acceso a los despachos del Vicerrectorado de Cultura.

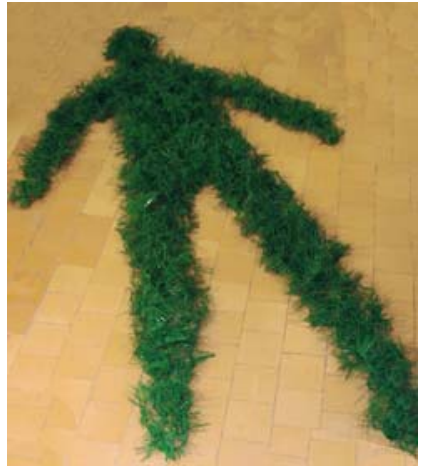

Inmaculada Abarca, Hombre vegetal, 2006.

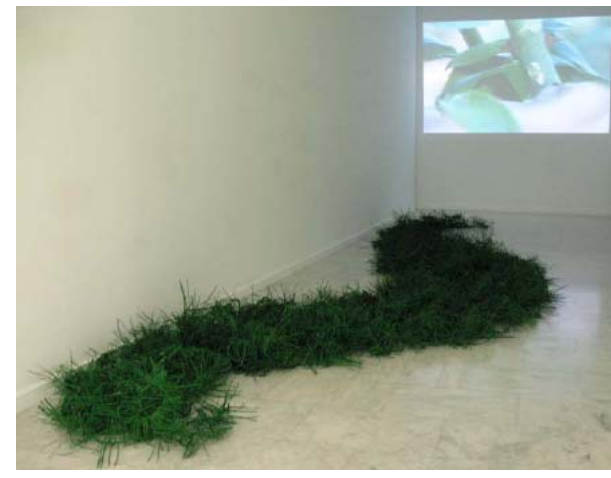

Inmaculada Abarca,

Epífitas en Gandía, 2007.

En el año 2006, organizamos y comisariamos la exposición colectiva y multidisciplinaria de arte contemporáneo Còrpora i Natura. Art Contemporany, en el Museo Municipal de I'Almodí de Xàtiva770. Aquí, con motivo de los planteamientos que dieron nombre a dicha exposición (la relación entre el cuerpo humano y la Naturaleza) los grupos de bridas adquirieron la forma de un ser humano extendido sobre el suelo, dando a entender que el hombre en su totalidad, forma parte del sentido vegetal de la Naturaleza. La pieza estuvo expuesta tanto en el exterior como en el interior del museo, y posteriormente, adquirió una nueva configuración en el interior de la galería de la Casa de la Cultura Marqués de Quirós, en Gandía (Valencia), formando aquí una especie de animal reptante que amenazaba con inundar y repoblar toda la sala.

En el año 2007 esta escultura fue seleccionada para participar en una muestra de arte contemporáneo en México. Esta iniciativa formaba parte de una serie de proyectos que buscaban llevar el arte mexicano a los espacios públicos y de tránsito usual de la Colonia Condesa, una de las zonas más populares de México, D.F. Este ejercicio de experimentación en el que convivieron las artes

768 DELEUZE, Gilles y GUATTARI, Félix, op. cit., pp. 56-57.

769 Véase AA. VV., // Bienal de Artes Visuales de Mérida, Instituto de Artes Visuales de Mérida, Mérida, Yucatán, 2004, p. 58.

770 ABARCA MARTÍNEZ, Inmaculada, "Reflexiones en torno a Còrpora i natura", en Còrpora $i$ natura. Art Contemporany, Museu de L’Almodí, Ayuntamiento de Xàtiva (Valencia), 21, diciembre, 2006-4, febrero, 2007, pp. 11-32. 
plásticas junto con disciplinas como el cine, la música o el video contó con la participación de veintitrés artistas. La intención era que los espectadores se enfrentaran a la creación y a los lenguajes del arte contemporáneo insertados en el ámbito moderno urbano, para con ello, denotar las molestias incómodas que sufrimos los ciudadanos ante los hábitos de los demás. Usted está aquí (2007) 771 , organizado por Neuronal Laboratorio + Creativo S.C. y comisariada por Edgardo Ganado Kim, tenía como finalidad generar una nueva, aunque efímera, cartografía en los Parques España y México de la Colonia Condesa. Las intervenciones artísticas se convertían así en uno más de esos habitantes incómodos que, como los taxis, los vendedores ambulantes, el tráfico lento, o las horas puntas en el metro, se convive en una ciudad como México.

Para esta muestra, la artista Betsabée Romero realizó una instalación llamada No todo lo verde es ecológico (2007). En nuestro caso, las nuevas Epífitas (2007) puesto que la pieza, en un entorno nuevo, se transforma casi por completo- se colocaron en diferentes lugares de un conocido y popular sitio de taxis para construir la metáfora de cómo las plantas, al igual que los humanos, crecen en lugares especiales en los que se dan las condiciones idóneas. Asimismo, ofrecen la lectura de poderse desplazar llevados, en este caso, por los taxis contagiándose así de la movilidad y convirtiéndose, en elementos perjudiciales para ciertos espacios.

Epífitas rojas (Cuscuta epithymum)772 (2007) es otra de las piezas que, mediante el estudio de los comportamientos de las plantas, nos hacen recapacitar sobre la necesitad de visualizar ciertas problemáticas. Los seres humanos necesitamos construir ficciones (parábolas, metáforas) para comprender la realidad; así, esta pieza realizada con plástico (tubo flexible) aportaba, como parte de la pieza, documentación fotográfica de la planta real (Cuscuta). La narrativa funcionaba como una analogía plástica y artificial de la intervención en el paisaje. La obra presentaba una reconstrucción de una realidad vegetal absolutamente natural: el comportamiento invasivo y asfixiante de esta planta filiforme con respecto a sus congéneres. La acción de intervenir en el espacio público de la ermita de Pedreguer773 establecía un paralelismo entre las plantas a las que se hacía alusión, de características y comportamientos atípicos, con ciertos hábitos invasivos del ser humano, cuestionando directamente, la artificialidad también

771 GANADO KIM, Edgardo, "Habitantes incómodos", en Usted está aquí.., op. cit., pp. $15-16$.

772 La denominada Cuscuta Epithymum es una planta epífita de la familia de las Convolvuláceas, se trata de una planta común aunque no muy conocida, cuya floración se produce en primavera y verano. También se conoce como cabellos de tomillo o barbas de capuchino y podemos encontrarla en toda la península ibérica, así como en otras partes del planeta. Se aloja en especies como el tomillo, romero, ajedrea y aliagas. Curiosamente parece tratarse de una planta que huele a sus presas o que toma decisiones, en el sentido de que elige en particular, ciertas plantas sobre las que desarrollarse. Sus pedúnculos filiformes se lanzan sobre otras plantas y la envuelven, asfixiándola.

773 Véase AA. VV., Estiu Art, 2007, Intervencions, Universitat Politècnica de València, Valencia, 2007, pp. 78-81. 
innata del ser humano. La idea pretendía poner en tela de juicio nuestra habitual mirada romántica sobre la Naturaleza. La bondad con la que habitualmente nos inclinamos a percibirla, permite ser compensada comprendiendo circunstancias y prácticas habituales en la misma, como lo son la invasión vital del espacio de unas plantas sobre otras. Sin duda, nuestra relación como humanos con la Naturaleza es muy similar a la de estas plantas. El hacer patentes estos aspectos nos permite reflexionar sobre nuestra propia naturaleza invasora $y$ agresivamente destructiva.

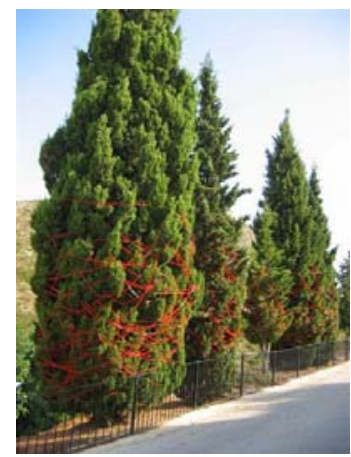

Inmaculada Abarca,

Epífitas rojas, 2007.
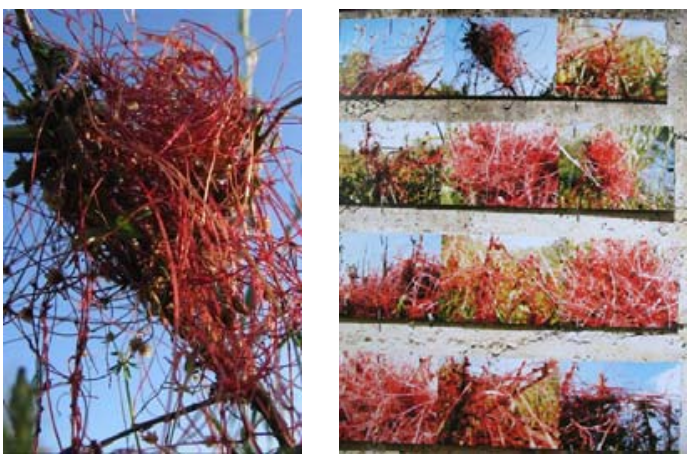

Inmaculada Abarca,

Epífitas rojas (Fotografías de la planta), 2007.

Las intervenciones en la comarca de la Marina (Alicante) realizadas en los últimos años y organizadas por el Grup de Reüll, han sido en este sentido escenarios abiertos para diferentes diálogos entre el público y los artistas. Sin lugar a dudas es importante contar con estas vías de expresión fuera de los espacios habituales expositivos. En este sentido el arte y el artista contemporáneo, han incursionado en la posibilidad de generar nuevos espacios expositivos tanto en entornos naturales como urbanos, que permitan establecer nuevas vías de comunicación con el público no especializado.

La intervención Epífitas rojas (2007) se distribuía sobre treinta cipreses, utilizando para ello, varios cientos de metros de tubo flexible de color rojo y de diferente calibre, que invadían la masa verde de los mismos. Con respecto al material utilizado, la reflexión gira en torno a nuestra costumbre de considerar el plástico como un material pernicioso para nuestro planeta. El uso del mismo en este proyecto pretende mostrar esta realidad que nos es habitual. La intervención se complementa con la presentación de varias fotografías de la planta Cuscuta, tomadas en la zona de Alicante, de manera que permite establecer un diálogo entre lo que es real, lo que es natural y la intervención artificial. Este tipo de piezas pretenden estrechar y potenciar la relación entre acción artística y entorno natural manifestando una voluntad de mayor cercanía con el espectador, a la vez que ponen en evidencia las prácticas artísticas que abogan por una manera más respetuosa de convivencia con nuestro entorno. 

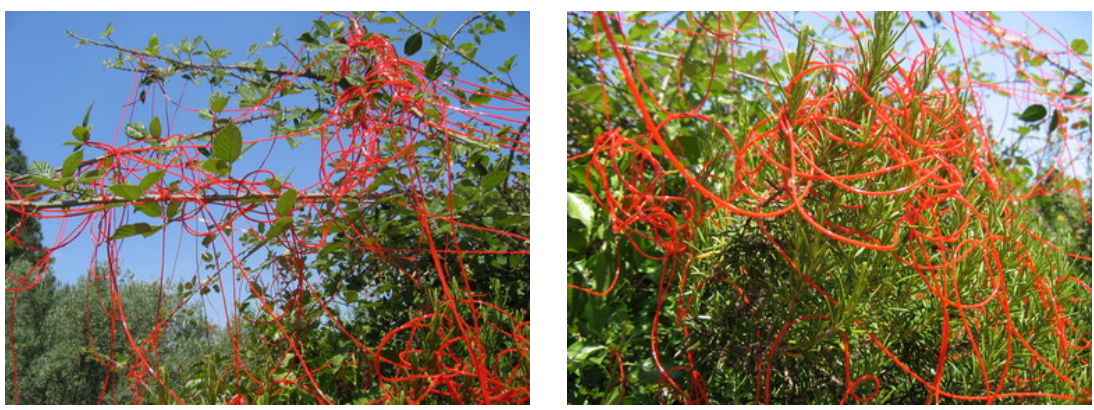

Inmaculada Abarca, Cuscuta Epithymum, 2007.

En el año 2007, en la ciudad de Xàtiva y, en el entorno de una finca particular llamada La Polaca, comisariamos y participamos en la exposición $X$-art. Intervencions plàstiques a la Polaca774. En esta ocasión, en la pieza realizada, Cuscuta Epithymum (2007), se utilizaba un hilo de plástico mucho más delgado que en el caso de los cipreses, lo que le proporcionaba una mayor flexibilidad y organicidad. Los hilos de color rojo, dibujaban un contraste de colores complementarios (rojo sobre verde) dispersándose caóticamente como madeja deshilachada, sobre unas abundantes matas de romero verde.

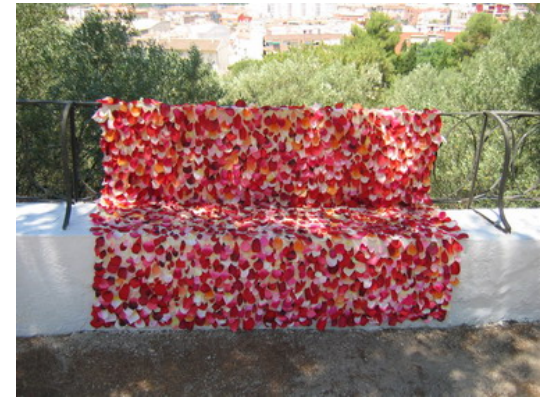

Inmaculada Abarca,

Invitación o la realidad seducida, 2007.

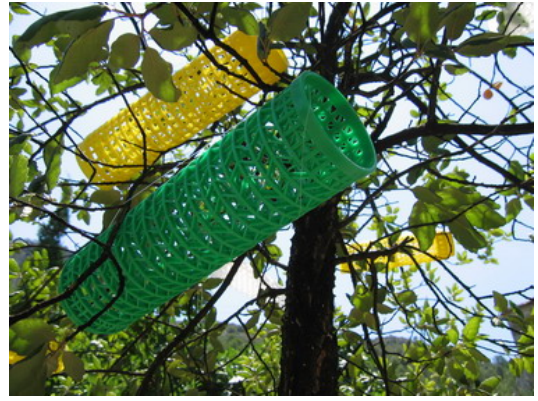

Inmaculada Abarca, Peluquería y reforestación urbanística, 2007.

Otra de las piezas realizadas para esta exposición mostraba una banca recubierta con una tela forrada de pétalos de rosa. Los pétalos fueron desgajados de flores artificiales, rosas de tela procedentes del desecho de flores del cementerio. En esta pieza, como su nombre indica Invitación o la realidad seducida (2007), se encuentra latente la idea de ilusionismo, de confundir la visión, de generar un simulacro que permita sorprender y refrescar la mirada para potenciar la percepción del sentido vital y de alegría existencial a través del color.

774 Véase información relativa al evento X-art. Intervencions plàstiques a la Polaca, Disponible en red: <http://www.xartlapolaca.blogspot.com/>, [Consulta 29, agosto, $2011]$. 

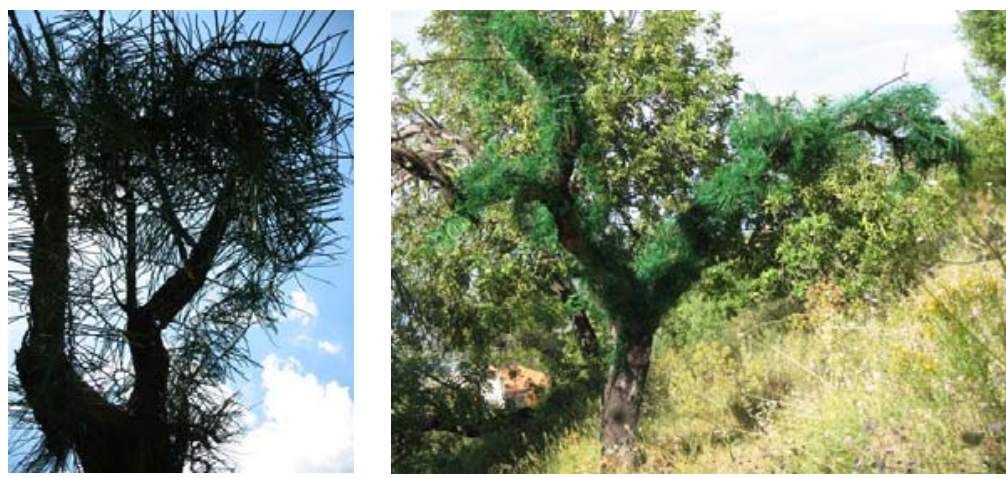

Inmaculada Abarca, Camuflaje, 2010.

Peluquería y reforestación urbanística (2007), jugaba con la ironía y el humor. La acción de colocar sobre el árbol unos rulos gigantes de peluquería, transformaba el mismo en un objeto de ornamentación y, mediante la construcción retórica de esta prosopopeya, el árbol quedaba desprovisto de su función natural, poniendo de manifiesto y denunciando humorísticamente, la burbuja inmobiliaria que ha desmantelado en las últimas décadas una inmensa mayoría del paisaje español. Este tipo de crecimientos desmesurados del ladrillo van acompañados generalmente con escasos o nulos desarrollos de parques mínimamente ajardinados, en donde los árboles destacan por una pequeñez y por la ambigüedad entre lo natural y lo artificial de las podas. Al respecto, apunta Baudrillard que, en la sociedad contemporánea, la tendencia a la personalización o prosopopeya (de la que, minimizando sus efectos, la publicidad ha hecho un uso desmedido), responde a la lógica de la uniformalización de la sociedad, en donde las personas y los objetos adquieren una peligrosa personalidad indiferenciada:

En la "personalización" hay un efecto semejante al de la "naturalización" que podemos ver aplicada por todas partes cuando se habla del ambiente y que consiste en restituir la naturaleza como signo después de haberla liquidado en la realidad. Así es como se tala un bosque para construir en el lugar un complejo bautizado "Ciudad verde" donde se plantarán algunos árboles que darán la imagen de la naturaleza-. Lo "natural" que está presente en toda la publicidad produce un efecto de make-up [...]775.

En el año 2010 y, en la misma dinámica de configurarse como pieza maleable y en constante trasformación, Epífitas (2010) fue expuesta en la ciudad de Orihuela, invadiendo en esta ocasión prácticamente la totalidad de la escalera de acceso a la biblioteca municipal en la exposición colectiva de escultoras: Esculpiendo la Igualdad, 19 Escultoras776. La racionalidad del edificio y la limpieza de sus ángulos y materiales, contrastaban fuertemente con la invasión

775 BAUDRILLARD, Jean, La sociedad de consumo. Sus mitos, sus estructuras, Siglo XXI, Madrid, 2009, pp. 95-96.

776 Véase material divulgativo de la exposición Esculpiendo la Igualdad, 19 Escultoras, Biblioteca Municipal Fernando de Loaces, Orihuela, 10, marzo, 2010. 
vegetal producida por la pieza que se desbordaba sobre las escaleras en el interior del recinto. Era una forma de poner en evidencia la grieta entre Naturaleza y Cultura, sin embargo, el material artificial de las abrazaderas producía una interrogación y un guiño a la mirada, minimizando la ruptura y propiciando el simulacro.
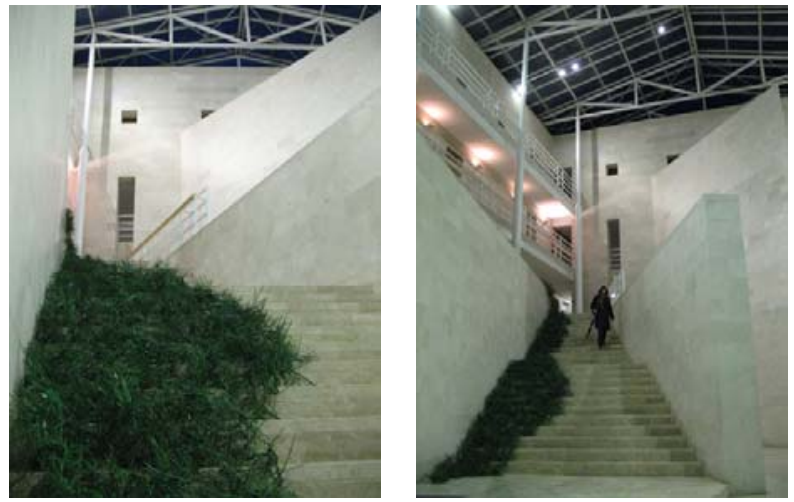

Inmaculada Abarca, Epífitas, 2010.

Mimetismo y camuflaje son estrategias habituales entre los seres vivos que responden principalmente, a la necesidad de preservar la vida, así como la necesidad de integración en una comunidad. En su libro en torno al camuflaje y sus relaciones con el arte contemporáneo, Maite Méndez destaca las cualidades de la Naturaleza como "artista camoufleur"777. Para el ser humano, como ente social, es también necesario e incluso, una cuestión de sobrevivencia, el integrarse o formar parte de un grupo o de un entorno. En general, la idea de disfrazar las apariencias atañe entre otras cosas a los significados relacionados con el camuflaje militar. En particular, el uso del camuflaje por parte del ser humano, se relaciona con el desarrollo y la evolución de la tecnología y las herramientas de combate: el ser menos visible se hizo cada vez más útil.

En principio, el camuflaje -cuya razón de ser es la de ocultar o engañar con eficacia al enemigo- es considerado como el diseño funcional por excelencia. Perceptualmente y casi por accidente, se convierte en una cuestión estética -a pesar de no ser ésta su razón última de ser-presentando así una doble naturaleza, que alienta diferentes paradojas 778. Esta circunstancia ha provocado que algunos artistas transfieran el concepto de camuflaje, del terreno militar al artístico, planteando así cuestiones relativas a la equivalencia entre arte y realidad. La finalidad de este tipo de estrategias presupone el poner de manifiesto, hacer visibles y en su caso desenmascarar, las complejas relaciones entre realidad y ficción o entre arte e institución. De esta manera, por ejemplo, se cuestionan tanto los mecanismos inherentes a las circunstancias sociales y

777 MÉNDEZ BAIGES, Maite, Camuflaje. Engaño y ocultación en el arte contemporáneo, Siruela, Madrid, 2007, p. 24.

778 MÉNDEZ BAIGES, Maite, op. cit., pp. 10-11. 
económicas contemporáneas como al capitalismo de ficción o a la representación de la imagen femenina.

En esta línea, la pieza Epífitas (2010) hacía uso del recurso del camuflaje. En un espacio interior -vinculado específicamente con el saber humano- como es una biblioteca, nos enfrentamos ante un guiño conceptual: la convivencia de la Cultura (representada por el espacio en sí) con una Naturaleza desbordante (intervención vegetal) que asciende por las escaleras. La invasión provoca en el espectador una construcción mental de armonía que se ve contrarrestada por la sorpresa de percibir que lo que ven sus ojos son en realidad, bridas de electricista engarzadas unas con otras.
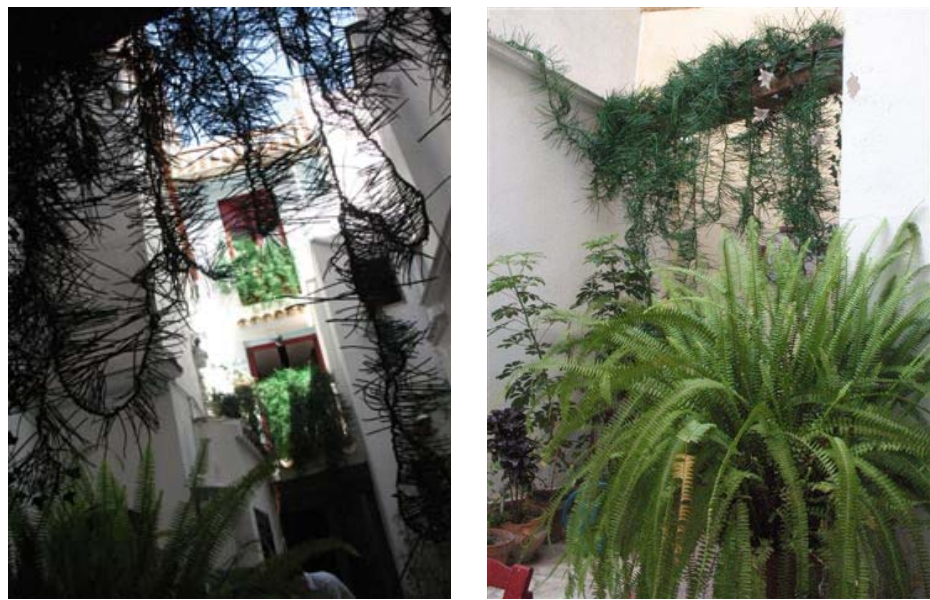

Inmaculada Abarca, Cohabitando con la invasión, 2010.

Posteriormente hemos construido la pieza de manera efímera, como parte integrante del evento Histeria Natural, Parque Temático y Visita Guiada, en Xàtiva, organizado por La Erreria House-of Bent, en esta ocasión la obra se Ilamó Camuflaje (2010). La elección del espacio a intervenir fue realizada con la particular intención de que la pieza, en este proceso de camuflaje, quedara integrada en el paisaje. Así, pasando prácticamente desapercibida, las bridas se colocaron sobre un árbol seco y quemado que, con la colocación del elemento artificial parecía haber reverdecido. A posteriori de la visita guiada, la intervención escultórica se instaló temporalmente en la Casa-Galería La Erreria House-of Bent, colgándose en los diferentes balcones, ventanas y vigas del patio de la construcción, de manera que daba la apariencia de que la casa hubiera sido invadida por una exuberante vegetación que convertía el espacio en una selva. La curiosa convivencia entre las bridas verdes de la obra Cohabitando con la invasión (2010) y los helechos y plantas reales que habían en la casa es, por un lado un guiño a la obra de Jerónimo Hagerman, de quien hemos hablado en esta investigación y por otra, recuerdan el trabajo de los suizos Steiner y Lenzlinger, en la extraña batalla entre plantas naturales y artificiales que se desata en sus obras. 


\subsection{Espinas, paisajes y enramadas por las que transita la vida}

Herederas de la serie de esculturas-híbridos entre el cuerpo humano y el vegetal surgen, a partir de 2003, algunas piezas en las se sigue trabajando con la alegoría del cuerpo humano expresada mediante el estereotipo de la pareja de muñecos Barbie y Kent. Utilizando como excusa la anécdota del cincuenta cumpleaños de Barbie, se juega con el concepto de juguete peligroso realizando una serie esculturas en bronce de ambos muñecos. Notablemente pesadas por el hecho de ser macizas, las piezas de Feliz cumpleaños Barbie o No hay rosas sin espinas (2003) están cubiertas de espinas de rosas fundidas en bronce de forma que nadie puede coger los muñecos, salvo con mucha precaución, convirtiéndose de esta manera en un objeto peligroso.

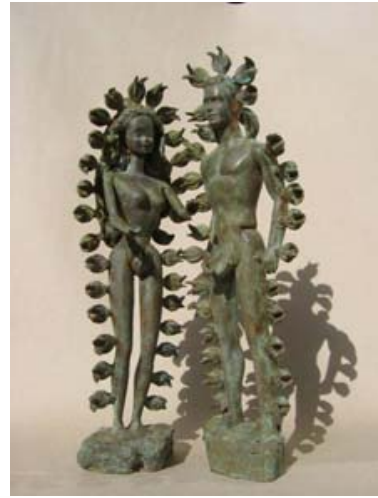

Inmaculada Abarca, Iconos contemporáneos, 2004.

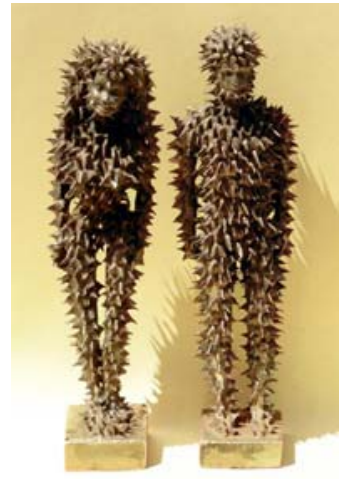

Inmaculada Abarca,

Feliz cumpleaños Barbie o

No hay rosas sin espinas, 2003.

Al emplear las espinas -sistema defensivo de las rosas- y aplicarlas sobre los muñecos, lo lúdico del juguete se transforma en un factor de riesgo. La intervención propone reflexionar en torno al daño que este tipo de muñecos ha generado con el tiempo, sobre las mentes infantiles de las niñas que, seducidas por la imagen ideal de estos estereotipos han enfermado durante su adolescencia -anorexia y bulimia- para conseguir adecuar sus cuerpos a esta imagen de perfección.

La idea de la peligrosidad se retoma en piezas similares como Iconos contemporáneos (2008), donde la misma pareja aparece con incrustaciones de semillas de uña de gato779. En este caso, los muñecos, tenían incrustadas las semillas en los laterales de sus cuerpos, de manera que parecen rayos, en una irradiación similar a la aureola radiante que se usa para caracterizar a los santos

779 Uña de gato es el nombre común que se le da a las semillas de la planta Martynia annua usada, en los países sudamericanos, para curar el cáncer y cuya forma se asemeja a la de una garra de gato con sus uñas. 
en la tradición católica. Este particular elemento, convierte las piezas en una especie de elementos de culto o, como su nombre indica, en unos nuevos iconos contemporáneos.

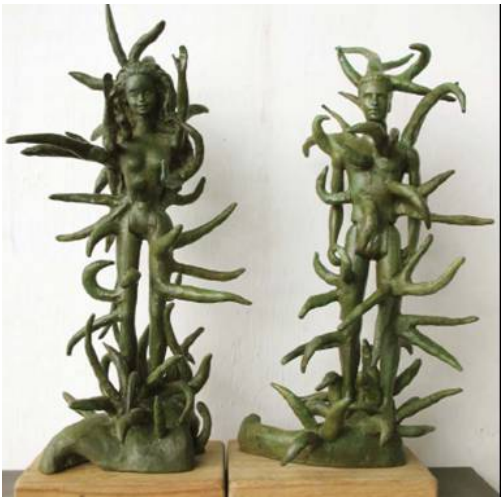

Inmaculada Abarca,

Nuestro señor y nuestra señora del chile, 2008.

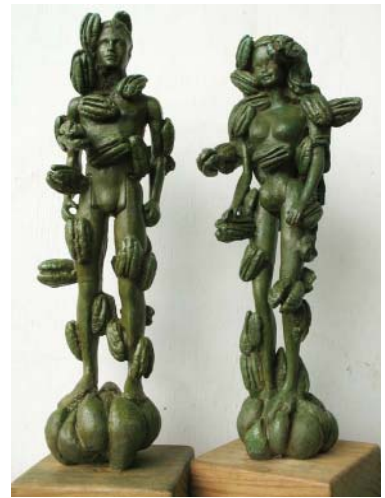

Inmaculada Abarca, Va de nuez, 2008.

Esta iconografía personal, se ha retomado en dos ocasiones más: Nuestro señor y nuestra señora del chile (2008) y Va de nuez (2008), donde aparecen elementos vegetales - pimientos y chiles secos de diferentes tamaños, ajos y nueces- que se presentan, interactuando sobre los cuerpos de las mismas figuras, en una especie de proliferación múltiple que recuerda a crecimientos orgánicos.

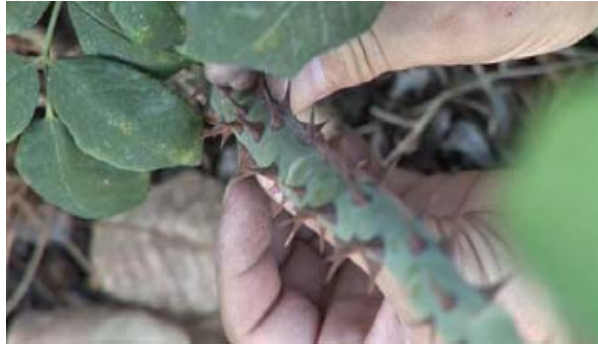

Inmaculada Abarca, La cosecha, 2006.

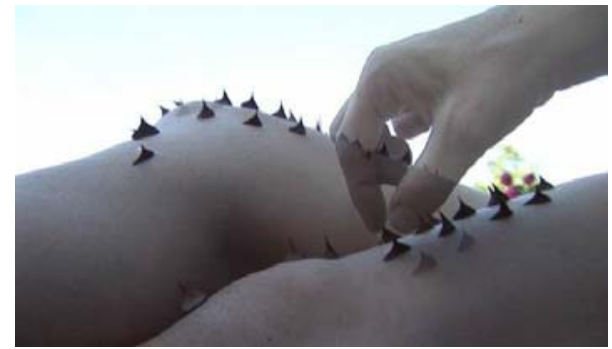

Inmaculada Abarca, La siembra, 2006.

No queremos dejar de hacer mención a un par de obras realizadas en video que consideramos importantes por dos razones: una, porque tienen su origen en procedimientos escultóricos y la otra, porque están íntimamente relacionadas con ideas en torno a la Naturaleza y sus vínculos con el ser humano. Enlazando con nuestra obra escultórica780, retomamos en video, las reflexiones sobre las estrechas relaciones entre lo humano y la naturaleza vegetal generando una

780 La pieza de video La cosecha/La siembra (2006) junto con la escultura Feliz cumpleaños Barbie o No hay rosas sin espinas (2003) forma parte desde el año 2008 y, a través del concurso público Mulier Mulieris, de la colección del Fondo de Arte Contemporáneo del Museo de Arte Contemporáneo de la Universidad de Alicante (MUA). 
metáfora sobre la fragilidad en la obra La Cosecha/La Siembra (2006). A través de una acción repetitiva y sutil que alude a las decisiones de elección, se construye un diálogo sobre la esencia del ser, la unidad y la protección.

Esta pieza realizada en dos partes conectadas entre sí, presenta por un lado una acción relacionada con la recolección de espinas La cosecha, en donde las manos de la artista recogen incansablemente espinas de un sembradío de rosales. A continuación, en La siembra, las espinas son colocadas cuidadosamente sobre el cuerpo de una mujer, utilizando únicamente saliva. El origen de esta pieza se encuentra en la acción realizada tantas veces con anterioridad, de recoger espinas para otras esculturas. La paradójica decisión de elegir la espina en lugar de la rosa nos habla de la necesidad de aprender a ver ambas (lejos de la disyuntiva maniqueísta) como caras de una misma moneda. Los primerísimos planos y la simbología que construye la obra, transforman el cuerpo femenino en tierra y en paisaje - una ambigüedad en ocasiones terrestre, en ocasiones paisaje marino, que es provocada por la respiración del cuerpo femenino que genera movimientos ondulantes-. La respiración no se oye, en su lugar, los sonidos agudos e insistentes de las cigarras acompasan toda la pieza que devuelve la calidez más tórrida de la estación estival. En este caso, el cuerpo humano se ha convertido en instrumento escultórico que nos acerca a la película Paysage-Corps-Demeure (1971) de Charles Simonds donde el artista, tumbado en el suelo y con ayuda de la arcilla, convierte su cuerpo en un paisaje habitado de arquitecturas en miniatura:

Me tumbé en el suelo y con ayuda de arcilla convertí mi cuerpo en paisaje, luego construí una morada imaginaria en el paisaje creado en mi cuerpo por el mismo suelo781.

La respiración humana, de la que prescindimos en este video, aparece en contraposición, maximizada, en Modos de construir el paisaje (2006). La temática de este video, realizado posteriormente, gira en torno a la ausencia de los seres queridos y distantes pero, a la vez, es un video inscrito de forma intrínseca, en el marco de la idea de Naturaleza y paisaje. Esta construcción visual partió originariamente de las investigaciones realizadas durante los cursos de doctorado en la Universitat Politècnica de València, pero fue desarrollándose en el tiempo y acabó concretándose en México. Como resultado se produjo un video-performance, donde se puede apreciar la acción de tomar en el transcurso de diversas sesiones- huellas o registros de los ombligos de más de doscientas cincuenta personas. Una de las primeras acciones se llevó a cabo al finalizar la inauguración del Primer Festival de Video-Performance (2006), de México, D.F., que se celebró en el X-Teresa, donde fue presentado el video de La Cosecha/La Siembra (2006).

El video Modos de construir el paisaje (2006) recoge las diferentes ocasiones y lugares -tanto públicos como privados- en los que se estuvieron haciendo moldes de ombligos. Entre ellos, debemos citar las acciones llevadas a cabo en

781 SIMONDS, Charles, en PIRSON, Jean-François, op. cit., p. 91. 
los campamentos populares en Reforma782, porque en estas circunstancias, nuestra labor se involucró con los ciudadanos allí acampados, al adquirir el compromiso social de construir con ellos la idea de un paisaje común, que propiciara a su vez, una organización política diferente. Uno de estos paisajes reunió todos los ombligos recopilados para reconstruir una geografía o mapa mundi distinto, donde el territorio se configuró con los ombligos de las personas y no con la tierra y sus fronteras. En otra secuencia, la cámara recorre un sorprendente paisaje lunar confeccionado también con los blancos ombligos dispuestos sobre una cama de harina que unifica la imagen.

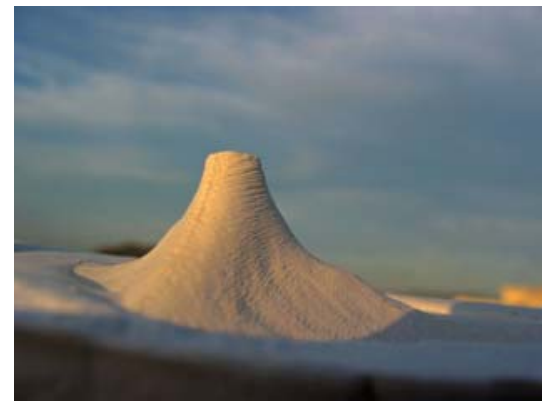

Inmaculada Abarca,

Modos de construir el paisaje, 2005

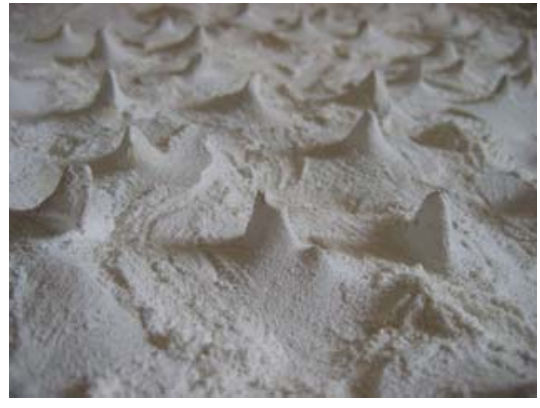

Inmaculada Abarca,

Modos de construir el paisaje, 2006.

La idea de esta acción, siguiendo los planteamientos de Giuseppe Penone, era la de hacer visible lo invisible. Penone, en sus esculturas, al hablar de resucitar el bosque contenido en mesas, suelos y travesaños, trataba de rescatar el árbol que permanecía oculto en el interior de la madera tratada mecánicamente o de la viga utilizada para la construcción. Su interés en sí, no va tras un rescate ecológico, sino que su planteamiento conceptual pretende hacer visible aquello cotidiano con lo que convivimos, pero que habitualmente no percibimos 783 .

En esta dinámica, la obra Modos de construir el paisaje (2006) se basa en darle corporeidad al vacío de nuestro ombligo que, como todos sabemos, es la huella o la cicatriz de nuestro primer contacto con el mundo. Habitualmente, estamos acostumbrados a percibir la forma del ombligo como un hueco. La acción de realizar un molde de escayola hace visible el vacío que, al ser positivado se convierte en una especie de montaña. Como cicatriz del cordón umbilical, el ombligo es la huella de nuestra primera relación con el mundo y nos remite a su vez, a un proceso de comunicación, en primer lugar con la madre y, posteriormente, por nuestra condición de seres sociales, al resto de nuestro entorno. En el proceso de colocar los diferentes moldes de ombligos unos junto a otros, Modos de construir el paisaje (2006) hace evidente la construcción de

\footnotetext{
782 Paseo de la Reforma es una de las principales avenidas de México, D.F. En esta calle, en el año 2006, se asentaron durante tres meses los campamentos de la Coalición por el Bien de Todos, organizados por el partido de la oposición al poder (PRD) para reivindicar, ante el supuesto fraude electoral, un nuevo recuento de votos.

783 Véase AA. VV., Giuseppe Penone, 1968 - 1998, op. cit.
} 
un paisaje, una suerte de geografía u orografía común entre los humanos y a la vez, con el mundo que nos rodea.

La pieza convoca una intención de ser pública ya que se parte de la necesidad de tomar múltiples registros de diferentes personas. Este requisito previo, requirió la interacción de un público -que tenía que tenderse y permanecer con la escayola en su ombligo hasta que ésta fraguara- y que asombrado, tomaba conciencia de cómo la acción de tomar un molde de su ombligo, los remitía a la relación entre lo humano y la Naturaleza. Por otra parte la multiplicidad de registros construían una narratividad relacionada con el tránsito de lo uno a lo múltiple (del universo de la identidad y la individualidad al de la diversidad y lo social), por otra, el acto performativo permite inscribir la obra en el paso de lo íntimo y lo privado, a lo público y compartido: al permitir nuestra intervención, las personas exponían su intimidad.

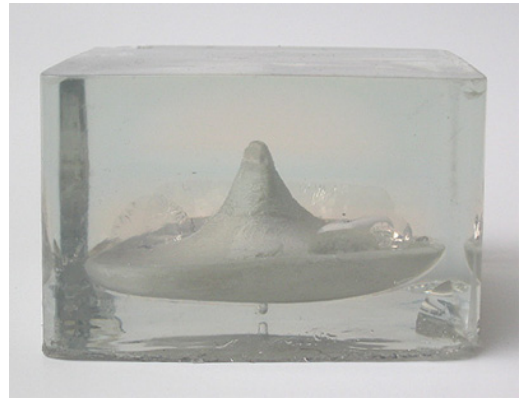

Inmaculada Abarca,

Modos de construir el paisaje, 2006.

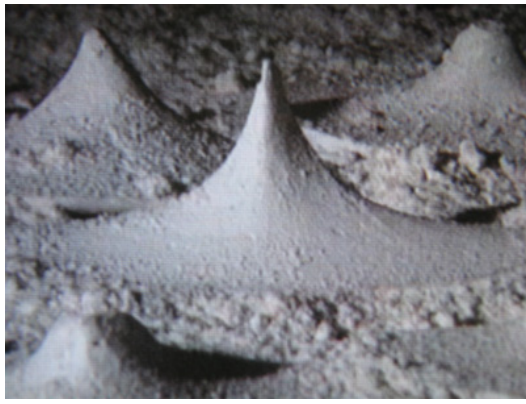

Inmaculada Abarca,

Modos de construir el paisaje, 2006.

Podemos considerar esta pieza como una obra abierta porque permite entre otras cosas, diferentes presentaciones. La obra completa -el video, junto con la instalación de los ombligos en yeso y las fotografías del registro de la acciónfue expuesta en 2006, en el World Trade Center de México, D.F., en el Concurso de Arte Contemporáneo Artfest. Dichas fotografías, recogían información fotográfica de las diferentes acciones, así como de las formas de los distintos ombligos. También había imágenes de los paisajes elaborados con todos ellos y, en particular primeros planos de los rostros de las personas que intervinieron, mostrando a la cámara su propio ombligo. Con posterioridad, algunos de los moldes de ombligos humanos realizados en yeso fueron envueltos en resina cristal. Como podemos ver en esta obra, la utilización de diferentes disciplinas: escultura, video, performance, fotografía, etc., es una característica que como apunta Fernando Castro Flórez, es común en los nuevos lenguajes de la postmodernidad:

El contextualismo [...] y la hibridación de lenguajes (fotografía, comportamientos pictóricos y obras site specific fusionados en numerosas poéticas) son característicos del arte de fin de siglo, sin que ello suponga la 
impugnación de otras posiciones plásticas o la altiva denominación de las mismas como "tradicionales"784.

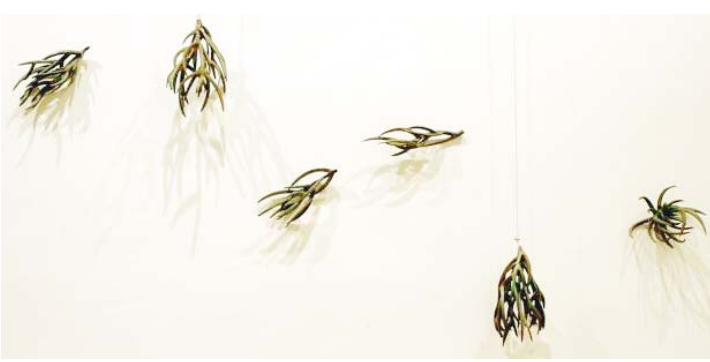

Inmaculada Abarca, Lo que crece, 2006.

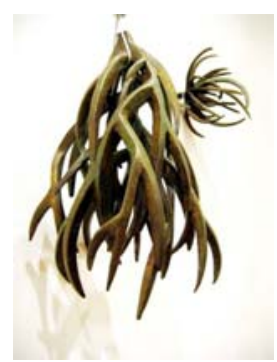

Inmaculada Abarca, Manglar, 2006.

Siguiendo el análisis de las obras realizadas, encontramos una constancia de la pulsión vital y creativa en Lo que crece (2006), una serie de esculturas en bronce, realizadas a partir de una plancha de cera recortada en tiras, con las que se iban construyendo las estructuras, a manera de un juego de enramadas. Estas piezas funcionan como vestigios vegetales de un crecimiento detenido en el tiempo que, como ya estamos habituados a entender en el contexto de nuestra obra, no remiten a un elemento vegetal en particular, sino a vínculos humanos. Se trata de estructuras repetitivas, que crecen y se estiran en el tiempo, haciendo referencia a piezas realizadas anteriormente, con las que establecen nuevas relaciones- formas que se acoplan unas con otras, como las partes de un todo más complejo que ellas mismas. Manglares, flores y ramas como esqueletos y esencias, todo ello, en un proceso que, dentro de la propia obra, establece una dinámica de autorreferencialidad -como una de las prácticas discursivas del arte contemporáneo-.

Mediante la repetición de formas, estas obras son como anotaciones y esquemas de crecimiento que confluyen en piezas como Híbrido (2008), donde el paralelismo entre una vaina vegetal, un brote de helecho o un esqueleto animal, denota una ambigüedad paradójica y ancestral que, resuena y hace eco en lo más profundo de nuestro ser. En su origen, estas ramas-brazos que parecen abrazar el vacío, fueron configuraciones de espacios más amplios, una especie de montañas que, metafóricamente, crecían tanto en el exterior, como en el interior del ser. Son reflejos del proceso de una búsqueda sobre la identidad que se experimenta participando de un todo universal, donde no existen diferencias cualitativas entre seres vivos y prevalece el respeto hacia el medio, en el que todos ellos se desarrollan y crecen.

784 CASTRO FLÓREZ, Fernando, "Tres notas anárquicas. La insubordinación, el bricolage y la propaganda", en POWER, Kevin et al., Diálogos iberoamericanos. II Simposium internacional. La identidad iberoamericana: modernidad y posmodernidad, Generalitat Valenciana, Valencia, 2000, p. 22. 


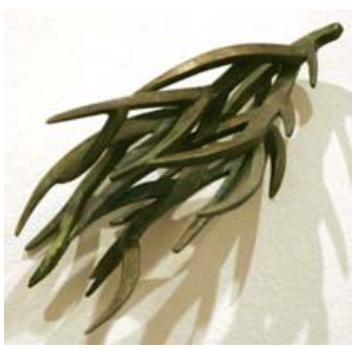

Inmaculada Abarca,

Rama, 2006.

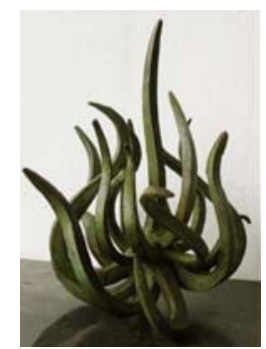

Inmaculada Abarca, Flor, 2008.

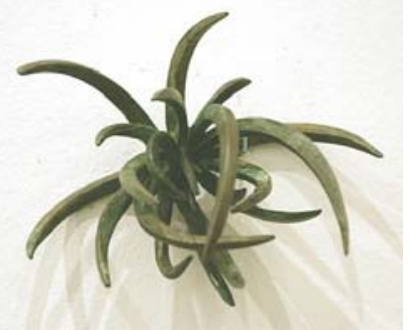

Inmaculada Abarca, Flor, 2006.

Algo en el mundo se concreta, como dice el poeta Benjamin Péret (esposo de Remedios Varo), al hablar del reino vegetal, cuando hasta el metal fundido, parece acariciar una brizna de hierba, al hacer aparecer en ella destellos violetas que evocan un mundo de relaciones mitológicas.

La brizna de hierba, destello surgido del choque de dos guijarros, se miró de la cabeza a los pies y dijo en voz baja: "Soy bella, pero de qué me sirve si estoy sola. Esto debe cambiar; debo ser contemplada”. Y se torció, se anudó y se desanudó hasta que una mínima parte de sí misma se desprendió y fue arrebatada por el viento que la depositó sobre una placa de mica785.

La proliferación de ramas define un campo metafórico que nos habla de multiplicidad de factores: de estructuras vegetales, de identidades humanas y de sus formas de relación, de reproducirse o de expandirse. Sin embargo, en la percepción de estas formas, debemos tener en cuenta lo que el biólogo Pere Alberch, en su artículo sobre los jardines internos, denomina como propiedades emergentes.

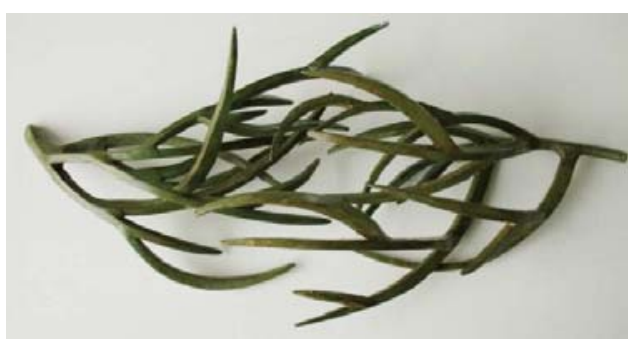

Inmaculada Abarca, Ramas enfrentadas, 2008.

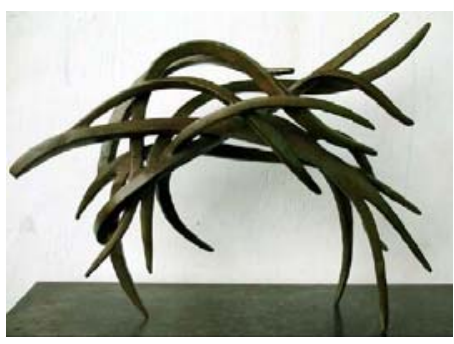

Inmaculada Abarca, Hierba puente, 2008.

Al hablar de morfología y de reiteración de las formas, Alberch hace referencia a las estructuras cuya génesis conducen a "la belleza de la imperfección", aquella que impide que dos formas orgánicas sean idénticas a pesar de generarse en las mismas condiciones ambientales. Su mensaje nos recuerda que las nuevas teorías en torno al estudio de las "propiedades de los sistemas biológicos

785 PÉRET, Benjamin, Historia natural, Artes de México, Colección Tiempo detenido, México, D.F., 2000, p. 37. 
obligan a desconfiar de la tendencia a imponer explicaciones sobre la Naturaleza y sus procesos, basadas en experiencias antropocéntricas"786, por lo que debemos buscarlas en el interior de sus propios sistemas.

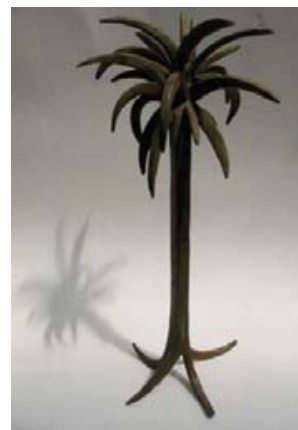

Inmaculada Abarca, Palmera, 2007.

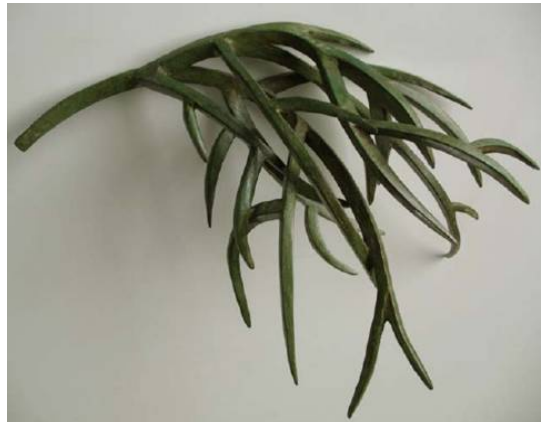

Inmaculada Abarca, Rama de pared, 2008.

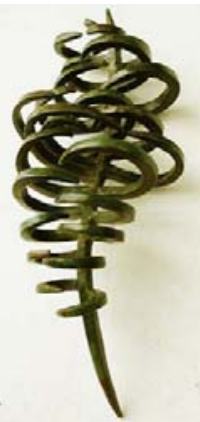

Inmaculada Abarca, Híbrido, 2008.

Con este tipo de obras rizomático-expansivas que se relacionan unas con otras, buscamos tanto la desterritorialización verticalizante del árbol como la disolución del poder unidireccional patriarcal, así como una pauta que sirva para instaurar una sociedad democratizante y liberadora en la que todos sus miembros ejerzan activamente su poder de expresión, siendo a la vez responsables de todo aquello que les rodea. Este discurso formal fluye de unas piezas a otras como un sistema transitivo de vasos comunicantes de la misma forma que funciona la metáfora que -como apuntan Juan Antonio Millán y Susana Narotzky- presupone la existencia de un isomorfismo ${ }^{787}$ entre ambos términos de la misma. En este caso, el isomorfismo se plantea aquí, como una semejanza experimental, en la que los seres humanos nos sentimos como partes-ramas de un sistema-sociedad común, donde prevalecen la tolerancia y la flexibilidad (simbolismo fundamental de las ramas). Piezas que, como el rizoma, no tienen ni principio ni fin y que pueden colocarse tanto en el suelo, como encima de diferentes superficies, dispuestas horizontalmente, inclinadas o en vertical; colgadas de un hilo o con clavos en la pared, solas o en relación con otras, siempre y cuando, aceptemos sus diferentes potencialidades.

Por último, haremos mención a las últimas piezas realizadas entre las que se encuentra la obra Tiempo vegetal (2010), intervención producida dentro del evento Empremtes Espacials III, Art al carrer 2010, en Calpe (Alicante). La obra estaba formada de elementos para piscina (espaguetis o churros) que se descolgaban de una escalera de servicio situada en el Centro Cívico de la Tercera Edad Mare de Déu de les Neus. Como resultado de nuestras investigaciones, podemos ver cómo la pieza refleja de manera sutil pero persistentemente, el dinamismo de una Naturaleza que siempre encuentra el

786 ALBERCH, Pere, "Jardines internos: Orden y caos en las formas orgánicas", en MADERUELO, Javier (dir.), Huesca: Arte y naturaleza..., op. cit., p. 35.

787 MILLÁN, Juan Antonio y NAROTZKY, Susana, “Introducción”, en LAKOFF, George y JOHNSON, Mark, op. cit., p. 17. 
camino para describir el devenir del tiempo. Dentro de este compromiso natural, los vegetales representan para el ser humano una de las manifestaciones más claras para comprender la constancia cíclica de la vida. La fuerza y la energía que representan a nuestros ojos, se convierten en nuestro mejor aliado para acceder a una percepción creativa de nuestra vida, en armonía y respeto con nuestro entorno. En definitiva, una manera de percibir el tiempo a través del movimiento de las cosas y de las metamorfosis que se producen en la Naturaleza. Un proceso creativo que se centra fundamentalmente en la utilización del crecimiento vegetal y la nueva relación con el tiempo, siguiendo a Collete Garraud, un "tiempo cósmico, tiempo geológico, tiempo cíclico de la vida vegetal" 788 .

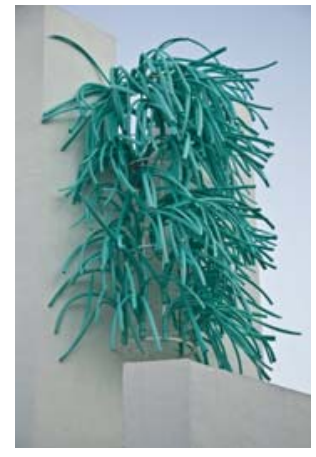

Inmaculada Abarca, Tiempo vegetal, 2010.

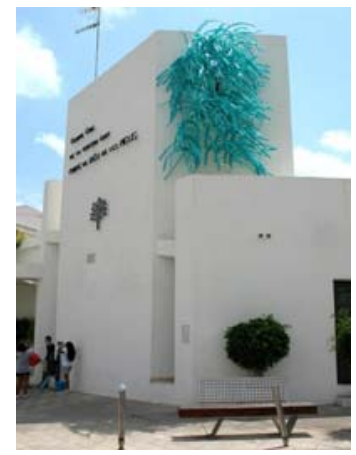

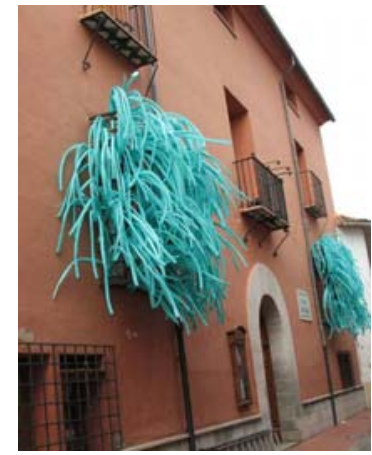

Inmaculada Abarca, Vida latente, 2010.

Para Roberta Quance quien identifica lo cíclico con la mujer y por definición con todo lo femenino y los procesos de la Naturaleza, esta conciencia cíclica sería, siguiendo a Bachofen 789 , un recurso para expresar la idea de que uno puede intervenir en el proceso de la Naturaleza ayudándola a hacer lo que de todos modos haría.

Esta es la visión de quien contempla el ciclo de la vida y la muerte (en la naturaleza) desde la repetición, desde allí donde se haya dado una vuelta completa a la rueda y sea posible contemplar la muerte (confusamente) no como lo que ha precedido el reverdecimiento sino como lo que lo ha permitido790.

Este concepto de muerte a través de las fuerzas de regeneración innatas en la Naturaleza conlleva siempre un simbolismo positivo, puesto que la misma es la que permite la continuidad del proceso de transformación. Es interesante percibir cómo los elementos que constituyen la pieza interactúan en un proceso

788 GARRAUD, Collete, "Arte y Naturaleza: Aspectos del tiempo", en MADERUELO, Javier (dir.), Huesca: Arte y naturaleza..., op. cit., pp. 79-93.

789 Johann Jacob Bachofen (1815-1887) jurista suizo, conocido por sus investigaciones sobre la historia del pensamiento religioso.

790 QUANCE, Roberta Ann, op. cit., p. 39. 
acumulativo, unos con otros. Asimismo, la limpieza formal de las líneas y los bloques del edificio, junto con la pulcritud del color blanco del mismo, contrastan fuertemente permitiendo destacar la intervención realizada. Las características de esta heterotopía se ven reforzadas también por el movimiento que, debido al viento, se produce en toda la escultura en una continua llamada de atención. De nuevo se pone en evidencia y es interesante percibir la descontextualización que supone el uso de un elemento empleado para una función en particular y convertido aquí en elemento constitutivo de una idea diferente, con todos los significados añadidos que eso conlleva. La pieza Vida latente (2010) se realizó en la localidad de Potríes (Valencia), siguiendo el mismo proceso. Con todo ello, nuestra tesis escultórica plantea la idea de que, si por mucho tiempo siempre fue el artista el que representaba a la Naturaleza, ahora es la Naturaleza la que, en un proceso de domesticación inverso, representa al hombre ${ }^{791}$.

Retales en clave de flor/Paisajes migratorios (2010) y Retales en clave de flor/Desechable (2011) son piezas que, en la misma dinámica de obras que adquieren diferentes configuraciones en base al lugar donde se exponen, fueron realizadas para participar en dos exposiciones colectivas diferentes. La primera en la Universidad de Cartagena (Facultad de Ciencias de la Empresa) y, la segunda en Hat Gallery792 (Valencia). La obra se compone de cincuenta y un bastidores de cuadros, vestidos y perchas de madera. En ambos casos, la utilización de ropa usada de mujer con una abrumadora presencia de elementos vegetales y flores, nos permite una reflexión en clave vegetal en torno a la representación misma, como una manera de subversión. El reciclaje de estas vestiduras femeninas impregnadas de historias y la acumulación de bastidores, esqueletos de madera revestidos con esas telas, construyen diferentes paisajes, tiempos y espacios, lugares comunes por los que transitan tanto las personas como las culturas.

La reutilización en un contexto artístico, de esos estampados vegetales, permite una nueva narrativa. Estos retales de realidad mantienen la huella y la medida de las personas que en otro tiempo fueron sus dueñas $y$, con vocación de regeneración, hacen resurgir flores de entre los montones de ropa desechada que hoy en día germinan en los mercados populares, testimoniando los hábitos de las sociedades desarrolladas. Productos en sí mismos del exceso, la sola presencia de estos montones de ropa denuncia la "globalización" de una economía mundial, infinita productora de basura, donde todo es desechado tarde o temprano, a favor de un mundo de, por y para el consumo.

791 Véase AA. VV., Espacios de transición, E2 Espacios expositivos, Antiguo Cuartel de Instrucción, Universidad Politécnica de Cartagena, Facultad de Ciencias de la Empresa, (Manifesta 8, Paralelo, 8), Grupo de investigación Arte, espacio público y paisaje de la Facultad de Bellas Artes de Murcia, Cartagena, noviembre, 2010-enero, 2011.

792 Véase material divulgativo de la exposición Disposable, Ciudad Juárez and the war of women, Galería Hat Gallery, Valencia, 7, julio, 2011. 


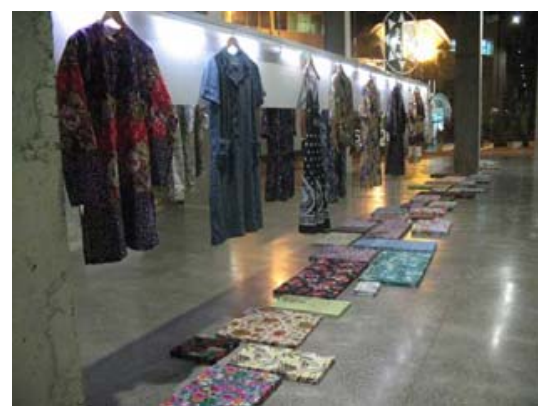

Inmaculada Abarca, Retales en clave de flor. Paisajes migratorios, 2010.

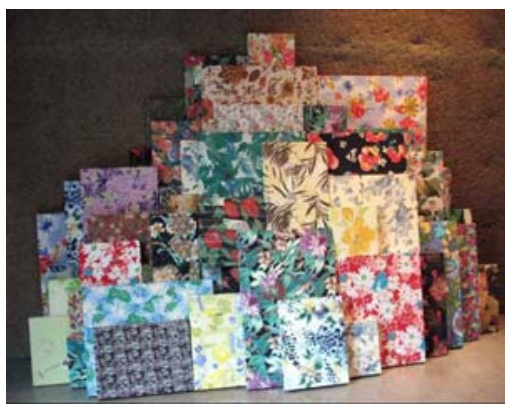

Inmaculada Abarca, Retales en clave de flor. Desechable, 2011.

Hechos a veces a medida y cosidos a mano, estos vestidos son retales de una infancia, recuerdos de madres que cosen, historias personales, agujas y máquinas de coser, cuerpos femeninos que se entrelazan con manos hábiles para unir, reciclar y mirar de nuevo. El desdoblamiento de la realidad relata una cotidianeidad doméstica, que más allá de las apariencias, proyecta una verdad que devela el aspecto más íntimo de nuestras pequeñas y diarias muertes. Estos cuadros revestidos no ponen entre paréntesis ni suspenden el referente al que remiten estas flores, modelos perfectos generadores aparentemente de felicidad, sino que trabajan teatralizando la representación y reconstruyendo la posibilidad del ritual mágico, aquel que permite exorcizar el mal y recuperar el universo simbólico de todo lo que germina de nuevo.

Desde la perspectiva de la simbología, el hombre ha identificado siempre las flores como imagen de la vida, considerándolas un medio para la expresión de los sentimientos más nobles del ser humano. Símbolos de la belleza, de la alegría, del placer e incluso del amor, generalmente, las flores están asociadas con lo efímero y lo vulnerable. Son para el hombre un signo dual que, por su esencia y por su forma, hacen referencia tanto a la vida más exuberante como a la muerte y la posibilidad de renacimiento. Las flores han desarrollado, dentro de la Cultura de todos los pueblos, patrones que aún siendo confusos, establecen un lenguaje, una forma de comunicación capaz de trasmitir valores. Dentro del arte contemporáneo, lo que más nos atrae de las mismas, es su poder de metamorfosis. La idea de expandir la reflexión sobre Arte y Naturaleza, genera nuevos sistemas participativos en donde el imaginario popular concibe las flores como parte de una iconografía que refleja una supuesta identidad femenina. El elemento vegetal como material de trabajo e idea fundamental nos trasmite el concepto de crecimiento, transformación y desarrollo. La reutilización del vestido como objeto y soporte ornamental alude a la representación mediante un proceso de simplificación en donde éste, convertido en modelo social, reiconiza la flor y la convierte en herramienta capaz de moldear, subvertir y trastocar las representaciones sociales. El cuadro-objeto revestido con estos tatuajes florales, adquiere una nueva identidad, convirtiéndose en escenario posible para el relato. Un discurso visual concebido como crítica social, en donde el motivo floral fluye y transita entre las reminiscencias del mismo en las diferentes culturas y en la búsqueda de la esencia de lo humano. 
Retales en clave de flor, en ambas versiones, es una metáfora directa de lo desechable y de lo efímero. Esta pieza se sirve de la indumentaria como elemento físico, pero usa la ornamentación vegetal y floral como metáfora de lo social, de lo doblemente utilizado. Más allá de ser contemplada como un reciclaje de objetos usados, resignifica una problemática social, convirtiéndose en una denuncia y un revulsivo contra la impunidad y el abuso ejercido contra las mujeres en cualquier otra parte del mundo. En un proceso de apropiación de la memoria colectiva y sobre el teatro de la misma, Retales en clave de flor, construye una mirada postmoderna que devela un horizonte común.

En definitiva, en nuestra obra, la conexión entre plantas y humanos sirve más allá del nivel formal, para generar una imagen del universo donde todo es uno y una idea de la vida como energía que transita entre los diferentes organismos del planeta. Compartimos con el artista Bob Verschueren que las plantas como referente son capaces de proporcionarnos -como material de trabajo, como idea o como proceso- "una especie de espejo"793 que nos acerca al conocimiento de nosotros mismos. Cabe recordar aquí las palabras del poeta Octavio Paz quien, en su libro Árbol adentro, nos remite al hombre como el "árbol de sangre" que "siente, piensa, florece y da frutos insólitos: las palabras" y que éstas, como "pulpos vegetales" transitan "del árbol a las raíces a través de un tacto ciego", para convertirse en el "oleaje verde" de dicha y alegría que mece los follajes y golpea las sienes y el pecho794. Palabras que, como ha sido nuestra intención, han contribuido a darle cuerpo y nuevo aliento -como esperamos- a todas nuestras reflexiones en torno al trabajo de un buen número de artistas contemporáneos. Sus obras son, entre otras cosas, el bastión para la comprensión y defensa de formas de vida tan fascinantes como la que ha dado origen a esta tesis.

793 GRANDE, John K., op. cit., p. 159.

794 Véase PAZ, Octavio, Árbol adentro, Seix Barral, Barcelona, 1990. 



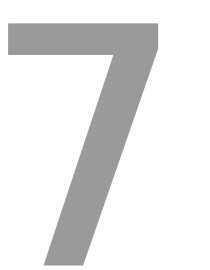

CONCLUSONES 

A lo largo de esta investigación, hemos podido corroborar la repercusión que el referente vegetal ha tenido y tiene en la escultura contemporánea mexicana. A través de la documentación aportada y de las reflexiones en torno a las prácticas artísticas de los artistas analizados en este estudio, hemos hecho patente que la utilización de plantas en un contexto artístico es, sin duda, un importante indicativo que caracteriza significativamente el interés que despierta el binomio Arte y Naturaleza. Todo ello nos ha permitido tener una mejor compresión del concepto de Naturaleza, así como de los vínculos que este término ha generado como construcción cultural a lo largo de la historia del ser humano. En este proceso, es importante destacar que hemos recurrido a la utilización de la retórica como herramienta de trabajo. Al seleccionar únicamente las plantas y por consiguiente, utilizar la parte por el todo -el referente vegetal por el conjunto de la idea de Naturaleza- la metonimia, como figura retórica (entre las muchas otras empleadas por los artistas: metáfora, analogía, prosopopeya, hipérbole, etc.) nos ha proporcionado una lectura más puntual y focalizada. Los aspectos que hemos encontrado en común, en las estrategias artísticas, nos han permitido, entre otras cosas, desentrañar las diferencias entre aquello considerado como natural -en lo que no ha intervenido el hombre-y lo que se considera artificial -como lo creado mediante su intervención.

En principio, nos hemos acercado al mundo vegetal a través de disciplinas como la Ciencia y la Botánica, esbozando una pequeña historia de las plantas, para comprender la trascendencia y las repercusiones de estos organismos en la historia del hombre. Posteriormente, hemos analizado algunas de sus implicaciones tanto en el arte, como a través de diferentes áreas del conocimiento como la simbología, la mitología, la antropología y la sociología. Todo ello nos ha permitido concluir que en su mayoría, las representaciones vegetales, mucho más allá de su representación formal y de la alusión a determinados vegetales, aluden a particularidades estrechamente relacionadas con todo lo humano. En esta dirección y, dentro del contexto del arte en México, cabe destacar la particular vinculación del mundo vegetal con la iconografía prehispánica que, en gran parte, ha logrado transferir el vínculo Arte y Naturaleza al arte moderno. La iconografía vegetal se entremezcla con la humana, generando híbridos que ponen de manifiesto esta relación y, hemos aportado evidencias de la misma en las obras de artistas característicamente mexicanistas como Frida Kahlo o Diego Rivera.

La aplicación de la metáfora de la vida vegetal al ámbito de las Ciencias Humanas es un recurso recurrente tanto en la filosofía como en el arte y, en esta investigación, nos ha servido para entender cómo, la utilización de las analogías relacionadas con ciertas partes de las plantas, como por ejemplo el rizoma, sirven a filósofos como Deleuze y Guattari para explicar procesos de pensamiento que caracterizan a la sociedad contemporánea, preocupada por encontrar, como apunta Bateson, las pautas que conectan a los seres vivos por encima de sus diferencias. Esta forma de entender la vida, nos hace percibir la misma como un continuun, algo que fluye más allá de las formas aparentes. 
Consideramos que esta conclusión, tiene indudables resonancias en la percepción que genera el uso de referentes vegetales en el arte contemporáneo.

En torno a la naturaleza vegetal en el arte contemporáneo hemos confirmado la abundancia de este tipo de referencias en la escultura contemporánea. Desde las primeras intervenciones relacionadas con la ecología de Joseph Beuys, a la plantación de amapolas de Sanja Ivekovic, ambas realizadas en eventos relacionados con la Documenta de Kassel, las plantas han descrito problemáticas relacionadas específicamente con la sociedad y con el mal uso de los recursos naturales durante las últimas décadas del siglo XX. Si bien, en primera instancia, la utilización de la referencia vegetal viene condicionada por el vínculo con la imagen de lo natural, directamente relacionada con el concepto de la Naturaleza en su conjunto, posteriormente, el uso de plantas derivará en la idea de ser un material susceptible de evidenciar procesos y tiempos diferentes a los de los humanos. Con ello, lejos de las problemáticas iniciales de los movimientos del Land Art o del Arte Povera, en la búsqueda de nuevos espacios o en la utilización de materiales alternativos, las plantas se emplean como generadores de significados que, en su mayoría se vinculan estrechamente con el individuo o con la sociedad. Sin embargo, como apunta Héctor J. Pérez, la relación que el arte contemporáneo guarda con la Naturaleza no puede entenderse hoy en día bajo los conceptos de "contemplación, expresión o asimilación"795. Las nuevas prácticas artísticas en relación al arte y la Naturaleza, evidencian la importancia de pasar a la acción mediante diferentes operaciones. Pese a ello, debemos concluir que, si bien, dentro del arte contemporáneo hemos observado que estas dinámicas se han comenzado a practicar, en México existe hasta cierto punto y todavía, una tendencia a un planteamiento más lírico.

En el segundo capítulo, hemos rastreado los posibles orígenes del vínculo Arte y Naturaleza en México, a través de intervenciones permanentes en el ámbito público, como el Espacio Escultórico, así como también en el espacio privado mítico-simbólico de Xilitla (ambas, en particular, por considerarlas intervenciones singularmente significativas en el imaginario colectivo mexicano). Asimismo hemos documentado las exposiciones relacionadas con la materia que han representado un punto y a parte en la historiografía del arte en México. Para algunos artistas, estas exposiciones constituyen hitos en cuanto al interés en el vínculo Arte y Naturaleza y en ellas, hemos destacado a través de algunos artistas, las referencias vegetales como muestras de esta tendencia. Los análisis describen una trayectoria que, retrospectivamente, nos llevan a considerar la obra de Helen Escobedo, Jan Hendrix o Marta Palau, como iniciadores de la tendencia Arte y Naturaleza en México que será continuada a partir de los años noventa por otros escultores. Una de las principales aportaciones de Helen Escobedo es la de incorporar en su obra, intervenciones in situ que tienen como punto de partida la reivindicación ecológica en torno al medio ambiente. Sus representaciones vegetales reflejan una cierta visión apocalíptica, no muy alejada de lo que sucede en ciudades consideradas megalópolis como México, D.F.

795 PÉREZ LÓPEZ, Héctor Julio, op. cit., p. 5. 
Por su parte, a Marta Palau debemos atribuirle la incorporación de materiales pobres, en numerosos casos procedentes del mundo vegetal que, en sus obras apuntan a una visión mágico-ancestral de la Naturaleza, canalizada a través del poder del arte como proceso, capaz de relacionar la creación con la vida. Por último, en el segundo capítulo hemos destacado la labor de Jan Hendrix quien, como observador y viajero $y$, a través del énfasis de su obra en torno al mundo vegetal, ha profundizado en la concepción del ser humano como parte de un universo, considerado como un todo indisociable. La estética, a partir de sus obras, es considerada una ética fundada en el registro metódico, la contemplación activa y la denuncia de la devastación de la Naturaleza.

Partiendo de estos tres artistas como antecedentes-introductores del binomio Arte y Naturaleza en México, hemos detectado una serie de usos del referente vegetal identificados en artistas puntuales. La conclusión a la que nos han llevado los datos recopilados propone que entre los artistas que utilizan las plantas como motivo o estrategia, existen fundamentalmente tres pautas discursivas por las que transitan sus obras, las cuales son estudiadas minuciosamente a lo largo de tres capítulos de esta tesis. Por un lado, en el capítulo tercero unificamos a los artistas que utilizan las plantas como referente formal, estructural o simbólico y para los que es imprescindible la representación más o menos figurativa del elemento vegetal, de algunas de sus partes o de la síntesis tendente a la abstracción de la planta. Sin embargo, podemos afirmar que sin lugar a dudas, en ninguno de estos casos es significativa, ni se persigue, la representación mimética. En el capítulo cuarto y, como segunda pauta fundamental, agrupamos a aquellos artistas que consideran la problemática ecológica como parte trascendental de su obra. En estas obras destaca, como característica principal, la vinculación arte-vida, destacando la relación de la obra con el propio artista, considerado a partir de aquí, como parte de la obra misma y, derivando todo ello, en un sentido casi místico de la relación humano-naturaleza vegetal. Por último, el vegetal como material de trabajo y como concepto, unido a un proceso y a unos tiempos específicos, lo encontramos en el tránsito y sustitución de la representación de la planta a la presentación in situ de la misma, lo cual, marca un cambio fundamental en el tratamiento y los resultados artísticos. En el paso de la representación a la presencia misma del acontecimiento, podemos detectar la transformación de la experiencia de la figuración, a la experiencia del concepto. Este tipo de obras -a diferencia de las obras que usan materia inanimadaimplican una dinámica diferente, en el sentido principalmente, que reflejan un sistema de vida que se desarrolla en el tiempo. De esta forma, los vínculos humano-vegetales que se preconizan en obras anteriores, presentan aquí una interactividad intrínseca, sin la cual la obra no puede materializarse. El sentido de dependencia de estas obras van más allá del proceso de coautoría entre el artista y la Naturaleza, propiamente dicha, trasmitiendo al espectador-público la posibilidad de vivenciar procesos naturales a través de este tipo de realizaciones. 
La clasificación que aquí proponemos no pretende establecer categorías cerradas, muy al contrario, sólo sugiere pautas de lectura, sabiendo que la obra de cada uno de los artistas se mueve de unas instancias a otras, con la permeabilidad que ofrece tanto la lectura abierta de las obras, como la personalidad de cada uno de los artistas. En todo caso, nos encontramos frente al uso de una serie de metáforas que, unidas a un proceso de evocación, hacen visible diferentes aspectos de nuestra experiencia, creando nuevas realidades y recontextualizando constantemente nuestro lugar como seres humanos en nuestro entorno.

El presente estudio -que explica el paso que algunos artistas (utilizando los vegetales como recurso) han realizado de la representación a la presentación de la Naturaleza, coincide con Fernando Castro Flórez, en considerar que este tránsito produce híbridos que son algo más que un "entrelazarse de lenguajes", estaríamos frente:

[...] un mestizaje de intenciones y sentidos, una voluntad comunicativa más que expresiva. [...]. Se ha producido un pasaje de la categoría de icono a la de índice, así como un desplazamiento teórico, donde una estética de la mímesis, de la analogía y de la semejanza da paso a una estética de la huella, del contacto, de la contigüidad referencial: transición del orden de la metáfora al de la metonimia796.

En definitiva, podemos afirmar con él que "no hay otra naturaleza que el paisaje artificial, un dominio contaminado en el que no se puede mantener la idea de un paseante buscando la revelación o la emboscadura [...]"797. Ésta es, en nuestra opinión una de las razones por las que hay artistas que en su discurso, optan por sustituir los materiales naturales por otros artificiales: ante la incapacidad de hablar de la naturalidad que imaginamos y queremos convocar, la estrategia consecuente será la "cita" que, en definitiva no pretende establecer ningún precedente de realidad.

Al respecto de los artistas que utilizan en su obra, el referente vegetal con cierto carácter figurativo -si bien, nunca pretenciosamente mimético- hemos concluido que sus planteamientos implican siempre otro tipo de reflexiones, algunas de las cuales reflejan en parte, ideas cercanas al pensamiento mágico, al que hacíamos alusión en el capítulo primero refiriéndonos a las culturas antiguas. Según este principio, lo similar atrae a lo similar, de forma que en estos casos, lo representado se torna un espejo de la evolución de nuestro yo esencial, circunstancial o cultural. Entre ellos, detectamos pautas comunes y coincidimos con Juan Bautista Peiró, en que algunos de estos discursos versan

\footnotetext{
796 CASTRO FLÓREZ, Fernando, "Notas intempestivas. Sobre el destino nihilista del arte contemporáneo", en AA. VV., Heterotopías. Cambres d'art, Project rooms, Interart 99, $14^{\text {a }}$ Fira Internacional d'Art, Generalitat Valenciana, Consorci de Museus de la Comunitat Valenciana, Valencia, 1999, p. 14.

797 CASTRO FLÓREZ, Fernando, "Notas intempestivas...", en AA. VV., Heterotopías..., op. cit., p. 27.
} 
sobre la propia identidad: "[...] cuando algunos artistas recurren a elementos secularmente asociados a la Naturaleza están profundizando en la suya propia, en su identidad personal e individual [...]"798. Esta identidad se diversifica en un sentimiento de identificación, con las llamadas "propiedades proyectivas" como Julio Héctor Pérez las denomina y que, siguiendo a Wolheim ${ }^{799}$ actúan, como un espejo proyectivo. Encontramos ejemplos representativos de este tipo de búsquedas, en las cuales el crecimiento y la forma son factores fundamentales, en la obra de Maribel Portela y Miriam Medrez (personajes que acompañan el crecimiento de semillas y plantas) o Verónica Sahagún (flores que impregnan los sentidos) y en lo cotidiano que ejerce el poder de atraer el guiño del espectador en los jardines que Naomi Siegmann despliega invadiendo el espacio. En este último caso se trata de obras que trabaja mediante el simulacro y que utilizando lo vegetal como una especie de guiño al espectador, buscan la manera de vincularlo a la obra a través de la percepción, de lo lúdico y de la seducción de la que nos habla Baudrillard en torno al trompe / oeil y la ilusión de "realidad". En Naomi Siegmann, la pseudo mímesis tiene que ver con la complicidad que hace dudar al espectador entre la realidad y lo representado, obra que se relaciona con artistas como Roxy Paine, Isa Genzken o Iraida Cano, de los que hicimos referencia en los primeros apartados de esta tesis.

En contraposición, la búsqueda de una identidad cultural-nacional se identifica con los símbolos patrios y la utilización de elementos iconográficos que referencian un seguimiento de la Cultura autóctona, como en el caso de Betsabée Romero. Se trata de una estética plagada de símbolos vegetales coloniales aplicada a elementos urbanos de la Cultura automotriz como el auto llamado vocho, coche característico de México, D.F. Encontramos incisiones aplicadas sobre parabrisas y llantas, en los espejos retrovisores o en gafas, en un principio, con elementos iconográficos de la Cultura prehispánica y posteriormente, con representaciones características de la flora en la Cultura mexicana. En una línea diferente, rescatamos la tendencia a la abstracción fundamentada en el deseo de habitar las ideas y, en esta dirección, Fernando González Gortázar y Federico Silva Lombardo habitan los espacios urbanos con esculturas públicas que quieren, como las plantas, crecer. Paisajes con movimiento, que incluyen al espectador en sus recorridos o que incorporan en sus esculturas, los comportamientos vegetales para aprender de ellos.

Metonímicamente, varios artistas utilizan ciertas partes de las plantas como las semillas, los frutos o las flores, como indicadores de crecimiento y exponentes de vida en potencia. Así, para Ivonne Domenge, las semillas y flores dan constancia de la vida que las formas son capaces de trasmitir. Partes vegetales y fragmentos humanos, se entrelazan en las obras de Xawery Volski, indefinición que nos habla sobre la ambigüedad ontológica, temática por otra parte recurrente en varios artistas como es nuestro caso en particular, al que nos dedicamos en el último capítulo. Por otra parte, los atributos connotativos de los vegetales son empleados por algunos artistas para expresar su cualidad de

\footnotetext{
798 PEIRÓ LÓPEZ, Juan Bautista, Otras naturalezas, op. cit., p. 11. 799 PÉREZ LÓPEZ, Héctor Julio, op. cit., p. 21.
} 
transformación matérica. En esta línea, encontramos la obra realizada por Gabriela León en Varanasi (India), como ejemplo interesante de un compromiso social de reivindicación. Un material como la mierda -empleada originariamente como combustible - se transforma en positivo, mediante la forma de flor símbolo de renacimiento- y la acción de la artista. Este caso se conecta con otras piezas en las que los materiales inciden en la importancia de su propia naturaleza, por sus características esenciales o por su poder de transmutación. Artistas como Verónica Sahagún (cera y esencias), Alfredo De Stéfano (luz y desierto, paisajes como escenarios), Hisae Ikenaga (Naturaleza e instrucciones de uso) y Sergio Rodríguez (Naturaleza y objetos cotidianos) usan lo vegetal por sus características nominativas, es decir, por sus cualidades formales de evocación, independientemente del carácter natural o artificial de los materiales de los que parten.

Por otro parte, no debemos olvidar que el referente vegetal implica y representa un proceso de desarrollo. Como hemos apuntado en capítulos precedentes, las plantas están vinculadas al ser humano por lo que éstas representan para nosotros, partiendo incluso, desde la idea del alimento, como proceso imprescindible para la sobrevivencia. Pero, el alimento ha sido siempre entendido como un símbolo, no sólo de nutrición material o corporal sino también de nutrición espiritual. Siendo organismos capaces de producir su propia alimentación, las plantas y la vegetación en general, como señala Juan Eduardo Cirlot ofrece en todas sus formas, dos aspectos principales a tener en cuenta:

[...] el de su ciclo anual, por el que simboliza la muerte y la resurrección, como el mismo invierno y las primaveras; y el de su abundancia, del que deriva un significado de fertilidad y fecundidad800.

La característica de estar frente a un ser vivo manifiesta, por otro lado, otra de las principales motivaciones para el uso del referente vegetal, ya que al entenderlo como un ser vivo que, como tal, conlleva un proceso, nos ofrece la posibilidad de reflexionar en torno a la problemática sobre la vida y la muerte. Como proceso, lo vegetal nos habla de cambio, de mutación, de desarrollo, de crecimiento y evolución, todos ellos, conceptos muy estrechamente relacionados con la existencia humana. Así, la vitalidad orgánica que implica la reproducción, la floración o la prosperidad, vinculada con el campo de la agricultura se transfieren a la vida del hombre. Por todas estas características el artista siente y expresa una identificación. En relación con la vitalidad orgánica y la exuberancia del mundo vegetal las plantas se presentan como seres vivos capaces de producir placer a través de los sentidos de la vista, del olfato, del gusto, etc. Así, la obra de Maribel Portela por ejemplo, se conecta con la sensualidad. La representación vegetal que busca la complicidad con el espectador a través de la forma y de la apariencia, se presenta en artistas que trabajan sobre la estructura formal como motivo relacionado con el equilibrio humano. En estos casos, cabe destacar la perfecta integración entre forma y función que presentan los

800 CIRLOT, Juan Eduardo, op. cit., p. 457. 
vegetales, en todas las fases de su desarrollo. Esta evocación directa al hombre mediante las formas vegetales es característica de los artistas que utilizan la representación vegetal como un símbolo, al margen de las características intrínsecas de los materiales utilizados. En estos casos es común que los artistas no necesiten materiales naturales para hacer referencia a un contexto natural.

En el capítulo cuarto abordamos la reflexión artística en torno a la problemática ecológica a través de artistas que muestran una ideología vitalista relacionada con una especie de panteísmo, en la que la Naturaleza se identifica con el ser humano desde la conciencia de sentirse un sólo ser con la Naturaleza. Se trata de una suerte de ideología-ética-ecológica, en la que los artistas trabajan alejados de la idea de figuración centrándose fundamentalmente, en aspectos relacionados con la ecología, el respeto y la sostenibilidad. Nos ha resultado interesante observar sin embargo, que estas propuestas de profundas resonancias sociales, se argumentan en ocasiones desde un ámbito muy íntimo:

[...] lo hacen con enfoques diferenciados, centrándose en aspectos necesariamente parciales (microcosmos) de ese vasto e irresoluble problema de infinitas facetas (macrocosmos). El monolito "naturaleza" se fragmenta en pedazos. Se nos invita a reflexionar sobre los aspectos menos evidentes, menos paisajísticos, menos representativos de la naturaleza colectiva y externa al hombre y más identificativos de la naturaleza individual e interior de cada uno de nosotros801.

Todas estas tendencias, relacionadas con la vida cotidiana, sirven de testimonio social y cultural y son, en definitiva una forma de acceder a la conciencia del mundo. En esencia, podemos afirmar que están relacionadas con la corriente conocida como Naturphilosophie (finales s. XVIII y comienzos del s. XIX) ligada al Romanticismo. Como tradición filosófica, esta forma de pensamiento encabezada por Goethe (escritor, poeta y botánico) mostraba un mayor interés, como apunta Steadman802, en las similitudes estructurales subyacentes a las especies que en las diferencias de las mismas. Así, Goethe desarrollaría un modelo teórico basado en una estructura vegetal, un prototipo en cuya existencia creía: la Urpflanze. Sus seguidores desarrollaron estudios morfológicos aplicándolos, tanto a las especies animales, como a las vegetales. Este movimiento, anterior a Darwin, parece inspirar obras como las de Yolanda Paulsen o Rosario García Crespo (recordemos también a Pamen Pereira en el ámbito internacional). Se trata de artistas que, en sus obras, utilizan el referente vegetal como representativo de toda la Naturaleza, sirviéndoles como defensa de los diferentes ecosistemas de organismos. En este grupo, con una conciencia éticamente ecológica, reunimos a artistas que parten del simbolismo de su propia herencia cultural, como Yolanda Gutiérrez o la de otros pueblos (Laura Anderson Barbata) y que buscan, a través de la rescate ecológico, una reflexión en torno a la esencia del espíritu humano, como ser integrante de la Naturaleza

801 PEIRÓ LÓPEZ, Juan Bautista, Otras naturalezas, op. cit., p. 11.

802 STEADMAN, Philip, op. cit., pp. 42-43. 
y a la que deben, como dictan los antiguos, respetar. Yolanda Paulsen, concretamente establece un paralelismo entre el interior y el exterior del cuerpo del ser humano, construyendo un discurso sobre la identidad de mismo y de su lugar en el mundo. Por su parte, el discurso generoso de Laura Anderson Barbata logra, a través del arte un acercamiento a otro tipo de culturas.

En estos casos, la búsqueda de conocimiento coincide con el descubrimiento del yo personal del artista, de manera que el cuerpo del mismo se funde (Ana Mendieta tierra-mujer) con la Naturaleza, anteponiendo el ritual y lo cultural en el propio descubrimiento individual. En general, junto a este tipo de procedimientos, los artistas recuperan el ritual como proceso de intervención. En estas obras se imponen los rituales sociales ( . $^{\mathrm{a}}$ Fernanda Cardoso), chamánico-religiosos (Marta Palau) o el ritual del artista como recolector, coleccionista y documentalista de registros (Jan Hendrix). Como vemos, el sentimiento panteísta de unicidad con la Naturaleza, convierte estos procesos de intervención en elaboraciones místicas, relacionadas con una suerte de nueva religiosidad. En el origen de estas propuestas subyace el concepto de que arte es igual a vida, de forma similar a artistas como Joseph Beuys, Giuseppe Penone, Nils Udo o Andy Goldsworthy, Dougherty's, Vitto Acconci para quienes la relación armónica del hombre con su medio natural es condición necesaria para un buen desenvolvimiento tanto individual como social del ser humano.

El artista, se convierte aquí en una especie de chamán, al concebir y realizar su obra, siguiendo las pautas de acción de la Naturaleza, se convierte en un hacedor-facilitador-generador-simulador de procesos, que actúa a la manera de... Una de las características más importantes de este grupo es que en sus obras, intervienen dos elementos muy importantes. Por una parte y, en general, son obras que se caracterizan por presentar materiales naturales, en el enfrentamiento entre lo natural y lo artificial, los artistas se decantan por el uso de materiales naturales o en algunos casos, por integrarse en el medio natural, trabajando en colaboración con la Naturaleza en una suerte de intervenciones mínimas con las que esperan causar el menor daño o repercusión posible en el medio en el cual se insertan. Sin embargo en este tipo de acciones, la paradoja se presenta al implicar generalmente, a posteriori, toda una suerte de medios ajenos que entran en contradicción con el pretendido naturalismo. Es el caso de la dependencia de la fotografía, los procesos de documentación de las obras, el video para el registro de acciones o la exposición en última instancia en espacios institucionalizados, museos o galerías, de las obras realizadas, etc. Recordemos en esta línea de trabajo, las obras de Anya Gallaccio y Meg Wester, que presentan procesos de creación, destrucción y transformación que son fundamentales para la comprensión de la obra al cuestionar la noción de permanencia y manifestar en ellas, una lucha por el equilibrio entre el crecimiento y la decadencia. Por otra parte, trabajan en colaboración con la Naturaleza, involucrando en sus obras, el concepto de tiempo como algo fundamental. En estas circunstancias, podemos hablar de un arte efímero, que si bien, en la concepción tradicional del arte resulta trasgresor por la dificultad de conservar los productos artísticos, ésta es, como señala José Fernández Arenas, simplemente una cuestión cultural: 
En muchas culturas el uso que se le da a los objetos que nosotros definimos como su arte, no tiene nada que ver con el que se da en las nuestras, y una de las formas frecuentes que se observan es la de hacerlos desaparecer803.

Consideramos efímero lo que corresponde a la obra, porque en realidad, lo que perdura y da sentido a la acción, es la acción en sí, la ofrenda como elaboración o el mantenimiento del ritual. Estos aspectos son fundamentales en obras como las de Goldsworthy o Udo. La Naturaleza participa en el proceso de la obra como sujeto de manera que, como indica Saborit, las obras se producen con una intención y una voluntad de integración camaleónica, que lleva a una natural mimetización con el entorno, imitando incluso el orden imperante en el medio804.

Por último, las estrategias de los artistas que hemos reunido en el quinto capítulo, persiguen procesos conceptuales vinculados al elemento vegetal y, prescindiendo en ocasiones, de la representación del mismo, generan un discurso ideológico basado en la presentación de los procesos vegetales. Su búsqueda se decanta por una experimentación entre la representación y la presentación del referente vegetal como actor de una paráfrasis sobre el binomio Naturaleza-Cultura. Alejados de planteamientos ecologistas, contemplan la Naturaleza como un constructo cultural, fruto de la percepción al que enfrentan la utopía de lo natural en el mundo contemporáneo, con la finalidad de hablarnos de límites entre Ciencia y Naturaleza. En estos casos, la idea es el sujeto principal de la obra y el referente vegetal ejerce como agente que nos permite visualizar el proceso al que nos enfrenta la obra. Se trata de una dialéctica que nos habla de límites entre Naturaleza y Cultura para expresar ideas diversas. Aquí, artistas como Perla Krauze (memoria y registro), Aurora Noreña (observación minuciosa), Pedro Reyes (sociedad como colectivo) o Jerónimo Hagerman (el tiempo de las plantas) plantean cómo la observación del mundo vegetal implica otro ritmo: las plantas no son estáticas, pero su movilidad, que es la de la expansión y el crecimiento, corresponde a un tiempo paralelo al de la civilización.

Ante la imposibilidad y la falacia de lo natural, el artista opone lo artificial, como forma coherente de pensamiento: Máximo González, con sus naturalezas vegetales envueltas en papel moneda, nos remite a la Naturaleza como objeto de consumo. Melanie Smith o Thomas Glassford, Gabriel Orozco, no hacen sino reafirmar la visión de la Naturaleza como moneda de cambio e imagen de mercado. Este discurso se relaciona con artistas como Alberto Baraya (herbario de plantas artificiales), Roxy Paine (cuestionamiento en torno a la realidad de la representación), Jane Benson (el bucle del artificio sobre el artificio). Así, el referente vegetal es llevado al límite, para evidenciar los abusos de un mundo invadido por la prepotencia del artificio y la falacia del kitsch (la obra de Jeff

803 FERNÁNDEZ ARENAS, José, op. cit., p. 34.

${ }^{804}$ ALBELDA, José y SABORIT, José, op. cit., p. 150. 
Koons o de Marc Quinn nos remite a los excesos, el vacío y lo cursi, entre paraísos reales, flores congeladas e ideas preconcebidas, que cuestionan la línea entre la vida y la muerte y nos enfrentan al uso mediático que de las aspiraciones y las nostalgias humanas, ejerce el mundo de la publicidad al seducirnos mediante una idílica, pero artificialmente manipulada Naturaleza). Encontramos así a artistas como Sofía Táboas quien enfatiza las cualidades matéricas de los materiales empleados en sus obras para dinamizar la percepción del espectador, de forma similar a Olafur Eliasson quien, en sus obras, explora los límites de la percepción, cuestionando nuestro concepto de realidad y convocándonos a reflexionar sobre la experiencia del sujeto que percibe. Ambos, llevando al límite las características de los materiales y sus diferentes lecturas en nuestra Cultura, se interesan por la relación de los espectadores con la pieza, privilegiando la percepción y la forma en la que la obra puede modificar un sitio específico.

En otra línea de planteamientos cercana a los cuestionamientos científicos y, con una cierta visión de futuro, la obra de artistas como Gerda Steiner y Jörg Lenzlinger y sus construcciones de utópicos y fantásticos jardines que juegan con el goce estético, sirven de parámetro para medir la pulsión entre lo natural y lo artificial. Naturaleza-Cultura-Ciencia exploran los límites entre ellas, las nuevas aportaciones del conocimiento científico, se alían para mediante la observación y el estudio, incursionar en el mundo de la biotecnología científica y el arte transgénico. Las investigaciones de Natalie Jeremijenko (clonación de árboles) y los experimentos realizados por George Gessert y Eduardo Kac (variación genética de organismos vegetales) tienen eco en las prácticas artísticas de Daniel Rivera (pasto transgénico con olor a jazmín para las ciudades contaminadas) o de Eduardo Rincón (cultivos in vitro de amates). Estamos en el último eslabón, en el que nos enfrentamos acaso, como apunta Virilio a un arte contra natura, en el que "puesto que la genética está en tránsito de convertirse en un arte, un arte transgénico" 805 , debemos ser conscientes de que la relación del arte contemporáneo con la Naturaleza, no puede seguir siendo entendida a manera de contemplación romántica. Sólo la acción -como apunta Julio Héctor Pérez- se adapta a los nuevos fenómenos creativos, como factor positivo y determinante, para identificar un cambio en las relaciones entre Naturaleza y Cultura.

Debe pensarse inmediatamente en el estado de la relación entre el planeta Tierra y el hombre como una condición a través de la cual cae toda una serie de determinaciones en el ámbito artístico806.

En definitiva, es evidente que los artistas contemporáneos han reflexionado a través de sus obras, en torno a la Naturaleza y sus relaciones con el arte, la Cultura y la sociedad, propiciando una revisión de lo sucedido en esta materia en las últimas décadas. Esto se debe en primera instancia, al abuso indiscriminado del ser humano, de nuestro entorno, urgiendo en consecuencia,

805 VIRILIO, Paul, El procedimiento silencio, op. cit., p. 68.

806 PÉREZ LÓPEZ, Héctor Julio, op. cit., p. 5. 
un crítico y serio replanteamiento de nuestra situación en un mundo que necesita de acciones drásticas. Por otro lado, entendemos que los fenómenos de globalización, movimientos de masas, así como las circunstancias económicas actuales, migraciones y movimientos humanos, tecnologías (internet) y economías globalizadas, han permitido que estos planteamientos se extiendan en ámbitos geográficamente muy diferentes, favoreciendo que Ilegaran hasta nosotros productos e información que en otro tiempo no era fácilmente accesible. Esta es la razón por la cual encontramos artistas cuya obra maneja planteamientos similares en cuanto a su apariencia.

Como conclusión final, hemos demostrado que efectivamente, hay un proceso de conceptualización contemporánea en México, en lo que se refiere al contexto de Arte y Naturaleza y, en el que los artistas de las nuevas generaciones (Ander Azpiri, Paola de Anda, Gustavo Gómez Brechtel) se comprometen de forma crítica con el propósito de generar nuevas ideas propositivas y esperanzadoras. A pesar de haber contado en el país con pocas referencias de los movimientos considerados originarios, como el Arte Povera o el Land Art, numerosos artistas han hecho patente con sus obras, desde diferentes contextos y mediante múltiples estrategias, su preocupación por la Naturaleza. Hemos evidenciado este interés, a través de un elemento en particular, que ha sido el objeto fundamental de nuestra investigación: el referente vegetal. Éste motivo nos ha servido de eje vertebrador de este estudio, facilitándonos la vinculación de los procesos y la elaboración de una multiplicidad de puntos de vista en el ámbito escultórico, que permite a los artistas hablar no sólo de la Naturaleza, sino más allá de ésta, de ellos mismos y de sus más profundas preocupaciones manifestadas en contextos tanto individuales e íntimos, como públicos, sociales y culturales.

Por último, como se aprecia en el capítulo sexto, nuestra investigación, tanto por las aportaciones teóricas, como por los ejemplos ilustrativos y el análisis empírico de las esculturas han servido en definitiva, para poner en un contexto crítico la obra que, como escultora, hemos realizado en los últimos años en México. Las hibridaciones entre el cuerpo humano y el referente vegetal aportan, a la luz de estas investigaciones, un valioso conocimiento que nos hace sentir parte fundamental, pionera e integrante de los procesos artísticos de un país que consideramos también como nuestro. Todo ello aporta sin lugar a dudas, un valor intrínseco que, en nuestro caso, propicia la elaboración de nuevos parámetros creativos que, a su vez, favorecen nuevas reflexiones y nuevas propuestas de trabajo.

Concretando, las aportaciones de la investigación que hemos realizado consisten en, por un lado, haber hecho visible la relación que la escultura contemporánea mexicana mantiene con el binomio Arte y Naturaleza y, por otro, en demostrar que dentro de este contexto, el referente vegetal es un elemento representativo y recurrente en la mayoría de los casos, para definir los términos de esta relación. 



\section{LIBROS}

AA. VV., Down the Garden Path: The Artist's Garden After Modernism, Queens Museum of Art, Nueva York, 2005.

AA. VV., Nueva enciclopedia Larousse, Planeta, Barcelona, 1981.

ÁBALOS, Iñaki y HERREROS, Juan, Natural-Artificial, Exit. LMI, Madrid, 1999.

ACHA, Juan, Introducción a la creatividad, Trillas, México, D.F., 1992.

AGUILERA, Carmen, El arte oficial tenochca. Su significación social, UNAM, Instituto de Investigaciones Estéticas, Cuadernos de Historia del Arte, México, D.F., 1985.

ALBELDA, José y SABORIT, José, La construcción de la naturaleza, Direcció General de Promoció Cultural, Museus i Belles Arts, Conselleria de Cultura, Educació i Ciència, Colección Arte, estética y pensamiento, Valencia, 1997.

ALCINA FRANCH, José, Arte y antropología, Alianza Forma, Madrid, 1982.

ANDERSON BARBATA, Laura, Shapono, Yanomami Owë Mamotima, Escuela Intercultural Bilingüe Yanomami, Platanal, Amazonas, 2001.

ANDRADE, Lourdes, Arquitectura vegetal. La casa deshabitada y el fantasma del deseo, Artes de México, Consejo Nacional para la Cultura y las Artes, México, D.F., 1994.

ANZORENA, Horacio, Arte y naturaleza, el mensaje de las formas: una revisión del mundo cotidiano y el arte, Ediunc, Mendoza, 1997.

ARACIL, Rafael et al. (eds.), Memòria de la Transició a Espanya i a Catalunya, Els jovens de la Transició, Universitat de Catalunya, Barcelona, 2003.

ARCHER, B.J. y VIDLER, A., Folies, Arquitectura para el paisaje de finales del siglo XX, Arquitectura, Madrid, 1984.

ARDENNE, Paul, Un arte contextual. Creación artística en un medio urbano, en situación, de intervención, de participación, Cendeac, Murcia, 2006.

ARGULLOL, Rafael, La atracción del abismo, Bruguera, Barcelona, 1983.

ARRIOLA, Magali, "Cuando la (mala) fe mueve fronteras: Ocho puntos para analizar la representación de México en el extranjero", en BENÍTEZ DUEÑAS, Issa M. ${ }^{a}$ (ed.), Crónicas del paraíso. Arte contemporáneo y sistema del arte en México, Ephemera, México, D.F., 2007.

ASHIDA, Carlos, Fernando González Gortázar. Sí, aún, Consejo Nacional para la Cultura y las Artes, México, D.F., 2000.

AUGÉ, Marc, Los no lugares. Espacios del Anonimato, Gedisa, Barcelona, 2001.

BACHELARD, Gaston, El aire y los sueños. Ensayo sobre la imaginación del movimiento, Breviarios del Fondo de Cultura Económica, México, D.F., 2002.

BACHELARD, Gaston, La poética del espacio. Breviarios del Fondo de Cultura Económica, México, D.F., 2005.

BACHELARD, Gaston, La tierra y las ensoñaciones del reposo. Ensayo sobre las imágenes de la intimidad, Breviarios del Fondo de Cultura Económica, México, D.F., 2006.

BACHOFEN, Johann Jakob, El matriarcado. Una investigación sobre la ginecocracia en el mundo antiguo según su naturaleza religiosa y jurídica, Akal, Madrid, 2008.

BAL, Mieke, Conceptos viajeros en las humanidades. Una guía de viaje, Cendeac, Murcia, 2009.

BARICCO, Alessandro, Next. Sobre la globalización y el mundo que viene, Anagrama, Colección Argumentos, Barcelona, 2002. 
BARLEY, Nigel, El antropólogo inocente. Notas desde una choza de barro, Anagrama Barcelona, 1989.

BARRIOS, José Luis, Símbolos, fantasmas y afectos. 6 variaciones de la mirada sobre el arte en México (SEMEFO, M. Lara, G. Suter, C. Amorales, M. Palau, S. Gruner), Libros de la Meseta, Casa Vecina, México, D.F., 2007.

BATESON, Gregory, Una unidad sagrada: pasos ulteriores hacia una ecología de la mente, Gedisa, Barcelona, 1999.

BAUDRILLARD, Jean, De la seducción, Cátedra, Madrid, 2007.

BAUDRILLARD, Jean, El sistema de los objetos, Siglo XXI, México, D.F., 2004.

BAUDRILLARD, Jean, La sociedad de consumo. Sus mitos, sus estructuras, Siglo XXI, Madrid, 2009.

BEARDSLEY, John, Earthworks and beyond: contemporary art in the landscape, Abbeville Press, New York, 1989.

BEIGBEDER, Olivier, Léxico de los símbolos, Encuentro, Vol. 15, Serie Europa Románica, Madrid, 1989.

BENÍTEZ DUEÑAS, Issa M. ${ }^{a}$ (Coord.), Hacia otra historia del arte en México, Disolvencias (1960-2000), Arte e imagen, Conaculta, México, D.F., 2004.

BENÍTEZ DUEÑAS, Issa M. ${ }^{a}$ et al., Tercer Simposio Internacional sobre Teoría del Arte Contemporáneo, SITAC, Patronato de Arte contemporáneo, Conaculta, INBA, México, D.F., 2004.

BENJAMIN, Walter, El libro de los Pasajes, Edición de Rolf Tiedemann, Akal, Madrid, 2004.

BERGER, John, Algunos pasos hacia una pequeña teoría de lo visible, Ardora, Madrid, 2002.

BERNÁLDEZ SANCHÍs, Carmen, Joseph Beuys, Nerea, Guipúzcoa, 1999.

BIEDERMANN, Hans, Diccionario de Símbolos, Paidós, Barcelona, 1993.

BLANCO, Alberto, Las voces del ver, 42 ensayos sobre artes visuales, Sello Bermejo, Consejo Nacional para la Cultura y las Artes, México, D.F., 1997.

BLANCO, Paloma et al., Modos de hacer. Arte público, esfera pública y acción directa, Universidad de Salamanca, Salamanca, 2001.

BLÁZQUEZ ABASCAL, Jimena, Arte y naturaleza. Guía de Europa, Parques de esculturas, Fundación NMAC y Documenta Artes y Ciencias Visuales, Cádiz, 2006.

BOERI, Stefano et al., Arte y Ciudad. Estéticas urbanas. Espacios públicos. ¿Políticas para el arte público? Segundo Simposio Internacional de Teoría sobre Arte Contemporáneo (SITAC), Patronato de Arte Contemporáneo, Conaculta, INBA, México, D.F., 2003.

BOETTGER, Suzaan, Earthworks, Art and landscape of de Sixties, University of California Press, Los Angeles, 2002.

BONFILL BATALLA, Guillermo, México Profundo. Una civilización negada, Grijalbo, México, D.F., 1994.

BOURRIAUD, Nicolás, Postproducción. La cultura como escenario: modos en que el arte reprograma el mundo contemporáneo, Adriana Hidalgo Editora, Buenos Aires, 2009.

BOURRIAUD, Nicolás, Estética relacional, Adriana Hidalgo Editora, Buenos Aires, 2008.

BOZAL, Valeriano, Mímesis: las imágenes y las cosas, Visor, Colección La balsa de la Medusa, Madrid, 1987.

BRANSCHWIG, Jacques et al., El saber griego, diccionario crítico, Akal, Madrid, 2000.

BREA, José Luis, Nuevas Estrategias Alegóricas, Tecnos, Madrid, 1991.

BROOKES, John, Guía completa de diseño de jardines, Blume, Barcelona, 2002.

BURKE, Edmund, Indagación filosófica sobre el origen de nuestras ideas acerca de lo sublime y de lo bello, Tecnos, Colección Metrópolis, Madrid, 1997. 
CAILLOIS, Roger, Piedras y otros textos, Siruela, La Biblioteca Azul, Serie mínima, Madrid, 2011.

CALABRESE, Omar, La era neobarroca, Cátedra, Madrid, 1999.

CALVO SERRALLER, Francisco, La senda extraviada del arte. Ensayos sobre lo excéntrico en las vanguardias, Mondadori, Madrid, 1992.

CARERI, Francesco, Walkscapes. El andar como práctica estética/Walking as an aesthetic practice, Land \& Scape Series, Gustavo Gili, Barcelona, 2003.

CASO, Alfonso, El pueblo de/ Sol, Fondo de Cultura Económica, México, D.F., 1987.

CEREIJIDO, Marcelino et al., El otro, el extranjero, Zorzal, Buenos Aires, 2003.

CIRLOT, Juan Eduardo, Diccionario de símbolos, Labor, Barcelona, 1988.

CIRLOT, Lourdes (Coord.), Arte, Arquitectura y Sociedad Digital, Universitat de Barcelona, Barcelona, 2007.

CLARK, Thomas A., The unpainted landscape, Corale Press, Scotish Arts Council, Londres, 1987.

COLAFRANCESCHI, Daniela, Landscape+100 palabras para habitarlo, Gustavo Gili, Barcelona, 2007.

COOPER, Paul, Living Sculpture, Octopus Publishing Groups Ltd, London, 2001.

CRESPO GARCíA, Ana, El Zen en el Arte Contemporáneo, Mandala, Madrid, 1997.

CROW, Thomas, El arte moderno en la cultura de lo cotidiano, Akal, Arte contemporáneo, Madrid, 2002.

CRUZVILLEGAS, Abraham, Round de sombra, Consejo Nacional para la Cultura y las Artes, México, D.F., 2006.

CUESTA, Salomé et al., Selección de textos sobre prácticas artísticas y espacio público II, Universitat Politècnica de València, Facultad de Bellas Artes, Departamento de Escultura, Valencia, 2002.

DE LA FUENTE, Beatriz et al., La pintura mural prehispánica en México III. Oaxaca, Tomo II, UNAM, Instituto de Investigaciones Estéticas, México, D.F., 2005.

DEBRAY, Régis, Vida y muerte de la imagen. Historia de la mirada en Occidente, Paidós, Barcelona, 1994.

DEL ANGEL, Varinia y LEÓN, Gabriela, El secreto de las plantas, Castillo, México, D.F., 2007.

DELEUZE, Gilles y GUATTARI, Félix, Rizoma. Introducción, Pretextos, Valencia, 2008.

DERRIDA, Jacques, El tiempo de una tesis. Desconstrucción e implicaciones conceptuales, Proyecto A, Biblioteca Universitaria, Barcelona, 1997.

DIDI-HUBERMAN, Georges, Ser cráneo. Lugar, contacto, pensamiento, escultura, Universidad Nacional de Colombia, Facultad de Bellas Artes, Colección Sin condición 17, Bogotá, 2008.

DORFLES, Gillo, Naturaleza y artificio, Lumen, Barcelona, 1972.

DUCROT, Oswald y TODOROV, Tzvetan, Diccionario enciclopédico de las ciencias del lenguaje, Siglo XXI (23a ed.), México, D.F., 2005.

DUQUE, Félix, Arte público y espacio político, Colección Arte y estética, Akal, 2001, Madrid 2001.

DURÁN, A. y RIECHMANN, J., Genes en el laboratorio y en la fábrica, Trotta, Fundación $1^{\circ}$ de mayo, Madrid, 1998.

ELIADE, Mircea, Tratado de historia de las religiones. Morfología y dialéctica de los sagrado, Cristiandad, Madrid, 2000.

ELIADE, Mircea, Lo sagrado y lo profano, Paidós Orientalia, Barcelona, 2003. 
ELIADE, Mircea, El mito del buen salvaje o el prestigio de los orígenes. Mitos, sueños y misterios, Kairós, Barcelona, 1999.

ESCOHOTADO, Antonio, De physis a polis: La evolución del pensamiento filosófico griego desde Tales a Sócrates, Anagrama, Barcelona, 1975.

ESPINOSA, César y ZÚÑIGA, Araceli, La perra brava. Arte, crisis y políticas culturales, UNAM, México, D.F., 2002.

FAGONE, Vittorio (ed.), Art in nature, Gabriele Mazzotta, Milán, 1996.

FERNÁNDEZ ARENAS, José (Coord.), Arte efímero y espacio estético, Anthropos, Barcelona, 1988

FERNÁNDEZ DEL CAMPO, Eva, Anish Kapoor, Nerea, San Sebastián, 2006.

FERNÁNDEZ POLANCO, Aurora, Arte Povera, Colección Arte Hoy, Nerea, Madrid, 1999.

FEYERABEND, Paul, La conquista de la abundancia, Paidós, Barcelona, 2001.

FONT QUER, Pío, Diccionario de botánica, Península, Barcelona, 2001.

FONTCUBERTA, Joan et al., Ciencia y fricción. Fotografía, naturaleza, artificio, Colección

Palabras de arte, $\mathrm{N}^{\circ}$ 4, Mestizo, Asociación Cultural de Murcia, Murcia, 1998.

FORTNUM, Rebecca, Contemporary british women artist: in their own words, Tauris, Londres, 2007.

FOUCAULT, Michel, Las palabras y las cosas, Siglo XXI, México, D.F., 1979.

FOSTER, Hal, El retorno de lo real. La vanguardia a finales de siglo, Akal, Arte contemporáneo, Madrid, 2001.

FOSTER, Hal, et al., Arte desde 1900, Modernidad, antimodernidad y posmodernidad, Akal, Madrid, 2004.

FRAZER, James George, La rama dorada. Magia y religión, Fondo de Cultura Económica, México, D.F., 1986.

GALOFARO, Luca, Artscapes. El arte como aproximación al paisaje contemporáneo. Art as an approach to contemporary landscape, Gustavo Gili, Barcelona, 2003.

GARCÍA BARRAGÁN, Elisa, Carlos Pellicer en el espacio de la plástica, Tomos I y II, Dirección General de Artes Plásticas, UNAM, México, D.F., 1997.

GARCÍA CANCLINI, Néstor, La globalización imaginada, Paidós, México, D.F., 1999.

GARCÍA CANCLINI Néstor, La sociedad sin relato. Antropología y estética de la inminencia, Katz, Madrid, 2011.

GARCÍA CORTÉS, José Miguel, El cuerpo mutilado. La Angustia de Muerte en el Arte, Direcció General de Museus i Belles Arts, Conselleria de Cultura, Educació i Ciència, Colección Arte, Estética y Pensamiento, Valencia, 1996.

GARCÍA CRESPO, Rosario, Caminar para descifrar, Consejo Nacional para la Cultura y las Artes, México, D.F., 2002.

GARCÍA CALVO, Agustín, Lucrecio. De la naturaleza de las cosas, Cátedra, Madrid, 2004.

GARRAUD, Collete, L'idée de nature dans l'art contemporain, Flammarion, Paris, 1994.

GHYKA, Matila C., El número de oro, Poseidón, Barcelona, 1978.

GHYKA, Matila C., Estética de las proporciones en la naturaleza y las artes, Poseidón, Barcelona, 1983.

PELT, Jean Marie et al., La historia más bella de las plantas. Las raíces de nuestra vida, Anagrama, Barcelona, 2001.

GOETHE, Johann Wolfgang, "Sobre verdad y verosimilitud en las obras de arte" (1798), en SALMERÓN, Miguel, Escritos de arte, J.W. Goethe, Síntesis, Madrid, 1999.

GOETHE, Johann Wolfgang, La metamorfosis de las plantas, Beta III Milenio, Bilbao, 1994.

GOLDBERG, Vicky et al., Robert Smithson: Slideworks, Carlo Frua, Milán, 1997.

GOMBRICH, E. H. Arte e ilusión, Gustavo Gili, Barcelona, 1979. 
GONZÁLEZ BUENO, Antonio, Linneo, el príncipe de los botánicos, Nivola Libros, Madrid, 2008.

GRACIA, Jordi y RÓDENAS DE MOYA, Domingo (eds.), Más es más. Sociedad y cultura en la España democrática (1986-2008), Iberoamericana, Madrid, 2008.

GRANDE, John K., Diálogos Arte-Naturaleza, Fundación César Manrique, Madrid, 2005.

GRANDE, John K., Balance: Art and Nature, Black Rose Books, Montreal, 2004.

GREENBERG, Clement, Arte y Cultura, Gustavo Gili, Barcelona, 1979.

GUASCH, Ana M. ${ }^{a}$, Arte y archivo, 1920-2010. Genealogías, Tipologías y discontinuidades, Akal, Arte contemporáneo, Madrid, 2011.

GUASCH, Ana M. ${ }^{a}$, El arte último del siglo XX. Del posminimalismo a lo multicultural. Alianza, Madrid, 2000.

GUASCH, Ana M. ${ }^{a}$, Los manifiestos del Arte Posmoderno, Textos de Exposiciones (1980-1995), Akal, Arte contemporáneo, Madrid, 2000.

HAWKINSON, Tim et al., Etre Nature, Fondation Cartier pour l'art contemporain, Paris, 1998.

HENCKMANN, Wolfhart y LOTTER, Konrad (eds.), Diccionario de estética, Crítica, Barcelona, 1998.

HERRERO UCEDA, Miguel, El alma de los árboles, Hedras, León, 2005.

HEYDEN, Doris, Mitología y simbolismo de la flora en el México prehispánico, UNAM, Instituto de Investigaciones Antropológicas, México, D.F., 1985.

HOMERO, La lliada, Ediciones ibéricas, Madrid, 1965.

HOMERO, La Odisea. La lliada, Edimat Libros, Madrid, 2000.

HOOKS, Margaret, Edward James y Las Pozas: un sueño surrealista en la selva mexicana, Madrid, Turner, 2005.

IMPELLUSO, Lucia, La naturaleza y sus símbolos: plantas, flores y animales, Electa, Barcelona, 2003.

INSAUSTI MACHINANDIARENA, Pilar de et al., El paisaje de los dioses, Universitat Politècnica de València, Valencia, 2002.

ISAAC, Joseph, El Transeúnte y el espacio urbano. Sobre la dispersión y el espacio urbano, Gedisa, Colección El mamífero parlante, Barcelona, 2002.

JAUSS, Hans Robert, Pequeña apología de la experiencia estética, Barcelona, Paidós, 2002. JIMÉNEZ, José y CASTRO FLÓREZ, Fernando (eds.), Horizontes del arte latinoamericano, Tecnos, Colección Metrópolis, Madrid, 1999.

JUNG, C. G., Recuerdos, sueños, pensamientos, Seix Barral, Los Tres Mundos, Barcelona, 2001.

$\mathrm{KAC}$, Eduardo, Telepresencia y bioarte. Interconexión en red de humanos, robots y conejos, Cendeac, Murcia, 2010.

KASSNER, Lily S., Diccionario de escultura mexicana del siglo XX, UNAM, México, D.F., 1983.

KASSNER, Lily S., Diccionario de escultores mexicanos del siglo XX, Tomos I y II, Consejo Nacional para la Cultura y las Artes, México, D.F., 1997.

KASSNER, Lily S. et al., Tiempo, piedra y barro, UNAM, Ciudad Universitaria, México, D.F., 2003.

KASSNER, Lily S., Yolanda Gutiérrez: el arte de divinizar la naturaleza, Consejo Nacional para la Cultura y las Artes, CONACULTA, México, D.F., 2006.

KASTNER, Jeffrey et al., Land and environmental art, Phaidon, Londres, 1998.

KARTOFEL, Graciela, Naomi Siegmann, Katún, Serie Artelibro 1, México, D.F., 1985. 
KRAUSS, Rosalind E., La originalidad de la Vanguardia y otros mitos modernos, Alianza, Madrid, 2006.

KRAUSS, Rosalind E., Pasajes de la escultura moderna, Akal, Arte contemporáneo, Madrid, 2002.

KRAUSS, Rosalind E., Beverly Pepper, Sculpture in place, Abbeville Press, Publishers, New York, 1986.

KUSPIT, Donald, El fin del arte, Akal, Arte contemporáneo, Madrid, 2006.

LAKOFF, George y JOHNSON, Mark, Metáforas de la vida cotidiana, Cátedra, Colección Teorema, Madrid, 2007.

LARRAURI, Maite, El deseo según Gilles Deleuze, Tándem, Colección Filosofía para profanos, Valencia, 2000.

LEÓN PORTILLA, Miguel, La Filosofía Náhuatl estudiada en sus fuentes, UNAM, Instituto de Investigaciones históricas, México, D.F., 1983.

LEÓN PORTILLA, Miguel, Los antiguos mexicanos a través de sus crónicas y cantares, Fondo de Cultura Económica, México, D.F., 2005.

LEÓN-PORTILLA, Miguel, Trece poetas del mundo azteca, Serie Cultura Náhuatl, Monografías 11, UNAM, Instituto de Investigaciones Históricas, México, D.F., 1984.

LHOTE, André, Tratado del paisaje, Poseidón, Buenos Aires, 1970.

LINDBERG, David C., Los inicios de la ciencia occidental. La tradición científica europea en el contexto filosófico, religioso e institucional (desde el 600 a. de C. hasta 1450), Paidós Ibérica, Barcelona, 2002.

LITVAK, Lily, El tiempo de los trenes: el paisaje español en el arte y la literatura del realismo: (1849-1918), Serbal, Barcelona, 1991.

LIVERANI, Mario, El antiguo Oriente, Historia, sociedad y economía, Crítica, Barcelona, 2008.

LÓPEZ AUSTIN, Alfredo, Cuerpo humano e ideología. Las concepciones de los antiguos nahuas, Vol. 1, UNAM, México, D.F., 1984.

LYNCH, Kevin, La imagen de la ciudad, Gustavo Gili Reprints, Barcelona, 2001.

LYOTARD, Jean-François, La condición postmoderna, Cátedra, Madrid, 1989.

LYOTARD, Jean François, La postmodernidad (explicada a niños), Gedisa, México, D.F., 1986.

MAGRINI, Gigliola, El libro de los jardines, Gustavo Gili, Barcelona, 1974.

MADERUELO, Javier, La pérdida del pedestal, Cuadernos del Círculo, Círculo de Bellas Artes, Madrid, 1994.

MADERUELO, Javier (dir.), Huesca: Arte y naturaleza, Actas del I Curso, Diputación de Huesca, Huesca, 1995.

MADERUELO, Javier (dir.), El paisaje: Arte y naturaleza, Actas del II Curso, Diputación de Huesca, Huesca, 1996.

MADERUELO, Javier, Nuevas visiones de lo pintoresco. El paisaje como arte, Fundación César Manrique, Lanzarote, 1996.

MADERUELO, Javier (dir.), El jardín como arte: Arte y naturaleza, Actas del III Curso, Diputación de Huesca, Huesca, 1997.

MADERUELO, Javier (dir.), Arte público: Arte y naturaleza, Actas del V Curso, Diputación de Huesca, Huesca, 1999.

MANRIQUE, Jorge Alberto, Arte y artistas mexicanos del siglo XX, Lecturas mexicanas, México, D.F., 2000.

MANRIQUE, Jorge Alberto, Una visión de arte y la historia, Tomo IV, UNAM, Instituto de Investigaciones Estéticas, México, D.F., 2001. 
MANRIQUE, Jorge Alberto, "Escultura viajera", en AA. VV., México en el mundo de las colecciones de arte. México Contemporáneo, Tomo I, Conaculta, UNAM, Secretaría de Relaciones Exteriores, México, D.F., 1994.

MARCHAMALO, Jesús y FLORES, Damián, Escultecturas Margivagantes: La arquitectura fantástica en España, Siruela, Colección Biblioteca Azul, Serie Menor, Madrid, 2006.

MARCHÁN FIZ, Simón, Del arte objetual al arte de concepto (1960-1974). Epílogo sobre la sensibilidad "postmoderna". Analogía de escritos y manifiestos, Akal, Madrid, 2001.

BROWN, Mark Stanky, Cream of the crops. A skinhead photobook, Street Music Publishing, Ibiza, 1997.

MARTÍN DE ARGILA, M. ${ }^{a}$ Luisa et al., La construcción del paisaje contemporáneo, Centro de Arte y Naturaleza, Fundación Beulas, Huesca, 2008.

MARTÍNEZ CORTÉS, Fernando et al., Historia General de la Medicina en México, Tomo 1, México Antiguo, UNAM, Facultad de Medicina, México, D.F., 1984.

MARTÍNEZ MUÑOZ, Amalia, De Andy Warhol a Cindy Shermann, Colección Arte del S. XX, Universitat Politècnica de València, Valencia, 2000.

MARTÍNEZ LIRA, Verónica et al., El lenguaje secreto de Hildegard Von Bingen. Vida y obra, Espejo de viento, UNAM, Fondo de Cultura Económica, Conaculta, México, D.F., 2004.

MÉNDEZ BAIGES, Maite, Camuflaje. Engaño y ocultación en el arte contemporáneo, Siruela, Madrid, 2007.

MERLEAU-PONTY, Maurice, Fenomenología de la percepción, Península, Barcelona, 2000.

MORIN, Edgar, La naturaleza de la naturaleza. El método., Vol. 1, Cátedra, Madrid, 1997.

MUNARI, Bruno, ¿Cómo nacen los objetos? Apuntes para una metodología proyectual, Gustavo Gili, 2008.

NAYDER, Jeremy y GAUGER, Gloria, Goethe y la Ciencia, Biblioteca de ensayo Siruela, Madrid, 2002.

NEMITZ, Barbara, Trans Plant. Living vegetation in contemporary art, Hatje Cantz Publishers, Stuttgart, 2000.

NORMAN, Donald A., El diseño emocional. Por qué nos gustan (o no) los objetos cotidianos, Paidós Transiciones, Barcelona, 2005.

NOVALIS, Granos de polen. Himnos a la noche. Enrique de Ofterdingen, SEP, Colección Cien del mundo, México, D.F., 1987.

NOVO, María (Coord.), Ciencia, arte y medioambiente, Mundi-Prensa, Madrid, 2002.

NURIDSANY, Claude, Eloge de l'herbe: Les formes cachées de la nature, Adam Biro, Paris, 1995.

PAZ, Octavio, El fuego de cada día, Seix Barral, Barcelona, 1989.

PAZ, Octavio, Árbol adentro, Seix Barral, Barcelona, 1990.

PELLICER, Carlos, Era mi corazón piedra de río. Poesía amorosa reunida, Colección Ars Amandi, Consejo Nacional para la Cultura y las Artes, Compañía Operadora del Centro Cultural y Turístico de Tijuana, Tijuana, 1997.

PENONE, Giuseppe, Respirar la sombra. Textos, Centro Galego de Arte Contemporánea, Xunta de Galicia, Santiago de Compostela, 1999.

PÉREZ-TAYLOR, Rafael et al., Antropología del desierto. Paisaje, naturaleza y sociedad, UNAM, Instituto de Investigaciones Antropológicas, México, D.F., 2007.

PEREC, Georges, Especies de espacios, Montesinos, Barcelona, 1999.

PEREC, Georges, Pensar-Clasificar, Gedisa, Barcelona, 1986.

PÉRET, Benjamin, Historia natural, Artes de México, Colección Tiempo detenido, México, D.F., 2000.

PÉREZ LÓPEZ, Héctor Julio, La naturaleza en el arte posmoderno, Akal, Madrid, 2004. 
PIRSON, Jean-François, La estructura y el objeto. Ensayos, experiencias y aproximaciones, Promociones y Publicaciones Universitarias, Barcelona, 1988.

PORTAL, Frédéric: El simbolismo de los colores. En la Antigüedad, la Edad Media y los tiempos modernos, José J. de Olañeta, Palma de Mallorca, 2005.

POPELARD, Marie Dominique, Ce que fait l'Art. Approche communicationnelle, Presses Universitaires de France, Paris, 2002.

POPPER, Frank, Arte, acción y participación. El artista y la creatividad de hoy, Akal, Arte y Estética, Madrid, 1989.

POWER, Kevin et al., Diálogos iberoamericanos. I/ Simposium internacional. La identidad iberoamericana: modernidad y posmodernidad, Generalitat Valenciana, Valencia, 2000.

PRADA, Juan Martín, La apropiación posmoderna. Arte, práctica apropiacionista y teoría de la posmodernidad, Fundamentos, Madrid, 2001.

QUANCE, Roberta Ann, Mujer o árbol. Mitología y modernidad en el arte y la literatura de nuestro tiempo. A. Machado Libros, Colección La balsa de la Medusa, Madrid, 2000.

RACIONERO, Luis, Textos de estética taoísta, Alianza, Madrid, 2002.

RAQUEJO, Tonia, Land Art, Nerea, Madrid, 1998.

RAMÍREZ, Juan Antonio y CARRILLO, Jesús (eds.) Tendencias del arte, arte de tendencias a principios del siglo XXI, Ensayos Arte Cátedra, Madrid, 2004.

RAMÍREZ, Juan Antonio, Corpus solus. Para un mapa del cuerpo en el arte contemporáneo, Siruela, Madrid, 2003.

REYES, Fabiola, Nature, Inspiración para el arte y el diseño, Instituto Monsa de Ediciones, Barcelona, 2008.

RIEMSCHNEIDER, B. y GROSENICK, U., Arte de hoy, Taschen, Köln, 2002.

RODRIGUEZ IZQUIERDO, Fernando, El Haiku Japonés. Historia y traducción. Evolución y triunfo del haiku, breve poema sensitivo, Hiperión, Madrid, 1994.

ROGER, Alain, Breve tratado del paisaje, Edición de Javier Maderuelo, Paisaje y Teoría, Biblioteca Nueva, Madrid, 2007.

ROSENZWEIG, Carmen, Simone, el desierto, Simone, el huerto, Gobierno del Estado de México, FONAPAS, Serie Juana de Asbaje, Colección Letras, Nº 14, Toluca, 1979.

ROSSET, Clément, La antinaturaleza, Taurus, Madrid, 1974.

RUDOMIN, Isaac et al., "Plant Lab: an AR plant laboratory for the typical home", 1st Workshop on Virtual Laboratories, Iberamia, en DE ITA LUNA, Guillermo et al. (eds.), Universidad Autónoma de Puebla, Cholula, 2004.

RUIDO LÓPEZ, María, Ana Mendieta, Nerea, San Sebastián, 2002.

RUY SÁNCHEZ, Alberto, Los jardines secretos de Mogador, Alfaguara, Voces de tierra, México, D.F., 2001.

SACHSSE, Rolf, Karl Blossfeldt. Fotografías, Benedikt Taschen, Köln, 1994.

SALABERT, Pere et al., Estética plural de la naturaleza, Laertes, Barcelona, 2006.

SAVATER, Fernando, Diccionario filosófico, Ariel, Barcelona, 2007.

SCHMELZ, Itala (Coord.), Memorias, 2001-2002, Sala de Arte Público Siqueiros, Instituto Nacional de Bellas Artes, México, D.F., 2002.

SCHMELZ, Itala (Coord.), Memorias, 2004, Sala de Arte Público Siqueiros, Instituto Nacional de Bellas Artes, México, D.F., 2004.

SCHMILCHUK, Graciela, Helen Escobedo. Pasos en la arena, Turner, Madrid, 2005.

SCHOPENHAUER, Arthur, Lecciones sobre metafísica de lo bello, Universitat de València, Valencia, 2004.

SENIE, Harriet F., Contemporary Public Sculpture. Tradition, Transformation and controversy, Oxford University Press, New York, Oxford, 1992. 
SIGLER, Gerardo et al., ¿Qué es la escultura hoy?, $7^{\circ}$ Congreso Internacional de Nuevos Procedimientos Escultóricos, Grupo de Investigación Nuevos Procedimientos Escultóricos, Universitat Politècnica de València, Valencia, 2002.

SOURIAU, Etienne, Diccionario de Estética, Akal, Madrid, 1998.

STANGOS, Nikos, Conceptos de Arte moderno, Alianza, Madrid, 1997.

STEADMAN, Philip, Arquitectura y Naturaleza. Las analogías biológicas en el diseño, Blume, Madrid, 1982.

STEVENS, Peter S., Patrones y pautas en la naturaleza, Salvat, Serie Biblioteca Científica Salvat, Barcelona, 1986.

TATARKIEWICZ, Wladyslaw, Historia de seis ideas. Arte, belleza, forma, creatividad, mímesis, experiencia estética, Tecnos-Alianza, Colección Neo-Metrópolis, Madrid, 2004.

THOMAS, Andy, Crops Circles. El enigma de un arte anónimo, Siruela, Madrid, 2003.

THOMPKINS, Peter et al., La vida secreta de las plantas. Exposición fascinante de las relaciones físicas, emocionales y espirituales entre las plantas y el hombre, Diana, México, D.F., 1991.

THOMPSON, D' Arcy, Sobre el crecimiento y la forma, Cambridge University Press, Madrid, 2003.

UBIETA, José Ángel, Biblia de Jerusalén, Editorial Española Desclée de Brouwer, Bilbao, 1975.

VIRILIO, Paul, La máquina de la visión, Cátedra, Madrid, 1989.

VIRILIO, Paul, Ciudad Pánico. El afuera comienza aquí, Libros del Zorzal, Buenos Aires, 2006.

VIRILIO, Paul, El procedimiento silencio, Paidós, 2ª reimpresión, Buenos Aires, 2005.

VIRILIO, Paul, Un paisaje de acontecimientos, Paidós, Buenos Aires, 1997.

WAGENSBERG, Jorge, La rebelión de las formas. O cómo perseverar cuando la incertidumbre aprieta. Tusquets, Barcelona, 2005.

WAGENSBERG, Jorge, Si la naturaleza es la respuesta, ¿cuál era la pregunta? Y otros quinientos pensamientos sobre la incertidumbre, Tusquets Editores, Barcelona, 2002.

WENT, Frits W., Las plantas, Colección de la Naturaleza de Time-Life, Offset Multicolor, México, D.F., 1980.

WESTHEIM, Paul, Ideas fundamentales del arte prehispánico en México, Biblioteca Era, Serie mayor, México, D.F., 1986.

WÖLFFLIN, Heinrich, Renacimiento y Barroco, Paidós, Barcelona, 2008.

WOLLHEIM, Richard, El arte y sus objetos: introducción a la estética, Seix Barral, Barcelona, 1972.

WOOD, Paul, La modernidad a debate. El arte desde los cuarenta, Akal, Madrid, 1999.

WORRINGER, Wilhelm, Abstracción y naturaleza, Fondo de Cultura Económica, México, D.F., 1983.

ZAMBRANO, María, Los bienaventurados. Centenario del nacimiento de María Zambrano (1904-1991), Siruela, Madrid, 2004.

ZÚÑIGA, Rodrigo, La Demarcación de los Cuerpos. Tres textos sobre arte y biopolítica, Metales Pesados, Santiago de Chile, 2008.

ZUMTHOR, Peter, Atmósferas, Gustavo Gili, Barcelona, 2006. 


\section{CATÁLOGOS}

AA. VV., Amate, Eduardo Rincón, Museo y Centro de Documentación Histórica del Ex-Convento de Tepoztlán, Morelos, Fondo Estatal para la Cultura y las Artes de Morelos, Instituto de Cultura de Morelos y Fondo Nacional para la Cultura y las Artes, México, D.F., 2001.

AA. VV., An expression of the New Millenium: Mexico's presence. 11 mexicans sculptors, Instituto Nacional de Bellas Artes, Secretaría de Relaciones Exteriores, Conaculta, México, D.F., 2001.

AA. VV., Ana Mendieta, Centro Gallego de Arte Contemporáneo, Santiago de Compostela, 1996.

AA. VV., Anish Kapoor. Entre el objeto y la imagen. Escultura Británica Contemporánea, Ministerio de Cultura, The British Council, Palacio de Velázquez, Madrid, 1986.

AA. VV., Ars Bene Moriendi, Arte joven mexicano, Museo de Arte Contemporáneo, Universidad de Chile, Facultad de Artes, Santiago de Chile, 1993.

AA. VV., Armas y Herramientas, X Salón de Arte Bancomer, Consejo Nacional para la Cultura y las Artes, INBA, Museo de Arte Moderno, México, D.F., 2004.

AA. VV., Arte y naturaleza. Montenmedio Arte Contemporáneo, Marina Abramovic, Pilar Albarracín, Gunilla Bandolin, Maurizio Cattelan, Anya Gallaccio, Sol LeWitt, Richard Nonas, Roxy Paine, Susana Solano, Fundación NMAC, Vejer de la Frontera, Cádiz, 2001.

AA. VV., Aurora Noreña, entre la dicha inicua y la consagración del desperdicio, Desperdicio de tiempo. Museo Tridimensional M-3D, Azcapotzalco, México, D.F., 2003/De Naturaleza Artificialy Jardín de las Esculturas, Jalapa, Veracruz, 2004.

AA. VV., Betsabeé Romero, Lágrimas negras, Museo Amparo, Puebla, 2008.

AA. VV., I/ Bienal de Artes Visuales de Mérida, Instituto de Artes Visuales de Mérida Yucatán, 2004.

AA. VV., III Bienal Internacional Site Santa Fe, Looking for a place, Santa Fe, 1999.

AA. VV., Botánica, Miguel Ángel Blanco-Jan Hendrix, Museo Nacional de la Estampa CONACULTA, INBA, MUNAE, México, D.F., 2003.

AA. VV., Cerámica Suro, diálogo y producción, Galería Jesús Gallardo, León Guanajuato, 2009.

AA. VV., Construyendo con la mirada, Museo Carrillo Gil, México, D.F., 2004.

AA. VV., Cuarto Creciente. Escultores contemporáneos, Biblioteca Nacional de Educación, México, D.F., 2001.

AA. VV., Cuerpos terrenales. Escultura en barro. Azcúnaga, Margáin, Marín, Medrez, Portela, Torres Vargas, Boris Hirmas, México, D.F., 2003.

AA. VV., Del Arte Povera a 1985, Palacio de Velázquez, Palacio de Cristal, Parque del Retiro, Madrid, Ministerio de Cultura, Dirección General de Bellas Artes y Archivos, 1985.

AA. VV., Earth art, Jan Dibbets, Hans Haacke, Neil Jenney, Richard Long, David Medalla, Robert Morris, Dennis Oppenheim, Robert Smithson, Günther Uecker, Andrew Dickson White Museum of Art, Cornell University, Ithaca, New York, 1969.

AA. VV., Eco: arte contemporáneo mexicano, Museo Nacional Centro de Arte Reina Sofía, Conaculta, Madrid, 2005.

AA. VV., Edén, La colección Jumex, Antiguo Colegio de San Ildefonso, Festival del Centro Histórico, México, D.F., 2004.

AA. VV., Eduardo Kac, IVAM Institut Valencià d'Art Modern, Valencia, 2007.

AA. VV., El Bosque/The Forest. Escultura/Sculpture, Naomi Siegmann, Buena Tinta, México, D.F., 2005. 
AA. VV., El Espacio Escultórico, Museo Universitario de Ciencias y Arte, Centro de Investigación y Servicios Museológicos, UNAM, México, D.F., 1980.

AA. VV., El Jardín salvaje, Fundación Caja de Pensiones, Madrid, 1991.

AA. VV., El objeto mismo, cuatro propuestas, Universitat Politècnica de València, Valencia, 2004.

AA. VV., Escultura Mexicana. De la Academia a la Instalación, Instituto Nacional de Bellas Artes y Landucci Editores, México, D.F., 2000.

AA. VV., Esculturas. Naomi Siegmann, Artista mexicano-norteamericana, Museo de Arte Moderno, Instituto Nacional de Bellas Artes, México, D.F., 1979.

AA. VV., Escultura social. A new generation of art from Mexico City, Museum of Contemporary art, Chicago, 2007.

AA. VV., Espacios de transición, E2 Espacios expositivos, Antiguo Cuartel de Instrucción, Universidad Politécnica de Cartagena, Facultad de Ciencias de la Empresa, (Manifesta 8, Paralelo, 8), Grupo de investigación Arte, espacio público y paisaje de la Facultad de Bellas Artes de Murcia, Cartagena, 2010.

AA. VV., Estiu-Art, 2007, Intervencions, Universitat Politècnica de València, Valencia, 2007. AA. VV., Germinal. Arte y Naturaleza, Vicerrectorado de Cultura, Universitat Politècnica de València, Valencia, 2006.

AA. VV., Giuseppe Penone, 1968-1998, Centro Galego de Arte Contemporánea, Xunta de Galicia, Consellería de Cultura, Comunicación Social e Turismo, Santiago de Compostela, 1999.

AA. VV., Helen Escobedo, 15 instalaciones. Estar y no estar, UNAM, Difusión Cultural, Dirección General de Artes Plásticas, México, D.F., 2000.

AA. VV., In urbe, Intervenciones Urbanas, Ayuntamiento de Alicante, Concejalía de Juventud, Alicante, 2005.

Intervencions plàstiques a La Marina, Consorci de Museus de la Comunitat Valenciana, Generalitat Valenciana, Valencia, 2002.

Intervencions plàstiques a La Marina, Consorci de Museus de la Comunitat Valenciana, Generalitat Valenciana, Valencia, 2003.

AA. VV., Is/a de las Esculturas, Diputación de Pontevedra, Pontevedra, 1999.

AA. VV., La razón mágica de Marta Palau. Nahualli, instalaciones, escultura, collage. Galería Expositum, México, D.F., 1991.

AA. VV., Las nuevas majas, Secretaría de Hacienda y Crédito Público, México, D.F., 1993.

AA. VV., Lesa Natura, Reflexiones sobre ecología, Museo de Arte Moderno, Grupo de los Cien, Cemex, Sedesol, La Vaca independiente, México, D.F., 1993.

AA. VV., Los Ecos de Mathías Goeritz, Antiguo Colegio de San Ildefonso, Instituto de Investigaciones Estéticas, Instituto Nacional de Bellas Artes, México, D.F., 1997.

AA. VV., Los géneros de la pintura: una visión actual, Centro Atlántico de Arte Moderno, Las Palmas de Gran Canaria, 1994.

AA. VV., Magiciens de la terre, Centre Pompidou, Paris, 1989.

AA. VV., Manifiesta 2. Cábula situacionista, Instituto Nacional de Bellas Artes, Ex Teresa Arte Alternativo, México, D.F., 1997.

AA. VV., Marta Palau. 30 esculturas en materiales textiles, Museo de Arte Moderno, Bosque de Chapultepec, Instituto Nacional de Bellas Artes, México, D.F., 1978.

AA. VV., Marta Palau, Mis caminos son terrestres: muros, esculturas, ambientaciones en fibra, Sala Nacional del Palacio de Bellas Artes, Instituto Nacional de Bellas Artes, Secretaría de Educación Pública, México, D.F., 1985. 
AA. VV., Marta Palau, Lo uno, lo múltiple y todas las guerras, Museo de Arte Contemporáneo Alfredo Zalce, Morelia, Michoacán, 2004.

AA. VV., Melanie Smith, Ciudad espiral y otros placeres artificiales/Spyral City and other artificial pleasures, MUCA, UNAM, A \& R Press, Turner, México, D.F., 2006.

AA. VV., Melanie Smith. Cuadrado rojo, imposible rosa, 54 Bienal de Venecia, Turner/ Instituto Nacional de Bellas Artes, México, D.F., 2011.

AA. VV., Metropolis mexica, Aspects de l'art contemporaine au Mexique, Musée de Picardie, Ville de Amiens, 2001.

AA. VV., Nopal urbano. Visión de 78 artistas, Impronta editores, México, D.F., 2004.

AA. VV., Obra social, Hans Haacke, Fundació Antoni Tapies, Barcelona, 1995.

AA. VV., Olafur Eliasson: Funcionamiento silencioso, Palacio de Cristal, Parque del Retiro, Museo Nacional Centro de Arte Reina Sofía, Madrid, 2003.

AA. VV., Orange Lush. Melanie Smith, Instituto Anglo Mexicano, México, D.F., 1997.

AA. VV., Pecho tierra, Betsabée Romero, obra reciente, Galería de Arte Mexicano (GAM), México, D.F., 2001-2002.

AA. VV., Por mi raza hablará el espíritu, Intercambio artístico México-Colombia, Museo Universitario del Chopo, UNAM, México, D.F., 1995.

AA. VV., Piedras, Richard Long, Palacio de Cristal, Parque del Retiro, Ministerio de Cultura, Madrid, 1986.

AA. VV., Siah Armajani, Museo Nacional Centro de Arte Reina Sofía, Madrid, 1999.

AA. VV., Soleils mexicains, CONACULTA, INAH, INBA, Musées de la Ville de Paris, Paris, 2000.

AA. VV., Un lugar en otro lugar, Centro Cultural de México, París, 2002.

AA. VV., Usted está aquí: Arte contemporáneo mexicano. Intervenciones a la ciudad, Colonia Condesa, Neuronal Laboratorio+Creativo, S.C., México, D.F., 2007.

AA. VV., Vito Acconci. Escritos, obras y proyectos, Polígrafa, Barcelona, 2001.

AA. VV., Yayoi Kusama, Phaidon Press, London, 2000.

AA. VV., Yvonne Domenge, Escultora. Visión antológica, Museo de Arte Moderno de México, Instituto Nacional de Bellas Artes, Conaculta-Fonca, México, D.F., 2005.

ABARCA MARTíNEZ, Inmaculada, "Reflexiones en torno a Còrpora i natura", en Còrpora $i$ natura. Art Contemporany, Museu de L’Almodí, Ayuntamiento de Xàtiva, Valencia, 2006-2007.

ACHA, Juan, Helen Escobedo, Museo Arte Moderno, México, D.F., 1974-1975.

ACHA, Juan, Hersúa: Obras/Escultura, Persona/Sociedad, UNAM, Coordinación de Humanidades, México, D.F., 1983.

ALBELDA, José, "Las enseñanzas de natura", en Plaisir de fleurir, Monique Bastiaans, Sala Parpalló, Valencia, 2007.

ALBELDA, José y SABORIT José, “¿Qué es la Naturaleza?", en El contrato Natural, Palau de la Música, Valencia, 1996.

ALBERTAZZI, Liliana (dir.), Différentes Natures, Visions de l'art contemporain, Etablissement Public pour I'Aménagement de la région de la Defense, Ministére de Culture et de la Francophone, Délegation aux Arts Plastiques, Paris, 1993.

ARTEAGA, Agustín, "Nuevas cadenas", en Yolanda Gutiérrez, Galería Espace d’Art Yvonnamor Palix, México, D.F., 1999.

BENITEZ DUEÑAS, Issa M. ${ }^{a}$ et al., Signos de origen, Centro de Diseño, Cine y Televisión, México, D.F., 2006.

BLAS, Susana, "Instrucciones para adentrarse en la obra de Hisae Ikenaga", en Muestra de Artes Visuales Creación InJuve, Madrid, 2007. 
BLOEMINK, Barbara, A natural order. The experience of Landscape in contemporary Sculpture, The Hudson River Museum, New York, 1990.

BRÜDERLIN, Markus et al., The Magic of trees, Verlg Gerd Hatje, Fondation Beyeler, Basilea, 1998.

CASTRO FLÓREZ, Fernando, "Notas intempestivas. Sobre el destino nihilista del arte contemporáneo", en AA. VV., Heterotopías. Cambres d'art, Project rooms, Interart 99, $14^{\text {a }}$ Fira Internacional d'Art, Generalitat Valenciana, Consorci de Museus de la Comunitat Valenciana, Valencia, 1999.

CASTRO FLÓREZ, Fernando, Esther Pizarro, Mapificar, Ayuntamiento de Granada, Granada, 2003.

CASTRO FLÓREZ, Fernando, "Escándalo es un escándalo. [Con una entonación sobradamente conocida]", en AA. VV., Intervencions plàstiques a la Marina, Consorci de museus de la Comunitat Valenciana, Valencia, 2004.

CALVO SERRALLER, Francisco, "Concepto e historia de la pintura de paisaje", en Los paisajes del Prado, Nerea, Madrid, 1993.

DRIVEN, Lelia, Landscapes. Perla Krauze, Gallery Iturralde, Los Ángeles, California.

ECHEVERRÍA, Adolfo, "Musa paradisíaca", en Eduardo Rincón. Musa paradisíaca, Casa Lamm, México, D.F., 2006.

ESPINOSA DE LOS MONTEROS, Santiago, "Entrevista a Laura Anderson”, en AA. VV., Laura Anderson Barbata. La piel de la tierra, Museo de Arte Moderno, Consejo Nacional para la Cultura y las Artes, México, D.F., 1995.

ESPINOSA DE LOS MONTEROS, Santiago, Yolanda Gutiérrez. Adentrarse a la tierra de la abundancia, Galería de Arte Mexicano, México, D.F., 2003.

FRIEDMAN, Terry, Andy Goldsworthy, A collaboration with nature, Harry N. Abrams, Inc., New York, 1990.

FRIEDMAN, Terry, Wood. Andy Goldsworthy, Viking-Penguin Group, Harmondsworth, 1996.

FRIEDMAN, Terry, Time. Andy Goldsworthy, Thames \& Hudson Ltd, Londres, 2000.

GANADO KIM, Edgardo, "Naturaleza y apariencia", en Naturaleza suspendida. Perla Krauze, Galería Menocal, México, D.F., 2001.

GOODBALL, Donald B., Esculturas Naomi Siegmann, 1971-1992, Material divulgativo de la exposición, Museo Universitario del Chopo, México, D.F., 1992.

GOODMAN, J., Petah Coyne, Sculpture, Galería Lelong, Washington, D.C., 1999.

GUTIÉRREZ, Yolanda, "Un proceso de encuentros", en El final del Eclipse. El arte en América Latina en la transición al Siglo XXI, Fundación Telefónica, Madrid, 2001.

HAGERMAN, Jerónimo, "Contemplando la invasión", en SCHMELZ, Itala (Coord.), Memorias 2004, Sala de Arte Público Siqueiros, Instituto Nacional de Bellas Artes, México, D.F., 2004. HINOJOSA, Francisco, "Semilla adentro", en Eduardo Rincón. Via Sativa, Casa Lamm, Centro de Cultura, México, D.F., 2004.

HEANEY, Seamus, BENÍTEZ DUEÑAS, Issa M. ${ }^{a}$, Jan Hendrix, Diario de fatigas, Turner, Fundación Cultural Artención, México, D.F., 2002.

IBARROLA, Agustín et al., Omako basoa. El bosque de Oma, Universidad del País Vasco, Bilbao, 2000.

JUANES, Jorge, "Lo riguroso/Lo abierto", en Inmaculada Abarca, Material divulgativo de la exposición, Galería Kin, México, D.F., 1997.

ISAAC, Claudio, "La partitura secreta", en Eduardo Rincón, Donde se origina el arte, El aire Centro de arte, México, D.F., 2001. 
JANKA, J. Frederick, "Perla Krauze. Paisajes: huellas y recorridos", en Perla Krauze. Paisajes: huellas y recorridos, Material divulgativo de la exposición, Galería Nina Menocal, México, D.F., 2005.

JÉZIK, Enrique, "Silvestre, Sofía Táboas", en SCHMELZ, Itala (Coord.), Memorias, 2001-2002, Sala de Arte Público Siqueiros, Instituto Nacional de Bellas Artes, México, D.F., 2002.

JURGENSEN, Andreas et al., Trilogi: Kunst-Natur-Videnskab/Trilogy: art-nature-science, Odense, Kunsthallen Brandts Klaedefabrik, Botanical Gardens, Copenhagen, 1996.

KATZEW, Ilona, "Laura Anderson Barbata y el Amazonas", en AA. VV., Laura Anderson Barbata, Terra incógnita, Proyecto Intervenciones Sociales, Ex Teresa Arte Actual, Instituto Nacional de Bellas Artes, México, D.F., 2003.

LARA, Magali, "La tierra y el cuerpo", en Marta Palau, Nahualli, esculturas y dibujos, Galería Juan Martín, México, D.F., 2001.

LEAL, Esther, Miriam Medrez: Cuerpo y superficie, Fondo Editorial de Nuevo León, Monterrey, 2009.

MARTÍN LOZANO, Luis, "Yolanda Gutiérrez: una artista con serios compromisos estéticos", en At/-Agua, Yolanda Gutiérrez, Museo Amparo, Puebla, 2000.

MATEO, Regino, "La casa de la Esfinge", en Azder Azpiri. Hábitat. Entorno y morada, Centro Municipal de las Artes y Alcorcón y Fundación ArtSur, Madrid, 2010.

MEDINA, Cuauhtémoc, "20 Million Mexicans can't be wrong, 20 millones de mexicanos no pueden estar equivocados", en 20 millones de mexicanos no pueden estar equivocados, South London Gallery, London, 2002.

MEDINA, Cuauhtémoc y STELLWEG, Carla, Jan Hendrix, Consejo Nacional para la Cultura y las Artes, Eindhoven, 1994.

MEDINA, Cuauhtémoc et al., La era de la discrepancia. The age of discrepancies, Arte $y$ cultura visual en México. Art and visual Culture in Mexico, 1968-1997, UNAM, Instituto de Investigaciones Estéticas, Turner, México, D.F., 2007.

MORENO VILLARREAL, Jaime. "Caminata por la vía", en Caminata. Rosario García Crespo, Museo Carrillo Gil, Consejo Nacional para la Cultura y las Artes, México, D.F., 1996.

PEIRÓ LÓPEZ, Juan Bautista et al., Otras naturalezas, Cimal Arte Internacional, Valencia, 2003.

PORRAZ FRASER, Paloma, "Naturalezas", en Perla Krauze, naturalezas, Galería Nina Menocal, México, D.F., 1998.

PIMENTEL, Taiyana et al., Las implicaciones de la imagen, Vol. I, UNAM, Museo Universitario de Ciencias y Arte, Colección Isabel y Agustín Coopel, UNAM, México, D.F., 2008.

POZZI, Gianni, Cracking Art, Naturale/Artificiale, Marzotta, Milano, 1999.

QUIROZ, Ana, “Añoranzas de tierra. Cruzando fronteras", en Marta Palau. Nómadas II. Arte ritual, Material divulgativo de la exposición, Kunsthaus Santa Fe, San Miguel de Allende, 1999.

RIUS CASO, Luis, "Aurora Noreña, entre la dicha inicua y la consagración del desperdicio", en Desperdicio de tiempo/De Naturaleza Artificial, Museo Tridimensional M-3D, Azcapotzalco, Estado de México, 2003.

RIUS CASO, Luis, Naomi Siegmann, Des-ilusiones, Museo Federico Silva, Escultura Contemporánea, San Luis Potosí, 2007.

SPRINGER, José Manuel, "El espejo de piedra", en Inmaculada Abarca, Material divulgativo de la exposición, Galería Kin, México, D.F., 1994. 
STEIN, Axel, "Cuentos del Orinoco y otros relatos", en Cuentos del Orinoco y otros relatos, Laura Anderson Barbata, Sala Mendoza, Caracas, 1999.

TORRES, Cristina, en Tridimensión actual. Inmaculada Abarca, Erik Bächtol, Selma Guisande, Laura Rosete y Shiori Chi, Galería de la Secretaría de Hacienda y Crédito Público, Guatemala, Nº 8, México, D.F., 2003.

YARD, Sally, InSITE94, A Binational Exhibition of Installation and Site-Specific Art, San Diego-Tijuana, Tijuana, 1994.

ZAMORA, Juan Carlos, Yolanda Paulsen, Galería OMR, México, D.F., 2000.

\section{REVISTAS Y PERIÓDICOS}

ABARCA, Inmaculada, "Del simulacro a la magia de la realidad", en D[X]I Magazine. Cultura \& Post-diseño, $\mathrm{N}^{\circ}$ 30, Valencia, 2008.

ABAD VIDAL, Julio César, "Los desplazamientos del objeto de Hisae Ikenaga", en Formato Cómodo, $\mathrm{N}^{\circ} 001$, Madrid, 2008.

ALBELDA, José, "Intervenciones mínimas, poéticas de la preservación", en Cimal, Arte Internacional. "Arte y Naturaleza", $2^{a}$ etapa, № 51, Valencia, 1999.

ALBELDA, José, "Arte y Naturaleza, evolución de un vínculo", en Exitbook, № 7, Olivares y Asociados, Madrid, 2007.

ALONSO, Guadalupe, "Entrevista con Jan Hendrix. Storyboard", en Revista de la Universidad de México, N 46, UNAM, México, D.F., 2007.

ANDRADE, Lourdes, "Ruinas y bosques", en Saber ver lo contemporáneo del arte, $\mathrm{N}^{\circ} 35$, Fundación Cultural Televisa, México, D.F., 1997.

ANDRADE, Lourdes, "El extraño paraíso de James", en Saber ver lo contemporáneo del arte, Nº 35, Fundación Cultural Televisa, México, D.F., 1997.

AUDEFROY, Joel, "Las Pozas, Xilitla. Arquitectura surrealista de Edward James", en Esencia y Espacio, Arte y Cultura Urbana, Año 3, No 19, Escuela Superior de Ingeniería y Arquitectura, Unidad Tecamachalco, Instituto Politécnico Nacional, Estado de México, 2004.

BADER, Joerg, “Carsten Höller”, en Lápiz, N² 206, Madrid, 2004.

BARANDA, María, “Amate, de Eduardo Rincón”, en La Jornada Morelos, 18, febrero, 2001.

BARRIOS, José Luis, "Efecto Invernadero: Humor y Restitución", en Curare, Espacio crítico para las artes, $\mathrm{N}^{\circ} 23$, México, D.F., 2004.

BATAILLE, Georges, "El lenguaje de las flores", en Exit, $\mathrm{N}^{\circ} 28$, Flores/Flowers, Olivares y Asociados, Madrid, 2007 (Publicado por $1^{\text {a }}$ vez en Documents, 1, 1929).

BAUTISTA, Juan Carlos, "Dos notas a propósito del Jardín Radial de Jerónimo Hagerman", en Galleta China. Revista de Arte \& Propaganda, $\mathrm{N}^{\circ} 1$, Casa Vecina, Espacio Cultural y Fundación del Centro Histórico de la Ciudad de México, México, D.F., 2010.

BAZÁN, Homero Gibrán, "El mundo estético de Inmaculada Abarca", en Excelsior, México, D.F., 19, noviembre, 1998.

BORRAS, M. ${ }^{a}$ Lluisa, "Laura Anderson Barbata. Entre la poesía y el compromiso", en ArtNexus, $\mathrm{N}^{\circ}$ 36, Miami (Florida), 2000.

BORRÁS, M. ${ }^{a}$ Luisa, "Yolanda Gutiérrez, vivencias, metáforas y mitologías", en ArtNexus, $\mathrm{N}^{\circ}$ 39, Miami (Florida), 2001.

BUSTAMANTE, Maris, "Un artista de hoy: Eduardo Kac en Cahctas", en Arte al Día News Mex, Año 3, N² 27, Manifiestos, México, D.F., 2006.

CARRASCO, Marta, "Jan Hendrix, pintor. El arte ha quedado para la élite", en $A B C$ de Sevilla, Sección Cultura, 12, mayo, 2005. 
CUEVAS, Tatiana, "Pedro Reyes's functional utopias", en Bomb, $\mathrm{N}^{\circ}$ 94, 2005, Gary Indiana et al. (eds.), Brooklyn (NY).

D'AVOSSA, Antonio, “Joseph Beuys, Domani la terra”, en Cimal. Arte internacional, № 41 , Valencia, 1993.

DEFFEBACH, Nancy, "Images of Human-Plant Hibrids in the Art of Frida Kahlo and Leonora Carrington", en Curare, Espacio crítico para las artes, № 11, México, D.F., 1997.

FOUCAULT, Michel, "Des espaces autres. Hétérotopies", en Architecture, Mouvement, Continuité, $\mathrm{N}^{\circ} 5$, Paris, 1984.

GALINDO, Carlos-Blas, "Aurora Noreña”, en El Financiero, Columna Artes Visuales, 4, julio, 2003.

GARCÍA CANCLINI, Néstor, "Un país que podría globalizarse", en Exit México, Olivares y Asociados, Madrid, 2005.

GENER, Mónica, "Arte en lugares públicos", en Cimal. Arte international. Arte Público, $\mathrm{N}^{\circ} 54$, Valencia, 2001.

GÓMEZ AGUILERA, Fernando, "La Naturaleza ya no será más la Naturaleza", en El Cultural, El Mundo, Madrid, 1, junio, 2006.

GRANDE, John K., "Extended efimeral. The South Carolina Botanical Garden's Linving Laboratory of Botanical Sculptures", en Sculpture, Vol. 23, $\mathrm{N}^{\circ} 2$, International Sculpture Center, Washington, 2004.

GRANDE, John K., "Suspended in Time: A Conversation with Yolanda Gutiérrez", Sculpture, Vol. 23, N 10, International Sculpture Center, Washington, 2004.

GUTIÉRREZ GALINDO, Blanca, "Las artes visuales en México: 1960-2004", Exit México, Olivares y Asociados, Madrid, 2005.

HAGERMAN, Jerónimo, "Acuéstese-Inhale-Disfrute, Azotea Jardín. Lie Down-Breathe Deeply-Enjoy. Roof Garden", en [ESPACIO], Arte contemporáneo, № 1, Diamantina, México, D.F., 2005.

HERRERA, Adriana, "Pedro Reyes, el conexionista. Las esculturas para usar del artista mexicano sorprenden a los espectadores en The Americas Society, en Mueva York", en Poder y negocios, México, D.F., 27, marzo, 2007.

HONTORIA, Javier, "Hisae Ikenaga, productora de ironías", en El Cultural, El Mundo, Madrid, 1, mayo, 2008.

JUNCA, Humberto, "El jardinero infiel. Alberto Baraya, artista... plástico", en Arcadia, Periodismo cultural, N 9, Bogotá, 2006.

KRAUZE, Perla, "Correo Mayor, 109, Azotea Jardín, Roof Garden, 07.2004", en [ESPACIO], Arte contemporáneo, $\mathrm{N}^{\circ}$ 1, Diamantina, México, D.F., 2005.

LARA ELIZONDO, Lupina, "Yvonne Domenge, Búsquedas profundas en el terreno de lo espiritual", Resumen, Pintores y pintura mexicana. Irma Palacios, Yvonne Domenge, Promoción de arte mexicano, Año 10, № 76, México, D.F., 2005.

LEÓN-PORTILLA, Miguel, "Las flores en la poesía náhuatl", en Arqueología mexicana. Las flores en el México prehispánico, Vol. XIII, N 78, INAH, CNCA, Raíces, México, D.F., 2006.

LEÓN PORTILLA, Miguel, "Universo de flores. La palabra de Mesoamérica", en Flores, Artes de México, N 47, México, D.F., 1999.

L. VELASCO LOZANO, Ana M. a y NAGAO, Debra, "Mitología y simbolismo de las flores", en Arqueología mexicana. Las flores en el México prehispánico, Vol. XIII, № 78, INAH, CNCA, Raíces, México, D.F., 2006.

MAC MASTERS, Merry, "Silvestre recrea un jardín que había en la Sala Siqueiros", en $L a$ Jornada, México, D.F., 25, mayo, 2002. 
MARTíN DEL CAMPO, David, "Cinco torres, antes y después. Escultura Moderna en México", en MP Memoria de papel, Crónicas de la cultura en México, Consejo Nacional para la Cultura y las Artes, México, D.F., 4, octubre, 1992.

MOLTER, Michael, "Douglas Buis: home and Oasis", en Espace Sculpture, № 31, Québec, Canadá, 1995.

NAVARRETE, Sylvia, "Flor, espejo de los sentidos", en Flores, Arte de México, № 47, México, D.F., 1999.

NAVARRO, Mariano, "Máximo González. Letal macetero de vida", en El Cultural, El Mundo, Madrid, 8, marzo, 2007.

NUTTALL, Zelia, "Los jardines del antiguo México", en Arqueología mexicana. Antiguos jardines mexicanos, Vol. X, No 57, Instituto Nacional de Antropología e Historia, Consejo Nacional para la Cultura y las Artes, Raíces, México, D.F., 2002.

OHLENSCHLÄGER, Karin, "Eduardo Kac y la Interacción Arte Ciencia Vida", en Cuadernos del IVAM, N 10, Valencia, 2007.

OLES, James, "Thomas Glassford”, en Poliester, N²26, México, D.F., 1999.

ORIARD, Andrés, "Los críticos hacen sus apuestas", en Exit Express, $\mathrm{N}^{\circ} 18$, Olivares y Asociados, Madrid, 2006.

OLIVARES, Rosa, "Dígaselo con flores", en Exit, № 28, Flores/Flowers, Olivares y Asociados, Madrid, 2007.

PALACIOS GOYA, Cynthia, "El caminar, una forma de pensamiento. Exposición pictórica de Rosario García Crespo", en El Nacional, Sección Cultura, México, D.F., 15, marzo, 1996.

PEIRÓ LÓPEZ, Juan Bautista, "Pamen Pereira: Huellas de luz, sombras de tiempo", en Cimal, Arte y Naturaleza, № 51, Cimal Internacional, Valencia, 1999.

PÉREZ GAVILÁN, Ana Isabel, "La distancia del deseo", en Origina, Año 11, № 132, 2004.

ROCA, José Ignacio, "Flora necrológica. Imágenes para una geografía política de las plantas", en Lápiz, N 178, 2001.

RUIZ DE SAMANIEGO, Alberto, "Arte público: enemigo público", en Cimal. Arte international. Arte Público, N 54, Valencia, 2001.

RUÍZ DE SAMANIEGO, Alberto, "El tiempo de un bodegón", en Exit, $\mathrm{N}^{\circ} 18$, Naturaleza muerta/Still.life, Olivares y Asociados, Madrid, 2005.

SAN MARTín, Francisco Javier, "Entrevista con Giuseppe Penone", en Lápiz, Nº152, Madrid, 1999.

SÁNCHEZ MECA, Diego, "Los conceptos griegos de physis y theoria en la interpretación de Goethe", en Daimon, Revista de Filosofía, № 16, Universidad de Murcia, Murcia, 1998.

SAUNDERS, Gill, "De especímenes a símbolos sexuales: flores en fotografía", en Exit, № 28 , Flores/Flowers, Olivares y Asociados, Madrid, 2007.

SANTAMARINA, Guillermo, "Panchito en Baviera (o un condensado de reflexiones sobre viejas y nuevas estrategias, internacionalismo y, desde luego, obligaciones en el arte mexicano", en Exit México, Olivares y Asociados, Madrid, 2005.

Sin autor, "Entrevista a Mauricio Rocha. Vista aérea y zonas de vegetación", en Cambio, 10, noviembre, México, D.F., 2002.

SOSA, Jorge, "La poética de lo inminente. Sobre la obra escultórica de Aurora Noreña", ("The poetics of the Imminent. On the work of Aurora Noreña"), en RIM, $\mathrm{N}^{\circ} 3$, México, D.F.Los Ángeles, 2003.

TIBOL, Raquel, "Por mi lava hablará el espíritu", en Proceso, № 130, México, D.F., 1978.

TIBOL, Raquel, “Acercamiento a Joseph Beuys en México", en Proceso, № 652, México, D.F., 1989. 
URIARTE, M. ${ }^{a}$ Teresa, "Flores en la pintura prehispánica", en Arqueología mexicana. Las flores en el México prehispánico, Vol. XIII, Nº 78, INAH, CNCA, Raíces, México, D.F., 2006. VAL, Eusebio, "La última revolución creativa. Llegan los artistas de laboratorio. El bioarte se hace un espacio usando bacterias y genes como expresión estética”, en La Vanguardia, Madrid, 16, agosto, 2005.

VARGAS, Ángel, "Incursión en el performance de la Jornada Semanal. La cábula situacionista y lo insólito en el Centro Histórico", en La Jornada, Sección Cultura, México, D.F., 26, abril, 1997.

VÉLEZ, Gonzalo, "Yolanda Paulsen y la vulnerabilidad de lo que está vivo", en Boletín de información técnica [de] A/TIM (Asociación de Investigación Técnica de las Industrias de la Madera), N² 241, Madrid, 2006.

\section{PÁGINAS WEB}

ABELLEYRA, Angélica, "Betsabée Romero: el arte, única forma de resistencia", en La Jornada Semanal, México, D.F., 28, octubre, 2007, Disponible en red en <http://www.jornada. unam.mx/2007/10/28/sem-angelica.html>, [Consulta 20, abril, 2009].

ACEVEDO, Alejandro, "Helen Escobedo: Artist and Promoter of the Mexican Avant Garde", Disponible en red: <http://www.pintomiraya.com.mx/lapala_nuevaweb/ingles/engentre vista4.htm $>$, [Consulta 24, febrero, 2005].

AGUILAR, Cecilia <http://www.conaculta.gob.mx/saladeprensa/2002/06may/taboas. htm $>$, [Consulta 9, marzo, 2005].

ALMELA, Ramón, "Gabriela León en la India. Arte de contexto y situación", Disponible en red: <http://www.criticarte.com/Page/file/art2005/GabrielaLeon.India.html>, [Consulta 14, julio, 2009].

ANDERSON BARBATA, Laura, "Sin lo uno no hay lo otro", Conferencia Forum TEDxDF, $\mathrm{X}=$ Independently organizad TED event, 27, octubre, 2010, Teatro de la Ciudad, México, D.F., Disponible en red: <http://www.youtube.com/watch?v=zRzYfaUCCXI>.

ARANDA MÁRQUEZ, Carlos, "Los (h)usos de la Historia”, septiembre, 2007, Disponible en red: <http://www.arteamerica.cu/14/dossier/aranda.htm>, [Consulta 12, febrero, 2008].

BARBROOK, R., "Die heiligen Narren. Deleuze, Guattari und die High-tech Geschenksökonomie“, (22.12.1998), en Telepolis: Medientheorie, Diponible en red en:<http://www.heise.de/tp/deutsch/special/med/6344/1.html>,

[Consulta 13, septiembre, 2011].

BANAI, Nuit, "Excerpts from New Views-World Financial Center", Disponible en red: $<$ http://janebenson.net $>$ [Consulta 9, abril, 2010].

BETANCOURT, Jeannette, "El campo expandido: tridimensión y su geografía de transgresión. Naturaleza incierta", en Milenio, Vol. 12, Puerto Rico, 2008, Disponible en red: <http://www.uprb.edu/milenio/milenio-XII.htm>, [Consulta 22, julio, 2010].

BETANCOURT, Jeannette, "La certeza de lo incierto", México, D.F., 2007, Disponible en red: <http://www.arteven.com/naomi_siegmann.htm>, [Consulta 13, abril, 2009].

BLANDINO, Bayardo, "Betsabée Romero, ciudades habitadas", en Lágrimas negras, Museo Amparo, Puebla, 2008, Disponible en red: <http://textoblanco.blogspot.com/>, [Consulta 26, julio, 2011 ].

BORRÀS M. ${ }^{a}$ Lluïsa et al., "Thomas Glassford, Ciudad de México. Torre de los Vientos. Galería OMR", en México, Identidad y ruptura, Fundación Telefónica, Madrid, 2003, Disponible en red: <http://www.fundacion.telefonica.com/es/at/mexico/paginas/ 05.html $>$, [Consulta 20, agosto, 2011 ]. 
BRITO, Sara, "Casas que cantan en la selva. Edward James levantó en la mexicana Xilitla un onírico entramado constructivo", en El País, Madrid, 6, mayo, 2006, Disponible en red: $<$ http://elviajero.elpais.com/articulo/viajes/Casas/cantan/selva/elpviavia/20060506elpv iavje_13/Tes $>$, [Consulta 19, febrero, 2008].

BRAUNŠTAJN, Helena, "Intervención artística de Jerónimo Hagerman en el Atrio de San Francisco", Disponible en red: <http://www.lugarcero.com/index.php/atrio-de-sanfrancisco/aqui-y-ahora-jardin-radial-jeronimo-hagerman $>$, [Consulta 10, agosto, 2009]. CASTILLERO, Silvia Eugenia, "Desconfines: La Ciénega y La Flor", Disponible en red en:<http://www.arte-mexico.com/lopezquiroga/FernandoGonzalezGortazar/texto.htm>, [Consulta 12, abril, 2009].

CASTRO FLÓREZ, Fernando, "El entropólogo deconstructor", en $A B C D$, Las Artes y las letras, 21 , junio, 2008, $\mathrm{N}^{\circ} 855$, Disponible en red: <http://www.abc.es/abcd/noticia.asp $? \mathrm{id}=10022 \&$ num $=855 \& \mathrm{sec}=36>$, [Consulta 8, marzo, 2010].

CHÁVEZ SILVA, Eduardo A., "La Escultura de Yvonne Domenge", Disponible en red: <http://www.domenge.com/artman/publish/escultura_214.shtml>, [Consulta 2, noviembre, 2004].

CONDE, Teresa del, "Dos exposiciones", en La Jornada, México, D.F., 9, mayo, 2000, <http://www.jornada.unam.mx/2000/may00/000509/delconde.html>, [Consulta 25, marzo, 2004].

DÍAZ INFANTE, Juan José, "Todavía, la magia. Los nuevos soportes, el arte, México, los independientes", en Revista virtual de arte contemporáneo y nuevas tendencias, 08/01/2009, Basado en un ensayo publicado en la Revista $A R C O$, por Juan José Díaz Infante, artista independiente y curador en Jefe de Transitio $m \times 3$, septiembre, 2003, México, D.F., Nueva edición, julio 2009, Disponible en red :<http://revista.escaner.cl /node/1441>, [Consulta 27, agosto, 2009].

EDER, Rita, et al., "Marta Palau a cuatro voces", Disponible en red en: < http:// www.martapalau.com/uploads / MartaPalaucuatrvoce.htm>, [Consulta 7, febrero, 2008].

ESPINOSA DE LOS MONTEROS, Santiago, "Botánica: Exposición gráfica de Jan Hendrix y Miguel Ángel Blanco, Disponible en red: <http://www.replica21.com/archivo/articulos /e_f/331_espinosa_botanic.html>, [Consulta 8, marzo, 2004].

GANADO KIM, Edgardo, "Ponchadas por el paisaje o El paisaje como vía de construcción de la utopía” , México, D.F., junio, 2005, Disponible en red:<http://www.arte-mexico.com/ betsa/texto.htm>, [Consulta 25, julio, 2011].

GERBER BICECCI, Verónica, "Naturaleza muerta con jícamas", en Letras Libres, México, D.F., 29, octubre 2010, Disponible en red: <http://www.letraslibres.com/beta/blogs/

naturaleza -muerta-con-jicamas $>$, [Consulta 2, agosto, 2011].

GÓMEZ HARO, Germaine, "Maribel Portela (II y Última)", en La Jornada Semanal, Artes visuales, No 722, México, D.F., 4, enero, 2009, Disponible en red: <http://www.jornada. unam.mx/2009/01/04/sem-haro.html $>$, [Consulta 27, julio, 2011].

HERNANDO, Javier, "Energía convulsiva. Barrocos Neobarrocos. El infierno de lo bello", en El Cultural, El mundo, Madrid, 6, octubre, 2005, Disponible en red: http://www.elcultural.es/version_papel/ARTE/12858/Energia_convulsiva/>, [Consulta 9, abril, 2010].

HERRERO UCEDA, Miguel, "Sistema de comunicación en el mundo vegetal", en Tecnociencia, Periódico gratuito de divulgación científico-técnica, $\mathrm{N}^{\circ} 4$, junio, 2006, p. 5, Disponible en línea: <http://www.tecnociencia.org/pdf/Tecnociencia4.pdf>, [Consulta 30, enero, 2008]. 
HOBLER, Martin, "La globalización en las Artes", entrevista con Xawery Wolski, Zürich, 2008, Instituto de Política de Europa Oriental, Universidad de Berlín, Disponible en red:<http:// www.xwolski.com>, [Consulta 13, enero, 2005].

KATZEW, Iona, Disponible en red en <http://www.esay.edu.mx/directorio/ficha.php?ld Personal $=6>$, [Consulta 15, noviembre, 2004].

LANDA, Isabel, "Vaivén de objetos globalizados. La artista mexicana Hisae Ikenaga expone sus últimos trabajos en Madrid", en El país, Madrid, 30 de abril, 2007, Disponible en red <http://www.elpais.com/articulo/cultura/Vaiven/objetos/globalizados/elpvidcul/20070 430elpepucul_1/Tes $>$, [Consulta 30, julio, 2011].

LÓPEZ CUENCA, Alberto, "El desarraigo como virtud: México y la deslocalización del arte en los años 90", en Revista de Occidente, $N^{\circ} 285$, febrero, 2005, Disponible en red en $<$ http://www.revistasculturales.com/articulos/97/revista-de-occidente/260/2/eldesarraigo-como-virtud-mexico-y-la-deslocalizacion-del-arte-en-los-anos-90.html>, [Consulta 20, abril, 2009].

LORDA, Joaquín, "El repertorio a la romana: Las transformaciones del acanto", Departamento de Teoría e Historia, Escuela de Arquitectura, Universidad de Granada, Disponible en red en: <http://www.unav.es/teohistarq/histarq/MEb/romana/

candelabro.html $>$, [Consulta 3, febrero, 2008].

LLORENS, Nuria, "Estética y ética del paisaje en Los Moralistas", Disponible en red en: $<$ http://ddd.uab.cat/pub/locus/11359722n8p349.pdf>, [Consulta 5, febrero, 2008].

MAC MASTER, Merry, "Laura Anderson trae del Amazonas a Chiapas su proyecto para hacer papel", Disponible en red:<http://www.fundacion.telefonica.com/at/mexico/ paginas/03.html $>$, [Consulta 8, agosto, 2011 ].

MARCíN, Mauricio, "El colectivo regiomontano Tercerunquinto altera con su arte el paisaje urbano", Disponible en red: <http://cronica.com.mx/nota.php?id_nota=158867> [Consulta 16, agosto, 2011].

MILLER, Keith, "Revisioning Nature", Disponible en red <http://www.keith-miller.com /curatorial/nature/index.html>, [Consulta 28, agosto, 2011].

MEDINA, Cuauhtémoc, "Artesanías alegóricas. Arte In Situ/La torre de los vientos", en Reforma, México, D.F., 2, agosto, 2000.

MOLINA, Juan Antonio, "Inscripciones en el paisaje", Disponible en red en:<http://static. scribd.com/docs/g5Ir00ajnrr5s.pdf>, [Consulta 29, julio, 2009].

MOSQUERA, Gerardo, "Ana Mendieta", Disponible en red en Biblioteca virtual Luis Ángel Arango, Banco de la República:<http://www.lablaa.org/blaavirtual/letra-a/anam/ anam23a.htm $>$, [Consulta 30, octubre, 2011].

MUNGUÍA, Jorge, "Jardín Botánico. Entrevista a Patrick Charpenel", en Tomo. Arte, arquitectura y diseño, Suplemento Excelsior, $\mathrm{N}^{\circ} 10,2008$, Disponible en red: <http://tomo.com.mx/2008/10/25/jardin-botanico/>, [Consulta 19, agosto, 2011].

Nota de prensa y material de divulgación de la exposición: La estructura de la piel, Miriam Medrez, Museo Marco, Monterrey, 2008, Disponible en red, <http://www.marco.org.mx/ exposiciones/expo_anteriores /expo_miriam_medrez.htm>, [Consulta 26, julio, 2009].

PALACIOS, Víctor, "Sebastián Romo. La voluntad de las cosas", Centro Galego de Arte Contemporánea, Disponible en red: <http://www.cgac.org/index.php?id=65\&idn=582>, [Consulta 13, agosto, 2009].

RATTEMEYER, Christian, "Complicación de la Naturaleza", (Traducción libre), Disponible en red: <http://www.culturebase.net/artist.php?718>, [Consulta 8, marzo, 2005]. 
REIS, Paulo, "It is the truth that hides the fact that there is no truth", Dardo Magazine, $\mathrm{N}^{\circ} 9$, 2008, Santiago de Compostela, Disponible en red: <http://www.galerialeme.com /artistas_textos.php?lang=ing\&id=42\&text_id=139>, [Consulta 9, abril, 2010].

REYES, Pedro, "Jardines colgantes", Disponible en red en: <http://www.torredelos vientos.org/\#667857/2000-Pedro-Reyes >, [Consulta 15, agosto, 2011].

RIVERA, Daniel, "A propósito de la ciencia y el arte", La Jornada, México, D.F., 22, noviembre, 1999, Disponible en red: <http://www.jornada.unam.mx/1999/nov99

/991122/cien-rivera.html>, [Consulta 18, noviembre, 2005].

RODRÍGUEZ, Dunia, "Los nahuallis y erotismo mexicano, cubren las obras de Marta Palau", Disponible en red:<http://www.cimacnoticias.com/noticias/01 oct/01103101.html>, [Consulta 1, septiembre, 2011].

SILVA LOMBARDO, Federico, Página personal, Disponible en red:<http://www.

silvalombardo.com/obra_actual.html $>$, [Consulta 14, abril, 2009].

Sin autor, "Emari 09, Primer Ritual Internacional de Arte Actual de la Zona de la Ultzama", Disponible en red: <http://colectivoelpuente.com/emari_09/proyecto_emari_09.html>, [Consulta 20, agosto, 2009].

Sin autor, "El Museo Federico Silva le ha dado un nuevo rostro a San Luis Potosí", en El sonido 13, Portal digital de propuesta informativa en arte de San Luis Potosí, Disponible en red: <http://www.elsonido13.com/detalle-noticia.asp?id=14>, [Consulta 15, febrero, 2008].

Sin autor, Entrevista: "Arte: Jerónimo Hagerman", en Tomo. Arte Arquitectura y Diseño, Suplemento Excelsior, México, D.F., 23, junio, 2009, Disponible en red: <http://tomo.com.mx/2009/06/fresco-jeronimo-haggerman/>, [Consulta 10, agosto, 2009]

Sin autor, Belfast to bloom with new artwork. A humble flower is set to dominate the Belfast skyline in three years time", BBC News, (11-10-2005), Disponible en red: <http://news.bbc.co.uk/1/ hi/northern_ireland/4329710.stm>, [Consulta 30, octubre, $2011]$.

Sin autor, "Arte en el mundo, Paul Morrison", en El Cultural, 25, septiembre, 2003, Madrid, Disponible en red:<http://www.elcultural.es/version_papel/ARTE/7875/Paul_Morrison>, [Consulta 30, octubre, 2011].

SPRINGER, José Manuel, "Topologías del paisaje mental. Un análisis a vuelo de pájaro de aquello que identifica al artista citadino de hoy", Disponible en red: <http://www.replica21.com/archivo/articulos/s_t/345_springer_topo.html>, [Consulta 10 , agosto 2011 ].

SPRINGER, José Manuel, "Un recorrido cifrado", en Réplica 21. Obsesiva compulsión por lo visual, México, D.F., 1, abril, 2003, Disponible en red en <http://www. replica21.com/archivo/articulos/g_h/163_gardea_gcrespo.html>, [Consulta 9, agosto, $2011]$.

SUCKAER, Ingrid, "Desde la tierra reúne a cinco escultores que trabajan el barro", en $L a$ Jornada, 7, octubre, México, D.F., 2007, Disponible en red: <http://www.jornada. unam. $\mathrm{mx} / 2007 / 10 / 07 /$ index. php?section $=$ cultura\&article $=\mathrm{a} 06 \mathrm{n} 2 \mathrm{cul}>, \quad[$ Consulta 25 , julio, 2009].

TOSCANO, Javier, "El efecto invernadero o la impostura del sentido. Reflexiones en torno a una curaduría", Disponible en red en: http://www.lc060.org/invernadero/>, [Consulta 25, agosto, 2009]. 
VILLORO, Juan, "La mente del arquitecto", La Jornada Semanal, Domingo breve, México, D.F., 26, diciembre, 1999, Disponible en red en: <http://www.jornada. unam.mx/1999/12/26/sem-villoro.html>, [Consulta 14, abril, 2009].

\section{TEXTOS INÉDITOS}

RIUS CASO, Luis, "Yvonne Domenge: La Aventura del Centro", Texto inédito -en proceso de publicación- proporcionado por el crítico de arte a la autora de esta investigación, México, D.F., 2004.

RIVERA, Daniel y RUDOMIN, Isaac, "Naturaleza Aumentada. La ciencia es el arreglo ordenado que de momento, se parece a los hechos", Texto inédito proporcionado por el artista a la autora de esta investigación, México, D.F., 2004. 
La presente tesis doctoral, Tiempo vegetal. Referencias botánicas en la escultura mexicana contemporánea (1990-2010), aborda el estudio de las manifestaciones e implicaciones que el referente vegetal ha tenido y tiene en la escultura contemporánea mexicana. A través de la documentación aportada en este estudio, así como de las reflexiones en torno a las manifestaciones artísticas analizadas, se hace patente que la utilización de referencias botánicas en la práctica artística durante la última década del siglo XX y la primera del siglo XXI es, sin duda, un significativo indicio del interés que despiertan las relaciones entre arte y naturaleza en el contexto mexicano. Unas relaciones que ponen de manifiesto la importancia del constructo de lo natural y sus derivas conceptuales como un ámbito de investigación y creatividad dentro del arte contemporáneo.

La investigación realizada se inicia con una aproximación al mundo vegetal y a las relaciones que histórica y culturalmente el ser humano ha mantenido con éste, para lo que se ha recurrido a autores que, procedentes de diversos ámbitos del conocimiento la han abordado. Desde Homero, Demócrito y Lucrecio hasta Goethe, Foucault y Guattari. Esta diversidad referencial nos ha permitido trabajar desde perspectivas interdisciplinares en áreas como la simbología, la mitología, la antropología, la estética y/o la sociología. Para ello, nuestro estudio ha partido de las reflexiones y aportaciones realizadas, entre otros, por Worringer, Dorfles, Tatarkiewicz y Deleuze o por Eliade, Cirlot y Bachofen.

Si bien durante el periodo acotado en la tesis doctoral (1990-2010), la práctica escultórica mexicana presenta un creciente interés por la incorporación del elemento vegetal, existen antecedentes previos que nos han llevado a considerar la obra de autores que pueden calificarse como precursores en relación a esta temática, como son los casos de Helen Escobedo, Jan Hendrix o Marta Palau. Partiendo de la obra de estos tres antecedentes, la investigación analiza una serie de usos del referente vegetal en una amplia compilación de obras y artistas seguidores de esta tendencia y cómo dicho referente se manifiesta fundamentalmente bajo tres pautas discursivas.

En primer lugar, nuestro estudio aborda un conjunto de propuestas artísticas centrado en la utilización de las plantas como referente formal, estructural y/o simbólico. En dichas obras se hace imprescindible la representación del elemento vegetal o de algunas de sus partes, llegándose incluso a un trabajo tendente a la abstracción y a la síntesis representativa.

En segundo lugar, el análisis realizado se centra en trabajos y proyectos que parten de la problemática ecológica como elemento básico de su discurso y en los que destaca como característica principal, no sólo la vinculación arte-vida, sino también la relación de la obra con el propio artista en tanto que ser humano integrado en un ecosistema. 
Por último, la tercera pauta discursiva trazada analiza aquellas manifestaciones en las que la presencia vegetal es empleada como material de trabajo y como concepto que se encuentra unido a un proceso y a unos tiempos específicos. En estas obras se da una sustitución de la representación de la planta por la presentación in situ de la misma, hecho que marca un cambio fundamental en el tratamiento y los resultados artísticos obtenidos. 
La present Tesi Doctoral, Temps vegetal. Referències botàniques en /'escultura mexicana contemporània (1990-2010), aborda l'estudi de les manifestacions i implicacions que el referent vegetal ha tingut i té en l'escultura contemporània mexicana. A través de la documentació aportada en aquest estudi, així com de les reflexions envers a les manifestacions artístiques analitzades, es fa patent que la utilització de referències botàniques en la pràctica artística durant I'última dècada del segle XX i la primera del segle XXI és, sens dubte, un significatiu indici de I'interès que desperten les relacions entre Art i Natura en el context mexicà. Unes relacions que fan palès la importància de la construcció del natural i les seves derivacions conceptuals com un àmbit d'investigació i creativitat dins de I'art contemporani.

La investigació realitzada comença amb una aproximació al món vegetal i a les relacions que històrica i culturalment I'ésser humà ha mantingut amb aquest, per la qual cosa hom ha recorregut a autors que, procedents de diversos àmbits del coneixement I' han abordat. Des d'Homero i Lucrecio fins Goethe, Foucault i Guattari. Aquesta diversitat de referents ens ha permès de treballar des de perspectives interdisciplinàries en àrees com la simbologia, la mitologia, I'antropologia, I' estètica i/o la sociologia. I és per això que el nostre estudi ha partit de les reflexions i aportacions realitzades, entre altres, per Worringer, Dorfles, Tatarkiewicz i Deleuze o per Eliade, Cirlot i Bachofen.

Encara que al Ilarg del període acotat en la tesi doctoral (1990-2010), la pràctica escultòrica mexicana presenta un creixent interès per la incorporació de l'element vegetal, existeixen antecedents previs que ens han portat a considerar l'obra d'autors que poden qualificar-se com a precursors en relació amb aquesta temàtica, com són els casos de Helen Escobedo, Jan Hendrix o Marta Palau. Partint de l'obra d'aquests tres antecedents, la investigació analitza una sèrie $d$ 'usos del referent vegetal en una ampla compilació $d$ 'obres $i d^{\prime}$ artistes seguidors $d$ 'aquesta tendència i com l'esmentat referent es manifesta fonamentalment sota tres pautes discursives.

En primer $\mathrm{lloc}$, el nostre estudi aborda un conjunt de propostes artístiques centrat en la utilització de les plantes com a referent formal, estructural i/o simbòlic. En les citades obres es fa imprescindible la representació de l'element vegetal o alguna de les seves parts, arribant-se fins i tot a un treball tendint a I’abstracció i a la síntesi representativa.

En segon Iloc, I' anàlisi realitzat es centra en treballs i projectes que partint de la problemàtica ecològica com element bàsic del seu discurs i en els que destaca com a característica principal, no sols la vinculació art-vida, si no també la relació de l'obra amb el propi artista com ésser humà integrat en un ecosistema. Per últim, la tercera pauta discursiva analitza aquelles manifestacions en les que la presència és emprada com a material de treball i com a concepte que es troba unit a un procés i a uns temps específics. En aquestes obres es dóna una substitució de la representació de la planta per la representació in situ de la mateixa, fet que marca un canvi fonamental en el tractament i els resultats artístics obtinguts. 
This Doctoral Thesis; Vegetable era. Botanic references in Mexican contemporary sculpture (1990-2010), is dedicated to the study of expression and implications that the vegetable kingdom has had on contemporary Mexican sculpture. By means of the documentation provided in this study, as well as analysed botanical references in artistic performance, it is clear that the use of botanical references in artistic practice over the last decade of the 20th Century and beginning of the $21 \mathrm{st}$ is without a doubt, an important sign of the interest that arises in the relationship between Art and Nature in the Mexican context. This proves the importance of the natural construct and its conceptual ramifications in the field of research and creativity in contemporary art.

The investigation carried out starts off with an approach to the vegetable kingdom and the historical and cultural relationship between the human being and plant life. This has been approached by authors of varied backgrounds and from different angles of knowhow, such as, Homero, Demócrito and Lucrecio, to Goethe, Foucault and Guattari. This referential has allowed us to work from different interdisciplinary perspectives in areas such as, symbology, mythology, anthropology, aesthetics and/or sociology. As a result, our study starts off with reflexions and contributions from Worringer, Dorfles, Tatarkiewicz, Deleuze or Eliade, Cirlot and Bachofen, among others.

During the preparation period of this doctoral thesis (1990-2010), Mexican sculpture has shown an increasing interest for the use of plant elements. There are previous records for such practice: Helen Escobedo, Jan Hendrix, or Marta Palau. Starting with the work of these artists, the research analyses a number of uses of vegetal references in a wide compilation of art works and artists aligned with this trend, expressed themselves in three different discursive lines.

First of all, our study addresses a number of artistic proposals that focus on the use of the plants as formal, structural and symbolic reference. In these works, the representation of the vegetal element or parts thereof is imperative. These works may also show a trend towards abstraction and synthetical representation.

Secondly, the analysis focuses on art works and projects with a concern for environmental issues as a basis for their discourse. The main aspect of these works are twofold; on one hand, the strong link between art and life and on the other hand, the relationship between art work and the artist himself as a human being, as part of one ecosystem.

Finally, a third analysis deals with those artistic expressions where vegetal presence is used as work material and as a concept linked to a particular process and specific time frame. In these cases, the artistic representation of the plant is substituted, in situ, by the plant itself, bringing a fundamental change in the treatment and artistic results achieved. 